В. А. КОЗЛОВ, А. А. САВЧЕНКО, И. В. КУДРЯВЦЕВ,

И. Г. КОЗЛОВ, Д. А. КУДЛАЙ, А. П. ПРОДЕУС, А. Г. БОРИСОВ

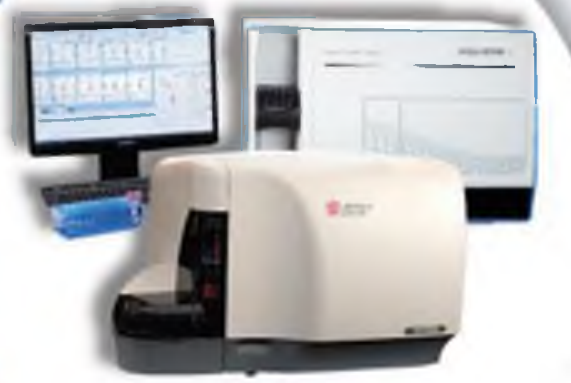

Практическое пособие для врачей

\title{
КЛИНИЧЕСКАЯ ИММУНОЛОГИЯ
}




\section{РОССИЙСКАЯ АКАДЕМИЯ НАУК}

СИБИРСКОЕ ОТДЕЛЕНИЕ

ФИЦ КНЦ СО РАН

НАУЧНО-ИССЛЕДОВАТЕЛЬСКИЙ ИНСТИТУТ МЕДИІ ИНСКИХ ПРОБЛЕМ СЕВЕРА

ИНСТИТУТ КЛИНИЧЕСКОЙ ИММУНОЛОГИИ

В.А. Козлов, А.А. Савченко, И.В. Кудрявцев, И.Г. Козлов, Д.А. Кудлай, А.П. Продеус, А.Г. Борисов

\section{КЛИНИЧЕСКАЯ ИММУНОЛОГИЯ}

ПРАКТИЧЕСКОЕ ПОСОБИЕ ДЛЯ ВРАЧЕЙ 
УДК 616-035.9

ББК 52.7

K 49

Козлов В.А. Клиническая иммунология / В.А. Козлов, А.А. Савченко, И.В. Кудрявцев, И.Г. Козлов, Д.А. Кудлай, А.П. Продеус, А.Г. Борисов. - Красноярск: Поликор, 2020. - 386 с. ISBN 978-5-6044565-6-9

В монографии обобщены современные данные о диагностике и лечении нарушений функции иммунной системы. Описаны методы клинической и лабораторной диагностики иммунных нарушений. Особое внимание уделено разделу иммунотерапии в клинике внутренних болезней и современным методам коррекции иммунных нарушений.

Книга представляет интерес для врачей клиницистов, а именно анестезиологовреаниматологов, акушеров-гинекологов, врачей общей практики, гастроэнтерологов, дерматовенерологов, инфекционистов, клинических фармакологов, кардиологов, отоларингологов, онкологов, педиатров, ревматологов, стоматологов, пульмонологов, терапевтов, хирургов, урологов, эндокринологов

Табл. 121. Ил. 133. Библиография.: 132 назв.

Р е ц е н $з$ е н т ы

доктор медицинских наук, профессор Э.В. Каспаров доктор медицинских наук, профессор Е.П. Тихонова доктор медицинских наук, профессор В.В. Цуканов

Утверждено к печати Ученым советом

Научно-исследовательского института медицинских проблем

Севера ФИЦ КНЦ СО РАН

Без объявления

ISBN 978-5-6044565-6-9
(C) В.А. Козлов, А.А. Савченко, И.В. Кудрявцев, И.Г. Козлов, Д.А. Кудлай, А.П. Продеус, А.Г. Борисов, 2020

(C) НИИ медицинских проблем Севера ФИЦ КНЦ СО РAH, 2020

(C) Институт клинической иммунологии, 2020 


\section{Содержание}

Предисловие

\section{Раздел 1. Иммунная система}

Глава 1.

Компоненты иммунной системы .

Глава 2.

Мукозальный иммунитет

Глава 3.

Врожденный иммунитет

Глава 4

Адаптивный иммунитет

61

Глава 5.

Элиминация и регенерация

\section{Раздел 2 Методы исследования иммунной системы}

Глава 6.

Клинические методы исследования иммунной системы ..

Глава 7.

Исследование клеточного звена иммунитета

Глава 8.

Исследование гуморального звена иммунитета

Глава 9.

\section{Раздел 3. Диагностика иммунных нарушений}

Глава 10. $\quad$ Иммунологический диагноз ............................ 151

Глава 11. Топическая диагностика иммунных нарушений ............. 161

Глава 12. Болезни иммунной системы ............................... 183

Глава 13. Индуцированные иммунные нарушения ….............. 211

Глава 14. Болезни гиперчувствительности ............................ 223

\section{Раздел 4. Лечения больных с иммунными нарушениями}

Глава 15. $\quad$ Принципы лечения больных с иммунными нарушениями.. 233

Глава 16. $\quad$ Устранение причины иммунных нарушений ............... 235

Глава 17. $\quad$ Устранение патогенного агента .......................... 245

Глава 18. $\quad$ Применение средств, влияющих на клеточное окружение 269

Глава 19. $\quad$ Метаболическая терапия ................................... 277

\section{Раздел 5. Иммуноактивная терапия}

Глава 20.

Методы иммунотерапии

Глава 21.

Заместительная терапия

Глава 22.

Иммуностимулирующая терапия

Глава 23.

Глава 24.

Иммунодепрессивная терапия

Глава 25.

Клеточно-тканевая терапия

Заключение ....

Авторский коллектив 


\section{Список основных изображений}

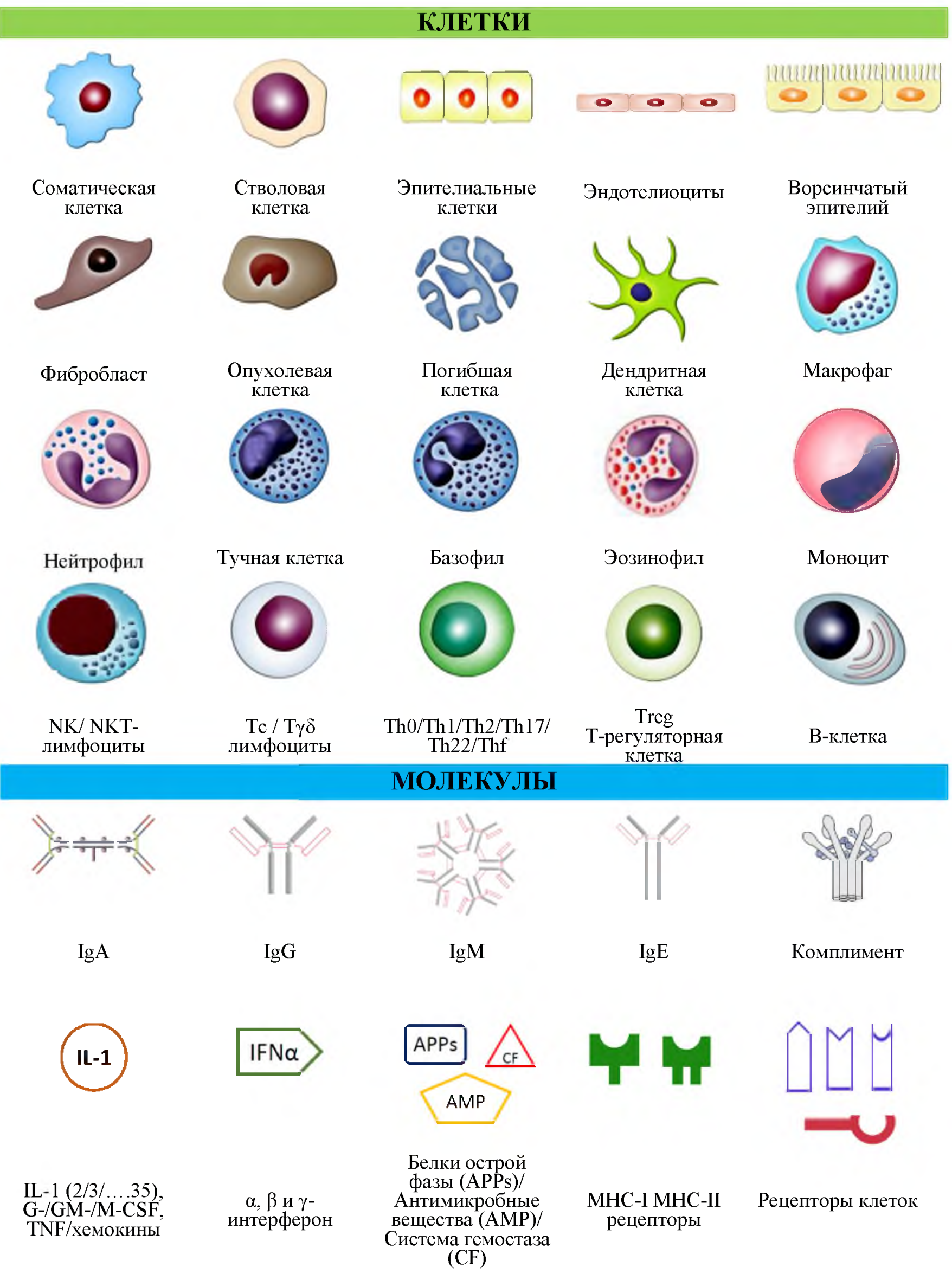

В экспозиции обложки использовано изображение компании «Beckman Coulter Life Sciences» 


\section{Список основных сокращений}

\begin{tabular}{|c|c|c|}
\hline $\mathrm{Ab}, \mathrm{AT}$ & - & antibody, антитело \\
\hline $\mathrm{Ag}, \mathrm{A} \Gamma$ & - & antigen, антиген \\
\hline AIDS, СПИД & - & $\begin{array}{l}\text { acquired immunodeficiency syndrome, синдром } \\
\text { приобретенного иммунодефицита }\end{array}$ \\
\hline AMPs & - & antimicrobial peptides, антимикробные пептиды \\
\hline АРС, АПК & - & antigen-presenting cell, антигенпрезентирующие клетки \\
\hline APPs & - & acute-phase proteins, белки острой фазы \\
\hline B-cell & - & В-лимфоцит \\
\hline BCR & - & B-cell receptor, В-клеточный рецептор \\
\hline $\mathrm{Bph}$ & & basophil, базофил \\
\hline $\mathrm{CD}$ & - & cluster of differentiation, кластер дифференцирования \\
\hline $\mathrm{CF}$ & - & coagulation factors, факторы свертывания крови \\
\hline СМV, ЦМВ & - & cytomegalovirus, цитомегаловирус \\
\hline CR & - & complement receptor, рецептор к комплементу \\
\hline CRP, СРБ & - & C-reactive protein, C-реактивный белок \\
\hline DAMP & - & $\begin{array}{l}\text { danger-associated molecular pattern, связанный с опасностью } \\
\text { молекулярный паттерн }\end{array}$ \\
\hline DC, ДК & - & dendritic cells, дендритная клетка \\
\hline EBV, ВЭБ & - & Epstein-Barr virus, вирус Эпштейна-Барр \\
\hline ELISA, ИФА & - & $\begin{array}{l}\text { enzyme-linked immunosorbent assay, иммуноферментный } \\
\text { анализ }\end{array}$ \\
\hline Eo, & - & eosinophil, эозинофил \\
\hline EPO & - & erythropoietin, эритропоэтин \\
\hline Fab & - & $\begin{array}{l}\text { monovalent Ig antigen-binding fragment after papain digestion } \\
\text { моновалентный антигенсвязывающий фрагмент } \\
\text { иммуноглобулина }\end{array}$ \\
\hline FDC, ДКф & - & follicular dendritic cell, фолликулярная дендритная клетка \\
\hline G-/GM-/M-CSF & - & $\begin{array}{l}\text { granulocyte/granulocyte-macrophage/ macrophage colony- } \\
\text { stimulating factor, гранулоцитарный/ гранулоцитарно- } \\
\text { макрофагальный/ макрофагальный колонистимулирующий } \\
\text { фактор }\end{array}$ \\
\hline HBsAg & - & $\begin{array}{l}\text { hepatitis B surface antigen, поверхностный антиген гепатита } \\
\text { В }\end{array}$ \\
\hline HIV, ВИЧ & - & $\begin{array}{l}\text { human immunodeficiency virus, вирус иммунодефицита } \\
\text { человека }\end{array}$ \\
\hline HLA & - & $\begin{array}{l}\text { human leukocyte antigens, лейкоцитарные антигены } \\
\text { человека }\end{array}$ \\
\hline $\mathrm{HSC}$ & - & hematopoietic stem cell, гемопоэтические стволовые клетки \\
\hline HTLV & - & $\begin{array}{l}\text { human T-cell leukemia virus, вирус Т-клеточного лейкоза } \\
\text { человека }\end{array}$ \\
\hline ICAM & - & $\begin{array}{l}\text { intercellular adhesion molecule, молекула межклеточной } \\
\text { адгезии }\end{array}$ \\
\hline $\begin{array}{l}\text { IFN } \alpha / \text { IFN } \beta \text {, } \\
\text { IFN } \gamma\end{array}$ & - & $\alpha$-interferon (also IFN $\beta$, IFN $\gamma$ ), интерферон- $\alpha / \beta / \gamma$ \\
\hline $\mathrm{Ig} \mathrm{A} / \mathrm{D} / \mathrm{E} / \mathrm{M} / \mathrm{G}$ & & $\begin{array}{l}\text { immunoglobulin A D E M G, иммуноглобулины класса A D } \\
\text { E M G }\end{array}$ \\
\hline & - & interleukin-1 (also IL-2, IL-3, etc.), интерлейкины \\
\hline JAK & - & Janus kinases, Янус киназы \\
\hline
\end{tabular}




\begin{tabular}{|c|c|c|}
\hline KIR & - & killer immunoglobulin-like receptors, киллерные \\
\hline LPS & - & $\begin{array}{l}\text { иммуноглобулин-подобные рецепторы } \\
\text { lipopolysaccharide (endotoxin), липополисахарид } \\
\text { (эндотоксин) }\end{array}$ \\
\hline $\mathrm{mAb}$ & - & monoclonal antibody, моноклональное антитело \\
\hline MAC & - & membrane attack complex, мембранно-атакующий комплекс \\
\hline MAIT & & $\begin{array}{l}\text { mucosal associated invariant T cell, инвариантные Т-клетки, } \\
\text { связанные со слизистой оболочкой }\end{array}$ \\
\hline MALT & - & $\begin{array}{l}\text { mucosa-associated lymphoid tissue, лимфоидная ткань, } \\
\text { ассоциированная с слизистыми }\end{array}$ \\
\hline Mc & & mast cell, тучная клетка \\
\hline MHC & - & $\begin{array}{l}\text { major histocompatibility complex, главный комплекс } \\
\text { гистосовместимости }\end{array}$ \\
\hline MRSA & - & $\begin{array}{l}\text { methicillin-resistant Staphylococcus aureus, Метициллин- } \\
\text { резистентный золотистый стафилококк }\end{array}$ \\
\hline Mph, M & - & macrophage, макрофаг \\
\hline NADP & - & $\begin{array}{l}\text { nicotinamide adenine dinucleotide phosphate, никотинамид } \\
\text { адениндинуклеотид фосфат }\end{array}$ \\
\hline $\mathrm{Nph}$ & - & neutrophil, нейтрофил \\
\hline NK & - & $\begin{array}{l}\text { natural killer cell, натуральный киллер (естественная клетка- } \\
\text { убийца0 }\end{array}$ \\
\hline NKT cell & - & natural killer T cell, естественные киллерные Т лимфоциты \\
\hline NLR & - & NOD-Like Receptors, NOD-подобные рецепторы \\
\hline PAMP & - & $\begin{array}{l}\text { pathogen-associated molecular pattern, патоген- } \\
\text { ассоциированный молекулярный паттерн }\end{array}$ \\
\hline PG(E) & - & prostaglandin (E etc.), простагландин \\
\hline SARS, OРВИ & - & $\begin{array}{l}\text { severe acute respiratory syndrome, острое респираторное } \\
\text { заболевание }\end{array}$ \\
\hline $\operatorname{sIg}$ & - & secretor IgA, секреторный иммуноглобулин А \\
\hline SIRS & - & $\begin{array}{l}\text { system inflammatory responsitive syndrome, синдром } \\
\text { системного воспалительного ответа }\end{array}$ \\
\hline STAT & - & $\begin{array}{l}\text { signal transducer and activator of transcription, } \\
\text { преобразователь сигналов и активатор транскрипции }\end{array}$ \\
\hline TB & - & tubercle bacillus, возбудитель туберкулеза \\
\hline T-cell & - & thymus-derived lymphocyte, Т-лимфоцит \\
\hline $\mathrm{T} \gamma \delta$-cells & & gamma delta $\mathrm{T}$ cells, гамма-дельта T-клетки \\
\hline Tc & - & cytotoxic T-cell, цитотоксические Т-клетки \\
\hline $\operatorname{Th}(1 / 2 / 3 / 9 / 17)$ & - & $\begin{array}{l}\text { T-helper cell (subset 1, 2, 3, } 9 \text { or 17), Т-хелпер (1/2/3/9/17) } \\
\text { типа }\end{array}$ \\
\hline Treg & - & Regulatory T cells, T-регуляторные лимфоциты \\
\hline THF & - & thymic humoral factor, гуморальный фактор тимуса \\
\hline TIL & - & $\begin{array}{l}\text { tumor infiltrating lymphocytes, лимфоциты, } \\
\text { инфильтрирующие опухоль }\end{array}$ \\
\hline TLR & - & Toll-Like Receptors, Toll-подобные рецепторы \\
\hline TNF & - & tumor necrosis factor, фактор некроза опухоли \\
\hline TPO & - & thrombopoietin, тромбопоэтин \\
\hline VCAM & - & $\begin{array}{l}\text { vascular cell adhesion molecule, молекула адгезии клеток } \\
\text { сосудов }\end{array}$ \\
\hline
\end{tabular}




\section{Предисловие}

Предисловие - это то, что предварительно «сказывается» перед основным текстом книги. А книга называется: "КЛИНИЧЕСКАЯ ИММУНОЛОГИЯ. ПРАКТИЧЕСКОЕ ПОСОБИЕ ДЛЯ ВРАЧЕЙ”. Ну, во-первых, что такое клиническая иммунология? А что, есть не клиническая иммунология? Логия - это переводится с греческого как наука, учение. Так что, две науки: клиническая и не клиническая иммунология? Такое может быть? Думаю., вернее, уверен, что нет. Есть одна наука - иммунология! А слово клиническая - это чтобы подчеркнуть направленность науки иммунологии, её фундаментальных результатов в решение проблем, связанных со здоровьем человека, с процессами участия иммунной системы в механизмах беременности, роста организма от рождения и до старения и, наконец, с ролью иммунной системы в возникновении того или иного заболевания, в его течении, выраженности и исходе. Стоп! Надо четко себе представлять, что все то, что изучается в клинике касательно иммунной системы - это фундаментальные данные о роли иммунной системы в патогенезе данного конкретного заболевания.

Очень важно, чтобы каждый, который будет читать, изучать, учиться, образовываться иммунологически с помощь данного учебника-книги-пособия, был убежден в первостепенной важности иммунной системы в патогенезе основных заболеваний современного человека, включая инфекции, аутоиммунные и аллергические заболевания, атеросклероз и онкологические заболевания. Тогда будет совершенно другое отношение к написанному в данном пособии. Тогда, после прочтения пособия, по-другому будут оцениваться симптомы заболевания, данные лабораторных исследований и, естественно, методы терапии, где уже сейчас методы иммунотерапии всех без исключения названных выше заболеваний постепенно, шаг за шагом начинают занимать ведущее положение. И это очень важно понять врачу любой специальности, ибо он должен сделать все возможное и невозможное, чтобы помочь больному справиться с недугом. И в этом ему обязательно поможет знакомство с фундаментальной иммунологией в клинической ее приложении.

Понятно, что это пособие не всеобъемлющее. Но без него трудно будет врачу. Оно (пособие) поможет начинать понимать, что без знаний об иммунной системе врач - это еще не сегодняшний врач. Вчерашний - да, но не сегодняшний.

Читайте! Изучайте! Задавайте вопросы! Отвечайте на них! Не стойте на месте с нагруженном на вас институтским багажом. Поверьте, там много лишнего, а многого и очень мало, или вообще нет. Копите сами свой новый багаж и благодарность больных вам будет преогромнейшая!

Научный руководитель

НИИ фундаментальной и клинической иммунологии

Почетный вице-президент

Российского научного общества иммунологов

Академик РАН

В.А. Козлов 


\section{Благодарности}

Авторы выражают благодарность всем лицам, оказавшим помощь в подготовке данной книги, прежде всего рецензентам д.м.н. профессору Э.В. Каспарову, д.м.н., профессору Е.П. Тихоновой, д.м.н., профессору В.В. Цуканову чьи практические, критические и редакционные замечания были очень полезны.

Особая благодарность д.м.н., профессору Д.В. Черданцеву, д.м.н., профессору П.А. Шестерне, д.м.н., профессору Д.Э. Здзидовецкому, д.м.н., профессору О.В. Первовой, д.м.н., профессору С.А. Догадину, к.м.н. Е.Н. Анисимовой, к.м.н. А.А. Модестову, к.м.н. Р.Н. Борисову, к.м.н. Ю.С. Калининой, к.б.н. Е.В. Слепову, к.м.н. Ю.Л. Тонких, врачу-ревматологу А.А. Мастеровой, врачам-инфекционистам С.В. Левицкому и А.А. Упировой, врачу-онкологу О.Г. Тоначевой, научным сотрудникам В.Д. Беленюку, И.И. Гвоздеву, А.В. Мошеву, совместные работы с которыми послужили основанием для написания этой книги.

На создание данной книги большое влияние оказали наши друзья-коллеги академик А.А. Тотолян, член-корреспондент А.С. Симбирцев, член-корреспондент В.Т. Манчук, д.м.н., профессор С.В. Смирнова, д.м.н., профессор, Н.М. Калинина, д.м.н., профессор А.В. Зурочка, д.м.н., профессор Т.Г. Федоскова, д.м.н., профессор Е.И. Прахин, д.м.н. И.А. Балдуева, д.м.н. И.А. Корсунский, д.б.н. С.В. Хайдуков, д.б.н. Т.Н. Заботина, д.б.н. И.А. Пашнина, к.м.н. А.В. Новик, к.б.н. Е.Г. Костоломова, к.б.н. Т.Л. Нехаева, к.б.н. К.Б. Остроумов, к.б.н. А.Е. Кондаков с которыми в течении длительного времени мы обсуждали многие аспекты данной книги. Мы благодарны им за это.

За административное сопровождения данной книги благодарим сотрудников НИИ медицинских проблем Севера к.б.н. Е.П. Бронникову, к.м.н. А.Н. Латышеву, к.б.н. А.Ю. Холомееву.

Мы благодарим компании: «Бекмен Культер», «БиоХимМак», «Аламед», «Си Эс Эл Беринг Биотэрапис», «Бристол-Майерс Сквиб», «Биотех», «ГЕНЕРИУМ», «Гилеад Сайенсиз Раша», «Диаэм», «ЛабТЭК», «Люминекс», «Мерк», «Пептек», «Петровакс Фарм», «Полисорб», «Хеликон», их руководителей и сотрудников за поддержку в издании данной книги.

Приносим благодарности врачам А.О. Бабушкину, С.А. Борисову, А.А. Радкевичу, за предоставленный фотоматериал, И.С. Маслову за изготовление рисунков.

Должны сказать большое спасибо директору ООО «Поликор» А.Н. Щелканову и всему коллективу участвующему в создании настоящей книге.

Можно с уверенностью сказать, что без этой искренней помощи всех этих замечательных людей мы не смогли бы никогда выпустить в свет данную книгуучебник, которая крайне необходима врачу-клиницисту каждому из многочисленных врачебных специальностей. Мы очень уверены и хотели бы, чтобы наша уверенность передалась врачам, что без иммунологических знаний у современной медицины нет перспектив для успешного развития. А это в первую очередь аукнется здоровьем Человека.

Еще много и много раз спасибо всем тем, кто своим прекрасным отношением к иммунологии способствовал изданию этого печатного труда. 


\section{ИММУННАЯ СИСТЕМА}

\section{Глава 1. Компоненты иммунной системы}

Иммунная система - функционально взаимосвязанный комплекс органов, тканей, клеток, специфических белков и регуляторных компонентов, способная распознавать различные структуры как чужеродные для себя, так и измененные свои с дальнейшей их нейтрализацией и уничтожением с формированием невосприимчивости организма при их повторной встрече. Помимо этого, иммунная система контролирует пролиферацию клеток, процессы регенерации, осуществляет элиминацию и детоксикацию опасных для организма и разрушенных макро- и микромолекул и обеспечивает взаимодействие с нормальной микрофлорой [38, 93, 116, 117, 124, 127, 129].

Компоненты системы иммунитета входят во все ткани организма, поэтому, с одной стороны изменения в системе иммунитета будут сказываться на функционировании одного или нескольких органов, а с другой - та или иная патология органов и систем будет влиять и на иммунитет. Вот почему иммунная система практически при любой патологии - неотъемлемый участник патологических процессов (рис. 1).
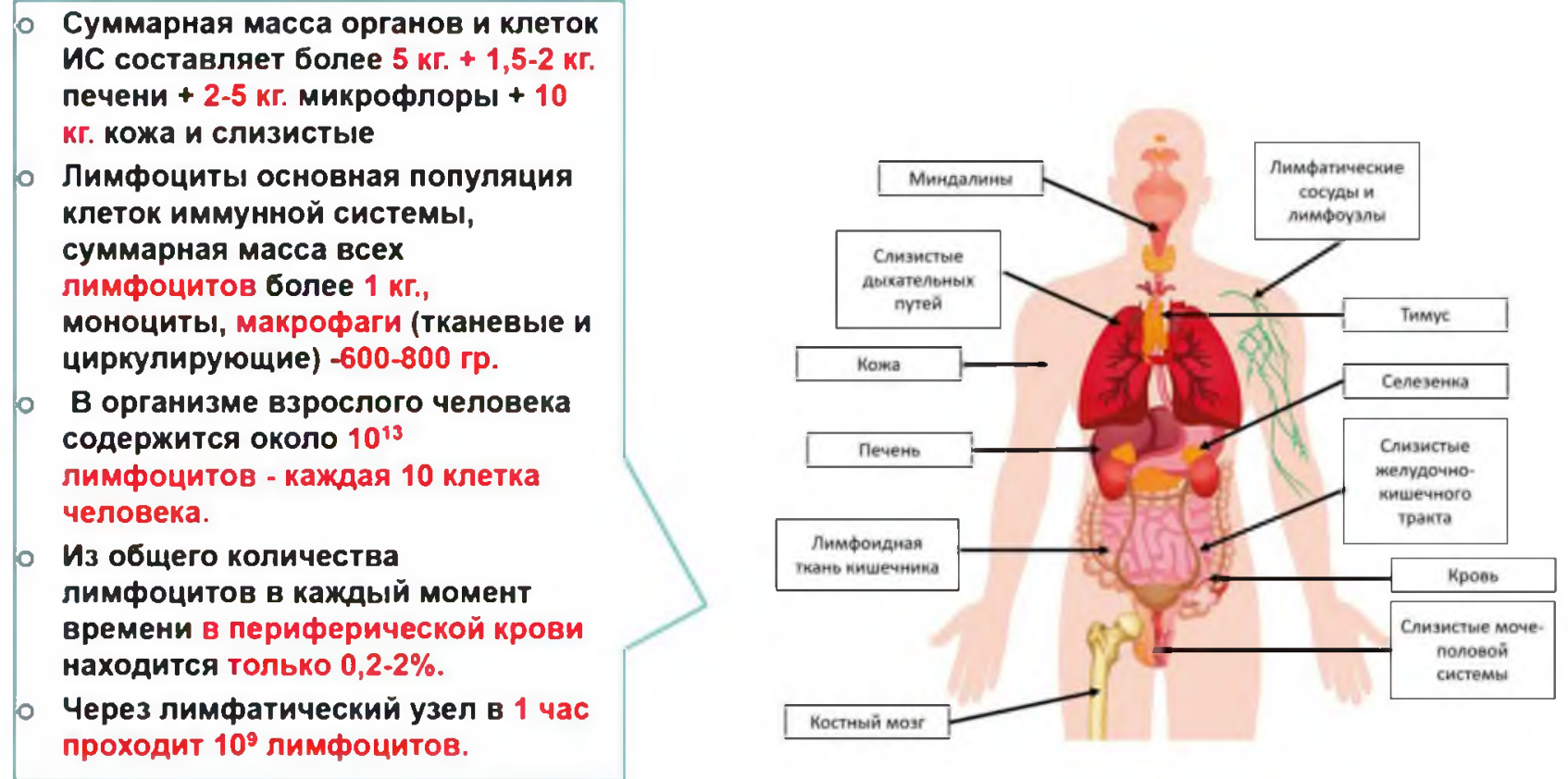

\section{Рис. 1. Иммунная система человека.}

С функциональной точки зрения можно выделить три уровня защиты: барьерный или мукозальный, врожденный или неспецифический, адаптивный (приобретенный) или специфический иммунитет. Помимо этого, большое значение в защитных функциях принадлежит нормальной микрофлоре человека (рис. 2). 


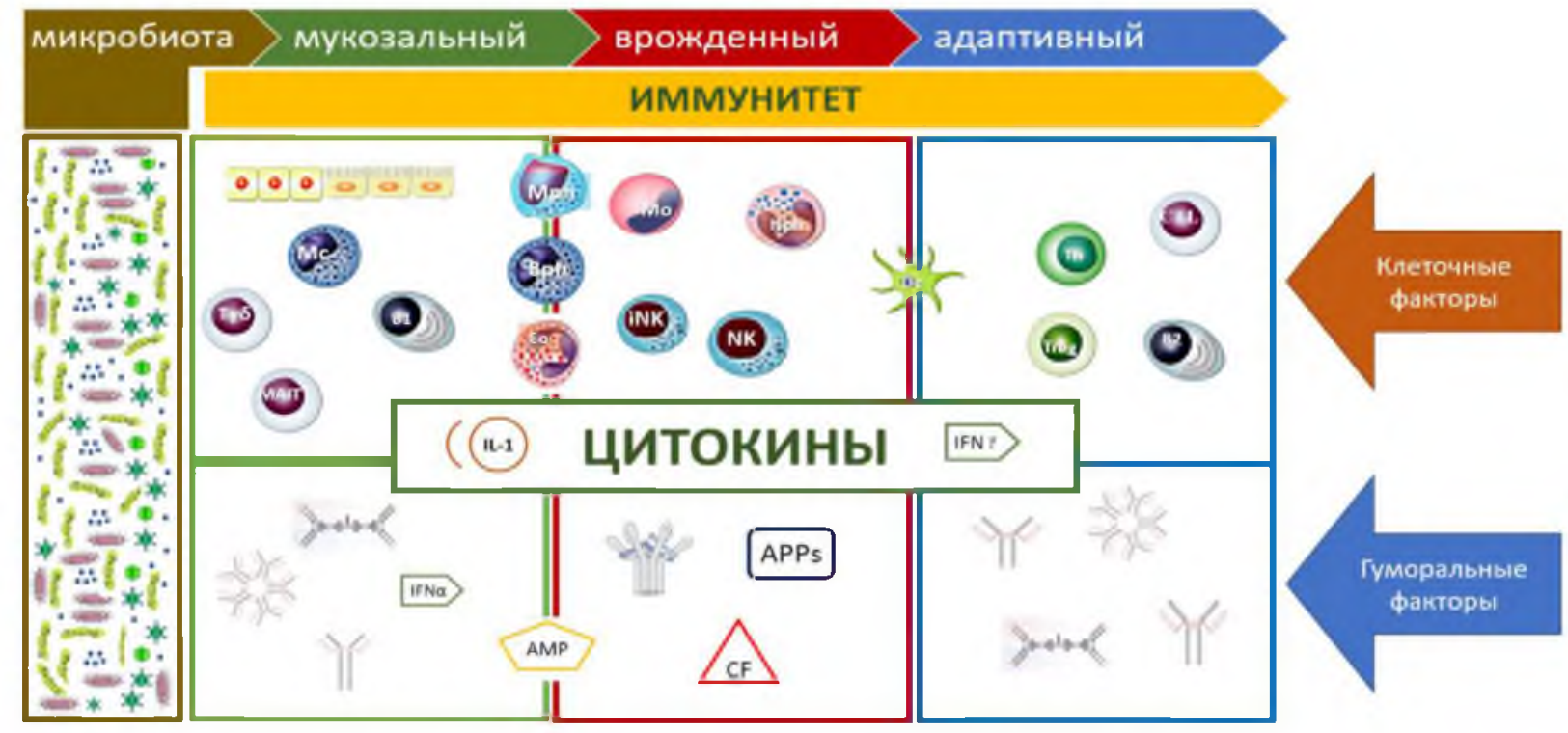

Рис. 2. Функциональная организация иммунной системы человека.

Клетки иммунной системы являются ее основной функциональной единицей и включают в себя различные популяции (табл. 1) различного происхождения (рис. 3) [38,90,95].

Таблица 1

\section{Клетки иммунной системы}

\begin{tabular}{|c|c|c|c|}
\hline $\begin{array}{c}\text { Клетки } \\
\text { иммунитета }\end{array}$ & Эффекторные клетки & $\begin{array}{c}\text { Антигенпрезентующие } \\
\text { клетки }\end{array}$ & $\begin{array}{c}\text { Регуляторные } \\
\text { клетки }\end{array}$ \\
\hline $\begin{array}{l}\text { Клетки } \\
\text { барьерных } \\
\text { органов }\end{array}$ & $\begin{array}{l}\text { Макрофаги (в т.ч. } \\
\text { альвеолярные, клетки Купфера } \\
\text { и Лангерганса, микроглия и } \\
\text { т.д.), М-клетки, клетки Панета, } \\
\text { тучные клетки, базофилы, } \\
\text { эозинофилы, резидентные } \\
\text { лимфоидные клетки, В1- } \\
\text { лимфоциты, тромбоциты }\end{array}$ & \multirow{5}{*}{$\begin{array}{l}\text { Макрофаги } \\
\text { Дендритные клетки. } \\
\text { В-клетки, } \\
\text { Эпителиальные клетки, } \\
\text { Меланоциты } \\
\text { Кератиноциты } \\
\text { Эндотелиоциты } \\
\text { Эозинофилы }\end{array}$} & $\begin{array}{l}\text { Макрофаги } \\
\text { Th1, Th2, Th17 } \\
\text { T-регуляторные } \\
\text { Базофилы }\end{array}$ \\
\hline \multirow[t]{2}{*}{$\begin{array}{l}\text { Клетки } \\
\text { врожденного } \\
\text { иммунитета }\end{array}$} & $\begin{array}{l}\text { Нейтрофилы } \\
\text { Эозинофилы } \\
\text { Базофилы } \\
\text { Макрофаги } \\
\text { NК-лимфоциты }\end{array}$ & & \multirow[t]{2}{*}{$\begin{array}{l}\text { Миелоидные } \\
\text { супрессорные } \\
\text { клетки }\end{array}$} \\
\hline & Внутриэпитеальные & & \\
\hline \multirow{2}{*}{$\begin{array}{l}\text { Клетки } \\
\text { адаптивного } \\
\text { иммунитета }\end{array}$} & лимфоидные клетки & & \multirow{2}{*}{$\begin{array}{l}\text { В-лимфоциты } \\
\text { Th1, Th2, Th17 } \\
\text { Т-регуляторные }\end{array}$} \\
\hline & $\begin{array}{l}\text { В-лимфоциты } \\
\text { Цитотоксические Т-лимфоциты }\end{array}$ & & \\
\hline
\end{tabular}

Клетки иммунной системы вырабатывают большое количество биологически активных молекул, которые выполняют эффекторные и регуляторные функции (табл. 2). Все эти вещества играющие важную роль в процессе распознавания и элиминации из организма человека чужеродных веществ, тесно взаимосвязаны между собой и в то же время могут функционировать автономно. Поэтому они оказывают на организм очень разностороннее и, порой, неоднозначное действие [30, 38, 113, 115, 124, 129]. 


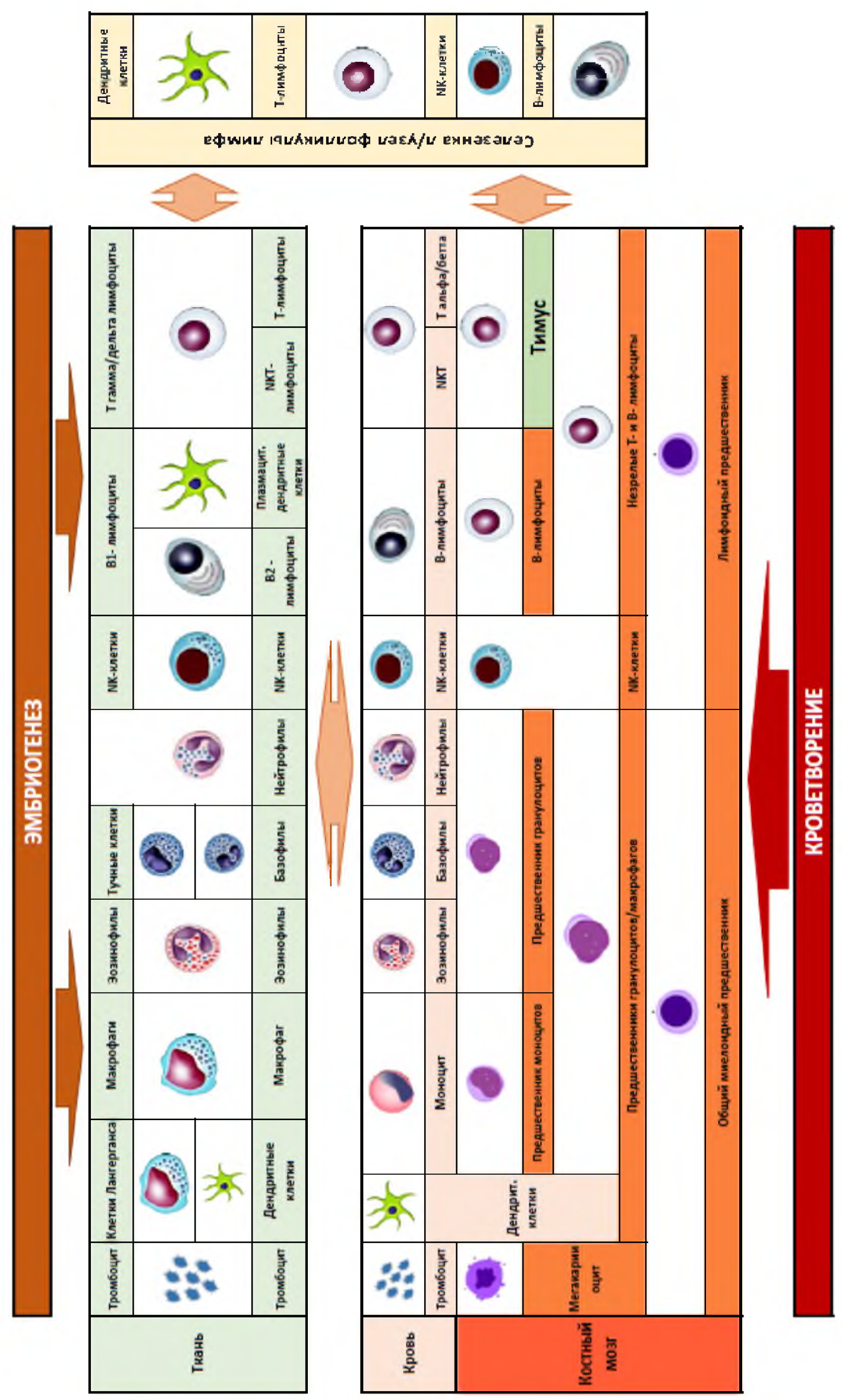

है' 


\section{Молекулы иммунной системы}

\begin{tabular}{|l|l|l|l|l|}
\hline \multicolumn{2}{|c|}{ Эффекторные } & \multicolumn{3}{|c|}{ Регуляторные } \\
\hline \multicolumn{1}{|c|}{ Специфические } & Неспецифические & \multicolumn{1}{|c|}{ Цитокины } & \multicolumn{1}{|c|}{ Медиаторы } & Гормоны \\
\hline Антитела & $\alpha$ и $\beta-$ & Интерлейкины & Гистамин & Тимозин \\
(иммуноглобулины & интерфероны, & ү-интерферон & Серотонин & Тимопоэтин \\
А М G E D) & комплемент, СРБ, & ФНО, КСФ, & Простагландины & \\
& ПКТ и др. белки & хемокины, & Лейкотриены & \\
& острой фазы, & факторы роста & & \\
& факторы & & & \\
& свертывания & & & \\
& крови & & & \\
\hline
\end{tabular}

Основными эффекторными продуктами адаптивного иммунитета являются иммуноглобулины (антитела). Это белки, продуцируемые плазматическими клетками (конечный этап дифференцировки В-лимфоцитов), относящиеся к $\gamma$-глобулиновой фракции белков крови (рис. 4).

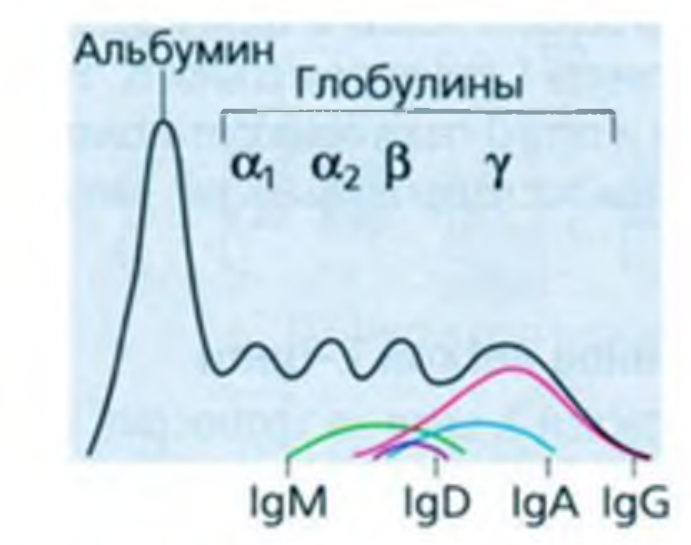

$\lg \mathrm{M}-0,5-2,5$ r/л

Период

полураспада

-5 дней
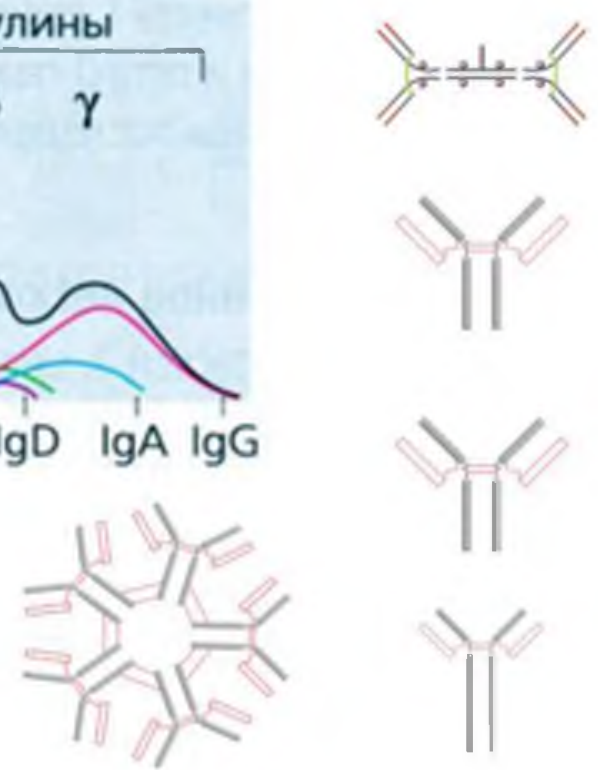

Рис. 4. Иммуноглобулины человека.

Гуморальная регуляция межклеточных взаимодействий в иммунной системе осуществляется цитокинами (более 200). Они представляют собой белковые или полипептидные продукты в основном клеток иммунной системы и других клеток (эндотелиальные и эпителиальные клетки, адипоциты, миоциты, фибробласты и пр.). С их помощью их осуществляется межклеточная коммуникация: регулируется функция клеток, пролиферация и дифференцировка, хемотаксис, активация специфических мембранных рецепторов, секреция других цитокинов и иммуноглобулинов. Традиционно цитокины подразделяют на несколько групп: интерфероны, интерлейкины, семейство фактора некроза опухолей, хемокины, ростовые и факторы дифференцировки (табл. 3) [30, 35, 38, 115, 117, 130]. 
Таблица 3.

\section{Цитокины и их биологическое действие}

\begin{tabular}{|l|l|l|}
\hline $\begin{array}{c}\text { Биологическое } \\
\text { действие }\end{array}$ & \multicolumn{1}{|c|}{ Стимулируют } & \multicolumn{1}{|c|}{ Угнетают } \\
\hline Гемопоэтическое & ГМ-КСФ, Г-КСФ, ИЛ-11 & ИФН- $\alpha$ \\
\hline Воспаление & $\begin{array}{l}\text { ИЛ-1, ИЛ-5, ИЛ-6, ИЛ-8, ИЛ-17, ИФН- }, \\
\text { ИФН- } \alpha, \text { ФНО }\end{array}$ & ИЛ-10 \\
\hline Клеточный ответ & ИЛ-1, ИЛ-2, ИЛ-12, ИФН-, ФНО & ИЛ-4, ИЛ-10 \\
\hline Гуморальный ответ & $\begin{array}{l}\text { ИЛ-4, ИЛ-5, ИЛ-6, ИЛ-10, ИЛ-13, ИЛ-14, } \\
\text { ИЛ-17 }\end{array}$ & ИФН- $\gamma$ \\
\hline
\end{tabular}

Клетки и молекулы, участвующие в формировании иммунного ответа, наиболее эффективно действуют в составе специальных тканей и органов, объединенных в лимфоидную систему. Эта система представляет собой совокупность органов и рассеянных в организме других структурных лимфоидных образований, которые имеют между собой слабые анатомические связи, но объединены в единую систему кровеносными и лимфатическими сосудами и функционируют согласованно за счет иммунной регуляции (рис. 1).

Выделяют первичные (центральные) и вторичные (периферические) лимфоидные органы. Отдельной структурой является мукозо-ассоциированная лимфоидная ткань.

У человека к первичным лимфоидным органам относят тимус (вилочковая железа) и красный костный мозг. В этих органах происходит дифференцировка лимфоцитов, закладываются основные рецепторы, определяющие распознавание всего разнообразия антигенных структур организма. Иммунологические процессы осушествляются в основном в лимфоидной ткани вторичных лимфоидных органов - в лимфоузлах, селезенке, миндалинах, скоплениях лимфоидной ткани под слизистой оболочкой кишечника, гортани, бронхов, мочеполовых органов, а также в почках и коже. Структурированная лимфоидная ткань представлена в виде миндалин, аппендикса, групповых лимфатических фолликул (Пейеровы бляшки), а также организована в виде некапсулированных фолликулов. В этой лимфоидной ткани осуществляются реакции врожденного и адаптивного иммунитета. В Пейеровых бляшках (аналог сумки Фабрициуса птиц), дифференцируются Т- и В-лимфоциты. [38, 84, 115, 124

В каждой клетке протекают сотни химических реакций, совокупность которых представляет обмен веществ (метаболизм). Однако в организме обмен веществ протекает не хаотично; он интегрирован и тонко настроен $[20,38,62,70,71]$

Основные метаболические пути являются общими для большинства клеток и организмов и включают в себя три взаимосвязанных между собой процесса (рис. 5):

- распад органических веществ (углеводы, жиры, белки) с аккумуляцией энергии энергетическое звено;

- синтез мономеров и макромолекул (с затратой энергии), в том числе гормонов, ферментов, кофакторов и пр. - пластическое звено;

- процесс обезвреживания и выведения токсичных продуктов полученных в результате обмена веществ (продуктов метаболизма), в том числе свободных радикалов - звено утилизации. 


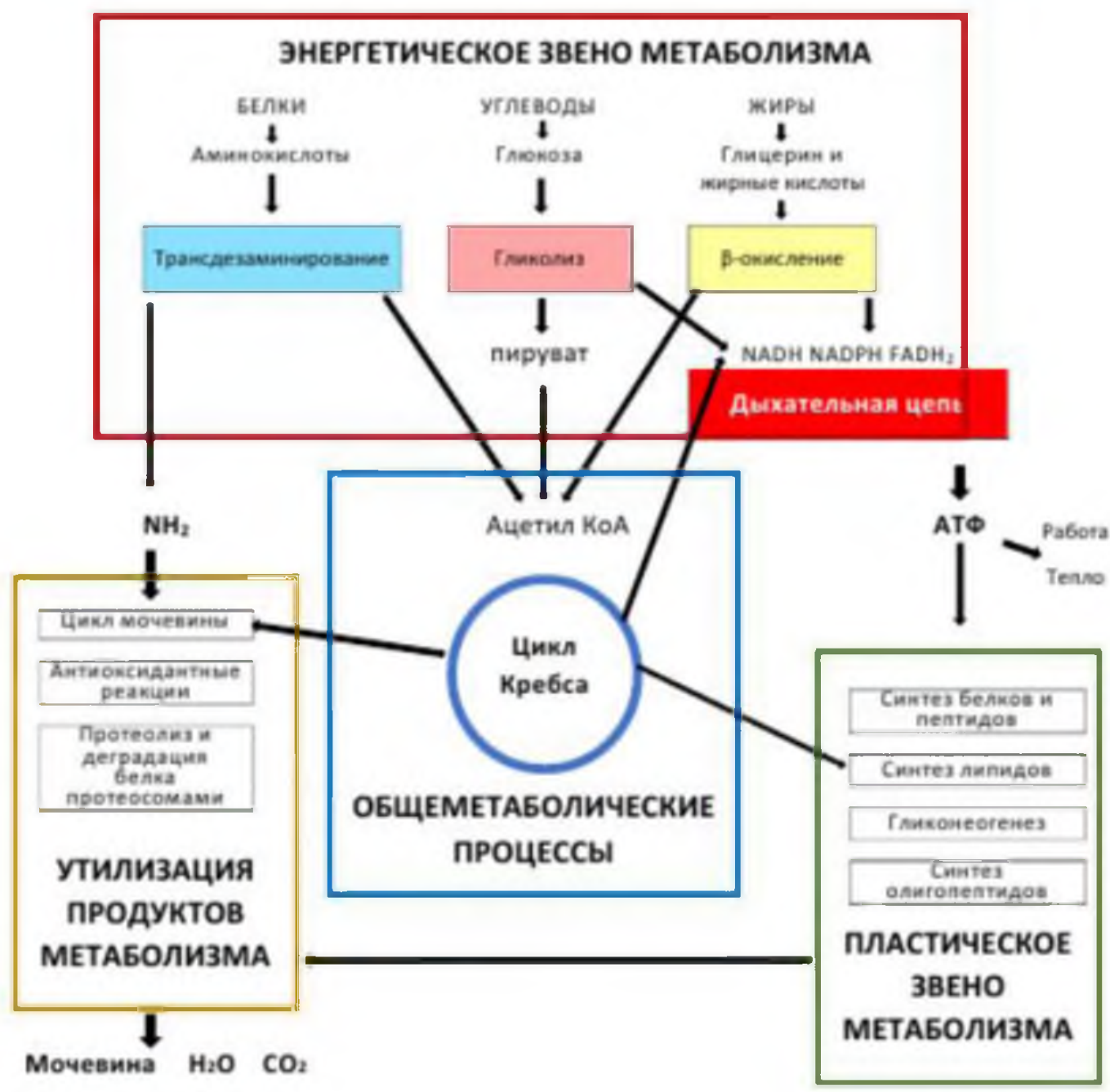

Рис. 5. Основные метаболические пути клеток иммунной системы.

Из многочисленных метаболитов наиболее важны пируват и ацетил-КоА. Эти соединения служат связующими элементами между метаболизмом белков, углеводов и липидов. К метаболическому пулу принадлежат также промежуточные метаболиты лимонной цикла. Этот циклический путь (цикл трикарбоновых кислот, цикл Кребса) играет как катаболическую, так и анаболическую роль, т.е. является амфиболическим. К конечным продуктам разрушения органических веществ у животных относятся диоксид углерода $\left(\mathrm{CO}_{2}\right)$, вода $\left(\mathrm{H}_{2} \mathrm{O}\right)$ и аммиак $\left(\mathrm{NH}_{3}\right)$. Аммиак превращается в мочевину и в такой форме выводится из организма.

Энергетическое звено метаболизма. Полученные из питательных веществ (белки, углеводы, нуклеиновые кислоты и липиды) на I этапе катаболизируются до простых метаболитов: глюкозы, отдельных аминокислот, глицерина, жирных кислот, которые получаются в пищеварительном тракте. Высвобождение энергии осуществляется в результате окислительно-восстановительного распада. В дальнейшем, полисахариды расщепляются до моносахаридов (обычно гексоз). Жиры распадаются на глицерин и высшие жирные кислоты, а белки - на составляющие их свободные аминокислоты. Эти процессы в основном являются гидролитическими, и, освобождающаяся в небольшом количестве, энергия используется в качестве тепла. 
На II этапе мономерные молекулы (гексозы, глицерин, жирные кислоты и аминокислоты) подвергаются дальнейшему распаду, в процессе которого образуются богатые энергией фосфатные соединения и ацетил-КоА.

Этот процесс сопровождается образованием ограниченного числа богатых энергией фосфатных связей путем субстратного фосфорилирования. Высшие жирные кислоты на этом этапе распадаются до ацетил-КоА, в то время как глицерин окисляется по гликолитическому пути до пировиноградной кислоты и далее до ацетил-КоА. Использования аминокислот, как источника энергии (при дефиците углеводов), осуществляется по-разному. Одни аминокислоты непосредственно превращаются в метаболиты цикла Кребса (глутамат), другие опосредованно через глутамат (пролин, гистидин, аргинин), третьи - в пируват и далее в ацетилКоА (аланин, серин, глицин, цистеин). Ряд аминокислот, в частности лейцин, изолейцин, расщепляется до ацетил-КоА, а из фенилаланина и тирозина, помимо ацетил-КоА, образуется оксалоацетат через фумаровую кислоту. Таким образом, II этап - это этап образования ацетилКоА, являющегося в клетках по существу единым (общим) промежуточным продуктом катаболизма основных пищевых веществ. На III этапе ацетил-КоА подвергаются окислению («сгоранию») в цикле трикарбоновых кислот. Окисление сопровождается образованием восстановленных форм НАДН и ФАДН 2 . По существу, первые три этапа можно определить, как процесс катаболического превращения крупных молекул.

Ha IV этапе осуществляется перенос электронов от восстановленных нуклеотидов на кислород (через дыхательную цепь). Он сопровождается образованием конечного продукта молекулы воды. Этот транспорт электронов сопряжен с синтезом АТФ в процессе окислительного фосфорилирования.

Окислительное фосфорилирование самый эффективный способ синтеза АТФ, в результате которого компоненты дыхательной цепи катализируют перенос электронов от НАДН (или восстановленного убихинона) на молекулярный кислород. При этом образуется энергия для синтеза АТФ. Это постоянно действующий и наиболее эффективный путь энергообразования в клетках всех типов, так как в нем наряду с глюкозой, могут быть использованы не только жирные кислоты, но и кетоновые тела.

При снижении парциального давления кислорода до 90 мм.рт.ст. скорость аэробного гликолиза и окислительного фосфорилирования существенно снижаются. Клиническим эквивалентом этого снижения являются слабость, разбитость, плохое самочувствие в целом.

Помимо основного источника энергии, описанного выше, существуют альтернативные источники получения энергии:

- Анаэробный гликолиз - при отсутствии или недостатке в клетке кислорода пировиноградная кислота подвергается восстановлению до молочной кислоты. Под действием лактатдегидрогеназы молочная кислота окисляется снова в пируват. Кроме того, током крови молочная кислота переносится в печень, где превращается в глюкозу, которая через кровь разносится по всему организму (цикл Кори). Анаэробный гликолиз может покрывать кратковременные энергетические нагрузки, даже субмаксимальные. Однако при заболеваниях анаэробный гликолиз не обеспечивает в полной мере потребности клеток в энергии, при этом накапливается молочная кислота, и в результате этого возникает недостаточность функциональных систем, в том числе, не связанных напрямую с пораженной системой или органом.

- Суб̆стратное фосфорилирование - образование АТФ в ходе метаболического цикла (переход сукцинат-КоА в сукцинат в цикле Кребса и образование пирувата при гликолизе). Эти реакции способны на некоторое время поддержать жизнедеятельность организма в отсутствии окислительного фосфорилирования.

- Пентозофосфатный путь окисления глюкозы (или «пентозный шунт») необходим для ресинтеза жирных кислот и предшественников нуклеотидов. При этом образуется НАДФН и продукты способные включаться в гликолиз и далее в цикл трикарбоновых кислот. 
- $\quad$ Гидролиз креатинфосфата - быстрый и кратковременный путь получения энергии за счет гидролиза креатинфосфата.

- $\quad$ Образование инозинмонофосфата в результате конверсии АДФ в АТФ и АМФ

- $\quad \beta$-Окисление жирных кислот, которое происходит в митохондриях, при низкой концентрации пирувата и высоком содержание НАД ${ }^{+}$

Таким образом, основным источником энергии является цикл Кребса сопряженный с окислительным фосфорилированием. Главным и быстро мобилизуемым исходным субстратом служит глюкоза. Ее метаболизм покрывает основной обмен и обеспечивает жизнедеятельность организма. Главным регуляторным механизмом цикла трикарбоновых кислот и окислительного фосфорилирования является кругооборот окислительно-восстановительных эквивалентов, которые определяются отношением НАДН/НАД ${ }^{+}$.

Пластическое звено метаболизма. Синтез мономеров и макромолекул, в том числе гормонов, ферментов, кофакторов является основным фактором жизнедеятельности клетки, без которого невозможно представить нормальную жизнедеятельность организма.

Наиболее сложным и важным является процесс синтеза белка. От этого зависит приспособление к физиологическим потребностям при изменении внутренних и внешних условий. То есть синтез белка регулируется внешними и внутренними факторами и условиями, которые диктуют клетке, какой набор белка и его количество необходимо синтезировать для выполнения физиологических функций, которое реализуется за счет простых химических реакций - метилирование ДНК и деацетилирование гистонов. Эти механизмы служат для подавления экспрессии генов.

Биосинтез белка - сложнейший многостадийный процесс создания полипептидной цепи в клетках живых организмов. Упрощенно биосинтез белка можно разделить на стадии транскрипции и трансляции.

Транскрипция - процесс считывания генетического кода с молекулы ДНК. Трансляция заключается в синтезе полипептидной цепи в соответствии с информацией, закодированной в мРНК. В дальнейшем при помощи вспомогательных белков шаперонов складывается биологически активная конформация пептидной цепи (свертывание). При посттрансляционном созревании у многих белков удаляются части пептидной цепи или присоединяются дополнительные группы, например олигосахариды или липиды. Затем готовая белковая молекула транспортируется в нужное место клетки.

Значительно проще синтезируются углеводы и липиды. Это не что иное, как цикл простых биохимических реакций, катализируемых ферментами. Исходными субстратами служат вещества, поступившие в клетку или полученные при метаболизме.

В условиях дефицита углеводов необходимая концентрация глюкозы в крови может поддерживаться за счет ее синтеза (глюконеогенез). Синтез глюкозы протекает, как и при гликолизе, но в обратном направлении. Исходными соединениями для глюконеогенеза являются некоторые аминокислоты, лактат, а также глицерин, то есть те вещества, которые способны превратиться в пируват или любой другой метаболит глюконеогенеза (аспартат в оксалоацетат, глицерин в триозофосфат и т.д.). При различных физиологических состояниях для глюконеогенеза используются различные первичные вещества. В условиях голодания используется тканевой белок, который распадается до аминокислот. При интенсивной физической работе используется лактат, образующийся в эритроцитах и мышечной ткани при недостатке кислорода. При распаде жиров образуется глицерин.

Синтез высших жирных кислот может протекать в клетках различных органов и тканей, однако основная масса соединений этого класса синтезируется в печени и в жировой ткани, а важнейшим субстратом, продукты метаболизма которого используются для синтеза липидов, является глюкоза.

Биосинтез липидов основан на синтезе жирных кислот из ацетил-КоА с дальнейшим превращением их в жиры, воск, фосфолипиды и некоторые другие более специализированные биологически активные вещества. 
Необходимо отметить, что ряд полиненасыщенных жирных кислот не синтезируется в организме, хотя они необходимы для нормального функционирования. Поэтому линолевая и линоленовая кислоты являются незаменимыми (эссенциальными) и должны поступать в достаточном количестве с пищей.

Арахидоновая кислота может синтезироваться в клетках животных из линоленовых кислот, однако в условиях недостаточного поступления линоленовой кислоты с пищей арахидоновая кислота также становится незаменимой жирной кислотой. Эндогенный синтез других липидов осуществляется в цитозоле клетки. Все необходимые организму глицерофосфолипиды могут синтезироваться в его клетках, причем в клетках могут функционировать несколько альтернативных метаболических путей биосинтеза глицерофосфолипидов.

Все эти реакции требуют энергетических затрат. Энергия для синтеза доставляется реакцией расщепления АТФ. Поэтому каждое звено биосинтеза всегда сопряжено с распадом AT $\Phi$.

Утилизация продуктов метаболизма. В процессе жизнедеятельности человека, как описано выше, ежедневно разрушается и образуется большое количество органических вешеств, прежде всего белков. Это постоянное разрушение и синтез позволяют клеткам быстро приводить в соответствие метаболические потребности с внешними воздействиями. Внутриклеточное разрушение белков происходит частично в лизосомах, частично в протеасомах (в них разрушаются неправильно свернутые или денатурированные белки).

При нарушении процессов деградации накапливаются лизосомы с разрушаемыми негидролизовавшимися фрагментами органелл и макромолекул (остаточные тела), что может привести к необратимому повреждению клеток и как результат - к нарушению функций соответствующих органов.

Другая, хорошо регулируемая система деградации белков, локализована в цитоплазме. Она состоит из больших белковых комплексов, протеасом в виде бочковидной структуры. Белки, которым предстоит разрушение в протеасоме (например, содержащие ошибки транскрипции или состарившиеся молекулы), метятся путем ковалентного связывания с небольшим белком убиквитином. Меченые убиквитином (убиквитинированные) молекулы попадают в протеосомы, где происходит их деградация, при этом убиквитин не разрушается и после активации используется вновь.

В ходе деградации белков, если полученные аминокислоты повторно не используются для биосинтеза, они расщепляются до конечного продукта - аммиака. Аммиак является конечным продуктом метаболизма белков, аминокислот и других азотистых соединений, то есть конечным продуктом распада белка. Он высокотоксичен для организма человека, являясь клеточным ядом. Инактивация аммиака осуществляется, прежде всего, за счет образования мочевины, которое происходит преимущественно в печени. Накапливающийся в тканях аммиак, соединяясь с глутаматом (в основном) и с аспарагиновой кислотой, образуют нетоксичные комплексы для транспортировки - глутамин и аланин.

В печени, за счет ферментов - трансаминаз, происходит высвобождение аммиака из глутамина и аланина. В дальнейшем аммиак синтезируется в нетоксичную мочевину. Мочевина образуется в результате циклической последовательности реакций с участием гидрокарбоната, $\mathrm{N}$-ацетилглутамата, орнитина, аспартата и фумарата (орнитиновый цикл). Биосинтез мочевины требует больших затрат энергии. При необходимости небольшая молекула мочевины может проходить через мембраны. По этой причине, а также из-за ее хорошей растворимости в воде, мочевина легко переносится кровью и выводится с мочой.

Часть аммиака выводится непосредственно почками, где он высвобождается из глутамина за счет гидролиза амидной группы и диффундирует через клеточные мембраны в просвет канальца (в мочу).

Другими повреждающими факторами для клетки, которые возникают в процессе нормального обмена веществ, являются свободные радикалы. Свободные радикалы жизненно важные и необходимые для клетки соединения. Их образование осуществляется при участии 
определенных ферментных систем. Многие из них несут очень важные физиологические функции. Так, семихиноны, коэнзим Q и флавопротеины, используются в качестве окислительно-восстановительных систем, служащих посредниками в передаче электрона.

Гидроксидрадикал необходим для синтеза ряда биологических регуляторов (например, простагландинов). Радикалы оксида азота (NO) участвуют в регуляции сокращения стенок кровеносных сосудов, а пероксинитрит стимулирует запрограммированную клеточную гибель (апопто3). Свободные радикалы участвуют в формировании клеточного иммунитета.

Однако при изменении условий функционирования дыхательной цепи, при воздействиях ионизирующего излучения, ультрафиолетового облучения, под воздействием попавших в организм посторонних соединений, ксенобиотиков, при взаимодействии кислорода с ионами металлов и т.д. в организме образуются весьма активные молекулярные соединения: перекись водорода, гипохлорит и гидроперекиси липидов. Они являются сильными окислителями способными модифицировать белки, нуклеиновые кислоты, индуцировать перекисное окисление липидов (ПОЛ) и в результате цепных реакций приводить к множественным нарушениям мембран и к гибели клеток. Именно эти процессы вызывают развитие патологических состояний, и лежат в основе канцерогенеза, атеросклероза, хронических воспалений и нервных дегенеративных болезней.

Все процессы в иммунной системе связаны с другими органами и системами организма человека. В основном это осуществляется за счет метаболизма клеток (рис. 6).

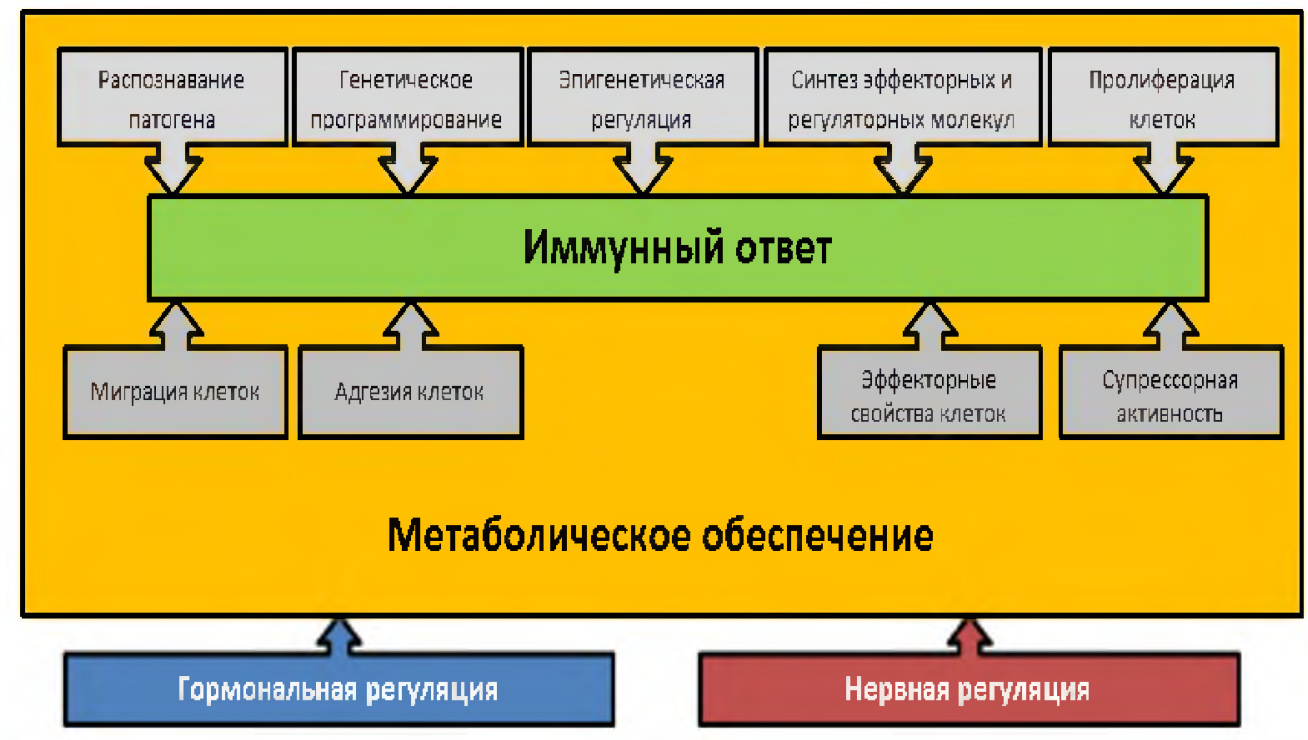

Рис. 6. Факторы, влияюшие на иммунный ответ.

Отдельной структурой не относящиеся непосредственно к человеку, но тем не менее очень важной для нормальное функционирования организма в том числе его защиты является микробиота. Микробиота (нормальная микрофлора, нормофлора, комменсалы, биотоп) сообщество более 1000 видов симбиотических и комменсальных бактерий, архей, простейших, грибов и вирусов населяющих организм человека в пределах тканей и жидкостей. Объем микробиоты оценивается в $10^{14}$ клеток, составляя до $1 \%$ массы человека (около 1 кг). По количеству клеток микробиота сопоставима с общим количество клеток человека, однако общий ее геном (микробиом) больше в 100 раз. Стоит обратить внимание, что при оценке микробиома в расчет не принимают вирусы и фаги, присутствующие в различных средах организма, которые по численности превосходят количество бактерий на порядок $[38,124]$.

С клинической точки зрения необходимо выделить микроорганизмы постоянно живущие основные (резидентная микробиота - около 90\%), постоянно живущие сопутствующие (факультативная микробиота - менее 9,5\%) и случайно попавшие (транзиторная микробиота - до $0,5 \%$ ). К транзиторной микробиоте относятся патогенные микроорганизмы. 
Популяция микробов их количество и состав в различных тканях существенно отличаются (рис. 7). Если количество микробов увеличивается за пределы своих типичных диапазонов (чаще всего из-за нарушения функции иммунной системы) или микробы заселяют (например, из-за травмы), участки организма, где они обычно не присутствуют или стерильные зоны (кровь, брюшная полость и др.), возникают заболевания.
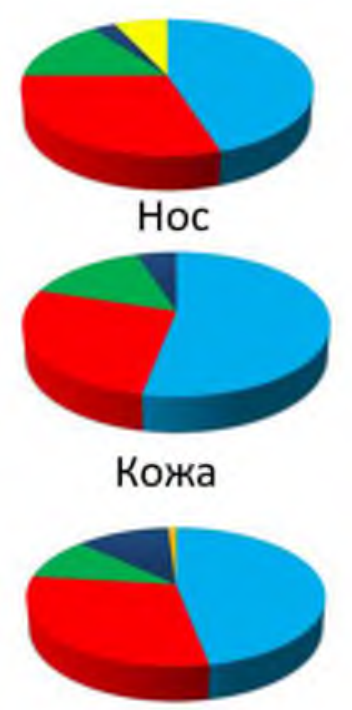

Желудок

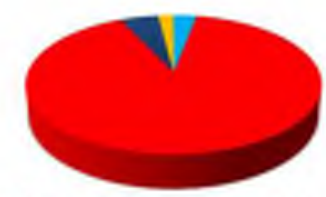

Половые органы

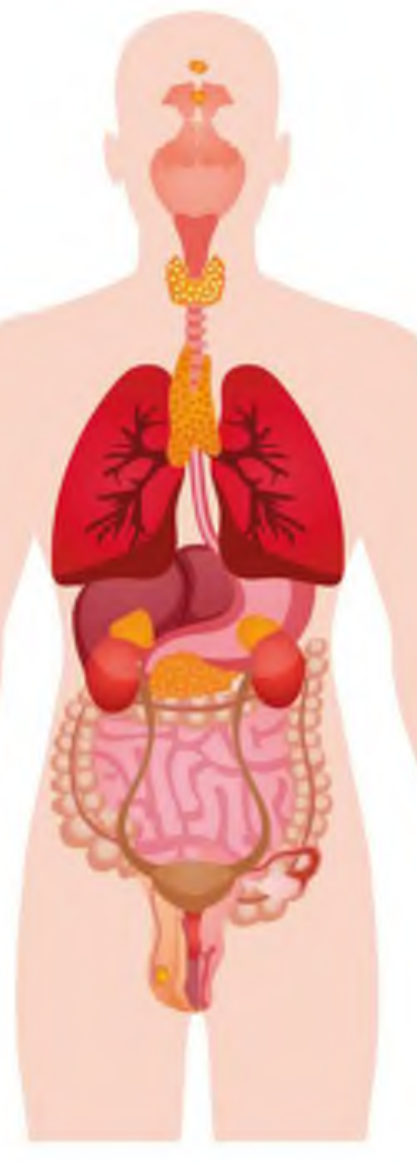

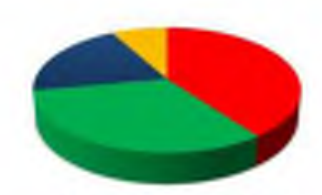

Полость рта

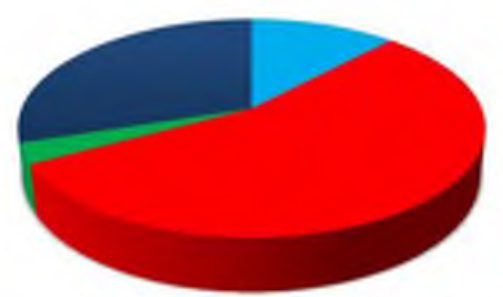

Кишечник

Actinobacteria

Firmicutes

Proteobacteria

Bacteroides

Cyanobacteria

Fusobacteria

\section{Рис. 7. Состав микробиоты человека.}

Состав микробиоты человека может меняться со временем. Чаще всего такое изменение связано с изменением диеты и общего состояния здоровья.

Наиболее исследованной и самой большой по объему является микробиота желудочнокишечного тракта (более $75 \%$ ). Она представлена в основном анаэробами (табл. 4). Состав кишечных бактерий каждого человека индивидуален и формируется в зависимости от возраста, местоположения, характера питания, образа жизни и состояния здоровья. На основе микробного состава по преобладанию тех или иных ключевых родов бактерий Bacteriodes, Prevotella u Ruminococcaceae выделяют три основных энтеротипа (как группа крови): При 1-м энтеротипе доминируют представители рода Bacteroides, при 2-м - Prevotella, при 3-м Ruminococcus

Перспективным является разделять микроорганизмы, заселяющие кишечник, на гидрогенотрофы (способные метаболизировать, как источник энергии, молекулярный водород), ацетогенные бактерии (генерирует ацетат), сульфатредуцирующие бактерии (реализуют анаэробное дыхание с использованием сульфата). 


\section{Микробиота интестинального тракта}

\begin{tabular}{|l|l|l|}
\hline \multicolumn{1}{|c|}{ Тип } & \multicolumn{1}{|c|}{ Класс } & \multicolumn{1}{c|}{ Семейство, вид } \\
\hline \multirow{2}{*}{ Firmicutes (50\%) } & Clostridia & $\begin{array}{l}\text { Lachnospiraceae (20-25\%) - Faecalicatena contorta } \\
\text { Clostridiaceae (1-3\%), Heliobacteriaceae }\end{array}$ \\
\cline { 2 - 3 } & & Ruminococcaceae (10-15\%) - Faecalibacterium prausnitzii \\
\cline { 2 - 3 } & \multirow{2}{*}{ Bacilli } & $\begin{array}{l}\text { Bacilliales - Bacillaceae, Staphylococcaceae } \\
\text { Lactobacillus - Lactobacillaceae, Enterococcaceae, } \\
\text { Streptococcaceae }\end{array}$ \\
\cline { 2 - 4 } & Mollicutes & Clostridium, Mycoplasma u Ureaplasma \\
\cline { 2 - 3 } & Negativicutes & Veilonellaceae \\
\hline Bacteroidetes (30\%) & Bacteroides & $\begin{array}{l}\text { Bacteroidaceae (10-15\%), Porphyromonadaceae (4-8\%), } \\
\text { Rickenellaceae (3-5\%) }\end{array}$ \\
\cline { 2 - 4 } & Prevotella & Prevotellaceae (4-8\%) \\
\hline Proteobacteria (3\%) & Enterobacteriaceae & Escherichia, Klebsiella \\
\hline Actinobacteria (1\%) & Bifidobacterium & Bifidobacterium, Propionebacterium, Atopobium \\
\hline Fusobacteria & Fusobacteriia & Fusobacterium \\
\hline Verrucomicrobia & Verrucomicrobiae & Verrucomicrobium spinosum \\
\hline Archaea (do 20\%) & Methanobacteria & Methanobrevibacter smithii \\
\hline
\end{tabular}

Основная масса микрофлоры (пристеночная микрофлора) фиксирована и тесно связана с энтероцитами, образуя биопленку (микробно-тканевой комплекс, включающий в себя микроколонии бактерий и их метаболитов, секреты бокаловиднх клеток, клеток Панета, эндокриноцитов и клеток иммунной системы), незначительная часть находится в просвете кишки (просветная микрофлора).

Микробиота активно участвует в пищеварении расщепляя основные пищевые субстанции и синтезируя новые. Многие виды белков, жиров и углеводов, из рациона человека, могут быть расщеплены только определенными кишечными микроорганизмами (табл. 5).

Помимо этого, нормальная микрофлора участвует в синтезе короткоцепочечных жирных кислот (ацетат, бутират, пропионат и пр.), аминокислот (аргинин, глутамин), витаминов (К, В1, В2, В3, В5, В6, В12, С, Д, биотина, пантотеновой кислоты), гормонов. Она способствует всасыванию ионов железа, кальция, обеспечивая полностью питательными и энергетическими вешествами эпителий кишечника, определяя его созревание и регенерацию. Также микробиота, участвуя в обмене солей желчных кислот и холестерина, обеспечивает гиполипидемический эффект.

Микробные метаболиты способствуют укреплению эпителиального барьера, например индол, за счет связывания белков цитоскелета формирует плотные контакты между эпителиоцитами. 


\section{Участие микробиоты в обмене вешеств человека}

\begin{tabular}{|c|c|c|}
\hline Тип бактерий & Участие в метаболизме & Диета \\
\hline Bacteroides & $\begin{array}{l}\text { Расщепляют клетчатку, гидролиз белков, } \\
\text { переработка сложных углеводов }\end{array}$ & Мясные и сладкие блюда \\
\hline Prevotella & Переработка сложных и простых углеводов & $\begin{array}{l}\text { Растительная диета, } \\
\text { вегетарианцы, сладкоежки }\end{array}$ \\
\hline $\begin{array}{l}\text { Firmicutes } \\
\text { faecalibacterium }\end{array}$ & $\begin{array}{l}\text { Производят масляную кислоту за счет } \\
\text { расщепления сложных углеводов. }\end{array}$ & $\begin{array}{l}\text { Большое потребление } \\
\text { овощей, фруктов и злаков }\end{array}$ \\
\hline $\begin{array}{l}\text { Firmicutes } \\
\text { ruminococcus }\end{array}$ & $\begin{array}{l}\text { Способны перерабатывать целлюлозу, } \\
\text { крахмала }\end{array}$ & $\begin{array}{l}\text { Макароны, картофель } \\
\text { зеленые бананы, чечевица, } \\
\text { зеленый горошек, белая } \\
\text { фасоль }\end{array}$ \\
\hline $\begin{array}{l}\text { Firmicutes } \\
\text { eubacterium }\end{array}$ & $\begin{array}{l}\text { Превращают лактат в кишечнике в } \\
\text { масляную кислоту. }\end{array}$ & Цельные злаки, бурый рис \\
\hline $\begin{array}{l}\text { Firmicutes } \\
\text { blautia }\end{array}$ & $\begin{array}{l}\text { Расщепляет сложных углеводы с } \\
\text { образованием ацетата }\end{array}$ & $\begin{array}{l}\text { При большом употреблении } \\
\text { клетчатки }\end{array}$ \\
\hline $\begin{array}{l}\text { Firmicutes } \\
\text { roseburia }\end{array}$ & $\begin{array}{l}\text { Расщепляют растительные маннаны. } \\
\text { Контролируют воспалительных процессов в } \\
\text { кишечнике, атеросклероз }\end{array}$ & $\begin{array}{l}\text { в орехах, бобовых, кокосах, } \\
\text { томатах, кофейных зернах }\end{array}$ \\
\hline $\begin{array}{l}\text { Firmicutes } \\
\text { coprococcus }\end{array}$ & $\begin{array}{l}\text { расщепляют разные виды волокон и } \\
\text { производят масляную кислоту }\end{array}$ & $\begin{array}{l}\text { При большом употреблении } \\
\text { клетчатки }\end{array}$ \\
\hline $\begin{array}{l}\text { Firmicutes } \\
\text { erysipelotrichia }\end{array}$ & метаболизируют жиры & Жирная пища \\
\hline Bifidobacterium & $\begin{array}{l}\text { синтезируют молочную, уксусную, } \\
\text { муравьиную, янтарную и гамма- } \\
\text { аминомасляную кислоты. Подавлять рост } \\
\text { патогенных бактерий. }\end{array}$ & $\begin{array}{l}\text { Ферментированные продукты } \\
\text { (кефир, хлеб на закваске, } \\
\text { квашеная капуста), соя, } \\
\text { чеснок, томаты, лук, банан, } \\
\text { яблоко, спаржа, мед. }\end{array}$ \\
\hline Lactobacillus & $\begin{array}{l}\text { Образуют антибиотические вещества - } \\
\text { лактолин, лактоцидин, ацидофилин. }\end{array}$ & Молочные продукты \\
\hline Akkermansia & $\begin{array}{l}\text { Участвуют в обмене муцина, синтезирует } \\
\text { жирные кислоты. Противовоспалительное } \\
\text { действие }\end{array}$ & Голодание \\
\hline
\end{tabular}

Детоксикационная функция микробиоты осуществляется путем нейтрализации экзогенных и эндогенных токсических продуктов, в т.ч. канцерогенов (амины, тиолы, фенолы, ксенобиотики и др.), которые в дальнейшем утилизируются в реакциях метаболизма и/или выводятся из организма с кишечным содержимым.

Одной из основных функций нормальной микрофлоры является предотвращение развития патогенных макроорганизмов, в основе которого лежит принцип микробного антагонизма. Помимо этого, в качестве защиты бактерии микробиоты кишечника вырабатывают антимикробные пептиды и другие метаболиты с антимикробными свойствами, изменяют $\mathrm{pH}$, а также физически противодействуют колонизации патогенами.

Считается, что у генетически восприимчивого хозяина дисбаланс во взаимодействии микробиоты и иммунитета в определенных условиях окружающей среды вносит вклад в патогенез множества иммуноопосредованных заболеваний. 
Микробиота играет решающую роль в обучении и развитии основных компонентов врожденной и адаптивной иммунной системы хозяина, в то время как иммунная система регулирует поддержание ключевых характеристик симбиоза хозяина и микроба. Любой инфекционный процесс можно считать дисбиозом, т.к. когда начинает превалировать патогенный микроорганизм снижается количество и разнообразие числа других бактерий. Как защитную функцию можно рассматривать процессы взаимодействия иммунной системы и нормальной микробиоты с формированием толерантности микробиоты и организма человека.

Аналогичные функции выполняет нормальная микрофлора и на других участках. Кожа дыхательные пути, урогенитальный тракт и пр. имеют свой состав микрофлоры, который активно участвуют в формировании мукозального иммунитета.

В отличии от нормальной микробиоты организм человека постоянно соприкасается с микроорганизмами (рис. 8), способными вызывать заболевания при естественных для данного микроба условиях заражения (патогены, возбудители). Они имеют структуры, ферментативные системы и другие факторы способные преодолевать защитные факторы организма и прежде всего мукозальный иммунитет. Развитие заболевания, вызванное микроорганизмами, происходит за счет прямого воздействия на клетки организма человека, и/или производством эндотоксинов, которые повреждают клетки организма, и/или за счет сильной стимуляции иммунного ответа, приводящий к повреждению клеток и тканей организма человека.

Bce патогенные микроорганизмы имеют молекулярные структуры, отсутствующие в организме человека. PAMP (Pathogen-associated molecular patterns (образы патогенности) чужеродные структуры патогенов). Это пептидогликаны, ЛПС (липополисахариды), липопротеины, липотейхоевая и тейхоевая кислоты, флагеллин, нуклеиновые кислоты вирусов и бактерий, вирусные белки и др. являющиеся составными частями микроорганизма [60].

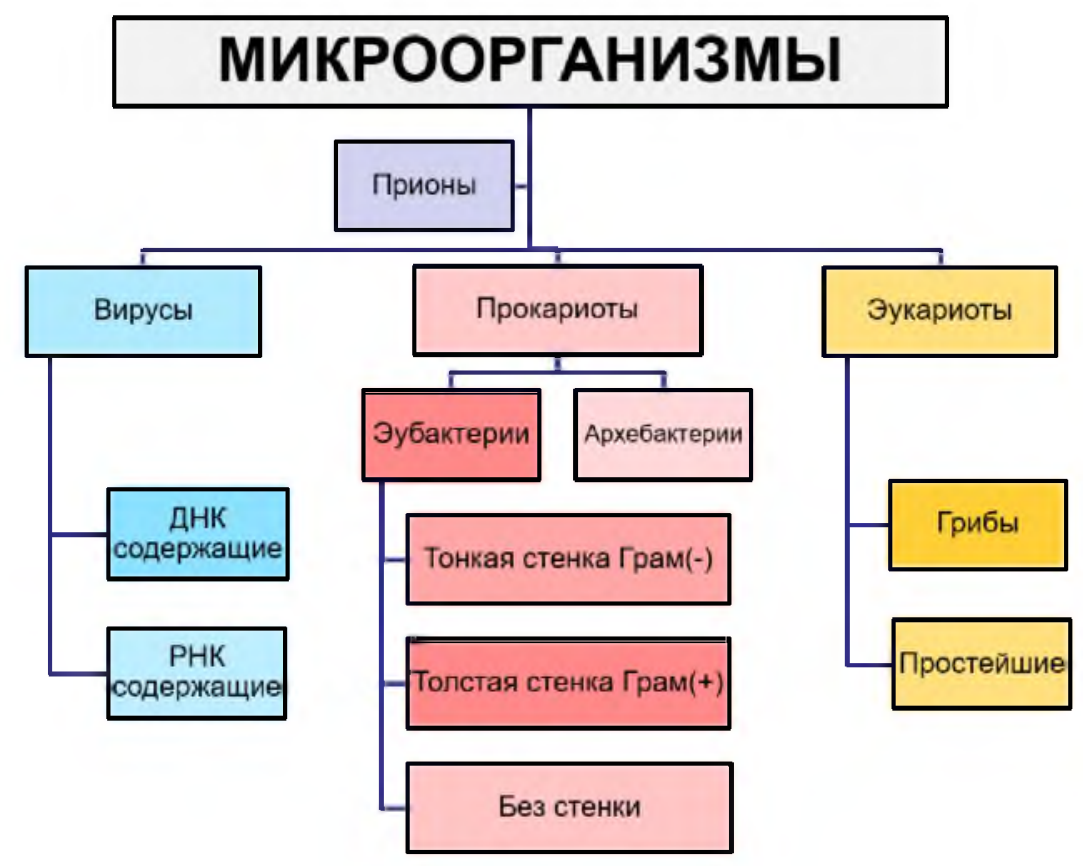

Рис. 8. Патогены.

Помимо патогенов иммунная система распознает и нейтрализует молекулярные структуры, связанные с повреждением собственных тканей - DAMP (danger-associated molecular patterns (образы опасности), эндогенные вещества клеток (белки теплового шока, белки S100, фибриллы амилоида-ß, дефенсины, кателицидины, галектины, аннексины, тимозины, цитокины (ИЛ-1 $\alpha$ и ИЛ-33), хроматин-связанный белок HMGB1, мочевая кислота и др.), образуемые при повреждении клеток и клеточном стрессе). 
Помимо PAMP и DAMP, которые могут распознаваться разными рецепторами, иммунная система способна распознавать и индивидуально формировать рецепторы (иммуноглобулиновые и/или специальные Т-клеточные рецепторы совместно с молекулами МHC II-класса) к генетически чужеродным молекулярным структурам - антигенам (АГ). Это длительный сложный процесс, зависящий от многих факторов, но способный обеспечить распознавание молекулярной структуры любой природы. Принято выделять экзогенные и эндогенные АГ. Экзогенные АГ инфекционные и паразитарные молекулярные структуры вирусов, риккетсий, бактерий, грибов, одно- и многоклеточных паразитов и неинфекционные чужеродные белки; белоксодержащие соединения; антигены и гаптены в составе пыли, пищевых продуктов, пыльцы растений, ряда лекарственных средств перерабатываемые антигенпредставляющими клетками с презентацией АГ. Подобные реакции могут запускать и собственные структуры организма распознанные как чужеродные (повреждённые белки и содержащие белок собственные клетки, неклеточные структуры и жидкости организма, при конъюгации с ними гаптенов, в результате мутаций, приводящих к синтезу аномальных белков, при сбоях иммунной системы).

Процесс взаимодействия между патогенными молекулами и иммунной системой происходит по рецепторному типу. В качестве лиганда выступает АГ, который образует комплекс с клеточным рецептором, отвечающим за обнаружение такого лиганда. После чего в клетке происходят серия биохимических реакций, инициируемых стимулом (первый мессенджер), передаваемым внутрь клетки через вторичные мессенджеры, которые усиливают сигнал и направляют его эффекторным молекулам, заставляя клетку реагировать на первоначальный стимул в виде биохимических, физиологических или фармакологических эффектов (рис. 9).

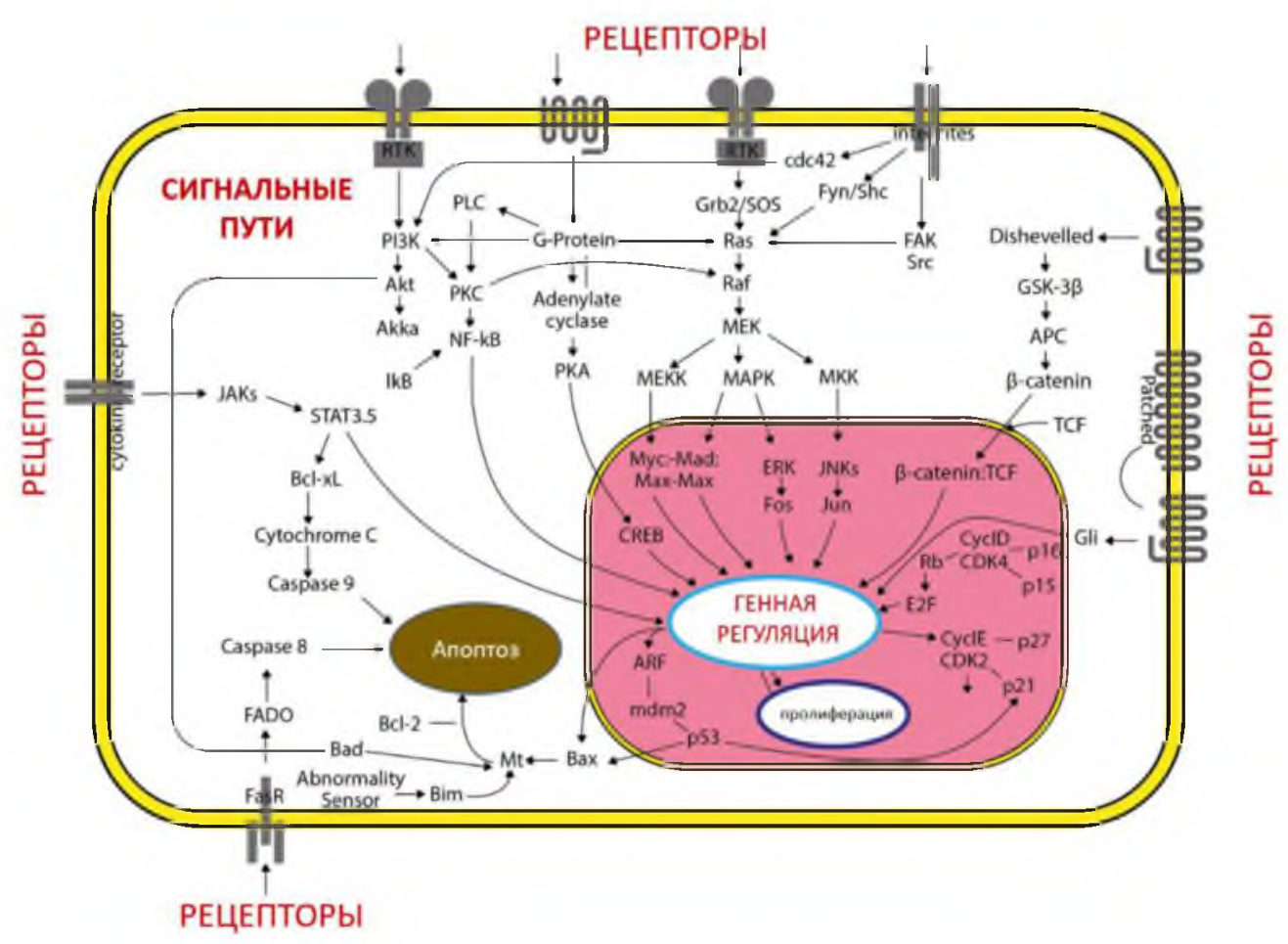

Рис. 9. Передача сигнала.

Выделяют рецепторы врожденной иммунной системы (табл. 6) и рецепторы адаптивного иммунитета (табл. 7). Рецепторы врожденного иммунитета одинаковы у разных людей, ограничены по количеству и разнообразию, напротив рецепторы адаптивного иммунитета генерируемые при сборки имеют большого количество рецепторов используя случайные комбинации генов. 


\section{Рецепторы врожденной иммунной системы}

\begin{tabular}{|c|c|c|}
\hline Рецептор & Лиганд & Функция \\
\hline $\begin{array}{l}\text { Рецепторы } \\
\text { распознавания } \\
\text { образов (PRR) }\end{array}$ & $\begin{array}{l}\text { патоген- ассоциированные } \\
\text { молекулярные паттерны } \\
\text { (РАМР) }\end{array}$ & $\begin{array}{l}\text { Посредством производства цитокинов } \\
\text { инициируют воспаление }\end{array}$ \\
\hline $\begin{array}{l}\text { Киллер- } \\
\text { активируемые и } \\
\text { киллер- } \\
\text { ингибируемые } \\
\text { рецепторы (KAR и } \\
\text { KIR) }\end{array}$ & $\begin{array}{l}\text { МНС I + молекулы стресса } \\
\text { (МІСА и МІСВ). Лектины С- } \\
\text { типа и пр. }\end{array}$ & $\begin{array}{l}\text { Позволяет NK-клеткам идентифицировать } \\
\text { аномальные клетки-хозяева (KAR) или } \\
\text { подавлять несоответствующее разрушение } \\
\text { клеток-хозяев (KIR) }\end{array}$ \\
\hline $\begin{array}{l}\text { Рецепторы } \\
\text { комплемента }\end{array}$ & $\begin{array}{l}\text { белки комплемента, } \\
\text { например, микробов }\end{array}$ & $\begin{array}{l}\text { Позволяют фагоцитам и В-клеткам распознавать } \\
\text { микробы и иммунные комплексы }\end{array}$ \\
\hline Рецепторы Fc & $\begin{array}{l}\text { комплексы эпитоп- } \\
\text { антитело }\end{array}$ & Стимулируют фагоцитоз \\
\hline $\begin{array}{l}\text { Цитокиновые } \\
\text { рецепторы }\end{array}$ & цитокины & Регуляция и координация иммунных ответов \\
\hline
\end{tabular}

Таблица 7

\section{Рецепторы врожденной иммунной системы}

\begin{tabular}{|l|l|l|}
\hline \multicolumn{1}{|c|}{ Рецептор } & \multicolumn{1}{|c|}{ Лиганд } & \multicolumn{1}{|c|}{ Функция } \\
\hline $\begin{array}{l}\text { Антиген } \\
\text { распознающие } \\
\text { рецепторы }\end{array}$ & $\begin{array}{l}\text { эпитопы (антигенные } \\
\text { детерминанты) }\end{array}$ & $\begin{array}{l}\text { Дифференцировка В-клеток в плазматические } \\
\text { клетки и пролиферация }\end{array}$ \\
\hline $\begin{array}{l}\text { Рецепторы Т- } \\
\text { клеток }\end{array}$ & $\begin{array}{l}\text { линейные эпитопы, } \\
\text { связанные с МНС }\end{array}$ & Активировать Т-клетки \\
\hline
\end{tabular}




\section{ИММУННАЯ СИСТЕМА}

\section{Глава 2. Мукозальный иммунитет}

Первой линией обороны против инфекционных агентов служат слизистые оболочки и кожа, которые совместно с клетками и молекулами иммунной системы образуют мукозоассоциированную лимфоидную ткань (mucosa-associated lymphoid tissue - MALT) препятствующую проникновению микроорганизмов. В ней сконцентрирована основная масса иммунной системы (на общей площади 400 м2 (120 м2 - дыхательная система, 250-400 м2 желудочно-кишечный тракт, кожа - 1,5-2,0 м2, мочеполовая система - 1,5-2,0 м2) располагаются около 50\% клеток иммунной системы). Структуризация MALT зависит от анатомической локализации барьерной ткани (табл. 8) [115, 118, 125, 129].

Таблица 8

\section{Структуры мукозо-ассоциированной лимфоидной ткани (MALT)}

\begin{tabular}{|c|c|c|}
\hline Наименование & $\begin{array}{c}\text { Анатомическая } \\
\text { локализация }\end{array}$ & $\begin{array}{c}\text { Механизмы } \\
\text { защиты }\end{array}$ \\
\hline SALT & кожа (дерма) & Клиренс кератоцитов, кислый рН, кожное сало, \\
\hline NALT & $\begin{array}{l}\text { носовая полость, рот и ротоглотка, } \\
\text { конъюнктива }\end{array}$ & $\begin{array}{l}\text { Чихание, слюна, слезы, катионный белок, } \\
\text { гистатины, лизоцим }\end{array}$ \\
\hline BALT & трахея, бронхи, легкие & $\begin{array}{l}\text { Кашель, катионный белок, дефенсины, } \\
\text { гликоконъюгаты, муцин }\end{array}$ \\
\hline VALT & половые органы & Кислый рН, катионный белок, спермин, муцин \\
\hline GALT & $\begin{array}{l}\text { - пищевод, желудок, тонкий } \\
\text { кишечник; } \\
\text { - толстый кишечник; } \\
\text { - урогенитальный тракт; }\end{array}$ & $\begin{array}{l}\text { Рвота, перистальтика, слизь, кислый рН, трипсин, } \\
\text { дефензины, лизоцим и пр. } \\
\text { Диарея, мочеиспускание, катионный белок, } \\
\text { дефензины }\end{array}$ \\
\hline
\end{tabular}

Мукозальный иммунитет - это сложное взаимодействие между врожденными и адаптивными механизмами иммунной системы, зависящие от анатомического строения органов. Функционально он обеспечивается клетками, непосредственно находящимися в ткани (резидентные). Структура мукозального иммунитета имеет сходную организацию во всех анатомических отделах (рис. 10).

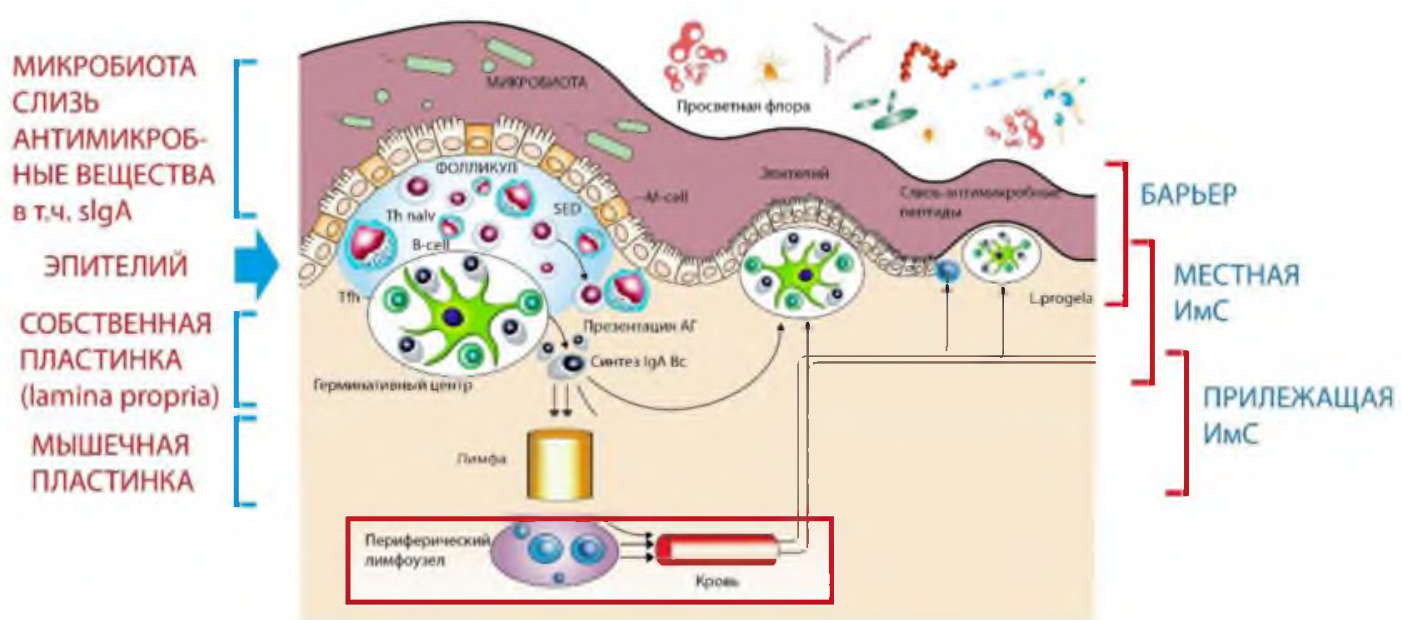

Рис. 10. Организация мукозо-ассоциированной лимфоидной ткани. 
Механическая защита, осуществляемая эпителием, образующим границу внешней и внутренней среды организма (табл. 9). В эпителии отсутствуют межклеточное вещество и кровеносные сосуды, он непроходим для большинства патогенов. Помимо клеток эпителия в эпителиальном пласте находится большое количество резидентных клеток иммунной системы.

Таблица 9

\section{Виды эпителия}

\begin{tabular}{|c|c|}
\hline Ткань & Тип (подтип) эпителия \\
\hline \multicolumn{2}{|r|}{ Кожа и серозные оболочки } \\
\hline Поверхностный слой & Многослойный, ороговевающий \\
\hline Плевра, брюшина, перикард & Простой плоскоклеточный (мезотелий) \\
\hline \multicolumn{2}{|r|}{ Дыхательная система } \\
\hline Ротоглотка, голосовые связки & Многослойный, неороговевающий эпителий \\
\hline Гортань трахея бронхи, нос & $\begin{array}{l}\text { Псевдостратифицированный столбчатый, реснитчатый (дыхательный } \\
\text { эпителий) }\end{array}$ \\
\hline $\begin{array}{l}\text { Воздуховоды из придаточных } \\
\text { пазух носа }\end{array}$ & Многослойный столбчатый \\
\hline $\begin{array}{l}\text { Терминальные бронхиолы, } \\
\text { дыхательные бронхиолы }\end{array}$ & Простой кубовидный, реснитчатый \\
\hline Каверны & Простой плоскоклеточный \\
\hline \multicolumn{2}{|r|}{ Желудочно-кишечный тракт } \\
\hline $\begin{array}{l}\text { Десна, твердое небо, задняя часть } \\
\text { языка }\end{array}$ & Многослойный ороговевающий \\
\hline Пищевод & Многослойный неороговевающий \\
\hline Желудок & Простой столбчатый, не ресничный (эпителий желудка) \\
\hline $\begin{array}{l}\text { Тонкая кишка, толстая кишка } \\
\text { прямая кишка, Желчный пузырь }\end{array}$ & Простой столбчатый, не ресничный (кишечный эпителий) \\
\hline Анус & $\begin{array}{l}\text { Многослойный плоский неороговевающий и } \\
\text { многослойный чешуйчатыми, ороговевающий }\end{array}$ \\
\hline \multicolumn{2}{|r|}{ Мочеполовая система } \\
\hline Уретра & Псевдостратифицированный столбчатый, не реснитчатый \\
\hline $\begin{array}{l}\text { Почечные лоханки, мочеточник, } \\
\text { мочевой пузырь, }\end{array}$ & Переходный (уротелий) \\
\hline Почки & $\begin{array}{l}\text { Простой кубовидный с микроворсинками и без микроворсинок, простой } \\
\text { плоскоклеточный, простой кубоидальный }\end{array}$ \\
\hline Яичники, яички & Простой кубоидальный (зародышевый эпителий) \\
\hline $\begin{array}{l}\text { Фаллопиевы трубы, эндометрий } \\
\text { (матка) }\end{array}$ & Простой столбчатый, реснитчатый \\
\hline Шейка матки (эндоцервикс) & $\begin{array}{l}\text { Простой столбчатый и } \\
\text { Многослойный, неороговевающий }\end{array}$ \\
\hline Вагина & Многослойный, неороговевающий \\
\hline Половые губы & Многослойный, ороговевающий \\
\hline $\begin{array}{l}\text { Придатки яичка, протоки, } \\
\text { семеные везикулы }\end{array}$ & Псевдостратифицированный столбчатый \\
\hline $\begin{array}{l}\text { Эякуляторный проток, } \\
\text { бульбоуретральные железы }\end{array}$ & Простой столбчатый \\
\hline
\end{tabular}


К другим механическим факторам, способствующим защите поверхности эпителия, можно отнести вымывающее действие слизи, слез, слюны, мочи. Слизь, действует как защитный барьер, препятствующий прикреплению бактерий к эпителиальным клеткам. Микробы и другие чужеродные частицы, захваченные слизью, удаляются механическим путем за счет движения ресничек эпителия, с кашлем и чиханием. При патологических процессах эти процессы усиливаются, возникает рвота, диарея, ринорея, слущивание (образование перхоти, шелушение). С другой стороны, плотный слой слизи отделяет кишечный эпителий от резидентных микробов, обеспечивая защиту за счет статического экранирования гликокаликсом (пушистое покрытие на внешней поверхности мембран) и ограничивая захват дендритными клетками кишечника микробов, содержит их в противовоспалительном состояние.

Многочисленные секреторные клетки вырабатывают вещества различной химической природы (табл. 10). Так, например, в кишечнике функционально схожие с нейтрофилами клетки Панета под воздействием бактерий или бактериальных антигенов секретируют антимикробные пептиды (дефензины, лизоцим и фосфолипазу А2) в просвет кишечной железы, тем самым способствуя поддержанию желудочно-кишечного барьера.

Отдельная популяция клеток, инициирующая иммунные реакции слизистой оболочки, мультискладчатые клетки (М-клетки). За счет своих особенностей (не секретируют слизь или пищеварительные ферменты и имеют более тонкий гликокаликс) они за счет эндоцитоза и/или фагоцитоза, и/или трансцитоза переносят микробы и частицы через слой эпителиальных клеток и доставляют их к антигенпрезентирующим клеткам, интраэпителиальным макрофагам и лимфоцитам.

Таблица 10

\section{Растворимые факторы секретов}

\begin{tabular}{|c|c|c|}
\hline Факторы & Локализация & Механизм действия \\
\hline Кислый рH & $\begin{array}{l}\text { Кожа, влагалище, } \\
\text { желудок }\end{array}$ & Подавляет рост бактерий \\
\hline Жирные кислоты & Пот & Подавляет рост бактерий \\
\hline $\begin{array}{l}\text { Муцины и } \\
\text { агглютинины }\end{array}$ & Секреты & Агрегация бактерии \\
\hline Пероксидазы & Секреты & $\begin{array}{l}\text { Катализируют окисление липидных мембран } \\
\text { бактерий }\end{array}$ \\
\hline Ингибиторы протеазы & Секреты & $\begin{array}{l}\text { Подавляют функцию } \\
\text { активность протеаз }\end{array}$ \\
\hline $\begin{array}{l}\text { Лизосомальные } \\
\text { ферменты }\end{array}$ & Пот и секреты & $\begin{array}{lcc}\text { Уничтожают } & \text { бактерии, } & \text { гидролизуя } \\
\text { полисахаридный компонент клеточной стенки. }\end{array}$ \\
\hline Лактоферрин & Секреты & Подавляет рост бактерий, связывая железо \\
\hline Гистатины & Слюна & $\begin{array}{l}\text { Обладают противогрибковыми свойствами, } \\
\text { нарушая функцию митохондрий }\end{array}$ \\
\hline Катионные белки & Пот и секреты & $\begin{array}{lcr}\text { Обладают } & \text { антибактериальной } & \text { активностью, } \\
\text { связываясь } & \text { с } & \text { липидными } \\
\text { мембранами } & & \text { клеточными } \\
\end{array}$ \\
\hline $\begin{array}{l}\text { Дефенсины и другие } \\
\text { антибактериальные } \\
\text { пептиды }\end{array}$ & Секреты & $\begin{array}{l}\text { Секретируются лейкоцитами и активны против } \\
\text { бактерий, грибков и вирусов в оболочке }\end{array}$ \\
\hline
\end{tabular}

В качестве факторов защиты в ответ на вторжение вируса и некоторых бактериальных агентов зараженные клетки различных тканей вырабатывают интерфероны I и III типа (IFN). 
Они секретируются сразу после контакта с вирусом и прямо пропорционально заражающей дозе. Под воздействием IFN в клетке происходит выработка сотен белков, вызывающих различные эффекты. Прежде всего РНК-активируемая протеинкиназа и рибонуклеаза L, приводящие к разрушению вирусной РНК, в результате чего подавляется синтез белков вирусной оболочки. В результате новые вирусные частицы, либо вовсе не формируются, либо их число уменьшается в десятки или сотни раз $[35,79,80]$.

Помимо предотвращения репликации вирусов, секретируемый IFN защищает соседние клетки от вирусов, активирует клетки иммунной системы, подавляет пролиферацию клеток, усиливает экспрессию МНС I класса, представляя вирусные АГ цитолитическим Т-лимфоцитам (ЦТЛ). Участвует IFN и в формировании системных реакций (лихорадка, слабость, недомогание, головная боль), в регуляции гемопоэза и клеток иммунной системы (рис. 11).

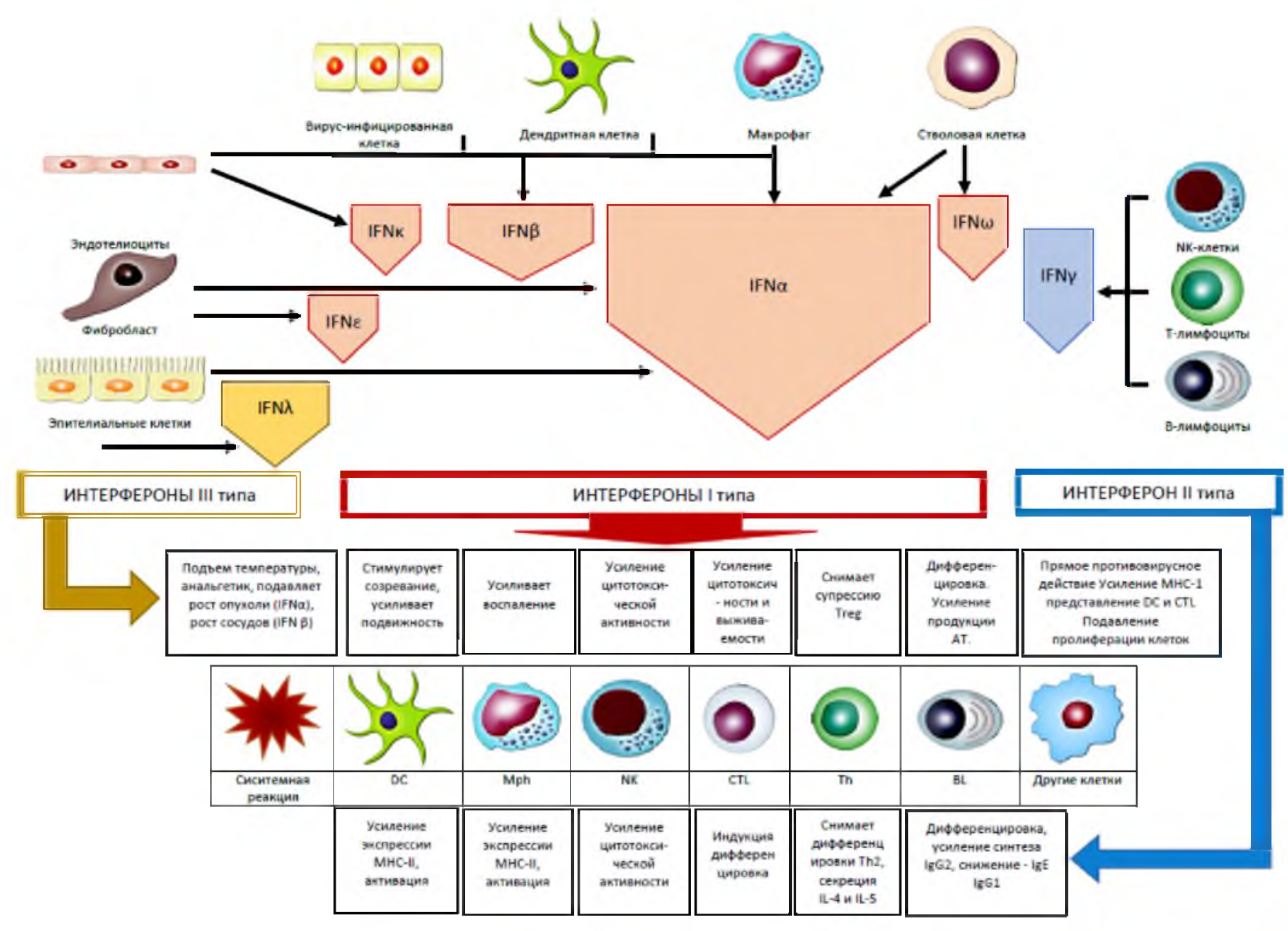

\section{Рис. 11. Интерфероны.}

Все остальные защитные механизмы осуществляются за счет рецепторного распознавании чужеродных структур, приводящие к иммунному ответу, которые можно разделить на два типа: врожденный и адаптивный иммунный ответ.

Врожденный иммунный ответ основан на распознавании чужеродных агентов с помощью специальных патоген-распознающих рецепторов (PRR). По функции все PRR могут быть разделены на сигнальные и эндоцитозные (рис. 12). 


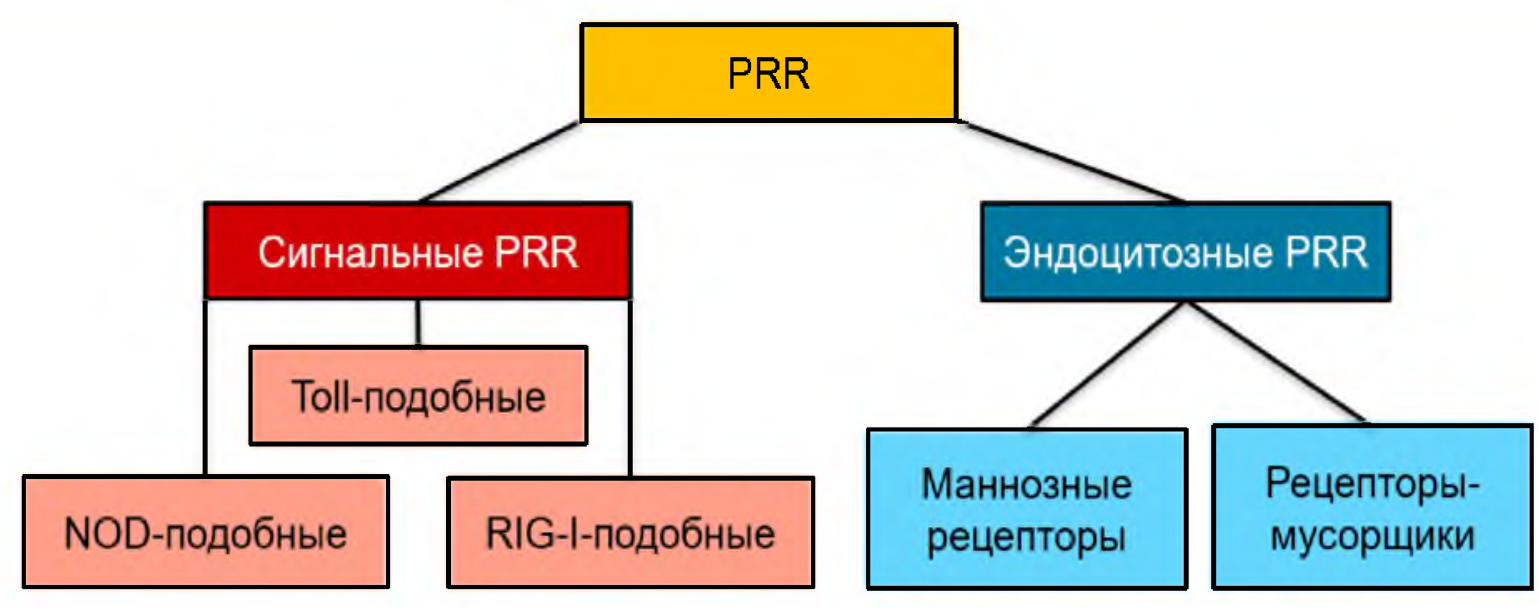

\section{Рис. 12. Патоген-распознающие рецепторы.}

Первая группа рецепторов позволяет выявлять патоген-ассоциированные молекулярные структуры - РАМР, отсутствующие в организме человека (пептидогликаны, липополисахариды, липопротеины, липотейхоевая и тейхоевая, кислоты, флагеллин, нуклеиновые кислоты вирусов и бактерий, вирусные белки и др.), и/или молекулярные структуры, связанные с повреждением - DAMP - эндогенные вещества клеток, образуемые при гибели клеток и клеточном стрессе (белки теплового шока, белки S100, фибриллы амилоида- $\beta$, дефенсины, кателицидины, галектины, аннексины, тимозины, цитокины ИЛ-1 $\alpha$ и ИЛ-33, хроматин-связанный белок HMGB1, мочевая кислота и др.).

Вторая группа рецепторов - эндоцитозные PRR обеспечивает процессы фагоцитоза и последующую доставку патогена в лизосомы (начало адаптивного иммунного ответа) и активирует эффероцитоз (узнавание и поглощение апоптотических клеток).

Эпителиальные клетки имеют патоген-распознающие рецепторы, позволяющие выявлять PAMP. Взаимодействие PRR с PAMP и/или DAMP (рис. 13) через последовательную активацию адапторных белков, протеинкиназ и транскрипционных факторов, приводит к синтезу и секреции цитокинов (ИЛ-1, $-2,-6,-8,-12$, ФНО- $\alpha$, ИФН- $\gamma$, ГМ-КСФ). За счет этого происходит активации самих клеток, несущих PRR, значительно усиливается их защитный потенциал (активируется продукция противомикробных пептидов и комплемента, усиливается фагоцитоз, переваривающая активность, продукция активных форм кислорода).

Эпителиальные клетки в основном имеют сигнальные PRR. Однако от их способности синтезировать защитные пептиды, обеспечить доступ лейкоцитов к тканям зависит исход развития заболевания.

Подобные PRR экспрессируются и на других клетках, находящихся в тканях и, прежде всего, на тканевых гранулоцитах (тучные клетки, базофилы, эозинофилы), системе мононуклеарных фагоцитов (моноциты, макрофаги и дендритные клетки), группе «тканевых» лимфоцитов и других неиммунных клеток (эндотелиальные клетки, фибробласты и др.). Именно активный синтез цитокинов привлекает периферические нейтрофилы, эозинофилы, базофилы и тучные клетки к субэпителиальным областям кишечника и ускоряет активацию и дифференцировку местных лимфоцитов.

Показано, что популяции тучных клеток, базофилов и эозинофилов из их миелоидных предшественников функционально можно рассматривать как единую систему тканевых гранулоцитов $[38,115,127,132]$. 


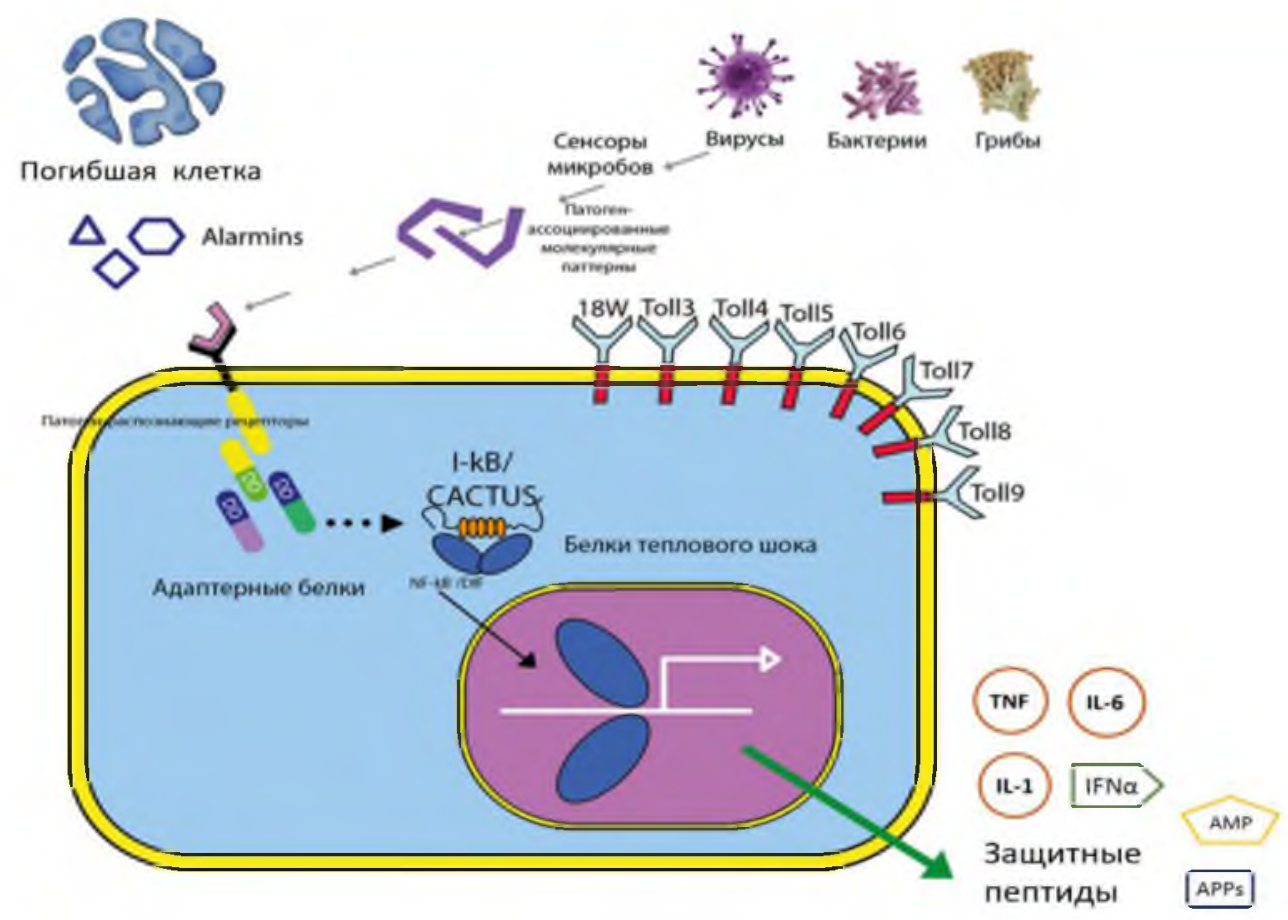

Рис. 13. Упрощенная схема активация эпителиальных клеток.

Тучные клетки богатые гранулами иммунные клетки, которые распределены по всему организму в областях, где обычно возможно соприкосновение с микроорганизмами (барьерные ткани), таких как слизистые оболочки и кожа, а также в большинстве тканей, окружающих кровеносные сосуды и нервы. Традиционно выделяют две подгруппы тучных клеток: клетки соединительной ткани (СТМС) и клетки слизистой оболочки (МMC). По происхождению СТMC делят на самоподдерживающиеся, которые заселены в тканях до рождения, и СТМС, поддерживаемые костным мозгом. У ММС четыре подгруппы: тучные клетки, содержащие триптазы, при отсутствии химазы (МСТ), клетки; содержащие химазу, но не содержащие триптазу (МСB); клетки, содержащие триптазу, химазу и карбоксипептидазу (МСТC) и клетки, экспрессирующих триптазу и карбоксипептидазу А3, но не химазу (МСC). Однако такое разделение неоднозначно, поскольку экспрессия протеаз может изменяться в зависимости от тканевого окружения. Непонятно и как именно их фенотип способствует развитию заболеваний человека.

Тучные клетки признаны регуляторными и эффекторными клетками как врожденного, так и адаптивного иммунитета, принимающими активное участие в развитии острых и хронических аллергических, аутоиммунных, воспалительных заболеваний и рака. Эти первичные, сигнальные клетки, связаны со многими иммунными и неиммунными клетками, которые реагируют на патогены и инициируют защитный ответ, высвобождая медиаторы, оказывающие различное действие на окружающие ткани (вазоактивное, сокращение гладкой мускулатуры, стимулирование периферических нервных окончаний, регулирование гемостаза и др., табл. 11). Они активно участвуют в формировании воспаления, аллергии и анафилаксии. Также тучные клетки играют важную роль в заживлении ран, ангиогенезе, иммунной толерантности, защите от патогенов и формировании гематоэнцефалического барьера.

Активация тучных клеток происходит за счет распознавания DAMP и/или PAMP и/или рецепторов, связанных с G-белком, так же активаторами могут служить белки комплемента. Отдельный механизм связан с рецептором IgE. Тучные клетки экспрессируют высокоаффинный рецептор (FcєRI) для Fc-области IgE. Этот рецептор имеет высокое сродство и связывание его c IgE необратимо. В результате чего тучные клетки покрываются IgE. Как и любое AT оно специфично к одному конкретному антигену (аллергену). Аллерген связывается с вариабельными участками $\operatorname{IgE}$, находящимся на поверхности тучных клеток и/или базофилов, 
активируют их. И, если в первом случае, медиаторы высвобождаются медленно (по частям), то $\mathrm{IgE-опосредованный} \mathrm{механизм} \mathrm{подразумевает} \mathrm{быстрое} \mathrm{высвобождение} \mathrm{(анафилактическая}$ дегрануляция) содержимого гранул. Этим и обусловлены аллергические реакции, хотя изначально эта реакция связана с защитой от бактерий, простейших и гельминтов. Помимо острых немедленных явлений, аллергический процесс включает более поздние фазы, отмеченные инфильтрацией лейкоцитов и инициированием адаптивного иммунного ответа, за которыми следует хроническая фаза, которая включает стойкое воспаление, ремоделирование тканей и фиброз.

Таблица 11

\section{Медиаторы тучных клеток и базофилов и их свойства}

\begin{tabular}{|c|c|}
\hline Медиаторы & Биологическое действие \\
\hline \multicolumn{2}{|c|}{ Находящиеся в связанном с гранулярным матриксом состоянии, быстро высвобождаемые } \\
\hline Гистамин & $\begin{array}{l}\text { Повышает сосудистую проницаемость; гиперсекрецию слизи; } \\
\text { вызывает сокращение гладкой мускулатуры; вызывает зуд } \\
\text { (Н1); образование простагландинов; повышение уровня } \\
\text { цАМФ (Н2) или цГМФ (Н1) либо торможение (Н2) хемотаксиса } \\
\text { нейтрофилов и эозинофилов }\end{array}$ \\
\hline $\begin{array}{l}\text { Эозинофильный хемотаксический } \\
\text { фактор анафилаксии (ЭХФА) }\end{array}$ & \multirow[t]{2}{*}{$\begin{array}{l}\text { Вызывают хемоаттракцию и инактивацию эозинофилов и } \\
\text { нейтрофилов }\end{array}$} \\
\hline ЭХФА-олигопептиды & \\
\hline $\begin{array}{l}\text { Нейтрофильный хемотаксический } \\
\text { фактор }\end{array}$ & Вызывает хемоаттракцию и инактивацию нейтрофилов \\
\hline Арилсульфатаза A & Гидролиз ароматических сульфатных эфиров \\
\hline \multicolumn{2}{|c|}{ Находящиеся в связанном с гранулярным матриксом состоянии, прочно связанные } \\
\hline Гепарин & $\begin{array}{l}\text { Антикоагуляция; торможение активации комплемента; } \\
\text { высвобождение липопротеинлипазы и фосфолипазы }\end{array}$ \\
\hline $\begin{array}{l}\text { Химаза (химотрипсиноподобный } \\
\text { фермент) }\end{array}$ & $\begin{array}{l}\text { Гидролиз протеогликанов; повышение сосудистой } \\
\text { проницаемости }\end{array}$ \\
\hline $\begin{array}{l}\text { Триптаза (трипсиноподобный } \\
\text { фермент) }\end{array}$ & $\begin{array}{l}\text { Генерация СЗа анафилатоксина; протеолиз; деградация } \\
\text { кининогена }\end{array}$ \\
\hline Пероксидаза & Инактивация лейкотриенов \\
\hline Супероксид дисмутаза & Дисмутация $\mathrm{O}_{2}$ в пероксид водорода \\
\hline \multicolumn{2}{|c|}{ Образуемые в ходе активации клетки } \\
\hline Лейкотриены C4, D4, E4 & $\begin{array}{l}\text { Сокращение гладкой мускулатуры, повышение } \\
\text { проницаемости стенок сосудов; синергизм с гистамином; } \\
\text { генерация простагландинов }\end{array}$ \\
\hline Простагландин D2 & $\begin{array}{l}\text { Сокращение гладкой мускулатуры; повышение } \\
\text { артериального давления; повышение уровня цАМФ }\end{array}$ \\
\hline Тромбоксан A2 & $\begin{array}{l}\text { сокращение гладкой мускулатуры; стимуляция агрегации } \\
\text { тромбоцитов; стимуляция агрегации тромбоцитов }\end{array}$ \\
\hline Эндопероксиды (G2, H2) & Сокращение гладкой мускүлатуры \\
\hline $\begin{array}{l}\text { Фактор, активации тромбоцитов } \\
\text { (ФАТ) }\end{array}$ & $\begin{array}{l}\text { Агрегация тромбоцитов, высвобождение из них аминов; } \\
\text { повышение проницаемости стенок сосудов; }\end{array}$ \\
\hline $\begin{array}{l}\text { Простагландингенерирующий } \\
\text { фактор }\end{array}$ & Индукция образования простагландинов, тромбоксана В2 \\
\hline $\begin{array}{l}\text { Базофильный калликреин } \\
\text { анафилаксии (в базофилах) }\end{array}$ & $\begin{array}{l}\text { Бронхоспазм; расширение сосудов; повышение сосудистой } \\
\text { проницаемости; боль }\end{array}$ \\
\hline
\end{tabular}


Благодаря большому разнообразию других рецепторов, тучные клетки реагируют на различные типы стимулов, включая микробные, нервные, иммунные, гормональные, метаболические и химические триггеры, тем самым, проявляя антимикробные, неврологические, иммунные и метаболические функции. Именно взаимодействие тучных клеток и нервов способствует возникновению боли и зуда.

Базофилы наименее распространенный в периферической крови тип гранулоцитов, составляющий от 0,5 до $1 \%$ циркулирующих лейкоцитов. Морфологически, в отличии от других гранулоцитов крови, имеют базофильные гранулы, а в отличии от тучных клеток сегментированное ядро, меньшие размеры и округлую форму.

Базофилы функционально тесно связаны с тучными клетками, хотя совершенно разные по своему происхождению и развиваются из разных гемопоэтических клонов. В отличие от тучных клеток, базофильные гранулы базофилов содержат меньше протеаз, кроме того, этих гранул в базофилах в целом меньше. Базофилы секретируют сравнительно немного активных веществ, однако по количеству выделяемого IL-4 они главный источник в организме, превосходя даже Т-клетки.

На поверхности базофилов представлено большое число хемотаксических рецепторов, однако спектр Toll-подобных рецепторов (PRR) представлен скудно. Подобно тучным клеткам, базофилы имеют два типа рецепторов к иммуноглобулинам E: высокоаффинные (FcعRI) и низкоаффинные (FceRII, или CD23), а также гистаминовые рецепторы H2. За счет этого базофилы быстро рекрутируются в лимфатические узлы, могут функционировать как антигенпрезентирующие клетки и имеют решающее значение для индукции дифференцировки Th2-клеток, а также связанных с ними воспалительных реакций после контакта с паразитами гельминтов или аллергенами. Все это дает основание предполагать, что базофилы в основном являются регуляторными, а не эффекторными клетками иммунитета.

Эозинофилы - разновидность гранулоцитов с крупными эозинофильными гранулами и сегментированным ядром. Это больше тканевые клетки, чем циркулирующие, поэтому в периферической крови их не более 150 клеток/мкл (1-3\%). Дифференцировка эозинофилов регулируется цитокинами (ИЛ-3, ИЛ-5, ГМ-КСФ). После созревания IL-5 контролирует миграцию эозинофилов из костного мозга в кровь. Исходно эозинофилы локализуются в вилочковой железе, желудочно-кишечном тракте, матке и молочной железе. Эозинофилы способны секретировать на исходном уровне или при стимуляции большое количество разнообразных медиаторов (табл. 12).

Таблица 12

\section{Состав гранул эозинофилов}

\begin{tabular}{|c|c|c|}
\hline $\begin{array}{c}\text { Гранулы } \\
\text { эозинофилов }\end{array}$ & Основное содержание & $\begin{array}{l}\text { Назначение } \\
\text { содержимого }\end{array}$ \\
\hline $\begin{array}{l}\text { Специфические } \\
\text { (крупные, } \\
\text { вторичные) }\end{array}$ & $\begin{array}{l}\text { Главный основный белок } 1 \text { (MBP-1); главный основный } \\
\text { белок } 2 \text { (МВР-2); эозинофильный нейротоксин (EDN); } \\
\text { эозинофильный катионный белок (ECP); эозинофильная } \\
\text { пероксидаза (EPO). }\end{array}$ & Внеклеточный цитолиз \\
\hline Мелкие & Арилсульфатаза В, кислая фосфатаза, пероксидаза & Бактерицидность \\
\hline Первичные & $\begin{array}{l}\text { Лизофосфолипаза (кристаллы Шарко -Лейдена или } \\
\text { галектин-10), митохондриальная ДНК }\end{array}$ & Липидный метаболизм \\
\hline Липидные тельца & $\begin{array}{l}\text { Арахидоновая кислота, липоксигеназа, циклоксигеназа } \\
\text { для синтеза простагландинов, простациклинов, } \\
\text { тромбоксанов, лейкотриенов и др. }\end{array}$ & Выработка эйкозаноидов \\
\hline $\begin{array}{l}\text { Секреторные } \\
\text { везикулы }\end{array}$ & $\begin{array}{l}\text { Ферменты: эластаза, гистаминаза, коллагеназа. } \\
\text { Цитокины: IL-1, IL-2, IL-4 , IL-5, IL-6, IL-8, IL-13, TNF альфа, } \\
\text { GM-CSF, TNFa. Факторы роста TGF beta , VEGF и PDGF. } \\
\text { Хемокины CCL3, CCL5, CCL11, CXCL13 }\end{array}$ & Регуляторная роль \\
\hline $\begin{array}{l}\text { Активные формы } \\
\text { кислорода }\end{array}$ & $\mathrm{O}_{2}, \mathrm{H}_{2} \mathrm{O}_{2}$, Гидроксильные радикалы Синглетный кислород & Бактерицидность \\
\hline
\end{tabular}


Исходя из локализации (паренхима/барьерная ткань), морфологии ядра (кольцеобразная/сегментированная), поверхностному фенотипу, азличают два типа эозинофилов - резидентный (rEOS) и воспалительный (iEOS).

Характерной особенностью эозинофилов является их защитная антипаразитарная функция. Гельминты и их продукты их жизнедеятельности, медиаторы воспаления (прежде всего, гистамин) и хемокины, макрофагов, тучных и эпителиальных клеток привлекают эозинофилы в ткани.

Оказавшись в месте повреждения, эозинофилы прикрепляются к поверхности паразитов за счет своего рецептора к C3b (большинство гельминтов активируют систему комплемента по альтернативному пути с образованием C3b), высвобождают свои цитотоксические гранулярные белки, а также предварительно сформированные цитокины и липидные медиаторы, способствуя уничтожению паразитов, развитию воспаления и повреждению тканей.

Эозинофилы являются эффекторами в метаболизме гистамина, секретируемого тучными клетками. Фермент гистаминаза, выделяемый эозинофилами, катализирует расщепление гистамина, результатом чего является снижение концентрации гистамина в тканях. Эозинофилы фагоцитируют гистаминсодержащие гранулы тучных клеток, адсорбируют гистамин на своей плазмалемме, связывая его своими рецепторами. Эозинофилы секретируют и выводят вещество - фактор, тормозящий дегрануляцию и высвобождение гистамина из цитоплазмы тучных клеток. Эозинофилы являются предполагаемыми антигенпрезентирующими клетками и играют существенную роль в активации тучных клеток, коммуникации и функции Т-клеток.

Тканевые гранулоциты уже на уровне слизистых осуществляют активный фагоцитоз, однако основными фагоцитирующими клетками являются нейтрофилы, моноциты, дендритные клетки (они будут описаны в разделе врожденного иммунитета) и макрофаги.

Под фагоцитозом понимают процесс поглощения объекта с дальнейшим ферментативным разрушением его структуры. Процесс имеет несколько этапов (рис. 14).

Захваченная клетка или макромолекула подвергается действию целого ряда бактерицидных механизмов обезвреживания. Ряд микробов, будучи фагоцитированы, погибают в анаэробных условиях цитоплазмы. Бактерицидность обусловлена также снижением в вакуолях рН. Лизосомальные ферменты (лизоцим, липазы, нуклеазы, пероксидазы, протеазы, эстеразы, карбогидразы, фосфорилазы, нейраминидаза и др) вызывают деструкцию. Помимо лизосомальных ферментов катионные белки разрушают бактериальную мембрану, лактоферрин, связывает железо, кальпротектин - цинк необходимый для метаболических процессов бактерий.

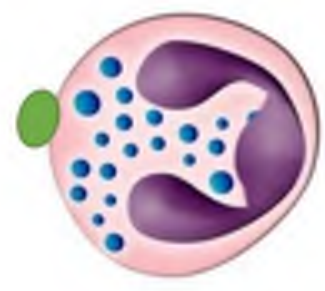

Адгезия

(прилипание к объекту)

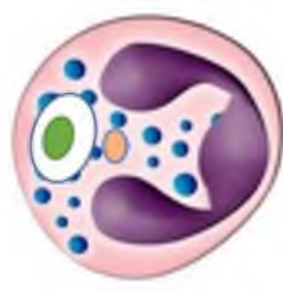

Погружение в клетку с образованием фагосомы

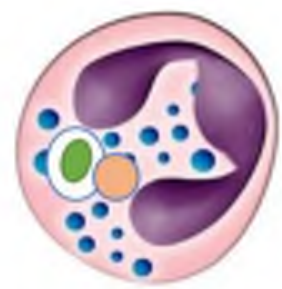

Слияние фагосомы с лизосомой

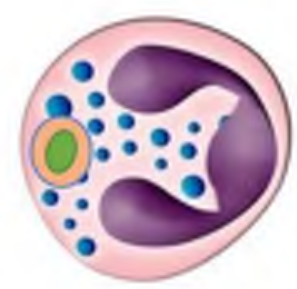

Переработка фагоцитированного материала

\section{Рис. 14. Этапы фагоцитоза}

Мощное бактерицидное действие оказывают супероксиданион, пероксид водорода, синглетный активный кислород и гидроксильные радикалы возникающие за счет изменения метаболизма. Усиление окисление глюкозы (гексозомонофосфатный шунт) и генерирации НАДФН, который используется для восстановления молекулярного кислорода, связанного с 
уникальным мембранным цитохромом. Микробные клетки обычно погибают в фагоцитах в течение нескольких минут. Более того, сочетание пероксида, миелопероксидазы и ионов галогенов создает мощную систему галогенирования, способную вызвать гибель не только бактерий, но и вирусов. После переваривания бактерий продукты деградации либо высвобождаются из клетки, либо содержимое вакуоли растворяется в цитоплазме и фагоцит аутолизируется.

Весь набор ферментов гранулоцитов может действовать не только внутри клетки, но и высвобождаться в окружающие ткани, уничтожая таким образом паразитов, не подвергающихся фагоцитозу по своим размерам.

Нейтрофилы и другие гранулоциты и тучные клетки при особой программируемой смерти (NET-oce) могут высвобождать так называемые нейтрофильные внеклеточные сети, ловушки (NET), которые в основном состоят из содержимого их клеточных ядер, таких как ДНК и гистоны, и обладают антимикробным действием.

Макрофаги и другие антигенпрезентующие клетки, находящиеся в большом количестве в MALT, также распознают и фагоцитируют патогены. В последующем они с помощью протеолитических ферментов расщепляя патоген на пептидные фрагменты (процессинг) и в комплексе с молекулой МНС II класса представляют фрагменты патогена (АГ) на поверхность клетки (презентация АГ), тем самым запускают процесс нейтрализации патогенов по распознаванию уникальной чужеродной структуры (AГ). На уровне MALT под эпителием в lamina propria находятся изолированные лимфоидные фолликулы, куда и доставляется АГ дендритными клетками (рис. 10). Находящиеся там Т-хелперы (Th1, Th2 и Th17) и В-лимфоциты инициируют гуморальный адаптивный иммунный ответ. В основном синтезируется IgA (70\% синтеза всех иммуноглобулинов). Практически все IgA поступают на слизистые поверхности в виде димеров. В связи со своей структурой (закрытые Fс-фрагменты) sIgA ограничивает нормальную микрофлору от воздействия комплемента и гранулоцитов.

Учитывая, что система барьерных тканей тесно связана с регионарными лимфатическими образованиями: лимфатическим узлами, аппендиксом, миндалинами и пр. это позволяют перевести иммунный ответ с местного уровня на системный. С другой стороны часть антиген-специфических клеток выходит в системный кровоток и расселяется (хоминг) в другие участки MALT, формируя на месте синтез AT на данный АГ чем и обеспечивается глобальная защита всех барьерных тканей. Эффект действия пробиотиков можно объяснить в том числе и этим механизмом.

Основными клетками именно мукозального иммунитета являются макрофаги. Макрофаги представляют собой крупные клетки, которые присутствуют во всех органах и тканях, где может произойти микробное вторжение или накопление инородных частиц. В зависимости от местоположения имеют разные названия: моноциты - костный мозг / кровь, клетки Купфера - печень, гистиоциты - лимфатические узлы и соединительная ткань, микроглия - центральная нервная система, остеокласты - кость, внутриклубочковые мезангиальные клетки - почки, альвеолярные макрофаги - легкие, макрофаги красной пульпы - селезенка и т.д..

По происхождению необходимо выделять популяцию тканевых (или резидентных) макрофагов и макрофаги моноцитарного (костномозгового) происхождения. Тканевые макрофаги заселяют ткани в период эмбриогенеза и поддерживают свою численность за счёт пролиферации. Это долгоживущие клетки имеют выраженную тканеспецифичность и превалируют по численности над моноцитарными макрофагами, однако с возрастом организма их доля уменьшается.

Популяция макрофагов моноцитарного происхождения короткоживущая, однако их количество резко увеличивается при воспалении и нормализуется по его окончании. Это независимые друг от друга популяции выполняют многочисленные функции.

Во-первых, удаление умирающих или мертвых клеток и клеточного мусора. Во-вторых, играют решающую роль в инициации иммунного ответа, представляя антигены. В-третьих, за счет синтеза широкого спектра цитокинов макрофаги регулируют развитие воспаления, 
мукозальный, врожденный и адаптивный иммунные ответы. Синтезируя протеин С, тромбомодулин, тканевой фактор, фактор VII, фактор XIII и ингибитор активатора плазминогена, регулируют гемостаз.

Под воздействием различных сигнальных молекул макрофаги активируются с формированием различных функциональных фенотипов. Традиционно макрофаги разделяют на «классически активированные» макрофаги (M1 фенотип) и «альтернативно активированные» макрофаги (М2 фенотип), что позволило сформулировать гипотезу об их поляризации (по типу Th1/Th2). Однако накопившиеся сведения про другие типы макрофагов, которые отличались от фенотипов М1- и М2-макрофагов и метаболическое перепрограммирование макрофагов из M1 в M2 и наоборот не позволяют однозначно определять различные типы макрофагов. Тем не менее, на основе их функции и ключевых маркеров можно выделить популяцию M1 и 4 популяции M2 макрофагов (рис. 15).

M1 макрофаги формируются под воздействием PAMP, DAMP и провоспалительных цитокинов (IFN- $\gamma, \mathrm{TNF}$ ). Эти клетки обладают высокой фагоцитарной активностью, что позволяет им нейтрализовать любые патогены и фагоцитировать апоптозные нейтрофилы и другие клетки, обильно продуцируют цитокины.

Альтернативно активированные макрофаги М2 формируются при стимуляции их интерлейкинами, глюкокортикоидами, иммунными комплексами, агонистами TLR и др. Они мигрируют в зоны инвазии гельминтов, скапливаются в очагах фиброза, в заживающих ранах кожи и опухолях. На основе их функции и ключевых маркеров M2 макрофаги разделены на четыре отдельных типа - M2a, M2b, M2c и M2d. M2a наблюдаются вокруг личинок гельминтов и простейших, аллергены которых индуцируют иммунный Th2 ответ, сопровождающийся продукцией ИЛ-4 и ИЛ-13. М2b функционально близки к M1 макрофагам, продуцируют провоспалительные медиаторы, но и ИЛ10, усиливают продукцию антител. М2с макрофаги обладают супрессивными

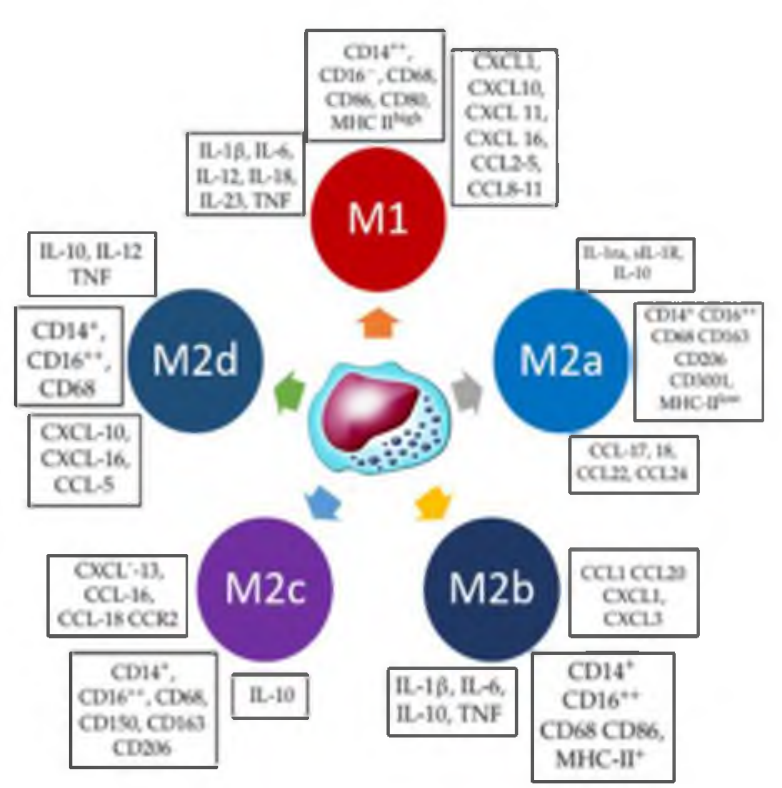

Рис. 15. Фенотипы макрофагов.

свойствами - тормозят активацию и пролиферацию $\mathrm{CD} 4^{+}$-лимфоцитов, вызванную антигенной стимуляцией и способствуют элиминации активированных Т-клеток. M2d особая группа макрофагов, формирующиеся в ответ на ИЛ-6 и аденозины. Эти макрофаги также рассматриваются как ассоциированные с опухолью макрофаги (ТАМ). Они стимулируют миграцию раковых клеток, образование метастазов и ангиогенез. ТАМ не способны лизировать опухолевые клетки, но в большом количестве синтезируют противовоспалительные цитокины, за счет чего снижается противоопухолевая активность Т- и NK-клеток.

Особыми защитными свойствами в основном без фагоцитоза на слизистых и в ткани обладают резидентные лимфоидные клетки. Эти популяции включают резидентные Тклетки памяти (T-RM) и «нетрадиционные» T-клетки (инвариантные NKT (iNKT) -клетки,

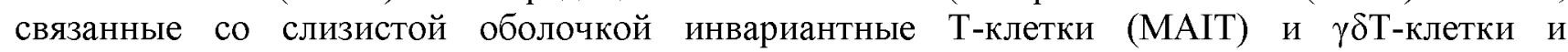
появляющееся семейство резидентных в ткани NK (trNK) -клетки. Они представляют большую группу лимфоцитов, выстилающие весь желудочно-кишечный тракт человека (на десять эпителиальных клеток приходится один лимфоцит). Часть из них представлено интраэпителиально (кишечные интраэпителиальные лимфоциты (iIEL), часть находится в собственной пластинке кишечника, образуя совместно с другими клетками иммунной системы 
лимфоидные структуры, такие как брыжеечные лимфатические узлы и пейеровы бляшки, а также диффузные лимфоидные фолликулы.

T-RM-клетки памяти обеспечивают передовую защиту от вторжения патогенов из-за их массивного присутствия в барьерных тканях. Это ранее сформировавшиеся ЦТЛ.

Считается, что Т-клетки стимулируются АПК, подвергаются клональной экспансии и дифференцируются в эффекторные Т-клетки, которые мигрируют к месту инфекции. После устранения инфекции меньшая часть этих эффекторных Т-клеток остается в живых и дифференцируется в Т-клетки памяти, которые могут быть обнаружены в крови (Т-клетки центральной памяти (Т-CM) и во вторичных лимфоидных органах (Т-клетки эффекторной памяти (Т-EM), но большая часть - это нециркулирующие Т-клетки памяти, которые остаются резидентными в периферических тканях (T-RM). При рестимуляции T-RM-клетки дают вторичные T-RM-клетки, которые участвуют в различных эффекторных функциях, включая цитолитическую активность, секрецию провоспалительных цитокинов (IFN- $\gamma$, ИЛ-12, TNF- $\alpha$ ), а также рекрутирование других клеток адаптивного и врожденного иммунитета. Группа iIEL включает разные подмножества $\mathrm{CD} 4^{+} \mathrm{TCR} \alpha \beta^{+}, \quad \mathrm{CD} 4^{+} \mathrm{CD} 8 \alpha \alpha^{+} \mathrm{TCR} \alpha \beta^{+}, \quad \mathrm{CD} 8 \alpha \beta^{+} \mathrm{TCR} \alpha \beta^{+}$, $\mathrm{CD} 8 \alpha \beta^{+} \mathrm{CD} 8 \alpha \alpha^{+} \mathrm{TCR} \alpha \beta+, \mathrm{CD} 8 \alpha \alpha^{+} \mathrm{TCR} \alpha \beta^{+}, \mathrm{iCD} 8 \alpha, \mathrm{iCD} 3^{+}$, однако функция многих из них не определена.

Клетки iNKT представляют собой липид-чувствительные Т-клетки врожденного иммунитета, напоминающие клетки ILC1 и ILC3, которые мы опишем ниже. Они играют значительную роль в надзоре за опухолью и контроле некоторых вирусных и бактериальных инфекций.

Клетки МАIT очень распространены у людей и проявляют функции аналогичные для клеток iNKT. MAIT-клетки помимо слизистых оболочек могут быть в крови, печени и легких. Клетки МАІТ реагируют на воспалительные цитокины (ИЛ-7, ИЛ-12, ИЛ-15, ИЛ-18, IFN- $\alpha / \beta$ ). Инфицированные клетки слизистых представляют АГ МАIT-клеткам, которые лизируют бактериально-инфицированные клетки, используя гранзим В. МАІТ так же вырабатывают провоспалительные цитокины и цитокины, активирующие адаптивный иммунитет, формируют иммунную память. При всех этих процессах необходимо большое количество витамина В2 (рибофлавин).

MAIT обнаружены и в первичных, и метастатических опухолях. Однако до сих пор неясно, играют ли они отягчающую роль в злокачественных новообразованиях или способствуют противораковому иммунитету.

Гамма/дельта Т-лимфоциты, (интраэпителиальные лимфоциты, $\quad \gamma \delta \mathrm{T}$-клетки). «Неклассическая» субпопуляция Т-лимфоцитов обладают одновременно свойствами эффекторных и регуляторных клеток. Основное место локализации MALT: слизистая оболочка кишечника и респираторного тракта, эпидермис кожи. В периферической крови человека содержание $\gamma \delta \mathrm{T}$-клеток не более $5 \%$ от числа лимфоцитов. Они участвуют в формировании 1-й линии иммунной защиты, играя роль цитотоксических клеток; выступая в качестве регуляторных Т-клеток ограничивают интенсивный иммунный ответ и аутоагрессию; способны к фагоцитозу мигрируя в лимфатические узлы, выступают как АПК и способствуют регенерации эпителия при его повреждениях. В основном распознают АГ без представления пептидных эпитопов в МНС, играют важную роль в распознавании липидных антигенов, могут запускаться сигналами тревоги, формировать иммунную память.

Резидентные в ткани NK (trNK) клетки. Клетки trNK были выделены из NK-клеток и считаются «врожденными аналогами» T-RM-клеток. Впервые описаны в печени. В дальнейшем дифференцируются в матке, коже, почках, легких и жировой ткани. Подмножество клеток $\operatorname{trNK}$ представляет собой CD56 bright-клетки, экспрессируют Ig-подобный рецептор киллерных клеток (KIR), с низким уровнем CD16, CD57 и перфорина. Они продуцируют высокие уровни воспалительных цитокинов, таких как IFN- $\gamma$, TNF и GM-CSF, плохо дегранулируют при стимуляции. Этот тип клеток был идентифицирован на границе раздела матери и плода. Их уменьшение ухудшает развитие плода и приводит к задержке роста плода. 
Большую роль в формировании мукозального иммунитета принадлежит В-лимфоцитам. Пул этих клеток можно разделить на 3 популяции: В1-, фолликулярные или В2-лимфоциты и В-клетки маргинальной зоны. Первые две популяции в большом количестве находятся в слизистых.

В1-лимфоциты - это небольшая популяция В-клеток (около 5 \% от общей популяции Вклеток). Они осуществляют быстрые реакции на проникновение через барьеры широко распространённых бактерий (противобактериальные «пограничники»), поэтому и локализованы в основном в прибарьерных полостях (брюшная и плевральная полости). Там же находятся и клетки-предшественники В1-лимфоцитов, т.к. их пул поддерживается без участия стволовых клеток костного мозга. В1-лимфоциты продуцируют IgM (определяется как IgM крови, который в основном и вырабатывается В1-лимфоцитами). Помимо этого, В1-лимфоциты продуцируют аутоантитела, структурно похожие на бактериальные антигены, например, белки системы групп крови АВО. Имеется мнение, что В1-клетки можно разделять на подклассы В1a $\left(\mathrm{CD}^{+}\right)$и $\mathrm{B} 1 \mathrm{~b}\left(\mathrm{CD}^{-}\right)$, хотя они сходные по своим свойствам.

В2 (фолликулярные)-лимфоциты - обычные «классические» В-лимфоциты, созревают в костном мозге, затем мигрируют в селезенку, проходя через две переходные стадии: Т1 и Т2. Т2 дифференцируются в фолликулярные (FO) В-клетки, или В-клетки маргинальной зоны (MZ). В2-клетки - наиболее распространенный тип В-клеток, не циркулируют в крови, обнаруживаются в основном в лимфоидных фолликулах (содержащих зародышевые центры), селезенке и лимфатических узлах. В отличии от других В-лимфоцитов, В2-клетки экспрессируют высокие уровни $\operatorname{IgD}$ и $\mathrm{CD} 23$, низкие уровни $\mathrm{CD} 21$ и $\operatorname{IgM}$, при отсутствии CD1 или CD5. Основная их функция: связываться с антигеном, получая помощь от Т-хелперов, дифференцироваться в плазматическую клетку, которая секретирует большое количество антител. В слизистых - это секреторные антитела $\operatorname{IgA}(\mathrm{SIgA})$. Данные антитела представляют собой димеры молекул IgA, соединенных Ј-цепью и секреторным компонентом, который транспортируется через барьер эпителиальных клеток в просвет органа (до 5 г в день). Секреторный компонент $\operatorname{sgA}$ защищает иммуноглобулин от действия протеолитических ферментов. SIgA связывается со слоем слизи желудочно-кишечного тракта, предстательной железы, респираторного эпителия, слезой, слюной, потом, выделением из мочеполовых путей покрывает эпителий, и действует как антигенспецифический барьер для патогенов и токсинов. Наличие его в молозиве обеспечивает иммунитета новорождённых и способствует формированию, а в дальнейшем и регулированию состава комменсальной микробиоты. Этот эффект достигается тем, что Fc-концы SIgA сшиты и не активируют фагоциты и комплемент.

Таким образом, мукозальный иммунитет - это первый уровень защиты организма с элементами взаимодействия врожденного и адаптивного иммунитета. На уровне MALT происходит основная защита организма от патогенных возбудителей. Чаще всего именно адекватные механизмы мукозального иммунитета обеспечивают бессимптомное течение инфекций. Однако, если происходит повреждение эпителия большой площади с проникновением в организм патогенных микроорганизмов и/или интенсивный синтез и секреция цитокинов, формируются системные реакции врожденного и адаптивного иммунитета и вовлечение всего организма в патологический процесс 


\section{КОМПАНИЯ “БИОХИММАК” ПЕРЕДОВЫЕ РЕШЕНИЯ ДЛЯ ЛАБОРАТОРНОЙ ДИАГНОСТИКИ}

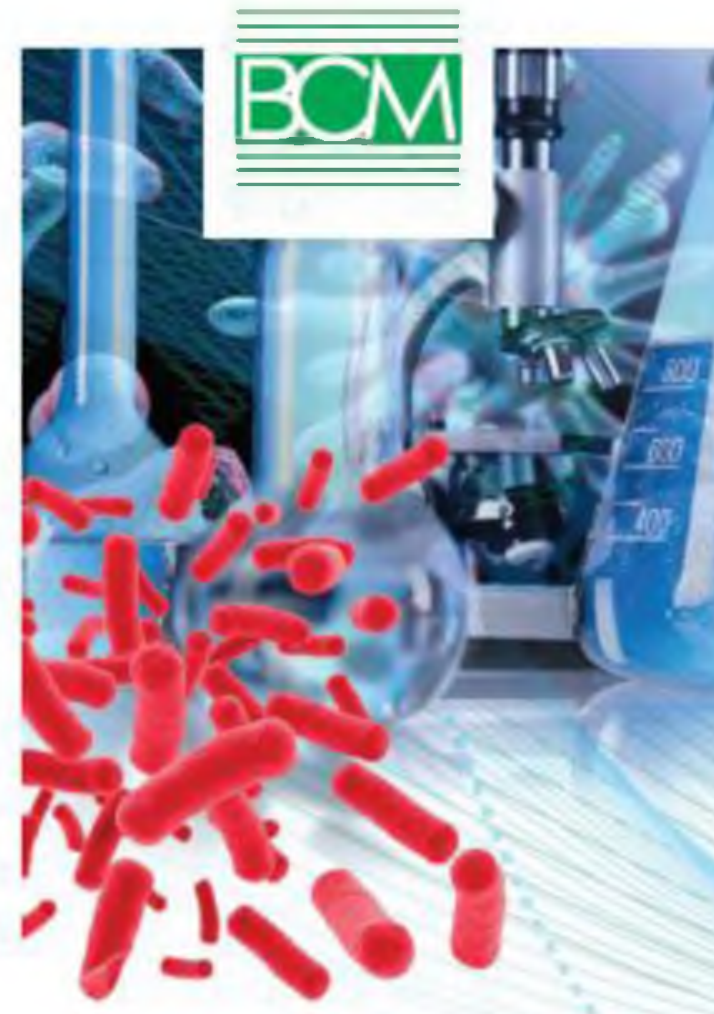

\section{КЛИНИЧЕСКИЕ ИССЛЕДОВАНИЯ}

- ИФА, ИММУНОХИМИЯ

- Биохимия

- ГЕМОСТАЗ

- ГЕМАТОЛОГИЯ

- ЦИтоМЕТРИЯ

- МОЛЕКУЛЯРНАЯ ДИАГНОСТИКА

- ЭКСПРЕСС-ДИАГНОСТИКА
МОЛЕКУЛЯРНЫЕ МЕТОДЫ

- ОБОРУДОВАНИЕ ДЛЯ РАЗНЫХ ЗАДАЧ

- TEHETИKA

- ГEHOMИKA

- HLA-ТИПИРОВАНИЕ

- КЛЕТОЧНЫЕ ТЕХНОЛОГИИ
СЕРВИС

- ПРОФЕССИОНАЛЬНЫЕ КОНСУЛЬТАЦИИ И ОБУЧЕНИЕ

- КОМПЛЕКСНЫЕ РЕШЕНИЯ В ОСНАЩЕНИИ ЛАБОРАТОРИЙ

- АВТОМАТИЗАЦИЯ И ЛИС

- ВВОД В ЭКСПЛУАТАЦИЮ И ОБСЛУЖИВАНИЕ ОБОРУДОВАНИЯ 


\section{ИММУННАЯ СИСТЕМА}

\section{Глава 3. Врожденный иммунитет}

Любой повреждающий агент-фактор, который по силе и длительности превосходит адаптационные возможности ткани, может вызвать ответную защитную реакцию организма. Эти факторы принято делить на внешние (экзогенные - микроорганизмы, химические вещества, физические воздействия) и внутренние (эндогенные - появляющиеся в самом организме в результате патологического процесса). Защитная реакция направлена на то, чтобы не допустить распространения патогена, ограничив и уничтожив его на месте проникновения, привлекая факторы всего организма (в отличии от мукозального иммунитета, где реакции обычно ограничиваются «местными» клетками и молекулами). Это достигается, прежде всего, воспалением, которое формируется в ответ на взаимодействие PRR c PAMP и/или DAMP описанными выше (рис. 16).

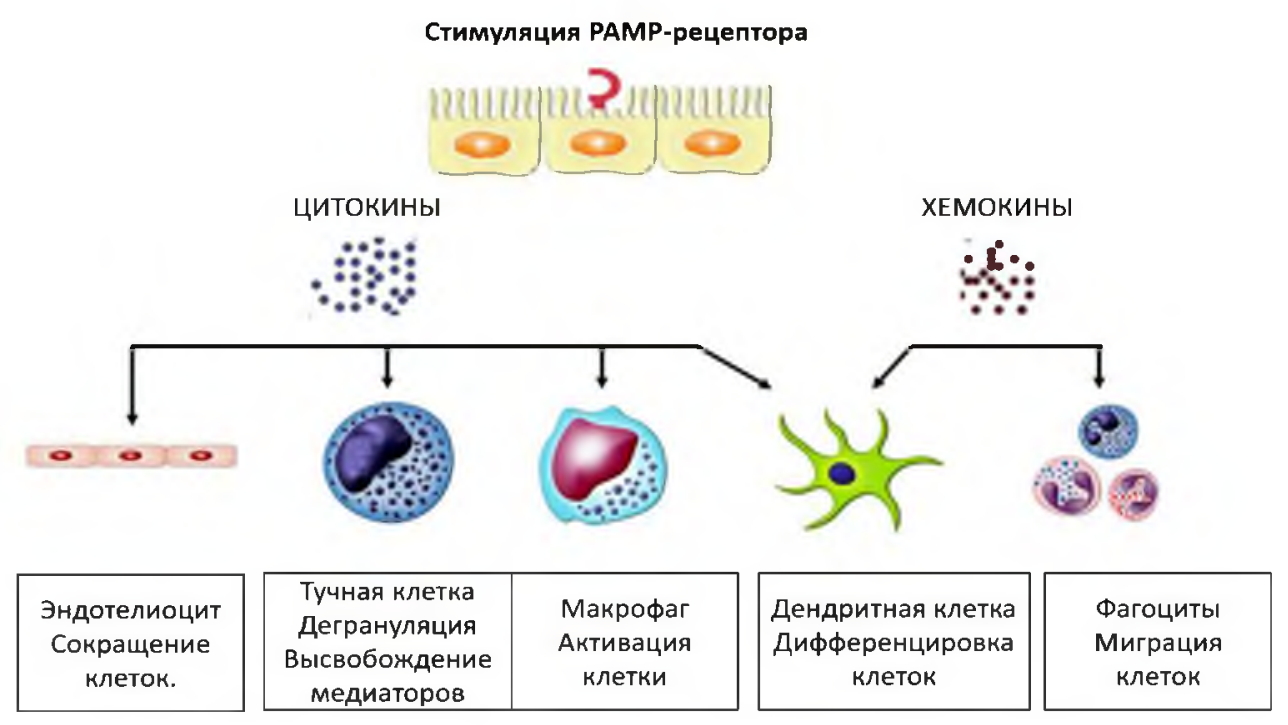

Рис. 16. Системные эффекты стимуляции РАМР.

Воспаление представляет собой скоординированный каскад системных иммунных, эндокринных и неврологических реакций, возникающий, в случае, когда повреждающий агент по силе и длительности превосходит барьерные возможности ткани, проявляется в локальных и системных реакциях, направленных на устранение патогена и максимального восстановления зоны повреждения $[19,38,74,92,113,115,126]$.

Воспаление всегда начинается с повреждения ткани и распознавания чужеродных веществ. При этом причиной повреждение клеток (некроз) может быть различной этиологии физической, химической, вирусной и т. д. С первичным повреждениями всегда связано вторичное которое возникает из-за запрограммированной гибели клеток. Механизмы такой гибели достаточно обширные (табл. 13). Однако важнейшим, с клинической точки зрения, является возникающее и/или поддерживающееся гибелью клеток воспаление $[21,38,115,125]$ 


\section{Виды клеточной гибели}

\begin{tabular}{|c|c|}
\hline Вид & Механизм \\
\hline Некроз & $\begin{array}{l}\text { Местная гибель ткани (омертвение) за счет экзогенных (травма, бактерии, вирусы, } \\
\text { токсины и пр.) и/или эндогенных (ишемия, трофоневротические расстройства) } \\
\text { факторов, приводящих к нарушению целостности клеточной мембраны и } \\
\text { высвобождению продуктов гибели клеток (DAMP) во внеклеточное пространство с } \\
\text { развитием воспаления. }\end{array}$ \\
\hline $\begin{array}{l}\text { Некроз, зависимый от } \\
\text { проницаемости } \\
\text { митохондрий (МРТ) }\end{array}$ & $\begin{array}{l}\text { При сильном окислительном стресс и значительном повышении концентрации } \\
\text { ионов кальция в цитозоле происходит исчезновению электрохимического } \\
\text { градиента на мембране митохондрий с дальнейшим их разрушением. }\end{array}$ \\
\hline Некроптоз & $\begin{array}{l}\text { Запрограммированная форма некроза или воспалительной гибели клеток. } \\
\text { Развивается в результате клеточного повреждения или инфильтрации патогенами }\end{array}$ \\
\hline Пироптоз & $\begin{array}{l}\text { Под воздействием бактериальных липополисахаридов и активаци каспазы- } 1 / 4 / 5 \\
\text { формируются поры в плазматической мембраны с последующей гибелью клетки. } \\
\text { Воспалительный тип гибели клеток. }\end{array}$ \\
\hline Ферроптоз & $\begin{array}{l}\text { Инициированная окислительными нарушениями повреждение клеточных } \\
\text { липидов из-за ионов железа, некроз с повреждением митохондрий. }\end{array}$ \\
\hline Партанатос & $\begin{array}{l}\text { Независимая от каспаз гибель клеток за счет активации PARP1 (Поли (АДФ-рибоза) } \\
\text { полимераза) фермента, обнаруживающего повреждение ДНК с последующей } \\
\text { биоэнергетической катастрофой и деградацией ДНК. }\end{array}$ \\
\hline $\begin{array}{l}\text { Лизосомальная } \\
\text { гибель клеток (LDCD) }\end{array}$ & $\begin{array}{l}\text { При повреждении лизосом происходит высвобождение в цитоплазму их } \\
\text { содержимого (протеолитические ферменты), за счет чего активируются } \\
\text { внутриклеточные каскады, приводящие к гибели клетки. }\end{array}$ \\
\hline $\begin{array}{l}\text { Иммуногенная } \\
\text { клеточная гибель }\end{array}$ & Гибель клетки, которая определяется активацией адаптивного иммунного ответа. \\
\hline Немо3 & $\begin{array}{l}\text { Процесс активации и гибели фибробластов создает большое количество } \\
\text { медиаторов воспаления (простагландины). }\end{array}$ \\
\hline $\begin{array}{l}\text { Апоптоз: } \\
\text { внешний и } \\
\text { внутренний }\end{array}$ & $\begin{array}{l}\text { За счет внешних сигналов (рецепторный путь) и/или выхода апоптогенных белков } \\
\text { из митохондрий в цитоплазму клетки (митохондриальный путь), клетка под } \\
\text { действием каспазного каскада распадается на отдельные апоптотические тельца, } \\
\text { ограниченные плазматической мембраной. Апоптические тельца фагоцитируются } \\
\text { макрофагами и расщепляются в их лизосомах, без воспаления. }\end{array}$ \\
\hline Аноикис & $\begin{array}{l}\text { Специфический вариант внутреннего апоптоза, инициированного потерей } \\
\text { интегрин-зависимого закрепления. }\end{array}$ \\
\hline Митотическая смерть & Внутренний апоптоз, вызванный митотической катастрофой. \\
\hline Эриптоз & $\begin{array}{l}\text { Гибель эритроцитов, которая возникает в поврежденных эритроцитах из-за } \\
\text { различных факторов, включая гиперосмолярность, окислительный стресс, } \\
\text { истощение энергии, воздействие тяжелых металлов или ксенобиотиков. }\end{array}$ \\
\hline Аутофагия & $\begin{array}{l}\text { Компоненты клетки захватываются лизосомой (микроаутофагия), окружаются } \\
\text { мембранной и сливаясь с лизосомами (макроаутофагия) или денатурированные } \\
\text { белки доставляются в лизосомы шаперонами (шапероновая аутофагия). Остатки } \\
\text { клетки (дебрис) поглощаются макрофагами, без воспаления. }\end{array}$ \\
\hline Эффероцитоз & Механизм захвата и удаления мертвых клеток и их фрагментов фагоцитами. \\
\hline $\begin{array}{l}\text { Энтотическая гибель } \\
\text { клеток }\end{array}$ & $\begin{array}{l}\text { Возникает в результате актомиозин-зависимой интернализации клетки, в клетке } \\
\text { (энтоза) осуществляется лизосомами. }\end{array}$ \\
\hline Корнификация & $\begin{array}{l}\text { Клетки внешнего слоя эпидермиса погибают за счет накопления кератина, образуя } \\
\text { роговой слой (слой мертвых кератиноцитов - ороговевание). }\end{array}$ \\
\hline Параптоз & $\begin{array}{l}\text { Гибель клеток за счет активации митоген-активированной протеинкиназа и N- } \\
\text { концевые киназы с внутриклеточным образованием вакуолей и набуханием } \\
\text { митохондрий. }\end{array}$ \\
\hline
\end{tabular}

Можно выделить шесть групп молекулярных механизмов, имеющих большое значение в патогенезе повреждения клетки. 
1. Липидные механизмы повреждения клетки, происходящие за счет перекисного окисление липидов, активации мембранных фосфолипаз и детергентного действия свободных жирных кислот.

2. Кальциевые механизмы - повреждение клетки обусловлено повышением концентрации ионов кальция в ее цитоплазме. В основе такого повышения могут лежать два механизма: избыточное поступление $\mathrm{Ca}^{2+}$ в цитоплазме и нарушение удаления их из цитоплазмы.

3. Электролитно-осмотические механизмы обусловлены сдвигами в содержании главных клеточных катионов $\left(\mathrm{Na}^{+}\right.$и $\left.\mathrm{K}^{+}\right)$.

4. Ацидотические механизмы - в основе этой группы механизмов повреждения лежит увеличение концентрации ионов водорода в клетке, т.е. внутриклеточный ацидоз.

5. Протеиновые механизмы, включающие в себя ингибирование ферментов (обратимое и необратимое), денатурацию (нарушение нативного строения белковых молекул в результате изменений вторичной и третичной структур белка, обусловленных разрывом нековалентных связей) и протеолиз, осуществляющийся под действием лизосомальных гидролитических ферментов (катепсинов) и $\mathrm{Ca}^{2+}$-активируемых протеаз.

6. Основу нуклеиновых механизмов повреждения клеток составляют нарушения трех процессов: репликации ДНК, транскрипции и трансляции.

На субклеточном уровне реализация рассмотренных выше молекулярных механизмов повреждения клетки приводит к нарушению строения и функции отдельных ее органелл. Поскольку большинство из них относится к мембранным образованиям, универсальным механизмом повреждения субклеточных структур является нарушение проницаемости и целостности клеточных мембран.

Повреждение цитоплазматической мембраны может проявляться нарушениями ее барьерной функции, расстройствами систем активного транспорта веществ $\left(\mathrm{Na}^{+}, \mathrm{K}^{+}-\right.$и $\mathrm{Ca}^{2+}$ насосов, $\mathrm{Na}^{+}, \mathrm{Ca}^{2+}$ - и $\mathrm{Na}^{+}, \mathrm{H}^{+}$-обменных механизмов и др.), изменениями белков, образующих специфические каналы ионной проводимости, повреждением рецепторных макромолекул, воспринимающих внешние регуляторные сигналы, нарушениями белковых комплексов, осуществляющих межклеточные взаимодействия, и, наконец, изменениями гликопротеидов, определяющих антигенность клетки.

Наиболее характерными проявлениями повреждения митохондрий являются эффекты разобщения окисления и фосфорилирования и угнетение клеточного дыхания. Основной патогенетический фактор разобщения окисления и фосфорилирования - нарушение барьерной функции внутренней митохондриальной мембраны, в результате чего не может быть реализован механизм сопряжения клеточного дыхания и ресинтеза АТФ.

Повреждение эндоплазматического ретикулума проявляется нарушениями свойственных ему многочисленных функций: синтетической, детоксикационной, депонирующей и др.

Повреждение лизосом сопровождается выходом и активацией многочисленных гидролитических ферментов, в результате чего повреждение клетки становится необратимым, происходит ее аутолиз.

С повреждением микротрубочек и микрофиламентов могут быть связаны изменения формы клетки, нарушение ее подвижности, угнетение процессов клеточного деления.

Процесс повреждение клетки всегда связан с повреждением митохондрий клеток. Начинает преобладать гликолиз, возникает дефицит АТФ и энергии, идет накопление недоокисленных продуктов (молочной кислоты), возникает ацидоз, развитие, которого, в свою очередь, приводит к нарушению активности ферментных систем, к дезорганизации метаболического процесса. Повреждение мембран лизосом с высвобождением лизосомальных ферментов ведет к летальному повреждению клеток и высвобождению медиаторов. Кроме того, лизосомальные ферменты, действуя на субстраты, образуют новые биологические активные вешества, токсически действующие на клетку и усиливающие повреждение ткани. Повреждение мембран и недостаток АТФ ведет к нарушению основной транспортной системы 
- калиево-натриевого насоса. Универсальным проявлением повреждения любой ткани всегда будут выход калия из клеток и задержка в клетках натрия, с которой связано еще одно тяжелое или летальное повреждение - задержка в клетках воды, т.е. внутриклеточный отек. Выход калия ведет к углублению процесса дезорганизации метаболизма. Нарушение биоэнергетики в этом комплексе проявляется в снижении потребности кислорода тканью, уменьшается тканевое дыхание. Универсальным показателем повреждения любой ткани является дегрануляция тучных клеток.

B процессе разрушения клеток выходит большое количество DAMP, которые совместно с РАMP распознаются макрофагами, эпителиальными клетками и кератоцитами с формированием в них инфламмасом (цитозольный мультибелковый олигомер ответственный за активацию воспалительных реакций) с активным синтезом провоспалительных цитокинов и инициации пироптоза.

На повреждение отвечают все элементы ткани: микроциркуляторные единицы (артериолы, капилляры, венулы), соединительная ткань, тучные и нервные клетки. Формируется воспаление. Несмотря на многообразие факторов, вызывающих воспалительную реакцию, закономерности ответа на повреждение, которые происходят в тканях, однотипны. Они представлены единством трех основных явлений, которые хоть и взаимосвязаны, но идут независимо друг от друга (рис. 17).

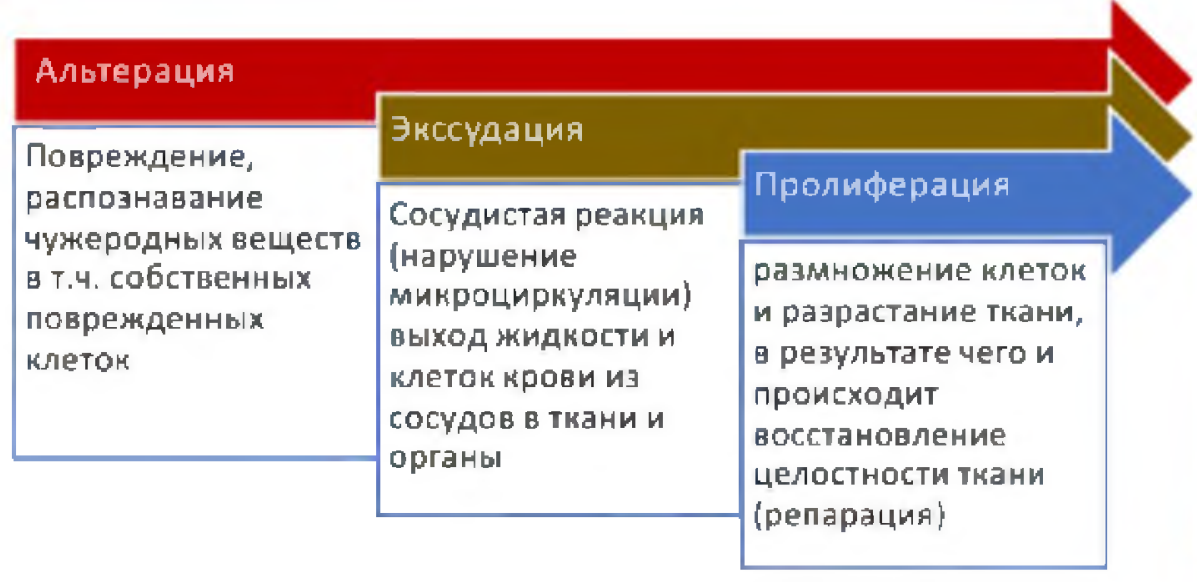

ВОСПАЛЕНИЕ

rubor - местное покраснение

tumor - опүхоль (отёк).

calor -

повышение

температуры.

dolor - боль.

functio laesa -

нарушение

функции

Рис. 17. Воспаление

Сосудистая реакция начинается со спазма сосудов - кратковременной реакции, которая переходит в фазу артериальной гиперемии (более длительная). Гиперемия - это усиленное кровенаполнение ткани за счет увеличенного притока крови: возрастает скорость кровотока, повышается давление в сосудах и интенсивность обмена веществ в капиллярах. Отсюда внешние признаки воспаления на этой фазе - покраснение, местный жар (повышение температуры), боль, вызванная действием медиаторов. Уже на этой стадии начинается процесс экссудации.

Под действием медиаторов происходит выход жидкой части плазмы за пределы сосуда экссудация. Экссудат содержит большое количество белка в связи с нарушением проницаемости сосуда. Он сдавливает венулы и происходит смена артериальной гиперемии на венозную. Чем больше экссудата, тем более выражены явления венозного застоя. Венозная гиперемия постепенно переходит в венозный стаз. Именно в этой фазе происходят значительные изменения поврежденной ткани - так называемые явления вторичного повреждения. Любой венозный застой сопровождается гипоксией: переход на анаэробный процесс окисления - гликолиз, возникновение ацидоза за счет недоокисленных продуктов, т.е. те изменения, которые характерны для первичного повреждения. Накопление кислых продуктов в фазу венозного застоя достигает колоссальных количеств. Наблюдается резко 
выраженный ацидоз (сдвиг рН до 6,0 - 5,8), а такой сдвиг рН уже непереносим клетками, и они погибают. В центре очага воспаления возникает некроз. При незначительном повышении концентрации водородных ионов (на периферии очага воспаления), нелетальных повреждений клеток незначительный сдвиг рН стимулирует разрастание грануляционной ткани - образуется грануляционный вал на периферии, здоровая ткань отграничивается от поврежденной. Она богата фиксированными макрофагами, способна поглощать поврежденные клетки, токсины, очищая очаг.

Вторичное повреждение также проявляется гиперосмией и гиперонкией. Развитие гиперосмии определяется усиленным катаболизмом и распадом тканей. Распад белковых частиц, жиров, углеводов, выброс калия из клеток с усилением диссоциации солей создают высокую осмотическую концентрацию - гиперосмию. Гиперонкия - увеличение концентрации белков за счет распада ткани, экссудации плазменных белков из сосудов с нарушенной проницаемостью. Эти явления создают порочный круг, усиливая процесс экссудации. Белки как бы притягивают воду, а гиперосмия является повреждающим фактором, который повышает проницаемость стенки сосуда.

При экссудации изменяются биологические свойства крови - увеличивается ее вязкость, кровоток замедляется, усиливаются процессы тромбообразования, наблюдается краевое стояние лейкоцитов, которые выстраиваются вдоль сосудистой стенки, а затем наблюдается их миграция в очаг воспаления. Изменение спектра плазменных белков (выход альбумина, повышение концентрации $\gamma$-глобулинов, простагландинов и других медиаторов) влияет на состав мембран, повышает ригидность, преобразует поверхностное натяжение мембран эритроцитов, что усиливает их способность к агрегации (причина ускореного СОЭ).

Тромбоциты тоже приобретают способность к агрегации, но в отличие от эритроцитов этот процесс идет на поверхности сосудистой стенки, в месте ее повреждения. При воспалении происходит ее повреждение, количество простациклина, который предотвращает адгезию и агрегацию тромбоцитов, уменьшается, начинаются процессы адгезии и агглютинации тромбоцитов. Из тромбоцитов выделяются тромбоксаны - мощные стимуляторы процессов адгезии и агрегации. В нормальных условиях эта простациклин-тромбоксановая система уравновешена. При воспалении происходит активация фактора Хагемана, уменьшение содержания гепарина, что ведет к коагуляции и множественным процессам тромбообразования в очаге воспаления.

Экссудация способствует отграничению очага воспаления, препятствует оттоку токсинов, микробов, распавшихся тканей. В составе экссудата в поврежденную ткань выходят биологические активные вещества, медиаторы, которые способны нейтрализовать токсины, защитные белки, АТ, лейкоциты.

За счет увеличения проницаемости сосудистой стенки происходит проникновение не только белков, но и клеток - клеточная миграция. При этом различные популяции мигрирующих клеток появляются в очаге воспаления в определенном порядке. Первыми, как правило, прибывают нейтрофилы (через 1,5-2 часа). В течение первых суток их популяция преобладает среди пула клеток воспалительного экссудата.

На вторые сутки в очаг начинают поступать мононуклеарные фагоциты и лимфоциты. Позже других мигрируют цитотоксические Т-клетки и В-лимфоциты. Следует отметить, что, как и многие другие процессы при воспалении, миграцию не всегда удается трактовать однозначно. Она изменчива и зависит от целого ряда факторов как эндотелиального, так и лейкоцитарного происхождения. Миграция зависит и от анатомической области, где протекает воспаление, и от присутствия хемотаксических молекул, и от наличия различных цитокинов в тканях (прежде всего хемокинов), и от характера активации мигрирующих клеток (наличие на их поверхности рецепторов) и т.д. В процессах миграции можно выделить несколько основных этапов (рис. 18):

Адгезия лейкоцитов на эндотелии сосудов, осуществляемая за счет молекул межклеточной адгезии (связанные с плазматической мембраной белки, обеспечивающие механическое взаимодействие клеток друг с другом). Выделяют: интегрины - молекулы, 
функционирующие как клеточно-субстратные, так и межклеточные адгезивные рецепторы; адгезивные рецепторы суперсемейства иммуноглобулинов (ICAM), которые участвуют в межклеточной адгезии, заживлении ран и иммунном ответе; селектины $(\mathrm{L}, \mathrm{P}$ и $\mathrm{E})$ обеспечивает адгезию лейкоцитов к эндотелиальным клеткам; адрессины - находятся на мембране эндотелиоцитов - лиганды для селектинов, с которыми обеспечивают адгезию клеток к стенке сосуда, и дальнейшего проникновения в очаг поражения; кадгерины - кальцийзависимые гомофильные межклеточные адгезивные белки; хоминговые рецепторы - молекулы, обеспечивающие попадание лимфоцитов в специфическую лимфоидную ткань.

- Трансэндотелиальная миграция лейкоцитов, осуществляемая под действием медиаторов воспаления, взаимодействия интегринов и молекул адгезии, клетки преодолевают эндотелиальный слой за счет повышенной сосудистой проницаемости и тока жидкости из сосуда в ткань, а базальные мембраны за счет лизосомальных протеиназ, растворяющие ее, и катионных белков,

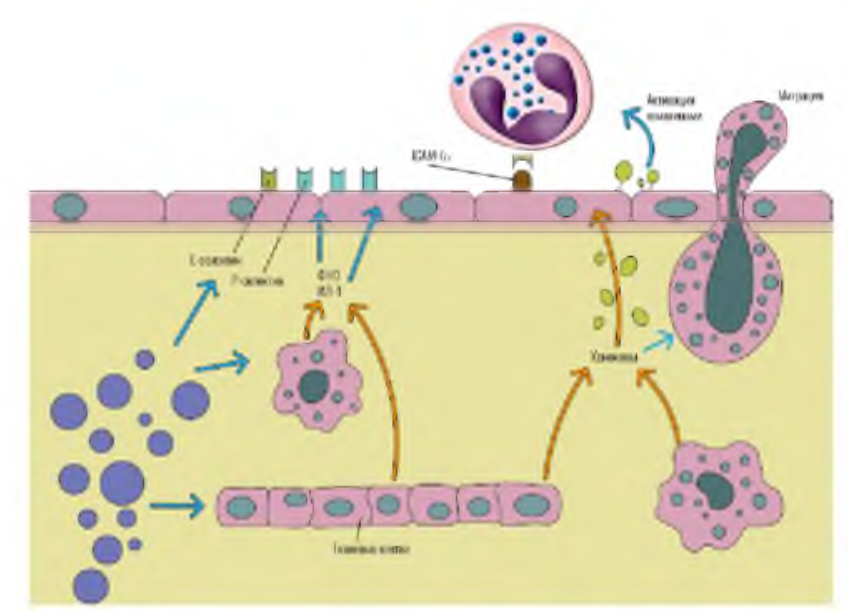

Рис. 18. Клеточная миграция. изменяющие ее коллоидное состояние.

- Хемотаксис - направленная миграция в межклеточном пространстве за счет градиента концентрации хемотаксических веществ в очаге воспаления (продукты протеолиза тканей) и разностью потенциалов между отрицательно заряженным лейкоцитом и положительным зарядом ткани. Хемотаксис имеет значение на всех этапах миграции лейкоцитов, особенно в ткани, в которой отсутствуют сосуды.

Во всех процессах миграции большая роль принадлежит хемокинам и их рецепторам. Семейство этих небольших цитокинов или сигнальных белков, секретируемых практически всеми видами клеток, играют центральную роль в регуляции миграции клеток, особенно лейкоцитов (табл. 14). Однако с активацией хемокинов связано и множество других биологических процессов, включая пролиферацию, выживаемость, дифференцировку, продукцию цитокинов, дегрануляцию и респираторный взрыв (рис.19). У человека известно около 50 хемокинов (по структуре это четыре группы: СXC, CC, CX3С, С). Рецепторы хемокинов экспрессируются во всех лейкоцитах (наибольшее их количество и разнообразие на Т-лимфоцитах). Именно от различных комбинаций хемокиновых рецепторов (описано 19 хемокиновых рецепторов четырех семейств) зависят различные пути миграции лейкоцитов.

Таблица 14

\section{Хемокины привлекающие клетки иммунной системы}

\begin{tabular}{|l|l|}
\hline \multicolumn{1}{|c|}{ Привлекаемые клетки } & \multicolumn{1}{c|}{ Хемокины } \\
\hline Моноциты / макрофаги & CCL2, CCL3, CCL5, CCL7, CCL8, CCL13, CCL17 и CCL22 \\
\hline \multirow{2}{*}{ т-лимфоциты } & CCL2, CCL1, CCL22 и CCL17 CXCR3 \\
\cline { 2 - 2 } & индуцируемые IFN-ץ хемокины CXCL9, CXCL10 и CXCL11 \\
\hline тучные клетки & CCL2 и CCL5 $\quad$ CXCL8 ингибирует тучные клетки \\
\hline Эозинофилы & $\begin{array}{l}\text { CCL11, CCL24, CCL26, CCL5, CCL7, CCL13 и CCL3 } \\
\text { CCL11 (эотаксин) CCL5 (RANTES) }\end{array}$ \\
\hline Нейтрофилы & CXCL8 (IL-8) \\
\hline
\end{tabular}


По выполняемым функциям хемокины можно разделить на постоянно вырабатывающиеся (гомеостатические) для миграции лейкоцитов и образующиеся при патологических состояниях (воспалительные) $[35,45,79,88,118,127]$ :

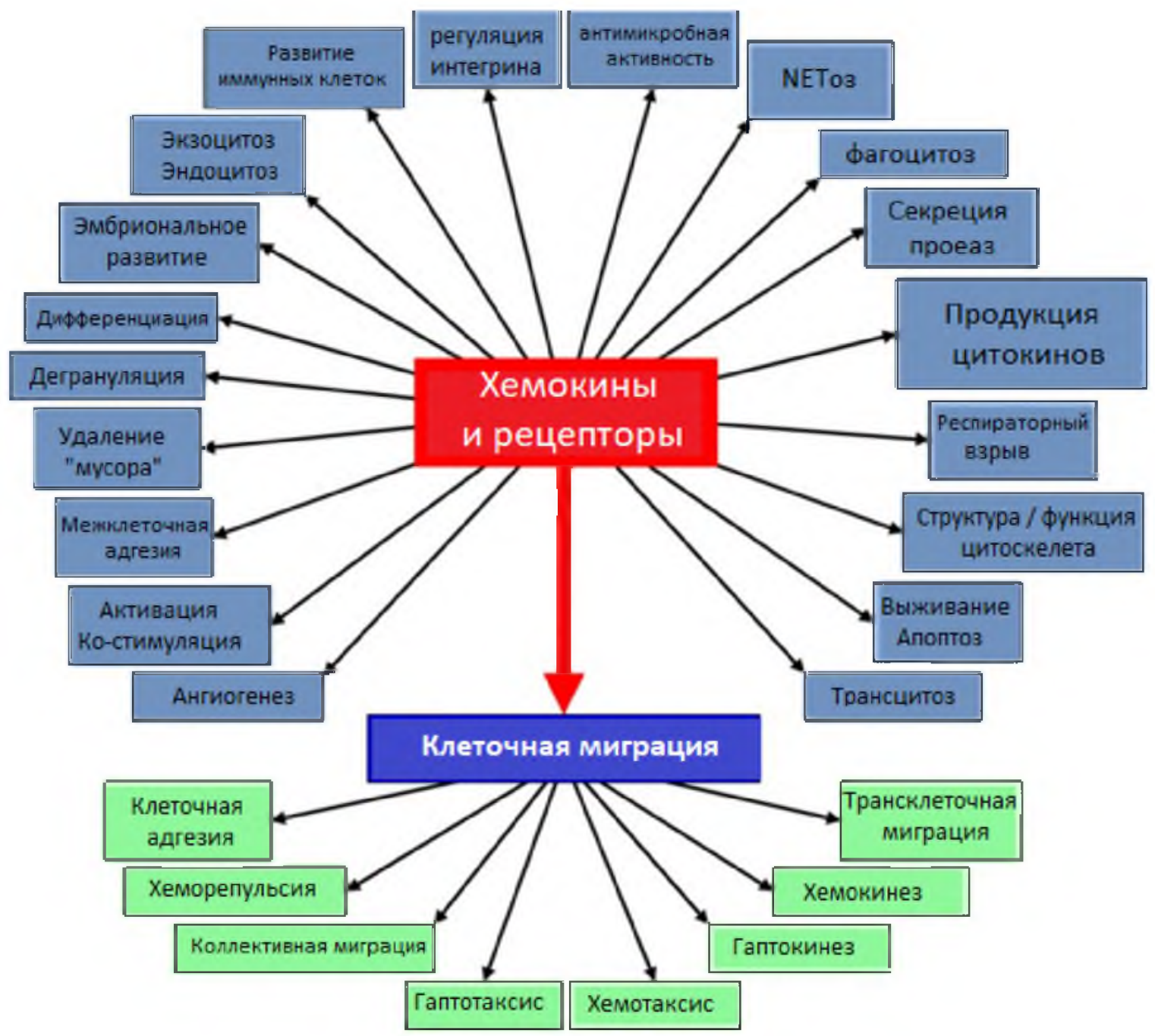

\section{Рис. 19. Функции хемокинов и их рецепторов}

Гомеостатические хемокины CCL19 и CCL21 (экспрессируемыми в лимфатических узлах) и их рецептор CCR7 направляет антигенпрезентирующие клетки к лимфатическим узлам. CCR9 поддерживает миграцию лейкоцитов в кишечник, CCR10 - к коже и CXCR5 - Bклеток к фолликулам лимфатических узлов. CXCL12 (SDF-1), способствует пролиферации Вклеток-предшественников в микроокружении костного мозга.

Воспалительные хемокины продуцируются в высоких концентрациях во время инфекции или травмы и определяют миграцию воспалительных лейкоцитов в поврежденную область (CCL2, CCL3 и CCL5, CCL11, CXCL1, CXCL2, CXCL8, CXCL10). Основной из них CXCL-8, действует как хемоаттрактант для нейтрофилов. Поэтому клеточный состав экссудата в значительной степени зависит не только от этиологического фактора, но и от состава хемокинов и их рецепторов. Так, если воспаление вызвано стафилококками и стрептококками, в вышедшей жидкости преобладают нейтрофильные гранулоциты, если оно протекает на иммунной основе (аллергия) или вызвано паразитами (гельминты) - содержится много эозинофилов. При хроническом воспалении (туберкулез, сифилис) в экссудате имеется много мононуклеаров (лимфоциты, моноциты). 
После завершения воспалительного процесса в очаге наблюдается постепенное исчезновение клеток крови, начиная с тех лейкоцитов, которые появились раньше (нейтрофильные гранулоциты). Позже элиминируются лимфоциты и моноциты.

Процесс миграции может не только стимулироваться, но и подавляться. Ингибиторы хемотаксиса вырабатываются активированными лимфоцитами.

В процессе развития воспаления клетки участники синтезируют и секретируют большое количество цитокинов, обладающих как про- так и противовоспалительным действием. Цитокины - это низкомолекулярные регуляторные белки или гликопротеины, секретируемые клетками иммунной системы и различными другими клетками в ответ на ряд стимулов. Они представляют собой универсальную, полиморфную, регуляторную сеть медиаторов, предназначенных для контроля процессов пролиферации, дифференцировки и функциональной активности клеточных элементов в кроветворной, иммунной и в других гомеостатических системах организма. Они регулируют развитие иммунных эффекторных клеток, некоторые цитокины обладают собственными эффекторными функциями. Некоторые цитокины могут связываться с рецепторами на мембране той же самой клетки, которая его секретировала, оказывая аутокринное действие; он может связываться с рецепторами на клетке-мишени в непосредственной близости от клетки-продуцента, оказывая паракринное действие; в некоторых случаях он может связываться с клетками-мишенями в отдаленных частях тела, оказывая системное действие $[35,38,79]$.

В одних случаях один и тот же цитокин может стимулировать пролиферацию клеток, в других их дифференцировку, в-третьих, - изменять функциональное состояние. Многие цитокины характеризуются целым спектром эффектов, оказываемых на различные ткани тканеспецифичность действия, которая определяется различными типами рецепторов, экспрессирующихся на клетках, и факторами транскрипции, активирующимися при передаче сигнала. При этом биологические эффекты, оказываемые разными цитокинами, могут в значительной степени перекрываться, поскольку многие рецепторы используют общие цепи и/или запускают сходные внутриклеточные каскады. Именно от их баланса зависит исход развития патологического процесса как в ранний, так и в отсроченный период (рис 20).

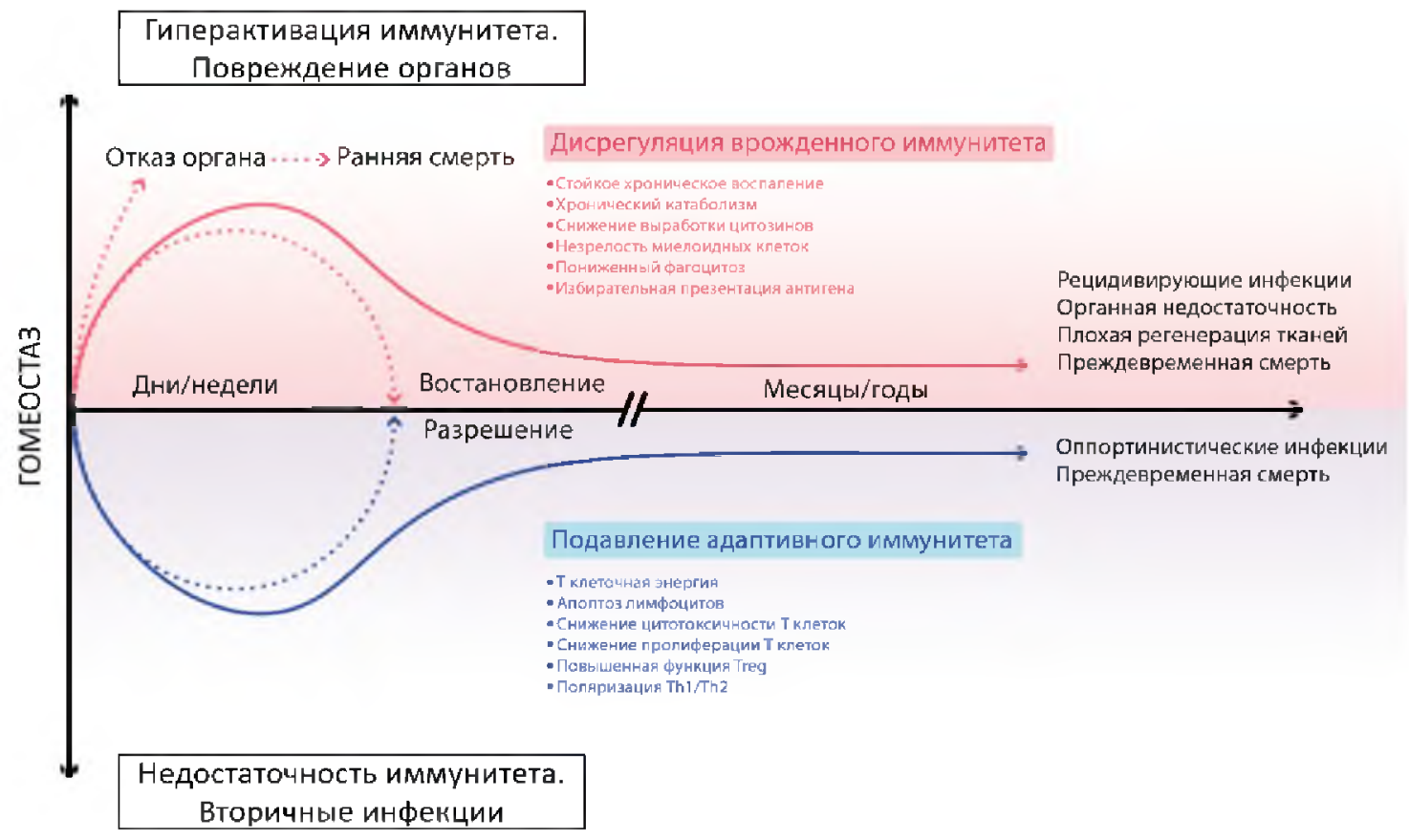

Рис. 20. Биологическое эффекты цитокинов при патологических процессах.

У здоровых людей концентрация цитокинов в крови ничтожно мала (пикограммы-10$12 /$ мл), при развитии патологического процесса «по запросу» начинается синтез и секреция 
цитокинов, но они вырабатываются непродолжительное время (матричная РНК цитокинов короткоживущая). При отсутствии «запроса» клетка, синтезирующая цитокины, переключается на синтез супрессорных цитокинов и/или экспрессирует ингибиторные рецепторы или рецепторы для сигналов к апоптозу. При несостоятельности местных защитных реакций синтез цитокинов возрастает в разы. Прежде всего, это синтез провоспалительных цитокинов врожденного иммунитета (табл. 15), в меньшей степени провоспалительных цитокинов продукта активированных Т-лимфоцитов. (табл. 16) [35, 114, 129].

Таблица 15

\section{Провоспалительные цитокины (врождённого иммунитета)}

\begin{tabular}{|c|c|c|c|}
\hline Цитокины & Клетки-продуценты & Мишени & Эффекты \\
\hline $\begin{array}{l}\text { Семейство } \\
\text { ил-1 (ил- } \\
1 \alpha, \text { ил--1 } \\
\text { ил-18, ил- } \\
33, \text { ил-36, } \\
\text { ил-37, ил- } \\
38)\end{array}$ & $\begin{array}{l}\text { Моноциты, макрофаги, } \\
\text { дендритные клетки, NK- } \\
\text { клетки, В-лимфоциты, } \\
\text { эпителиальные и } \\
\text { эндотелиальные клетки, } \\
\text { кератиноциты }\end{array}$ & $\begin{array}{l}\text { Клетки сосудистой } \\
\text { системы, } \\
\text { гипоталамуса, } \\
\text { печени }\end{array}$ & $\begin{array}{l}\text { Вызывает воспалительные сосудистые } \\
\text { реакции, повышение температуры тела, } \\
\text { индукцию секреции белков острой фазы. }\end{array}$ \\
\hline $\begin{array}{l}\text { Семейство } \\
\text { ил-6 (ил-6, } \\
\text { ил-27, ил- } \\
31, \text { LIF) }\end{array}$ & $\begin{array}{l}\text { Макрофаги, Т-клетки, } \\
\text { эндотелиальные клетки, } \\
\text { кератиноциты другие в } \\
\text { т.ч. опухолевые клетки }\end{array}$ & $\begin{array}{l}\text { Гепатоциты, } \\
\text { моноциты, Th, B- } \\
\text { лимфоциты, } \\
\text { плазматические } \\
\text { клетки }\end{array}$ & $\begin{array}{l}\text { Индукция секреции белков острой фазы, } \\
\text { ингибитор ФНО и ИЛ-1, стимулирует } \\
\text { дифференцировку В-клеток, активация Т- } \\
\text { лимфоцитов и дифференцировка их в } \\
\text { Th17-клетки. Миокины. }\end{array}$ \\
\hline 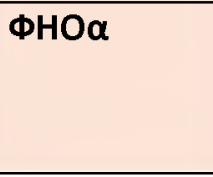 & $\begin{array}{l}\text { В основном макрофаги, а } \\
\text { также моноциты, NK-, } \\
\text { Th1-клетки }\end{array}$ & $\begin{array}{l}\text { Сосудистая система, } \\
\text { печень, нейтрофилы } \\
\text { и многие другие } \\
\text { типы клеток }\end{array}$ & $\begin{array}{l}\text { Кахексия. Сосудистые реакции, индукция } \\
\text { секреции белков острой фазы, } \\
\text { активирует нейтрофилы, вызывает } \\
\text { апоптоз клеток в т.ч. опухолевых. }\end{array}$ \\
\hline
\end{tabular}

Таблица 16

\section{Провоспалительные цитокины (продукты активированных Т-лимфоцитов)}

\begin{tabular}{|c|c|c|c|}
\hline Цитокины & Клетки-продуценты & Мишени & Эффекты \\
\hline$\Phi H O \beta(L T \alpha)^{*}$ & Тh1, ЦТЛ & Многие типы клеток & $\begin{array}{l}\text { Активность сходна с ФНОа, сильное } \\
\text { противоопухолевое действие }\end{array}$ \\
\hline $\begin{array}{l}\text { ИЛ-5 (CSF Аля } \\
\text { эозинофилов) }\end{array}$ & Th2, тучные клетки & $\begin{array}{l}\text { Эозинофилы, } \\
\text { В-лимфоциты }\end{array}$ & $\begin{array}{l}\text { Дифференцировка и активация } \\
\text { эозинофилов. Переключение } \\
\text { синтеза на IgA }\end{array}$ \\
\hline ил-16 & $\begin{array}{l}\text { ЦТЛ, эпителиальные } \\
\text { клетки, эозинофилы }\end{array}$ & $\begin{array}{l}\text { Т-лимфоциты, } \\
\text { дендритные клетки, } \\
\text { макрофаги, моноциты, } \\
\text { эозинофилы }\end{array}$ & $\begin{array}{l}\text { Хемоаттрактант и активатор для } \\
\text { клеток, экспрессирующих CD4 (Th,, } \\
\text { макрофаги, дендритные клетки, } \\
\text { моноциты, эозинофилы Участвует в } \\
\text { развитии хронического воспаления }\end{array}$ \\
\hline $\begin{array}{l}\text { Семейство } \\
\text { ил-17 (ИЛ- } \\
17 A, \text { ил-17B, } \\
\text { ил-17C, ил- } \\
17 D, \text { ил-17F, } \\
\text { ил-25) }\end{array}$ & Т-лимфоциты (Th17) & $\begin{array}{l}\text { Эпителиальные и } \\
\text { эндотелиальные } \\
\text { клетки, фибробласты }\end{array}$ & $\begin{array}{l}\text { Стимулирует секрецию } \\
\text { провоспалительньгх цитокинов, } \\
\text { хемокинов и простагландинов, } \\
\text { стимулирует ангиогенез }\end{array}$ \\
\hline ИФНү & $\begin{array}{l}\text { Th1-, NK-, ЦТЛ, } \\
\text { В-лимфоциты }\end{array}$ & $\begin{array}{l}\text { Моноциты, макрофаги, } \\
\text { В-лимфоциты, Th2- } \\
\text { лимфоциты }\end{array}$ & $\begin{array}{l}\text { Активация макрофагов и } \\
\text { нейтрофилов. усиление МHC I и II, } \\
\text { индукция молекул адгезии на } \\
\text { эндотелии }\end{array}$ \\
\hline
\end{tabular}


Действие цитокинов на кроветворную систему связано с существенной активацией гемопоэза за счет цитокинов, влияющих на гемопоэз (табл.17). Увеличение числа лейкоцитов необходимо для наращивания количества клеток, убивающих патогены, и для восполнения потерь нейтрофильных гранулоцитов в очаге гнойного воспаления. Они попадают в циркуляцию и их действие проявляется на системном уровне. Формируется системная воспалительная реакция. Она может проявляться множеством симптомов, начиная от легких, похожих на грипп (лихорадка, утомляемость, головная боль, сыпь, артралгии и миалгия), до тяжельх угрожающих жизни проявлений чрезмерной воспалительной реакции.

Таблица 17.

\section{Основные гемопоэтические цитокины}

\begin{tabular}{|c|c|c|c|}
\hline Цитокин & Клетки-продуценты & Мишени & Эффекты \\
\hline Эритропоэтин & $\begin{array}{l}\text { один из гормонов почек, } \\
\text { также секретируется в } \\
\text { клетках печени }\end{array}$ & $\begin{array}{l}\text { Стимулятор } \\
\text { эритропоэза }\end{array}$ & $\begin{array}{l}\text { Связываясь с рецептором } \\
\text { эритропоэтина (ЕроR) блокирует } \\
\text { апоптоз эритроид. предшественников }\end{array}$ \\
\hline Тромбопоэтин & $\begin{array}{l}\text { клетки печенью, в } \\
\text { меньшей степени-в почках } \\
\text { и поперечно-полосатой } \\
\text { мускулатуре }\end{array}$ & $\begin{array}{l}\text { Стимулирует } \\
\text { выработку и } \\
\text { дифференцировку } \\
\text { мегакариоцитов }\end{array}$ & $\begin{array}{l}\text { Повышении числа тромбоцитов } \\
\text { уменьшает уровень тромбопоэтина за } \\
\text { счет связывания c mpl (CD 110), } \\
\text { воздействие на мегакариоциты }\end{array}$ \\
\hline $\begin{array}{l}\text { Ил-1 } \alpha \\
\text { (гемопоэтин-1) }\end{array}$ & $\begin{array}{l}\text { Моноциты, макрофаги, } \\
\text { дендритные клетки, NK- } \\
\text { клетки, В-лимфоциты, } \\
\text { эпителиальные клетки }\end{array}$ & $\begin{array}{l}\text { Клетки сосудистой } \\
\text { системы, печени } \\
\text { гипоталамуса, }\end{array}$ & $\begin{array}{l}\text { Вызывает воспалительные сосудистые } \\
\text { реакции, повышение температуры тела, } \\
\text { индукцию секреции белков острой } \\
\text { фазы }\end{array}$ \\
\hline M-CSF(CSF1)* & $\begin{array}{l}\text { Моноциты, гранулоциты, } \\
\text { фиброблласты и } \\
\text { эндотелиальные клетки }\end{array}$ & $\begin{array}{l}\text { Стволовые клетки } \\
\text { костного мозга } \\
\text { (СККМ), моноциты, } \\
\text { гранулоциты }\end{array}$ & $\begin{array}{l}\text { Стимулирует пролиферацию } \\
\text { моноцитов, активирует их и макрофаги, } \\
\text { стимулирует секрецию } \\
\text { провоспалительных цитокинов }\end{array}$ \\
\hline GM-CSF(CSF2)* & $\begin{array}{l}\text { Фибробласты, } \\
\text { эндотелиальные клетки, } \\
\text { макрофаги, Th }\end{array}$ & $\begin{array}{l}\text { СККМ, клетки } \\
\text { миелоидного ряда, } \\
\text { эндотелиальные } \\
\text { клетки }\end{array}$ & $\begin{array}{l}\text { Стимулирует пролиферацию } \\
\text { гранулоцитов и моноцитов. } \\
\text { Хемотрактант для нейтрофилов, } \\
\text { стимулирует фагоцитоз, вызывает } \\
\text { созревание дендритных клеток } \\
\end{array}$ \\
\hline G-CSF(CSF3)* & $\begin{array}{l}\text { Эндотелиальные клетки } \\
\text { нейтрофилы, моноциты, } \\
\text { макрофаги, фибробласты }\end{array}$ & $\begin{array}{l}\text { СККМ, гранулоциты, } \\
\text { клетки плаценты }\end{array}$ & $\begin{array}{l}\text { Стимулирует пролиферацию } \\
\text { предшественников гранулоцитов }\end{array}$ \\
\hline $\begin{array}{l}\text { Ил-3 (мульти- } \\
\text { CSF) }\end{array}$ & $\begin{array}{l}\text { Кератиноциты, тучные } \\
\text { клетки, эндотелиальные } \\
\text { клетки, Т-лимфоциты, NK- } \\
\text { клетки, моноциты } \\
\end{array}$ & $\begin{array}{l}\text { СККМ, макрофаги, } \\
\text { мегакариоциты, } \\
\text { эозинофилы, тучные } \\
\text { клетки }\end{array}$ & $\begin{array}{l}\text { Направляет дифференцировку СКК в } \\
\text { сторону миелоидного ряда, } \\
\text { стимулирует пролиферацию всех клеток } \\
\text { миелоидного ряда }\end{array}$ \\
\hline $\begin{array}{l}\text { ИЛ-7 (CSF Аля } \\
\text { лимфоцитов) }\end{array}$ & $\begin{array}{l}\text { Строма тимуса и костного } \\
\text { мозга, эпителиальные } \\
\text { клетки кишечника }\end{array}$ & $\begin{array}{l}\text { Предшественники B } \\
\text {-лимфоцитов, T- } \\
\text { лимфоциты, NK- } \\
\text { клетки, моноциты, } \\
\text { мегакариоциты, }\end{array}$ & $\begin{array}{l}\text { Направляет дифференцировку СКК в } \\
\text { сторону лимфоидного ряда, } \\
\text { стимулирует пролиферацию В- и Т- } \\
\text { лимфоцитов, стимулирует синтез } \\
\text { воспалительных цитокинов } \\
\text { моноцитами } \\
\end{array}$ \\
\hline ил-11 & Строма костного мозга & $\begin{array}{l}\text { Мегакариоциты, } \\
\text { остеокласты, } \\
\text { адипоциты, } \\
\text { гепатоциты }\end{array}$ & $\begin{array}{l}\text { Стимулирует пролиферацию клеток- } \\
\text { предшественников мегакариоцитов и } \\
\text { эритроцитов. Стимулирует секрецию } \\
\text { белков острой фазы. Ингибирует } \\
\text { адипоциты }\end{array}$ \\
\hline $\begin{array}{l}\text { SCF (фактор } \\
\text { стволовых } \\
\text { клеток) }\end{array}$ & $\begin{array}{l}\text { Фибробласты, клетки } \\
\text { стромы костного мозга } \\
\text { эндотелиальные клетки }\end{array}$ & $\begin{array}{l}\text { СКKM, меланоциты, } \\
\text { тучные клетки, } \\
\text { врожденные } \\
\text { лимфоидные клетки } \\
\text { (ILC3) } \\
\end{array}$ & $\begin{array}{l}\text { Связывается с рецептором KIT (CD117) } \\
\text { увеличивает выживаемость } \\
\text { гемопоэтических стволовых клеток, } \\
\text { тучных клетках, меланоцитах и половых } \\
\text { клетках }\end{array}$ \\
\hline
\end{tabular}


Одно из первых проявлений, связанно с действием цитокинов на терморегуляторный центр гипоталамуса, с подъемом температуры тела. Увеличение температуры является одной из эффективных защитных реакций, так как при повышенной температуре снижается способность ряда бактерий к размножению, и, напротив, возрастает пролиферация лимфоцитов.

В печени под влиянием цитокинов увеличивается синтез острофазных белков и компонентов системы комплемента, необходимых для борьбы с патогеном, одновременно снижается синтез альбумина. Т.е. на уровне регуляции генов цитокины направляют энергетические потоки, для развития защитных реакций. Действие провоспалительных цитокинов на ЦНС приводит так же к снижению аппетита и изменению всего комплекса поведенческих реакций. Более тяжелые случаи характеризуются гипотонией, а также высокой температурой и могут прогрессировать до неконтролируемой системной воспалительной реакции с цитокиновым штормом, требующим реанимационных мероприятий

Цитокиновый шторм (гиперцитокинемия) - является реакцией врожденного иммунитета с неконтролируемым и чрезмерным синтезом провоспалительных цитокинов врожденного иммунитета, с дисбалансом цитокинов, регулирующих пролиферацию и дифференцировку клеток кроветворной системы. Агрессивный цитокиновый ответ может приводить к стойкой, тяжелой дисфункции и поражению органов и систем (полиорганная недостаточность) и неблагоприятному исходу, представляя большую проблему, нежели сама инфекция. Могут развиваться респираторные симптомы в виде кашля и тахипноэ, а в некоторых случаях могут прогрессировать до острого респираторного дистресс-синдрома, почечная недостаточность или признаки сердечной дисфункции, нейротоксичность. Поэтому важно, чтобы своевременно началась выработка противовоспалительных цитокинов (табл. 18).

Таблица 18

\section{Противовоспалительные цитокины}

\begin{tabular}{|c|c|c|c|}
\hline Цитокин & $\begin{array}{c}\text { Клетки- } \\
\text { продуценты }\end{array}$ & Мишени & Эффекты \\
\hline $\begin{array}{l}\text { Семейство } \\
\text { ил-10 (иЛ- } \\
10, \text { ил-19, } \\
\text { ил-20, ил- } \\
22, \text { ил-24) }\end{array}$ & $\begin{array}{l}\text { T-(Th1, Th2 и Th22) и B- } \\
\text { лимфоциты, } \\
\text { моноциты, макрофаги, } \\
\text { кератиноциты }\end{array}$ & $\begin{array}{l}\text { Th1, ЦТЛ, В-лимфоциты, } \\
\text { антигенпрезентирующие } \\
\text { клетки }\end{array}$ & $\begin{array}{l}\text { Ингибирование функции макрофагов } \\
\text { (снижение секреции ФНО, ИЛ-1, ИЛ-12, } \\
\text { угнетение экспрессии МНС II), Th1 } \\
\text { (угнетение ИЛ-2, ИЛ-3, ИФНү), стимуляция } \\
\text { пролиферации В-лимфоцитов }\end{array}$ \\
\hline ИЛ-4 & Th2, тучные клетки & B- и Th & $\begin{array}{l}\text { Подавляет активность макрофагов, } \\
\text { стимулирует экспрессии MHC-II } \\
\text { переключает синтез антител на IgG1 и IgE }\end{array}$ \\
\hline $\begin{array}{l}\text { ИЛ-8 } \\
\text { (хемокин } \\
\text { CXCL8) }\end{array}$ & $\begin{array}{l}\text { Моноциты, } \\
\text { макрофаги, эндотелий }\end{array}$ & $\begin{array}{l}\text { Нейтрофилы, наивные Т- } \\
\text { лимфоциты }\end{array}$ & $\begin{array}{l}\text { Мобилизация, активация и дегрануляция } \\
\text { нейтрофилов, хемотаксис лимфоцитов. } \\
\text { Стимулирует ангиогенез }\end{array}$ \\
\hline ил-13 & Th2, тучные клетки & $\begin{array}{l}\text { Макрофаги, } \\
\text { В-лимфоциты, эпителий } \\
\text { кишечника }\end{array}$ & $\begin{array}{l}\text { Подавляет макрофагов, переключение } \\
\text { синтеза антител на IgG1 и IgE, стимуляция } \\
\text { выработки слизи, медиатор аллергического } \\
\text { воспаления }\end{array}$ \\
\hline Ил-26 & Т-лимфоциты & Эндотелиальные клетки & $\begin{array}{l}\text { Усиливает секрецию ИЛ-8 и ИЛ-10 } \\
\text { эндотелиальными клетками }\end{array}$ \\
\hline ТФР $\beta$ & $\begin{array}{l}\text { Т-лимфоциты, } \\
\text { макрофаги, } \\
\text { эндотелиальные } \\
\text { клетки, многие } \\
\text { опухолевые клетки }\end{array}$ & Многие типы клеток & $\begin{array}{l}\text { Ингибирование роста Т-клеток и } \\
\text { макрофагов, эндотелиальных клеток, } \\
\text { кератиноцитов, фибробластов, гепатоцитов. } \\
\text { Переключение синтеза антител на IgA. } \\
\text { Стимуляция роста сосудов }\end{array}$ \\
\hline ИЛ-1RA & $\begin{array}{l}\text { макрофаги, моноциты, } \\
\text { нейтрофилы, } \\
\text { эпителиальные } \\
\text { клетки, фибробласты } \\
\end{array}$ & Многие типы клеток & 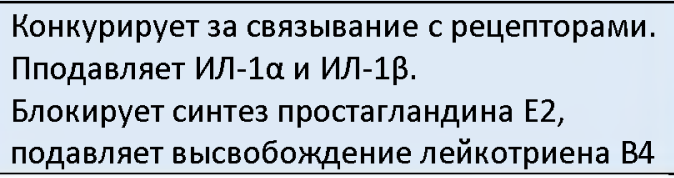 \\
\hline
\end{tabular}


Действие на систему свертывания крови направлено на усиление свертываемости, которое необходимо для остановки кровотечения и для прямого блокирования патогена. Система гемостаза - сложный комплекс механизмов, обеспечивающих жидкое состояние циркулируюшей крови, ее свертывание в месте повреждения сосуда, формирование сгустка и его растворение. Она включает в себя свертывающую, противосвертывающую и фибринолитическую системы. Для формирования воспаления большое значение принадлежит так называемому сосудисто-тромбоцитарному (микроциркуляторному) гемостазу (рис. 21).

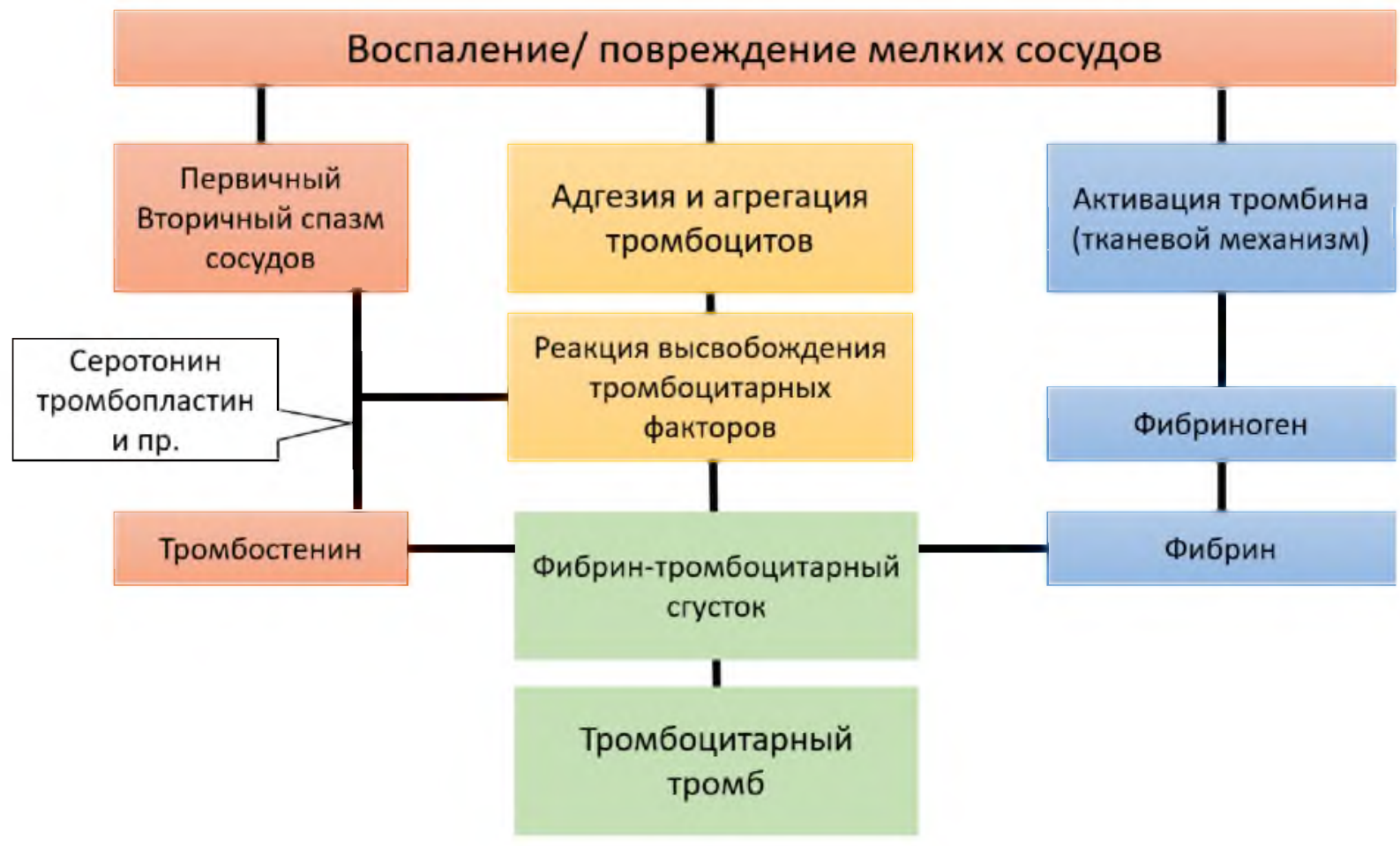

Рис. 21. Микроциркуляторный гемостаз.

Сосудисто-тромбоцитарный гемостаз сводится к образованию тромбоцитарной пробки или тромбоцитарного тромба (белого тромба). Можно выделить 3 стадии его развития:

1) временный (первичный) спазм сосудов, обусловленный выбросом в кровь в ответ на болевое раздражение адреналина и норадреналина. В дальнейшем наступает вторичный спазм, обусловленной активацией тромбоцитов с выходом в кровь сосудосуживающих агентов - серотонина, тромбоксана А2, адреналина и др.

2) образование тромбоцитарной пробки за счет адгезии (прикрепление к поврежденной поверхности) и агрегации (склеивание между собой) кровяных пластинок;

3) ретракция (сокращение и уплотнение) тромбоцитарной пробки.

Основными клетками сосудисто-тромбоцитарного гемостаза являются тромбоциты. Тромбоциты образуются в красном костном мозге из мегакариоцитов. Образование тромбоцитов регулируется тромбоцитопоэтинами. Тромбоцитопоэтины образуются в костном мозге, селезенке, печени. Активность тромбоцитопоэтинов регулируется интерлейкинами (ИЛ6, ИЛ-11). Количество тромбоцитопоэтинов повышается при воспалении, необратимой агрегации тромбоцитов. Продолжительность жизни тромбоцитов от 5 до 11 дней. Разрушаются кровяные пластинки в клетках системы макрофагов.

Основная задача воспалительной реакции - уничтожение чужеродного вещества. Киллинг возбудителя осуществляется как клетками иммунной системы, так и гуморальными факторами. При этом клеточные и гуморальные факторы активно дополняют друг друга. 
Среди циркулирующих протеинов крови важнейшим цитолитическим фактором является система белков комплемента. Большая часть компонентов комплемента синтезируется гепатоцитами и мононуклеарными фагоцитами и циркулируют в крови в неактивной форме. В условиях воспалительной реакции эти белки в самые ранние сроки попадают к месту проникновения возбудителя. Первый компонент этой системы (C3) распознает комплекс АГ-АТ. Также возможна активация комплемента по альтернативному и лектиновому пути в результате контакта с АГ на поверхности бактериальных клеток

Последовательная активация всех компонентов системы комплемента имеет ряд последствий.

Во-первых, происходит каскадное усиление реакции, образуется большое количество продуктов реакции, которые обладают, в частности, хемотаксической активностью.

Во-вторых, на поверхности бактерии фиксируются компоненты (C9) комплемента, резко усиливающие фагоцитоз этих клеток.

В-третьих, при ферментативном расщеплении белков системы комплемента образуются фрагменты, обладающие мощной воспалительной активностью. При включении в комплекс АГ-АТ последнего компонента комплемента этот комплекс приобретает способность формировать пору в клеточной мембране и, тем самым, вызывать гибель чужеродных клеток (рис. 22).

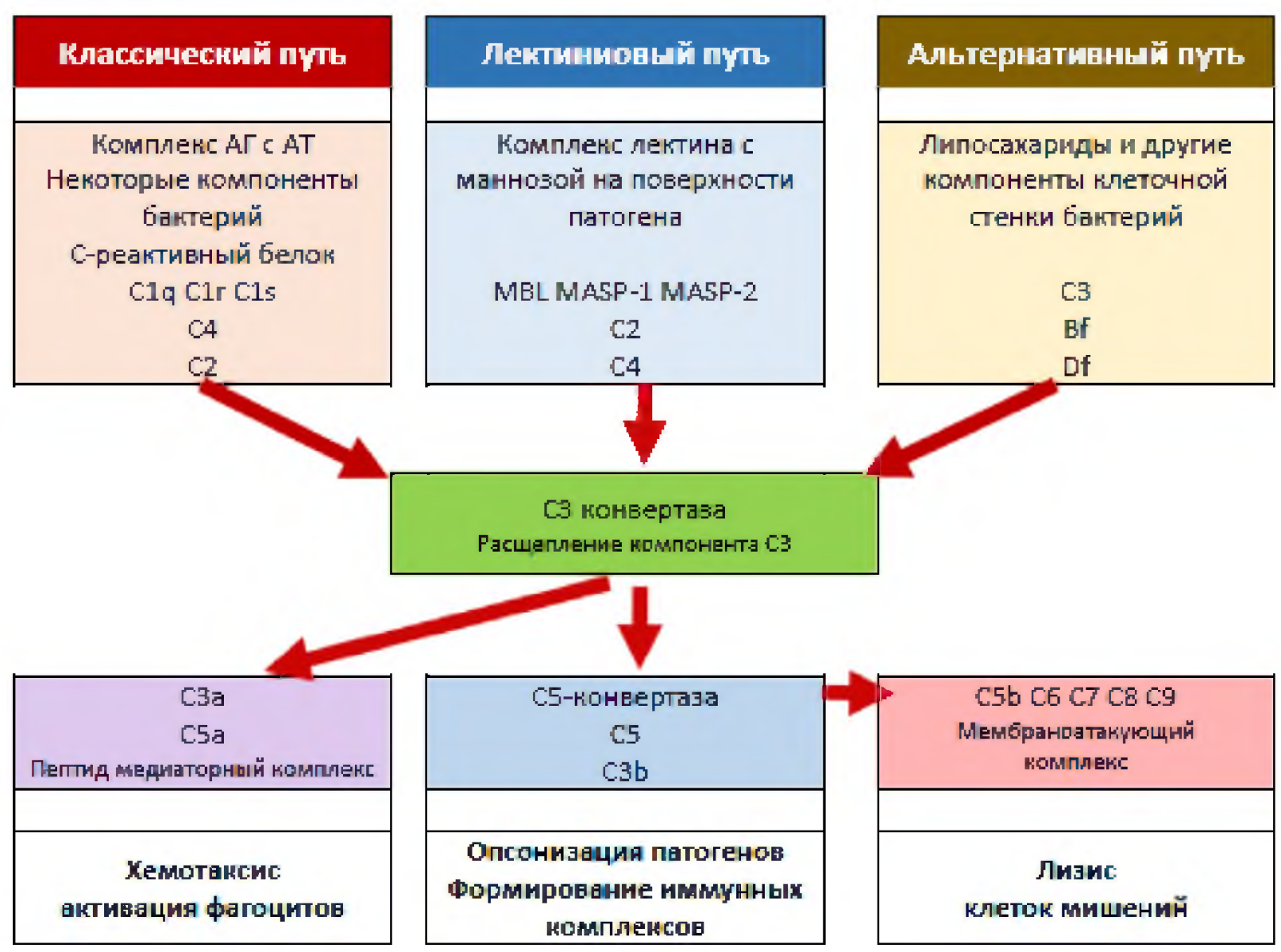

\section{Рис. 22. Система белков комплемента}

Комплемент активируется любым комплексом АГ-АТ, недостаточность в системе комплемента может приводить к развитию патологических процессов.

Помимо комплемента и цитокинов к гуморальным факторам врожденного иммунитета относятся и другие белки, и пептиды, относящиеся к системе врожденного иммунитета. Это прежде всего белки острой фазы, концентрация которых в плазме увеличивается или 
снижается в ответ на воспаление. Их синтез усиливается под влиянием провоспалительных цитокинов наряду с реакцией острой фазы воспаления, сопровождающейся лихорадкой, увеличением числа периферических лейкоцитов за счет циркулирующих нейтрофилов и их предшественников. Действие их многообразно: некоторые действуют, чтобы разрушить или подавить рост микробов, другие влияют на коагуляцию ограничивая инфекцию и улавливая патогены в сгустках крови, так же продукты системы свертывания крови могут вносить вклад в систему врожденного иммунитета благодаря своей способности увеличивать проницаемость сосудов и действовать как хемотаксические агенты для фагоцитарных клеток (табл. 19)

Таблица 19.

\section{Белки острой фазы}

\begin{tabular}{|c|c|c|}
\hline Наименование & Механизм действия & Эффект действия \\
\hline $\begin{array}{l}\text { С-реактивный } \\
\text { белок }\end{array}$ & $\begin{array}{l}\text { Связывается с лизофосфатидилхолином } \\
\text { мертвых или умирающих клеток и } \\
\text { некоторых типов бактерий. Активирует } \\
\text { систему комплемента через С1q }\end{array}$ & $\begin{array}{l}\text { За счет опсонизация патогенных молекул, } \\
\text { микробов, апоптотических клеток } \\
\text { значительно усиливается фагоцитоз и } \\
\text { распознавание NK-клетками }\end{array}$ \\
\hline $\begin{array}{l}\text { SAA } \\
\text { сывороточный } \\
\text { амилоид A }\end{array}$ & $\begin{array}{l}\text { Активирует каскад инфламмасом } \\
\text { индуцируя синтез провоспалительных } \\
\text { цитокинов, является хемотаксиком для } \\
\text { нейтрофилов и тучных клеток }\end{array}$ & $\begin{array}{l}\text { Играет ключевую роль в развитии } \\
\text { амилоидоза А-типа, участвует в } \\
\text { патогенезе хронических воспалительных } \\
\text { заболеваний, ревматоидном артрите, } \\
\text { атеросклерозе }\end{array}$ \\
\hline $\begin{array}{l}\text { MBL лектин, } \\
\text { связывающий } \\
\text { маннозу }\end{array}$ & $\begin{array}{l}\text { Распознает образцы углеводов, } \\
\text { обнаруженные на поверхности большого } \\
\text { количества патогенных } \\
\text { микроорганизмов, включая бактерии, } \\
\text { вирусы, простейшие и грибы }\end{array}$ & $\begin{array}{l}\text { Активации лектинового пути системы } \\
\text { комплемента. Связывает стареющие, } \\
\text { апоптотические клетки и дебрис } \\
\text { усиливает поглощение фагоцитами }\end{array}$ \\
\hline Ферритин & $\begin{array}{l}\text { Связывает железо, ингибирование } \\
\text { потребление железа микробами }\end{array}$ & Препятствие развитие микроорганизмов \\
\hline Гепсидин & $\begin{array}{l}\text { Ингибирует перенос железа из } \\
\text { кишечника ограничивает потребление } \\
\text { железа микробами }\end{array}$ & Препятствие развитие микроорганизмов \\
\hline Церулоплазмин & $\begin{array}{l}\text { Основной белок крови, переносящий } \\
\text { медь, участвует в метаболизме железа }\end{array}$ & $\begin{array}{l}\text { подавляет образование свободных } \\
\text { кислородных радикалов }\end{array}$ \\
\hline $\begin{array}{l}\text { Фибриноген, } \\
\text { протромбин, } \\
\text { фактор } \\
\text { Виллебранда }\end{array}$ & $\begin{array}{l}\text { Образование локальных тромбов в } \\
\text { области воспаления. Улавливают } \\
\text { вторгшиеся микробы. Вызывают } \\
\text { хемотаксис }\end{array}$ & Ограничение воспаления \\
\hline $\begin{array}{l}\text { Альфа-1- } \\
\text { антитрипсин, } \\
\text { альфа-1- } \\
\text { антихимотрипсин }\end{array}$ & $\begin{array}{l}\text { Противодействуют повышенному } \\
\text { высвобождению протеаз }\end{array}$ & уменьшение повреждения тканей \\
\hline
\end{tabular}

Важнейшую роль в работе врождённого иммунитета играет система мононуклеарных фагоцитов (моноциты, макрофаги и дендритные клетки), гранулоциты (нейтрофилы, эозинофилы, базофилы, тучные клетки) и врождённые лимфоидные клетки.

Мононуклеарные фагоциты по их онтогенезу, расположению, функциям и фенотипу можно разделить на 3 группы: моноциты, макрофаги и дендритные клетки. Помимо фагоцитоза, описанного выше, они выполняют множество других функций во время иммунных ответов.

Макрофаги присутствуют во всех органах и тканях, и описаны нами выше (см.стр.32).

Моноциты самые крупные из лейкоцитов клетки с крупным бобовидным ядром и большим количеством цитоплазмы, в которой находится большое количество лизосом. Число в 


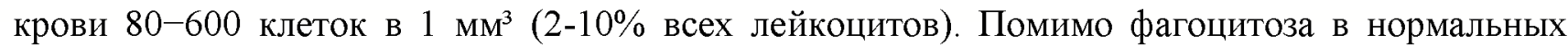
условиях пополняют пул резидентных макрофагов, в ответ на сигналы воспаления миграция в ткани с последующей дифференцировкой в макрофаги или дендритные клетки для осуществления иммунного ответа и/или поддерживая общего количества. В стабильном состоянии выполнять фагоцитоз. Фагоцитоз, антигенпрезентация и секреция цитокинов обеспечивает одну из ключевых ролей моноцитов в иммунном ответе, особенно при бактериальной инфекции. Благодаря секреции факторов роста хемокинов и ИЛ-10 (основной противовоспалительный цитокин) моноциты активно участвуют в репаративных процессах, кроветворении, гемостазе и фибринолизе. Выделяют как минимум 3 типа моноцитов (табл. 20) $[23,58,59,121]$.

Таблица 20

\section{Моноциты}

\begin{tabular}{|c|c|c|}
\hline Популяция & $\begin{array}{l}\text { Фенотипическая } \\
\text { характеристика }\end{array}$ & Функция \\
\hline $\begin{array}{l}\text { Классические } \\
\text { моноциты }\end{array}$ & $\mathrm{CD}_{14}^{++} \mathrm{CD}^{-} 6^{-}$ & $\begin{array}{l}\text { Высокая фагоцитарная активность апоптотических телец, } \\
\text { опсонизированных патогенов, за счет выраженной экспрессии } \\
\text { рецепторов-мусорщиков, слабая антигенпрезентация }\end{array}$ \\
\hline $\begin{array}{l}\text { Неклассические } \\
\text { моноциты }\end{array}$ & CD14 + CD16 ++ & $\begin{array}{l}\text { Основная функция антигенпрезентация и продукция } \\
\text { провоспалительных цитокинов TNFa, ИЛ-1ß, ИЛ-12, ИЛ-10. } \\
\text { Активируют Th2 и ингибируют Th1. Слабо выражен фагоцитоз. }\end{array}$ \\
\hline $\begin{array}{l}\text { Переходные } \\
\text { моноциты }\end{array}$ & CD14 ++ CD16 + & $\begin{array}{l}\text { Считается, что эти клетки образуются в результате активации и } \\
\text { дифференцировки классических моноцитов. Их основные } \\
\text { функции: IgG опосредованный фагоцитоз, распознавание PAMP и } \\
\text { синтез цитокинов (противовоспалительные цитокины (TNF } \alpha \text {, IL-1ß и } \\
\text { пр.) и IL-10), антигенпрезентация. Низкая экспрессия рецепторов- } \\
\text { мусорщиков, участвующих в репаративных процессах (синтезируют } \\
\text { факторы роста, хемокины) }\end{array}$ \\
\hline
\end{tabular}

Дендритные клетки - это крупные круглые или овальные клетки с эксцентрически расположенным ядром и многочисленными разветвлёнными отростками. Являются посредниками между врожденным и адаптивным иммунитетом, т.к. представляют Т- и Влимфоцитам обработанный антигенный материал. Группа достаточно гетерогенная, до сих пор неясно сколько существует подтипов дендритных клеток, как они связаны друг с другом и чем они отличаются от других мононуклеарных фагоцитов, тем не менее выделяют нескольких подтипов с уникальными функциями (рис. 23).

Миелоидные дендритные клетки 1 типа (cDC1) обладают высокой способностью презентовать антигены через MHC класса I, активировать Th1 и CD $8^{+}$T-клеток за счет секреции ИЛ-12, активировать NK-клетки, продуцировать интерфероны III типа, обеспечивая противовирусную активность.

Миелоидные дендритные клетки 2 типа (cDC2) - основная популяция миелоидных дендритных клеток крови, тканях и лимфоидных органах человека. По экспрессии различных рецепторов выделяют две подгруппы $\mathrm{cDC} 2$ : «DC-подобную» и «моноцитоподобную». Оснащены широким спектром лектинов, TLR, NOD- и RIG-I-подобных рецепторов, хорошо распознают и презентуют липополисахариды, флагеллин, гликолипидные антигены микобактерий и других патогенов. Секретируют ИЛ-23, ИЛ-1, ФНО- альфа, ИЛ-8 и ИЛ-10, но слабо синтезируют интерфероны III типа. Мощные активаторы Th1, Th2, Th17 и CTL.

Плазмацитоидные дендритные клетки (pDC) в отличии от $\mathrm{CDC}$, роль которых связана с презентацией антигена, обычно реагируют на вирусную РНК и ДНК посредством продукции высоких уровней интерферонов I и III типа, воспалительными цитокинами (ИЛ-6 и TNFa). Однако $\mathrm{pDC}$ могут экспрессировать MHCII и костимулирующие молекулы и поэтому могут действовать как антиген-презентующие клетки. 


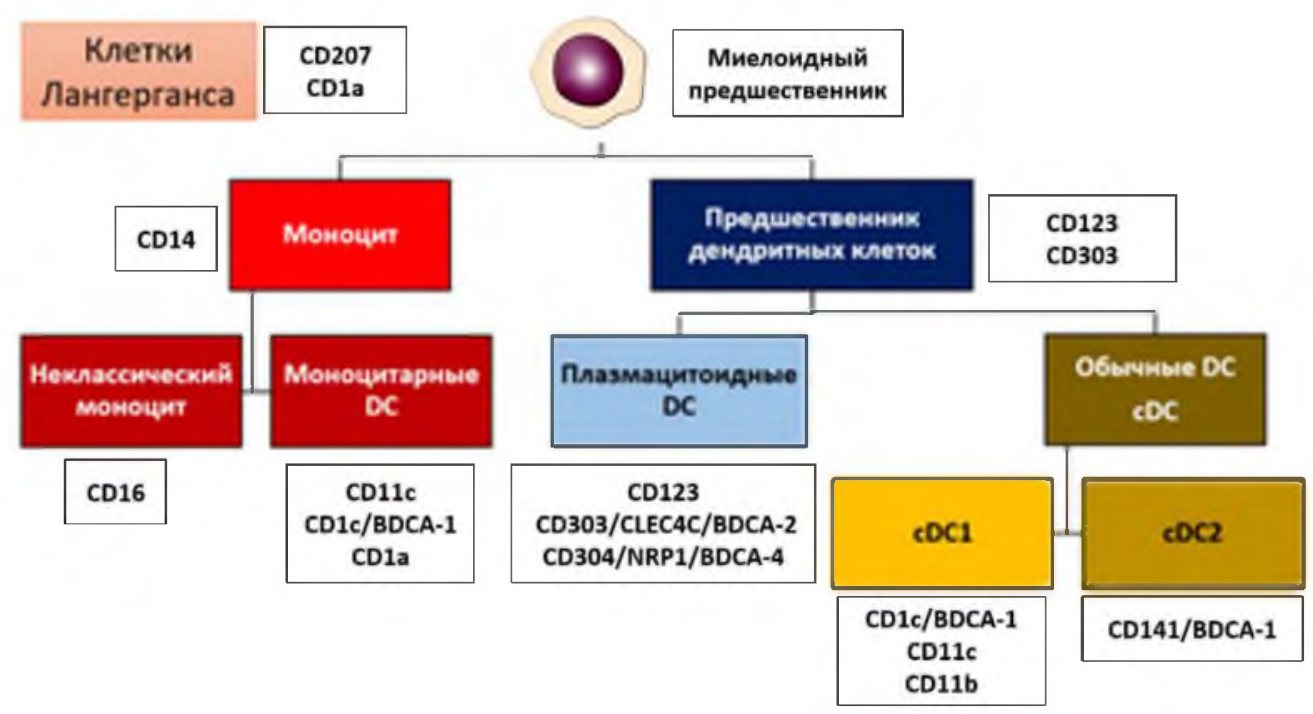

\section{Рис. 23. Подтипы дендритных клеток и их отличительные поверхностные рецепторы}

Клетки Лангерганса (LC) - это специализированные DC, которые населяют базальный эпидермис и другой многослойный плоский эпителий. В отличии от макрофагов, к которым традиционно их причисляют после захвата антигена, они мигрируют в лимфатические узлы. В отличии от других дендритных клеток LC способны к локальному самообновлению, независимо от костного мозга, хотя LC слизистой оболочки больше зависят от предшественников костного мозга.

Воспалительные ДК, происходящие из моноцитов, доминируют по составу клеток при перитоните, воспалительных заболеваниях кишечника, синовитах, экземе, псориазе, аллергических реакциях хотя нет полной ясности о грани между моноцитами, макрофагами и DC при описания воспалительных клеток, происходящих из моноцитов. Неклассические моноциты так же рассматриваются как предшественники cDC2.

\section{Гранулоциты - клетки,} осуществляющие защитные функции в основном за счет фагоцитоза (нейтрофильные гранулоциты) и/или выполняющие внеклеточный цитолиз мишеней за счет секреции токсических субстанций, содержащихся в их гранулах (эозинофилы, базофилы, тучные клетки). Зрелые нейтрофилы характеризуются

сегментированными ядрами и цитозольными гранулами. Все формы гранулоцитов происходят из общей полипотентной СК в костном мозге (рис. 24).

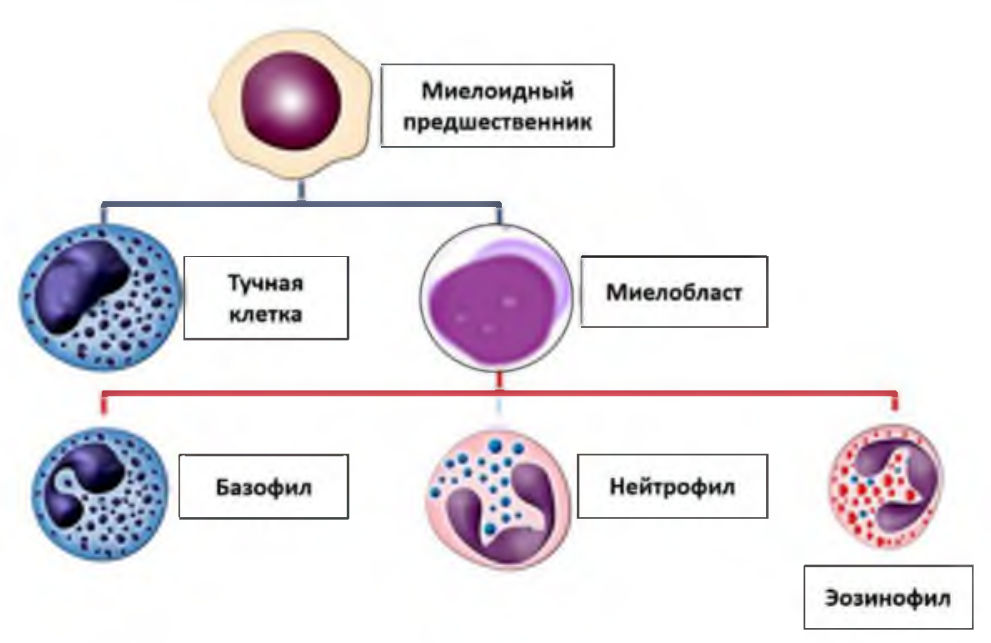

\section{Рис. 24. Гранулоциты}

Нейтрофилы полиморфно-ядерные лейкоциты $\mathrm{c}$ сегментированным ядром и цитозольными гранулами. Классически считаются клетками, определяющими первую линию защиты врожденного иммунитета. Они быстро мигрируют в больших количествах к участкам 
воспаления, уничтожая патогены в первые дни заражения. Основной состав гноя. Уничтожения патогенов нейтрофилами происходит с помощью [25, 38, 30, 38, 125]:

- фагоцитоза, способны поглощать микроорганизмы или частицы (описан выше);

- дегрануляции, высвобождение набора белков из гранул (табл.21) которые обладают антимикробными свойствами;

- NETоза, запрограммированная гибель нейтрофилов с высвобождением внеклеточных ловушек нейтрофилов (NET).

Таблица 21

\section{Состав гранул нейтрофилов}

\begin{tabular}{|l|l|}
\hline \multicolumn{1}{|c|}{ Гранулы нейтрофилов } & \multicolumn{1}{|c|}{ Содержание гранул } \\
\hline Секреторные везикулы & $\begin{array}{l}\text { Молекулы адгезии, которые обеспечивают возможность миграции } \\
\text { нейтрофилов из сосудистой системы к месту повреждения }\end{array}$ \\
\hline Гранулы желатиназы & $\begin{array}{l}\text { Катепсин, желатиназа, коллагеназа, матричная металлопептидаза - } \\
\text { которая обеспечивает миграцию нейтрофилов }\end{array}$ \\
\hline Гранулы азурофилов & $\begin{array}{l}\text { Миелопероксидаза, дефенсины, сериновые протеазы, эластаза } \\
\text { нейтрофилов и катепсин G (убивают патогены) и эластазы, разрушающие } \\
\text { наружные мембраны бактерий }\end{array}$ \\
\hline Особые гранулы & $\begin{array}{l}\text { Щелочные фосфатазы, лизоцим, НАДФН-оксидаза, лактоферрин, } \\
\text { гистаминазы и кателицидин-задерживают вещества, необходимые для } \\
\text { роста бактерий, а также разрушают мембраны }\end{array}$ \\
\hline
\end{tabular}

Нейтрофилы активно секретируют цитокины ИЛ-1 $\beta$, ФНО, ИЛ-6, ИЛ-12, ИЛ-17А, ГКСФ и хотя отдельно по количеству генерируемых цитокинов нейтрофилы в десятки раз уступают другим лейкоцитам, но большое количество их в очаге воспаления приводит к тому, что цитокины нейтрофильного происхождения достигают значительных величин.

Морфологическая характеристика нейтрофилов определяется степенью зрелости клеток: юные, палочкоядерные и сегментоядерные нейтрофилы. Эти популяции можно дополнительно идентифицировать с помощью набора клеточных маркеров (незрелые нейтрофилы экспрессируют CD15 и CD11b, при достижения полной зрелости - CD16 и CD10. Сегментоядерные нейтрофилы - терминально дифференцированные клетки, которые во время воспаления могут мигрировать в ткани и выполнять свои эффекторные функции (например, фагоцитоз, производство реактивных форм кислорода (ROS) и уничтожение бактерий). Важно отметить, что нейтрофилы, могут быстро менять свои характеристики и поведение по мере того, как они активируются, стареют или входят в новую среду при остром или хроническом воспалении (реализуют совершенно разные эффекторные механизмы). При изучении множества параметров нейтрофилов (функции, маркеры клеточной поверхности, плавучесть, зрелость, локализация) были установлены некоторые фенотипы нейтрофилов (табл. 22).

Нейтрофильные гранулоциты обладают рядом свойств обусловливающих их участие в патогенезе острого воспаления это: богатый набор цитотоксических факторов; высокая чувствительность к всевозможным локальным изменениям гомеостаза; способность накапливаться в очагах поражения и инициировать цепную реакцию с выделением цитотоксических веществ и созданием локального перевеса в балансе эффектор-ингибитор; секреция биологически активных веществ, активирующих предшественников медиаторов воспаления.

Нейтрофилы принимают участие в реализации иммунокомплексного повреждения тканей и в антителозависимых цитотоксических реакциях 


\section{Основные популяции нейтрофилов}

\begin{tabular}{|c|c|c|}
\hline $\begin{array}{l}\text { Субпопуляции } \\
\text { нейтрофилов }\end{array}$ & Локализация & Характеристика \\
\hline Незрелые & $\begin{array}{l}\text { В норме в костном мозге, при } \\
\text { патологических состояниях - в } \\
\text { периферической крови }\end{array}$ & $\begin{array}{l}\text { Незрелый пул клеток-предшественников } \\
\text { нейтрофилов. Являются одними из гибридных типов } \\
\text { антигенпредставляющих нейтрофилов, } \\
\text { обнаруживаемые на ранних стадиях рака }\end{array}$ \\
\hline $\begin{array}{l}\text { Временного } \\
\text { локализованные } \\
\text { нейтрофилы }\end{array}$ & $\begin{array}{l}\text { Селезенка, печень, костный } \\
\text { мозг, легкие, кожа }\end{array}$ & $\begin{array}{l}\text { Резерв нейтрофилов. В норме располагается рядом с } \\
\text { кровеносными сосудами и/или находятся и/или } \\
\text { катятся по стенке кровеносных сосудов, патрулируя } \\
\text { кровеносное пространство }\end{array}$ \\
\hline В-хелперные & В маргинальной зоне селезенки & $\begin{array}{l}\text { B-хелперные нейтрофилы поляризованы эндогенными } \\
\text { медиаторами (например, IL-10, GM-CSF) или } \\
\text { микробными продуктами (например, LPS), } \\
\text { присутствующими в локальной среде в селезенке }\end{array}$ \\
\hline $\begin{array}{l}\text { Циркулирующие } \\
\text { подмножества } \\
\text { нейтрофилов, } \\
\text { зрелые }\end{array}$ & $\begin{array}{l}\text { В норме и при патологических } \\
\text { состояниях в периферической } \\
\text { крови, нейтрофилы } \\
\text { нормальной плотности (NDN, } \\
\text { CD177 }{ }^{+} \text {) }\end{array}$ & $\begin{array}{l}\text { Большинство нейтрофилов периферической крови, } \\
\text { популяция нейтрофилов высокой плотности. Основной } \\
\text { пул клеток до поступления в ткани }\end{array}$ \\
\hline $\begin{array}{l}\text { Зрелые } \\
\text { активированные }\end{array}$ & $\begin{array}{l}\text { При патологических состояниях } \\
\text { в периферической крови }\end{array}$ & $\begin{array}{l}\text { Активные форму зрелых нейтрофилов в месте } \\
\text { инфекции/повреждения. Нейтрофилы низкой } \\
\text { плотности }\end{array}$ \\
\hline $\begin{array}{l}\text { Нейтрофилы } \\
\text { низкой } \\
\text { плотности }\end{array}$ & $\begin{array}{l}\text { При патологических } \\
\text { состояниях. Количество в } \\
\text { периферической крови, зависят } \\
\text { от воспалительных стимулов, } \\
\text { коррелируют с } \\
\text { прогрессированием } \\
\text { заболевания }\end{array}$ & $\begin{array}{l}\text { гетерогенные содержат незрелые }\left(\mathrm{CD}^{-}\right) \text {и зрелые } \\
\text { (CD10') нейтрофилы: при раке в основном } \\
\text { миелоидные супрессорные клетки (MDSC; } \\
\text { описываются ниже), при аутоиммунных болезнях } \\
\text { провоспалительный фенотип (LDG), при инфекциях } \\
\text { активированный тип наряду с антигенпредставляюще- } \\
\text { подобными нейтрофилами }\end{array}$ \\
\hline $\begin{array}{l}\text { Зрелые } \\
\text { активированные } \\
\text { супрессивные } \\
\text { нейтрофилы }\end{array}$ & $\begin{array}{l}\text { популяция зрелых } \\
\text { активированных нейтрофилов } \\
\left.\text { цельной крови (CD16 }{ }^{\operatorname{dim}} \mathrm{CD} 62^{\text {hi }}\right)\end{array}$ & $\begin{array}{l}\text { эти клетки ингибируют пролиферацию и продукцию } \\
\text { цитокинов [например, IFN-ץ и интерлейкина (IL) -13] } \\
\text { CD4 } 4^{+} \text {и CD8 } 8^{+} \text {T-клетками }\end{array}$ \\
\hline Стареющие & $\begin{array}{l}\text { В тканях. Количество в } \\
\text { периферической крови (CXCR4 } \\
+ \text { CD62L-) зависит от } \\
\text { разрешения воспаления }\end{array}$ & $\begin{array}{l}\text { Проявляют противовоспалительные свойства. } \\
\text { Возвращаясь из очага воспаления в костный мозг, } \\
\text { регулируют пролиферацию незрелых нейтрофилов. }\end{array}$ \\
\hline $\begin{array}{l}\text { Полиморфно- } \\
\text { ядерные } \\
\text { миелоидные } \\
\text { супрессорные } \\
\text { клетки (PMN- } \\
\text { MDSC, MDSC) }\end{array}$ & $\begin{array}{l}\mathrm{CD}^{-} 4^{-} \mathrm{CD} 11 \mathrm{~b}^{+} \mathrm{CD} 15^{+} \text {(или } \mathrm{CD} 66 \mathrm{~b}^{+} \text {) } \\
\text { нейтрофилы. Увеличиваются в } \\
\text { периферической крови при } \\
\text { неблагоприятном прогнозе } \\
\text { развития заболевания }\end{array}$ & $\begin{array}{l}\text { Нейтрофилы низкой плотности, способны существенно } \\
\text { подавлять пролиферацию Т-клеток, а также функцию } \\
\text { NК- и В-клеток при раке, сепсисе, инфекции и } \\
\text { сердечно-сосудистых заболеваниях, беременности }\end{array}$ \\
\hline $\begin{array}{l}\text { нейтрофилы } \\
\text { N1/N2 }\end{array}$ & В тканях, зрелые нейтрофилы & $\begin{array}{l}\text { Нейтрофилы низкой плотности. Наименование } \\
\text { применяется в концепции опухолевых нейтрофилов } \\
\text { (TAN). N1 - противоопухолевые, N2 - проопухолевые. } \\
\text { N2 - имеют большое значение при инфаркте и } \\
\text { инсульте }\end{array}$ \\
\hline
\end{tabular}


Эозинофилы, базофилы, тучные клетки еще одна группа гранулоцитов, описанная выше. В отличии от нейтрофилов их защитная функция осуществляется не фагоцитозом, a мощной цитотоксической реакцией за счет дегрануляции.

Учитывая их полиморфизм, с клинической точки зрения следует различать клетки относимые к мукозальному иммунитету, которые заложены со времени эмбриогенеза (резидентные эозинофилы, тучные клетки) и традиционные эозинофилы и базофилы (продукты CKKM).

Врожденные лимфоидные клетки (ILC) - система клеток врожденного иммунитета (отсутствует антиген-специфические рецепторы), которые происходят от общего лимфоидного предшественника (CLP) и принадлежат к лимфоидной линии. На основании путей развития, фенотипа и продуцируемых сигнальных молекулах, ILC разделены на 5 групп: NK-клетки, ILC1, ILC2, ILC3 и LTi (рис.25).

Помимо эффекторной функции ILC участвуют во многих других физиологических функциях, включая гомеостаз ткани, морфогенез, метаболизм, репарацию и регенерацию. Многие из их функций аналогичны Т-клеткам, поэтому предполагается, что они являются врожденными аналогами Т-клеток. Нарушение регуляции ILC может привести к иммунной патологии (аллергии, аутоиммунные заболевания)

ILC1 и NK-клетки имеют много общих маркеров и функций, однако основная отличительная черта то, что в ткани LC1 это нецитотоксические или слабоцитотоксические клетки реагирующие инфекций, вызываемых вирусами и некоторыми бактериями. Однако основными клетками этой группы лимфоцитов являются NK-клекти

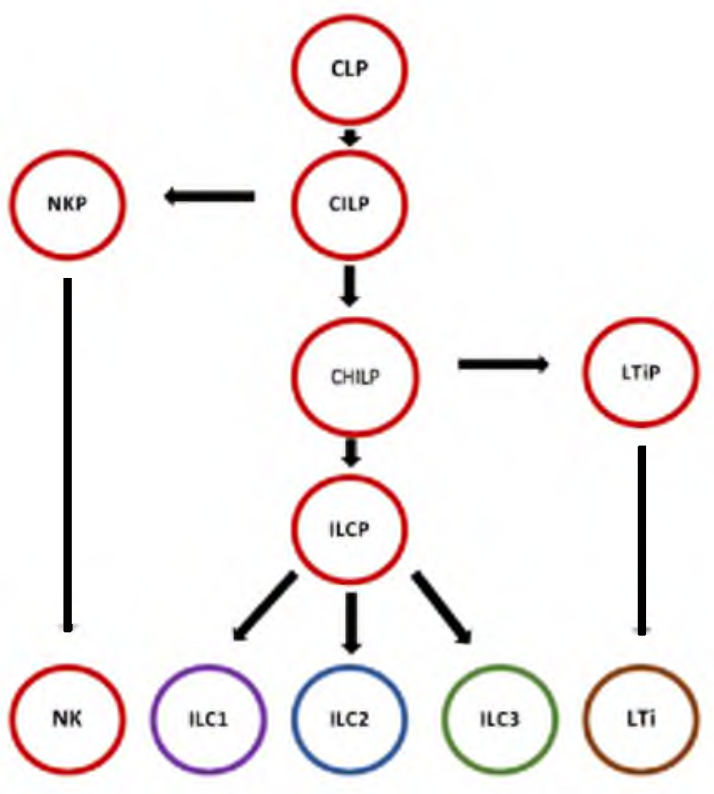

Рис. 25. Развитие врожденных
лимфоидных клеток

Естественные или натуральные киллеры (NK). Большие гранулярные лимфоциты («нулевые клетки», «не Т-, не В-клетки»). Число NK в крови - 5-15\%; в лимфоузлах и селезенке 2,5-5\% (от всех мононуклеаров). Срок жизни - 7-10 суток (IL-15). T- клеточный рецептор отсутствует. В тимусе не «обучаются», созревают в лимфотических узлах. Популяция не клонируется.

Мишени - вирус-трансформированные и опухолевые клетки. Распознают «чужое» по отсутствию «своего» - ключевая роль принадлежит активирующим и ингибирующим сигналам:

- считается, что основными лигандами активирующих рецепторов являются молекулы, которые появляются на поверхности собственных клеток организма при различных «стрессовых» ситуациях и инфицировании различными патогенами;

- ингибиторные рецепторы - KIRs (иммуноглобулиновое суперсемейство) и гетеродимер NKG2A (лектиновый рецептор) - CD94. Их лигандами являются молекулы MHC I класса: KIRs связываются с HLA-A, -B или -C, тогда как лигандом NKG2/CD94 является HLA-E. В норме, эти молекулы представлены постоянно на поверхности нормальных, неизмененных клеток. Распознавание происходит следующим образом:

- Активирующие рецепторы, связываясь с собственными лигандами на поверхности клетки, формируют активирующий сигнал.

- Ингибиторные рецепторы, связываясь с молекулами МНС I, плотность экспрессии которых на собственных «неизмененных» клетках организма всегда высока, индуцируют 
ингибиторный сигнал, подавляя активацию NK. В случае снижения уровня экспрессии молекул MHC I класса на клетках-мишенях, NK-клетки на получают достаточно эффективного ингибирующего сигнала, что приводит в активации NK-клетки.

- Fc-рецепторы (CD16) представлены на поверхности NK-клеток. Они способны распознавать молекулы антител, связавшиеся со своими лигандами на поверхности клеток. Fcрецепторы обладают ITAМ-последовательностью и способны активировать NK-клетки после связывания с молекулами антител.

- Эффекторные функции NK-клеток регулируются комплексом сигналов, полученных как от стимулирующих, так и от ингибирующих рецепторов.

В настоящее время описано три способа индукции апоптоза цитотоксическими клетками в клетках-мишенях:

- во-первых, это цитолиз, осуществляемый за счет высвобождения перфорина, способного к полимеризации в плоскости мембраны клетки-мишени. Данный процесс приводит к образованию каналов для проникновения к клетку гранзимов и гранулизинов, запускающих апоптоз по каспаза-зависимому и/или каспаза-независимому пути;

- во-вторых, это запуск апоптоза в клетке-мишени за счет активации на ее поверхности рецепторов, принадлежащих к семейству TNF-подобных белков;

- в-третьих, индукция апоптоза в клетках-мишенях при помощи растворимых молекул семейства TNF, которые способны вызывать кластеризацию рецепторов и активацию каскада каспаз внутри клеток-мишеней.

Контактный цитолиз происходит в четыре этапа:

Первый этап представляет собой распознавание клеток-мишеней эффекторной клеткой. В случае позвоночных животных ключевую роль в процессах распознавания клеток-мишеней играют молекулы главного комплекса гистосовместимости I класса (МНC).

Второй этап контактного цитолиза, сопровождается формированием контакта (или иммунологического синапса) между клеткой-эффектором и клеткой-мишенью, что приводит к поляризации киллерной клетки. Ключевую роль в этих процессах играют интегриновые рецепторы. При этом движение гранул, содержащих перфорин и гранзимы, в зону контакта направляют микротрубочки, ориентированные в сторону клетки-мишени. Сокращение актиновых волокон приводит к выбросу гранул в зону контакта.

Третий этап - это экзоцитоз или выброс гранул клеткой-эффектором. В состав гранул цитотоксических клеток входит несколько компонентов, ключевыми являются перфорин и гранзим В.

И, наконец, последним - четвертым этапом контактного цитолиза является индукция апоптоза клетки-мишени при помоши описанных ниже механизмов.

Основная характеристика ключевых молекул, принимающих участие в реакциях контактного цитолиз является перфорин, гранзимы и гранзулимы.

Перфорин относится к семейству белков МАСРF (от англ. «membrane attack complex and perforin»), к которому также принадлежат белки мембран-атакующего комплекса - компоненты каскада комплемента С6, C7, С8 и С9. Функция - формирования пор в мембране клетки-мишени (процесс является $\mathrm{Ca}^{2+}$-зависимым).

Изменение конформационной структуры перфорина сопровождается появлением на его поверхности гидрофобного участка, обладающего сродством к фосфотидилхолину плазматической мембраны.

Перфорин встраивается в состав мембраны только в форме мономера, однако в окружении гидрофобных частей фосфолипидов он обретает способность к полимеризации. В состав такого комплекса может входить до 20 молекул перфорина, при этом диаметр сформированного канала может достигать 15-20 нм, что вполне достаточно для проникновения в клетку не только различных ионов и молекул воды, но и высокомолекулярных белковых молекул.

Гранзимы - семейство белков, являющихся сериновыми протеазами. В гранулах цитотоксических Т-лимфоцитов и NK-клеток это семейство представлено гранзимами А и В. 
Гранзимы В способны расщеплять белки, обогащенные остатками кисльх аминокислот, в особенности, остатками аспарагиновой кислоты. Кроме того, данная группа белков запускает апоптоз по каспаза-зависимому пути, при этом используются два механизма активации каспаз.

Во-первых, одной из основных мишеней гранзимов В является каспаза-3, взаимодействие с которой сопровождается ее активацией и запуском апоптоза. Во-вторых, гранзимы В способны нарушать целостность наружной мембраны митохондрий и активировать белок $\mathrm{Bid}$, входящий в состав семейства bcl-2. Все это приводит к запуску митохондриального механизма развития апоптоза в клетке-мишени. Активация Bid сопровождается выходом в цитоплазму цитохрома $\mathrm{C}$ и других проапоптогенных белков, отвечающих за запуск каскадов реакций, приводящих к гибели клетки-мишени.

Гранулизины относятся к семейству сапонин-подобных белков. Эти низкомолекулярные белки (около 9 кДа) способны проникать через поры, образованные перфорином, и взаимодействовать с липидами митохондрий, что приводит к нарушению целостности и высвобождению в цитоплазму проапоптотических факторов Кроме того, гранулизины способны напрямую активировать каспазу-3. Следует отметить, что все эффекты гранулизинов в настоящее время еще не изучены.

Запуск апоптоза в клетке-мишени осуществляется также за счет активации на ее поверхности рецепторов, принадлежащих к семейству TNF-подобных белков, пар молекул TRAIL - DR4, DR5, FASL - FAS и TNF - TNFRI. Эти рецепторы в цитоплазматической части содержат домен смерти DD (Death Domain), активация которого и запуск апоптотического сигнала происходят при тримеризации рецептора, вызываемой связыванием лигандов. Тримеризация рецепторов и их внутриклеточных DD придаёт последним способность образовывать «сигнальные комплексы», которые приобретают сродство к некоторым инициаторным прокаспазам, обычно прокаспазе 8, которая может активировать каспазу 3 и запустить апоптоз.

NK-клетки синтезируют такие цитокины как IFN $\gamma$, TNF $\alpha$, GM-CSF, IL-10 или IL -13. IFN $\gamma$ ингибирует пролиферацию опухолевых клеток in vitro и косвенно рост опухоли in vivo путем индукции антиангиогенных факторов; IFN $\gamma$ усиливает цитотоксичность NK-клеток за счет избыточной экспрессии молекул адгезии и повышения чувствительности опухолевых клеток к цитотоксичности, обусловленной высвобождением гранул или TNF. 


\section{Abcam - всегда отличный результат!}

- Выбор из 6олее 150 теlс. продүнтов

- Гарантированное кәчестео

- Постаеки 2 раза в месяц
Abpromise guarantes
(fit) Globol sclemplile nupport
Eosy to follow protocols

Abpromise - гарантия пронвводителя для проверенных прмложений.

Abtrial - програнына тестирования дла новых направлений применения Без риска для понүпателя. Abreyiew - честные отывывы исспедователей по наждомын продукту.

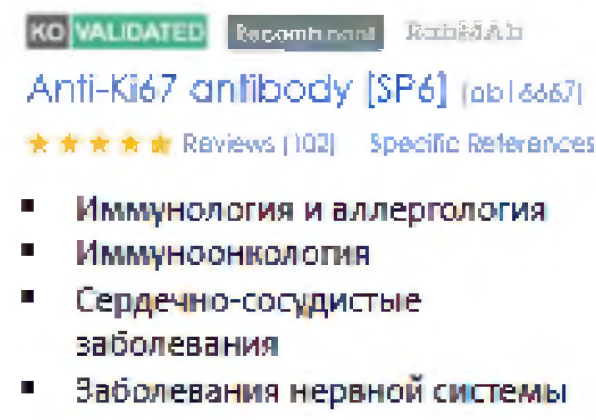

Полная информация и готовье пошатовые протоноль। Отыывы исследователей Віссонан ццитируемопть в пуылинацияя

\section{Неконъюгированнье и конъюгированнь|е первичные антитела}

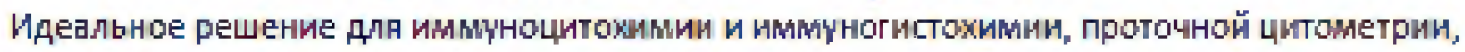
мммуноболотинга и др.

Отличный реэүльтат дане при высоной птепени рајєедения.

Средн болес 62 тыс. первниныж антител:

RabMab - высоночщвствитепьные кроличьи моноклональные антитела;

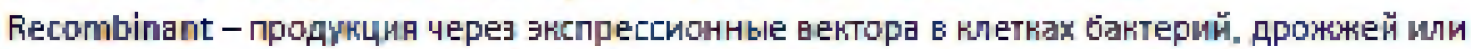

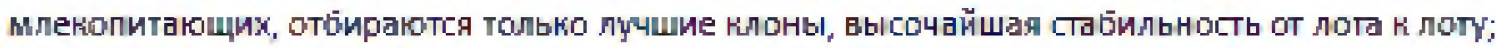
1\% Walidated - спецімфичноть валмдирована на нонаутных нлетнах;

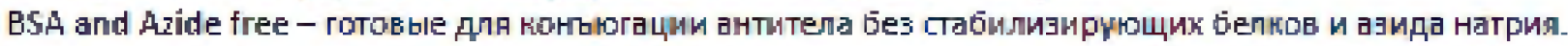
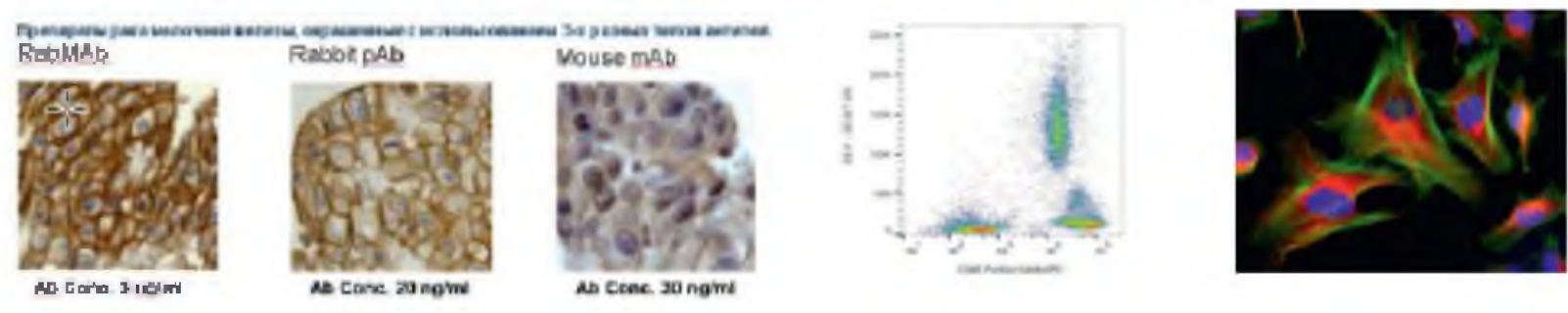

\section{Конъюгаты вторичных антител}

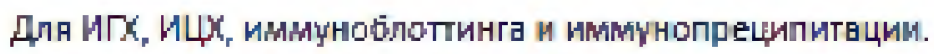

Eолег 2,8 тыс. раэличныл вариантов.

Хромогенные и флүоресцентные конъюгты, в. т. ч. и для многоцветного аналиэа.

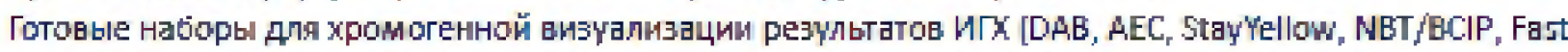
Fied и AP.j. 


\section{ИММУННАЯ СИСТЕМА}

\section{Глава 4. Адаптивный иммунитет}

Начиная данный раздел, следует отметить, что ключевую роль в активации клеточных и гуморальных реакций системы адаптивного иммунитета играет процесс, получивший название «презентация» (иногда «представление») антигенов (рис.26) [39, 52, 53, 57, 59].

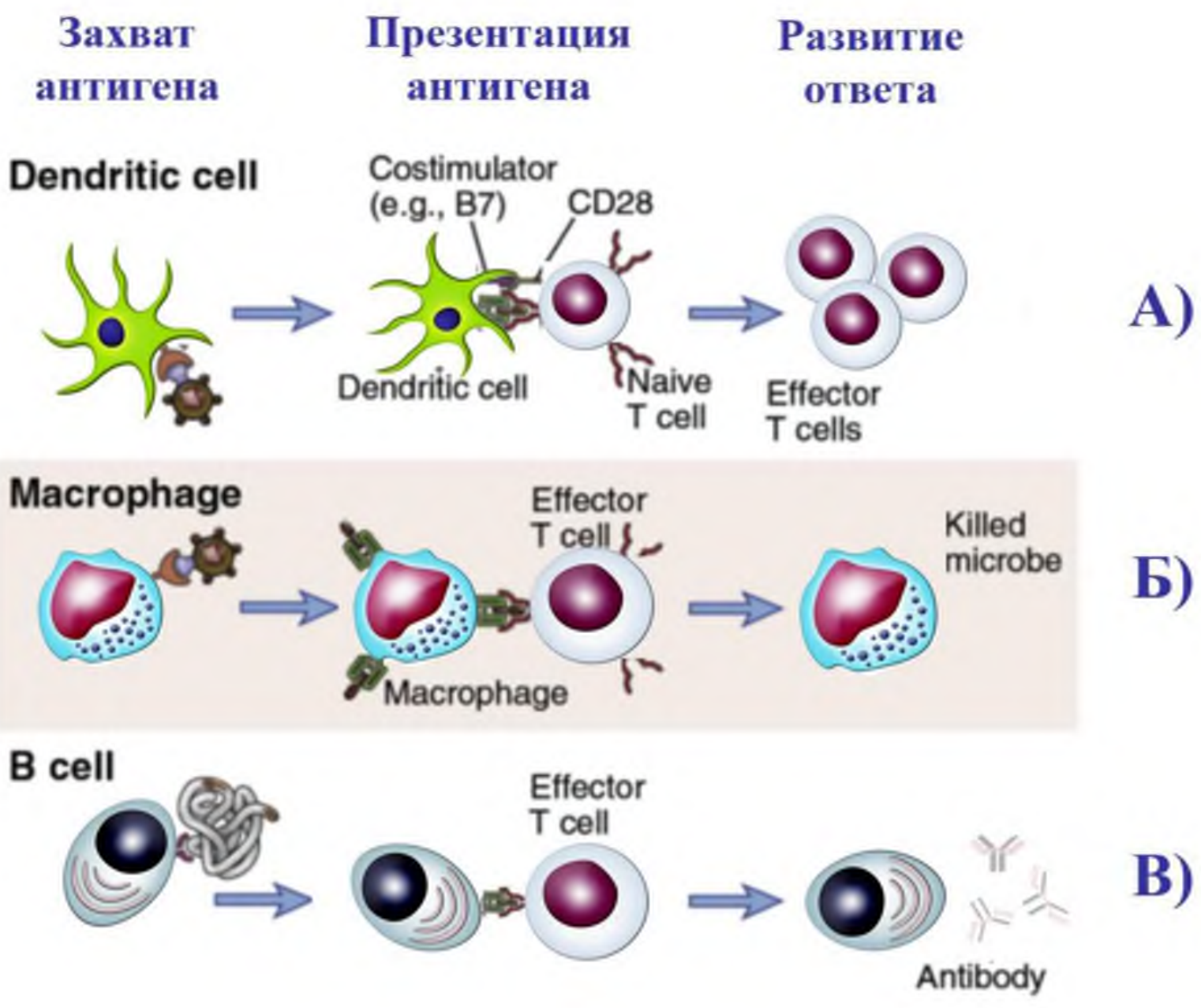

Рис. 26. Основные этапы развития специфического иммунного ответа

А) Активация «наивных» клеток, клональная экпанасия, формирование эффекторов Б) Активация эффекторной клетки - продукция цитокинов, активация макрофагов (клеточный ответ)

В) Активация эффекторной клетки - активация В-лимфоцитов, продукция антител (гуморальный ответ)

За реализацию всех процессов, связанных с презентаций антигенов, отвечают так называемые антиген-презентирующие клетки (АПК) - гетерогенная популяция лейкоцитов с выраженными иммуностимулирующими свойствами, обладающие способностью осуществлять «процессинг» антигена и предоставлять («презентировать»его иммунокомпетентным клеткам (в первую очередь, различным популяциям Т-хелперов и цитотоксическим Т-лимфоцитам). 
Процессинг антигенов - это частичный (ограниченный) протеолиз белковых антигенов (расщепление до 5-20 аминокислотных остатков), упаковка полученных фрагментов антигена на молекулы главного комплекса гистосовместимости 1 и 2 классов (MHC I и MHC II). А также последующая экспрессия образующихся комплексов на поверхность АПК - т.е. презентация антигена в иммуногенной форме (той самой форме, которая может вызвать развитие специфического иммунного ответа с последующим формирование иммунологической памяти).

Какие клетки отвечают за презентацию антигенов? Обычно выделяют «профессиональные» АПК - дендритные клетки, макрофаги и В-лимфоциты - на поверхности этих клеток молекулы МНС II класса присутствуют постоянно. Наряду с «профессиональными» АПК, некоторые типы соматических клеток (кератиноциты, тироциты, эндотелиоциты) при различных воспалительных процессах в условиях активации цитокинами также приобретают способность участвовать в презентации антигенов. Что же касается молекул МHC I класса, то они постоянно (конститутивно) представлены на поверхности большинства клеток организма (кроме клеток трофобласта), а под действием провоспалительных факторов (цитокины, патоген-ассоциированные молекулярные паттерны, молекулы клеточной опасности и т.д.) уровень их экспрессии может существенно повышаться.

Основные этапы развития специфического иммунного ответа:

1). Первичное проникновение патогена через барьерные ткани;

2). Захват патогена или его фрагментов АПК, которые могут быть локализованы в барьерных тканях (например, дендритные клетки) или в лимфе, собранной из тканей в лимфатическом узле (В-лимфоциты).

3). Процессинг и доставка антигенов в Т-зависимые зоны периферических лимфоидных органов активированными антигеном АПК (в этом случае АПК активируется и начинает экспрессировать рецепторы «хоуминга» в лимфоидную ткань и, в первую очередь, в Тзависимые зоны, где вероятность встречи с Т-лимфоцитом максимальна, а также созданы все необходимые условия - формирование микроокружения - для презентации антигенов и клональной экспансии Т-клеток);

4). Презентация антигенов патогена Т-лимфоцитам в Т-зависимых зонах периферических лимфоидных органов;

5). Развитие специфического ответа, связанного с получением Т-клеткой трех активационных сигналов (от Т-клеточного рецептора $=$ распознавание специфического антигена; от ко-стимулирующих молекул, которые появляются исключительно на активированной через паттерн-распознающие рецепторы АПК = подтверждение того, что Тклеткой было распознано именно «чужое», а не «свое); и от цитокинов, которые синтезируются активированной АПК и активированными Т-лимфоцитами), дальнейшей клональной экспансией и формированием пула эффекторных клеток, способных мигрировать в очаг проникновения патогена.

В том случае, если этапы 1-3 могут протекать как в периферических тканях (в случае макрофагов и дендритных клеток как АПК), так и в лимфоидной ткани (В-клетки как АПК), то последующие этапы (4 и 5) в норме протекают исключительно в периферических лимфоидных органах. Именно поэтому периферические органы иммунной системы расположены по регионарному принципу, что позволяет контролировать поступление антигенов из определенных частей тела и развивать иммунный ответ. Так, каждый лимфатический узел контролирует строго определенную часть тела, от которой к нему поступает лимфа; тогда как селезенка является барьером для антигенов, поступивших в кровоток. Кроме того, существуют лимфоидные органы и скопления лимфоидных клеток, непосредственно контактирующие с барьерными тканями - слизистыми оболочками и с кожей (см. Главу 2).

Реализация противовирусного и противоопухолевого иммунного ответа происходит за счет презентация антигенов, локализованных в цитоплазме клеток, при помощи МНС I класса -Этот процесс протекает постоянно во всех клетках организма (кроме клеток трофобласта); ключевую роль в распознавание клеток, несущих в своей цитоплазме «чужие» (инфицированные вирусами или некоторыми бактериями, живущими в цитоплазме без 
мембранной упаковки) или собственные «измененные» (переродившиеся опухолевые клетки) антигены играют цитотоксические Т-лимфоциты с фенотипом CD3+CD8+. Именно благодаря молекуле CD8 (которая способна к специфическому взаимодействию с MHC I) эти клетки получают подтверждающие сигнал о том, что они распознали антигены, локализованные в цитозоле, и могут запустить процессы, связанные с индукцией апоптоза в этой клетки. Презентация антигенов через молекулы МНC I класса традиционно разбивается на несколько стадий (рис.27):

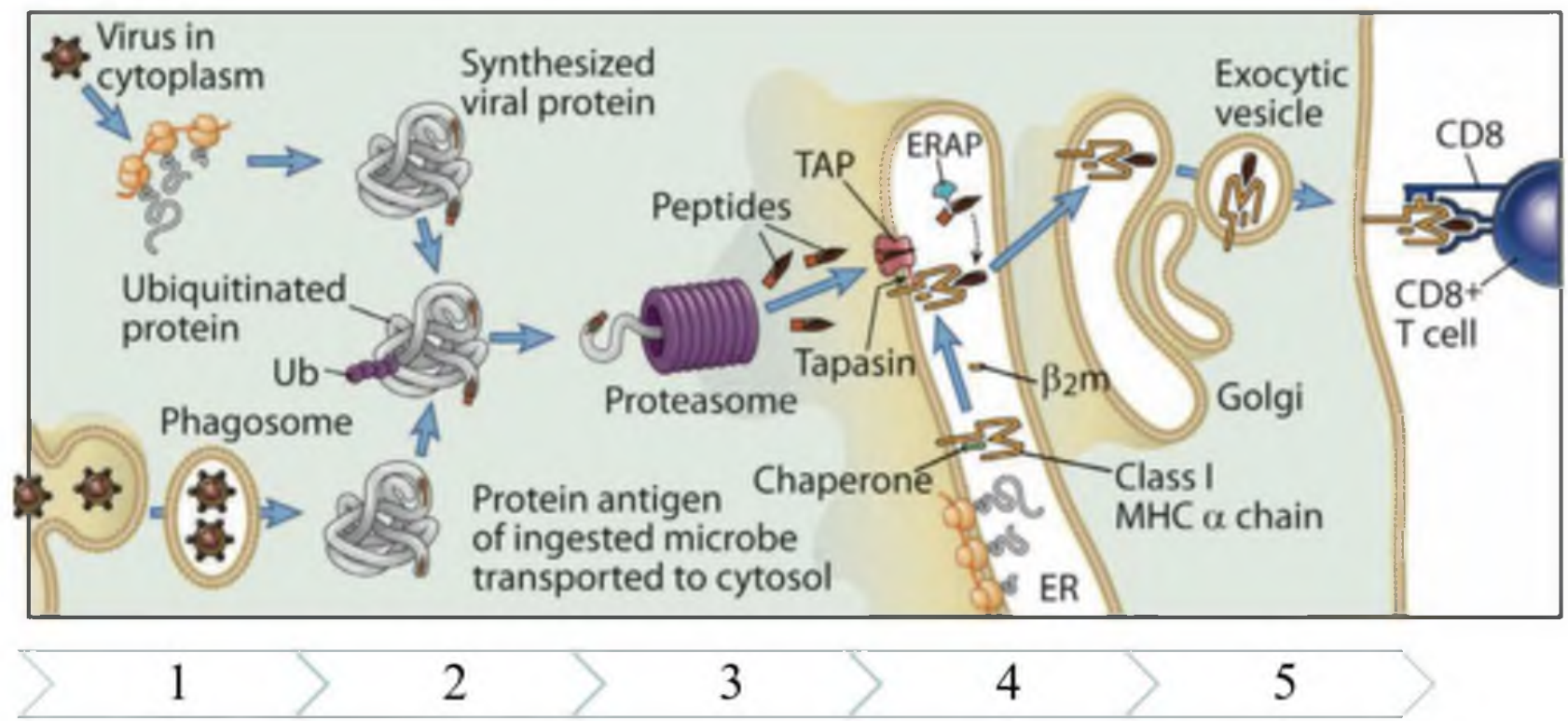

Рис. 27. Презентация антигенов, локализованных в цитоплазме клеток, при помощи МНС I класса - реализация противовирусного и противоопухолевого специфического иммунного ответа (Cellular and Molecular Immunology by Drs. Abul K. Abbas, Andrew H. H. Lichtman, and Shiv Pillai 9th edition, 2017).

1. Синтез белков в цитоплазме клетке на свободных рибосомах;

2. Ограниченный протеолиз белков (обычно около $30 \%$, а при активации клеток - до $70 \%$ от общего объема вновь синтезированных белков) в специальной белковой «мясорубке» - протеасоме (ее активность также зависит провоспалительных сигналов извне клетки);

3. Все полученные фрагменты белков (уже их можно называть антигенами) специфическим образом маркируются и переносятся при помощи специализированных белков-транспортеров семейства ТАР из цитозоля в полость ЭПС;

4. Загрузка пептида на МHC I

5. Перемещение комплекса «MHC I-пептид» на наружную мембрану клетки для распознавания цитотоксическим Т-клетками.

Вместе с тем многие патогены используют стратегии избегания или снижения эффективности иммунного ответа за счет нарушения презентация антигенов через МНС I. Так, способностью к снижению активности протеосомы обладают белки вирусов EBV и CMV, что снижает эффективность процессинга вирусных белков. Некоторые белки HSV способны блокировать работу белков-транспортеров семейства ТАР, что снижает эффективность доставки процессированных антигенов в ЭПС. Аденовирусы и CMV подавляют синтеза молекул MHC I в инфицированной клетке и/или нарушают его перемещение по ЭПС. Более того, CMV способствует удаление MHC I из ЭПС, тогда как CMV вызывает продукцию MHCIподобных молекул, на которые возможность загрузки собственных пептидов резко снижена.

Презентация внеклеточных антигенов при помощи МНС II класса - реализация специфического иммунного ответа против патогеном, локализованных в межклеточном пространстве. Этот процесс протекает постоянно в профессиональных АПК (а также некоторых активированных клетках); ключевую роль в распознавание клеток, поглотивших при помощи различных типов эндоцитоза «чужие» (бактерии, грибы, гельминты, вирусы и т.д.) антигены 
играют T-хелперы с фенотипом CD3+CD4+. Именно благодаря молекуле CD4 (которая способна к специфическому взаимодействию с МHC II) эти клетки получают подтверждающие сигнал о том, что они распознали антигены, поглощенные АПК из межклеточного пространства, и могут запустить процессы, связанные продукцией цитокинов, направленных на активации различных эффекторных клеток. Презентация антигенов через молекулы МНС II класса традиционно разбивается на несколько стадий (рис.28).

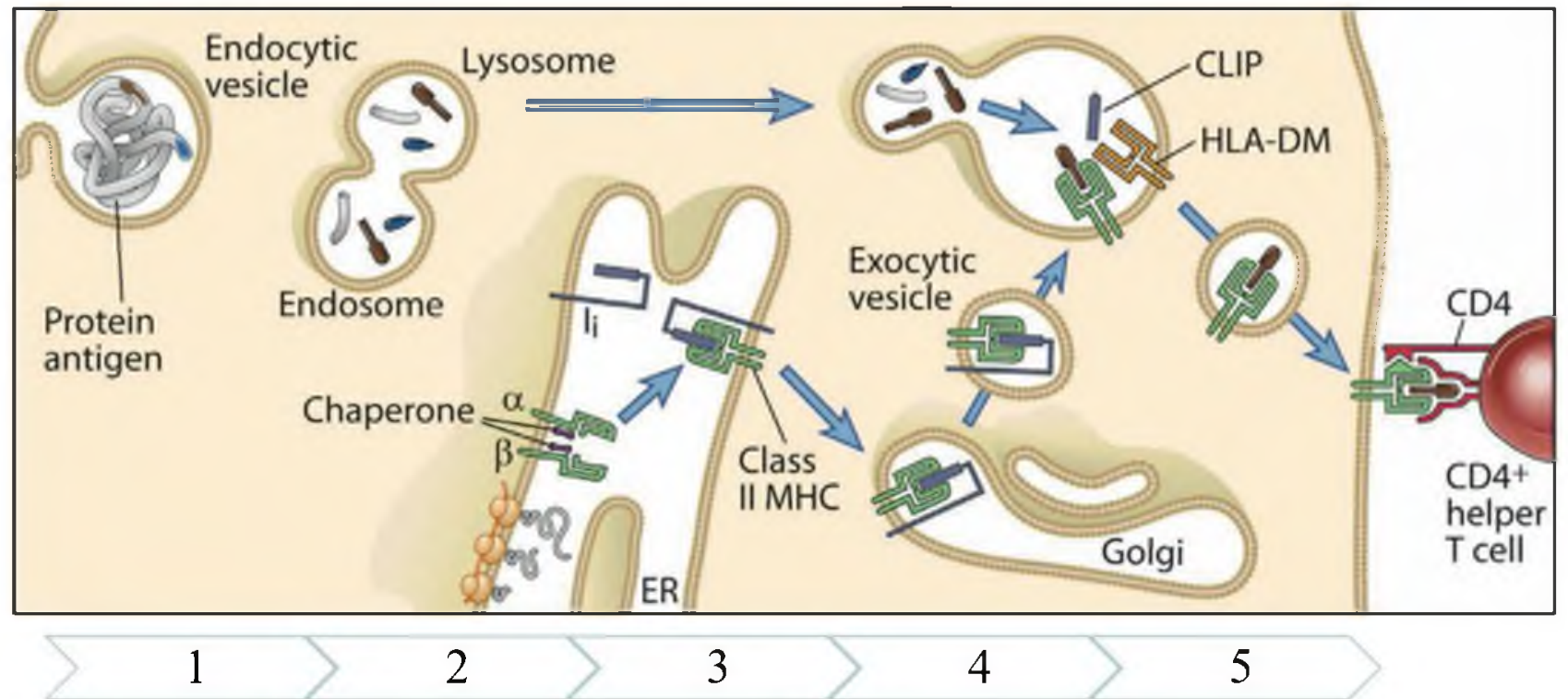

Рис. 28. Презентация внеклеточных антигенов при помощи МНС II класса - реализация специфического иммунного ответа против

внеклеточных патогенов (Cellular and Molecular Immunology by Drs. Abul K. Abbas,

Andrew H. H. Lichtman, and Shiv Pillai 9th edition, 2017).

1. Эндоцитоз внеклеточного антигена АПК;

2. Ограниченные протеолиз поглощенного антигена в фаголизосоме/эндосоме;

3. Синтеза молекул МНС II в ЭПС с последующим их транспортом в эндомосу с процессированным антигеном (при этом сайт для связывания с антигенов на МНC II закрыт специальным белком-заглушкой - это позволяют предотвратить загрузку внутриклеточных антигенов, которые находятся в полости ЭПС, на данную молекулу);

4. Удаление белка-заглушки с MHC II и загрузка антигена на МНC II в после слияния везикул; Т-хелперами

5. Перемещения образовавшегося комплекса «МHC II-антиген» на поверхность клетки для распознавания

Следует отметить, что подобно МНС I класса, многие патогенны - в первую очередь, бактерии и грибы - используют различные стратегии избегания или снижения эффективности презентации своих антигенов за счет нарушения данного процесса презентации через МНC II.

Например, многие бактерии нарушают процессы созревания фаголизосом, что позволяет им избежать не только собственной гибели, но и процессинга собственных антигенов. Некоторые виды Mycobacterium и Ehrlichia блокируют созревание фагосом в самом начале, тогда как сальмонеллы позволяет фагосомам немного большее созревание, a, например, Coxiella высвобождается в цитоплазму уже из зрелой фаголизосомы. На аналогичной стадии фаголизосомы способны покидать некоторые виды Listeria и Rickettsia.

Итак, патогены применяют весьма эффективные стратегии избегания презентации собственных антигенов. Именно поэтому были разработаны многочисленные фармакологические подходы, целью которых являлось повышение эффективности распознавания антигенов клетками иммунной системы. В онкологии применяются различные химиотерапевтические препараты, одним из эффектов которых является увеличение экспрессии молекул MHC I класса (например, цисплатин или гемцитабин) на клетках, включая перерожденные опухолевые клетки, организма пациента. На разных стадия клинических 
исследований испытаний находятся препараты на основе ингибиторов тирозинкиназ, способные усиливать экспрессию молекул МНC I и II классов. А также оказывать влияние на плотность экспрессии ко-стимулмрующих молекул CD86 и CD40. Препараты, содержащие интерфероны I и II типов, также оказывают стимулирующее действие как на соматические клетки (за счет усиления экспрессии MHCI и белков семейства TAP), так и в случае IFN $\gamma$ еще и на профессиональные АПК, на поверхности которых увеличивается уровень не только МНС II, содержащих пептиды, но и ко-стимуляционных молекул. Столь же эффективны различные препараты, содержащие в своем составе агонисты TOLL-подобных рецепторов. Например, такой агонист TLR 2/4 как БЦЖ способен повышать экспрессии на АПК как MHC-II, так и костимулирующих CD80/CD86 и адгезионных ICAM молекул.

\section{Активация Т-лимфоцитов АПК. Формирование «иммунного» синапса}

Когда комплекс TcR распознает MHC-ассоциированные пептиды на АПК, то сразу несколько поверхностных и внутриклеточных сигнальных молекул Т-клеток быстро собираются в месте контакта Т-клетка-АПК. Эта область физического контакта между Тклеткой и АПК формирует макромолекулярную структуру, которая называется «иммунным» синапсом или надмолекулярным активационным кластером (SMAC, от англ. «supramolecular activation cluster»)).

B самом центре SMAC находятся такие молекулы как T-клеточный рецептор в ассоциации с CD3 (все цепи, включая $\zeta$ ), корецепторы CD4 или CD8 (в случае T-хелпера или цитотоксического Т-лимфоцита, соответственно), различного рода внутриклеточные сигнальные молекулы, главной из которых является протеинкиназа $\theta$ (PKC- $\theta$ ), а также адапторные белки, отвечающие за передачу сигнала на ядро активированного Т-лимфоцита. В этой области синапса, называемой также c-SMAC (центральная часть SMAC, от англ. «central SMAC»), расстояние между плазматической мембраной Т-лимфоцита и мембраной АПК составляет около 15 нм. Адгезионные молекулы, в первую очередь интегрины (LFA-1 co стороны Т-лимфоцита контактирует с иммуноглобулиновыми молекулами ICAM-1 на поверхности АПК), формируют периферическую часть «иммунного» синапса и играют ведущую роль в стабилизации сайта взаимодействия между Т-клеткой и АПК. Эта область получила название периферическая часть SMAC или p-SMAC (от англ. «peripheral SMAC»). B этой внешней части синапса мембраны контактируюших клеток разделяет расстояние в пределах 40 нм. Кроме того, по периферии со стороны Т-лимфоцита формируется дополнительное кольцо из молекул CD44 и CD45, получившие название d-SMAC (от англ. «distal SMAC»).

В покоящейся Т-клетке все эти сигнальные и адгезионные молекулы обычно располагаются диффузно в плоскости плазматической мембраны лимфоцита в составе так называемых липидными «рафтов» (от англ. «lipid rafts») или плотов, то есть фрагментов мембраны, обогащенных гликолипидами. Только после активации Т-клеточного рецептора и ко-стимуляционных молекул липидные «рафты» за счет белков цитоскелета_направленно мигрируют в зону контакта с АПК и сливаются вместе, формируя иммунологический синапс. Таким образом, иммунный синапс выполняет несколько важнейших функций, связанных с активацией Т-лимфоцита (рис. 29).

Во-первых, это стабилизация области распознавания Т-клеточным рецептором антигена в ассоциации с МНС, что позволяет Т-лимфоциту провести фосфорилирование сигнальных молекул, необходимых для активации пролиферации и синтеза ряда поверхностных и растворимых молекул. На поверхности АПК комплекс МНС с антигеном (точнее, эпитопом антигена), который был распознан Т-лимфоцитом, может быть представлен всего лишь несколькими молекулами (необходимо помнить, что в ходе ограниченного протеолиза антиген разрезается на множество отдельных эпитопов, которые могут презентироваться АПК одновременно). Поэтому формирование синапса позволяет собрать вместе несколько комплексов MHC-антиген, чтобы активировать сразу несколько TcR. Более того, сродство или aффинность TcR к антигену может быть весьма низким, но длительное взаимодействие гарантирует эффективное проведение сигнала и активацию лимфоцита. 

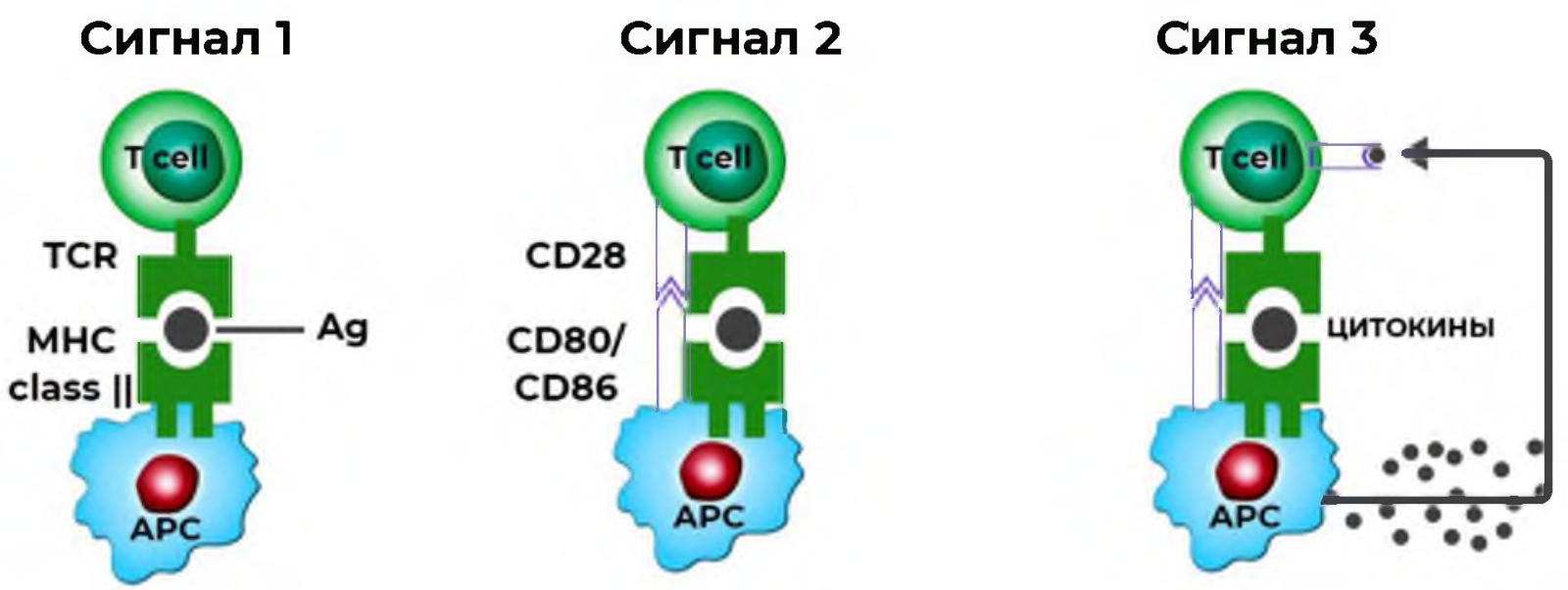

\section{Рис. 29. Схематическое изображение трех основных «сигналов», необходимых для активации Т-лимфоцита и запуска антигензависмой стадии дифференцировки в периферических лимфоидных органах}

Во-вторых, именно в составе синапса происходит обмен сигналами, основанными на цитокинах, между АПК и Т-лимфоцитом. Условная изолированность внутреннего пространства синапса позволяет локально повысить концентрацию этих цитокинов, что также обеспечивает эффективное проведение сигнала и активацию Т-лимфоцита.

B-третьих, «иммунный» синапс, особенно в своей центральной части c-SMAC, также может быть важным для эффективной передачи сигнала внутрь клетки. Следует помнить о том, что после фосфорилирования и активации сигнальных молекул последние быстро убиквитинируются (посттрансляционное присоединение ферментами убиквитинлигазами одного или нескольких мономеров убиквитина с помощью ковалентной связи к боковым аминогруппам белка-мишени) и расщепляются. Эта деградация сигнальных белков способствует прекращению активации Т-клеток.

Итак, для активации Т-лимфоциты и запуска антигензависимой стадии дифференцировки в периферических лимфоидных органах необходимо три сигнала:

1. Распознавание Т-клеточным рецептором антигена в ассоциации с молекулами главного комплекса гистосовместимости I (для цитотоксических Т-лимфоцитов) или II (для Тхелперов) класса;

2. Взаимодействие между ко-стимуляционными молекулами АПК и Т-клетки;

3. Цитокины, секретируемые АПК, необходимы для эффективной активации и клональной экспансии. (рис. 30)?

Для чего необходимы «костимулирующие» сигналы при развитии иммунного ответа

1. Костимулирующие молекулы CD80/CD86 появляются на поверхности АПК только в случае активации на ней рецепторов врожденного иммунитета (то есть исключительно в ответ на распознавание «чужого», а не случайно презентируемого «своего»);

2. Именно патогены являются индукторами экспрессии ко-стимулирующих молекул на АПК (без патогена и/или его компонентов запуск иммунного ответа невозможен - это свойство применяется, например, при создании эффективных вакцин, где лиганды TLR и других паттернраспознающих рецепторов являются одними из важнейших компонентов);

3. Взаимодействие между CD80/CD86 и CD28 необходимо для активации Т-лимфоцита, распознавшего именно «чужеродный», а не собственный антиген; 


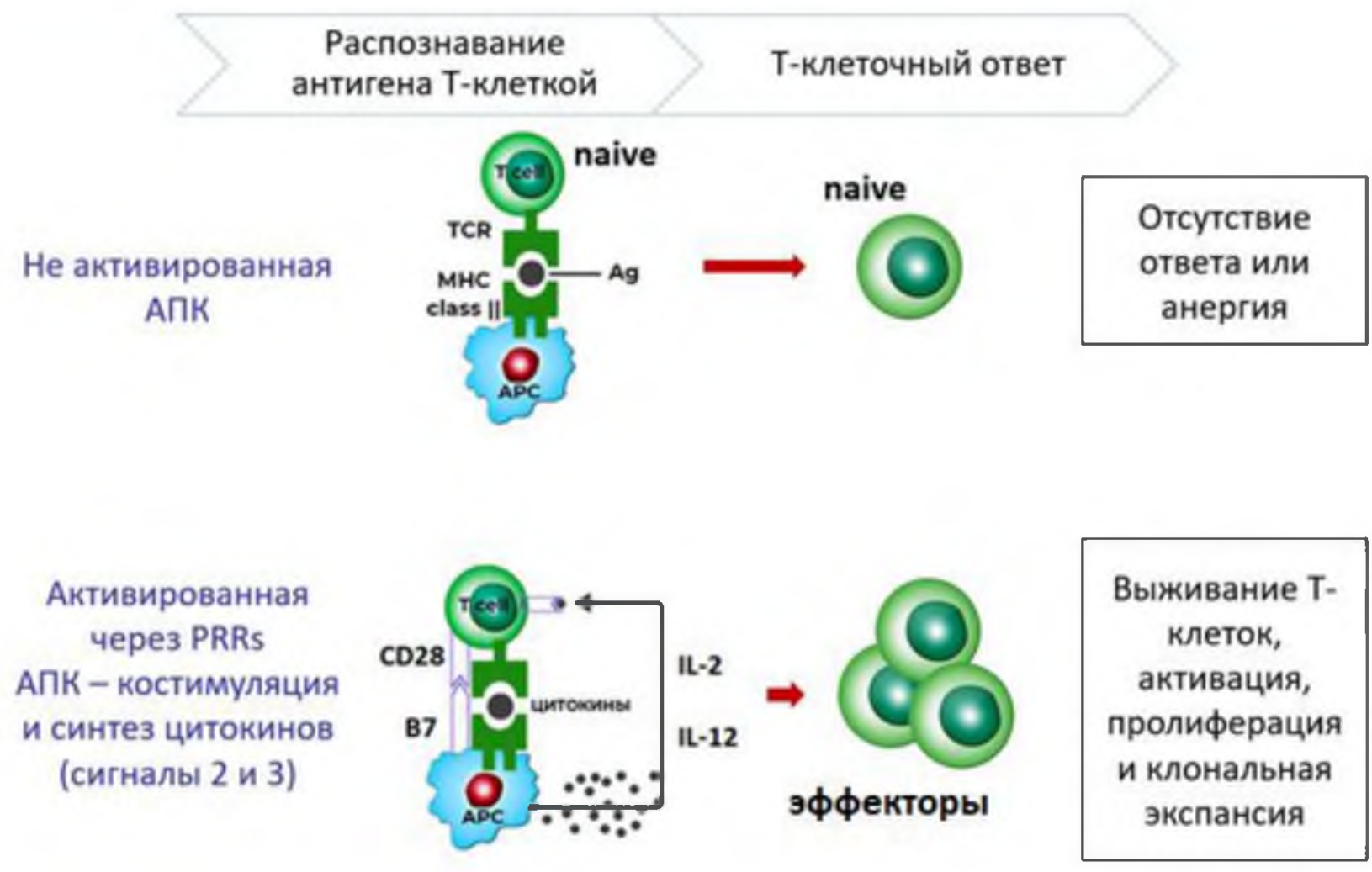

Рис. 30. Костимуляционные молекулы, роль в активации Т-лимфоцитов

4. Молекулы CD80/CD86 и CD28 играют ведущую роль в поддержание периферической толерантности (именно на этом свойстве основаны разработка и эффективное применение некоторых современные биологических препаратов, некоторые из которых стали, например, поводом для присуждения Джеймсу Эллисону Нобелевской премии по медицине и физиологии в 2018 году);

5. Срыв периферической толерантности лежит в основе аутоиммунных патологических состояний, поэтому ко-стимуляционные молекулы являются перспективными мишенями для терапии.

Итак, основные функции взаимодействия CD80/CD86 со стороны АПК и CD28 со стороны Т-лимфоцита. Под действием этого сигнала активированный Т-лимфоцит, распознавший своим Т-клеточным рецептором антиген в ассоциации с $\mathrm{MHC}$, начинает:

- увеличивать экспрессию анти-апоптотических белков (белков, блокирующих апоптоз - так как любая активированная клетка специфического иммунитета потенциально опасна для организма, так как может распознать собственные антигены и запустить аутоиммунное воспаление) - это сигнал на выживание для Т-лимфоцита;

- синтез и секреция $\mathrm{IL}-2$; увеличение экспрессии CD25 на поверхности клетки (IL-2 является важнейшим аутокринным ростовым фактором для Т-клеток, без него Т-клетки не могут пролиферировать и формировать клон эффекторных клеток; чтобы избежать потенциальных “ошибок» в активации аутореактивных клеток, способностями к синтезу IL-2 и его «восприятию» - формированию высоко-аффинного рецептора для этого цитокина за счет синтеза CD25 - обладают только Т-лимфоциты, способные к распознаванию исключительно «чужого» антигена);

- пролиферация или клональная экспансия - наработка пула клеток, обладающих Тклеточным рецептором заданной специфичности (исходно была одна «наивная Т-клетки, которая покинула тимус с уникальным рецептором - для эффективного ответа на патоген необходимо множество таких клеток, чем их больше - тем ответ протекает быстрее и с минимальным повреждением организма, вызванного действием патогена); 
- увеличение уровня экспрессии белков-циклинов, отвечающих за продвижение активированного Т-лимфоцита по клеточному циклу - выход из фазы покоя и переход к митозу (только лимфоцит, распознающий исключительно «чужеродный» антиген получает разрешение на клонирование - в этом еще одна важнейшая роль ко-стимуляции);

- в дальнейшем - дифференцировка в эффекторные клетки и клетки памяти (эффекторы должны бороться с патогеном в очаге его проникновения в организм, тогда как клетки памяти отвечают на ускоренный ответ при повторном проникновении патогена - именно формирование пула клеток памяти является главнейшей задачей при вакцинации).

Что же касается АПК, то она тоже получается сигналы от Т-лимфоцита - обмен сигналами носит взаимный характер! Так, после взаимодействия CD80/CD86 и CD28 на поверхности активированной T-клетки экспрессируется CD40L. Данная молекула связывается с CD40 на поверхности АПК, что приводит к усилению экспрессии CD80/CD86 и продукции цитокинов, необходимых для выживания и дифференцировки Т-клетки. Таким образом клетки стимулируют друг друга на выживание и проявление эффектов, необходимых для развития иммунного ответа.

Основные модели, описывающие дифференцировку и созревание отдельных субпопуляций Т-лимфоцитов.

В современной иммунологической литературе встречаются упоминания о четырех основных моделей, описывающих возможные пути развития зрелых эффекторных клеток из «наивных» Т-лимфоцитов. Однако большая часть этих моделей обычно рассматривается и проверяется экспериментально на примере цитотоксических Т-лимфоцитов с фенотипом $\mathrm{CD} 3+\mathrm{CD} 8+$. B первую очередь, следует упомянуть о модели «линейной дифференцировки» эффекторных клеток и клеток памяти от единого «наивного» предшественника. В данном случае после активации «наивных» Т-клеток происходит формирование эффекторных клеток, которые формируют как короткоживущие эффекторные клетки, элиминация избытка которых происходит путем апоптоза после завершения эффекторной фазы специфического иммунного ответа, так и эффекторные клетки памяти, способные впоследствии формировать долгоживущие клетки центральной памяти $[18,42,49,51,54,85,86,105]$.

Альтернативой может служить модель, получившая в англоязычной литературе название «separate-precursor model», в соответствии с которой CD3+CD8+ T-клетка, которая покидает тимус после прохождения антиген-независимой дифференцировки, уже может быть «коммитирована» к формированию преимущественно либо долгоживущих клеток памяти, либо же к развитию в эффекторные клетки. Большинство исследователей считают такой способ формирования различных популяций Т-клеток маловероятным, так как существуют данные о том, что «наивный» Т-лимфоцит является «мультипотентной» клеткой, которая способна формировать как эффекторные лимфоциты, так и дифференцироваться в сторону Т-клеток памяти, включая СМ и ЕМ клетки (рис. 31А).

В качестве альтернативы описанным выше моделям дифференцировки CD3+CD8+ лимфоцитов можно рассматривать «асимметричную» или «бифуркационную» модель, впервые предложенную в 2007 году. В основе данной гипотезы находится тот факт, что после первого митотического цикла формируются две дочерние клетки, которые в ходе дальнейшей клональной экспансии дадут начало клонам эффекторов или клеткам памяти (рис. 31Б). Так, первый «дочерний» лимфоцит, который после первого раунда деления будет находиться в непосредственной близости от АПК, и будет содержать все структуры, входящие в состав иммунного синапса (первый и второй сигналы). Более того, активированная антигеном АПК синтезирует широкий спектр цитокинов, регулирующих дифференцировку Т-клеток, максимальная концентрация которых будет наблюдаться именно в близи этой АПК (третий сигнал). Таким образом, этот лимфоцит будет получать максимально сильные сигналу от АПК, что в дальнейшем приведет к формированию клона эффекторных CD3+CD8+ клеток. Тогда как вторая дочерняя клетка, оказавшаяся в результате цитокенеза на несколько большем расстоянии от активированной АПК, - не несущая на своей поверхности иммунного синапса и получающая слабые сигнал от цитокинов - будет формировать клетки памяти. 


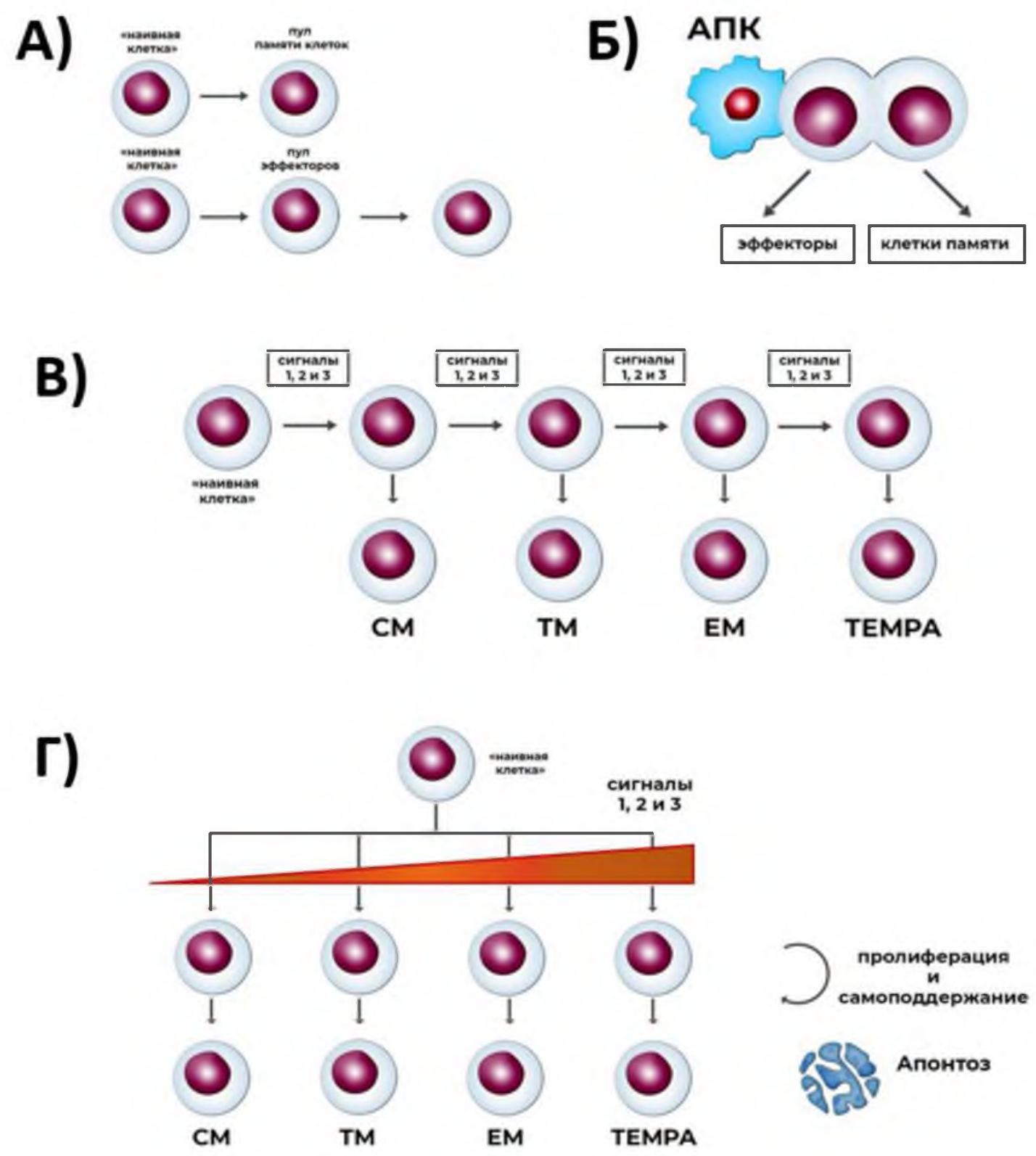

Рис. 31. Основные модели, описывающие формирование клеток памяти и эффекторных клеток в ходе антиген-зависимой дифференцировки CD3+CD8+

A - модель дифференцировки, получившая название «separate-precursor model»,

Б - «асимметричная» или «бифуркационная» модель;

В - модель дифференцировки, получившая название «signal-strength model»;

Г - модель «снижающегося потенциала»

В основе упомянутой выше модели находится гипотеза о том, что именно длительность («сила») трех межклеточных сигналов - от TcR (сигнал 1), от таких костимулирующих молекул как CD27 и CD28 (сигнал 2), а также синтезируемых АПК растворимых молекул (сигнал 3) могут определять направление дифференцировки разных типов Т-клеток. В англоязычной литературе эта модель получила название «signal-strength model», то есть модель, в рамках которой направление дифференцировки Т-клеток определяется совокупной силой трех активационных сигнала, получаемого «наивной» антиген-специфической Т-клеткой в момент ее активации в лимфоидной ткани (рис. 31B). В том случае, если все три сигнала, действующие 
на «наивную» Т-клетку, достаточно сильны и пролонгированы по времени (развитие воспалительной реакции на фоне большого объема патогенов, которые вызывают активацию АПК и эффективную стимуляцию клеток врожденного иммунитета, продуцирующих провоспалительные цитокины длительное время), то формируются короткоживущие или «терминально-дифференцированные» эффекторные клетки. По мере снижения уровня стимулирующих факторов в ходе дифференцировки «наивной» Т-клетки получаются ЕМ и СМ клетки, соответственно.

На предположении о том, что созревание «наивных» Т-лимфоцитов находится в прямой зависимости от силы и продолжительности указанных выше трех активирующих сигналов, построена еще одна модель (рис. 31Г), получившая в англоязычной литературе название «decreasing-potential model» или модель «снижающегося потенциала». В этом случае, созревание и дифференцировка CD3+CD8+ лимфоцитов от «наивных» клеток в сторону эффекторов рассматривается с точки зрения постепенного накопления эффекторных свойств на фоне уменьшения способности к пролиферации. Ведущая роль принадлежит «наивному» Тлимфоциту, который в ходе антиген-зависимой дифференцировки последовательно переходит в стадию клеток центральной памяти, затем из него формируются лимфоциты, обладающие фенотипом EM, и, наконец, в стадию TEMRA.

Таким образом, ключевым отличием от упомянутой выше модели, подчеркивающей ведущую роль микроокружения в формировании из «наивных» клеток более зрелых типов лимфоцитов, является постепенное приобретение эффекторных свойств через некоторые промежуточные стадии, наличие которых показано как для циркулирующей крови, так и в периферических лимфатических тканях. Косвенным подтверждением этой теории являются клинические наблюдения, основанные на применении антибиотиков и вакцин на основе дендритных клеток, предварительно нагруженных антигеном интереса.

Применение антибиотиков на фоне инфекционного процесса снижает уровень продукции провоспалительных цитокинов и сокращает объем доступного антигена, но не блокирует презентацию антигенов и развитие специфического иммунного ответа. Введение зрелых антиген-презентирующих клеток, уже успешно процессировавших антиген, в организм пациента обычно не сопровождается развитием воспаления, но способствует формированию клона антиген-специфических клеток. Оба эти подхода связаны с формированием слабого цитокинового сигнала (сигнал 3) и относительно низкой доступностью антигена. В результате формируются преимущественно Т-клетки центральной памяти, a не клоны клеток с эффекторным фенотипом. Итак, описанная выше модель дифференцировки CD3+CD8+ лимфоцитов сочетает в себе общие положения модели «линейной дифференцировки» Т-клеток и моделей, основанных на ведущей роли микроокружения в процессах регуляции созревания клеток $[13,37,41,43,44,46,48,49,54,72]$

Следует отметить, что в последние годны были детально охарактеризованы новые типы $\mathrm{CD} 3+\mathrm{CD} 4+$ и $\mathrm{CD} 3+\mathrm{CD} 8+$ лимфоцитов - например, клетки памяти, обладающие свойствами стволовых клеток, или тканевые «резидентных» Т-клетки памяти, обладающие выраженной способностью к самообновлению и самоподдержанию в периферических тканях, а также некоторые другие популяции, которые пока еще не нашли своего определенного места в современных классификация и моделях. Все это указывает на тот факт, что в ближайшие годы схемы созревания Т-лимфоцитов могут существенно модифицироваться.

Особенно хочется обратить внимание на то, что подавляющее большинство упомянутых выше гипотез и моделей были построены на результатах исследования цитотоксических Тлимфоцитов, а не CD3+CD4+ клеток. Более того, значительная часть ключевых экспериментов была проведена с использованием экспериментальных моделей на лабораторных животных, а лишь незначительная часть - на человекообразных обезьянах или клетках человека в условиях in vitro. В дальнейшем полученные результаты переносятся на процессы, протекающие у человека в условиях in vivo, хотя часть данных базируется на клинических наблюдениях. Однако, большинство современных исследователей сходятся во мнение, что созревание и дифференцировка антиген-специфических Т-лимфоцитов в периферических лимфоидных 
органах скорее всего имеет последовательный или линейный характер - «наивные» лимфоциты, $\mathrm{T}_{\mathrm{SMC}}, \mathrm{CM}$ клетки, EM клетки и эффекторные клетки популяции TEMRA.

Проявление эффекторных свойств клетками адартивного иммунитета.

T-хелперы (рис.32). Среди всех клеток систем врожденного и приобретенного иммунитета Т-хелперы (Th) выделяются особенным разнообразием выполняемых функций, что находит свое отражение в крайне высокой гетерогенности данной популяции (табл.23). Исходно на основании продукции цитокинов среди $\mathrm{CD} 3+\mathrm{CD} 4+$ лимфоцитов выделяли клетки, способные к синтезу IFN $\gamma$ и получившие название T-хелперов 1 типа (Th1), и клетки, названные T-хелперами 2 типа (Th2) и синтезировавшие IL-4. Далее были описаны Th17 и фолликулярные T-хелперы (Tfh). Мы остановимся только на этих четырех типах клеток, так как их реальное существование не подвергается сомнению. Следует отметить, что с завидной регулярностью появляются работы, свидетельствующие о возможности перехода Тh из одной популяции в другую в зависимости от микроокружения, типа получаемых цитокиновых сигналов метаболизма клеток и широчайшего спектра других факторов $[34,40,45,73,81,87]$.

\begin{tabular}{|c|c|c|c|c|c|}
\hline Т-келперы & Цитокины & $\begin{array}{l}\text { Клетки } \\
\text { мишени }\end{array}$ & Инмунная резкция & Пэтоген & Роль в болезни \\
\hline & $|F| \psi$ & & Актив:ация макрофагов & $\begin{array}{l}\text { Еннутринлеточные } \\
\text { патоген в: }\end{array}$ & $\begin{array}{c}\text { Аутонммунитет, } \\
\text { хроническое } \\
\text { воспаление }\end{array}$ \\
\hline & $\begin{array}{l}\text { IL-4 } \\
\text { IL-5 } \\
\text { IL-13 }\end{array}$ & & $\begin{array}{c}\text { Активация эозинофилов и } \\
\text { тучны) клеток }\end{array}$ & Гельминть- & Аллергия \\
\hline & $\begin{array}{l}\text { IL-17 } \\
\text { IL-22 }\end{array}$ & & $\begin{array}{c}\text { Привлечение нейтрюфилов } \\
\text { и их антивацня }\end{array}$ & $\begin{array}{l}\text { Внеклеточные } \\
\text { бактерим и грибы }\end{array}$ & $\begin{array}{c}\text { Аутонммунитет; } \\
\text { воспаление }\end{array}$ \\
\hline & $\begin{array}{l}\text { IL-22 } \\
\text { (н IFNY } \\
\text { или IL-4) }\end{array}$ & & Производство антител & $\begin{array}{c}\text { Внеклетоцные } \\
\text { патогень }\end{array}$ & $\begin{array}{l}\text { Аутоиммунитет } \\
\text { [аутоантитела] }\end{array}$ \\
\hline
\end{tabular}

\section{Рис. 32. Основные популяции «поляризованных» Т-хелперов и их мишени}

\section{Таблица 23}

\section{Основные характеристики «поляризованных» Т-хелперов, используемые для выявления отдельных субпопуляций клеток.}

\begin{tabular}{|c|c|c|c|c|}
\hline $\begin{array}{c}\text { Популяции } \\
\text { Т-хелперов } \\
\text { человека }\end{array}$ & $\begin{array}{c}\text { Ключевые } \\
\text { цитокины для } \\
\text { дифференцировки }\end{array}$ & $\begin{array}{c}\text { Ключевые } \\
\text { факторы } \\
\text { транскрипции }\end{array}$ & $\begin{array}{c}\text { Ключевые } \\
\text { секретируемые } \\
\text { цитокины }\end{array}$ & $\begin{array}{c}\text { Ключевые } \\
\text { поверхностные } \\
\text { молекулы }\end{array}$ \\
\hline Th1 & IL-12, IFN- & T-bet & IFN- $-\gamma$ & CXCR3, CCR5 \\
\hline Th2 & IL-4, IL-5, IL-13 & GATA3 & IL-4, IL-5, IL-13 & CCR4,CCR8, CD294 \\
\hline Th17 & IL-6, IL-23, IL-21, TGFb & ROR-үt & IL-17A, IL-17F, IL-22 & CCR6, CD161 \\
\hline Tfh & $\begin{array}{c}\text { IL-21, IL-6, IL-27, } \\
\text { IL-12 }\end{array}$ & BCL6 & IL-21, IL-10 & CXCR5, PD-1, CD40L \\
\hline
\end{tabular}

Для Th1 характерна продукция провоспалительных цитокинов IFN $\gamma$ и TNF $\alpha$, а также IL2 и IL-15, наличие транскрипционного фактора T-bet и экспрессия на поверхностной мембране CXCR3, CCR5 и рецептора для IL-18 (IL-18R). Ключевую роль в «поляризации» Th0 в Th1 играет IL-12, синтезируемый в лимфоидной ткани активированными дендритными клетками, 
хотя IL-18 и IL-33 в присутствии IL-12 также способствуют появлению CD3+CD4+ клеток со свойствами Th1. Основной задачей Th1 является активация тканевых макрофагом и мигрировавших в периферические ткани моноцитов с целью повышения эффективности уничтожение поглощенных этими клетками патогенов. Основным же факторов, обеспечивающим реализацию этих функций, является IFN $\gamma$. К важнейшим свойствам данного цитокина относятся:

1). IFN $\gamma$ является ключевым цитокином, вызывающим активацию макрофагов;

2). IFN $\gamma$ стимулирует микробицидную активность макрофагов и их поляризацию в сторону M1;

3). IFN $\gamma$ способствует переключению класса синтезируемых В-лимфоцитов антител с $\operatorname{IgM}$ на некоторые изотипы IgG (например, у мышей - на IgG2a или IgG2c), подавляя синтез и секрецию IgE;

4). IFN $\gamma$ способствует «поляризации» «наивных» Тх в сторону Tx1, подавляя Тх 2 и Tx17 программы дифференцировки;

5). IFN $\gamma$ способствует увеличению интенсивности презентации антигенов через МНC II, тем самым, усиливая клеточный ответ.

При гиперфункции Thl, связанной с продукцией цитокинов (в первую очередь, IFN $\gamma$ и $\mathrm{TNF} \alpha$ ), в организме могут формироваться очаги хронического воспаления, вызывающие повреждения окружающих тканей (как это показано при формировании гранулем). Более того, формирование клонов аутореактивных Thl связано с развитием органно-специфических и системных аутоиммунных заболеваний.

Th2 синтезируют $\mathrm{IL}-4, \mathrm{IL}-5, \mathrm{IL}-6$, IL-9, IL-10 и $\mathrm{IL}-13$, отвечающие за регуляцию клеточного и гуморального иммунного ответа, в их цитоплазме и ядре обнаруживается транскрипционный фактор Gata3, а на своей мембране они несут CD294, CCR3, CCR4, CCR8 и некоторые дополнительный антигены. При отсутствии IL-12 в окружающей ткани, но наличии $\mathrm{IL}-4$ и IL-33, Th0 дифференцируются в Th2 клетки. Основной задачей Th2 является активация тканевых тучных клеток и мигрировавших в периферические ткани из крови базофилов и эозинофилов с целью повышения эффективности уничтожение крупных многоклеточных патогенов (в первую очередь, гельминтов) и грибов. Поэтому, помимо активации лейкоцитов цитокины Th2 влияют на функционирование глакомышечных клеток трубчатых органов, эндотелий сосудов и тканевые макрофаги. Основные эффекты цитокинов Th2:

1). IL-4 стимулирует переключение синтезируемых антител B-клетками с $\operatorname{IgM}$ на IgE;

2). IL-4 играет ведушую роль в формировании Th2 из «наивных» Th и является важнейшим аутокринным ростовым факторов для дифференцировки Th2;

3). IL-4, совместно с IL-13, отвечает за формирование и функциональную активность M2 макрофагов в очаге воспаления;

4). IL-4 (и IL-13) стимулирует перистальтику кишечника, а сам IL-13 повышает секрецию слизи эпителиальными клетками ВДП и ЖКТ;

5). IL-4 и IL-13 привлечение лейкоцитов (в первую очередь, эозинофилов) в очаг воспаления за счет активации эндотелия сосудов микроциркуляторного русла и секреции хемокинов.

6). IL-5, совместно с IL-3 и GM-CSF, действует как фактор, стимулирующий эозинофилы, причем, IL-5 стимулирует пролиферацию и дифференцировку предшественников эозинофилов, тогда как IL-3 и GM-CSF действуют на более ранних стадиях развития. IL-5 также стимулирует дифференцировку В-клеток в плазматические клетки, секретирующие IgA.

Гиперактивация Th2 и продукция ими цитокинов для активации тучных клеток и базофилов тесто связана с развитием аллергических заболеваний, что находит широкое клиническое применение - например, блокада IL-5 при помощи терапевтических антител при бронхиальной астме). Вместе с тем, именно Th2 стимулируют «поляризацию» Тканевых макрофагов в сторону М2, что способствует запуску процессов репарации ткани при гельминтозах, хотя гиперпродукция цитокинов может сопровождаться формированием очагов фиброза в тканях (рис.33). 


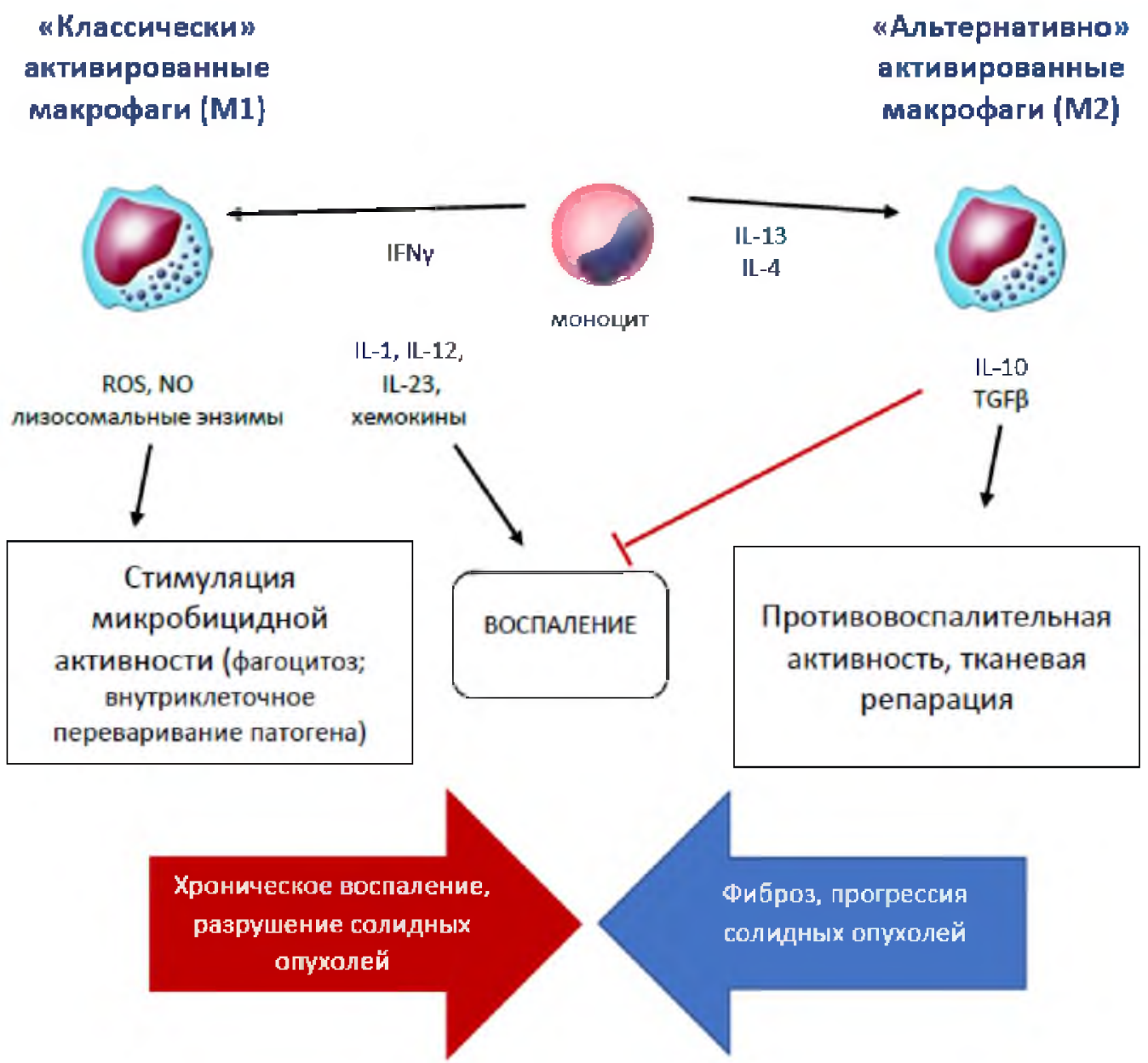

\section{Рис. 33. Роль Тх1 и Тх2 в «поляризации» тканевых макрофагов}

Th17 были впервые описаны в 2005 как клетки с фенотипом CD3+CD4+, способные к синтезу и секреции IL-17A, IL-17F, IL-21 и IL-22. Формирование Th17 из «наивных» клеток у мыши и человека происходит под действием таких цитокинов как TGF- $\beta, \mathrm{LL}-1 \beta, \mathrm{LL}-6, \mathrm{IL}-21$ и IL-23. На на поверхностной мембране Th17 обнаружена высокая плотность таких антигенов как CXCR4, CCR6 и CD161. Основной задачей Th17 является активация тканевых и мигрировавших в периферические ткани из крови нейтрофилов с целью повышения эффективности уничтожение внеклеточных патогенов за счет фагоцитоза. Поэтому, помимо активации лейкоцитов цитокины Th17 влияют на функционирование клеток эпителиальных пластов с целью повышения из барьерных функций, а также на активацию клеток эндотелия сосудов, тканевых макрофагов и фибробластов. К основным эффектам цитокинов Th17 относятся (рис.34):

1). IL-17 активирует макрофаги и дендритные клетки на продукцию провоспалительных медиаторов, что способствует индукции воспаления;

2). Действуя на клетки эпителиальных пластов $\mathrm{LL}-17$ (совместно с IL-22) усиливает секрецию ими слизи и антимикробных пептидов, а также хемокинов, что увеличивает защитные свойства барьерных тканей;

3). $\quad \mathrm{IL}-17$ стимулирует фибробласты соединительной ткани на продукцию провоспалительных цитокинов и хемокинов, что способствует увеличению эффективности клеточных реакций в очаге проникновения патогена;

4). Совместно с другими цитокинами IL-17 обладает рядом системных эффектов, связанных с активацией клеток микроциркуляторного русла, гепатоцитов печени, мышечных клеток сердца и скелетной мускулатуры. 
В целом, Th17 играют ведущую роль в защите от внеклеточных патогенов бактерий и грибов - вызывая активацию нейтрофилов («нейтрофильное» воспаление) и клеток барьерных тканей. Более того, Th17 совместно с Th1 регулируют функциональную активность фагоцитов (нейтрофилов и моноцитов) при реализации клеточно-опосредованных реакций врожденного иммунитета. Однако, гиперактивация Thl7 может служить причинной развития широкого спектра патологических состояний, в основе которых находятся неконтролируемые воспалительные процессы в различных тканях - псориаз, воспалительное заболевание кишечника, ревматоидный артрит и рассеянный склероз. Именно поэтому Th17 являются мишенью для различных биологических препаратов, направленных на поляризующие и эффекторные цитокины (анти- $L-6$, анти- $\amalg-17$, анти- $L-23$, антиTNF терапевтические моноклональные антитела).

По результатам взаимодействия между АПК и «наивным» Т-лимфоцитов, а также клональной экспансии и дифференцировки, формируется, как уже

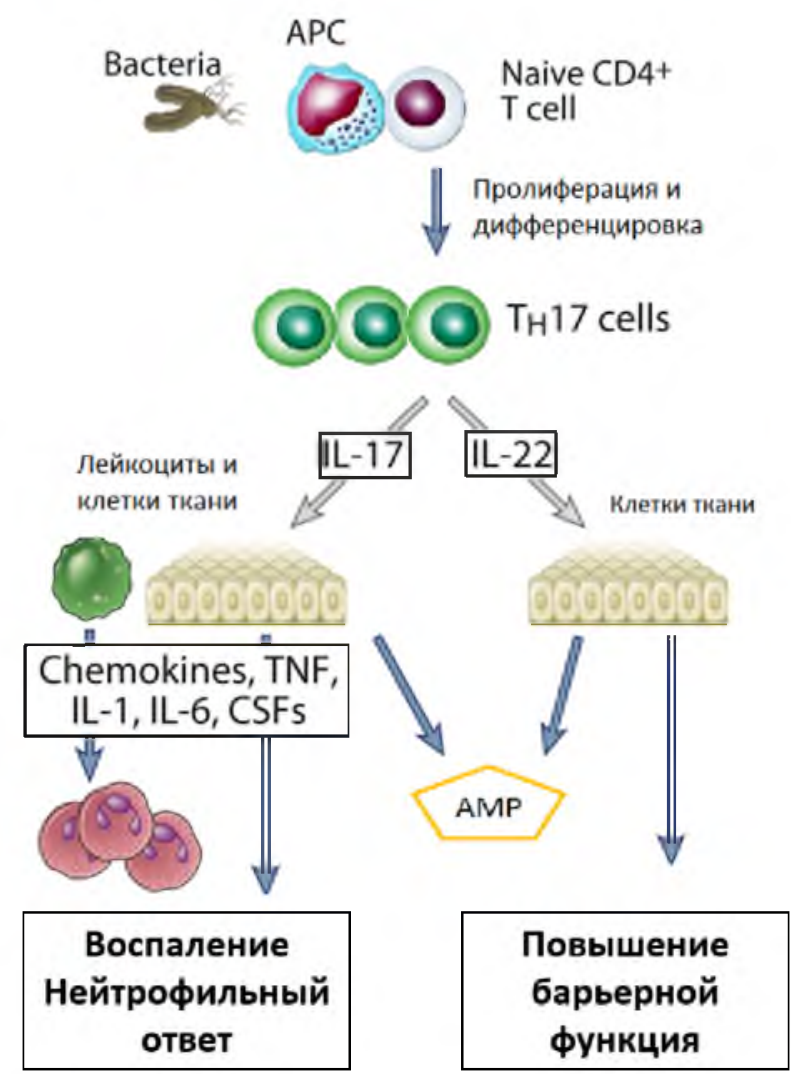

Рис. 34. Т-хелперы 17 - роль в реализации клеточных реакций приобретенного иммунитета, роль IL-17 и IL-22 отмечалось выше несколько типов Т-хелперов, которые различаются по своим свойствам:

1. Т-лимфоциты центральной памяти:

- способны пролиферировать и быстро дифференцироваться (обычно 3-5 дней) в эффекторные клетки;

- локализуются в периферических лимфоидных органах, а, благодаря способности к «рециркуляции», регулярно посещаю («патрулируют») периферические лимфоидные органы различной локализации, живут годами - отвечают за долговременный иммунитет;

- нуждаются в презентации антигена в периферических лимфоидных органах и костимуляции для проявления своих свойств и клональной экспансии;

- не обладают выраженными эффекторными свойствами.

2. Т-лимфоциты эффекторной памяти:

- постоянно находятся в периферических тканях - потенциальных участках повторного проникновения патогена;

- быстро активируются и увеличивают уровень продукции цитокинов и других эффекторных молекул;

- не нуждаются в презентации антигена в периферических лимфоидных органах и костимуляции;

- обладают низкой способностью к пролиферации.

3. Эффекторные Т-лимфоциты:

- время жизни 10-20 дней;

- локализуются преимушественно в периферических тканях;

- не способны к пролиферации. 
- обладают выраженными эффекторными свойства, играют ведущую роль в продукции цитокинов, необходимых для эффективного функционирования эффекторных клеток (моноцитов и макрофагов в случае Th1; тучных клеток, базофилов и эозинофилов в случае Th2; клеток соединительной ткани, эпителиальных платов и нейтрофилов в случае Тh17) врожденного иммунитета.

Фолликулярные Т-хелперы. В начале 2000-ых годов впервые в составе миндалин была охарактеризована субпопуляция Т-хелперов, экспрессировавшая $\mathrm{CXCR5}$ и $\mathrm{CCR} 7$ хемокиновые рецепторы, отвечающие за направленную миграцию клеток в В-клеточные фолликулы (В-зависимые зоны периферических лимфоидных органов) и периферические лимфоидные ткани, соответственно. В настоящее время известно, что для «поляризации» Тh0 в сторону Tfh необходим целый спектр цитокинов, к числу которых относятся IL-6, IL-21, IL-12, $\mathbb{L}-23, \mathbb{L}-2, \mathbb{L}-7$ и TGFb, запускающие экспрессию факторов транскрипции Bcl-6, STAT1, STAT3, STAT4, Batf, IRF4, c-Maf, TCF-1, а также Acl2. Основной функцией Tfh является участие в формировании и развитии специфического гуморального иммунного ответа, опосредованного В-лимфоцитами. Причем, рассматриваемая субпопуляция Тh способствуем выживанию и пролиферации активированных антигеном В-клеток во вторичных лимфоидных органах, участвует в регуляции процессов переключения класса синтезируемых антител и запуске соматических гипермутаций, а также дифференцировку В-лимфоцитов в сторону плазматических клеток и долгоживущих В-клеток памяти. Итак, секретируемые Tfh цитокины влияют на следующие процессы:

1). за счет продукции цитокинов (IL-4 и BAFF) и контактных взаиомдействий (CD40L cз стороны Т-клетки и CD40 со стороны В-клетки) Tfh блокируют запуск апоптоза в активированной В-клетке;

2). при помощи взаиомдействия CD40L (со стороны Tfh) и CD40 (со стороны В-клетки) в послденей запускается пролиферация;

3). IL-21, синтезируемый Tfh, запускает дифференцировку В-клетки в плазматическую клетку;

4). под действие цитокинов (IL-4 и IL-21) в B-клетке инициируется процесс соматических гипермутаций, приводящий (после селекции полученных клонов) к увеличению аффинности В-клеточного рецептора и секретируемых антител;

5). цитокины, секретируемые Tfh ( $\mathbb{L}-4, \mathbb{L}-17, \mathrm{IL}-21)$, стимулируют переключение класса синтезируемых В-клеткой антител с IgM на $\operatorname{IgG}, \operatorname{IgA}$ или IgE;

Наличие CXCR5 на поверхности клетки позволяет направленно мигрировать в Взависимые зоны лимфатических узлов по градиенту концентрации хемокина CXCL13, также известного как ВCA-1 (от англ. «B cell-attracting chemokine 1»). Данный хемокин синтезируется клетками стромы мантийной зоны и зародышевых центров В-клеточных фолликулов в периферических лимфоидных органах, что и определяет миграцию В-клеток и фолликулярных T-хелперов в эти области. Ключевыми поверхностными молекулами Tfh, помимо CXCR5 (CD185), являются CD40L (CD152), ICOS (CD278), SAP и PD-1 (CD279), которые необходимы для контактных взаимодействий между В-лимфоцитами и фолликулярными Т-хелперами.

\section{Фолликулярные Т-хелперы и развитие специфического гуморального ответа.}

Следует отметить, что при развитии специфического гуморального ответа ключевую роль играет взаимодействие между активированным антигенов В-лимфоцитом и антигенспецифическим фолликулярных Т-хелпером. Считается, что контакты этих клеток возможно в периферических лимфоидных органах различной локализации и имеют место на границе Т- и B-зависимых зон лимфоидной ткани. Однако, еще до специфического взаимодействия этих клеток должно произойти два ключевых события, которые тесно связаны с процессами распознавания и презентации антигенов:

1). Антиген должен быть доставлен в лимфоидную ткань дендритной клеткой из периферических тканей в Т-зависимые зоны для презентации и активации Tfh (при первичном ответе Tfh формируются впервые за счет поляризующих цитокинов, а при вторичном ответе ключевую роль в повторном распознавание антигена играют Tfh памяти); 
2). Антиген должен быть доставлен в лимфоидную ткань с током лимфа и распознан Вклеткой в В-зависимой зоне лимфоидной ткани. Более того, в дальнейшем антиген должен быть поглощен при помощи рецептор-опосредованного эндоцитоза, процессирован и презентирован активированным В-лимфоцитом, которые в данном случае выполняет роль АПК.

Следует отметить, что В-клетки, выполняя функции АПК, распознают так называемые «конформационные» антигены - то есть антигены «нативные» или не процессированные, способные обладать высокой молекулярной массой в силу того, что являются частью крупных молекул или даже целых вирусов и бактерий. В ходе дальнейших процессов, связанных с процессингом и презентацией, эти крупные «конформационные» антигены разделяются на небольшие фрагменты (отдельные эпитопы), которые можно будет загрузить на молекулы МНС II класса. Суть этого процесса сводится к тому, что исходно один «антиген», поглощенный и «разрезанный» на отдельные фрагменты В-клеткой, может быть распознан несколькими Tfh, обладающими различной специфичностью уже к отдельным эпитопам исходно большой молекулы - этот механизм, по-видимому, увеличивает вероятность встречу В- и Т-клеток в пределах лимфоидной ткани. Более того, подобно АПК в периферических тканых, В-клетка также нуждается в сигнале от паттерн-распознающих рецепторов врожденного иммунитета (например, от CD21 - рецептора для фрагментов C3 компонента каскада комплемента). Получение этого подтверждающего сигнала о том, что был распознан именно «чужеродный» антиген, является очередной защитой от потенциальной аутореактивности. И, наконец, получая эти сигналы от рецепторов врожденного иммунитета, В-лимфоцит начинает экспрессировать молекулы миграции в Т-зависимые зоны (в первую очередь, CCR7).

Таким образом, в Т-зависмой зоне имеет место активация и клональная экспансия антиген-специфических Tfh, которые начинают двигаться в сторону В-зависимых зон, тогда как в из В-зависимых зон им на встречу устремляются активированные антигеном В-лимфоциты. Считается, что встреча этих клеток происходит как раз на границе Т- и В-зависимых зон периферических лимфоидных органов, где В-клетка презентирует антиген Tfh. В случае распознавания антигена в ассоциации с МHC II класс Т-клеточным рецептором Tfh запускается процесс формирования «иммунного» синапса и обмен сигналами между клетками. Именно в это время В-лимфоцит перестает выполнять функции АПК, и в нем активируются программы, свойственные лимфоцитам, главной из которых является клональная экспансия антигенспецифического лимфоцита.

1). Ключевую роль в данном процессе играют взаимодействие CD40L-CD40 и продукция цитокинов фолликулярным $\mathrm{Th}$, про что было рассказано ранее.

2). В ходе клональной экспансии и серии последовательных циклом митоза формирование части В-клеток может происходить вне В-клеточного фолликула (формирование короткоживущих плазматических клеток, которые секретируют антитела той же специфичности, что и исходный В-лимфоцит);

3). Однако часть активированных В-клеток возвращается в В-зависимые зоны, что приводит к формированию В-клеточных фолликулов сложной морфологической структуры и клеточного состава.

Именно с формирование В-клеточного фолликула связано появление В-клеток памяти и плазматических клеток, способных к синтезу и секреции высоко-аффинных антител классов, отличных от IgM. Ключевую роль в формировании фолликула принимают фолликулярные Th, а также специализированных тип дендритных клеток, получивших название фолликулярных дендритных клеток:

- фолликулярные Тh обеспечивают В-клетки необходимыми цитокинами и контактными сигнальными молекулами, необходимыми для пролиферации, активации процесса соматических гипермутаций, а также переключения класса синтезируемых антитед;

- фолликулярные дендритные клетки - в отличие от всех остальных типов ДК фолликулярные дендритных клеток способны сорбировать и сохранять на своей поверхности антигены в том виде, в котором они поступили в лимфатических узел с током лимфа, то есть, это хранилище тех самых неизменных или «нативных» «конформационных» антигенов; этот 
запас антигенов необходим для селекции В-клеток после того, как они изменили состав своих антиген-распознающих рецепторов после соматических гипермутаций.

Итак, в сформированном В-клеточном фолликуле протекают следующие процессы:

1. клональная экспансия (пролиферация В-клеток под действием цитокинов $\mathrm{Tfh}-$ все это происходит в темной зоне фолликула, которая прилежит к границе между В- и Т-зависимыми обслатями);

2. соматические гипермутации - фермента AID (от англ. «activation-induced deaminase») замещает случайным образом $\mathrm{C}$ на $\mathrm{U}$ в пределах участков $\mathrm{CDR}$, где вероятность точечных мутаций крайне высока. В дальнейшем U может заменяться на T при репликации ДНК, тем самым, в свою очередь, С тоже может заменяться на Т;

3. увеличение аффинности В-клеточного рецептора - за счет селекции вновь образовавшихся клонок В-клеток после гипермутация - только В-клетки, которые сформировали случайным образом высоко-аффинный В-клеточный рецептор могут «отнять» антиген у фолликулярной дендритной клетки, чтобы его процессировать и презентировать Tfh для получения сигнала на выживание. По большому счету, в данном случае работает принцип «естественного отбора» - сигнал на выживание получает клетка, способная антиген связать (без этого не будет «помощи» от фолликулярного Тh), а так как количество антигена сильно лимитировано, то связывание будет только с самыми высоко-аффинными рецепторами, а остальные В-лимфоциты сигналов на выживание получал, и будут элиминированы при помощи апоптоза (эти процессы протекают в светлой зоне фолликула, содержание клеток в которой снижается на порядки по сравнению с темной зоной именно в следствие процессов селекции).

4. переключение класса синтезируемых антител с $\operatorname{IgM}$ на $\operatorname{IgG}, \operatorname{IgA}$ или $\operatorname{IgE}$ за счет цитокинов микроокружения и Тfh. Каждый класс антител обладает своими специфическим свойствами, так $\operatorname{IgG}-1$ ). опсонизация внеклеточных патогенов для повышения эффективности фагоцитоза макрофагами и нейтрофилами; 2). активация каскада комплемента по классическому пути - борба с внеклеточнами патогенами, локализованными в межклеточном пространстве; 3). антитело-зависимая клеточная цитотоксичность НК-клеток по отношению к вирус-инфицированным и опухолевым клеткам; 4). возможность переноса через плаценту формирование гуморальной защиты новорожденных. Антитела класса IgA обеспечивают мукозальный иммунитет, защиту слизистых оболочек, состав микрофлоры кишечника. Антитела класса IgE - регуляция активности тучных клеток, базофилов и эозинофилов, борьба многоклеточными патогенами и грибами.

Таким образом, в результаты взаимодействия В-лимфоцита и фолликулярного Th формируется несколько типов В-клеток, которые принципиально различаются по своим функциональным свойствам:

1. В-клетки памяти:

- способны пролиферировать и быстро дифференцироваться в плазматические клетки (обычно 3-5 дней);

- при повторном контакте с антигеном способны увеличивать аффинность антител (соматические гипермутации, переключекие класса синтезируемых антител);

- локализуются периферических лимфоидных органах, способны к «рециркуляции», живут годами, отвечают за формирование долговременной иммунологической памяти.

2. Долгоживущие плазматические клетки:

- конститутивно (на постоянной основе) синтезируют антитела только одного класса и только одной специфичности;

- быстро активируются и увеличивают уровень продукции антиген-специфических антител при повторном контакте с антигенов;

- преимущественно располагаются в пределах красного костного мозга;

- не способны к пролиферации и клональной экспансии.

3. Короткоживущие плазматические клетки:

- время жизни 10-20 дней; 
- локализуются преимущественно в периферических лимфоидных органах и соединительной ткани, подстилающей барьерные ткани организма;

- не способны к пролиферации, переключению класса синтезируемых антител и запуска процесса соматических гипермутаций, то есть продукция антител только одного класса и только одной специфичности.

Плазматические клетки (как коротко- так и долгоживущие) продуцируют антитела (иммуноглобулиновые молекулы различных классов, про которые мы уже упоминали выше), выполняющие широкий спектр функций, связанных с «наведением» атаки клеточных и гуморальных факторов на патоген. В целом все многообразие функций антител можно свести в четырем основным (рис.35):

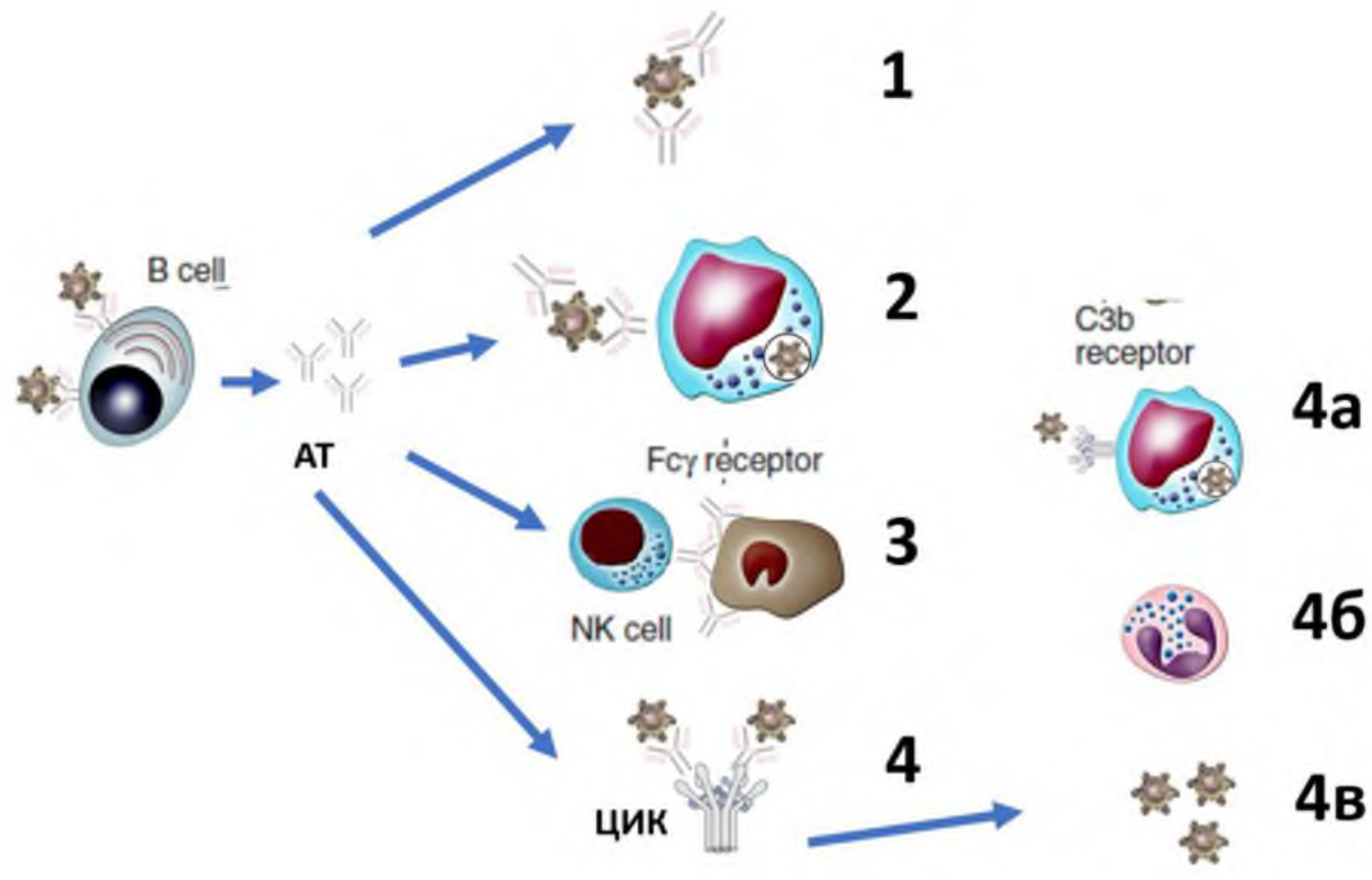

\section{Рис. 35. Основные функции секретируемых антител при реализации гуморальных реакций приобретенного иммунитета}

1. Нейтрализация патогенов и их токсинов (например, блокада контакта патогенов с клетками эпитеалиальных пластов слизистых оболочек - IgA; или нейтрализация различных токсинов при помощи (gM);

2. Опсонизация и усиление фагоцитоза патогенов (взаимодействие комплексов IgG-антиген и Fçрецепторов на поверхности фагоцитов в очаге воспаления);

3. Антитело-зависимая клеточная цитотоксичность (вирус-специфические или опухольспецифические IgG, связавшиеся с клеткой-мишенью, и Fс $\gamma$-рецепторы на поверхности НК-клеток); 4. Активация каскада комплемента - данная функция связана, в первую очередь, с сывороточными антителами классов IgM и IgG, которые образовали «иммунные комплексы» со специфическими антигена, которые могут находиться как в жидкой фазе, так и на поверхности клеток-мишеней. При этом можно выделить три аспекта, связанные с активаций каскада комплемента. Так как данный белкоый каскад участвует в:

a) дополнительной опсонизации патогена и усилении его поглощения при помощи фагоцитоза за счет

С3 и его производных, к которым на поверхности фагоцитов имеются специфические рецепторы;

б) усилении воспаления за счет формирования анафилатоксинов С3а и С5а, привлекающих и активирующих лейкоциты в очаге проникновения патогена;

в) сборка мембранно-атакующего комплекса и лизис клеток-мишеней.

Таким образом одна из основных функций иммунной системы, если не главная, является формирование иммунитета к чему-либо, в основе которого лежит иммунный ответ со своим началом (запуском, индукцией) и своим конечным результатом в виде образования иммунокомпетентных клеток эффекторов. Вся наиболее распространенная патология человека 
связана с иммунным ответом. Инфекция - иммунный ответ к возбудителю; аллергия иммунный ответ к аллергену; онкология - иммунный ответ к опухолевым антигенам; аутоиммунные заболевания - иммунный ответ к собственным, аутоантигенам; атеросклероз по существу, это иммунный ответ к собственным антигенам, которые образуются в процессах жизнедеятельности клеток в организме. И как всякая функция в организме, иммунный ответ находится под жестким контролем «контролирующей» системы, куда входит нейроэндокринная регуляция со своими механизмами и внутрисистемная регуляция со своими гуморально-клеточными факторами.

Гуморальная регуляция в системе адаптивного иммунитета так осуществляется за счет цитокинов. Часть цитокинов мы описали выше (см Главу 3). Цитокины, регулирующие адаптивный иммунитет представлены в таблице (табл.24).

Таблица 24

\section{Иммунорегуляторные цитокины}

\begin{tabular}{|c|c|c|c|}
\hline Цитокин & Клетки-продуценты & Мишени & Эффекты \\
\hline $\begin{array}{l}\text { Семейство ИЛ-2 } \\
\text { (ИЛ-2, ИЛ-4, ИЛ- } \\
7, \text { ИЛ-9, ИЛ-15, } \\
\text { ИЛ-21) }\end{array}$ & Т-лимфоциты & Лимфоциты & $\begin{array}{l}\text { Стимулирует пролиферацию Т- и В- } \\
\text { лимфоцитов, NK-клеток }\end{array}$ \\
\hline $\begin{array}{l}\text { Семейство ИЛ-12 } \\
\text { (ИЛ-12, ИЛ-23, } \\
\text { ИЛ-27, иЛ-35) }\end{array}$ & $\begin{array}{l}\text { Макрофаги, дендритные } \\
\text { клетки, В-лимфоциты }\end{array}$ & NK-клетки, Th1 и Th2 & $\begin{array}{l}\text { Вызывает дифференцировку Th1, } \\
\text { ингибирует Th2, стимулирует секрецию } \\
\text { ФНОß и ИФНү, усиливает активность NK- } \\
\text { клеток и ЦТЛ }\end{array}$ \\
\hline ИЛ-14 & $\begin{array}{l}\text { Т-лимфоциты, В- } \\
\text { лимфоцитарные опухоли }\end{array}$ & В-лимфоциты & $\begin{array}{l}\text { Контролирует рост и пролиферацию В- } \\
\text { клеток, подавляет секрецию Ig }\end{array}$ \\
\hline ИЛ-18 & $\begin{array}{l}\text { Макрофаги, дендритные } \\
\text { клетки, эпителиальные } \\
\text { клетки }\end{array}$ & $\begin{array}{l}\text { Th1, NK-клетки, B- } \\
\text { лимфоциты }\end{array}$ & $\begin{array}{l}\text { Стимулирует выработку IFNv, увеличивает } \\
\text { активность NK-клеток, усиливает } \\
\text { продукцию IgG2a, стимулирует ангиогенез }\end{array}$ \\
\hline ИЛ-34 & $\begin{array}{l}\text { Клетками селезенке, } \\
\text { тимусе, печени, } \\
\text { кишечника, легких, } \\
\text { сердца, почек и пр. } \\
\end{array}$ & $\begin{array}{l}\text { CD14+ макрофаги и } \\
\text { моноциты }\end{array}$ & $\begin{array}{l}\text { Регулирует дифференцировку, } \\
\text { пролиферацию и выживание моноцитов, } \\
\text { макрофагов и остеокластов }\end{array}$ \\
\hline ИФНу & $\begin{array}{l}\text { Th1-, NK-, ЦТЛ, } \\
\text { В-лимфоциты }\end{array}$ & $\begin{array}{l}\text { Моноциты, макрофаги, } \\
\text { В-лимфоциты, Th2- } \\
\text { лимфоциты }\end{array}$ & $\begin{array}{l}\text { Противовирусный и противоопухолевый } \\
\text { эффект (стимулирует экспрессию МНС I и II) } \\
\text { Активация макрофагов и нейтрофилов. } \\
\text { Индукция молекул адгезии на эндотелии, } \\
\text { подавляет Th2. Подавляет ангиогенез. }\end{array}$ \\
\hline APRIL & $\begin{array}{l}\text { Дендритные клетки, } \\
\text { макрофаги, моноциты, } \\
\text { нейтрофилы, Т-клетки }\end{array}$ & В-лимфоциты & $\begin{array}{l}\text { Дифференцировка В-лимфоцитов } \\
\text { выживания долгоживущих плазматических } \\
\text { клеток в костном мозге }\end{array}$ \\
\hline BAFF & $\begin{array}{l}\text { Т-лимфоциты, } \\
\text { макрофаги, дендритные } \\
\text { клетки, В-лимфоциты }\end{array}$ & В-лимфоциты & $\begin{array}{l}\text { Фактор активации и дифференцировки В- } \\
\text { лимфоцитов, продуцируется аутокринно и } \\
\text { стимулирует пролиферацию } \\
\text { активированных В-лимфоцитов }\end{array}$ \\
\hline MIF & $\begin{array}{l}\text { макрофаги, лимфоциты, } \\
\text { эпителиальные клетки } \\
\text { (легких, кишечника и } \\
\text { кожи) опухолевые клетки }\end{array}$ & $\begin{array}{l}\text { Макрофаги, многие } \\
\text { другие клетки }\end{array}$ & $\begin{array}{l}\text { Связываясь с CD74 на иммунных клетках, } \\
\text { ингибирует их миграции. Предотвращает } \\
\text { апоптоз опухолевых клеток. Важное } \\
\text { значение при развитии ГЧзТ }\end{array}$ \\
\hline $\begin{array}{l}\text { VEGF (A, B, C, D, E } \\
\text { и F) }\end{array}$ & $\begin{array}{l}\text { Макрофаги, клетки } \\
\text { эпителия, гипофиза, } \\
\text { гладких мышц, } \\
\text { опухолевые клетки }\end{array}$ & $\begin{array}{l}\text { Эндотелиальные } \\
\text { клетки, макрофаги, } \\
\text { гранулоциты }\end{array}$ & $\begin{array}{l}\text { Участвует в формировании сосудов. } \\
\text { Стимулирует миграцию и пролиферацию } \\
\text { эндотелиальных клеток, хемотаксис } \\
\text { макрофагов и гранулоцитов }\end{array}$ \\
\hline
\end{tabular}

Что касается регуляторных клеток то описано более 20 разных популяций и субпопуляций клеток, обладающих супрессорной функцией в отношении активности других 
клеток. Однако ведущая роль в этой иерархии регуляторных клеток, по-видимому, принадлежит Т регуляторным клеткам (Treg), наиболее активным участникам любого иммунного ответа, любого иммунопатологического состояния. Однако, супрессорной активностью в отношение Тклеток эффекторов могут, при определенных условиях, обладать такие клеточные элементы, как макрофаги, дендритные клетки, эритробласты, клетки миэлоидного происхождения и др.

Интерес к регуляторным Т-лимфоцитам как основной популяции клеток периферической крови, способной подавлять развитие воспалительных реакций, не угасает уже многие годы. Практически сразу же после появления маркеров, позволявших с высокой точностью выявлять эту популяцию в рамках Т-хелперов периферической крови, определение уровня Treg показало -свою значимость при целом спектре патологических состояний. При онкологических заболеваниях, например, увеличение относительного содержания Treg было отмечено у больных $\mathrm{c}$ различными видами опухолей и оказалось связанным с прогрессированием опухолевого роста - например, при раке поджелудочной железы и аденокарциноме молочной железы. Более того, уровень этих клеток в циркуляции и в окружающих опухоль тканях оказался значимым для прогноза течения заболевания и эффективности применяемой терапии. Столь же существенной оказалась роль циркулирующих Treg в подавлении иммунного ответа на внедрившийся патоген в рамках различных инфекционных процессов. Например, при инфицировании вирусным гепатитом С именно Treg подавляли пролиферативную активность антиген-специфических CD3+CD8+ клеток, нарушая формирование клонов клеток, способных к уничтожению клеток-мишеней и элиминации патогена. В периферической крови больных туберкулезом возрастал уровень Treg, тогда как их удаление в рамках экспериментов ex vivo сопровождалось увеличением относительного содержания IFN $\gamma$-синтезирующих антиген-специфических клеток. В случае же противопаразитарных защитных реакций, на примере инвазии Plasmodium falciparum, уровень Treg в периферической крови существенно возрастал по сравнению с контролем и был связан с более высокими темпами роста паразита in vivo. Таким образом, уже на самых ранних этапах развития современных представлений о Treg на клинических примерах была доказана их роль в нарушении эффективности развития противоопухолевого и противоинфекционного иммунного ответа.

С другой стороны, у больных с различными аутоиммунными патологическими состояниями изменялась функциональная активность Treg, что вызывало нарушение толерантности к собственным антигенам организма. При анализе данных литературы по динамике Treg периферической крови при аутоиммунной патологии соединительной ткани- на примере системной красной волчанки, склеродермии, ревматоидного артрита и ювенильного идиопатического артрита - были выявлены работы, в которых данный показатель мог либо увеличиваться относительно группы контроля, либо уменьшаться, хотя также встречались исследования, в которых показатели больных достоверно не отличались от контрольных значений. Подобные результаты выявлены не только при ревматических заболеваниях, но и при аутоиммунном тиреоидите, псориазе.

В настоящее время клиническая значимость определения относительного содержания общей популяции Treg показана для пациентов с сепсисом, у которых увеличение уровня этих клеток в циркуляции тесно связано с неблагоприятным прогнозом течения данного состояния, хотя и это опровергается некоторыми авторами. В ряде исследований была проанализирована корреляция между содержанием CD4+CD25+Foxp3+ Treg в трансплантате и/или крови реципиента и последующим развитием острой или хронической реакции трансплантат-противхозяина, причем тяжесть аллогенной трансплантат-против-хозяина обратно пропорциональна низкой экспрессии FoxP3.

Популяция Treg не является однородной, описаны как минимум две субпопуляции, циркулирующих в периферической крови и принципиально различающиеся по происхождению. Во-первых, это «тимические» или «натуральные» регуляторные Т-лимфоциты (от англ. «thymus derived» или «natural» Treg, nTregs или tTregs), дифференцирующиеся в тимусе в ходе антиген-независимой стадии созревания Т-клеток и обладающие фенотипом 
«наивных» - CD45RA+CD45R0-CD62L+CCR7+ - клеток периферической крови. Во-вторых, это «периферические» или «индуцибельные» или «адаптивные» Treg (от англ. «peripherally derived», «induced» или «adaptive» Treg, iTregs) - регуляторные Т-клетки, формирующиеся в процессе антиген-зависимой дифференцировки в периферических лимфоидных органах. В 2013 году была предпринята попытка стандартизировать номенклатуру Treg, когда было предложено Treg, дифференцирующиеся в тимусе, обозначать как nTreg, a Treg, формирующиеся из Th0 на периферии - в лимфатических узлах - при иммунном ответе, как pTreg, тогда как название iTreg следовало употреблять для регуляторных Т-клеток, которые были получены в ходе дифференцировки в условия in vitro (от англ. «in vitro-induced» Treg), чтобы отличать их от pTreg, формирующихся in vivo.

Принципиальным различием между nTreg и pTreg является зависимость pTregs oт TGFb - ключевого цитокина, необходимого для «поляризации» «наивных» Treg в сторону регуляторных Т-клеток, тогда как для nTreg такой зависимости не выявлено. В случае «наивных» Th0 клеток, контактирующих с АПК в периферических лимфоидных органах, сигнал от TGFb вызывает активацию экспрессии как FoxP3, так и RORgt. Однако, в отсутствие IL-6 FoxP3 способен ингибировать RORgt путем прямого взаимодействия, что сопровождается «поляризацией» Th0 в сторону pTreg. В случае же воспалительных реакций, когда уровень провоспалительных цитокинов (в том числе IL-6) еще достаточно высок, запускается каскад сигнальных молекул, связанный с активацией STAT3, что приводит не только к подавлению экспрессии FoxP3, но и усилению синтеза рецептора для IL-23 (IL-23R). Bce это приводит к смещению баланса в сторону преимущественного формирования из Th0 Th17, a не регуляторных T-клеток. Помимо IL-6 сходным эффектором обладает еще и IL-21, который в присутствие TGFb способствует дифференцировке Th0 в сторону Th17. Помимо цитокинового микроокружение показана важная роль гипоксии в регуляции экспрессии FoxP3 и RORgt. Таким образом, наличие стадии созревания pTreg, способной к одновременной активации транскрипции FoxP3 и RORgt, свидетельствует о высокой «пластичности» данной популяции клеток, что создает дополнительные трудности в оценке этого типа лимфоцитов при различных патологических состояниях. Однако появление некоторых форм «атипичных» Treg, повидимому, характерно для некоторых аутоиммунных заболевания, патогене которых до конце еще не исследован.

\section{Эффекторные молекулы регуляторных Т-лимфоцитов (рис.36).}

Основными клетками-мишенями для Treg являются иммунокомпетентные клетки врожденного (тканевые макрофаги, антиген-презентирующие клетки, натуральные киллеры) и приобретенного иммунитета (эффекторные цитотоксические Т-лимфоциты и Т-хелперы, а также В-лимфоциты). Для реализации функций Treg используют различные механизмы, которые традиционно разделяют на «бесконтактные» (опосредованные действием высвобождаемых регуляторными Т-клетками различных растворимых молекул, диффундирующих в тканевых жидкости) и «контактные» (опосредованные взаимодействием рецепторов Treg и поверхностных структур на клетке-мишени).

«Бесконтактные» механизмы супрессии Treg. Ключевыми иммунорегуляторными сывороточными молекулами Treg человека являются $\mathrm{LL}-10$, TGFb и IL-35, а также внеклеточный аденозин, образование которого из АТФ протекает за счет активности поверхностных мембранно-ассоциированных ферментов CD39 и CD73, локализованных на поверхности Treg.

IL-10 является белком с молекулярной массой около 18 кДа, который, помоимо Treg, синтезируется и секретируемся различными клетками - моноцитами, дендритными клетками, нейтрофилами, различными субпопуляциями Th (например, Th17 и Th22, как уже отмечалось ранее) и В-лимфоцитами (значение этих популяций В-клеток будет рассмотрена в следующей главе данной монографии). Ключевыми функциями данного цитокина являются: 


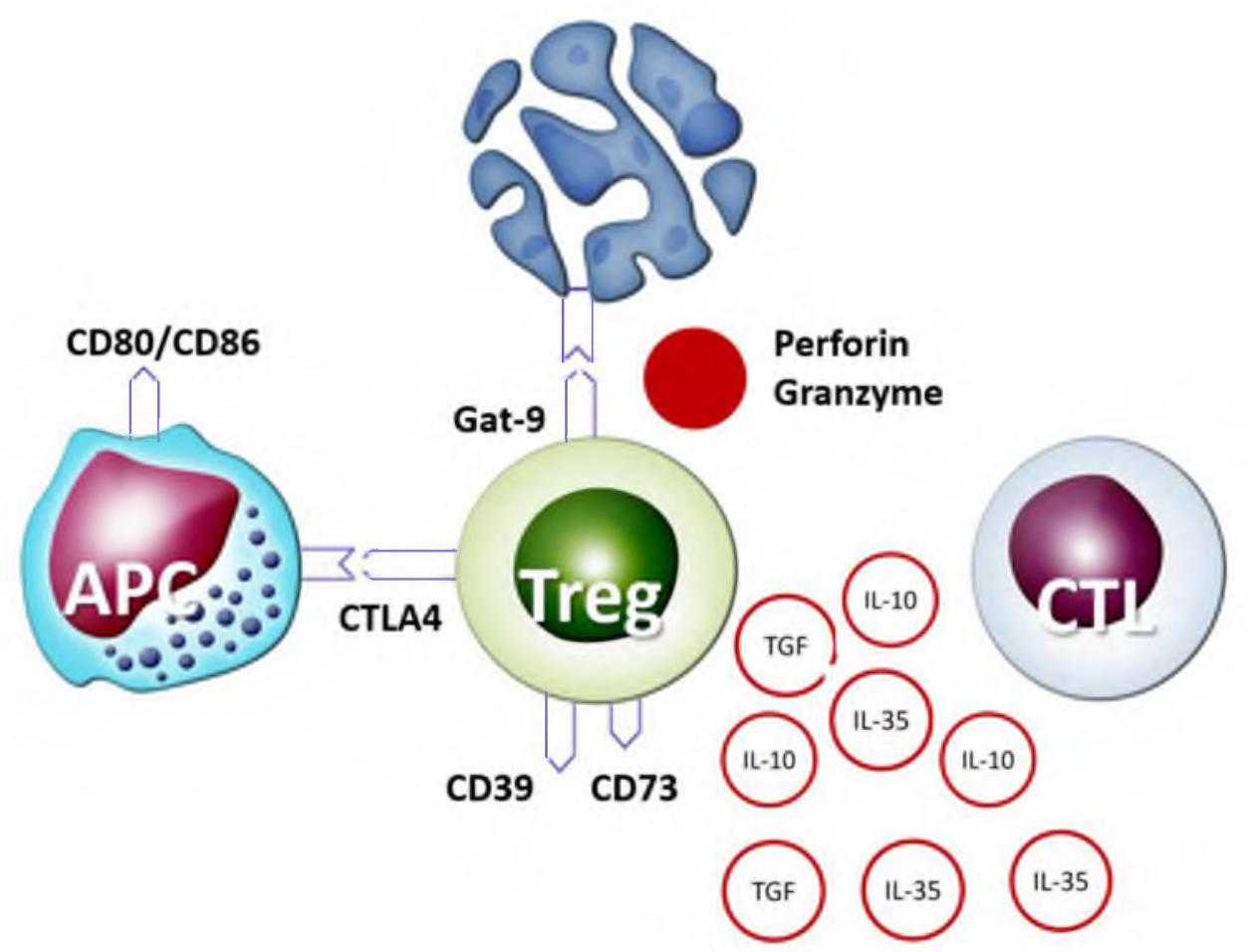

\section{Рис. 36. Эффекторные молекулы регуляторных Т-лимфоцитов}

- угнетение продукции провоспалительных цитокинов и, в первую очередь, IL-12, играющего ведущую роль в «поляризации» Th0 в сторону Th1, что сопровождается снижением продукции IFNg и формированием эффекторных Th1;

- в очаге воспаления IL-10 увеличивает эффективность фагоцитоза, повышая скорость элиминации клеточного дебриса, а также, отчасти за счет блока эффектов IFNg, способствует дифференцировки тканевых макрофагов в М2, которые также являются продуцентами протиивоспалительных цитокинов - IL-10 и TGFb;

- снижение эффективность взаимодействия между АПК и антиген-презентирующими клетками, блокируя активацию PI3K/AKT пути передачи сигнала от TcR на ядро лимфоцитов (Taylor et al., 2006). В случае AПK, IL-10 снижает экспрессию как ко-стимуляционньх молекул CD80 и CD86, так и плотность экспрессии комплексов антиген-МНC II, что сущесвтенно ограничивается пролиферативную активность, созревание и дифференцировку клона антигенспецифических лимфоцитов;

- для самих Treg IL-10 является мощнейшим факторов ауто- и паракринной активации, так как способствует активации транксрипционного фактора STAT3, его транслокации в ядро клетки, что сопровождается увсилением продукции противовспалительных цитокинов, включая IL-10.

TGFb является белком с молекулярной массой около 25 кДа, который секретируется в виде неактивного пептида, состоящего из собственно TGFb и пептида LAP (от англ. «LatencyAssociated Peptide»). Он способен снижать пролиферативную активность активированных Tлимфоцитов (за счет снижения уровня синтеза и секреции IL-2) и подавлять их дифференцировку в эффекторные клетки. Кроме того, TGFb оказывает существенно влияние на «поляризацию» «наивных» Тh0 клеток, вызывая преимущественное формирование регуляторных Т-лимфоцитов, стимулируя экспрессию транскрипционного фактора FOXP3, a в присутствие $\mathbb{L}-6$, способствующего активации экспрессии гена транскрипционного фактора STAT3 (необходимого для индукции RORgt), еще и Th17. Более того, под действием этого цитокина снижается уровень активации тканевых макрофагов, дендритных клеток и натуральных киллеров, равно как и пролиферация активированных В-лимфоцитов. 
IL-35 принадлежит к семейству IL-12 и является гетеродимерным белком, состоящим из двух субъединиц - p35 и Ebi3 (Olson et al., 2013). В отличие от остальных членов данного семейства ( $\mathbb{L}-12, \mathbb{L}-23$ и $\amalg-27)$, обладающих провоспалительными свойствами, $\amalg-35$ обладает выраженной иммуносупрессивной активностью. Основными функциями данного цитокина являются подавление пролиферативной активности «наивных» Т-лимфоцитов, а также «поляризация» Th0 в сторону Трег, обладающих выраженной супрессорной активностью за счет продукции большого количества IL-35 и получивших еще название «iTr35». Считается, что именно IL-35 является мощнейшим фактором, ограничивающим провоспалительную функциональную активность Th17, так как он способен подавлять дифференцировку Th в сторону эффекторных Th17.

Аденозин подавляет адгезию лейкоцитов к эндотелиальным клеткам микроциркуляторного русла, снижает продукцию супероксид анионов нейтрофилами и снижает синтез и секрецию провоспалительных цитокинов клетками различного происхождения. С другой стороны, аденозин способствует выходу противовоспалительного IL10 из моноцитов, а также запускает продукцию VEGF - мощного индуктора ангиогенеза и сосудистой проницаемости. Большинство из этих эффектов реализуются через различных представителей семейства А2 рецепторов. Аденозин подавляет активность эффекторных Тлимфоцитов, ингибирует дифференцировку Th1 и Th2 за счет снижения уровня пролиферативной активности и продукции IL-2, что выражается еще и в снижении продукции эффекторных цитокинов, свойственных Th1 и Th2 линиям дифференцировки Т-хелперов. Он также угнетает активность и других популяций Т-клеток (например, проявление цитолитических свойств или синтез цитокинов), в частности, Th17. Сходные эффекты аденозина были отмечены и в случае цитотоксических Т-лимфоцитов, когда было показано, что внесение аденозина снижало продукцию IFNg и IL-2, а также проявление цитолитических свойств в отношении клеток-мишеней. Под действием аденозина снижается экспрессия костимуляционных молекул - CD2 и CD28 - активированными Т-лимфоцитами. Еще одной мишенью для аденозина являются антиген-презентирующие клетки. Например, под его действием дендритные клетки начинают повышать уровень экспрессии VEGF, IL-8, IL-6, IL-10, COX-2 и противовоспалительного TGF-beta. Появление этих молекул на поверхности АПК сопровождается снижением эффективности созревания и дифференцировки Т-лимфоцитов, что, в конечном итоге, приводит к завершению клональной экспансии. Для самих Treg аденозин является мощнейшим фактором активации для самих регуляторных Т-лимфоцитов. Причем, на поверхности Treg увеличивалась плотность таких супрессорных молекул как CTLA-4, CD39 и CD73, равно как и уровень экспрессии CD25. Также было отмечено увеличение уровня Treg после культивирования in vitro в присутствие аденозина, что указывает на активацию процессов пролиферации данной популяции клеток.

«Контактные» механизмы иммуносупрессии основаны на взаимодействии рецепторов Treg и поверхностных структур на клетке-мишени.

CTLA-4 (от англ. «Cytotoxic T-lymphocyte-associated antigen 4», или CD152) экспрессируется Treg, его главными лигандом являются ко-стимуляционные молекулы семейства В7, с которыми CTLA-4 связывается более эффективно, чем CD28 остальных Tлимфоцитов, также являющийся лигандом семейства В 7. Именно поэтому основной функцией данной молекулы является «экранирование» В7.1/B7.2 от активированных Т-клеток, а также как результат этого взаимодействия - интернализация или трансцитоз CD80 и CD86 антигенпрезентирующей клеткой, что существенно снижает эффективность презентации антигена и угнетает формирование клона антиген-специфических Т-клеток. С другой стороны, Treg регулируют созревание дендритных клеток, модулируя взаимодействие через CD80/86 и CTLA4. Известно, что CTLA-4 экспрессируется в высокой плотности Treg клетками и ингибирует иммунный ответ. Показано, что CTLA-4 связывает молекулы CD80 (B7-1) и CD86 (B7-2) с более высокой аффинностью по сравнению с CD28, тем самым ингибируется вторичный сигнал, необходимый для активации иммунного ответа (Shevach, 2009). LAG3 (от англ. «LymphocyteActivation Gene 3» или CD223). Основным лигандом являются молекулы главного комплекса 
гистосовместимости II класса на АПК, причем аффиность взаимодействия LAG3-MHC II существенно выше такового комплекса CD4-MHC II.

Treg способны вызывать апоптоз в эффекторных клетках при помощи двух основных механизмов:

- это секреция в окружающее пространство перфорина и гранзимов, как это показано для натуральных киллеров и эффекторных цитотоксических Т-лимфоцитов. Одним из механизмом супрессорной функции Treg является цитолизис посредствам гранзима А. Известно, что Treg могут подавить иммунный ответ, вызывая апоптоз. В данном случае механизмы апоптоза используются для регуляции развития тимоцитов, формирования репертуара Т-клеток, их селекции и для координации событий, ведущих к иммунному ответу в периферии. Treg могут управлять иммунным ответом при помощи перфорин/гранзимных путей. Показано, что адаптивные Treg в основном экспрессируют гранзим В и могут вызывать гибель аллогенных клеток-мишеней перфорин-зависимым механизмами. У людей активированные Treg экспрессируют гранзим А и очень небольшое количество гранзима В. Это свидетельствует в пользу того, что Treg супрессорную способность при помощи цитотоксической активности.

- экспрессия на поверхности Treg галектина-9 (Gal-9) - $\beta$-галактозидаза-связывающего белка, способного связываться с TIM-3 (от англ. «T cell immunoglobulin and mucin domain 3» или CD366) на поверхности зрелых эффекторных клеток. Результатом такого взаимодействия является индукция апоптоза в клетке-мишени за счет активации каспаз. Кроме того, за счет Gal9 осуществляется подавление пролиферации антиген-специфических Т-клеток. С применением экспериментальных моделей на лабораторных животных было показано, что Gal-9 угнетает «поляризацию» Тh клеток в сторону Th17 и способствует дифференцировке Treg. Снижение относительного содержания Gal-9+ Treg было отмечено в периферической крови пациентов с аутоиммунным гепатитом при сравнении с условно здоровыми донорами. В рамках указанной популяции Treg больных было снижено содержание клеток, способных к продукции противовспалительных цитокинов IL-10 и TGFb, тогда как Treg, синтезирующие IFNg и IL-17, были повышены относительно группы сравнения.

Иммунологическую супрессию нельзя путать с иммунологической толерантностью (неспособностью иммунного ответа).

В настоящее время существуем множество различных определений такого важнейшего иммунологического понятия как «иммунологическая толерантность», некоторые из которым приводятся ниже.

Иммунологическая толерантность - отсутствие иммунного ответа при наличии в организме антигенов (толерогенов), доступных лимфоцитам.

Иммунологическая толерантность (на уровне организма или иммунной системы) специфическая ареактивность к какому-либо антигену, индуцированная предшествующим контактом с этим антигеном.

Иммунологическая толерантность (на уровне отдельных клонов клеток иммунной системы) - это отсутствие активации лимфоцитов (и, соответственно, продукции эффекторных молекул) при наличие специфического антигена.

Для чего так необходим процесс формирования иммунологическая толерантность, основные предпосылки:

1. В результате реаранжировки возникают уникальные Т- и В-клеточные рецепторы, способные к распознаванию широчайшего спектра антигенов - каждая клетка - Т- или Влимфоцит - УНИКАЛЬНА - ключевое отличие от клеток врожденного иммунитета, как мы уже обсуждали это ранее;

2. В результате реаранжировки возникают уникальные Т- и В-клеточные рецепторы, способные к распознаванию широчайшего спектра антигенов, включая антигены собственного организма - то есть «аутоантигены». Именно этот процесс лежит в основе развития аутоиммунных заболеваний - «свое» по каким-то причинам распознается системой приобретенного иммунитета как «чужое»; 
3. Именно поэтому необходим контроль за процессом реаранжировки Т- и В-клеточных рецепторов, так как реаранжировка, как считается, носит «случайных» характер - поэтому необходимы механизмы «селекции» при созревании Т- и В-клеток (так называемая «центральная» толерантность), а также формирование «центральной» толерантности (контроль за потенциальными «беглецами», В-клетками, которые изменяют специфичность своего рецептора в ходе развития иммунного ответа, а также АПК, презентирующими свои собственные антигены).

Центральная (иногда называет «естественная») толерантность - элиминация аутореактивных клеток в центральных органах иммунной системы. ОДНАКО, часть клеток избегает апоптоза. Механизмы: негативная селекция клеток; редактирование рецепторов (Вклетки), а также формирование «натуральных» или «тимических» Трег, способных распознавать собственные антигены и блокировать развитие иммунного ответ на них при помощи механизмов, которые детально описаны нами в разделе, посвященном данной популяции Т-лимфоцитов.

Итак, «естественная) иммунологическая толерантность - обусловлена отрицательной селекцией аутореакгивных клонов лимфоцитов. Толерантность к собственным антигенам организма развивается в процессе онтогенеза за счет уничтожения аутореакгивных клонов Т- и В-лимфоцитов. Классическим примером формирования толерантность к собственным антигенам организма является процесс «негативной» селекции тимоцитов) будущих Тлимфоцитов) в тимусе. Так, по результатам позитивной селекции сигнал к выживанию получают клетки, распознающие молекулы главного комплекса гистосовместимости в ассоциации с собственными антигенами организма и способные, как следствие, проводить сигнал от TcR. Остальные тимоциты не получают необходимый сигнал от TcR и в дальнейшем гибнут путем апоптоза. Клетки, прошедшие положительную селекцию (то есть сформировавшие функционально-активный Т-клеточный рецептор), проходят следующий этап отбора, получившего название «негативной» селекции.

B основе этого механизма находится оценка интенсивности формируемого TcR сигнала при распознавании аутоантигенов, то есть собственных антигенов организма. Высокоаффинное связывание TcR c комплексом антиген-MHC генерирует более сильный сигнал, запускающий в тимоцитах процесс апоптоза, а слабый сигнал, свидетельствующий о низкой аффинности связывания TcR c аутоантигеном, дает возможность клетке продолжить свое развитие. В то же время «промежуточные» значения этого сигнала способствуют формированию тимических или натуральных регуляторных Т-лимфоцитов. Следует особо подчеркнуть, что тонкие механизмы негативной селекции в настоящее время слабо исследованы и носят теоретический характер. Ключевая роль в негативной селекции отводится антиген-презентирующим и эпителиальным клеткам. Медуллярные тимические эпителиальные клетки экспрессируют ядерный белок, называемый AIRE (аутоиммунный регулятор, от англ. «autoimmune regulator»), который, как считается, способен индуцировать экспрессию множетсвамножества различных генов, но на весьма низком уровне. Белковые продукты этих генов обычно экспрессируются только в определенных периферических органах и тканях (так называемые «тканеспецифичные» антигены). Иx AIRE-зависимая экспрессия в тимусе делает эти «тканеспецифичные» антигены доступными для презентации и распознавания незрелыми Т-клеткам. Возможно, что именно этот механизм лежит в основе негативной селекции, удаления аутореактивных клонов и формирования пула тимических регуляторных Т-клеток, способных подавлять ответ на собственные антигены организма в периферических лимфоидных органах. Косвенным подтверждением такого механизма селекции и роли AIRE в формировании центральной толерантности является тот факт, что мутации в гене, кодирующем белок AIRE, приводят к развитию аутоиммунного полиэндокринного синдрома.

Таким образом, центральная толерантность - это совокупность механизмов, направленная на уничтожения аутореактивных клеток в центральных лимфоидных органах (тимус и красный костным мозг) в ходе их (клеток) созревания и дифференцировки. Периферическая толерантность - это совокупность механизмов, направленная на уничтожения 
аутореактивных клеток в периферических лимфоидных органах (лимфатические узлы, Пейеровы бляшки и т.д.) при инициации иммунного ответа.

Периферическая толерантность - элиминация "беглецов" (Т- и В-клеток) и вновь образованных аутореактивных клеток после гипермутаций рецепторов (В-клетки) в следствие нарушения процессов распознавания антигенов (со стороны системы приобретенного иммунитета) и ошибок в презентации антигенов со стороны врожденного иммунитета. Ведушую роль в регуляции механизмов поддержания периферической толерантности играют «ауто-реактивные» Треги. Например, наиболее сильно аутоиммунные реакции проявляются при генетических дефектах, затрагивающих развитие Treg-клеток - это наблюдается у больных c IPEX-синдромом (врожденные иммунодефицит, $\mathrm{X}$-ассоциированная иммунная дисрегуляция, полиэндокринопатия, энтеропатия), которые развиваются в результате мутации гена FOXP3/Foxp3 и связаны с множественными аутоиммунными реакциями. Как уже нами отмечалось ранее, Fохр3 является ключевым маркером регуляторных Т-клеток, которые необходимым для формирования в тимусе и поддержания всего пула Treg на периферии, а также крайне важен для реализации супрессорных функций этих клеток.

Периферическая толерантность развиваться по следующим направлениям:

- делеция клона лимфоцитов, связавших антиген и (вместо активации) погибающие в результате сигнала на апоптоз;

- анергия клона лимфоцитов из-за отсутствия активации лимфоцитов со стороны АПК (отсутствие ко-стимуляционных молекул на АПК), связавших антиген своими Т- или Вклеточными рецепторами;

- проявление эффекторных свойств Трег (продукция противовспалительных цитокинов, образование аденозина и широкий спектр контактных взаимодействий с клетками-мишенями). 


\section{ИММУННАЯ СИСТЕМА}

\section{Глава 5. Элиминация и регенерация}

Важнейшая роль в исходе любого иммунного ответа принадлежит инактивации и удалению из организма как самого антиген-чужеродного вещества, так и конечных продуктов его распада. Нарушение, связанное с элиминацией, приводит к накоплению в организме токсических веществ, развитию интоксикации и вторичному повреждению клеток и тканей.

Процесс элиминации токсических веществ достаточно сложный. В организме человека его осуществляет большое количество клеток и органов. Прежде всего, инактивация и элиминация патогенных агентов, иммунных комплексов и других продуктов иммунного ответа осуществляются макрофагами с помощью фагоцитоза. Основное значение в элиминации продуктов распада имеют поглотительно-выделительные функции печени и выделительные функции почек, а также региональный кровоток, который способствует элиминации продуктов распада из ткани (рис.37).

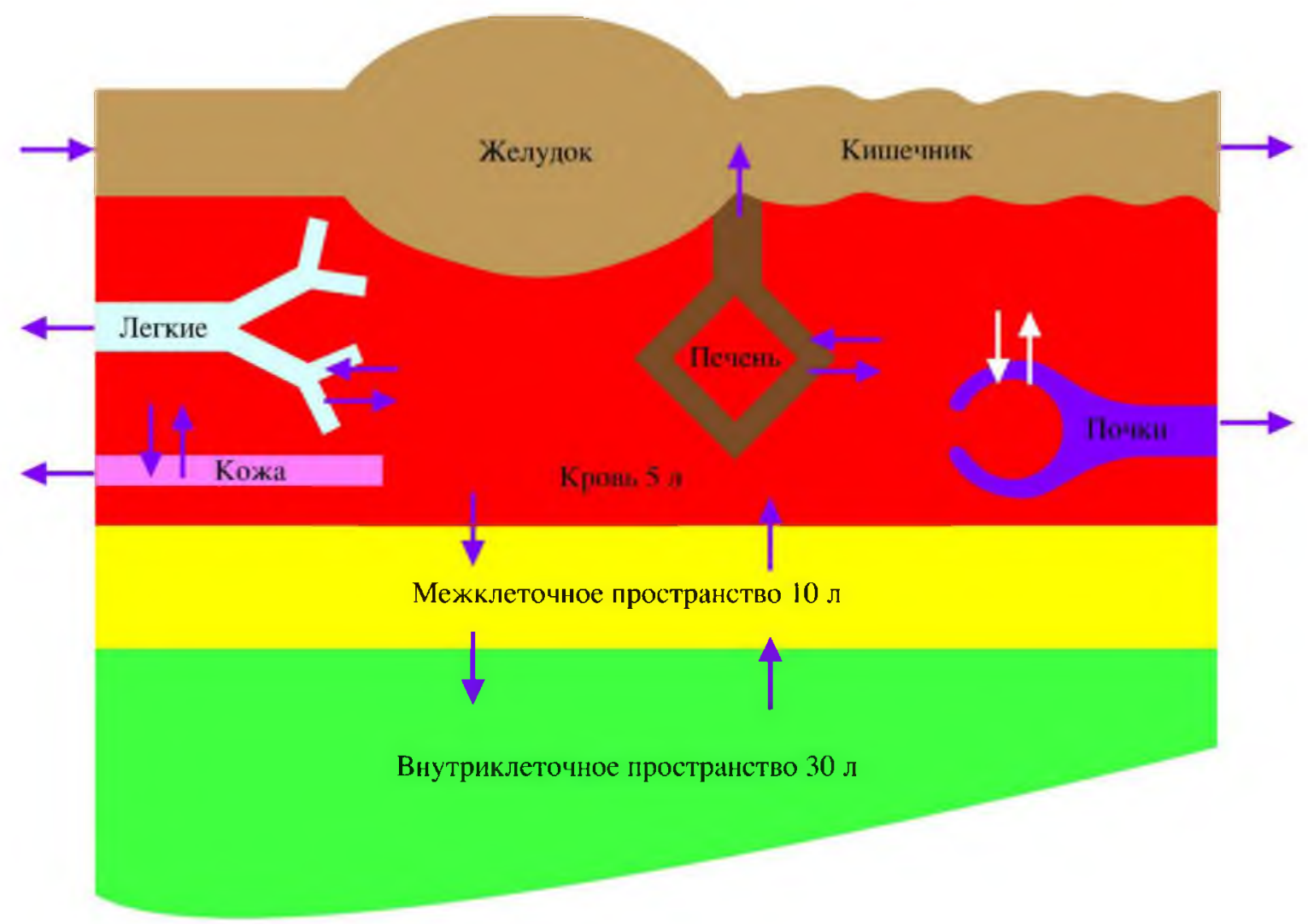

Рис.37. Жидкостные пространства организма человека

Как отмечалось выше, фагоцитоз начинается с накопления фагоцитарных клеток в очаге воспаления. Результатом внутриклеточного переваривания могут быть два варианта исхода (процесс переваривания описан выше): 
1) адекватное дозированное освобождение лизосомальных ферментов ведет к разрушению только объекта фагоцитоза, а сам фагоцит остается интактным;

2) чрезмерное выделение лизосомальных ферментов приводит к разрушению, как объекта фагоцитоза, так и самого фагоцита с последующей утилизацией этих клеток другими фагоцитами.

Переваренные продукты инактивированного антиген-чужеродного вещества, соединяясь со специфическими АТ, образуют иммунные комплексы (ИК). Образование ИК это естественная реакция, направленная на выведение из организма чужеродного АГ и сохранение гомеостаза. ИК поступают в интерстициальное (межклеточное) пространство. Это одно из трех водных пространств организма, которое связано, с одной стороны, через клеточные стенки с внутриклеточным пространством, с другой стороны через обширную поверхность стенок капилляров, высокопроницаемых для воды и электролитов, с внутрисосудистым пространством.

Интерстициальная жидкость представляет собой внешнюю среду для большинства клеток организма. Состав ее, несмотря на существенные изменения в поглощении и выделении различных веществ клетками, колеблется незначительно. Состав плазмы и интерстициальной жидкости различается только в отношении белков, так как их крупные молекулы не могут свободно проходить через стенку капилляров. Белки и жидкость из межклеточного пространства собирает система лимфатических сосудов, т.е. под действием эффективного фильтрационного давления 0,5 \% общего объема плазмы, протекающей через капилляры, переходит в области артериального конца капилляра в интерстициальное пространство. Поскольку эффективное реабсорбционное давление несколько меньше, чем фильтрационное, лишь $90 \%$ этого объема реабсорбируются в венозном конце капилляра, а остальные $10 \%$ удаляются из интерстициального пространства через лимфатические сосуды. Таким образом, происходит своеобразная фильтрация межклеточного пространства. Средняя скорость фильтрации во всех капиллярах организма составляет около 14 мл/мин, или 20 л в сут. Скорость реабсорбции равна примерно 12,5 мл/мин, т.е. 18 л в сут. По лимфатическим сосудам оттекает 2 л в сутки. При этом объем всей интерстициальной жидкости составляет около 10 л. Необходимо отметить, что при нарушении микроциркуляции сильно увеличивается вторичная интоксикация.

Система лимфатических сосудов состоит из лимфатических капилляров, которые собираются в более крупные лимфатические сосуды, впадающие в вены. Главные лимфатические сосуды, открывающиеся в вены, - это грудной лимфатический проток и правый лимфатический протоки. Стенки лимфатических капилляров образованы однослойным эндотелием, через который легко проходят растворы электролитов, углеводы, жиры и белки. В стенках более крупных лимфатических сосудов имеются гладкомышечные клетки и такие же клапаны, как в венах. По ходу сосудов расположены лимфатические узлы, которые задерживают наиболее крупные частицы, имеющиеся в лимфе. Лимфатические сосуды - это дополнительная дренажная система, по которой тканевая жидкость стекает в кровеносное русло. Основная функция лимфатической системы заключается в удалении из интерстициального пространства тех белков и других веществ, не реабсорбирующихся в кровеносных капиллярах. Именно нормальная микроциркуляция обеспечивает первый этап дезинтоксикации. Наоборот изменение процессов микроциркуляции ведет к нарушениям в доставке питательных веществ и кислорода к тканям и клеткам, удалению из них углекислоты и «шлаков».

В соответствии с общепринятой классификацией расстройства микроциркуляции разделяют на внутрисосудистые нарушения, связанные с изменением самих сосудов, и внесосудистые.

Внутрисосудистые нарушения. Наиболее важные - расстройства реологических особенностей крови в связи с изменением суспензионной стабильности клеток крови и ее вязкости. К ним частично относятся нарушения свертывания крови и образование 
гемокоагуляционных микротромбов, а также нарушение перфузии крови через микроциркуляторное русло, где измененена скорость кровотока.

Нарушение проницаемости сосудов. Механизм перехода веществ через сосудистую стенку может быть активным и пассивным. Активный характер транспорта веществ осуществляется против концентрационного и электрохимического градиента и для его реализации требуется определенное количество энергии. Пассивный механизм осуществляется в основном за счет диффузии, скорость которой зависит от характера вещества (размера молекулы, еe конфигурации, степени гидратации, расположения электрического заряда), проницаемости стенки капиллярных сосудов и тканей, количества функционирующих сосудов, степени их расширения и скорости кровотока в них. При патологии часто наблюдается увеличение или уменьшение интенсивности перехода веществ через сосудистую стенку не только вследствие изменения интенсивности кровотока, но и в результате истинного нарушения сосудистой проницаемости, которое сопровождается изменением структуры стенки сосудов. В морфологическом отношении повышение сосудистой проницаемости характеризуется увеличением промежутков между эндотелиоцитами вследствие их сокращения и усилением везикулярного транспорта, в функциональном - интенсивным переходом крупномолекулярных вешеств (белков).

Внесосудистые нарушения. Наиболее важными являются два типа таких нарушений: за счет медиаторов воспаления, о чем говорилось выше, и за счет нарушений окружающей соединительной ткани, включающие в себя изменения периваскулярного транспорта интерстициальной жидкости вместе с растворенными в ней веществами, образования и транспорта лимфы.

Все это необходимо учитывать при проведении детоксикационных мероприятий.

В последующем поступающие из лимфатических сосудов в кровоток ИК и другие продукты распада удаляются системой фиксированных моноцитарных фагоцитов и ретикулоэндотелиальной системой с помощью звездчатых ретикулоэндотелиоцитов печени.

Печень - самый крупный из внутренних органов, участвующих в гомеостазе. Она контролирует многие обменные процессы, играющие важную роль в поддержании постоянного состава крови. В ацинусе (основной функциональной единицы печени) происходит взаимодействие между кровью, гепатоцитами и купферовскими клетками. Гепатоциты участвуют в синтезе и хранении белков, трансформации углеводов, синтезе холестерина, желчных солей и фосфолипидов, детоксикации, модификации и выводе из организма эндогенных субстанций. Купферовские клетки обладают способностью к фагоцитозу и участвуют в разрушении старых, изношенных эритроцитов и в поглощении патогенных организмов [38, 110, 131].

Печень служит фильтром для большей части крови, в том числе оттекающей от органов брюшной полости, поэтому гепатоциты метаболизируют как эндогенные, так и экзогенные вешества, токсичные для организма. Бактерии и другие патогенные организмы удаляются из крови купферовскими клетками, а токсины, которые они выделяют, обезвреживаются в результате биохимических реакций, происходящих в гепатоцитах. К этому приводят такие реакции, как окисление, восстановление, метилирование или конденсация с другой органической или неорганической молекулой. После детоксикации эти вещества, теперь уже в виде безвредных продуктов, выводятся почками или желчью.

Нарушение защитной функции печени проявляется снижением фагоцитарной активности купферовских клеток (звездчатых эндотелиоцитов), других макрофагальных элементов и антитоксической (обезвреживающей) функции. При этом уменьшается способность печеночных макрофагов элиминировать путем фагоцитоза из крови жировые капли, старые эритроциты, микроорганизмы, их токсины, особенно поступающие с портальным кровотоком из кишечника, что приводит к возникновению токсемии с разнообразными проявлениями (лейкоцитоз, лихорадка, гемолиз эритроцитов, почечная недостаточность, эрозии кишечника и др.). Кроме того, при ослаблении фагоцитоза как неспецифической защитной реакции снижается устойчивость организма к инфекционным факторам. В то же 
время повышается частота развития аллергических (аутоаллергических) процессов как в самой печени, так и в других органах и системах, что обусловлено нарушением захвата из крови и разрушения макрофагами печени АГ и ИК (в норме в звездчатых эндотелиоцитах расщепляется $95 \%$ веществ с антигенными свойствами).

Понижение антитоксической функции печени связано с нарушением ее метаболической активности - синтеза мочевины (обезвреживание токсического аммиака), окисления (ароматических углеводородов), восстановления (превращение нитробензола в парааминофенол), ацетилирования (детоксикация сульфаниламидных препаратов), гидролиза (связывание алкалоидов и сердечных гликозидов), конъюгации (образования парных соединений с глюкуроновой кислотой, гликоколом, цистеином, таурином - для связывания непрямого билирубина, скатола, фенола, индола и др.). При патологии печени нарушается еще один путь детоксикации - превращение водонерастворимых (аполярных) веществ в растворимые (полярные) соединения, которые могут быть выведены из организма с желчью и мочой. К ослаблению антитоксической функции печени приводит повреждение гепатоцитов как локусов обезвреживания, уменьшение активности ферментов, катализирующих реакции детоксикации, и дефицит энергии. Нарушение антитоксической функции печени при ее поражении может обусловить повышение чувствительности организма к различным лекарственным средствам (хинину, морфину, барбитуратам, наперстянке и др.). Это связано с тем, что при уменьшении их расщепления в печени токсичность веществ увеличивается, вызывая отравление организма. Кроме того, в процессе метаболических превращений токсических соединений в гепатоцитах могут образоваться еще более токсичные вещества (синтез гепатотоксических веществ - метаболитов ряда медикаментов, например изониазида; образование канцерогенных веществ). Нарушение экскреторной функции печени при затруднении выделения желчи также может привести к накоплению токсичных веществ в организме.

Через ЖКТ с желчью выходят в основном высокомолекулярные вещества, которые в дальнейшем в кишечнике способны расщепляться под влиянием ферментов пищеварительного тракта и микрофлоры кишечника. Некоторые из них могут реабсорбироваться в кровь и вновь поступать в печень (печеночно-кишечная циркуляция).

Другие токсические вещества выводятся в небольшом количестве через слюнные, потовые и молочные железы, но конечный этап выделения осуществляется почками.

Почки играют важнейшую роль в поддержании постоянства объема жидкостей (изоволемии), осмотической концентрации (изотонии), ионного состава (изоионии) и концентрации ионов водорода (изогидрии). Нарушения в их деятельности могут привести к вторичным изменениям указанных показателей. Некомпенсированные нарушения основных гомеостатических констант являются отражением недостаточности функции почек.

Не менее важна роль почек по выведению из организма продуктов азотистого обмена и различных чужеродных веществ. Соответственно нарушение экскреции веществ - одно из важных проявлений недостаточности почек. Наиболее частым следствием нарушения синтеза мочевины является накопление аммиака в крови. Количество его может увеличиваться при резко выраженном дефекте выделительной функции почек. Токсическое действие аммиака обусловлено прежде всего его влиянием на ЦНС. Оно может быть прямым и опосредованным, последнее заключается в усиленном обезвреживании аммиака вследствие связывания его глутаминовой кислотой. Выключение глутаминовой кислоты из обмена проявляется ускорением переаминирования аминокислот с $\alpha$-кетоглутаровой кислотой, которая тем самым отвлекается от участия в цикле трикарбоновых кислот (цикл Кребса). Торможение цикла Кребса приводит к задержке утилизации ацетил-СоА, который, превращаясь в кетоновые тела, способствует развитию коматозного состояния.

Почки также регулируют состав и объем плазмы и всю внеклеточную жидкость. Кроме того, поскольку вода и многие растворенные вещества проходят через клеточные мембраны, от функции почек зависят состав и объем внутриклеточной жидкости. 
В почечной экскреции участвуют многие механизмы, обеспечивающие тонкую регуляцию выведения воды и электролитов, а также удаление экзогенных соединений и продуктов азотистого обмена - мочевины и креатинина.

Почки - это главный орган выделения и осморегуляции. Их функции включают выведение из организма ненужных продуктов обмена и чужеродных веществ, регуляцию химического состава жидкости тела путем удаления веществ, количество которых превышает текущие потребности, регуляцию содержания воды и регуляцию $\mathrm{pH}$ жидкости тела. Почки обильно снабжаются кровью и гомеостатически регулируют ее состав. Благодаря этому поддерживается оптимальный состав тканевой жидкости и, следовательно, внутриклеточной жидкости омываемых ею клеток, что обеспечивает их эффективную работу. Конечным продуктом деятельности почек является моча, объем и состав которой варьируют в зависимости от физиологического состояния организма.

Нормальная функция общей системы естественной детоксикации дает достаточно надежное очищение организма от токсических веществ. В противном случае происходит накопление метаболитов, обладающих выраженным токсическим действием и как следствие вторичным повреждением клетки. Такое повреждение - типичный патологический процесс, основу которого составляют нарушения внутриклеточного гомеостаза, приводящие к дефекту структурной целостности клетки и ее функциональных способностей.

Все это позволяет считать систему элиминации и детоксикации одним из этапов развития нормального иммунного ответа. Оценка степени интоксикации и проведения детоксикационных мероприятий при лечении больных с иммунными нарушениями - один из видов комплексного лечения.

Не менее важным фактором для развития любого патологического процесса является этап восстановления, регенерация.

Регенерация (от лат. regenerate - возрождение, возобновление) - восстановление (возмещение) структурных элементов ткани взамен погибших. Регенераторные процессы - это одно из важнейших звеньев поддержания гомеостаза. Восстановление структуры может происходить на разных уровнях - молекулярном, субклеточном, клеточном, тканевом и органном, однако всегда речь идет о возмешении структуры, которая способна выполнять специализированную функцию. Регенерация - это восстановление как структуры, так и функции. Значение регенеративного процесса - материальное обеспечение гомеостаза.

Восстановление структуры и функции может осуществляться с помощью клеточных или внутриклеточных гиперпластических процессов. На этом основании различают клеточную и внутриклеточную формы регенерации. Для первой характерно размножение клеток митотическим и амитотическим путем, для второй увеличение числа (гиперплазия) и размеров (гипертрофия) ультраструктур (ядра, ядрышек, митохондрий, рибосом, пластинчатого комплекса и т.д.) и их компонентов. Внутриклеточная форма регенерации является универсальной, свойственной всем органам и тканям. Клетки постоянно обновляются. Старые клетки в основном за счет программируемой клеточной смерти (см. главу 3) погибают и перерабатываются макрофагами. Новые появляются за счет деления из имеющихся клеток или стволовых клеток. Ритм обновление клеток при этом в разных органах и тканях разный (рис. 38). Преобладание той или иной формы в определенных органах и тканях определяется их функциональным назначением, структурно-функциональной специализацией $[22,38,129]$.

В настоящее время принято считать, что в организме имеются три категории специализированных клеток по их способности к делению.

Клетки I категории к моменту рождения в первый период жизни достигают высокоспециализированного состояния структур за счет минимизации функций. В организме отсутствует источник возобновления этих клеток в случае их дисфункции. К таким клеткам относятся нейроны. Клетки I категории способны к внутриклеточной регенерации, в результате которой восстанавливаются утраченные части клеток, если сохранены ядерный аппарат и трофическое обеспечение. 


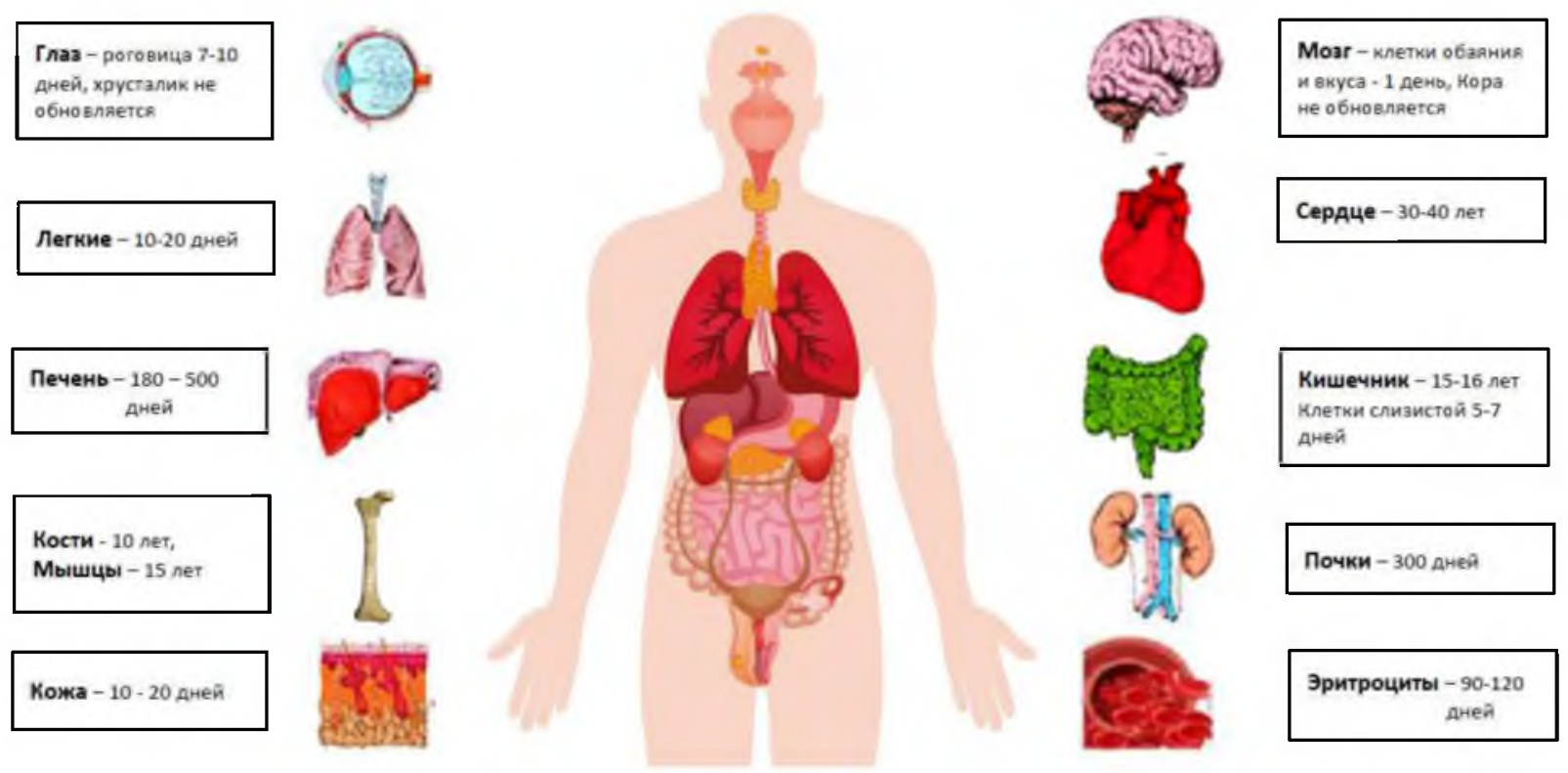

\section{Рис.38. Цикл обновления клеток организма}

Клетки II категории - высокоспециализированные, выполняющие какие-либо определенные функции и затем либо «изнашивающиеся», либо слущивающиеся с различных поверхностей, причем, иногда очень быстро. Подобно клеткам I категории, они не способны размножаться, однако в организме имеется механизм для их непрерывного воспроизводства. Такие клеточные популяции называются обновляющимися, а состояние, в котором они находятся, - стационарным.

Клетки III категории отличаются большой продолжительностью жизни, их деление после полного завершения специализации в нормальных условиях онтогенеза происходит редко, но способность к этому процессу у них сохраняется. При стимуляции, возникающей, например, после травмы, они начинают интенсивно делиться, в результате чего воспроизводятся соответствующие специализированные клетки. Примером таких клеток служит гепатоцит или гормонально активная клетка.

Особую группу клеток составляют стволовые клетки. Стволовые клетки - это недифференцированные клетки, способные делиться и давать начало различным формам специализированных клеток. В соответствии со своей возможностью к дифференцировке выделяют разновидности стволовых клеток: тотипотентные - клетки, способные дифференцироваться в любые клетки организма. плюрипотентные - клетки, способные образовывать множество различных клеток, но не целый организм, мультипотентные - клетки, способные образовывать клетки одного типа тканей, унипотентные - клетки дающие начало только одному типу клеток. Клетки развивающегося эмбриона изначально тотипотентны, но теряют это свойство после нескольких клеточных делений, т.е. они дифференцируются. Некоторые из клеток организма, не дифференцируются окончательно, а становятся плюрипотентными, т.е. способны давать лишь некоторые типы клеток целого организма. Тотипотентные клетки называют так же - эмбриональные стволовые клетки, а плюри- и мультипотентные клетки организма называют - взрослыми стволовыми клетками они и являются основой регенерации.

Различают три вида регенерации: физиологическую, репаративную и патологическую. 
Физиологическая регенерация совершается в течение всей жизни и характеризуется постоянным обновлением клеток, волокнистых структур, основного вещества соединительной ткани. Нет таких структур, которые не подвергались бы физиологической регенерации. Так происходит постоянная смена покровного эпителия кожи и слизистых оболочек, секреторного эпителия экзокринных желез, клеток, выстилающих серозные и синовиальные оболочки, клеточных элементов соединительной ткани, эритроцитов, лейкоцитов и тромбоцитов крови и т.д. В тканях и органах, где клеточная форма регенерации утрачена, например в сердце, головном мозге, происходит обновление внутриклеточных структур. Наряду с обновлением клеток и субклеточных структур постоянно совершается биохимическая регенерация, т.е. обновление молекулярного состава всех компонентов тела.

Репаративная или восстановительная регенерация наблюдается при различных патологических процессах, ведущих к повреждению клеток и тканей. Механизмы репаративной и физиологической регенерации едины. Репаративная регенерация - это усиленная физиологическая регенерация. Однако в связи с тем, что репаративная регенерация побуждается патологическими процессами, она имеет качественные морфологические отличия от физиологической регенерации.

Репаративная регенерация может быть полной и неполной. Полная, или реституция, характеризуется возмешением дефекта тканью, которая идентична погибшей. В соединительной ткани, костях, коже и слизистых оболочках даже относительно крупные дефекты органа могут путем деления клеток замещаться тканью, идентичной погибшей. При неполной регенерации, или субституции, дефект замещается соединительной тканью, рубцом, поскольку при регенерации происходит восстановление структуры, способной к выполнению специализированной функции. Смысл неполной регенерации не в замещении дефекта рубцом, а в компенсаторной гиперплазии элементов оставшейся специализированной ткани, масса которой увеличивается, то есть происходит гипертрофия ткани. Такая гипертрофия возникает как выражение регенераторного процесса, поэтому ее называют регенерационной, в ней биологический смысл репаративной регенерации. Регенераторная гипертрофия может осуществляться двумя путями - c помощью гиперплазии клеток или гиперплазии и гипертрофии клеточных ультраструктур, т.е. гипертрофии клеток.

Восстановление исходной массы органа и его функции за счет преимущественно гиперплазии клеток происходит при регенерационной гипертрофии печени, почек, поджелудочной железы, надпочечников, легких, селезенки и др. Регенерационная гипертрофия за счет гиперплазии клеточных ультраструктур характерна для миокарда, головного мозга, т.е. тех органов, где преобладает внутриклеточная форма регенерации. Оба пути гипертрофии не исключают друг друга, a, наоборот, нередко сочетаются. Так, при регенерационной гипертрофии печени происходит не только увеличение числа клеток в сохранившейся после повреждения части органа, но и гипертрофия их, обусловленная гиперплазией ультраструктур. Нельзя исключить того, что в мышце сердца регенерационная гипертрофия может протекать не только в виде гипертрофии волокон, но и путем увеличения числа составляющих их мышечных клеток.

Восстановительный период обычно не ограничивается только тем, что в поврежденном органе развертывается репаративная регенерация. Если воздействие патогенного фактора прекращается до гибели клетки, происходит постепенное восстановление поврежденных органелл. Следовательно, проявления репаративной реакции должны быть расширены за счет включения восстановительных внутриклеточных процессов в дистрофически измененных органах. Общепринятое мнение о регенерации только как о завершающем этапе патологического процесса малооправдано. Репаративная регенерация не местная, а общая реакция организма, охватывающая различные органы, но реализующаяся в полной мере лишь в том или ином из них.

О патологической регенерации говорят в тех случаях, когда в результате тех или иных причин имеется извращение регенеративного процесса, нарушение смены фаз пролиферации и дифференцировки. Такая регенерация проявляется в избыточном или недостаточном 
образовании регенерирующей ткани (гипер- или гипорегенерация), а также в превращении в ходе регенерации одного вида ткани в другой. Примерами могут служить гиперпродукция соединительной ткани с образованием келоида, избыточная регенерация периферических нервов и избыточное образование костной мозоли при срастании перелома, вялое заживление ран и метаплазия эпителия в очаге хронического воспаления. Патологическая регенерация обычно развивается при нарушениях общих и местных условий регенерации (нарушение иннервации, белковое и витаминное голодание, хроническое воспаление и т. д.).

Морфогенез регенеративного процесса складывается из двух фаз - пролиферации и дифференцировки. Об источниках регенерации есть две точки зрения. Согласно одной из них (теория резервных клеток), происходит пролиферация СК и клеток-предшественников, которые, интенсивно размножаясь и дифференцируясь, восполняют убыль высокодифференцированных клеток данного органа, обеспечивающих его специфическую функцию. Другая точка зрения допускает, что наряду со СК источником регенерации могут быть и высокодифференцированные клетки органа, которые в условиях патологического процесса могут перестраиваться, утрачивать часть своих специфических органелл и одновременно приобретать способность к митотическому делению с последующей пролиферацией и дифференцировкой.

Рассматривая процессы репаративной регенерации различных органов и тканей необходимо отметить их различную способность и интенсивность к восстановлению. Эффективность процесса регенерации в большой мере определяется условиями, в которых он протекает. Огромное значение в этом имеет общее состояние организма. Истощение, гиповитаминоз, нарушение иннервации и другие изменения оказывают значительное влияние на ход репаративной регенерации, затормаживая ее и способствуя переходу в патологическую. Существенное влияние на ее интенсивность оказывает степень функциональной нагрузки, правильное дозирование которой благоприятствует этому процессу. Скорость репаративной регенерации в известной мере определяется и возрастом, что приобретает особое значение в связи с увеличением продолжительности жизни и соответственно числа оперативных вмешательств у лиц старших возрастных групп. 


\section{МЕТОДЫ ИССЛЕДОВАНИЯ ИММУННОЙ СИСТЕМЫ}

\section{Глава 6. Клинические методы исследования иммунной системы}

Клиническая диагностика иммунной системы основана на выявление иммунных нарушений используя классические подходах диагностики заболеваний. При иммунопатологические состояниях вовлечены многие органы и системы организма человека, поэтому внимательное обследование больного, анализ всех даже мелких второстепенных признаков позволяют поставить наиболее достоверный диагноз. Необходимо отметить, что все обнаруженные симптомы (объективные и субъективные) следует оценивать в динамике, так как они постоянно изменяются в зависимости от клинического состояния.

На первом этапе проводится расспрос больного, выясняются жалобы на момент осмотра. Вначале устанавливается наличие общепатологических симптомов (лихорадка, слабость, нарушение сознания, снижение веса и др.), а затем активным опросом по органам и системам выявляют основные и второстепенные признаки, уточняя их по времени, интенсивности, продолжительности, локализации и т.д. Уже на данном этапе врач составляет представление о преобладающей патологии. При характеристике жалоб больного необходимо их уточнять, обращая внимание на определенные выше синдромы с детальным восстановлением всего хода заболевания $[5,26,28,38,74,91,112]$.

Для иммунопатологических состояний наибольший интерес представляют следующие проявления.

1. Повышение температуры тела является одним из главных признаков воспалительной реакции, как при инфекциях, так и при аутоиммунных заболеваниях, опухолях, некоторых формах аллергии. По температурной кривой можно определить диагноз заболевания (малярия, возвратный тиф, паразитарные инвазии, бруцеллез и пр.). Для вирусных инфекций характерно, что продолжительность лихорадки не превышает 5 дней, наоборот длительное повышение температуры тела (свыше месяца) свидетельствует о хроническом течении инфекционного (бактериального) или другого воспалительного процесса. Отсутствие температурной реакции при инфекциях говорит о недостаточности макрофагально-фагоцитарного звена иммунитета. Для объективной оценки такой реакции необходимо производить измерения температуры тела через 2 ч. с построением температурной кривой.

2. Боли, их локализация и интенсивность, особенности проявления непосредственно свидетельствуют о поражении определенного органа. При этом выраженность какой-либо органной патологии может доминировать в клинической картине заболевания и служит основанием для определения диагноза. Боли характерны при инфекционных и других поражениях любого органа, а в суставах являются почти универсальным симптомом ревматических болезней. Головная боль - один из признаков интоксикации и т.д.

3. Реакция дыхательных путей (кашель, одышка, чихание, заложенность носа) есть проявление инфекционных или аллергических поражений респираторного тракта человека. Кашель - защитная реакция организма при скоплении в гортани, трахее и бронхах слизи или иного инородного образования. Под одышкой понимается субъективное ощущение больным нехватки воздуха, сдавливание груди; крайняя степень - удушье (приступ удушья - астма). 
4. Реакция ЖКТ (рвота, диарея, запоры, желтуха). Диарея (понос) - учащенное (свыше 2-х раз в сутки) выделение жидких испражнений. Многообразие ее причин - наиболее частое возникновение острых проявлений (до 2-х нед.), связанных с микробными поражениями и аллергическими реакциями. Хронические диареи (продолжающиеся более 2$\mathrm{x}$ нед. или имеющие рецидивирующее течение) могут быть при нарушениях микробного соотношения в кишечнике, аутоиммунных заболеваниях и опухолях. По этим же причинам у пациента могут быть и запоры. По набору жалоб можно ориентировочно судить об уровне поражения ЖКТ.

5. Желтушное окрашивание кожи (желтуха) - хорошо заметный признак, обращающий на себя внимание не только врача, но и больного. Одна из причин ее - это хроническая вирусная инфекция, другие тяжелые инфекции, аутоиммунные поражения печени.

6. Высыпания на коже (экзантемы) имеют большое значение в диагностике иммунопатологий. Это связано с тем, что они встречаются при многих иммунопатологических состояниях и отчетливо заметны. Экзантемы весьма разнообразны, они различаются по характеру отдельных элементов, локализации, этапности высыпания, наличию зуда.

7. Отделяемое из очага воспаления имеет большое значение в дифференциальной диагностике. Гнойные (зеленое, желтое) выделения характерны для бактериальных инфекций, при вирусных инфекциях и аллергических реакциях - бесцветное серозное отделяемое. При грибковых поражениях отделяемое невыраженное с белым оттенком.

8. При всех реакциях иммунитета задействованы лимфатическая система и непосредственно лимфатические узлы. Нередко пациент сам обращает внимание на их увеличение и болезненность.

Анализ анамнестических данных - основной этап в постановке диагноза дисфункции иммунной системы. Анализ анамнеза позволяют выявить основные синдромы иммунных нарушений, понять причины, приведшие к формированию дисфункций, определить прогноз и эффективность лечения, наследственную предрасположенность к иммунопатологиям.

Для первичного приема пациенту следует подготовить всю имеющуюся, предыдущую медицинскую документацию в возможно более полном объеме. Это могут быть: все медицинские, амбулаторные карты с места жительства (начиная с детской медицинской карты с периода новорожденности), с места учебы и работы и пр; выписки из других лечебных учреждений, в которых пациент проходил лечение амбулаторно или был госпитализирован; все сохранившиеся результаты клинико-лабораторных анализов и аппаратных исследований (за возможно более длительный период времени); все данные о ранее проводившихся (по любому поводу!) видах лечения.

Анализируя документацию и проведя расспрос пациента, следует выяснить, как часто он болеет вирусными, бактериальными и грибковыми инфекциями (грипп и другие ОРВИ, бронхит, пневмония, ангины, гайморит и другие синуситы, пиелонефрит, фурункулез и т.д.), какова в настоящее время, и прошлая, их частота, преимущественная локализация. Носят ли эти заболевания затяжной характер, есть ли очаги хронической инфекции, имеется ли рецидивирующая герпетическая инфекция, хронический вирусный гепатит, дисбактериоз. Определить возможность регенеративных процессов (как заживают раны, другие повреждения).

Грубые иммунодефициты позволяют длительно персистировать в организме различным видов патогенной бактериальной и вирусной микрофлоры, в том числе хламидиям, ВГЧ, ВЭБ, ЦМВ, энтеровирусам, вирусам гепатита В и С, вирусам папилломы человека и другим внутриклеточным инфекциям. Все это ведет не только к дальнейшему осложнению состояния организма человека, но и вызывает риск появления онкологических изменений, особенно, если у ближайших родственников больного уже отмечались случаи таких заболеваний. Очень грубые формы иммунодефицитов вызывают ВИЧ-инфекции, что даже дало «второе» название этой инфекции - синдром приобретенного иммунодефицита (СПИД). В процессе своей жизнедеятельности в организме больного ВИЧ-инфекция вызывает 
дальнейшее усугубление тяжести иммунопатологического состояния и в большинстве случаев приводит к возникновению СПИД-ассоциированных заболеваний.

На грубые нарушения функции иммунной системы указывают аллергические и аутоиммунные заболевания у пациента и его ближайших родственников.

При наличии аллергических реакций необходимо установить: какая пища, лекарства и другие факторы вызывают зуд, сыпь на коже, приступы удушья, отеки различной локализации, немотивированный внезапный насморк. Возникают ли эти состояния немотивированно или связаны с чем-то еще. Предположительно выявить этиологически значимый аллерген. Установить факторы риска, способствующие развитию аллергийнаследственная предрасположенность, влияние окружающей среды (климата, погоды, физических факторов, сезонности). Определить влияние бытовых факторов (скученность, домашние животные, птицы, сырость в помещении, мягкая мебель, ковры и т.д.). Оценить клинический эффект от применения антиаллергических средств и/или элиминации аллергена.

Также необходимо выявить у больного опухоли различных типов и локализаций, анемии и лейкопении, увеличение лимфатических узлов, наличие у родственников лимфопролиферативных и онкологических заболеваний.

Суммарно для оценки иммунной системы можно предложить ответить на следующие вопросы и, чем больше вопросов, на которые пациент ответит «Да», тем ориентировочно сильнее расстройства функции иммунной системы (табл.25)

Как правило, даже при возникновении сравнительно легких форм иммунопатологий у человека отмечается: снижение работоспособности; склонность к частой заболеваемости; общее ухудшение качества жизни; у ребенка понижается способность к обучению.

Более грубые иммунопатологии приводят и к более тяжелым нарушениям здоровья: аллергиям (аллергический дерматит, поллиноз, нейродермит, атопический дерматит и пр.); иммунодефициту (частые ОРВИ, хронический ринит, бронхит, ларингит, фарингит, ангина, аденоиды, хроническая пневмония и усталость, стрептодермит/стрептодермия, стафилодермит/стафилодермия, микоз, кандидоз, молочница, трихофития и др.).

При сборе анамнеза у детей необходимо уделять внимание на: характер течения антенатального периода с целью определения возможной внутриутробной сенсибилизации; наличие внутриутробной гипоксии, что может способствовать ранней сенсибилизации плода; характер вскармливания ребенка и диету кормящей матери в период естественного вскармливания (период лактации); время введения прикормов, соков, их объемов и кратности.

Особенно сложные отдаленные последствия вызывают иммунопатологические состояния в детском возрасте, когда идет быстрое формирование ребенка. Основы здоровья человека, в основном, закладываются во время внутриутробного развития и на первом году жизни. Нарушение развития в эти периоды приводит к существенным изменениям нормального функционирования организма в дальнейшем. Во время вынашивания беременности это в основном: токсикозы беременности; угроза самопроизвольного прерывания беременности (угроза выкидыша); различные заболевания и применение лекарственных препаратов; работа или жизнь будущей мамы в условиях, связанных с вредностью, особенно в первой половине беременности.

Серьезные иммунные нарушения могут возникать в результате поступления (особенно длительного) в организм токсичных веществ (в том числе промышленных, сельскохозяйственных, бытовых, многих пищевых добавок и консервантов и др.), воздействия ионизирующей радиации, а также электромагнитных полей и волн, особенно метрового, дециметрового и сантиметрового диапазонов.

Дополнительно достаточно большой объем информации можно получить, анализируя:

- результаты всех ранее проведенных по любому поводу диагностических исследований как нормальных (в них разброс различных параметров в пределах нормы индивидуален), так и патологически измененных;

- ранее сделанные по любому поводу инструментальные исследования; 


\section{Вопросы для выявления иммунопатологии}

Oсновные вопросы

$\checkmark$ Часто ли бывают простудные заболевания (> 4 раз в году у взрослых и 6 раз у ребенка)?

$\checkmark$ Бывает ли без причины температура $37,0-37,5^{\circ}$ С раз в неделю или чаче?

$\checkmark$ Выявляются ли заболевания органов дыхания чаще 2 раз в год? Кашель более 1 мес? Камель с отделением мокроты в течение года более 2 мес? Отделение мокроты суммарно в течение года более 1 мес? Возникает ли чувство удуиья (при простудных заболеваниях, при чветении растений, на пыль, без видимых причин)? Отмечается ли заложенность и зуд в носу, чихание, обильное выделение из носа?

$\checkmark$ Поражения ЖКТ. Диарея, продолюающаяся более 2 нед. или имеющая рецидивирующее течение, желтуха?

$\checkmark$ Имеются ли хропические воспалительные заболевания (хронический бронхит, тонзиллит, отит, простатит, цистит, уретрит, нефрит, гайморит, фронтит, синусит и т.д.)? Носят ли болезни затяжной характер с госпитализацией?

$\checkmark$ Диагностировались ли у пациента хронический вирусный гепатит (B, $C$, Д и др.), герпес с обострением чаще 2 раз в течение года, иитомегаловирусная инфекиия (ІцМВ), иифекиия, вызванная вирусом Эпитейна Барра, ВИЧ-инфекиия, дисбактериоз кииечника, аллергические реакиии, аутоиммунные заболевания?

$\checkmark$ В течение года были хронических синуситов (гайморит, фронтит, этмондит), ангина, отит, обострение бронхита с гнойным отоеляемым, пиодермия, фурункулез, гидраденит, грибковые инфекиии кожи (кандидамикоз, дерматомикоз), ногтей, слизистых оболочек (молочнича), внутренних органов?

$\checkmark$ Диагностировались ли у больного в последние три года абсиессы, флегмоны, септические гранулемы, парапроктит, чистит, пиелонефрит, другие инфекиии мочеполовой системы, язвенная болезнь, колит, энтероколит, хламидиоз, микоплазмоз, папиломатоз?

$\checkmark$ Диагностировались ли доброкачественные и/или злокачественныле опухоли, менингоэниефалит, сепсис, перитонит, пневмонии более одного раза в течение жизии, туберкулез, сифилис, малярия, стафилококковый эндокардит, паразитарные инвазии (лямблиоз, описторхоз, дифиллоботриоз, токсоплазмоз и пр.)?

$\checkmark$ Болел ли пациент после 16 лет корью, краснухой, эпидемическим паротитом (свинкой), вирусным гепатитом А, ветряной оспой, опоясываюиим герпесом, стоматитом?

$\checkmark$ Диагностировались ли заболевания, вызываемые различными инфекциями, у которых затяжное речидивирующее течение?

$\checkmark$ Встречались ли заболевания, устойчивые к стандартным методам лечения?

$\checkmark$ Развивались ли осложнения основного заболевания?

$\checkmark$ Медленно ли заживают у пачиента раны?

$\checkmark$ Имеются ли врожденные аномалии? Страдает ли паџиент или его родственники каким-либо онкологическим, аутоиммунным заболеванием, аллергиями?

Дополнительные вопросы

$\checkmark$ у какого врача находится на диспансерном учете;

$\checkmark$ профессиональные вредности и факторы внешней среды (контакт с химическими веществами, лекарствами, биопрепаратами, воздействие радиации, магнитного поля, высокие или низкие температуры, постояниые стрессовые ситуачии);

$\checkmark$ интоксикачии, хирургические вмешательства, травмы, наруиения питания;

$\checkmark$ длительная терапия цитостатиками, лучевая и гормональная, антибиотиками;

$\checkmark$ принадлежность к группам риска (наркомания, половые перверсии, хронический алкоголизм, курение);

$\checkmark$ реакции на переливание крови и ее продуктов;

$\checkmark$ патология беременности (бесплодие, выкидыии). 
- развернутое исследование инфекционного статуса, зачастую с дополнительными исследованиями на гепатиты и урогенитальные инфекции;

- клинический анализ крови (определяется общее количество клеток иммунной системы в периферической крови);

- биохимический анализ крови, включающий в различных случаях ли-пидограмму, белковые фракции, коагулограмму, билирубин и другие показатели;

- бактериологическое исследование отделяемого из носа и мазка из зева или других органов;

- исследование на кишечный дисбактериоз (одной из важных характеристик для лечения и дальнейшего прогноза течения иммунных нарушений являются наличие и оценка дисбиотических процессов кишечника).

Анализируя анамнез больного, следует попытаться найти причину возникновения иммунодефицита и составить предварительное заключение о наличии дефекта в том или ином звене иммунной системы.

Зачастую больные с приобретенным иммунодефицитом могут достаточно четко определить сроки его возникновения. В этих случаях они указывают, что нарушения в состоянии здоровья возникли у них после стресса, тяжелого заболевания, облучения, перегрузок и т.д. В качестве причин иммунодефицита могут быть также профессиональные вредности: воздействие химикатов, канцерогенных веществ, облучение, контакт с гербицидами, сверхвысокими частотами и др.; злоупотребление алкоголем, курение, применение наркотиков.

Выяснение причины иммунодефицита очень важно, так как если она продолжает действовать, то рассчитывать на успех проводимой иммунотерапии не приходится. Следует предпринять все возможное, чтобы попытаться устранить или, по крайней мере, уменьшить степень воздействия неблагоприятного фактора. Если в качестве причины иммунодефицита врач-иммунолог выявил тяжелую соматическую патологию, то иммунотерапию надо проводить совместно с врачом-терапевтом.

Тщательный анализ анамнеза позволяет сделать предварительное заключение о поражении определенного звена иммунитета. Наиболее важный момент - это анализ перечня перенесенных заболеваний. В этом смысле важно опираться на знание болезней-«масок» иммунодефицита. Указания в анамнезе на вирусные инфекции, грибковые поражения, наличие аутоиммунной патологии, онкозаболеваний дают основание думать о возможных нарушениях в Т-клеточном звене иммунитета. В то же время, если у больного отмечается целый ряд перенесенных бактериальных инфекций (сепсис, остеомиелит, бактериальные пневмонии, анги-ны, аднексит и др.), то, скорее всего, можно предположить нарушение гуморального звена иммунитета. В тех случаях, когда у пациента имеются данные о перенесенных им болезнях-«масках» как клеточного, так и гуморального иммунитета, предполагается комбинированный тип поражения иммунной системы.

Достаточно трудно, скорее невозможно, клинически дифференцировать болезни«маски» гуморальной недостаточности и нарушений фагоцитоза. Как в том, так и в другом случае у больных на первый план выходят заболевания бактериальной природы. Решающими в этом случае будут данные лабораторных исследование иммунной системы.

Важно отметить, что практически всегда иммунные реакции нарушаются разнонаправлено - когда одни из них неадекватно понижаются, другие неадекватно повышаются, что называется дисбалансом иммунной системы. Поэтому у больных с аллергией почти всегда наблюдаются и признаки недостаточности эффекторного звена (хронические воспалительные процессы или склонность к частым ОРВИ и др.), а у пациентов с иммунодефицитными состояниями присутствует в какой-либо форме и симптоматика аллергии. Следует помнить, что при всяком длительно протекающем воспалительном процессе обязательно происходит местная сенсибилизация. И в этом еще одна опасность осложнений, которую несут хронические воспалительные процессы. В частности, 
хронические или частые бронхиты могут спровоцировать возникновение бронхоспазмов и бронхиальной астмы.

Объективный осмотр: посистемный осмотр пациента поможет определить диагноз заболевания и выявить признаки поражения иммунной системы. Специфических симптомов признаки дисфункции иммунной системы не имеют. Тем не менее при физикальном обследовании можно оценить состояние органов и тканей иммунной системы (лимфатических узлов, селезенки, миндалин), описать иммунопатологические реакции.

Посистемный осмотр пациента поможет определить диагноз заболевания и выявить признаки поражения иммунной системы. Специфических симптомов признаки дисфункции иммунной системы не имеют. Тем не менее при физикальном обследовании можно оценить состояние органов и тканей иммунной системы (лимфатических узлов, селезенки, миндалин), описать иммунопатологические реакции.

Осмотр кожных покровов позволяет выявить многие патологические состояния. Нередко на коже появляются различные морфологические элементы, отражающие разнообразные заболевания. Многие иммунопатологические состояния имеют специфические признаки поражения (атопический дерматит, СКВ, герпес, абсцессы, фурункулы и т.д.).

Осмотр кожных покровов позволяет выявить многие патологические состояния. Различают следующие проявления поражения кожи, связанные с иммунными реакциями (рис. 39-50).

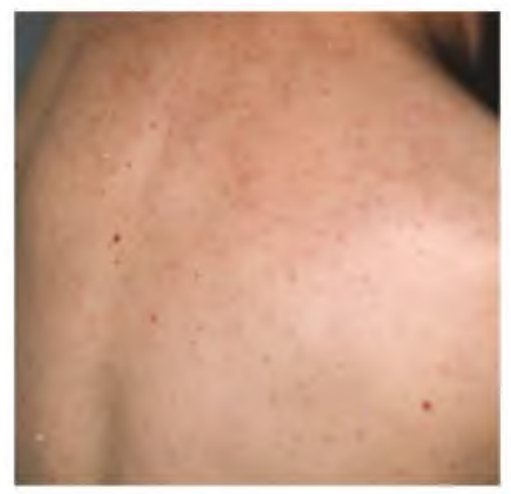

Рис. 39. Розеола - небольшое пятнышко (2-5 мм) розового или красного цвета, возникающее за счет расширения сосудов.

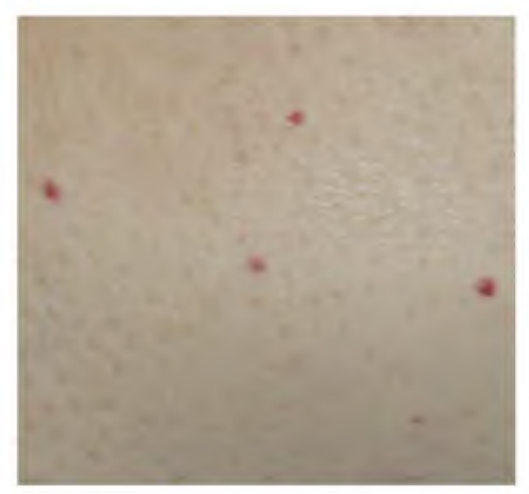

Рис. 42 Папула -

бесполостное поверхностное образование кожи размером $1-20$ мм. Слияние отдельных папул бляшки.

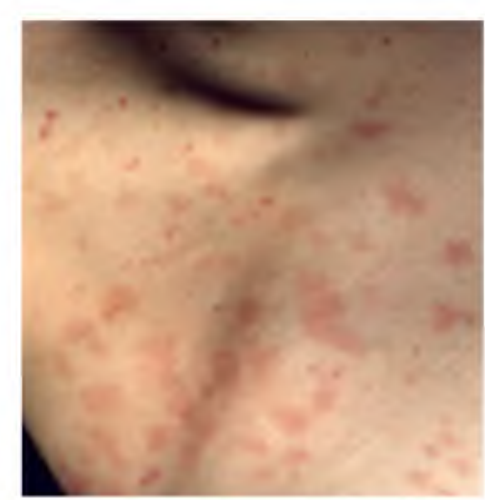

Рис. 40. Пятно - аналогичное розеоле образование размером 5 $20 \mathrm{MM}$.

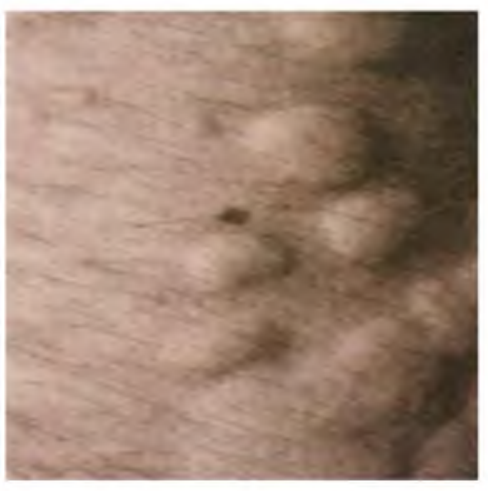

Рис. 43. Бугорок -

бесполостное образование от 3-5 до 20 мм. В отличие от папулы бугорок залегает глубоко в дерме.

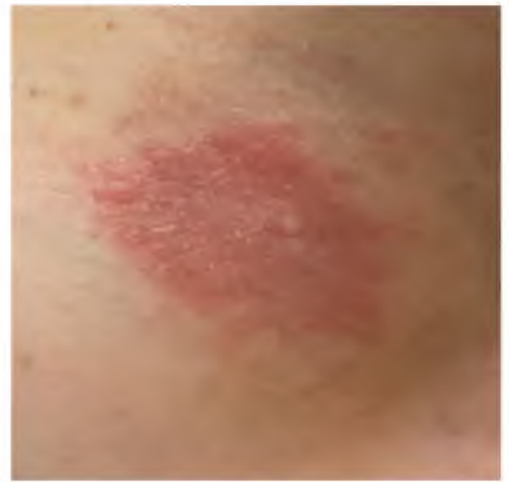

Рис. 41. Эритема - это обширные участки гиперемированной кожи красного цвета, обычно результат слияния крупных пятен.

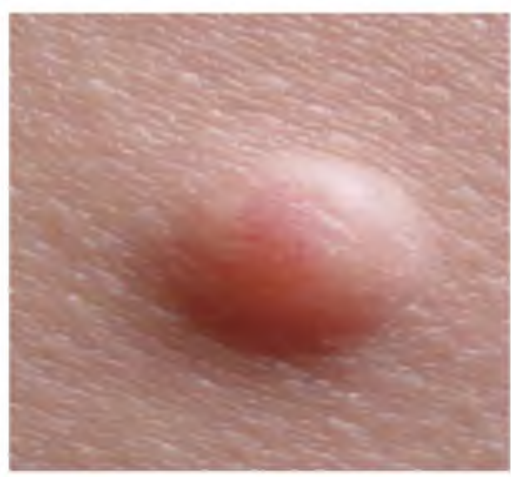

Рис. 44. Узел - ограниченное плотное образование от $1-5$ см и более, расположенное в глубоких отделах дермы 


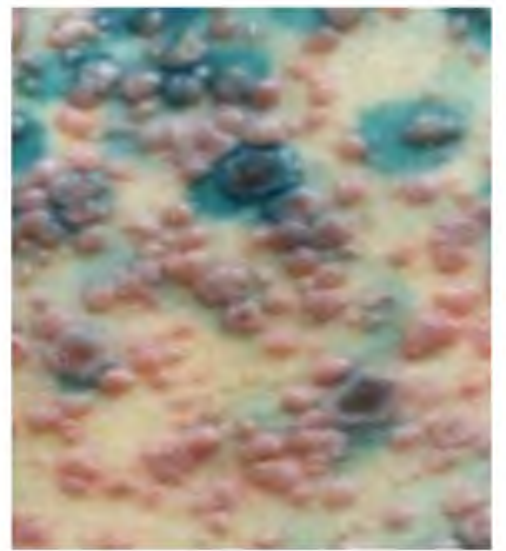

Рис 45. Пузырек - полостное образование, содержащее серозную и/или геморрагическую жидкость, размером 1,5-5 мм.

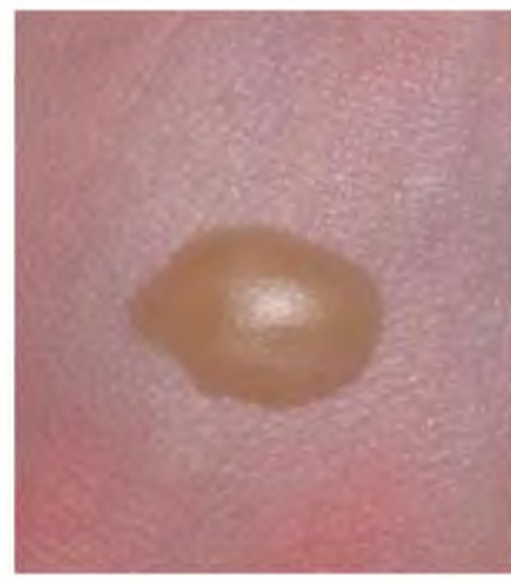

Рис. 48. Волдырь бесполостной элемент островоспалительного характера.

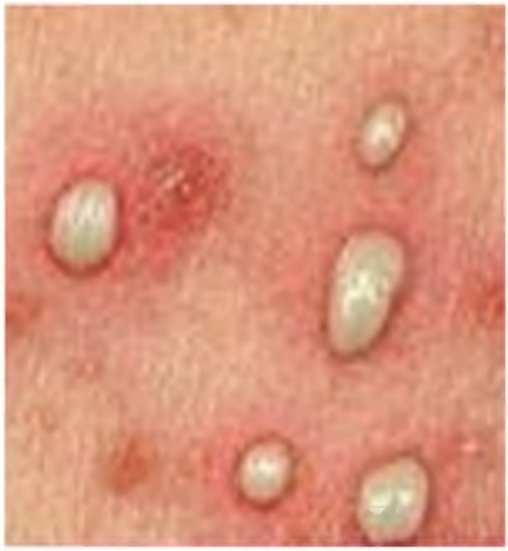

Рис. 46. Пустула или

гнойничок - пузырек с гнойным содержимым.

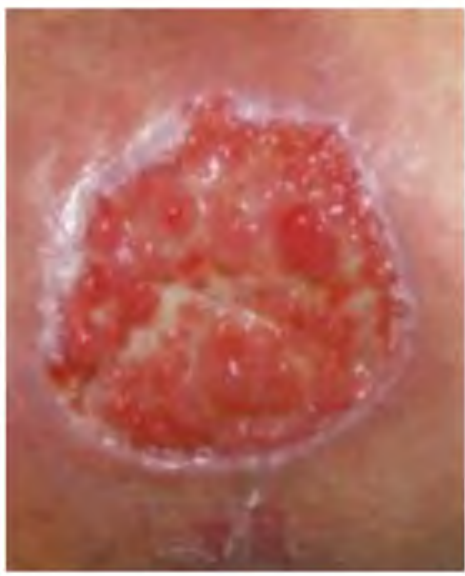

Рис. 49 Эрозия - дефект эпидермиса, обычно появляются после вскрытия пузырей, пустул.

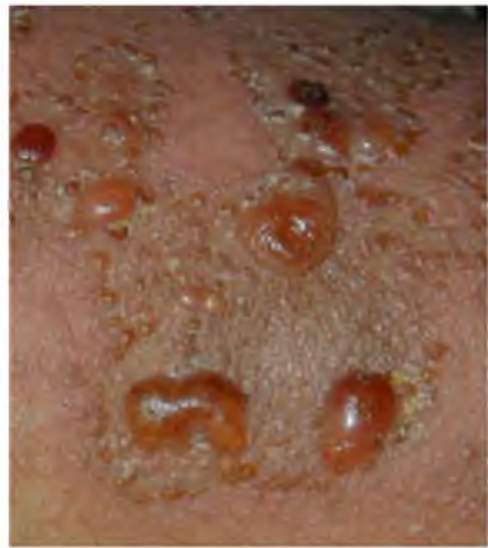

Рис. 47. Пузырь- полостное образование более 5 мм с серозным или серозногеморрагическим содержимым.

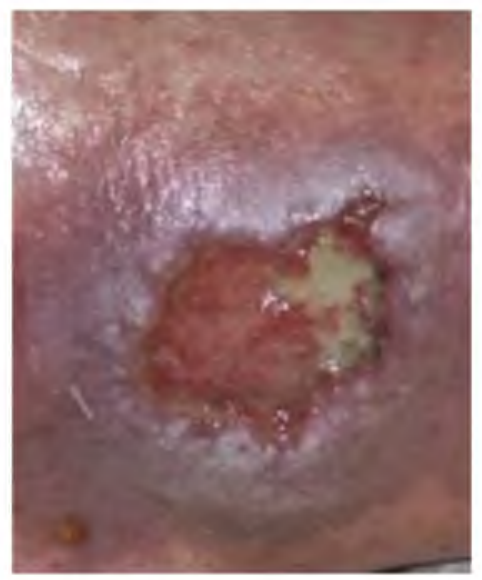

Рис.50. Язва - глубокий дефект кожи, захватывающий эпидермис, дерму, иногда и подлежашие ткани.

На коже тела и видимых слизистых могут быть и другие морфологические образования: папилломы, фибромы, ангиомы, меланомы, лимфомы и пр. При выявлении подобных образований пациента необходимо направить к хирургу или онкологу.

Изучение лимфатических узлов - еще один из

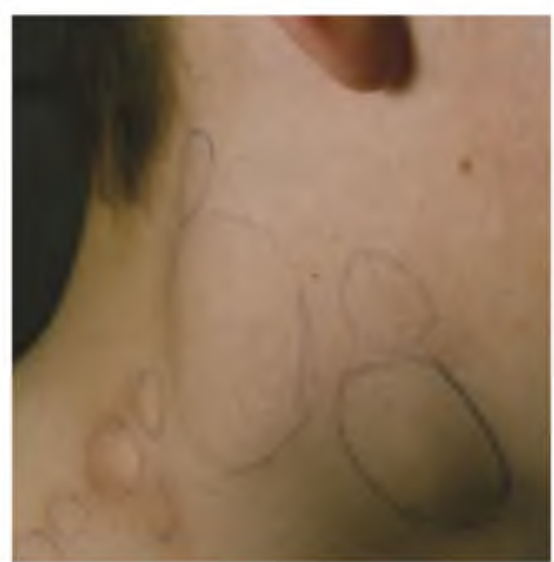

Рис. 51. Лимфатические узлы важнейших этапов диагностики иммунных нарушений. Лимфатические узлы в норме не видны и практически не прощупываются, они увеличиваются при многих инфекционных заболеваниях (рис. 51). В зависимости от характера патологического процесса их размеры могут достигать до 3-4 см., а также увеличиваться локально только в одной области (подчелюстные, шейные и пр.) или в нескольких группах (генерализованная лимфаденопатия).

Состояние опорно-двигательной системы имеет большое значение для диагностики аутоиммунных заболеваний. Локализация, динамика развития, характер поражения, оценка нарушения функции позволяют достоверно установить диагноз и оценить степень иммунопатологических реакций при этих заболеваниях. 
При оценке респираторной системы можно выявить инфекционно-воспалительные и аллергические реакции. В зависимости от иммунопатологических реакций могут преобладать поражения того или иного отдела органов дыхания (ринит, ринофарингит, бронхит, пневмония и др.) с определенными данному уровню поражения проявлениями.

Часто при иммунопатологических состояниях встречаются поражения ЖКТ. Проявления инфекции и дисбиотические расстройства (вздутие живота, болезненность и урчание при пальпации, язык с грязно-белыми налетами и пр.) являются признаками гипоэргических реакций больного. Большое значение при осмотре придается печени и селезенки. Увеличение этих «иммунных» органов в большинстве случаев свидетельствует о дисфункции иммунитета. При этом следует обращать внимание на степень увеличения и плотность органов, а также их болезненность (рис. 52). Также для поражения печени характерна желтушность кожных покровов и иктеричность склер (рис.53).

Нарушения деятельности сердечно-сосудистой системы, найденные при осмотре, обычно характеризуют тяжесть состояния больного (тахикардия, гипотония). Выявленные признаки миокардита или перикардита сопровождают антителозависимый цитотоксический синдром.

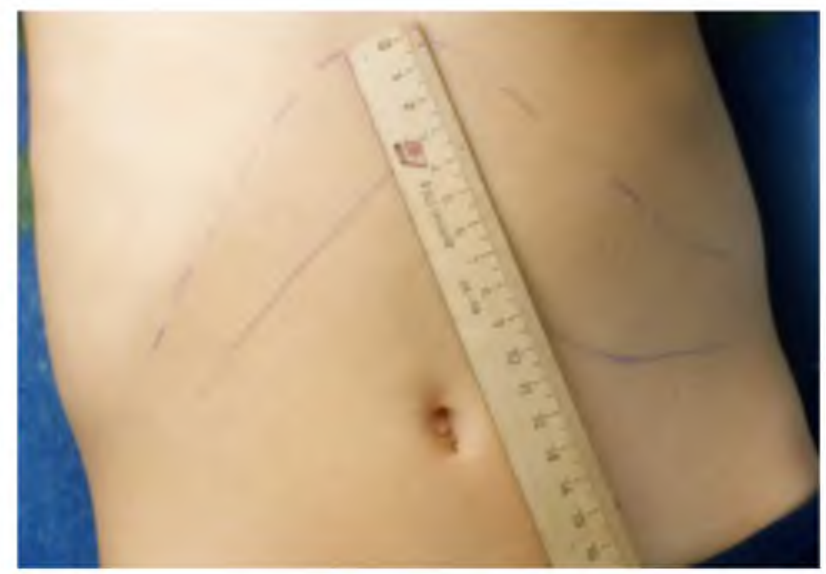

Рис. 52. Увеличение печени и селезенки
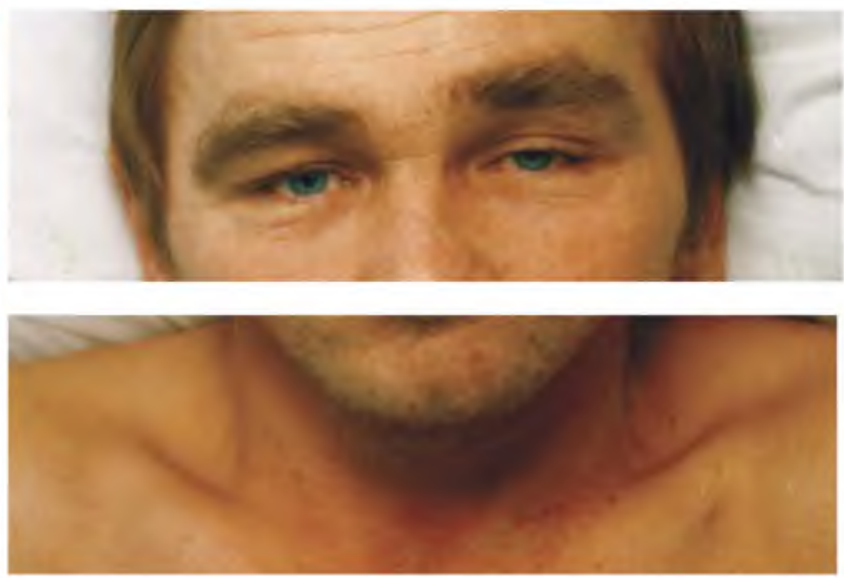

Рис. 53. Иктеричность склер, желтуха кожи.

Уровень интоксикации обычно характеризуют признаками поражения ЦНС (заторможенность, эйфория, сопор, кома).

Отдельно необходимо остановиться на клинических методах диагностики аллергических заболеваний, в которой огромная роль принадлежит выяснению этимологически значимого аллергена. К настоящему времени спектр определяемых аллергенов очень широк (табл.26) полный спектр их можно найти на сайте http://www.allergen.org/

Для диагностики аллергенов можно проводить кожные пробы $[1,31,66,67,94]$.

Выбор кожной пробы зависит от предполагаемой этиологии заболевания, степени сенсибилизации больного и стадии процесса. Показаниями для проведения кожных проб будут данные анамнеза, указывающие на роль того или иного аллергена или группы аллергенов в генезе заболевания.

Противопоказания кожного тестирования:

- острая фаза аллергического заболевания;

- обострение сопутствующих хронических заболеваний;

- острые интеркурентные инфекционные заболевания, вираж туберкулиновых проб;

- декомпенсированные состояния при болезнях сердца, печени, почек;

- заболевания крови, онкозаболевания, системные и аутоиммунные заболевания;

- период лечения антигистаминными препаратами и мембраностабилизаторами, гормонами, бронхоспазмолитиками; 


\section{Основной спектр аллергенов}

\begin{tabular}{|c|c|}
\hline $\begin{array}{l}\text { Группа } \\
\text { аллергенов }\end{array}$ & Аллергены \\
\hline $\begin{array}{l}\text { Пыльцевые } \\
\text { аллергены }\end{array}$ & $\begin{array}{l}\text { Травы: тимофеевка, лисохвост, пырей, овсяница и др. } \\
\text { Злаки: овес, пшеница, ячмень, рож, кукуруза } \\
\text { Культивируемые растения: сахарная свекла, клевер, щавель, подсолнечник и т.д. } \\
\text { Деревья: дуб, клен, ольха, орешник, береза, тополь, осины, сосны, ели, липы и т.д.; } \\
\text { Сорняки: одуванчик, амброзия, подорожник, крапивы, полынь, лебеда и т.д.; } \\
\text { Фруктовые деревья: яблони, вишни, груши и т.д.; } \\
\text { Садовые цветы: маргаритки, розы, тюльпаны, нарциссы, лилии и т.д. }\end{array}$ \\
\hline $\begin{array}{l}\text { Пищевые } \\
\text { аллергены. }\end{array}$ & $\begin{array}{l}\text { Облигатные аллергены 1-й группы - кофе, какао, шоколад, цитрусовые, клубника, } \\
\text { земляника, куриное яйцо, мясо курицы, мед, рыба, икра, крабы, раки; } \\
\text { Облигатные аллергены 2-й группы - молоко, морковь, свекла, томаты, крупы и т.д. }\end{array}$ \\
\hline $\begin{array}{l}\text { Бытовые } \\
\text { аллергены }\end{array}$ & $\begin{array}{l}\text { вещества животного, растительного происхождения, продукты жизнедеятельности } \\
\text { грибов, насекомых, бактерий. Основа домашней пыли - клещи Dermatophagoides, } \\
\text { которые особенно активно размножаются в октябре и марте-апреле. }\end{array}$ \\
\hline $\begin{array}{l}\text { Эпидермальные } \\
\text { аллергены }\end{array}$ & $\begin{array}{l}\text { Перхоть человека, лошади, свиньи; шерсть собаки, кошки, кролика, морской свинки, } \\
\text { мыши, овцы, козы и т.д. }\end{array}$ \\
\hline $\begin{array}{l}\text { Инсектные } \\
\text { аллергены }\end{array}$ & $\begin{array}{l}\text { При ужалении перепончатокрылых, укусах двукрылых и клопов, при контакте с } \\
\text { выделениями и частями тел чешуйчатокрылых. }\end{array}$ \\
\hline $\begin{array}{l}\text { Лекарственные } \\
\text { аллергены }\end{array}$ & Химические, ферментные препараты и продукты грибкового синтеза. \\
\hline $\begin{array}{l}\text { Промышленные } \\
\text { аллергены. }\end{array}$ & Пестициды, синтетические полимеры \\
\hline $\begin{array}{l}\text { Аллергены } \\
\text { микроорганизмов }\end{array}$ & Составные части бактериальной клетки, грибов \\
\hline $\begin{array}{l}\text { Аллергены } \\
\text { гельминтов }\end{array}$ & $\begin{array}{l}\text { Составные части взрослых особей (аскариды, эхинококки, трихинеллы, описторхи) и их } \\
\text { личинок. }\end{array}$ \\
\hline
\end{tabular}

- судорожный синдром, нервные и психические болезни;

- беременность, кормление ребенка грудью, первые 2-3 дня менструального цикла;

- возраст до 3 лет;

- анафилактический шок, синдромы Лайела, Стивенса-Джонсона в анамнезе.

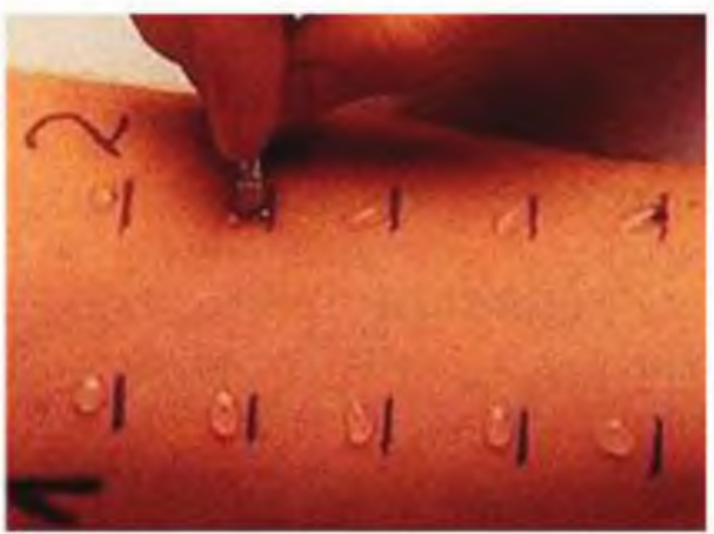

Рис. 54. Накожные пробы
Накожные пробы: капельная проба. Используется при высокой сенсибилизации, особенно к химическим веществам и иногда к лекарствам. Техника постановки: на обезжиренную сгибательную поверхность кожи предплечья наносят каплю аллергена и параллельно, в качестве контроля, каплю растворителя. Оценивают через 20 мин (рис.54).

\section{1.}

Используется

Аппликационная

проба. ирофессиональной аллергии, контактных дерматитов. 
Техника постановки: на сгибательную поверхность предплечья, предварительно обработанную 70\%-м спиртом, наносят тампон, смоченный в растворе аллергена, и параллельно тампон с растворителем. Оценивают через 30 мин. Оценка кожной аппликационной пробы происходит аналогично капельной.

2. Скарификационные кожные пробы: с их помощью выявляют причинно-значимый аллерген и степень сенсибилизации к нему. Их проводят со всеми неинфекционными аллергенами. Одновременно можно поставить не более 10-15 проб. Причем при высокой степени сенсибилизации количество аллергена одного наименования ограничено (4-5 серий д/п).

Техника постановки: кожу сгибательной поверхности предплечья обрабатывают 70\%м спиртом, затем наносят разными шприцами по капле $0,01 \%$-го гистамина, аллергенов и тестконтрольной жидкости на расстоянии 4-5 см друг от друга. Стерильными скарификаторами проводят отдельно через каждую каплю по две параллельные царапины длиной 4-5 мм и расстоянием между ними 2 мм. Обязательным условием является отрицательный результат с тест-контрольной жидкостью и положительный с гистамином.

При оценке скарификационного кожного тестирования следует учитывать возможность появления ложноположительной реакции на тест-контрольную жидкость. Это бывает в тех случаях, когда имеется повышенная чувствительность кожных покровов к механическому воздействию, а также в случае возникновения реакции на компоненты, входящие в тест-контрольную жидкость.

Ложноотрицательные пробы с аллергенами возможны при отсутствии полного серийного набора аллергенов одного типа (например, домашней пыли), другом механизме аллергической реакции, неправильном хранении аллергенов, нарушении техники введения аллергена (очень поверхностно), проведении кожного тестирования на фоне обострения аллергического или тяжелого соматического заболевания, приеме антигистаминных препаратов, мембраностабилизаторов, гормонов или бронхолитиков.

3. Тест уколом (Prik-тест): проводится специальным иглодержателем. Он позволяет регулировать глубину укола, исключает раздавливание капли при уколе. Оценка проводится так же, как и оценка скарификационных проб.

4. Внутрикожные пробы: ставятся, главным образом, с инфекционными аллергенами (бактериальными, грибковыми и др.), при которых скарификационная реакция очень слабая. С неинфекционными аллергенами их проводят только тогда, когда аппликационные или скарификационные тесты отрицательны или сомнительны, а анамнез четко положительный.

Техника постановки: кожа сгибательной поверхности предплечья или кожа на спине обрабатывается 70\%-м спиртом, затем туберкулиновым или инсулиновым шприцем вводят 0,02 мл неинфекционного или 0,05-0,1 мл инфекционного аллергена. В качестве контроля вводят внутрикожно тест-контрольную жидкость и скарификационно раствор гистамина.

Поскольку внутрикожное тестирование более чувствительно по сравнению со скарификационным, вводимый внутрикожно аллерген должен быть в 10 раз меньшей концентрации, чем при скарификационном тестировании. Внутрикожная проба менее специфична часто дает ложноположительные результаты, может спровоцировать нежелательные осложнения (количество аллергенов не должно превышать 4 - 5). Оценка внутрикожной пробы проводится так же, как и оценка скарификационных проб.

Примером внутрикожной пробы может служить проба с аллергеном туберкулезным рекомбинантным (Диаскинтест, АО Генериум, Россия) для раннего выявления туберкулезной инфекции. Содержит два антигена (ESAT6/CFP10), присутствующие в вирулентных штаммах микобактерий туберкулеза и отсутствующие в вакцинном штамме БЦЖ. При внутрикожном введении Диаскинтест® вызывает у лиц с туберкулезной инфекцией специфическую кожную реакцию, являющуюся проявлением гиперчувствительности замедленного типа (ГЧЗТ). Препарат не вызывает реакцию на вакцинный штамм БЦЖ и именно поэтому может использоваться для раннего выявления как активного туберкулеза, так и латентной туберкулезной инфекции. 
Провокационные тесты - это более достоверный метод диагностики, позволяющий достичь контакта шокового органа с аллергеном. Их используют в случае расхождения данных анамнеза и результатов кожного тестирования. В зависимости от вида аллергена и способа его введения в организм различают следующие провокационные тесты: назальный, конъюнктивальный, ингаляционный, подъязычный, оральный. Противопоказания для их проведения такие же, как и при кожном тестировании.

1. Назальный тест. Проводят с бытовыми, эпидермальными, пыльцевыми, бактериальными аллергенами для диагностики аллергических риносинуситов, трахеитов, бронхитов, бронхиальной астмы в стадии ремиссии

2. Ингаляционный тест. Основные показания для проведения ингаляционного теста: выявление этиологически значимых аллергенов, неспецифических факторов, вызывающих бронхоспазм, оценка эффективности медикаментозного лечения, определение профессиональной пригодности пациента (обнаружение латентного бронхоспазма).

Проводится с бытовыми, эпидермальными, пыльцевыми, бактериальными аллергенами с 4-5-летнего возраста при отрицательном результате назального теста или же несовпадении данных анамнеза с результатами кожного тестирования.

3. Подъязычная проба. Данный тест используют для диагностики пищевой и лекарственной аллергии. Аллерген наносится на слизистую подъязычной области. При пищевой аллергии применяются натуральные продукты в разведении $1: 10$, при лекарственной - 1/8-1/4 разовой дозы растворенного вещества. Тест считается положительным при появлении в подъязычной области гиперемии, отека, зуда, учащения пульса, высыпаний на коже, чихания, кашля.

4. Оральный тест. Тест используется для диагностики пищевой аллергии. В качестве аллергенов используют натуральные продукты. 3а 2-3 дня до проведения теста из питания исключают исследуемый продукт. Затем вводят этот продукт в рацион, оценивая общее состояние и состояние шокового органа.

Проба считается положительной при появлении реакции со стороны шокового органа в течение часа.

Для объективной диагностики иммунопатологических состояний больного необходимо наблюдать в динамике

На первичном приеме каждому поступившему пациенту определяется свой необходимый в данном случае объем диагностики, исходя из результатов осмотра, беседы с больным и изучения всей представленной предыдущей медицинской информации и т.д. После получения всех результатов разрабатывается индивидуальный курс лечения данного пациента. На первом этапе диагностики можно не только установить нозологическую форму заболевания, но и предположить его этиологию и назначить иммунотерапию.

В дальнейшем проведение лабораторно-иммунологических исследований позволяег идентифицировать конкретные нарушения иммунной системы, подтвердить клинический диагноз

Затем через каждые 1-2 нед. проводятся повторные амбулаторные приемы для необходимой коррекции лечеб́ного процесса.

Лечебный процесс следует вести до достижения стойкой нормализации здоровья, подтверждаемой не только хорошим самочувствием пациента, но и результатами объективных исследований.

Через 2-3 мес. после первичной диагностики проводится повторные исследования для объективного определения изменений в состоянии пациента.

Следует отметить, что выявление причин иммунных нарушений у данного конкретного пациента - крайне сложная задача, так как организм есть единое взаимосвязанное целое, и стоит в его деятельности измениться чему-либо одному, как в той или иной степени изменяется функция и всего остального. И что первично в этих нарушениях, и что является их следствием - все это можно диагностировать только методами современной медицины, что 


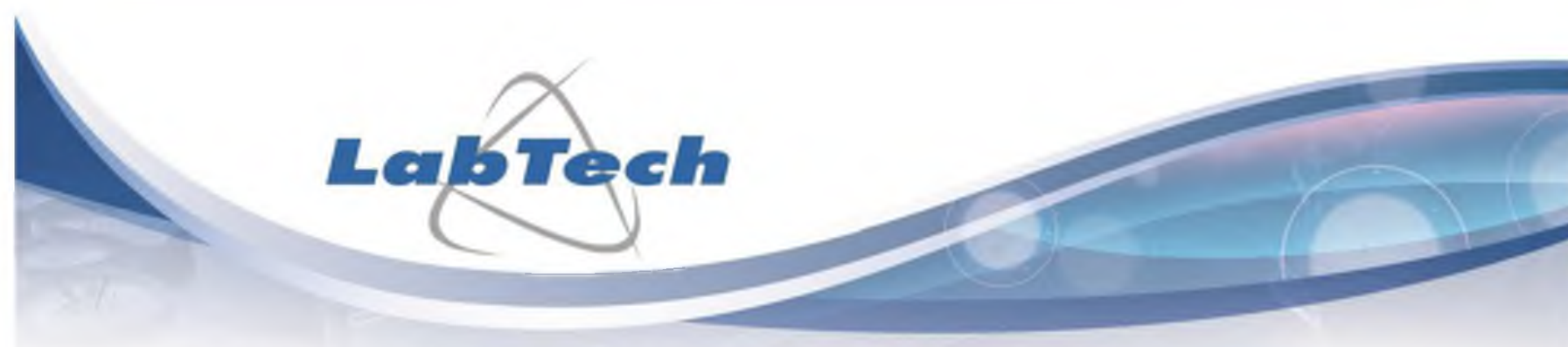

ОФИЦИАЛЬНЫЙ ДИСТРИБЬЮТОР KOMПАНИИ ВECKMAN COULTER INT. S.A.

$\rightleftharpoons$ Биохимические анализаторы

$\rightleftharpoons$ Гематологические анализаторы

$\rightleftharpoons$ Иммунохимические анализаторы

$\curvearrowright$ Микробиологические анализаторы

$\approx$ Анализаторы мочи

П Проточные цитофлуориметры

¿ Центрифуги

Лабораторные роботы

\section{BECKMAN} COULTER

IL Werfen

I

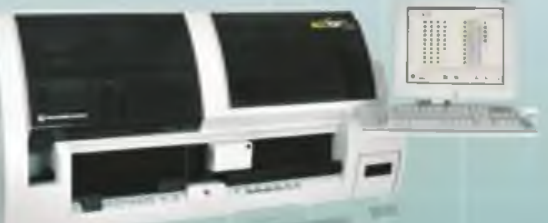

ОФИЦИАЛЬНЫЙ ДИСТРИБЬЮТОР КОМПАНИИ INSTRUMENTATION LABORATORY

$\approx$ Анализаторы газов крови и электролитов $\rightleftharpoons$ Анализаторы для исследования системы гемостаза $\approx$ Реагенты для коагулометрии

\section{ОФИЦИАЛЬНЫЙ ДИСТРИБЬЮТОР КОМПАНИИ SARSTEDT}

\section{SARSTEDT}

$\rightleftharpoons$ Системы взятия венозной крови S-Monovette

$\approx$ Системы взятия капиллярной крови Microvette

$\approx$ Контейнеры для биологических образцов

$\curvearrowright$ Пробирки

$\rightleftharpoons$ Расходные материалы для бактериологии, ПЦР-диагностики, культивирования клеток,

$\rightleftharpoons$ Наконечники для автоматических пипеток

\section{0 «ЛабТэк»}

191186, г. Санкт-Петербург, а/я 238 Тел.: (812) 313-0203, факс: (812) 313-0204 www.labtech.su / labtech@labtech.su 
требует не только должной квалификации лечащего врача, но и наличия в его распоряжении соответствующей очень широкой диагностической базы как лабораторной, так и инструментальной. При этом огромное значение имеет не только объем проведенных исследований, но и их достоверность, так как именно достоверные результаты диагностических исследований являются основанием для успешного лечения.

\section{Лабораторные и инструментальные исследования иммунной системы.}

Общепринято считать, что для диагностики иммунных нарушений необходимы специальные иммунологические исследования. Это отчасти верно. Хотя и другие лабораторные исследования дают значимую информацию о работе иммунной системы и причинах ее неадекватной работы.

Прежде всего, основным лабораторным тестом для оценки иммунитета является клинический анализ крови с оценкой количественных и качественных характеристик всех классов форменных элементов и определение скорости оседания эритроцитов.

Повышение количества лейкоцитов (лейкоцитоз) характерно для воспалительных процессов в том числе, связанных с онкологическими заболеваниями, при вирусных и бактериальных инфекциях, интоксикациях, инфаркте внутренних органов, гемобластозах. При инфекциях (брюшной тиф и паратифы, бруцеллёз, туберкулёз, грипп, корь, ветряная оспа, вирусный гепатит, краснуха, малярия, сыпной тиф), приёме лекарственных средств (антибиотики, цитостатики, нестероидные противовоспалительные средства, тиреостатики и др.), аутоиммунных заболеваниях, после воздействия ионизирующего излучения, при истощении и кахексии, анемиях различного генеза, спленомегалии, алейкемических вариантах гемобластозов - определяется снижение количества лейкоцитов (лейкопения).

По своему составу лейкоциты не однородны, различные популяции лейкоцитов выполняют разные функции. $\mathrm{K}$ клеткам врожденного иммунитета следует отнести нейтрофилы, эозинофилы, базофилы и моноциты. Основная часть лимфоцитов относится к клеткам адаптивного иммунитета.

Наибольшую популяцию лейкоцитов составляют нейтрофилы. Основная их функция - распознавание, захват, уничтожение бактерий и продуктов распада, получаемых в процессе адаптивного иммунитета. Традиционно считаясь индукторами воспалительной реакции, нейтрофилы способны параллельно включать механизмы, влияющие на ограничение и разрешение воспаления. Установлено, что нейтрофилы продуцируют цитокины, принадлежащие к самым различным семействам, включая иммунорегуляторные, провоспалительные, противовоспалительные цитокины семейства фактора некроза опухоли (TNF), хемокины, ангиогенные и фиброгенные факторы.

Средняя продолжительность жизни нейтрофила - 4-5 суток. При выходе из костного мозга в кровеносное русло нейтрофилы, прилипают к эндотелию кровеносного сосуда (пристеночный пул), затем в течение 8-10 часов, поступают в периферические ткани.

При контакте с инфекционным агентом, стрессе, физических нагрузках и др. число нейтрофилов в крови может резко увеличится в течение нескольких часов. Это происходит за счёт мобилизации пристеночного пула и ускорения выхода нейтрофилов из костного мозга. Нейтрофилией (нейтрофильным лейкоцитозом) считают повышение количества нейтрофилов более 7,0*10\%. Для правильной интерпретации гемограммы необходимо учитывать региональные нормы, т.к. нормальные диапазоны анализа крови могут варьироваться от лаборатории к лаборатории.

Выделяют шесть видов нейтрофильного лейкоцитоза:

1. без ядерного сдвига - увеличение количества зрелых сегментоядерных нейтрофилов на фоне общего лейкоцитоза;

2. с гипорегенеративным ядерным сдвигом влево - увеличение содержания палочкоядерных форм нейтрофилов (свыше $5 \%$ ) на фоне абсолютной нейтрофилии (характерно для легкого течения инфекций и воспалений). Указывает на незначительное снижение реактивности организма. 
3. с регенеративным ядерным сдвигом влево - на фоне нейтрофилии и увеличенного содержания палочкоядерных форм появляются метамиелоциты (более 1\%); (характерно для гнойно-септических процессов, является критерием остроты процесса, указывает на высокий уровень резистентности организма);

4. с гиперрегенеративным ядерным сдвигом влево - появление в гемограмме миелоцитов и промиелоцитов при значительно выраженном лейкоцитозе, эозинофилы часто вообще отсутствуют (анэозинофилия). Подобная картина является тревожным прогностическим признаком, указывающим на неблагоприятное течение инфекционных и гнойно-септических заболеваний.

Иногда в крови могут обнаруживаться нормальные (а не опухолевые) миелобласты, а суммарное количество лейкоцитов может быть выше 50*10\%. Такое гиперактивное состояние опасно последующим истощением костного мозга и развитием костномозговой недостаточности.

5. с дегенеративным ядерным сдвигом влево - повышение содержания палочкоядерных нейтрофилов сопровождается появлением значительного числа деструктивно измененных сегментоядерных форм (пикноз ядер, токсогенная зернистость и вакуолизация цитоплазмы и т. д.). Дегенеративный ядерный сдвиг влево является показателем угнетения функциональной активности костного мозга и может иметь место при тяжелом течении инфекционных заболеваний, при эндогенной интоксикации и т. д.;

6. с дегенеративным ядерным сдвигом вправо - характеризуется появлением в гемограмме гиперсегментированных (свыше 5 сегментов) нейтрофилов, значительным снижением или полным отсутствием палочкоядерных форм, что указывает на первичное подавление миелопоэза (наблюдается при лучевой болезни, некоторых видах анемий). Иногда может обнаруживаться и у практически здоровых людей.

Слишком высокое повышение уровня лейкоцитов может быть следствием онкогематологического заболевания - острого или хронического лейкоза. При этом в мазке крови находят морфологически измененные клетки, а также незрелые формы лейкоцитов (бласты), которые в норме не должны выходить в периферическую кровь.

Нейтропения - характеризуется аномально низким уровнем нейтрофилов (ниже $\left.2,0 * 10^{9} / л\right)$. Снижение количества нейтрофилов менее $0,5^{*} 10^{9} / л$ ведет к серьезным расстройствам иммунитета. Степень тяжести определяется количеством клеток:

- Легкая степень тяжести нейтропении $-1,0-1,5 * 10^{9} / л$

- Умеренная степень тяжести нейтропении - 0,5-1,0*109/л

- Тяжелая степень тяжести нейтропении - менее $0,5 * 10^{9} / л$

Эозинофилы. Как и нейтрофилы, способны к фагоцитозу бактерий, однако, основная их роль - борьба с паразитами и контроль аллергических реакций. В циркулирующей крови находятся от 30 минут до нескольких часов, после чего поступают в ткани.

Эозинофилией считается повышение их абсолютного количества более $0,5 * 10^{9} /$ л. Эозинофилия подразделяется на легкую $\left(0,5-1,5 * 10^{9} / \pi\right)$, умеренную (от 1,5 до $5,0 * 109 /$ л) или тяжелую (более 5,0*109/л). В том случае, когда абсолютное количество эозинофилов сохраняется высоким на протяжении длительного времени, возможно возникновение поражения внутренних органов, вызванное эозинофильной инфильтрацией и воздействием токсических продуктов кислорода и гранулярных белков.

Снижение количества эозинофилов (ниже $0,01 * 10^{9} /$ л или менее $0,5 \%$ для относительного содержания вплоть до полного исчезновения) может быть признаком заболеваний различной природы и разной степени тяжести (начала воспалительного процесса, тяжелой гнойной инфекции, шока, отравления тяжёлыми металлами, интоксикаций).

Базофилы. основная их функция - выброс гистамина и других медиаторов в аллергических реакциях различного типа. Базофилией считается увеличение их количества более $0,2 * 10^{9} /$ л. Повышение базофилов в крови может быть физиологическим явлением или сопутствующим признаком некоторых заболеваний. Базофилия наблюдается при аллергиях, в том числе лекарственных, некоторых инфекциях (грипп, ветряная оспа, туберкулёз) язвенном 
колите, при злокачественных новообразованиях, определенных онкогематологических заболеваниях и анемиях. Базопению (уменьшение базофилов) очень трудно заметить, поскольку это самая низкая по количеству популяция циркулирующих лейкоцитов. Отсутствие базофилов может быть связано с тяжелой аллергической реакцией.

Моноциты. Предшественники макрофагов и дендритных клеток. Являются частью врожденного иммунного ответа, выполняют функции, сходные с функциями гранулоцитов, а именно - распознавание, захват и уничтожение бактерий и грибов, однако помимо фагоцитарной активности они перерабатывают патогены и презентируют их клеткам адаптивного иммунитета. Из кровотока моноциты в течении суток переходят в ткани, где дифференцируют в тканеспецифичные макрофаги. Макрофаги фагоцитируют погибшие лейкоциты, повреждённые клетки, очищая очаг воспаления, регулируют процессы регенерации. Время жизни этих клеток может достигать нескольких лет.

Моноцитоз - увеличение абсолютного количества моноцитов более $1,0 * 10^{9} /$ л. Моноцитоз отмечается при злокачественных новообразованиях, острых и хронических инфекционно-воспалительных процессах, состоянии после перенесённого инфекционного заболевания, аутоиммунных заболеваниях. Индикатором раннего сепсиса является ширина распределения моноцитов (MDW). Использование Early Sepsis Indicator с показателем MDW более 20,0 U, позволяет эффективно диагностировать сепсис (рис. 55).

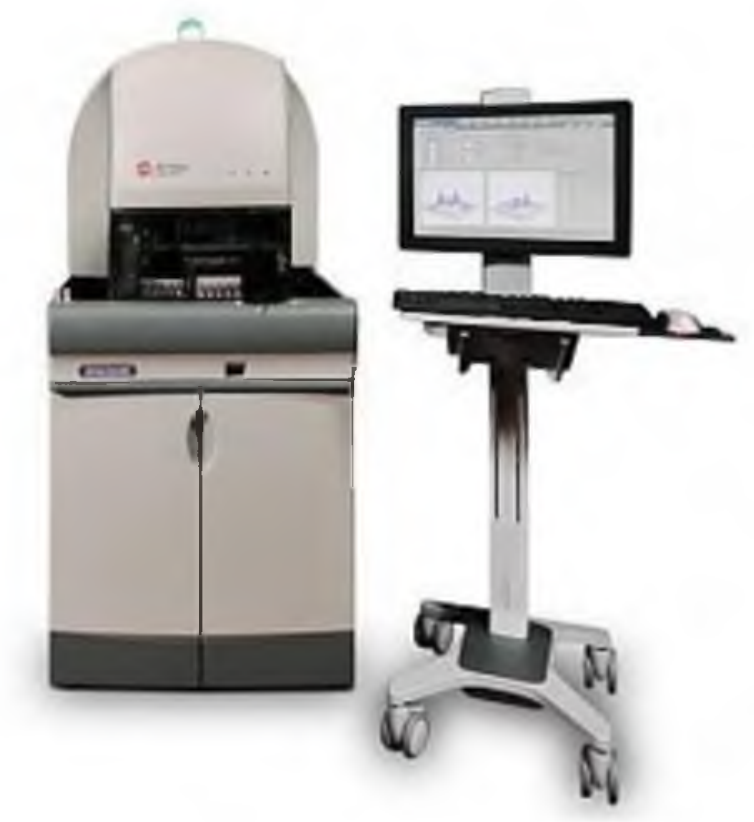

\section{Рис.55 Гематологический анализатор UniCell DxH 800 (Beckman Coulter) использующий систему раннего обнаружения сепсиса.}

Наибольшим разнообразием отличаются лимфоциты. Основные клетки адаптивного иммунитета, которые за счет экспрессии на поверхности уникальных антигенных рецепторов распознают различные антигены. В дальнейшем в зависимости от типа клетки они формируют гуморальный иммунитет (за счет синтеза антител различных классов) или клеточный иммунитет (формирования пула цитотоксических лимфоцитов). Часть лимфоцитов является клетками памяти, которые сохраняют информацию о ранее встречавшемся антигене. Они быстро пролиферируют и продуцируют большие количества антител при повторной встрече с известным антигеном. Лимфоциты обладают способностью синтезировать и секретировать в кровь различные белковые регуляторы - цитокины, посредством которых осуществляют координацию и регуляцию иммунного ответа. Часть лимфоцитов (NK- и NKT-клетки) обеспечивают противоопухолевый врожденный иммунитет. 
Лимфоцитозом считается повышение абсолютного количества лимфоцитов более $5,0 * 10 \%$ л, лимфопенией снижение лимфоцитов менее $1,0 * 10 \%$ л.

Единичные морфологически измененные лимфоциты (атипичные мононуклеары), встречающиеся в мазке крови, не имеют диагностического значения. В значительном количестве атипичные мононуклеары появляются в крови пациентов с инфекционным мононуклеозом, ассоциированным с вирусом Эпштейна-Барра (EBV), но могут обнаруживаться и при других вирусных заболеваниях. К патологии можно отнести и появление в переферической крови плазматических клеток (антителообразующие клетки, которые должны находятся в лимфатических узлах и селезёнке).

Анализируя данные клинического анализа крови возможно определить тип и характер иммунного ответа. Тип реакции иммунной системы рассчитывается из соотношения абсолютного количества гранулоцитов и лимфоцитов и характеризует состояние врожденного и адаптивного иммунитета (табл. 27).

Таблица 27

Определение типа реакции иммунитета по развернутому анализу крови

\begin{tabular}{|c|c|c|c|c|}
\hline \multirow{2}{*}{\multicolumn{2}{|c|}{ Показатели }} & \multicolumn{3}{|c|}{ Лимфоциты, абс. } \\
\hline & & понижены & норма & повышены \\
\hline \multirow{3}{*}{ 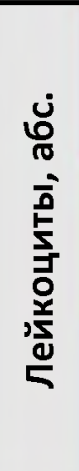 } & повышены & $\begin{array}{c}\text { Активация } \\
\text { врожденного } \\
\text { иммунитета }\end{array}$ & $\begin{array}{c}\text { Активация } \\
\text { врожденного } \\
\text { иммунитета }\end{array}$ & $\begin{array}{c}\text { Активация } \\
\text { адаптивного } \\
\text { иммунитета }\end{array}$ \\
\hline & норма & $\begin{array}{c}\text { Угнетение } \\
\text { иммунитета }\end{array}$ & $\begin{array}{c}\text { Ареактивность } \\
\text { иммунитета }\end{array}$ & $\begin{array}{c}\text { Активация } \\
\text { адаптивного } \\
\text { иммунитета }\end{array}$ \\
\hline & понижены & $\begin{array}{c}\text { Угнетение } \\
\text { иммунитета }\end{array}$ & $\begin{array}{c}\text { Угнетение } \\
\text { иммунитета }\end{array}$ & $\begin{array}{c}\text { Активация } \\
\text { адаптивного } \\
\text { иммунитета }\end{array}$ \\
\hline
\end{tabular}

Определение типа реакции рассчитывается из соотношения процентного и абсолютного количества лимфоцитов в крови пациента и характеризует механизм реакции костного мозга, формирующий соответствующее состояние иммунной системы (табл. 28).

Таблица 28

Характер реакции иммунитета по развернутому анализу крови

\begin{tabular}{|c|c|c|c|c|}
\hline \multirow{2}{*}{\multicolumn{2}{|c|}{ Показатели }} & \multicolumn{3}{|c|}{ Лимфоциты, \%. } \\
\hline & & понижены & норма & повышены \\
\hline \multirow{3}{*}{ 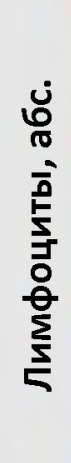 } & повышены & $\begin{array}{c}\text { Ассиметричная } \\
\text { стимуляцией } \\
\text { лейкопоэза }\end{array}$ & $\begin{array}{c}\text { Активация } \\
\text { лимфопоэза }\end{array}$ & Активация лимфопоэза \\
\hline & норма & $\begin{array}{c}\text { Ассиметричная } \\
\text { стимуляцией } \\
\text { лейкопоэза }\end{array}$ & Нормореакция & $\begin{array}{c}\text { Недостаточная } \\
\text { активация лимфопоэза }\end{array}$ \\
\hline & понижены & $\begin{array}{c}\text { Декомпенсированный } \\
\text { лейкопоэз }\end{array}$ & $\begin{array}{c}\text { Недостаточная } \\
\text { активация } \\
\text { лимфопоэза }\end{array}$ & $\begin{array}{c}\text { Недостаточная } \\
\text { активация лимфопоэза }\end{array}$ \\
\hline
\end{tabular}


Выделенные иммунотипы позволяют в дальнейшем определить тактику иммунологических исследований, в том числе используя методы проточной цитометрии проводить топическую диагностику нарушений в отдельных звеньях иммунной системы.

Помимо данных лейкоцитарной формулы важным является определение концентрации гемоглобина, количества эритроцитов, величины гематокрита и эритроцитарных индексов (MCV, RDW, MCH, MCHC).

Снижение количества эритроцитов в единице объёма, гемоглобина и гематокрита свидетельствует об анемии (различной этиологии) или гипергидратации. Повышение - об обезвоживании (при выраженной диарее, рвоте, повышенном потоотделении, диабете, ожоговой болезни, перитоните), недостаточности дыхательной и сердечно-сосудистой системы, поликистозе почек, эритремии.

Понижение значений MCV (средний объём эритроцитов), МСН (среднее количества гемоглобина в 1 эритроците), МСНС (средняя концентрация гемоглобина в эритроцитах) характерно для железодефицитной анемии, анемии хронических заболеваний, некоторых видах гемоглобинопатий. Повышение значений MCV при В12-дефицитной и фолиеводефицитной анемии, апластической анемии, заболеваниях печени, гипотиреозе, аутоиммунной анемии.

Повышение значений RDW (Red cell Distribution Width, распределение эритроцитов по величине) связано с анемиями миелодиспластического, мегалобластного и сидеробластного типов, вследствие успешного лечения анемии, состояних после переливания эритроцитарной массы, холодовых аллергиях, хронических лимфолейкемиях, гипергликемии. При анемия хронических заболеваний, анемия вследствие острой кровопотери, апластической анемии, генетически обусловленных заболеваниях (талассемия, наследственные мембранопатии, наличие гемоглобина E) не характерно увеличение RDW

Тромбоциты - фрагменты мегакариоцитов, которые функционируют в системе свертывания крови. Тромбоциты циркулируют от 7 до 12 суток. Около одной трети всегда временно удерживаются в селезенке. Количество тромбоцитов, как правило, от $140 * 10^{9} / л$ до $440 * 10^{9}$ л. Низкая концентрация тромбоцитов (тромбоцитопения) возникает из-за снижения образования (недостаточности синтеза тромбопоэтина) или увеличения разрушения. Повышенная концентрация тромбоцитов (тромбоцитоз) может быть врожденной, реактивной (увеличиваться под воздействием воспалительных цитокинов), либо обусловлена нерегулируемым производством (при некоторых миелопролиферативных новообразованиях).

Традиционно для диагностики воспалительных состояний и мониторинга их течения определяется неспецифический показатель, отражающий изменения белкового состава плазмы крови - скорость оседания эритроцитов (СОЭ). При появлении в плазме крови большого количества белков острой фазы воспаления (фибриноген, С-реактивный белок, орозомукоид, альфа 1-антитрипсин, церулоплазмин и гаптоглобин) сила отталкивания между эритроцитами снижается, и эритроциты оседают быстрее. При острых воспалительных и инфекционных процессах ус $\neg$ корение СОЭ наступает через 24 часа или через несколько дней (2-4 дня), в период развертывания клинической картины заболевания, после повышения температуры и увеличения числа лейкоцитов. Нормализация этого показателя после выздоровления происходит медленнее, и может занять от нескольких дней до двух, и более, недель.

При анемии СОЭ повышается в соответствии с уменьшением числа эритроцитов и гематокрита. Некоторые морфологические варианты эритроцитов также могут оказывать влияние на СОЭ: анизоцитоз, сфероцитоз и дрепаноцитоз ингибируют агрегацию эритроцитов; макроциты имеют заряд, соответствующий их массе, и оседают быстрее.

Не маловажными являются биохимические исследования, определяющие различные компоненты иммунной системы.

При количественном определение фракций общего белка крови выделяют 6 стандартных фракций: 1 - альбумины 2 - альфа1-глобулины, 3 - альфа2-глобулины, 4 - бета1глобулины 5 - бета-2 глобулины 6 - гамма-глобулины. 
Альфа1-глобулины - это белки острой фазы воспаления: альфа1-антитрипсин основной компонент этой фракции (ингибитор многих протеолитических ферментов трипсина, химотрипсина, плазмина и т. д.), а также альфа1-кислый гликопротеин (орозомукоид). Альфа2-глобулины - альфа2-макроглобулин, гаптоглобин, церулоплазмин (острофазные белки участвующие в развитии инфекционных и воспалительных реакций). Бета-глобулины состоят из трансферрина, гемопексина, компонентов комплемента.

Гамма-глобулины - это иммуноглобулины (IgG, $\operatorname{IgA}, \operatorname{IgM}$, $\mathrm{IgE}), \quad$ представляющие собой антитела, которые обеспечивающие адаптивное гуморальное звено иммунитета.

Изменения отдельных фракций белков сыворотки крови зависят от многих причин (наследственных, острых или хронических заболеваний). Например, при миеломной болезни на электрофореграмме выявляются дополнительные фракции парапротеинов (моноклонального или М-белка), концентрация которого может быть более 15 г/л.

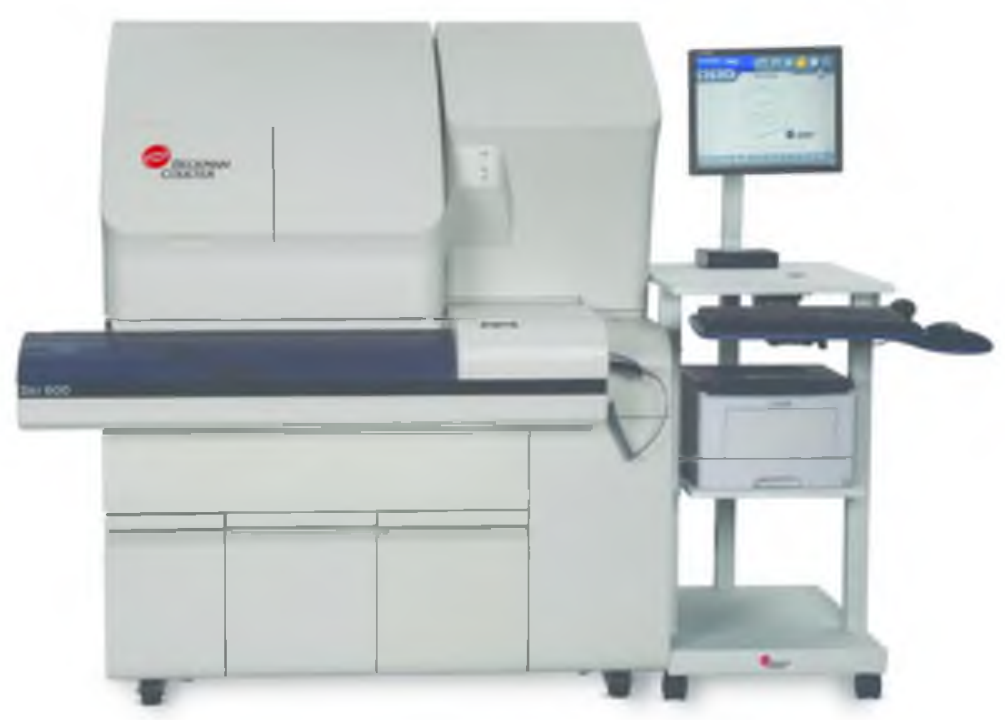

Самым быстрым и чувствительным индикатором повреждения тканей при новообразовании, воспалении, некрозе, травме является белок острой фазы С-реактивный белок (СРБ), который стимулирует фагоцитоз, активирует классическую систему комплемента, участвует во взаимодействии Т- и В-лимфоцитов.

Синтезируется преимущественно в гепатоцитах, за счет индукции антигенами, иммунными комплексами, бактериями, грибами, при некрозе тканей. При этом концентрация СРБ в плазме возрастает очень быстро (в первые 4-8 часов после повреждения) и весьма значительно (в 20-100 раз, а иногда и в 1000 раз). Величина СРБ (нормальная концентрация в плазме здорового человека - 1,0 мг/л) высоко коррелирует с активностью заболевания и стадией процесса. При бактериальной инфекции наблюдаются самые высокие уровни СРБ (100 мг/л и выше). При эффективной терапии уровень СРБ снижается уже на следующий день, если нет - необходимо более эффективное антибактериальное лечение. Это позволяет использовать мониторинг СРБ для наблюдения за течением болезни и контролем адекватности терапии.

При вирусной инфекции уровень СРБ повышается незначительно (меньше 20 мг/л), что позволяет отличить вирусные инфекции от бактериальных. Но при нейтропении у взрослого пациента уровень СРБ более 10 мг/л может быть единственным объективным указанием на бактериальную инфекцию.

При злокачественных опухолях возможны различные изменения уровней СРБ, так как их интенсивность зависит от присоединения инфекции, некроза тканей, нарушения функций органов из-за непроходимости респираторных путей или желудочно-кишечного тракта, влияния иммуносупрессии и химиотерапии. Некрозы тканей (инфаркт миокарда, опухолевый некроз тканей почки, легких, толстого кишечника) вызывают такой же сильный острофазный ответ, как и бактериальная инфекция. Если при высоком уровне СРБ нет явных признаков воспаления, больного следует обследовать на онкозаболевания.

Определение других белков острой фазы количество которых увеличивается (фибриноген, сывороточный амилоид А и Р, эозинофильный катионный белок) или 
уменьшается (преальбумин, альбумин, трансферин) при воспалении в клинической практике применяется реже.

На состояния иммунной системы большое влияние оказывают нарушения обменных процессов и/или функции отдельных органов и систем.

Важным являются для диагностики белкового обмена общий уровень белка и альбумина. Снижение их количества менее 60 г/л и 30 г/л соответственно свидетельствуют о белковой недостаточности. Это можно расценивать как причину иммунных нарушений.

О нарушении углеводного обмена будет свидетельствовать повышение/понижение уровня глюкозы (гипергликемия более 6 ммоль/л, гипогликемия менее 4 ммоль/л). Глюкоза основной субстрат энергетического обмена человека. В опухолевых клетках идет активное потребление глюкозы за счет гликолиза с последующим образованием лактата. Лактоацидоз (значение лактата более 2,2 ммоль/л) основная причина слабости и утомления.

По рекомендациям ВО3 тестом для выявления нарушений углеводного обмена является определение гликированного гемоглобина. Показатель $\geq 6.5 \%$ - критерий сахарного диабета, $<6 \%$ - отсутствие нарушений углеводного обмена.

На нарушение липидного обмена будет указывать увеличение или снижение уровня холестерина (норма от 3 до 5,2 ммоль/л).

На недостаточность функции печени будет указывать уровень билирубина более 30 ммоль/л, АлАТ - более 35 Ед/л. На недостаточность функция почек - повышенная альбуминурия (стойкое повышение экскреции альбумина с мочой $>30$ мг/сут.) или отношение альбумина к креатинину мочи $>30$ мг/г.

На нарушение системы регуляции агрегатного состояния крови указывают изменения показателей содержания плазменных факторов и тромбоцитов более чем на 20\% от границ физиологической нормы. Повышение уровня ЛДГ наблюдается при любых заболеваниях, сопровождающихся повреждением тканей и разрушением клеток. В связи с этим она является важным маркером тканевой деструкции. Несмотря на то, что увеличение активности фермента не указывает на какую-то определенную болезнь, определение активности его изоферментов в комплексе с другими лабораторными анализами помогает в диагностике локализации повреждения.

Лактацидоз (повышение значений лактата - продукта анаэробного метаболизма глюкозы (гликолиза) у онкологических больных проявление метаболических нарушениях с развитием ацидоза и эндотоксикоза.

Одними из важнейших и простых методов диагностики являются микроскопические и цитологические исследования.

Микроскопическое исследование соскобов кожи, ногтевых пластинок, волосяных фолликулов используется для диагностики поверхностных микозов кожи, ее придатков и демодекоза. Выявление спор и мицелия дерматофитов, плесневых грибов (Scopulariopsis brevicaulis, Penicillium spp. и др.) или псевдомицелия дрожжеподобных грибов рода Candida и их сочетаний с очагов поражения ногтевых пластинок является подтверждением онихомикоза. Наличии в препарате клещей, личинок, яиц, пустых яйцевых оболочек клеща рода Demodex позволяют определить причину фолликулитов и акне. Исследование отделяемого мочеполовых органов позволяет оценить состояние эпителия, качественный состав микрофлоры (морфотипы), дать полуколичественную оценку общей микробной обсемененности, выявить воспаление, поставить диагноз кандидоза, трихомониаза и гонореи.

Цитологическое исследование позволяет оценить структуру клеток в материале, полученном различными способами из патологического очага с целью установления диагноза доброкачественной или злокачественной опухоли и неопухолевых поражений. Так, цитологическое исследование мазков с шейки матки является высокоэффективным скринигтестом по раку этой локализации, при этом значительно увеличивается относительная частота обнаружения рака в ранних и доклинических стадиях. 
Цитологическое исследование мокроты или отделяемого из носа (риноцитограмма) позволяет оценить качественный и количественный состав клеток, характерных для аллергических, инфекционных заболеваниях, злокачественных опухолей.

Оценка степени выраженности лейкоцитарной реакции, проявление фагоцитоза, его завершенность позволяет оценить степень тяжести воспаления. Так, например, незавершенный фагоцитоз позволяет определить недостаточность фагоцитарного звена иммунитета (рис. 55).

Для видовой идентификации микроорганизмов, определения чувствительности к лекарственным препаратам необходимо культуральное исследование.

Большое значение для здоровья человека принадлежит нормальной микробиоте (табл.29). Микробиота - устойчивое сообщество микроорганизмов, обитающих на определённом участке организма хозяина.

\section{Состав биотопов}

\begin{tabular}{|c|c|}
\hline Органы и ткани & Основные микроорганизмы \\
\hline Кожа & $\begin{array}{l}\text { Actinobacteria }(51.8 \%) \text {, Firmicutes (24.4\%), Proteobacteria (16.5\%), } \\
\text { Bacteroidetes }(6.3 \%) \text {, грибы. }\end{array}$ \\
\hline $\begin{array}{l}\text { Слизистая } \\
\text { оболочка глаз }\end{array}$ & $\begin{array}{l}\text { Грамположительные кокки (Staphylococcus и Streptococcus), } \\
\text { грамотрицатльные палочки и кокки (Haemophilus and Neisseria) и грибки } \\
\text { (Candida, Aspergillus, and Penicillium) }\end{array}$ \\
\hline $\begin{array}{l}\text { Респираторный } \\
\text { тракт }\end{array}$ & $\begin{array}{l}\text { Hoc - S. aureus, S. ерidermidis, непатогенные нейссерии,коринебактерии. } \\
\text { Небные миндалины - S.pyogenes), S.pneumoniae, H.influenzae, } \\
\text { неспорообразующие анаэробы. } \\
\text { Легкие - Prevotella, Sphingomonas, Pseudomonas, Acinetobacter, Fusobacterium, } \\
\text { Megasphaera, Veillonella, Staphylococcus, и Streptococcus. Грибы: Candida, } \\
\text { Malassezia, Neosartorya, Saccharomyces, Aspergillus }\end{array}$ \\
\hline $\begin{array}{l}\text { Урогенетильный } \\
\text { тракт }\end{array}$ & 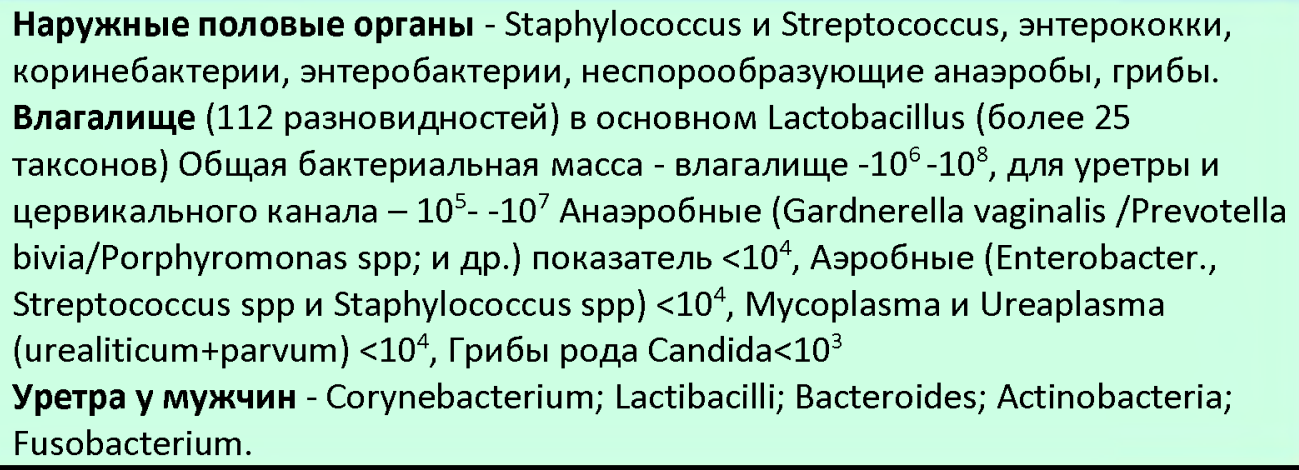 \\
\hline $\begin{array}{l}\text { Пищеварительный } \\
\text { тракт }\end{array}$ & $\begin{array}{l}\text { Полость рта (более } 275 \text { разновидностей) - Анаэробные бактерии } \\
\text { Actinomyces, Arachnia, Bacteroides, Bifidobacterium и др, Lactobacillus, } \\
\text { Leptotrichia, Peptococcus, Peptostreptococcus. Грибы. } \\
\text { Желудок и 12-перстная кишка } 10^{3} \text { KOE /мл. - Firmicutes, Actinobacteria, } \\
\text { Bacteroidetes, Proteobacteria, Fusobacteria } \\
\text { Тонкий кишечник } 10^{4}-10^{8} \mathrm{KOE} / \text { мл - Firmicutes, Actinobacteria, Bacteroidetes } \\
\left.\text { Толстый кишечник } 10^{9}-10^{13} \mathrm{KOE} / \text { мл. - Firmicutes (грам+) (болеe } 50 \%\right) \text {, } \\
\text { Bacteroidetes (30\%), Proteobacteria (грам-)(3\%), Actinobacteria (грам+)(болеe } 1 \\
\%), \text { Verrucomicrobia, Fusobacteria }\end{array}$ \\
\hline
\end{tabular}


На определении специфических антигенов и антител микроорганизмов основана диагностика инфекционных заболеваний. Наличие той или иной инфекции свидетельствует о нарушении функции иммунитета, при этом некоторые инфекции патогномоничны для нарушения того или иного звена иммунитета (табл.30).

Таблица 30.

\section{Сочетание инфекции с поражением звена иммунитета}

\begin{tabular}{|c|c|c|}
\hline Звено иммунитета & Основные возбудители инфекций & Основные причины \\
\hline $\begin{array}{l}\text { Недостаточность } \\
\text { гуморального } \\
\text { звена иммунитета }\end{array}$ & $\begin{array}{l}\text { Пневмококк } \\
\text { Hemophilus influenzae } \\
\text { Pneumocystis jirovecii } \\
\text { Giardia intestinalis } \\
\text { Cryptosporidium parvum }\end{array}$ & $\begin{array}{l}\text { Первичный В-клеточный } \\
\text { иммунодефицит } \\
\text { Множественная миелома } \\
\text { Хронический лимфолейкоз } \\
\text { СпиД }\end{array}$ \\
\hline $\begin{array}{l}\text { Недостаточность } \\
\text { клеточного звена } \\
\text { иммунитета }\end{array}$ & $\begin{array}{l}\text { Внутриклеточные возбудители, включая } \\
\text { вирус простого герпеса, микобактерии, } \\
\text { Listeria и внутриклеточных грибковых } \\
\text { инфекций }\end{array}$ & $\begin{array}{l}\text { Первичный Т-клеточный } \\
\text { иммунодефицит } \\
\text { Трансплантация костного мозга и } \\
\text { другая трансплантация } \\
\text { СПИД } \\
\text { Химиотерапия рака } \\
\text { Лимфома } \\
\text { Глюкокортикоидная терапия } \\
\end{array}$ \\
\hline $\begin{array}{l}\text { Дефицит } \\
\text { гранулоцитов }\end{array}$ & $\begin{array}{l}\text { Enterobacteriaceae } \\
\text { Устные стрептококки } \\
\text { Pseudomonas aeruginosa } \\
\text { Виды энтерококков } \\
\text { Грибы Candida, Aspergillus } \\
\end{array}$ & $\begin{array}{l}\text { Химиотерапия } \\
\text { Трансплантация костного мозга } \\
\text { Дисфункция, такая как хроническая } \\
\text { гранулематозная болезнь }\end{array}$ \\
\hline $\begin{array}{l}\text { Дефицит } \\
\text { комплемента }\end{array}$ & $\begin{array}{l}\text { Виды Neisseria } \\
\text { Пневмококк }\end{array}$ & Врожденные недостатки \\
\hline Аспления & $\begin{array}{l}\text { Бактерии , инкапсулированные в } \\
\text { полисахариды, в частности: Streptococcus } \\
\text { pneumoniae, Haemophilus influenzae, } \\
\text { Neisseria meningitidis, плазмодии } \\
\end{array}$ & $\begin{array}{l}\text { Спленэктомия } \\
\text { Травма } \\
\text { Серповидноклеточная анемия }\end{array}$ \\
\hline
\end{tabular}

Особо важное значение имеют эти исследования при инфекциях, повреждающие иммунную систему - ВИЧ, ВЭБ, герпесвирус человека 8 тип, онкогенных вирусах - вирус гепатита $\mathrm{B}$, вирус гепатита $\mathrm{C}$, вирус гепатита $\mathrm{D}$, папилломовирусов (табл. 31 ).

Таблица 31.

\section{Папилломовирусная инфекция}

\begin{tabular}{|l|l|l|}
\hline \multicolumn{1}{|c|}{ Группа } & \multicolumn{1}{|c|}{ типы } & \multicolumn{1}{c|}{ Заболевания } \\
\hline $\begin{array}{l}\text { Неонкогенные } \\
\text { папилломавирусы }\end{array}$ & $1,2,3,4,7,10,28,41$ & $\begin{array}{l}\text { подошвенные бородавки, плоские бородавки, } \\
\text { вульгарные бородавки. }\end{array}$ \\
\hline $\begin{array}{l}\text { Онкогенные } \\
\text { папилломавирусы } \\
\text { низкого риска }\end{array}$ & $\begin{array}{l}\text { 1,6,8,11,12,14,15, } \\
43,44\end{array}$ & $\begin{array}{l}\text { аногенитальные бородавки } \\
\text { ларингеальный папилломатоз } \\
\text { бородавчатую эпидермоплазию. }\end{array}$ \\
\hline $\begin{array}{l}\text { Онкогенные } \\
\text { папилломавирусы } \\
\text { высокого риска }\end{array}$ & $\begin{array}{l}16,18,31,33,35,39,45,51,52,24,25,42, \\
56,58,59 \text { и 68 }\end{array}$ & $\begin{array}{l}\text { бовеноидный папуллез } \\
\text { интраэпителиальная неоплазия шейки матки. }\end{array}$ \\
\hline
\end{tabular}


Выявление различных антигенов важно для ранней диагностики рака, который можно диагностировать уже в стадии равновесия (табл.32) совместно с другими лабораторными и инструментальными исследованиями.

Таблица 32.

\section{Опухолевые маркеры}

\begin{tabular}{|c|c|}
\hline Тип рака & Онкомаркеры \\
\hline Рак яичников & CA 125, остеопонтин, РЭА, SMRP, HE4, Ингибин В \\
\hline Рак шейки матки & SCCA, РЭА, цитокератины (CYFRA-21.1, TPS) \\
\hline \multirow{4}{*}{ Рак легкого } & Аденокарцинома - CYFRA-21.1, CEA, CA 125, TPA, TPS, TU M2-PK \\
\hline & Плоскоклеточный - SCCA, CYFRA-21.1, CEA, CA 125, TPA, TPS, TU M2-PK \\
\hline & Крупноклеточная карцинома - CYFRA-21.1, CEA, CA 125, TPA, TPS, TU M2-PK \\
\hline & Мелкоклеточный - NSE и ProGRP, CA 125, TPA, TPS, TU M2-PK \\
\hline Рак молочной железы & uPA, PAI-1, CA15-3, PЭA, TPA, TPS, HER-2 \\
\hline Рак печени & АФП, ферритин, \\
\hline Рак желудка & CA19.9, СА 72,4, СЕА,, РЭА, цитокератины \\
\hline Меланома & S-100, VEGF, bFGF, CD44 \\
\hline Колоректальный рак & TIMP, CA242, PЭA, CA19-9 \\
\hline Рак мочевого пузыря & UPC, NMP22, BTA, TRAP, цитокератины \\
\hline Опухоли яичника & АФП, ХГЧ, ЛДГ, ПЩР, NSE \\
\hline Рак простаты & свободный и связанный ПСА \\
\hline $\begin{array}{l}\text { Рак поджелудочной } \\
\text { железы }\end{array}$ & CA19-9 CA242, PЭA, CA72-4, TPS, OPN, TIMP-1 \\
\hline
\end{tabular}

Инструментальные методы исследования обычно уточняют изменения, происходящие в различных органах и системах. Наиболее информативными являются магнитно-резонансная (MPT) и компьютерная томография (КТ), а в некоторых случаях позиционно-эмиссионная томография (ПЭТ). Ультразвуковые исследования (УЗИ) печени, селезенки, периферических лимфоузлов, тимуса и других органов. Необходимо обратить внимание на то, что флюорография и рентгенография при дифференциальной диагностике практического значение в настоящее время не имеют.

Проанализировав клинические и лабораторные исследования, необходимо выделить основные иммунологические синдромы заболевания, что дает основание сформулировать предварительный иммунологический диагноз (см. главу 10). 


\section{МЕТОДЫ ИССЛЕДОВАНИЯ ИММУННОЙ СИСТЕМЫ}

\section{Глава 7. Исследование клеточного звена иммунитета}

Учитывая многообразие клеток иммунной системы, их идентификация и оценка активности является первоочередным мероприятием по оценки функции иммунитета. В общей практике такие исследования проводятся ежедневно в большом количестве при исследовании клинического анализа крови (см. гл.6). Однако для детального изучения клеток иммунной системы этого исследования недостаточно. В клинической практике и научных исследованиях широкое применение нашли методы основанные на идентификации поверхностных дифференцировочных антигенов на клетках иммунной системы с помощью моноклональных антител. Суть метода заключается в связывании дифференцировочных АГ лимфоцитов с моноклональными АТ и дальнейшим их окрашиванием антиглобулиновыми AT, меченными флуорохромом (метод непрямой иммунофлуоресценции). В дальнейшем происходит измерение меченых клеток с помощью различных методов где безусловнывм лидером является проточная цитометрия.

Проточная цитофлуориметрия - современная технология быстрого измерения характеристик клеток при помощи моноклональных антител или других зондов, позволяющая судить об их типе (по наличию того или иного набора клеточных маркеров) и их функциональном состоянии (по изменению протекающих в них процессов).

Созданная для ускорения анализа в клинической цитологии и цитодиагностике, эта технология постепенно развилась в эффективный подход к решению многих важных задач биологии клетки, иммунологии, клеточной инженерии и т.д. Области применения проточной цитометрии весьма разнообразны [29, 33, 89, 98-104, 108].

Помимо морфологических характеристик клеток с помощью моноклональных АТ можно: достоверно определять популяционный и субпопуляционный состав лимфоцитов; выявлять стадию дифференцировки и активации клеток; оценивать уровень функциональной активности лимфоцитов; определять внутриклеточные и секретируемые цитокины; проводить исследования фагоцитоза; анализировать клеточный цикл, оценивать апоптоз и пролиферацию.

Технология измерения различных характеристик клеток или их органелл следущая: Клеточная суспензия, предварительно меченная флуоресцирующими моноклональными АТ или флуоресцентными красителями, подается к потоковому элементу. Клетки идут одна за другой, где в проточной ячейке их пересекает лазерный луч, под действием которого окрашенные клетки флуоресцируют. Далее через оптическую систему излучение попадает на регистрирующее устройство, где в дальнейшем обрабатывается.

С помощью проточной цитометрии можно определить размеры клетки, соотношение ядра и цитоплазмы, степень асимметричности и интенсивность флуоресценции. Допускаются измерение до 21 флуоресцентного параметра одновременно и с высокой чувствительностью и воспроизводимости при шести длин волн возбуждения (до 6 лазеров). При исследовании допустима оценка свойств от нескольких десятков до нескольких миллионов клеток. (рис. 56). 


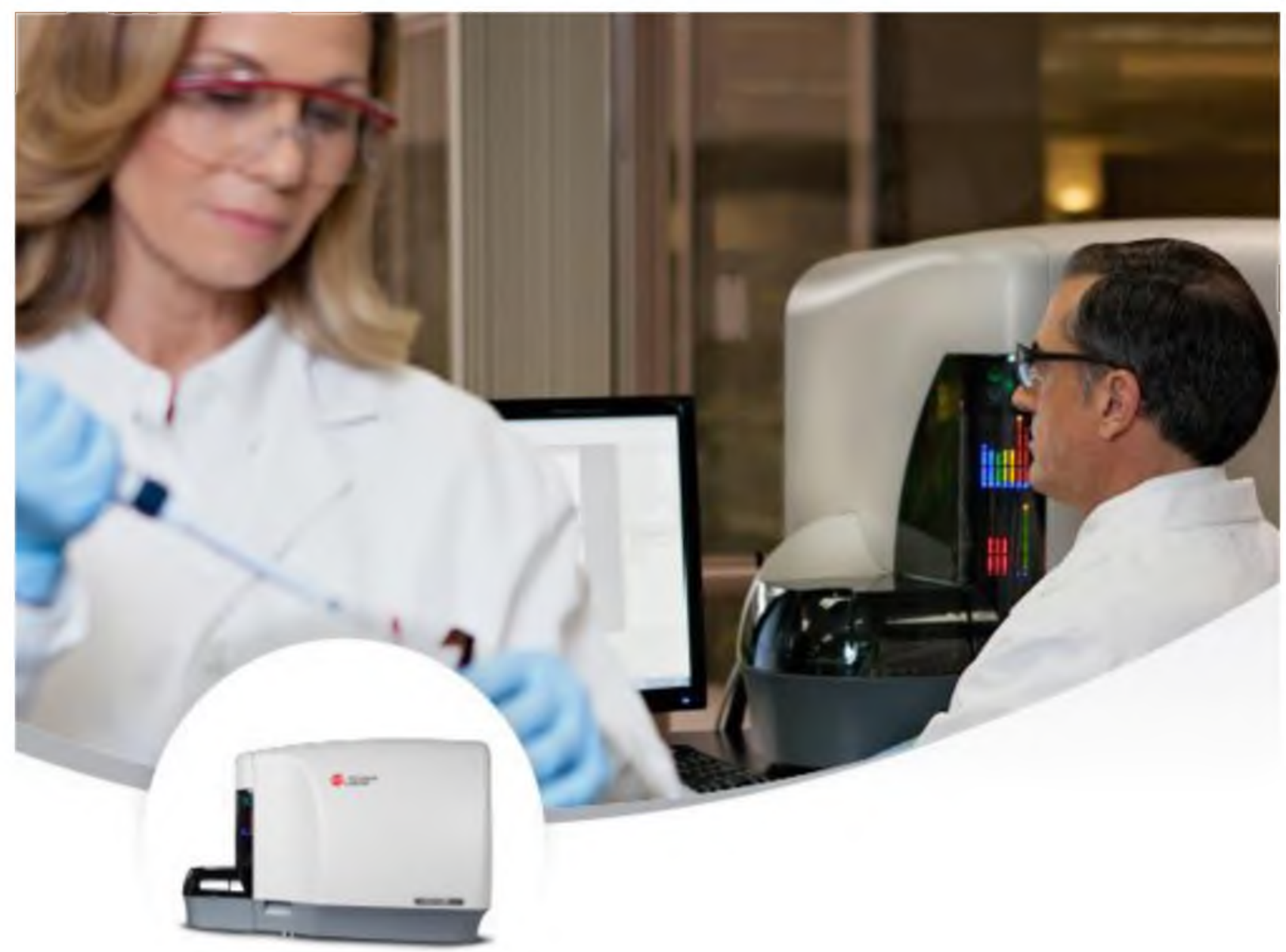

\section{ПРОТОЧНЫЙ ЦИТОФАУОРИМЕТР NAVIOS}

АЛЯ КАИНИЧЕСКОЙ АИАГНОСТИКИ IN VITRО

10-цветный анализ в оАной пробирке

2 ими 3 мазера и до 10 фиуоресцентных Аетекторов обеспечивают определение большого комичества популяций клеток

\section{Встроенный вортекс}

АЛя ИнАИЕИАУального перемешивания кажАой пробирки на борту анамизатора

\section{0 СОбЫтиЙ в СеКУНАУ}

Высокая скорость сокращает премя анализа, особенно Аля реаиАуальных клеток и Аругих реАКих событий

\section{Широкий спектр приможений}

Применяется в иммунологии,

онюогематомогии, аммергомогии и AD.

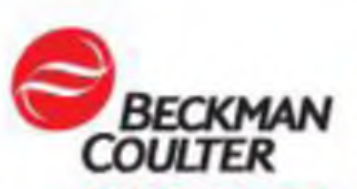
Life Sciences
Протоная цитометрия на расстоянии оАного киика https:/becisco/now-ru

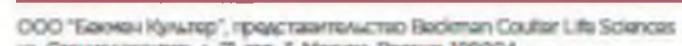

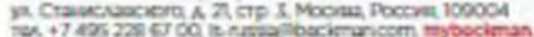

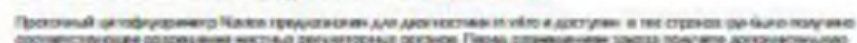

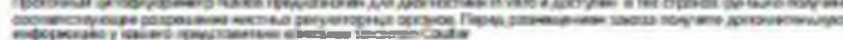
200.406 now

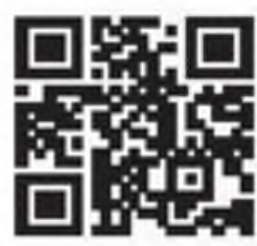




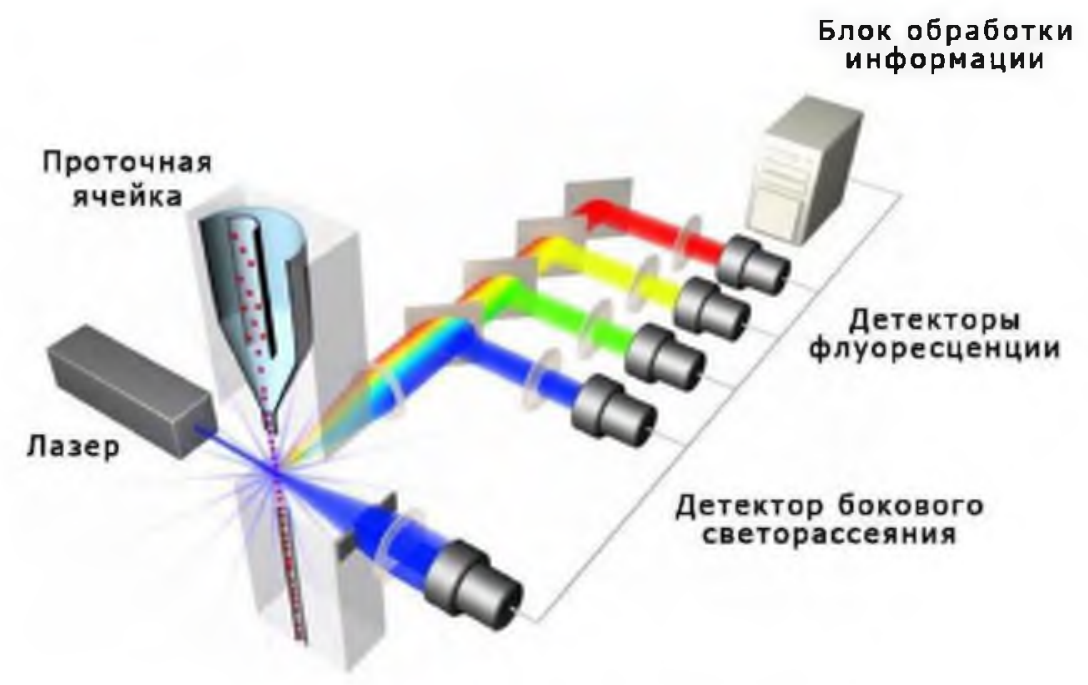

Детектор малоуглового

светорассеяния

\section{Рис.56. Принцип работы проточного цитометра}

Анализ параметров прямого (FS) и бокового (SS) светорассеяния позволяет получить информацию о таких параметрах клеток как относительный размер и «гранулярность», соответственно. После удаления эритроцитов из образца периферической крови на основании анализа FS и SS можно выявить три основные популяции лейкоцитов (рис. 57).

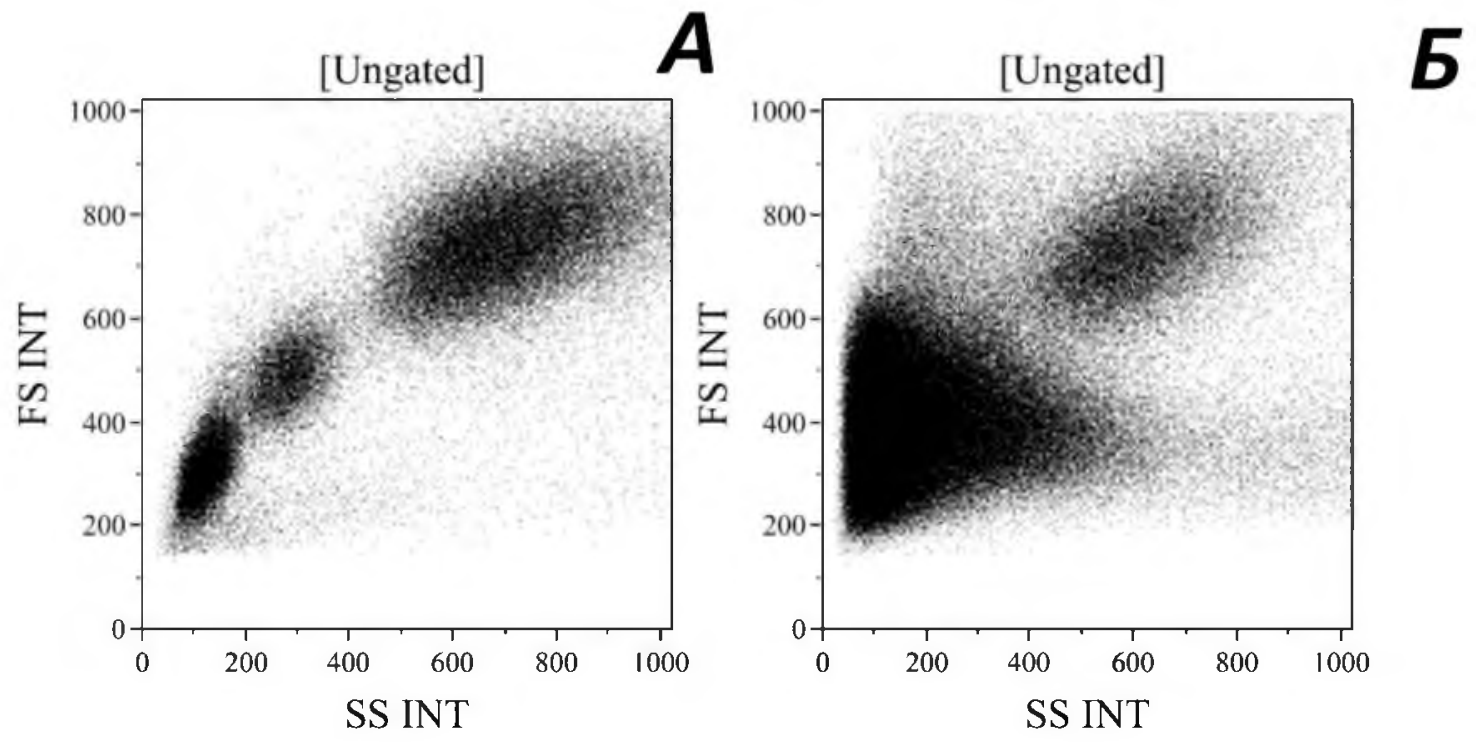

\section{Рис. 57. Анализ морфологических параметров лейкоцитов периферической крови при помощи проточной цитометрии. Комментарии в тексте.}

Во-первых, - это лимфоциты, расположенные в левой нижней части гистограммы А. Несмотря на то, что лимфоциты являются весьма гетерогенной популяцией клеток, их морфологические параметры не отличаются разнообразием. Диаметр этих клеток в капле свежей венозной крови условно здоровых людей находится в пределах 8-10 мкм (в мазке крови после фиксации и окраски он составляет около 7-8 мкм). При микроскопии у всех типов лимфоцитов можно увидеть интенсивно окрашивающееся ядро округлой, реже бобовидной, формы, содержащее компактный гетерохроматин, локализированный по периферии ядра. 
Ядро окружено относительно узким ободком базофильной цитоплазмы. В ней могут содержаться немногочисленные гранулы (следует отметить, что по этому параметру зрелые НК-клетки и цитотоксические Т-лимфоциты могут существенно отличаться от В-клеток и Тхелперов, так как в их цитоплазме накапливаются гранулы, содержащие цитолитические молекулы). Обычно в гистологических исследованиях лимфоциты описываются как клетки, обладающие высоким ядерно-цитоплазматическим отношением (отношение между площадью цитоплазмы и площадью ядра).

Во-вторых, - это моноциты, расположенные несколько выше по FS и правее по SS от популяции лимфоцитов. Как известно, моноциты имеют диаметр в свежей капле венозной крови в пределах 9-12 мкм (в мазке крови - 18-20 мкм) - поэтому их относительный размер превосходит таковой лимфоцитов (выше по FS). Структура цитоплазмы также несколько сложнее за счет наличия крупного ядра обычно бобовидной или подковообразной формы, по всему объему которого располагаются скопления гетерохроматина, a в составе обнаруживаются одно или несколько ядрышек. Структура цитоплазмы мелкозернистая из-за наличия мелких азурофильных зерен (лизосом) и иногда фагоцитарных вакуолей. За счет этих структур в составе ядра и цитоплазмы, способных преломлять свет, моноциты обладают более высокими параметрами бокового светорассеяния по сравнению с лимфоцитами. Моноциты тоже являются гетерогенной популяцией клеток, однако их разделение на отдельные группы проводится на основании экспрессии поверхностных молекул (в первую очередь, CD14 и CD16).

B-третьих, - это гранулоциты, расположенные выше по оси ординат и правее по оси абсцисс по сравнению с моноцитами. Подавляющее большинство клеток в рамках гранулоцитарной популяции относится к нейтрофильным гранулоцитам. Нейтрофилы циркулируют в периферической крови в виде сферических клеток диаметром от 12 до 15 мкм, что существенно превосходит размеры лимфоцитов и моноцитов (отсюда такое «высокое» расположение по FS). Ядро нейтрофила сегментировано и может состоять из трех-пяти связанных между собой долек, отсюда еще одно название нейтрофила - «полиморфноядерный лейкоцит». Цитоплазма содержит большое число гранул, которые подразделяются на два основных типа. Большинство гранул - это «специфические» гранулы, заполненные такими протеолитическими ферментами как лизоцим, коллагеназа и эластаза. Эти гранулы не сильно окрашиваются основными и кислотными красителями (гематоксилин и эозин, соответственно), что отличает гранулы нейтрофилов от гранул двух других типов циркулирующих гранулоцитов, называемых базофилами и эозинофилами (по окраске, соответственно). Второй тип гранул нейтрофила - это азурофильные гранулы (лизосомы), в составе которых обнаруживаются различные ферменты и другие микробицидные вещества, включая дефенсины и кателицидины. Наличие большого числа гранул, а также сегментов, на которые разделено ядро, существенно увеличивают способность этих клеток рассеивать или преломлять свет, который собирается детектором бокового светорассеяния, что делает эту группу клеток самой сложной по организации внутреннего объема цитоплазмы среди всех лейкоцитов периферической крови.

Что же касается двух других популяций лейкоцитов - базофилов и эозинофилов, то для их выявления необходимо использовать флуорохром-коньюгированные моноклональные антитела, так как по параметрам светорассеяния они «накладываются» на популяции лимфоцитов и гранулоцитов, соответственно. Дендритные клетки, которые могут обнаруживаться в незначительном количестве в периферической крови, по прямому и боковому светорассеянию обычно располагаются между лимфоцитами и моноцитами, не формируя четко оформленных популяций. Для их выявления также необходимо применять моноклональные антитела, конъюгированные с флуорохромами.

В случае некачественного лизирования эритроцитов (не полного их удаления из образцов) выявление популяции лимфоцитов для последующего анализа не представляется возможным. Это связано в первую очередь с тем, что относительные размеры лимфоцитов и эритроцитов, определяемые при помощи прямого светорассеяния, практически полностью 
совпадают, как это показано на рисунке 58. Поэтому долгое время искали методический прием, позволяющий не зависеть от качества лизирования эритроцитов в образцах. Преимушеством использования антител против CD45 является почти что полная независимость от качества лизиса эритроцитов на этапе подготовки образца для анализа, что позволяет практически всегда выделить популяцию лимфоцитов для последующего детального исследования. Именно поэтому анализ экспрессии CD45 на лейкоцитах периферической крови входит в международные рекомендации по клеточному анализу в качестве одного из первых этапов. Основным недостатком этого метода является необходимость использования дополнительного моноклонального антитела, что в целом способно увеличить стоимость исследования. Кроме того, это требует задействовать отдельный флуоресцентный канал для измерения интенсивности флуоресценции CD45, что накладывает определенные ограничения в случае работы приборов с малым количеством одновременно анализируемых флуоресцентных сигналов.

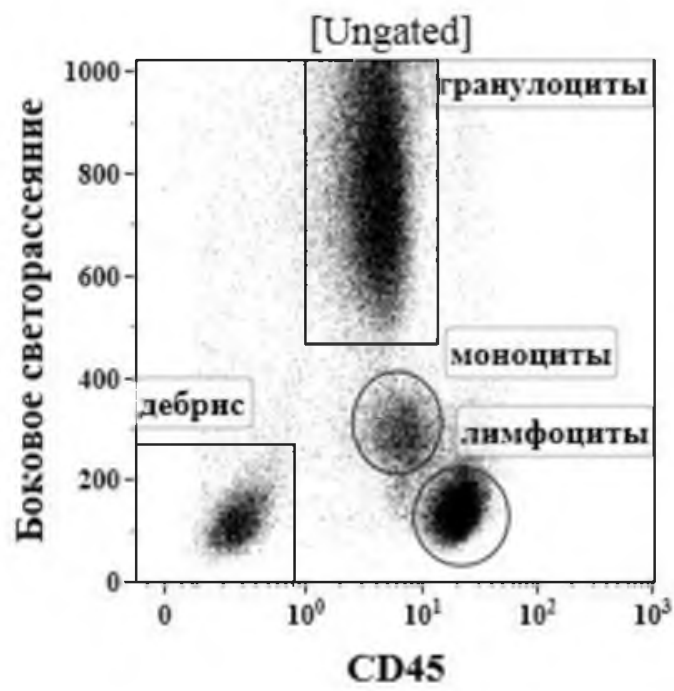

Рис. 58. Анализ экспрессии CD45 лейкоцитами периферической крови.

По оси абсцисс - уровень экспрессии CD45; по оси ординат - боковое светорассеяние. Комментарии в тексте.
CD45, также известный как LCA (от англ. «leukocyte common antigen») или Т200, является трансмембранным гликопротеином I типа $\mathrm{c}$ молекулярной массой 180-240 кДа (в зависимости от изоформы молекулы), в составе внутриклеточной части полипептидной цепи которого находятся два каталитических домена, обладающие свойствами тирозиновых протеинфосфотаз. Тирозинспецифическая фосфатаза CD45 принимает участие в передаче сигналов внутрь клетки и регулирует различные процессы, связанные с активацией клеток, продвижением их по клеточному циклу, дифференцировкой и т.д. Однако в случае проточной цитометрии антитела против данной молекулы применяются для того, чтобы отделить лейкоциты от неклеточных элементов крови (эритроцитов и тромбоцитов, не экспрессирующих CD45 на своей поверхности).

Уровень экспрессии CD45 существенно различается и среди различных субпопуляций лейкоцитов. Так, лимфоциты (Т- и В-клетки, а также натуральные киллеры) обладают очень высокой плотность экспрессии данной молекулы, что, принимая во внимание относительно небольшую структурированность их цитоплазмы (отсутствие крупных гранул, шаровидное ядро, богатое гетерохроматином, и т.д.), позволяет отделить эти клетки от остальных клеток крови при помощи гистограммы «боковое светорассеяние»-против-экспрессии CD45. и описать их как SSlowCD45bright. На моноцитах периферической крови экспрессия CD45 несколько уступает таковой на лимфоцитах, при этом организация цитоплазматического компартмента моноцитов значительно сложнее за счет наличия лизосом и крупного ядра, имеющего бобовидную, подковообразную или, реже, дольчатую форму с многочисленными выступами и углублениями. Все это позволяет выявить популяцию моноцитов как SSdimCD45dim. Что же касается гранулоцитов (в первую очередь, нейтрофилов, которые в норме составляют подавляющее большинство клеток данной фракции), то на нейтрофилах плотность экспрессии CD45 уступает таковой на лимфоцитах и моноцитах. Однако, именно эти клетки характеризуются наличием огромного числа структурных элементов в своей цитоплазме - специфические гранулы и лизосомы, а также сильно сегментированное ядро, что 
позволяет относить их к полиморфоядерным лейкоцитам. Используя терминологию, принятую в проточной цитометрии, нейтрофилы можно описать как SShighCD45dim.

Помимо CD45 на клетках иммунной системы находятся и другие рецепторы, которые можно определить с помощью моноклональных антител или каких либо других зондов (иммунофенотипировать).

Набор клеточных маркеров позволяет судить о типе (табл.33) и функциональном состоянии (табл.34) той или иной клетке.

Таблица 33

\section{CD-антигены, определяющие тип клетки}

\begin{tabular}{|c|c|}
\hline $\begin{array}{c}\text { CD- } \\
\text { антиген }\end{array}$ & Клеточная экспрессии \\
\hline CD3 & $\begin{array}{l}\text { Т-клетки (в комплексе с TCR - передача сигнала при антигенном распознавании T } \\
\text { клеткой) }\end{array}$ \\
\hline CD4 & $\begin{array}{l}\text { T-хелперы, субпопуляции моноцитов, субпопуляции кортикальных тимоцитов, EBV } \\
\text { трансформированные В-клетки (корецептор МHC II класса, рецептор для ВИЧ) }\end{array}$ \\
\hline CD5 & зрелые Т-клетки, субпопуляции В-клеток (лиганд CD72 на В-клетках) \\
\hline CD8 & $\begin{array}{l}\text { Т-цитотоксические, субпопуляции NK-клеток, субпопуляции кортикальных тимоцитов, } \\
\text { (корецептор МНС І класса) }\end{array}$ \\
\hline CD14 & моноциты (LSP рецептор) \\
\hline CD16 & NK-клетки, гранулоциты, макрофаги (Fcg RIII) \\
\hline CD19 & предшественники В-клеток и В-клетки \\
\hline CD20 & субпопуляции предшественников В-клеток, зрелые В-клетки \\
\hline CD21 & зрелые В-клетки (рецептор C3d, CD23 и рецептор EBV) \\
\hline CD34 & стволовая кроветворная клетка \\
\hline CD45RA & “наивные”, непремированные Т клетки (изоформа CD45) \\
\hline CD45RO & Т- клетки памяти (изоформа CD45) \\
\hline CD56 & NK-клетки, некоторые Т-клетки (молекула адгезии NK клеток N-CAM) \\
\hline CD127 & $\begin{array}{l}\text { активированные В и Т лимфоциты, макрофаги, NK клетки (ранний маркер } \\
\text { лимфоцитарной активации) }\end{array}$ \\
\hline
\end{tabular}

Оценка функции фагоцитарных клеток. Процесс фагоцитоза состоит из нескольких этапов: хемотаксис, адгезия, поглошение, дегрануляция, киллинг и разрушение объекта фагоцитоза. Их изучение имеет определенную значимость в оценке фагоцитарного процесса, так как сушествуют иммунодефициты, связанные с наличием поломок практически на каждом этапе.

Адгезивную способность нейтрофилов можно измерить по прилипанию к волокнам из нейлона.

Миграцию и хемотаксис фагоцитирующих клеток оценивают при использовании агарозных тестов (реакция торможения миграции лейкоцитов). Поглотительную способность лейкоцитов измеряют по захвату ими различных частиц (микроорганизмы, частицы латекса). Метаболическая активность клеток может быть оценена в тесте с нитросиним тетразолием (НСТ-тест) или с помощью хемилюминесцентного метода. 
Таблица 34

\section{CD-антигены, используемые для оценки функционального состояния клеток иммунной системы.}

\begin{tabular}{|c|c|}
\hline $\begin{array}{c}\text { CD- } \\
\text { антиген }\end{array}$ & Клеточная экспрессии \\
\hline HLA-DR & $\begin{array}{l}\text { Определяется на всех В-лимфоцитах и моноцитах, на активных Т-лимфоцитах } \\
\text { (маркер поздней активации). При наличии HLA-DR на моноцитах менее 50\% является } \\
\text { неблагоприятным патогномоничным признаком развития тяжелой бактериальной } \\
\text { инфекции (сепсис, перитонит) }\end{array}$ \\
\hline CD11b & $\begin{array}{l}\text { Экспрессируется на большинстве лейкоцитов. Относится к наиболее важным для } \\
\text { миграции клеток интегринам, которые определяют активность фагоцитоза, } \\
\text { клеточной цитотоксичности, хемотаксиса и клеточной активации Т-эффекторов, NK- } \\
\text { клеток, макрофагов и гранулоцитов. }\end{array}$ \\
\hline CD14 & $\begin{array}{l}\text { Находится на всех моноцитах периферической крови. Сочетание его с CD16+ } \\
\text { маркером указывает на число провоспалительных моноцитов, который является } \\
\text { критерием тяжести инфекционно-воспалительных заболеваний. }\end{array}$ \\
\hline CD23 & $\begin{array}{l}\text { Экспрессируется на активированных В клетках, макрофагах, клетках тимического } \\
\text { эпителия, эозинофилах, тромбоцитах. Показатель активности В-клеток. }\end{array}$ \\
\hline CD25 & $\begin{array}{l}\alpha \text {-Цепь рецептора ИЛ2. Экспрессируется на различных типах клеток периферической } \\
\text { крови: CD4+, CD8+, NK, NKT-клетках, B-лимфоцитов, моноцитах. Маркер ранней } \\
\text { активации Т-лимфоцитов. может говорить о воспалительном процессе любой } \\
\text { природы (инфекционный, аутоиммунный). }\end{array}$ \\
\hline CD27 & $\begin{array}{l}\text { Дополнительный маркер В2-лимфоцитов. Указывает на переход В-лимфоцитов из } \\
\text { наивных клеток в клетки памяти }\end{array}$ \\
\hline CD28 & $\begin{array}{l}\text { Экспрессируется на большинстве активированных Т-лимфоцитах, NK-клетках и } \\
\text { плазматических клетках. Необходим как костимулирующий фактор для индукции } \\
\text { иммунного ответа (пролиферации и активации клеток). }\end{array}$ \\
\hline CD38 & $\begin{array}{l}\text { Циклическая АДФ-рибозил гидролаза находится на поверхности лимфоцитов, } \\
\text { обеспечивает адгезию, передачу сигнала. CD38 является так же маркером активации } \\
\text { клеток (метаболический маркер). Понижается при ВИЧ- инфекции, лейкемии, } \\
\text { миеломе, солидных опухолях, диабете II тип. }\end{array}$ \\
\hline CD50 & $\begin{array}{l}\text { Межклеточная молекулы адгезии (ICAM-3) помимо этого является мощной } \\
\text { сигнальной молекулой. Представлена на всех лейкоцитах, эндотелиальных и } \\
\text { дендритных клетках. Обеспечивает костимуляторные сигналы для Т-клеток и } \\
\text { регулирует адгезию клеток путем взаимодействия с интегринами. Показано } \\
\text { снижение количества CD50+ клеток при опухолевых заболеваниях. }\end{array}$ \\
\hline CD57 & $\begin{array}{l}\text { Экспрессируется на субпопуляции 15-20\% мононуклеарных клеток периферической } \\
\text { крови, у } 60 \% \text { NK клеток и Т-клеток. Повышение показателей определяется у } \\
\text { онкологических больных, больных после трансплантации, у пациентов с ВИЧ, а так же } \\
\text { с ревматоидным артритом и синдромом Фелти. Снижение патогномонично при } \\
\text { хронизации болезни Лайма. }\end{array}$ \\
\hline CD62L & $\begin{array}{l}\text { Представитель семейства молекул клеточной адгезии (L-селектин), находящийся на } \\
\text { клеточной поверхности лейкоцитов (Т и NK клеток, моноцитов, гранулоцитов), } \\
\text { обеспечивает транслокацию лейкоцитов из крови в лимфоидную ткань, где они } \\
\text { взаимодействуют с антигеном. }\end{array}$ \\
\hline
\end{tabular}


Показатели фагоцитарной активности нейтрофилов оцениваются в тестах спонтанного и стимулированного микробными полисахаридами (продигиазаном и зимазаном) фагоцитоза, что позволяет при сравнении аналогичных показателей до и после стимуляции оценивать резервные возможности клеток $[74,75,76$,

Определяется поглотительная способность нейтрофилов с подсчетом фагоцитарного индекса, т. е. процента (относительного числа) фагоцитирующих нейтрофилов. Оценивается фагоцитарное число, или среднее число частиц, поглощенных одним нейтрофилом. Метод основан в умении полиморфноядерных лейкоцитов (или моноцитов) периферической крови связывать на своей поверхности, поглощать и переваривать чужеродные агенты (микробные агенты, индифферентные частицы, например, используемый в тестах латекс). Бактерицидная активность фагоцитов основана на подсчете жизнеспособных бактерий, оставшихся внутри клеток после инкубации. В норме фагоцитарный показатель составляет: спонтанный - 62-68 $\%$, стимулированный - 80-88 \%. Фагоцитарное число - спонтанное $3-5$, стимулированное 7 11.

Фагоцитарная активность нейтрофилов обычно повышается в начале развития воспалительного процесса. Ее снижение ведет к хронизации заболевания, развитию синдрома ИК за счет того, что нарушается функция разрушения и выведения ИК.

Учитывая, что главным итогом работы нейтрофила и моноцита являются киллинг и разрушение микроба, т.е. завершенный фагоцитоз, то для оценки киллинга можно рекомендовать образование активных форм кислорода в процессе фагоцитоза. Если нет возможности определять активные формы кислорода с помощью хемилюминесцентного метода, то о появлении супероксидного радикала можно судить по восстановлению НСТ. Но в данном случае следует помнить, что киллинг микробов в фагоците осуществляется с помощью как кислородозависимых, так и кислородонезависимых механизмов, т.е. определение активных форм кислорода не дает полной информации об этом процессе.

\section{Иммуногистохимия}

Еще один метод, основанный на принципе специфического связывания антител с антигенами в биологических тканях.

По методу визуализации выделяют хромогенную иммуногистохимию, при которой антитело конъюгировано с ферментом, таким как пероксидаза (комбинация, называемая иммунопероксидазой), который может катализировать реакцию образования цвета и иммунофлуоресценция, когда антитело мечено к флуорофору (флуоресцеину или родамину).

Иммуногистохимическое окрашивание широко используется как для фенотипирования и/или диагностики аномальных клеток, так и для определения клеточных событий, таких как пролиферация или гибель клеток (апоптоз и другие виду клеточной смерти).

Следующим шагом развития проточной цитометрии является иммуноскопия проточная цитометрия с визуализацией (ПЦВ) (рис.59) или проточная микроскопия. Наиболее полно данная революционная технология реализована в проточном цитометре Amnis ImageStream ${ }^{\circledR}$ Mk II (Luminex, USA), который сочетает в себе возможности проведения высокопроизводительного, многопараметрического анализа методом проточной цитометрии с получением морфологических и пространственных параметров методом микроскопии на уровне единичной клетки. Эта уникальная комбинация позволяет использовать широкий спектр алгоритмов с анализом изображения клеток для получения множества научных и/или клинических данных, которые невозможно осуществить цитометрическими и микроскопическими методами отдельно.

За несколько минут прибор может обработать сотки тысяч клеток, получив и охарактеризовав несколько миллионов изображений как самих клеток, так и их флуоресценции. Высока производительность делает данную технологию подходящей для анализа редких типов клеток (таких как циркулирующие опухолевые клетки) и переходных состояний (фазы клеточного цикла). 

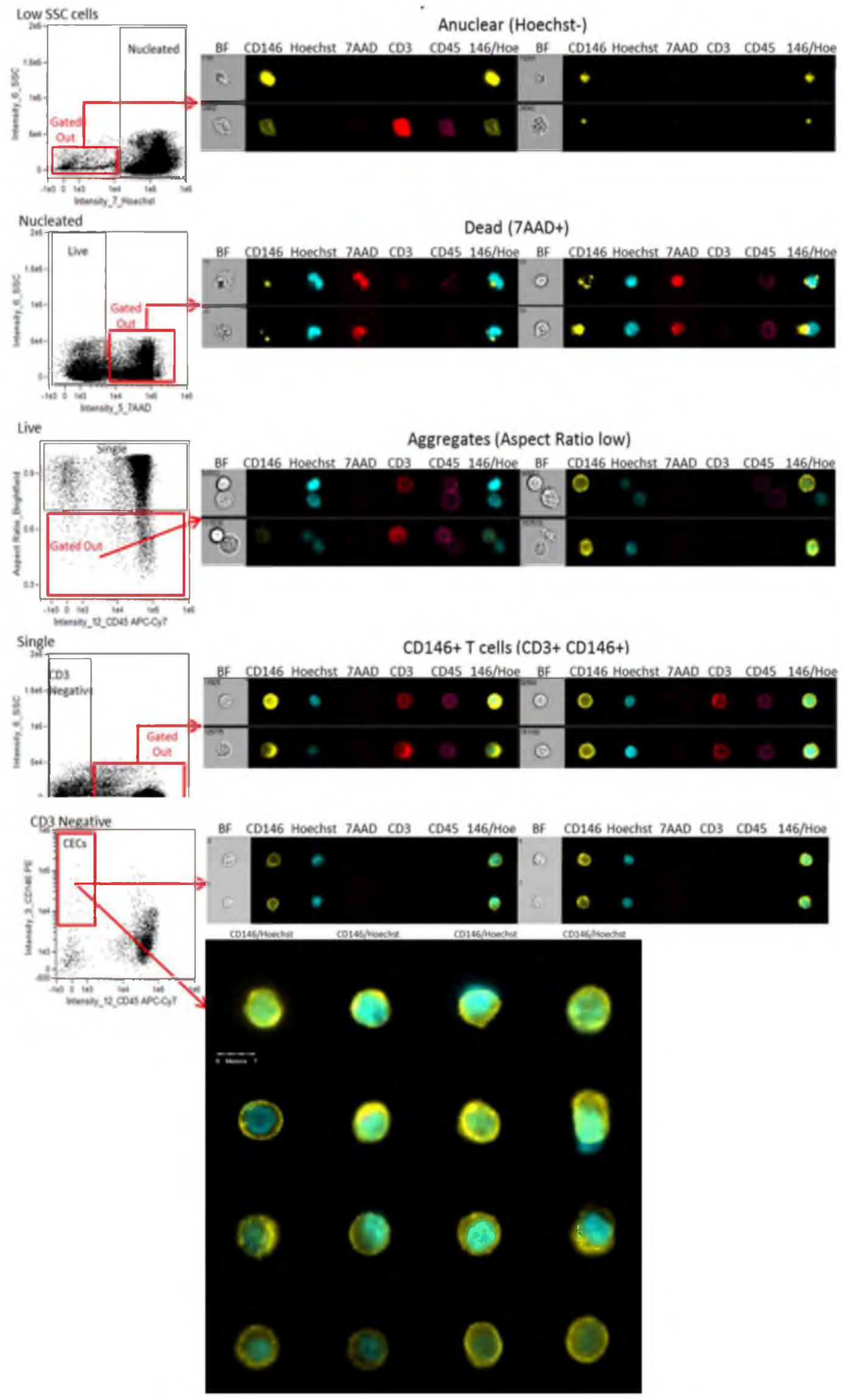

Рис.59. Проточная цитометрия с визуализацией 
Анализ изображений, полученных методом ПЦВ, позволяет получить множество параметров интересующих объектов (включая белки, нуклеиновые кислоты и гликолипиды) в различных областях клетки (ядро, митохондрии и тд). Большое количество получаемой информации делает ПЦВ идеальной платформой для высоко контентного анализа и машинного обучения, помогая создавать профили сложных клеточных фенотипов, идентификации редких событий и, что не мало важно, поиска мишеней для диагностики заболеваний, в персонализированной медицине и разработке лекарств.

В перспективе, ПЦВ может применяться, например, для диагностики острой или хронической лимфоцитарной/миелойдной лейкемии в неокрашенных/необработанных образцах крови, что позволит сохранить «естественные» свойства и состояние образцов. Или автоматизировать быструю визуализацию клеток интереса, характер локализации экспрессирующих антигенов и оценку цитогенетические аномалии в одном тесте.

Другие потенциальные применения ПЦВ - поиск редких клеток в биологических жидкостях, например, поиск остаточных лейкозных клеток после лечения, жидкостная биопсия и анализ циркулирующих опухолевых клеток. ЖБ может выявлять рак на ранней стадии, циркулирующие метастатические клетки или лекарственно-устойчивые неопластические клетки, нарушения свертываемости или аномалии развития плода. Использование алгоритмов машинного обучения совместно с ПЦВ позволяет выявлять одну опухолевую клетку среди миллионов нормальных с очень высокой точностью.

Несмотря на огромные перспективы технологии, в основном она используется в научных целях. Одним из основных препятствий можно назвать анализ данных: он сильно разница от эксперимента к эксперименту, требует ручная настройка и интерпретации. Однако эти препятствия можно с легкостью преодолеть, используя машинное обучение. Кроме того, для ПЦВ требуется внедрение СОПов с стандартизованного контроля качества работы приборов. Хотя это и является обычной практикой в традиционной проточной цитометрии, в ПЦВ это до сих пор не внедрено.

Стратегия гейтирования при исключении событий, неудовлетворяющих требованиям циркулирующих эндотелиальных клеток и последующее визуальное подтверждение 


\section{МЕТОДЫ ИССЛЕДОВАНИЯ ИММУННОЙ СИСТЕМЫ}

\section{Глава 8. Исследование гуморального звена иммунитета}

Гуморальный иммунитет обеспечивается различными молекулами, которые осуществляют эффекторные и регуляторные функции иммунной системы. Их концентрация в организме обычно стабильно и изменяется при развитии каких-либо патологических процессов.

Наибольшее распространение в определении различных гуморальных показателей иммунитета получил метод иммуноферментного анализа (ИФА). Метод основан на регистрации комплекса АГ-АТ при помощи АТ, маркированных определенными ферментами, с последующим образованием легко регистрируемых продуктов ферментного превращения. С помощью ИФА можно определить уровень специфических АТ, общего IgE и специфических IgE- и IgG4-антител, различных цитокинов (IFN, IL и т.д.), аутоиммунные маркеры. Существуют два варианта ИФА. Первый - гомогенный, при котором ингибирование или активация фермента происходит в результате взаимодействия АГ-АТ без разделения компонентов реакции на несколько этапов. В медицинской практике гомогенный ИФА применяют для быстрого выявления низкомолекулярных АГ. Второй вариант - гетерогенный, при проведении этой методики требуется разделение компонентов реакции. Основа гетерогенного ИФА - прикрепление АГ или АТ к твердой фазе (обычно планшет из полимерного материала). В дальнейшем к АГ или АТ, «сидящему» на твердой фазе, присоединяются комплементарные АТ или АГ. Затем, образовавшиеся ИК метят ферментом, входящим в состав конъюгата, и на заключительном этапе наличие фермента выявляют с помощью хромогенной субстратной смеси. (рис. 60).

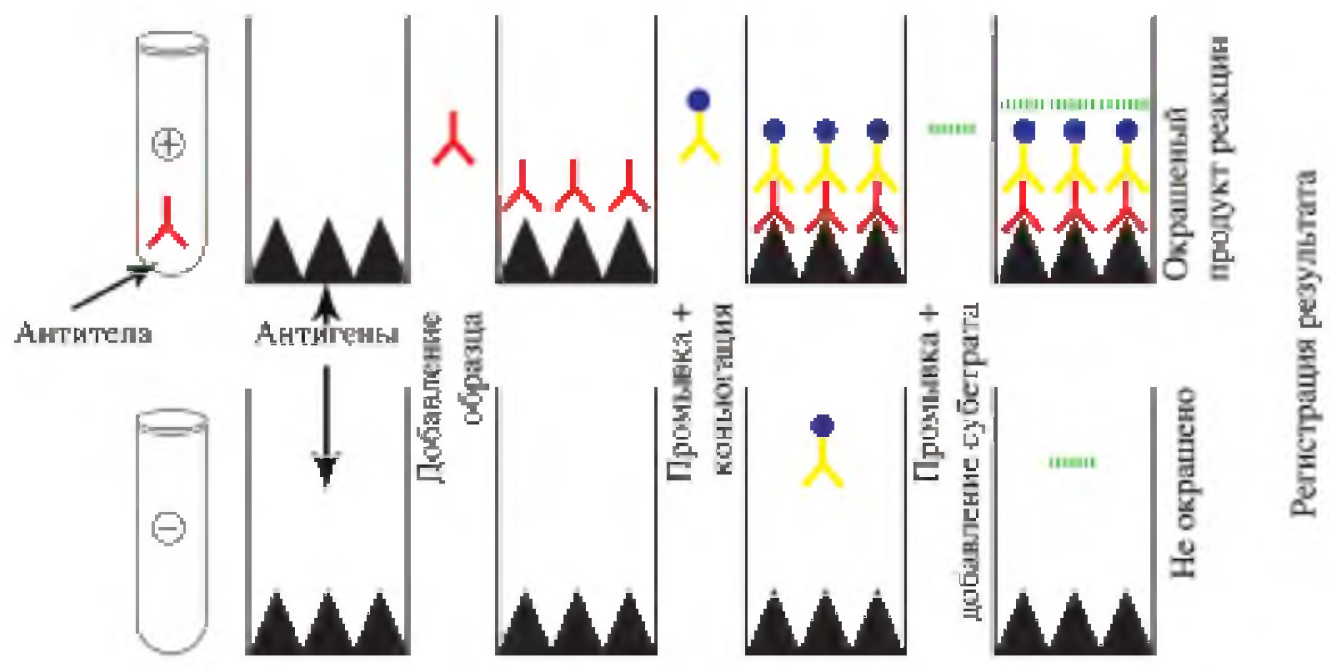

Рис.60 Принцип иммуноферментного анализа 
Для диагностики противоинфекционной защиты помимо ИФА применяются другие различные методы определения АТ в сыворотке крови больных к инфекционным АГ. Для этого используют серологические методы диагностики пассивной и активной гемагглютинации связывания комплемента и т.д., хотя с активным внедрением ИФА эти методы применяются все реже.

Для определения ЦИК в сыворотке крови человека используют метод нефелометрии, основанный на различной растворимости мономеров иммуноглобулинов в составе ЦИК при наличии в среде полиэтиленгликоля. Установление уровня ЦИК в сыворотке крови - один из диагностических приемов определения степени тяжести и активности иммунопатологических процессов. Этот метод, так же, как и метод радиальной иммунодиффузии в геле, недорогой, прост в постановке, имеет большую диагностическую значимость. Обнаружение ЦИК полезно при оценке и мониторинге активности аутоиммунных, аллергических и инфекционных заболеваний. Увеличение его концентрации выше 90 о.е. свидетельствует о наличии иммунокомплексного синдрома.

Более значимо для оценки патологических состояний определение ИК, фиксированных в тканях и сосудах с помощью гистохимических исследований. Но за счет большой сложности и трудоемкости использование таких методов ограничено

Тесты по выявлению комплемента подразделяются на два типа. Определение общей гемолитической активности - принцип основан на лизисе эритроцитов сенсибилизированными АТ в присутствии комплемента. Инкубируя такие эритроциты с различными разведениями комплемента, можно провести его полуколичественное определение. За единицу количества комплемента принимают активность, необходимую для гемолиза $50 \%$ эритроцитов. И выявление активности комплемента его отдельных компонентов с помощью ИФА.

Оценка функциональных свойств комплемента существенна у больных с подозрением на врожденный дефицит комплемента и полезна при наблюдении больных с различными иммунными расстройствами, мониторинге эффекта лечения.

Преимущество ИФА не обсуждается не даром он занимает ведущее местов идентификации различных молекул, однако в последние годы получил развитие мультиплексный анализ (рис.61).

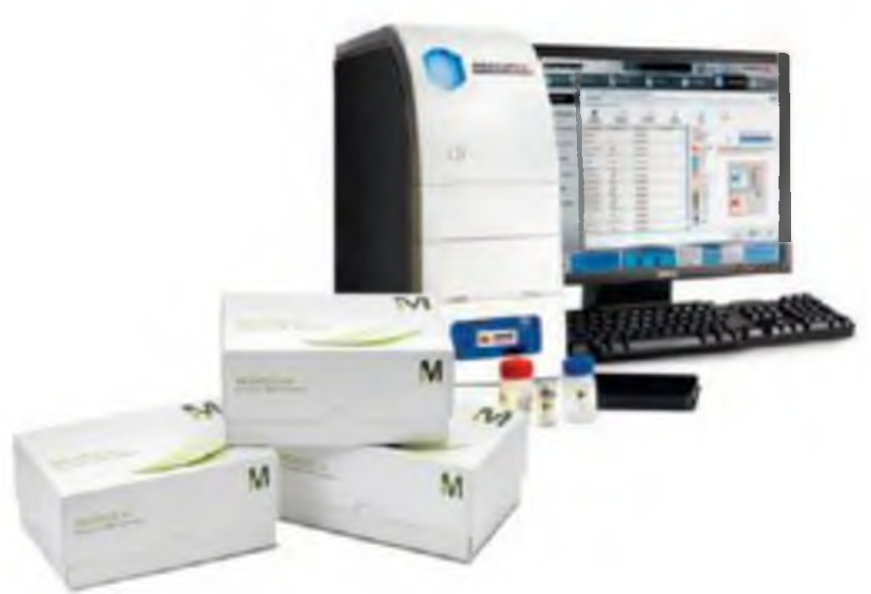

Рис.61. Комплект оборудования на платформе Luminex для проведения мультиплексного анализа.
Система MAGPIX® является современным комплексным решением на основе эффективной технологии Luminex® xMAP® для скрининга биомаркеров и анализа белков, а также с доступом к крупнейшему ассортименту мультиплексных наборов. В качестве партнера компании Luminex, Merck является дистрибьютером целого спектра приборов Luminex, включая LX 2007M, FLEXMAPTM $3 \mathrm{D}$ и MAGPIX ${ }^{\circledR}$ платформы, охватывающие полный спектр возможностей мультиплексного анализа.

Система MAGPIX®: CCDприборы, включающие основные компоненты сбора данных хМАР®, а также высокоскоростную и точную систему детекции, благодаря использованию магнитных частиц. 


\section{Рабочий процесс технологии хМАР®} Luminex использует запатентованные технологии для создания внутреннего цветового кода микросфер с двумя флуоресцентными красителями.

За счет точных концентраций данных красителей могут быть созданы 100 различных наборов окрашенных частиц, каждый из которых покрыт специфичными антителами.

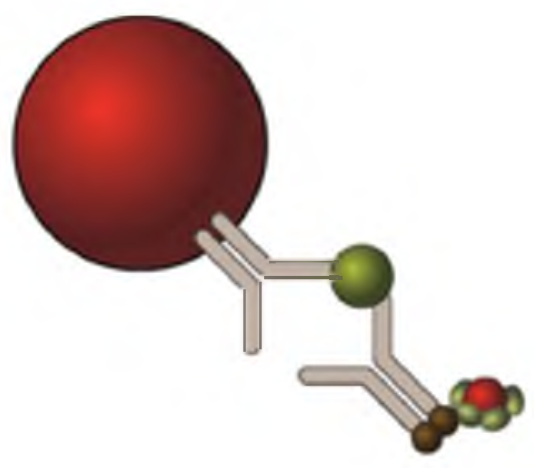

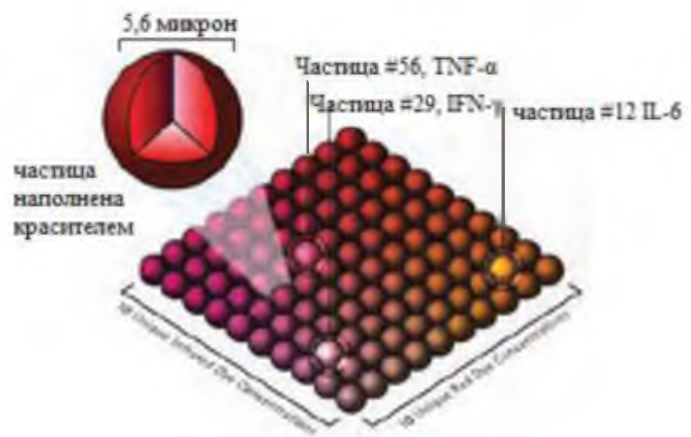

После того как аналит из тестового образца захватывается частицей, вводятся биотинилированные антитела для детекции. Реакционная смесь затем инкубируется с стрептавидиновым - PE (фикоэритрин) конъюгатом, репортной молекулой, для завершения реакции на поверхности каждой микросферы.

Микросферы переносятся в магнитную камеру с LED, который возбуждает внутренние красители, маркирующие набор микрочастиц

A также PE, флуоресцентный краситель на репортной молекуле. MAGPIX получает изображения частиц в камере с помощью $\mathrm{CCD}$ камеры (рис.62)

Алгоритмы обработки изображений позволяют получить результаты анализа в виде суммарной таблицы.

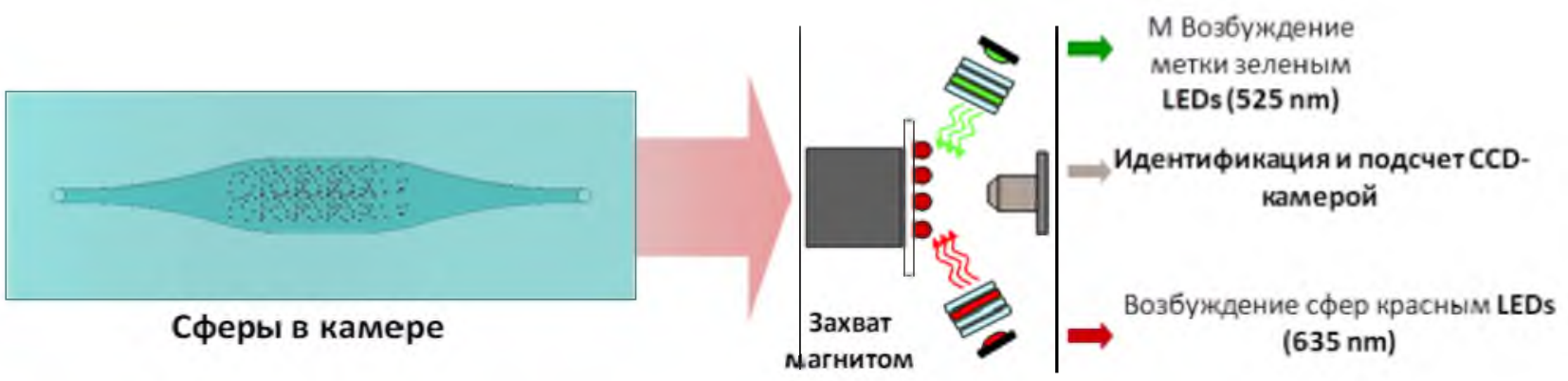

\section{Рис. 62 Принцип работы мультиплексного анализа.}

Преимущества хМАР при сравнении с другими современными системами детекции аналитовв биологических жидкостях:

- Скорость/Высокая производительность: возможность одновременного измерения концентраций большого числа различных аналитов в одном образце, что позволяет быстрее выполнять исследования, получая своевременные и исчерпывающие результаты, так важные для работы.

- Универсальность: единая система, основанная на технологии хМАР®, может выполнять анализ в нескольких различных форматах, включая нуклеиновые кислоты и взаимодействие антиген-антитело, наряду с ферментативными, рецептор-лигандными и другими белковыми взаимодействиями.

- Гибкость: технология может быть адаптирована под специфичные требования пользователя на основе целевых аналитов 


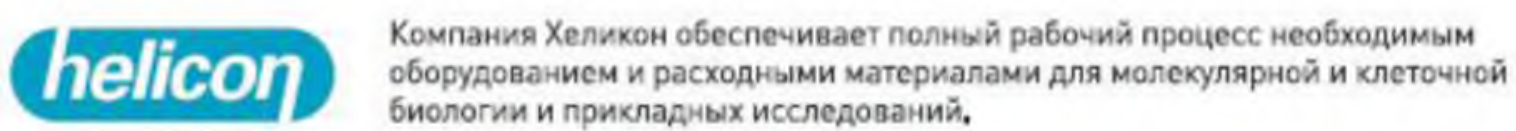

\section{ДЕЛАЕМ ВОЗМОЖНОЙ РАБОТУ РОССИЙСКИХ ЛАБОРАТОРИЙ НА МИРОВОМ УРОВНЕ}

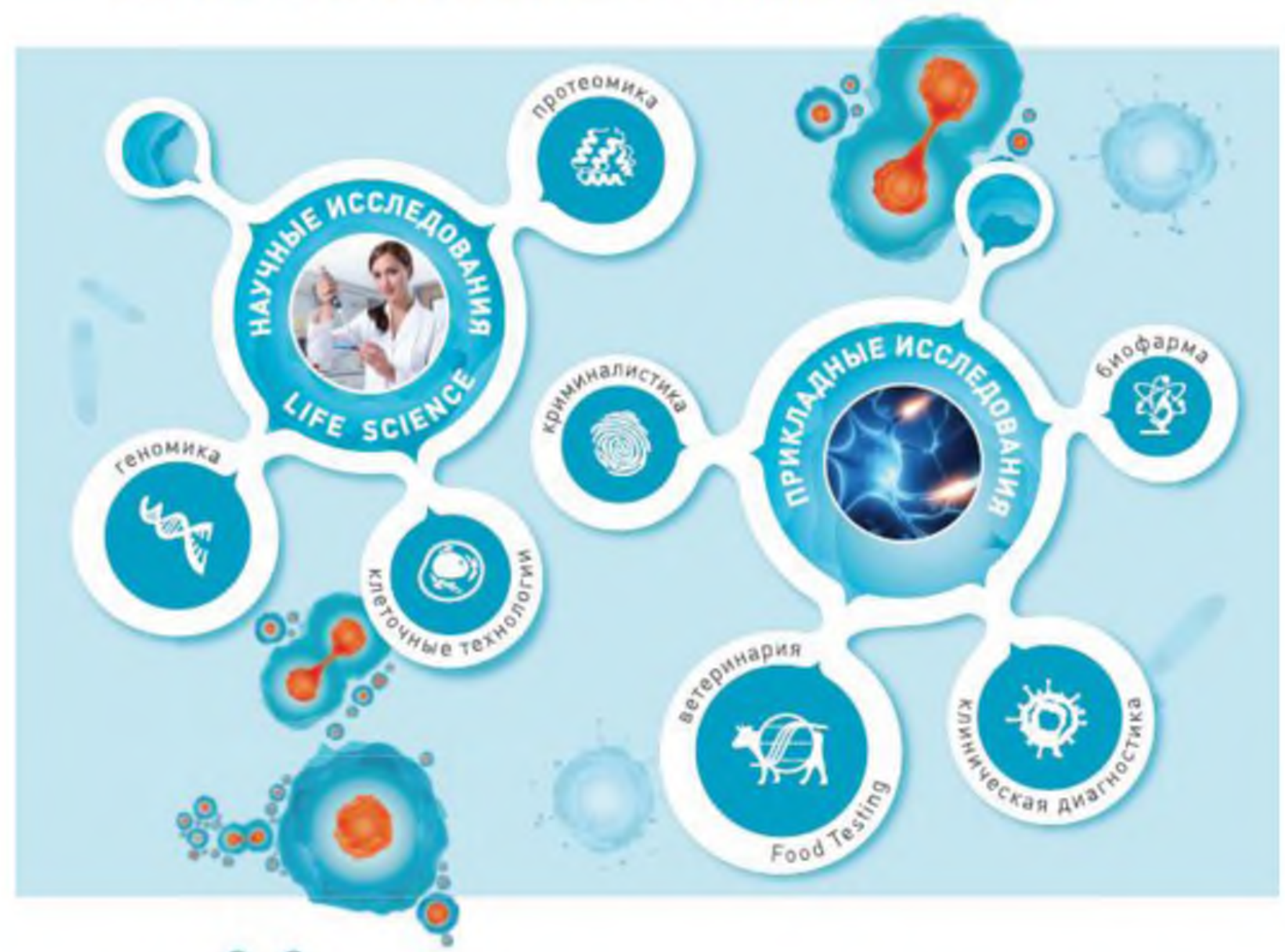

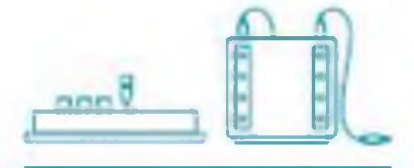

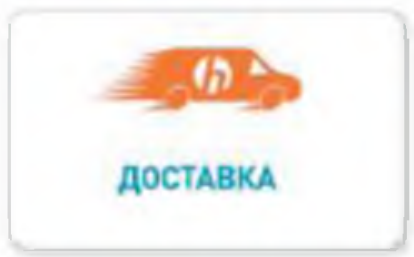

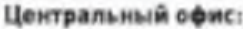

121374 г. Москва, Кутуровский проспект, А. 88

Tea. $8[300]$ 770-71-2]

mailehelicen,ru

heliconaru
000 жККомпания Хеликонм постевляст персдовыс рсшения ведущих мировых брендов и производит лабораторное оборудование для молекулярной биологии. noàpo6wee ma coùme wmw. helicon.ru

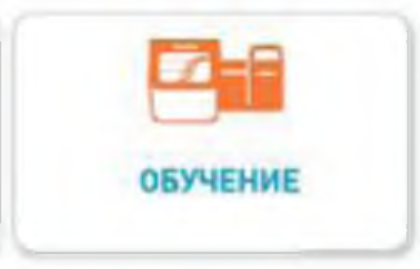

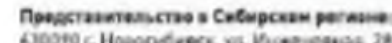

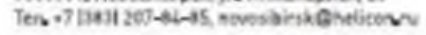

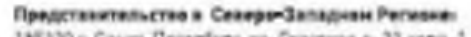

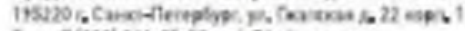

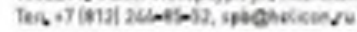

\section{x递}

CEРВИСНОЕ ОБСЛУЖИВАНИЕ

\section{U二}

МЕТОДИЧЕСКАЯ ПОДДЕРЖКА

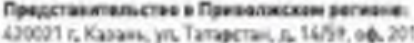

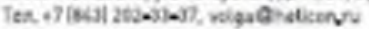

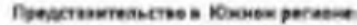

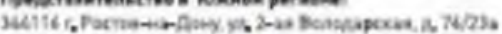

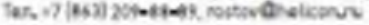


- $\quad$ Точность: технология хМАР® производит анализ в режиме реального времени и с высокой степенью точности осуществляет количественную оценку молекулярных взаимодействий.

- Воспроизводимость: производство высокообъемных микросфер хМАР® позволяет стандартизировать анализ образцов в отличие от использования твердофазных плоских поверхностей.

- Малый объем образца: при минимальной работе вручную вы можете проанализировать более 40 аналитов в одном образце, используя всего лишь 25 мкл исследуемого материала.

- Технология, основанная на использовании магнитных частиц: быстрая и эффективная реакция на действие магнитного поля способствует ускорению и улучшению качества процедуры отмывки, включая использование опций с высокой пропускной способностью.

Модификацией ИФА является и метод ELISPOT (от англ. Enzyme-Linked ImmunoSpot). позволяет идентифицировать конкретные антитела или цитокины, выделяемые живыми клетками. Принцип заключается в специфической реакции сенсибилизированных антител с секретируемыми клеткой молекулами. В результате этой реакции формируются окрашенные точки (пятна)

\section{Стадии метода ELISPOT.}

\begin{tabular}{|c|c|c|}
\hline 1 & EMY & $\begin{array}{l}\text { Моноклональные или поликлональные антитела, } \\
\text { специфические к определенному антигену наносятся } \\
\text { на микропланшет со специальным носителем. }\end{array}$ \\
\hline 2 & & Блокировка несвязанных сайтов с помощью протеина. \\
\hline 3 & & $\begin{array}{l}\text { К носителю с антителами добавляются анализируемые } \\
\text { клетки и специфический антиген (например, бактерии } \\
\text { Mycobacterium tuberculosis, вызывающие туберкулез). }\end{array}$ \\
\hline 4 & \multicolumn{2}{|c|}{$\begin{array}{l}\text { Образец подвергается инкубации в специальных условиях в течение некоторого } \\
\text { времени. Если клетки из исследуемого образца крови уже имели контакт с данным } \\
\text { антигеном, то во время инкубации они активируются и начинают выделять } \\
\text { специфические цитокины. Выделенные цитокины связываются с антителами, } \\
\text { нанесенными на поверхность носителя. }\end{array}$} \\
\hline 5 & & $\begin{array}{l}\text { После окончания периода инкубации клетки, антиген и } \\
\text { субстрат смывают с поверхности носителя. На нем } \\
\text { остаются только антитела и связавшиеся с ними } \\
\text { цитокины }\end{array}$ \\
\hline 6 & & $\begin{array}{l}\text { Добавляются биотинилированные вторичные анти- } \\
\text { цитокиновые антитела. }\end{array}$ \\
\hline 7 & & Добавить стрептавидин-Пероксидазу \\
\hline 8 & & $\begin{array}{l}\text { Добавить субстрат и контролировать формирование } \\
\text { окрашенных точек. В результате окраски на образце } \\
\text { образуются специфические пятна, давшие название } \\
\text { анализу (от англ. spot - пятно). }\end{array}$ \\
\hline
\end{tabular}


Метод ELISPOT исходно предназначался для количественного определения Влимфоцитов, секретирующих специфические антитела. В дальнейшем этот анализ был адаптирован к различным задачам, и, прежде всего, к идентификации и количественному определению клеток, вырабатывающих цитокины. ELISPOT позволяет визуализировать секретируемый продукт на поверхности активированной или стимулированной к иммунному ответу индивидуальной клетки, что дает и качественную (тип иммунного белка), и количественную (число отвечающих клеток) информацию.

Каждое пятно в общем случае представляет собой единственную клетку, секретирующую специфический цитокин. Пятна подсчитываются либо вручную (с помощью стереомикроскопа), либо с использованием ELISPOT-ридеров (рис.63), которые обладают компьютерными возможностями визуализации активно продуцируемых цитокинов. Это позволяет максимально автоматизировать анализ и обеспечить более высокую его точность.
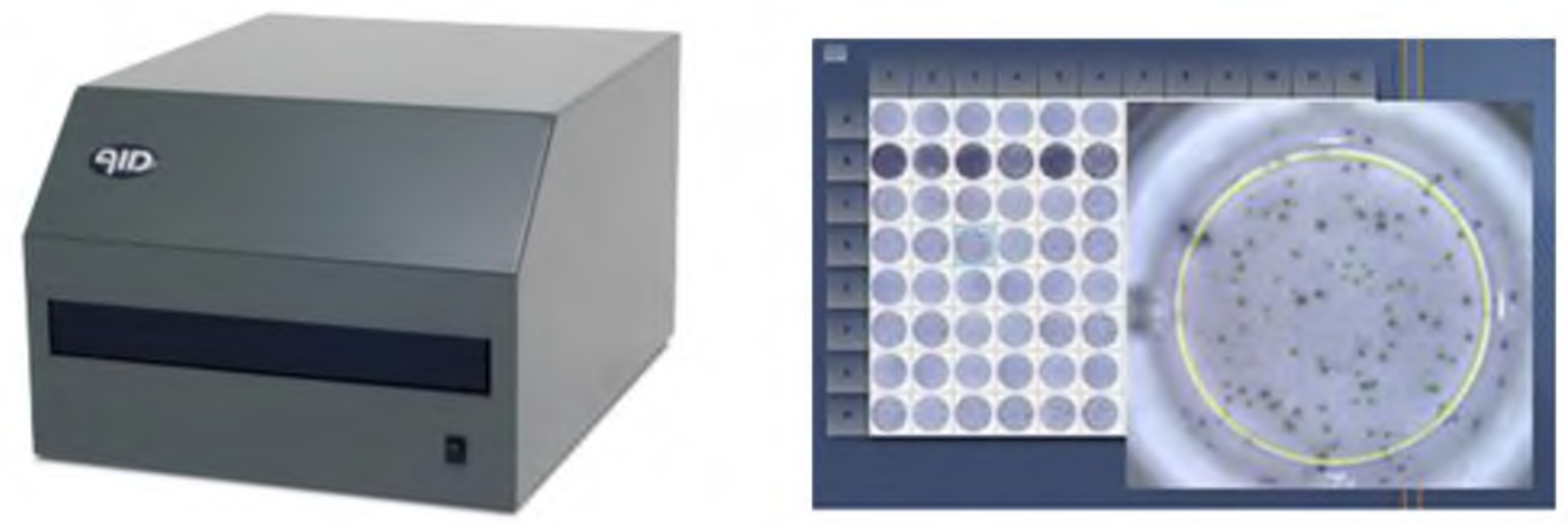

Рис.63. ELISPOT-ридер: AID EliSpot Reader.

Визуализация ELISPOT-анализа с помощью автоматического ридера

Благодаря уникально высокой чувствительности ELISPOT-анализа, идентификация малочисленных клеточных популяций (при антиген-специфичных ответах), которая была недоступна ранее, теперь стала относительно простой задачей. Такая уникально высокая чувствительность, во многом, определяется тем, что детектируемый продукт в момент анализа находится на поверхности секретирующей клетки, будучи связан с ее рецепторами, до того, как он растворится в супернатанте или деградирует. Это делает ELISPOT-анализ значительно более чувствительным, чем ИФА. Пределы его чувствительности ниже $1 / 100$ 000, что делает этот метод очень полезным для мониторинга антиген-специфичных ответов в различных областях иммунологических исследований, включая исследования рака, пересадку органов, инфекционные заболевания и разработку вакцин.

Метод ELISPOT, благодаря своей высокой чувствительности, воспроизводимости и простоте, остается сегодня эталонной технологией для измерения специфических ответов Тлимфоцитов с применением в различных областях исследований (разработка вакцин, диагностика инфекционные заболевания, аллергии, опухоли и аутоиммунные заболевания). Так например в AO «Генериум» локализовано производство набора T-SPOT.TB® (компании Oxford Immunotech) для диагностики туберкулеза. Иммунный ответ на инфицирование М. tuberculosis является преимушественно клеточно-опосредованным. В процессе этого ответа, T клетки сенсибилизируются к антигенам M. tuberculosis. Активированные эффекторные T клетки, $\mathrm{CD} 4$ и $\mathrm{CD} 8$, выделенные из крови, могут быть подсчитаны благодаря способности стимулироваться этими антигенами in vitro. Применение специально подобранных антигенов ESAT-6 и CFP10, входящих в состав микобактерий комплекса M. tuberculosis (M tuberculosis, $\mathrm{M}$ bovis, $\mathrm{M}$ africanum), повышает эффективность и специфичность теста, так как эти антигены 
отсутствуют в БЦЖ и во многих других не вирулентных для человека микобактериях, находящихся в окружающей среде. Тесты ELISPOT могут быть использованы для оценки иммунной памяти (иммунного отклика), для определения количества специфичных для вирусных антигенов лимфоцитов, секретирующих цитокины, и для определения Т-хелперного профиля иммунного ответа вакцинированного.

Т-клеточный ответ важен для устранения вируса и контроля развития заболевания у пациентов с COVID-19, которые были естественно инфицированы SARS-CoV-2. В частности, набор Тигра-Тест® SARS$\mathrm{CoV}-2$ для выявления in vitro в крови Т-лимфоцитов, специфически отвечающих на антигены вируса SARSCoV-2) позволяет подсчитать отдельные активированные SARS-CoV-2-специфичные T-клетки.

B настоящее время некоторые биотехнологические компании наладили выпуск исследовательских наборов Т- и В-клеточных ELISPOT для SARS-CoV-2, что позволит качественно усилить борьбу с пандемией COVID-19.

Мультиплексной модификацией метода ELISPOT является метод FLUOROSPOT. Основное отличие состоит в том, что анализ FLUOROSPOT позволяет одновременно выявлять наличие нескольких аналитов на одном планшете с лунками, за счет использования флуоресценции, а не ферментативной реакции для обнаружения (рис.64).
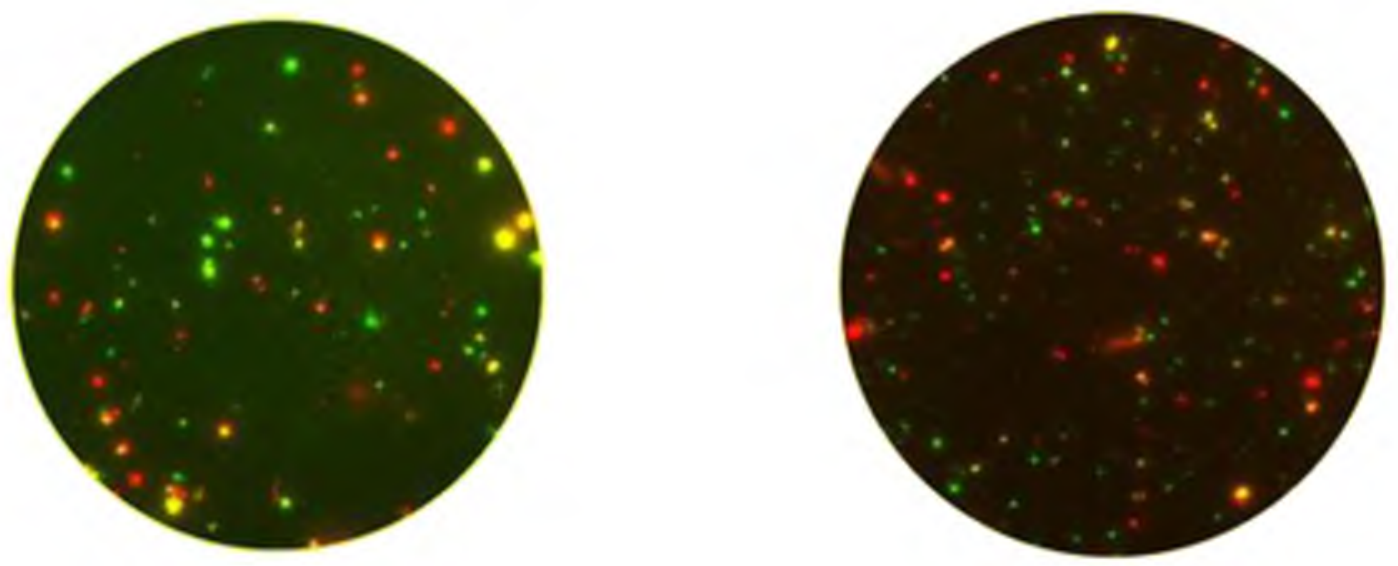

\section{Рис. 64. AID CoV-iSpot обнаруживает реакцию IFN- $\gamma$ и IL-2 специфически активированных Т-клеток против коронавирусов (смесь пептидов PAN-Corona) и / или SARS-CoV-2 (смесь пептидов SARS-CoV-2).}

В ближайшее время для идентификации аналита будет использоваться, массспектрометрия с мониторингом множественных реакций (MRM). Анализы MRM основаны на определении пептидах целевых белков, которые уникальны для протеолитически расшепленных белков. Обнаружение и количественная оценка основаны на выборе этих конкретных пептидов и их фрагментов, а также на различении всех других аналитов в образце. Это исследование в отличие от анализов на основе антител позволяет одновременно обнаруживать и количественно определять несколько биомаркеров за один цикл анализа без необходимости в специфических антителах. Кроме того, анализы на основе MRM для абсолютного количественного определения являются более экономичными по времени и стоимости для каждого параметра и образца, чем ELISA, и можно легко добавлять новые аналиты. Таким образом, MRM облегчает количественную оценку белков в широком динамическом диапазоне в сложной матрице образца, такой как сыворотка человека. За 
последнее десятилетие методы MRM на основе пептидов успешно применялись для обнаружения и количественного определения биомаркеров, например, для заболеваний коронарных артерий, различных типов рака, гипертонии, артрита и ограничения внутриутробного развития. 


\section{МЕТОДЫ ИССЛЕДОВАНИЯ ИММУННОЙ СИСТЕМЫ}

\section{Глава 9. Молекулярно-генетические исследования в иммунологии}

В основе этих методов лежат манипуляции с ДНК и/или РНК, и молекул формирующиеся в цепочки ген-белок-функция. Это сложные методы диагностики, требуют определённых лабораторных условий и подготовки квалифицированного персонала. Однако в последнее время в связи с внедрением автоматизации и информационных технологий они все шире внедряются в клиническую практику, а некоторые как например ПЦР практически вытеснили традиционные лабораторные исследования Первый этап всех методов - получение образцов ДНК или РНК и их идентификация, затем определение различных полипептидов и затем определение метаболических реакций реализуемых определенным пептидом.

Полимеразная цепная реакция (ПЦР). Самый распространенный молекулярногенетический метод исследования. На сегодняшний день существуют десятки модификаций этого метода, однако наиболее распространенной является ПЦР в реальном времени (qPCR, Real-Time PCR, ПЦР-РВ, кПЦР).

Принцип ПЦР основывается на многократной амплификации целевого фрагмента ДНК с помощью ДНК-полимеразы. Как известно, ДНК представляет собой двуцепочечную молекулу, состоящую из четырех типов нуклеотидов (дезоксинуклеозидтрифосфатов): аденозина, тимидина, цитидина и гуанозина. Цепи ДНК направлены антипараллельно и удерживаются вместе за счет водородных связей между азотистыми основаниями, входящими в состав нуклеотидов. Связи образуются по принципу комплементарности: аденин соединяется с тимином (или урацилом в РНК), а гуанозин - с цитидином. Таким образом, имея одну цепь ДНК, легко построить ее пару.

Цикл ПЦР состоит из трех этапов: денатурации, отжига праймеров и элонганции (синтеза ДНК) (рис. 65). Обычно выполняется 20-35 циклов.
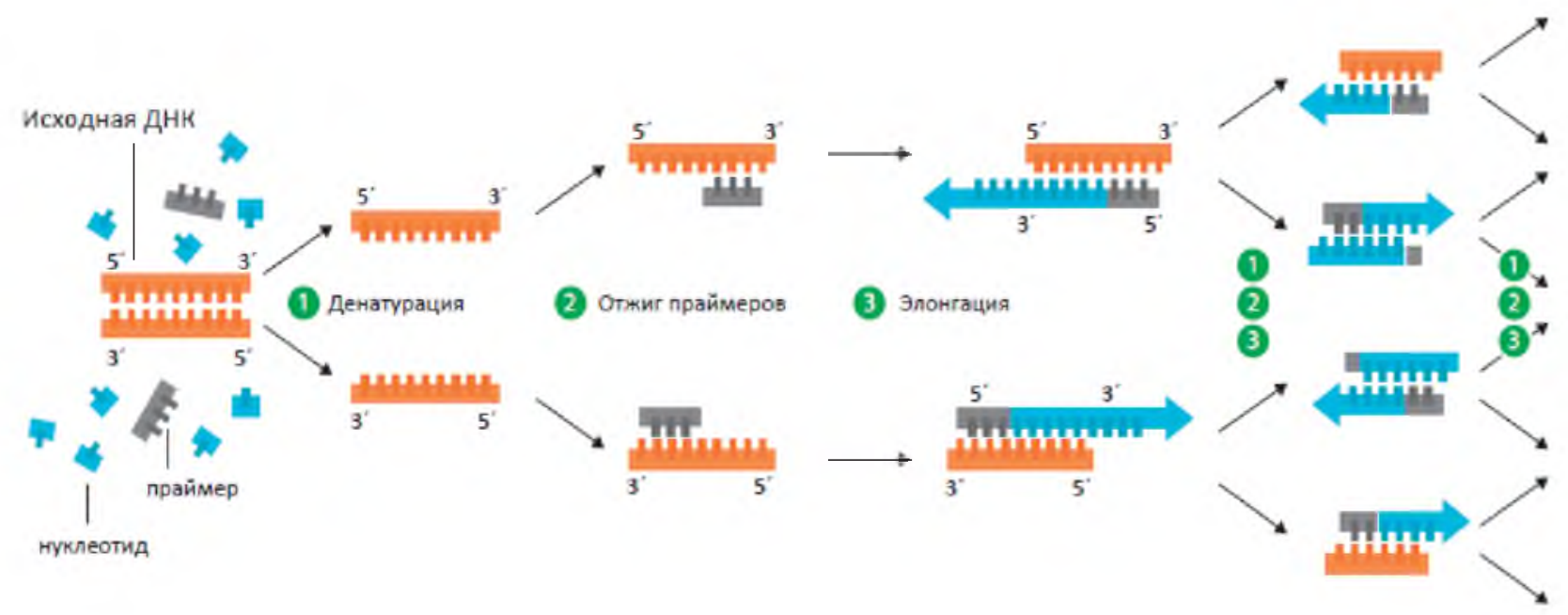

Рис.65. Схема полимеразной цепной реакции 
В результате число копий фрагмента растет в геометрической прогрессии и через 25 циклов амплификации синтезируются $10^{6}$ таких копий. Благодаря этому происходит многократное увеличение количества специфических фрагментов ДНК, что значительно упрощает дальнейший анализ. (Рис. 66).

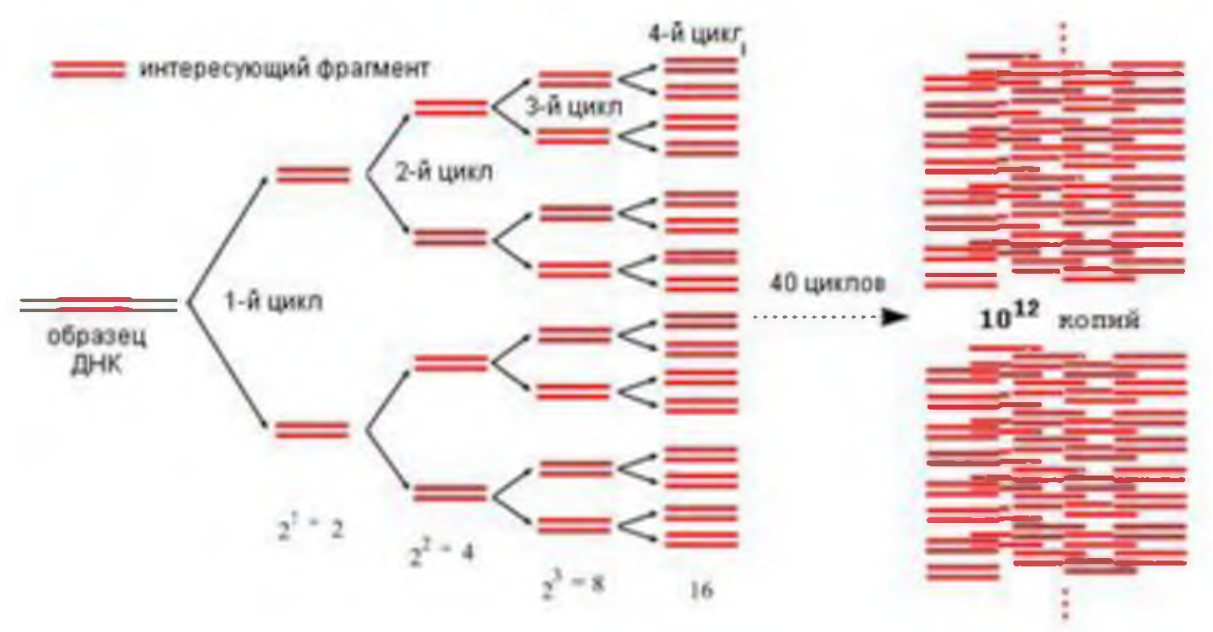

Рис.66. ПЩР анализ

ПЦР состоит из трех основных процедур: 1) подготовка исследуемой пробы материала, которая в большинстве случаев сводится к выделению ДНК или РНК; 2) амплификации (собственно ПЦР); 3) детекция продукта ПЦР (амплифицированной нуклеиновой кислоты).

Для визуализации результатов амплификации используют различные методы. Ранее использовался метод электрофореза, основанный на разделении молекул ДНК по размеру. Однако этот метод не позволяет точно определить содержание ДНК в исходном образце. Для решения этой задачи используют метод ПЦР в реальном времени, или количественной ПЦР.

ПЦР в реальном времени. Для проведения ПЦР в реальном времени необходимы те же компоненты, что и для стандартной ПЦР, а также интеркалирующий краситель или флуоресцентный гибридизационные зонды. С их помощью возможна детекция накопления продуктов ПЩ оптическими датчиками, встроенными в амплификатор. Наиболее часто использующийся интеркалирующий краситель - SYBR Green I, резко увеличивающий флуоресценцию (в 1000 раз) после связывания с двухцепочечной ДНК. Среди флуоресцентных гибридизационных зондов наиболее популярны зонды типа TaqMan.

Они представляют собой небольшие

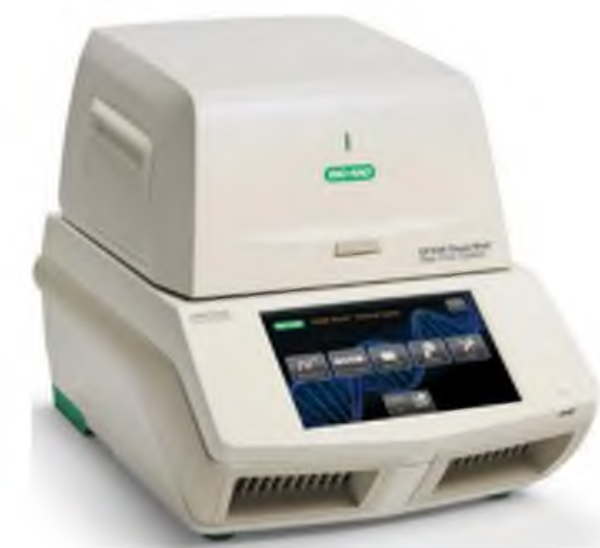

Рис.67. Амплификатор СЕХ96

Touch для проведения ПЦР в реальном времени. олигонуклеотиды, внутреннему участку амплифицируемого фрагмента ДНК, и содержат два флуорофора: репортер и гаситель. Пока зонд связан с матрицей, гаситель поглощает флуоресцентный сигнал от репортера, однако когда ДНК-полимераза доходит до зонда, она его разрушает, репортер и гаситель отдаляются друг от друга, и флуоресценция заметно разгорается. Это детектируется после каждого цикла ПЦР, таким образом, можно в реальном времени наблюдать за накоплением продукта.

Один из наиболее популярных приборов для проведения ПЩР в реальном времени - амплификатор CFX96 Touch производства компании Bio-Rad (рис. 67). 
Данные накопления продуктов ПЦР представляются в виде графика, который состоит из базовой линии, экспоненциальной фазы и плато (рис. 68). На начальных этапах флуоресценция слабая, так как продукта мало, поэтому её трудно отличить от фона. По мере накопления продукта сигнал растёт сначала экспоненциально, а затем выходит на плато. Ключевой параметр в ПЦР в реальном времени - это пороговый цикл, представляющий собой значение количества циклов реакции, при котором кривая амплификации и

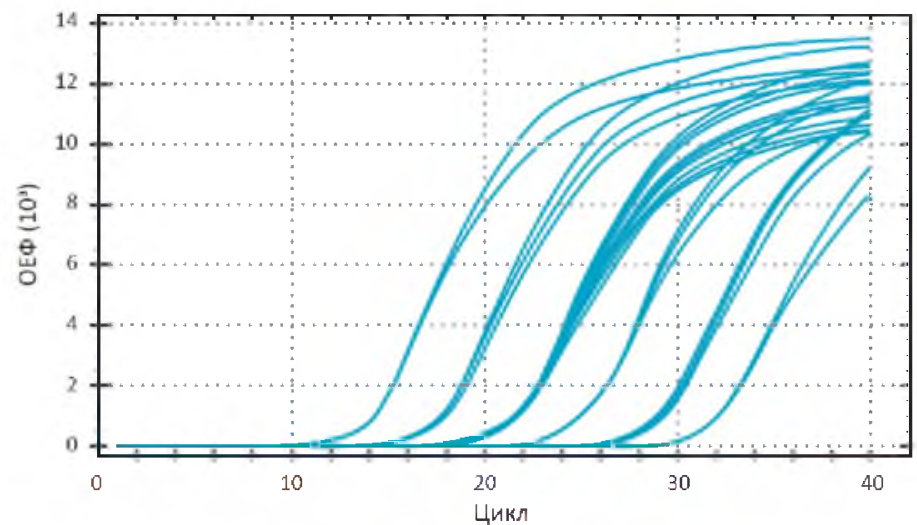

Рис.68. Зависимость относительного уровня флуоресценции от цикла ПЦР. прямая порога чувствительности прибора пересекаются. Номер порогового цикла обратно пропорционален концентрации ДНК в исходном образце. Для количественного определения ДНК необходимо построить калибровочную кривую, исходя из данных для образцов с известной концентрацией.

Метод ПЦР в реальном времени широко используется для диагностики инфекционных заболеваний, а также для определения вирусной нагрузки (например, у ВИЧ-инфицированных пациентов). Также метод ПЦР используется для исследования непосредственно клеток иммунной системы, в частности для HLA-типирования.

Один из видов ПЦР нашел применение в in vitro диагностике иммунодефицитных состояний. Для выявления дефектов того или иного звена иммунитета (гуморального или клеточного) применяется количественная мультиплексная полимеразная цепная реакция в режиме реального времени.

В процессе созревание Т- и Влимфоцитов в тимусе и костном мозге происходит формирование клеточньх рецепторов посредством рекомбинации генов в цепи эписомальной ДНК, с целью создания уникального участка, распознающего антиген. Во время каждой такой рекомбинации из цепи вырезается небольшой фрагмент, образующий эксцизионное кольцо. Эти кольца получили названия TREC (T-cell Receptor Excision Circle) и KREC (Kappa-deleting Recombination Excision Circle). TREC сопровождают созревание практически всех Т-лимфоцитов, а KREC - всех Bлимфоцитов и, таким образом, служат маркерами их количества (рис.69).

Методика позволяет судить о количестве Т- и В-лимфоцитов на

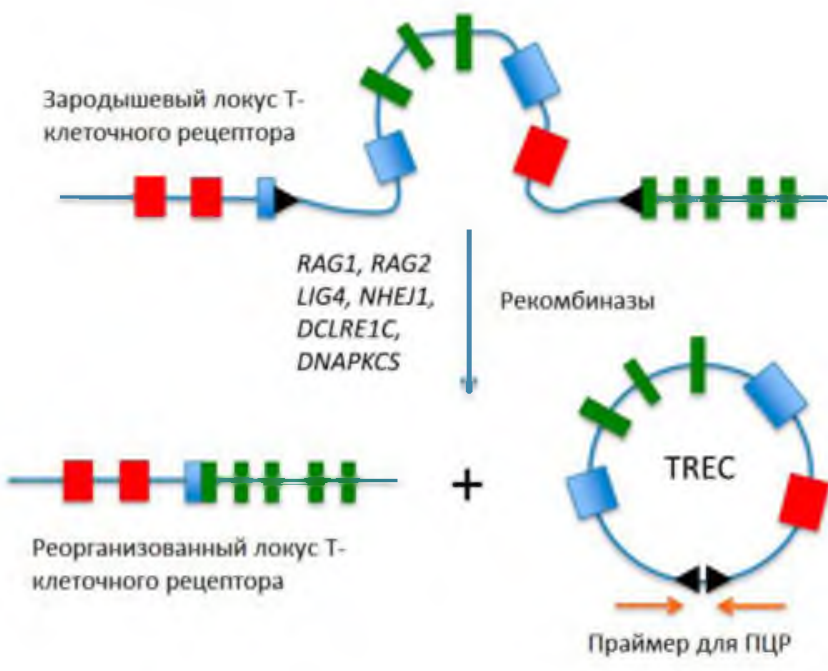

Рис.69. Молекулярные основы диагностики иммунодефицитов используя ПЦР.

основании измерения уровней TREC и KREC - побочных продуктов рекомбинации генов T- и B-клеточных рецепторов. Снижение количества TREC и/или KREC в крови свидетельствует о наличии иммунодефицитных состояний.

Материалом для исследования может служить как цельная кровь, так и сухое пятно крови (в том числе собираемое в ходе национальной программы скрининга новорожденных). 


\section{БИТ-TECT ЗНАТЬ, чтобы СПАСАТЬ}

Первичные иммунодефицитные состояния (ПИДС) представляют собой группу тяжелых, генетически детерминированных заболеваний, вызванных необратимым нарушением различных звеньев иммунитета

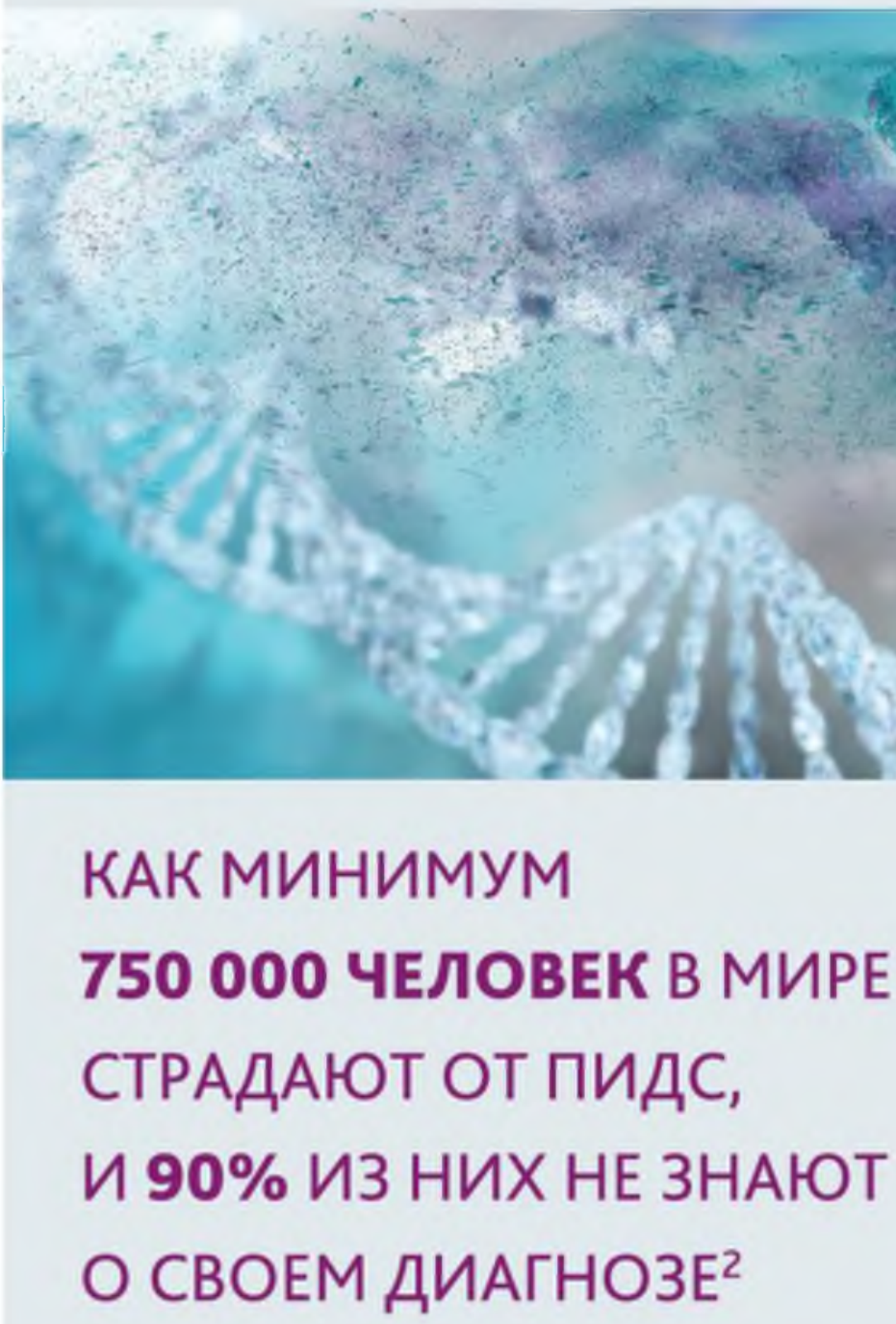

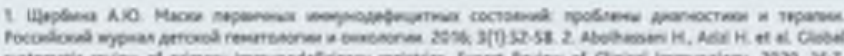

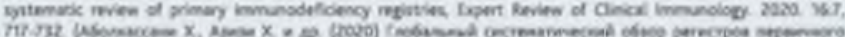
Tratr te Cy.

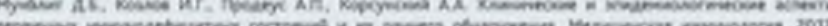
sia) $105-512$

ПИДС приводит к развитию тяжелых хронических рецидивирующих инфекций, устойчивых к стандартным схемам терапии, развитию аутоиммунных проявлений и патологической лимфопролиферации, 3

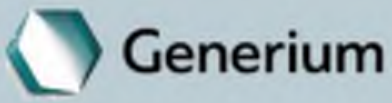

AO *ГЕНЕРИУМ» 601125, Владияирохая о6л., Петушинский район, пос. Вольгинский, ул. Занодская, стр. 273 Тел/факс + 7 (495) 988-47-94 
Капельная цифровая ПЦР. Наиболее точным методом определения количества ДНК является капельная цифровая ПЩР (кцЩР, ddPCR). В отличие от ПЩ в реальном времени, являющейся методом измерения относительного количества ДНК, кцПЦР - абсолютный количественный метод. Он позволяет определять количество копий ДНК в образце без необходимости построения калибровочных кривых. В основе кцПЦР лежит разделение пробы на тысячи капель (компартментов) и проведение ПЦР непосредственно в каждой капле. Определение количества ДНК проводят прямым подсчетом капель с наличием или отсутствием в них мишени, что существенно увеличивает стабильность системы и делает ее менее зависимой от эффективности ПЩ. Концентрация ДНК-мишени определяется в исходном образце в виде числа копий в микролитре с чувствительностью до 1 молекулы.

Такая точность необходима при исследовании различных геномных изменений, таких как вариации числа копий генов (CNV) или однонуклеотидные замены (SNP). Эти генетические полиморфизмы являются одним из ключевых механизмов развития онкологических и других заболеваний, в том числе аутоиммунных. Анализ экспрессии гена $H E R 2$ и вариаций числа его копий гена является важнейшим этапом в диагностике и лечении рака груди. Точность применяемых стандартных методов иммуноцитохимии и флуоресцентной гибридизации in situ (FISH) составляет лишь 80\%, тогда как кцПЦР - 99\%. Кроме того, метод отлично работает со сложным образцами, такими как фиксированные в формалине парафинизированные (FFPE) ткани. кцПЦР позволяет обнаруживать до $0,01 \%$ минорного генома в присутствии генома нормальной ткани. Например, можно детектировать 1 копию генома вируса герпеса человека 6 типа (HHV-6) среди 1,7 миллионов копий геномов человека. Также с помощью данного метода можно определять точечные мутации в сложных образцах, например, однонуклеотидные замены в гене $B R A F$ и других генах сигнального каскада RAS, обусловливающие развитие злокачественных опухолей.

Метод кцПЦР можно

использовать при неинвазивной жидкостной биопсии для поиска мутаций в свободно циркулирующей опухолевой ДНК, для подбора наиболее противоопухолевой терапии, а также диагностики рецидива или метастаз. Также можно детектировать контаминанты в образцах окружающей среды, например, аллергены в воздухе или пище. Общепризнанным лидером в области кцЩР является система QX200 производства компании BioRad. Система QX200 состоит из двух частей: генератора и ридера капель (рис. 70). Также для проведения

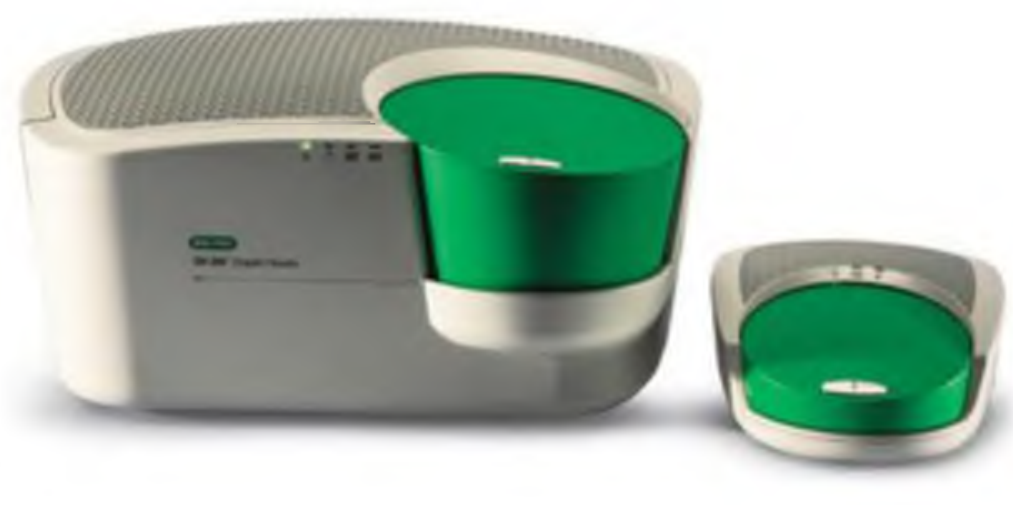

\section{Рис.70. Система кцПЦР QX200 QX200 Droplet Digital PCR System.}

Ридер капель (слева) и генератор капель (справа). кцПЦР необходим амплификатор.

На первом этапе при постановке кцПЦ готовится ПЦР-смесь с флуоресцентными зондами, меченными FAM и HEX (или VIC), или же с интеркалирующим красителем EvaGreen. Для этого используются только запатентованные реагенты, специально разработанные компанией Bio-Rad для генерирования капель.

На следующем этапе 20 мкл ПЦР-смеси, в которой требуется определить количество исследуемой ДНК, помещают в генератор капель и создают водно-масляную эмульсию. За счет системы микрофлюидики он разделяет реакционную смесь на 20000 капель 
нанолитрового объема. В процессе генерации капель образуются капли одинакового размера, что обеспечивает высокоточный количественный подсчет мишеней (рис. 71).
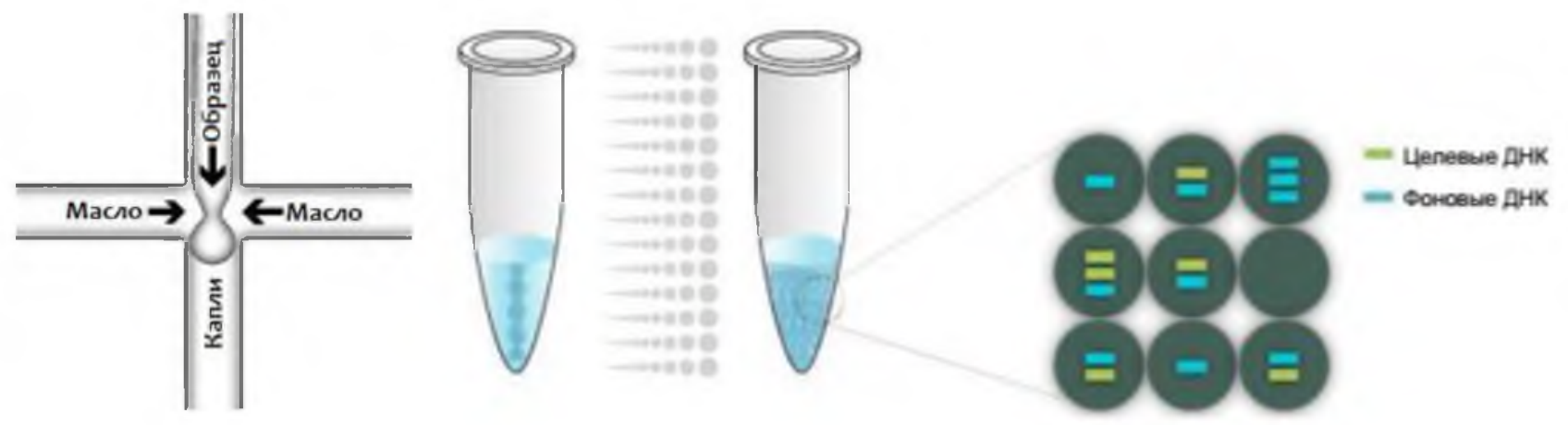

\section{Рис. 71. Процесс формирования одинаковых по размеру и объему капель.}

Генетический материал распределяется по каплям случайным образом, по закону распределения малых чисел Пуассона

На следующем этапе эмульсия в планшете переносится в термоциклер для амплификации мишени. В тех каплях, куда попала ДНК-мишень, образуется ПЦР-продукт, что приводит к увеличению уровня флуоресцентного сигнала. Для расчета концентрации целевой ДНК после ПЦР образцы переносят в ридер, где осуществляется прямой подсчет капель с положительным или отрицательным флуоресцентным сигналом с помощью двухцветной системы определения (настроенной для определения FAM и HEX [или VIC]). Капли, содержащие как минимум одну копию ДНК-мишени, дают повышенный флуоресцентный сигнал по сравнению с отрицательными каплями, в которых ДНК-мишени нет.

Далее программное обеспечение QuantaSoftm подсчитывает количество положительных и отрицательных капель для каждого флуорофора в каждом образце и, применяя алгоритм вычисления функции распределения Пуассона, выдает концентрацию ДНК-мишени в виде числа копий в микролитре.

Секвенирование определении линейного порядка следования компонентов макромолекулы (аминокислоты в белке, нуклеотиды в ДНК и РНК, моносахариды в полисахаридах, и т.д.). В генетике, это процесс определения последовательности нуклеиновой кислоты - порядка нуклеотидов в ДНК четырех оснований: аденина, тимина, гуанина и цитозина в различных генах. Ген — это последовательность ДНК содержащий информацию о структуре белков, влияющих на формирования биохимических процессов в организме, является структурной и функциональной единицей наследственности. Непосредственно гены определяют нашу внешность, показатели здоровья, непереносимость продуктов и лекарств и пр.. Всего в геноме человека более 20 тысяч генов. Несмотря на то, что одни и те же гены есть у каждого человека, тем не менее они имеют варианты одного и того же гена (полиморфизм гена).

Отличие между мутациями и полиморфизмом довольно условно: когда один из вариантов нуклеотидных последовательностей участка ДНК выявляется более чем у $1 \%$ людей в популяции и не приводит к развитию заболевания, это называется полиморфизмом, если же менее 1 \% или с высокой вероятностью приводит к болезни - мутацией.

Полиморфизм в генах могут изменить структуру белков и повлиять на функциональные показатели. Определение первичной нуклеотидной последовательности ДНК является важным этапом молекулярно-генетических исследований, так как различия в нуклеотидном составе могут обуславливать изменения важных функциональных характеристик интересующих нас образцов. Так, отдельные однонуклеотидные полиморфизмы (SNP), 
вариации копийности генов (CNV), делеции или инсерции (Indel) и структурные перестройки в ДНК могут быть причиной возникновения различных наследственных или аутоиммунных заболеваний. Анализ ДНК опухолевых клеток позволяет выявить степень злокачественности опухоли и подобрать необходимую персонализированную терапию. Важнейшее значение генетическим исследованиям принадлежит в диагностике первичных иммунодефицитов.

Один из ключевых методов определения первичной последовательности ДНК секвенирование - был изобретен более 50 лет назад. За десятилетия интенсивного развития удалось разработать несколько поколений секвенаторов и сконструировать не один десяток моделей приборов.

В настоящее время выделяют три поколения секвенирования:

1. Секвенирование по Сэнгеру

2. Массово-параллельное секвенирование нового поколения (Next Generation Sequencing, NGS)

3. Мономолекулярное секвенирование

1. Секвенирование по Сэнгеру (или капиллярный электрофорез) является одной из первых разработанных технологий секвенирования, которая и по сей день остаётся золотым стандартом точности.

Данный метод основан на использовании модифицированных флуоресцентно меченных, так называемых «терминирующих» нуклеотидов.

На этапе пробоподготовки к исходной ДНК добавляются праймеры. При таргетном секвенировании используются праймеры только к интересующим участкам. Если необходимо исследовать всю ДНК, то добавляются рандомные праймеры. С этих праймеров начинается достраивание второй цепи ДНК в последующей реакции ПЦР. Кроме того, к ДНК добавляются нуклеотиды - избыток стандартных немеченых дезоксирибонуклеотидов (dNTP) и некоторое количество специальных «терминирующих» нуклеотидов. Терминирующие нуклеотиды представляют собой дидезоксирибонуклеотиды (ddNTP). Их особенность заключается в том, что после включения в растущую цепь ДНК они не позволяют присоединиться следующему нуклеотиду, то есть после присоединения ddNTP цепь обрывается. Соотношение dNTP и ddNTP подобрано таким образом, что для каждого фрагмента ДНК ddNTP встраивается в случайный момент, и после определенного количества циклов ПЦР образуются фрагменты всех возможных длин (рис. 72).

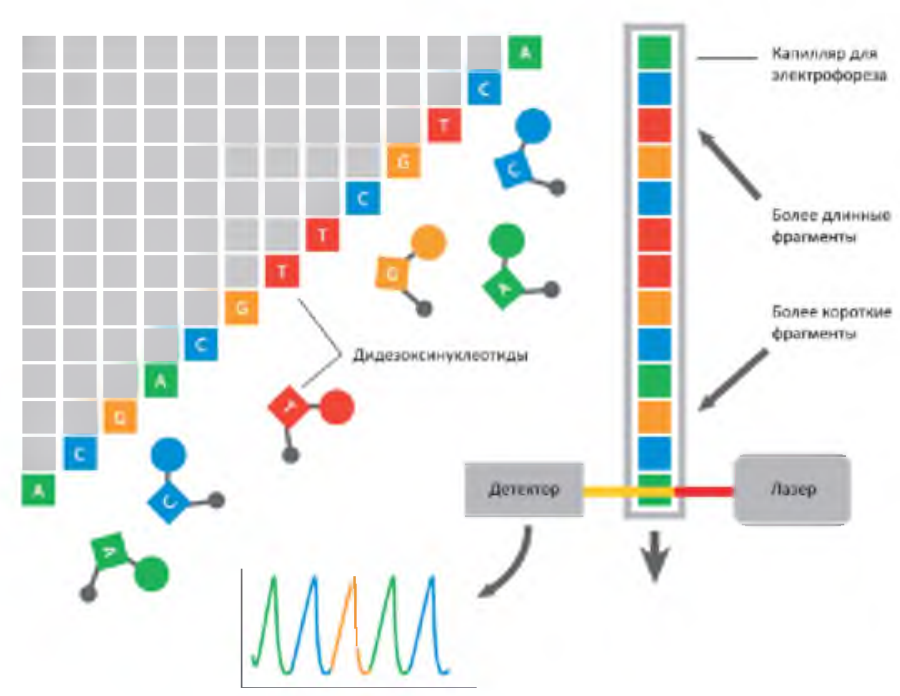

Рис. 72. Секвенирование по Сэнгеру (или капиллярный электрофорез)
После ПЦР с терминирующими нуклеотидами образуется смесь фрагментов всех возможных длин, отличающихся друг от друга на 1 нуклеотид. Разделение фрагментов по размеру происходит в длинном капилляре. Каждый цвет соответствует одному из четырех ddNTP на конце фрагмента ДНК.

Смесь фрагментов разделяется по своей массе в тонком длинном капилляре под действием электрического тока. Более короткие фрагменты двигаются быстрее, длинные - медленнее. В результате фрагменты выстраиваются в ряд по размеру с разрешением в один нуклеотид. При прохождении через дальний конец капилляра фрагменты облучаются лазерным лучом, и сигнал 
от разных флуоресцентных красителей фиксируется как определенный нуклеотид. Таким образом, зная нуклеотид, на котором оборвалась цепь ДНК при ПЦР, мы выстраиваем последовательность ДНК.

Кроме секвенирования в его классическом понимании, капиллярный электрофорез можно также использовать для фрагментного анализа, например, для исследования микросателлитных участков генома при идентификации личности. В таких анализах важно установить длину участков, а не их конкретную последовательность. Для этого флуоресцентно-меченные образцы направляются в капилляр одновременно с размерным стандартном, который мечен другим красителем. Длину фрагментов вычисляют путем сравнения с размерным стандартом.

Несмотря на высокую точность, секвенирование по Сэнгеру имеет ряд ограничений: низкую производительность (до 1200 нуклеотидов на 1 капилляр) и высокую стоимость исследования одного образца. Поэтому в настоящее время данная технология используется в основном для таргетного (целевого) секвенирования фрагментов ДНК с целью анализа мутаций и полиморфизмов в конкретных генах. (например, для типирования генов гистосовместимости человека (HLA) II класса), микросателлитного анализа и валидации данных, полученных на платформах секвенирования нового поколения (NGS).

NGS-секвенирование было разработано в начале XXI века с целью многократно увеличить производительность секвенаторов. Дело в том, что для анализа полного генома человека, как и любых других организмов, необходимо получить данные о миллионах нуклеотидов. Так, например, человеческий геном содержит более 3 млрд пар нуклеотидов, и для его оперативного анализа необходимы существенно более производительные методы, чем секвенирование по Сэнгеру.

Принцип NGS основан на одновременном секвенировании миллионов коротких (до 600 нуклеотидов) фрагментов ДНК, что дало ему название «массово-параллельное» секвенирование. Последующая специальная биоинформатическая обработка позволяет объединить данные последовательностей миллионов коротких фрагментов в длинную исходную цепь ДНК.

Технологический процесс NGS-секвенирования можно условно разделить на три этапа: подготовка библиотек, клональная амплификация и, непосредственно, само секвенирование.

На этапе подготовки библиотек исходная ДНК фрагментируется, и к фрагментам «пришиваются» адаптеры с известной последовательностью. Подобная смесь фрагментов ДНК, фланкированных адаптерами, называется библиотекой (Рис.73). Адаптеры служат сайтами посадки праймеров для дальнейших этапов амплификации фрагментов. В адаптеры также могут быть включены уникальные короткие последовательности, так называемые баркоды, для возможности одновременного (мультиплексного) секвенирования нескольких образцов за один запуск прибора.

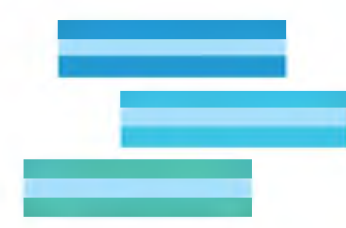

Иоходная ДНК
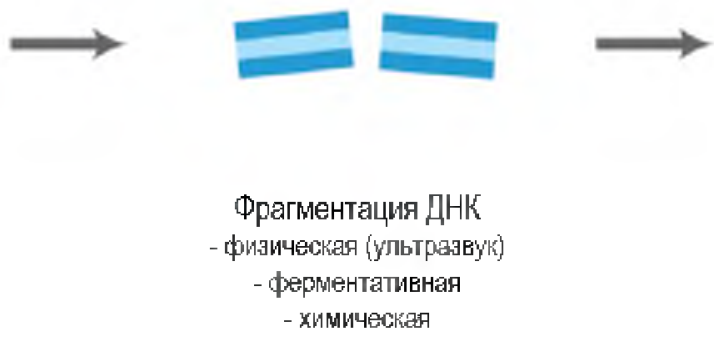

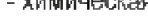

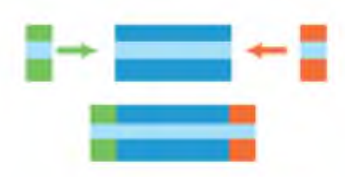

Пигирование адаптеров (и бankonos)

Рис. 73. Этапы подготовки NGS-библиотек 
Количество фрагментов, получаемых в ходе подготовки библиотек, обычно недостаточно для проведения этапа секвенирования, так как чувствительность прибора не позволяет работать с низкими концентрациями фрагментов ДНК. Поэтому после подготовки библиотек проводят клональную амплификацию полученных фрагментов, в ходе которой их количество увеличивается в тысячи раз.

Различные производители секвенаторов разработали свои собственные технологии клональной амплификации (Рис.74). В большинстве случаев для многократного увеличения количества фрагментов библиотеки используется метод ПЦР. ПЦР может проходить непосредственно на ячейке для секвенирования, либо в масляной эмульсии. В случае проведения ПЦР на проточной ячейке (Рис.74A) (технология Illumina), фрагменты библиотеки закрепляются на подложке благодаря взаимодействию с олигонуклеотидами, комплементарными адаптерным последовательностям (Рис.74А-1). В процессе так называемой «мостиковой ПЦР», или механизму «Golden Gate», в результате многократных циклов ПЦР, вокруг каждого исходного фрагмента библиотеки образуется кластер из одинаковых фрагментов. В ходе секвенирования к фрагментам кластеров присоединяются флуоресцентно-меченные нуклеотиды, и сигнал от кластера молекул уже может быть детектирован оптической системой секвенатора.

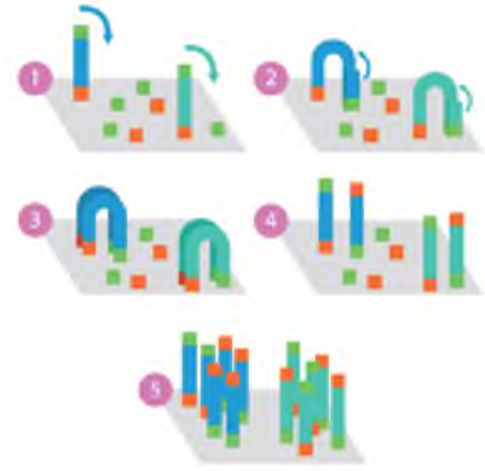

A

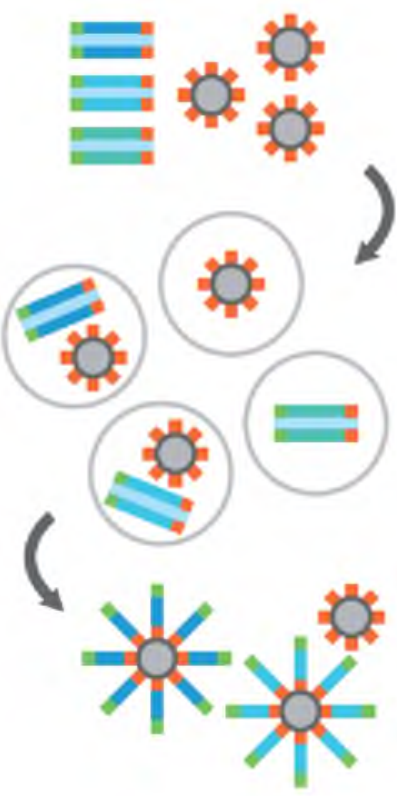

Б

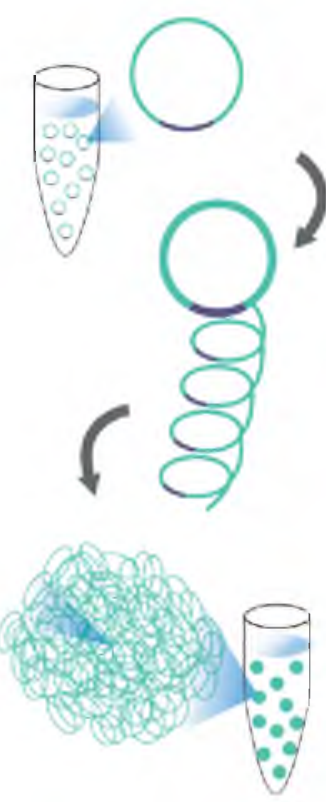

B

Рис. 74. Технологии клональной амплификации

А) Подготовка бибблотек на чипе - мостиковая ПЦР «Golden-gate», Illumina;

Б) Эму льсионная ПЦР, Ion Torrent, Thermo Fisher Scientific;

B) Линейная амплификация методом катящегося кольца, DNBSEQ, MGI.

Технология полупроводникового секвенирования Ion Torrent предполагает клональную амплификацию библиотек c помощью эмульсионной ПЦР. Фрагменты библиотеки помещаются в микроскопические капли масла вместе с компонентами ПЦР-реакции и специальными микросферами, покрытыми олигонуклеотидами (Рис.74Б). В процессе ПЦР микросферы полностью покрываются клонально амплифицированными фрагментами библиотеки. В дальнейшем микросферы наносятся на специальный полупроводниковый чип с микролунками, и с одной микролунки считывается сигнал для одного фрагмента библиотеки.

ПЦР является стандартным методом быстрого увеличения количества ДНК, однако у данного метода есть несколько недостатков, основной из которых - клональное накопление 


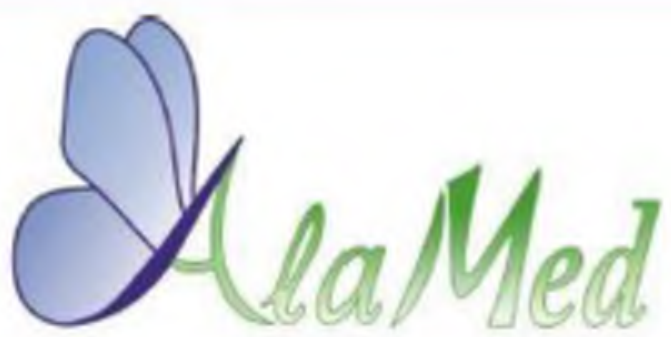

Свяжитесь с нами:

+7 (495) 614-45-97 info@alamed.ru

\section{Решения в Life Sciences}

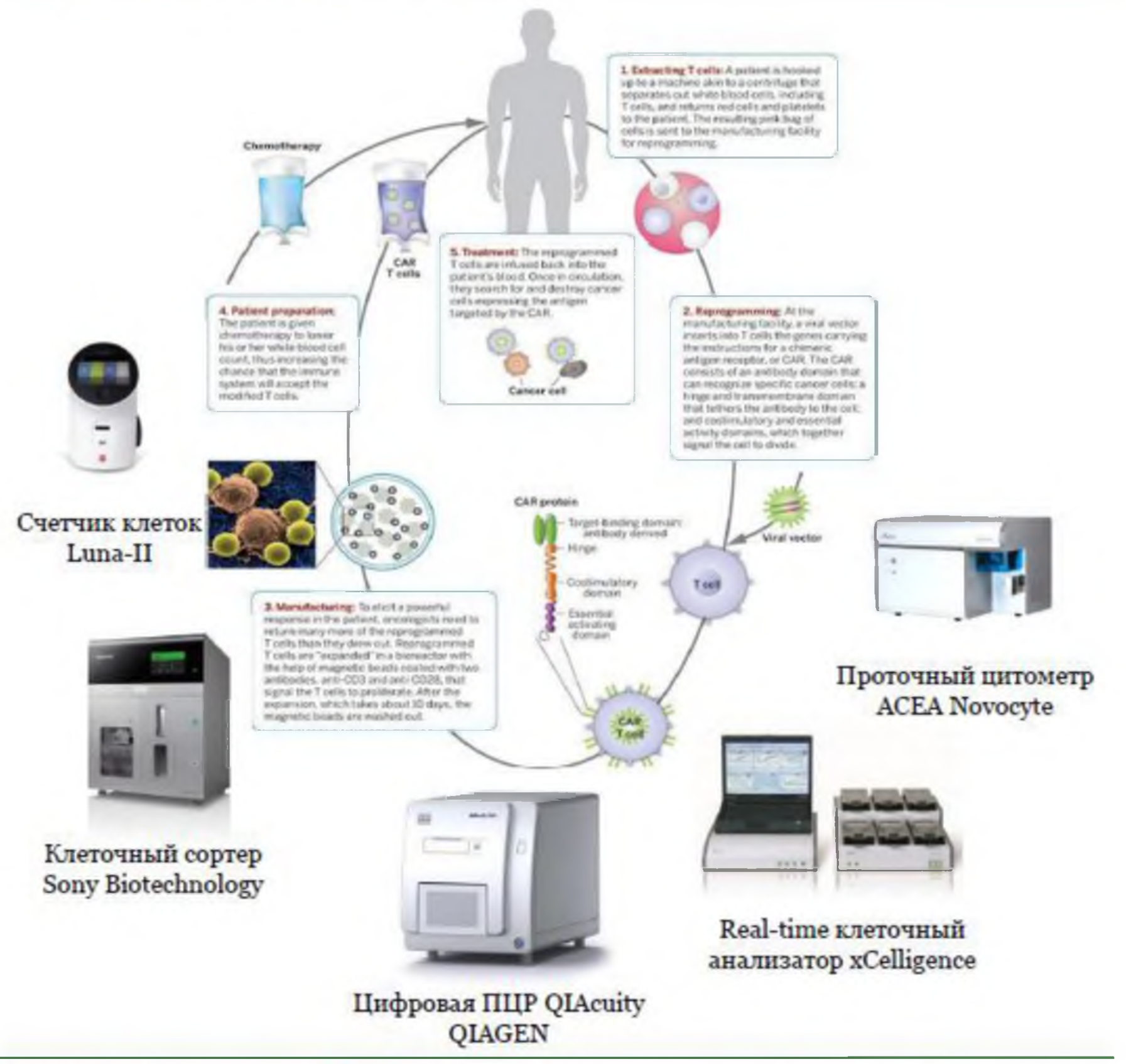

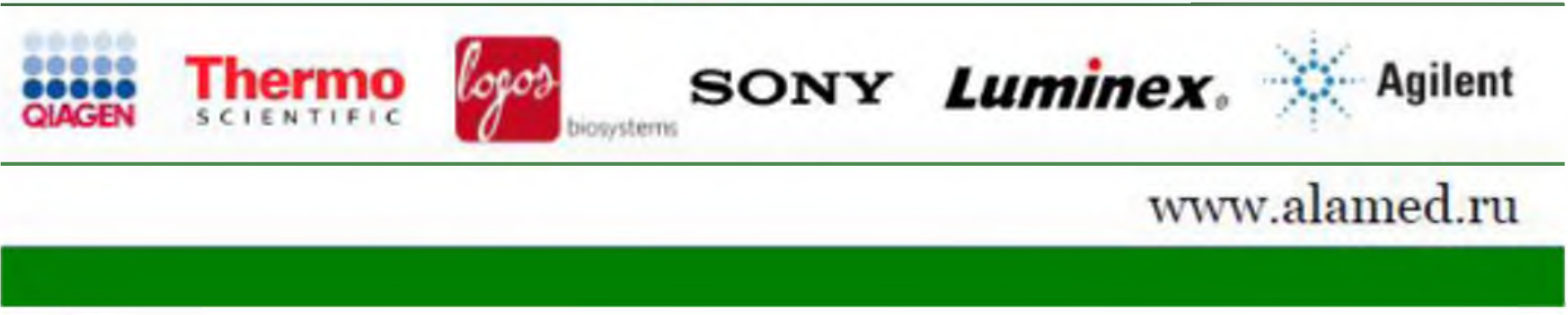


ошибок ДНК-полимеразы. Так как в каждом цикле вновь синтезированная ДНК служит матрицей для новых фрагментов, любая ошибка фермента будет копироваться в следующий фрагмент и накапливаться в геометрической прогрессии. Это затрудняет дальнейший анализ, так как не всегда очевидно, является ли найденный вариант истинной мутацией или ошибкой ПЦР. Проблема частично решается биоинформатической обработкой или добавлением специальных молекулярных индексов, с помощью которых метят каждую исходную молекулу ДНК. Однако, данные манипуляции увеличивают время и стоимость анализа

Инновационный подход к решению проблемы клонального накопления ошибок применяется в технологии DNBSEQ, MGI (Рис.74B). После лигирования адаптеров ДНК денатурируется до одноцепочечного состояния, и в реакцию добавляется олигонуклеотид, частично комплементарный обеим адаптерным последовательностям. В итоге фрагмент замыкается в одноцепочечное кольцо. На следующем этапе к кольцевым фрагментам добавляется специальная полимераза phi29, которая начинает по кругу достраивать вторую цепь ДНК. В какой-то момент полимераза наталкивается на участок, который она же сама синтезировала на предыдущем круге. Однако, благодаря хеликазной активности, phi29 не соскакивает с ДНК, а расплетает цепи и продолжает синтез второй цепи на исходной матрице. Подобный процесс называется линейной амплификацией по принципу «катящегося кольца». В результате многократных циклов формируется длинная одноцепочечная нить ДНК, состоящая из одинаковых повторов исходного фрагмента. Главным преимуществом такого метода является то, что полимераза в каждом цикле копирует исходную матрицу, и клональное накопление ошибок отсутствует. На следующем этапе за счет смены рН и ионной силы в растворе, одноцепочечная нить компактизируется до клубка, так называемого «наношарика» (DNA nanoball, DNB). Наношарики наносятся на проточную ячейку, где присоединяются к специальным заряженным зонам за счет электростатического взаимодействия. Секвенирование происходит путем детекции флуоресцентных меток на встраиваемых нуклеотидах.

Разные технологии секвенирования различаются между собой способом детекции нуклеотидов. Так, например, в технологиях DNBSEQ (MGI) и Illumina нуклеотиды мечены флуоресцентными красителями, и прибор в каждом акте секвенирования детектирует цвет нуклеотида, который в данный момент встраивается в растущую цепь ДНК. После встраивания очередного нуклеотида флуоресцентный краситель отщепляется, и может быть встроен следующий нуклеотид. Другие методы основаны на детекции различных продуктов реакции в ходе синтеза второй цепи ДНК на исходной матрице. Так, например, технология Ion Torrent (Thermo Fisher Scientific) предполагает детекцию протонов, высвобождающихся в процессе присоединения нуклеотида к растущей цепи ДНК. Секвенирование происходит на микрочипах в специальных лунках, к каждой из которых присоединён микро-рН-метр. Разные нуклеотиды подаются на чип последовательно и, в случае присоединения нуклеотида к растущей цепи, возникает локальный скачок $\mathrm{pH}$, который фиксируется прибором. Скачок $\mathrm{pH}$, увеличенный вдвое, означает, что присоединилось два нуклеотида подряд.

Длина фрагментов, получаемая при NGS-секвенировании, как правило, не превышает 600 нуклеотидов. Для выстраивания исходной последовательности ДНК миллионы коротких фрагментов биоинформатически собираются в группы и выравниваются на референсный геном (сравниваются со среднестатистическим «нормальным» геномом). Отличия от референса изучаются как потенциально значимые биомаркеры. В случае исследования экзотических живых организмов, для которых ранее не проводилось секвенирование, проводят так называемое секвенирование de novo. В этом случае сборку фрагментов производить сложнее, поэтому для таких задач желательно использовать максимально длинные прочтения.

Современные приборы позволяют получать сотни миллионов коротких прочтений за один запуск. Для достоверного анализа полного генома человека принято проводить секвенирование с тридцатикратным покрытием, то есть каждый нуклеотид генома должен 
быть прочитан минимум 30 раз (30x). Такое покрытие позволяет избежать ошибок и с достаточной степенью точности выявлять герминативные мутации.

Таким образом, для анализа полного генома человека нужно 30 раз отсеквенировать 3 млрд нуклеотидов, то есть, суммарно получить данные о 90 млрд нуклеотидов. Если длина одного прочтения секвенатора - 300 нуклеотидов, то для получения необходимого количества данных нужно сделать 300 млн прочтений.

Общее количество нуклеотидов, прочитанных за запуск секвенатора, называется выходом секвенирования, или производительностью, и обычно измеряется в Гигабазах (Гбаз $=1$ млрд нуклеотидов).

Выбор той или иной технологии и модели секвенатора зависит от конкретной исследовательской задачи. Так, для исследований транскриптома или крупных перестроек в геноме (например, поиск трисомий плода в образцах крови матери, НИПТ) достаточно использовать малые модели секвенаторов с короткими длинами прочтения (50 нуклеотидов). Для анализа образцов смешанных микробных сообществ (метагеном), или секвенирования de novo, наоборот требуются длинные прочтения (более 300 нуклеотидов).

Различные модели NGS-секвенаторов различаются между собой производительностью, длинами прочтения, скоростью и стоимостью секвенирования (рис. 75).

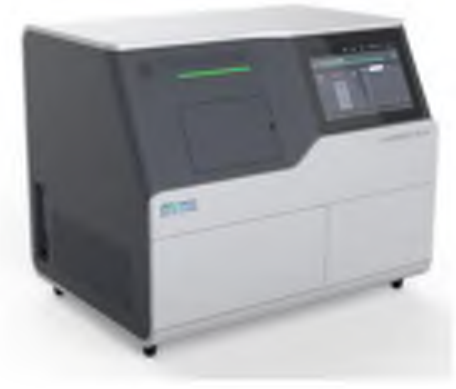

A

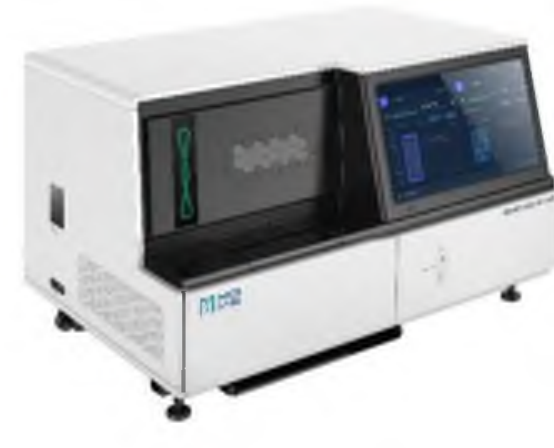

Б

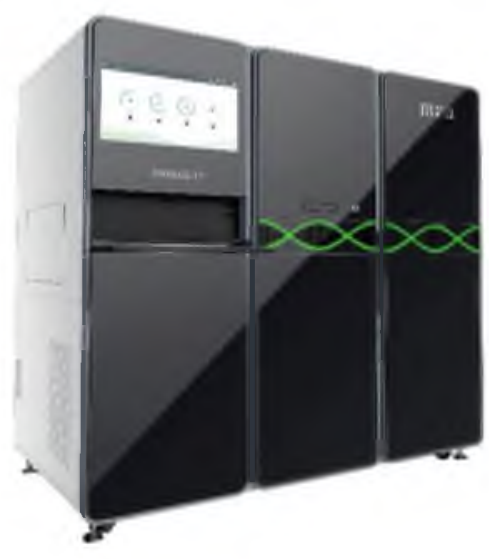

B

\section{Рис. 75. Модельный ряд NGS-секвенаторов DNBSEQ (MGI).}

A) DNBSEQ-G50. Выход до 150 Гбаз, длина прочтений до 150 нуклеотидов, приложения: таргетное секвенирование, секвенирование малых геномов (например, бактерий), репродуктивная генетика;

Б) DNBSEQ-G400. Выход до 1440 Гбаз, длина прочтений до 400 нуклеотидов, приложения: полноэкзомное, полногеномное секвенирование;

В) DNBSEQ-T7. Выход до 6000 Гбаз, длина прочтений до 150 нуклеотидов, приложения: полногеномное секвенирование

Области применения NGS-секвенирования очень разнообразны. Благодаря низкой стоимости данных в пересчете на один образец и высокой производительности, NGS становится рутинным методом как в медицинских исследованиях (поиск биомаркеров онкологических и наследственных заболеваний, репродуктивная генетика), так и в сельском хозяйстве и биотехнологии (генотипирование сельскохозяйственных животных и растений, поиск генов устойчивости к неблагоприятным условиям среды и маркеров качества).

В иммунологических исследованиях NGS широко применяется для глубокого анализа индивидуального разнообразия репертуаров антител и Т-клеточных рецепторов (клональность лимфоцитов), высокопроизводительного HLA-типирования и полногеномного анализа для изучения аутоиммунных и наследственных заболеваний.

Мономолекулярное секвенирование отличается от других платформ исключительно большой длиной прочтений (до 100 тысяч оснований). Определение последовательности ДНК 
происходит в реальном времени и может быть проанализировано ещё во время работы секвенатора (рис.76).

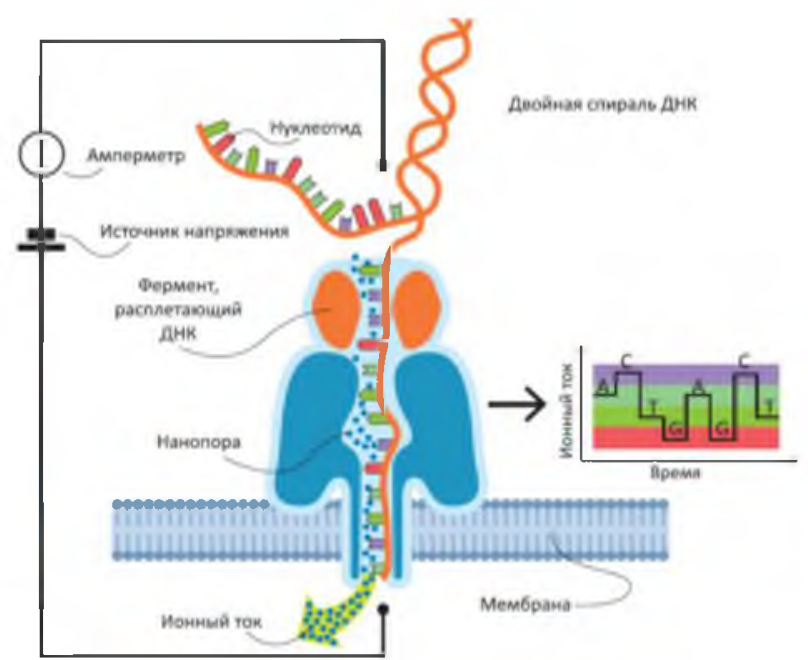

Рис. 76. Принцип мономолекулярного секвенирования
Самая широко используемая технология мономолекулярного секвенирования на данный момент - это нанопоровое секвенирование (Oxford Nanopore). При нанопоровом секвенировании молекулы ДНК под воздействием электрического поля проходят через специальные белковые нанопоры, закрепленные на билипидной мембране. При этом изменяется ток ионов через поры. В зависимости от нуклеотидной последовательности, которая в данный момент проходит через пору, ток изменяется на разную величину, и по графику изменения силы тока можно сделать вывод о нуклеотидной последовательности.

Данная технологи позволяет получать прочтения длиной в десятки тысяч нуклеотидов, что делает её незаменимой для de novo сборки геномов. Однако существенным недостатком на данный момент является высокий процент ошибок - до 10\%, то есть ошибка встречается в каждом десятом нуклеотиде. Для получения корректных данных рекомендуется комбинировать данные длинных нанопоровых прочтений с высокоточными данными NGSсеквенирования.

\section{Методы исследования метаболизма клеток.}

Развитие иммунного ответа, проявление различных заболеваний, созревание и репрограммирование клеток имеют под собой единую фундаментальную основу, а именно, изменение показателей клеточного метаболизма (см.главу 1). Лабораторные исследования позволяют выявить вклад различных метаболических путей, а именно глюколиза, пентозофосфата, окисления жирных кислот, глутаминолиза, цикла Кребса и окислительного фосфорилирования, в модуляции врожденных и адаптивных иммунных клеток на основе их состояния активация/дифференцировка. Используя анализатор Seahorse XF можно, одновременно измеряет показатели двух основных путей получения клеточной энергии: митохондриального дыхания и гликолиза (рис.77).

Измерение гликолиза происходит за счет ECAR (Extracellular Acidification Rate) измерение скорости внеклеточного закисления. В процессе гликолиза клетки генерируют АТФ без участия кислорода с побочными продуктами в виде лактата и протонов водорода. XFp Analyzer фиксирует показатели внеклеточного закисления протонами, тем самым оценивая интенсивность процессов гликолиза в клетках.

Митохондриальное дыхание оценивается за счет OCR (Oxygen Consumption Rate) измерение скорости поглощения кислорода. Митохондрии поглощают кислород в процессе синтеза АТФ с помощью митохондриального дыхания. Этот путь является наиболее оптимальным для получения максимального количества энергии. XFp Analyzer оценивает интенсивность митохондриального дыхания, фиксируя скорость поглощения клетками кислорода.

XFp Analyzer использует специальные транзиентные микрокамеры, позволяющие с высокой точностью и чувствительностью проводить метаболические исследования в 


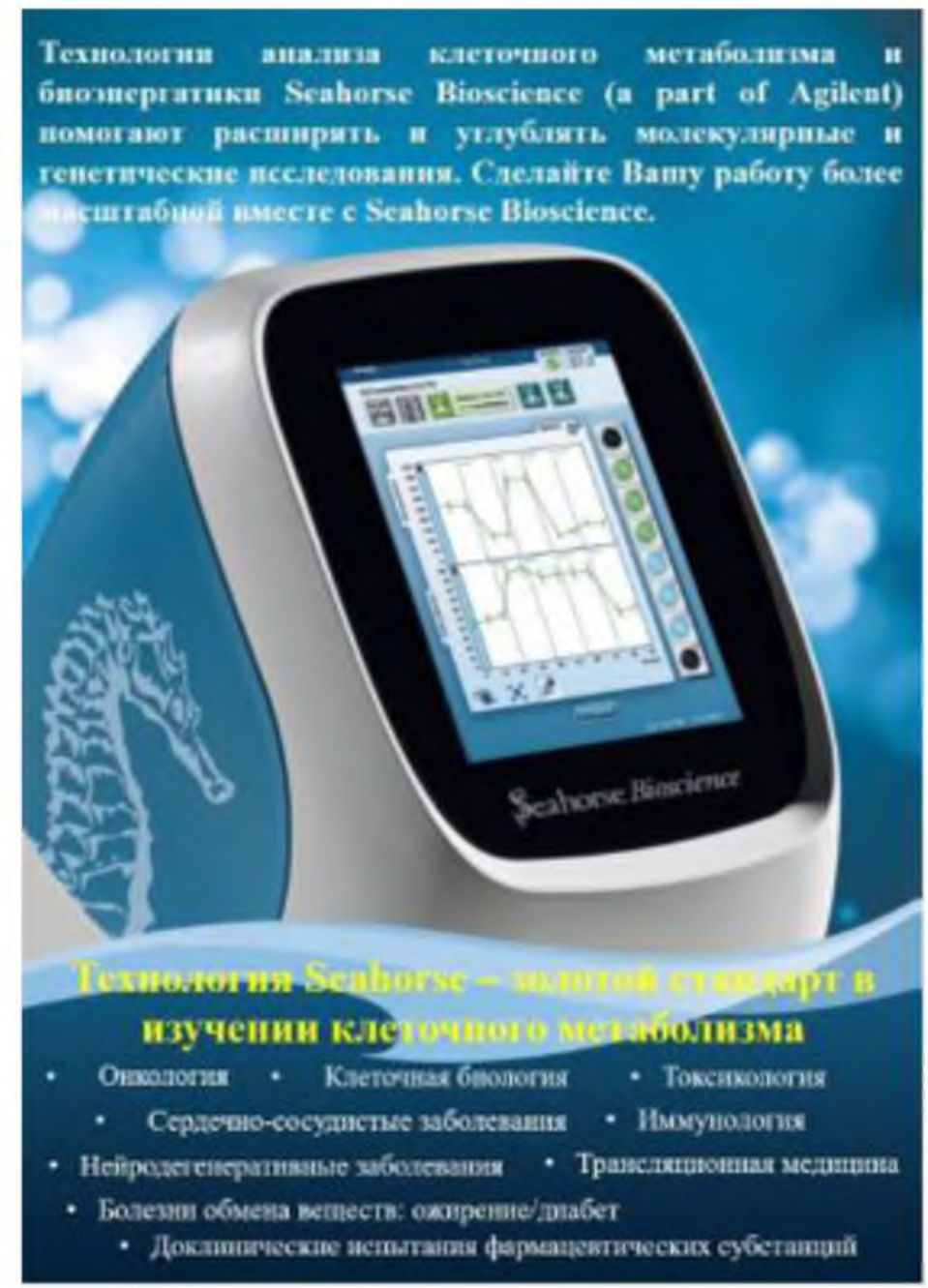

\section{Seahorse Bioscience}

A part of Agilent Technologies

\section{Основные черты технологии Seahorse Bioscience:}

- Подтодит аля работы с лиобыми типами клеток

- Клеточный ответ в реальном времени (1,5 - 2 часа запуок)

- Исследования в микропланшетах $(8,24$, 96 пунок)

- Анализ метаболических сдеигов

- Tесты на цитотоксичность

- Возможность добавления 4-x препаратов в реакционную среду

- Подбор эффективной дозы препарата

- Готовые тест-наборе

- Адаттированнеle аля каждого типа клеток протоколы

- Уаобное интумтивн понятное программнное обеспечение Wave Аля создания протоколов, анализа и

Seahorse
Bioscience
BipAndyeer

Групnа компанмй єБмоХимМахв

119991 Mocced, nersencue ropt, Mry

BCM

$\overline{\text { 6ИOXKWMAR }}$

Ten: (495) 939-2121, 647-2740, 932-9214. E-mait: infoobiochemmack ru, pcrabiochemmack.nu www.biochemmack.ru 
считанные минуты. Возможность автоматического добавления до 4-х веществ в реакционную среду делает XFp Analyzer идеальным инструментом для тестирования препаратов, подбора эффективной дозы и цитотоксических исследований в различных научных и медицинских приложениях.

A

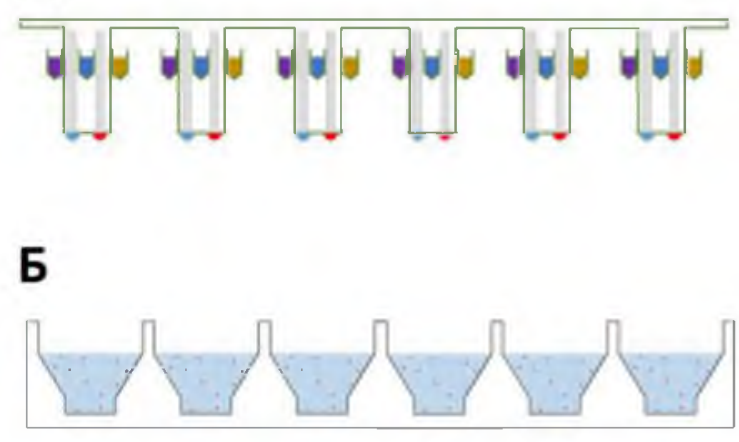

B

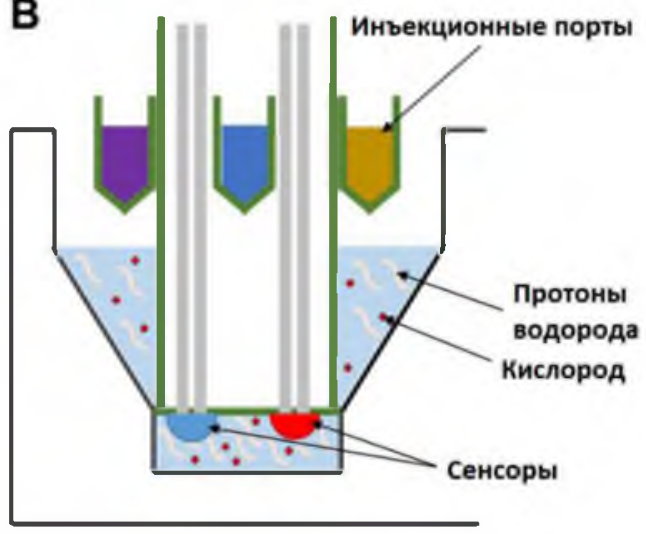

Рис. 77. Схема биоанализатора Seahorse XF.

А. Картридж датчика.

Б. Микропланшет для культивирования клеток.

В. Зонд с 4 портами для добавления любых соединений, и датчиками измерения уровня кислорода и рН раствора.

Биолюминесцентный анализ применим при оценке различных физиологических и патологических состояний человека, связанных с изменением интенсивности и направленности обменных процессов в организме, отдельных его системах. Определение метаболических параметров возможно в цельной крови и в ее составляющих (сыворотке крови или плазме, в эритроцитах, тромбоцитах, лейкоцитах, лимфоцитах), плевральном экссудате, спинномозговой жидкости. Возможна разработка методик для любого биологического материала. Метод основан на использовании биолюминесцентного определения активности ряда ферментов, их кофакторов и субстратов. В настоящее время разработаны методики для определения следующих метаболических параметров: глюкозо-6-фосфатдегидрогеназа;

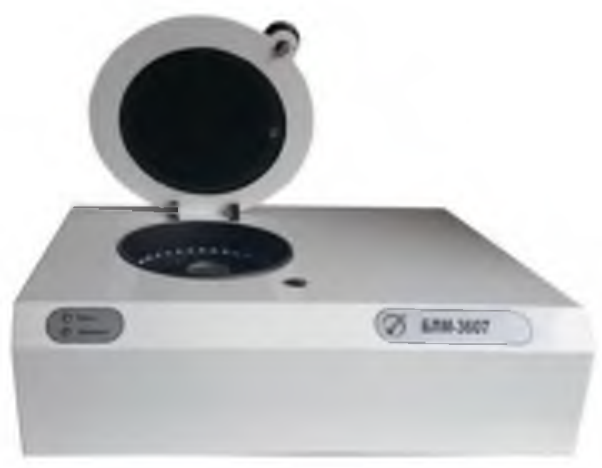
глицерол-3-фосфатдегидрогеназа; лактатдегидрогеназа (прямая и обратная реакция); малатдегидрогеназа (прямая и обратная реакция); малик-фермент (НАДФзависимая малатдегидрогеназа); декарбоксилирующая глутаматдегидрогеназа (прямая и обратная реакция); НАДФ-зависимая глутаматдегидрогеназа (прямая и обратная реакция); НАД-зависимая изоцитратдегидрогеназа; НАДФ-зависимая изоцитратдегидрогеназа; глутатионредуктаза; пируватдегидрогеназный комплекс; 2-оксоглутаратдегидрогеназный комплекс; АТФ; малат; пируват; лактат; глюкозо-6-фосфат; НАД и НАДФ [70, 71, 74, 75, 76, 82]..

Для исследований применяется биоферментный комплекс из светящихся бактерий, производимый в Институте биофизики ФИЦ КНЦ СО РАН. Определение вышеперечисленных параметров проводится на биолюминометрах, выпускаемых СКТБ «Наука» ФИЦ КНЦ СО РАН. Для проведения анализа используются микроколичества биологического материала. 
Доказана информативность и прогностическая значимость метаболических показателей при оценке влияния экологических (климатических и антропогенных) факторов на организм человека, для выделения групп риска по заболеваниям дыхательных путей и ЛОРорганов, для диагностики метаболической иммунодепрессии при таких заболеваниях как ЧДБ OP3, отиты, бронхиты, пневмонии, гепатиты, герпес-инфекции, грибковые и паразитарные инфекции. Определена необходимость тестирования метаболического состояния лимфоцитов крови при таких заболеваниях у детей как атопический дерматит и респираторные аллергозы. Оценка метаболического состояния лимфоцитов крови при вышеперечисленных заболеваниях позволяет более обосновано и корректно назначать медикоментозные средства, контролировать процесс лечения и выздоровления. В случае хронических заболеваний с помощью метаболических параметров возможно осуществлять прогноз время наступления и длительность ремиссии.

Хемилюминесцентный метод. Уровень хемилюминесценции при фагоцитозе характеризует интенсивность «респираторного взрыва» в клетках с продукцией активных форм кислорода, оказывающих бактерицидное действие. Первичные метаболиты активированного кислорода представляют собой супероксидный анион-радикал $\left(\mathrm{O}_{2}-\right)$, перекись водорода $\left(\mathrm{H}_{2} \mathrm{O}_{2}\right)$, гидроксильный радикал $\left(\mathrm{HO}_{2}\right)$, синглетный кислород $\left(\mathrm{O}_{2}\right)$. В качестве основных вторичных метаболитов необходимо отметить гипохлорную кислоту $(\mathrm{HClO})$, хлорамины и продукты перекисного окисления липидов. Взаимопревращения первичных и вторичных оксидантов с мощным энергетическим потенциалом создают динамический спектр молекул, которые прямо или косвенно вовлекаются в реакции фагоцитов. При этом взаимодействие высокоэнергетических оксидантов с люминесцирующими посредниками (люминол, люцигенин и др.) приводит к переходу последних в электронно-возбужденное состояние, выход из которого сопровождается испусканием кванта света. Регистрация светоизлучения хемилюминесцентной реакции производится на хемилюминометрах отечественного или зарубежного производства. В частности, на биохемилюминесцентном анализаторе БЛМ-3607, который выпускается ООО «МедБиоТех» (г. Красноярск, Россия). Механизм хемилюминесценции лейкоцитов зависит от природы стимулирующего агента, отличаясь своей специфичностью. Доказана высокая степень корреляции между уровнем хемилюминесценции фагоцитов и киллингом, поэтому определение хемилюминесценции лейкоцитов может использоваться как один из критериев их способности к завершенному фагоцитозу, позволяющих оценить функциональную активность лейкоцитов.

НСТ-тест. Восстановление НСТ в фагоцитозе прямо зависит от эффективности метаболических процессов в клетке. Интенсивность восстановления отражает активность генерации супероксидных радикалов. Этот метод является чувствительным индикатором раздражения клеток (спонтанный НСТ) и их функциональных резервов (стимулированный НСТ). В норме число НСТ-положительньх нейтрофилов составляет $10 \%$ (или 50-130 у.е.), после стимуляции - 40-80\% (80-200 у.е.). 


\section{ДИАГНОСТИКА ИММУННЫХ НАРУШЕНИЙ}

\section{Глава 10. Иммунологический диагноз}

Диагностика иммунных нарушений сопряжена с рядом проблем. Это связано со сложной многоуровневой организацией иммунной системы, высокой надежностью иммунитета $\mathrm{c}$ многочисленными компенсаторными механизмами, многочисленными регуляторными связями между компонентами иммунной системы и нервной и эндокринной системой. На эффективность иммунитета влияют многочисленные факторы как внутри, так и вне организма. Поэтому после проведения клинического осмотра и получения лабораторных исследований необходимо классифицировать имеющиеся иммунные нарушения для разработки стратегии и тактики эффективной терапии. Традиционно все нарушения функции иммунной системы классифицируют, исходя из проявления различных заболеваний. Во всем мире принято выделять:

1) первичные иммунодефициты;

2) вторичные иммунодефициты (ВИД);

3) аутоиммунные заболевания;

4) аллергии;

5) опухоли иммунной системы.

Нередко выделяют иммунопатологию, связанную с инфекцией и новообразованиями (иммунодефициты) и аутоиммунной патологией и аллергией (аутореакции и/или гиперчувствительность). Но во всех этих случаях мы диагностируем не нарушения функции иммунной системы, а непосредственно определенные заболевания. Однако в патогенезе развития иммунопатологического состояния принимает участие, как правило, не один, а несколько типов реакций, при этом, учитывая клонально-селекционный тип реагирования иммунной системы, могут даже сочетаться гипоэргические и гиперергические типы реакций при одной и той же патологии. Исходя из этого в клинической работе необходимо определить наличие и охарактеризовать тот или иной иммунопатологический синдром, оценить степень его тяжести, выявить причины его возникновения, провести дополнительные лабораторные и инструментальные исследования, сформировать именно иммунологический диагноз.

Схематично это можно описать как трехуровневый алгоритм диагностики нарушений функции иммунной системы. На первом этапе проводятся клинические исследования, на втором этапе анализируются лабораторные исследования, на третьем этапе проводятся иммунологические исследования с элементами топической диагностикой. На любом этапе как итог диагностики формируется иммунологический диагноз (предварительный, клинический, топический). В зависимости от диагноза определяется необходимая терапия и дальнейшая тактика ведения пациента (рис. 78).

Предварительный диагноз нарушений функции иммунной системы не требует дополнительно специальных лабораторных исследований и базируется только на основании анализа клинических данных, что мы отмечали выше [4-12, 26, 38, 111, 112],

Традиционно при иммунопатологии принято выделять ряд синдромов: инфекционный, аутоиммунный, аллергический, пролиферативный. Но все они, как и большинство заболеваний сопровождаются реакцией иммунитета - воспалением. 


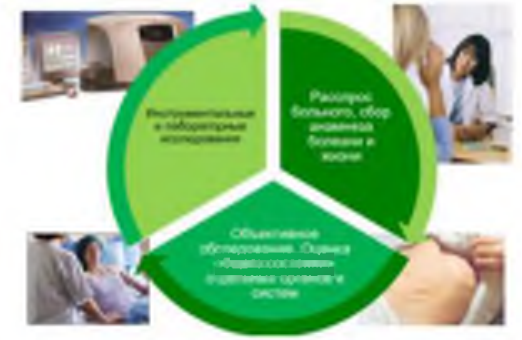

Предварительный иммунологический диагноз

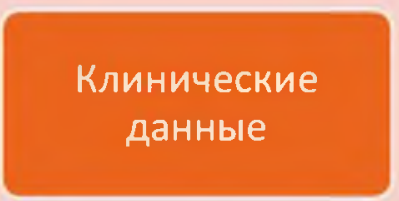

Решение вопроса о иммуноактивной терапии
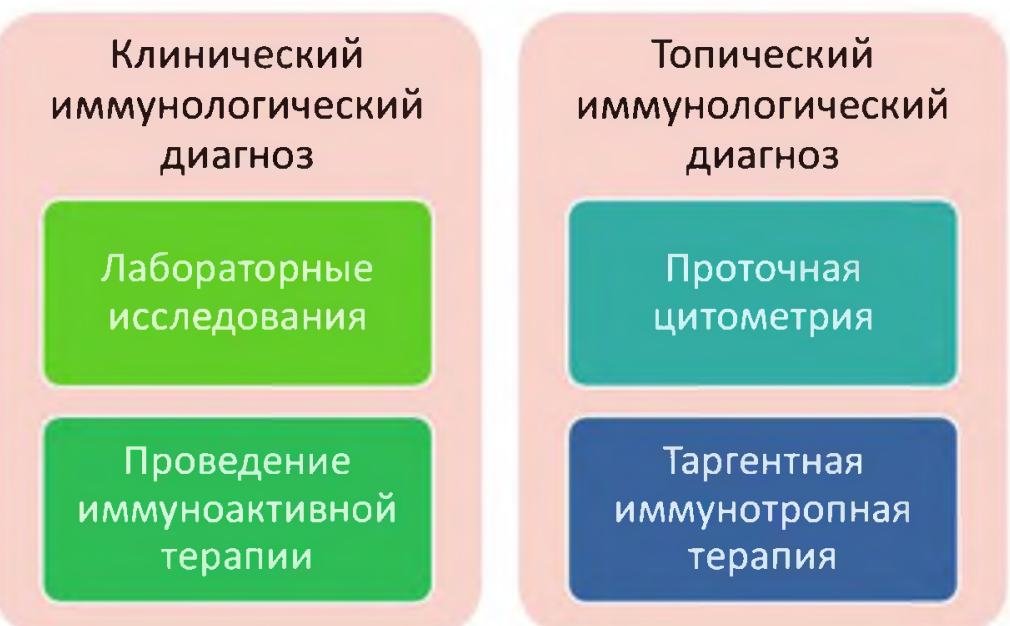

Рис. 78. Принципы формирования иммунологического диагноза.

Наиважнейшим диагностическим шагом в диагностик иммунопатологии является выявление локальных (местных) и системных признаков воспаления. Основной клинический синдром местного воспаления описанием которого в практике занимаются большинство врачей. Классически основными местными признаками воспаления описанные со времен Гиппократа являются припухание, боль, краснота, локальное повышение температуры и нарушение функции органа (рис.79).
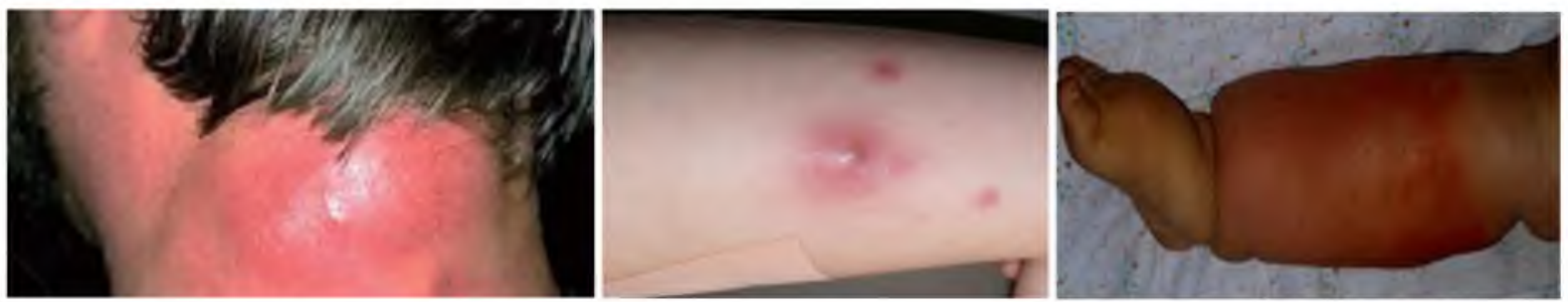

\section{Рис. 79. Местные признаки воспаления.}

Диагноз синдрома системного воспалительного ответа (CCBO или SIRS - systemic inflammatory response syndrome) появилось в связи с необходимостью повышения эффективности лечения сепсиса. Согласно принятой конвенции Американской коллегии торакальных хирургов и Общества специалистов интенсивной терапии, принятой на конференции в Чикаго в 1992 г. диагноз правомочен при наличии двух или более критериев указанных в таблице № 33 .

В последнее время выделяют еще ряд синдромов, связанных с системным воспалением. CARS - синдром компенсаторного противовоспалительного ответа, MARS- синдром смешанного антагониста ответа, PICS - стойкое воспаление, иммуносупрессия и синдром катаболизма. Все они формируются за счет иммунных про- и противовоспалительных реакций обычно на инфекцию (табл.35). 
Таблица 35 .

Критерии синдрома системного воспалительного ответа

\begin{tabular}{|c|c|c|}
\hline Показатель & \multicolumn{2}{|l|}{ Значение } \\
\hline Температура тела & $\begin{array}{l}\geq 38^{\circ} \mathrm{C} \text { (фебрильная } \\
\text { температура) }\end{array}$ & или $\leq 36^{\circ} \mathrm{C}$ (гипотермия) \\
\hline Частота сердечных сокращений & \multicolumn{2}{|l|}{ 2 90/мин (тахикардия) } \\
\hline Частота дыхания & \multicolumn{2}{|c|}{$\begin{array}{l}\text { 2 20/мин или содержание диоксида углерода в } \\
\text { крови } \leq 32 \mathrm{mmHg}\end{array}$} \\
\hline Клинический анализ крови & $\begin{array}{l}\text { Лейкоцитоз > } 12 \times 10^{9} / \text { л } \\
\text { или смещение } \\
\text { лейкоцитарной } \\
\text { формулы влево. }\end{array}$ & $\begin{array}{l}\text { или лейкопения } \\
<4 \times 10^{9} / л\end{array}$ \\
\hline
\end{tabular}

Исходя из этого в мировых критериях ССВО (табл.36) на основании клинических данных можно выделить две его разновидности I- преобладание провоспалительной реакции (фебрильная температура, лейкоцитоз и/или смещение лейкоцитарной формулы влево), II преобладание провоспалительной реакции (гипотермия, лейкопения и/или лимфопения).

Таблица 36.

\section{Реакций иммунитета при формировании синдромов системного ответа}

\begin{tabular}{|l|c|c|c|c|}
\hline Реакция иммунитета & SIRS & CARS & MARS & PICS \\
\hline Провоспалительная & +++ & + & +++ & ++ \\
\hline Противовоспалительная & + & +++ & +++ & + \\
\hline
\end{tabular}

В последующем по механизму развития воспаления следует выделять синдромы связанные с гипореактивным и гиперреактивным состоянием иммунной системы (рис. 80).

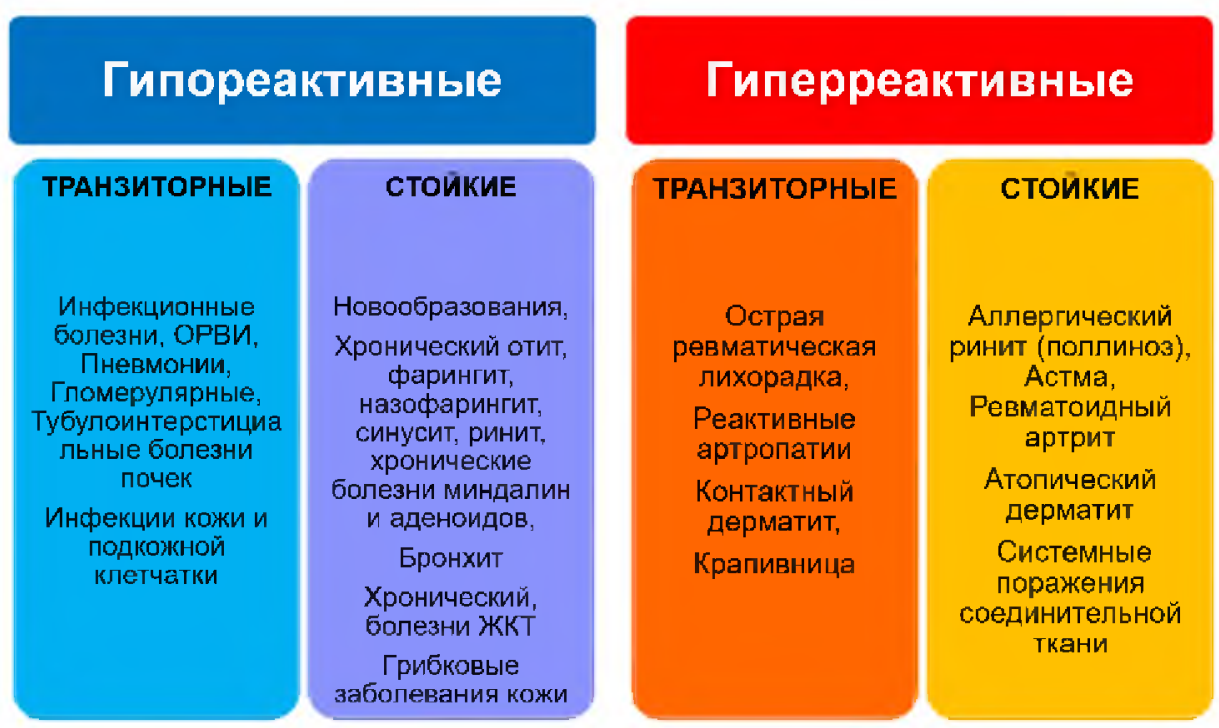

Рис.80. Синдромы и заболевания связанные с нарушением функции иммунной системы. 


\section{Синдромы гипореактивных (гипоэргических) состояний:}

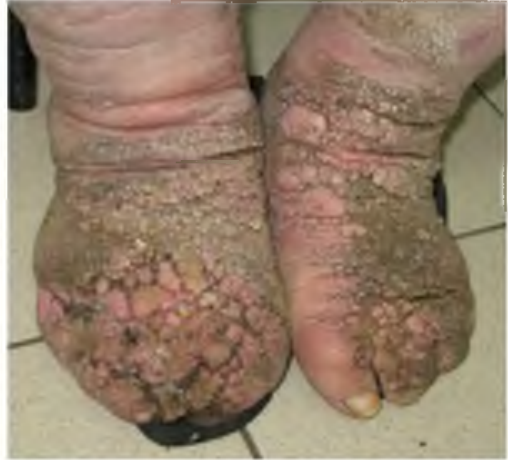

\section{Рис.81. ВПЧ стоп}

\section{1. Недостаточность (иммунодефицит) клеточно-} эффекторного звена иммунитета, этот синдром проявляется одним или несколькими следующими признаками, а именно:

- частые ОРВИ (более 4 раз в год);

- клинически выраженные инфекции, вызванные группой вирусов герпеса (рецидивирующее течение герпеса 1 и 2 типа, 3 типа (герпес зостера), цитомегаловирусная инфекция, заболевания, вызванные вирусом Эпштена-Барр; - все виды бородавок, остроконечные кондиломы, опосредованные папилломавирусом человека и контагиозным моллюском (рис.81);

- вирусные гепатиты (B, C, D, F, G);

- повторные детские инфекции и/или инфекции, развивающиеся после проведения вакцинации (у детей в возрасте старше 7 лет и взрослых);

- вирусные энтериты;

- грибковые инфекции (кандидамикоз, дерматомикоз) кожи, ногтей, слизистых оболочек (молочница), внутренних органов, трихофития;

- все виды опухолевых процессов.

2. Гуморально-эффекторный иммунодефицит (недостаточность) диагностирован при наличии у больного:

- бактериальных инфекций верхних дыхательных путей и ЛОР-органов (более 3-4 раз в год с затяжным течением, с остаточными явлениями в виде субфебрилитета, астении, ангина (рис.82));

- бактериальных инфекций легких (хронические бронхиты с бронхоспазмом или без него, пневмонии различной этиологии);

- бактериальных инфекций кожи и подкожной клетчатки (фурункулез, абсцессы, флегмоны, рецидивирующий парапроктит);

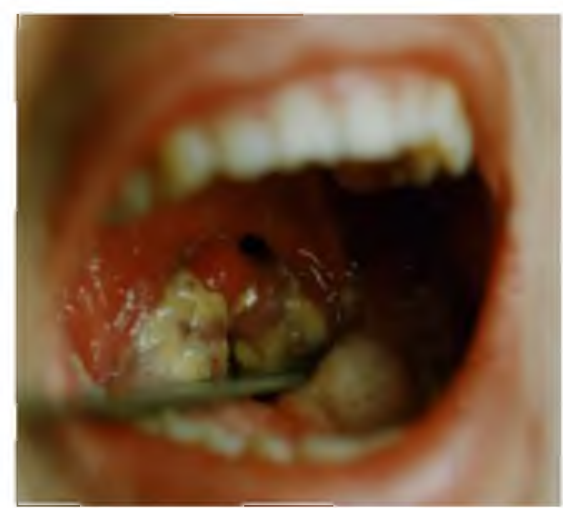

Рис. 82. Ангина

- инфекционно-воспалительных заболеваний органов мочеполовой системы (цистит, пиелонефрит и др.);- других бактериальных инфекций: менингоэнцефалита, артрита, сепсиса и пр.;

- заболеваний пищеварительного тракта, вызванные бактериями (стоматит, пародонтит, гастрит, гастродуоденит, язвенная болезнь, колит, энтероколит, холецистит, перитонит); - дисбактериоз, в том числе кишечный.

3. Синдром недостаточности макрофагальнофагоцитарного звена Диагностические признаки нередко идентичны признакам синдрома недостаточности гуморального звена иммунитета. Однако обычно при этом синдроме бактериальные инфекции протекают вяло, без высокой температуры и других признаков воспаления. Характерными признаками недостаточности макрофагально-фагоцитарного звена считаются рецидивирующие абсцессы разных локализаций и локальные бактериальные инфекции (рис. 83).

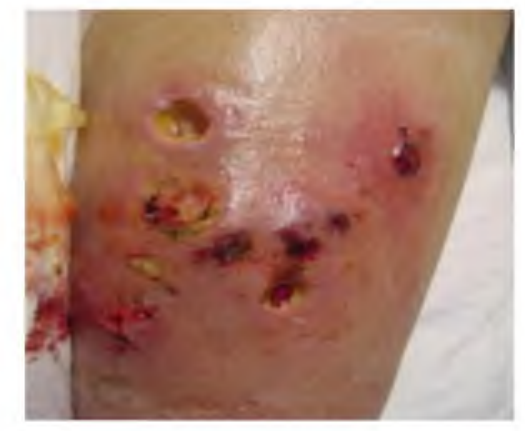

Рис.83. Абсцесс голени 


\section{4. Гипорегенеративный синдром}

Определяется тогда, когда после повреждения не происходит возмещение дефекта ткани, идентично погибшей, c восстановлением структуры и способности органа к выполнению специализированной функции (рис.84).

5. Синдром недостаточности регуляторного звена иммунитета. Диагностируется при сочетании вышеописанных синдромов. При этом необходимо выделить некоторые особенности течения этих заболеваний, а именно: - устойчивость к стандартной специфической терапии или быстрое развитие рецидива после лечения.

- затяжное или хроническое течение с частыми рецидивами (непрерывно рецидивирующие бактериальные и/или вирусные инфекции слизистых оболочек респираторного, желудочнокишечного и мочеполового трактов, кожных покровов);

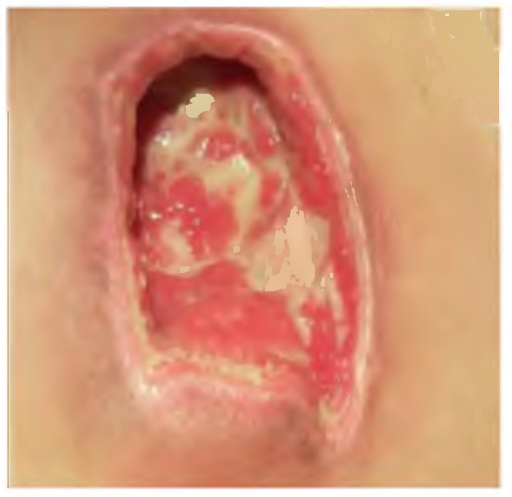

Рис. 84. Пролежень

- активация условно-патогенной флоры, микст-инфекция, смена возбудителя в динамике болезни (как правило, на фоне специфической терапии), вовлечение в процесс других органов;

\section{Синдромы гиперреактивных (гиперэргических) состояний:}

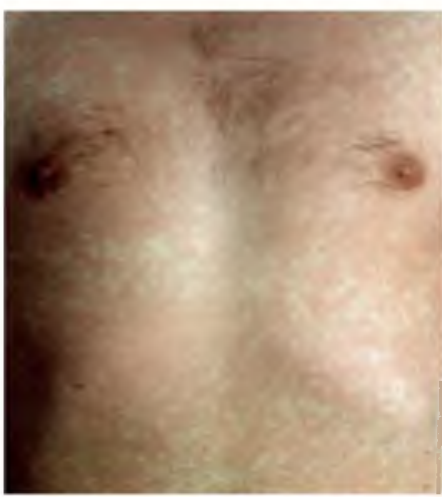

Рис.85. Крапивница

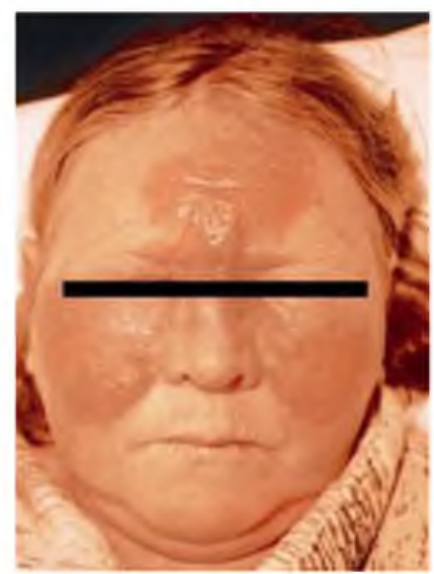

Рис. 86. Системная красная волчанка

\section{1. Реагиновый (анафилактический,} атопический) синдром. Его развитие связано $\mathrm{c}$ действием IgE и частично с IgG на тучные клетки. Синдром проявляется реакциями, возникающими обычно через 5-30 мин. после контакта сенсибилизированного организма со специфическим аллергеном. Они бывают общие (анафилактический шок) и местные (крапивница (рис.85), отек Квинке, бронхиальная астма, поллиноз, атопический дерматит, аллергический ринит).

\section{2. Антителозависимый цитотоксический} синдром (цитолитический или антителозависимая цитотоксическая гиперчувствительность). Он наблюдается при попадании в организм гомологичных антигенов, при лекарственной аллергии. Это один из механизмов развития аутоиммунных заболеваний, где в качестве антигена выступают собственные аутоантигены (рис. 86)

\section{3. Синдром патогенного воздействия} иммунных комплексов (рис.87). Проявления, обусловленные образованием иммунных комплексов, обычно связаны с хроническими персистирующими инфекциями, аутоиммунными заболеваниями, поступлениями большого количества антигена в сенсибилизированный или интактный организм (сывороточная болезнь) 
Клеточно-опосредованная цитотоксичность (гиперчувствительность замедленного типа). Клинически это проявляется через 21-28 суток с развитием гранулемы (рис.88), способствующей ограничению инфекции. К основным заболеваниям с реакциями гиперчувствительности замедленного типа относятся проказа, туберкулез, шистосомоз, саркоидоз, болезнь Крона, бруцеллез, сифилис.

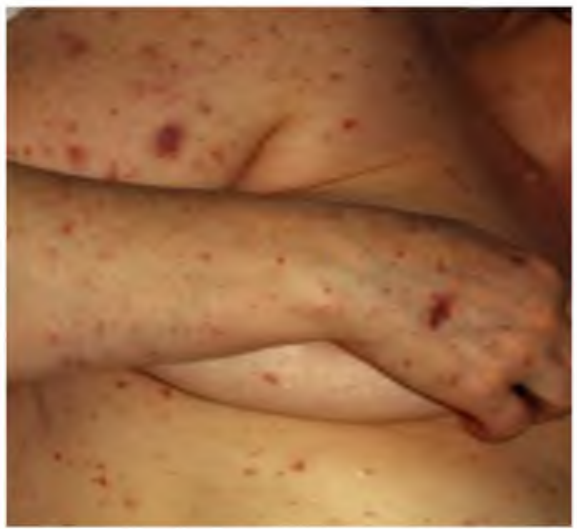

Рис.87. Менингококцемия

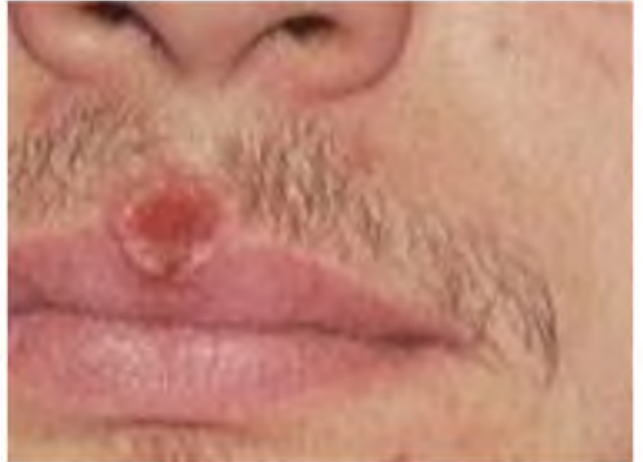

Рис.88. Гранулема

Принимая во внимание клонально-селекционный тип реагирования иммунной системы и то, что в развитии иммунных нарушений принимает участие, как правило, не один, а несколько типов реакций, по механизму действия выделяют смешанные, а по уровню нарушения - комбинированные иммунные нарушения.

Отдельным синдромом нужно выделить нарушения биотопом, прежде всего дизбиоз кишечника. Это клинико-лабораторный синдром, возникающий при заболевании и/или клинических ситуациях, характеризующийся изменением качественного и/или количественного состава микрофлоры определённой локализации. Основные причины дисбиозов представлены в таблице (табл. 37)

Таблица 37

Основные причины, приводящими к нарушению микробиоты

\begin{tabular}{|c|l|}
\hline \multicolumn{1}{|c|}{ Причины } & \multicolumn{1}{c|}{ Детализация } \\
\hline Иммунные нарушения & $\begin{array}{l}\text { Любые проявления гипо- или гиперреактивных состояний } \\
\text { иммунной системы. }\end{array}$ \\
\hline Болезни & $\begin{array}{l}\text { Заболевания внутренних органов, прежде всего болезни ЖКТ, } \\
\text { обмена веществ. }\end{array}$ \\
\hline $\begin{array}{l}\text { Инфекционные } \\
\text { заболевания }\end{array}$ & $\begin{array}{l}\text { Любые острые инфекционные заболевания. Обострение } \\
\text { хронических инфекций }\end{array}$ \\
\hline Лекарственные вещества & Антибактериальная терапия, ГКС, цитостатики, лучевая терапия \\
\hline Питание & $\begin{array}{l}\text { Дефицит пищевых волокон; несбалансированное по составу } \\
\text { нутриентов, витаминов, микроэлементов питание; } \\
\text { антибактериальные компоненты, красители, консерванты, } \\
\text { разрыхлители; резкая смена рациона и режима питания }\end{array}$ \\
\hline $\begin{array}{l}\text { Физиологические } \\
\text { изменения }\end{array}$ & $\begin{array}{l}\text { Стресс, нарушение биоритмов в связи с дальними поездками, } \\
\text { гормональная перестройка (климакс, период полового } \\
\text { созревания), функциональные нарушения моторики кишечника }\end{array}$ \\
\hline $\begin{array}{l}\text { Особенности } \\
\text { анатомического строения }\end{array}$ & $\begin{array}{l}\text { Дивертикулы, аномалии желчного пузыря, особенности строения } \\
\text { глоти }\end{array}$ \\
\hline
\end{tabular}


Клиническими проявлениями дисбиоза можно разделить на локальные которые обычно связаны с проявлением какого-либо заболевания (колит, энтерит, вульвовагинит и др.) подверженные лабораторными исследованиями и/или и системные которые проявляются в виде повышенной утомляемости, слабости, нарушение сна и т.д. Анализируя клиниколабораторные данные важно определить степень тяжести дисбактериоза. Это проводится при сопоставлении полученных результатов с референсными значениями (табл. 38 ).

Таблица 38.

Количество основных микроорганизмов при анализе кала на дисбактериоз

\begin{tabular}{|c|c|c|c|}
\hline \multirow[b]{2}{*}{ Виды микроорганизмов } & \multicolumn{3}{|c|}{ Возраст } \\
\hline & До 1 года & $\begin{array}{l}\text { От } 1 \text { года } \\
\text { до } 60 \text { лет }\end{array}$ & $\begin{array}{c}\text { Старше } 60 \\
\text { лет }\end{array}$ \\
\hline Bifidobacterium spp. (бифидобактерии) & от $10^{10}$ до $10^{11}$ & от $10^{9}$ до $10^{10}$ & от $10^{8}$ до $10^{9}$ \\
\hline Lactobacillius spp. (лактобактерии) & от $10^{6}$ до $10^{7}$ & от $10^{7}$ до $10^{8}$ & от $10^{6}$ до $10^{7}$ \\
\hline Бактероиды & от $10^{7}$ до $10^{8}$ & от $10^{9}$ до $10^{10}$ & от $10^{10}$ до $10^{11}$ \\
\hline Энтерококки & от $10^{6}$ до $10^{7}$ & от 105 до $10^{8}$ & от $10^{6}$ до $10^{7}$ \\
\hline Фузобактерии & $<10^{6}$ & от $10^{8}$ до $10^{9}$ & от $10^{8}$ до $10^{9}$ \\
\hline Эубактерии & от $10^{6}$ до $10^{7}$ & от $10^{9}$ до $10^{10}$ & от $10^{9}$ до $10^{10}$ \\
\hline Пептострептококки & $<10^{5}$ & от $10^{9}$ до $10^{10}$ & $10^{10}$ \\
\hline Клостридии & $<10^{3}$ & $<10^{5}$ & $<10^{6}$ \\
\hline E. coli типичные & от $10^{7}$ до $10^{8}$ & от $10^{7}$ до $10^{8}$ & от $10^{7}$ до $10^{8}$ \\
\hline E. Coli лактозонегативные & $<10^{5}$ & $<10^{5}$ & $<10^{5}$ \\
\hline E. Coli гемолитические & 0 & 0 & 0 \\
\hline $\begin{array}{l}\text { Другие } \\
\text { эсловно-патогенные } \\
\text { энтеробактерии в т.ч. Enterobacter spp. } \\
\text { Proteus spp. Klebsiella spp, Hafnia, } \\
\text { Serratia, Morganella, Citrobacter }\end{array}$ & $<10^{4}$ & $<10^{4}$ & $<10^{4}$ \\
\hline $\begin{array}{l}\text { Staphylococcus aureus } \\
\text { золотистый) }\end{array}$ & 0 & 0 & 0 \\
\hline $\begin{array}{l}\text { S. epidermis, S. saprophiticus (стафилококк } \\
\text { эпидермальный сапрофитный) }\end{array}$ & $<10^{4}$ & $<10^{4}$ & $<10^{4}$ \\
\hline $\begin{array}{l}\text { Неферментирующие бактерии } \\
\text { Pseudomonas spp. (синегнойная } \\
\text { палочка), Acinetobacter }\end{array}$ & 0 & 0 & 0 \\
\hline Clostridium spp. в m.ч. Clostridium difficile & 0 & 0 & 0 \\
\hline Грибы рода Candida & $<10^{3}$ & $<10^{4}$ & $<10^{4}$ \\
\hline
\end{tabular}

При нарушениях I степени тяжести выявляется увеличение или уменьшение общего количества кишечных палочек, у которых отсутствуют атипичные биологические свойства, количество бифидобактерий и лактобацилл неизменно, дисбактериоз латентный, компенсированный, кишечные дисфункции не регистрируются.

II степень характеризуется незначительным снижением количества бифидобактерий и лактобацилл. Наблюдаются количественные и качественные (появление форм с атипичными биологическими свойствами) изменения кишечных палочек. Высеваются в умеренном количестве условно-патогенные кишечные микроорганизмы. Дисбактериоз локальный (местный), субкомпенсированный. Кишечные дисфункции, как правило, не наблюдаются.

III степень - существенное снижение количества бифидобактерий (до 105-106) в сочетании с уменьшением содержания лактобацилл и резким изменением типичных свойств кишечных палочек (значительное преобладание гемолитических, лактозонегативных форм). 
Значительное увеличение количества условно-патогенных бактерий $\mathrm{c}$ патогенными свойствами (гемолитических форм) и патогенных дрожжеподобных грибов. Дисбактериоз локальный (местный), декомпенсированный. Как правило, наблюдаются кишечные дисфункции.

При IV степени тяжести обнаруживается резкое снижение бифидобактерий, значительное уменьшение количества лактобацилл, резкое снижение количества или отсутствие кишечных палочек с типичными свойствами, значительное возрастание количества как облигатных, так и факультативных видов (в норме не встречающихся) кишечных бактерий и дрожжеподобных грибов с патогенными свойствами. Выявляются патогенные кишечные бактерии (сальмонеллы, шигеллы, иерсинии). Дисбактериоз распространенный (с бактериемией), декомпенсированный (с угрозой генерализации инфекции, сепсиса или септикопиемии), наблюдаются выраженные кишечные дисфункции.

В дальнейшем при положительном ответе на наличие иммунопатологического состояния и определения иммунопатологических синдромов очень важно определить длительность его течения. Поэтому выделяют транзиторные и стойкие проявления дисфункции иммунной системы (табл.39).

Таблица 39

\section{Классификация иммунных нарушений по длительности}

\begin{tabular}{|c|c|}
\hline Транзиторные & Стойкие \\
\hline До 6 месяцев & Более 6 месяцев \\
\hline
\end{tabular}

1. Транзиторные (острые) иммунопатологические состояния развиваются за счет острых патологических процессов и воздействий (инфекции, травмы, интоксикации и т.д.) и по длительности протекают не более 6 мес., как правило, изменения со стороны иммунной системы спонтанно исчезают при устранении их причины.

2. Стойкие, хронические дисфункции иммунной системы возникают вследствие длительно действующих патологических процессов (хронические гнойно-воспалительные заболевания, аутоиммунные нарушения, опухоли, персистирующие инфекции и т.д.), диагностируемых более 6 мес.

По распространенности и по степени тяжести следует выделить иммунные нарушения легкой, среднетяжелой и тяжелой степени (табл. 40).

Таблица 40

\section{Определение степени тяжести иммунных нарушений}

\begin{tabular}{|l|c|c|c|}
\hline \multicolumn{1}{|c|}{ Признак } & \multicolumn{3}{|c|}{ Степень тяжести } \\
\cline { 2 - 4 } & Легкая & Среднетяжелая & Тяжелая \\
\hline $\begin{array}{l}\text { Локализация } \\
\text { процесса }\end{array}$ & $\begin{array}{c}\text { Локальная не более } \\
\text { одного органа }\end{array}$ & $\begin{array}{c}\text { Вовлечены другие } \\
\text { органы }\end{array}$ & $\begin{array}{c}\text { Генерализованный } \\
\text { процесс }\end{array}$ \\
\hline $\begin{array}{l}\text { Нарушение функции } \\
\text { пораженного органа }\end{array}$ & Нет & Имеются & Выражены \\
\hline $\begin{array}{l}\text { Периферические } \\
\text { лимфатические } \\
\text { органы }\end{array}$ & Не задействованы & Задействованы & Задействованы \\
\hline $\begin{array}{l}\text { Воздействие на } \\
\text { организм в целом }\end{array}$ & Нет & Не выражено & Выражено \\
\hline Угроза для жизни & Нет & Нет & Имеется \\
\hline
\end{tabular}

1. «Локальные (местные)» иммунные нарушения возникают на фоне патологии барьерных тканей (кожа, слизистые) чаще всего вследствие воспалительного процесса. Во 
внутренних органах повреждение местных клеток иммунной системы и затруднение поступления лимфоцитов, фагоцитов и АТ из крови могут происходить из-за нарушения микроциркуляции, ацидоза и т.п. Такие иммунодефициты имеют место у больных с хроническими неспецифическими заболеваниями верхних дыхательных путей, ЛОР-органов, ареактивно текущими ранами и ожогами, а также при состояниях тканей, описываемых онкологами как предраковые: хронический воспалительный процесс, рубцы, длительно незаживающие трофические язвы и т.д. Обычно такие иммунные нарушения бывают легкой степени.

2. Системные иммунные нарушения - это нарушения средней и тяжелой степени, когда в процесс вовлечены органы и системы всего организма. Предлагается выделять три степени тяжести: легкую, среднетяжелую и тяжелую. Иммунные нарушения легкой степени характеризуются локальным поражением с вовлечением в процесс одного органа без повреждений функций всего организма. При тяжелой степени - это генерализованные процессы с нарушением функций организма с угрозой для жизни больного. Все оставшиеся клинические случаи следует квалифицировать как среднетяжелые.

Следующим этапом необходимо попытаться определить причину возникновения (этиологию) иммунопатологического состояния (подробнее см. главы 12-13).

Суммируя этиологические и патогенетические факторы развития иммунопатологий, в том числе с учетом данных ВО3, можно выделить следующие причины их возникновения:

1. Генетические, врожденные, первичные иммунодефициты представляет собой врожденные нарушения иммунной системы, обусловленные генетическими нарушениями.

2. Инфекции: острые и хронические вирусные, бактериальные, микст-инфекции, имеющие многофакторное повреждающее действие на иммунную систему (воздействие токсинов, других иммуносупрессирующих факторов, микробов и вирусов, истощение антиоксидантной системы и повреждающее действие свободных форм кислорода) и др. Как причины могут служить: протозойные и глистные инвазии (малярия, токсоплазмоз, лейшманиоз, трихинеллез, аскаридоз и т.д.); - бактериальные инфекции (туберкулез, стафилококковая, пневмококковая, менингококковая инфекции, сифилис и др.); вирусные инфекции: а) острые - корь, краснуха, грипп, паротит, ветряная оспа, гепатит, герпес и др.; б) персистирующие - хронический гепатит В, подострый склерозирующий панэнцефалит, СПИД, и др.; в) врожденные - цитомегалия, краснуха.

3. Повреждающие факторы внешней среды физического и химического характера (температурные, лучевые, антропогенные загрязнения окружающей среды химическими токсическими веществами - тяжелыми металлами, пестицидами, хлорсодержащими веществами, радионуклидами и т.П., формирование разнообразных физических полей, широкое использование источников неионизирующих излучений), в том числе экологические (включая экологические катастрофы планетарного масштаба, типа аварии на ЧАЭС и др.).

4. Интоксикации различного генеза как экзогенные (отравления), так и эндогенные (тиреотоксикоз, декомпенсированный сахарный диабет).

5. Ятрогенные факторы: длительный прием иммуносупрессантов.

6. Метаболические факторы:

Алиментарные - дефицит белков, макро- и микроэлементов, витаминов и других жизненно важных веществ вследствие недостаточного поступления их с пищей (социальные причины, «модные» диеты, самостоятельное голодание с целью снижения веса, омоложения, лечения и т.д.) или повышенного расхода из-за нарушения расщепления, всасывания и/или транспорта необходимых веществ.

Гипоксические - вследствие гипоксии различного генеза.

Эндокринные - нарушения обмена веществ вследствие заболеваний органов эндокринной системы (гипотиреоз, тиреотоксикоз, недостаточность половых гормонов, сахарный диабет и др.).

Стрессовые - вследствие нарушения нейрогормональной регуляции. Истощение антиоксидантной системы в результате хронической инфекции, радиационных поражений, 
заболеваний внутренних органов. «Истощающие заболевания» - цирроз печени, обширные ожоги, анемия, алкоголизм, наркомания и др.

7. Оперативные вмешательства, травмы.

8. Злокачественные новообразования, в том числе лимфопролиферативные.

9. Аутоиммунные заболевания.

10. Состояния, приводящие к потере клеток иммунной системы и иммуноглобулинов (кровотечения, лимфорея, нефриты).

11. «Физиологические» иммунодефициты, возникающие в периоды физиологических изменений в иммунной системе: ранний детский и старческий возраст, беременность. Возрастная инволюция тимуса начинается после полового созревания. Фактически все люди более или менее рано становятся иммунными больными, причем само развитие процесса старения и сопутствующих ему болезней (хроническое воспаление, аутоиммунные болезни, аллергия, опухоли) в значительной степени связывают с нарушением функции иммунной системы.

В некоторых случаях дисфункции иммунной системы развивается без видимых причин такое состояние определяется как спонтанная форма иммунных нарушений.

При таком многообразии причин развития иммунных нарушений врачу тем не менее необходимо выявить причину иммунопатологии, т. к. простое исключение фактора, неблагоприятно влияющего на иммунитет, уже приведет к клиническому эффекту. Чтобы рассмотреть причины иммунодефицитов, уместно еще раз вспомнить, что иммунитет человека есть сложная многокомпонентная система, и в защите организма от инфекции участвуют факторы как врожденного, так и адаптивного иммунитета. Возможно, что дефект в этой системе может какое-то время не проявляться клинически в виде повышенной инфекционной заболеваемости, потому как все другие компоненты иммунитета находятся в нормальном функциональном состоянии и компенсируют этот дефект. Однако происходящие со временем и под влиянием различных неблагоприятных факторов изменения в этих компенсаторных компонентах могут давать суммарный эффект, ведущий к возникновению первичного дефекта и развитию повышенной заболеваемости.

Суммируя полученные данные на первом этапе на основании клинических данных, формируется иммунологический клинический диагноз (табл.41).

В качестве построения диагноза иммунных нарушений можно привести следующие примеры:

- Транзиторные, индуцированные (экзогенные), гиперреактивные нарушения гуморально-эффекторного звена иммунитета средней степени тяжести.

- Стойкие, спонтанные, гипореактивные нарушения макрофагально-фагоцитарного звена иммунитета легкой степени тяжести.

Таблица 41.

Клиническая классификация нарушений функции иммунной системы

\begin{tabular}{|c|c|c|c|c|}
\hline \multirow{2}{*}{$\begin{array}{c}\text { По } \\
\text { длительности }\end{array}$} & \multirow[b]{2}{*}{ По этиологии } & \multicolumn{2}{|c|}{ По патогенезу } & \multirow{2}{*}{$\begin{array}{c}\text { По степени } \\
\text { тяжести }\end{array}$} \\
\hline & & Механизм & $\begin{array}{c}\text { Уровень } \\
\text { нарушения }\end{array}$ & \\
\hline \multirow[t]{2}{*}{ Транзиторные } & \multirow{2}{*}{ Врожденные } & \multirow{2}{*}{ Гипореактивные } & $\begin{array}{c}\text { Клеточно- } \\
\text { эффекторное }\end{array}$ & \multirow{2}{*}{ Легкой степени } \\
\hline & & & $\begin{array}{c}\text { Гуморально- } \\
\text { эффекторное звено }\end{array}$ & \\
\hline \multirow[t]{3}{*}{ Стойкие } & \multirow[t]{2}{*}{ Индуцированные } & \multirow[t]{2}{*}{ Гиперреактивные } & $\begin{array}{c}\text { Макрофагально- } \\
\text { фагоцитарное звено }\end{array}$ & \multirow[t]{2}{*}{ Средней степени } \\
\hline & & & Регуляторное звено & \\
\hline & Спонтанные & Смешанные & Комбинированные & Тяжелой степени \\
\hline
\end{tabular}




\section{ДИАГНОСТИКА ИММУННЫХ НАРУШЕНИЙ}

\section{Глава 11 Топическая диагностика иммунных нарушений}

Определяя клинический иммунологический диагно3, мы тем самым выделяем определенный иммунотип в формировании заболевания. Иммунотипы (эндотипы иммунного ответа) это кластеры клинических компонентов заболевания (физиологические, иммунологические, патологические, генетические признаков, ответ на лечение и другие) которые в совокупности формируют фенотип заболевания. Однако наиболее важно ответить на вопрос какие конкретно нарушения имеются у иммунной системы. Учитывая сложность и многокомпонентность организации иммунной системы (клеточный/гуморальный, мукозальный/врожденный/ адаптивный иммунитет) необходимо точечная, топическая диагностика. Топическая диагностика (по аналогу определения в неврологии) - определение локализации и распространенности нарушений иммунной системы на основании выявленных при комплексном обследовании нарушений иммунной системы. Учитывая, что основная структурная и функциональная единица иммунной системы клетка, основной акцент на выявление нарушений функции иммунитета стоит сфокусировать на исследовании клеток иммунной системы и эффекторных и регуляторных молекулах. В настоящее время с помощью проточной цитометрии возможно дифференцировать практически любые виды клеток определить их функциональную активность. Однако в связи с тем, что основная масса клеток иммунной системы находится в ткани и их исследования в отличии от периферической крови имеют технические сложности требуется дополнительные разработки по клинической оценки топической диагностики иммунных нарушений. Тем не менее существующие методы исследования позволяют выявить нарушения в том или ином звене иммунитета. Не менее важным является оценка и гуморальных факиров иммунитета. Суммарно с позиций физиологии иммунный ответ возможно разделить на 3 этапа (рис. 89). Именно с этих позиций необходимо проводить и топическую диагностику.

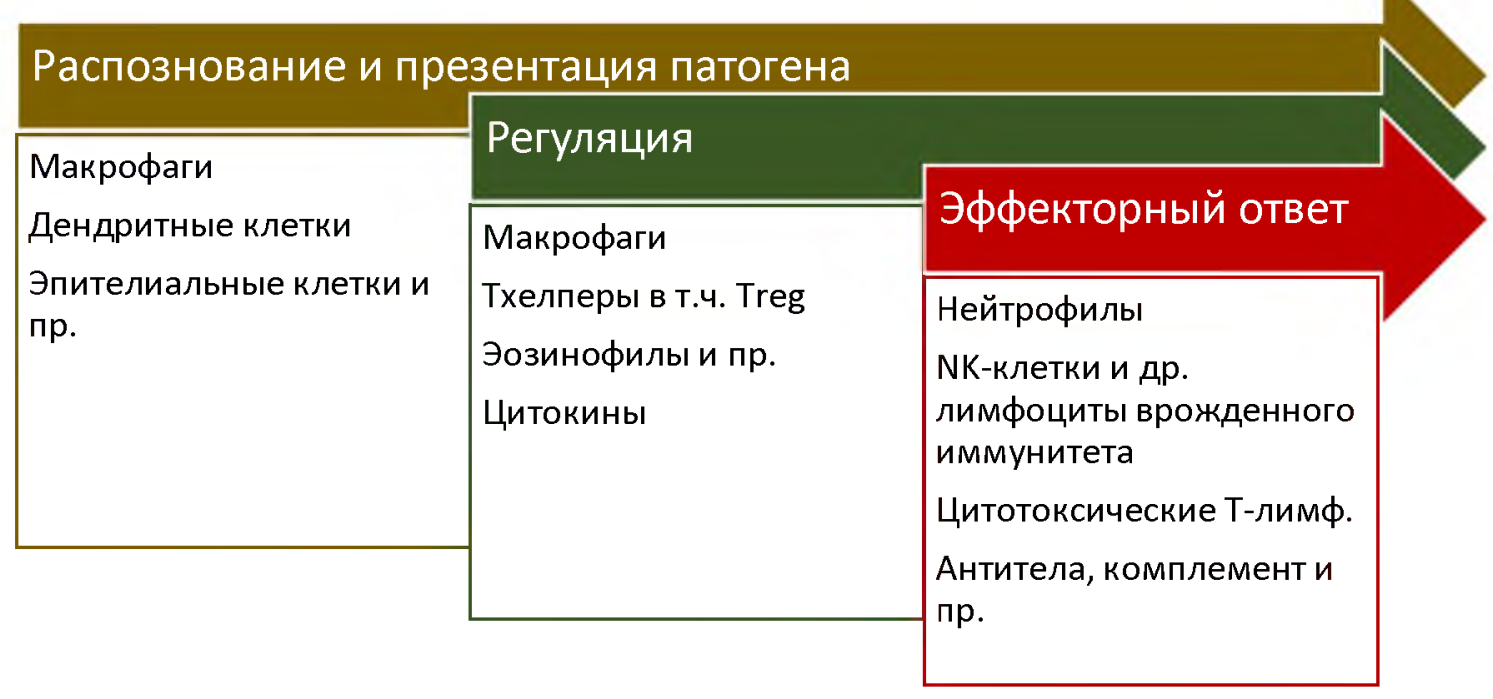

Рис. 89. Этапы развития иммунного ответа 
Эффекторный ответ основной функциональный продукт иммунной системы. Наиболее простые и достаточно информативные методы заключаются в определении концентрации иммуноглобулинов, специфических АТ и других показателей, характеризующих состояние гуморального звена иммунной системы. Наибольшее распространение в определении различных гуморальных показателей иммунитета получил метод иммуноферментного анализа (ИФА).

Определение уровня иммуноглобулинов - это по-прежнему важный и надежный метод оценки иммунитета. Его можно считать главным методом диагностики всех форм иммунодефицитов, связанных с биосинтезом АТ. Лабораторным методом можно определить не только уровни концентрации иммуноглобулинов $\mathrm{G}, \mathrm{A}, \mathrm{E}$ и $\mathrm{M}$ в сыворотке крови, но и субклассы иммуноглобулинов, особенно $\operatorname{IgG}$, секреторного $\operatorname{IgA}$, соотношения каппа (x)- и лямбда $(\lambda)$-цепей. Нормативные показатели зависят от возраста исследуемого (табл.42)

Таблица 42.

\section{Нормативные показатели уровня иммуноглобулина}

\begin{tabular}{|l|c|c|c|c|}
\hline \multirow{2}{*}{ Возраст } & \multicolumn{4}{|c|}{ Показатель } \\
\cline { 2 - 5 } & Ig E ( мг/дл) & Ig G (мг/дл) & Ig A (мг/дл) & Ig M (мг/дл) \\
\hline 1-3 мес. & $0-30$ & $3.3-9.1$ & $0.1-0.2$ & $0.4-1.2$ \\
\hline 4-12 мес. & $0-30$ & $3.2-12.8$ & $0.1-0.4$ & $0.4-0.8$ \\
\hline 12-24 мес. & $0-45$ & $4.6-14.6$ & $0.1-1.0$ & $0.6-1.8$ \\
\hline 2-5 лет. & $0-100$ & $8.8-15.4$ & $0.3-1.5$ & $0.8-1.6$ \\
\hline 6-8 лет. & $0-100$ & $9.7-11.7$ & $0.9-1.9$ & $0.8-1.9$ \\
\hline 9-11 лет. & $0-100$ & $9.4-16.6$ & $0.9-2.9$ & $0.6-2.0$ \\
\hline
\end{tabular}

Изменения концентрации иммуноглобулинов служат подтверждением гуморальноассоциированной иммунопатологии. Снижение такой концентрации в сыворотке крови больных может свидетельствовать о различных патологиях- от генетических дефектов синтеза иммуноглобулинов до транзиторных состояний, связанных с потерей белка организмом (гуморально-эффекторный иммунодефицит). Повышение концентраций относительно нормативных значений говорит о наличии аллергических, аутоиммунных процессов (АТ-зависимая цитотоксичность), оно характерно для инфекционных заболеваний на определенных этапах их развития (увеличение $\operatorname{IgM}$ в острый период заболевания и/или обострения хронической инфекции, $\operatorname{IgG}$ в стадии разрешения и/или формирования хронической инфекции). Кроме того, указанный метод является критерием эффективности проводимого лечения, в том числе заместительной терапии иммуноглобулинсодержащими препаратами.

Определение субклассов IgG представляет диагностическую ценность, так как при нормальном его уровне могут быть дефициты по субклассам иммуноглобулинов. У таких людей в ряде случаев наблюдаются иммунодефицитные состояния, проявляющиеся в повышенной частоте инфекционной заболеваемости. Так, IgG2 - субкласс иммуноглобулина $\mathrm{G}$, который преимущественно содержит АT против полисахаридов инкапсулированных бактерий (Haemophiluls influlenzae, Steptococculs pneumoniae). Поэтому дефицит, связанный с $\operatorname{IgG2}$, а также c IgA, ведет к повышенной заболеваемости респираторными инфекциями. Нарушения в соотношении субклассов IgA и в соотношении каппа (x)- и лямбда $(\lambda)$-цепей также могут быть причиной иммунодефицитных состояний.

Уровни сывороточных иммуноглобулинов, характерные для взрослых (IgM, IgG1, IgG3), достигают нормальных значений уже в раннем постнатальном периоде. Концентрации IgG2, IgG4, IgA не достигают нормы даже в период полового созревания. Распределение субклассов IgG в сыворотке крови взрослого человека следующее: IgG1 - 60-65 \%; IgG2 - 20$25 \%$; IgG3 - 10-20\%; IgG4 - 10-20\%. Наиболее часто у больных имеется ассоциация дефицитов $\operatorname{IgG} 2, \operatorname{IgG} 4, \operatorname{IgA}, \operatorname{IgE}[30,38,77,121]$. 
Определение уровня субклассов $\operatorname{IgG}$ существенно при повышенной чувствительности к бактериальным инфекциям. Дефициты установлены практически для всех иммуноглобулинов, где наиболее значимым будет дефицит IgG2, который часто сочетается с полным отсутствием IgA.

Определение специфических антител. Важную информацию о состоянии гуморального иммунитета дает определение АТ к различным АГ, так как степень защиты организма от данной конкретной инфекции зависит не от общего уровня иммуноглобулинов, а от количества специфических АТ к ее возбудителю. В настоящее время существует большое количество тест-систем по распознаванию уровня АТ к бактериальным, вирусным, грибковым инфекциям и инвазиям. Нет необходимости их перечислять. Спектр определения в большинстве случаев зависит от того, какие тест-системы имеются в лаборатории.

Особо важное значение имеют эти исследования при инфекциях, повреждающие иммунную систему - вирус иммунодефицита человека, вирус Эпштейна-Барр, герпесвирус человека (табл.43), онкогенных вирусах, при диагностике эритем (табл.44).

Таблица 43.

\section{Герпесвирусные инфекции}

\begin{tabular}{|c|c|c|}
\hline $\begin{array}{c}\text { Обозначен } \\
\text { ие }\end{array}$ & $\begin{array}{c}\text { Общепринятое } \\
\text { название }\end{array}$ & Клинический диагноз \\
\hline $\begin{array}{l}\text { HSV-1 } \\
(\mathrm{HHV}-1)\end{array}$ & Вирус простого герпеса 1 типа & $\begin{array}{l}\text { Герпес кожи и слизистых, нейрогерпес, офтальмогерпес, } \\
\text { генитальный герпес, интерстициальная пневмония, } \\
\text { герпетиформная экзема Капоши }\end{array}$ \\
\hline $\begin{array}{l}\text { HSV-2 } \\
(\mathrm{HHV}-2)\end{array}$ & Вирус простого герпеса 2 типа & То же \\
\hline $\begin{array}{l}\text { VZV } \\
(\mathrm{HHV}-3)\end{array}$ & $\begin{array}{l}\text { Вирус варицелла-зостер } \\
\text { (ветряной оспы) }\end{array}$ & $\begin{array}{l}\text { Ветряная оспа, офтальмогерпес, опоясывающий лишай, } \\
\text { постгерпетическая невралгия }\end{array}$ \\
\hline $\begin{array}{l}\text { EBN } \\
(\mathrm{HHV}-4)\end{array}$ & Вирус Эпштейна-Барр & $\begin{array}{l}\text { Инфекционный мононуклеоз, лимфаденопатия, } \\
\text { лимфома Беркита, волосатоклеточный лимфолейкоз }\end{array}$ \\
\hline $\begin{array}{l}\mathrm{CMV} \\
(\mathrm{HHV}-5)\end{array}$ & Цитомегаловирус & $\begin{array}{l}\text { Цитомегалия, гепатит, доброкачественная лимфома, } \\
\text { интерстициальная пневмония }\end{array}$ \\
\hline HSV-6 & Вирус внезапной экзантемы & $\begin{array}{l}\text { Вариант А синдром хронической усталости } \\
\text { Вариант В розеола новорожденных, мононуклеоз, } \\
\text { лимфоаденопатия, энцефалит }\end{array}$ \\
\hline HSV-7 & Вирус герпеса 7 типа & Розовый лишай, синдром хронической усталости \\
\hline $\begin{array}{l}\mathrm{KSHV} \\
\text { (HHV-8) }\end{array}$ & $\begin{array}{l}\text { Герпесвирус ассоциированный с } \\
\text { саркомой Капоши }\end{array}$ & Саркома Капоши \\
\hline
\end{tabular}

Таблица 44.

\section{Диагностика эритем}

\begin{tabular}{|c|c|}
\hline Заболевания & Лабораторная диагностика \\
\hline Kopb & ИФА специфические IgG ( с 10 дня) и IgМ (с 10 по 90 день). ДНК (ПЦР) \\
\hline Краснуха & ИФА специфические IgG ( с 14 дня) и IgМ (с 5 по 35 день). \\
\hline Парвовирус В19 & ИФА специфические IgG ( с 21 дня) и IgМ (с 5 по 120 день). ДНК (ПЦР) \\
\hline $\begin{array}{l}\text { Вирус Эпштейна - } \\
\text { Барр }\end{array}$ & $\begin{array}{l}\text { ИФА AТ Ig M, Ig G к ЕА- ранний антиген, VCA-капсидный антиген, EBNA-нуклеарный } \\
\text { антиген. ДНК (ПЦР) }\end{array}$ \\
\hline Скарлатина & бактериологический, ИФ, ИФА, латексная агглютинация, АСЛО \\
\hline Иерсиниозы & бактериологическая, ИФА и РСК или ИФА АТ Ig М, Ig G ДНК (ПЦР) \\
\hline Боррелиоз & ИФА AТ Ig M, Ig G к боррелиям. ДНК (ПЦР) \\
\hline Эрлихиоз & ИФА АТ Ig М, Ig G к риккетсиям. ДНК (ПЦР) \\
\hline
\end{tabular}


Большое значение определение АТ имеет диагностика хронических инфекций и инвазий в т.ч. сифилиса, туберкулеза, токсоплазмоза, бруцеллёза и пр.

Аутоиммунный процесс может диагностироваться у больных при обнаружении в сыворотке крови тех или иных аутоантител. В противном случае аутоиммунный генез заболеваний может быть исключен, что окажет существенное влияние на ход дальнейших исследований и тактику лечения. Нахождение в сыворотке крови АТ к нативной и денатурированной ДНК проводится также методом ИФА на твердофазном носителе (пластике). ДНК как АГ сорбирована на пластике, с этим АГ специфически взаимодействуют аутоантитела к ДНК, содержащиеся в исследуемой сыворотке (табл.45).

Таблица 45.

\section{Профили аутоантител для диагностики аутоиммунных заболеваний}

\begin{tabular}{|c|c|}
\hline Заболевание & Профиль \\
\hline Системная красная волчанка & $\begin{array}{l}\text { Антинуклеарный фактор (АНФ), АТ к двуспиральной ДНК, AT к } \\
\text { односпиральной ДНК, AT к экстрагированным ядерным АГ } \\
\text { (aSm, aRo/SS-A, aLa/SS-B, aPHП), антитела к кардиолипину - } \\
\text { aКЛ, aCIq AT к гистонам; AT к бета-2-гликопротеину }\end{array}$ \\
\hline Ревматоидный артрит & $\begin{array}{l}\text { IgM/IgA РФ, АТ к цитруллинированным белкам - АЦЦП, АМЦВ, } \\
\text { АКА, АПФ, антифилагриновые АТ, АТ к Ra 33, ВiР (Р-68) }\end{array}$ \\
\hline Системная склеродермия & $\begin{array}{l}\text { АТ к антигену Scl-70, антицентромерные антитела (АЦА), АТ к } \\
\text { нуклеосомам, АТ к цитоплазматическому АГ Јо-1 }\end{array}$ \\
\hline Полимиозит /дерматомиозит & $\begin{array}{l}\text { Антитела к аминоацилсинтетазам тPHK - Jo-1, PL-7, PL-12, EJ, OJ, } \\
\text { KS; антитела к SRP, Mi-2, PM-Scl, KJ) }\end{array}$ \\
\hline $\begin{array}{l}\text { Антифосфолипидный } \\
\text { синдром }\end{array}$ & $\begin{array}{l}\text { Антитела к аннексину V IgG/ IgM; АТ к кардиолипину IgG, IgM, } \\
\text { IgA; АТ к протромбину IgG, IgM, IgA; АТ к фосфолипидам } \\
\text { IgG/IgM; АТ к ФС-протромбиновому комплексу (PS-PT), IgG и } \\
\text { IgM; волчаночныйантикоагулянт }\end{array}$ \\
\hline Аутоиммунные гепатиты & $\begin{array}{l}\text { АНФ, антитела к гладкой мускулатуре (SMA), микросомам } \\
\text { печени и почек I типа - LKM1, цитоплазматическому антигену } \\
\text { печени LC-1, растворимому антигену печени/поджелудочной } \\
\text { железы SLA/LP, митохондриям - AMA-M2 }\end{array}$ \\
\hline $\begin{array}{l}\text { Воспалительные заболевания } \\
\text { кишечника }\end{array}$ & $\begin{array}{l}\text { IgG/IgA антитела к Saccharomyces Cerevisiae - } \\
\text { ASCA, пАНЦА, атипичные АНЦА; антинуклеарные АТ, АТ к } \\
\text { внутреннему фактору; АТ к митохондриям; АТ к париетальным } \\
\text { клеткам }\end{array}$ \\
\hline Аутоиммунный тиреоидит & $\begin{array}{l}\text { АТ к рецепторам ТТГ, АТ-МАГ (антитела к микросомальной } \\
\text { фракции тироцитов), АТ-ТГ, АТ-ТПО }\end{array}$ \\
\hline Поджелудочная железа & $\begin{array}{l}\text { Антитела к тирозин фосфатазе (IA-2), AT - GAD, AT к бета- } \\
\text { клеткам поджелудочной железы, AT к инсулину }\end{array}$ \\
\hline Сердце & Антитела к миокарду \\
\hline Тромбоцитопения & Антитела к тромбоцитам \\
\hline Целиакия & $\begin{array}{l}\text { АТ к глиадину IgA/ IgG; АТ к дезамидированным пептидам } \\
\text { глиадина IgA/lgG; AT к тканевой трансглутаминазе, IgA/ IgG; AT } \\
\text { к эндомизию } \operatorname{lgA} \text { и IgG }\end{array}$ \\
\hline $\begin{array}{l}\text { Аутоиммунные заболевания } \\
\text { почек }\end{array}$ & $\begin{array}{l}\text { АТ к рецептору фосфолипазы A2 (мембранозный } \\
\text { гломерулолофрит); АТ к базальной мембране гломерулярного } \\
\text { аппарата; АТ к С1q фактору комплемента }\end{array}$ \\
\hline
\end{tabular}

Выявление аутоантител к нативной и денатурированной ДНК имеет диагностическое значение при системных заболеваниях соединительной ткани, активных воспалительных процессах, хронических гепатитах, инфекционном эндокардите и других заболеваниях, сопровождающихся аутоиммунными процессами. Наличие аутоантител к ДНК при различных 
заболеваниях наряду с клиническими проявлениями может служить доказательством аутоиммунного процесса и служит базой для диагностики аутоиммунных заболеваний и васкулитов (табл. 45,46$)$.

Таблица 46.

\section{Профили аутоантител для диагностики васкулитов}

\begin{tabular}{|c|c|}
\hline Заболевание & Профиль \\
\hline $\begin{array}{l}\text { Системные васкулиты крупных } \\
\text { сосудов (болезнь Хортона, болезнь } \\
\text { Такаясу) }\end{array}$ & $\begin{array}{l}\text { Антитела к эндотелию (HUVEC), } \\
\text { Антинуклеарный фактор Нер2 }\end{array}$ \\
\hline $\begin{array}{l}\text { Системные васкулиты сосудов } \\
\text { среднего калибра (узелковый } \\
\text { полиартериит, болезнь Кавасаки) }\end{array}$ & $\begin{array}{l}\text { Антинейтрофильные антитела (АНЦА) } \\
\text { Антитела к базальной мембране клубочка }\end{array}$ \\
\hline $\begin{array}{l}\text { Системные васкулиты мелких } \\
\text { сосудов и капилляриты } \\
\text { (ранулематоз Вегенера, синдром } \\
\text { Чарг-Штраусса, микроскопический } \\
\text { полиангиит, пурпура Шонлейн- } \\
\text { Геноха, эссенциальный } \\
\text { криоглобулинемический васкулит } \\
\text { и др.) }\end{array}$ & $\begin{array}{l}\text { Антинейтрофильные антитела (АНЦА) } \\
\text { Криоглобулины с активностью РФ } \\
\text { Антитела к фактору комплемента С1q } \\
\text { Иммунофиксация парапротеинемий } \\
\text { Биопсия кожи с иммунофлюоресцентным исследованием }\end{array}$ \\
\hline
\end{tabular}

Тестирование аутоантител проводится для подтверждения диагноза у больных с недостаточным числом клинических проявлений. Обнаружение аутоантител при отсутствии клинических признаков не является основанием для постановки диагноза аутоиммунного заболевания, т.к. выявления аутоантител наблюдается у лиц пожилого и старческого возраста, на фоне приема лекарственных препаратов, при вирусных и бактериальных инфекциях, злокачественных новообразованиях. Для аутоиммунных заболеваний характерно наличие нескольких типов аутоантител (профиль аутоантител), которые увеличивает диагностическую ценность маркеров.

Помимо аутоантител на развитие аутоиммунного заболевания косвенно будут указывать неспецифические нарушения иммунитета (гипериммуноглобулинемия, снижение концентрации комплемента, увеличение альфа-интерферонов и пр.).

В аллергологии имеет важное значение определение общего уровня IgE. Увеличение общего уровня IgE - подтверждение атопического развития не только аллергии, но и любого воспалительного процесса. Существенно для диагностики синдрома гипер-IgE, полезно для дифференциальной диагностики атопических заболеваний наряду с IgG4. Одним из наиболее информативных и безопасных для больного методов диагностики атопического процесса выявление в сыворотке крови аллергенспецифических AT IgE-класса, а также субкласса IgG4.

Одним из наиболее информативных и безопасных для больного методов диагностики атопического процесса - выявление в сыворотке крови аллергенспецифических AT IgEкласса, а также субкласса IgG4. Определение аллергенспецифических AT IgE-класса в сыворотке крови проводится методом неконкурентного непрямого твердофазного ИФА с использованием поликлональных и моноклональных анти-IgE-AT, входящих в пероксидазный конъюгат, который способен выявлять в сыворотке крови больных аллергией AT IgE-класса, афинно взаимодействовать с аллергенами, сорбированными на полистироловой поверхности (может быть использована пробирка, плашка или шарик). Принцип метода основан на способности белка неспецифически прилипать к пластику, особенно к полистиролу. Для этого метода характерна высокая чувствительность и специфичность. 
В последнее время в клиническую практику для диагностики аллергий вошел метод мультиплексного твердофазного иммунофлуоресцентного исследования специфических антител класса IgE с использованием технологии биочипов - ImmunoCAP ISAC. Он позволяет определить специфические антитела к отдельным молекулярным компонентам аллергена, включая специфические и кросс-реагирующие молекулярные структуры, что значительно повышает информативность обследования и позволяет выявить причину перекрестных реакций. Алгоритм диагностики подразумевает, используя тесты Phadiatop (взрослым и детям старше 4 лет) и Phadiatop infant (детям до 4 лет) определить аллергическую природу заболевания, а затем использовать другие тесты (панели аллергенов). Определяются специфические IgE не к наиболее распространенным пищевым, пыльцевым, эпидермальным аллергенам, аллергенам плесневых грибов и насекомых, а к аллергокомпонентам.

Например, у коровьего молока и яичного белка их определяется 4 (овомукоид, овальбумин, кональбумин/ овотрансферин, ливетин/ сывороточный альбумин) у тимофеевки 8 у креветки 3. Некоторые молекулярные компоненты встречаются в разных аллергенах. Например, PR-10 протеин имеет береза, ольха, орешник, фундук, яблоко, персик, соевые бобы, арахис, киви, сельдерей. Профилин - береза, латекс, пролесник. Этим и обусловлены перекрестные аллергические реакции. Поэтому тест рекомендуется, когда история болезни и анализ истории болезни показывают: поливалентную аллергию (аллергия на несколько источников аллергенов), подозреваются перекрестные реакции. Результат теста определяет индивидуальный профиль сенсибилизации (рис.90).

\begin{tabular}{|c|c|c|}
\hline ИСТОМНИК & КОМПОНЕНT & ПРОТЕИНЫ: СЕМЕЙСТВО / ФУНКЦИЯ \\
\hline & 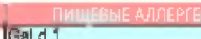 & \\
\hline 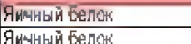 & GAld व & DEOHYKONA \\
\hline 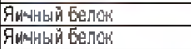 & Ginald 2 & 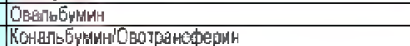 \\
\hline Яйцй го & Gald 3 & 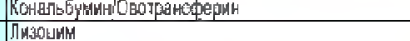 \\
\hline 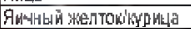 & Gitald 5 & 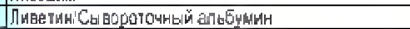 \\
\hline 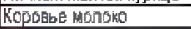 & Bosd4 & 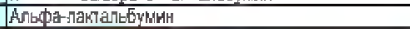 \\
\hline 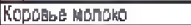 & Bos 5 & 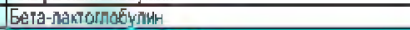 \\
\hline 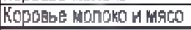 & Bos d 6 & 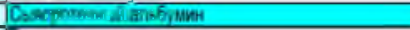 \\
\hline 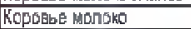 & Bes a 8 & Risewh \\
\hline 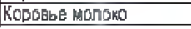 & 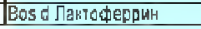 & 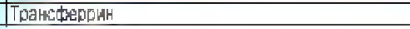 \\
\hline Kapn & Gyр с1 & 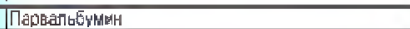 \\
\hline Tpecta & Gad C1 & 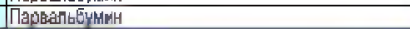 \\
\hline Kopeger 喵 & Pena 1 & 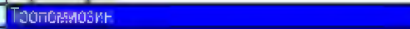 \\
\hline Kipentratia & Pen m 1 & 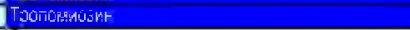 \\
\hline Kpesertia & $\operatorname{Pen~m2}$ & 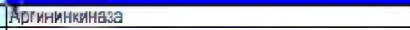 \\
\hline KDesertia & Pen m 4 & 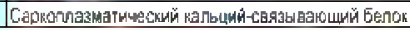 \\
\hline Keயแbì' & Ana 02 & 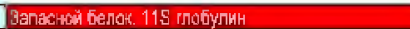 \\
\hline 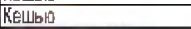 & AnIa 03 & 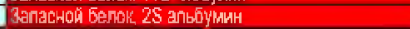 \\
\hline 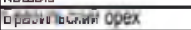 & Berel & Banacroh Genok. 25 anboymuh \\
\hline 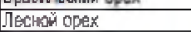 & Cor a 1.0401 & PR-10 \\
\hline 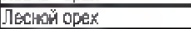 & Gor a & LTP \\
\hline 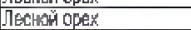 & Gor ag & 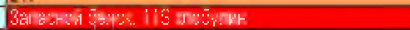 \\
\hline 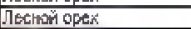 & Cor a 14 & 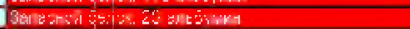 \\
\hline IFEUR, H LUES & togri & 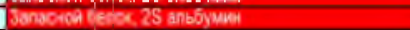 \\
\hline Грецкй орек & Jug $P 2$ & 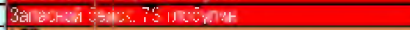 \\
\hline Грецкий оран & $\operatorname{lug} r^{3}$ & LTP \\
\hline 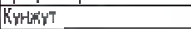 & & Banes: \\
\hline Aparknc & AFrah1 & 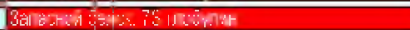 \\
\hline Apakak & hath 2 & Banderin $=1 . x .26$ antinkt \\
\hline ApáakC & $\operatorname{Arah} 3$ & 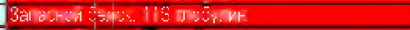 \\
\hline Apatac & Arah $B$ & 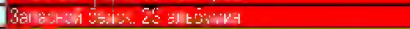 \\
\hline ApDasc & Arah 8 & PR-10 \\
\hline Apdakc & 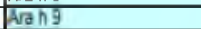 & $t^{+\infty}$ \\
\hline Cง & Gly m 4 & PR:TU \\
\hline Cos & Glit 15 & 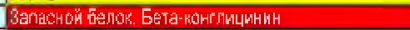 \\
\hline $\operatorname{Cog}$ & Gly m 6 & Зәпасной белок Глицин \\
\hline Грере4nxa & Fage? & 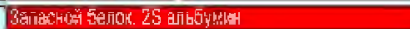 \\
\hline 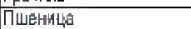 & $\ln a 14$ & LTP \\
\hline Пшенस H L L & Tria 19 & Омега 5-rлиаяин \\
\hline 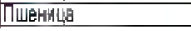 & Tाா & 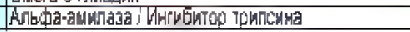 \\
\hline Kin: & Act d 1 & Цкитенин протеаза \\
\hline KinB & Act d2 & 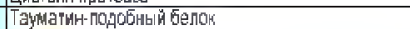 \\
\hline Kinl & Act 5 & 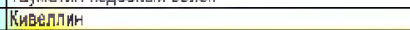 \\
\hline KNBB & Aet d 8 & PR-10 \\
\hline Cөльерей & Apig 1 & FR-10 \\
\hline ค6 & Wiald 1 & PR-10 \\
\hline 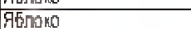 & Whald & 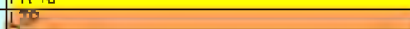 \\
\hline Пuppork & Prup 1 & Pिनार \\
\hline Пeppenk & Pru 03 & tor \\
\hline Пертаки & Pru o 4 & nocomint \\
\hline
\end{tabular}
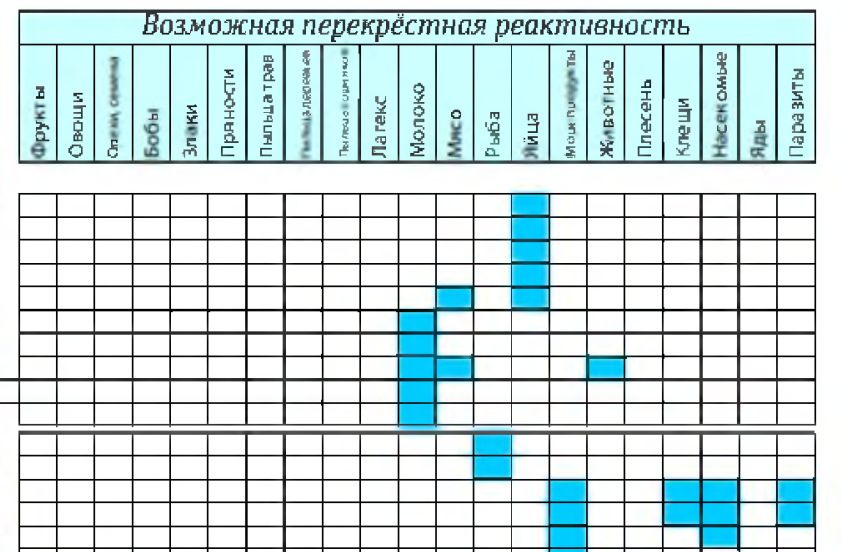

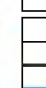
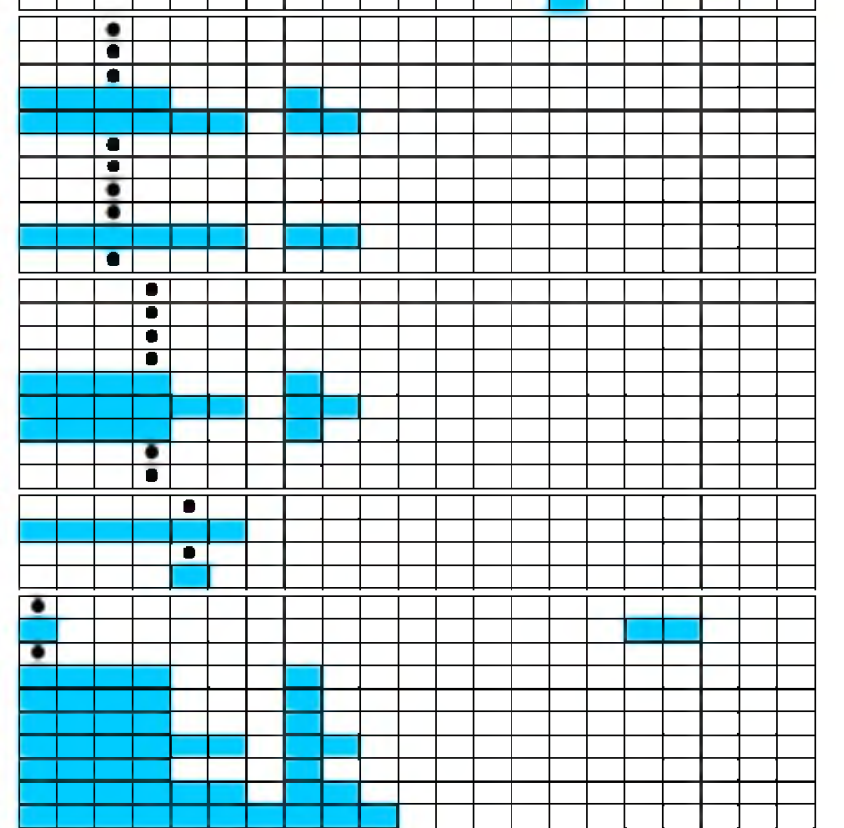

Рис. 90 Образец карты ImmunoСАР (пищевые аллергены) 
Одни из важнейших эффекторных молекул гуморального иммунитета белки системы комплемента. Центральными компонентами которого является компоненты С3 и С4. (табл.47).

Таблица 47.

Нормативные показатели в диагностики патологии системы комплемента

\begin{tabular}{|c|c|c|c|c|c|c|c|}
\hline \multirow[b]{2}{*}{ Возраст } & \multicolumn{7}{|c|}{ Показатель } \\
\hline & C3 (г/л) & C4 (г/л) & $\begin{array}{c}\text { ЦИК с } \\
\text { IgG (ед. } \\
\text { опт. пл.) }\end{array}$ & $\begin{array}{c}\text { ЦИК с } \\
\text { І gА (ед. } \\
\text { опт. пл.) }\end{array}$ & $\mathrm{CH} 50$ & $\begin{array}{c}\text { C1- } \\
\text { ингибитор } \\
(г / л)\end{array}$ & $\begin{array}{c}\text { С3- } \\
\text { активатор } \\
(г / л)\end{array}$ \\
\hline 1-3 мес. & $0.5-1.0$ & $0.12-0.36$ & $0,020-0,14$ & $0,3-0,7$ & $3.5-6.7$ & $0.36-0.38$ & $0.08-0.18$ \\
\hline 4-12 мес. & $0.7-1.2$ & $0.15-0.44$ & $0,020-0,14$ & $0,3-0,7$ & $3,5-6,7$ & $0.26-0.5$ & $0.16-0.24$ \\
\hline 12-24 мес. & $0.6-1.4$ & $0.13-0.37$ & $0,020-0,14$ & $0,3-0,7$ & $3,5-6,7$ & $0.24-0.48$ & $0.11-0.26$ \\
\hline 2-5 лет. & $0,7-1,1$ & $0,19-0,31$ & $0.020-0.14$ & $0,3-0,7$ & $3,5-6,7$ & $0.28-0.4$ & $0.14-0.25$ \\
\hline 6-8 лет. & $0.6-1.1$ & $0.14-0.27$ & $0.020-0.14$ & $0,3-0,7$ & $3,5-6,7$ & $0.21-0.43$ & $0.09-0.19$ \\
\hline 9-11 лет. & $0.6-1.1$ & $0.14-0.27$ & $0.020-0.14$ & $0,3-0,7$ & $3,5-6,7$ & $0.21-0.43$ & $0.09-0.19$ \\
\hline Старше 12 лет. & $0.6-1.1$ & $0.14-0.27$ & $0.02-0.14$ & $0.3-0.7$ & $3.5-6.7$ & $0.21-0.43$ & $0.09-0.19$ \\
\hline
\end{tabular}

Определение общей гемолитической способности комплемента (CH-50) позволяет выявить большинство нарушений этой системы. При наследственной недостаточности компонентов от С1 до С8 показатель СН50 приближен к нулю, а при недостаточности С9 он составляет примерно половину от нормы. При приобретенной недостаточности комплемента показатели СН50 зависят от характера и тяжести основного заболевания. Анализ не выявляет недостаточности факторов альтернативного пути и лектинового пути активации комплемента.

Компонент комплемента С3 - белок острой фазы воспаления, важнейшая часть защиты от инфекций. Он образуется в макрофагах и фибробластах, печени лимфоидной ткани и коже, составляет около $70 \%$ всех белков системы комплемента.

C3 компонент комплемента участвует как в классическом, так и в альтернативном пути активации системы комплемента (см. главу 3). Скорость синтеза приблизительно 1 мг/кг массы тела за один час. Скорость катаболизма - примерно $2 \%$ всего его объёма в плазме за один час, полупериод жизни 60 - 80 часов. Активация С 3 способствует выделению гистамина из тучных клеток и тромбоцитов, поддерживает фагоцитоз, усиливает проницаемость стенок сосудов, усиливает сокращение гладкой мускулатуры, хемотаксис лейкоцитов и соединение антител с антигеном; играет важную роль в развитии аутоиммунных заболеваний. Содержание C3 снижается вследствие его потребления при классическом и альтернативном пути активации системы комплемента.

Компонент комплемента $\mathbf{C 4}$ участвует только в классическом пути активации системы комплемента, имеет важное значение в развитии аутоиммунных заболеваний.

C1-ингибитор, связанный с количественной недостаточностью или сниженной активностью - один из наиболее частых врожденных дефектов системы комплемента. Он служит причиной наследственного ангионевротического отека, который проявляется повторными эпизодами сосудистого отека, захватывающего подслизистый слой дыхательных путей, пищеварительного тракта и подкожную клетчатку. Наиболее опасным является отек гортани. В большинстве случаев заболевание манифестирует в детстве, реже - во взрослом состоянии.

Циркулирующие иммунные комплексы (ЦИК) образуются при взаимодействии АГ и АТ в крови. В норме они выводятся системой мононуклеарных фагоцитов. При избыточном формировании иммунных комплексов и их неэффективной элиминации может возникнуть болезнь иммунных комплексов (гиперчувствительность III типа).

Антитела к С1q-фактору приводят к снижению уровня C1q в крови, способствуют образованию иммунных комплексов, которые, в свою очередь, откладываются в тканях и 
нарушают их функцию. Наличие антител к Clq напрямую связано с болезнью иммунных комплексов (васкулиты, аутоиммунные болезни, заболевания почек).

Нарушение функции комплемента подозревают во всех случаях рецидивирующего отека Квинке, аутоиммунных заболеваний, хронического нефрита или сегментарной липодистрофии, а также при частых гнойных инфекциях, диссеминации менингококковой или гонококковой инфекции и повторной бактериемии у больных любого возраста.

$\mathrm{He}$ менее важным является оценка клеточного компонента эффекторного ответа. Однако в отличии от гуморального звена иммунитета сделать это достаточно сложно т.к. основное количество клеток иммунной системы находятся в тканях и прежде всего в слизистых и коже (барьерные органы). Тем не менее с помощью проточной цитометрии возможно определить даже малые популяции клеток, которые свидетельствуют об активности или недостаточности той или иной популяции клеток.

Для первого этапа топической диагностики возможно использовать стандартизованную технологию «Исследование субпопуляционного состава лимфоцитов периферической крови с применением проточных цитофлюориметров-анализаторов». Первоначальный проект данного документа был опубликован в журналах: «Медицинская иммунология» (2012, Т.14, №3, с. 255-268) и «Проблемы стандартизации в здравоохранении» (2012, №5-6, с.28-44). После обсуждения на научных и научно-практических мероприятиях различного уровня, проводимых Всероссийским научно-практическим обществом по клинической лабораторной диагностике, Российским научным обществом иммунологов, а также в интернете на специализированном портале «Аллергологи-Иммунологи» (www.allergologi-immunologi.ru) был одобрен Профильной комиссией по клинической лабораторной диагностике Министерства Здравоохранения России 18.03.2014 г. и является руководством для проведения подобных исследований. В качестве нормативных показателей на территории Российской федерации применяют значения, полученных Хайдуковым С.В. и соавторами (табл. 48) [15, $24,47,97,106,107]$

Таблица 48.

\section{Относительное и абсолютное содержание основный популяций лимфоцитов в периферической крови условно здоровых добровольцев} (возраст - 17-50 лет).

\begin{tabular}{|c|c|c|}
\hline Популяции и субпопуляции & $\begin{array}{l}\text { Относительное кол-во } \\
\text { позитивных клеток (\%) }\end{array}$ & $\begin{array}{c}\text { Абсолютное кол-во кл/л } \\
\text { (х109) }\end{array}$ \\
\hline Лимфоциты (CD45bright) & $28-36$ & $1,363-2,808$ \\
\hline В-клетки общие (CD3-CD19+) & $7-17$ & $0,111-0,376$ \\
\hline NK-клетки (CD3-CD16+CD56+) & $8-17$ & $0,123-0,369$ \\
\hline Т-клетки общие (CD3+CD19-) & $61-85$ & $0,946-2,079$ \\
\hline T хелперы (CD3+CD4+) & $35-55$ & $0,576-1,336$ \\
\hline Т цитотоксические (CD3+CD8+) & $19-35$ & $0,372-0,974$ \\
\hline NKT клетки (CD16+CD56+CD3+) & $0,5-6$ & $0,007-0,165$ \\
\hline \multicolumn{3}{|c|}{ Расчетные показатели } \\
\hline Показатель & \multicolumn{2}{|c|}{ Нормативные показатели } \\
\hline Индекс соотношения (Тx/Тц) & \multicolumn{2}{|c|}{$1,5-2,6$} \\
\hline Контрольная сумма (T+B+NK) & \multicolumn{2}{|c|}{$100 \pm 5 \%$} \\
\hline
\end{tabular}

Большое значение при этом принадлежит определению абсолютного числа клеток т.к. именно их снижение или увеличение имеют клиническую значимость. Изменение относительного числа популяций клеток в большей степени свидетельствует о дисбалансе и требует обязательного перерасчета на абсолютное количество. 
Особое внимание при проведении иммунофенотипирования следует уделить подсчету контрольных сумм, характеризующих качество и достоверность проведенного исследования. Пожалуй, главной из них является сумма Т-, В- и НК-клеток, которая должна находиться в пределах 100\% (100\% $\pm 5 \%)$. Например, Т-лимфоциты составляют 69,23\%, В-лимфоциты $8,29 \%$, натуральные киллеры - 22,76\%. При помощи нехитрых подсчетов контрольная сумма будет равна 100,28\%, что полностью соответствует нормативным значениям. Еще одним «внутренним» контролем может являться то положение, что сумма Т-хелперов, выделенных при помощи CD3 и CD4, и цитотоксических Т-клеток с фенотипом CD3+CD8+ должна равняться общему числу CD3-позитивных клеток $\pm 5 \%$. Хотя даже в рамках приведенных выше рекомендаций допускается расхождение не более $10 \%$ из-за присутствия в образце $\gamma \delta \mathrm{T}-$ клеток (увеличение числа дважды-негативных клеток в образце, что сопровождается уменьшением суммарного показателя Т-лимфоцитов) или наличия большого числа клеток, коэкспрессирующих CD4 и CD8. В последнем случае сумма CD3+CD4+ и CD3+CD8+ может существенно превосходить общее число $\mathrm{CD} 3+$ клеток и выходить за прописанные в рекомендациях нормативы. Клиническая значимость этих параметров в настоящее время обсуждается при широком круге патологических состояний.

Однако для топической диагностики клеточного звена иммунитета стандартного исследования недостаточно. Используя проточную цитометрию возможно более детально охарактеризовать патологию клеток

К эффекторным клеткам традиционно относят гранулоциты, часть лимфоидных клеток врожденного иммунитета, популяции ЦТЛ, $\gamma \delta$-Т- и В-лимфоцитов.

Гранулоциты составляют большинство лейкоцитов в периферической крови и преобладают в областях воспаления. Ключевыми клетками в развитии воспаления являются нейтрофилы, которые являются высоко реактивными клетками врожденного иммунитета, способными быстро мобилизоваться в очаг воспаления. За счет широкого спектра рецепторов нейтрофильные гранулоциты являются очень чувствительными клетками к изменению гомеостаза организма.

В клинической практике возможно оценивать эти клетки морфологически (юные, палочко-, сегментоядерные нейтрофилы). Однако используя проточную цитометрию по набору клеточных маркеров возможно оценить функциональную активность и степень зрелости нейтрофилов. Так наличие большого количества нейтрофилов с экспрессией на поверхности CD15 и $\mathrm{CD} 11 \mathrm{~b}$ свидетельствует о нарушении дифференцировки нейтрофилов, наоборот

- CD16, CD64 свидетельствуют об активации нейтрофилов. (рис.73). Снижение экспрессии CD62L, CD50 позволяют выявить, дефекты миграции. Наличие на нейтрофилах HLA-DR свидетельствует о способности

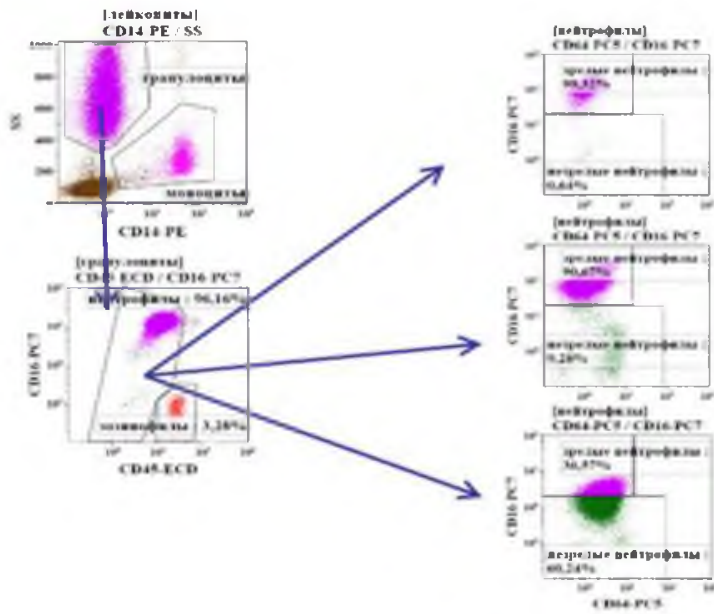

Рис.91 Гранулоциты

Анализ образов периферической крови проведен на проточном цитометре Navios 3/10 (Beckman Coulter Inc., USA), полученные результаты обработаны при помощи Kaluza Softvare 2.1 (Beckman Coulter Inc., USA) нейтрофилов к презентации АГ.

Одним из проявлений функциональной активности нейтрофилов является спонтанная и индуцированная люминол- и люцигенин-зависимая хемилюминесценция. Основные нормативные показатели которой представлены в таблице 49.

Количественный анализ базофилов и эозинофилов их клиническое значение описано выше (глава 6). Однако при топической диагностике заболеваний связанных с дегрануляцией базофилов хотелось бы выделить базофильный тест. 
Базофильный тест основан на выявлении маркера активации базофилов (CD203) под действием исследуемого аллергена in vitro методом проточной цитофлуориметрии. Исследование проводится в короткие сроки, абсолютно безопасен для пациента. В качестве аллергена можно использовать любые вещества в том числе лекарственные средства (наибольшее применение нашли препараты для местной анестезии и контрастные вещества). На настоящий момент базофильный тест является основным тестом клеточной диагностики, используемым для обследования пациентов с аллергическими заболеваниями за рубежом. Перспективным для травматологов и стоматологов является такие исследования по прогнозированию отторжения инплантов $[16,17]$

Таблица 49

Хемилюминесцентный анализ

\begin{tabular}{|c|c|c|c|}
\hline Показатель & Ед.изм. & \multicolumn{2}{|c|}{ Нормативный показатель } \\
\hline \multicolumn{4}{|c|}{ Люминол-зависимая хемилюминесценция } \\
\hline & & Спонтанная & Индуцированная \\
\hline Tmax -, & время, сек & $636-1545$ & $814-1526$ \\
\hline Imax - интенсивность & o.e. & $3110-14990$ & $6220-26550$ \\
\hline S - площадь & o.e. & $2085743,5-160627588$ & $3772475-439100000$ \\
\hline \multicolumn{2}{|l|}{ Индекс активации } & \multicolumn{2}{|c|}{$1,27-2,37$} \\
\hline \multicolumn{4}{|c|}{ Люцигенин-зависимая хемилюминесценция } \\
\hline Tmax -, & время, сек & $941-2881$ & $1389-2331$ \\
\hline Imax - интенсивность & o.e. & $2611-16536$ & $7586-28960$ \\
\hline S - площадь & o.e. & $3950000-41114989$ & $10700771-64610000$ \\
\hline \multicolumn{2}{|l|}{ Индекс активации } & \multicolumn{2}{|c|}{$1,17-3,10$} \\
\hline
\end{tabular}

Натуральные киллеры (NK-клетки). В настоящее время для локализации NK-клеток в периферической крови наиболее широко используют анализ экспрессии CD16 и CD56, конъюгированных с одним и тем же флуорохромом, на CD3-негативных клетках.

Нормативные показатели представлены в таблице 50. Данная комбинация моноклональных антител позволяет локализовать общую популяцию NK-клеток количественно, но не охарактеризовать их отдельные субпопуляции. Кроме того, у такого подхода есть чисто практическое значение, позволяющее упростить процедуру идентификации NKклеток в клинической практике. Как Таблица 50. известно, НК-клетки способны индуцировать апоптоз в клетках-мишенях, которые инфицированы вирусами и другими внутриклеточными антигенами, или же являются собственными «перерожденными» опухолевыми клетками, а также другие клетки аллогенного и ксеногенного происхождения (реакции отторжения трансплантата, например). Именно поэтому клиническая значимость определения NK-клеток при реакциях врожденного иммунитета, направленных на элиминацию внутриклеточных патогенов, не вызывает сомнений. Так, увеличение количества NK-клеток в периферической крови встречается при вирусных заболеваниях, повышается при злокачественных новообразованиях и лейкозах, в периоде реконвалесценции, в некоторых 
случаях увеличение фиксируется при бронхиальной астме, может быть связано с активацией иммунитета после трансплантаций. Снижение данного показателя наблюдается при различных врожденных иммунодефицитах, паразитарных инфекциях, аутоиммунных заболеваниях, облучении, лечении цитостатиками и кортикостероидами, стрессе, дефиците цинка.

Необходимо отметить, что NK-лимфоциты представляют собой гетерогенную популяцию клеток, и уже при иммунофенотипирование общей фракции NK-клеток по маркерам CD16 и CD56 можно выделить их основных субпопуляций (рис. 92).

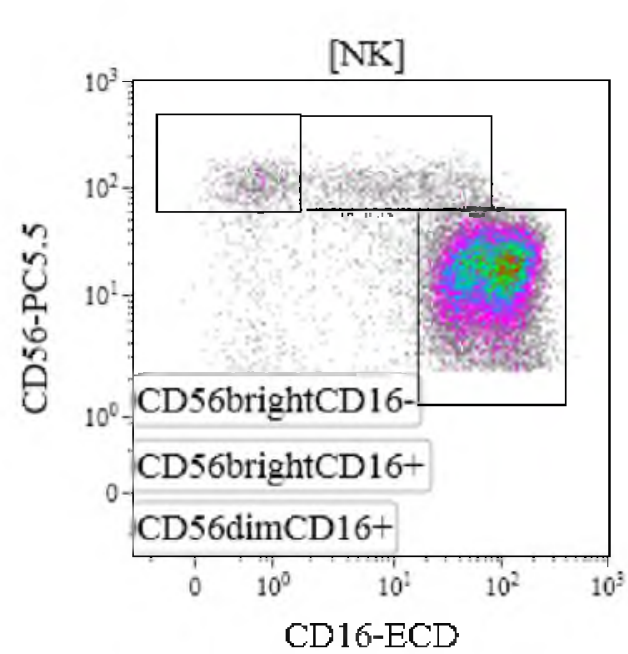

\section{Рис. 92. NK-клетки}

Анализ образов периферической крови проведен на проточном цитометре Cytomics FC500 (Beckman Coulter Inc., USA), полученные результаты обработаны при помощи Kaluza Softvare 2.1 (Beckman Coulter Inc., USA)
CD16 является низкоаффинным рецептором иммуноглобулинов G III типа (Fc $\gamma \mathrm{RIII})$, с помощью которого осуществляется механизм клеточной цитотоксичности. Маркер CD56 (NCAM, Leu-19, NKH-1) является гликопротеином, принадлежащим к суперсемейству иммуноглобулинов, и принимает участие в реализации межклеточных контактов. При этом NKклетки, активно экспрессирующие CD16 и CD56, определяются как зрелые. NKклетки с фенотипом CD16-CD56+ проявляют цитотоксическую активность. NK-клетки с фенотипом CD16+CD56- в ответ на стимуляцию IL2 начинают секретировать широкий спектр цитокинов, но проявляют слабую цитолитическую активность (цитокинпродуцирующие клетки).

Важным является определение на этих клетках различных маркеров активации характеризующие их функциональную активность и/или недостаточность. Среди них важнейшим является выделение субпопуляции цитолитических NK-клеток (обладают цитолитической активностью, но секретируют относительно немного цитокинов) и цитокинпродуцирующих натуральных киллеров (выделяют IFN- $\gamma$ для активации других клеток, но обладают меньшей цитолитической активностью) и NKT-клетки обладающие большей цитотоксичностью. Экспрессия различных рецепторов позволяет судить о той или иной функции NK-лимфоцитов (табл.51).

Таблица 51

\section{Основные популяции NK-клеток}

\begin{tabular}{|c|c|c|}
\hline Популяции NK клеток & Маркеры & $\begin{array}{c}\text { Показатель у здорового } \\
\text { человека (\%) }\end{array}$ \\
\hline Общая популяция & $\begin{array}{l}\text { CD3-CD16/CD56+CD19- } \\
\text { CD3-CD16+CD56+CD19- }\end{array}$ & $9.9-22.9$ \\
\hline Цитотолитические & CD16 ${ }^{\text {hi }}$ CD56 dim & $0,20-0,56$ \\
\hline Цитокинпродуцирующие & CD3-CD16-CD56 bright CD19- & $0,17-0,53$ \\
\hline NKT клетки & CD3+CD16+CD56+CD19- & $0,5-5,0$ \\
\hline Активированные & CD16/56+CD38+ & $1,52-4,18$ \\
\hline \multirow[t]{2}{*}{ Активно мигрирующие } & CD16/CD56+CD11b+ & \multirow[t]{2}{*}{$0,16-0,47$} \\
\hline & CD16/56+CD62L+ & \\
\hline Конечно-дифференцированные NK & CD16/56+CD57+ & $0,21-1,82$ \\
\hline
\end{tabular}


В норме увеличение той или иной субпопуляции клеток свидетельствует о наличии острого воспалительного процесса. При разрешении процесса происходит постепенно снижение показателя до нормального значения. Если количество активированных клеток находится на стабильно повышенном уровне, это может быть признаком хронического воспалительного процесса.

Оценка абсолютного и относительного содержания CD3+ T-лимфоцитов и их субпопуляций в периферической крови осуществляется в диагностике широкого спектра патологических состояний. (рис.92).

К числу которых, в первую очередь, относятся первичные и вторичные иммунодефициты. Патологии связанные с нарушением дифференцировки и созревании Тклеток (прежде всего лейкозы). Большое значение принадлежит оценки количества Т-лимфоцитов при острых и хронических вирусных инфекциях, включая ВИЧ-инфекцию и хронические вирусные гепатиты. Более того, определение уровня Т-лимфоцитов в периферической крови показало свою значимость при анализе образцов, полученных от пациентов с различными внутриклеточными инфекционными заболеваниями (например, при и нфицировании M.tuberculosis, M.lepra

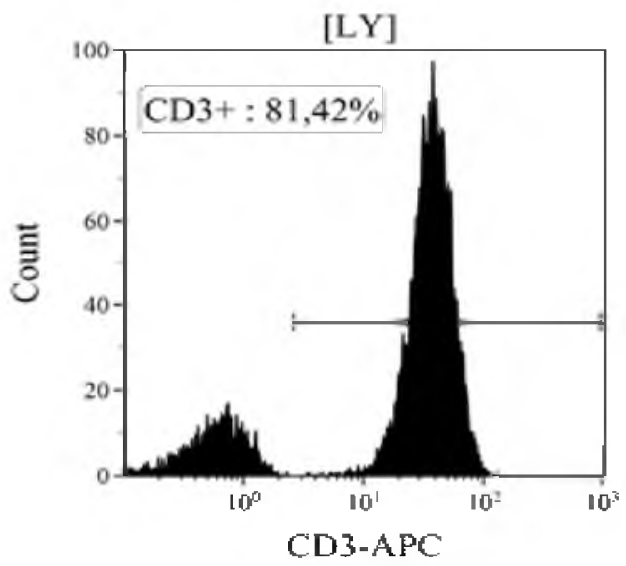

Рис.92 Определение общего количества Т-лимфоцитов

Анализ образов периферической крови проведен на проточном цитометре Navios 3/10 (Beckman Coulter Inc., USA), полученные результаты обработаны при помощи Kaluza Softvare 2.1 (Beckman Coulter Inc., USA).

или Leishmania spp.), при септических состояниях, диагностике отторжения пересаженного трансплантата, реакции "трансплантат-против-хозяина" и при другой патологии (табл.50).

Традиционно, абсолютного числа Т-лимфоцитов в периферической крови трактуется как свидетельство «гиперактивности» иммунной системы пациента, которое может быть тесно

Таблица 52.

\section{Показатели числа Т-лимфоцитов}

\begin{tabular}{|c|c|c|}
\hline \multirow{2}{*}{ Возраст } & \multicolumn{2}{|c|}{ Показатель } \\
\cline { 2 - 3 } & $\mathrm{CD} 3, \%$ & $\mathrm{CD} 3$, абс. \\
\hline $1-3$ мес. & $55-78$ & $2070-6540$ \\
\hline 4-12 мес. & $45-79$ & $2280-6450$ \\
\hline $12-24$ мес. & $53-81$ & $1460-5440$ \\
\hline $2-5$ лет. & $62-80$ & $1610-4230$ \\
\hline старше 6 лет & $66-76$ & $1400-2000$ \\
\hline
\end{tabular}

злокачественных новообразованиях, после травмы, операций, инфаркта, приеме цитостатиков. Повышение их числа в динамике заболевания или на фоне проведения соответствующей терапии принято рассматривать в качестве клинически благоприятного признака.

Важным и одним из основных методов исследования Т-лимфоцитов является диагностика при исследовании первичных иммунодефицитов. При ТКИД, синдром ДиДжорджи, синдром «голых лимфоцитов», Х-сцепленный лимфопролиферативный синдром, синдром Вискотта-Олдрича происходит значительное снижение Т-лимфоцитов. 
Наличие большого числа Т-клеток сопряжено с развитием аутоиммунных заболеваний.

Популяции Т-лимфоцитов состоит из различных субпопуляций. С клинической точки зрения важным является выделение эффекторных (цитотоксические и Түб- лимфоциты) и регуляторных (Т-хелперы и Treg) клетки.

Цитотоксические Т-лимфоциты основные клетки адаптивного иммунитета (рис.53). Определение уровня Тцитотоксических лимфоцитов с фенотипом $\mathrm{CD} 3+\mathrm{CD} 8+$ в периферической крови показало свою клиническую значимость при выявлении первичных иммунодефицитных состояниях, диагностике пациентов с различными вирусными инфекциями, при опухолевом росте и метастазировании, а также имеет важнейшее значение при исследовании специфической иммунологической памяти Таблица 53.

\section{Показатели числа ЦТЛ}

\begin{tabular}{|c|c|c|}
\hline \multirow{2}{*}{ Возраст } & \multicolumn{2}{|c|}{ Показатель } \\
\cline { 2 - 3 } & $\mathrm{CD} 3+\mathrm{CD} 8+, \%$ & $\mathrm{CD} 3+\mathrm{CD} 8+$, абс. \\
\hline $1-3$ мес. & $16-35$ & $650-2450$ \\
\hline $4-12$ мес. & $16-34$ & $720-2490$ \\
\hline $12-24$ мес. & $16-38$ & $570-2230$ \\
\hline $2-5$ лет. & $22-38$ & $630-1910$ \\
\hline Старше 6 лет. & $27-35$ & $600-900$ \\
\hline
\end{tabular}

(оценка эффективности вакцинации). Так, повышение выявляется практически при всех хронических инфекциях, вирусных, бактериальных, протозойных инфекциях. Является характерным для начале ВИЧ-инфекции. Снижение же уровня CD3+CD8+ клеток в периферической крови может свидетельствовать о вирусных гепатитах, хронической герпесвирусной инфекции, некоторых типах аутоиммунных заболеваниях.

Увеличение CD3+CD8+ обычно связано с ВИЧ-инфекцией, острыми вирусными инфекциями, парапротеинемиями, малярией, при дебют аутоиммунных заболеваний, множественной миеломе, хроническом вирусном гепатите, сепсисе, перитоните, гемофилии, шистосомозе, инфекционном мононуклеоз, абсцесс легкого, почки. Уменьшение при первичные иммунодефицитах (ТКИД, синдром Ди-Джорджи, синдром «голых лимфоцитов», $\mathrm{X}$-сцепленный лимфопролиферативный синдром, синдром Вискотта-Олдрича) вирусных инфекциях (герпес-вирусные инфекци (ВГ 1-2, 3 тип, ЦМВ, ВЭБ-инфекции), облучении, отравление диоксинами.

Для Т-хелперов, находящихся на терминальных стадиях дифференцировки, также характерно появление CD8 (обычно $\alpha \alpha$ гомодимера) на поверхностной мембране. CD8 может обнаруживаться на поверхности Т-клеток, несущих $\gamma \delta$-Тклеточный рецептор, а также на «инвариантных» НКТ-клетках. Способностью к экспрессии $а \alpha \mathrm{CD} 8$ обладают некоторые популяции НКклеток.

Важное значение принадлежит в определении стадии дифференцировки цитотоксических Т-лимфоцитов и определении на их поверхности активационных маркеров. В стадии дифференцировки CTL можно выделит: наивные CTL (Naïve), CTL центральной памяти (CM), CTL эффекторной памяти (EM) и терминально дифференцированные клетки памяти CTL (TEMRA) (рис.93).

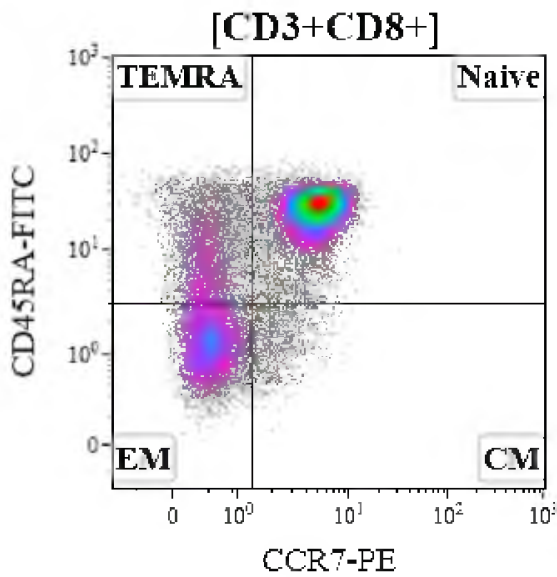

\section{Рис. 93. CTL разной стадии дифференцировки}

Анализ образов периферической крови проведен на проточном цитометре Navios 3/10 (Beckman Coulter Inc., USA), полученные результаты обработаны при помощи Kaluza Softvare 2.1 (Beckman Coulter Inc., USA). 
Определение клеток с этими маркерами позволяют определить нарушение дифференцировки и могут быть единственным подтверждением причины развития того или иного патологического процесса.

Итоговые основные популяции ЦТЛ их активационных маркеров и нормативные показатели представлены в таблице (табл.54)

Таблица 54

\section{Основные популяции цитотоксических Т-лимфоцитов (\% от CD3+CD8+ клеток)}

\begin{tabular}{|l|l|c|c|}
\hline \multicolumn{1}{|c|}{ Популяция } & \multicolumn{1}{c|}{ Маркеры } & \multicolumn{2}{c|}{$\begin{array}{c}\text { Показатель у здорового } \\
\text { человека }\end{array}$} \\
\cline { 3 - 4 } & & абс. \\
\hline Наивные CTL & CD3+CD8+CD45RA+CD62L+ & $2.0-18,0$ & $40-350$ \\
\hline CTL центральной памяти & CD3+CD8+CD45RA-CD62L+ & $1,0-8,0$ & $25-150$ \\
\hline CTL эффекторной памяти & CD3+CD8+CD45RA-CD62L- & $3,0-12,0$ & $50-220$ \\
\hline $\begin{array}{l}\text { Терминально } \\
\text { дифференцированные } \\
\text { клетки памяти CTL }\end{array}$ & CD3+CD8+CD45RA+CD62L- & $2,0-20,0$ & $40-300$ \\
\hline Активированные & CD8/HLA-DR & $5,0-25,0$ & $30-180$ \\
\hline $\begin{array}{l}\text { Имеющие } \\
\text { костимулирующий фактор }\end{array}$ & CD3+CD4-CD8+CD28 & $9,5-26,0$ & $120-600$ \\
\hline $\begin{array}{l}\text { Конечно- } \\
\text { дифференцированные }\end{array}$ & CD3+CD4-CD8+CD57 & менее 30 & менее 520 \\
\hline
\end{tabular}

По наличию тех или иных маркеров можно охарактеризовать функциональную активность клеток. Так CD3+CD4-CD8+CD25 CTL клетки с ранним маркером активации, CD3+CD4-CD8+CD38 - с метаболическим маркером активации, CD3+CD4-CD8+CD11b и CD3+CD4-CD8+CD62L - активно мигрирующие CTL, CD3+CD4-CD8+CD297(PD1) - конечно дифференцированные CTL. B недалёком бедующем появятся нормативные показатели и для этих субпопуляций клеток, но уже в настоящее время при отсутствии данных параметров можно топически определить причину развития той или иной иммунопатологии.

$\mathbf{T} \boldsymbol{\gamma} \boldsymbol{\delta}$ - лимфоциты. Так же, как и CTL осуществляют эффекторную функцию напрямую используя рецепторный аппарат так и с использованием АТ. Они выделяют большое количество провоспалительных цитокинов. Некоторые клетки выполняют функции АПК.

В отличии от основной Т-клеточной популяции экспрессирующей $\alpha \beta \mathrm{CD} 3$ рецепторов на них представлен $\gamma \delta$-рецептор. Отличительной чертой этих клеток является отсутствие на поверхности CD4 и CD8, что позволяет предварительно оценить количество Т $\gamma \delta$ - лимфоцитов в крови. Помимо лейкоцитарного маркера $\mathrm{CD} 45$, как функциональные маркеры Т $\gamma \delta-$ лимфоциты имеют рецепторы CD16 (к Fc-фрагменту антител), CD92L (запускает апоптоз клетки мишени), CD282 (TLR2), CD204 (скавенджер-рецепторы). На части клеток помимо MHC I продуцируются и МНC II класса.

Увеличение циркуляции субпопуляции Т $\gamma \delta$-клеток позволяет предположить наличие стимуляции иммунной системы, особенно на слизистых оболочках и коже. В острую фазу воспаления их количество в периферической крови может увеличится в разы. При медленно прогрессирующих инфекционных заболеваниях увеличение Т $\gamma \delta$ - лимфоцитов может служить дополнительным критерием активности процесса.

В настоящее время нормативных показателей для этих субпопуляций клеток нет, но по количеству клеток с той или иной функцией можно охарактеризовать функциональную активность Т $\gamma \delta$ - лимфоцитов, определить роль этих клеток например в процессах антигенпрезентации, эффекторных функций и/или процессах регенерации. 
В-лимфоциты. Выявление В-лимфоцитов производится на основании экспрессии CD 19. CD19 является важнейшим компонентом рецепторного аппарата В-клеток, без которого функционирование данной популяции лимфоцитов невозможно (рис.94). Экспрессия CD19 обнаруживается со стадии про-В-клетки и сохраняется на протяжении всей жизни Влимфоцита, несколько снижаясь лишь на плазматических клетках. Более того, этот антиген рассматривается в качестве «линейного» маркера всех В-лимфоцитов. Его экспрессия может быть обнаружена в некотором количестве на фолликулярных дендритных клетках, относительное содержание которых в периферической крови крайне низко.

Что касается плотности экспрессии CD19, то один В-лимфоцит несет на своей поверхности около 18 тысяч молекул. Поэтому для анализа экспрессии CD19 рекомендуется применять антитела, конъюгированные с яркими флуорохромами.

$$
\text { В-лимфоциты играют }
$$

ведущую роль в формировании эффективно функционирующего специфического гуморального иммунитета, благодаря своей способности дифференцироваться в антитело-синтезирующие

плазматические клетки и формированию долгоживущих клеток иммунологической памяти. Поэтому клиническая значимость определения уровня CD19+ лимфоцитов в циркулирующей крови показано при широком круге патологических состояний, связанных с нарушением синтеза антител (табл.55)

В первую очередь, определение В-клеток важно при диагностике первичных иммунодефицитов, связанных с наличием агаммаглобулинемии и дисгаммаглобулинемии. Данный показатель необходим при скрининге и выявлении системных аутоиммунных патологических состояний, связанных с наличием высокого титра аутореактивных антител в сыворотке крови (системная красная волчанка, ревматоидный артрит, синдром Шегрена и т.д.).

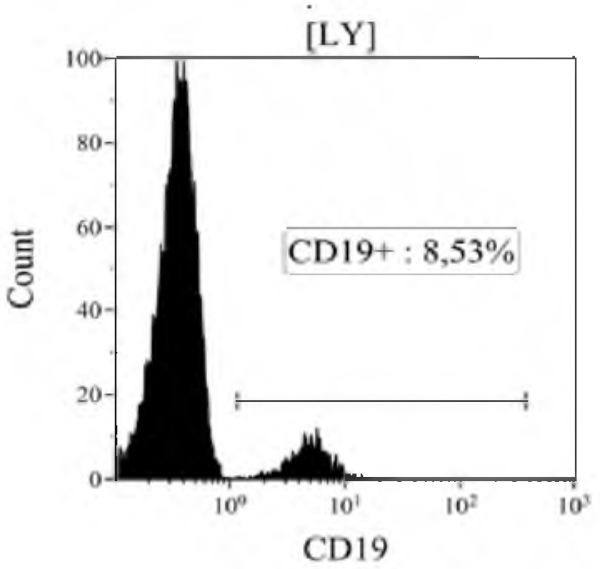

Рис. 94. Определение общего количества В-лимфоцитов

Анализ образов периферической крови проведен на проточном цитометре Navios 3/10 (Beckman Coulter Inc., USA), полученные результаты обработаны при помощи Kaluza Softvare 2.1 (Beckman Coulter Inc., USA

Таблица 55.

Показатели числа В-клеток

\begin{tabular}{|c|c|c|}
\hline \multirow{2}{*}{ Возраст } & \multicolumn{2}{|c|}{ Показатель } \\
\cline { 2 - 3 } & $\mathrm{CD} 19, \%$ & $\mathrm{CD} 19+$, абс. \\
\hline 1-3 мес. & $6-31$ & $300-2000$ \\
\hline $\mathbf{4 - 1 2}$ мес. & $11-41$ & $430-3000$ \\
\hline $\mathbf{1 2 - 2 4}$ мес. & $16-35$ & $720-2600$ \\
\hline $\mathbf{2 - 5}$ лет. & $14-33$ & $390-1400$ \\
\hline 6-12 лет. & $13-27$ & $270-860$ \\
\hline Старше 12 лет. & $10-22$ & $300-570$ \\
\hline
\end{tabular}

Кроме того, анализ содержания

В-лимфоцитов в перфиерической крови значим при инфекционных бактериальных заболеваниях и паразитарных инвазиях; злокачественных новообразования, связанных с неконтролируемым делением клонов В-лимфоцитов (лимфолейкозы, лимфомы, миеломная болезнь и т.д.). Так, снижение уровня этих клеток в циркуляции наблюдается при физиологических и врожденных иммунодефицитах, острой вирусной и хронической 
бактериальной инфекциях. Увеличение доли этих клеток в рамках лимфоцитарного пула отмечается при некоторых аутоиммунных заболеваниях, хронических заболеваниях печени, муковисцедозах, бронхиальной астме, паразитарных и грибковых инфекциях.

Важными показателями являются стадия дифференцировки и активационные маркеры В-лимфоцитов, а также идентификация в периферической крови В1-клеток (табл.56)

Таблица 56

\section{Основные суб̄популяции В-клеток (\% от В-клеток)}

\begin{tabular}{|c|c|c|}
\hline Популяция & Маркеры & $\begin{array}{c}\text { Показатель у здорового } \\
\text { человека }\end{array}$ \\
\hline В1 - лимфоциты & CD19+CD5+ & $8,0-16,0$ \\
\hline В2 лимфоциты & CD19+CD5- & $78,0-90,0$ \\
\hline В-клетки памяти & CD19+CD27+CD5- & $20,0-40,0$ \\
\hline Наивные В-лимфоциты & CD19+CD27-CD5- & $40,0-65,0$ \\
\hline «naïve» & CD19+ (CD27-lgD+) & $50,0-75,0$ \\
\hline «unsw memory» & $C D 19+(C D 27+\operatorname{lgD}+)$ & $8,0-20,0$ \\
\hline «sw memory») & CD19+ (CD27+lgD-) & $11,0-22,0$ \\
\hline «DN" & CD19+ (CD27-lgD-) & $2,0-6,0$ \\
\hline “наивные” Вm1 клетки & CD19+ IgD+CD38- & $7,0-16,0$ \\
\hline Bm2 клетки & CD19+ IgD+CD38+ & $45,0-70,0$ \\
\hline Bm2' клетки & CD19+ IgD+CD38++ & $4,0-10,0$ \\
\hline “Bm3+Bm4” клетки & CD19+ IgD-CD38++ & $0,5-1,5$ \\
\hline eBm5 клетки & CD19+ IgD-CD38+ & $8,0-17,0$ \\
\hline Bm5 клетки & CD19+ IgD-CD38- & $5,0-12,0$ \\
\hline
\end{tabular}

Окраска антителами против $\operatorname{IgD}$ и $\mathrm{CD} 38$ позволяет идентифицировать следующие популяции В-клеток: “наивные” Bm1 клетки с фенотипом IgD+CD38-, “активированные наивные” Bm2 клетки (IgD+CD38+), Bm2' - клетки-предшественники В-клеток герминального центра (IgD+CD38++), общая суб̆популяция, включающая в себя центробласты и центроциты - так называемые "Bm3+Bm4" клетки (IgD-CD38++), клетки ранней памяти eBm5 (IgD-CD38+) и покоящиеся клетки памяти Bm5 (IgD-CD38-). Окраска антителами против поверхностных молекул IgD и CD27 позволяет отделить группу «наивных» клеток с фенотипом IgD+CD27- от трех разновидностей клеток памяти - клетки памяти с непереключенным классом синтезируемых антител (“unswitched" IgD+CD27+), клетки памяти с переключенным классом синтезируемых антител (“class-switched" memory cells, IgD-CD27+) и так называемые «дваждынегативные» клетки памяти (IgD-CD27-).

Антиген презентующие клетки. Функция АПК клеток описана нами выше (см. главы 3 и 4). В периферической крови их достаточно мало и основным представителем здесь являются моноциты (рис.95).

Среди моноцитов (линейным маркером которых долгое время считался CD14) по экспрессии CD16 можно выявить ряд популяций. Популяция «классических» моноцитов CD16 не несет (на них обнаруживается только CD14, их фенотип описывается как $\mathrm{CD} 14^{++} \mathrm{CD} 16^{-}$), в то время как моноциты «неклассической» и «переходной» популяций CD16 экспрессируют (фенотипы $\mathrm{CD} 14^{+} \mathrm{CD} 16^{++}$и $\mathrm{CD} 14^{++} \mathrm{CD} 16^{+}$, соответственно). Основная функция классических моноцитов, как и макрофагов, фагоцитоз апоптотических телец. За счет низкой экспрессией HLA-DR, они слабо выполняют функцию антигенпрезентации. 
Наоборот,

моноциты слабо фагоцитируют апоптотические клеток, но за счет экспрессии большого количества HLADR и костимуляторных молекул они активно выполняют функцию антигенпрезентации и продукции провоспалительных цитокинов.

Переходные моноциты образуются в результате активации и дифференцировки классических моноцитов. Их основные функции: распознавание РАМР и синтез цитокинов (как провоспалительных -TNF $\alpha, I L-1 \beta$, так и противовоспалительных IL-10), IgGопосредованный фагоцитоз, антигенпрезентация.

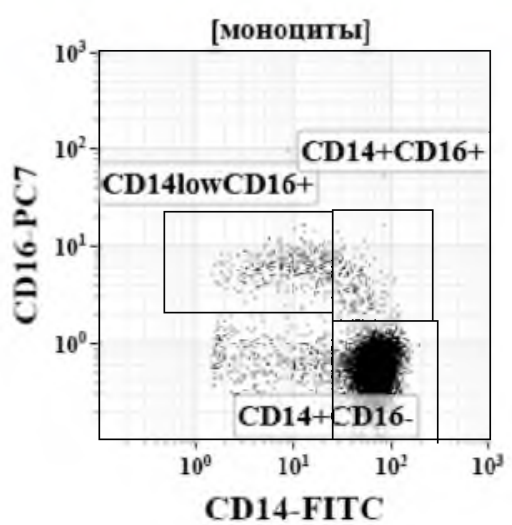

Рис. 95. Основные популяции моноцитов

Анализ образов периферической крови проведен на проточном цитометре Navios 3/10 (Beckman Coulter Inc., USA), полученные результаты обработаны при помощи Kaluza Softvare 2.1 (Beckman Coulter Inc., USA).

Одним из важнейших клинических критериев в диагностике прежде всего критических состояний принадлежит определению HLA-DR на моноцитах. Значительное снижение экспрессии HLA-DR может служить тестом для идентификации временной иммунодепрессии и коррелирует с неблагоприятным исходом при сепсисе, травме, панкреатите, при осложнениях в сердечно-легочной хирургии, после трансплантации у пациентов после удаления опухоли. Резкое снижение HLA-DR на моноцитах может служить показателем для применения более раннего терапевтического вмешательства с использованием IFN $\gamma$, растворов обогащенных глютамином и мурамилсодержащие гликопептиды, чтобы стимулировать иммунную систему и в первую очередь антигенпрезентирующую функцию моноцитов.

Нормативные показатели моноцитов представлены в таблице (табл.57). В настоящее время используя проточную цитометрию возможно оценить и другие функции моноцитов такие как миграционная активность $(\mathrm{CD} 11 \mathrm{~b}+, \mathrm{CD} 62 \mathrm{~L}+)$, метаболические свойства (CD38+, $\mathrm{CD} 184+$ ), костимуляторные возможности ( $\mathrm{CD} 80+, \mathrm{CD} 86+$ ), однако нормативные показатели и их клиническая интерпретация пока не описаны.

Таблица 57

\section{Основные показатели моноцитов (\% от моноцитов)}

\begin{tabular}{|l|l|c|}
\hline \multicolumn{1}{|c|}{ Популяция } & \multicolumn{1}{|c|}{ Маркеры } & $\begin{array}{c}\text { Показатель у } \\
\text { здорового человека }\end{array}$ \\
\hline Общий пул моноцитов (а6с.) & $\mathrm{CD}^{+}$ & $0.18-0.51$ \\
\hline Классические & $\mathrm{CD} 14+\mathrm{CD} 16-$ & $42.3-72.3$ \\
\hline Переходные & $\mathrm{CD} 14++\mathrm{CD} 16+$ & $16.2-52.2$ \\
\hline Неклассические & $\left.\mathrm{CD} 14\right|^{\text {ow } C D 16+}$ & $4.1-11.1$ \\
\hline Дендритные клетки & $\mathrm{CD} 3-/ \mathrm{CD} 19-/ \mathrm{CD} 16 / 56-/ \mathrm{CD} 45+$ & $0-2,0$ \\
\hline $\begin{array}{l}\text { Антиген-презентующие } \\
\text { моноциты }\end{array}$ & $\mathrm{CD} 14+\mathrm{HLA}-\mathrm{DR}+$ & $84.5-95.8$ \\
\hline
\end{tabular}

Регуляторные клетки. Большая популяция клеток врожденного и адаптивного иммунитета. Некоторые клетки (цитокинпродуцирующие NK-клетки, миелоидные супрессорные клетки) описаны нами выше. Некоторые клетки в практике идентифицировать практически невозможно. Основной популяцией регулирующие большинство этапов иммунного ответа являются Т-хелперы и Т-регуляторные лимфоциты. 
T-хелперы. CD4 представлен на поверхности отдельной субпопуляции Т-лимфоцитов, получивших название Т-хелперов и обладающих фенотипом CD3+CD4+, то есть клетки, экспрессирующие эти две молекулы одновременно. В ходе развития Т-лимфоцитов CD4 обнаруживается в тимусе, начиная со стадии DP, после чего сохраняется на T-хелперах до терминальных стадий дифференцировки. CD4 обнаружен на мембране моноцитов, макрофагов и некоторых популяций дендритных клеток.

Именно поэтому для корректного выделения Т-хелперных клеток в рамках проведения иммунофенотипирования необходимо оценивать ко-экспрессию CD3 и CD4, чтобы избежать контаминации данной популяции Т-лимфоцитов другими клетками периферической крови. Клинические нормативы числа Т-хелперов представлены в таблице (табл.58).

Определение содержания CD4+

Таблица 58.

Т-клеток отводится решающая роль при прогнозе течения ВИЧ-инфекции и эффективности проведения антиретровирусной терапии. Кроме того, изменения уровня Т-хелперов значимо при выявлении врожденных и приобретенных иммунодефицитных состояниях, связанных с нарушениями реакций клеточного иммунитета и дефектами продукции антител при специфическом гуморальном ответе, опосредованном В-лимфоцитами.

Так, увеличение абсолютного и относительного содержания CD3+CD4+ периферической крови тесно связано с наличием аутоиммунных заболеваний, может быть иметь место при некоторых типах аллергических реакциях и инфекционных процессах. Тогда как снижение абсолютного и относительного уровня Т-хелперов в циркуляции указывает на «гипореактивный» синдром с нарушением регуляторного звена иммунитета, а также встречается при различных хронических заболеваниях (бронхитах, пневмониях и т.д.), опухолевом росте (в первую очередь, при солидных опухолях различной локализации).

По наличию на Т-хелперов различных хемокинов рецепторов можно определить их субпопуляцию (табл. 59)

Таблица 59

\section{Основные популяции Т-хелперов (\% от CD3+CD4+ клеток)}

\begin{tabular}{|l|l|c|}
\hline \multicolumn{1}{|c|}{ Популяция } & \multicolumn{1}{|c|}{ Маркеры, фенотип } & $\begin{array}{c}\text { Показатель у здорового } \\
\text { человека }\end{array}$ \\
\hline Th0 & CXCR5-CXCR3-CCR6-CCR4- & $34-49$ \\
\hline Th1 & CXCR5-CXCR3+CCR6-CCR4+ & $10-15$ \\
\hline Th2 & CXCR5-CXCR3-CCR6-CCR4+ & $4-7$ \\
\hline 06щий пул Th17: & CXCR5-CCR6+ & $19-29$ \\
\hline - классические Th17 & CXCR5-CXCR3-CCR6+CCR4+ & $6-9$ \\
\hline - DN Th17 & CXCR5-CXCR3-CCR6+CCR4- & $1-2$ \\
\hline - DP Th17 & CXCR5-CXCR3+CCR6+CCR4+ & $4-7$ \\
\hline - Th17.1 & CXCR5-CXCR3+CCR6+CCR4- & $6-10$ \\
\hline O6щий пул Tfh: & CXCR5+ & $7-12$ \\
\hline - Tfh1 & CXCR5+CXCR3+CCR6- & $2-4$ \\
\hline - Tfh2 & CXCR5+CXCR3-CCR6- & $1-3$ \\
\hline - Tfh17 & CXCR5+CXCR3-CCR6+ & $2-4$ \\
\hline - DP Tfh & CXCR5+CXCR3+CCR6+ & $1-2$ \\
\hline
\end{tabular}



(табл.60).

Большое значение принадлежит определению стадии дифференцировки Т-хелперов Таблица 60

\section{Основные показатели Т-хелперов}

\begin{tabular}{|l|l|c|c|}
\hline \multicolumn{1}{|c|}{ Популяция } & \multicolumn{1}{|c|}{ Маркеры } & \multicolumn{2}{c|}{$\begin{array}{c}\text { Показатель у здорового } \\
\text { человека }\end{array}$} \\
\hline & & $44-53$ & $670-1050$ \\
\hline Общее количество Th & CD3+CD4+CD8- & $12-19$ & $190-325$ \\
\hline Наивные Th & CD3+CD4+CD45RA+CD62L+ & $16-23$ & $260-470$ \\
\hline Th центральной памяти & CD3+CD4+CD45RA-CD62L+ & $9-13$ & $130-240$ \\
\hline Th эффекторной памяти & CD3+CD4+CD45RA-CD62L- & $1-2$ & $3-15$ \\
\hline $\begin{array}{l}\text { Терминально } \\
\text { дифференцированные Th }\end{array}$ & CD3+CD4+CD45RA+CD62L- & & \\
\hline
\end{tabular}

Не потеряло свое значение анализ соотношения CD4/CD8. Соотношение субпопуляций Т-хелперов и цитотоксических Т-клеток (также известное под устаревшим названием «иммунорегуляторный» индекс) является расчетным показателем, получаемым в результате деления величины относительного (или абсолютного) содержания CD3 $+\mathrm{CD} 4+$ клеток на аналогичное значение CD3+CD8+ клеток (рис.96).

В норме это значение находится в пределах 1,5-2,6, тогда как при ряде патологических состояний, связанных с нарушениями в функционировании клеточных механизмов приобретенного иммунитета, эта величина существенно изменяется. Классическим примером является сниженное соотношение CD4/CD8 при ВИЧ-инфекции (см. рис. 79. На гистограммах приведены результаты анализа распределения клеток по экспрессии CD4 (ось абсцисс) и CD8 (ось ординат) в рамках популяции Т-лимфоцитов. У условно здорового донора CD4/CD8 составляет $2,09(62,17 / 29,68=2,09)$, тогда как у пациента с ВИЧ инфекцией - 0,55 $(31,87 / 58,29=0,55)$. В целом, устойчиво низкое соотношение $\mathrm{CD} 4 / \mathrm{CD} 8$ в течение длительного применения антиретровирусной терапии является маркером нарушений в функционировании иммунной системы, наличия хронического воспалительного процесса, а также высокого риска заболеваемости «сопутствующими» инфекциями, и, как следствие, повышенной вероятности летального исхода.
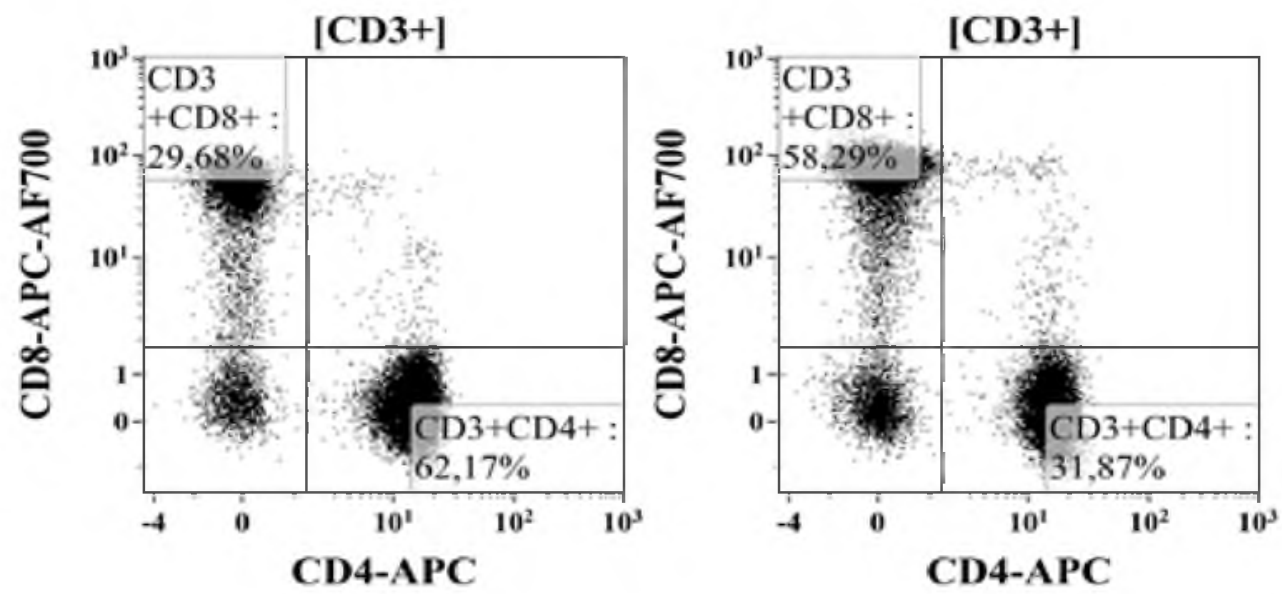

\section{Рис. 96. Анализ соотношения CD4/CD8 в норме (гистограмма слева) и при ВИЧ-инфекции (гистограмма справа).}

Анализ образов периферической крови проведен на проточном цитометре Navios 3/10 (Beckman Coulter Inc., USA), полученные результаты обработаны при помощи Kaluza Softvare 2.1 (Beckman Coulter Inc., USA 
Однако, снижение соотношения CD4/CD8 наблюдается и при врожденных иммунодефицитах (синдром Ди-Джоржи, Незелофа, Вискотта-Олдрича), при других вирусных и бактериальных инфекциях, хронических процессах, воздействии радиации и токсических химических веществ, множественной миеломе, стрессе, снижается с возрастом, при эндокринных заболеваниях, солидных опухолях. Увеличение соотношения CD4/CD8 более 3 отмечается при широком круге аутоиммунных заболеваний, остром Т-лимфобластном лейкозе, тимоме, хроническом Т-клеточном лейкозе.

T-регуляторные лимфоциты (Treg) это отдельная популяция Т-хелперов. Интерес к популяции этих клеток как основной популяции клеток, способной подавлять развитие иммунного ответа не обошел вниманием клиницистов. В настоящее время используя тактику «гейтирования», основанная на оценке CD25 и CD 127, возможно эффективно выделять Treg в периферической крови взрослых пациентов, пуповинной крови, а также клетках, выделенных из лимфатических узлов и тимуса, опухолевой ткани (рис.97).

Увеличение содержания Treg определяется у больных с различными видами опухолей и связан с прогрессированием опухолевого роста. Более того, уровень этих клеток в циркуляции и в окружающих опухоль тканях оказался значимым для прогноза течения заболевания и эффективности применяемой терапии. Существенную роль Treg играют в подавлении иммунного ответа при инфекциях. При вирусном гепатите C, туберкулезе, паразитарных инвазиях число Treg значительно повышается. При сепсисе увеличение уровня этих клеток напрямую связано с неблагоприятным течением данного заболевания. С другой стороны, у

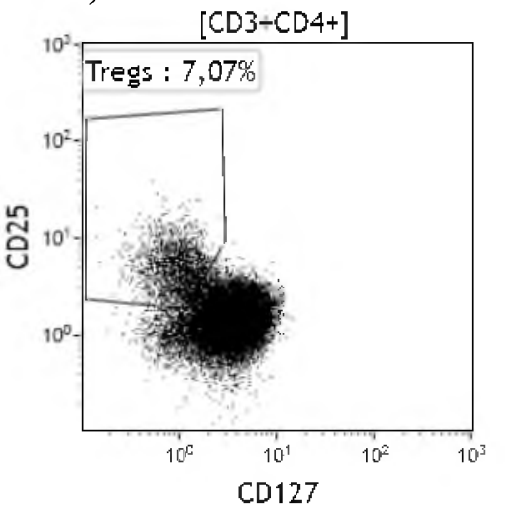

Рис. 97. Идентификация Трегуляторных клеток

Анализ образов периферической крови проведен на проточном цитометре Navios 3/10 (Beckman Coulter Inc., USA), полученные результаты обработаны при помощи

Kaluza Softvare 2.1 (Beckman Coulter Inc., USA). больных с различными аутоиммунными патологическими состояниями изменялась функциональная активность Treg, что вызывало нарушение толерантности к собственным антигенам организма.

Однако подобные закономерности не всегда выполняются, что указывает на то, что в развитии патологических процессов Treg имеют важное, но не единственное значение. Этим и обусловлена важность проведения топической диагностики. В этой связи интересно определение других показателей Т-регуляторных клеток (табл.61).

Таблица 61

Основные показатели Т-регуляторных клеток

\begin{tabular}{|l|l|c|c|}
\hline \multicolumn{1}{|c|}{ Популяция } & \multicolumn{1}{c|}{ Маркеры } & \multicolumn{2}{c|}{$\begin{array}{c}\text { Показатель у здорового } \\
\text { человека }\end{array}$} \\
\hline & & $\%$ & абс. \\
\hline Общее количество Treg (\% Th) & CD3+CD4+CD25++CD127- & $6-10$ & $30-60$ \\
\hline «тимиеские» Treg (\% Treg) & CD45RA+CD62L+Treg & $21-36$ & $11-24$ \\
\hline CM Treg (\% Treg) & CD45RA-CD62L+Treg & $50-60$ & $20-38$ \\
\hline EM Treg (\% Treg) & CD45RA-CD62L-Treg & $8-14$ & $4-8$ \\
\hline
\end{tabular}


Основными регуляторными молекулами иммунной системы являются цитокины. Как мы отмечали выше у здоровых людей концентрация цитокинов в периферической крови ничтожно мала и обычно не определяются т.к. их выработка и действие осуществляется местно, локально. Однако при развитии патологического процесса при несостоятельности местных защитных реакций синтез прежде всего провоспалительных цитокинов возрастает в разы, что может служить эффективным биомаркером (табл.62).

Таблица 62.

Нормативные значение цитокинов в клинических ситуациях

\begin{tabular}{|c|c|c|}
\hline Показатель & $\begin{array}{c}\text { Референсные } \\
\text { значения }\end{array}$ & Клинические ситуации, связанные с повышением \\
\hline $\begin{array}{l}\text { Интерлейкин } 1 \\
\text { бета }\end{array}$ & $<5$ пг/мл & $\begin{array}{l}\text { Воспалительные заболевания и бактериальные инфекции: } \\
\text { пневмокониоз, туберкулёз, саркоидоз; септический шок, } \\
\text { аутоиммунные заболевания: ревматоидный артрит, сахарный диабет } \\
1 \text { типа, воспалительное поражение кишечника; множественная } \\
\text { травма; опоржение почечного трансплантата; угроза прерывания } \\
\text { беременности; СПиД; острый и хронический миелолейкоз, } \\
\text { волосатоклеточный лейкоз; ДВС-синдром }\end{array}$ \\
\hline Интерлейкин 6 & $<7,0$ пг/мл & $\begin{array}{l}\text { Эссенциальная тромбоцитемия; тяжёлые воспалительные процессы, } \\
\text { инфекции и травмы; аутоиммунные заболевания; } \\
\text { ревматоидный артрит; сердечная миксома; болезнь Кастлемана; } \\
\text { псориаз; мезангиопролиферативный гломерулонефрит; саркома } \\
\text { Капоши; алкогольный цирроз; лимфома, миелома и карцинома } \\
\text { почек; обострение язвенной болезни желудка и 12-перстной кишки; } \\
\text { панкреатит; глютеновая энтеропатия; болезнь Крона; } \\
\text { неспецифический язвенный колит; вирусный гепатит; первичный } \\
\text { билиарный цирроз; сидром Кавасаки. }\end{array}$ \\
\hline Интерлейкин 8 & $<62$ пг/мл & $\begin{array}{l}\text { Ревматоидный артрит; инфаркт миокарда (острая фаза); } \\
\text { воспалительные заболевания лёгких; бактериальные инфекции (в том } \\
\text { числе менингококковая); септический шок; язвенный колит; } \\
\text { обострение гломерулонефрита; опухоли; алкогольный гепатит; } \\
\text { хроническое воспаление; псориаз. }\end{array}$ \\
\hline Интерлейкин 10 & $<9,1 п г / \mathrm{Mл}$ & $\begin{array}{l}\text { Неходжкинская лимфома; хроническая почечная недостаточность; } \\
\text { злокачественные опухоли. } \\
\text { Снижается при опоржение почечного трансплантата; инсульт } \\
\text { (неблагоприятное течение) }\end{array}$ \\
\hline $\begin{array}{l}\text { Фактор некроза } \\
\text { опухоли }\end{array}$ & $<-8,1 п г / \mathrm{мл}$ & $\begin{array}{l}\text { ДВС-синдром; сепсис; инфекционные заболевания (особенно, } \\
\text { инфекционный эндокардит, рецидивирующий герпес, хронический } \\
\text { гепатит С); травматический и ожоговый шок; аллергические и } \\
\text { аутоиммунные заболевания; онкологические заболевания; } \\
\text { отторжение трансплантанта; атеросклеротическое слабоумие; } \\
\text { коронарный атеросклероз; ревматоидный артрит; } \\
\text { хронический бронхит; грибовидный микоз; псориаз; миеломная } \\
\text { болезнь; коллагеноз. }\end{array}$ \\
\hline
\end{tabular}

Особенно важно их определять для диагностики вторичного гемофагоцитарного лимфогистиоцитоза (синдром активации макрофагов (MAS) синдрома системного воспалительного ответа (SIRS), и синдрома полиорганной дисфункции (MODS) они имеют общие клинические и лабораторные проявления (лихорадка; цитопения двух линий клеток; гипертриглицеридемия и/или гипофибриногенемия; гиперферритинемия (> 500 мкг/л), гемофагоцитоз; повышенный уровень растворимости рецептор интерлейкина-2 (CD25); снижение активности NK-клеток; спленомегалия; повышение ACT (>48 Ед/л)), когда повышение определенного цитокина служит основанием для проведения таргетной терапии. 
Хотелось бы обратить внимание на то, что не следует путать проявления иммунных нарушений и их классификацию с различной иммунопатологией определенной в том числе и в МКБ-10 (или уже МКБ-11). Так же как печеночная или сердечная недостаточность и, например хронический гепатит или инфаркт миокарда. Иммунопатологию можно определить как болезни иммунной системы, индуцированные состояния под воздействием факторов, влияющих на иммунную систему, и отдельная категория аутоиммунных и аллергических болезней с избыточным или извращенным реагированием иммунной системы. Они на сегодняшний день представляет группы заболеваний схожие клинически, но с различными иммунопатологическими механизмами (рис.98).

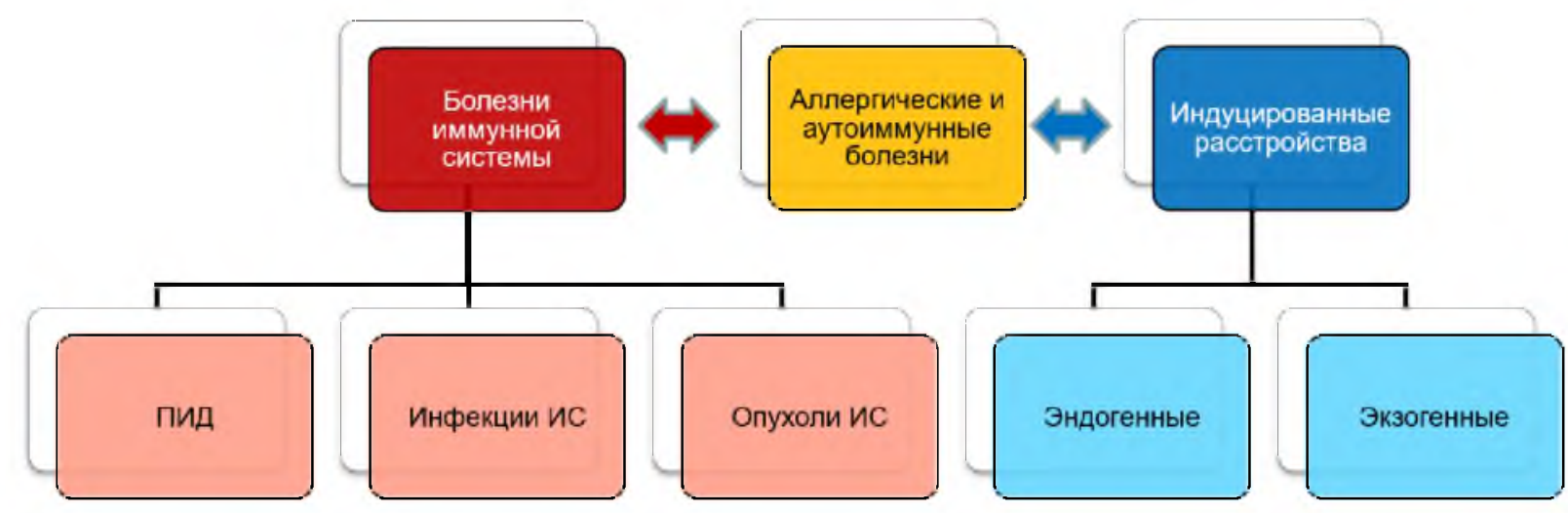

\section{Рис. 98. Патология иммунной системы}

Не исключается, что в основе многих, а может быть практически и всех клинических формах иммунных нарушений, лежит первичная иммунологическая недостаточность какогото компонента иммунной системы, скомпенсированная до определенного времени за счет нормальной или высокой функциональной активности других компонентов этой системы. Подтверждением такой возможности служит общая вариабельная иммунная недостаточность $(\mathrm{OBИН})$, чаще всего проявляющаяся в хронических, рецидивирующих инфекциях бронхолегочного аппарата и придаточных пазух носа. Для этого заболевания характерно понижение уровня всех классов иммуноглобулинов. При ОВИН имеется два пика заболеваемости: первый развивается между 6-10 годами жизни, второй - между 26-30 годами, причем до развития заболевания эти больные являются практически здоровыми людьми. Следовательно, этот дефект до определенного времени был компенсирован за счет нормальной или повышенной функциональной активности других компонентов иммунной системы, обеспечивающих защиту организма от инфекции. Помимо ОВИН есть ряд болезней, относящихся к первичным иммунодефицитам, но иногда проявляющихся клинически у взрослых (см. ниже глава 12). Как правило, в этих случаях отсроченное наступление симптомов заболевания является результатом наличия у данного индивидуума умеренного генетического дефекта. Но нельзя исключить и компенсаторной коррекции первичного дефекта за счет других компонентов иммунитета. Их изменение со временем и позволяет клинически проявиться первичному, пусть даже легкому дефекту иммунной системы. Поэтому если на настоящем этапе не выявлены причины иммунопатологии, то это не только следствие неадекватного методического подхода, использования несоответствующего материала для исследования, но и невозможность идентифицировать имеющуюся поломку на данном этапе развития науки [26, 36, 38, 115, $117,121,129]$. 


\section{ДИАГНОСТИКА ИММУННЫХ НАРУШЕНИЙ}

\section{Глава 12. Болезни иммунной системы}

Болезни иммунной системы - нарушает нормальное функционирование организма за счет поражения иммунной системы, проявляющиеся различными иммунологическими симптомами и признаками (синдромами). Болезнь может быть вызвана внешними факторами (патогены), и/или внутренними (генетические нарушения). Необходимо строго разграничить болезни (поражение) иммунной системы и функциональными нарушениями обусловленные воздействием на иммунную систему каких-либо воздействий приводящим к функциональному (временному) нарушению какого-то звена в системе иммунитета.

В связи с этим в группе болезней имеет смысл выделить генетические нарушения, инфекции и опухоли иммунной системы, болезни связанные со срывом толерантности и гиперчувствительности (аллергия и аутоиммунные нарушения). В группе функциональных нарушений определить иммунные дисфункции под воздействием внешних и/или внутренних факторов $[5,10,26,38,55,56,65-67,91,92,94,119-123,125,128,132] /$

Первичные иммунодефициты (ПИД) заболевания иммунной системы, в основе которых лежат генетичесие нарушения. ПИД встречаются достаточно часто (в среднем 1 на 500 человек). При этом 90\% детей с тяжелыми ПИД умирают без установленного диагноза. У взрослых ПИД протекает под маской рецидивирующих инфекций, ауто-воспалительных заболеваний различных органов и систем, аллергиями. Если ПИД выявлен вовремя и лечение проведено в полном объеме, то пациенты практически не отличаются от здоровых.

Экспертный комитет IUIS (Международный союз иммунологических обществ International Union of Immunologic Societies) по IEI (врожденным ошибкам иммунитета) раз в два года корригирует генотипическую классификацию всех этих расстройств. Для удобства пользователя и источником информации для врачей у постели больного дополнительно предлагается фенотипическая классификация в десяти таблицах (рис.99-115).

Анализируя данные таблицы, приходит понимания, что врачи многих специальностей сталкиваются с такими пациентами, особенно тогда, когда происходит частичный дефицит того или иного гена. При этом генетические дефекты моделируют ту или иную клиническую ситуацию при вторичных иммунодефицитах, с которыми клиницисты встречаются гораздо чаще.

Действительно при первичных иммунодефицитах чаще встречаются синдромы гипореактивных (гипоэргических) состояний. Это проявляется рецидивирующими бактериальными, вирусными и грибковыми инфекциями, которые определяются при всех видах тяжелых комбинированных иммунных нарушениях (ТКИН), ПИД с низкими CD4 и CD8 Т-лимфоцитами, ПИД с низкими иммуноглобулинами, ИД с множественной атрезией кишечника, гипер-IgЕ синдроме, синдроме Вискотта-Олдрича, синдроме Ройфмана, синдроме делеции 10p13-p14, синдроме Лоис-Дитца, синдроме Германски-Пудлака 2 типа, синдроме Чедиак Хигаши, синдроме активации STAT3, FILS синдроме, синдроме активации STAT1, синдроме эктодермальной дисплазии и иммунодефицита (EDA-ID), Good синдроме, гепатовено-окклюзионная болезнь с ИД, дефиците BCL10, IKBKB, MALT1, RelB, WIP, ARPC1B, PGM3, CD19, CD21, CD81, CD154, CD40-лиганда, трипептидил-пептидазы II, G6PD класса I., 
ICOS недостаточности, дефекте адгезии лейкоцитов (LAD-синдром), X-сцепленной хронической гранулематозной болезни (ХГБ), общей вариабельной иммунной недостаточности (ОВИН), кистозном фиброзе (муковисцидоз), спондилохондродисплазии с иммунной дисрегуляцией (SPENCD), иммуно- костной дисплазия Шимке, изолированный дефиците подкласса IgG. Особую группу составляют ТКИН, болезнь Брутона, дефицит FOXN1 («Голый ТКИН») и ADAM17 течение которых сопровождаются различными тяжелыми инфекциями. Все эти заболевания возможно отнести к заболеваниям со смешанными типом иммунных нарушений.

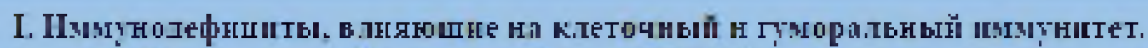

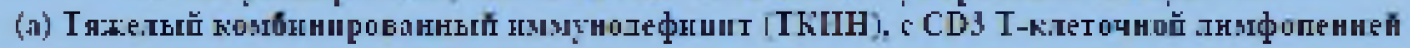

\begin{tabular}{|c|c|c|}
\hline \multicolumn{3}{|c|}{ CD19 M; ThIIH T-B+ } \\
\hline TKTIH T-B+ & \multicolumn{2}{|c|}{ TKTIH T- B- Nh- } \\
\hline \multirow{2}{*}{ 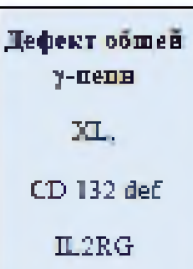 } & $\begin{array}{c}\text { Teque日I IL 7Ra } \\
\text { IIIT: }\end{array}$ & $\begin{array}{c}\text { Jeфragt } \\
\text { Coronito-14 }\end{array}$ \\
\hline & 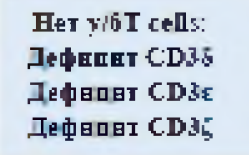 & 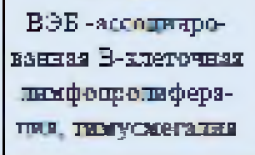 \\
\hline 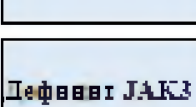 & $\begin{array}{l}\text { YibT cells H Hophe: } \\
\text { Jeterer CD45 } \\
\text { FTFRC }\end{array}$ & \multirow{2}{*}{ 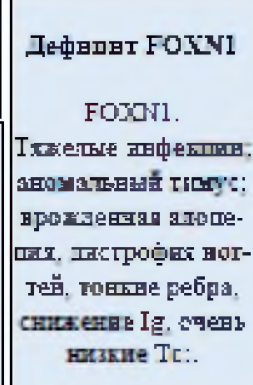 } \\
\hline $\begin{array}{l}\text { ARE. } \\
\text { [D } 172+ \\
\text { JALE] }\end{array}$ & 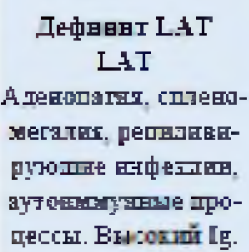 & \\
\hline
\end{tabular}

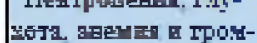

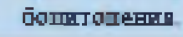

Дефент Fact. FAL2, $A D$ GOF

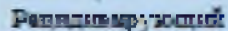

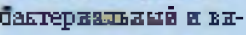
Py

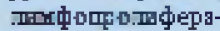

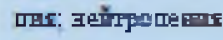

CIIS $\downarrow$ IFIH I- B -

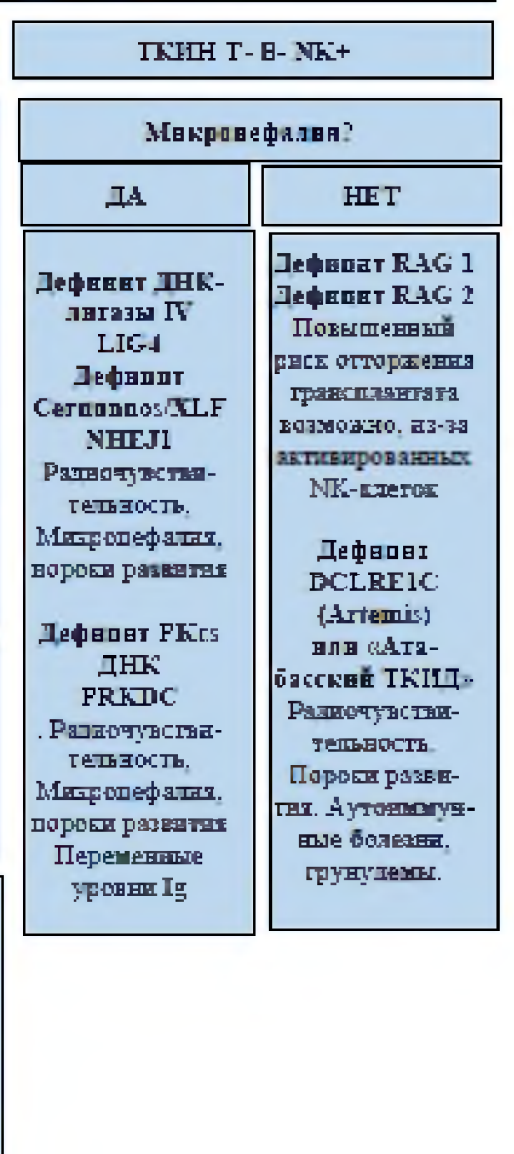

\section{Рис.99. Иммунодефициты, влияющие на клеточный и гуморальный иммунитет (А)}

К заболеваниям с нарушением гуморального звена иммунитета относятся ПИД, сопровождающиеся в основном развитием бактериальных инфекций, а именно: синдром Джоба, гипер-IgE синдром (HIES), синдромы гипер-IgM, преходящая гипогаммаглобулиемия, избирательный дефицит $\operatorname{IgA}$, дефицит подкласса $\operatorname{IgG}$ с дефицитом $\operatorname{IgA}$, дефицит Moesin и IL17RA. Дефицит CD21 и избирательный дефицит IgM сопряжен с развитием пневмококковой инфекцией. Дефицит компонентов комплемента С $5, \mathrm{C} 6, \mathrm{C} 7, \mathrm{C} 8$, С9, дефицит пропердина и фактора D приводят к распространению Neisserial инфекции. Предрасположенность к инвазивным бактериальным инфекциям (пиогенам: менингит, сепсис, артрит, остеомиелит и абсцессы, часто при высокой температуре связано с изолированной врожденной аспленией (ICA) вследствие дефицита RPSA, дефицитом IRAK4, MyD88, фактора I, фактора Н и факторН зависимого белка. 


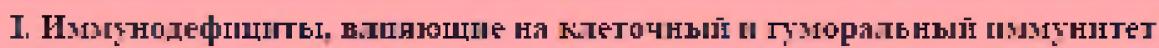

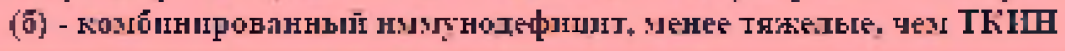

\begin{tabular}{|c|c|}
\hline 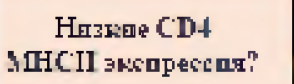 & Hris:re CDS \\
\hline 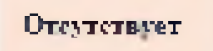 & Прпстетвит \\
\hline \multirow{3}{*}{ 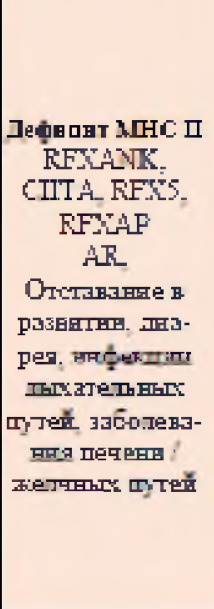 } & 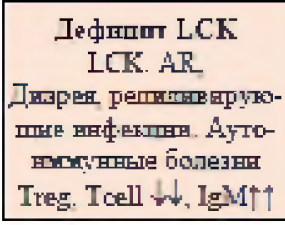 \\
\hline & 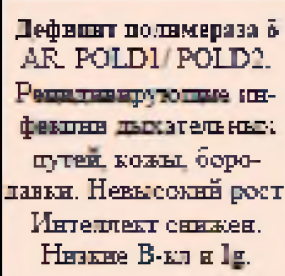 \\
\hline & 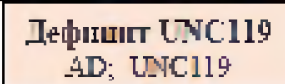 \\
\hline
\end{tabular}

CDR gezocthroquactb.

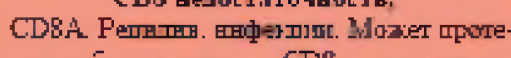

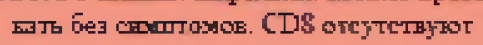

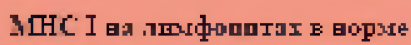

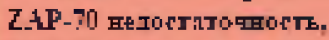

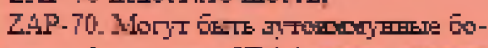

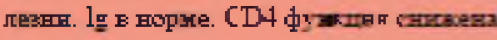

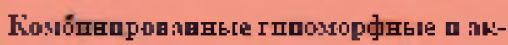

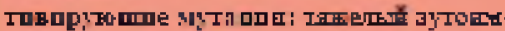

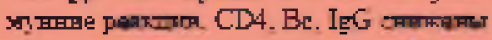

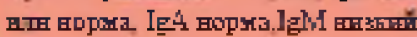

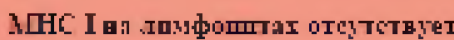
M1HE-I лeфuat

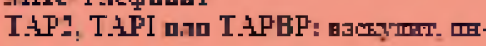

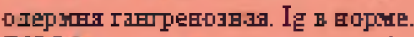

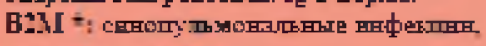

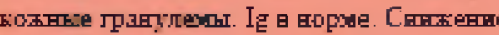

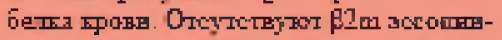

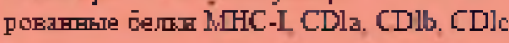

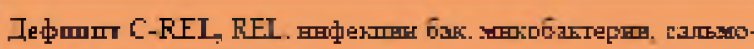

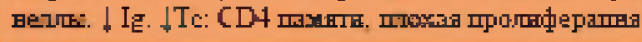

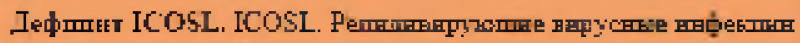

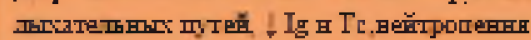

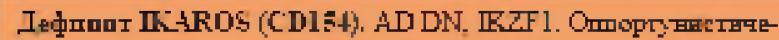

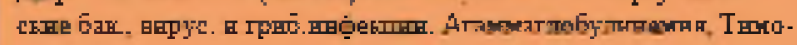

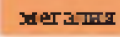

\begin{tabular}{|c|}
\hline Hnzine B-wotkn \\
\hline 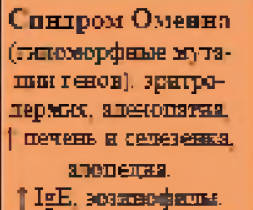 \\
\hline
\end{tabular}

\section{Imep-IgF Iposi, $A$ DOCKR.}

Imxenfar этоптат,

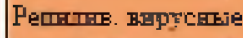

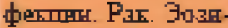

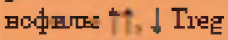
ICD 27-Bs. $\downarrow$ I $\uparrow \mathrm{I}$ E, $\downarrow$ MK

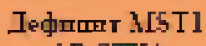 AR STK4

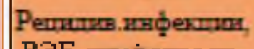

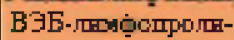
中ерज्ञात हाम

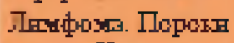

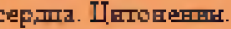
$\downarrow T \varepsilon_{3} \downarrow$ T nai $†$ TEMRG

בефіпппт П-21 4 표 21

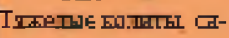

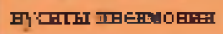

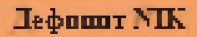

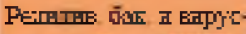

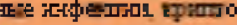
impम्नानक 부데 $\downarrow \mathrm{kr}$.

IeфफाmIr Moesin XI. MSN

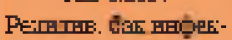

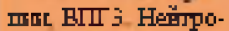
nersex

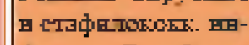
AR ML 4 F 3 K14

\begin{tabular}{|c|c|c|}
\hline Ie вop:nd & Iв впзине & \multirow{2}{*}{ 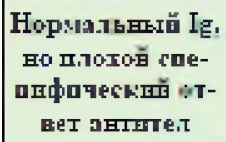 } \\
\hline 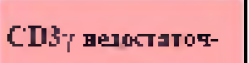 & \multirow{3}{*}{ 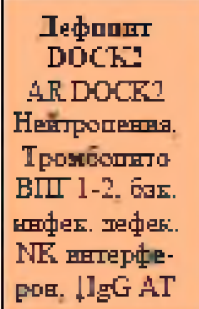 } & \\
\hline 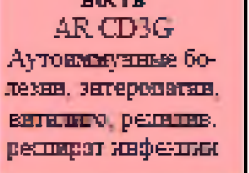 & & 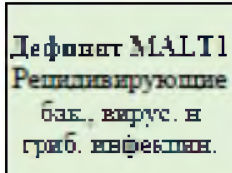 \\
\hline \multirow{2}{*}{ 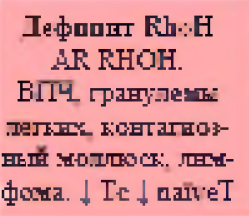 } & & \\
\hline & \multirow{2}{*}{ 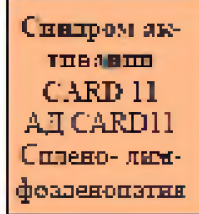 } & 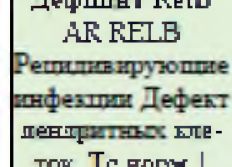 \\
\hline \multirow{3}{*}{ 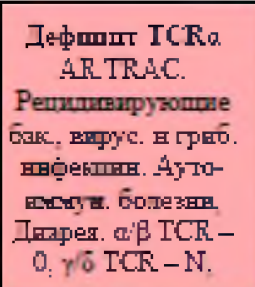 } & & \\
\hline & \multicolumn{2}{|c|}{ 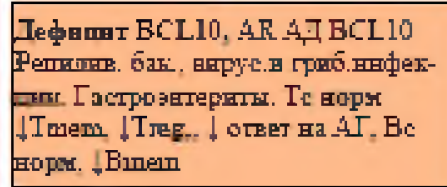 } \\
\hline & \multirow{2}{*}{\multicolumn{2}{|c|}{ 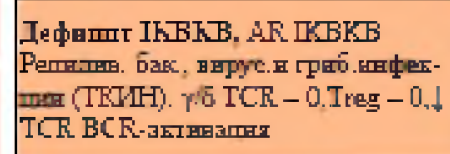 }} \\
\hline \multirow{2}{*}{ 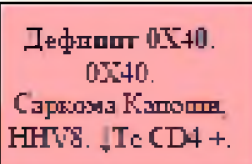 } & & \\
\hline & \multirow{2}{*}{\multicolumn{2}{|c|}{ 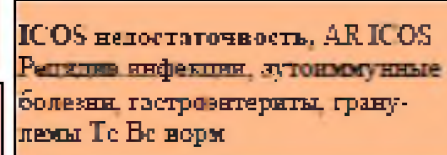 }} \\
\hline $\begin{array}{c}\text { 工ефаaIr FCHOl } \\
\text { FGHOl }\end{array}$ & & \\
\hline
\end{tabular}

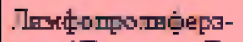

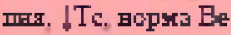
Sx Ig: Nl Hawm سен

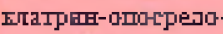
ванसा

Rel1 ringogenocTiTomortr ADI. REL 4

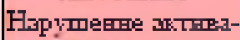

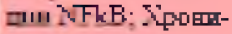

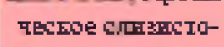

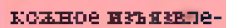

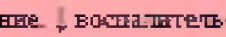

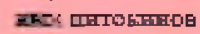

IIR тефп्ञाт

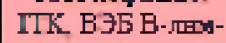

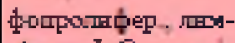

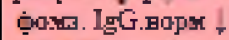
ICD4 Te IretónTOE: $\downarrow$ IETER. TE

IeфmuI IFRC AR TFRC

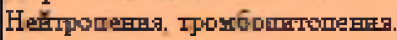

P

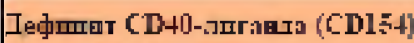
AR CDHULG (TNFSFS)

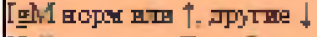

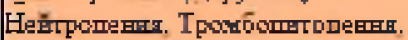

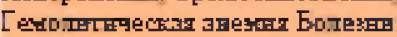

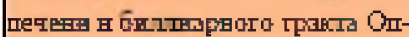

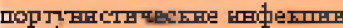

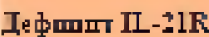

$A R$ IIIIR

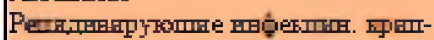

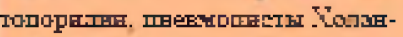

תㅍ, 하.

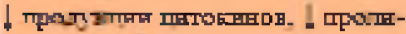

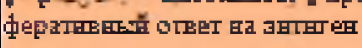

\section{Рис. 100. Иммунодефициты, влияющие на клеточный и гуморальный иммунитет (Б)}




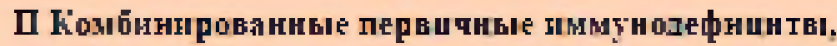
ассошигорованнее с синдромальными проввлениямн

\begin{tabular}{|c|c|}
\hline 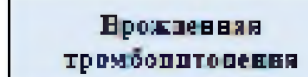 & 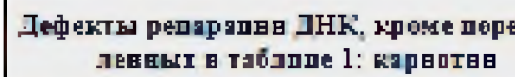 \\
\hline \multicolumn{2}{|c|}{ 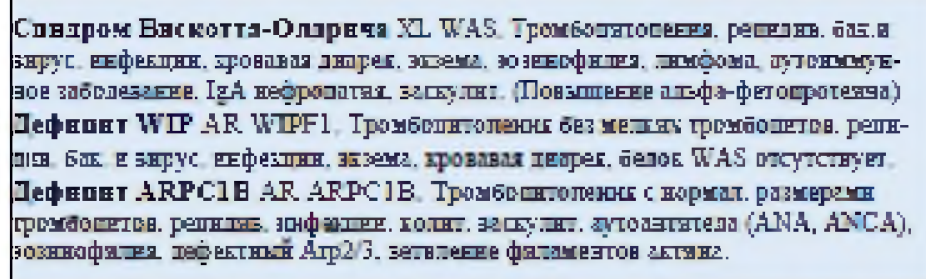 } \\
\hline
\end{tabular}

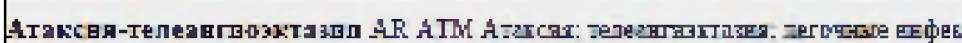

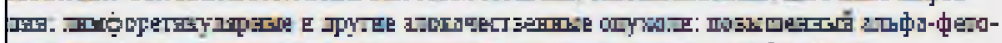

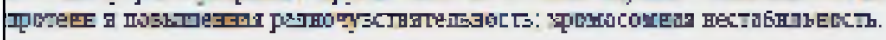

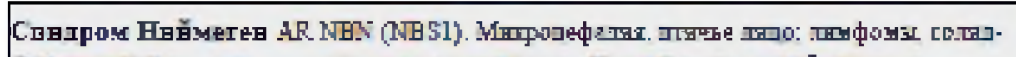

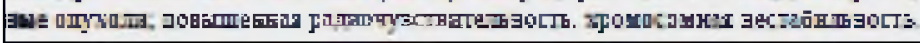

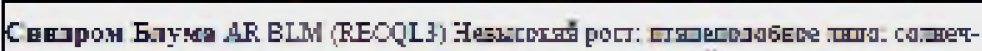

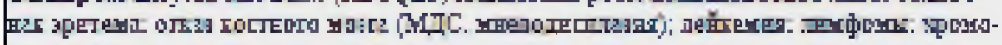

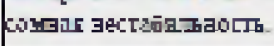

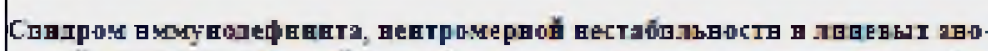

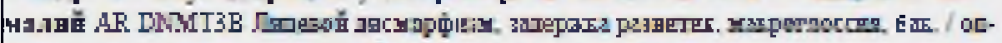

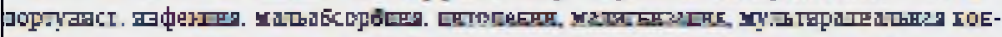

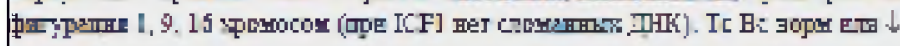

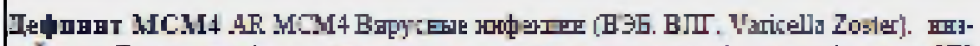

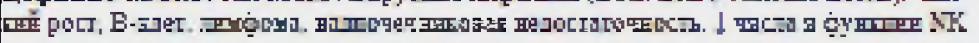

Де中в

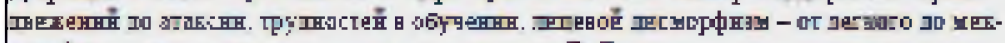

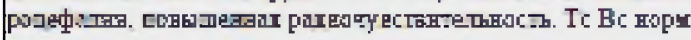

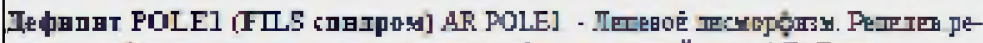

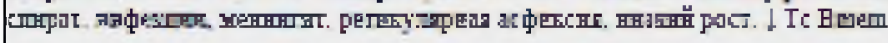

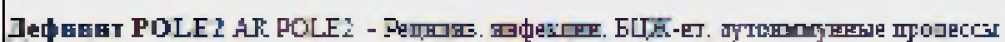

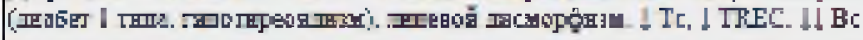

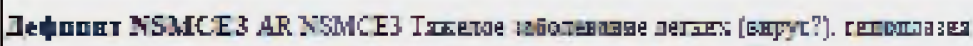

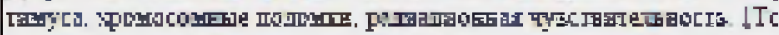

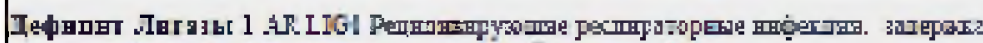

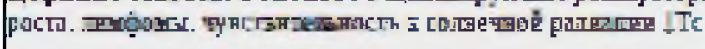

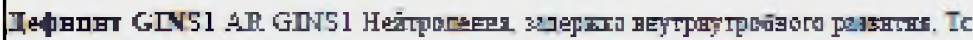

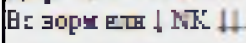

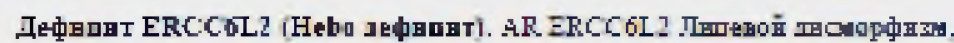

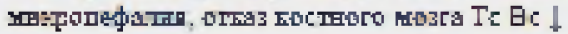

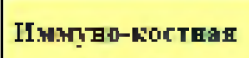

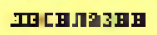

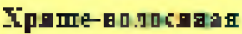

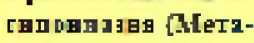

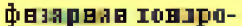

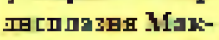

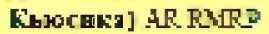

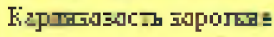

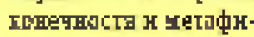

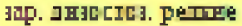

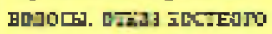

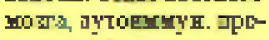

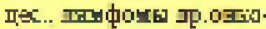

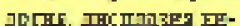
III늠묘. EJ

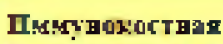
工医Dבت AR SWLARCH

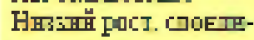

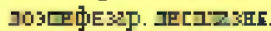

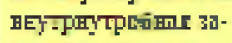

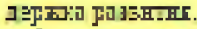

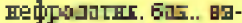

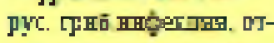

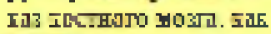
TH:LE

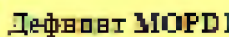

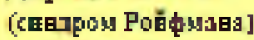

AR BL L4A IAC

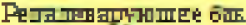

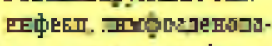

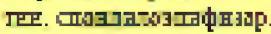

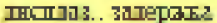

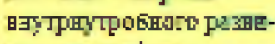

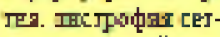

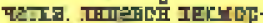

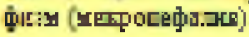

\section{It女mвнт E_ML}

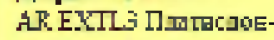

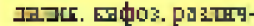

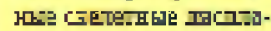

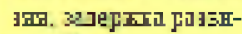
표. It 파표로.

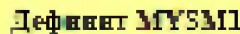
AR irrsul. Hes:

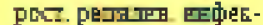

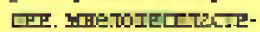

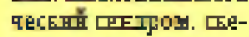

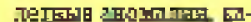

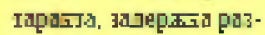

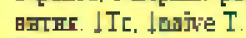

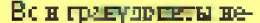
3Fetrie

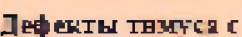

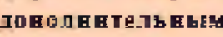

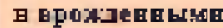 a 0 MIIHA \\ Свнтром Ти-

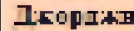

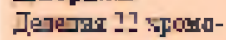

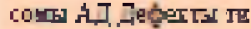

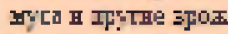

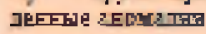

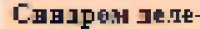
пвн 10p17-p]4

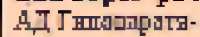
To03. जotesm $\mathrm{CL}^{2}$ पеट ImFatil 30 Iер

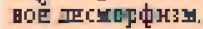

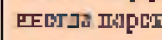
담플 $\mathrm{peJ}$ 표타

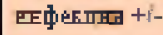

CH. 4 RE бн日בp ou $-1,5 \mathrm{TDT}$

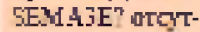

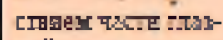

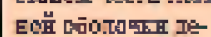
中еETh cep표. aTpe

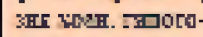
E⿺辶⿻二丨凵口. Ees무푤-

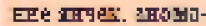

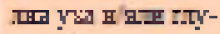

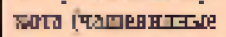

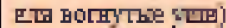
I햐다 ITHC. $\mathrm{Fr}$ THIIH $\downarrow$ TFE

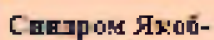

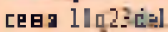

드맢. fecㅍㅍ

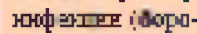

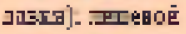

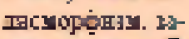

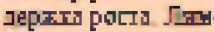

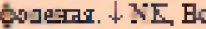
BIIE II

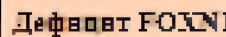

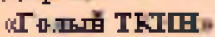

'LR FODTi1

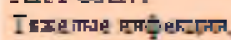

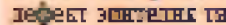

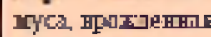

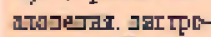

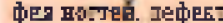

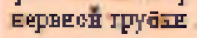
$\downarrow-\mathrm{Te}$

\section{Рис. 101. Комбинированные первичные иммунодефициты, ассоциированные с синдромальными проявлениями (А)}




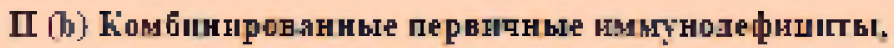 ассоцицрьв анные с синдромальными проявяениями}

\begin{tabular}{|c|}
\hline 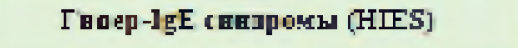 \\
\hline 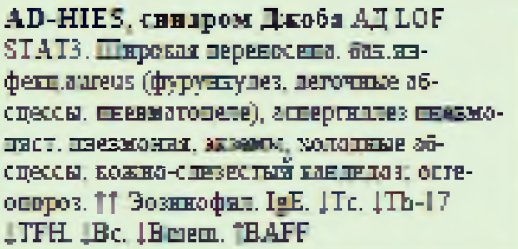 \\
\hline
\end{tabular}

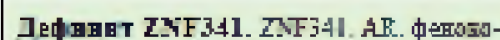

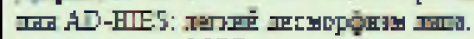

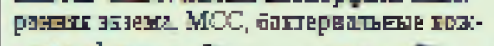

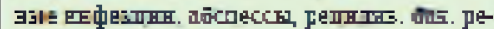

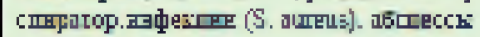

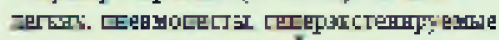

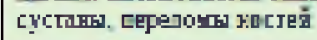

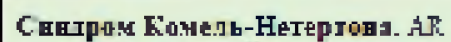

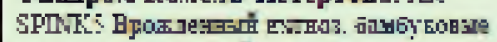

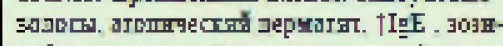

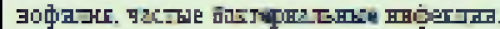

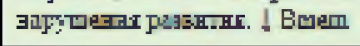

בe中нпнт PGML AR PGM

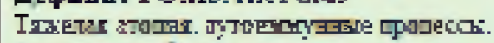

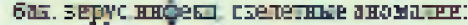

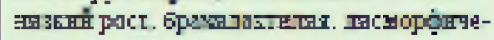

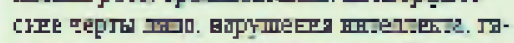

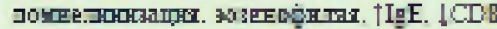

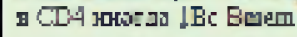

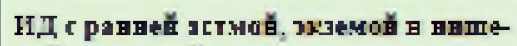

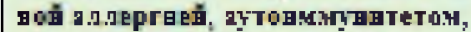

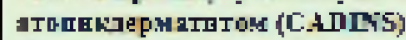

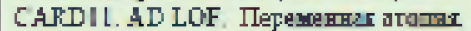

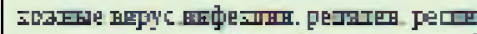

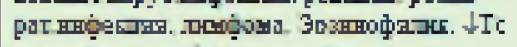

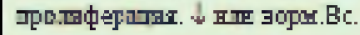

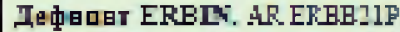

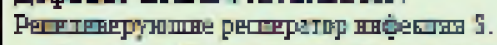

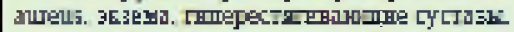

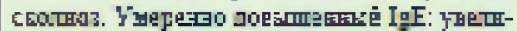
пентони Ттед.

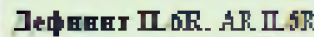

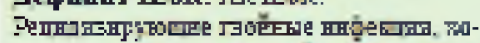

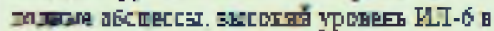
표이배

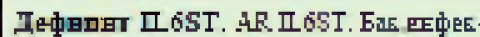

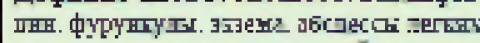

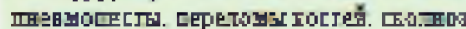
WHIIIE

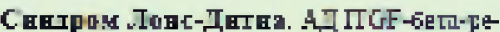

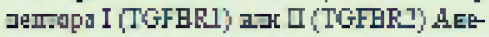

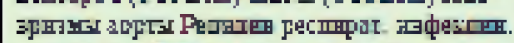

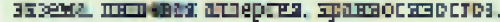

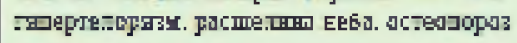

\begin{tabular}{|c|c|}
\hline 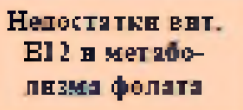 & 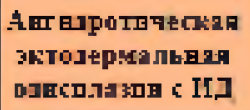 \\
\hline 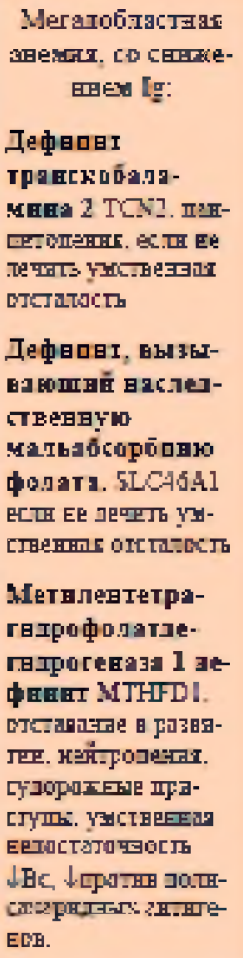 & 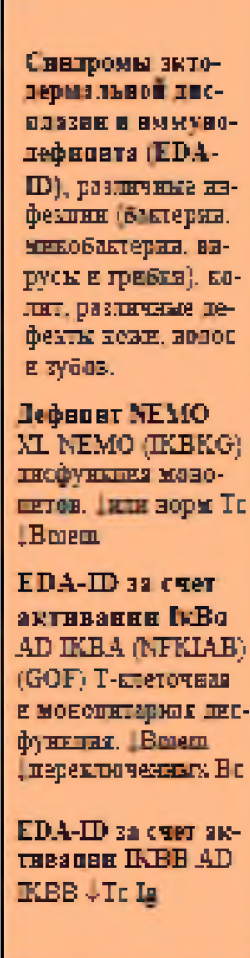 \\
\hline
\end{tabular}

\begin{tabular}{|c|}
\hline Ірңтве \\
\hline 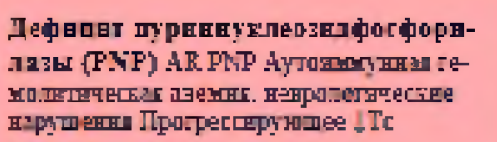 \\
\hline 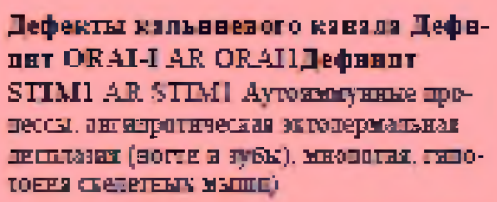 \\
\hline
\end{tabular}

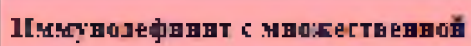
aтp

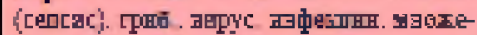

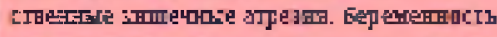

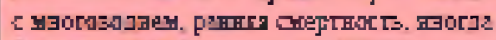

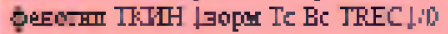

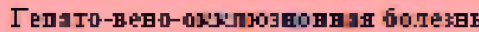

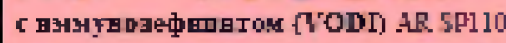

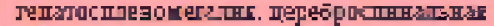

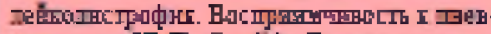

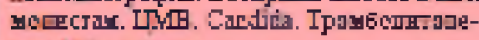

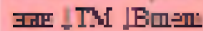

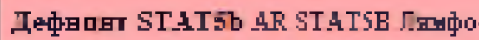

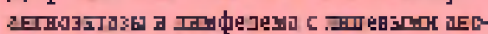

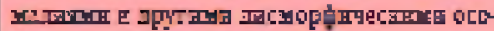

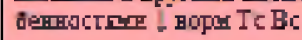

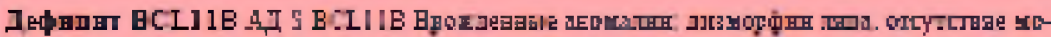

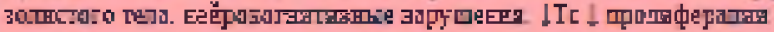

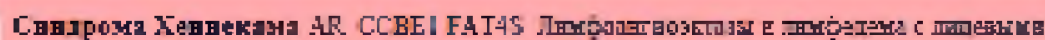

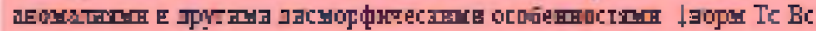

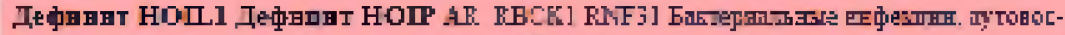

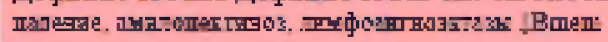

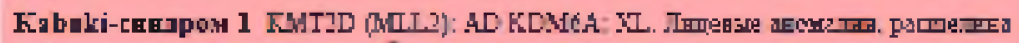

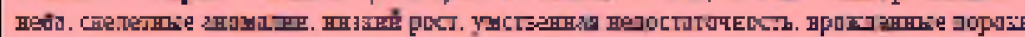

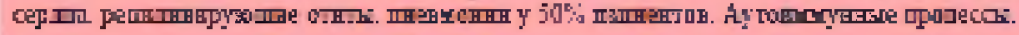

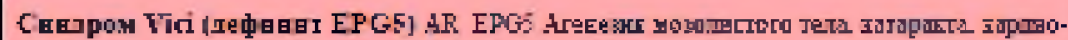

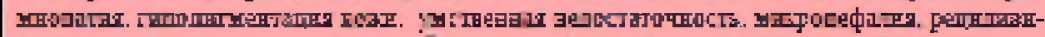

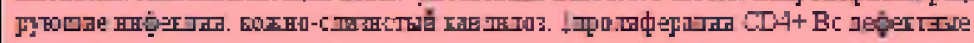

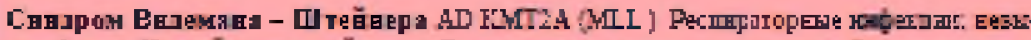

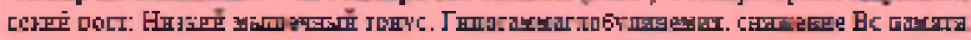

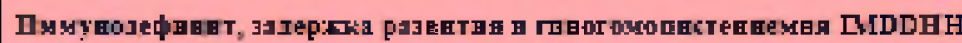

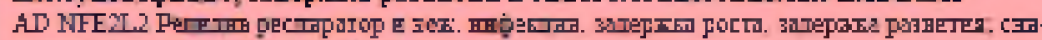

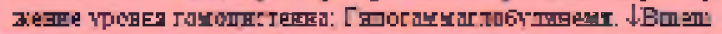

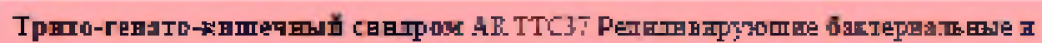

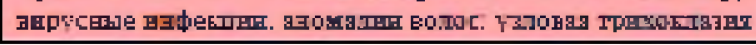

\section{Рис. 102 Комбинированные первичные иммунодефициты, ассоциированные с синдромальными проявлениями (Б)}




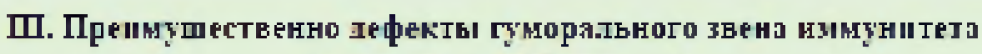

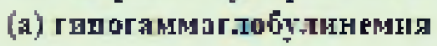

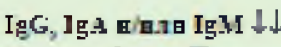

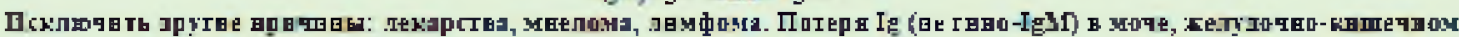

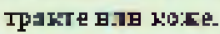

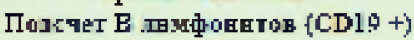

\begin{tabular}{|c|}
\hline 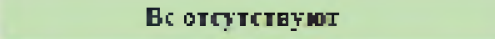 \\
\hline 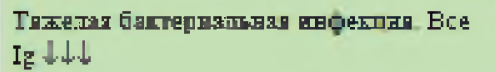 \\
\hline 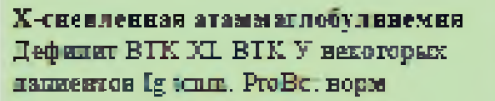 \\
\hline 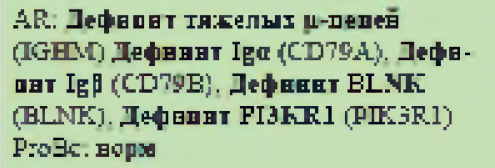 \\
\hline 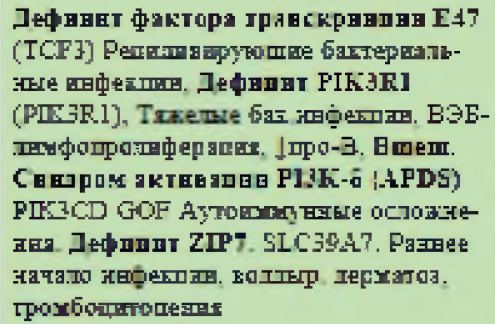 \\
\hline 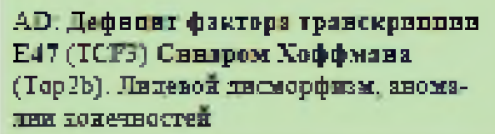 \\
\hline
\end{tabular}

\begin{tabular}{|c|}
\hline Ec $>1$ \\
\hline 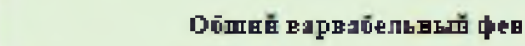 \\
\hline 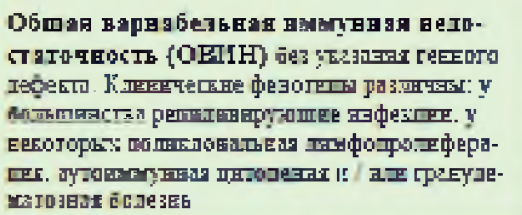 \\
\hline
\end{tabular}

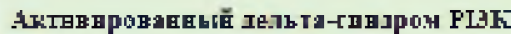

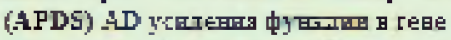

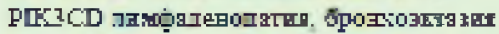

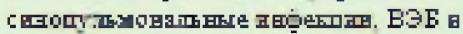

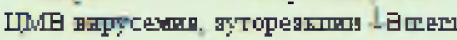

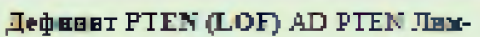

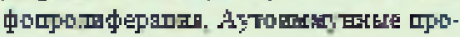
딷ㄷㄴㅡ

Jeфннет _tRHGEF1 SD ARHGEF Fert-

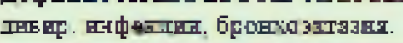

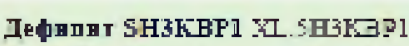

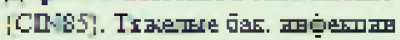

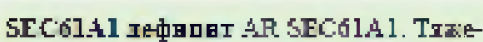

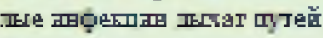

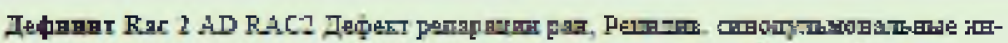

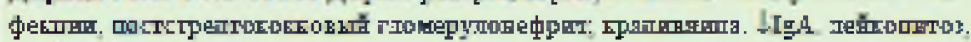
|вейтройштье

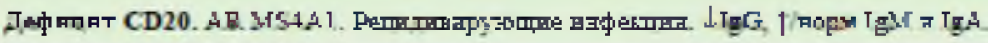

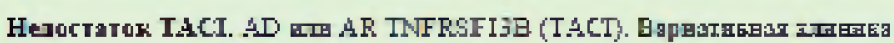

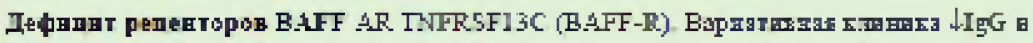
IE-W.

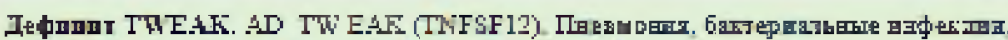

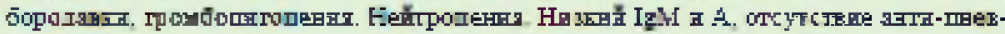

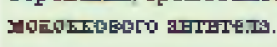

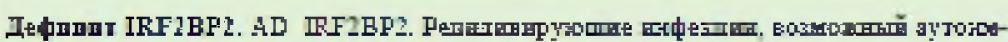

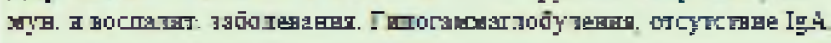

\section{Рис.103 Преимущественно дефекты гуморального звена иммунитета, гипогаммаглобулинемия.}

Нарушения клеточно-эффекторного звена обычно связано с вирусными и грибковыми инфекциями, повышенной восприимчивостью к микобактериям. Повышенная восприимчивость к микобактериям, БЦЖ-ит обусловлены синдромом MonoMac, ayтo-AT к IFNy, полным или частичным дефицитом рецептора 1 и 2 к IFN- $\gamma$, дефицитом цепи b1 рецептора IL-12 и IL-23, STAT1, Tyk2, JAK1, аутосомно-доминантным MSMD из-за частичного дефицита IFNGR1, недостаточностью SPPL2a. 


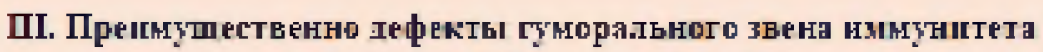

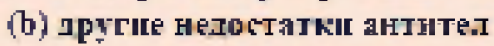

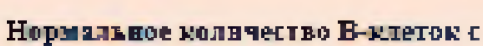

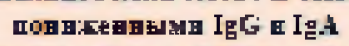

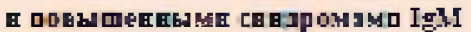
Chнрома ran ep-Iexl:

Дeфunur AID. AR II" AD AICDA.

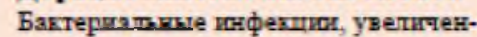

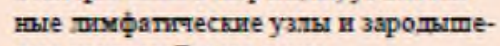
вые дентры. Bmem норм

Дефицит UNG AR UNG Увешгенғые

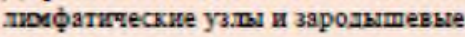
пентры

Дефnпut INO80 AR INOs0p Tsжетые бактериаль ные инфезий.

Дефnnut MSH6 AR MSH6 Hacte工. ственная отагощенность nо онкологт⿱ йд ватипе в анамнеје.

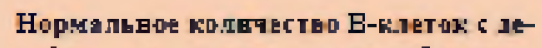

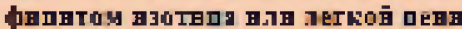

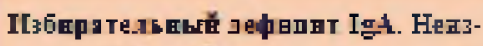

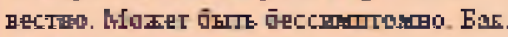

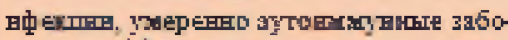

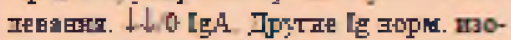

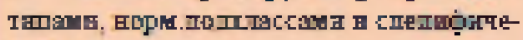
cavan :

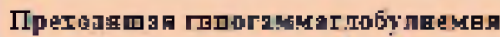

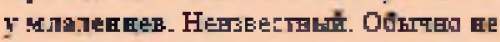

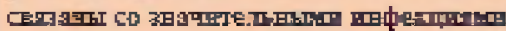

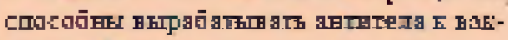

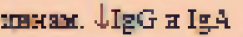

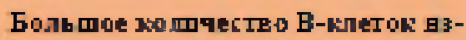

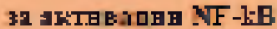

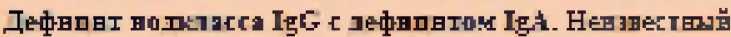

Fer

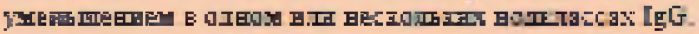

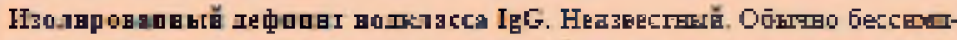

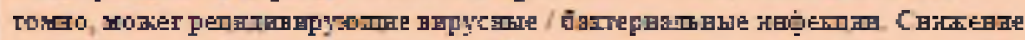

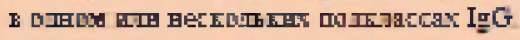

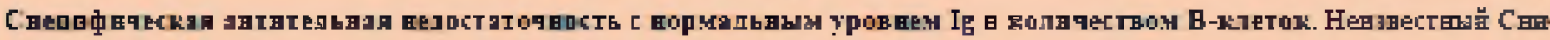

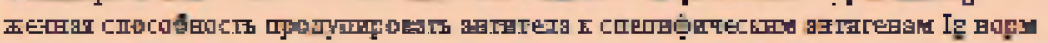

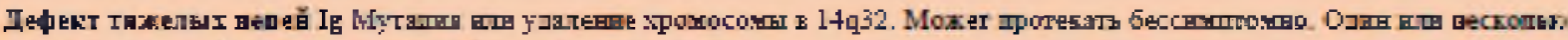

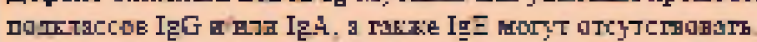

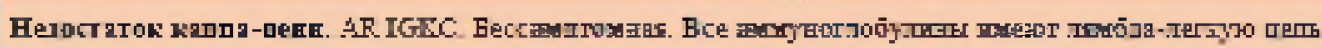

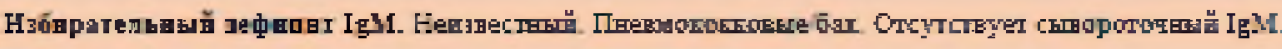

\section{Рис.104 Преимущественно дефекты гуморального звена иммунитета, другие недостатки антител.}

Дефекты врожденного иммунитета повышают восприимчивость к вирусным инфекциям, а именно тяжелое течение гриппа сопряжено с дефицитом MDAS(LOF), IRF7 и TLR3, при дефиците IL-18BP, развивается молниеносный вирусный гепатит. Дефицит STAT2. IFNAR1, IFNAR2 может приводить к диссеминированной вакцинальной кори. ВПЧинфекция и рак кожи при верруциформная эпидермодисплазия (HPV), при синдроме WHIM (бородавки, гипогаммаглобулинемия, иммунодефицит и синдром миелокатексиса), синдроме Якобсена и синдроме MonoMac, при дефиците EVER1, EVER2, CIB1, RhoH, NLRP1. ИД с низкими CD4 и B-клетками. Герпес вирусных инфекций при дефиците IFNAR2, CD16, PHKполимеразе III, а при дефиците UNC93B1, TRAF3, TICAM1, TBK1, IRF3, TLR3, DBR1 доминирующим клиническим проявлениями является энцефалит, вызванный вирусом простого герпеса типа. ВЭБ инфекция часто возникает при дефиците MCM4, NFKB1, CTPS1, CD70, CD27, LRBA (ОВИН с аутоиммунитетом), активированном дельта-синдроме PI3K (APDS). При более тяжелых ПИД (ТКИН, ИД с низкими В-лимфоцитами, Х-сцепленный лимфопролиферативный синдром 1 и 2 типа, дефиците MST1, ITK CD137) ВЭБ -инфекция обычно сопровождается лимфопролиферацией. 


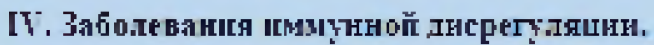

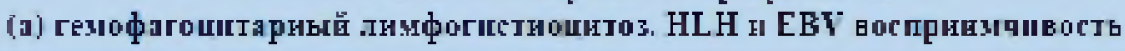

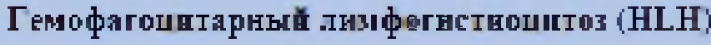

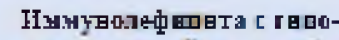
Еாтуง EЕзй.4

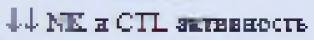

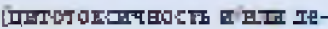

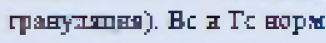

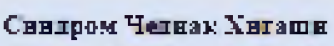

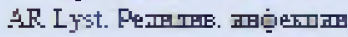

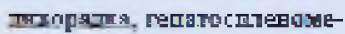

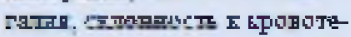

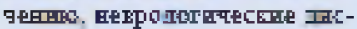

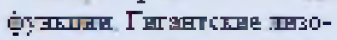

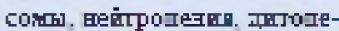
: THETIEE 따. Ts

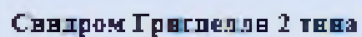

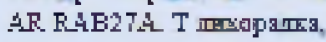

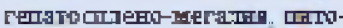

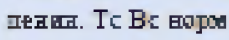

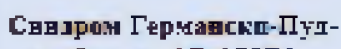

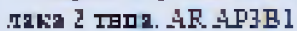

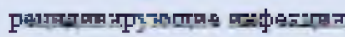

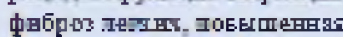

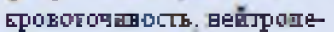

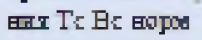

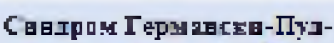

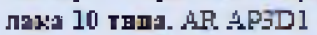
Г 져 30 工国

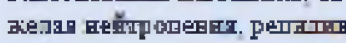

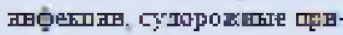

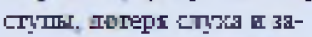

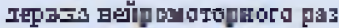

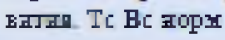

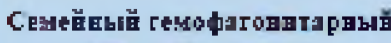

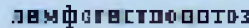

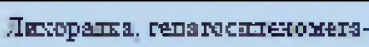

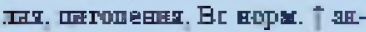

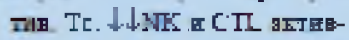

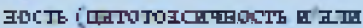

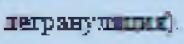

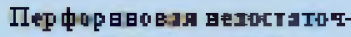
mocth (FHL2) AR PRF 1

Ie中 साா LNC13DANan: $13-4$

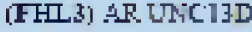

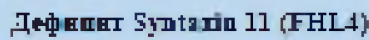
AR $5 T$ TX1

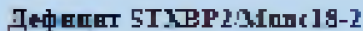
(FHL5) .MD AR STIEP2 энтерघдатіт

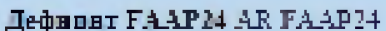

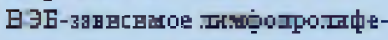

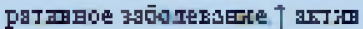
Ic. Hecaocoñ 70б

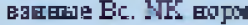

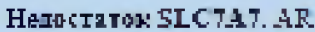

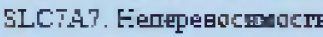

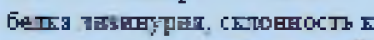

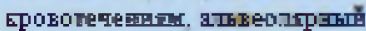

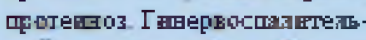

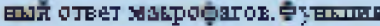

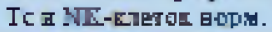

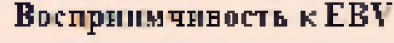

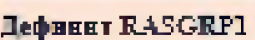

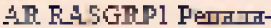

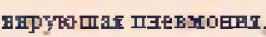

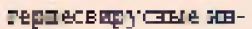

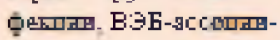

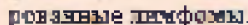 Te $\exists r$ !

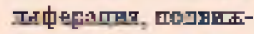

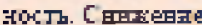

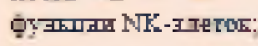

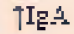

Ieфнвнт CD70 AR. CD70 (TVFFF?) Б्रF-

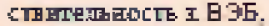

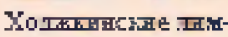

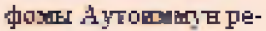

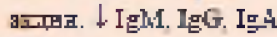

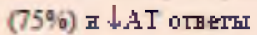

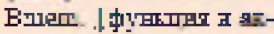
тrHa말 Treg

Де中н世ет C.TPS1 슨

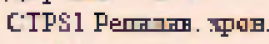

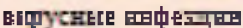

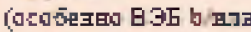
Varicella Zoster], F倠

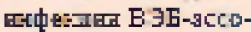

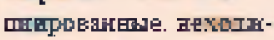

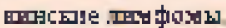

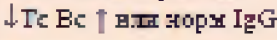

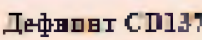
AR. TSFRSFO. EBT .파무유.

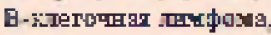

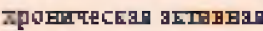

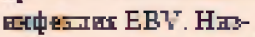

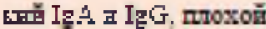

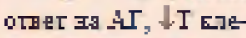
тoचner sarpaurs

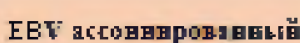
$\mathrm{HLH}$

IEфस⿴囗十 5B2DIA [X-

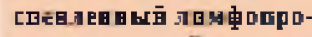

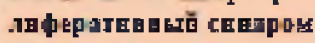
1 rgHe, 고 $P 1$ ) $\mathrm{XI}$

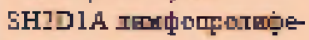

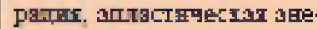

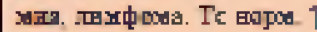

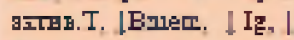
iฟराRT Hapy

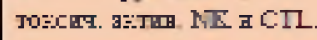

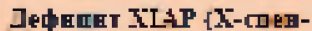

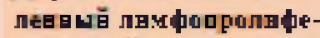

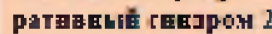

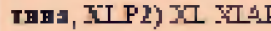

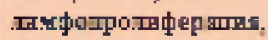

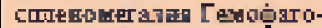

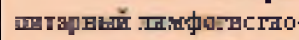

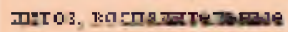

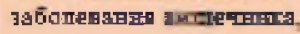

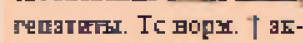

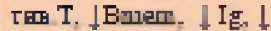
iNEI

Jе中Еாस CD27. Aㄱ CDI7 [TMFESF?

XPOA

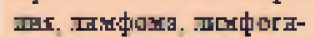

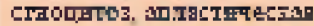

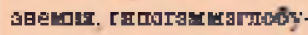

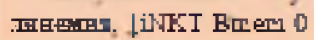

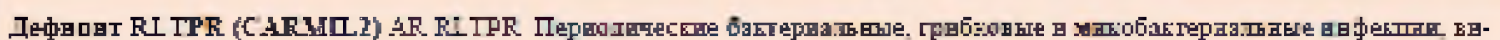

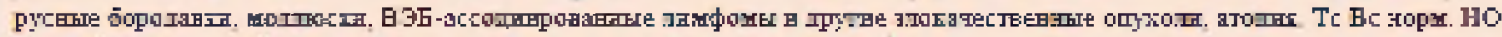

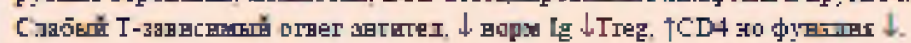

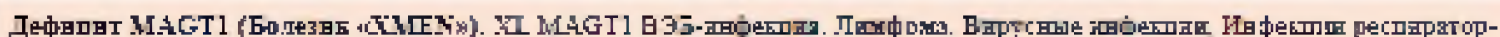

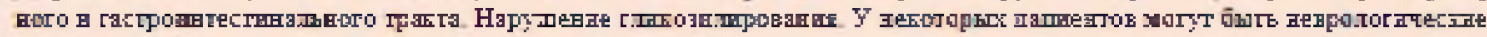

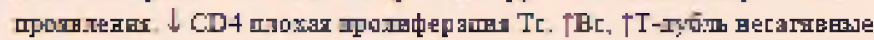

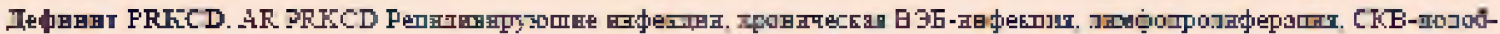

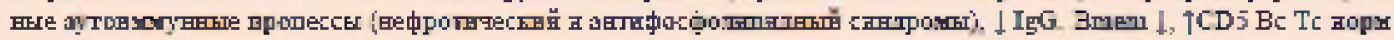

\section{Рис. 105. Заболевания иммунной дисрегуляции (А)}

Преимушественно грибковые инфекции формируются при синдроме Джоба, синдроме Vici, Х-сцепленной хронической гранулематозной болезни (ХГБ), соматические мутации связанной с ауто-AT на GM-CSF (легочный альвеолярный протеиноз), дефиците IKAROS (CD154), IL-21R, CARD9. Особую группу составляют ПИД со слизисто-кожным кандидозом (СМC), хронический слизисто-кожный кандидоз без эктодермальной дисплазии (изолированный или с синдромом APECED), аутоиммунная полиэндокринопатия c кандидозом и эктодермальной дистрофией (APS-1). 


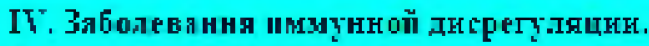

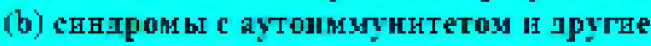

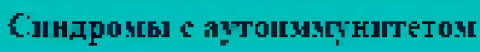

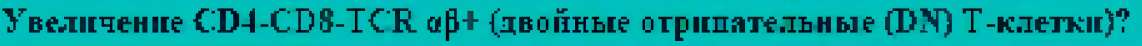

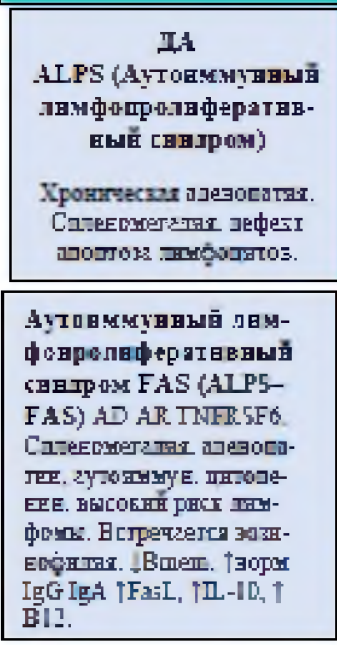

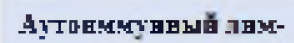
中о вролвфератвв:ный Gagpa FASLC

(ALPS-FASLG) AR

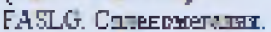

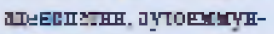

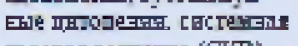

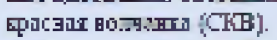

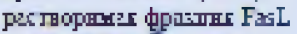

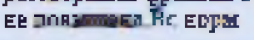

\begin{tabular}{|c|c|}
\hline \multicolumn{2}{|l|}{ Ferpiraropabe It中e } \\
\hline H正T & \\
\hline 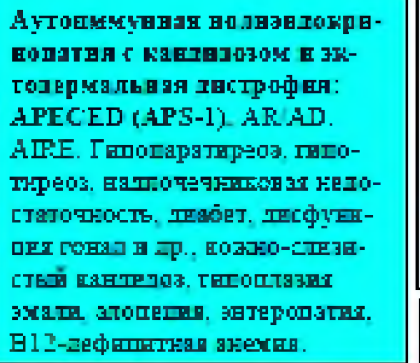 & \\
\hline 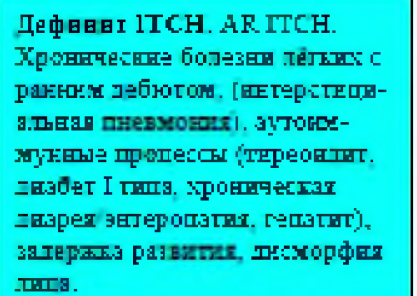 & \\
\hline
\end{tabular}

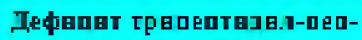

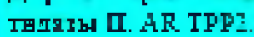

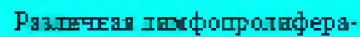

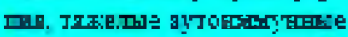

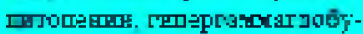

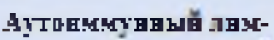

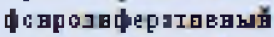
c日Hopor Caspeselo

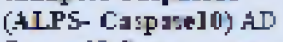

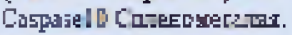

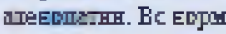

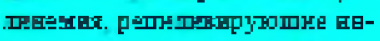

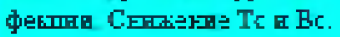

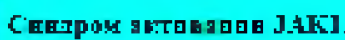

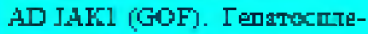

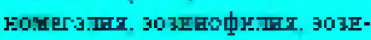

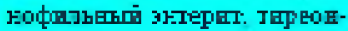

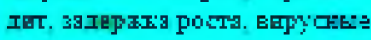

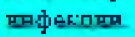

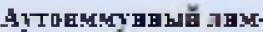

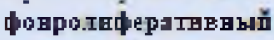
GHJPOM Caspse日 (HIPS-Caspases) ㄴ. Cuspa

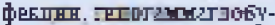

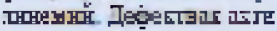
в

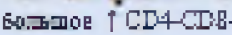

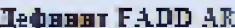

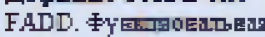

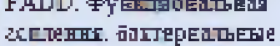
ㅍ

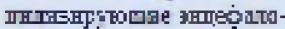

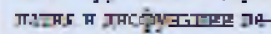
마래표

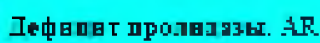
PEF[. 0काष ?:

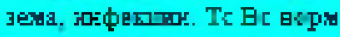

Пмнунн ан диереге-

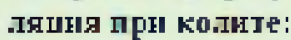
IED

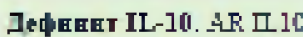
Фors

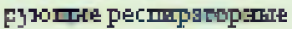

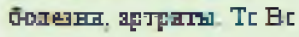
크마:도

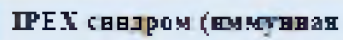
工Еср в-中ат Hн, энтероватвн

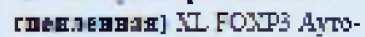

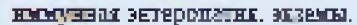

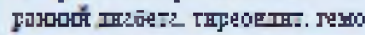

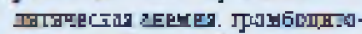

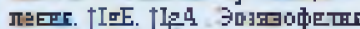

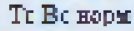

工ефнпвт C D25. AR I.RA

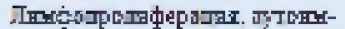

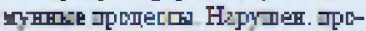

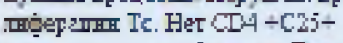

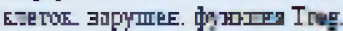
Bic 피리

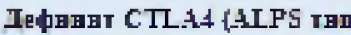

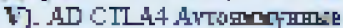

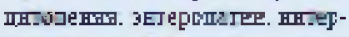

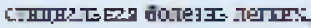

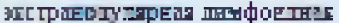

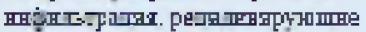

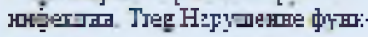

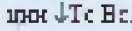

\section{Ieq日atr LFEA (OBIIH $\mathrm{c}$}

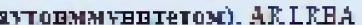

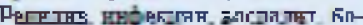

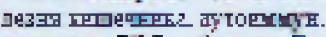

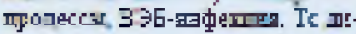
CTory. Bᄃ. $\downarrow$ IEG 프르.

工ефннвт I-10R. AR 프10R는 프묘

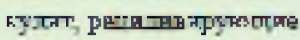

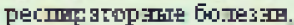

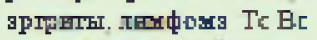

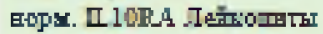
타 pegs

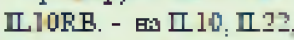

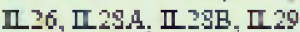

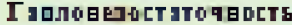

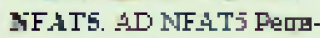

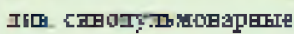

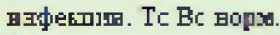

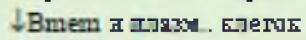

Деф вн日т TGF B1. ㅅ․

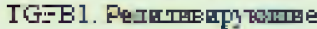

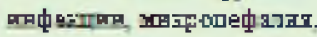

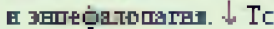

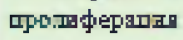

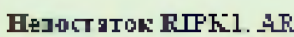

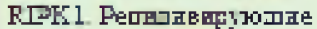

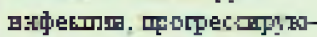

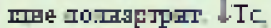

$\rightarrow$ expor E. E.

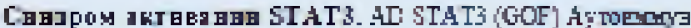

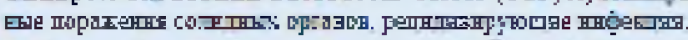

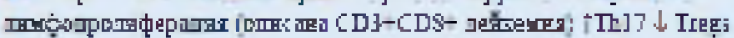
$\downarrow$ I в E $\mathrm{Bi}$

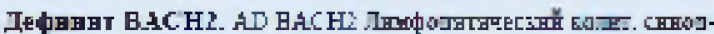

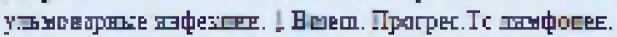

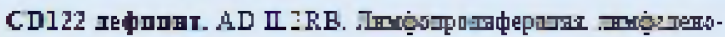

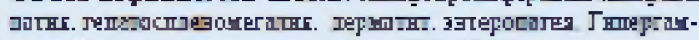

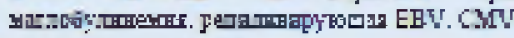

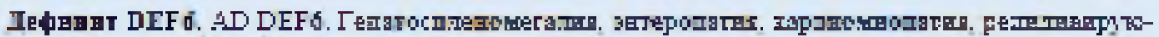

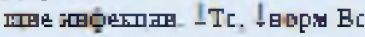

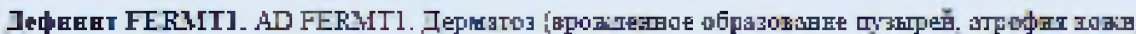

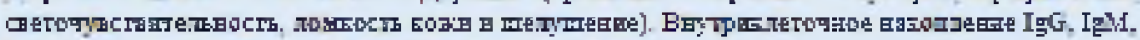

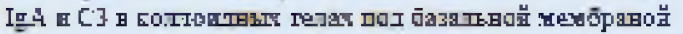

\section{Рис. 106. Заболевания иммунной дисрегуляции (Б)}

Различные виды рака так же достаточно часто встречаются при ПИД особенно при атаксии-телеангиоэктазии, гипер-IgE синдроме, синдроме Ниймегена, хряще-волосяной гипоплазии. Особенно часто при ПИД встречаются лимфомы (Т-клеточная лимфома подкожно-подобный панникулит (дефицит ТІМ3), хряще-волосяная гипоплазия, синдром Вискотта-Олдрича, синдром Ниймегена, синдром Блума, аутоиммунный лимфопролиферативный синдром FAS (ALPS-FAS), X-сцепленный лимфопролиферативный 
синдром 1 типа, дефицит RhoH, ITK, MCM4, CTPS1, CD27, CD137, IL-10R), Ходжкинская лимфома (дефицит CD70), лимфоаденопатия (TKИН, ALPS, APDS, синдром Оменна и Ройфмана, синдром активации STAT3 и CARD 11, гипер-IgM синдром, дефицит CD25, CD122, трипептидил-пептидазы II), гепатоспленомегалия (ALPS, XLP2, семейный гемофагоцитарный лимфогистиоцитоз, синдром Оменна, синдром активации CARD 11, синдром Грисцелли 2 типа, синдром Чедиак Хигаши, синдром активации CARD 11, синдром активации JAK1, CD122 дефицит), тимусмегалия (ТКИН, Good синдром, синдром ДиДжорджи, синдром делеции 10p13-p14, дефицит IKAROS (CD154)

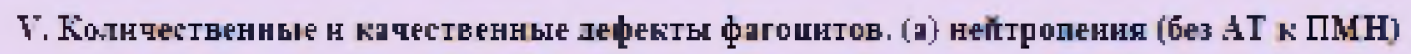

\begin{tabular}{|c|}
\hline 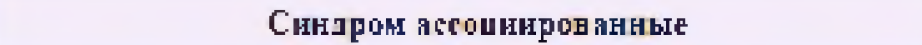 \\
\hline 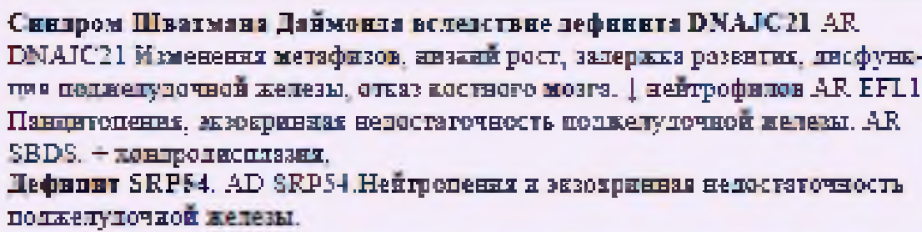 \\
\hline
\end{tabular}

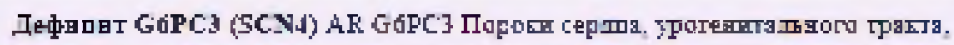

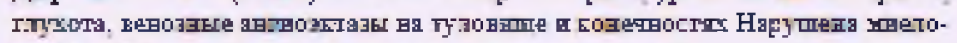

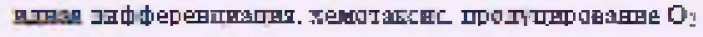

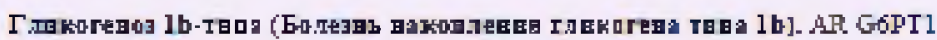

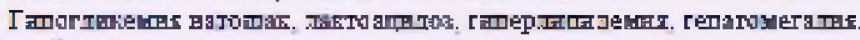

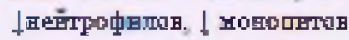

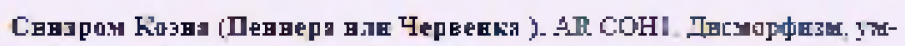

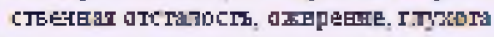

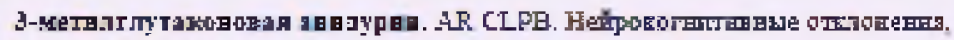

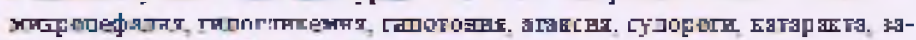

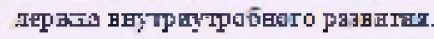

Снвтүй Блрта (

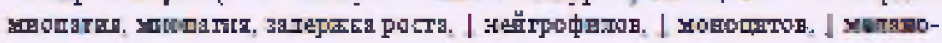
며늘

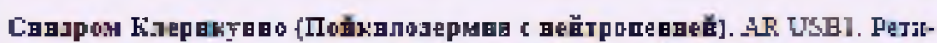

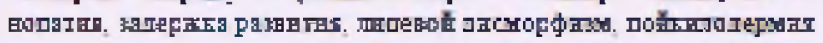

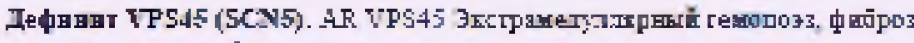

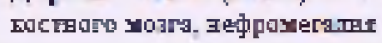

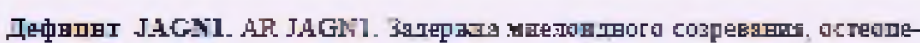
빧.

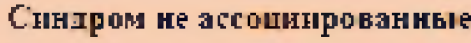

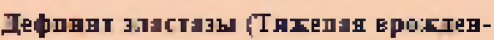

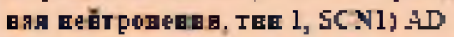

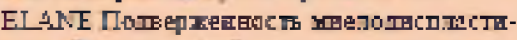

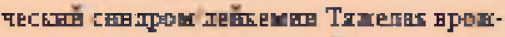

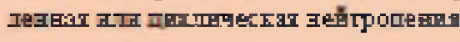

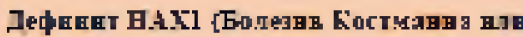

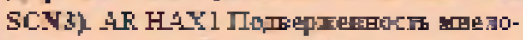

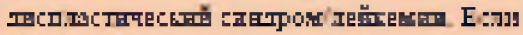

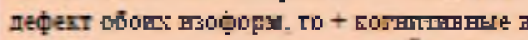

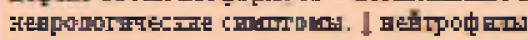
$\uparrow$ 는

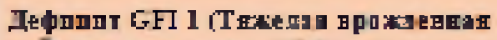

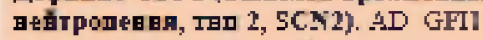

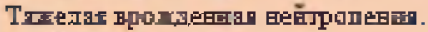

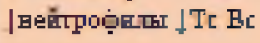

T-снен.ленвая вейтронения/ мпепотвг-

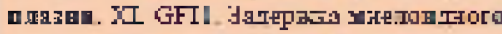

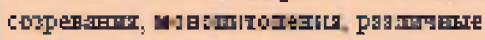

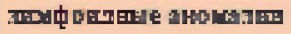

\section{בeфnemt penertopa G-CSF}

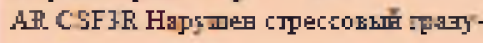

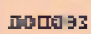

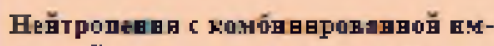

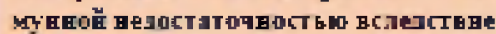
тер

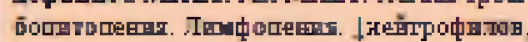
| NADG0IIITSE, LTR

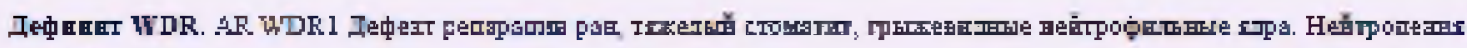
다료담

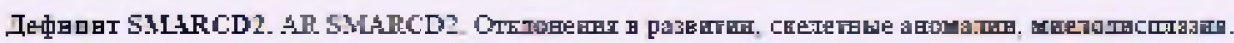

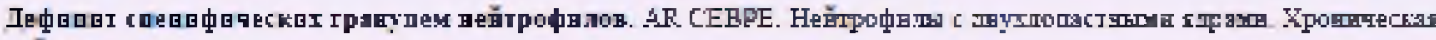

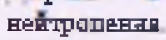

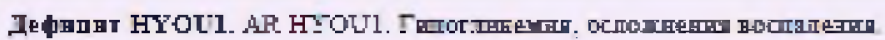

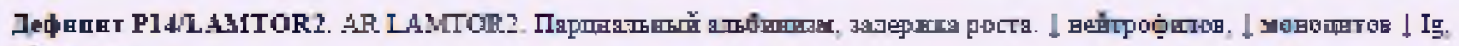
Jọy

Рис.107. Количественные и качественные дефекты фагоцитов (А) 


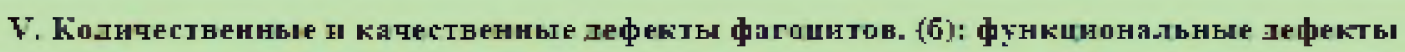

Синлром не связан: анализ на дипарородамия (DHF) пII HCT-IER'?

\begin{tabular}{|c|c|}
\hline \multicolumn{2}{|c|}{ Синдрам ассошиярованные } \\
\hline 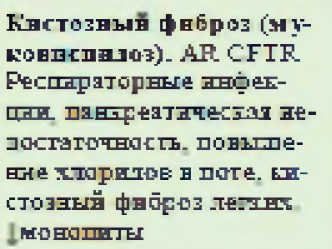 & 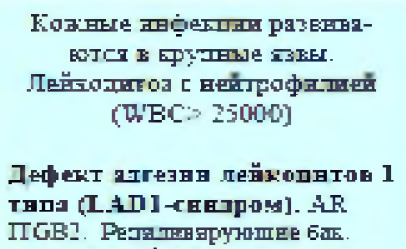 \\
\hline 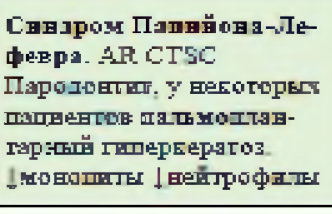 & 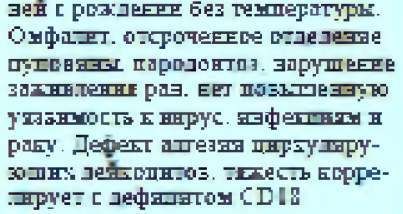 \\
\hline 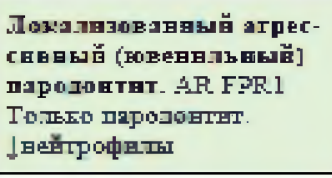 & 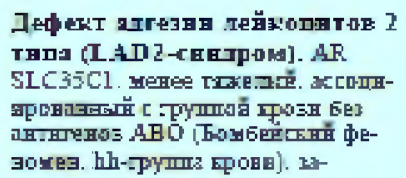 \\
\hline 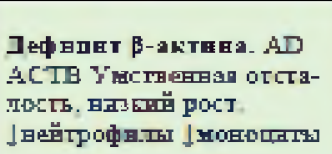 & 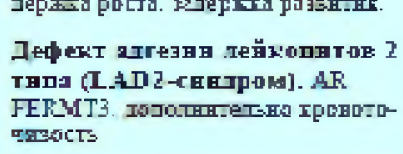 \\
\hline
\end{tabular}

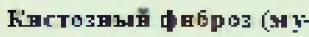

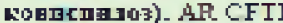
CT.

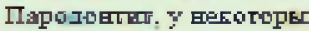

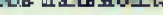

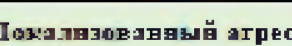

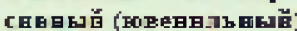
חנP0בRTBT. AR. FPR

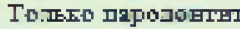

\section{Рис. 108. Количественные и качественные дефекты фагоцитов (Б)}

\begin{tabular}{|c|c|}
\hline 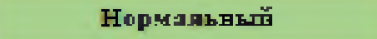 & Невормалтвй \\
\hline 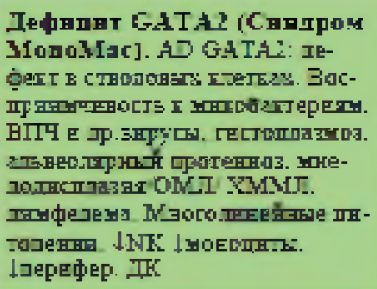 & 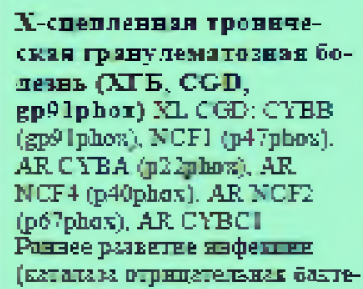 \\
\hline 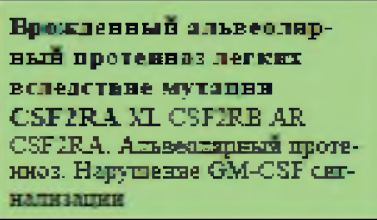 & 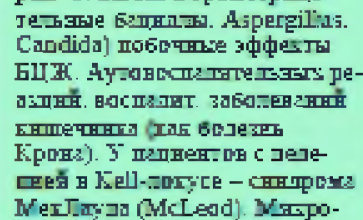 \\
\hline & 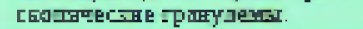 \\
\hline
\end{tabular}

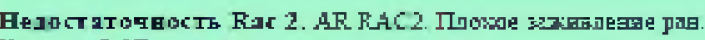

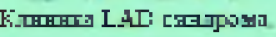

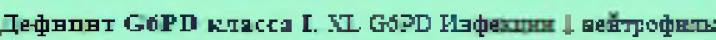

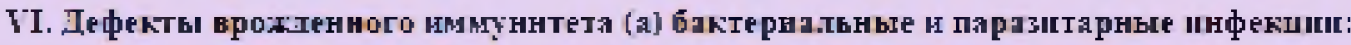

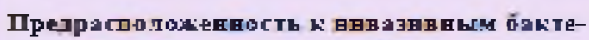

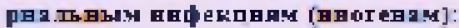

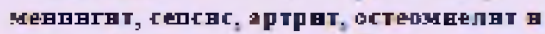

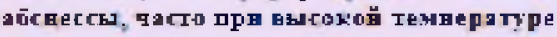

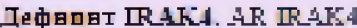

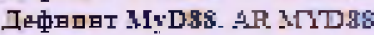

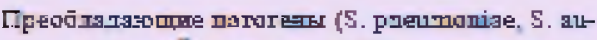

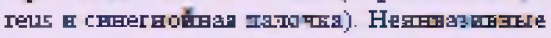

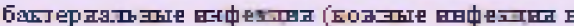

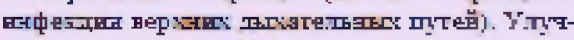

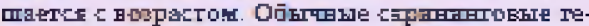

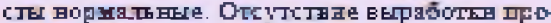

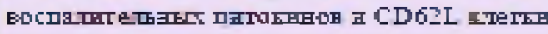

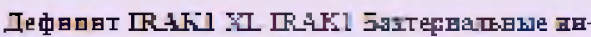

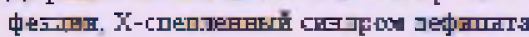
4⿻一𠃋十

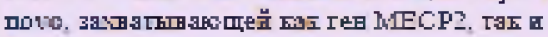
IFHA 1

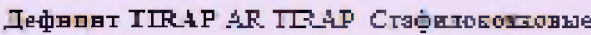

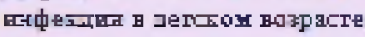

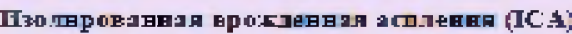

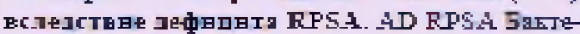

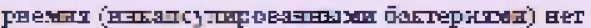

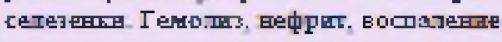

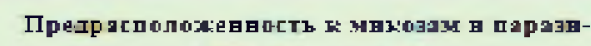

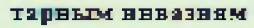

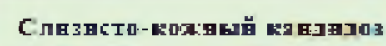

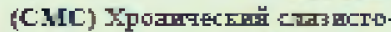

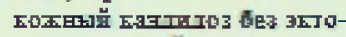

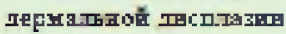

C

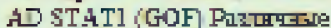

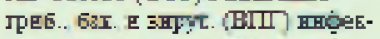

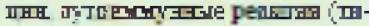

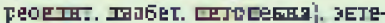

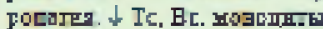

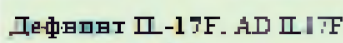

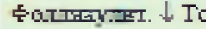

工е中впвт П-17RA. AR 표 1TF

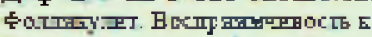

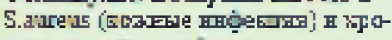

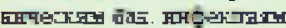

工ефвпвт 프-1 JFC. AR II 1.RC

Дефвпнт ACT1 AR. JFAF3IF-

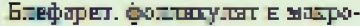
IDocchr. + Te

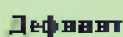

C.AFTh $A R$

CAFDO $\pi_{p e C}$

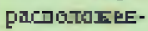

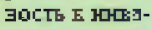

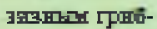

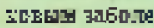

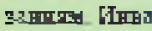
उनSम2K $\mathrm{MFTH}$ -

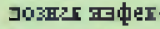

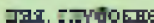
әерматорфе더저. 파달 zавмзатық TPEBTGOEETE EEфезити.

\section{Дефнтвт} APOLI (тp日п3. AD APOLI

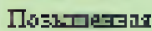

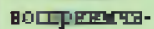

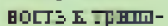
EDCayos!

\begin{tabular}{|c|}
\hline Дрүгте \\
\hline 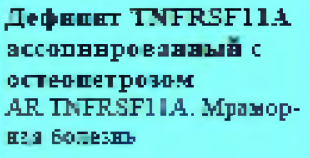 \\
\hline 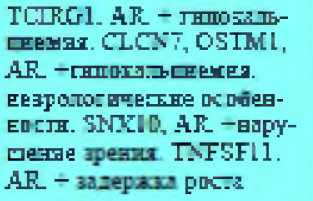 \\
\hline 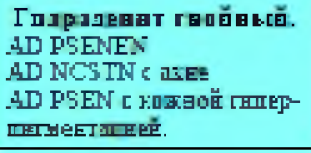 \\
\hline 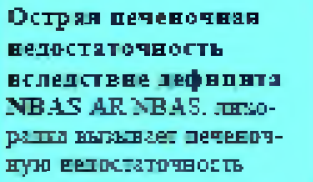 \\
\hline 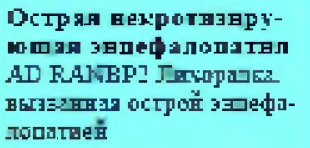 \\
\hline
\end{tabular}

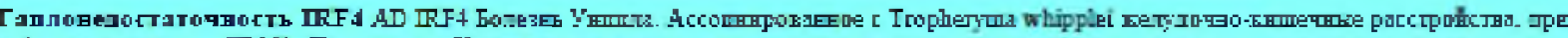

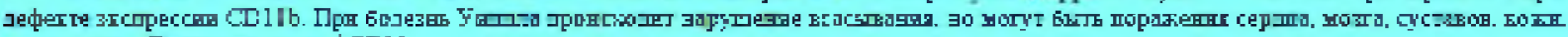

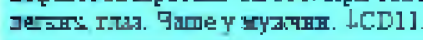

Рис.109. Дефекты врожденного иммунитета (А) 


\begin{tabular}{|c|c|c|c|c|}
\hline \multicolumn{5}{|c|}{ 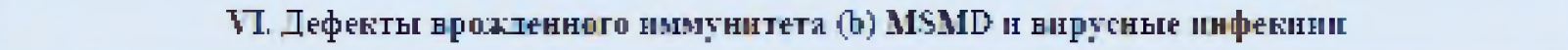 } \\
\hline \multicolumn{2}{|c|}{ 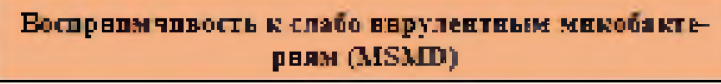 } & \multicolumn{3}{|c|}{ 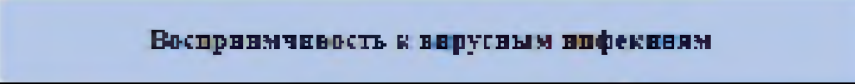 } \\
\hline 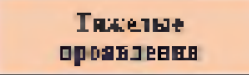 & 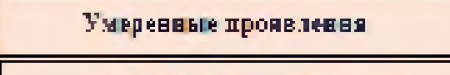 & \multirow{2}{*}{ 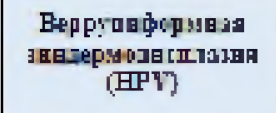 } & \multirow{2}{*}{ 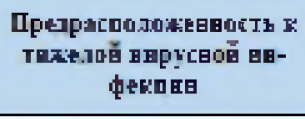 } & 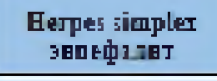 \\
\hline \multirow{6}{*}{ 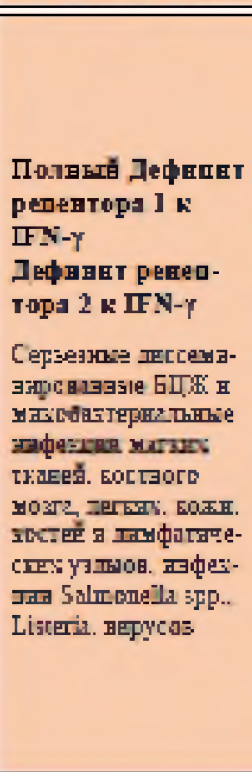 } & \multirow{6}{*}{ 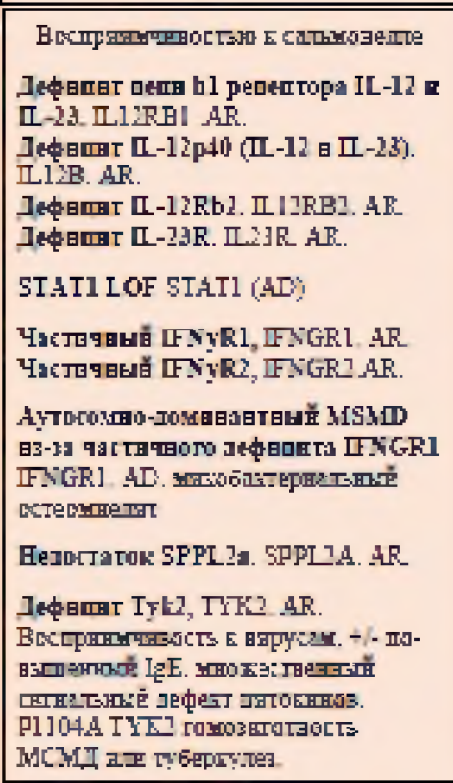 } & & & \multirow{11}{*}{ 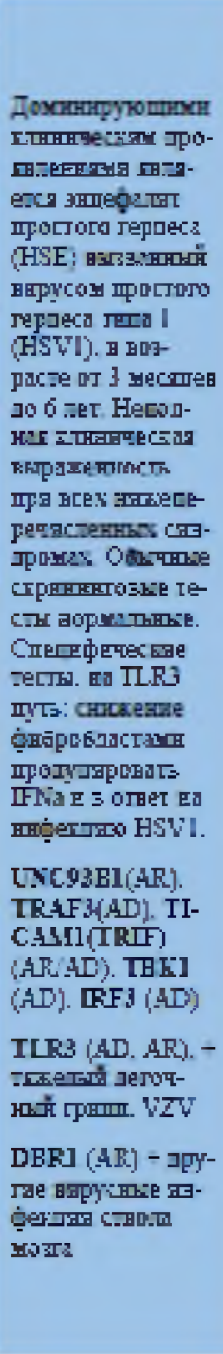 } \\
\hline & & \multirow{2}{*}{ 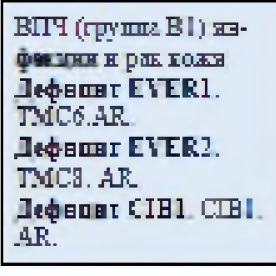 } & 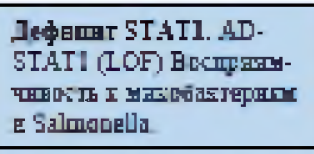 & \\
\hline & & & 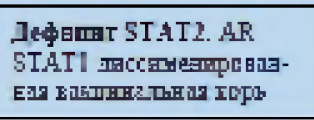 & \\
\hline & & \multirow{3}{*}{ 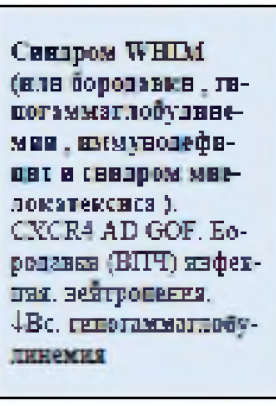 } & 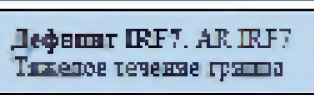 & \\
\hline & & & 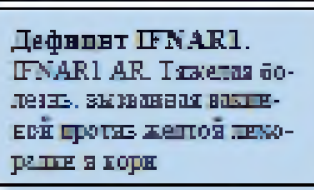 & \\
\hline & & & 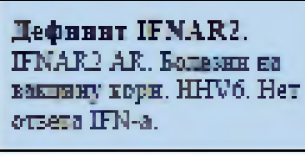 & \\
\hline & \multirow{3}{*}{ 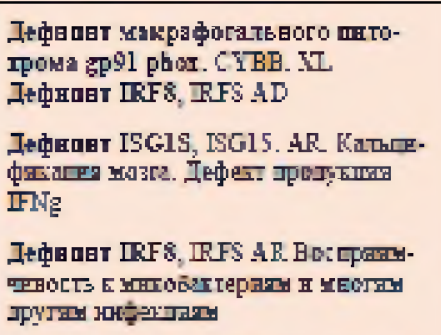 } & & \multirow[t]{2}{*}{ 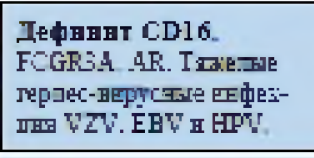 } & \\
\hline & & & & \\
\hline & & & 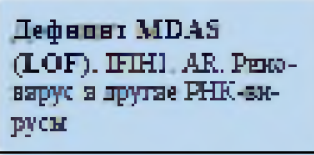 & \\
\hline & 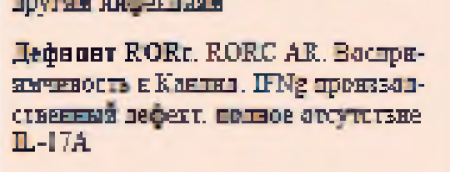 & & 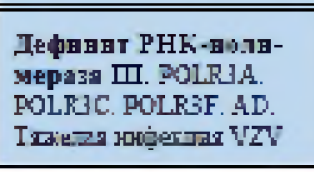 & \\
\hline & 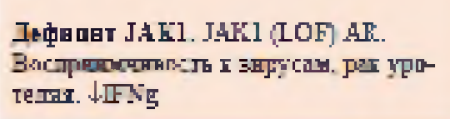 & & 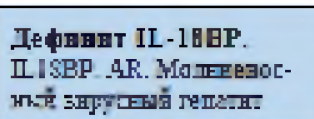 & \\
\hline
\end{tabular}

\section{Рис. 110. Дефекты врожденного иммунитета (Б)}

Как нарушения макрофагально-фагоцитарного звена необходимо рассматривать всю группу заболеваний с количественным и качественным дефектом фагоцитов (врожденные нейтропении, хроническая гранулематозная болезнь и др.), и дефекты системы комплемента. А также заболевания сопровождающиеся гранулематозном (Атабасский ТКИД, ПИД с CD8 недостаточностью, общая вариабельная иммунная недостаточность (OBИН), изолированный дефицит подкласса IgG4, дефицит RhoH, ICOS)

Гиперэргические реакции возникают не только при ПИД с ауто-воспалительными заболеваниями, и группе заболеваний иммунной дисрегуляции с аутоиммунными синдромами но и при других иммунодефицитах. Это могут быть ТКИД, ИД с низкими CD4, CD8, синдроме Вискотта-Олдрича, хряще-волосяной гипоплазии, Kabuki-синдроме, APDS, дефиците TCRa, ICOS, PGM3, NFKB1, CD70, избирательном дефиците Ig, ХГБ). ПИД с васкулитами так же можно расценивать как гиперэергическую реакцию (синдром Вискотта-Олдрича, семейная средиземноморская лихорадка, ПИД с CD8 недостаточностью, STING- 


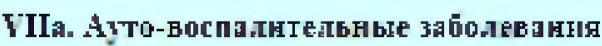

\begin{tabular}{|c|c|c|}
\hline 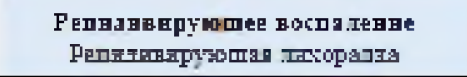 & 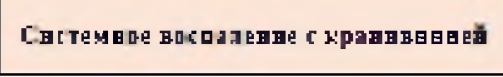 & Дрభ̧冖e \\
\hline \multirow{2}{*}{ 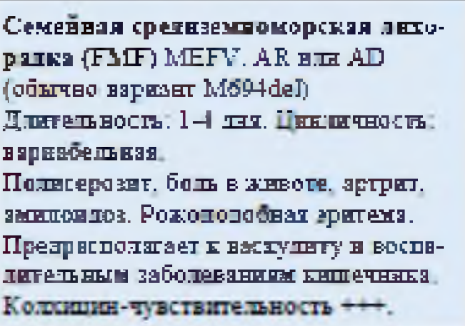 } & 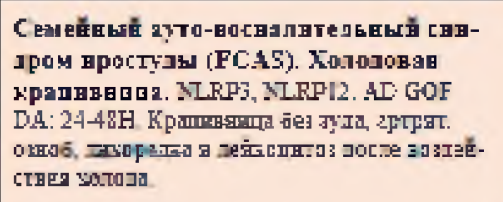 & \multirow{2}{*}{ 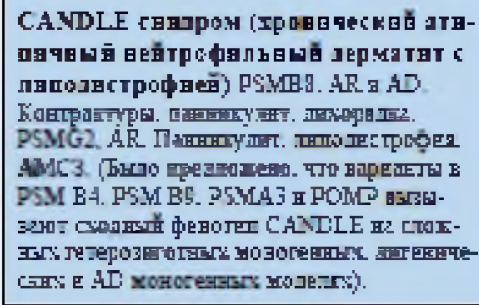 } \\
\hline & \multirow{2}{*}{ 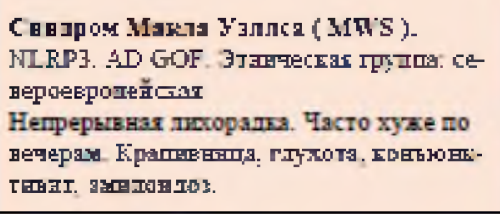 } & \\
\hline \multirow{2}{*}{ 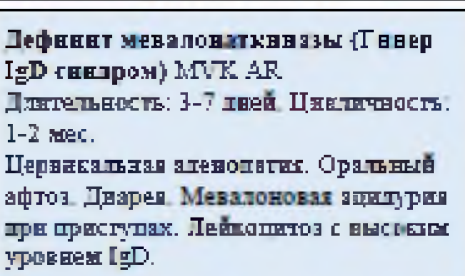 } & & 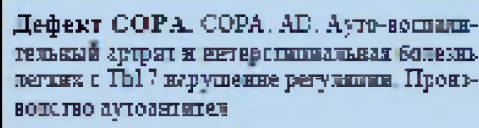 \\
\hline & \multirow{3}{*}{ 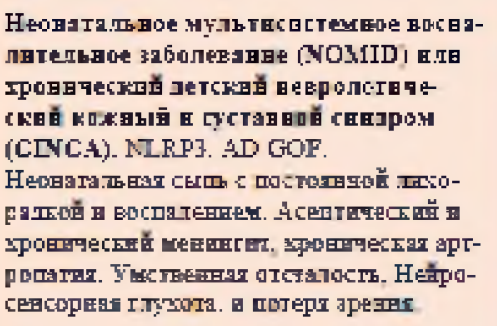 } & 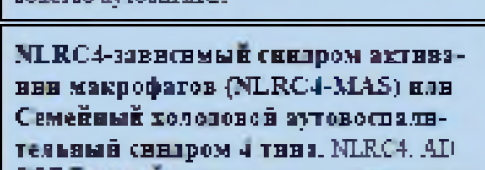 \\
\hline \multirow{4}{*}{ 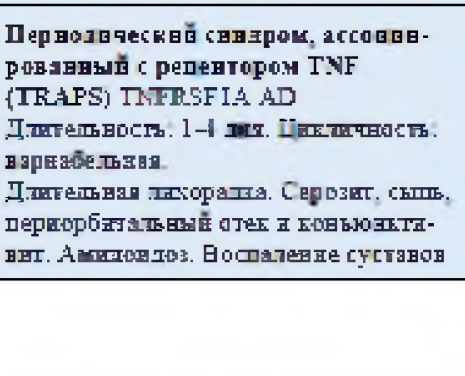 } & & 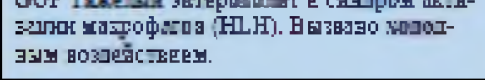 \\
\hline & & \multirow{2}{*}{ 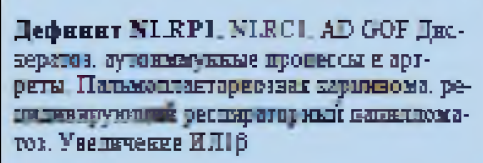 } \\
\hline & 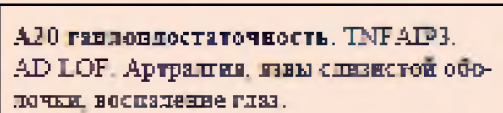 & \\
\hline & 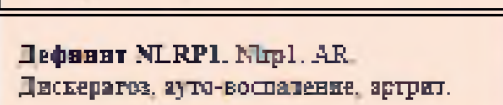 & 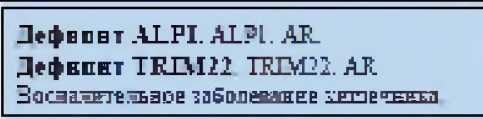 \\
\hline \multicolumn{2}{|c|}{ 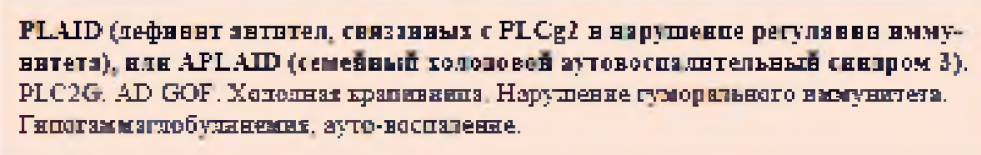 } & 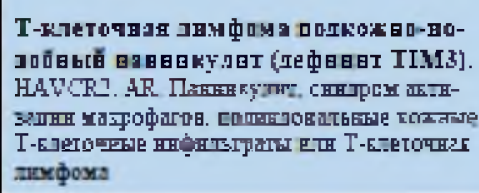 \\
\hline
\end{tabular}

\section{Рис.111. Ауто-воспалительные заболевания (А)}

ассоциированная васкулопатия с дебютом в младенчестве, дефицит ADA2). И если ранее ПИД ассоциировали с инфекцией, то в настоящее время многие аутоиммунные заболевания имеют основу первичных иммунодефицитов. Системная красная волчанка (СКВ) может иметь основу интерферонопатии I типа и/или дефицита комплемента (дефицит C1q, C1R, C1S, C2). AR C2). Причиной различных артритов может быть группа ауто-воспалительных заболеваний с поражением основном костей и суставов, дефект COPA, дефицит NLRP1, IL10 , $\mathrm{L}-10 \mathrm{R}$, семейная средиземноморская лихорадка (FMF), периодический синдром, ассоциированный с рецептором TNF (TRAPS), A20 гаплонедостаточность, семейный аутовоспалительный синдром простуды (FCAS), холодовая крапивница, криопиринопатии. Остеопороз может быть обусловлен синдромом Джоба, Лоис-Дитца, остеопетроз (мраморная болезнь) дефицитом TNFRSF11A. Большая группа воспалительных заболеваний кишечника может быть обусловлена дефицитом XIAP (X-сцепленный лимфопролиферативный синдром 2 типа), дефицитом BACH2, дефицитом LRBA (OBИН с аутоиммунитетом), CTLA4 (ALPS тип V), CD122, ХГБ, болезнью Уиппла, FMF, синдромом Блау, семейным холодовым аутовоспалительным синдромом 4 типа, IPEX синдромом APECED (APS-1), синдром CHAPLE, синдром активации STAT1. Стойкие и/или перемежающие лихорадка характерны при синдроме Чедиак Хигаши, семейном гемофагоцитарном лимфогистиоцитозе, группе рецидивирующих лихорадок, семейном аутовоспалительном синдроме простуды (FCAS), холодовой крапивнице, синдроме Макла Уэллса (MWS), CANDLE синдроме, дефицит ADA2. 


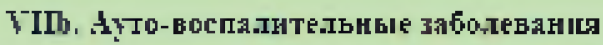

\begin{tabular}{|c|c|c|}
\hline \multicolumn{2}{|c|}{ 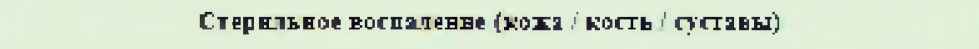 } & \multirow{4}{*}{ 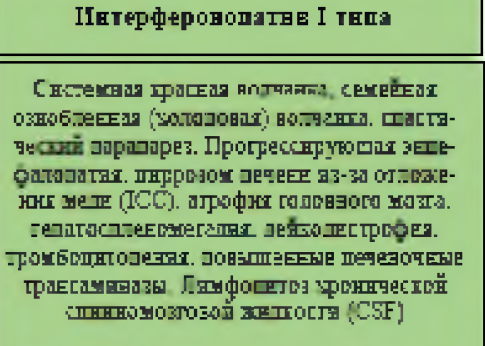 } \\
\hline 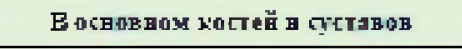 & B bctobutu saxe & \\
\hline \multirow{3}{*}{ 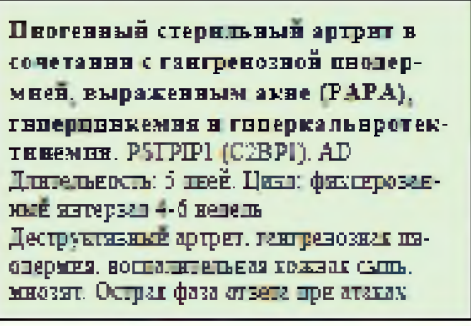 } & 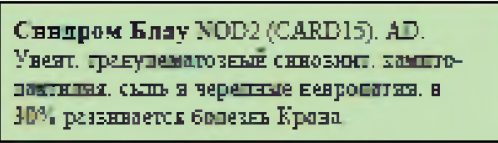 & \\
\hline & 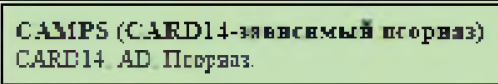 & \\
\hline & \multirow{3}{*}{ 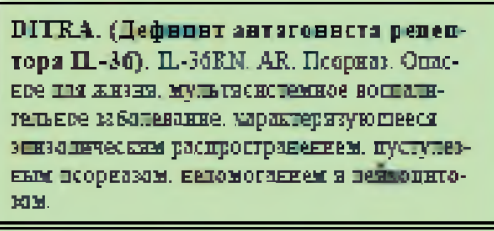 } & \multirow{2}{*}{ 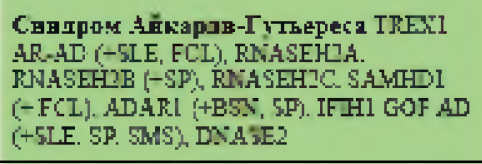 } \\
\hline \multirow{4}{*}{ 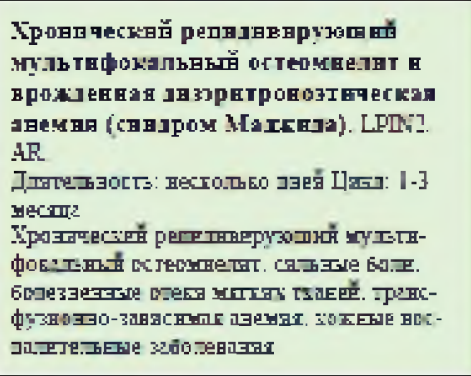 } & & \\
\hline & & \multirow{3}{*}{ 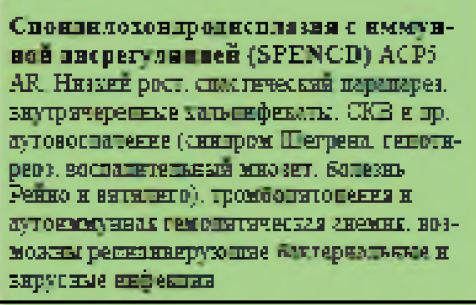 } \\
\hline & 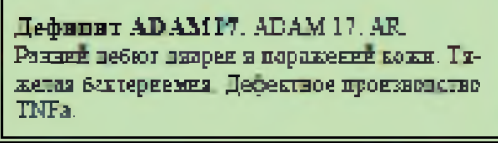 & \\
\hline & \multirow{2}{*}{ 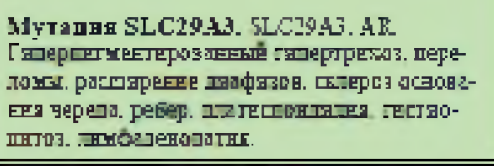 } & \\
\hline \multirow[b]{2}{*}{ 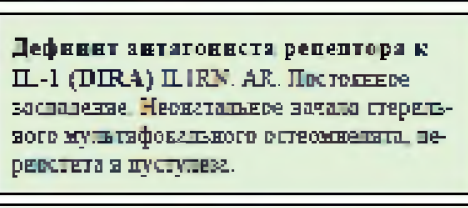 } & & \multirow{2}{*}{ 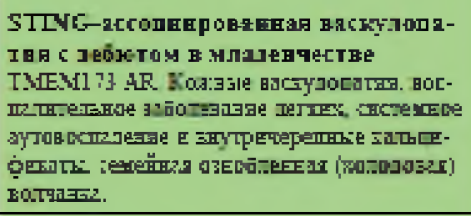 } \\
\hline & 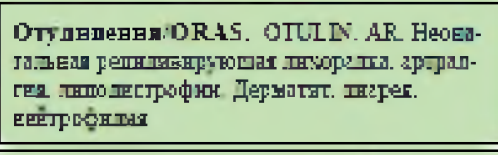 & \\
\hline 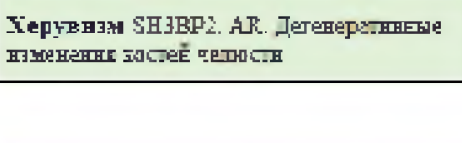 & 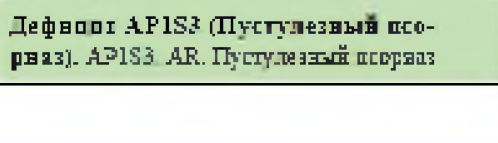 & 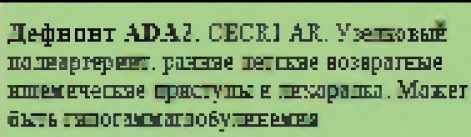 \\
\hline
\end{tabular}

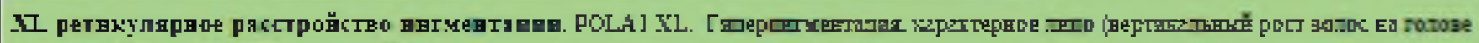

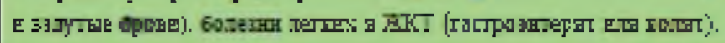

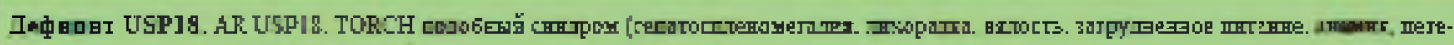

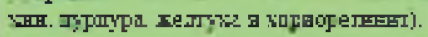

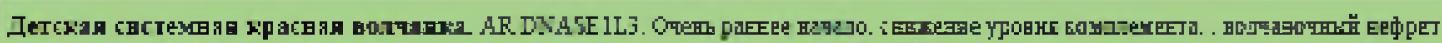

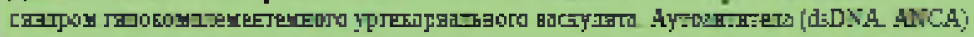

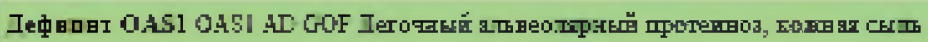

\section{Рис.112. Ауто-воспалительные заболевания (Б)}

В некоторых случаях предположить о наличии ПИД возможно из внешнего осмотра больного, т.к. для многих заболеваний характерны пороки развития. Так, например при ТКИН, синдромах Ниймегена, Блума, Ройфмана, Vici, Hebo дефиците, синдром недостаточности костного мозга характерна микроцефалия, при синдромах делеции 10p13-p14, Якобсена, Клерикуцио, HIES, Kabuki-синдроме, дефиците STAT5b, херувизме - лицевой дисморфизм, для ИД с низкими CD4, синдроме Блума, Якобсена, Швахмана-Даймонда, Барта, Видемана Штейнера, FILS синдроме, Kabuki-синдроме, синдром активации JAK1, LAD2-синдроме, иммунокостной дисплазия Шимке, синдром недостаточности костного мозга характерна задержка роста, нередки аномалии и пороки скелета (ТКИН, Синдромы ДиДжорджи, Ройфмана, Швахмана-Даймонда, делеции 10p13-p14, CHARGE синдром, Kabuki-синдром, HIES, метафизарная хондродисплазия Мак-Кьюсика, анемия Фанкони), дефекты кожи, волос и зубов (синдромы эктодермальной дисплазии и иммунодефицита (EDA-ID)), 


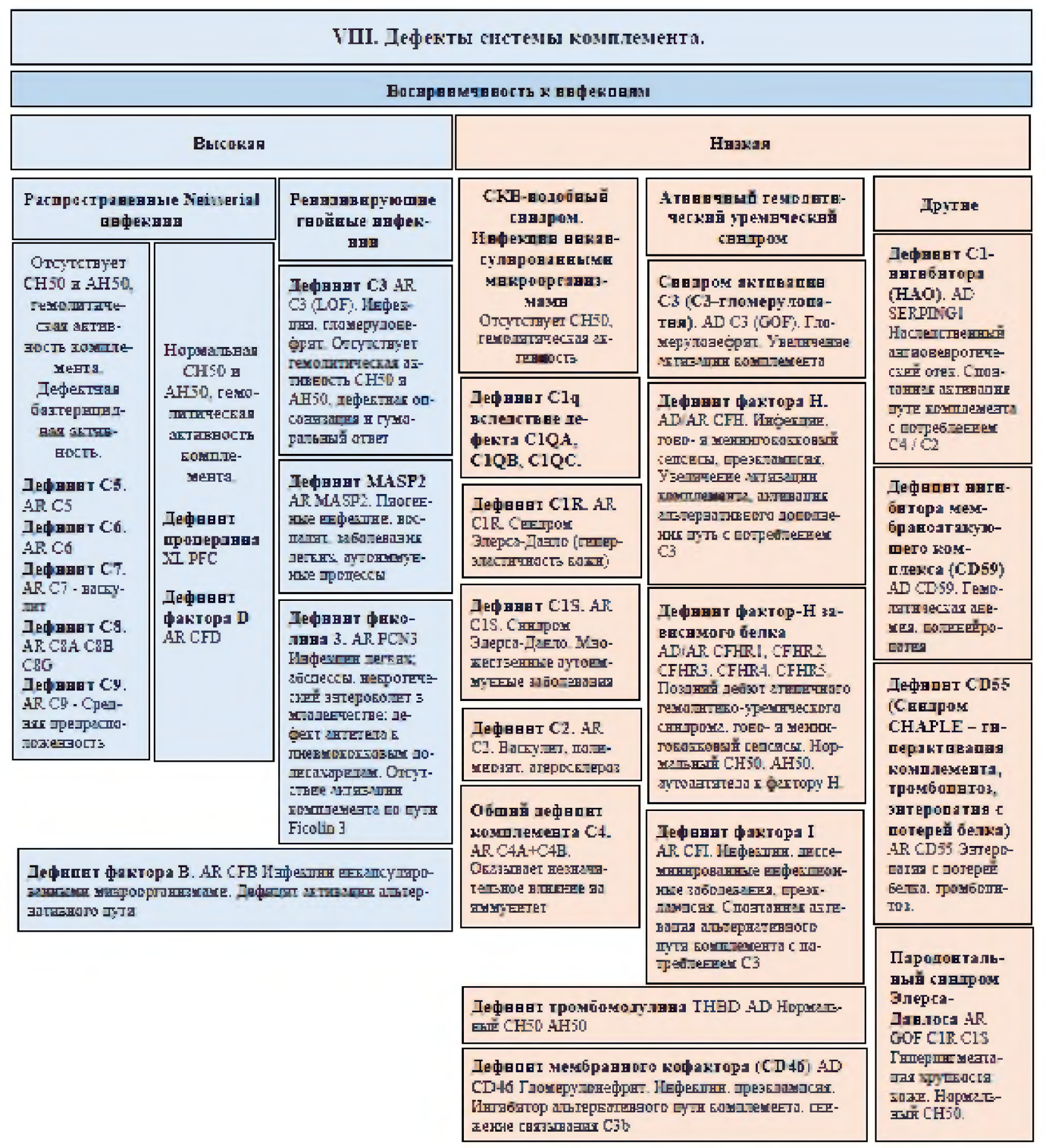

\section{Рис.113. Дефекты системы комплемента}

Врачи психоневрологи встречаются с ПИД у пациентов при наличии дефектов ЦНС (CHARGE синдром, анемия Фанкони) и других неврологические нарушениях (дефицит пуриннуклеозидфосфорилазы, дефицит ингибитора мембраноатакующего комплекса (CD59), синдром Чедиак Хигаши), атаксия (атаксия-телеангиоэктазия, 3-метилглутаконовая ацидурия), отставание в развитии умственной недостаточности (ИД с низкими СD4, недостатки витамина В12 и метаболизма фолата, Kabuki-синдром, синдромы Vici, ШвахманаДаймонда, Коэна, дефицит TRNT1, $\beta$-актина, LAD2-синдром), когнитивными нарушениями (ТКИН, 3-метилглутаконовая ацидурия), нарушение слуха (ТКИН, синдром делеции 10р13p14, CHARGE синдром, дефицит TRNT1, G6PC3, синдромы Коэна, синдром Макла-Уэллса). 


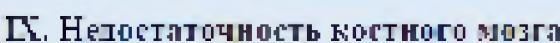

\begin{tabular}{|c|c|c|c|}
\hline \multirow{5}{*}{ 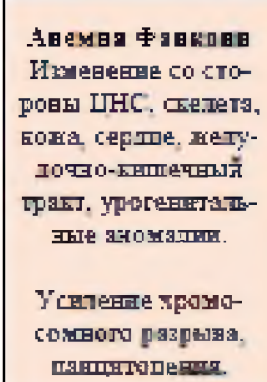 } & \multirow{3}{*}{ 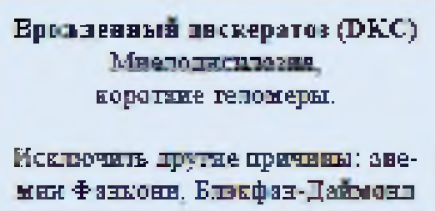 } & \multirow{2}{*}{ 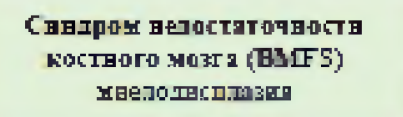 } & \\
\hline & & & \multirow{4}{*}{ 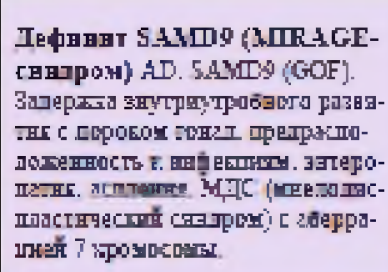 } \\
\hline & & Сндром велостаторнаств & \\
\hline & \multirow{4}{*}{ 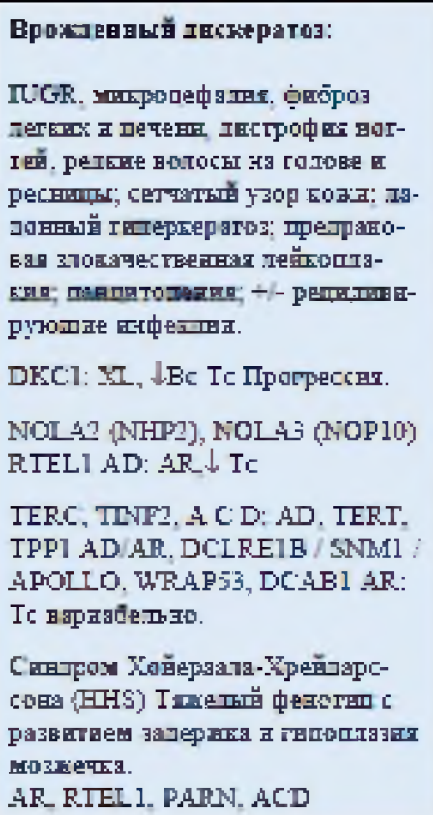 } & 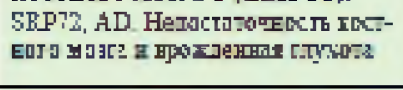 & \\
\hline & & & \\
\hline 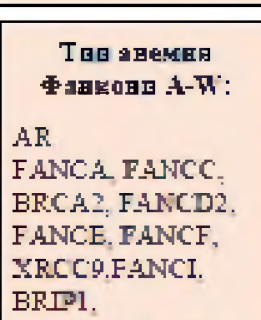 & & 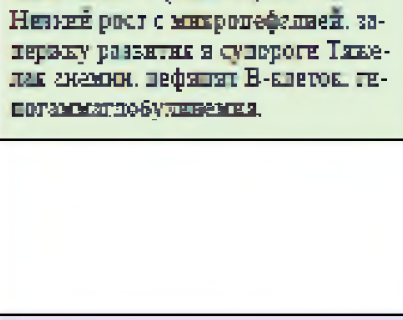 & 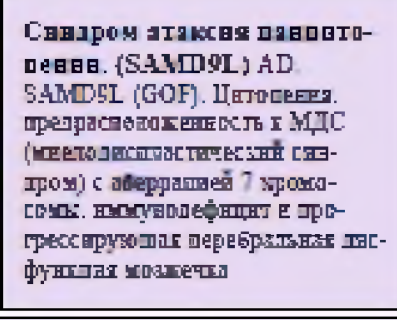 \\
\hline 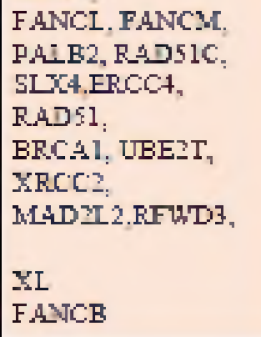 & & \multicolumn{2}{|c|}{ 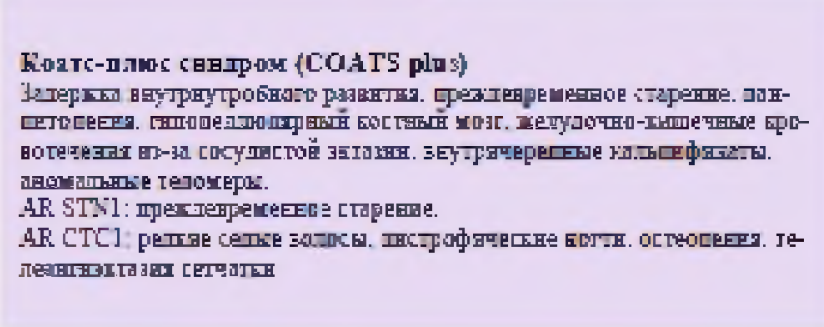 } \\
\hline
\end{tabular}

\section{Рис. 114. Недостаточность костного мозга}

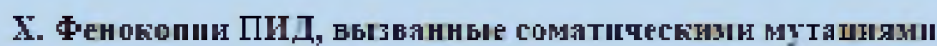

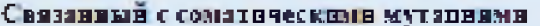

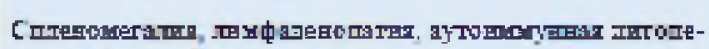

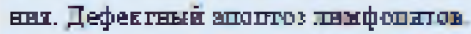

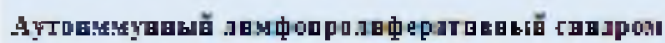

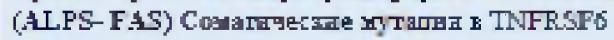

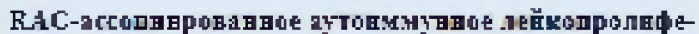

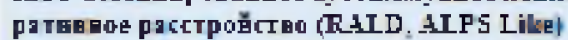

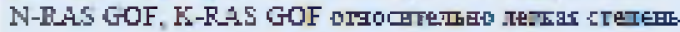

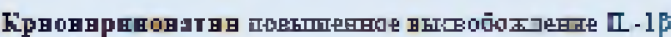

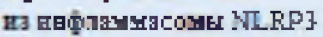

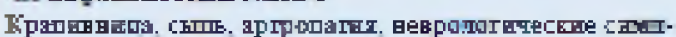

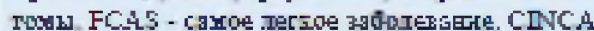

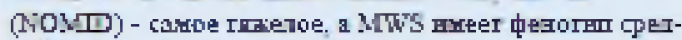

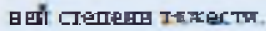

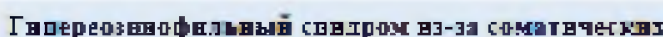

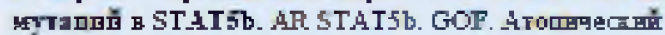

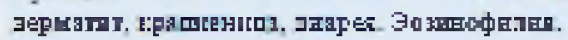

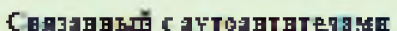

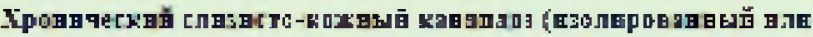

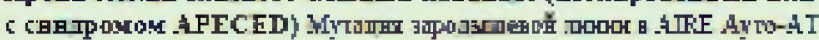

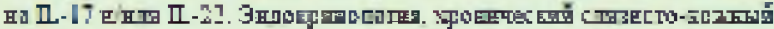

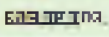

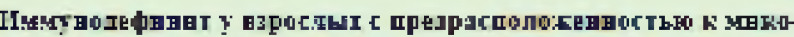

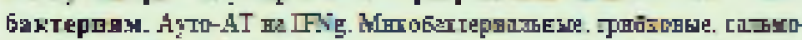

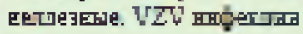

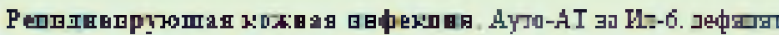

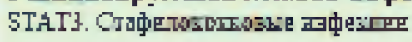

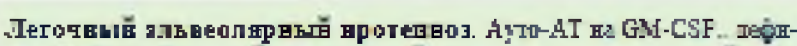

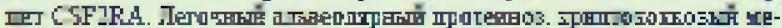

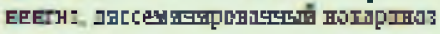

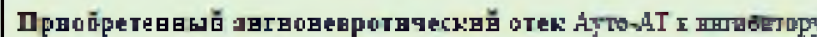

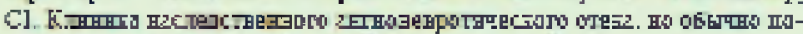

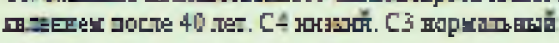

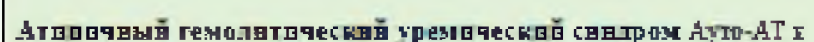

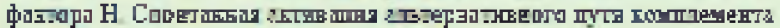

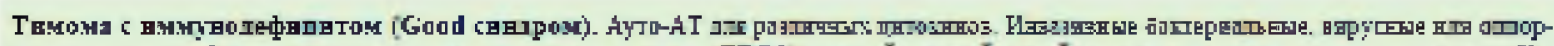
лүएبс B-포끄르모. 
ПИД с эндокринными нарушениями встречаются при болезни накопления гликогена типа $1 \mathrm{~b}$, синдроме Коэна, аутоиммунной полиэндокринопатии с кандидозом и эктодермальной дистрофией, муковисцидозе, SPENCD, синдроме Швахмана Даймонда.

С большой группой заболеваний с ПИД встречаются дерматологи. Это инфекции кожи (ИД с низкими CD4, дефицит IL-17RA, связанные с аутоантителами на Ил-6 рецидивирующая кожная инфекция), пиодермия (ПИД с CD8 недостаточностью, дефицит С3, MASP2, фиколина 3, фактора В, пиогенный стерильный артрит в сочетании с гангренозной пиодермией, выраженным акне (PAPA), фолликулит (дефицит IL-10, IL-10R, IL-17RA, ACT1), панникулит (CANDLE синдром, Т-клеточная лимфома подкожно-подобный панникулит), экзема (синдромы Вискотта-Олдрича, Джоба, Лоис-Дитца, HIES, IPEX синдромы), хронические слизисто-кожные изъязвления (RelA гаплонедостаточность), нарушение заживления ран (дефект адгезии лейкоцитов), крапивница (группа системное воспаление с крапивницей, криопиринопатии, гипереозинофильный синдром из-за соматических мутаций в STAT5b), псориаз (CAMPS (CARD14-зависимый псориаз) DITRA. (дефицит антагониста рецептора IL-36), дефицит AP1S3 (Пустулезный псориаз), врожденный ихтиоз (синдром Комель-Нетертона), гипопигментация или альбинизм (синдромы Vici, Чедиак-Хигаши, Грисцелли 2 типа, Германски-Пудлака 2 типа), гиперпигментированный гипертрихоз (Мутация SLC29A3, XL ретикулярное расстройство пигментации, пародонтальный синдром Элерса-Данлоса), дерматоз с врожденное образование пузырей (Дефицит FERMT1), алопеция (ТКИН, Синдром Оменна, дефицит FOXN1, NFKB1, APECED (APS-1), телеангиоэктазии (атаксия-телеангиоэктазия, дефицит G6PC3, синдром Клерикуцио, врожденный дискератоз). Совместно с аллергологами дерматологи также встречаются с тяжелой атопией (гипер-IgE синдром, гипереозинофильный синдром из-за соматических мутаций в STAT5b, синдром Комель-Нетертона, дефицит PGM3), пищевой аллергией (синдром Лоис-Дитца), ангионевротический отек (дефицит С1-ингибитора (наследственный ангионевротический отек), спонтанная активация пути комплемента с потреблением C4 / C2, приобретенный ангионевротический отек за счет ауто-АТ к ингибитору $\mathrm{C} 1)$.

Пульмонологи могут встречаться с ПИД проявляющимися не только инфекциями описанными выше но и альвеолярный протеинозом (ТКИН, синдром MonoMac, недостаток SLC7A7, мутации CSF2RA, ауто-AT на GM-CSF), фиброзом легких (синдром ГерманскиПудлака 2 типа, ммуковисцидоз, врожденный дискератоз), интерстициальная болезнь легких (дефицит CTLA4, дефект COPA).

Помимо воспалительных заболеваний кишечника гастроэнтерологи могут диагностировать ПИД при стойкой диарее (ИД с низкими CD4, дефицит TCR $\alpha$, BCL10, WIP, мевалонаткиназы (Гипер IgD синдром), ADAM17, синдром Вискотта-Олдрича, гипереозинофильный синдром, ICOS недостаточность), колите (дефицит IL-10), эозинофильном энтерите (синдром активации JAK 1 ), кишечной атрезии (ИД с множественной атрезией кишечника), дисплазия кишечника (хряще-волосяная гипоплазия), патология печени (ТКИН, ИД с низкими CD4, дефицит CD40-лиганда (CD154), дефицит IL$21 \mathrm{R}$, гепато-вено-окклюзионная болезнь с ИД, острая печеночная недостаточность вследствие дефицита NBAS).

Дифференциальная диагностика с ПИДу кардиологов и кардиохирургов возникает при кардиомиопатии (синдром Барта), пороках сердца (синдром делеции 10p13-p14, CHARGE синдром Kabuki-синдром, дефицит G6PC3, анемия Фанкони), аневризме аорты (синдром Лоис-Дитца).

Нефрологи встречаются с ПИД при пороках урогенитального тракта (дефицит G6PC3, анемия Фанкони), гломерулонефрите (дефицит CD19, детская системная красная волчанка (синдром активации С3), другими нефропатиями (иммунокостная дисплазия Шимке, синдром делеции 10p13-p14). Отдельная группа ИД с атипичным гемолитическим уремическим синдромом. 
Отличительной особенностью ПИД в хирурги являются холодные абсцессы (синдром Джоба), рецидивирующий остеомиелит (синдром Маджида, дефицит антагониста рецептора к L-1 (DIRA). В стоматологии пародонтит (синдром Папийона-Лефевра, локализованный агрессивный (ювенильный) пародонтит), оральный афтоз (гипер $\operatorname{IgD}$ синдром, A20 гаплонедостаточность).

Помимо клеток иммунной системы для некоторых ПИД характерна анемия (ТКИН, анемия Фанкони, IPEX синдром APECED (APS-1) SPENCD, недостаток витамина В12 и метаболизма фолата, дефицит CD40-лиганда (CD154), PNP, TRNT1), тромбоцитопения (ТКИН, синдром Вискотта-Олдрича, Якобсена, CHARGE синдром, SPENCD, IPEX синдром, гепато-вено-окклюзионная болезнь, дефицит TFRC, CD154, WIP, ARPC1B, FOXN1).

Для удобства дифференциальной диагностики врачей различных специальностей приводим таблицу, где суммированы данные по ПИД (табл. 63)

Таблица № 63

\section{Дифференциальная диагностика ПИД}

\begin{tabular}{|c|c|}
\hline $\begin{array}{l}\text { Клинические } \\
\text { проявления }\end{array}$ & Дифференциальная диагностика с ПИД \\
\hline $\begin{array}{l}\text { Рецидивирующие } \\
\text { бактериальные, вирусные } \\
\text { и грибковые инфекции }\end{array}$ & $\begin{array}{l}\text { Все виды тяжелых комбинированных иммунных нарушениях (TKИН), ПИД } \\
\text { с низкими СD4 и CD8 T-лимфоцитами, ПиД с низкими } \\
\text { иммуноглобулинами, ИД с множественной атрезией кишечника, гипер- } \\
\text { IgE синдром, синдром Вискотта-Олдрича, синдром Ройфмана, синдром } \\
\text { делеции 10р13-р14, синдром Лоис-Дитца, синдром Германски-Пудлака } 2 \\
\text { типа, синдром Чедиак Хигаши, синдром активации STAT3, FILS синдром, } \\
\text { синдром активации STAT1, синдром эктодермальной дисплазии и } \\
\text { иммунодефицита (EDA-ID), Good синдром, гепато-вено-окклюзионная } \\
\text { болезнь С ИД, дефицит BCL10, IKBKB, MALT1, ReIB, WIP, ARPC1B, PGM3, } \\
\text { CD19, CD21, CD81, CD154, CD40-лиганда, трипептидил-пептидазы II, G6PD } \\
\text { класса I., ICOS недостаточность, дефект адгезии лейкоцитов (LAD- } \\
\text { синдром), X-сцепленная хроническая гранулематозная болезнь (XГБ), } \\
\text { общей вариабельная иммунная недостаточность (ОВИН), кистозный } \\
\text { фиброз (муковисцидоз), спондилохондродисплазия с иммунной } \\
\text { дисрегуляцией (SPENCD), иммуно- костная дисплазия Шимке, } \\
\text { изолированный дефицит подкласса IgG, болезнь Брутона, дефицит FOXN1 } \\
\text { («Голый ТКИН») и ADAM17 }\end{array}$ \\
\hline $\begin{array}{l}\text { Восприимчивость к } \\
\text { вирусным инфекциям, } \\
\text { тяжелое течение гриппа }\end{array}$ & дефицит MDAS(LOF), IRF7 и TLR3, \\
\hline $\begin{array}{l}\text { Молниеносный } \\
\text { вирусный гепатит }\end{array}$ & дефицит IL-18BP \\
\hline $\begin{array}{l}\text { Диссеминированная } \\
\text { вакцинальная корь. ВПЧ- } \\
\text { инфекция }\end{array}$ & Дефицит STAT2. IFNAR1, IFNAR2 \\
\hline $\begin{array}{l}\text { Верруциформная } \\
\text { эпидермодисплазия (HPV) }\end{array}$ & $\begin{array}{l}\text { Синдром WHIM (бородавки, гипогаммаглобулинемия, иммунодефицит и } \\
\text { синдром миелокатексиса), синдром Якобсена и синдром МопоМас, } \\
\text { дефицит EVER1, EVER2, CIB1, RhoH, NLRP1. ИД с низкими CD4 и B-клетками }\end{array}$ \\
\hline $\begin{array}{l}\text { Герпес вирусные } \\
\text { инфекций с энцефалитом }\end{array}$ & $\begin{array}{l}\text { Дефицит IFNAR2, CD16, PHК-полимеразы III, UNC93B1, TRAF3, TICAM1, } \\
\text { TBK1, IRF3, TLR3, DBR1 }\end{array}$ \\
\hline ВЭБ инфекция & $\begin{array}{l}\text { Дефицит MCM4, NFKB1, CTPS1, CD70, CD27, LRBA (OBИH с } \\
\text { аутоиммунитетом), активированном дельта-синдроме PI3K (APDS). При } \\
\text { ПИД (ТКИН, ИД с низкими В-лимфоцитами, X-сцепленный } \\
\text { лимфопролиферативный синдром } 1 \text { и } 2 \text { типа, дефиците MST1, ITK CD137) } \\
\text { в сочетании с лимфопролиферацией. }\end{array}$ \\
\hline
\end{tabular}




\section{Таблица № 63 (продолжение)}

\section{Дифференциальная диагностика ПИД}

\begin{tabular}{|c|c|}
\hline Клинические проявления & Дифференциальная диагностика с ПИД \\
\hline $\begin{array}{l}\text { Рецидивирующие } \\
\text { бактериальных инфекций }\end{array}$ & $\begin{array}{l}\text { Синдром Джоба, гипер-IgE синдром (HIES), синдромы гипер-IgM, } \\
\text { преходящая гипогаммаглобулиемия, избирательный дефицит IgA, } \\
\text { дефицит подкласса IgG с дефицитом IgA, дефицит Moesin и IL-17RA. }\end{array}$ \\
\hline $\begin{array}{l}\text { Пневмококковая } \\
\text { инфекция }\end{array}$ & Дефицит CD21 и избирательный дефицит IgM \\
\hline Neisserial инфекции & $\begin{array}{l}\text { Дефицит компонентов комплемента C5, C6, C7, C8, C9, дефицит } \\
\text { пропердина и фактора D }\end{array}$ \\
\hline $\begin{array}{l}\text { Пиогенные } \\
\text { бактериальные инфекции } \\
\text { (менингит, сепсис, артрит, } \\
\text { остеомиелит и абсцессы) }\end{array}$ & $\begin{array}{l}\text { изолированная врожденная аспления (ICA) вследствие дефицита } \\
\text { RPSA, дефицит IRAK4, MyD88, фактора I, фактора Н и фактор-H } \\
\text { зависимого белка. }\end{array}$ \\
\hline $\begin{array}{l}\text { Повышенная } \\
\text { восприимчивость к } \\
\text { микобактериям, БЦЖ-ит }\end{array}$ & $\begin{array}{l}\text { синдром MonoMac, ауто-AT к IFNy, полный или частичный дефицит } \\
\text { рецептора } 1 \text { и } 2 \text { к IFN-ү, дефицит цепи b1 рецептора IL-12 и IL-23, } \\
\text { STAT1, Tyk2, JAK1, аутосомно-доминантный MSMD из-за частичного } \\
\text { дефицита IFNGR1, недостаточность SPPL2a. }\end{array}$ \\
\hline $\begin{array}{l}\text { Рецидивирующий } \\
\text { остеомиелит }\end{array}$ & Синдром Маджида, дефицит антагониста рецептора к IL-1 (DIRA). \\
\hline Пародонтит & $\begin{array}{l}\text { Синдром Папийона-Лефевра, локализованный агрессивный } \\
\text { (ювенильный) пародонтит), оральный афтоз (гипер lgD синдром, } \\
\text { А20 гаплонедостаточность). }\end{array}$ \\
\hline Холодные абсцессы & Синдром Джоба \\
\hline $\begin{array}{l}\text { Нарушение заживления } \\
\text { ран }\end{array}$ & Дефект адгезии лейкоцитов \\
\hline Инфекции кожи в т.ч. & $\begin{array}{l}\text { ИД с низкими CD4, дефицит IL-17RA, связанные с аутоантителами } \\
\text { на Ил-6 рецидивирующая кожная инфекция), }\end{array}$ \\
\hline пиодермия & $\begin{array}{l}\text { ПИД с CD8 недостаточностью, дефицит С3, MASP2, фиколина 3, } \\
\text { фактора В, РАРА (пиогенный стерильный артрит в сочетании с } \\
\text { гангренозной пиодермией, выраженным акне) }\end{array}$ \\
\hline фолликулит & дефицит IL-10, IL-10R, IL-17RA, ACT1 \\
\hline панникулит & $\begin{array}{l}\text { CANDLE синдром, Т-клеточная лимфома подкожно-подобный } \\
\text { панникулит (дефицит ТІМЗ) }\end{array}$ \\
\hline Грибковые инфекции & $\begin{array}{l}\text { Синдроме Джоба, Vici, X-сцепленная хроническая гранулематозная } \\
\text { болезнь (ХГБ), соматические мутации связанной с ауто-AT на GM- } \\
\text { CSF (легочный альвеолярный протеиноз), дефиците IKAROS } \\
\text { (CD154), IL-21R, CARD9. }\end{array}$ \\
\hline $\begin{array}{l}\text { Хронический слизисто- } \\
\text { кожный кандидоз }\end{array}$ & $\begin{array}{l}\text { без эктодермальной дисплазии (изолированный или с синдромом } \\
\text { APECED), аутоиммунная полиэндокринопатия с кандидозом и } \\
\text { эктодермальной дистрофией (APS-1). }\end{array}$ \\
\hline $\begin{array}{l}\text { Слизисто-кожные } \\
\text { изъязвления }\end{array}$ & RelA гаплонедостаточность \\
\hline Экзема & Синдромы Вискотта-Олдрича, Джоба, Лоис-Дитца, HIES, IPEX \\
\hline Крапивница & $\begin{array}{l}\text { Группа системных аутоиммуно-воспаленых с крапивницей, } \\
\text { криопиринопатии, гипереозинофильный синдром из-за } \\
\text { соматических мутаций в STAT5b }\end{array}$ \\
\hline Псориаз & $\begin{array}{l}\text { CAMPS (CARD14-зависимый псориаз) DITRA. (дефицит антагониста } \\
\text { рецептора IL-36), дефицит AP1S3 (Пустулезный псориаз) }\end{array}$ \\
\hline
\end{tabular}


Таблица № 63 (продолжение)

\section{Дифференциальная диагностика ПИД}

\begin{tabular}{|c|c|}
\hline Клинические проявления & Дифференциальная диагностика с ПИД \\
\hline Пищевая аллергия & Синдром Лоис-Дитца \\
\hline Атопический дерматит & $\begin{array}{l}\text { гипер-IgE синдром, гипереозинофильный синдром из-за } \\
\text { соматических мутаций в STAT5b, синдром Комель-Нетертона, } \\
\text { дефицит PGM3 }\end{array}$ \\
\hline Ангионевротический отек & $\begin{array}{l}\text { Дефицит С1-ингибитора (наследственный ангионевротический } \\
\text { отек), спонтанная активация пути комплемента с потреблением С4 } \\
\text { / С2, приобретенный ангионевротический отек за счет ауто-АТ к } \\
\text { ингибитору С1 }\end{array}$ \\
\hline Врожденный ихтиоз & Синдром Комель-Нетертона), \\
\hline $\begin{array}{l}\text { Гипопигментация } \\
\text { альбинизм }\end{array}$ & $\begin{array}{l}\text { синдромы Vici, Чедиак-Хигаши, Грисцелли } 2 \text { типа, Германски- } \\
\text { Пудлака } 2 \text { типа }\end{array}$ \\
\hline $\begin{array}{l}\text { Гиперпигментированный } \\
\text { гипертрихоз }\end{array}$ & $\begin{array}{l}\text { Мутация SLC29A3, XL ретикулярное расстройство пигментации, } \\
\text { пародонтальный синдром Элерса-Данлоса), }\end{array}$ \\
\hline $\begin{array}{l}\text { Дерматоз с врожденное } \\
\text { образование пузырей }\end{array}$ & Дефицит FERMT1 \\
\hline Телеангиоэктазии & $\begin{array}{l}\text { Атаксия-телеангиоэктазия, дефицит G6РС3, синдром Клерикуцио, } \\
\text { врожденный дискератоз }\end{array}$ \\
\hline Алопеция & ТКИН, Синдром Оменна, дефицит FOXN1, NFKB1, APECED (APS-1) \\
\hline $\begin{array}{l}\text { Дефекты кожи, волос и } \\
\text { зубов }\end{array}$ & Синдромы эктодермальной дисплазии и иммунодефицита (EDA-ID) \\
\hline $\begin{array}{l}\text { Воспалительные } \\
\text { заболеваний кишечника }\end{array}$ & $\begin{array}{l}\text { Дефицит XIAP (X-сцепленный лимфопролиферативный синдром } 2 \\
\text { типа), дефицит BACH2, дефицит LRBA (ОВИН с аутоиммунитетом), } \\
\text { CTLA4 (ALPS тип V), CD122, ХГБ, болезнью Уиппла, FMF, синдром } \\
\text { Блау, семейный холодовой аутовоспалительный синдром } 4 \text { типа, } \\
\text { IPEX синдромом APECED (APS-1), синдром CHAPLE, синдром } \\
\text { активации STAT1. }\end{array}$ \\
\hline Стойкая диарея & $\begin{array}{l}\text { ИД с низкими CD4, дефицит TCRa, BCL10, WIP, мевалонаткиназы } \\
\text { (Гипер IgD синдром), ADAM17, синдром Вискотта-Олдрича, } \\
\text { гипереозинофильный синдром, ICOS недостаточность }\end{array}$ \\
\hline Колит & Дефицит IL-10 \\
\hline Эозинофильный энтерит & Синдром активации ЈАК1 \\
\hline Кишечной атрезии & ИД с множественной атрезией кишечника \\
\hline Дисплазия кишечника & Хряще-волосяная гипоплазия \\
\hline Патология печени & $\begin{array}{l}\text { TKИН, ИД с низкими CD4, дефицит CD40-лиганда (CD154), дефицит } \\
\text { IL-21R, гепато-вено-окклюзионная болезнь с ИД, острая } \\
\text { печеночная недостаточность вследствие дефицита NBAS. }\end{array}$ \\
\hline Альвеолярный протеиноз & $\begin{array}{l}\text { TКИН, синдром MonoMac, недостаток SLC7A7, мутации CSF2RA, } \\
\text { ауто-АТ на GM-CSF }\end{array}$ \\
\hline Фиброзом легких & $\begin{array}{l}\text { Синдром Германски-Пудлака } 2 \text { типа, муковисцидоз, врожденный } \\
\text { дискератоз }\end{array}$ \\
\hline $\begin{array}{l}\text { Интерстициальная } \\
\text { болезнь легких }\end{array}$ & Дефицит CTLA4, дефект COPA. \\
\hline Пороки сердца & $\begin{array}{l}\text { Синдром делеции 10p13-p14, CHARGE синдром Kabuki-синдром, } \\
\text { дефицит G6PC3, анемия Фанкони }\end{array}$ \\
\hline Кардиомиопатии & Синдром Барта \\
\hline Аневризма аорты & Синдром Лоис-Дитца \\
\hline
\end{tabular}




\section{Таблица № 63 (продолжение)}

\section{Дифференциальная диагностика ПИД}

\begin{tabular}{|c|c|}
\hline Клинические проявления & Дифференциальная диагностика с ПИД \\
\hline $\begin{array}{l}\text { Пороки урогенитального } \\
\text { тракта }\end{array}$ & Дефицит G6PC3, анемия Фанкони \\
\hline Гломерулонефрит & $\begin{array}{l}\text { Дефицит CD19, детская системная красная волчанка (синдром } \\
\text { активации C3 }\end{array}$ \\
\hline Нефропатии & иммунокостная дисплазия Шимке, синдром делеции 10p13-р14 \\
\hline $\begin{array}{l}\text { Гемолитически- } \\
\text { уремический синдром }\end{array}$ & ИД с атипичным гемолитическим уремическим синдромом. \\
\hline Эндокринные нарушения & $\begin{array}{l}\text { При болезни накопления гликогена типа 1b, синдроме Коэна, } \\
\text { аутоиммунной полиэндокринопатии с кандидозом и } \\
\text { эктодермальной дистрофией, муковисцидозе, SPENCD, синдроме } \\
\text { Швахмана Даймонда. }\end{array}$ \\
\hline $\begin{array}{l}\text { Дефекты ЦНС и } \\
\text { неврологические } \\
\text { нарушения в т.ч. }\end{array}$ & $\begin{array}{l}\text { CHARGE синдром, анемия Фанкони, дефицит } \\
\text { пуриннуклеозидфосфорилазы, дефицит ингибитора } \\
\text { мембраноатакующего комплекса (CD59), синдром Чедиак Хигаши, }\end{array}$ \\
\hline атаксия & атаксия-телеангиоэктазия, 3-метилглутаконовая ацидурия \\
\hline $\begin{array}{l}\text { когнитивные } \\
\text { нарушения }\end{array}$ & ТКИН, 3-метилглутаконовая ацидурия \\
\hline $\begin{array}{l}\text { умственная } \\
\text { недостаточность }\end{array}$ & $\begin{array}{l}\text { ИД с низкими CD4, недостатки витамина B12 и метаболизма фолата, } \\
\text { Kabuki-синдром, синдромы Vici, Швахмана-Даймонда, Коэна, } \\
\text { дефицит TRNT1, } \beta \text {-актина, LAD2-синдром }\end{array}$ \\
\hline нарушение слуха & $\begin{array}{l}\text { TKИH, синдром делеции 10p13-p14, CHARGE синдром, дефицит } \\
\text { TRNT1, G6PC3, синдромы Коэна, синдром Макла-Уэллса }\end{array}$ \\
\hline $\begin{array}{l}\text { Аномалии и пороки } \\
\text { скелета }\end{array}$ & $\begin{array}{l}\text { TКИН, Синдромы ДиДжорджи, Ройфмана, Швахмана-Даймонда, } \\
\text { делеции 10p13-р14, CHARGE синдром, Kabuki-синдром, HIES, } \\
\text { метафизарная хондродисплазия Мак-Кьюсика, анемия Фанкони }\end{array}$ \\
\hline Остеопороз & синдромом Джоба, Лоис-Дитца \\
\hline $\begin{array}{l}\text { Остеопетроз (мраморная } \\
\text { болезнь) }\end{array}$ & Дефицитом TNFRSF11A \\
\hline Микроцефалия & $\begin{array}{l}\text { ТКИН, синдромах Ниймегена, Блума, Ройфмана, Vici, Hebo } \\
\text { дефиците, синдром недостаточности костного мозга }\end{array}$ \\
\hline Лицевой дисморфизм & $\begin{array}{l}\text { Синдромы делеции 10p13-p14, Якобсена, Клерикуцио, HIES, Kabuki- } \\
\text { синдром, дефицит STAT5b, херувизме }\end{array}$ \\
\hline Задержка роста & $\begin{array}{l}\text { ИД с низкими CD4, синдромы Блума, Якобсена, Швахмана- } \\
\text { Даймонда, Барта, Видемана - Штейнера, FILS синдром, Kabuki- } \\
\text { синдром, синдром активации JAK1, LAD2-синдром, иммунокостная } \\
\text { дисплазия Шимке, синдром недостаточности костного мозга }\end{array}$ \\
\hline $\begin{array}{l}\text { Различные виды } \\
\text { солидного рака }\end{array}$ & $\begin{array}{l}\text { Атаксия-телеангиоэктазии, гипер-IgЕ синдром, синдроме } \\
\text { Ниймегена, хряще-волосяной гипоплазия. }\end{array}$ \\
\hline Лимфомы & $\begin{array}{l}\text { Хряще-волосяная гипоплазия, синдром Вискотта-Олдрича, синдром } \\
\text { Ниймегена, синдром Блума, аутоиммунный } \\
\text { лимфопролиферативный синдром FAS (ALPS-FAS), X-сцепленный } \\
\text { лимфопролиферативный синдром } 1 \text { типа, дефицит RhoH, ITK, MCM4, } \\
\text { CTPS1, CD27, CD137, IL-10R }\end{array}$ \\
\hline Ходжкинская лимфома & дефицит CD70 \\
\hline
\end{tabular}




\section{Таблица № 63 (продолжение)}

\section{Дифференциальная диагностика ПИД}

\begin{tabular}{|c|c|}
\hline Клинические проявления & Дифференциальная диагностика с ПИД \\
\hline $\begin{array}{l}\text { Стойкие и/или } \\
\text { перемежающие } \\
\text { лихорадка }\end{array}$ & $\begin{array}{l}\text { Синдроме Чедиак Хигаши, семейном гемофагоцитарном } \\
\text { лимфогистиоцитозе, группа рецидивирующих лихорадок, семейный } \\
\text { ауто-воспалительный синдром простуды (FCAS), холодовая } \\
\text { крапивница, синдром Макла Уэллса (MWS), CANDLE синдром, } \\
\text { дефицит ADA2. }\end{array}$ \\
\hline $\begin{array}{l}\text { Ауто-воспалительными } \\
\text { заболевания }\end{array}$ & $\begin{array}{l}\text { ТКИД, ИД с низкими CD4, CD8, синдроме Вискотта-Олдрича, хряще- } \\
\text { волосяной гипоплазии, Kabuki-синдроме, APDS, дефиците TCR } \alpha \text {, } \\
\text { ICOS, PGM3, NFKB1, CD70, избирательном дефиците Ig, ХГБ }\end{array}$ \\
\hline Васкулиты & $\begin{array}{l}\text { Синдром Вискотта-Олдрича, семейная средиземноморская } \\
\text { лихорадка, ПИД с CD8 недостаточностью, STING-ассоциированная } \\
\text { васкулопатия с дебютом в младенчестве, дефицит ADA2 }\end{array}$ \\
\hline $\begin{array}{l}\text { Системная красная } \\
\text { волчанка (СКВ) }\end{array}$ & $\begin{array}{l}\text { Интерферонопатии I типа и/или дефицита комплемента (дефицит } \\
\text { C1q, C1R, C1S, C2). AR C2). }\end{array}$ \\
\hline Артриты & $\begin{array}{l}\text { Ауто-воспалительные заболеваний с поражением костей и суставов, } \\
\text { дефект СOPA, дефицит NLRP1, IL-10, IL-10R, семейная } \\
\text { средиземноморская лихорадка (FMF), периодический синдром, } \\
\text { ассоциированный с рецептором TNF, семейный ауто- } \\
\text { воспалительный синдром простуды (FCAS), холодовая крапивница, } \\
\text { криопиринопатии. }\end{array}$ \\
\hline Лимфоаденопатия & $\begin{array}{l}\text { TKИH, ALPS, APDS, синдром Оменна и Ройфмана, синдром активации } \\
\text { STAT3 и CARD 11, гипер-IgM синдром, дефицит CD25, CD122, } \\
\text { трипептидил-пептидазы II }\end{array}$ \\
\hline Гепатоспленомегалия & $\begin{array}{l}\text { ALPS, XLP2, семейный гемофагоцитарный лимфогистиоцитоз, } \\
\text { синдром Оменна, синдром активации CARD 11, синдром Грисцелли } \\
2 \text { типа, синдром Чедиак Хигаши, синдром активации CARD 11, } \\
\text { синдром активации JAK1, CD122 дефицит }\end{array}$ \\
\hline Тимусмегалия & $\begin{array}{l}\text { TКИН, Good синдром, синдром ДиДжорджи, синдром делеции } \\
\text { 10p13-р14, дефицит IKAROS (CD154). }\end{array}$ \\
\hline Гранулематоз & $\begin{array}{l}\text { Атабасский ТКИД, ПИД с CD8 недостаточностью, общая } \\
\text { вариабельная иммунная недостаточность (OBИH), изолированный } \\
\text { дефицит подкласса IgG4, дефицит RhoH, ICOS }\end{array}$ \\
\hline Анемия & $\begin{array}{l}\text { ТКИН, анемия Фанкони, IPEX синдром APECED (APS-1) SPENCD, } \\
\text { недостаток витамина B12 и метаболизма фолата, дефицит CD40- } \\
\text { лиганда (CD154), PNP, TRNT1) }\end{array}$ \\
\hline Тромбоцитопения & $\begin{array}{l}\text { TKИН, синдром Вискотта-Олдрича, Якобсена, CHARGE синдром, } \\
\text { SPENCD, IPEX синдром, гепато-вено-окклюзионная болезнь, дефицит } \\
\text { TFRC, CD154, WIP, ARPC1B, FOXN1) }\end{array}$ \\
\hline
\end{tabular}

Бактериальные, вирусные, грибковые инфекции с одной стороны развиваются на фоне нарушения функции иммунной системы, с другой стороны сами достаточно активно влияют на иммунную систему.

Основная инфекция, поражающая иммунную систему человека, инфекция, вызванная вирусом иммунодефицита человека (ВИЧ). ВИЧ вызывается одним из четырех ретровирусов (чаще всего ВИЧ-1), которые поражают Т-хелперы, моноциты, макрофаги, дендритные клетки (CD4+ лимфоциты), за счет чего ослабевает иммунитет, увеличивая риск развития различных в том числе оппортунистических инфекций и раковых заболеваний (табл. 64). С 1984 г. по настоящее время зарегистрировано более 78 млн человек заразившихся ВИЧ, из них 35 млн умерли (данные UNAIDS на 2018 год). 


\section{СПИД-индикаторные заболевания}

Таблица 64

Бактериальные инфекции, множественные или рецидивирующие

Пневмония, рецидивирующая

Диссеминированная и/или легочная и/или внелегонная инфекция Mycobacterium avium (MAC) или инфекция, вызеанная Mycobacterium kansasii, түберкулез, вызванный Мүсobacterium tuberculosis, Mycobacterium, другими видами или неидентифицированньми видами Септицемия, вызванная Salmonella (нетифоидной), рецидивирующая

Кандидоз бронхов, трахей или легких, пищевода

Кокцидиоидомикоз, диссеминированный или внелёгочный

Внелёгочный криптококкоз

Гистоплазмоз, диссеминированный или внелёгочный

Криптоспоридиоз хронический кишечный (продолжительностью > 1 месяца)

Токсоплазмоз головного мозга, развивающийся в возрасте старше 1 месяца

Пневмония, вызванная Pneumocystis jirovecii (ранее известная как Pneumocystis carinii)

Изоспориаз (цистоизоспориаз), хронический кишечный (продолжительностью > 1 месяца)

Цитомегаловирусная болезнь (кроме печени, селезёнки или лимфоузлов) нанинается в возрасте старше 1 месяца

Цитомегаловирусный ретинит (с потерей зрения)

Простой герпес: хрони'еские язвы (длительность > 1 месяца) или бронхит, пневмонит или эзофагит (начало болезни происходит в возрасте старше 1 месяца)

Рак шейки матки, инвазивный

Саркома Капоши

Лимфома Бёркитта (или эквивалентный термин)

Лимфома иммунобластная (или эквивалентный термин)

Первичная церебральная лимфома

Прогрессивная многоочаговая лейкодистрофия

Кахексия, ассоциируемая с Вич

Энцефалопатия, связанная с Вич

Заражение может произойти при попадании вируса в биожидкостях (кровь, сперма, влагалищный секрет) непосредственно в крово- или лимфоток человека, а также на повреждённые слизистые оболочки (рис. 116). При риске инфицирования не позднее чем через 72 часа после вероятного проникновения вируса обязательна химиопрофилактика (четырёхнедельный курс высокоактивной антиретровирусной терапии). Период от момента заражения до появления реакции организма обычно составляет от 3 нед до 3 мес (в единичных случаях может затягиваться и до года), поэтому для исключения диагноза ВИЧ с 3 месяца, раз в 3 месяца в течении года обязательные лабораторные исследования на выявления ВИЧинфекции (определение АТ и вирусной нагрузки)

В стадии первичных проявлений (стадия 2) происходит резкое снижение Т-хелперов, прежде всего Т-лимфоцитов центральной памяти, и дендритных клеток. Частыми клиническими проявлениями этой стадии являются субфебрильная температура, крапивница, стоматит, лимфаденопатия (по типу инфекционного мононуклеоза). Гибель CD4+ клеток происходит в результате прямого цитопатического действия ВИЧ, апоптоза зараженных клеток, действием NK-клеток и ЦТЛ (CD8+). Затем происходит активная продукция антител (определяются АТ к ВИЧ). Стадия первичных проявлений обычно продолжается 7 - 14 дней и диагностируется чаще всего как ОРВИ или инфекционный мононуклеоз (стадия 2Б). Если развиваются вторичные заболевания (стадия 2В) различной этиологии (ангина, бактериальная и пневмоцистная пневмония, кандидозы, герпетическия инфекция и др.) стадия первичных проявлений может затянуться на несколько месяцев. 


\begin{tabular}{|c|c|c|c|c|}
\hline $\begin{array}{l}\text { 1. Стадия } \\
\text { инкубации }\end{array}$ & \multicolumn{3}{|c|}{ ВИЧ-ИНФЕКЦИИ } & 5. Терминальная \\
\hline \multicolumn{5}{|l|}{ 1-12 mec } \\
\hline $\begin{array}{l}\text { 2. Стадия первич- } \\
\text { ных проявлений }\end{array}$ & $\begin{array}{c}\text { 3. Субклиническая } \\
\text { стадия }\end{array}$ & до 8 лет & $\begin{array}{l}\text { 4. Стадия вторичных } \\
\text { заболеваний }\end{array}$ & \\
\hline $\begin{array}{l}\text { А. Бессимптомное } \\
\text { Б. Острая инфек- } \\
\text { ция Без вторичных } \\
\text { заболеваний } \\
\text { В. Острая инфек- } \\
\text { ция с вторичными } \\
\text { заболеваниями }\end{array}$ & & $\begin{array}{l}\text { 4А. Потеря массы } \\
\text { тела менее } 10 \% \text {, } \\
\text { гри бковые, вирус- } \\
\text { ные, бактериаль- } \\
\text { ные поражения } \\
\text { кони и слизистых, } \\
\text { повторные фарин- } \\
\text { гиты, синуситьы, } \\
\text { опоясывающий ли- } \\
\text { шай. }\end{array}$ & $\begin{array}{l}\text { 4Б. Потеря массы тела } \\
\text { более } 10 \% \text {, неоБъяс- } \\
\text { нимая диарея или ли- } \\
\text { хорадна более ме- } \\
\text { сяца, повторные стой- } \\
\text { кие вирусные, бакте- } \\
\text { риальные, гриБновые, } \\
\text { протозойные пораже- } \\
\text { ния внутренних орга- } \\
\text { нов, локализованная } \\
\text { сарнома Капоши, по- } \\
\text { вторный или диссеми- } \\
\text { нированный опоясь- } \\
\text { вающий лишай. }\end{array}$ & $\begin{array}{l}\text { 4В. Кахексия. Генерали- } \\
\text { зованные вирусные, } \\
\text { Бактериальные, мико- } \\
\text { Бактериальные, гриБ- } \\
\text { ковые, протозойные, } \\
\text { паразитарные заболе- } \\
\text { вания, в том числе: кан- } \\
\text { дидоз пищевода, Брон- } \\
\text { ков, трахеи, легких; } \\
\text { пневмоцистная пнев- } \\
\text { мония; злокачествен- } \\
\text { ные опухоли; пораже- } \\
\text { ния центральнай нерв- } \\
\text { ной системы. }\end{array}$ \\
\hline & & $\begin{array}{l}\text { Фаза: } \\
\text { прогрессирование в } \\
\text { отсутствие антиретро- } \\
\text { вирусной терапии, на } \\
\text { фоне антиретровирус- } \\
\text { ной терапии. }\end{array}$ & & $\begin{array}{l}\text { Фаза: } \\
\text { ремиссия (спонтанная, по- } \\
\text { сле антиретровирусной те- } \\
\text { рапии, на фоне антиретро- } \\
\text { вирусной терапии). }\end{array}$ \\
\hline
\end{tabular}

\section{Рис.116. Клиническая классификация ВИЧ-инфекции}

После чего отмечается стабилизация процесса с увеличением числа CD4 клеток, что инициирует субклиническую стадию. На этой стадии происходит активное размножение вируса со снижением CD4 клеток (0,05-0,07*109/л в год). Основным местом, где происходит репликация ВИЧ, является вторичная лимфоидная ткань, и прежде всего лимфоидную ткань кишечника (GALT). Основной резервуар ВИЧ в организме моноциты, макрофаги и дендритные клетки. Непрерывная репликация ВИЧ вызывает состояние генерализованной иммунной активации, сохраняющейся на протяжении всей субклинической стадии.

Длительность субклинической стадии продолжается от 2 до 20 и более лет (в среднем 6-7 лет). Клиническим характерным симптомом этой стадии является лимфоаденопатия (увеличение двух и более лимфатических узлов не менее чем в двух не связанных между собой группах (не считая паховые). Продолжающаяся репликация ВИЧ, приводящая к гибели и/или истощению Т-хелперов, приводит к развитию стадия вторичных заболеваний - СПИД (стадия 4).

СПИД определяется при наличии СПИД-индикаторные заболевания (табл. 15) и/или количеству Т-хелперов (CD4+ Т-лимфоцитов периферической крови) $<200 /$ мкл и/или $\leq 14 \%$. В зависимости от тяжести вторичных заболеваний выделяют стадии 4А, 4Б, 4В и фазы прогрессирования (на фоне отсутствия противоретровирусной терапии или на фоне противоретровирусной терапии) и ремиссии (спонтанной или на фоне противоретровирусной терапии) заболевания.

В терминальная стадии вторичные заболевания приобретают необратимое течение. Адекватно проводимые противовирусная терапия и терапия вторичных заболеваний не эффективны. Для этой стадии типично снижение количества Т-хелперов ниже $0,05 \times 10^{9} /$ л.

Другая инфекция, непосредственно поражающая клетки иммунной системы - это инфекция, вызываемая вирусом Эпштейна-Барр. Вирус Эпштейна-Барра (EBV) два его типа (EBV-1 и EBV-2) представитель семейства Herpesviridae (Gammaherpesvirinae, герпесвирус человека 4 типа (HHV4). Является одним из наиболее распространенных вирусов 
в мире. До 5 лет заражается более 50\% детей, взрослые заражены практически все несмотря на то, что вирус не является очень контагиозным и не выявляется в окружающей среде.

Вирус, проникая в верхние отделы дыхательных путей поражает эпителий и лимфоидную ткань (кольцо Пирогова-Вальдейера), заражает наивные В-клетки, активируя их в пролиферирующие латентно инфицированные бласты. Эти клетки затем перемещаются в зародышевые центры (GC) лимфатических узлов, селезенки и других лимфоидных образований, репликация вируса в В-лимфоцитах стимулирует их активную пролиферацию и дифференцировку в плазмоциты. Последние секретируют иммуноглобулины низкой специфичности. Одновременно нарастает количество и активность Т-лимфоцитов. Цитотоксические Т-лимфоциты уничтожают инфицированные вирусом клетки, распознавая мембранные вирус-индуцированные антигены. Однако латентно инфицированных В-клетки памяти не повреждаются ЦТЛ. Вирус остаётся в организме и персистирует в нём в течение всей последующей жизни, обусловливая хроническое течение заболевания с реактивацией инфекции при снижении иммунитета. В любое время небольшое подмножество латентно инфицированных В-клеток памяти инициирует литическую реактивацию в сочетании $\mathrm{c}$ сигналами терминальной дифференцировки. Этот процесс приводит к высвобождению вируса, который может попасть в слюну для распространения инфекции или инфицировать новые наивные В-клетки.

Инкубационный период от 5 дней до 1,5 мес. Первичная инфекция Эпштейна - Барр обычно бессимптомная, может провялятся длительной утомляемостью в течении нескольких месяцев (обычно 2-3 недели) и/или увеличении лимфатических узлов, протекать в виде ОРВИ и/или инфекционного мононуклеоза. При инфекционном мононуклеозе у большинства пациентов наблюдается присутствует лихорадка (до $39,5^{\circ} \mathrm{C}-40,5{ }^{\circ} \mathrm{C}$ ), фарингит (с выраженным болевым и эксудативным симптомом, напоминает стрептококовую ангину), лимфаденопатия (обычно симметричная, может поражать любую группу узлов, особенно затылочные, шейные и подчелюстные). Помимо этого, встречаются и другие симптомы: спленомегалия и гепатомегалия, различные сыпи, желтуха, гранулоцитопения, тромбоцитопения, гемолитическая анемия. Патогномоничным является обнаружение в периферической крови атипичных мононуклеаров (клетки с широкой базофильной цитоплазмой). Могут возникать неврологические осложнения (энцефалит, синдром Гийена Барре, периферическая невропатия, вирусный менингит, миелит, параличи черепных нервов). С инфекционным мононуклеозом вызванным EBV могут быть сходными инфекции ВИЧ, вирусные гепатиты А, В, С, цитомегаловирусная и аденовирусная инфекция, токсоплазмоз, краснуха.

После первичной инфекции вирус Эпштейна-Барр остается в организме, прежде всего в B- (EBV-1) и Т-лимфоцитах (EBV-2), пожизненно, с бессимптомным вирусовыделением пожизненно. Однако возможно развитие лимфопролиферативных (лимфома Ходжкина, лимфома Беркитта, первичная церебральная лимфома, диффузная В-клеточная лимфома, лимфогистиоцитоз) и нелимфоидных злокачественных опухолей (рак желудка, рак легких, рак носоглотки, саркомы мягких тканей, лейомиосаркома), нелимфопролиферативных заболеваний (рассеянный склероз, системная красная волчанка, хроническая активная инфекция EBV, волосатая лейкоплакия, болезнь Кикучи (некротический лимфаденит), синдром Алисы в стране чудес (AIWS), гепатит, ангина, посттрансплантационные лимфопролиферативные заболевания).

Менее известная инфекции, которая вызывается Т-лимфотропными вирусами человека и так же поражает иммунную систему человека. Это HTLV-1 и HTLV-2 инфекция.

HTLV-1-инфекция вызываемая одним из шести подтипов человеческого Т-клеточного лимфотропного вируса 1 типа, относящегося к дельта ретровирусам. По оценкам экспертов, около 20 миллионов человек во всем мире инфицированы HTLV-1. Считается, что инфекция обычно протекает бессимптомно, 90\% зараженных людей остаются носителями в течение своей жизни, однако иммунопатогенез этого ретровируса связан с постоянной персистенцией в CD4+-лимфоцитах и может определятся прямым воздействием вируса на иммунную систему 
и/или следствием реакции иммунной системы на вирус вызывая субклиническую иммуносупрессию. C HTLV-1 связана повышенная частота инфекций, таких как туберкулез и стронгилоидоз, увеит, повреждения кожи, миозит и полимиозит, полинейропатия, миелопатия (тропический спастический парапарез), психические расстройства. Около 1-5\% инфицированных людей заболевают раком в виде Т-клеточная лейкемия/лимфома взрослых и Т-клеточной лимфомы кожи.

Патогенез HTLV-2 инфекция связана с так же с повреждением Т-лимфоцитов (чаще всего CD8+ - лимфоцитов). Она связана с увеличением числа случаев пневмонии, острого бронхита, сенсорные невропатии, аномалии походки, дисфункция мочевого пузыря, легкое когнитивное нарушение, нарушения моторики, миелопатии. В отличие от HTLV-1 инфекции, HTLV-2-ассоциированной миелопатии обычно также включает в периферической невропатии и атаксии, однако неврологические заболевания у пациентов c HTLV-2-инфекцией встречаются значительно реже, чем у пациентов, инфицированных HTLV-1 или ВИЧ.

Другие вирусные, бактериальные инфекции и микозы обычно не обладают прямым повреждающим действием на иммунную систему, но они активно используют иммуносупрессивные механизмы для уклонения от защитных механизмов хозяина.

Отдельной группой болезней иммунной системы являются состояния, когда полностью отсутствует тот или орган иммунной системы или происходит его недоразвитие из-за генетических дефектов.

Аспления - это врожденная или приобретенная патология, характеризующаяся отсутствием селезенки. Данное состояние проявляется повышенным тромбообразованием и снижением резистентности организма к инфекциям. При наличии врожденного порока обычно аспления сочетается с дефектами других органов (сердца, сосуды, кишечник, печень и др.) и проявляется нарушением функций именно этих органов. Гораздо чаще отсутствие селезенки связано с хирургическеми вмешательствами при травматическом разрыве органа, больших кистах и абсцессах, новообразованиях, инфаркте селезенки. Достаточно часто ранее удаляли селезенку в комплексной терапии при тяжелой наследственной гемолитической желтухе, серповидноклеточной и аутоиммунной гемолитической анемиях, идиопатической тромбоцитопенической пурпуре, лимфогранулематозе, хроническом лейкозе.

Диагноз устанавливают на основании анамнестических данных и инструментальных исследованиях (УЗИ, сцинтиграфии селезенки, МРТ). При сочетании аномалии развития селезенки и других органов показано хирургическое вмешательство в зависимости от вида порока.

Аплазия тимуса - это группа заболеваний, обусловленная генетическими дефектами иммунной системы.

Синдром Ди-Джорджа. Наряду с аплазией железы возможна аплазия паращитовидных желез с проявлениями гипопаратиреоза. В патогенезе имеет место дефицит циркулирующих Т-лимфоцитов, резкое угнетение реакции клеточного иммунитета, относительное увеличение числа В-лимфоцитов и сохранение реакции гуморального иммунитета (нормальный уровень иммуноглобулинов в крови, гипокальциемия). Характерными признаками заболевания являются судороги, начиная с неонатального периода, рецидивируюшие инфекции дыхательной и пищеварительной систем. Обычно сочетается с аномалиями развития дуги аорты, нижней челюсти, мочек уха, с гипоплазией лимфатических узлов и недоразвитием тимусзависимых зон.

Синдром Незелофа - первичный иммунодефицит группы ТКИН, обусловленный гипо- или дисплазией тимуса без аплазии околощитовидных желез с недоразвитием тимусзависимых зон в лимфатических узлах и селезенке. При этом в результате его функциональной недостаточности происходит нарушение дифференцировки Т-лимфоцитов (дефицит клеточной системы иммунитета). С неонатального периода отмечаются рецидивирующие бронхиты, пневмонии, энтероколиты вирусной или грибковой этиологии, герпетические высыпания, сепсис. Больные погибают в раннем возрасте. 
Синдром Луи-Бара - наследственное заболевание, при котором, аплазия железы, сочетается с уменьшением лимфоцитов в тимусзависимых зонах лимфатических узлов и селезенке, демиелинизации в мозжечке. Наиболее постоянный признак - низкий уровень или отсутствие $\operatorname{IgA}$. Клинически проявляется нарушением координации движений (атаксия, как правило, с 4-летнего возраста и постепенно прогрессирует), наличием множественных очагов расширенных мелких сосудов конъюнктивы и кожи (телеаниэктазия обнаруживаются к концу первого года жизни), недоразвитие половых органов, умственной отсталостью. С раннего детства появляются рецидивирующие инфекции респираторного тракта.

Посттонзиллэктомический синдром. Заболевания связано с удалением миндалин и/или аденоидов. Оно проявляется рецидивирующими воспалительными заболевания верхних дыхательных путей, гиперплазией лимфоидной ткани на задней стенке носоглотки и в области дужек миндалин («фолликулы»). При лабораторном исследовании возможно умеренное снижение Т-лимфоцитов, дисбаланс их субпопуляционного состава, уменьшение Влимфоцитов, дисиммуноглобулинемия со снижением IgM.

Отдельной группой болезней иммунной системы являются опухоли иммунной системы - гемобластозы. Они подразделяют на системные заболевания - лейкозы (лейкемии), и локальные - лимфомы. Однако при тяжелых поражениях лимфомы дают обширные метастазы, в том числе и в костный мозг т.е. поражение становится системным. Но при лимфомах костный мозг поражается вторично в результате метастазирования.

Лейкозы, группа рака крови, которая приводит к образованию большого количества аномальных клеток крови (бластные или лейкозные клетки). По мере прогрессии лейкозные клетки разрастаются и замещает нормальные ростки кроветворения, в результате чего у больных лейкозом развиваются различные варианты цитопений (анемия, тромбоцитопения, лимфоцитопения, гранулоцитопения) с формированием соответствующей клинической картины - повышенная кровоточивость, синяки, бледность кожи, лихорадка, рецидивирующие инфекции, лихорадки, увеличение селезенки или печени и пр.

Клинически и патологически лейкоз подразделяется на множество больших групп (рис.117)

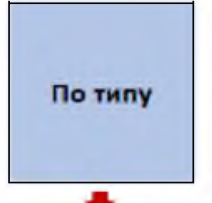

$+$

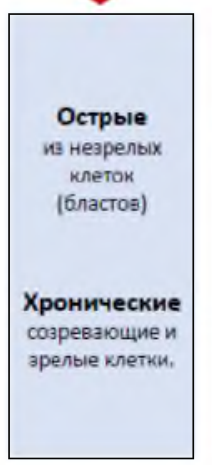

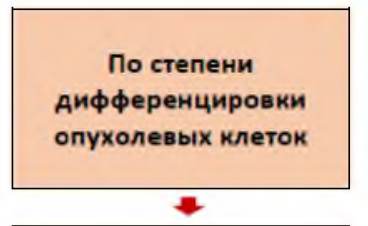

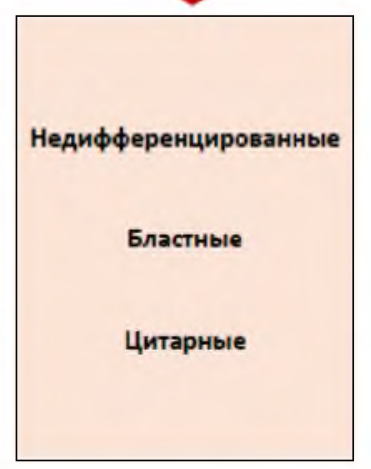

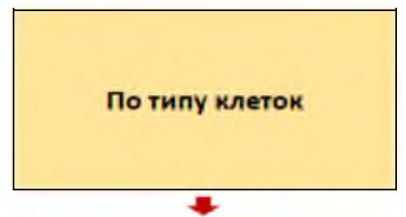

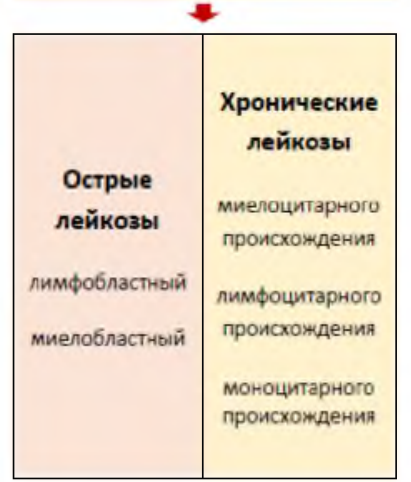

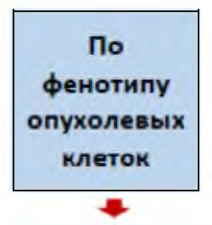

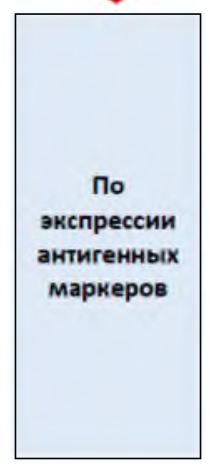

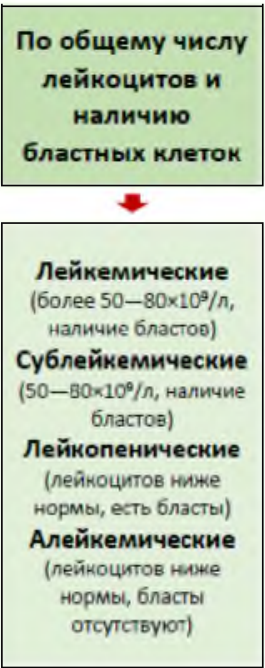

Рис. 117. Классификация лейкозов

Лимфомы - группа злокачественных новообразований крови, которые развиваются из лимфоцитов. Признаки и симптомы могут включать увеличение лимфатических узлов, лихорадку, сильный пот, потерю веса, зуд и постоянное чувство усталости.

Классифицируют лимфомы по типу клеток (по фенотипическим и/или молекулярным и/или цитогенетическим характеристикам) из которой возникает новообразование. Эти пять групп подтипов лимфомы (BO3, 2008 г.): 
- Лимфома Ходжкина

- Предшественники лимфоидных новообразований

- Зрелые В-клеточные новообразования

- Зрелые Т-клетки и новообразования из естественных киллеров (NK) Лимфопролиферативные заболевания, связанные с иммунодефицитом

Лимфома Ходжкина (лимфогранулематоз, болезнь Ходжкина, злокачественная гранулёма) - злокачественное заболевание лимфоидной ткани, характерным признаком которого является наличие гигантских клеток Рид - Березовского - Штернберга, и их одноядерных предшественников, клеток Ходжкина, обнаруживаемых при микроскопическом исследовании поражённых лимфатических узлов. Выделяют две клинико-патологических подгруппы лимфомы Ходжкина: нодулярный тип лимфоидного преобладания и классическую лимфому Ходжкина. В классической лимфоме Ходжкина различают четыре основных гистологических подтипа: нодулярный склероз, смешанно-клеточный вариант, вариант с большим количеством лимфоцитов и вариант с лимфоидным истощением. Эти подтипы имеют различные морфологические черты, отличаются своеобразием клинической картины и частотой выявления Эпштейн-Барр вирусной инфекции (EBV)

Неходжкинские лимфомы разнообразная группа раковых заболеваний крови, которые все возникают из лимфоцитов. Они имеют множество различных подтипов, которые бывают либо медленно растущие, либо агрессивными (быстрорастущие).

Зрелые В-клеточные лимфомы (около 85-90\% случаев лимфом). Агрессивный тип: диффузная В-крупноклеточная лимфома, лимфома из клеток мантии (как агрессивная вялотекушая), лимфобластная лимфома, лимфома Беркитта, первичная медиастинальная (тимическая) крупноклеточная лимфома, трансформированные фолликулярные и трансформированные лимфоидные лимфомы, ассоциированные со слизистой оболочкой (MALT), В-клеточная лимфома высокой степени злокачественности с двойным или тройным поражением, первичные кожные, первичные центральной нервной системы, лимфома, связанная с синдромом приобретенного иммунодефицита (СПИД). Медленнорастущий тип: фолликулярная лимфома, лимфома маргинальной зоны, хронический лимфоцитарный лейкоз/мелкоклеточный лимфоцитарная лимфома, лимфоидная лимфома, связанная со слизистой оболочкой желудка (MALT), лимфоплазмоцитарная лимфома, макроглобулинемия Вальденстрема, узловая лимфома маргинальной зоны, лимфома маргинальной зоны селезенки.

Зрелые Т-клеточные лимфомы и лимфомы естественных киллеров (NK) (около 10-15\% случаев лимфом). Агрессивный тип: периферическая Т-клеточная лимфома, системная анапластическая крупноклеточная лимфома, лимфобластная лимфома, гепатоспленочная гамма/дельта-Т-клеточная лимфома, подкожная панникулитоподобная Тклеточная лимфома, кишечная Т-клеточная лимфома энтеропатического типа, первичная кожная анапластическая крупноклеточная лимфома, ангиоиммунобластная Т-клеточная лимфома. Медленнорастущий тип: кожная Т-клеточная лимфома, грибовидный микоз, синдром Сезари, Т-клеточный лейкоз/лимфома взрослых, экстранодальная NK/T-клеточная лимфома.

Для точной диагностики В-клеточной лимфомы рекомендована панель имуногистохимии включающая: CD20, CD3, CD5, CD10, BCL2, BCL6, CD21 или CD23, с анализом маркеров клеточной поверхности с помощью проточной цитометрии: каппа/лямбда, CD19, CD20, CD5, CD23, CD10.

Для Т-клеточной лимфомы панель должна включать CD20, CD3, CD10, BCL6, Ki-67, CD5, CD30, CD2, CD4, CD8, CD7, CD56, CD21, CD23, EBER-ISH, TCRbeta, TCRdelta, $\mathrm{PD} 1 / \mathrm{CD} 279$ и $\mathrm{ALK}$, с анализом маркеров клеточной поверхности методом проточной цитометрии: каппа/лямбда, CD45, CD3, CD5, CD19, CD10, CD20, CD30, CD4, CD8, CD7, CD2; TCRalpha, TCRbeta и TCRgam. 


\section{ДИАГНОСТИКА ИММУННЫХ НАРУШЕНИЙ}

\section{Глава 13. Индуцированные иммунные нарушения}

Существуют другие причины иммунных нарушений, которые так же приводят к изменениям функции иммунной системы (табл.65), многие из которых возможно устранить. Эти причины не менее многочисленные в основном вызывают разнонаправленные нарушения и поражают как правило несколько компонентов иммунной системы. Поэтому при вторичных иммунодефицитах большее значение принадлежит иммунологическим исследованиям

Таблица 65

\section{Основные причины иммунных нарушений}

\begin{tabular}{|c|c|}
\hline Причина & Факторы \\
\hline $\begin{array}{l}\text { Протозойных и глистные } \\
\text { инвазии }\end{array}$ & Описторхоз, аскаридоз, дифиллоботриоз, лямблиоз и пр. \\
\hline $\begin{array}{l}\text { Бактериальные и вирусные } \\
\text { инфекции, микозы }\end{array}$ & $\begin{array}{l}\text { Хронические вирусные гепатиты В, C, D, E, корь, стафилококк, } \\
\text { пневмококк и пр. }\end{array}$ \\
\hline $\begin{array}{l}\text { Повреждающие факторы } \\
\text { внешней среды }\end{array}$ & $\begin{array}{l}\text { Повреждающие факторы атомной, химической и } \\
\text { металлургической промышленности, неблагоприятная экология, } \\
\text { сверхвысокие и сверхнизкие температуры. }\end{array}$ \\
\hline Интоксикации & Курение, наркомания, токсикомания, алкоголизм \\
\hline Ятрогенные & $\begin{array}{l}\text { Длительный прием антибиотиков, цитостатиков, } \\
\text { глюкокортикостероидов и пр.. Оперативные вмешательства, } \\
\text { травмы, кровопотери }\end{array}$ \\
\hline $\begin{array}{l}\text { Метаболические } \\
\text { нарушения }\end{array}$ & Анемия. Дефицит белков, макро- и микроэлементов, витаминов. \\
\hline $\begin{array}{l}\text { Заболеваниях эндокринной } \\
\text { системы или гормональные } \\
\text { нарушения регуляции }\end{array}$ & $\begin{array}{l}\text { Гипотиреоз, тиреотоксикоз, недостаточность половых гормонов, } \\
\text { сахарный диабет и др.. Стресс }\end{array}$ \\
\hline $\begin{array}{l}\text { «Физиологические» } \\
\text { иммунодефициты }\end{array}$ & Старческий возраст, беременность, младенчество \\
\hline
\end{tabular}

Одна из основных причин иммунных нарушений которая может быть устранена и после чего обычно нормализуются функция иммунной системы это инфекции и инвазии. В организме человека могут паразитировать более 260 видов гельминтов и более 60 видов простейших (рис. 117). Протозойных и глистные инвазии широко распространены во всем мире. По данным ВО3 более 4,5 млрд. человек поражены гельминтами. Гельминтозы заболевания, связанные с заражением паразитическими червями. Протозойные инфекции, или протозоозы - инфекции, вызываемые паразитическими простейшими. Течение инфекции может сильно различаться в зависимости от гельминта. 


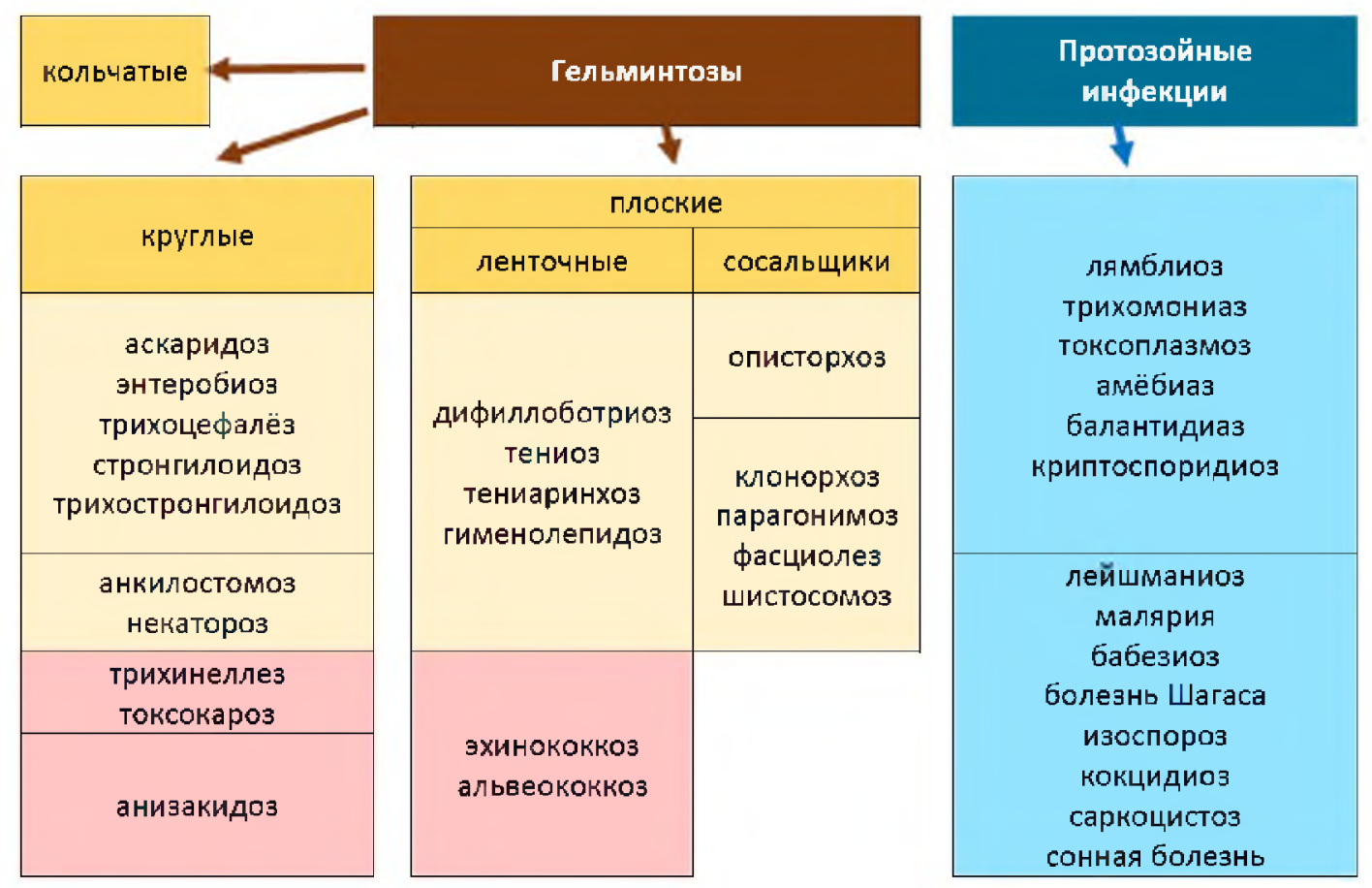

Рис. 117. Основные глистные и протозойные инвазии, поражающие человека

Выживание гельминтов, а некоторые из них могут жить более 20 лет является результатом процесса адаптации паразита к пораженному человека не повреждая хозяина. В противном случае организм способен генерировать эффективный иммунный ответ для удаления паразита.

Являясь патогенами в организме, гельминты вызывают иммунный ответ. При первичной инвазии обычно возникает острая гиперэргическая реакция, которая может привести к анафилаксии. Характерна эозинофилия, отеки, различные сыпи, в некоторых случаях артриты. Эозинофелия может достигать гигантских цифр (до 80\%). Наиболее выражена токсико-аллергическая реакция в местах локализации гельминта (кожа, легкие, печень, кишечник, центральная нервная система, глаза). В последующем в процессе взаимодействия паразита и хозяина острые реакции снижаются, однако та или иная симптоматика может проявляется длительное время. За счет выделения гельминтами токсических, иммунодепрессивных вещества формируются гипоэргические синдромы. Определенной клинической картины и/или превалировании того или иного иммунопатологического синдрома для определенных инвазий нет, в основном это зависит от локализации инвазии.

Бактериальные, вирусные, грибковые инфекции с одной стороны развиваются на фоне нарушения функции иммунной системы, с другой стороны сами достаточно активно влияют на иммунную систему.

Нарушения иммунной системы может формироваться при воздействии экзогенных воздействий. Это повреждающие факторы внешней среды, связанные с работой на предприятиях атомной, химической и металлургической промышленности, неблагоприятная экология, в том числе сверхвысокие и сверхнизкие температуры. Классическим является развитие тяжелых инфекций после переохлаждения. К этой же группе можно отнести хронические интоксикации (курение, наркомания, токсикомания, алкоголизм) и ятрогенные воздействия (длительный прием антибиотиков, цитостатиков, глюкокортикостероидов и пр.). 
Большая группа иммунных нарушений связана с «основными» заболеваниями человека. Учитывая тесную взаимосвязь между иммунной, нервной и эндокринной системами, заболевания и/или нарушения функции эндокринной и нервной системы влияют на иммунореактивность организма. Наиболее распространенная из них стресс.

Стресс (от англ. stress «нагрузка, напряжение;») — реакция организма на различные неблагоприятные раздражители-стрессоры (физические или психологические). Известно, что иммунная, эндокринная и нервная системы взаимодействуют друг с другом, обеспечивая скоординированный ответ на внешние раздражители. При остром стрессе наряду с реакцией «бой или бегство», формируется провоспалительная реакция, которая в последующим снижается, за счет отрицательной обратной связи гормонов стресса, основными которыми являются кортизол и катехоламины, хотя и другие гормоны оказывают большое внимание на иммунную систему. (рис.118).

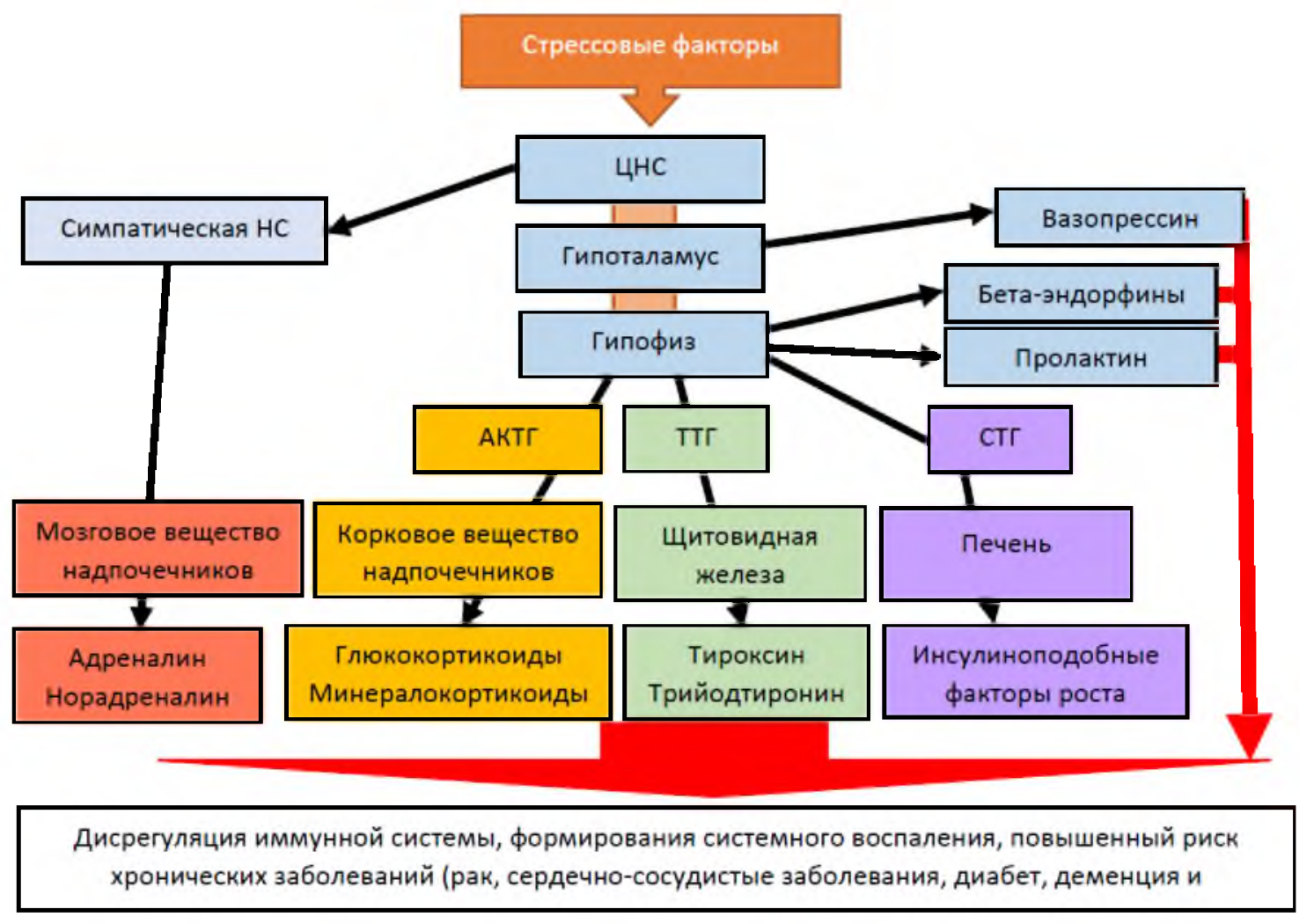

\section{Рис. 118. Основные гормональные пути влияния на иммунную систему при хроническом стрессе.}

Если стресс сохраняется дольше (хронический стресс), модуляция иммунной функции с помощью кортизола и других гормонов напрямую на клетки иммунной системы или опосредованно путем нарушения регуляции продукции цитокинов продолжается. Происходит длительная дисфункция иммунитета за счет перепрограммирования иммунных клеток из-за эпигенетических и метаболических изменений. Снижается интерферон- $\gamma$ (ИФН- $\gamma)$ и увеличивается уровень ИЛ-6 и ИЛ-10, за счет чего подавлен клеточный (Th1) адаптивный иммунитет. Активность NK-клеток увеличивается, но пролиферация лимфоцитов в целом уменьшается. Формируется PICS-подобный синдром (синдром стойкого воспаления, иммуносупрессии и катаболизма). Кроме того, хронический стресс приводит к десенсибилизации и резистентности к глюкокортикоидам с неспособностью кортизола подавлять воспаление независимо от его уровня в крови. Формируются различные хронические заболевания. 
Лабораторные исследования по увеличению гормонов гипофизарно-надпочечниковой системы позволяют подтвердить наличие стресса (табл.65).

Таблица 65

Референтные значения гормонов гипофизарно-надпочечниковой системы

\begin{tabular}{|l|c|c|}
\hline \multicolumn{1}{|c|}{ Гормон } & Утро (до 10 часов) & Вечер (после 14 часов) \\
\hline Кортизол (Гидрокортизон) & $100,0-540,0$ нмоль/л & $65,0-450,0$ нмоль/л \\
\hline Кортизол в моче & \multicolumn{2}{|c|}{ менее 450 нмоль в сутки } \\
\hline $\begin{array}{l}\text { АКТГ (Адренокортикотропный } \\
\text { гормон) }\end{array}$ & менее 46 пг/мл & \\
\hline
\end{tabular}

Не менее распространенными являются нарушения, связанные с регуляция общего развития и энергообмена осуществляемое системой тиреотропных гормонов. Это гормоны щитовидной железы - тироксин (Т4) и трийодтиронин (Т3), тиреотропным гормоном (ТТГ) гипофиза стимулирующий биосинтез и секрецию гормонов щитовидной железы и тиролиберин (ТРГ - Тиреотропин Рилизинг Гормон) гипоталамуса стимулирующий секреция ТТГ. Т3 и Т4 действуют на продукцию ТРГ и ТТГ по принципу отрицательной обратной связи поддерживаясь на относительно постоянном уровне.

К функции гормонов щитовидной железы относят: регуляцию роста и развития организма в целом и прежде всего развития ЦНС, стимуляция аэробного дыхания, контроль метаболизма белков, липидов и углеводов, транспорта ионов, температуры). Щитовидная железа стимулирует сердечно-сосудистую, дыхательную и центральную-нервную системы, регулирует репродуктивную функцию и иммунные реакции. При нарушении гормональной регуляции щитовидной железы происходят те или иные изменения, которые нередко интерпретируются как синдром хронической усталости, вызванной инфекционным патогеном (табл. 66).

Таблица 66

\section{Симптомы нарушения функции щитовидной железы}

\begin{tabular}{|c|c|}
\hline Гипотиреоз & Гипертиреоз \\
\hline Дефицит гормонов & Повышенная выработкой гормонов \\
\hline \multicolumn{2}{|c|}{$\begin{array}{c}\text { Изменения эмоционально-психологического состояния - плаксивость и раздражительность взамен прежнего } \\
\text { спокойствия или равнодушие к ранее значимым вещам; } \\
\text { Депрессия, перепады настроения } \\
\text { Значительные изменения массы тела без явных причин; } \\
\text { Дрожь в руках, повышенная потливость; } \\
\text { Приступы головокружения и слабости; } \\
\text { Ощущение жара или холода при адекватной температуре; } \\
\text { Повышенное выпадение волос } \\
\text { У женщин - нерегулярность менструального цикла; } \\
\text { У мужчин - снижение сексуального влечения; } \\
\end{array}$} \\
\hline $\begin{array}{l}\text { Вялость, сонливость, заторможенность, } \\
\text { флегматичность, панические атаки, усталость, } \\
\text { нарушение памяти. }\end{array}$ & $\begin{array}{l}\text { Раздражительность, чувство тревоги, плаксивость, } \\
\text { нервозность, бессонница, жажда, потливость }\end{array}$ \\
\hline Чувствительность к холоду & Непереносимость жары \\
\hline Увеличение веса, отеки & Потеря веса на фоне повышенного аппетита \\
\hline Одышка, брадикардия, гипотония & Тахикардия, мерцательная аритмия \\
\hline Понижение температуры & Субфебрильная температура тела \\
\hline Нарушение обмена липидов, анемия & $\begin{array}{l}\text { Фиброзно-кистозная мастопатия, остеопороз, } \\
\text { нарушение толерантности к углеводам }\end{array}$ \\
\hline Запоры дискинезия желчевыводящих путей & Нарушение функции печени вплоть до гепатита. Поно \\
\hline
\end{tabular}


Взаимосвязь между гормонами щитовидной железы и клетками иммунной системы сложна, Т3 и Т4 могут модулировать иммунные ответы как через геномные, так и негеномные механизмы, прежде всего через регуляцию метаболизма этих клеток. В моноцитах, макрофагах, гранулоцитах, естественных киллерах и лимфоцитах широкий спектр иммунных функций, таких как хемотаксис, фагоцитоз, генерация активных форм кислорода, а также синтез и высвобождение антител и цитокинов, изменяются в условиях гипо- и гипертиреоидной болезни. В целом, гипертиреоз уменьшает провоспалительную активность моноцитов и макрофагов, тогда как усиление фагоцитоза и повышение уровня АФК могут происходить во время гипотиреоза. Однако в клетках Купффера провоспалительная активность может быть результатом повышенных уровней Т3. При гипотиреозе выявляется стойкое понижение количества Т-лимфоцитов и их функциональной активности. В то же время при субклиническом гипотиреозе определяется повышенное содержание лимфоцитов в крови и увеличение уровня активированных Т-лимфоцитов. Не найдено четкой корреляции между аномально высоким или низким уровнями Т3 и/или Т4 и их количеством и/или активностью. Значения тиреоидных гормонов представлены в таблице (табл.67).

Таблица 67

Референсные значения тиреоцдных гормонов

\begin{tabular}{|l|c|}
\hline \multicolumn{1}{|c|}{ Гормон } & Значение \\
\hline Трийодтиронин общий (ТЗ общий) & $0,95-2,50$ нмоль/л \\
\hline Трийодтиронин свободный (ТЗ свободный) & $3,0-10,0$ пмоль/л \\
\hline Тироксин общий (Т4 общий) & $62,00-150,00$ нмоль/л \\
\hline Тироксин свободный (Т4 свободный) & $9,00-20,00$ пмоль/л \\
\hline Тиреотропный гормон (ТТГ) с 8 до 18 ч (min) & $0,4-4,0$ мЕд/л \\
\hline
\end{tabular}

Большое распространение связанные с иммунными нарушениями имеют и другие метаболические нарушения и прежде всего нарушения регулируемых по системе обратной связи инсулином и глюкагоном. Инсулин основной анаболический гормон организма, способствующий превращению небольших молекул в крови в большие молекулы внутри клеток. Он повышает проницаемость мембран для аминокислот, усиливает синтеза мРНК, повышает синтез и подавляет распад белка, активирует утилизацию глюкозы клетками, усиливает процессов фосфорилирования и гликолиза, подавляет распад и стимулирует синтеза гликогена, стимулирует синтез свободных жирных кислот и триглицеридов из глюкозы, активирует гидролиз связанных с липопротеинами крови триглицеридов и поступления жирных кислот в клетки жировой ткани, активирует окисление кетоновых тел, подавляет распад жира. Обратным действием обладает глюкагон. Антагонистами инсулина так же являются катехоламины, кортизол, тиреоидные гормоны и гормоны роста. Основным маркером нарушения баланса между этими гормонами является уровень глюкозы крови и связанные с ним другие показатели (табл.68).

Заболевания и патологические состояния связанные с их нарушениями их регуляции сахарный диабет 1 и 2 типа, метаболический синдром и ожирение. Особенно необходимо обратить внимание на ожирение (ИМТ более $30 \mathrm{\kappa г} / \mathrm{M}^{2}$ ) и избыточную массу тела (ИМТ от 25 до $30 \mathrm{\kappa} / \mathrm{M}^{2}$, окружность талии более $80 \mathrm{~cm}$ у женщин и более $94 \mathrm{~cm} \mathrm{у} \mathrm{мужчин} \mathrm{(для}$ европеоидов), т.к. за счет жировой ткани увеличиваются свободные жирные кислоты, инсулин, глюкоза, лептин, провоспалительные цитокины, снижается уровень адипонектина. Становится больше провоспалительных М1 макрофагов уровень ФНО, ИЛ-6 и ИЛ-1, а также моноцитарных хемоаттрактантов MCP-1, CCL-2 и MIF увеличивается. Описано так же повышенная экспрессия ИЛ-8, $-10,-12,-17,-18,-22$, гамма-интерферона. Тучные люди имеют меньше цитотоксических T- и NK-клеток, снижается количество Treg клетки, которые специально расположенные в брюшной полости жировых депо теряются при ожирении. 


\section{Показатели углеводного обмена}

\begin{tabular}{|c|c|}
\hline Показатель & Значение \\
\hline Глюкоза (в крови) & 4,1 - 6,0 ммоль/л \\
\hline Гликированный гемоглобин & $\begin{array}{c}<6 \% \\
\geq 6.5 \% \text { - сахарный диабет }\end{array}$ \\
\hline $\begin{array}{l}\text { Глюкозотолерантный тест с определением } \\
\text { глюкозы в венозной крови натощак и после } \\
\text { нагрузки (75 г глюкозы) через } 2 \text { часа }\end{array}$ & $\begin{array}{c}<\text { 7,8 ммоль/л - норма } \\
\text { 7,8 - 11,1 ммоль/л - нарушение } \\
\text { толерантности к глюкозе } \\
>11,1 \text { ммоль/л - сахарный диабет }\end{array}$ \\
\hline Лактат & $0,5-2,2$ ммоль/л \\
\hline С-Пептид & 260 - 1730 пмоль/л \\
\hline $\begin{array}{l}\text { Инсулин натощак после ночного периода } \\
\text { голодания у здоровых нетучных людей с ИМТ } \\
\text { до } 30 \text { кг/м2 }\end{array}$ & 2,7 - 10,4 мкЕд/мЛ \\
\hline
\end{tabular}

Прямым следствием нарушенной адаптивного иммунитета усиления роста опухоли. Изучение роли В-клеток находится на начальной стадии. Выяснено, что некоторые популяции В-клеток усугубляют воспаление через взаимодействие с другими иммунными клетками жировой резидентов, в частности CD4 + T-клеток. Популяции B-клеток секретирующие ИЛL10 обладают противовоспалительными и инсулин-сенсибилизирующее воздействие при ожирении. Диеты с высоким содержанием жира с некоторыми полиненасыщенными жирными кислотами могут улучшить активность В клеток.

Важное значение особенно в период полового созревания и беременности принадлежит половым гормонам. Половые гормоны (гонадостероиды) - гормоны, обеспечивающие развитие и функционирование человека по мужскому или женскому типу. Андроге́ны (тестостерон, андростендиол, дигидротестостерон и др.) формируют мужские половые признаки, эстрогены (эстрон, эстрадиол, эстриол и др.) и прогестогены (прегненолон, прогестерон, аллопрегнанолон и др.) - женские.

Андрогены оказывают анаболическое и анти-катаболическое действие, повышают синтез белков и тормозят их распад увеличивая мышечную массу и силу, повышают утилизацию глюкозы клетками. Способствуют снижению количества подкожного жира и уменьшению жировой массы при этом снижают содержание в крови ЛПВП и увеличивая концентрацию ЛПНП.

Эстрогены являются основными женскими половыми гормонами. Они отвечают за развитие и регулирование женской репродуктивной системы и вторичных половых признаков. Под их воздействием ускоряется обмен вешеств, увеличивается накопления жира за счет увеличения ЛПВП, триглицеридов и уменьшение ЛПНП. Эстрогены угнетают резорбцию костной ткани, стимулируют синтез транспортных белков, фибриногена, факторов свертывания крови (II, VII, IX, X), снижают концентрацию антитромбина III.

Снижение содержания эстрогенов сопровождается у многих женщин сосудодвигательной и терморегулирующей нестабильностью («приливы» крови к коже лица), расстройствами сна, а также прогрессирующей атрофией органов мочеполовой системы. Вследствие дефицита эстрогенов в постменопаузном периоде у женщин развивается остеопороз (главным образом позвоночника)

Основная функция прогестогенов обеспечение наступления и поддержания беременности (гестации). Они обладают антиандрогенной активностью.

На репродуктивную функцию влияют и другие гормоны, и факторы, которые представлены в таблице (табл.69). 


\section{Половые гормоны}

Таблица 69

\begin{tabular}{|c|c|c|c|}
\hline \multirow{3}{*}{ Гормон } & \multicolumn{3}{|c|}{ Показатель } \\
\hline & \multirow[t]{2}{*}{ мужчины } & \multicolumn{2}{|c|}{ женщины } \\
\hline & & & Фаза менструации \\
\hline $\begin{array}{l}\text { Тестостерон } \\
\text { (нмоль/л) }\end{array}$ & $\begin{array}{l}9 \text { - } 11 \text { лет }<0,8 \\
11 \text { - } 16 \text { лет }-1,25-22,0 \\
16-18 \text { лет }-5,0-27,5 \\
18 \text { - } 50 \text { лет }-12,0-42,0 \\
\text { старше } 50 \text { лет - 8,5 - 23,0 }\end{array}$ & \multicolumn{2}{|l|}{$\begin{array}{l}\text { 0,52-1,72 } \\
\text { Беременные до 5,0 }\end{array}$} \\
\hline $\begin{array}{l}\text { Свободный } \\
\text { тестостерон } \\
\text { (пг/мл) }\end{array}$ & $\begin{array}{l}19-55 \text { лет }-1,00-28,3 \\
>55 \text { лет }-0,70-21,5\end{array}$ & \multicolumn{2}{|l|}{$\begin{array}{l}<2,85 \\
<1,56\end{array}$} \\
\hline $\begin{array}{l}\text { Эстрадиол } \\
\text { (пмоль/л) }\end{array}$ & $\begin{array}{l}12 \text { месяцев - } 5 \text { лет }<84 \\
5 \text { лет - } 14 \text { лет }-<113 \\
14 \text { лет - } 18 \text { лет }-<182 \\
\text { от } 18 \text { лет }-40-161\end{array}$ & $\begin{array}{l}<98 \\
<355 \\
<953 \\
\text { Постменопауза }-<73\end{array}$ & $\begin{array}{l}\text { Фолликуллярная - 68 - } \\
1269 \\
\text { Овуляторная - } 131 \text { - } \\
1655 \\
\text { Лютеиновая - } 91-861 \\
\end{array}$ \\
\hline \multirow[t]{3}{*}{$\begin{array}{l}\text { Прогестерон } \\
\text { (нмоль/л) }\end{array}$} & \multirow[t]{3}{*}{$\begin{array}{l}<9 \text { лет }<1,1 \\
>18 \text { лет - 0,3 - 2,2 }\end{array}$} & $\begin{array}{l}\text { Пубертат, стадии } \\
\text { Таннера: } 1,2-<1,1 \\
3-0,3-14,4 \\
4,5-0,3-41,6\end{array}$ & $\begin{array}{l}\text { Фолликулярная фаза - } \\
0,3 \text { - 2,2 } \\
\text { Овуляторная фаза - 0,5 - } \\
9,4 \\
\text { Лютеиновая фаза - 7,0 - } \\
56,\end{array}$ \\
\hline & & \multicolumn{2}{|l|}{ Постменопауза - <0,6 } \\
\hline & & \multicolumn{2}{|c|}{$\begin{array}{l}\text { Беременность I триместр- 8,9 - 468,4 II трим - 71,5 - } \\
303,1 \text { III трим - 88,7 - 771,5 }\end{array}$} \\
\hline $\begin{array}{l}\text { Антимюллеро } \\
\text { в гормон } \\
\text { (нг/мл) } \\
\end{array}$ & $\begin{array}{l}\text { до } 18 \text { лет - 0,43-144,48 } \\
18-50 \text { лет: } 0,73-16,05 \\
50-60 \text { лет: } 15,11-266,59\end{array}$ & \multicolumn{2}{|c|}{$\begin{array}{l}18-25 \text { лет }-0,96-13,34 \\
26-40 \text { лет }-0,03-7,37 \\
41-45 \text { лет }-<3,27 \geq 46 \text { лет }-<1,15\end{array}$} \\
\hline $\begin{array}{l}\text { Фолликулости } \\
\text { мулирующий } \\
\text { гормон (ФСГ) } \\
\text { (мМЕ/мл) }\end{array}$ & $\begin{array}{l}1-5 \text { лет }-0,00-1,45 \\
6-10 \text { лет }-0,0-3,04 \\
11-14 \text { лет }-0,36-6,29 \\
15-20 \text { лет }-0,49-9,98 \\
>20 \text { лет }-0,95-11,95\end{array}$ & $\begin{array}{l}1 \text { 1-5 лет - 0,60-6,12; } \\
6-10 \text { лет- } 0,0-4,62 ; \\
11-14 \text { лет - 0,19-7,97; } \\
15-20 \text { лет - 0,57-8,77 } \\
\text { постменопауза - 26,72- } \\
133.41\end{array}$ & $\begin{array}{l}\text { фолликулярная - } \\
3,03-8,08 \\
\text { овуляторный - } \\
2,55-16,69 \\
\text { лютеиновая - 1,38-5,47 }\end{array}$ \\
\hline $\begin{array}{l}\text { Лютеинизиру } \\
\text { ющий гормон } \\
\text { (ЛГ) (мМЕ/мл) }\end{array}$ & $\begin{array}{l}\text { 1-5 лет- менее } 0,92 \\
\text { 5-14 лет- менее } 1,03 \\
14-20 \text { лет }-0,78-4,93 \\
>20 \text { лет- } 1,14-8,75\end{array}$ & $\begin{array}{l}\text { до } 5 \text { лет - менее } 0,27 \\
5-10 \text { лет менее } 0,46 \\
10-14 \text { лет - менее } 15,3\end{array}$ & $\begin{array}{l}\text { Фолликулярная: 1,80- } \\
\text { 15,0 } \\
\text { Середина цикла: } 21,9- \\
\text { 56,6 } \\
\text { Лютеиновая фаза: 0,6- } \\
\text { 16,30 } \\
\text { Постменопауза - 14,20- } \\
\text { 52,3 }\end{array}$ \\
\hline $\begin{array}{l}\text { Пролактин } \\
\text { ММЕ/л }\end{array}$ & $\begin{array}{l}\text { до } 19 \text { лет: } 88,2-483.84 \\
\text { от } 19 \text { лет: } 72,66-407,40\end{array}$ & \multicolumn{2}{|c|}{$\begin{array}{l}\text { от } 1 \text { года - до } 19 \text { лет: } 88,2-483.84 \\
\text { от } 19 \text { лет - } 108,78-557,13\end{array}$} \\
\hline
\end{tabular}

В настоящее время хорошо известно, что наши иммунные реакции зависят от половых гормонов. Это иллюстрируется преобладанием женщин в развитии аутоиммунных и инфекционно-воспалительных заболеваний, развитии рака. Половые гормоны регулируют молекулярные механизмы врожденной и адаптивной иммунной системы. 
Сложное взаимодействие гормонов и факторов окружающей среды у генетически восприимчивых людей приводит к нарушению регуляции иммунного ответа, что приводит к иммуноопосредованным заболеваниям, включая аутоиммунные заболевания. Так экстрогены подавляют развитие Т-клеток, понижают отрицательный отбор ауто-реактивных Т-клеток, увеличивая активацию Т-клеток за счет митохондриальной функции, увеличивает дифференцировку Th1 и Th17, Tfh усиливает функцию подавления Treg, подавляет дифференцировку В-клеток от про-В до стадии до В-клеток, при этом способствует выживанию аутореактивных В-клеток, стимулирует выработку антител Ig, ИЛ-1, -10, IFN- $\gamma$. Прогестерон уменьшает пролиферацию Т-клеток, индуцирует апоптоз, уменьшает Th1 Th17 дифференциацию, увеличивает дифференцировку Treg, подавляя цитотоксичность, уменьшает переключение класса и выработку антител, зависимых от Т-клеток, увеличивает IL-4, уменьшает IFN- $\beta$, IL-17, способствует производству Ил-10. Андрогены стимулирует тимопоэз, способствуя удалению аутореактивных Т-клеток, ингибирует Th1 и способствует Th2, в то же время стимулируя Treg, подавляют В лимфопоэз, снижают В-клетки и синтез антител. Лептин способствует дифференцировке Th1 и Th17, увеличивает активацию и пролиферацию ЦТЛ (стимулируя гликолиз), способствуя аутоиммунитету, подавляет распространение и активность Treg, увеличивает TNF, IL-6 и IL-10. Важным для формирования иммунного бесплодия и вынашивания беременности является наличие NKклеток. В конце менструального цикла и первом триместре беременности в матке происходит значительное накопление NK-клеток с фенотипом CD56++CD16+/- (uNK - клетки естественных киллеров матки). Они не являются цитотоксичными, продуцируют факторы, способствующие росту плода до полного формирования плаценты т.е. выполняя роль плаценты. При старости происходит снижение половых гормонов, что влечет развития иммунных нарушений и не только развития частых заболеваний, но и нарушения процессов регенерации.

Еще один важный гормон участвующий в формировании одной из основных причин иммунных нарушений анемии, эритропоэтин. Анемия - это уменьшение количества эритроцитов и/или гемоглобина и/или в снижение способности эритроцитов переносить кислород. В результате чего происходит к развитию кислородного голодания тканей. Клинически это проявляется слабостью, быстрой утомляемостью, общим недомогание, снижение концентрации внимания, нарушения сна, аппетита, полового влечения, а также головную боль, шум в ушах. Большинство больных с анемией отмечают повышенное выпадение волос, ломкость и расслоение ногтей, закусы, изменение вкуса. При тяжелой анемии присоединяются признаки сердечной недостаточности (сердцебиения, одышка при незначительной или умеренной нагрузке, боли за грудиной). При осмотре выявляется бледность кожи и слизистых оболочек, тахикардия. Однако у многих людей симптомы анемии могут быть незначительными или полностью отсутствовать, поэтому на первый план диагностики выходят лабораторные исследования (табл. 70).

Таблица 70

Диагностические критерии анемии и степени ее тяжести

\begin{tabular}{|c|c|c|c|c|c|c|}
\hline \multirow{2}{*}{ Группы } & \multirow{2}{*}{$\begin{array}{c}\text { Эритроциты } \\
\text { (х106/мкл) }\end{array}$} & \multirow{2}{*}{$\begin{array}{c}\text { Гематокрит } \\
\% \\
\end{array}$} & \multicolumn{4}{|c|}{ Гемоглобин (г/л) } \\
\hline & & & Норма & Легкая & Средняя & Тяжёлая \\
\hline Дети до 11 лет & $3,8-4,8$ & $32-42$ & $110-140$ & $100-109$ & $70-99$ & $<70$ \\
\hline $12-15$ лет & $3,9-5,1$ & $34-43$ & $120-150$ & $110-119$ & $80-109$ & $<80$ \\
\hline Мужчины & $4,3-5,7$ & $39-49$ & $130-170$ & $110-129$ & $80-109$ & $<80$ \\
\hline Женщины & $3,8-5,3$ & $35-47$ & $120-160$ & $110-119$ & $80-109$ & $<80$ \\
\hline Беременные & $3,8-5,3$ & $35-47$ & $110-160$ & $100-109$ & $70-99$ & $<70$ \\
\hline
\end{tabular}


Типичные причины анемии по механизму развития представлены на рисунки (рис.119).

\begin{tabular}{|c|c|c|}
\hline \multicolumn{2}{|r|}{ AHEMTH } & \multirow[b]{2}{*}{$\begin{array}{c}\text { ЧРЕЗMEPHЫЙ } \\
\text { ГЕMOЛИ3 }\end{array}$} \\
\hline $\begin{array}{c}\text { ПОТЕРИ } \\
\text { ЭРИТРОЦИТОВ }\end{array}$ & HАРУШЕННЕ ЭРНTРОПОЭЗА & \\
\hline 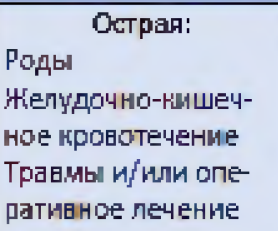 & \multirow{2}{*}{ 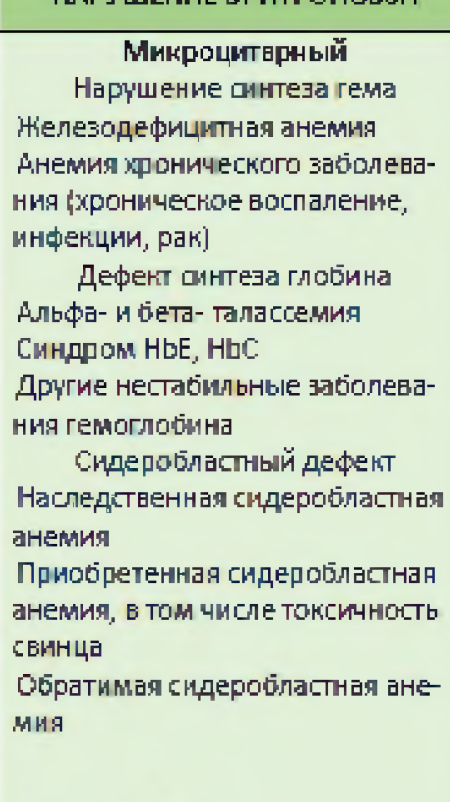 } & \multirow{2}{*}{ 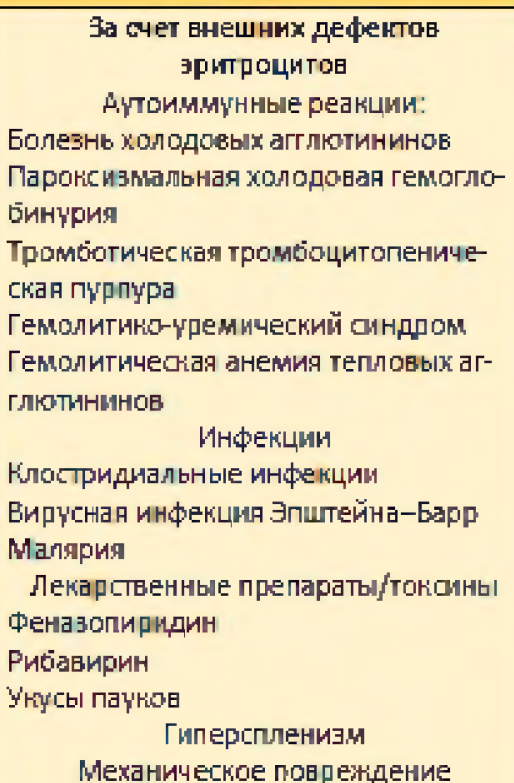 } \\
\hline 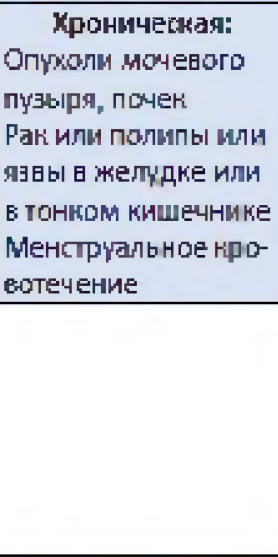 & & \\
\hline \multicolumn{2}{|c|}{ 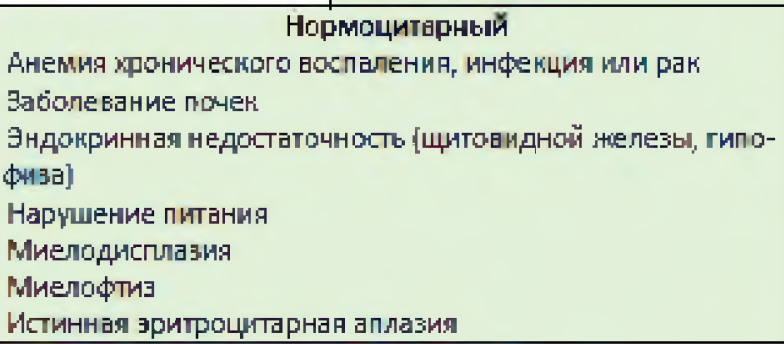 } & \multirow{2}{*}{ 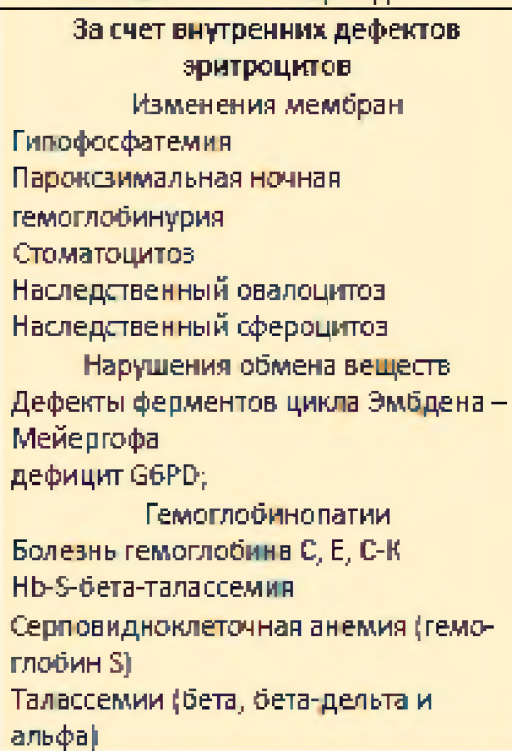 } \\
\hline 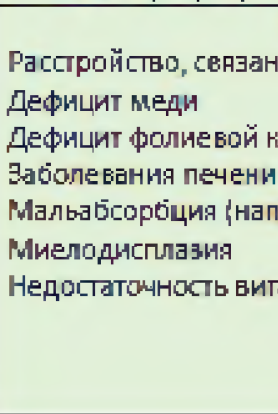 & $\begin{array}{l}\text { нроцитарный } \\
\text { с үпотевлленнсм алнюголя }\end{array}$ & \\
\hline
\end{tabular}

\section{Рис. 119. Основных механизма развития анемии}

По данным экспертов ВОЗ, недостаточность питания и гиповитаминозы являются самой распространенной причиной иммунной недостаточности. Взаимосвязь иммунитета с содержанием витаминов является очевидной. Не вызывает сомнений, что недостаточность витаминов влечет за собой нарушения со стороны иммунной системы, поскольку все процессы, имеют определенное метаболическое обеспечение. Витамины - это необходимые для нормальной жизнедеятельности низкомолекулярные органические соединения, синтез которых у организмов данного вида отсутствует или ограничен. По составу и механизму действия витамины отличаются большим разнообразием строения и биологической активностью. Многие витамины участвуют во множестве биохимических реакций, выполняя каталитическую функцию в составе активных центров большого количества разнообразных 
ферментов, ряд витаминов выполняют сигнальные функции экзогенных прогормонов и гормонов, а некоторые витамины обладают антиоксидантным действием (табл.71)

Таблица 71

\section{Источники и функции витаминов}

\begin{tabular}{|c|c|c|}
\hline $\begin{array}{c}\text { Витамин } \\
\text { потребность }\end{array}$ & Основной источник & Функции \\
\hline $\begin{array}{c}\text { Витамин A } \\
\text { (ретинол) } \\
0,5-2,5 \text { мг. }\end{array}$ & $\begin{array}{l}\text { Рыбий жир, печень, яичные желтки, } \\
\text { сливочное масло, молочные } \\
\text { продукты. Каротиноиды: темно- } \\
\text { зеленые и желтые овощи, желтые и } \\
\text { оранжевые фрукты }\end{array}$ & $\begin{array}{l}\text { Образование родопсина } \\
\text { (Фоторецепторного пигмента в } \\
\text { сетчатке). Целостность эпителия. } \\
\text { Стабильность лизосом } \\
\text { Синтез гликопротеина }\end{array}$ \\
\hline $\begin{array}{c}\text { Витамин D } \\
\text { (холекальциферол, } \\
\text { эргокальциферол) } \\
\mathbf{2 , 5}-\mathbf{1 0 ~ м г . ~}\end{array}$ & $\begin{array}{l}\text { Прямое облучение кожи (главный } \\
\text { источник), обогащенные молочные } \\
\text { продукты, рыбий жир, жирная рыба, } \\
\text { печень }\end{array}$ & $\begin{array}{l}\text { Поглощение кальция и фосфата. } \\
\text { Минерализация и восстановление } \\
\text { костной ткани. Инсулин и } \\
\text { функционирование щитовидной } \\
\text { железы }\end{array}$ \\
\hline $\begin{array}{c}\text { Витамин Е } \\
\text { (токоферолы) } \\
\mathbf{8 - 1 5} \text { мг. } \\
\end{array}$ & Растительные масла, орехи & $\begin{array}{l}\text { Внутриклеточный антиоксидант. } \\
\text { Акцептор свободных радикалов в } \\
\text { биологических мембранах }\end{array}$ \\
\hline $\begin{array}{l}\text { Витамин B1 } \\
\text { (тиамин) } \\
\mathbf{1 , 5}-\mathbf{2 , 5} \text { мг. }\end{array}$ & $\begin{array}{l}\text { Цельное зерно, мясо, обогащенные } \\
\text { зерновые продукты, орехи, бобовые, } \\
\text { картофель }\end{array}$ & $\begin{array}{l}\text { Метаболизм углеводов, жиров, } \\
\text { аминокислот и алкоголя. Функция } \\
\text { нервной системы. Миокардиальная } \\
\text { функция }\end{array}$ \\
\hline $\begin{array}{c}\text { Витамин В2 } \\
\text { (рибофлавин) } \\
\mathbf{1 , 5}-\mathbf{3} \text { мг } \\
\end{array}$ & $\begin{array}{l}\text { Молоко, сыр, печень, мясо, яйца, } \\
\text { обогащенные зерновые продукты }\end{array}$ & $\begin{array}{l}\text { Углеводный и белковый } \\
\text { метаболизм. Целостность слизистых } \\
\text { оболочек }\end{array}$ \\
\hline $\begin{array}{c}\text { Витамин В3 } \\
\text { (никотиновая } \\
\text { кислота) } \\
15-20 \text { мг. }\end{array}$ & $\begin{array}{l}\text { Печень, красное мясо, рыба, } \\
\text { домашняя птица, бобовые, цельное } \\
\text { зерно или обогащенные злаки и хлеб }\end{array}$ & $\begin{array}{l}\text { Окислительно-восстановительные } \\
\text { реакции. Углеводный и клеточный и } \\
\text { метаболизм }\end{array}$ \\
\hline $\begin{array}{c}\text { Витамин В6 } \\
\text { (пироксидин, } \\
\text { пиридоксал, } \\
\text { пиридоксамин) } \\
\mathbf{2 - 2 , 2} \text { мг. }\end{array}$ & $\begin{array}{l}\text { Субпродукты (например, печень), } \\
\text { цельные злаки, рыба, бобовые }\end{array}$ & $\begin{array}{l}\text { Метаболизм азота (порфирин и } \\
\text { синтез гема, трансаминирования, } \\
\text { преобразование триптофана в } \\
\text { ниацин), биосинтез нуклеиновой } \\
\text { кислоты, метаболизм жирных } \\
\text { кислот, липидов и аминокислот }\end{array}$ \\
\hline $\begin{array}{c}\text { Витамин В9 (фолат } \\
\text { фолиевая кислота) } \\
\text { 7-10 - мг. }\end{array}$ & $\begin{array}{l}\text { Сырые зеленые листовые овощи, } \\
\text { фрукты, субпродукты (например, } \\
\text { печень), обогащенные злаки и хлеб }\end{array}$ & $\begin{array}{l}\text { Созревание эритроцитов, синтез } \\
\text { пуринов, пиримидинов, и } \\
\text { метионина, развитие } \\
\text { эмбриональной нервной системы }\end{array}$ \\
\hline $\begin{array}{c}\text { Витамин В12 } \\
\text { (кобаламины) } \\
\mathbf{2} \text { - } 5 \text { мкг }\end{array}$ & $\begin{array}{l}\text { Мясо, домашняя птица, яйца, } \\
\text { обогащенные злаки, молоко и } \\
\text { молочные продукты, моллюски, } \\
\text { үстрицы, макрель, лосось }\end{array}$ & $\begin{array}{l}\text { Созревание эритроцитов, функции } \\
\text { ЦНС, Синтез ДНК, синтез и } \\
\text { регенерация миелина }\end{array}$ \\
\hline $\begin{array}{c}\text { Витамин С } \\
\text { (аскорбиновая } \\
\text { кислота) } \\
90-100 \mathrm{мг}\end{array}$ & $\begin{array}{l}\text { Цитрусовые, помидоры, картофель, } \\
\text { брокколи, земляника, сладкий перец }\end{array}$ & $\begin{array}{l}\text { Формирование коллагена, костей и } \\
\text { кровеносных сосудов, карнитина, } \\
\text { гормонов и аминокислот. }\end{array}$ \\
\hline
\end{tabular}


В человеческом организме витамины практически не синтезируются или синтезируют в недостаточном количестве, поэтому они должны в достаточном количестве поступать в организм извне. Необходимо отметить, что несмотря на то, что суточная потребность в витаминах невелика, при недостаточном их поступлении наступают характерные и опасные для человека патологические изменения.

В современных условиях питание населения России характеризуется рядом серьезных нарушений. В ряде исследований демонстрируются дефицит большинства витаминов (аскорбиновой кислоты - у 70-100\% населения; тиамина, рибофлавина и фолиевой кислоты до $60 \%$ населения; $\beta$-каротина - у 40-60\%). Основные клинические проявления витаминной недостаточности представлены в таблице (табл. 72 ).

Таблица 72

\section{Наиболее часто встречающиеся симптомы гиповитаминоза}

\begin{tabular}{|c|c|}
\hline Симптомы & Недостаточность витамина \\
\hline Ангулярный стоматит, хейлоз & Рибофлавин, пиридоксин \\
\hline Глоссит & $\begin{array}{l}\text { Рибофлавин, пиридоксин, цианокобаламин, } \\
\text { никотиновая кислота, фолиевая кислота }\end{array}$ \\
\hline Бледность кожи и слизистых оболочек & $\begin{array}{l}\text { Аскорбиновая кислота, цианокобаламин, } \\
\text { никотиновая кислота, фолиевая кислота, } \\
\text { биотин, ретинол }\end{array}$ \\
\hline Сухость кожи & $\begin{array}{l}\text { Аскорбиновая кислота, пиридоксин, биотин, } \\
\text { ретинол }\end{array}$ \\
\hline Себорейное шелушение кожи & Рибофлавин, пиридоксин, биотин, ретинол \\
\hline Угри, фурункулы & Пиридоксин, никотиновая кислота, ретинол \\
\hline Сухость, волос, выпадение, перхоть & Пиридоксин, биотин, ретинол \\
\hline $\begin{array}{l}\text { Диспептические расстройства, диарея, } \\
\text { нарушения моторики кишечника }\end{array}$ & $\begin{array}{l}\text { Цианокобаламин, никотиновая кислота, } \\
\text { фолиевая кислота, ретинол }\end{array}$ \\
\hline Конъюнктивит & Рибофлавин, пиридоксин, ретинол \\
\hline Микроцитарная гипохромная анемия & Пиридоксин \\
\hline Микроцитарная гиперхромная анемия & Цианокобаламин, фолиевая кислота \\
\hline Парестезии & Тиамин, цианокобаламин \\
\hline Периферические полиневриты & Тиамин, пиридоксин \\
\hline $\begin{array}{l}\text { Повышенная восприимчивость к } \\
\text { инфекциям }\end{array}$ & Аскорбиновая кислота, ретинол \\
\hline Астенический синдром & $\begin{array}{l}\text { Аскорбиновая кислота, тиамин, рибофлавин, } \\
\text { цианокобаламин, ретинол, токоферол }\end{array}$ \\
\hline Раздражительность, беспокойство & $\begin{array}{l}\text { Аскорбиновая кислота, тиамин, пиридоксин, } \\
\text { цианокобаламин, никотиновая кислота, } \\
\text { биотин }\end{array}$ \\
\hline Бессонница & Пиридоксин, никотиновая кислота \\
\hline $\begin{array}{l}\text { Светобоязнь, нарушение сумеречного } \\
\text { зрения }\end{array}$ & Ретинол, рибофлавин \\
\hline Склонность к геморрагиям & Аскорбиновая кислота, токоферол \\
\hline Тошнота & Тиамин, пиридоксин \\
\hline
\end{tabular}

Для подтверждения гиповитаминоза целесообразно определение витаминов и микроэлементов крови. Особенно это важно для витамина D, B12 и фолиевой кислоты особенно женщинам в период беременности. Показатели содержания витаминов представлены в таблице (табл.73). 
Таблица 73

\section{Референсные значения содержания витаминов и причины их изменений}

\begin{tabular}{|c|c|c|c|}
\hline \multirow{2}{*}{ Витамин } & \multirow{2}{*}{ Значение } & \multicolumn{2}{|c|}{ Основная причина понижения } \\
\hline & & Заболевания & Препараты \\
\hline $\begin{array}{l}\text { Витамин A } \\
\text { (ретинол) }\end{array}$ & $\begin{array}{c}0,3-0,43 \\
\mathrm{Mкг} / \mathrm{Mr}\end{array}$ & $\begin{array}{l}\text { Гипотиреоз, хронические инфекции, } \\
\text { болезни печени, ЖКТ, панкреатиты, } \\
\text { алкоголизм. }\end{array}$ & $\begin{array}{l}\text { Препараты аллопуринола, } \\
\text { холестирамина, колестипола, } \\
\text { неомицина. }\end{array}$ \\
\hline $\begin{array}{l}\text { Витамин B1 - } \\
\text { тиамин }\end{array}$ & $\begin{array}{l}1,06-3,98 \\
\mathrm{Hг/Mл}\end{array}$ & $\begin{array}{l}\text { Голодание. Сепсис, ожоги, травмы. } \\
\text { Патология желудочно-кишечного } \\
\text { тракта с нарушением всасывания. } \\
\text { Диализ. Алкоголизм. }\end{array}$ & $\begin{array}{l}\text { После } \\
\text { хирургии. }\end{array}$ \\
\hline $\begin{array}{l}\text { Витамин В2 - } \\
\text { рибофлавин }\end{array}$ & $\begin{array}{l}\text { 40-240 } \\
\text { нг/Мл. }\end{array}$ & $\begin{array}{l}\text { Алкоголизм. Гипотиреоз. Болезни } \\
\text { печени. Анорексия. Мальабсорбция. }\end{array}$ & Фототерапия детей с желтухой \\
\hline $\begin{array}{l}\text { Витамин В3 - } \\
\text { никотинамид }\end{array}$ & $\begin{array}{l}5,2-72,1 \\
\mathrm{нг/Mл}\end{array}$ & Анорексия. Язвенный колит. & $\begin{array}{l}\text { Глибенкламид, изониазид, } \\
\text { вальпроевая кислота }\end{array}$ \\
\hline $\begin{array}{l}\text { Витамин В5 - } \\
\text { пантотеновая } \\
\text { кислота }\end{array}$ & $\begin{array}{l}0,037-0,147 \\
\text { Мкг/мл }\end{array}$ & $\begin{array}{lcc}\text { Хронические } & \text { нарушения } & \text { питания. } \\
\text { Болезни } & \text { сердечно-сосудистой } \\
\text { системы. } & \text { Язвенная } & \text { болезнь. } \\
\text { Ревматизм. Алкоголизм. } & \end{array}$ & \\
\hline $\begin{array}{l}\text { Витамин В6, } \\
\text { пиридоксин }\end{array}$ & 5-50 нг/мл. & $\begin{array}{lcr}\text { Нарушения } & \text { всасывания. } & \text { Уремия. } \\
\text { Беременность. } & \text { Астма. } & \text { Инфаркт. } \\
\text { Алкоголизм. } & & \\
\end{array}$ & 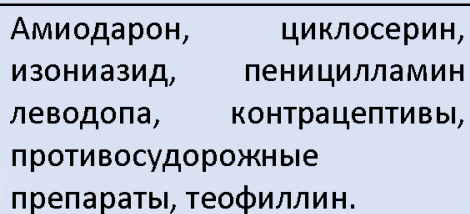 \\
\hline $\begin{array}{l}\text { Фолиевая } \\
\text { кислота }\end{array}$ & $\begin{array}{l}\text { 3,1-20,5 } \\
\text { нг/мл. }\end{array}$ & $\begin{array}{l}\text { Анорексия. Беременность, лактация. } \\
\text { Анемия. Пожилой возраст. Лихорадка, } \\
\text { септические состояния. Болезни } \\
\text { печени. } \\
\text { заболевания. Миелопролиферативные } \\
\text { опухоли. Гемодиализ. Алкоголизм. }\end{array}$ & $\begin{array}{l}\text { Аспирин, противосудорожные } \\
\text { препараты, контрацептивы, } \\
\text { эстрогены, нитрофуранов, } \\
\text { антациды, холестирамин, } \\
\text { сульфасалазина, метотрексат, } \\
\text { азатиоприн и пр. }\end{array}$ \\
\hline $\begin{array}{l}\text { Витамин В12, } \\
\text { Голотранскоба- } \\
\text { ламин }\end{array}$ & $\begin{array}{l}25,0-165,0 \\
\text { пмоль/л }\end{array}$ & $\begin{array}{l}\text { Резекция различных участков ЖКТ. } \\
\text { Хронические воспалительные } \\
\text { заболевания жКт. Паразитарные } \\
\text { инвазии. Болезнь Аддисона - Бирмера. } \\
\text { Синдром Иммерслунда - Гресбека. } \\
\text { Дефицит фолиевой кислоты; } \\
\text { Вегетарианская диета. Алкоголизм. }\end{array}$ & $\begin{array}{l}\text { Противосудорожных средств } \\
\text { (фенобарбитал, фенитоин), } \\
\text { антибиотики, холестирамина, } \\
\text { контрацептивы, ранитидин, } \\
\text { циметидин, метформин, } \\
\text { триамтерен. }\end{array}$ \\
\hline $\begin{array}{l}\text { Витамин С, } \\
\text { аскорбиновая } \\
\text { кислота }\end{array}$ & $\begin{array}{l}4,0-15,0 \\
\text { мкг/мл }\end{array}$ & $\begin{array}{l}\text { Гемодиализ. Анемия. Беременность. } \\
\text { Стеаторея. Алкоголизм. Нарушения } \\
\text { всасывания. } \\
\text { Онкологические заболевания. }\end{array}$ & 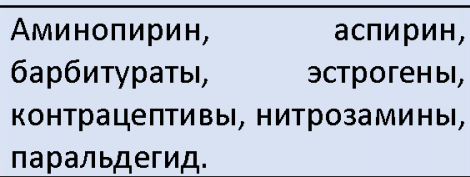 \\
\hline $\begin{array}{l}\text { Витамин D, } \\
\text { гидроксикальце- } \\
\text { ферол }\end{array}$ & $\begin{array}{l}\text { 30-100 } \\
\mathrm{Hг} / \mathrm{M} л\end{array}$ & $\begin{array}{l}\text { Нарушения питания, мальабсорбция. } \\
\text { Стеаторея. Цирроз. Остеомаляция. } \\
\text { Тиреотоксикоз. Панкреатит. Целиакия. } \\
\text { Воспалительные } \\
\text { кишечника, резекция каболевания } \\
\text { Рахит. }\end{array}$ & $\begin{array}{lr}\text { Применение } & \text { гидроксида } \\
\text { алюминия, } & \text { холестирамина, } \\
\text { холестипола, } & \text { этидроната } \\
\text { динатрия, глюкокортикоидов, } \\
\text { изониазида, рифампина. }\end{array}$ \\
\hline $\begin{array}{l}\text { Витамин } \\
\text { альфа- } \\
\text { токоферол }\end{array}$ & $\begin{array}{l}0,1-40 \\
\text { мкг/мл. }\end{array}$ & 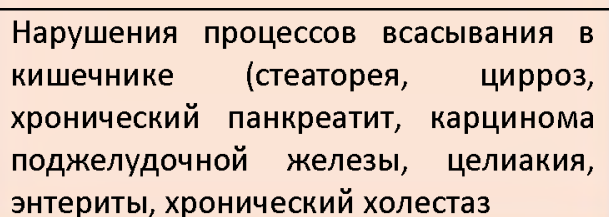 & $\begin{array}{l}\text { противосудорожные } \\
\text { препараты холестирамина, } \\
\text { этанол, минеральных масел. }\end{array}$ \\
\hline
\end{tabular}




\section{ДИАГНОСТИКА ИММУННЫХ НАРУШЕНИЙ}

\section{Глава 14. Болезни гиперчувствительности}

Аллергии и аутоиммунная патология - это обширная группа разнородных по клиническим проявлениям заболеваний, развивающихся вследствие патологической реакции антител и/или клонов киллерных клеток против нормальных тканей и органов организма с развитием воспаления (гиперчувствительность). Все типы гиперчувствительности являются результатом нарушения механизма реализации иммунного ответа организма (табл.74).

Таблица 74

\section{Механизмы, лежащие в основе развития гиперчувствительности}

\begin{tabular}{|c|c|}
\hline Патофизиологические проявления & Клинические проявления \\
\hline \multicolumn{2}{|c|}{ I тип - анафилактический } \\
\hline $\begin{array}{l}\text { При первичном контакте с антигеном } \\
\text { образуются IgE, прикрепляющиеся Fс-фрагментом } \\
\text { к базофилам и тучным клеткам. Повторное } \\
\text { введение антигена вызывает его связывание с } \\
\text { антителами и дегрануляцию клеток с выбросом } \\
\text { медиаторов воспаления (гистамина и др.). }\end{array}$ & $\begin{array}{l}\text { 1-6 ч после воздействия аллергена. Крапивница, отек, } \\
\text { бронхоспазм, анафилактический шок и др. } \\
\text { Эозинофильный эзофагит }\end{array}$ \\
\hline \multicolumn{2}{|c|}{ II тип - цитотоксический } \\
\hline $\begin{array}{l}\text { Расположенный на мембране клетки антиген } \\
\text { распознается антителами. После этого происходит } \\
\text { разрушение клетки путём: фагоцитоза в основном } \\
\text { макрофагами и нейтрофилами и/или комплемент- } \\
\text { зависимого цитолизиса и/или антителозависимой } \\
\text { клеточной цитотоксичности NК-лимфоцитами }\end{array}$ & $\begin{array}{l}\text { 5-15 дней от начала приема препарата Лекарственная } \\
\text { аллергия (агранулоцитоз) } \\
\text { Миокардит, синдром Дресслера, антигломерулярный } \\
\text { нефрит, пузырчатка, крапивница, гемолитическая анемия, } \\
\text { дерматомиозит, полимиозит, болезнь Грейвса, синдром } \\
\text { Шегрена, антифосфолипидный синдром, тромбоцитопения, } \\
\text { ревматическая лихорадка, миастения, грануломатоз Вегенера }\end{array}$ \\
\hline \multicolumn{2}{|c|}{ III тип - иммунокомплексный } \\
\hline $\begin{array}{l}\text { Антитела классов IgG, IgM образуют с } \\
\text { антигенами иммунные комплексы, откладываться } \\
\text { при недостатке лизирующего их комплемента на } \\
\text { стенке сосудов, базальных мембранах с } \\
\text { последующим развитием воспаления }\end{array}$ & $\begin{array}{l}\text { На 1-21-й день от начала приема лекарствен, } \\
\text { препарата Сывороточная болезнь } \\
\text { Бактериальный эндокардит, дискоидная красная } \\
\text { волчанка, ревматоидный артрит, системная красная } \\
\text { волчанка, васкулит, идиопатическая криогло-булинемия }\end{array}$ \\
\hline \multicolumn{2}{|c|}{ IV тип - клеточный } \\
\hline $\begin{array}{l}\text { Взаимодействие антигена с макрофагами и Т- } \\
\text { хелперами 1-го типа со стимуляцией клеточного } \\
\text { иммунитета с активацией моноцитов и/или } \\
\text { эозинофилов и/или нейтрофилов и/или } \\
\text { цитотоксических Т лимфоцитов и/или Th }\end{array}$ & $\begin{array}{l}\text { На 1-21-й день контактный дерматит, лекарственная } \\
\text { аллергия, экзема, буллезная экзантема, Макулопа } \\
\text { пулезная экзантема, синдром Стивенса-Джонсона Острый } \\
\text { генерализованный экзантематозный пустулез } \\
\text { Аутоиммунный гепатит, интерстициальный цистит, } \\
\text { сахарный диабет } 1 \text { типа, аутоиммунный тиреоидит, } \\
\text { целиакия, язвенный колит, синдром Гийена - Барре, } \\
\text { рассеянный склероз }\end{array}$ \\
\hline \multicolumn{2}{|c|}{ V тип - реакции врожденного иммунитета } \\
\hline $\begin{array}{l}\text { Воспаление формируется без участия } \\
\text { взаимодействия антител и/или } \\
\text { сенсибилизированных лимфоцитов }\end{array}$ & $\begin{array}{l}\text { Псевдоаллергические реакции } \\
\text { Аутовоспалительные заболевания в т.ч. подагра, } \\
\text { болезнь Крона, псориаз, саркоидоз и пр. }\end{array}$ \\
\hline
\end{tabular}


Механизмы развития аллергии и аутоиммунной патология схожи. Принципиальным различием являются то, что гиперчувствительность при аллергии формируется на внешние факторы (пыльца, продукты питания, укус насекомых и реакции на лекарства), а при аутоиммунной патологии формируется иммунный ответ к антигенным детерминантам органов и тканей собственного организма.

В основе аллергической и аутоиммунной реакций лежит иммунологический механизм, т.е. сенсибилизированный организм отвечает реакцией только на антигенные структуры (детерминанты), использованные для сенсибилизации, или же на родственные им молекулы. В отдельные группы заболеваний необходимо выделить типы гиперчувствительности без специфической сенсибилизации, что имеет решающее значение при лечении пациента. Это группа псевдоаллергических реакций, когда дегрануляция тучных клеток и базофилов происходит без IgE-зависимой реакции гиперчувствительности и группа аутовоспалительных болезней, в основе которых лежат нарушение регуляции механизмов воспаления.

Аллергия - это хроническое заболевание, вызванное неадекватной, нежелательной и неожиданной реакцией иммунной системы на воздействие веществ, которые обычно не приводят к заболеванию и не наносят вред человеку (продукты питания, лекарства, пыльца растений, яд насекомых и пр.). Ожидается, что к середине тысячелетия (2050 год) половина человечества будет страдать аллергией. В настоящее время эти цифры так же высоки (табл.75). Любой врач практически ежедневно сталкивается с этой патологией.

Таблица 75.

\section{Эпидемиология аллергических заболеваний.}

\begin{tabular}{|l|l|}
\hline \multicolumn{1}{|c|}{ Тип аллергии } & \multicolumn{1}{|c|}{ Распространенность } \\
\hline Аллергический ринит & 5-11\% населения \\
\hline Астма & 3-6\% населения. Увеличение за последнее десятилетие на 50\% \\
\hline Атопический дерматит & $9 \%$ населения, около 1\% тяжелые \\
\hline Укус насекомого & $\begin{array}{l}\text { У 15\% взрослых легкие локализованные аллергические } \\
\text { реакции. Системные реакции у 3\% взрослых и 1\% детей }\end{array}$ \\
\hline Пищевые аллергии & $\begin{array}{l}\text { 1-3\% среди взрослых и 4\%-6\% среди детей. } \\
\text { Наиболее сильную реакцию вызывают: изделия из дробленого } \\
\text { зерна, содержащие глютен, моллюски и ракообразные, яйца, } \\
\text { рыба, арахисы, соя, молоко и лесные орехи. }\end{array}$ \\
\hline $\begin{array}{l}\text { Множественная аллергия (астма, } \\
\text { экзема и аллергический ринит вместе) }\end{array}$ & $\begin{array}{l}\text { около 4\% населения мира, увеличение на 50 48,9\% в период с } \\
\text { 2001. }\end{array}$ \\
\hline Анафилаксия & $\begin{array}{l}\text { Не менее 40 смертей в год от укуса насекомых, около 400 } \\
\text { смертей из-за анафилаксии пенициллина, не менее 150 человек } \\
\text { умирают от пищевой аллергии }\end{array}$ \\
\hline
\end{tabular}

Аллергия характеризуется общим и/или местным воспалительным ответом на аллергены (табл. 76), при этом в формирование клинических проявлений аллергии и развитие отдельных нозологических форм вовлечены, как правило, не один, а несколько типов реакций гиперчувствительности. Например, в анафилактических реакциях (помимо основного, ведущего - I типа) может участвовать и тип II, а при лекарственной аллергии определяются все 4 типа гиперчувствительности.

В клиническом течении развития аллергии необходимо выделить фазы раннего и позднего ответа. Фаза раннего иммунного ответа (немедленного типа) формируется за счет чрезмерной секреции $\mathrm{IgE}$, образование антител и/или сенсибилизированных лимфоцитов, адсорбции их на тучных клетках и базофилах. Последующий контакт с тем же специфическим аллергеном приводит к дегрануляции чувствительных мастоцитов и базофилов на внедрение аллергена (иммунологическая стадия). Активированные клетки выделяют гистамин, лейкотриены и другие медиаторы воспаления (патохимическая стадия аллергии). Под воздействием медиаторов происходит вазодилатация, секреция слизи, раздражение нервных окончаний, сокращение гладких мышц в стенках бронхов и т.д. (см.гл.2-3). 
Таблица 76.

Клинические проявления аллергии

\begin{tabular}{|l|l|}
\hline \multicolumn{1}{|c|}{ Орган } & \multicolumn{1}{|c|}{ Признаки и симптомы } \\
\hline Нос & $\begin{array}{l}\text { Отек слизистой оболочки носа (ринит), насморк, } \\
\text { чихание }\end{array}$ \\
\hline Пазухи & Синусит со слизистым отделяемым \\
\hline Глаза & Покраснение и зуд конъюнктивы, слезотечение \\
\hline Дыхательные пути & $\begin{array}{l}\text { Чихание, кашель, бронхоспазм, хрипы и одышка , } \\
\text { иногда прямые приступы астмы, в тяжелых случаях } \\
\text { сужение дыхательных путей из-за отека, известного } \\
\text { как отек гортани }\end{array}$ \\
\hline Уши & $\begin{array}{l}\text { Боль и нарушение слуха из-за отсутствия дренажа } \\
\text { евстахиевой трубы. }\end{array}$ \\
\hline Кожа & Сыпь, экзема или крапивница \\
\hline Желудочно-кишечный тракт & Боль в животе, вздутие живота, рвота, диарея \\
\hline $\begin{array}{l}\text { Системный аллергический ответ, } \\
\text { анафилакся }\end{array}$ & $\begin{array}{l}\text { Кожные реакции, бронхоспазм, отёк, гипотонию, кому } \\
\text { и даже смерть }\end{array}$ \\
\hline
\end{tabular}

Фаза позднего иммунного ответа (замедленного типа) развивается после прекращения действия медиаторов воспаления спустя 4-6 часов после первичной реакции и может продлиться 1-2 дня. Она формируется за счет миграции в очаг воспаления нейтрофилов, лимфоцитов, эозинофилов и макрофагов.

Вообше иммунный ответ с использованием $\operatorname{IgE}$ необходимо рассматривать как альтернативный в некотором смысле запасной более мощный воспалительный ответ в отличии от иммунитета, формируемого другими иммуноглобулинами и поэтому часто IgE повышается при гипогаммаглобулинемиях с развитием псевдоаллергической реакции.

Псевдоаллергическая реакция (антигеннезависимая дегрануляция тучных клеток) это IgE-независимые реакции гиперчувствительности с теми же патофизиологическими последствиями и клиническими проявлениями, что и при истинной аллергии (атопии). Триггерами могут быть продукты деградации коллагена, хемокины (ИЛ-8, МСР-1, МІР-1а, RANTES), цитокины (ИЛ-3, GM-CSF), продукты активированного комплемента анафилатоксины (C5a, C3a), катионный белок эозинофилов, естественные пептиды (субстанция $\mathrm{P}$, нейропептиды, нейротензин, каллидин, брадикинин и др.), лекарственные средства (опиаты, ацетилсалициловая кислота и другие НПВС, цитостатики, рентгеноконтрастные вещества и пр.), пищевые продукты (табл.77), физические факторы (физические нагрузки, переохлаждение, перегревание, инсоляция и т.д.). Неспецифическое высвобождение гистамина способны индуцировать: грамотрицательные и грамположительные бактерии и компоненты их стенок, белок А стафилококка, гемолизины и фосфолипаза С синегнойной палочке, консерванты (Е 102, E 110, Е 127, Е 160, Е 210, Е 211/219, Е 200-208, е 621-625,).

Таблица 77.

Гистаминосодержащие продукты и гистаминолибераторы

\begin{tabular}{|c|l|}
\hline \multicolumn{1}{|c|}{$\begin{array}{c}\text { Продукты с большим содержанием } \\
\text { гистамина и его аналогами }\end{array}$} & \multicolumn{1}{|c|}{ Продукты гистаминолибераторы } \\
\hline \multicolumn{1}{|c|}{ Клубника, помидоры, моллюски, шоколад, шпинат, яйца } \\
\hline $\begin{array}{l}\text { Сыр, бананы, вино, пиво, рыба, курица, } \\
\text { говядина, консервированные продукты }\end{array}$ & $\begin{array}{l}\text { Ананас, курица, соя и ее продукты, специи, } \\
\text { цитрусовые }\end{array}$ \\
\hline
\end{tabular}

Развитие псевдоаллергии может быть связано с нарушение процессов инактивации гистамина и накоплению его в тканях, при длительном приеме некоторых медикаментов (снижении содержания моноаминооксидазы), при циррозе печени (заброс крови из системы 
печеночной вены в общий кровоток), при избыточном поступлении или образовании гистамина в кишечнике (пищевые продукты гистаминолибераторы и содержащие гистамин, повышении проницаемости слизистой кишечника, избыточное образование гистамина и тирамина за счет кишечной микрофлоры).

Важным является дифференциальная диагностика атопических реакциях и других заболеваний со схожей клинической картиной (табл. 78).

\section{Таблица 78}

\section{Характеристика поражений кожи при гиперчувствительности}

\begin{tabular}{|c|c|}
\hline Возможная этиология & Отличительные характеристики \\
\hline Анафилаксия & $\begin{array}{l}\text { Боль в животе, головокружение, гипотензия, большие эритематозные пятна, } \\
\text { одышка, стридор, тахикардия }\end{array}$ \\
\hline Атопический дерматит & $\begin{array}{l}\text { Зуд, признаки трения или царапин (макулопапулезная, чешуйчатая сыпь) } \\
\text { разгибательных поверхностей передней части лодыжек кожи вокруг глаз или } \\
\text { шеи, в анамнезе астмы или аллергического ринита (в т.ч. у родственников), } \\
\text { наличие сухой кожи (в течение последнего года) }\end{array}$ \\
\hline $\begin{array}{l}\text { Аллергия на лекарства } \\
\text { (прямая дегрануляция } \\
\text { тучных клеток) }\end{array}$ & $\begin{array}{l}\text { Использование или изменение приема лекарственных средств. Часто } \\
\text { буллезная сыпь, гиперпигментация }\end{array}$ \\
\hline Пищевая аллергия & Прием пищи, связанные с симптомами \\
\hline $\begin{array}{l}\text { Холинергическая } \\
\text { крапивница }\end{array}$ & $\begin{array}{l}\text { Маленькие волдыри (от } 1 \text { до } 3 \text { мм); жжение или зуд; вызвано жарой, } \\
\text { физическими упражнениями или стрессом }\end{array}$ \\
\hline $\begin{array}{l}\text { Пигментная крапивница } \\
\text { (кожный мастоцитоз) }\end{array}$ & $\begin{array}{l}\text { Мелкие поражения (от } 1 \text { до } 3 \text { мм), пигментация от желтого до коричневого, } \\
\text { диффузное утолщение, пузыри }\end{array}$ \\
\hline Контактный дерматит & $\begin{array}{l}\text { Нечеткие края сыпи, папулезные, стойкие поражения, присутствует } \\
\text { эпидермальный компонент }\end{array}$ \\
\hline Красный плоский лишай & Полиморфные высыпаний с папулами, сопровождающееся зудом \\
\hline $\begin{array}{l}\text { Розовый лишай, } \\
\text { лишай Жибера }\end{array}$ & Пятнистыми высыпаниями от 4 до 6 недель, без зуда \\
\hline Вирусные экзантемы & $\begin{array}{l}\text { Отсутствие зуда, продрома, лихорадки, пятнисто-папулезных поражений, } \\
\text { отдельных поражений продолжительностью несколько дней. Выявление } \\
\text { инфекций }\end{array}$ \\
\hline Паразитарные инвазии & Наличие эпидемиологического анамнеза Выявление инвазии \\
\hline ХВГВ ХВГС ВИЧ & Криоглобулинемия, выявление инфекций \\
\hline $\begin{array}{l}\text { Аутоиммунное } \\
\text { заболевание }\end{array}$ & Боль в суставах, увеит, лихорадка, системные симптомы \\
\hline $\begin{array}{l}\text { Аутовоспалительные } \\
\text { синдромы }\end{array}$ & Сыпью, артрит, лихорадка признаки системного воспаления \\
\hline $\begin{array}{l}\text { Аутоиммунный } \\
\text { прогестероновый дерматит }\end{array}$ & Предменструальный обострение. Беременность \\
\hline Лимфома & Потеря веса (непреднамеренная), лихорадка, ночная потливость \\
\hline Пурпура Геноха-Шенлейна & Чаще на нижних конечностей, пурпурные поражения, системные симптомы \\
\hline Уртикарный васкулит & $\begin{array}{l}\text { Волдыри, сохраняющаяся более } 24 \text { часов, непрозрачные папулы, жжение или } \\
\text { другой дискомфорт, остаточная гиперпигментация, лихорадка, артралгии }\end{array}$ \\
\hline Буллезный пемфигоид & $\begin{array}{l}\text { Поражения продолжительностью более } 24 \text { часов, волдыри, признак } \\
\text { Никольского (легкое трение вызывает эрозию или везикулу) }\end{array}$ \\
\hline Многоформная эритема & $\begin{array}{l}\text { Поражения, продолжающиеся несколько дней, папулы в форме радужки, } \\
\text { целевой вид, возможно повышение температуры }\end{array}$ \\
\hline Гипотиреоз & Тиромегалия, увеличение веса, непереносимость холода \\
\hline
\end{tabular}

Аутоиммунные заболевание представляет собой состояние, возникающее вследствие ненормального иммунного ответа аутореактивными лимфоцитами, которые распознают антигены собственного организма как чужеродные и запускают патологические эффекторные процессы аутоиммунных заболеваний. Патологические реакции реализуются через 
гуморальные (аутоантитела) и/или клеточные (аутореактивные клоны лимфоцитов) иммунные реакции с деструкцией клеток-мишеней и тканей-мишеней, с нарушением их функций (как сниженной, так и усиленной) и формированием хронического воспаления.

Существует более 100 различных аутоиммунных заболеваний, при которых может быть задействована практически любая область организма человека. Распространенность диагностированных аутоиммунных состояний в разных странах составляет от 2 до 8\%, поражаются преимущественно женщины подросткового возраста и/или от 40 до 50 лет. Легкие формы заболевания диагностируются редко.

В основе запуска аутоиммунной патологии можно выделить три этиопатогенных фактора: генетический, триггер окружающей среды и ошибки в регуляции иммунного ответа.

Существует множество доказательств генетической предрасположенности $\kappa$ развитию аутоиммунных заболеваний. Основные гены, имеющие сильную связь со многими аутоиммунными заболеваниями, находятся в локусе МНС. Это анкилозирующий спондилит (HLA- B27), реактивный артрит (HLA-B27), псориаз (HLA B-13, B-16, B-17), системная красная волчанка (HLA-DR2 и DR3), ревматоидный артрит (HLA-DR4), сахарный диабет 1 типа (HLA-DR3 и DR4), рассеянный склероз (HLA-DR2). Генетические аномалии NOD2/CARD15 и NFкB приводят к индукции воспаления слизистой оболочки кишечника. Однако не всегда у носителей определенного гена и/или мутации того или иного гена развивается заболевание. Так, например 90\% пациентов с анкилозирующим спондилитом имеют ген HLA-B27, но не у всех людей с этим геном развивается заболевание. Первичные иммунодефициты также могут проявляться в виде гиперэргических синдромом с аутоиммунными заболеваниями.

Поэтому большое значение приобретают триггеры окружающей среды и прежде всего инфекции и инвазии и связанные с ними механизмы, а именно:

- Антигенная мимикрия патогенов прежде всего вирусов (они включают в состав своего генома гены клеток хозяина) индуцирует иммунный ответ с перекрёстной реактивностью с собственными антигенами. В дальнейшем аутоиммунный процесс не выходит в режим полноценной иммуносупрессии, поскольку свой антиген не может быть элиминирован и продолжает активировать аутореактивные лимфоциты.

- Микробные суперантигены вызывают поликлональную активацию лимфоцитов. Какие-то из клонов лимфоцитов, специфичные к собственным антигенам, могут войти в режим эффекторного иммунного ответа. Этим и обусловлено влияние микробиоты на развитие аутоиммунных болезней.

- Деструкция тканей патогеном (цитопатогенное действие вирусов, бактерий и др.) приводит к попаданию тканевых антигенов в активированные (тем же патогеном) ДК, которые могут утратить способность к индукции толерантности к собственным антигенам и вместо этого запускать иммунный ответ, реализуемый, как правило, с участием Th1-лимфоцитов.

- Т-лимфоциты могут нести 2 и более разньх по специфичности рецептора. Есть вероятность, что один из TCR может иметь специфичность к патогену, а второй - к аутоантигену. Активация иммуногенеза патогеном приведёт к созданию клона лимфоцитов, которые будут работать в качестве эффекторов против обоих антигенов - чужеродного и своего.

Нарушение функции регуляции одна из основных причин развития аутоиммунной патологии. И прежде всего это связано со срывом толерантности. Механизмы контроля иммунной системой содержат и элементы иммунной невосприимчивости к собственным антигенам (толерантность). Толерантность индуцируется и поддерживается центральными, и периферическими механизмами делеции «запрещенных клонов лимфоцитов», их клональной делеции с анергией на данный антиген (толероген). Толерантность является селективной в отношении толерогена, который ее индуцировал, что способствует постоянной реакции на другие антигены. Этим она отличается от общего подавления иммунитета (например, индуцированного иммуносупрессивными препаратами). Важное значение для селекции имеет и аутоиммунный регулятор фактора транскрипции (AIRE). Он регулирует разрушения T- 
клетки, которые реагируют на антигены собственного организма. Дефицит AIRE приводит к аутоиммунной полиэндокринопатии-кандидозу-эктодермальной дистрофия (APECED), так же может проявляться множеством других аутоиммунных заболеваний.

Но это не единственный механизм. Дефицит количества и/или функции Treg приводит к аллергическим, аутоиммунным и другим воспалительным заболеваниям из-за потери толерантности за счет супрессивного действия Treg напрямую на аутореактивные клоны Tклеток посредством межклеточного взаимодействия и/или за счет подавления синтеза противовоспалительных цитокинов, таких как IL-10 и TGF- $\beta$. При этом TGF- $\beta$ в присутствии L-6 (например, из активированных макрофагов во время инфекции) и $\amalg-23$ также может стимулировать индукцию Th17 т.e. TGF- $\beta$ может регулировать воспаление через Treg, либо способствовать воспалению через Th17. Лимфоциты врожденного иммунитета также участвуют в регуляции аутоиммунных реакций (см. главу 3 ).

Нарушение взаимодействия между Т-клеточным ко-рецептором $\mathrm{CD} 28$ и костимулирующими молекулами антигенпрезентирующих клеток CD80/86 приведет к анергии, так же, как и взаимодействие с CTLA-4 и PD-1.

Толерантность В-клеток связана с тем, что при нормальном развитии В-клеток, Вклетки, распознающие аутоантигены, удаляются посредством апоптоза или становятся анергическими.

Признаки и симптомы зависит от места и типа возникающего аутоиммунного ответа. Основные области локализации аутоиммунных заболеваний: кровеносные сосуды, подлежащие соединительные ткани, суставы и мышцы, кишечник, эритроциты, кожа и эндокринные железы, такие как щитовидная железа или поджелудочная железа. Некоторые заболевания специфичны для органов и ограничиваются поражением определенных тканей, в то время как другие являются системными заболеваниями, поражающими многие ткани по всему телу. Признаки и симптомы могут различаться в зависимости от того, к какой из этих категорий относится заболевание.

У больного одновременно может быть симптомы нескольких заболеваний, при этом для аутоиммунных болезней характерна общая симптоматика в виде усталости, периодических подъёмов температуры, общим недомоганием, болями в мышцах и суставах, сыпью на разных участках кожи. Появление этих признаков и симптомов может меняться, и обычно появляются при обострении.

Несмотря на обширный класс разнородных по клиническим проявлениям заболеваний, по механизму аутоиммунизации можно выделить органоспецифичные и системные аутоиммунные заболевания, часть заболеваний имеют промежуточное положение (табл.79).

Органоспецифичные аутоиммунные заболевания - развиваются за счет нарушения гистогематических барьеров органов, обособленных от иммунной системы. В результате иммунная система реагирует на неизмененные антигены этих органов.

У системных аутоиммунных заболеваний - ведущими факторами являются нарушения в системе иммунобиологического надзора. Аутоиммунизация развивается по отношению к антигенам многих органов и тканей, в которых возникают изменения, характерные для гиперчувствительности как замедленного, так и немедленного типов.

Аутоиммунные заболевания промежуточного типа проявляются синдромами гиперчувствительности как замедленного, так и немедленного типов с поражением нескольких органов.

Отдельную группу заболеваний составляют аутовоспалительные заболевания гетерогенная группа заболеваний, патогенетически связанных с аномальной активацией врожденного иммунитета, клинически проявляются повторяющимися эпизодами лихорадки с системным воспалением, различными типами поражения кожи и/или слизистых и/или суставов (табл.80). 
Таблица 79.

\section{Основные аутоиммунные заболевания}

\begin{tabular}{|c|c|c|c|}
\hline Болезнь & $\begin{array}{c}\text { Основной } \\
\text { пораженный } \\
\text { орган }\end{array}$ & $\begin{array}{l}\text { Аутоантиген/ } \\
\text { аутоантитела }\end{array}$ & Клиническая картина \\
\hline \multicolumn{4}{|c|}{ Органоспецифические аутоиммунные заболевания } \\
\hline $\begin{array}{l}\text { Рассеянный } \\
\text { склероз }\end{array}$ & $\begin{array}{l}\text { Центральная } \\
\text { нервная система }\end{array}$ & \begin{tabular}{|l|} 
Основной белок миелина, \\
белок олигодендроцитов \\
миелина
\end{tabular} & $\begin{array}{l}\text { Потеря зрения, слабость } \\
\text { конечностей, сенсорные аномалии, } \\
\text { недержание мочи. }\end{array}$ \\
\hline $\begin{array}{l}\text { Симпатическая } \\
\text { офтальмия }\end{array}$ & Глаз & $\begin{array}{l}\text { Различные увеальные } \\
\text { антигены }\end{array}$ & $\begin{array}{l}\text { Боль в глазах, потеря зрения, } \\
\text { чувствительность к свету }\end{array}$ \\
\hline $\begin{array}{l}\text { Тиреоидит } \\
\text { Хасимото }\end{array}$ & $\begin{array}{l}\text { Щитовидная } \\
\text { железа }\end{array}$ & $\begin{array}{l}\text { Тиропероксидаза, } \\
\text { тиреоглобулин }\end{array}$ & $\begin{array}{l}\text { Гипотироидизм (увеличение веса, } \\
\text { запор, изменения кожи, } \\
\text { микседематозная деменция) } \\
\end{array}$ \\
\hline Асперматогения & Яички & Сперматозойды & Иммунное бесплодие \\
\hline $\begin{array}{l}\text { Иммунная } \\
\text { тромбоцитопения }\end{array}$ & Тромбоциты & $\begin{array}{l}\text { Гликопротеины на } \\
\text { поверхности тромбоцитов }\end{array}$ & Легкие синяки, кровотечения \\
\hline \multicolumn{4}{|c|}{ Системные аутоиммунные заболевания } \\
\hline $\begin{array}{l}\text { Ревматоидный } \\
\text { артрит }\end{array}$ & $\begin{array}{l}\text { Суставы, легкое, } \\
\text { нервы }\end{array}$ & \begin{tabular}{|l|} 
Цитрулиновые пептиды в \\
суставе, IgG
\end{tabular} & $\begin{array}{l}\text { Деформирующий артрит, кожные } \\
\text { узелки, иногда поражение легких и } \\
\text { нервов }\end{array}$ \\
\hline $\begin{array}{l}\text { Системная } \\
\text { красная волчанка }\end{array}$ & $\begin{array}{l}\text { Почки, кожа, } \\
\text { суставы, } \\
\text { центральная } \\
\text { нервная система } \\
\end{array}$ & $\begin{array}{l}\text { ДНК, гистоны, } \\
\text { рибонуклеопротеины } \\
\text { Недостаток утилизации ЦИК }\end{array}$ & $\begin{array}{l}\text { Артрит, кожные высыпания, почечная } \\
\text { недостаточность, поражение нервов }\end{array}$ \\
\hline $\begin{array}{l}\text { Системная } \\
\text { склеродермия }\end{array}$ & Кожа, мышцы & $\begin{array}{l}\text { Антиядерные антитела, } \\
\text { антицентромерные, анти- } \\
\text { scl70, к топоизомеразе. }\end{array}$ & $\begin{array}{l}\text { Диффузный кожный системный } \\
\text { склероз }\end{array}$ \\
\hline $\begin{array}{l}\text { Анкилозирующий } \\
\text { спондилит }\end{array}$ & $\begin{array}{l}\text { Суставы, } \\
\text { позвоночник }\end{array}$ & СD8 Т-клетки & $\begin{array}{l}\text { Боль в спине. Скованность } \\
\text { пораженных суставов }\end{array}$ \\
\hline \begin{tabular}{l|} 
Гранулематоз \\
Вегенера
\end{tabular} & Легкие, почки & Протеиназа 3 (c-ANCA) & $\begin{array}{l}\text { Синусит, одышка, почечная } \\
\text { недостаточность }\end{array}$ \\
\hline Псориаз & Кожа, суставы & CD8 Т-клетки & Кожные высыпания, артрит \\
\hline \multicolumn{4}{|c|}{ Аутоиммунные заболевания промежуточного типа } \\
\hline Болезнь Грейвса & $\begin{array}{l}\text { Щитовидная } \\
\text { железа }\end{array}$ & \begin{tabular}{|l|l|} 
Рецептор тиротропина & \\
\end{tabular} & Гипертиреоз, экзофтальм \\
\hline Миастения & Мышцы & Рецептор ацетилхолина & Слабость мышц, утомляемость \\
\hline \begin{tabular}{l|} 
Синдром \\
Шегрена
\end{tabular} & $\begin{array}{l}\text { Слюнные и } \\
\text { слезные железы }\end{array}$ & Ядерные антигены (SSA, SSB) & $\begin{array}{l}\text { Сухие глаза, сухость во рту, болезни } \\
\text { легких и почек }\end{array}$ \\
\hline $\begin{array}{l}\text { Сахарный диабет } \\
\text { I типа }\end{array}$ & $\begin{array}{l}\text { Поджелудочная } \\
\text { железа }\end{array}$ & $\begin{array}{l}\text { Островковые клетки, инсулин, } \\
\text { декарбоксилаза глутаминовой } \\
\text { кислоты }\end{array}$ & $\begin{array}{l}\text { Полифагия, полиурия, полидипсия, } \\
\text { похудание }\end{array}$ \\
\hline Болезнь Крона & Кишечник & микробные антигены & $\begin{array}{l}\text { Геморрагическая диарея, боли в } \\
\text { животе, дренирующие свищи } \\
\end{array}$ \\
\hline Язвенный колит & Толстая кишка & микробные антигены & $\begin{array}{l}\text { Геморрагическая диарея, боли в } \\
\text { животе }\end{array}$ \\
\hline Целиакия & Кишечник & $\begin{array}{l}\text { Т-лимфоциты, тканевая } \\
\text { трансглутаминаза, } \\
\text { эндомизиальный IgA, } \\
\text { глиадиновый IgA } \\
\end{array}$ & диарея, боли в животе \\
\hline $\begin{array}{l}\text { Синдром } \\
\text { Гудпастура }\end{array}$ & Легкие, почки & $\begin{array}{l}\text { Базальная мембрана } \\
\text { клубочков (коллаген IV типа) }\end{array}$ & $\begin{array}{l}\text { Почечная и дыхательная } \\
\text { недостаточность }\end{array}$ \\
\hline
\end{tabular}




\section{Аутовоспалительные заболевания}

\begin{tabular}{|c|c|}
\hline Причина & Заболевание \\
\hline $\begin{array}{l}\text { Нарушения активации } \\
\text { IL-1 } \beta\end{array}$ & 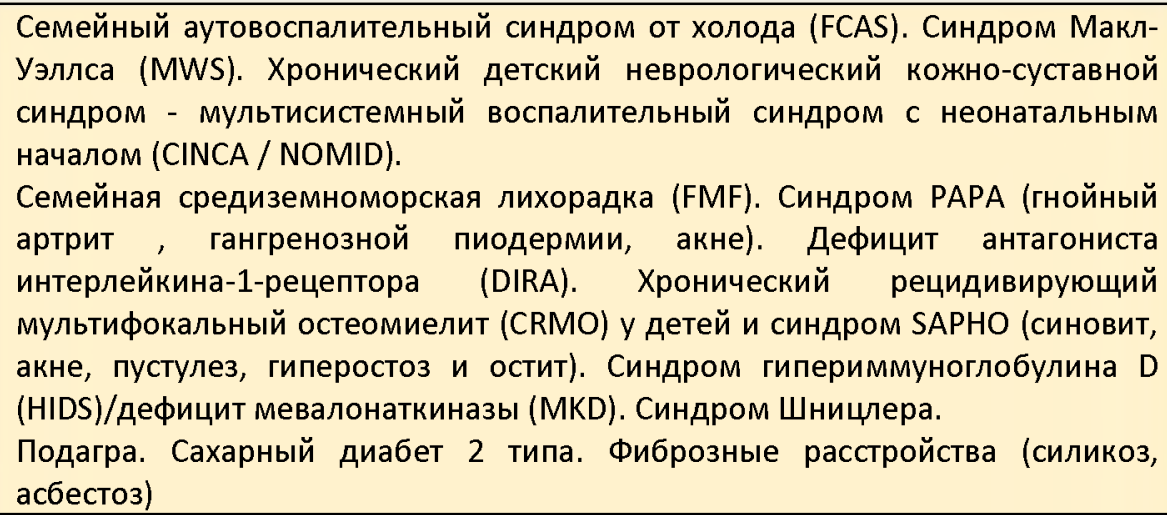 \\
\hline $\begin{array}{l}\text { Нарушения активации } \\
\text { NF- кB }\end{array}$ & $\begin{array}{l}\text { Семейный холодовой аутоиммунный синдром (FCAS2). Синдром Блау. } \\
\text { Синдром Яо (ҮАOS) } \\
\text { Болезнь Крона }\end{array}$ \\
\hline $\begin{array}{l}\text { Рецепторные } \\
\text { нарушения структуры } \\
\text { белков врожденной } \\
\text { иммунной системы }\end{array}$ & 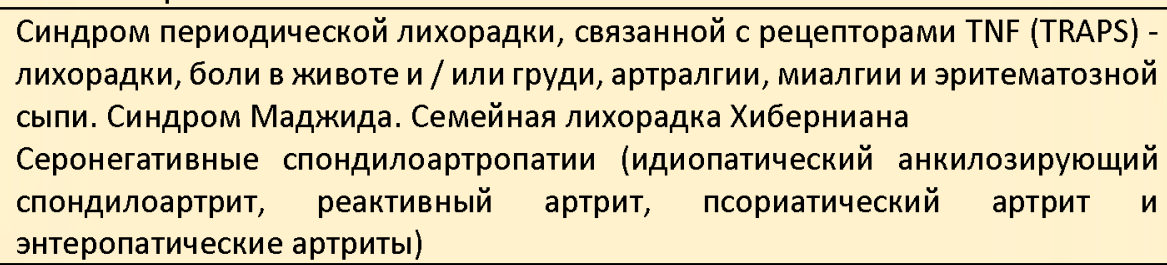 \\
\hline $\begin{array}{l}\text { Расстройства } \\
\text { комплемента }\end{array}$ & $\begin{array}{l}\text { Периодическая лихорадка, афтозный фарингит и аденопатия шейки матки } \\
\text { (РFAРА) } \\
\text { Приобретенный гемолитико-уремический синдром (аГУС) - гемолитическая } \\
\text { анемия, тромбоцитопения и почечная недостаточность, часто с } \\
\text { артериальной гипертензией и лихорадкой } \\
\text { Возрастная дегенерация желтого пятна -дефицит С1-ингибитор (подавление } \\
\text { системы комплемента) }\end{array}$ \\
\hline $\begin{array}{l}\text { Нарушения передачи } \\
\text { цитокиновых сигналов }\end{array}$ & Херувизм. Болезнь Фопта - Коянаги - Харада \\
\hline $\begin{array}{l}\text { Нарушения активация } \\
\text { макрофагов }\end{array}$ & $\begin{array}{l}\text { Семейный гемофагоцитарный лимфогистиоцитоз (HLH). Синдром Чедиака- } \\
\text { Хигаси. Синдром Гризелли. Х-сцепленный лимфопролиферативный } \\
\text { синдром. Синдром Германского-Пудлака (HPS). Болезнь Бехчета } \\
\text { Вторичный HLH. Атеросклероз }\end{array}$ \\
\hline
\end{tabular}

При классических моногенных аутовоспалительных заболеваниях поражения являются результатом различных мутаций в одном гене, который регулирует врожденный иммунитет. Эти мутации вызывают неконтролируемую активацию инфламмасомы, что приводит к сверхэкспрессии интерлейкина $I L-1 \beta$ и хемокинов, которые вызывают рекрутинг нейтрофилов, ключевых клеток аутовоспаления. Однако подобный патогенез заболеваний характерен и для других заболеваний, когда под воздействием множества как экзогенных, так и эндогенных стимулов происходит сверхнормальный синтез провоспалительных медиаторов, вызывающих повреждение ткани. Эти стимулы широкого спектра: холод, асбест, диоксид кремния и квасцы, эндогенных вещества (мочевая кислота и другие эндогенные продукты метаболизма).

Для эффективной терапии необходимо проводить четкое различие между аутовоспалительными заболеваниями, которые отражают дефекты врожденной иммунной системы, и аутоиммунными заболеваниями, которые выражают дефекты адаптивной иммунной системы. Хотя воспаление является проявлением, того и другого заболевания, но подходы к терапии будут различными. 
Отдельно хотелось бы остановится на синдроме вторичного гемофагоцитарного лимфогистиоцитоза (HLH) или синдроме активации макрофагов (MAS) - это термин, был впервые описан в ревматологии при потенциально опасном для жизни осложнения системных воспалительных заболеваний (системный ювенильный идиопатический артрит, системная красная волчанка (СКВ), болезнь Кавасаки, и периодические лихорадки). Гемофагоцитоз определяется как поглощение клеток крови, включая эритроциты (повышение ферритина), лейкоциты и тромбоциты, фагоцитарными клетками. Помимо этого, острая фаза MAS связана с заметно повышенным уровнем провоспалительных цитокинов. Этот цитокиновый шторм запускает каскад воспалительных процессов, которые, если их не лечить, приводят к повреждению тканей и смерти. Для MAS характерна неспособность NK-клеток и цитолитических CD8-T-клеток лизировать инфицированные и иным образом активированные антигенпрезентирующие клетки, что приводит к пролонгированному межклеточному взаимодействию и усилению провоспалительного цитокинового каскада (особенно IL-6, который снижает цитолитическую функцию NK-клеток).

В дальнейшем выяснилось, что MAS осложняет множество воспалительных состояний, включая, помимо аутоиммунной и аутовоспалительной патологией, злокачественные новообразования, инфекции (например, COVID-19, ВЭБ, сепсис) и первичные иммунодефициты.

Клиническими проявлениями синдроме активации макрофагов указаны в таблице (табл.81). Синдром определяется при наличии по крайней мере 5 диагностических критериев и/или при наличии мутации в гене, обуславливающем данное заболевание.

Таблица 81.

Клинические критерии диагностики синдрома активации макрофагов

\begin{tabular}{|l|l|}
\hline \multicolumn{1}{|c|}{ Симптом } & \multicolumn{1}{|c|}{ Показатель } \\
\hline Лихорадка & $\begin{array}{l}\text { максимальный подъем температуры тела }>38,5^{\circ} \mathrm{C} \text { на } \\
\text { протяжении }>7 \text { дней }\end{array}$ \\
\hline Спленомегалия & $\begin{array}{l}\text { селезенка пальпируется >3 см ниже края реберной } \\
\text { дүги }\end{array}$ \\
\hline $\begin{array}{l}\text { Цитопения с вовлечением> 2 } \\
\text { клеточных ростков }\end{array}$ & $\begin{array}{l}\mathrm{Hb}<90 \text { г/л, } \\
\text { нейтрофилы }<1 \times 10^{9} / л, \\
\text { тромбоциты < } 100 x 10^{9} / л,\end{array}$ \\
\hline Гипертриглицеридемия & $\begin{array}{l}\text { Триглицериды натощак >3,0 ммоль/л или превышение } \\
\text { возрастной нормы на >3 стандартных отклонений или }\end{array}$ \\
\hline Гипофибриногенемия & $\begin{array}{l}\text { фибриноген <1,5 г/л или снижение возрастной нормы } \\
\text { на >3 }\end{array}$ \\
\hline Гемофагоцитоз & $\begin{array}{l}\text { в биоптатах костного мозга, селезенки или } \\
\text { лимфатических узлов }\end{array}$ \\
\hline NК-клетки, Цтл & $\begin{array}{l}\text { Снижение или отсутствие активности естественных } \\
\text { киллеров }\end{array}$ \\
\hline Ферритин в сыворотке & $>500$ мкг/л \\
\hline Уровень растворимого IL-2 (CD25) & $>2400$ Ед/мл или очень высокие для своего возраста \\
\hline
\end{tabular}




\title{
Abcam - всегда отличный результат
}

\section{Наборы для иммуноферментного анализа (ИФА)}

Готовые наборы, подобранные пары антител и готовые наборы реагентов для самостоятельного изготовления наборов ИФА.

Классические на6оры, на6оры с высокой чүвствительностью для определения низких концентраций аналита, наборы с ускоренной пробоподготовкой SimpleStep, иммунохроматографические наборы. Колориметрическая, хемилюминесцентная и флуоресцентная детекция.

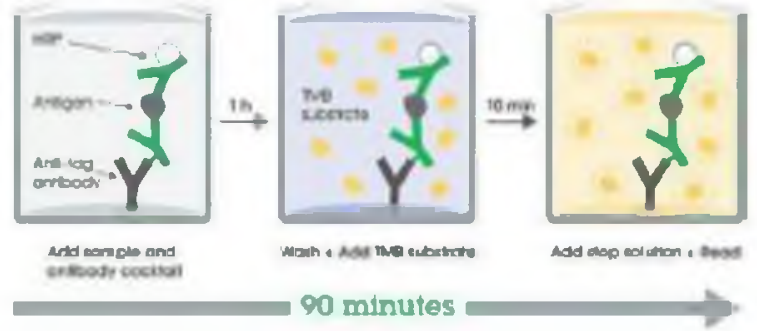

\author{
SimpleSted ELISA \\ CatchPoint Simplestep \\ In-Cell ELISA \\ High Sensitivity \\ ELISPOT Kit \\ Dipstick Assary Kit
}

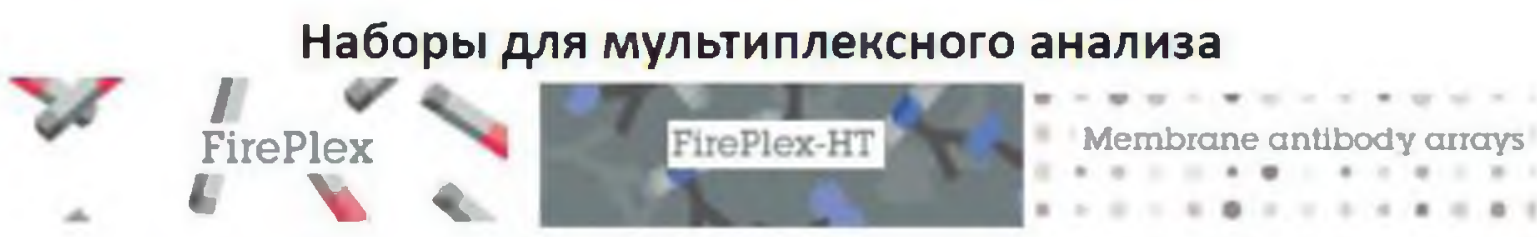

FirePlex - определение до 70 белков или 400 микроРНК в одном образце при анализе на проточном цитометре.

FirePlex-HT - определение до 13 белков в одном образце при анализе на системе высокопроизводительного скрининга (HCS), в 96- и 384-лүночных планшетах.

Membrane antibody array - определение до 96 цитокинов или других белков на мембранных чипах.

\section{Биохимические реагенты для клеточного анализа}

\section{Белки и пептиды}

- сигнальные белки;

- рецепторы и поверхностные клеточные маркеры;

- цитокины, хемокины и факторы роста;

- ферменты, в Т. ч. для функционального анализа;

" функционально активные нативные и идентичные им белки;

- иммуноглобулины;

- синтетические пептиды-иммуногены;

- токсины.

\author{
Агонисты, антагонисты, \\ активаторы и ингибиторы
}

abcam

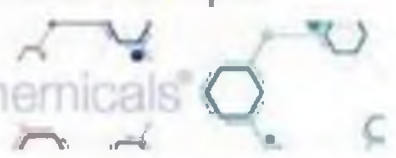

Обширная коллекция

нокаутных культур клеток и их лизатов

\section{0 «Диазм»}

\begin{tabular}{|c|c|}
\hline 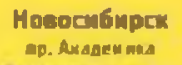 & $\begin{array}{c}\text { Казамы } \\
\text { wa. Roonmened }\end{array}$ \\
\hline ejembers a. od & Konmmo. A. 6 \\
\hline $\begin{array}{r}\text { Ten. } \\
\text { (383) } 320\end{array}$ & $\begin{array}{l}\text { 1en. } \\
(0+3] 210-20000\end{array}$ \\
\hline ahe & lasancodia m.ru \\
\hline
\end{tabular}

Mockad

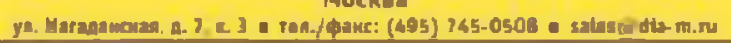

C.-Петербур 4. Mputecion กlakow. 4. 23$$
\text { Itex }
$$
(B12) $372-6040$

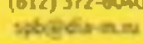

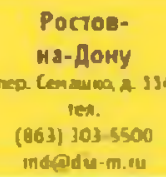
กepm:

1en.

(342) $202-2239$ Deumidid-m.tu

Bоромех Mreaciantits Ien.

(473) 232-4412 woronethedla-1m, n1 (094) 01-0873 momedia-m.rn

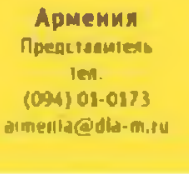
Y36енистан npenctatumel (\$o) $354-8569$ arcedio-m,n 


\section{ЛЕЧЕНИЕ БОЛЬНЫХ С ИММУННЫМИ НАРУШЕНИЯМИ}

\section{Глава 15. Принципы лечения больных с иммунными нарушениями}

В настоящее время не определено единых подходов к лечению иммуноопосредованных заболеваний. Это связано с большим разнообразием иммунопатологических реакций и разными «сценариями» развития одного и того же заболевания. При этом лечение больного с нарушением функции иммунитета не может ограничивается только иммуноактивной терапией. Каждое заболевание процесс мультифакторный и исходя из этого лечение любого больного должно быть комплексным и индивидуальным, тем не менее необходимо соблюдать пять основных принципов лечения (рис. 120).
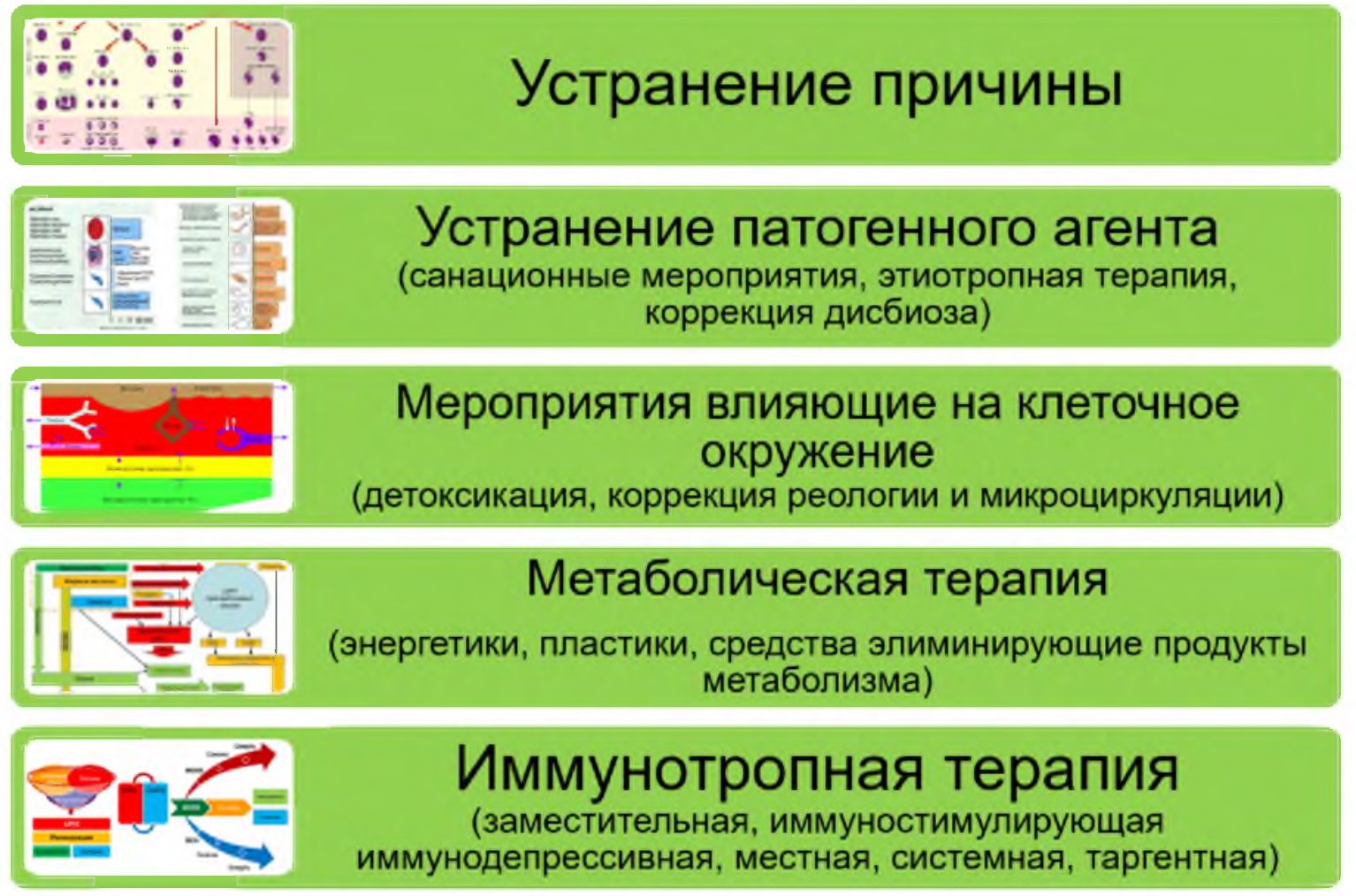

\section{Рис. 120. Принципы лечения больных с иммуноопосредованными заболеваниями.}

Современные достижения иммунологии и других смежных специальностей, позволяют врачу оказать реальную и долговременную помощь больным с иммунными нарушениями. Однако стандартное лечение без учета всех патогенетических факторов развития болезни не всегда приводит к положительным результатам. Поэтому при лечении больных с иммунными нарушениями помимо исключения этиологических факторов, если они выявлены, необходимо проводить комплексную терапию и решать следующие задачи, а именно: 
- Удалить если это возможно патогенный очаг неважно опухоль это или инфекция. всеми возможными способами (хирургически, лучевая и химиотерапия).

- Применить средства, влияющие на метаболизм клетки и клеточное окружение, в том числе все необходимые виды дезинтоксикации.

- Провести иммуноактивную терапию в том числе в особо тяжелых слу чаях необходимо рассматривать вопрос о заместительной терапии.

Алгоритм обеспечения иммунологической помощи больным представлен на рисунке (рис.121). Он включает в себя несколько этапов проведения диагностических и лечебных мероприятий.

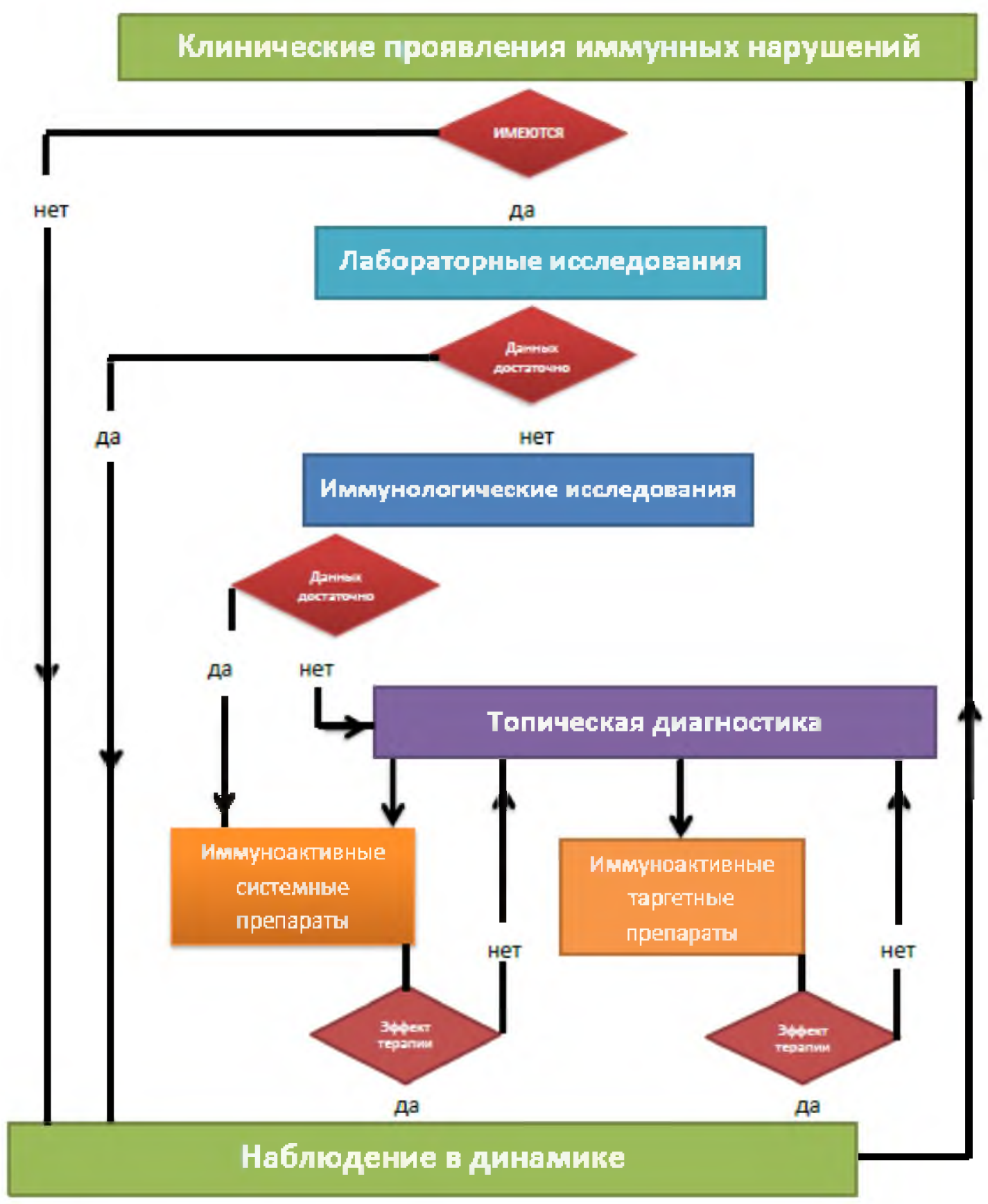

\section{Рис. 121. Алгоритм обеспечения иммунологической помоши больных с иммуноопосредованными заболеваниями.}




\section{ЛЕЧЕНИЕ БОЛЬНЫХ С ИММУННЫМИ НАРУШЕНИЯМИ}

\section{Глава 16. Устранение причины иммунных нарушений.}

Выявив и устранив причину иммунных нарушений возможно практически полностью решить проблемы связанные с иммуноопосредованной патологией. Как отмечалось ранее традиционно иммунные нарушения делят на две больших группы первичные и вторичные иммунодефициты. При этом аутоиммунные и аллергические заболевания так же можно рассматривать как иммунодефицит, связанный с нарушением процессов толерантности и/или супрессорных механизмов иммунитета. Во многих случаях, когда воздействие на иммунную систему не приобрело необратимый характер лечебные мероприятия позволяют излечить больного (табл. 82). Даже возможно излечить ПИД. Успешная трансплантация гемопоэтических стволовых клеток позволяет полностью восстановить иммунологический дефект. Сегодня такая трансплантация показана для пациентов с ТКИН, синдромами Вискотта-Олдрича, Оменна, Ниймигена, при хронической гранулематозной болезни, гипер $\operatorname{IgM}$ синдроме. В ближайшее время имеется надежда, используя технологию CRISPR/Cas9 редактируя поврежденный геном у больных ПИД полностью нормализовать работу иммунитета. Ниже будут описаны подходы к лечению больных с нарушением функций иммунной системы, но важное значение принадлежит мероприятия связанными со здоровым образом жизни.

Таблица 82

\section{Подходы к устранению причин иммунных нарушений}

\begin{tabular}{|l|l|}
\hline \multicolumn{1}{|c|}{ Причина } & \multicolumn{1}{|c|}{ Методы лечения и профилактики } \\
\hline $\begin{array}{l}\text { Первичные } \\
\text { иммунодефициты }\end{array}$ & $\begin{array}{l}\text { Заместительная терапия в том числе трансплантация } \\
\text { костного мозга }\end{array}$ \\
\hline $\begin{array}{l}\text { Протозойных и глистных } \\
\text { инвазий }\end{array}$ & Дегельминтизация и/или противопротозойная терапия \\
\hline $\begin{array}{l}\text { Бактериальных и вирусных } \\
\text { инфекций }\end{array}$ & Антибактериальная и противовирусная терапия \\
\hline $\begin{array}{l}\text { Повреждающих факторов } \\
\text { внешней среды }\end{array}$ & $\begin{array}{l}\text { Профилактика и предотвращение воздействия факторов } \\
\text { внешней среды }\end{array}$ \\
\hline Интоксикациях & Наркомания, токсикомания \\
\hline $\begin{array}{l}\text { Ятрогенные } \\
\text { Коррекция терапии, полноценные } \\
\text { иммунореабилитационные мероприятия после лечения } \\
\text { основного заболевания }\end{array}$ \\
\hline Метаболические нарушения & Полноценное питание, иммунологическая диета \\
\hline $\begin{array}{l}\text { Заболеваниях эндокринной } \\
\text { системы }\end{array}$ & Гормональная коррекция \\
\hline Стресс & Повышенная физическая активность, Полноценный сон \\
\hline $\begin{array}{l}\text { «Физилогические» } \\
\text { иммунодефициты }\end{array}$ & Поддерживающая терапия \\
\hline
\end{tabular}


Существует огромное количество рецептов по укреплению иммунитета. Необходимо понимать, что при тяжелых повреждениях иммунной системы методики «народной медицины», ни решат никакой проблемы с другой стороны иммунная система это мощная эшелонированная, многокомпонентная система, которую сложно вывести из равновесия и часто при незначительных сбоях работы иммунитета самое главное иммунной системе «не мешать» она сама восстановится. Общепризнанными мероприятиями по улучшению функции иммунитета является сбалансированное питание, полноценный сон и режим отдыха, двигательная активность, ограничение стресса. Неотъемлемой частью этих мероприятий является санация хронических инфекции в том числе с удалением любых образований на коже и слизистых.

Сбалансированное полноценное здоровое питание для иммунитета - это, пища которое поддерживает функции иммунных клеток, позволяя им инициировать эффективные ответы против патогенов, а также быстро разрешать ответ при необходимости и избегать какого-либо хронического воспаления. Потребности иммунной системы в энергии и питательных веществах могут быть удовлетворены из внешних источников, например, из рациона или, если пищевые источники неадекватны, из эндогенных источников, таких как запасы глюкозы и жира. Точный состав разнообразного, сбалансированного и здорового питания зависит от индивидуальных особенностей (таких как возраст, пол, образ жизни и степень физической активности), культурного контекста, имеющихся местных продуктов и обычаев в области питания. Однако основные принципы здорового питания остаются одинаковыми. Согласно рекомендациям ВО3:

Потребление энергии (калорий) должно быть сбалансировано с eе расходом. В зависимости от того, насколько получаемая человеком с пищей энергия и белок соответствует потребности в ней, формируется определенный пищевой статус человека. Потребность в энергии определяется путем умножения базального метаболизма (Мб) и коэффициента активности:

\begin{tabular}{|c|}
\hline Суточная потребность энергии $=$ Мб Ка \\
\hline $\begin{array}{l}M \sigma=88,362+(13,397 \cdot \text { вес в кг)+(4,799・ рост в см)- } \\
(5,677 \cdot \text { возраст в годах })-\text { для мужчин }\end{array}$ \\
\hline $\begin{array}{l}M \sigma=447,593+(9,247 \cdot \text { вес в к2) }+(3,098 \cdot \text { рост в см })- \\
(4,330 \cdot \text { возраст в годах) - для женицин }\end{array}$ \\
\hline $\begin{array}{l}\text { Ка - коэффициент активности } \\
\text { 1,2 - Малоподвижный образ жизни } \\
\text { 1,375 - Умеренная активность (лёгкие физические } \\
\text { нагрузки либо занятия 1-3 раз в неделю) } \\
\text { 1,55 - Средняя активность (занятия 3-5 раз в } \\
\text { неделю) } \\
\text { 1,725 - Высокая активность (интенсивные } \\
\text { нагрузки, занятия 6-7 раз в неделю) } \\
\text { 1,9-Спортсмены }\end{array}$ \\
\hline
\end{tabular}

Практически на все формы иммунитета влияет белково-энергетическое недоедание. Универсальным показателем пищевого статуса (сбалансированного питания) является индекс массы тела (ИМТ).

$$
\boldsymbol{H} \boldsymbol{M} \boldsymbol{T}=\frac{\mathrm{BEC}(\text { кг })}{(\mathrm{POCT}(\mathrm{M}) * \text { РOCT }(\mathrm{M})}
$$


Благоприятными для здоровья показателями с учетом возраста и пола представлены в таблице (табл.83). Снижение показателей свидетельствует о дефиците массы тела, повышение о избыточной массе тела и ожирении. И тот и другой показатель является неблагоприятным фактором для иммунной системы.

Таблица 83

\section{Индекс массы тела}

\begin{tabular}{|c|c|c|}
\hline Возраст & мужчины & женщины \\
\hline $18-25$ & $20-25$ & $19-24$ \\
\hline $26-35$ & $21-26$ & $20-25$ \\
\hline $36-45$ & $22-27$ & $21-26$ \\
\hline $46-55$ & $23-28$ & $22-27$ \\
\hline $56-65$ & $23,5-28,5$ & $23-28$ \\
\hline старше 65 & $24-29$ & $23,5-28,5$ \\
\hline
\end{tabular}

У людей различного типа телосложения этот показатель увеличивается (гиперстеники) или уменьшается (астеники) на 10\%. Тип телосложения определяется путем измерения самого тонкого места на запястье (индекс Соловьева (табл. 84).

\section{Таблица 84}

\section{Определение типа телосложения}

\begin{tabular}{|l|c|c|}
\hline \multirow{2}{*}{ Тип телосложения } & \multicolumn{2}{|c|}{ Окружность запястья (см) } \\
\cline { 2 - 3 } & мужчины & женщины \\
\hline Нормостеник & $18-20$ & $15-17$ \\
\hline Гиперстеник & более 20 & более 17 \\
\hline Астеник & менее 18 & менее 15 \\
\hline
\end{tabular}

На наличии лишнего веса и висцеральное ожирение указывает объем талии. Оптимальное значение для мужчин $-94-95 \mathrm{~cm}$, для женщин не более $80 \mathrm{~cm}$. При повышении объема 102 см для мужчин и 88 см для женщин показатель ожирения.

Для здорового питания прежде всего необходимо сбалансированное потребление белков, жиров и углеводов. В рационе должны присутствовать все три компонента. Соотношения их потребления зависит от возраста, активности, образа жизни.

Белок (протеин) основной компонент, из которого состоят все клетки и ткани нашего организма. Основным источником белка являются мясные и молочные продукты. Мясные продукты содержат достаточно большое количество жира (насыщенные жирные кислоты), поэтому необходимо заменять мясные продукты с повышенным содержанием жира на тощее мясо, мясо птицы, рыбу, которые содержат меньше насыщенных жиров.

- Ежедневное потребление по меньшей мере, 400 г. фруктов, овощей, бобовых (чечевица, фасоль), орехи и цельные злаки (не переработанная кукуруза, просо, овес, пшеница и неочищенный рис) обеспечит ежедневное поступление клетчатки. Необходимо всегда включать в рацион овощи, употреблять в качестве закуски разнообразные свежие фрукты и овощи, потреблять сезонные фрукты и овоши. Необходимо исключить картофель, и других крахмалсодержащих корнеплоды.

- Свободные сахара (все сахара, добавляемые в пищевые продукты или напитки производителем, поваром или потребителем, а также сахара, естественным образом присутствующие в меде, сиропах, фруктовых соках и их концентратах) должны составлять менее $10 \%$ от общей потребляемой энергии. Это эквивалентно 50 г (или 12 чайным ложкам без верха) на человека с нормальным весом, потребляющего около 2000 калорий в день. В 
идеале, в целях обеспечения дополнительных преимуществ для здоровья, они должны составлять менее 5\% от общей потребляемой энергии.

Снижение потребление сахаров достигается путем ограничить потребление пищевых продуктов и напитков с высоким содержанием сахаров (сладкие закуски, конфеты, все типы напитков, содержащих свободные сахара (газированные и негазированные прохладительные напитки, фруктовые и овощные соки и напитки, жидкие и порошковые концентраты, воды со вкусовыми добавками, энергетические и спортивные напитки, готовый чай, готовый кофе и молочные напитки со вкусовыми добавками) и заменой сладких закусок свежими фруктами и овощами.

- Жиры должны составлять менее $30 \%$ от общей потребляемой энергии. Необходимо отдавать предпочтение ненасыщенным жирам (содержащимся в рыбе, авокадо и орехах, а также в подсолнечном, соевом, рапсовом и оливковом масле). Рекомендуется сократить потребление насыщенных жиров, содержащихся в жирном мясе, сливочном масле, пальмовом и кокосовом масле, сливках, сыре, свином сале до менее 10\% и трансжиров всех видов, включая как трансжиры промышленного производства (содержащиеся в запеченных и жареных продуктах, заранее упакованных закусочных и других продуктах, таких как замороженные пиццы, пироги, печенье, вафли, кулинарные жиры и бутербродные смеси), так и трансжиры естественного происхождения (содержащиеся в мясной и молочной продукции, получаемой от жвачных животных, таких как коровы, овцы, козы и верблюды) до менее $1 \%$ от общей потребляемой энергии. При этом промышленные трансжиры (кондитерский жир, маргарин), пальмовое, кокосовое масло, необходимо полностью исключить из рациона.

Потребление жиров, особенно насыщенных жиров и трансжиров промышленного производства, можно сократить готовя пищу на пару или варить, а не жарить и не запекать, заменять сливочное масло, свиное сало на растительные масла, богатые полиненасыщенными жирами, такие как соевое, каноловое (рапсовое), кукурузное, сафлоровое и подсолнечное масло, употреблять в пищу молочную продукцию со сниженным содержанием жиров и постное мясо или обрезать видимый жир с мяса, ограничивать потребление запеченных и жареных продуктов, а также заранее приготовленных закусочных и других продуктов (например, пончиков, кексов, пирогов, печенья и вафель), содержащих трансжиры промышленного производства.

- Потребление соли на уровне менее 5 г (эквивалентно примерно одной чайной ложке) в день. Соль должна быть йодированной.

Потребление соли можно сократить ограничив количество соли и приправ с высоким содержанием натрия (например, соевого соуса, рыбного соуса и бульона), добавляемых во время приготовления еды, не ставить на стол соль и соусы с высоким содержанием натрия, ограничить потребление соленых закусок, выбирать продукты с низким содержанием натрия.

Именно несбалансированное питание и излишний вес могут активно поддерживать системное хроническое воспаление путем которое играет важную роль в развитии хронических сердечно-сосудистых, онкологических и инфекционно-воспалительных заболеваний.

Диета, положительно влияющая на функцию иммунитета должна, содержать достаточное количество белка, в частности, глютамина, аргинина и аминокислот с разветвленной цепью, высокое содержание омега-3 жирных кислот и низкое содержание насыщенных, трансжиров и омега-6 жирных кислот, низкое содержание рафинированного сахара, высокое содержание клетчатки, например, цельного зерна, и микроэлементов, включая витамин А, витамин D, витамин C, витамин Е, витамины группы В, цинк, селен и железо, а также полифенолы и каротинойды (табл.85). С позиций влияния на функцию иммунитета пищевые продукты и компоненты получили так называемый - диетический воспалительный индекс (DII)

Упрощенно оценить баланс потребления про- или противовоспалительных продуктов возможно при подсчете диетического воспалительного индекса (табл. 86). 


\section{Диетические источники}

Таб̆лица 85

\begin{tabular}{|c|c|c|c|c|c|}
\hline $\begin{array}{c}\text { Компонент - } \\
\text { DII }\end{array}$ & Источники & Кол-во & $\begin{array}{c}\text { Компонент - } \\
\text { DII }\end{array}$ & Источники & Кол-во \\
\hline \multirow{5}{*}{$\begin{array}{c}\text { Белок } \\
\text { (г/100 г или } \\
\text { мл) } \\
\text { DII }(0,021)\end{array}$} & Говядина & 25,3 & \multirow{4}{*}{$\begin{array}{l}\text { Витамин C } \\
\text { (мг/100 г) } \\
\text { DII }(-0,424)\end{array}$} & Лимон/Апельсин & 53,2 \\
\hline & Курица & 19,3 & & Брокколи & 89,2 \\
\hline & Яичный белок & 11 & & \multirow{2}{*}{ Брюссельская капуста } & \multirow{2}{*}{85} \\
\hline & Йогурт & 3,5 & & & \\
\hline & Соевые бобы & 25,9 & \multirow{4}{*}{$\begin{array}{c}\text { Витамин В } 6 \\
\text { (мг/100 г) } \\
\text { DII }(-0,365)\end{array}$} & Арахис & 0,5 \\
\hline \multirow{5}{*}{$\begin{array}{c}\text { Липиды (мг / } \\
100 \text { г) с } \\
\text { высоким } \\
\text { содержанием } \\
\text { омега-3 } \\
\text { DII }(0,06)-\end{array}$} & Семена чиа & 1783 & & Чечевица & 0.2 \\
\hline & Авокадо & 111 & & Тунец & 1 \\
\hline & Лосось & 2314 & & Моллюски & 0,4 \\
\hline & Тунец & 1337 & \multirow{3}{*}{$\begin{array}{c}\text { Витамин B } 12 \\
\text { (мкг/100 г) } \\
\text { DII }(0,106)\end{array}$} & Моллюски & 14,1 \\
\hline & Овсяная каша & 18 & & Йогурт & 0,4 \\
\hline \multirow{5}{*}{$\begin{array}{c}\text { Углеводы (г / } \\
100 \text { г) } \\
\text { DII }(0,097)\end{array}$} & Черника & 14,5 & & Куриная грудка & 0.2 \\
\hline & Инжир & 19,2 & \multirow{4}{*}{$\begin{array}{c}\text { Цинк } \\
\text { (мr/100 г) } \\
\text { DII }(-0,313)\end{array}$} & Семена тыквы & 7 \\
\hline & Овсяная каша & 12 & & Говядина & 7,4 \\
\hline & Хлеб & 42,7 & & Моллюски & 16,6 \\
\hline & Черные бобы & 23,7 & & Ягненок & 4,9 \\
\hline \multirow{5}{*}{$\begin{array}{c}\text { Клетчатка (r / } \\
100 \text { г) } \\
\text { DII }(-0,663)\end{array}$} & Семена чиа & 34,4 & \multirow{5}{*}{$\begin{array}{c}\text { Железо (мг/100 } \\
\text { г) } \\
\text { DII }(0,032)\end{array}$} & Абрикосы сухие & 2,7 \\
\hline & Апельсин & 2,4 & & Семечки & 5,3 \\
\hline & Капуста & 3,8 & & Моллюски & 5,1 \\
\hline & Чечевица & 7,9 & & яйцо & 1,8 \\
\hline & Нут & 7,6 & & Телятина & 1.4 \\
\hline \multirow{4}{*}{$\begin{array}{l}\text { Витамин A } \\
\text { (мкг/100 г) } \\
\text { DII }(-0,401)\end{array}$} & Морковь & 835 & \multirow{4}{*}{$\begin{array}{c}\text { Медь } \\
\text { (мг / } 100 \text { г) } \\
\text { DII }(-0,484)\end{array}$} & Орехи кешью & 2,2 \\
\hline & Дыня & 169 & & Грибы & 0,3 \\
\hline & Манго & 54 & & Говядина & 0.2 \\
\hline & Яйца & 160 & & Моллюски & 1,6 \\
\hline \multirow{3}{*}{$\begin{array}{l}\text { Витамин D } \\
\text { (мкг/100 г) } \\
\text { DII }(-0,446)\end{array}$} & Лосось & 14,4 & \multirow{4}{*}{$\begin{array}{c}\text { Селен (мкг / } 100 \\
\text { г) } \\
\text { DII }(-0,191)\end{array}$} & Семечки & 53 \\
\hline & Яйцо сырое & 2,1 & & Моллюски & 77 \\
\hline & Курица & 0,14 & & Лосось & 47 \\
\hline \multirow{4}{*}{$\begin{array}{c}\text { Витамин E } \\
\text { (мr/100 г) } \\
\text { DII }(-0,419)\end{array}$} & Семечки & 35,2 & & Индейка & 37 \\
\hline & Орехи миндаль & 25,6 & \multirow{5}{*}{$\begin{array}{c}\text { Полифенолы } \\
\text { (мг / } 100 \text { г) } \\
\text { (DII -0,467) }\end{array}$} & Цитрусовые & 42,6 \\
\hline & Черника & 0.6 & & Черника (сырая) & 163,5 \\
\hline & Киви & 1,5 & & Клубника & 33,6 \\
\hline \multirow{2}{*}{$\begin{array}{c}\text { Каротиноиды } \\
\text { (мг/100 г) } \\
\text { DII }(-0,584)\end{array}$} & Шпинат & 10.8 & & Черный чай & 115,3 \\
\hline & Капуста & 9 & & Яблочный сок & 6 \\
\hline
\end{tabular}

DII - диетический воспалительный индекс 


\section{Упрощенная система подсчета диетического воспалительного индекса}

\begin{tabular}{|c|c|c|c|}
\hline Про воспалительные продукты & + 2 балла & + 1 балл & 0 - баллов \\
\hline $\begin{array}{l}\text { Красное мясо, переработанное } \\
\text { мясо, органное мясо }\end{array}$ & $\geq 7$ раз/нед. & 2-6 раз в неделю & $<2$ раз в неделю \\
\hline $\begin{array}{l}\text { Нежирная рыба, яйца, } \\
\text { сахаросодержащие напитки, } \\
\text { помидоры }\end{array}$ & $\geq 7$ раз в неделю & 5-6 раз в неделю & $<5$ раз в неделю \\
\hline Очищенные злаки / белый рис & & $\geq 3$ чашек в день & $<3$ чашек в день \\
\hline Хлеб / лапша & & $\geq 7$ раз в неделю & $<7$ раз в неделю \\
\hline Противо воспалительные продукты & - 2 балла & - 1 балл & 0 - баллов \\
\hline Зеленые листовые овощи & $\begin{array}{l}\geq 14 \text { раз в } \\
\text { неделю }\end{array}$ & 7-13 раз в неделю & $<7$ раз в неделю \\
\hline Темно-желтые овощи & $\geq 7$ раз в неделю & 5-6 раз в неделю & $<5$ раз в неделю \\
\hline Фруктовый сок, жирная рыба & $\geq 5$ раз в неделю & 2-4 раз в неделю & <2 раз в неделю \\
\hline Кофе чай (чашка-250 мл.) & $\geq 2$ чашек в день & 1 чашка в день & $<1$ чашек в день \\
\hline \multirow{2}{*}{$\begin{array}{l}\text { Вино/ крепкие напитки / пиво } \\
\text { (Доза } 150 \text { мл/45мл/355 мл) не более } \\
5 \text { за } 1 \text { раз }\end{array}$} & 7-20 доз/нед. & 2-6 доз/нед. & $\begin{array}{l}<2 \text { или } \\
\geq 21 \text { доз/нед. } \\
\end{array}$ \\
\hline & 7-13 доз/нед. & 5-6 доз/нед. & $\begin{array}{l}<5 \text { или } \\
\geq 14 \text { доз/нед. }\end{array}$ \\
\hline
\end{tabular}

Основные противовоспалительные продукты необходимые для ежедневного применения представлены на рисунке (рис.122)

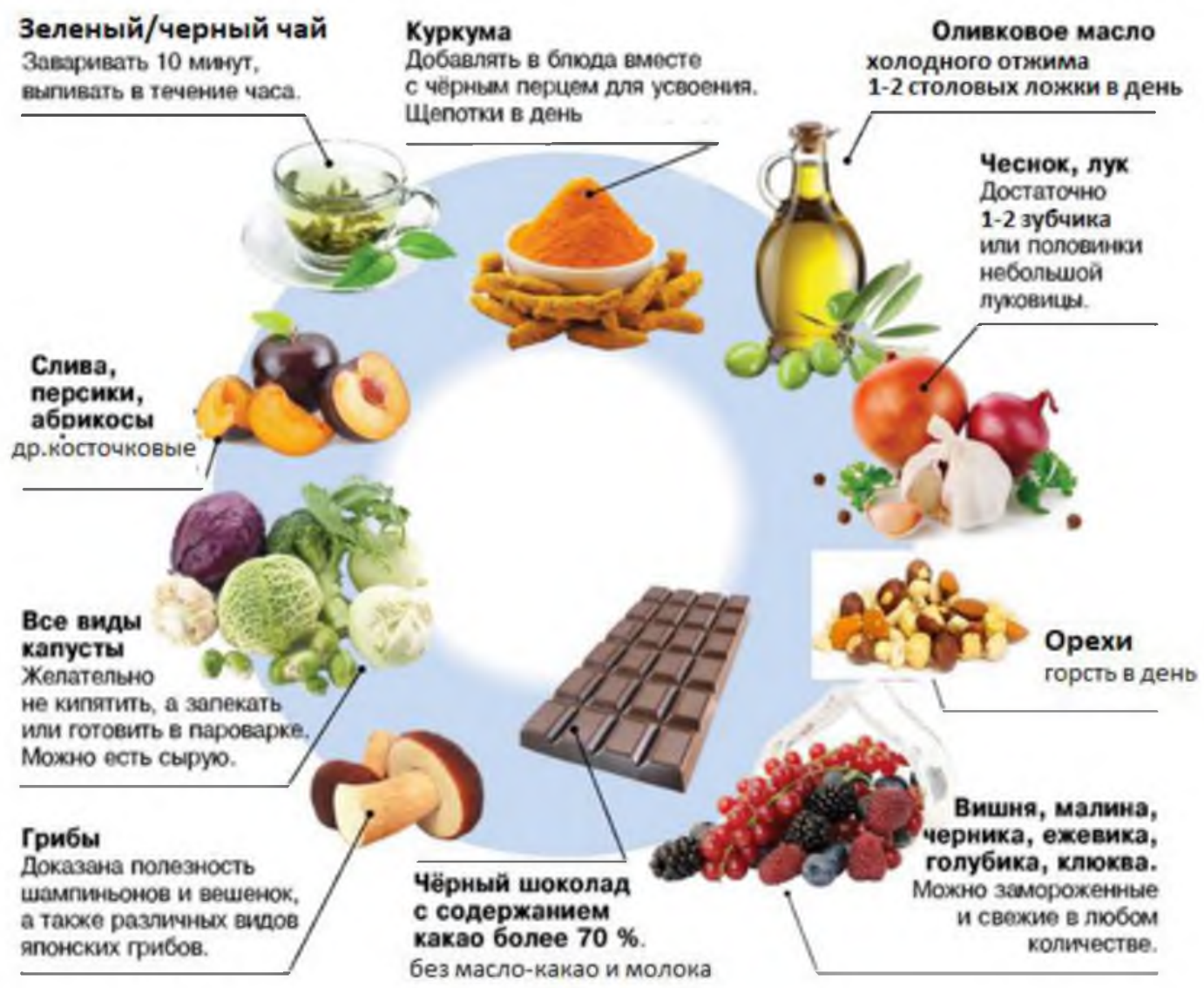

Рис. 122 Продукты с выраженным противовоспалительным действием 
На основании проведенного анализа данных предлагается нами адаптированная противовоспалительная диета (табл.87).

\section{Противовоспалительная диета}

\begin{tabular}{|c|c|}
\hline Исключить: & Рекомендовано: \\
\hline $\begin{array}{l}\text { Сахар, маргарины, кондитерский жир. Соль } \\
\text { Кондитерские изделия. Торты с масляным } \\
\text { кремом, чипсы, картофель-фри. } \\
\text { Любые жаренные блюда. } \\
\text { Хлебобулочные изделиях вафли, печенье. } \\
\text { Шоколад и шоколадные конфеты на основе } \\
\text { масло-какао. }\end{array}$ & $\begin{array}{l}\text { Продукты, богатые хролофилом (все, что имеет зеленый } \\
\text { цвет) с высоким уровнем пищевых волокон } \\
\text { Капуста. Гречка, семена чиа. Овес, чечевица, фасоль, горох, } \\
\text { нут (одна чашка, два раза в неделю). Миндаль, кедровые и } \\
\text { другие орехи . Лук, чеснок. } \\
\text { Чистый темный шоколад без сахара (какао 70-95\% и выше). }\end{array}$ \\
\hline $\begin{array}{l}\text { Любой хлеб, ржаной хлеб, слоеное и сдобное } \\
\text { тесто, пирожки, торты, бисквит, печенье } \\
\text { вчерашний выпечки, сухари, сухой бисквит. }\end{array}$ & Хлеб и сахар исключен. \\
\hline $\begin{array}{l}\text { Жирные сорта мяса (свинина, баранина, утка, } \\
\text { гусь), печень, почки, мозги, свиной, бараний, } \\
\text { говяжий жир, рыба соленая. } \\
\text { Жирные мясные бульоны. } \\
\text { Копчености в любом виде, колбасы, ветчина, } \\
\text { бекон, мясные консервы и соусы на мясной } \\
\text { основе и пр. }\end{array}$ & $\begin{array}{l}\text { Нежирные сорта мяса - говядина, кролик, язык говяжий. } \\
\text { Свиное сало соленое (20-30 грамм в день). } \\
\text { Птица - курица, индейка. } \\
\text { Рыба - жирные сорта рыбы (лосось, скумбрия муксун, чир, } \\
\text { белуга, кета, осетрина, севрюга, нельма). } \\
\text { Куриный бульон рыбные и грибные бульоны. }\end{array}$ \\
\hline $\begin{array}{l}\text { Рафинированное растительное масло } \\
\text { (пальмовое, подсолнечное, кукурузное, соевое, } \\
\text { масло из косточек винограда). }\end{array}$ & $\begin{array}{l}\text { Льняное, рапсовое, оливковое масло одна-две столовые } \\
\text { ложки в день (Extra Virgin нерафинированное в темной } \\
\text { бутылки с печатью DOP, срок годности не прошел половины). }\end{array}$ \\
\hline $\begin{array}{l}\text { Жирный творог, соленый и острый сыр, } \\
\text { мороженое, сливочное масло. }\end{array}$ & Кефир. \\
\hline $\begin{array}{l}\text { Очищенные злаки (пшеница, овес, ячмень, } \\
\text { рожь, пшено, кукуруза, рис (включая дикий), } \\
\text { гречневая крупа. }\end{array}$ & $\begin{array}{l}\text { Семена чиа. Цельнозерновые продукты овес, рис (бурый или } \\
\text { коричневый рис), полба, ячмень (перловая крупа), просо, } \\
\text { гречиха. Цельнозерновые макаронные изделия, овсяные, } \\
\text { ячменные хлопья, каши и прочие блюда из неочищенных } \\
\text { круп. }\end{array}$ \\
\hline Баклажаны, помидоры, перец, картофель. & $\begin{array}{l}\text { Капуста в т.ч. квашеная, брокколи, брюссельская капуста, } \\
\text { морковь, тыква, кабачки, свекла, артишок, шпинат, огурцы, } \\
\text { лук, чеснок, листовая зелень, горчица. }\end{array}$ \\
\hline \multirow[t]{3}{*}{$\begin{array}{l}\text { Сахара, мед, варенье, джемы из спелых и } \\
\text { сладких фруктов и ягод, мармелад, пастила, } \\
\text { зефир, фруктовые и ягодные соусы. }\end{array}$} & $\begin{array}{l}\text { Груши, яблоки, авокадо, мандарин, апельсин, гранат, } \\
\text { грейпфрут. } \\
\text { Косточковые (абрикосы, персики, слива, вишня). Сухофрукты } \\
\text { - чернослив, курага, инжир, изюм. }\end{array}$ \\
\hline & $\begin{array}{l}\text { Черника, брусника, клюква, малина, смородина, клубника, } \\
\text { ежевика. }\end{array}$ \\
\hline & Миндаль, грецкие, кедровые орехи, фисташки \\
\hline Газированные напитки, сладкие напитки, соки & Зеленый, черный чай. Кофе (не более 2 чашек в день) \\
\hline $\begin{array}{l}\text { Алкогольные напитки более } 20 \text { доз (пива не } \\
\text { более } 13 \text { доз) в неделю, не более } 5 \text { доз за } 1 \text { раз. }\end{array}$ & $\begin{array}{l}1 \text { доза: вино - 150мл, } \\
\text { крепкие напитки - } 45 \mathrm{mл}, \\
\text { пиво - } 355 \text { мл. }\end{array}$ \\
\hline
\end{tabular}

Пищу готовят в основном в измельченном и протертом виде, варят в воде, на пару, запекают. Очень горячие и холодные блюда исключаются. Использование интервального голодание (в течение суток: прием пищи - 6 часов, полный отказ от пищи - 18 часов) позволяет активировать процессы аутофагии и тем самым предотвращать хроническое системное воспаление.

Некоторые микроэлементы играют ключевую роль в иммунной системе. Это некоторые аминокислоты (глютамин, аргенин, лизин), витамины C, D, A, E, B6, В12, фоливая кислота, 
цинк, железо, медь, селен, магний. Они поддерживают структурную и функциональную целостность клеток слизистой оболочки врожденных барьеров, обеспечивают синтез антимикробных факторов и антител, участвуют в дифференциации, пролиферации, функционировании и микрации клеток врожденного и адаптивного иммунитета, распозновании антигена, играют важную роль в воспалении, антиоксидантных эффектах и эффектах окислительного взрыва.

Например, глютамин является незаменимой аминокислотой, которая обеспечивает важный источник энергии для многих типов клеток, включая клетки, участвующие в иммунных реакциях. Он также служит предшественником синтеза нуклеотидов, особенно актуален для быстро делящихся клеток, таких как иммунные клетки, во время иммунного ответа. Аминокислота аргинин необходима для генерации оксида азота макрофагами, а микроэлементы витамин А и цинк регулируют деление клеток и поэтому необходимы для успешного пролиферативного ответа в иммунной системе. С другой стороны, аргинин стимулирует рост опухолевых клеток и репликацию вируса. В противовес ему лизин блокирует репликацию вируса и рост опухолевых клеток. Используя соотношения лизин/аргенин определены продукты с повышенным поступлением лизина (табл. 88).

Таблица 88

\section{Подбор продуктов с использованием коэффициента лизин/аргенин}

\begin{tabular}{|l|c|l|c|l|c|}
\hline \multicolumn{1}{|c|}{ ПродУКт } & Лиз/Арг & \multicolumn{1}{|c|}{ ПродУкт } & Лиз/Арг & \multicolumn{1}{|c|}{ ПРОДУкт } & Лиз/Арг \\
\hline Йогурт & 2.979 & Сыр & 2.755 & Масло & 2.250 \\
\hline Молоко & 2.192 & Мороженое & 2.190 & Творог & 1.780 \\
\hline Рыба & 1.535 & Свинина & 1.416 & Сосиски & 1.395 \\
\hline $\begin{array}{l}\text { Куриная } \\
\text { грудка }\end{array}$ & 1.337 & Куриная ножка & 1.307 & Бифштекс & 1.315 \\
\hline Ветчина & 1.306 & Печень & 1.106 & Икра & 1.154 \\
\hline Яйцо & 1.057 & Моллюски & 1.024 & Креветка & 0.993 \\
\hline Рис & 1.727 & Овсянка & 1.007 & Пшеница & 0.591 \\
\hline Свекла & 2.400 & Помидоры & 1.519 & Картофель & 1.357 \\
\hline Бобы & 1.213 & Капуста & 1.051 & Морковь & 0.917 \\
\hline Редька /редис & 0.889 & Горох & 0.741 & Огурцы & 0.611 \\
\hline Манго & 2.179 & Абрикос & 2.146 & Яблоко & 2.125 \\
\hline Груша & 1.917 & Ананас & 1.393 & Персик & 1.250 \\
\hline Слива & 1.216 & Арбуз & 1.053 & Мандарины & 0.730 \\
\hline Щербет & 2.192 & Клубника & 0.949 & Грибы & 0.667 \\
\hline Арахис & 0.287 & Миндаль & 0.267 & Грецкий Орех & 0.185 \\
\hline
\end{tabular}

Селен является микроэлементом, который, как и цинк, играет важную роль в ряде белков. Витамина Е играет роль антиоксиданта, ингибитора активности протеинкиназы С и потенциально взаимодействует с ферментами и транспортными белками. 
Важным является пища для питания и формирования микробиоты. Пребиотики, неперевариваемые олигосахариды, такие как фруктоолигосахариды и галактоолигосахариды избирательно используется микроорганизмами человека, приносят пользу для его здоровья

При лечении аллергических заболеваний высокоэффективна и обязательна элиминация или ограничение воздействия аллергена, вплоть до переезда больного в другую местность. Соблюдение гипоаллергенной диеты с исключением продуктов, вызывающих аллергию.

Применять гипоаллергенную диету необходимо при всех видах аллергии. На первом этапе надо исключить из своего рациона высокоаллергенные и средеаллергенные продукты. Такую диету надо соблюдать взрослым 2-3 недели, детям младшего возраста обычно бывает достаточно 7-10 дней. Если в течение этого времени наступает улучшение, то исключенные продукты вновь вводят в рацион: по одному, начиная с небольших количеств, не чаще чем через 3 дня, и внимательно наблюдают, не возобновились ли аллергические реакции. Если в течение 3 дней после введения нового продукта симптомы аллергии возобновились, значит этот продукт и является вашим аллергеном.

Аллергенный продукт может быть не один, поэтому такую процедуру (включение в рацион одного нового продукта и наблюдение в течение 3 дней) надо проделывать с каждым продуктом. Если же заметного улучшения не наступило, то продолжают последовательно исключать из рациона продукты, начиная с наиболее аллергенных из оставшихся, при этом внимательно наблюдая за состоянием больного и, возможно, вводя некоторые из исключенных на первом этапе продуктов. Аллергические реакции у конкретного человека может вызвать любой продукт, даже считающийся очень низкоаллергенным. Поэтому подбор гипоаллергенной диеты должен быть сугубо индивидуальным (табл. 89.)

\section{Продукты при гипоаллергенной диете}

Таблица 89.

\begin{tabular}{|c|c|c|}
\hline ИСКЛЮЧИТЬ & ОГРАНИЧИТЬ & $\begin{array}{c}\text { Рекомендуется с учетом } \\
\text { индивидуальной } \\
\text { переносимости }\end{array}$ \\
\hline $\begin{array}{l}\text { все продукты, содержащие красители, } \\
\text { ароматизаторы, консерванты; } \\
\text { рыба, икра, морепродукты; } \\
\text { коровье молоко, цельномолочные } \\
\text { продукты, сыры; } \\
\text { яйца; } \\
\text { копченые продукты, колбаса, сосиски, } \\
\text { сардельки; } \\
\text { острые, соленые, маринованные и } \\
\text { консервированные продукты; } \\
\text { соусы и специи; } \\
\text { овощи: красный перец, тыква, } \\
\text { помидоры, свёкла, морковь, квашеная } \\
\text { капуста, щавель, баклажаны; } \\
\text { фрукты и ягоды, красного и оранжевого } \\
\text { цвета их соки и компоты } \\
\text { все цитрусовые; } \\
\text { фруктовые и газированные воды; } \\
\text { сухофрукты; } \\
\text { мед, все грибы и орехи; } \\
\text { мармелад, карамель, шоколад } \\
\text { изделия из него; } \\
\text { кофе, какао; } \\
\text { спиртные напитки; } \\
\text { все экзотические для местности вашего } \\
\text { постоянного проживания продукты }\end{array}$ & 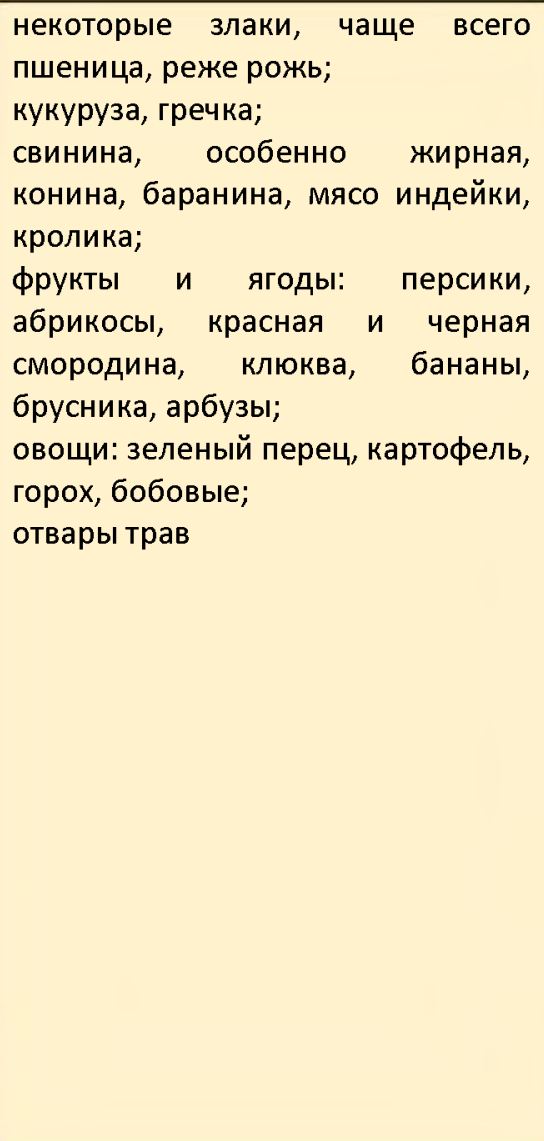 & 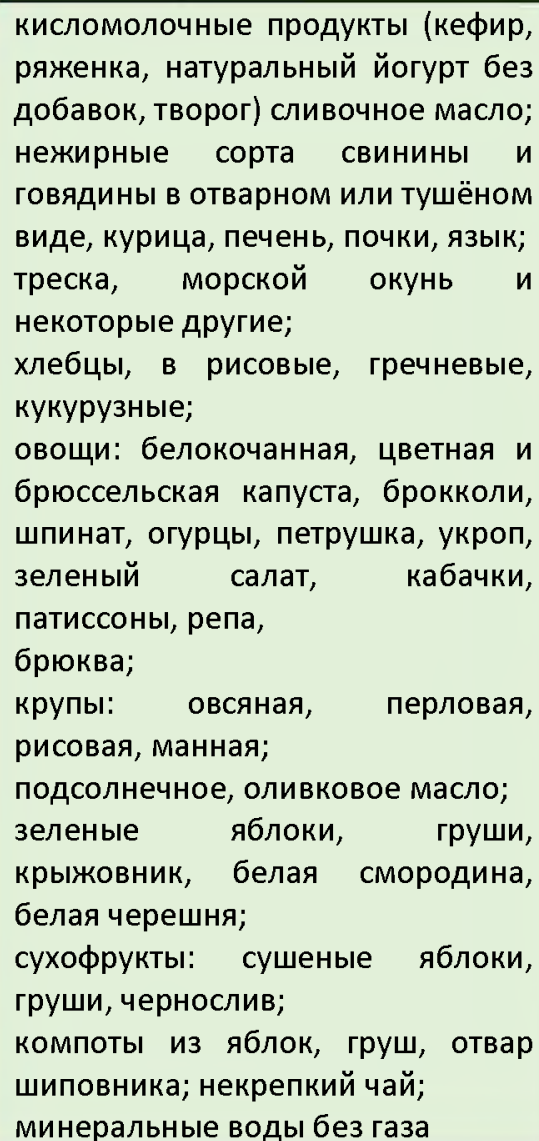 \\
\hline
\end{tabular}


Полноценный сон вторая составляющая формирования «хорошего» иммунитета. Сон - это естественное повторяющееся состояние организма, характеризующееся измененным сознанием, с подавлением сенсорной и мышечной активностью. Внутренние циркадные часы способствуют ежедневному сну ночью. Во время сна большинство систем организма находятся в анаболическом состоянии способствующее восстановлению иммунной, нервной, скелетной и мышечной систем.

$\mathrm{CoH}$ регулируется гомеостатически, что означает, что продолжительность и интенсивность сна увеличивается после длительного периода без сна. В дополнение к этому гомеостатическому компоненту, второй процесс, который не зависит от предшествующего бодрствования, модулирует время сна, а именно циркадную систему. Эта система отвечает за наложение и синхронизацию ритма, близкого к 24-часовому, для некоторых типов поведения и функций организма, включая склонность ко сну или бодрствованию в течение 24-часового цикла сна и бодрствования.

Сон влияет на различные параметры иммунной системы, связан со снижением риска инфицирования и может улучшить исход инфекции и реакцию на вакцинацию. Индукция гормонального фона, поддерживающего иммунные функции, является одним из вероятных механизмов, лежащих в основе иммуностимулирующих эффектов сна. Длительный дефицит сна (например, короткая продолжительность сна, нарушение сна) может привести к хроническому системному воспалению низкой степени и связан с различными заболеваниями, имеющими воспалительный компонент, такими как диабет, атеросклероз и нейродегенерация. Стимуляция иммунной системы микробами вызывает воспалительную реакцию, которая, в зависимости от ее величины и времени, может вызвать увеличение продолжительности и интенсивности сна, а также нарушение сна. $\mathrm{CoH}$ и иммунитет связаны двунаправленно. Активация иммунной системы изменяет сон, а сон, в свою очередь, влияет на врожденную и адаптивную часть защитной системы нашего тела.

Цикл сна делится на две стадии: медленный сон - 70-90 минут и быстрый сон (парадоксальный сон или стадия быстрого движения глаз) от 10 до 20 минут. Стадия медленного сна делится еще на четыре стадии (засыпание, неглубокий сон, медленный сон, глубокий медленный сон). У здорового человека обычно проходит пять циклов сна. Поэтому идеальная продолжительность сна взрослого человека составляет 7-8 часов в сутки, для детей не меньше 10 часов в сутки. При этом необходимо ложиться и просыпаться в одно и то же время вне зависимости от дня недели.

Учитывая циркадные ритмы организма лучше всего ложиться спать до 23 часов. Для быстрого засыпания поможет прогулка перед сном на свежем воздухе, расслабление, теплая ванна или душ, негромкая спокойная музыка, звуки природы, колыбельные и т.П.. В спальном помещении должно быть темно. Спать лучше в минимальном количестве одежды идеально обнаженным, при необходимости используя дополнительное одеяло. Спальное место должно быть ровным, не слишком мягким и не слишком жестким. После пробуждения нужно не спеша потянуться и встать.

Помимо сна необходимо чередовать пассивный отдых и физические нагрузки. Любые аэробные упражнения (физического упражнения низкой или умеренной интенсивности выполняемые длительное время - ходьба или походы (10000 шагов), бег трусцой, плавание, коньки, лыжи, танцы, баскетбол, теннис и пр.) способствуют выработки эндорфинов так же как и смех, секс, прослушивание музыки и употребление «вкусной» пищи. Эндорфины способствуют ликвидации тревожности и депрессии. Таким же действием обладает дофамин, который в больших количествах вырабатывается во время положительного, по представлению человека действию (например: секс, приём вкусной пищи, приятные телесных ощущений) и противостоит стрессу.

Устранение других причин иммунных нарушений, будет описана нами ниже, и/или должна осуществляться врачами соответствующего профиля гормональные нарушенияэндокринологом, наркомания, токсикомания, алкоголизм наркологом, кровопотери и потери белка трансфузиологом и т.д. 


\section{ЛЕЧЕНИЕ БОЛЬНЫХ С ИММУННЫМИ НАРУШЕНИЯМИ}

\section{Глава 17. Устранение патогенного агента}

Устранение патогенного агента - основной метод в лечении больных с иммунопатологическими состояниями. Сложно получить положительный результат лечения без санационных мероприятий, этиотропной терапия и нормализация микрофлоры.

Санационные мероприятия. Основным мероприятием при лечении больного с иммунными нарушениями является санация патогенного очага. Обычно это хирургические вмешательства. Данная операция приводит к уменьшению интоксикации, подавлению инфекции, как в очаге, так и в организме больного в целом. Характер вмешательства зависит от основного заболевания и является прерогативой хирургов.

Однако санация подразумевает не только хирургические мероприятия. При лечении заболеваний верхних дыхательных путей (ангина, ОРВИ, острые и хронические синуситы и т.д.) это полоскание горла, и промывание носа с применением гипертонического раствора и/или противовоспалительными и антибактериальными средствами. При бронхитах и пневмониях ингаляции и вибромассаж, применение муколитиков, при заболеваниях мочеполовой системы - гигиенические процедуры, с использованием антибактериальных средств. Важным является местное применения антисептиков (табл.90).

Таблица 90.

\section{Антисептики}

\begin{tabular}{|c|c|}
\hline Группа антисептиков & Наименование препарата \\
\hline $\begin{array}{l}\text { Галогенсодержащие } \\
\text { соединения }\end{array}$ & $\begin{array}{l}\text { Хлорамин Б, хлоргексидин, натрия гипохлорид, } \\
\text { раствор йода спиртовой, повидон-йод (бетадин), йодоформ, йодинол }\end{array}$ \\
\hline $\begin{array}{l}\text { Соединения } \\
\text { ароматического ряда } \\
\text { (группа фенола) }\end{array}$ & $\begin{array}{l}\text { Карболовая кислота (фенол) Резорцин } \\
\text { Деготь березовый (мазь Вишневского) }\end{array}$ \\
\hline $\begin{array}{l}\text { Соединения } \\
\text { алифатического ряда } \\
\text { (альдегиды и спирты) }\end{array}$ & $\begin{array}{l}\text { Спирт этиловый 70-95\% Формальдегид (формалин) } \\
\text { Метенамин (уротропин) }\end{array}$ \\
\hline Красители & $\begin{array}{l}\text { Бриллиантовый зеленый Метилтиония хлорид (метиленовый синий) } \\
\text { Этакридина лактат (риванол) }\end{array}$ \\
\hline Окислители; & $\begin{array}{l}\text { Калия перманганат } \\
\text { Раствор перекиси водорода (3\%) }\end{array}$ \\
\hline $\begin{array}{l}\text { Производные } \\
\text { нитрофурана }\end{array}$ & Нитрофурал (фурацилин) \\
\hline Кислоты и щелочи & $\begin{array}{l}\text { Борная кислота } \\
\text { Раствор аммиака (нашатырный спирт) }\end{array}$ \\
\hline Соли металлов & $\begin{array}{l}\text { Растворы ртути дихлорида (сулема) Ртути окись желтая ртути амидохлорид } \\
\text { Серебра нитрат (ляпис) Серебра протеинат (протаргол) Серебро коллоидное } \\
\text { (колларгол) Цинка сульфат }\end{array}$ \\
\hline Детергенты & Бензалкония хлорид Цетилпиридиния хлорид Мирамистин \\
\hline
\end{tabular}




\section{Этиотропная терапия}

Этиотропная терапия выполняют защитную функцию, аналогичную функции иммунной системы. Назначение препаратов обосновывается этиологией заболевания, его патогенезом с учетом физиологических особенностей организма, тяжестью и периодом болезни. Разделение таких препаратов на группы по преимущественной активности базируется на классификации возбудителей инфекционных заболеваний человека. Выделяют антибактериальные (антибиотики, сульфаниламиды и ко-тримоксазол, нитроимидазолы, нитрофураны); противогрибковые; противовирусные; противопротозойные; противогельминтные препараты.

Антибактериальные препараты представляют собой самую многочисленную группу лекарственных средств. Их можно классифицировать по механизму действия, химической структуре, типу действия на микробную клетку (табл.91).

Таблица 91.

\section{Классификация антибактериальных препаратов}

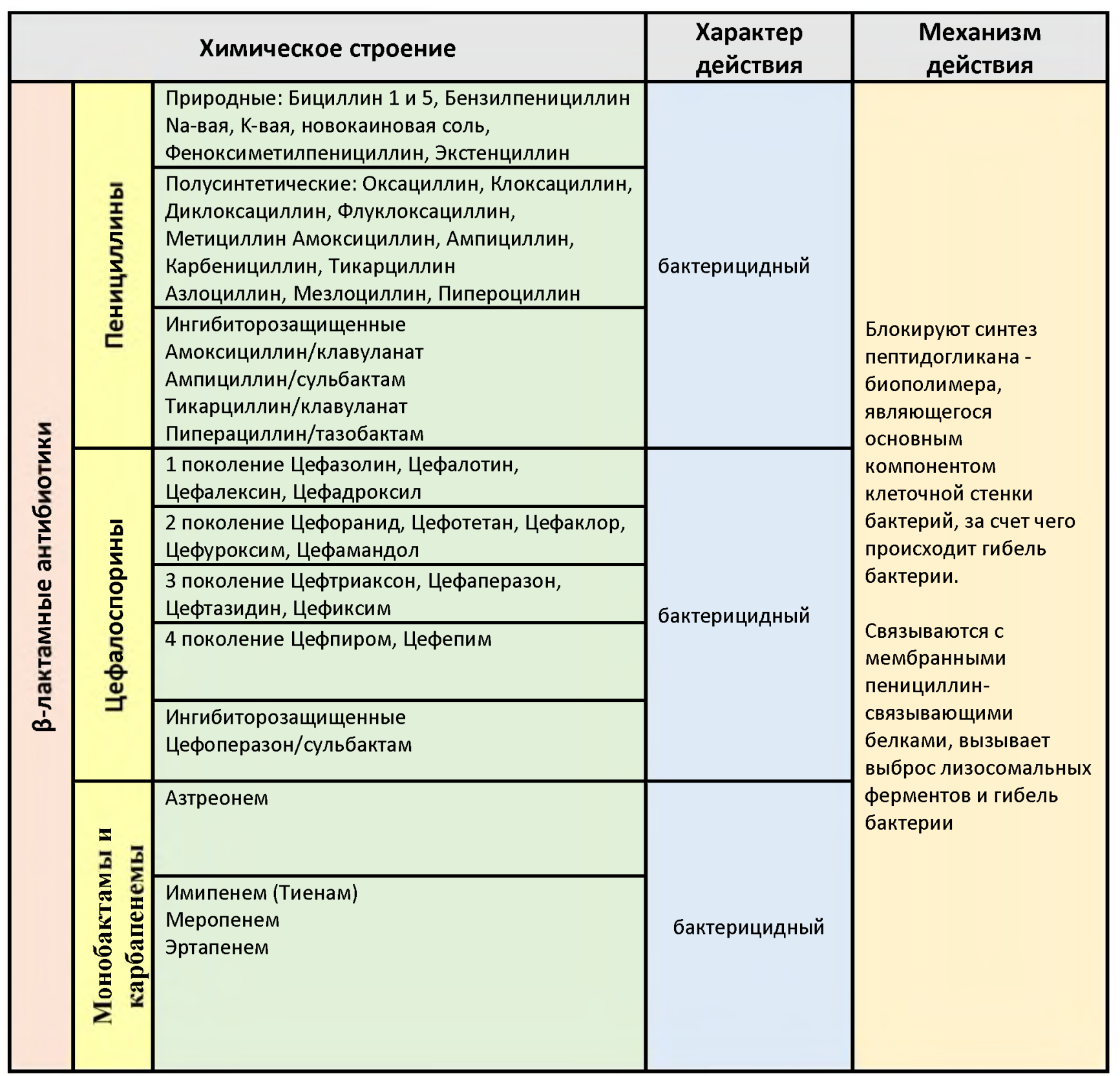


Таблица 91 (продолжение)

\section{Классификация антибактериальных препаратов}

\begin{tabular}{|c|c|c|c|}
\hline & Химическое строение & $\begin{array}{l}\text { Характер } \\
\text { действия }\end{array}$ & Механизм действия \\
\hline \multirow{3}{*}{ 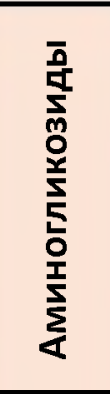 } & $\begin{array}{l}1 \text { поколение - природные } \\
\text { Стрептомицин, Канамицин } \\
\text { Мономицин, Неомицин }\end{array}$ & \multirow[t]{3}{*}{ бактерицидный } & \multirow{3}{*}{$\begin{array}{l}\text { Связывается с рецепторами } \\
\text { рибосомы, синтезируются } \\
\text { дефектные мембраные белки, } \\
\text { нарушают проницаемость } \\
\text { мембраны бактерии. } \\
\text { Вызывают распад полисом на } \\
\text { рибосомы }\end{array}$} \\
\hline & $\begin{array}{l}2 \text { поколение - полусинтетические } \\
\text { Гентамицин, Тобрамицин } \\
\text { Сизомицин, Нетилмицин }\end{array}$ & & \\
\hline & $\begin{array}{l}3 \text { поколение } \\
\text { Амикацин }\end{array}$ & & \\
\hline \multirow{2}{*}{ 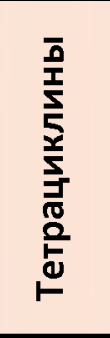 } & $\begin{array}{l}1 \text { поколение - природные } \\
\text { Тетрациклин, Хлортетрациклин } \\
\text { Окситетрациклин }\end{array}$ & \multirow[t]{2}{*}{ бактериостатический } & \multirow[t]{2}{*}{$\begin{array}{l}\text { Связываются с рецепторами } \\
\text { рибосомы, как следствие } \\
\text { нарушается рост полипептидной } \\
\text { цепи бактерии }\end{array}$} \\
\hline & $\begin{array}{l}2 \text { поколние - полусинтетические } \\
\text { Доксициклин, } \\
\text { Метациклин, Миноциклин }\end{array}$ & & \\
\hline \multirow{4}{*}{ 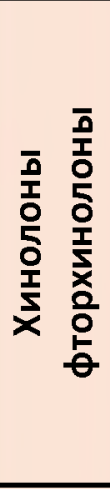 } & $\begin{array}{l}1 \text { поколение (хинолоны): } \\
\text { Налидиксовая кислота, } \\
\text { Пипемидовая кислота }\end{array}$ & \multirow[t]{4}{*}{ бактерицидный } & \multirow{4}{*}{$\begin{array}{l}\text { ингибируя два жизненно важных } \\
\text { фермента микробной клетки } \\
\text { (ДНК-гиразу и топоизомеразу IV), } \\
\text { нарушают синтез ДНК, что } \\
\text { приводит к гибели бактерий }\end{array}$} \\
\hline & $\begin{array}{l}2 \text { поколение: Ломефлоксацин, } \\
\text { Норфлоксацин, Офлоксацин, } \\
\text { Ципрофлоксацин }\end{array}$ & & \\
\hline & $\begin{array}{l}3 \text { поколение: } \\
\text { Левофлоксацин, Спарфлоксацин }\end{array}$ & & \\
\hline & $\begin{array}{l}\text { IV поколение: } \\
\text { Моксифлоксацин }\end{array}$ & & \\
\hline \multirow{2}{*}{ 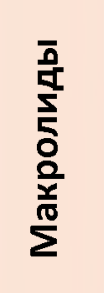 } & $\begin{array}{l}1 \text { поколение - природные } \\
\text { Эритромицин, Олеандомицин }\end{array}$ & \multirow[t]{2}{*}{ бактериостатический } & \multirow{3}{*}{$\begin{array}{l}\text { Связываются с рецепторами } \\
\text { рибосомы, что приводит к } \\
\text { нарушению процессов } \\
\text { транслокации аминокислот с } \\
\text { аминоацильного на } \\
\text { пептидильный центр рибосомы, } \\
\text { как следствие прекращается рост } \\
\text { полипептидной цепи бактерии }\end{array}$} \\
\hline & $\begin{array}{l}2 \text { поколние - полусинтетические } \\
\text { Азитромицин, Кларитромицин } \\
\text { Рокситромицин, Спирамицин } \\
\text { Джозамицин }\end{array}$ & & \\
\hline 童 & $\begin{array}{l}\text { Линкомицин } \\
\text { Клиндамицин }\end{array}$ & бактериостатический & \\
\hline $\begin{array}{l}\overline{\mathbf{0}} \\
\mathbf{5} \\
\mathbf{y} \\
\mathbf{5} \\
\mathbf{1} \\
\stackrel{\theta}{\mathbf{y}}\end{array}$ & $\begin{array}{l}\text { Левомецитин } \\
\text { Синтомицин }\end{array}$ & бактериостатический & $\begin{array}{l}\text { Нарушают синтез белков } \\
\text { микроорганизмов и блокирует } \\
\text { полимеризацию активированных } \\
\text { аминокислотных остатков, } \\
\text { связанных с матричной РНК }\end{array}$ \\
\hline
\end{tabular}


Таблица 91 (продолжение)

\section{Классификация антибактериальных препаратов}

\begin{tabular}{|c|c|c|c|}
\hline & Химическое строение & $\begin{array}{l}\text { Характер } \\
\text { действия }\end{array}$ & Механизм действия \\
\hline \multirow{3}{*}{ 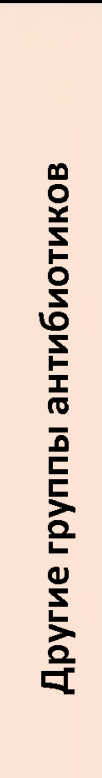 } & $\begin{array}{l}\text { Гликопептиды } \\
\text { Ванкомицин } \\
\text { Тейкопланин }\end{array}$ & бактерицидный & $\begin{array}{l}\text { Нарушают включение D-аланил-D- } \\
\text { аланила в клеточную стенку } \\
\text { бактерий, что приводит } \\
\text { осмотической неустойчивость и } \\
\text { гибели клетки }\end{array}$ \\
\hline & $\begin{array}{l}\text { Полимиксины } \\
\text { Полимиксин-М, В, E }\end{array}$ & бактерицидный & $\begin{array}{l}\text { Связываются с фосфолипидами } \\
\text { клеточных мембран, нарушают } \\
\text { проницаемость мембран это } \\
\text { приводит к гибели бактерии }\end{array}$ \\
\hline & $\begin{array}{l}\text { Оксазолидиноны } \\
\text { Линезолид } \\
\text { Тедизолид }\end{array}$ & бактериостатический & $\begin{array}{l}\text { Связывается с бактериальными } \\
\text { рибосомами, предотвращает } \\
\text { процесса трансляции при синтезе } \\
\text { белка бактерии. }\end{array}$ \\
\hline \multirow{2}{*}{ 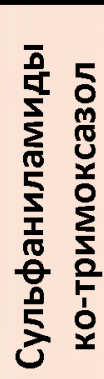 } & $\begin{array}{l}\text { Сульфагуанидин, Сульфадиазин } \\
\text { Сульфален, Сульфаниламид } \\
\text { Сульфасалазин } \\
\text { Фталилсульфатиазол }\end{array}$ & бактериостатический & \multirow{2}{*}{$\begin{array}{l}\text { Аналог ПАБК ингибируют фермент, } \\
\text { ответственный за синтез } \\
\text { предшественника фолиевой } \\
\text { кислоты, которая является } \\
\text { важнейшим фактором } \\
\text { жизнедеятельности } \\
\text { микроорганизмов. }\end{array}$} \\
\hline & Ко-тримоксазол & бактерицидный & \\
\hline 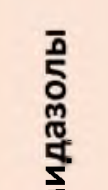 & $\begin{array}{l}\text { Метронидазол } \\
\text { Орнидазол } \\
\text { Секнидазол } \\
\text { Тинидазол }\end{array}$ & бактерицидный & $\begin{array}{l}\text { Нарушают репликацию ДНК и } \\
\text { синтез белка в микробной клетке, } \\
\text { ингибируют тканевое дыхание }\end{array}$ \\
\hline 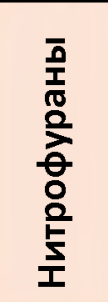 & $\begin{array}{l}\text { Нитрофурантоин } \\
\text { Фуразидин } \\
\text { Нифуроксазид } \\
\text { Фуразолидон } \\
\text { Нифурател }\end{array}$ & бактериостатический & $\begin{array}{l}\text { Нарушают процесс клеточного } \\
\text { дыхания бактерий, ингибируют } \\
\text { биосинтез нуклеиновых кислот }\end{array}$ \\
\hline
\end{tabular}

Основным показанием к антибактериальной терапии является наличие бактериальной инфекции (в некоторых случаях допускается применение антибиотиков в качестве профилактике). При этом главное и решающее в выборе антибактериального средства — это возбудитель и его чувствительность к избранному препарату. 
Для установления возбудителя традиционно проводят бактериологическое исследование. Определение чувствительности микроорганизмов к антибиотикам позволяет выявить резистентные штаммы, а полученная антибиотикограмма служит хорошим подспорьем клиницисту для выбора препарата. При этом забор материала для микробиологических исследований необходимо брать до начала антибактериальной терапии, срок транспортировки материала от забора до посева на среду не должен превышать 2 ч.. Для предварительной диагностики необходимо прибегать к экспресс-методам по этиологической диагностике, к которым относятся микроскопия мазка, окрашенного по Граму, методы прямой иммунофлюоресценции определения АГ в мокроте или мазке со слизистых. При бактериоскопии в мазке мокроты можно дифференцировать пневмококки, стрептококки, стафилококки, гемофильные палочки и, как минимум, определить преобладание грамположительной или грамотрицательной флоры, что, собственно, и имеет значение для выбора антибиотика первого ряда. После получения бактериологического заключения о характере микрофлоры и ее чувствительности к антибиотикам при необходимости следует произвести смену антибиотика.

Нередко при микроскопии мокроты дифференцировать микроорганизмы не удается и необходимо ориентироваться лишь на преобладание грамположительной или грамотрицательной флоры, а также на наличие смешанной флоры. Необходимо знать региональную ситуацию с антибиотикорезистентностью наиболее актуальных возбудителей и учитывать наличие у больного риска инфицирования данными устойчивыми возбудителями. Многие инфекционные поражения - полимикробные, и в силу этого для их лечения может понадобиться комбинация антибиотиков.

Выбор антибактериальных средств при установленной этиологии определяется с учетом наиболее эффективных в отношении той или иной флоры антибиотиков (табл. 92). Больным с иммунными нарушениями предпочтительнее назначать препараты бактерицидного действия: $\beta$-лактамы, аминогликозиды, ванкомицин, фосфомицин, фторхинолоны.

Однако в реальной жизни врач крайне редко располагает достоверными данными о возбудителе и обычно ориентируется на спектр действия имеющихся антибиотиков, региональных особенностях приобретенной резистентности бактерий к антибиотикам, клиническим свойствам течения болезни и своего опыты (табл.93). Нередко в клинической практике используется комбинированная антибиотикотерапия. Она показана при: смешанных инфекциях; необходимости предупреждения развития устойчивости микроорганизмов к антибиотику; усилении антибактериального эффекта; недостаточной чувствительности возбудителей к моноантибиотикам. При применении комбинированной терапии необходимо учитывать антагонистическое взаимодействие антибиотиков, что объясняется их механизмом действия на микробную клетку. Оптимальной является комбинация двух бактерицидных антибактериальных средств. При лечении бактериальных инфекций с внутриклеточной локализацией возбудителя следует учитывать разную степень проникновения антибактериальных препаратов в клетку. Наиболее активны макролиды и фторхинолоны, которые хорошо проходят в клетку и оказывают антибактериальный эффект на внутриклеточные бактерии. При инфекциях центральной нервной системы важно, чтобы антибактериальный препарат хорошо проникал через гематоэнцефалический барьер, это левомицетин, сульфаниламиды, ко-тримоксазол, нитроимидазолы, флуконазол. Только при воспалении проникают - пенициллины, цефалоспарины и тетрациклины.

Продолжительность антибактериальной терапии зависит от клинического течения нозологической формы. Обычная продолжительность антибиотикотерапии $7-10$ дней. При микоплазменных и хламидийных пневмониях антибиотики применяются $10-14$ сут. Оценка эффективности проводимой терапии проводится через 48 - 72 ч после ее начала. При правильном выборе антибиотика температура тела и лейкоцитарная формула нормализуются в течение 2 - 4 суток. Если через 48 ч (реже 72) делается вывод о неэффективности проводимой терапии, необходима коррекция лечения. 
Таблица 92

\section{Спектр действия антибактериальных средств при заболеваниях человека}

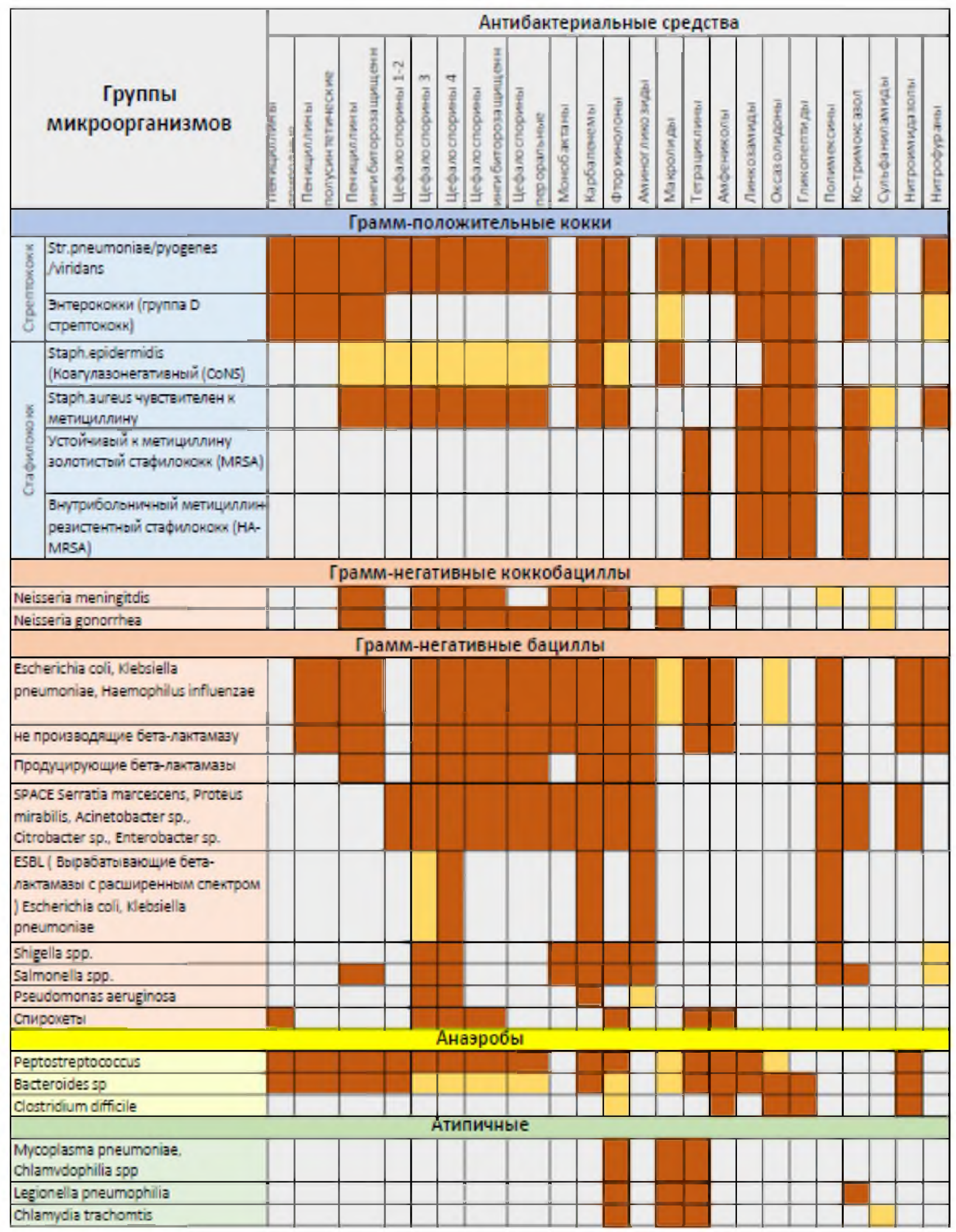


Таблица 93

\section{Применение антибактериальных средств при заболеваниях человека}

\begin{tabular}{|c|c|c|c|}
\hline Заболевание & $\begin{array}{c}\text { Основной } \\
\text { возбудитель }\end{array}$ & $\begin{array}{c}\text { Первоочередной } \\
\text { антибиотик }\end{array}$ & Антибиотики резерва \\
\hline \multicolumn{4}{|c|}{ КОЖА И МЯГКИЕ ТКАНИ } \\
\hline $\begin{array}{l}\text { Гидраденит, } \\
\text { фурункул, карбункул, } \\
\text { мастит }\end{array}$ & $\begin{array}{l}\text { Staphylococcus } \\
\text { aureus }\end{array}$ & $\begin{array}{l}\text { Оксацилин, } \\
\text { ампицилин, } \\
\text { цефалоспорины }\end{array}$ & $\begin{array}{l}\text { Ингибиторозащищенные } \\
\text { пенициллины (ИП), } \\
\text { макролиды, линкозамиды }\end{array}$ \\
\hline Импетиго & $\begin{array}{l}\text { Staphylococcus } \\
\text { pyogenes }\end{array}$ & Цефалоспорины & $\begin{array}{l}\text { ИП, макролиды, } \\
\text { линкозамиды }\end{array}$ \\
\hline Рожа & $\begin{array}{l}\text { Стрептококки } \\
\text { группы А, }\end{array}$ & $\begin{array}{l}\text { Природные } \\
\text { пенициллины }\end{array}$ & ИП, линкозамиды \\
\hline $\begin{array}{l}\text { Диабетическая язва } \\
\text { стопы, тяжелые } \\
\text { пролежни }\end{array}$ & $\begin{array}{l}\text { Полимикробная } \\
\text { этиология }\end{array}$ & $\begin{array}{l}\text { ИП или карбапенемы } \\
+ \text { метронидазол или } \\
\text { ванкомецин }\end{array}$ & $\begin{array}{l}\text { Цефалоспорины III } \\
\text { поколения или } \\
\text { фторхинолоны + } \\
\text { метронидазол или } \\
\text { линкозамиды }\end{array}$ \\
\hline \multicolumn{4}{|c|}{ КОСТИ И СУСТАВЫ } \\
\hline $\begin{array}{l}\text { Инфекционный } \\
\text { артрит, тендовагенит }\end{array}$ & $\begin{array}{l}\text { St. aureus, St. } \\
\text { pyogenes }\end{array}$ & $\begin{array}{l}\text { Оксацилин, } \\
\text { цефалоспорины }\end{array}$ & ИП \\
\hline \multirow{2}{*}{$\begin{array}{l}\text { Инфекционный } \\
\text { артрит связанный с } \\
\text { зППП }\end{array}$} & $\begin{array}{l}\text { Neisseria } \\
\text { gonorrhoeae }\end{array}$ & Цефалоспорины & Хинолоны +рифампецин \\
\hline & $\begin{array}{l}\text { Chlamydia } \\
\text { trachomatis }\end{array}$ & Макролиды & Тетрациклины \\
\hline Бурсит & St. aureus & $\begin{array}{l}\text { Оксацилин, } \\
\text { цефалоспорины, ИП }\end{array}$ & \\
\hline \multirow[t]{2}{*}{ Остеомиелит } & St. aureus & Цефалоспорины & ИП, карбапенемы \\
\hline & $\begin{array}{l}\text { Haemophilus } \\
\text { influenzae }\end{array}$ & Цефалоспорины & Карбапенемы \\
\hline \multicolumn{4}{|c|}{ ВЕРХНИЕ ДЫХАТЕЛЬНЫЕ ПУТИ И ЛОР-ОРГАНЫ } \\
\hline Отит наружный & St. aureus & $\begin{array}{l}\text { Оксацилин, } \\
\text { ампицилин, } \\
\text { цефалоспорины } \\
\end{array}$ & $\begin{array}{l}\text { ИП, макролиды, } \\
\text { фторхинолоны }\end{array}$ \\
\hline Острый средний отит & $\begin{array}{l}\text { Streptococcus } \\
\text { pneumoniae }\end{array}$ & Аминопенецилины & $\begin{array}{l}\text { ИП, макролиды, } \\
\text { фторхинолоны }\end{array}$ \\
\hline \multirow{2}{*}{$\begin{array}{l}\text { Хронический } \\
\text { средний отит }\end{array}$} & St. aureus & ИП+аминогликазиды & \\
\hline & $\begin{array}{l}\text { Pseudomonas } \\
\text { aeruginosa }\end{array}$ & Цефалоспорины & \\
\hline Синуситы & $\begin{array}{l}\text { Streptococcus } \\
\text { pneumoniae, } \\
\text { Haemophilus } \\
\text { influenzae }\end{array}$ & ИП, макролиды & $\begin{array}{l}\text { Цефалоспорины II, III } \\
\text { поколения }\end{array}$ \\
\hline Тонзилит & $\begin{array}{l}\text { Streptococcus } \\
\text { pyogenes }\end{array}$ & $\begin{array}{l}\text { Пенициллины, } \\
\text { аминопенециллины }\end{array}$ & ИП, макролиды \\
\hline
\end{tabular}


Таблица 93 (продолжение)

Применение антибактериальных средств при заболеваниях человека

\begin{tabular}{|c|c|c|c|}
\hline Заболевание & $\begin{array}{c}\text { Основной } \\
\text { возбудитель }\end{array}$ & $\begin{array}{c}\text { Первоочередной } \\
\text { антибиотик }\end{array}$ & $\begin{array}{c}\text { Антибиотики } \\
\text { резерва }\end{array}$ \\
\hline \multicolumn{4}{|c|}{ ПОЛОСТЬ РТА И ЧЕЛЮСТНО-ЛИЦЕВАЯ ОБЛАСТЬ } \\
\hline Пульпит, гингивит & $\begin{array}{l}\text { Streptococcus milleri и } \\
\text { неспорообразующие } \\
\text { анаэробы }\end{array}$ & $\begin{array}{l}\text { Природные } \\
\text { пенициллины }\end{array}$ & ИП \\
\hline Периодонтит & $\begin{array}{l}\text { Грамотрицательные } \\
\text { анаэробы и спирохеты }\end{array}$ & ИП & $\begin{array}{l}\text { макролиды + } \\
\text { метронидазол }\end{array}$ \\
\hline $\begin{array}{l}\text { Периостит и } \\
\text { остеомиелит }\end{array}$ & $\begin{array}{l}\text { St. aureus, анаэробная } \\
\text { флора }\end{array}$ & $\begin{array}{l}\text { Оксациллин или } \\
\text { цефалоспорины }\end{array}$ & ИП \\
\hline \multicolumn{4}{|c|}{ ДЫХАТЕЛЬНЫЕ ПУТИ } \\
\hline $\begin{array}{l}\text { Хронические } \\
\text { обструктивные } \\
\text { болезни легких } \\
\text { (ХОБЛ) } \\
\text { неосложненные }\end{array}$ & $\begin{array}{l}\text { Streptococcus pneumoniae, } \\
\text { Haemophilus influenzae, } \\
\text { Moraxella catarrhalis }\end{array}$ & $\begin{array}{l}\text { Аминопенецилины, } \\
\text { макролиды }\end{array}$ & ИП, фторхинолоны \\
\hline ХОБЛ осложненные & $\begin{array}{l}\text { Haemophilus influenzae, } \\
\text { Moraxella catarrhalis, } \\
\text { Streptococcus pneumoniae, } \\
\text { Enterobacteriaceae }\end{array}$ & \multicolumn{2}{|c|}{ ИП, макролиды, фторхинолоны } \\
\hline $\begin{array}{l}\text { ХОБЛ с факторами } \\
\text { риска синегнойной } \\
\text { палочки }\end{array}$ & $\begin{array}{l}\text { Haemophilus influenzae, } \\
\text { Moraxella catarrhalis, } \\
\text { Streptococcus pneumoniae, } \\
\text { Enterobacteriaceae, } \\
\text { Pseudomonas aeruginosa }\end{array}$ & \multicolumn{2}{|l|}{ Фторхинолоны } \\
\hline $\begin{array}{l}\text { Пневмония } \\
\text { нетяжелая }\end{array}$ & $\begin{array}{l}\text { Streptococcus pneumoniae, } \\
\text { Moraxella catarrhalis, } \\
\text { Chlamydophyla pneumoniae, } \\
\text { Haemophilus influenzae, }\end{array}$ & $\begin{array}{l}\text { Аминопенецилины, } \\
\text { макролиды }\end{array}$ & $\begin{array}{l}\text { ИП, фторхинолоны, } \\
\text { тетрациклины }\end{array}$ \\
\hline $\begin{array}{l}\text { Пневмония } \\
\text { нетяжелая с } \\
\text { сопутствующей } \\
\text { патологией }\end{array}$ & $\begin{array}{l}\text { Streptococcus pneumoniae, } \\
\text { Chlamydophyla pneumoniae, } \\
\text { Haemophilus influenzae, } \\
\text { Enterobacteriaceae, } \\
\text { Staphylococcus aureus }\end{array}$ & ИП & $\begin{array}{l}\text { Линкозамиды или } \\
\text { фторхинолоны + } \\
\text { цефалоспорины }\end{array}$ \\
\hline Тяжелая пневмония & $\begin{array}{l}\text { Streptococcus pneumoniae, } \\
\text { Enterobacteriaceae, } \\
\text { Staphylococcus aureus, } \\
\text { Legionella }\end{array}$ & ИП + макролид & \\
\hline $\begin{array}{l}\text { Абсцесс легкого, } \\
\text { Эмпиема плевры }\end{array}$ & Анаэробные возбудители & ИП & $\begin{array}{l}\text { Цефалоспорины III- } \\
\text { IV поколения+ } \\
\text { карбапенемы или } \\
\text { метронидозол }\end{array}$ \\
\hline
\end{tabular}


Таблица 93 (продолжение)

Применение антибактериальных средств при заболеваниях человека

\begin{tabular}{|c|c|c|c|}
\hline Заболевание & $\begin{array}{c}\text { Основной } \\
\text { возбудитель }\end{array}$ & $\begin{array}{c}\text { Антибиотик } \\
\text { первоочередного } \\
\text { выбора }\end{array}$ & Антибиотики резерва \\
\hline \multicolumn{4}{|c|}{ ЖЕЛУДОЧНО-КИШЕЧНЫЙ ТРАКТ } \\
\hline $\begin{array}{l}\text { Гастрит, } \\
\text { язвенная } \\
\text { болезнь }\end{array}$ & Helicobacter pylori & $\begin{array}{l}\text { Омепразол (или } \\
\text { аналог) + } \\
\text { кларитромицин + } \\
\text { метронидазол }\end{array}$ & $\begin{array}{l}\text { Омепразол (или аналог) + } \\
\text { тетрациклин + метронидазол }\end{array}$ \\
\hline \multirow[t]{2}{*}{ Диарея } & $\begin{array}{l}\text { Shigella, } \\
\text { Salmonella, E.colli, } \\
\text { Yersinia }\end{array}$ & Фторхинолоны & $\begin{array}{l}\text { Цефалоспорины III } \\
\text { поколения }\end{array}$ \\
\hline & $\begin{array}{l}\text { Clostridium, } \\
\text { Entamoeba, Giardia } \\
\text { lamblia }\end{array}$ & Метронидазол & \\
\hline $\begin{array}{l}\text { Холангит } \\
\text { Дивертикулит }\end{array}$ & \multirow[t]{4}{*}{$\begin{array}{l}\text { E.colli, Klebsiella, } \\
\text { Enterobacteriaceae } \\
\text {, Pseudomonas } \\
\text { aeruginosa }\end{array}$} & ИП+метронидазол & $\begin{array}{l}\text { Цефалоспорины+метронидаз } \\
\text { ол, карбапенемы, } \\
\text { ампицилин+ } \\
\text { аминогликозиды II-III пок.+ } \\
\text { метронидазол }\end{array}$ \\
\hline \multirow[t]{2}{*}{ Абсцессы } & & & \\
\hline & & $\begin{array}{l}\text { ИП или цефалоспорины } \\
\text { III покол } \\
\text { +метронидазол }\end{array}$ & $\begin{array}{l}\text { Игибиторозащищенные } \\
\text { цефалоспорины + } \\
\text { метронидазол, карбапенемы }\end{array}$ \\
\hline Перитонит & & $\begin{array}{l}\text { Цефалоспорины III-IV } \\
\text { покол + метронидазол }\end{array}$ & $\begin{array}{l}\text { Карбапенемы, } \\
\text { ингибиторозащищенные } \\
\text { цефалоспорины + } \\
\text { метронидазол }\end{array}$ \\
\hline \multicolumn{4}{|c|}{ МОЧЕВЫВОДЯЩИЕ ПУТИ } \\
\hline Цистит & \multirow[t]{2}{*}{$\begin{array}{l}\text { E.colli, Klebsiella, } \\
\text { Enterobacteriaceae }\end{array}$} & Фторхинолоны & ИП \\
\hline Пиелонефрит & & Фторхинолоны & $\begin{array}{l}\text { ИП, Цефалосорины II-ІІІ } \\
\text { поколения }\end{array}$ \\
\hline Карбункул почки & St. aureus & $\begin{array}{l}\text { Оксациллин или } \\
\text { цефалоспорины }\end{array}$ & $\begin{array}{l}\text { Ингибиторозащищенные } \\
\text { цефалоспорины, } \\
\text { карбапенемы }\end{array}$ \\
\hline
\end{tabular}

Выбор антибиотика второго ряда является не менее ответственным и чаще всего осуществляется по клиническим данным, так как в эти сроки возбудитель обычно культурально не установлен. Если он установлен, и антибиотик первого ряда не соответствовал биологической чувствительности микроорганизма, самое простое решение назначение антибиотика соответствующего спектра действия. Сложнее решается вопрос, если установленный возбудитель входил в спектр действия антибиотика, но терапевтический эффект не получен. Вариантами решений могут быть: увеличение дозы применявшегося антибиотика; назначение препарата другой группы, но сходного спектра действия; использование антибиотиков с ингибиторами $\beta$-лактамаз. 
В большинстве случаев антибиотики используются в среднетерапевтических дозах. Уменьшение дозировок препаратов допустимо только при почечной недостаточности в зависимости от степени, которой редуцируется доза. При лечении септической или осложненной инфекции нередко используются высшие дозы антибактериальных средств, введение которых начинается, как правило, парентерально. Пероральная терапия возможна, если она обеспечивает необходимые концентрации в сыворотке крови и тканях или когда высокие концентрации антибиотика уже не требуются. При циклических, но не рецидивирующих инфекциях антибактериальный препарат можно отменить через $1-2$ дня после получения клинического эффекта. При циклических, но рецидивирующих болезнях антибактериальное лечение продолжают столько времени, сколько болезнь протекала бы без этиотропной терапии. При ациклических инфекциях, к числу которых относится сепсис, а также большинство заболеваний, вызванных условно-патогенной флорой, антибактериальные препараты назначают в эмпирически установленные оптимальные сроки с учетом клинического выздоровления.

При лечении антибактериальными препаратами необходимо иметь в виду вторичную резистентность микроорганизмов. К $\beta$-лактамам, тетрациклинам, линкозамидам, левомицетину, ванкомицину, фосфомицину, фторхинолонам, нитрофуранам, нитроимидазолам вторичная устойчивость развивается медленно («пенициллиновый» вид резистентности), а к аминогликозидам, макролидам, рифамицинам, фузидину, производным 8-оксихинолина, хинолонам I и II поколения - быстро («стрептомициновый» вид резистентности). Поэтому эти препараты следует назначать курсом не более $5-7$ дней или комбинировать с другими антибактериальными препаратами.

При планировании комплексной этиопатогенетической терапии необходимо учитывать взаимное усиление возможных побочных (нежелательных) эффектов антибиотиков, патогенетических препаратов и алкоголя. Данные о несовместимости лекарственных веществ с антибиотиками указаны в инструкциях к этим препаратам и комбинации указанных препаратов не рекомендуют для применения на практике, поскольку они в той или иной степени неблагоприятны для пациентов. В группу лекарственных веществ, комбинации которых $\mathrm{c}$ антибиотиками следует особо внимательно контролировать, включают антикоагулянты, антидиабетические вещества, соли металлов, диуретики, ненаркотические анальгетики и нестероидные противовоспалительные средства.

Иногда коррекция антибактериальной терапии требуется не из-за неэффективности препарата, а в связи с развитием побочных эффектов. Отмена применяемого антибиотика нужна во всех случаях развития аллергических реакций (нередко аллергические реакции возникают на 6 - 7-й день лечения). Если в этот период продолжение химиотерапии необходимо по жизненным показаниям, то следует продлить лечение препаратами других групп (препараты «резерва»). В частности, если проявилась реакция на пенициллины, то рискованно лечить любым $\beta$-лактамным антибиотиком (цефалоспорины, карбапенемы). При токсических побочных эффектах производится замена препарата на антибиотики, которым не свойственны отмеченные нежелательные явления. Наиболее часто при антибактериальной терапии развивается дисбактериоз. Если проводимая терапия эффективна и есть необходимость ее продолжать, то отменять антибиотик не следует. Обычно в зависимости от конкретных обстоятельств назначаются противогрибковые препараты или средства, нормализующие флору кишечника.

Одним из рациональных подходов к применению антимикробной терапии является ступенчатая терапия (двухэтапное применение антиинфекционных препаратов) - переход с парентерального на непарентеральный (чаще пероральный) путь введения в возможно более короткие сроки с учетом клинического состояния больного. Следует иметь в виду, что угрожающие жизни инфекции (бактериальный эндокардит, менингит и др.), на протяжении почти всего курса антибактериальной терапии требуют парентерального назначения антибиотиков, тогда как при инфекциях мочевыводящих путей могут быть с самого начала препараты прописаны перорально. 
Важным фактором при ступенчатой терапии является срок перевода больного на пероральный путь введения антибиотика; ориентиром могут служить стадии инфекции. Выделяют три стадии инфекционного процесса у больных, находящихся на стационарном лечении.

I стадия продолжается 2-3 дня и сопровождается нестабильной клинической картиной: возбудитель и его чувствительность к антибиотику, как правило, не известны, антибактериальная терапия носит эмпирический характер, поэтому чаще всего назначают препарат широкого спектра действия.

На II стадии клиническая картина стабилизируется или улучшается, возбудитель и его чувствительность могут быть установлены, что позволяет провести коррекцию терапии.

На III стадии (примерно через 7 дней от начала заболевания) наступает выздоровление, и антибактериальная терапия завершается.

Оптимальным временем для перевода больного на пероральную терапию является II стадия инфекционного процесса. Выделяют клинические, микробиологические и фармакологические критерии перевода на второй этап ступенчатой терапии при следующих клинических критериях - отсутствие лихорадки (температура тела $<38^{\circ} \mathrm{C}$ в течение 24-48 ч) и нарушения всасывания в ЖКТ, тенденция к нормализации клинического анализа крови, СРБ отрицательный, улучшение/стабилизация клинической картины, возможность перорального приема пищи и жидкости. Хорошо если к этому времени выделен возбудитель и определена его чувствительность к антибиотику.

Побочное действие антибиотиков. В процессе антибиотико- и химиотерапии нужно не только хорошо знать противомикробную активность применяемых для лечения препаратов, но и представлять возможность побочного их действия, его патогенез, формы проявления, профилактику и лечение. Побочное действие антибиотиков и химиопрепаратов в основном сводится К аллергическим, токсическим реакциям или зависит от побочного химиотерапевтического эффекта - реакция бактериолиза, дисбактериоз, суперинфекции и др.

Клинические проявления аллергических реакций выражаются в виде анафилактического шока, поражения кожи, слизистых оболочек, отека Квинке, астматического бронхита.

Проявления токсических реакций характеризуются четкой симптоматикой и возникают чаще аллергических. При приеме аминогликозидов могут развиваться: неврит слухового нерва, поражение зрительного нерва, вестибулярные расстройства, полиневрит, токсическое поражение почек. Тетрациклины, рифампицин, эритромицин, сульфаниламиды обладают гепатотоксичным действием. Патологическое влияние на кроветворную систему могут оказывать хлорамфеникол, рифампицин, стрептомицин. Токсически действуют на ЖКТ тетрациклин, эритромицин, амфотерицин и др.

Противомикробные препараты могут вызвать дисбактериоз, снижение напряженности иммунного ответа организма, что в конечном итоге проявляется реинфекцией или суперинфекцией. Вследствие подавления нормальной микрофлоры кишечника может развиться гиповитаминоз.

Противогрибковые химиопрепараты. Это достаточно обширный класс разнообразных химических соединений как природного происхождения, так и полученных путем химического синтеза, обладающих специфической активностью в отношении патогенных грибов. В зависимости от химической структуры они разделяются на несколько групп, отличающихся по особенностям спектра активности, фармакокинетике и клиническому применению при различных грибковых инфекциях (табл.94).

С клинической точки зрения препараты необходимо применять в зависимости от формы грибковых заболеваний (микозов) (табл.95). 
Таблица 94

\section{Классификация противогрибковых препаратов}

\begin{tabular}{|c|c|c|}
\hline Группы препаратов & Локального действия & Системные \\
\hline $\begin{array}{l}\text { Полиены } \\
\text { природные антимикотины } \\
\text { используемый } \\
\text { преимущественно для } \\
\text { лечения тяжелых системных } \\
\text { микозов }\end{array}$ & \multicolumn{2}{|c|}{$\begin{array}{l}\text { Нистатин } \\
\text { Леворин } \\
\text { Натамицин } \\
\text { Амфотерицин В } \\
\text { Амфотерицин В липосомальный }\end{array}$} \\
\hline $\begin{array}{l}\text { Азолы } \\
\text { синтетических } \\
\text { антимикотиков } \\
\text { спектр лечения } \quad \text { грибковых } \\
\text { инфекций }\end{array}$ & $\begin{array}{l}\text { Клотримазол } \\
\text { Миконазол } \\
\text { Бифоназол } \\
\text { Эконазол } \\
\text { Изоконазол } \\
\text { Оксиконазол }\end{array}$ & $\begin{array}{l}\text { Кетоконазол } \\
\text { Флуконазол } \\
\text { Итраконазол } \\
\text { Вориконазол }\end{array}$ \\
\hline $\begin{array}{l}\text { Аллиламины } \\
\text { синтетические антимикотики } \\
\text { для } \\
\text { дерматомикозов }\end{array}$ & Нафтифин & Тербинафин \\
\hline $\begin{array}{l}\text { Эхинокандины } \\
\text { как препаратов выбора при } \\
\text { большинстве клинических } \\
\text { форм инвазивных микозов }\end{array}$ & & $\begin{array}{l}\text { Каспофунгин, } \\
\text { Микафунгин, } \\
\text { Анидулафунгин }\end{array}$ \\
\hline Препараты разных групп & $\begin{array}{l}\text { Аморолфин } \\
\text { Циклопирокс } \\
\text { Ундецин (Нитрофунгин) } \\
\text { Антисептики }\end{array}$ & $\begin{array}{l}\text { Гризеофульвин } \\
\text { Калия йодид } \\
\text { Флуцитозин }\end{array}$ \\
\hline
\end{tabular}

Таблица 95

\section{Спектр действия противогрибковых препаратов}

\begin{tabular}{|c|c|c|}
\hline $\begin{array}{c}\text { Системные (глубокие) } \\
\text { микозы }\end{array}$ & $\begin{array}{c}\text { Поверхностные микозы } \\
\text { (дерматомикозы) }\end{array}$ & Кандидамикозы \\
\hline $\begin{array}{l}\text { Кокцидиомикоз, } \\
\text { криптококкоз, гистоплазмоз, } \\
\text { бластомикоз }\end{array}$ & 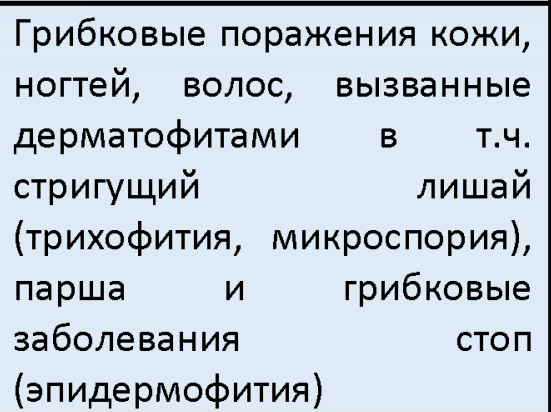 & $\begin{array}{l}\text { Инфекции вызванные Candida } \\
\text { albicans поражающий } \\
\text { слизистых оболочек рта, глотки, } \\
\text { кишечника, бронхов, наружных } \\
\text { половых органов может быть } \\
\text { кандидамикозный сепсис }\end{array}$ \\
\hline $\begin{array}{lr}\text { Амфотерицин } & \text { В, } \\
\text { Микогептин, } & \text { Миконазол, } \\
\text { Кетоконазол, } \\
\text { Итраконазол }\end{array}$ & $\begin{array}{l}\text { Гризеофульвин, Тербинафин } \\
\text { Клотримазол, Миконазол, } \\
\text { Эконазол, Кетоконазол, } \\
\text { Тербинафин, нитрофунгин }\end{array}$ & $\begin{array}{l}\text { Амфотерицин В, } \begin{array}{l}\text { Нистатин, } \\
\text { Леворин, } \\
\text { клотримазол, } \\
\text { тербиафиназол, }\end{array} \\
\text { миконазол }\end{array}$ \\
\hline
\end{tabular}


Противовирусные препараты. Спектр противовирусных препаратов в последнее время значительно увеличился. Благодаря чему стало возможно практически полностью излечить хронические инфекции (ВГС) и/или добиться стойкой ремиссии (ВИЧ, ХГВ). Противовирусные препараты предназначены для лечения конкретной вирусной инфекции, реже используются в профилактических целях. В последнее время производятся попытки классифицировать противовирусные препараты по механизму действия с учетом жизненного цикла вируса (табл.96), однако к клинической практике удобнее рассматривать препараты к конкретному вирусу (грипп, герпесы, гепатиты, ВИЧ-инфекции и др.)

\section{Противогерпетические препараты.}

Основным противогерпетическим препаратом является аналог нуклеозидов ацикловир и его версии валацикловир, пенцикловир и фамцикловир. Все эти лекарственные средства блокируют синтез ДНК у размножающихся вирусов герпеса герпеса человека в том числе Herpes simplex типы 1 и 2, Varicella zoster, Epstein-Barr и цитомегаловируса.

Ганцикловир по структуре, метаболизму и механизму действия очень близок к ацикловиру, но значительно более токсичен. Рассматривается как препарат для лечения ЦМВ. Ганцикловир, как правило, вводится только внутривенно, реже применяется внутрь.

Применение противогерпетических препаратов не ведет к полному излечению, так как вирус герпеса сохраняется в организме в неактивном (латентном) состоянии. Резистентность к противогерпетическим препаратам - редкое явление, особенно у пациентов с нормальным иммунитетом.

Препараты против вирусов респираторного тракта. При лечении ОРВИ учитываю большое количество разновидностей патогенных вирусов (более 2000) этиотропная терапия отсутствуют. Исключения составляет грипп и коронавирус (см. ниже). В тяжельх случаях при ОРВИ особенно вызванное РС-вирусом рекомендовано применять рибавирин. Аналогичным действием обладает триазавирин. Они действуют против широкого спектра РНК- содержащих вирусов в том числе вирусов ОРВИ и гриппа, ротавирусной инфекции, серозных менингитах, клещевом энцефалите, лихорадке Денге и других геморрагических лихорадках в том числе вызванной вирусом Эбола. Препаратами как для лечение, так и для профилактики в том числе не только ОРВИ, но и других вирусных инфекций стоит рассматриваться альфа интерфероны.

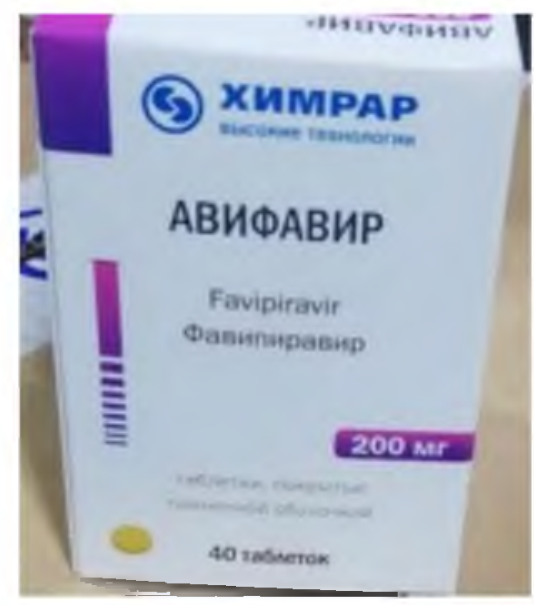

Препараты против коронавируса. связи с глобальной пандемией 2020 гс поиск препаратов против коронавиру активно ведется, но на момент выхс книги можно представить толь фавипиравир (авифавир, ареплив) коронавир). Препарат ингибирует $\mathrm{PH}$ зависимую РНК-полимера участвующую в репликации не толь вируса гриппа, но и других РНК-ов вирусов. Доказано его ингибируюш действие на вирус SARS-CoV вызывающий новую коронавирусн. инфекцию COVID-19. 


\section{Классификация противовирусных препаратов}

\begin{tabular}{|c|c|c|}
\hline Этап & Группа & Препараты \\
\hline \multirow{3}{*}{$\begin{array}{l}\text { Адсорбция на } \\
\text { клетки-мишени }\end{array}$} & Ингибиторы рецепторов & Маравирок (ВИЧ) \\
\hline & Ингибиторы слияния (фузии) & $\begin{array}{l}\text { Энфувиртид (ВИЧ) Нобазит Умифеновир } \\
\text { (ОРВИ) Йодантипирин (КЭ) }\end{array}$ \\
\hline & Антитела & Внутривенные иммуноглобулины \\
\hline $\begin{array}{l}\text { Проникновение } \\
\text { в цитоплазму }\end{array}$ & $\begin{array}{l}\text { Бокируют проникновение вирусов в } \\
\text { клетку }\end{array}$ & $\begin{array}{l}\text { Производные адамантана (ремантадин, } \\
\text { амантадин) Булевиртид (ВГВ и HDV). }\end{array}$ \\
\hline $\begin{array}{l}\text { Транспорт } \\
\text { внутри клетки }\end{array}$ & Препараты ингибирующие интегразы & $\begin{array}{l}\text { Долутегравир Элвитегравир } \\
\text { Биктегравир (ВИЧ) }\end{array}$ \\
\hline \multirow[t]{10}{*}{$\begin{array}{l}\text { Внутриклеточная } \\
\text { репродукция }\end{array}$} & $\begin{array}{l}\text { Средства, блокирующие синтез } \\
\text { вирусной Днк }\end{array}$ & $\begin{array}{l}\text { Ацикловир, валацикловир, пенцикловир } \\
\text { фамцикловир ганцикловир (группа } \\
\text { герпесвирусов) }\end{array}$ \\
\hline & $\begin{array}{l}\text { Ингибиторы обратной транскриптазы. } \\
\text { Нуклеотиды }\end{array}$ & $\begin{array}{l}\text { Тенофовир (ВИЧ, ВГВ) Адефовир (ВГВ, } \\
\text { герпесы), фосфазид (ВИЧ) }\end{array}$ \\
\hline & Нуклеозиды: & $\begin{array}{l}\text { Абакавир, Диданозин, Зальцитабин, } \\
\text { Зидовудин, Ставудин, Эмтрицитабин, (ВИЧ) } \\
\text { Ламивудин, (ВИЧ, ВГВ) } \\
\text { Энтекавир (ВГВ) }\end{array}$ \\
\hline & Ненуклеозиды: & $\begin{array}{l}\text { Делавирдин, Невирапин, Эфавиренз, } \\
\text { Этравирин, Рилпивирин (ВИЧ) }\end{array}$ \\
\hline & $\begin{array}{l}\text { Средства, блокирующие синтез } \\
\text { вирусной РНК: }\end{array}$ & $\begin{array}{l}\text { Рибавирин (ОРВИ, ВГС, Вирус Эбола), } \\
\text { Триазавирин (ОРВИ, КЭ), Рибонуклеаза (КЭ), } \\
\text { Фавипиравир (короновирусная инфекция) }\end{array}$ \\
\hline & Нуклеотидные ингибиторы & $\begin{array}{l}\text { Софосбувир (ВГС) Балоксавира марбоксил } \\
\text { (грипп) Инозин пранобекс }\end{array}$ \\
\hline & Ненуклеозидные ингибиторы & Беклабувир, дасабувир (ВГС) \\
\hline & Ингибитор вирусных протеаз & $\begin{array}{l}\text { Ампренавир Атазанавир Индинавир } \\
\text { Нелфинавир Ритонавир Саквинавир } \\
\text { Типранавир Фосампренавир Дарунавир } \\
\text { (ВИЧ) } \\
\text { Воксилапревир, глекапревир, гразопревир. } \\
\text { Асунапревир, нарлапревир/паритапревир (с } \\
\text { ритонавиром) Боцепревир, телапревир (ВГС) }\end{array}$ \\
\hline & $\begin{array}{l}\text { Ингибитор вирусных регуляторных } \\
\text { белков }\end{array}$ & $\begin{array}{l}\text { Велпатасвир, пибрентасвир, Даклатасвир, } \\
\text { ледипасвир, омбитасвир, элбасвир (ВГС) }\end{array}$ \\
\hline & Интерфероны-альфа (ИФ-альфа) & ИФ-альфа 1а, 1в, 2а,2в, ПЭГ, ЦеПЭГ \\
\hline Сборка вириона & Ингибитор сборки вирусных частиц & Ледипасвир (ВГС), Метисазон (оспа) \\
\hline Выход вируса & Ингибиторы нейраминидазы & $\begin{array}{l}\text { Озельтамивир, занамивир, перамивир, } \\
\text { ланинамивир (грипп) }\end{array}$ \\
\hline $\begin{array}{l}\text { Вирус вне } \\
\text { клетки }\end{array}$ & $\begin{array}{l}\text { Антисептики } \\
\text { Оксолин }\end{array}$ & $\begin{array}{l}\text { Этанол, гипохлорит, перекись водорода, } \\
\text { нитрат серебра, хлоргексидин } \\
\text { Оксолиновая мазь (риновирусная инфекция, } \\
\text { профилактика гриппа) }\end{array}$ \\
\hline
\end{tabular}

Противогриппозные преnараты. В мире для лечения гриппа рекомендуется три группы препаратов: препараты, блокирующие депротеинизацию вирусов за счет блокирования М2-каналов вируса гриппа А (амантадин, ремантадин); ингибиторы нейроаминидазы препятствующие откреплению вирионов от поверхности инфицированной клетки (осельтамивир (тамифлю), занамивир (реленза), перамивир (рапиваб), ланинамивир (инавир)); ингибитор инициацию синтеза мРНК балоксавира марбоксил (ксофлюза). 
В России также рекомендуются к применению ингибиторы слияния (фузии) - нобазит и умифеновир. Несмотря на частичную или полную устойчивость к препаратам, в том числе последнего поколения, их применение оправдано, так как непонятно есть ли у данного конкретного возбудителя устойчивость к препарату. Так же доказано, что при применении противогриппозных препаратов снижается тяжесть симптомов, сокращается продолжительность заболевания, уменьшается частота вторичных осложнений. Препараты для лечения гриппа и ОРВИ целесообразно использовать в первые три дня заболевания т.к. от этого зависит эффективность лечения.

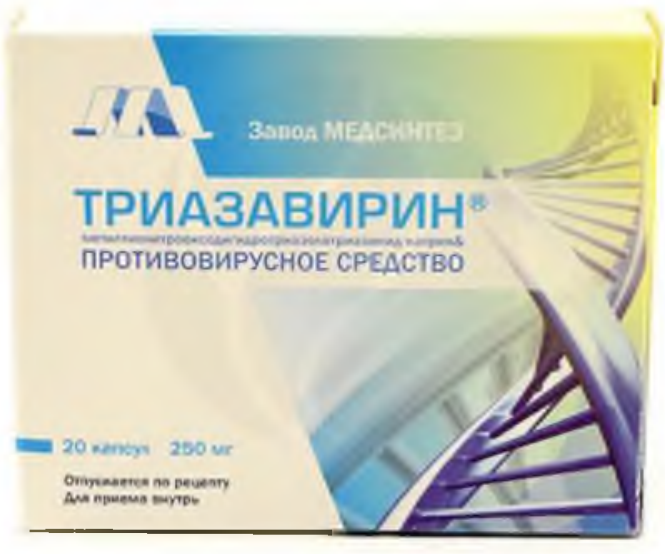

Препараты для лечения клещевого энцефалита и геморрагических лихорадок. Растущий уровень заболеваемости, развитие тяжелых форм болезни, хронизация процесса не оставляет сомнения в поиски новых методов терапии. К сожалению, до настоящего времени с позиций доказательной терапии этиотропные препараты для лечения этих заболеваний отсутствуют. C позиций патогенетической терапии обосновано применение альфа интерферонов, которые блокируют сборку вируса. Специфические иммуноглобулины в высоких титрах к этим инфекциям блокируют адсорбцию вируса на клетки-мишени.

При клещевом энцефалите в России активно применяется йотантипирин (как ингибиторы слияния (фузии), триазавирин и рибонуклеаза (как средство, блокирующее синтез вирусной РНК). Хороший эффект от применения рибаверина блокирующие синтез вирусной РНК. В некоторых случаях при хроническом клещевом энцефалите удается добиться стабилизирующего эффекта, усиливая специфический иммунитет вакциной. Вакцину для профилактики клещевого энцефалита вводят подкожно тремя курсами: первый курс по 0,5-1,0 мл трехкратно с интервалами в 5 дней; второй курс через 4-5недель по 0,5-1,0 мл трехкратно с интервалами в 3 дня; третий курс через 5-6 месяцев трехкратно по 1,0 мл через 1 день.

Антиретровирусные препараты. Основная задача проведения антиретровирусной терапии используя несколько препаратов достигнуть нулевой вирусной нагрузки. Комбинация препаратов собирается из двух, трёх или четырёх компонентов. Все компоненты относятся к различным группам (табл.96). Это нуклеозидные, нуклеотидные и ненуклеозидные ингибиторы обратной транскриптазы, ингибиторы протеазы, ингибиторы интегразы, ингибиторы слияния (ингибиторы фузии), ингибиторы рецепторов.

Применение АРВП проводится под контролем врачей-инфекционистов в специализированных медицинских учреждениях (центрах по профилактике и борьбе со СПИД, инфекционных больницах). В последнее время выпускаются уже готовые комбинации препаратов с однократным приёмом препаратов в сутки, что повышает эффективность проводимой терапии. Современные варианты лечения практически не имеют побочных эффектов, безопасны для человека и состоят в приёме одной таблетки в сутки либо одной инъекции в один или два месяца.

Антиретровирусные препараты не излечивают от СПИДа и не предупреждают заражение ВИЧ, однако снижение вирусной нагрузки до менее 20-50 копий/мл способствуют восстановлению количества $\mathrm{CD} 4$-лимфоцитов и, формированию адекватного иммунного ответа. Благодаря этому не развивается СПИД, не формируются заболевания, ухудшающие качество жизни больного. Увеличивается продолжительность и качество жизни. ВИЧположительный человек с нулевой вирусной нагрузки ничем не отличается от ВИЧотрицательных людей. 


\section{Препараты для лечения вирусного гепатита В.}

Для лечения хронического гепатита В (ХГВ) в настоящее время используется долгосрочная терапия аналогами нуклеоз(т)идов, которые принимаются внутрь 1 раз в день. $\mathrm{У}$ пациентов с нетяжелыми формами заболевания также возможно проведение монотерапии пегилированным интерфероном альфа в течение 48 недель с возможным увеличением длительности у отдельных пациентов с HBeAg-негативным ХГВ. Острый гепатит В не требует назначения противовирусной терапии. Однако, больным с молниеносными формами и/или сопутствующей дельта-инфекцией и/или с проявлениями иммунных нарушений лечение показано.

Согласно действующим в настоящий момент рекомендациям EASL 2017 года, при ХГВ начало терапии может быть рассмотрено по результатам оценки сочетания трех критериев:

- $\quad$ уровень ДНК вируса гепатита В (ВГВ);

- $\quad$ уровень АЛТ в сыворотке крови;

- $\quad$ тяжесть заболевания печени.

Лечение должно быть обязательно назначено пациентам с $\mathrm{HBeAg-позитивным} \mathrm{или}$ негативным ХГВ; пациентам с циррозом печени и любым определяемым уровнем ДНК ВГВ (независимо от уровня АЛТ); пациентам с ДНК ВГВ $>20000 \mathrm{ME} /$ мл и АЛТ $>2$ ВГН (независимо от тяжести поражения печени по гистологическому исследованию).

Долгосрочное применение высокоактивных аналогов нуклеоз(т)идов с высоким барьером резистентности является терапией выбора вне зависимости от тяжести поражения печени. Предпочтительными в качестве монотерапии являются препараты ETV (энтекавир), TDF (тенофовира дизопроксила фумарат) и TAF (тенофовира алафенамид). Не рекомендуются к применению препараты ламивудин и телбивудин.

Кроме того, учитывая профиль безопасности TDF при долгосрочном применении, в некоторых случаях следует отдавать предпочтение назначению ETV и TAF. TAF по сравнению с TDF обеспечивает сходные показатели вирусологической супрессии, более высокую частоту нормализации АЛТ и лучшую переносимость

Показания к предпочтительному применению ETV или TAF вместо TDF (У пациентов, ранее получавших аналоги нуклеоз(т)идов, применение TAF более предпочтительно, чем ETV):

В случае развития резистентности к ламивудину, телбивудину или энтекавиру, рекомендуется переключение на TDF или TAF. В случае резистентности к TDF или TAF переключение на ETV ( при отсутствии опыта терапии ламивудином ) или добавление к режиму ETV ( в случае, если есть резистентность к ламивудину ). При множественной резистентности рекомендуется переключение на ETV в комбинации с TDF или TAF.

Представителем нового класса противовирусных средств для лечения ХГВ с дельта-агентом является булевиртид. Механизм противовирусного действия объясняется высокоспецифичным и стабильным связыванием с расположенным на поверхности гепатоцитов транспортным белок, отвечающий за реабсорбцию желчных кислот в печени и используемым HBV и HDV в качестве рецептора для проникновения в клетку. Булевиртид препятствует

присоединению к нему вирусов, блокирует проникновение вирусов в клетку и последующие этапы их репликации. Не происходит образование новых вирусных частиц и поражение здоровых гепатоцитов. Наряду со снижением вирусной нагрузки происходит уменьшение воспалительного и цитолитического процессов в печени. Замедляется прогрессирования фиброза и цирроза печени и уменьшает риск связанных с ними осложнений. 
Препараты для лечения вирусного zепатита С. В терапии хронического гепатита С (ХГС) произошел существенный прорыв в последние годы. Внедрение высокоэффективных режимов на основе ПППД позволило достигать излечения у более 95\% пациентов независимо от генотипа вируса. Согласно Главной целью глобальной стратегии ВО3 является элиминация вирусного гепатита как проблемы общественного здравоохранения со снижением к 2030 г. числа новых случаев инфицирования вирусным гепатитом на $90 \%$ и смертности от вирусного гепатита на $65 \%$.

Основные международные рекомендации (EASL, AASLD, BO3) сходятся во мнении, что все пациенты с ХГС должны получать противовирусную терапию.

В 2020 году были обновлены рекомендации Европейской ассоциации по изучению печени (EASL), где также описаны и подходы по упрощенному подходу к диагностике и лечению ХГС (табл.97).

Таблица 97

\section{Рекомендации EASL 2020 по лечению ХГС (включая ко-инфекцию с ВИЧ)}

у пациентов старше 18 лет (EASLiver, EASL recommendations on treatment of hepatitis C - Final update of the series, Journal of Hepatology (2020), https://doi.org/10.1016/j.jhep.2020.08.018.)

\begin{tabular}{|c|c|c|c|c|c|c|}
\hline \multicolumn{3}{|c|}{ Варианты инфекции } & \multicolumn{4}{|c|}{ Препараты } \\
\hline Генотип & Цирроз & $\begin{array}{c}\text { Предшес } \\
\text { твующая } \\
\text { терапия }\end{array}$ & SOF/VEL & GLE/PIB & $\begin{array}{l}\text { SOF/VEL/ } \\
\text { VOX }\end{array}$ & EBR/GZR \\
\hline \multicolumn{7}{|c|}{ Упрощенный подход без определения генотипа/субтипа } \\
\hline \multirow{4}{*}{ Bce } & \multirow{2}{*}{ HET } & HET & \multirow{4}{*}{12 недель } & \multirow{3}{*}{8 недель } & \multirow{4}{*}{ HET } & \multirow{4}{*}{ HET } \\
\hline & & ДА & & & & \\
\hline & \multirow{2}{*}{ ДА } & HET & & & & \\
\hline & & ДА & & 12 недель & & \\
\hline \multicolumn{7}{|c|}{ Терапия в зависимости от генотипа/субтипа } \\
\hline \multirow{4}{*}{$\begin{array}{c}1 a, 1 b, 2 \\
4,5 \text { и } 6\end{array}$} & \multirow{2}{*}{ HET } & HET & \multirow{4}{*}{12 недель } & \multirow{3}{*}{8 недель } & \multirow{4}{*}{ HET } & \multirow{4}{*}{$\begin{array}{c}12 \text { недель } \\
\text { (генотип } \\
1 \text { b) }\end{array}$} \\
\hline & & ДА & & & & \\
\hline & \multirow{2}{*}{ ДА } & HET & & & & \\
\hline & & ДА & & 12 недель & & \\
\hline \multirow{4}{*}{3} & \multirow{2}{*}{ HET } & HET & \multirow{2}{*}{12 недель } & 8 недель & \multirow{2}{*}{ HET } & HET \\
\hline & & ДА & & 12 недель & & HET \\
\hline & \multirow[t]{2}{*}{ ДА } & HET & \multirow{2}{*}{$\begin{array}{c}12 \text { недель с } \\
\text { рибавирином }\end{array}$} & $\begin{array}{c}8-12 \\
\text { недель }\end{array}$ & \multirow[t]{2}{*}{12 недель } & HET \\
\hline & & ДА & & 16 недель & & HET \\
\hline \multirow{4}{*}{$\begin{array}{c}\text { Субтипы } \\
\text { 1l, 4r, 3b, } \\
3 \mathrm{~g}, 6 \mathrm{u}, 6 \mathrm{v} \\
\text { Мутации } \\
\text { в регионе } \\
\text { NS5A }\end{array}$} & \multirow{2}{*}{ HET } & HET & \multirow{4}{*}{ неизвестно } & \multirow{4}{*}{ неизвестно } & \multirow{4}{*}{12 недель } & \multirow{4}{*}{ HET } \\
\hline & & ДА & & & & \\
\hline & \multirow{2}{*}{ ДА } & HET & & & & \\
\hline & & ДА & & & & \\
\hline
\end{tabular}

SOF/VEL - софосбу вир/велпатасвир (Epclusa)

GLE/PIB - глекапревир/пибрентасвир (Mavyret)

SOF/VEL/VOX - софосбувир/велпатасвир/воксилапревир (Vosevi) - не зарегистрирован в РФ EBR/GZR - гразопревир/элбасвир (Zepatier)

цирроз - компенсированный цирроз печени (класс A по Child-Turcotte-Pugh) 
○ эпклюзА

sonnatacsир/сосьосбуаир $100 \mathrm{mr} / 400 \mathrm{mr}$ rabnerkn

\section{IPOCTO}

ВЫЛЕЧИТЬ ГEПАТИТ C'

ЗПКЛЮЗА० - ЕДИНСТВЕННЫЙ РЕХИМ ТЕРАПИИ ХГС В ОДНОЙ ТАБЛЕТКЕ АЛЯ ПРИЕМА ОДИН РАЗ В АЕНБ, ЭФФЕКТИВНЫЙ ПРРИ ПЮБОМ ГЕНОТИПЕ И СТАДИИ ОИБРОЗА ПЕЧЕНИ НЕЗАВИСИМО ОТ ОПИТА ЛЕЧЕНИЯ

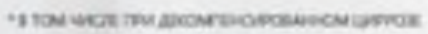

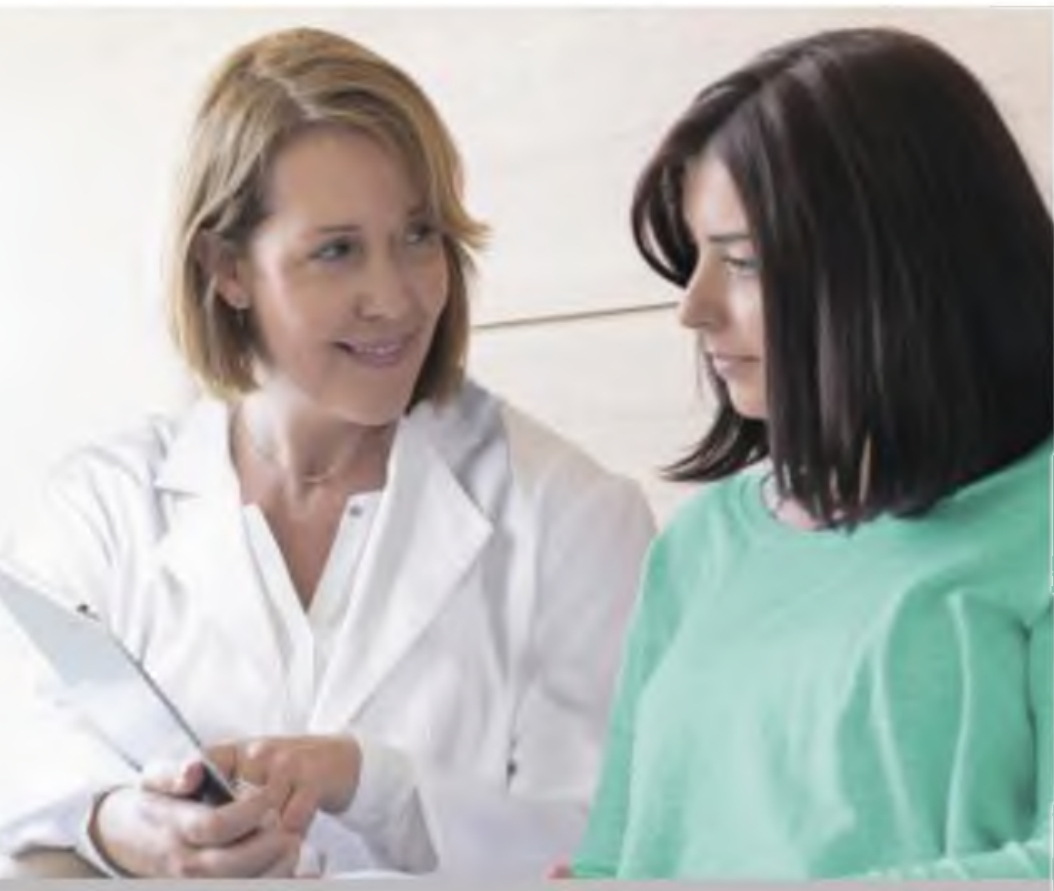

(2)

ПРОСТО аля вРАчА

(8) ПРОСТО аля пациЕнтА:

КРАТКАЯ ИНСТРУКЦИИЯ ПО МЕДИЦИНСКОМУ ПРИМЕНЕНИЮ ПРЕПАРАТА ЭПКЛЮЗА*

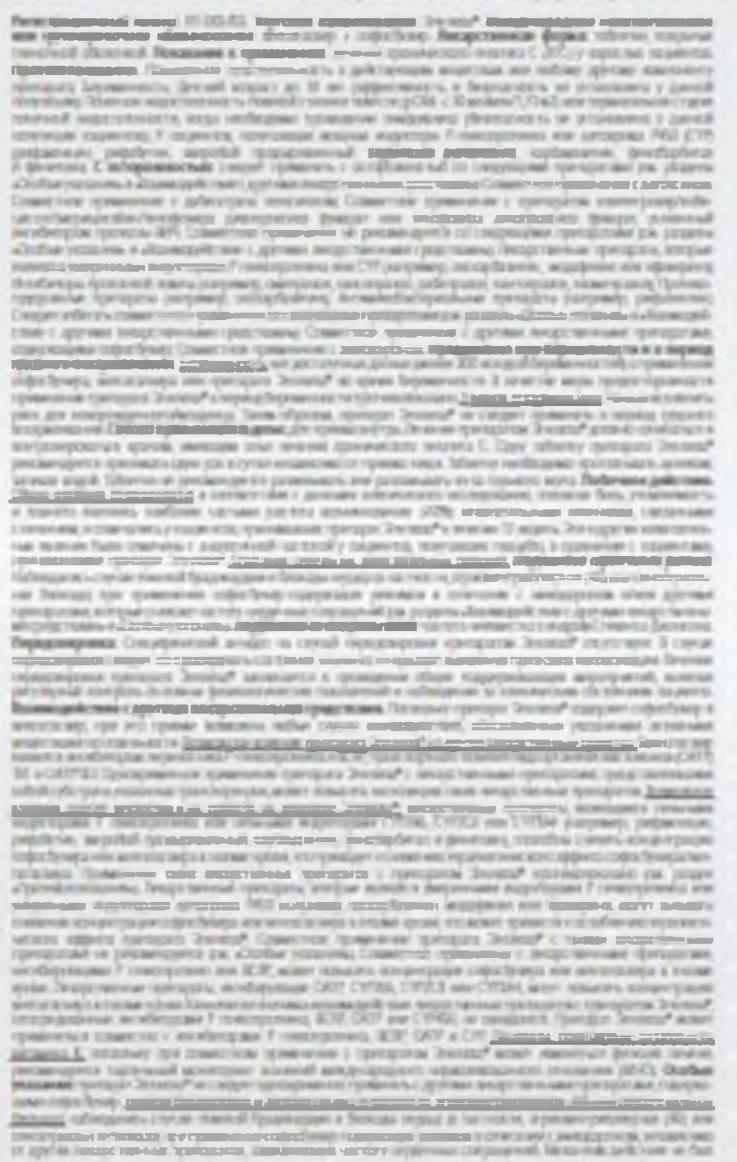

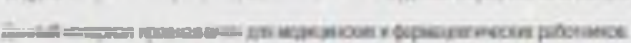

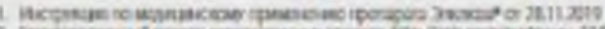

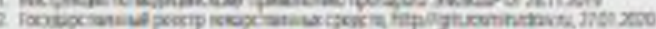

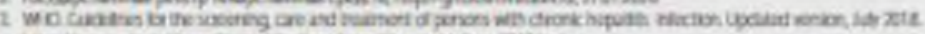

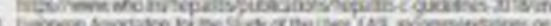

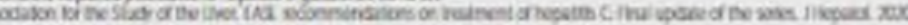

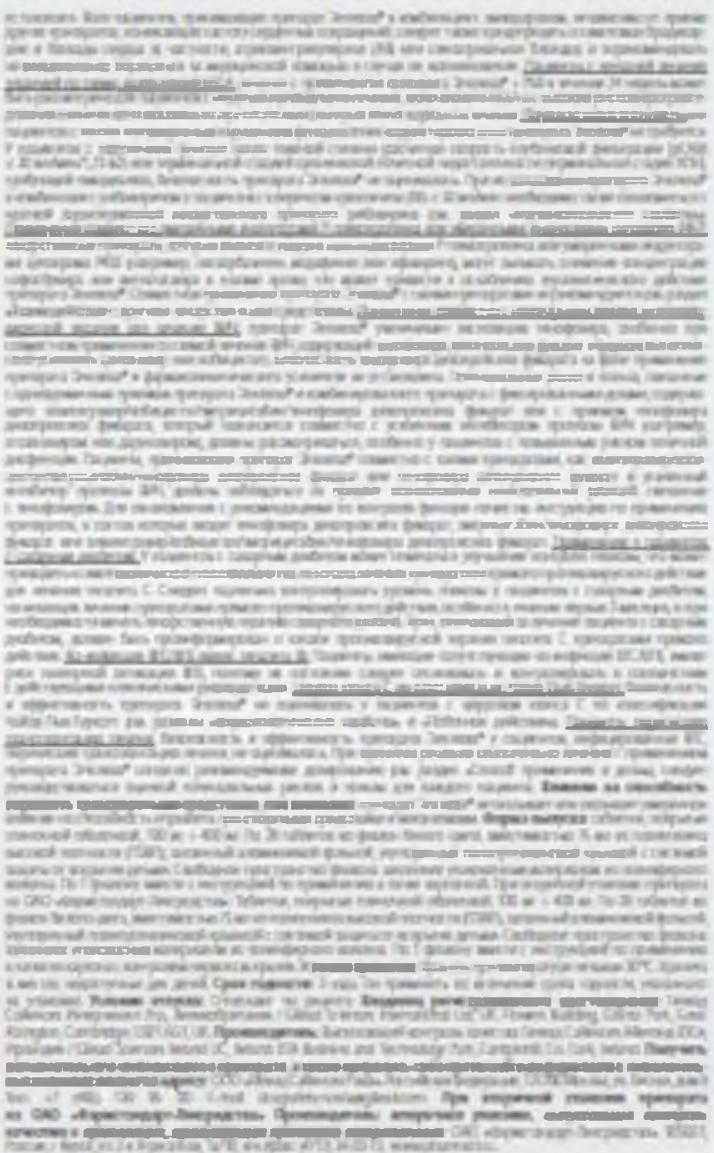

$\emptyset$ GILEAD

RUHCV20200t0005 
Режим в одной таблетке для приема 1 раз в день независимо от приема пищи софосбувир/велпатасвир представляет собой универсальную опцию терапии ХГС, которая может быть использована у пациентов независимо от генотипа и степени фиброза печени, а также у пациентов с циррозом печени, в том числе декомпенсированным.

Комбинация глекапревир/пибрентасвир в виде 3х таблеток, принимаемых однократно в сутки во время еды, также может назначаться пациентам с любым генотипом вируса гепатита С без цирроза и с компенсированным циррозом печени. В случае декомпенсированного цирроза применение схемы глекапревир/пибрентасвир противопоказано в связи с тем, что в состав режима входит ингибитор протеазы глекапревир.

Противопротозойные препараты. Класс препаратов предназначенных для лечения инфекций, вызванных одноклеточными простейшими. В России наиболее распространенными из них являются ляблиоз, токсоплазмоз, трихомониаз, в мире - малярия, лейшманиоз, амёбиаз, трипаносомозы. В связи с большим распространением ВИЧ-инфекции актуальность приобретают криптоспоридиоз, изоспороз, пневмоцистоз. Основные группы препаратов и спектр их действия представлен в таблице (табл.98)

Таблица 98

\section{Спектр действия противопротозойных препаратов}

\begin{tabular}{|c|c|c|c|c|c|c|c|c|c|c|}
\hline Препараты & $\sum_{\substack{0 \\
\leftarrow}}^{\stackrel{0}{0}}$ & 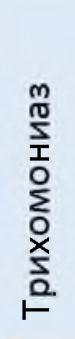 & 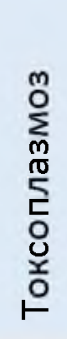 & 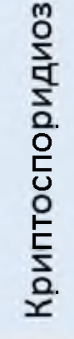 & 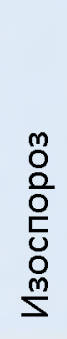 & 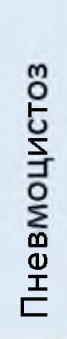 & $\begin{array}{l}\frac{\pi}{2} \\
\frac{2}{0} \\
\sum_{5}^{\frac{0}{2}} \\
\sum\end{array}$ & 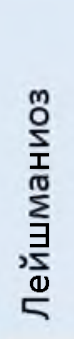 & 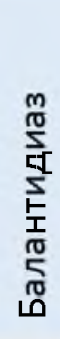 & $\sum_{\substack{\infty \\
\hdashline}}^{\substack{n \\
:}}$ \\
\hline $\begin{array}{l}\text { Хинолины: Хлорохин, Хинин, } \\
\text { Мефлохин, Примахин Тафенохин }\end{array}$ & + & & & & & & + & & & + \\
\hline Бигуаниды: Прогуанил & & & & & & & + & & & \\
\hline $\begin{array}{l}\text { Диаминопиримидины: } \\
\text { Пириметамин }\end{array}$ & & & + & & & & + & & & \\
\hline $\begin{array}{l}\text { Фенантренметанолы: } \\
\text { Галофантрин }\end{array}$ & & & & & & & + & & & \\
\hline $\begin{array}{l}\text { Терпенлактоны: Артемизинин и его } \\
\text { производные }\end{array}$ & & & & & & & + & & & \\
\hline $\begin{array}{l}\text { Сульфаниламиды: Сульфадоксин, ко- } \\
\text { тримоксазол }\end{array}$ & & & + & & + & + & + & & & \\
\hline $\begin{array}{l}\text { Тетрациклины: Тетрациклин, } \\
\text { Доксициклин }\end{array}$ & & & & & & & + & & + & \\
\hline Линкозамиды: Клиндамицин & & & + & & & + & + & & & \\
\hline Аминогликозиды: Паромомицин & & & & + & & & & $t$ & & + \\
\hline $\begin{array}{l}\text { Нитроимидазолы: Метронидазол, } \\
\text { тинидазол, орнидазол, секнидазол }\end{array}$ & + & + & & & + & & & & + & + \\
\hline $\begin{array}{l}\text { Макролиды: Спирамицин, } \\
\text { азитромицин, кларитромицин, } \\
\text { рокситромицин. }\end{array}$ & & & + & + & & & & & & \\
\hline Милтефозин & & & & & & & & + & & \\
\hline
\end{tabular}


Противоглистные средства. Арсенал препаратов, используемых при гельминтозах достаточно небольшой. Можно выделить производные бензимидазола (левамизол, мебендазол, албендазол) и препараты других химических групп (пирантела памоат, диэтилкарбамазин, никлозамид, празиквантел) (табл.99).

Таблица 99

\section{Антигельминтные препараты}

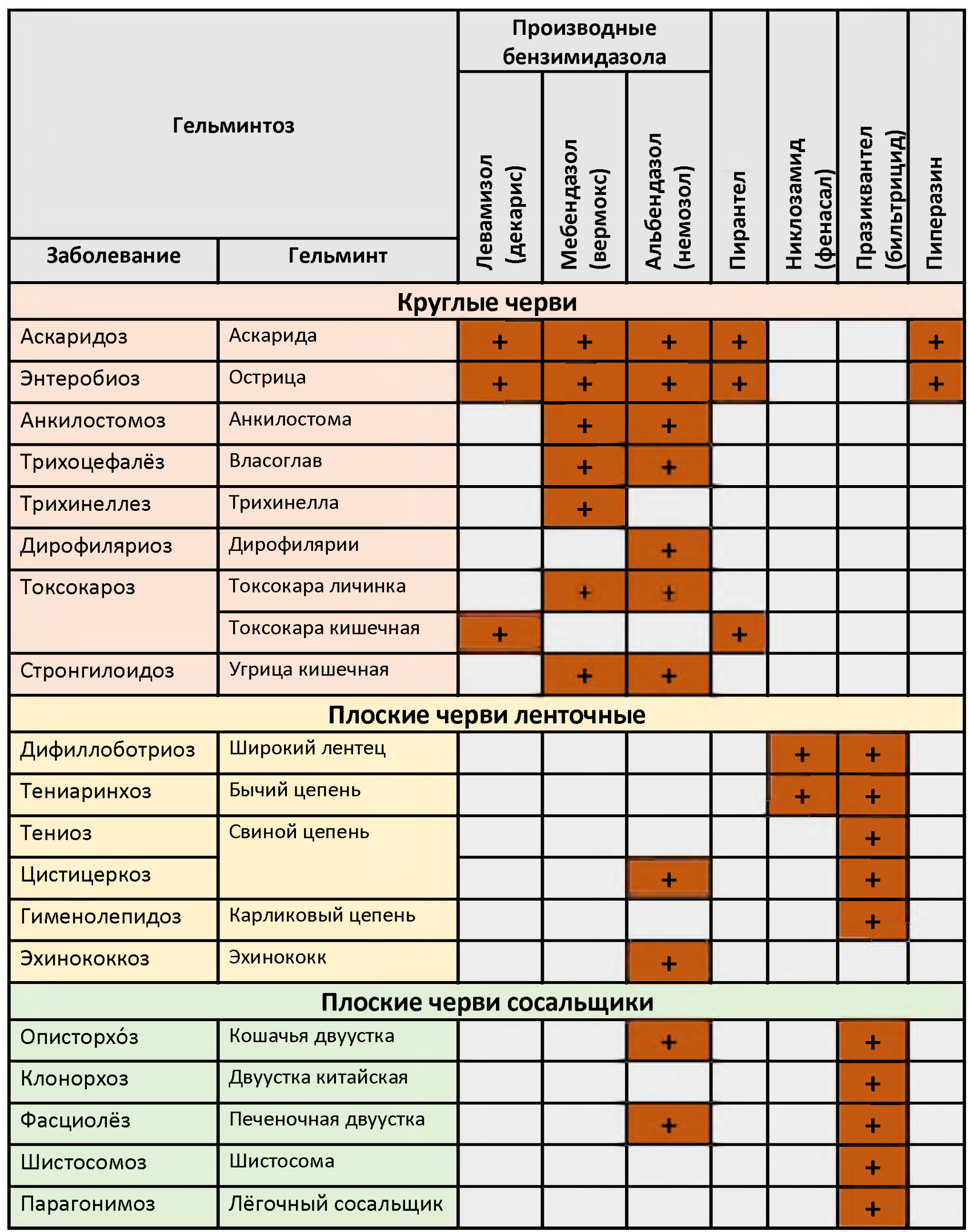


Противогельминтный эффект производных бензимидазола обусловлен нарушением синтеза клеточного тубулина, нарушением биоэнергетики гельминтов и как следствие парализующим действием. И если мебендазол (вермокс) всасывается плохо (не более 10\%), то альбендазол (немозол) обладает более высокой биодоступностью в тканях и способен проникать через ГЭБ и внутрь личиночных кист (при эхинококкозе, цистицеркозе). Производное пиримидина пирантел на гельминтов действует как деполяризующий миорелаксант.

Выраженным антигельминтным действием при многих гельминтозах обладает производное изохинолина празиквантель (бильтрицид). Его действие обусловлена генерализованным сокращением мускулатуры паразитов с последующим развитием стойкого паралича. Альтернативой при лечении ленточных гельминтов является никлозамид (фенасал), производное салициланилида Действие препарата связано с развитием паралича у гельминтов и уменьшением их устойчивости к протеолитическим ферментам ЖКТ. Ниже приведены схемы применения этих препаратов (табл. 100).

Таблица 100

\section{Схемы применения основных антигельминтных препаратов}

\begin{tabular}{|c|c|c|}
\hline Препарат & Заболевание & Схема применения \\
\hline \multirow{4}{*}{ 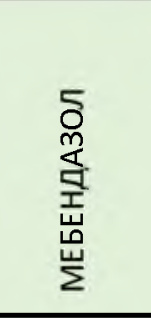 } & $\begin{array}{l}\text { аскаридоз, } \\
\text { трихоцефалез }\end{array}$ & от 2 лет в дозе 100 мг два раза в день в течение 3-х дней \\
\hline & энтеробиозе & в дозе 100 мг однократно в один прием, через 2 нед. повторить \\
\hline & токсокарозе & $\begin{array}{l}\text { взрослым по } 100 \text { мг два раза в день, детям - } 5 \text { мг/кг/сут. курс 7-10 дней; при } \\
\text { необходимости повторить }\end{array}$ \\
\hline & трихинеллез & $\begin{array}{l}\text { взрослым по } 100 \text { мг три раза в день, детям - } 5 \text { мг/кг/сут. в два приема курсом } \\
\text { 7-14 дней. }\end{array}$ \\
\hline \multirow{4}{*}{ 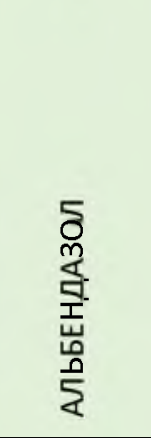 } & $\begin{array}{l}\text { аскаридозе, } \\
\text { энтеробиоз }\end{array}$ & $\begin{array}{l}\text { от } 2 \text { лет и старше в дозе } 5 \text { мг/кг массы или } 400 \text { мг для взрослых однократно в } \\
\text { один прием или в два приема после еды }\end{array}$ \\
\hline & $\begin{array}{l}\text { трихоцефалез, } \\
\text { стронгилоидоз }\end{array}$ & $\begin{array}{l}\text { от } 2 \text { лет и старше в дозе } 10 \text { мг/кг массы или } 400 \text { мг для взрослых однократно } \\
\text { в один прием } 3 \text { дня. Через неделю повторить }\end{array}$ \\
\hline & $\begin{array}{l}\text { токсокароз, } \\
\text { трихинеллез }\end{array}$ & $\begin{array}{l}\text { от } 14 \text { лет с массой тела более } 60 \text { кг по } 400 \text { мг } 2 \text { раза в день, менее } 60 \text { кг - по } \\
200 \text { мг } 2 \text { раза в день. Дети } 10 \text { мг/кг /сут. в } 2 \text { приема. Курс от } 7 \text { до } 14 \text { дней. } \\
\text { Повторно с интервалом в 2-4 нед. }\end{array}$ \\
\hline & $\begin{array}{l}\text { эхинококкоз, } \\
\text { цистицеркоз }\end{array}$ & $\begin{array}{l}\text { от } 14 \text { лет с массой тела более } 60 \text { кг по } 400 \text { мг } 2 \text { раза в день, менее } 60 \text { мг - из } \\
\text { расчета } 15 \text { мг/кг/сут. } 2 \text { раза в день. Курс терапии } 28 \text { дней. } 3 \text { курса терапии с } \\
\text { интервалом в } 14 \text { дней. }\end{array}$ \\
\hline 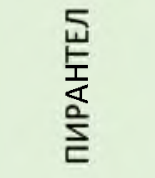 & $\begin{array}{l}\text { аскаридоз, } \\
\text { энтеробиоз, } \\
\text { стронгилоидозе }\end{array}$ & $\begin{array}{l}\text { в дозе } 10 \text { мг/кг однократно в один прием, } \\
\text { при стронгилоидозе - в течение } 3 \text { дней }\end{array}$ \\
\hline \multirow{3}{*}{ 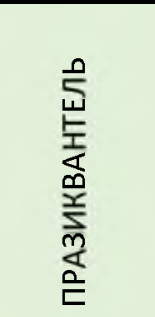 } & описторхоз & $\begin{array}{l}\text { из расчета } 40 \text { - } 75 \text { мг/кг массы при однодневном курсе в три приема с } \\
\text { интервалом четыре часа, после еды. }\end{array}$ \\
\hline & $\begin{array}{l}\text { тениоз, } \\
\text { тениаринхоз, } \\
\text { дифиллоботриоз }\end{array}$ & в дозе 25 мг/кг массы однократно. \\
\hline & гименолепидоз & 25 мг/кг в три приема через 6 ч в течение суток, через 2 недели повторить \\
\hline \multirow{2}{*}{ 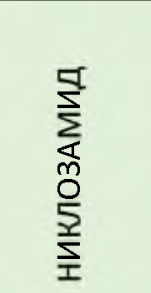 } & тениоз & $\begin{array}{l}\text { Суточная доза для взрослых - 2-3 г. принимают натощак с сахарным сиропом, } \\
\text { через } 2 \text { часа - солевое слабительное, через } 1 \text { месяц - прием препарата } \\
\text { повторить }\end{array}$ \\
\hline & $\begin{array}{l}\text { тениаринхоз, } \\
\text { дифиллоботриоз }\end{array}$ & $\begin{array}{l}\text { Утром натощак или вечером через 3-4 часа после легкого ужина, через } 2 \text { часа } \\
\text { - солевое слабительное. }\end{array}$ \\
\hline
\end{tabular}




\section{Коррекция дисбактериоза}

Как описывалось выше нарушение состава микробной флоры связано с нарушениями функции иммунной системы организма человека. Поэтому нормализация кишечного дисбактериоза может быть одним из основных мероприятий по коррекции иммунных нарушений. При построении тактики рационального, индивидуального лечения и профилактики дисбактериоза кишечника врачу необходимо решить следующие задачи:

1. Нормализовать работу кишечника (избавить больного от поносов и/или запоров).

2. Санировать кишечника от патогенной и условно-патогенной флоры (бактериофаги, кишечные антисептики, фитонциды и антибактериальные препараты).

3. Создать условия, способствующие более благоприятному развитию собственной флоры (аутофлоры) организма - коррекция нормальной микрофлоры кишечника с помощью различных пробиотиков, проведение энтеросорбции и энтеропротекции (карболен, полифепан, смекта и др.).

4. Обеспечить функциональное питание.

5. Сохранять и поддерживать микробную экологию кишечника.

Санации кишечника от патогенной и условно-патогенной микрофлоры обязательна у пациентов с III и IV степенями тяжести дисбиотического процесса, с признаками микробной контаминация кишечника. Препараты назначают с учетом вида и чувствительности возбудителя. При острых диареях бактериальной этиологии применяются антибиотики, противомикробные средства из группы хинолонов (нитроксолин), фторхинолонов (офлоксацин, иипрофлоксаиин и др.), производные нитрофурана (фурадонин, фуразолидон). При хронических инфекциях предпочтение отдается кишечным антисептикам - интетрикс, энтероседива нифуроксазид, Целесообразно одновременно с ними или отдельно назначать и лечебные бактериофаги: коли, коли-протейный, стафилококковый, клебсиеллезный, «пиобактериофаг», поликомпонентные препараты. Решение о назначении того или иного антибиотика применяется с учетом лабораторных исследований в идеале с проведением антибиотикограммы. Как альтернатива предлагается при выявлении аэробных микроорганизмов пользоваться антибиотиками, при анаэробной - нитроимидозольными препаратами, при бактериально-кандидозном дисбалансе обязательно дополнительно антимикотики.

Как средство для санации кишечника рекомендуется иммуноглобулиновый комплексный препарат (КИП) представляющий собой белковые фракции сыворотки крови человека, лиофильно высушенные, и содержит $\operatorname{IgA}$, M и G. B комплексном лечении и как монотерапию при I II степени дисбиоза для санации кишечника предлагаются сборы трав: на 1 этапе - шалфей, календула, крапива, зверобой, тысячелистник, донник, ольха и бадан; затем на 2 этапе - шиповник, крапива, смородина, клевер, элеутерококк, календул, рябина, анис и душиц.

Для восстановления нормальной микрофлоры кишечника применяют три группы препаратов: пробиотики, пребиотики, синбиотики (табл.101).

Пробиотики - живые микроорганизмы, которые, при назначении в адекватных количествах приносить пользу здоровью хозяина. С позиций QPS (Qualified Presumption of Safety - квалифицированная презумпция безопасности) пробиотики могут содержать либо один штамм, либо смесь двух или более штаммов бактерий. Это 5 видов бифидобактерий (Bifidobacterium spp.), 33 вида лактобактерий (Lactobacillus spp.), а также Lactoccocus lactis, Leuconostoc spp., Pediococcus spp., Propionibacterium freudenreichii и Streptococcus thermophilus. 
Механизм действия пробиотиков связан с производством антимикробных веществ, ингибирование выработки бактериальных токсинов, иммуноактивное действие (по типу вакцины)

Пребиотики - субстрат, который избирательно используется микроорганизмамихозяевами, приносящими пользу для здоровья. Это пищевые вещества в основном состоящие из некрахмальных полисахаридов и олигосахаридов, плохо перевариваемых человеческими ферментами.

Синбиотики представляет собой комбинацию пробиотика и пребиотика обладающих синергическим эффектом на физиологические функции и метаболизм человека в целом.

Таблица 101

\section{Препараты для восстановления нормальной микрофлоры кишечника}

\begin{tabular}{|c|c|}
\hline Препарат & Состав \\
\hline \multicolumn{2}{|r|}{ Пробиотики } \\
\hline Бифидумбактерин & лиофильно высушенные Bifidobacterium bifidum $5 \times 10^{8} \mathrm{KOE}$ \\
\hline Лактобактерин & лактобактерии ацидофильные менее 2 млрд KOE \\
\hline Колибактерин & живых бактерий кишечной палочки не менее 1 млрд КОЕ \\
\hline Бактиспорин & лиофилизированные живые бактерий Bacillus subtilis 1-5 млрд KOE \\
\hline Энтерол & лиофилизированных Saccharomyces boulardii 250 мг \\
\hline Ацилакт сухой & L.acidophilus - 3 разных штамма \\
\hline Бификол & кишечная палочка и бифидобактерий В. bifidum \\
\hline Биоспорин & лиофильно высушенные живые B.subtilis и B.licheniformis \\
\hline Линекс & B.infantis, L.acidophilus, E. faecium \\
\hline Бифиформ & B. longum n E. faecium \\
\hline Пробифор & В. bifidum, адсорбированные на активированном угле \\
\hline Бифилиз сухой & B.bifidum и лизоцим (комбинированный пробиотик) \\
\hline \multicolumn{2}{|r|}{ Пребиотики } \\
\hline Инулин & олигофруктоза \\
\hline Лактулоза & олигосахариды \\
\hline Хилак форте & $\begin{array}{l}\text { биосинтетическая молочная кислота и ее буферные соли и другие } \\
\text { короткоцепочечные летучие жирные кислоты }\end{array}$ \\
\hline Лактофильтрум & $\begin{array}{l}\text { двухкомпонентный препарат, состоящий из пребиотика (лактулозы) и } \\
\text { сорбента (лигнина) }\end{array}$ \\
\hline \multicolumn{2}{|r|}{ Синбиотики } \\
\hline Нормоспектрум & $\begin{array}{l}\text { инулин, бифидобактерии и лактобациллы (9 штаммов), витамины: Е, С, B1, B2, } \\
\text { В6, В12, никотинамид, пантотеновая кислота, фолиевая кислота, биотин), } \\
\text { минеральные вещества (цинк, селен) }\end{array}$ \\
\hline Бион-3 & $\begin{array}{l}\text { пробиотические культуры (Lactobacillus gasseri Bifidobacterium bifidum } \\
\text { Bifidobacterium longum); витамины A, B1, В2, В6, В12, C, D3, Е, никотинамид, } \\
\text { пантотеновая кислота, фолиевая кислота, биотин; минеральные вещества } \\
\text { (фосфат, магний, железо, цинк, марганец, йод, селен, хром, молибден) }\end{array}$ \\
\hline Бифидум-Мульти & бифидобактерии (6 штаммов), пектин яблочный; инулин \\
\hline Биовестин-лакто & $\begin{array}{l}\text { Bifidobacterium adolescentis (1 млрд KOE/мл); Lactobacillus plantarum (100 млн. } \\
\text { КОЕ/мл); продукты метаболизма бифидо- и лактобактерий }\end{array}$ \\
\hline ВитаФлор & $\begin{array}{l}\text { Лиофилизированные Lactobacillus acidophilus не менеe } 100 \text { млн. KOE, } \\
\text { аскорбиновая кислота (витамин С) }-12,5 \text { мг; молоко сухое обезжиренное; } \\
\text { сахароза; желатин пищевой; автолизат пекарских дрожжей; лукаротин ( } \beta \text { - } \\
\text { каротин). }\end{array}$ \\
\hline Аципол & L.acidophilus и полисахариды кефирных грибков \\
\hline
\end{tabular}


В качестве одного из эффективных способов лечения позволяющий полностью восстанавливать микробиоту кишечника является фекальные трансплантация. Она показала высокую эффективность при терапии псевдомембранозного колита (CDI). B настоящее время рассматривается возможность его применения при других патологических состояниях (воспалительные заболевания кишечника, атеросклероз, неалкогольные жировые заболевания печени, ожирение, нервно-психические заболевания, микроорганизмы с множественной лекарственной устойчивостью).

Задача поддержания нормального микробиоценоза толстой кишки осуществляется принципами функционального питания, включающего в себя прием пищевых волокон в различных формах, лечебных молочнокислых продуктов, содержащих ацидофильные бактерии и бифидобактерии («Бифидок», бифидумкефир, биойогурты). Кроме того, рекомендуется периодический, короткими курсами, прием хилак форте, mpaвяных чаев $u$ сборов.

Для стабилизации микробиоценоза толстой кишки необходимо постоянное его поддерживание, так как после прекращения приема биологически активных препаратов бактериологическое обследование через $2-4$ нед. вновь выявляет состояние дисбактериоза в той или иной степени выраженности. С этой целью предложена методика пульстерапии: каждый последующий месяц на протяжении полугода пациенту проводят укороченные курсы лечения препаратами, которые использовались для первоначальной санации - кишечные антисептики $1-2$ дня, а затем бактериальные препараты $7-10$ дней. Одновременно продолжается постоянный прием витаминно-минеральных комплексов, травяных сборов, по показаниям применяются ферментные препараты. 


\section{ЛЕЧЕНИЕ БОЛЬНЫХ С ИММУННЫМИ НАРУШЕНИЯМИ}

\section{Глава 18. Применение средств влияющих на клеточное окружение}

Первым и очень важным звеном «подготовки» к лечению пациентов с нарушениями функции иммунной системы является улучшить состояния межклеточного взаимодействия. Во многих случаях без этого этапа в лечении реакция на иммуномодулирующую терапию может быть неадекватной или даже парадоксальной. Под действием токсинов, микробных супрессивных белков, длительного избыточного воздействия $А Г$, оксидантов, провоспалительных цитокинов и других факторов меняются свойства мембран клеток иммунной и сопряженной с ними систем, блокируются рецепторы мембран. После длительной активации тех или иных клеток наступает фаза их супрессии или гипореактивности.

Крайняя степень интоксикация проявляется в виде инфекционно-токсического шока (табл. 102).

Таблица 102.

\section{Клиническое определение степеней инфекционно-токсического шока}

\begin{tabular}{|c|c|c|c|}
\hline $\begin{array}{l}\text { Критерии } \\
\text { тяжести }\end{array}$ & І степень & II степень & III степень \\
\hline Сознание & Возбуждение & Заторможенность & $\begin{array}{l}\text { Спутанное, } \\
\text { отсутствует }\end{array}$ \\
\hline Реакция зрачков & Сужены & \multicolumn{2}{|c|}{ Расширены, реакция вялая } \\
\hline Температура & Гипертермия & \multicolumn{2}{|c|}{ Критическое падение } \\
\hline Кожные покровы & $\begin{array}{c}\text { Цианоз губ и } \\
\text { нотевых фаланг }\end{array}$ & $\begin{array}{l}\text { Акроцианоз, } \\
\text { холодный пот }\end{array}$ & $\begin{array}{l}\text { Тотальный } \\
\text { цианоз }\end{array}$ \\
\hline Дыхание & Не нарушено & Легкая одышка & $\begin{array}{c}\text { Поверхностная } \\
\text { одышка }\end{array}$ \\
\hline АД & норма & $\begin{array}{c}\text { Снижено } \\
\text { до } 80 \text { мм рт.ст. }\end{array}$ & $\begin{array}{c}\text { Снижено } \\
\text { менее } 80 \text { мм рт.ст. }\end{array}$ \\
\hline Пульс & $\begin{array}{l}\text { Умеренная } \\
\text { тахикардия }\end{array}$ & $\begin{array}{c}\text { Тахикардия } \\
\text { более } 100 \text { в минуту }\end{array}$ & $\begin{array}{l}\text { Нитевидный, } \\
\text { не определяется }\end{array}$ \\
\hline $\begin{array}{l}\text { Индекс } \\
\text { Аллговера } \\
\text { (САД/пульс) }\end{array}$ & До 1,0 & $1-1,5$ & Более 1,5 \\
\hline Диурез & $\begin{array}{l}\text { Несколько } \\
\text { снижен }\end{array}$ & Олигоурия & Анурия \\
\hline $\begin{array}{l}\text { Геморрагический } \\
\text { синдром }\end{array}$ & Не характерен & \multicolumn{2}{|c|}{$\begin{array}{c}\text { Рвота «кофейной гущей», гематурия, } \\
\text { мелена, ДВС-синдром }\end{array}$} \\
\hline
\end{tabular}


Медикаментозные стимулирующие или модулирующие воздействия на таком фоне могут быть малоэффективны или даже вредны. Для предотвращения этих процессов используется детоксикационная терапия, средства для улучшения реологии крови.

Детоксикационная (эфферентная) терапия (от лат. efferens - выводить) - метод лечения, направленный на выведение из организма токсических и балластных веществ, метаболитов.

Эндогенная интоксикация, свойственная большинству заболеваний, представляет собой основную точку приложения эфферентных методов. Влияние эфферентной терапии на патологические процессы не исчерпывается прямой детоксикацией. При некоторых состояниях целью применения таких методов лечения является необходимость коррекции иммунологических нарушений (путем выведения избытка ЦИК, иммунокомпетентных клеток, аутоантител). Практическое значение имеет также возможность направленной коррекции белкового и водно-электролитного состава крови.

Детоксикация - это комплекс лечебных мероприятий, проводимых с целью прекращения воздействия токсичных веществ и их удаления из организма. Достижению этой цели служит большое число методов, направленных на стимуляцию естественной детоксикации, а также проведение искусственной и антидотной дезинтоксикационной терапии.

Эфферентную терапию следует с полным основанием относить к этиопатогенетическим методам лечения, поскольку возможно связывание и удаление не только микробных токсинов, но и самих бактерий и вирусов. Вместе с тем такая терапия эффективна только в комплексе с обычным этиотропным и поддерживающим лечением соответственно нозологической форме заболевания.

В клинической практике методы детоксикации проводятся либо путем стимуляции естественной детоксикации, либо путем активной искусственной (эфферентная терапия).

Можно выделить следующие виды детоксикации: 1) стимуляция естественных процессов выведения - очищение ЖКТ, форсированный диурез; 2) неинвазивные методы эфферентной терапии; 3) инвазивные методы эфферентной терапии.

Как способ дезинтоксикации возможно также рассматривать описанные выше методы стимуляция биотрансформации - регуляция ферментативной функции гепатоцитов за счет фармакологической или физико-химической индукции или ингибиции, и стимуляция активности иммунной системы - фармакологическая коррекция - физиогемотерапия.

К методам, направленным на усиление физиологической детоксикации, относятся очищение ЖКТ, форсированный диурез, регуляция активности ферментов, создание гиперили гипотермии и др. При их проведении используются рвотные и слабительные средства, препараты, обеспечивающие водно-электролитную нагрузку, осмотические диуретики и салуретики. Следует отметить, что стимуляция естественных механизмов детоксикации возможна только при условии сохранения функции элиминирующих систем организма.

\section{Стимуляция выведения токсинов.}

Очищение желудочно-кишечного тракта - пищеварительная система поставляет питательные вещества и удаляет отработанные элементы, если в работе органов пищеварения происходят какие-то нарушения, сбои в работе других органов и систем. Одна из причин дисфункции пищеварительной системы связана с нарушением вывода продуктов обмена вешеств и накоплением их в организме, что приводит к хронической эндогенной интоксикации. Прежде всего, при очищении кишечника большое значение имеет диета. Список запрещенных продуктов включает жирное мясо и мясопродукты, копчености, белый хлеб и кондитерские изделия, макаронные изделия и крупы (кроме овсяной), жирное цельное молоко, творог, сахар, алкоголь. Обязательное условие: принимать не менее 2 - 3 л жидкости в день, а на ночь выпивать стакан любого кисломолочного продукта (кефир, йогурт, ряженка).

Большое значение имеет очищение кишечника и печени. Промывание кишечника через задний проход - постановка клизмы, один из древнейших способов очищения. В настоящее время арсенал промывания через задний проход весьма широк - от проведения микроклизм с 
введением небольших объемов, обычно лекарственных веществ, до сифонных клизм и промывания желудка с помощью специальной аппаратуры (гидроколонотерапия).

Достаточно эффективное средство для очищения и промывания желчных протоков слепой тюбаж. Процедура помогает избавиться от застоя желчи и как следствие способствует выделению продуктов обмена веществ. Наиболее простой вид слепого тюбажа - с помощью минеральной воды. Процедуру лучше проводить рано утром, перед этим натощак (не едят минимум 6 ч) выпивают 250 - 300 мл минеральной воды, обладающей желчегонным действием (Ессентуки № 4). Предварительно из воды нужно выпустить все газы и подогреть до $36-38^{\circ} \mathrm{C}$, затем положить на область печени теплую грелку и лечь на правый бок. Воду в грелке нужно также обновлять. Необходимо допить минеральную воду (200-250 мл). Общая продолжительность процедуры 1,5 ч, эффектом будет являться разжиженный стул с зеленоватым оттенком. Помимо минеральной воды можно использовать раствор сернокислой магнезии (1 чайная ложка на стакан воды), мед (1 столовая ложка на стакан воды), яблочный сок, овсяный отвар, растительное масло с лимонным соком.

При детоксикации достаточно широко применяются внутривенные введения растворов. Однако при этом необходимо учитывать распределение воды в организме, изменения других жидкостей и электролитов.

Удельная масса воды в организме колеблется от 50 до $70 \%$. Она состоит из внутриклеточной жидкости, которая составляет примерно 40 \% от массы тела, и внеклеточной воды: внутрисосудистой, составляющей $5 \%$, и интерстициальной, составляющей $15 \%$ от массы тела. Водный баланс за сутки 2000 мл. Поступает в организм 1500 мл воды за счет питья и 500 мл - за счет еды. Выделяется 250 мл с испражнениями, $800-1500$ мл - с мочой и 600 мл - неощутимые потери влаги. Изменения жидкостей в организме может осуществляться за счет трех причин: изменения объема, изменения концентрации ионов и изменения состава ионов.

Дефицит объема жидкости - наиболее частая проблема у хирургических больных и больных с инфекционной патологией (рис.106). Причиной является потеря жидкости при рвоте, через свищи, при кровотечениях и перемещение жидкости в интерстициальное пространство при травмах и инфекционных процессах. Клинически при этом наблюдаются ортостатическая гипотензия, снижение диуреза и небольшое понижение температуры тела (табл. 122). Лечение заключается в восполнении циркулирующего объема плазмы изотоническими солевыми растворами. Важное значение при проведении дезинтоксикационной терапии принадлежит сохранению или восстановлению нормального состава ионов в плазме (натрий, калий, кальций). Прежде всего необходимо решить вопрос, требуется ли возмещение этих веществ в ходе инфузионной терапии.

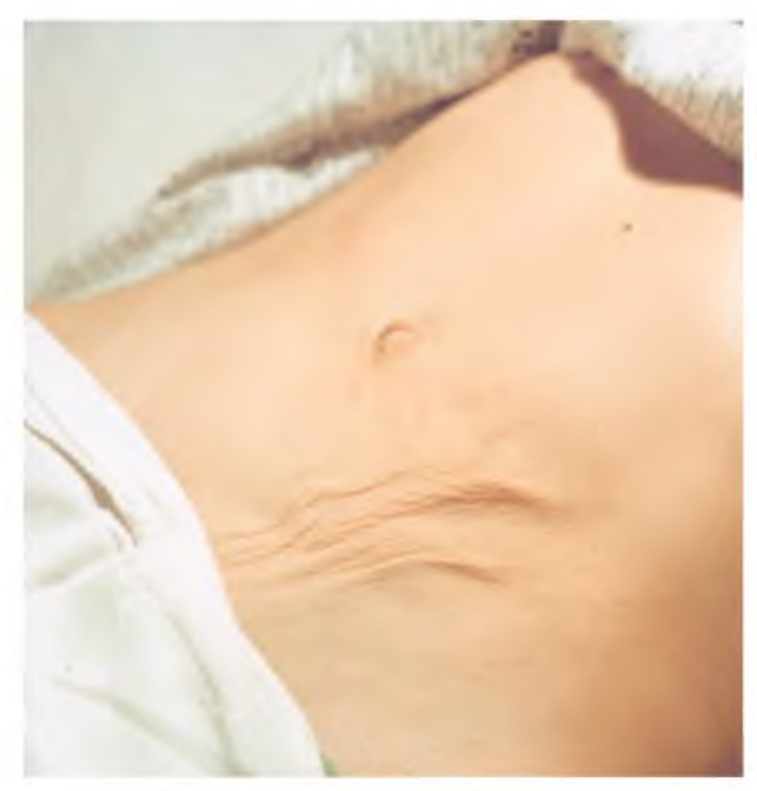

\section{Рис. 122 Нарушение тургора кожи при большой потере жидкости}

Совместно с инфузионной терапией для проведения дезинтоксикационных мероприятий применяется форсированный диурез. Этот метод детоксикации основан на применении препаратов, способствующих возрастанию диуреза, и является наиболее распространенным методом консервативного лечения, а также достаточно универсальным методом удаления из организма токсических веществ. 


\section{Клинические проявления дегидратации}

\begin{tabular}{|c|c|c|c|c|}
\hline \multirow{2}{*}{$\begin{array}{c}\text { Клинические } \\
\text { проявления }\end{array}$} & \multicolumn{4}{|c|}{ Дегидратация: степень (потеря жижкости в \% от массы тела) } \\
\hline & I (до 3\%) & II $(4-6 \%)$ & III (7-9\%) & IV (более 9\%) \\
\hline $\begin{array}{l}\text { Общее } \\
\text { состояние }\end{array}$ & Не нарушено & $\begin{array}{l}\text { Слабость, } \\
\text { головокружение и } \\
\text { обмороки. } \\
\text { Температура тела } \\
\text { нормальная или } \\
\text { субфебрильная. } \\
\text { Кратковременные } \\
\text { судороги мышц }\end{array}$ & $\begin{array}{l}\text { Сознание сохранено, } \\
\text { жажда. За счет } \\
\text { развития ацидоза (рН } \\
\text { 7,3-7,36) учащенное } \\
\text { шумное дыхание. Но } \\
\text { отсутствуют } \\
\text { вторичные } \\
\text { нарушения гемостаза } \\
\text { и органная патология }\end{array}$ & $\begin{array}{l}\text { Генерализованные } \\
\text { продолжительные } \\
\text { судороги, «рука } \\
\text { акушера», «конская } \\
\text { стопа» судорожные } \\
\text { сокращения мышц } \\
\text { живота, икота. } \\
\text { Дыхание учащено, до } \\
60 \text { в мин. } \\
\text { поверхностное, }\end{array}$ \\
\hline $\begin{array}{l}\text { Проявление со } \\
\text { стороны } \\
\text { желудочно- } \\
\text { кишечного } \\
\text { тракта }\end{array}$ & $\begin{array}{l}\text { Жидкий } \\
\text { кашицеобразный } \\
\text { до } 10 \text { раз в сутки, } \\
\text { не более } 3 \text { суток. } \\
\text { Рвоты нет }\end{array}$ & $\begin{array}{l}\text { Жидкий } \\
\text { обильный до } 10-15 \\
\text { раз в } \\
\text { Возможна рвота до } \\
10 \text { раз в сутки без } \\
\text { предшествующей } \\
\text { тошноты }\end{array}$ & $\begin{array}{l}\text { Обильный } \\
\text { водянистый стул 10- } \\
20 \text { раз в сутки, рвота } \\
\text { более } 20 \text { раз в сутки } \\
\text { при обезвоживании } \\
\text { рвота болезненная, } \\
\text { затруднена }\end{array}$ & $\begin{array}{l}\text { Непрерывная } \\
\text { дефекация («дорожка } \\
\text { фекальных масс»). } \\
\text { Обильная } \\
\text { мучительная рвота }\end{array}$ \\
\hline $\begin{array}{l}\text { Проявление со } \\
\text { стороны } \\
\text { сердечно- } \\
\text { сосудистой } \\
\text { системы }\end{array}$ & $\begin{array}{l}\text { АД в пределах } \\
\text { возрастной } \\
\text { нормы, } \\
\text { лабильность } \\
\text { пульса }\end{array}$ & $\begin{array}{l}\text { Тахикардия, } \\
\text { гипотония }\end{array}$ & $\begin{array}{l}\text { АД значительно } \\
\text { снижено. } \\
\text { частый, слабый }\end{array}$ & $\begin{array}{l}\text { АД резко снижено, } \\
\text { пульс не } \\
\text { определяется, на } \\
\text { периферических } \\
\text { сосудах. ЭКГ - } \\
\text { диастолическая } \\
\text { перегрузка правых } \\
\text { отделов сердца }\end{array}$ \\
\hline Мочеиспускание & $\begin{array}{l}\text { Диурез } \\
\text { изменен }\end{array}$ & Диурез не изменен & Олиго- или анурия & Анурия \\
\hline $\begin{array}{l}\text { Кожа и } \\
\text { слизистые }\end{array}$ & $\begin{array}{l}\text { Сухость слизистых } \\
\text { рта Кожа влажная, } \\
\text { тургор не } \\
\text { изменен, цианоза, } \\
\text { судорог нет }\end{array}$ & $\begin{array}{lr}\text { Язык } & \text { сухой, } \\
\text { обложен } & \text { бурым } \\
\text { налетом, сухость во } \\
\text { рту, } \\
\text { голос. Бледность и } \\
\text { сухость } \\
\text { покровов }\end{array}$ & $\begin{array}{l}\text { Кожа и слизистые } \\
\text { сухие, тургор кожи } \\
\text { снижен, кожная } \\
\text { складка медленно, } \\
\text { расправляется, кожа } \\
\text { рук морщинистая } \\
\text { («руки прачки»), } \\
\text { акроцианоз }\end{array}$ & $\begin{array}{lr}\text { Кожные } & \text { покровы } \\
\text { холодные, покрыты } \\
\text { липким } \\
\text { тотальный } \\
\text { «руки цианом, } \\
\begin{array}{l}\text { кожная складка не } \\
\text { расправляется } \\
\text { течение часа }\end{array}\end{array}$ \\
\hline $\begin{array}{l}\text { Лабораторные } \\
\text { данные }\end{array}$ & $\begin{array}{l}\text { Показатели крови } \\
\text { (вязкость, } \\
\text { гематокрит, } \\
\text { электролиты) не } \\
\text { отклоняются от } \\
\text { нормы }\end{array}$ & $\begin{array}{l}\text { Нарушения } \\
\text { электролитного } \\
\text { состава крови } \\
\text { непостоянны, } \\
\text { наблюдается } \\
\text { гипокалиемия и } \\
\text { гипохлоремия }\end{array}$ & $\begin{array}{l}\text { Сгущение крови } \\
\text { умеренное, } \\
\text { гипокалиемия, } \\
\text { гипохлоремия, } \\
\text { компенсаторная } \\
\text { гипернатриемия }\end{array}$ & $\begin{array}{l}\text { Эритроцитоз, } \\
\text { лейкоцитоз, } \\
\text { гипокалиемия (до 2,5 } \\
\text { ммоль/л), } \\
\text { гипохлоремия, } \\
\text { гипонатриемия, } \\
\text { декомпенсированный } \\
\text { метаболический } \\
\text { ацидоз (рН < 7,3), } \\
\text { одновременно } \\
\text { респираторный } \\
\text { алкалоз малого круга } \\
\text { кровообращения }\end{array}$ \\
\hline
\end{tabular}

Форсированный диурез всегда проводится в три этапа: предварительная водная нагрузка, быстрое введение диуретика и заместительная инфузия раствором электролитов. Обычно этот метод проводится на фоне интенсивно проводимой инфузионной терапии $1,0-$ 
1,5 л $5 \%$-й глюкозы, солевых и плазмозаменяющих растворов. Как мочегонное средство применяют мочевину или маннитол (15 - 20\%-й раствор). Их вводят внутривенно струйно в количестве 1,0 - 1,5 г на 1 кг массы тела больного. Возможно также применение фуросемида. В последующем вводится раствор электролитов со скоростью, равной скорости диуреза. При форсированном диурезе необходимо проводить строгий учет введенной и выделенной жидкости, определение гематокрина и электролитов крови. Метод противопоказан при тяжелых сердечно-сосудистых заболеваниях, а также при нарушении функции почек.

\section{Неинвазивные сорбционные методы детоксикации.}

К неинвазивным сорбционным методам детоксикации относят методы детоксикации, метаболической и иммунологической коррекции, в процессе проведения которых не осуществляется прямой контакт сорбента с кровью. У больных практическое применение нашла гастроинтестинальная энтеросорбция.

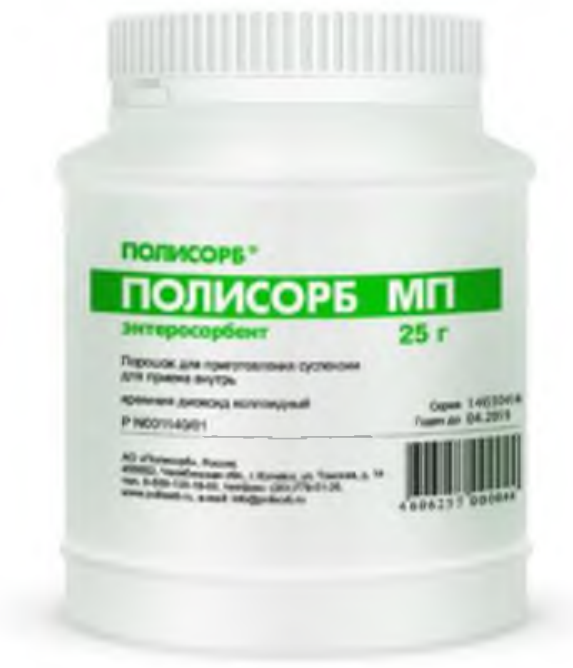

Сорбенты. В качестве энтеросорбентов используют углеродные сорбенты на основе активированного угля (карболен, карбактин, уголь активированный и др.), кремнийсодержащие энтеросорбенты (полисорб МП и др.), пористые полимеры природного происхождения (пектины, полифепан, лигносорб и др.), ионообменные материалы (холестирамин, вазозан), синтетические полимеры (энтеродез, энтеросорб). Выбор сорбентов зависит от конкретных задач терапии, сорбционной емкости и удобства приема препарата, возможности применения у детей с рождения, беременных и кормящих женщин, у пациентов с отягощенным аллергоанамнезом и наличием сопутствующих заболеваний и других условий. При инфекционной патологии и аллергических заболеваниях наиболее эффективны современные сорбенты, способные связывать молекулы разного размера и массы, а также бактерии, вирусы, токсины, аллергены и биологически активные вещества (полисорб МП, препараты на основе лигнина). Накопленный к настоящему времени опыт этого вида лечения показал целесообразность его применения как в остром периоде заболевания, так и с целью профилактики рецидивов.

Энтеросорбция может назначаться по синдромальному принципу до установления этиологического диагноза. При острых инфекционных заболеваниях и токсических отравлениях эффективность энтеросорбции существенно повышается в случае применения ее в первые часы (дни) болезни. По степени детоксикации энтеросорбция в течение 1-2 дней сопоставима с однократной экстракорпоральной процедурой. Так же, как и другие методы эфферентной терапии, энтеросорбция не заменяет, а дополняет обычное этиотропное и патогенетическое лечение. По сравнению с экстракорпоральной гемокоррекцией, сфера применения энтеросорбции при заболеваниях гораздо шире и охватывает легкие и среднетяжелые формы интоксикаций.

\section{Инвазивные методы эфферентной терапии.}

Инвазивные методы эфферентной терапии показаны при тяжелых интоксикациях, также отмечен их эффект при различных хронических иммунопатологических состояниях.

К экстракорпоральной гемокоррекции (ЭГ) относятся трансфузиологические операции направленного количественного и качественного изменения клеточного, белкового, водно-электролитного, ферментного, газового состава крови во внеорганизменном перфузионном контуре кровообращения. 
Эти изменения на сегодняшний день реализуются с помощью мембранной, сорбционной, центрифужной, электромагнитной и преципитационной технологий обработки крови, проведением внутривенных вливаний.

Гемодиализ - метод детоксикации, основанный на принципе диффузионного и фильтрационного переноса через полупроницаемую мембрану низкомолекулярных токсических субстанций, электролитов и внутрисосудистой жидкости из циркулирующей экстракорпорально крови в диализирующий раствор.

Гемофильтрация и ультрафильтрация - методы детоксикации, основанные на принципе фильтрационного переноса жидкости и некоторых токсических субстанций через полупроницаемую мембрану из циркулирующей экстракорпорально крови за счет градиента давления.

Гемосорбция (гемокарбоперфузия) - метод детоксикации, основанный на выведении из крови больного токсических субстанций путем перфузии через адсорбенты в экстракорпоральном контуре. Для сорбции наиболее часто применяются активированные угли и ионообменные смолы.

Лимфосорбция - метод ЭГ, основанный на дренировании грудного лимфатического протока, эксфузии и фракционной сорбции лимфы с последующим ее введением в сосудистое русло. Удаление значительного количества лимфы для достижения детоксикационного эффекта оказывалось нередко неблагоприятным для больного в силу невозможности полной компенсации составных частей удаляемой лимфы и клеток, что нарушало белковый и иммунный гомеостаз.

Плазмаферез - это метод ЭГ, основанный на замене плазмы больного электролитными растворами, препаратами крови и/или кровезаменителями. Если плазмаферез проводят в объеме, превышающем 50 \%-й объем циркулирующей плазмы, то он носит название плазмообмена. Плазмаферез в силу больших возможностей варьирования методик его проведения (скорость, объем перфузии, объем и качество плазмозамещения, трансфузионная и медикаментозная программа) может иметь детоксикационную, иммунокорригирующую и реокорригирующую направленность.

Цитаферез - метод ЭГ, основанный на выведении определенных клеточных компонентов крови больного и замене их компонентами, препаратами крови и (или) кровезаменителями. Различают следующие варианты цитафереза: эритроцитаферез, тромбоцитаферез, лимфоцитаферез, гранулоцитаферез, стемаферез (выведение СК крови). Как правило, цитаферез дополняет специфические эффекты действия плазмафереза.

Гемоксигенация - метод гемокоррекции, основанный на изменении состава крови путем ее оксигенации при перфузии в экстракорпоральном контуре. В зависимости от массообменного устройства различают пузырьковую, пленочную, мембранную оксигенацию и оксигенацию с помощью фторорганического переносчика кислорода. Наиболее физиологичной представляется мембранная оксигенация.

Перитонеальный диализ - метод детоксикации, в основе которого лежит диффузионный и фильтрационный перенос через живую мембрану (брюшину) низко-, среднемолекулярных токсических субстанций и жидкости из внутри- и внесосудистого пространства в естественно существующую полость брюшины. С помощью этой технологии можно удалять из крови и всей внутренней среды организма прежде всего экзогенные и эндогенные водорастворимые вещества.

Фотогемотерапия представляет собой дозированное облучение крови квантами света длиной волны 280-680 нм (верхняя часть ультрафиолетового спектра и видимый свет). Считается, что коротковолновое облучение крови (до 400 нм) обусловливает в основном иммунокорригирующий эффект, а длинноволновое облучение оптического диапазона существенно улучшает реологические свойства крови и микроциркуляцию.

Фотогемотерапия в клинической практике реализуется методами трансфузии аутокрови или внутрисосудистым облучением крови как самостоятельно, так и в комбинации с другими методами эфферентной терапии. 
Как отдельное направление инвазивной эфферентной терапии возможно рассматривать методы с использованием межклеточных детоксикантов. В настоящее время единственным таким препаратом является азоксимера бромид (полиоксидоний). Он сорбирует на себе растворимые токсические вещества, микрочастицы и другие алармины которые в дальнейшем захватываются макрофагами. За счет этого снижается концентрация РАMP и DAMP чем и обусловлено в какой то мере его противовоспалительный эффект.

Проведение дезинтоксикации (очищения организма) - одно из самых важных мероприятий при лечении больного с иммунными нарушениями. Клеткам постоянно угрожает загрязнение: вредные вещества поступают как из внешней среды, так и образуются внутри организма в процессе жизнедеятельности. Если внутреннюю среду не очищать, клетки погибнут. Это дает нам основания назвать дезинтоксикационную терапию одним из важнейших блоков в лечении пациента.

\section{Средства, влияющие на реологию крови}

К этой группе можно отнести антикоагулянты и антиагреганты. Антикоагулянты предотвращают образование сгустков (тромбов), влияя на активность белков, участвующих в свертывании крови (факторов свертывания), в то время как антиагреганты, предотвращают агрегацию тромбоцитов и препятствуют образованию тромбов. Наиболее распространенным побочным эффектом применения антикоагулянтнов и/или антиагрегантнов является склонность к кровотечению. Данные препараты нашли широкое применение в кардиологии для предотвращения инсультов и инфарктов. Однако с целью улучшение микроциркуляции и трофики ткани, для предотвращения хронического системного воспаления целесообразен прием данной группы препаратов.

Антиагреганты ингибируют агрегацию тромбоцитов и эритроцитов, уменьшают их способность к склеиванию и прилипанию (адгезии) к эндотелию кровеносных сосудов. Снижая поверхностное натяжение мембран эритроцитов, они облегчают их деформирование при прохождении через капилляры и улучшают текучесть крови. Антиагреганты способны не только предупреждать агрегацию, но и вызывать дезагрегацию уже агрегированных кровяных пластинок.

Ингибирующее влияние на склеивание (агрегацию) тромбоцитов (и эритроцитов) оказывают в той или иной степени лекарственные средства разных фармакологических групп (органические нитраты, блокаторы кальциевых каналов, производные пурина, антигистаминные препараты и др.). Выраженное антиагрегантное действие оказывает ацетилсалициловая кислота, которая широко применяется в целях профилактики тромбообразования.

Ацетилсалициловая кислота является в настоящее время основным представителем антиагрегантов. Она оказывает тормозящее влияние на спонтанную и индуцированную агрегацию и адгезию тромбоцитов, на высвобождение и активацию тромбоцитарных факторов 3 и 4. Показано, что ее антиагрегационная активность тесно связана с влиянием на биосинтез, либерацию и метаболизм простагландинов. Она способствует высвобождению эндотелием сосудов простагландинов, в том числе простагландина-I2 (простациклина). Последний активирует аденилатциклазу, снижает в тромбоцитах содержание ионизированного кальция одного из трех главных посредников агрегации, а также обладает дезагрегационной активностью. Кроме того, АСК, подавляя активность циклооксигеназы, уменьшает 
образование в тромбоцитах тромбоксана А2-простагландина с противоположным типом активности (проагрегационный фактор). В больших дозах АCK тормозит биосинтез простациклина и других антитромботических простагландинов (D2, E1 и др.). B связи с этим в качестве антиагреганта АCK назначают в относительно небольших дозах (75 - 325 мг в сут).

Другая группа препаратов - антагонисты рецепторов к аденозиндифосфату: тиенопиридины. Производные тиенопиридина - тиклопидин (тиклид) и клопидогрель (плавикс) угнетают АДФ-зависимый путь агрегации тромбоцитов. Их действие наступает медленнее, чем действие аспирина, поэтому в начале лечения используются нагрузочные дозы препаратов. Иногда отмечаются нейтропения и тромбоцитопения, поэтому необходимо выполнение клинического анализа крови с подсчетом тромбоцитов через каждые 2 нед. на протяжении первых 3 мес лечения. Считается, что меньшими побочными эффектами обладает плавикс.

Также к антиагрегантам относится курантил. Механизм дипиридамола (курантила) заключается в действии на метаболизм арахидоновой кислоты, увеличении продукции простациклина и торможении синтеза тромбоксана А2. По антиагрегационной активности дипиридамол уступает тиклопидину, близок к АСК. Применяется перорально и внутривенно.

Некоторой антиагрегационной активностью обладает и пентоксифиллин (трентал). Он блокирует аденозиновые рецепторы тромбоцитов, способствует накоплению в тромбоцитах цАМ $\Phi$, дезагрегации, уменьшает их агрегацию. Реологическое воздействие осуществляется за счет увеличения деформируемости эритроцитов.

Антикоагулянты - лекарственные средства, оказывающие влияние на различные звенья процесса коагуляционного гемостаза (свёртывающей системы крови), препятствуют образованию тромбов, продлевая время свертывания. По механизму действия различают антикоагулянты прямого и непрямого действия (табл. 104).

Таблица 104.

\section{Антикоагулянты}

\begin{tabular}{|c|c|}
\hline Группа препаратов & Наименование препаратов \\
\hline \multicolumn{2}{|r|}{ прямого действия } \\
\hline $\begin{array}{l}\text { Гепарины } \\
\text { (антитромбин III) }\end{array}$ & Гепарин, Сулодексид, Эноксипарин. \\
\hline Тромболитики & $\begin{array}{l}\text { Стрептокиназа, Фибринолизин, Тенектеплаза, Альтеплаза, } \\
\text { Урокиназа, Протеин С, Анкорд. }\end{array}$ \\
\hline \multicolumn{2}{|r|}{ непрямого действия } \\
\hline Антагонисты витамина К & Варфарин, Аценокумарол, Фениндион. \\
\hline $\begin{array}{l}\text { Прямые ингибиоторы } \\
\text { фактора Ха }\end{array}$ & Ривароксабан (Ксарелто), Апиксабан (Эликвис), Эндоксабан \\
\hline $\begin{array}{ll}\text { Прямые } & \text { ингибиторы } \\
\text { тромбина }\end{array}$ & $\begin{array}{l}\text { Бивалирудин (Ангиокс), } \\
\text { Ксимеланатран, Десирудин, Меланатран, Аргатробан. }\end{array}$ \\
\hline $\begin{array}{l}\text { Другие } \\
\text { антитромботические } \\
\text { средства }\end{array}$ & Фондапаринукс, Дефибротид, Сульфат дерматана \\
\hline
\end{tabular}

Препараты, влияют не только на агрегацию тромбоцитов и свертывание крови, но и улучшающие реологические свойства крови улучшая микроциркуляцию 


\section{ЛЕЧЕНИЕ БОЛЬНЫХ С ИММУННЫМИ НАРУШЕНИЯМИ}

\section{Глава 19. Метаболическая терапия}

Большое значение в лечении больного с наличием иммунных нарушений имеет нормализация и/или стимуляция работы клетки. К препаратам этой группы относится множество лекарственных средств, прямо или опосредованно влияющих на различные клетки человека, поэтому такой подход рекомендован в комплексной терапии и иммунных нарушениях. В настоящее время в современной фармакопии это следующие препараты витамины, (водо- и жирорастворимые), антиоксиданты, анаболики, естественные метаболиты, средства, стимулирующие процессы регенерации и т.д. Однако уже сегодня необходимо выделять лекарственные средства, непосредственно влияющие на различные звенья метаболизма клетки (рис.123).

К этой группе необходимо отнести и большое количество иммуномодуляторов, применяемых в России, т.к. они в основном не обладают избирательным действием на иммунную систему, а действуют через метаболизм клеток иммунной системы.

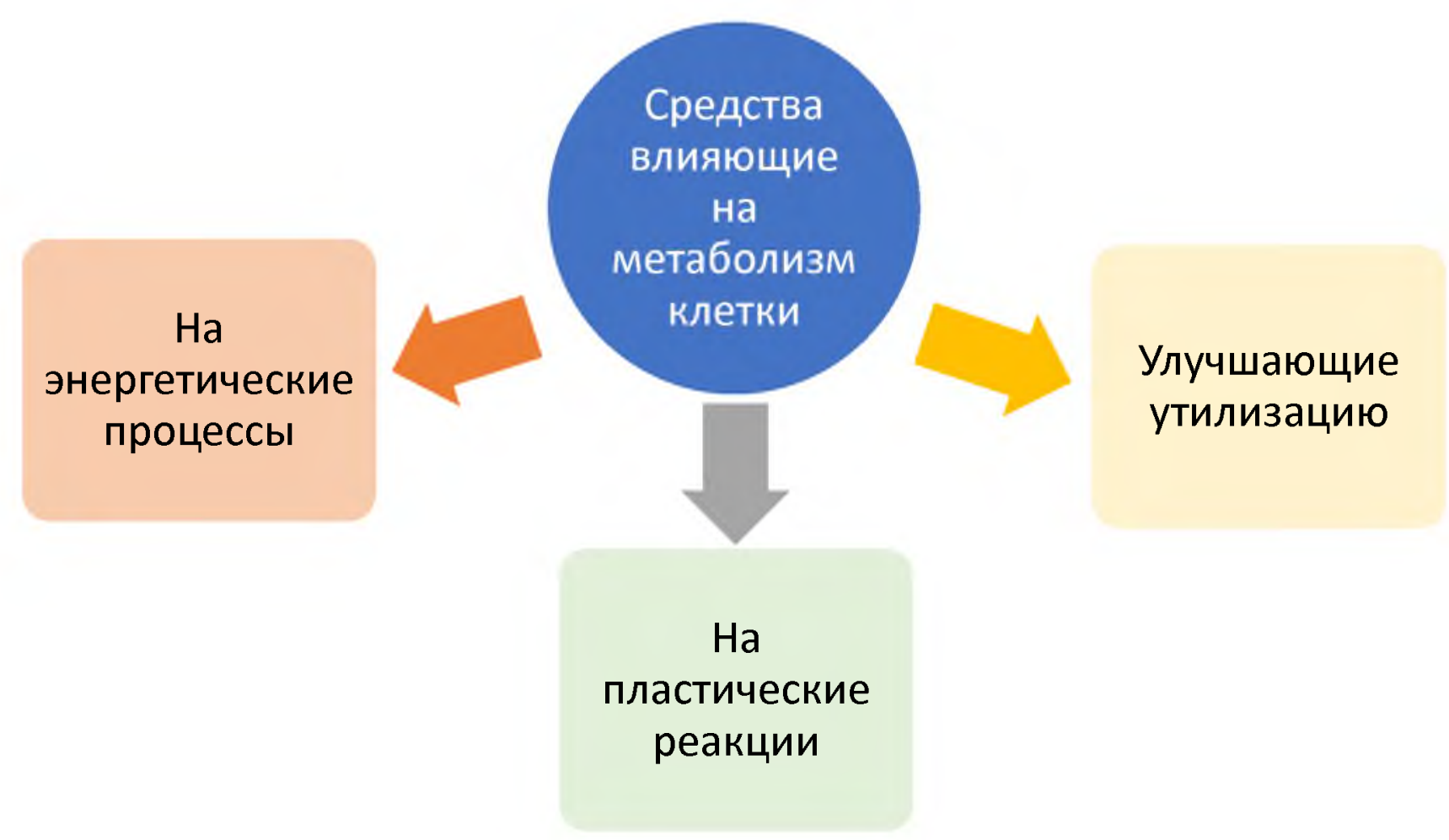

Рис.123. Метаболические препараты 
С позиций биохимических реакций в каждой группе необходимо выделить препараты, действующие на регуляцию какой-либо реакции (гормоны, ферменты и коферменты) и субстраты этой реакции (естественные метаболиты).

\section{Препараты, преимущественно влияющие на энергетические процессы клетки.}

В эту группу входит большое количество водорастворимых витаминов и естественных метаболитов.

Витамин В1 (тиамин) содержится в дрожжах, зародышах и оболочках пшеницы, овса, гречихи, а также в хлебе, изготовленном из муки простого помола. Суточная потребность взрослого человека в витамине В1 составляет 1,5 - 2 мг.

Препараты группы витамина В1 активно влияют на различные функции организма, вмешиваясь в обмен веществ и нервно-рефлекторную регуляцию. С помощью фермента тиаминпирофосфаткиназы тиамин в организме превращается в тиаминпирофосфат, который является кофактором окислительного дезаминирования $\alpha$-кетокислот. При гиповитаминозе В1 наблюдается снижение иммуногенеза по отношению к корпускулярным АГ, устойчивости к некоторым инфекциям. Влияние на фагоцитоз происходит путем вмешательства в углеводнофосфорный обмен фагоцитов.

Витамин В2 (рибофлавин) в организм человека поступает, главным образом, с мясными и молочными продуктами. Он широко распространен в растительном и животном мире и содержится в дрожжах, молочной сыворотке, яичном белке, мясе, рыбе, печени, горохе, зародышах и оболочках зерновых культур. Получен синтетически. Суточная потребность в витамине В2 для взрослого человека составляет 1,5 - 2 мг.

При поступлении в организм рибофлавин с помощью фермента рибофлавинкиназы превращается во флавинмононуклеотид, реакция которого с АТФ, катализируемая ФМНаденилилтрансферазой, приводит к образованию флавинадениндинуклеотиду. Оба продукта являются коферментами оксидоредуктаз и участвуют в переносе протонов и регулировании окислительно-восстановительных процессов, этим обусловлена их роль в углеводном, белковом и жировом обмене.

Витамин РP (никотиновая кислота). Продукты богатые витамином РP - говяжья печень, дрожжи, брокколи, морковь, сыр, кукурузная мука, финики, яйца, рыба, молоко, арахис, свинина, картофель, помидоры, проростки пшеницы, продукты из цельных злаков. Травы - люцерна, корень лопуха, листья одуванчика, котовник кошачий, кайенский перец, ромашка, песчанка, очанка, семя фенхеля, пажитник сенной, женьшень, хмель, хвощ, коровяк, крапива, овес, петрушка, мята перечная, листья малины, красный клевер, плоды шиповника, шалфей, щавель. Суточная потребность в никотиновой кислоте и никотинамиде составляет для взрослого человека около 20 мг, при тяжелом физическом труде - около 25 , для детей в зависимости от возраста - от 6 до 18 мг.

Витамин существует в двух формах - никотиновой кислоты и никотиномида. Включается в простетическую группу ферментов, являющихся переносчиками водорода: никотинамидадениндинуклеотида (НАД) и никотинамидадениндинуклеотидфосфата (НАДФ), регулирует окислительно-восстановительные процессы, тканевое дыхание, синтез белков и жиров, распад гликогена. Угнетает липолиз в жировой ткани, уменьшает скорость синтеза липопротеидов низкой плотности. Нормализует липидный состав крови: снижает уровень общего холестерина, липопротеидов низкой плотности, триглицеридов и повышает уровень липопротеидов высокой плотности, обладает антиатерогенными свойствами.

Витамин С (аскорбиновая кислота) содержится в значительных количествах в плодах шиповника, капусте, лимонах, апельсинах, хрене, ягодах, хвое и др. Небольшое содержание - в печени, мозге, мышцах животных. Для медицинских целей витамин С получают синтетическим путем. В обычных условиях суточная потребность взрослого человека в аскорбиновой кислоте составляет $70-100$ мг. 
Основные эффекты обусловлены участием в регуляции окислительновосстановительных процессов, поскольку аскорбиновая кислота легко переходит в дегидроаскорбиновую и обратно, донируя или акцептируя два протона (окисляя или восстанавливая соответствующие субстраты). Витамин $\mathrm{C}$ активирует деятельность желез внутренней секреции, регулирует все виды обмена, свертываемость крови, регенерацию тканей, образование стероидных гормонов, синтез коллагена, проницаемость капилляров и др. Аскорбиновая кислота, оказывая стимулирующее влияние на организм в целом, повышает его адаптационные возможности, резистентность к инфекциям. Дефицит витамина С приводит к отчетливому нарушению Т-системы иммунитета.

Система гуморального иммунитета более устойчива к С-витаминной недостаточности. Кроме величины дозы большое значение имеет характер сочетания витамина $\mathrm{C}$ с другими препаратами, например с витаминами группы В (B9 и В12). Стимуляция фагоцитоза связана с непосредственным влиянием витамина на фагоциты и зависит от дозы препарата. Полагают, что витамин С увеличивает чувствительность бактерий к лизоциму.

Декстроза (глюкоза, глюкостерил) субстратно обеспечивает энергетический обмен, поддерживает объем циркулирующей плазмы. Изотонический раствор восполняет объем потерянной жидкости, повышенная осмотическая активность гипертонических растворов увеличивает выход тканевой жидкости в сосудистое русло и удерживает ее в нем, повышает диурез и выведение токсических веществ. Молекулы декстрозы утилизируются в процессе энергетического обеспечения.

Янтарная кислота за счет стимуляции окислительно-восстановительных реакций, процессов дыхания и синтеза АТФ способна активировать физиологические функции органов и тканей, тем самым улучшая адаптационные и компенсаторно-защитные возможности организма.

Гамма-аминомасляная кислота (аминалон, нооклерин) активирует энергетические процессы, повышает дыхательную активность тканей, улучшает утилизацию глюкозы и удаление токсических продуктов обмена. Взаимодействует со специфическими ГАМКэргическими рецепторами А и Б типов. Улучшает динамику нервных процессов в головном мозге, увеличивает продуктивность мышления, обладает антигипоксическим действием.

Предуктал обусловливает эффект действия повышением энергетического потенциала, активацией окислительного декарбоксилирования и рационализацией потребления кислорода (усиление аэробного гликолиза и блокада окисления жирных кислот). Предотвращает внутриклеточное истощение АТФ и фосфокреатинина. В условиях ацидоза нормализует функционирование ионных каналов мембран, нормализует внутриклеточную концентрацию $\mathrm{K}+$, препятствует накоплению $\mathrm{Ca} 2+$ и $\mathrm{Na}+$ в кардиомиоцитах. Уменьшает внутриклеточный ацидоз и концентрацию фосфатов, обусловленных ишемией, ишемических повреждений миокарда выход креатинфосфокиназы из клеток. Останавливает повреждающее действие свободных радикалов, сохраняет целостность клеточных мембран, предотвращает активацию нейтрофилов в зоне ишемии, увеличивает продолжительность электрического потенциала.

Энерион представляет собой средство, регулирующее метаболические процессы клетки. Синтетическое соединение, близкое по строению к тиамину (имеет открытый тиазольный цикл, дополнительную дисульфидную связь и липофильный эфир). Обладает высокой эффективностью при симптоматическом лечении больных с функциональными астеническими состояниями.

Цитохром C является катализатором клеточного дыхания, стимулирует окислительные реакции и активизирует тем самым обменные процессы в тканях, уменьшает гипоксию тканей при различных патологических состояниях.

\section{Средства, направленные на пластические реакции клетки}

В основе фармакологической регуляции пластических реакций клетки лежит стимуляция белкового синтеза, пролифирации и дифференцировки клеток. Для стимуляции этих процессов могут быть использованы различные группы лекарственных препаратов: 1) 
регуляторы - витамины, анаболические гормоны и другие синтетические средства в т.ч. индукторы ИФН и синтетические иммуномодуляторы; 2) естественные метаболиты в т.ч. препараты дезоксирибонуклеиновой кислоты.

Витамин В3 (пантотеновая кислота). Наиболее богаты витамином В3 мясо и субпродукты, пивные дрожжи, отруби, зародыши пшеницы, зеленые овощи, орехи, маточное молочко пчел.

Витамин может синтезироваться кишечными бактериями, но в недостаточном количестве, учитывая суточную потребность организма для детей и подростков $5-7$ мг, для взрослых - 10 - 12 мг, хотя при лечении доза может быть увеличена в несколько раз. В организме является субстратным (единственный незаменимый компонент) стимулятором синтеза кофермента А. Последний катализирует в организме ацилирование, участвует практически во всех метаболических процессах (цикл трикарбоновых кислот, обмен углеводов, жиров и жирных кислот, фосфолипидов, белков и др.), обеспечивает образование кортикостероидов, ацетилирование холина. Обладает противовоспалительным действием, стимулирует процессы репарации и регенерации.

Витамин В6. (пиридоксин). Это групповое название трех производных пиридина: пиридоксаля, пиридоксина и пиридоксамина. Витамин В6 содержится в растениях и органах животных, особенно в неочищенных зернах злаковых культур, в овощах, мясе, рыбе, молоке, печени трески и крупного рогатого скота, яичном желтке, дрожжах. Суточная потребность взрослого человека составляет 2 мг и удовлетворяется частично продуктами питания, частично синтезом микрофлоры кишечника. Пиридоксин, поступая в организм, фосфорилируется и в этой форме катализирует декарбоксилирование и переаминирование аминокислот.

Витамин В9 (фолиевая кислота). Содержится в свежих овощах (бобах, шпинате, томатах и др.), а также в печени и почках животных. В организме человека, кроме того, синтезируется микрофлорой кишечника. Суточная потребность взрослых людей в фолиевой кислоте равна 200 мкг, беременных и кормящих женщин - 400-600 мкг, детей первого года жизни - $40-60$ мкг. Для медицинских целей (в том числе, при интоксикации, вызванной противоопухолевыми препаратами) используют синтетическую фолиевую кислоту, хотя сама она неактивна и в организме восстанавливается до тетрагидрофолиевой, являющейся коферментом многих метаболических процессов. В первую очередь катализирует перенос одноуглеродистых фрагментов в синтезе пуринов и пиримидинов, а значит, необходима для образования РНК и ДНК. Ее дефицит нарушает митотическое деление клеток, их созревание и функционирование.

Витамин В12 (цианокобаламин). Комплексное соединение, имеющее в основе цикл коррина и содержащее координационно связанный ион кобальта. В тканях животных не синтезируется. Источниками витамина В12 служат различные виды мяса, рыба, яйца, молоко, сыр, но он полностью отсутствует в растительной пище. Витамин всасывается слизистой желудка только в присутствии секретируемого (эндогенного) гликопротеина, так называемого внутреннего фактора. Назначение этого мукопротеида заключается в связывании цианокобаламина и тем самым в защите от деградации. В крови В12 также связывается специальным белком - транскобаламином. Его синтез в природе осуществляется только микроорганизмами. Потребности человека и животных в нем обеспечиваются микрофлорой кишечника, откуда цианокобаламин поступает в органы, накапливаясь в наибольших количествах в почках, печени, стенке кишечника. Суточная потребность в этом витамине составляет 0,003 мг. Витамин В12 в организме превращается в коферментные формы метилкобаламин и дезоксиаденозилкобаламин. Как кофермент участвует в различных метаболических процессах, включая метаболизм жиров и углеводов и синтез белка. Является фактором роста и стимулятором гемопоэза, оказывает благоприятное влияние на функции печени и нервной системы, активирует процессы свертывания крови. Очевидна эффективность витамина В12 в нормальных дозах при крайне расстроенных гемопоэтических и имунологических функциях (нарушение дифференцировки В-клеток, снижение числа 
плазмоцитов, АТ, лейкопения, мегалобластная анемия, рецидивирующая инфекция). Однако отмечается стимулирующее влияние витамина В12 на рост опухоли (в отличие от В1, В2, B6). Одно из основных иммуномоделирующих действий витамина В12 - влияние на обмен нуклеиновых кислот и белков.

Витамин U (S-метилметионин). Содержится в соке капусты, картофеля и других сырых овощах. Суточная доза не определена. Препарат рассматривается как активированная форма метионина. Полагают, что механизм действия связан со стимуляцией заживления повреждений слизистой оболочки ЖКТ. Это объясняется способностью препарата отдавать свои метильные группы, необходимые для процессов синтеза в организме. Метилируя гистамин, витамин U превращает его в неактивную форму, а это способствует уменьшению желудочной секреции и обусловливает обезболивающий эффект.

Витамин А. Его синтетические аналоги и гомологи относят к ретиноидам производным ретиноевой кислоты. Биологически активными формами витамина А являются ретинол, ретиналь и сама ретиноевая кислота. Этот витамин содержится в продуктах животного происхождения - рыбьем жире, сливочном масле, яичном желтке, печени некоторых рыб (треска, морской окунь и др.) и морских животных (кит, морж, тюлень). В растительных пищевых продуктах ретинол не встречается. Однако многие из них (морковь, шпинат, салат, петрушка, зеленый лук, щавель, красный перец, черная смородина, черника, крыжовник, персики, абрикосы и др.) содержат каротин, представляющий собой провитамин А, из которого в организме образуется ретинол. Витамин А регулирует процессы ороговения, образование и выделение сала в коже (секрет сальных желез), необходим для нормального роста волос, поддержания иммунитета, участвует в противоопухолевой защите организма.

Витамин D. В настоящее время называют два жирорастворимых, близких по химическому строению и действию вещества - эргокальциферол (витамин D2) и колекальциферол (витамин D3). Основное свойство этих соединений - способность предупреждать и лечить рахит, в связи с чем их иногда называют противорахитическими витаминами. Витамин D2 в небольшом количестве содержится в пищевых продуктах: яичном желтке, сливочном масле, сыре, молоке, икре, жирных сортах рыбы (угорь, лосось, макрель, сардины), устрицах, печени трески, говяжей печени, хлебе из зерен крупного помола. Витамин D3 образуется в коже человека под воздействием солнечных лучей. За 25 мин. пребывания на солнце организм синтезирует до $2000 \mathrm{ME}$ витамина D. Более того, в этом случае невозможно «превысить дозу». По биологической активности витамины D2 и D3 практически не различаются, поскольку в организме оба, вероятно, превращаются в кальцитриол - активный метаболит витамина D. Считается что нужно потреблять ежедневно $50-200$ мг витамина $\mathrm{D}$, a после 50-ти лет дозу необходимо удвоить (1 мг витамина D равен $40 \mathrm{ME}$ ).

Основным свойством витамина D является его участие в метаболизме кальция. B настоящее время витамин рассматривают не только как витамин, но и как гормон, регулирующий вместе с гормоном паращитовидной железы концентрацию ионов кальция в плазме крови, в том числе всасывание кальция в пищеварительном тракте, отложение его в костях, препятствуя резорбции из костной ткани. Витамин D регулирует также содержание фосфора в организме. Применяют его для профилактики и лечения рахита и заболеваний костей, вызванных нарушениями обмена кальция (остеомаляция и некоторые формы остеопороза). В последнее время доказано иммунотропное действие витамина D. Терапия высокими дозами витамина D эффективна в предотвращении активации латентных форм туберкулеза и для профилактики рака.

Анаболические гормоны. Эта группа препаратов активно действует на клетку (в том числе и на клетки иммунной системы), так как активно способствует биосинтезу продуктов обмена (белков, жиров, углеводов). Анаболическое действие оказывают некоторые стероидные и нестероидные соединения.

Из стероидных веществ анаболической активностью обладают препараты мужских половых гормонов. Специально синтезированные препараты на основе мужских половых гормонов - метандиенон (метандростенолон) и нандролон (феноболин, ретаболил)- 
практически не обладают андрогенной активностью. Наиболее характерное свойство веществ этой группы - их способность стимулировать синтез белка в организме и вызывать уменьшение выведения азота (положительный азотистый баланс). Снижается также выделение необходимых для синтеза белков калия, серы и фосфора. Клинически действие стероидных анаболиков проявляется в повышении аппетита, улучшении работоспособности, общего состояния больных, увеличении массы тела. Для достижения выраженного эффекта одновременно с анаболическими препаратами больные должны получать с пищей адекватные количества белков, жиров, углеводов, витаминов и минеральных веществ.

Левокарнитин (элькар, карнитен, карнифит) - является кофактором метаболических процессов, обеспечивающих поддержание активности КоА. Оказывает анаболическое действие, снижает основной обмен, замедляет распад белковых и углеводных молекул. Способствует проникновению через мембраны митохондрий и расщеплению длинноцепочечных жирных кислот (пальмитиновой и др.) с образованием ацетил-КоА (необходим для обеспечения активности пируваткарбоксилазы в процессе глюконеогенеза, образования кетоновых тел, синтеза холина и его эфиров, окислительного фосфорилирования и образования АТФ). Оказывает жиромобилизующее действие, обусловленное наличием трех лабильных метильных групп. Конкурентно вытесняя глюкозу, включает жирнокислотный метаболический шунт, активность которого не лимитирована кислородом (в отличие от аэробного гликолиза), поэтому эффективен при острой гипоксии мозга и других критических состояниях. Вызывает незначительное угнетение ЦНС, повышает секрецию и ферментативную активность пищеварительных соков (желудочного и кишечного), улучшает усвоение пищи. Снижает избыточную массу тела и уменьшает содержание жира в мускулатуре. Увеличивает запасы гликогена в печени и мышцах, способствует более экономному его использованию. Повышает порог резистентности к физической нагрузке, приводит к ликвидации посленагрузочного ацидоза и, как следствие, восстановлению работоспособности после длительных истощающих физических нагрузок.

\section{Естественные метаболиты.}

К этой группе относят препараты предшественников пуриновых или пиримидиновых оснований, либо продукты частичного гидролиза нуклеиновых кислот.

Инозин (рибоксин, рибонозин). Нуклеозид - предшественник АТФ. Субстратно стимулирует синтез адениновых нуклеотидов, повышает активность некоторых ферментов цикла Кребса. Принимает непосредственное участие в обмене глюкозы и способствует активизации обмена при гипоксии и при отсутствии АТФ. Стимулирует окислительновосстановительные процессы. Интенсифицирует метаболизм пировиноградной кислоты, нормализует процесс тканевого дыхания, способствует повышению активности ксантиндегидрогеназы. Оказывает положительное влияние на обменные процессы в миокарде, повышает его энергетический баланс, улучшает коронарное кровообращение, снижает агрегацию тромбоцитов, активирует регенерацию тканей.

Калия оротат (1,2,3,6-Тетрагидро-2,6-диоксо-4-пиримидинкарбоновая кислота) обеспечивает синтез пиримидиновых нуклеотидов, входящих в состав нуклеиновых кислот, участвующих в образовании белковых молекул.

Кальция глицерофосфат восстанавливает уровень кальция в организме, стимулирует анаболические процессы.

Метионин - незаменимая аминокислота, регулирующая азотистый баланс. Содержит подвижную метильную группу и участвует в процессах метилирования, обеспечивающих синтез холина, адреналина, креатина и других биологически важных соединений, обезвреживание токсичных продуктов, образование фосфолипидов. Тормозит отложение в печени нейтрального жира, оказывает липотропный эффект (удаление из печени избытка жира). Модулирует эффект гормонов и витаминов (В12, аскорбиновой и фолиевой кислот). 
Глутаминовая кислота - заменимая аминокислота поступает в организм с пищей, а также синтезируется в организме при переаминировании в процессе катаболизма белков. Участвует в белковом и углеводном обмене, стимулирует окислительные процессы, препятствует снижению окислительно-восстановительного потенциала, повышает устойчивость организма к гипоксии. Принимает в норму обмен веществ, изменяя функциональное состояние нервной и эндокринной систем. Принимеет участие в синтезе других аминокислот, ацетилхолина, АТФ, способствует переносу ионов калия, улучшает деятельность скелетной мускулатуры (является одним из компонентов миофибрилл). Оказывает дезинтоксикационное действие, способствует обезвреживанию и выведению из организма аммиака. Нормализует процессы гликолиза в тканях, оказывает гепатопротекторное действие, угнетает секреторную функцию желудка.

Гептрал (адеметионин) - биологическое вещество, входящее в состав всех тканей и жидких сред организма. Его молекула включена в большинство биологических реакций, в том числе как донор метиловой группы - в процесс метилирования в составе липидного слоя клеточной мембраны (трансметилирование); как предшественник эндогенных тиоловых соединений - цистеина, таурина, глютатиона, коэнзима А (транссульфурирование); как предшественник полиаминов - путресцина, стимулирующего регенерацию клеток, пролиферацию гепатоцитов, спермидина, спермина, входящих в структуру рибосом (аминопропилирование). Гептрал включается в биохимические процессы организма, одновременно активизируя действие выработки эндогенного адеметионина. Восполняет дефицит адеметионина и стимулирует его выработку в организме, в первую очередь в печени и мозге. Повышает содержание глутамина в печени, цистеина и таурина в плазме, снижает содержание метионина в сыворотке крови, нормализуя метаболические реакции в печени. После декарбоксилирования участвует в процессах аминопропилирования как предшественник полиаминов - путресцина (стимулятор регенерации клеток и пролиферации гепатоцитов), спермидина и спермина, входящих в структуру рибосом.

Таурин (дибикор, тауфон) - аминокислота, образующаяся в организме в процессе превращения цистеина. Играет большую роль в липидном обмене, способствует нормализации функции клеточных мембран, оптимизации энергетических и обменных процессов, сохранению электролитного состава цитоплазмы (за счет накопления ионов калия и кальция), входит в состав парных желчных кислот (таурохолиевой, тауродезоксихолевой), способствующих эмульгированию жиров в кишечнике. В головном мозге выполняет функцию нейромедиатора, тормозящего синаптическую передачу, обладает противосудорожной и кардиотонической активностью. Вызывает нормализацию метаболизма глазных тканей при заболеваниях дистрофического характера.

Глутоксим играет важную роль в регуляции метаболических процессов в клетках и тканях. Он оказывает селективное воздействие на сульфгидрильные группы поверхностноклеточных и растворимых рецепторов, что приводит к восстановлению их функционально активной конформации, чувствительности к регуляторным и транспортным молекулам пептидной природы, определяет иммуномодулирующий и цитотропные эффекты препарата. Глутоксим способствует реализации действия регуляторных молекул пептидной природы на нормальные (регуляция метаболических процессов) и трансформированные (индукция апоптоза) клетки, стимулирует на каскадные механизмы фосфатной модификации ключевых белков сигналпередающих систем; инициацию действия системы цитокинов, в том числе ИЛ1, ИЛ-2, ИЛ-6, ТNF, ИФН, эритропоэтина. 


\section{Средства, устраняющие продукты метаболизма в клетке}

В эту группу препаратов входят средства способствующие утилизации продуктов метаболизма клетки, антиоксиданты и стабилизаторы мембран.

\section{Средства, способствующие утилизации продуктов метаболизма клетки.}

Витамин В15 (пангамовая кислота). Так как витамин В15 широко представлен в семенах растений, в связи с этим и получил свое название - пангамовая кислота (от греч. pan - всюду и gату - семя). Наибольшее содержание пангамовой кислоты обнаружено в семенах злаковых растений и в ядрах косточковых плодов, а также в большом количестве содержится в печени, почках, яичном желтке, икре рыб, горохе, рисе, дрожжах, отрубях. Суточная потребность 2 мг в сутки. Пангамовая кислота активирует окислительные процессы, уменьшает явления гипоксии, оказывает детоксицирующее действие, улучшает липидный обмен, участвует в образовании холина, увеличивает содержание гликогена и креатинфосфата в мышцах, является донором метильных групп.

Глицин (аминоуксусная кислота) обладает глицин- и ГАМК-эргическим, $\alpha 1$ адреноблокирующим, антиоксидантным, антитоксическим действием; регулирует деятельность глутаматных (NMDA) рецепторов, за счет чего препарат является регулятором обмена веществ.

Милдронат - аналог $\gamma$-бутиробетаина, подавляет $\gamma$-бутиробетаингидроксиназу, снижает синтез карнитина и транспорт длинноцепочечных жирных кислот через оболочки клеток, препятствует накоплению в клетках активированных форм неокисленных жирных кислот - производных ацилкарнитина и ацилкоэнзима А. В условиях ишемии восстанавливает равновесие процессов доставки кислорода и его потребления в клетках, предупреждает нарушение транспорта АТФ, одновременно с этим активирует гликолиз, который протекает без дополнительного потребления кислорода. В результате снижения концентрации карнитина усиленно синтезируется $\gamma$-бутиробетаин, обладающий вазодилатирующими свойствами.

Натрия тиосульфат оказывает дезинтоксикационное, противовоспалительное, десенсибилизирующее действие.

Унитиол способствует дезинтоксикационному действию. Увеличивает выведение некоторых катионов (особенно $\mathrm{Cu} 2+$ и $\mathrm{Zn} 2+$ ) из металлосодержащих ферментов клеток. Активные сульфгидрильные группы восстанавливают функции ферментных систем организма.

Аллопуринол-Эгис - средство, нарушающее синтез мочевой кислоты. Является структурным аналогом гипоксантина. Ингибирует фермент ксантиноксидазу, который участвует в превращении гипоксантина в ксантин и ксантина в мочевую кислоту. Этим обусловлено уменьшение концентрации мочевой кислоты и ее солей в жидких средах организма и моче, что способствует растворению имеющихся уратных отложений и предотвращает их образование в тканях и почках. При приеме аллопуринола повышается выделение с мочой гипоксантина и ксантина.

Как способ утилизации продуктов метаболизма, особенно хронических ее форм, можно стимулировать биотрансформации. Биотрансформация токсических веществ - один из важнейших путей естественной детоксикации организма. При этом может произойти повышение активности индукции ферментов, главным образом в микросомах печени, ответственных за метаболизм токсичных соединений, или снижение активности этих метаболитов (ингибиция), влекущее за собой замедление метаболизма. В клинической практике используются препараты - индукторы или ингибиторы ферментов, влияющие на биотрансформацию ксенобиотиков с целью снижения их токсического действия. В настоящее время известно более двухсот веществ, способных влиять на активность микросомальных ферментов (цитохром Р-450). Наиболее изученными индукторами являются барбитураты, в частности фенобарбитал или бензонал и специальный препарат - зиксорин. Под влиянием этих препаратов в митохондриях печени увеличиваются уровень и активность цитохрома Р- 
450, что обусловлено стимуляцией процессов их синтеза. Лечебное действие проявляется не сразу, а спустя 1,5 - 2 сут. В качестве ингибаторов ферментативной активности предложены ниаламид (ингибитор моноаминооксидазы), левомицетин, тетурам и т.д. Однако их клиническое применение показано только при отравлении.

\section{Антиоксиданты.}

Протекающие в организме процессы биологического окисления состоят из последовательных реакций дегидрирования, при которых атомы водорода переходят от субстрата (жирные кислоты, углеводы) к акцептору. Кислород вовлекается в тканевое дыхание в завершающей цитохромоксидной реакции, соединяясь с акцептированными атомами водорода. Биологическое окисление структурно организовано в клетке, строго регулируется, ступенчато освобождает макроэрги и в конечной стадии образует нетоксичные продукты ( $\mathrm{H} 2 \mathrm{O}$ и $\mathrm{CO} 2)$. Наряду с биологическим окислением в организме могут происходить реакции прямого присоединения кислорода к субстрату - аутоокисление. Обычно они начинаются с образования частиц с неспаренным электроном - свободными радикалами, образуя промежуточные соединения - перекиси. Соответственно эти процессы называют свободнорадикальным или перекисным окислением. Свободнорадикальное окисление развивается как цепной лавинообразный процесс, вовлекающий все новые молекулы субстрата. Усиление свободнорадикального окисления в организме наблюдается при многих заболеваниях.

Общими признаками являются: повышение гидрофильности мембран и как следствие увеличение их проницаемости; разобщение дыхания и фосфорилирования; нарушение связи фосфолипидов со структурными и рецепторными белками клеточных мембран; повреждение нуклеиновых кислот и инактивация ферментов; лизис мембран лизосом, сопровождающийся выходом из них фосфолипаз и других гидролитических ферментов, способных вызвать аутолиз клетки.

Свободнорадикальные механизмы угнетают клеточный и гуморальный иммунитет. Развитие этого окисления может быть прекращено ингибиторами, восстанавливающими свободные радикалы в стабильную молекулярную форму, не способную продолжать цепь аутоокисления.

Лекарственное влияние реализуется либо непосредственным связыванием свободных радикалов - так действуют прямые антиоксиданты, либо через активацию антиоксидантной системы организма - группа непрямых антиоксидантов. Можно выделить основные принципы их применения.

1. Приоритетное использование природных биоантиоксидантов, полностью лишенных побочных эффектов.

2. Учет алиментарного фактора. В зимне-весенний период обязательно назначение прямых антиоксидантов, летом и осенью при высоком содержании в рационе овощей и фруктов предпочтительны антиоксиданты непрямого действия.

3. Комбинированное применение. Процессы свободнорадикального окисления могут развиваться как в липидной, так и в водной фазе клеточных и неклеточных структур. Соответственно необходимо одновременное введение липидорастворимых и гидрофильных антиоксидантов

4. Адекватный выбор дозировки препаратов. Дозирование антиоксидантов должно базироваться на учете не только массы тела, но и возраста человека, характера его питания.

5. Достаточно продолжительный курс фармакопрофилактики или фармакотерапии, который определяется длительностью воздействия фактора или ситуации, способствующих усилению свободнорадикального окисления (от 1 - 2 нед до 2 - 3 мес).

Классическим антиоксидантом является витамин Е. Под этим названием известен ряд соединений (токоферолов), близких по химической природе и биологическому действию. Наиболее активен из них $\alpha$-токоферол. Токоферолы содержатся в зеленых частях растений, особенно в молодых ростках злаков, также богаты ими растительные масла (подсолнечное, 
хлопковое, кукурузное, арахисовое, соевое, облепиховое). Некоторое количество их содержится в мясе, жире, яйцах, молоке. Потребность в витамине Е составляет 8 - 10 МЕ для взрослых и от 3-7 ME для детей (в зависимости от возраста). Витамин Е является эндогенным противоокислительным фактором (антиоксидантом), тормозящим перекисное окисление липидов клеточных мембран. Участвует в биосинтезе белков, в тканевом дыхании, пролиферации клеток и других важнейших процессах.

Высокой антиоксидантной активностью обладают дибунол и пробукол - препараты с широким спектром биологических свойств. В зависимости от дозы они способны подавлять биосинтез белка за счет включения торможения аминокислот и ингибирования синтеза РНК, повышать активность оксигеназ печени, стимулируя биотрансформации многих соединений, ускорять регенерацию тканей, интенсифицируя вступление клеток в фазу синтеза ДНК и повышая активность РНК-полимераз.

Многие биофлавоноиды (витамин Р) имеют выраженные антиоксидантные свойства за счет прямого антирадикального действия. Это растительные биофлавоноиды, представляющие собой группу биологически активных веществ (рутин, катехины, кверцетин, цитрин, гесперидин, эриодиктиол, цианидин). Всего известно около 150 биофлавоноидов, обладающих сходными биологическими действиями. Витамин $\mathrm{P}$ находится обычно в тех же растительных продуктах, в которых встречается и аскорбиновая кислота. Особенно много его содержится в цитрусовых, черной смородине, плодах шиповника, щавеле, зеленом чае, салате. В гречихе, белой оболочке под кожурой цитрусовых немного меньше его присутствие в помидорах, винограде, капусте, петрушке, сливах, яблоках, ягодах. Данный витамин не вырабатывается нашим организмом и поэтому должен быть включен в ежедневный рацион питания. Суточная потребность взрослого человека в рутине - 30 мг, кверцетине - 15 , геспередине - 100 мг. Витамин $\mathrm{P}$ - эффективный антиоксидант, способный восстанавливать клеточную структуру, в основе действия которого лежит свойство перехватывать свободные радикалы кислорода и обезвреживать их. Являясь мощными природными антиоксидантами, биофлавоноиды предохраняют клетки нашего организма от разрушительного воздействия свободных радикалов, предотвращая старение организма, нарушения иммунитета, возникновение различных заболеваний. Традиционно считается, что биофлавоноиды обладают капилляроукрепляющим свойством: нормализуют и поддерживают структуру, эластичность, функцию и проницаемость кровеносных сосудов, предупреждают их склеротическое поражение, снижают проницаемость стенок сосудов, препятствуют выработке гистамина и серотонина.

Существенный интерес вызывает и их способность оказывать сберегающий эффект в отношении аскорбиновой кислоты.

Прямое антирадикальное действие оказывает эмоксипин. Он эффективен при быстром и чрезмерном нарастании свободнорадикальных процессов, например при острой лучевой болезни, при воздействии света высокой интенсивности (ретинопротекторное действие) и т.д. Побочных эффектов обычно не дает.

Глутатион - глутамилцистеинглицин как трипептид при приеме внутрь гидролизуется на составляющие аминокислоты. Предшественниками глутатиона являются метионин и глутаминовая кислота. В последние годы вместо метионина используется его более активная форма - метилметионинсульфоний. Все указанные соединения проявляют актиоксидантное действие и оказывают нормализующий эффект в отношении показателей липидного обмена.

\section{Стабилизаторы мембран.}

Тиоктовая кислота (берлитион, липоевая кислота, $\alpha$-липоевая кислота, октолипен, тиоктацид, тиогамма) - эндогенный антиоксидант (связывает свободные радикалы), в организме образуется при окислительном декарбоксилировании $\alpha$-кетокислот. В качестве коэнзима митохондриальных мультиферментных комплексов участвует в окислительном декарбоксилировании пировиноградной кислоты и $\alpha$-кетокислот. Способствует снижению концентрации глюкозы в крови и увеличению гликогена в печени, а также преодолению 
инсулинорезистентности. По характеру биохимического действия препарат близок к витаминам группы В. Участвует в регулировании липидного и углеводного обмена, стимулирует обмен холестерина, улучшает функцию печени. Оказывает гепатопротекторное, гиполипидемическое, гипохолестеринемическое, гипогликемическое действие. Улучшает трофику нейронов. Использование трометамоловой соли тиоктовой кислоты в растворах для в/в введения (имеющей нейтральную реакцию) позволяет уменьшить выраженность побочных реакций.

Эссенциале - эссенциальные фосфолипиды, которые представляют собой высокоочищенную фракцию фосфатидилхолина. По своей химической структуре подобны эндогенным мембранным фосфолипидам, превосходя их по своим функциональным свойствам за счет высокого содержания в них полиненасыщенных жирных кислот, особенно липоевой кислоты. Фосфолипиды являются основными структурными элементами клеточных мембран и органел. Они принимают участие в дифференциации, размножении и регенерации клеток. Функциональное значение основывается на их амфифильных свойствах, которые позволяют регулировать проницаемость клеточной оболочки. Улучшают функцию мембран, в частности ионный обмен, процесс внутриклеточного дыхания, биологического окисления, влияют на связывание ферментов внутриклеточного дыхания в митохондриях, а также на процесс окислительного фосфорилирования в энергетическом обмене клеток. В физиологических условиях синтез фосфолипидов удовлетворяет нормальные потребности гепатоцитов, которые содержат достаточное количество фосфолипидов. Эссенциале является универсальным стабилизатором мембран. Известно, что структура клеточных мембран, функция ферментных систем при заболеваниях печени и биосинтез фосфолипидов, дефицит которых приводит к изменению функции клеточной мембраны, нарушаются. Эссенциале Форте устраняет указанные нарушения, способствует регенерации клеточных мембран, реактивирует мембраносвязанные ферментные системы и рецепторы, повышает детоксикационную способность печени и таким образом нормализует ее функцию. Кроме того, эссенциале представляют как индуктор иммуномодулирующих свойств эритроцитов, так как эритроциты, обработанные эссенциале стимулируют развитие иммунного ответа на Тзависимые АГ, но не влияют на выраженность иммунного ответа, индуцированного Тнезависимыми АГ.

Целесообразно применение и других стабилизаторов мембран - ксидифона, димефосфона. Ксидифон - мембраностабилизирующий препарат, обладающий способностью “включаться" в структуры липидного слоя мембран, способствуя образованию фосфолипидов, менее проницаемых для биологически активных веществ (75 - 100 мг/кг веса в сут, в зависимости от возраста - в виде $2 \%$ раствора 3 раза в день, в течение месяца). Полиненасыщенные фосфолипиды, внедряясь в наружный слой мембраны, оказывает влияние на содержание ненасыщенных жирнокислотных радикалов, обладают антиоксидантными свойствами и могут оказывать влияние на структуру мембраны за счёт снижения интенсивности постоянно протекающих процессов перекисного окисления липидов мембраны.

К активным стимуляторам метаболизма клетки относится и большие группы препаратов с непонятным пока механизмом действия. Однако эти лекарственные средства достаточно часто в больших количествах применяются в медицине. Нередко за ними нет никакой доказательной базы. Прежде всего применяемые для улучшения регенерации безбелковые препараты, получаемые из крови крупного рогатого скота, солкосерил и актовегин. Их используют в виде мази, желе или геля местно для улучшения обменных процессов и ускорения регенерации при язвенно-некротических процессах, ожогах, травмах.

В неврологии и травматологии широко используются тканеспецифические стимуляторы регенерации - церебролизин и румалон (при дистрофии хряща и длительно незаживающих переломах) 

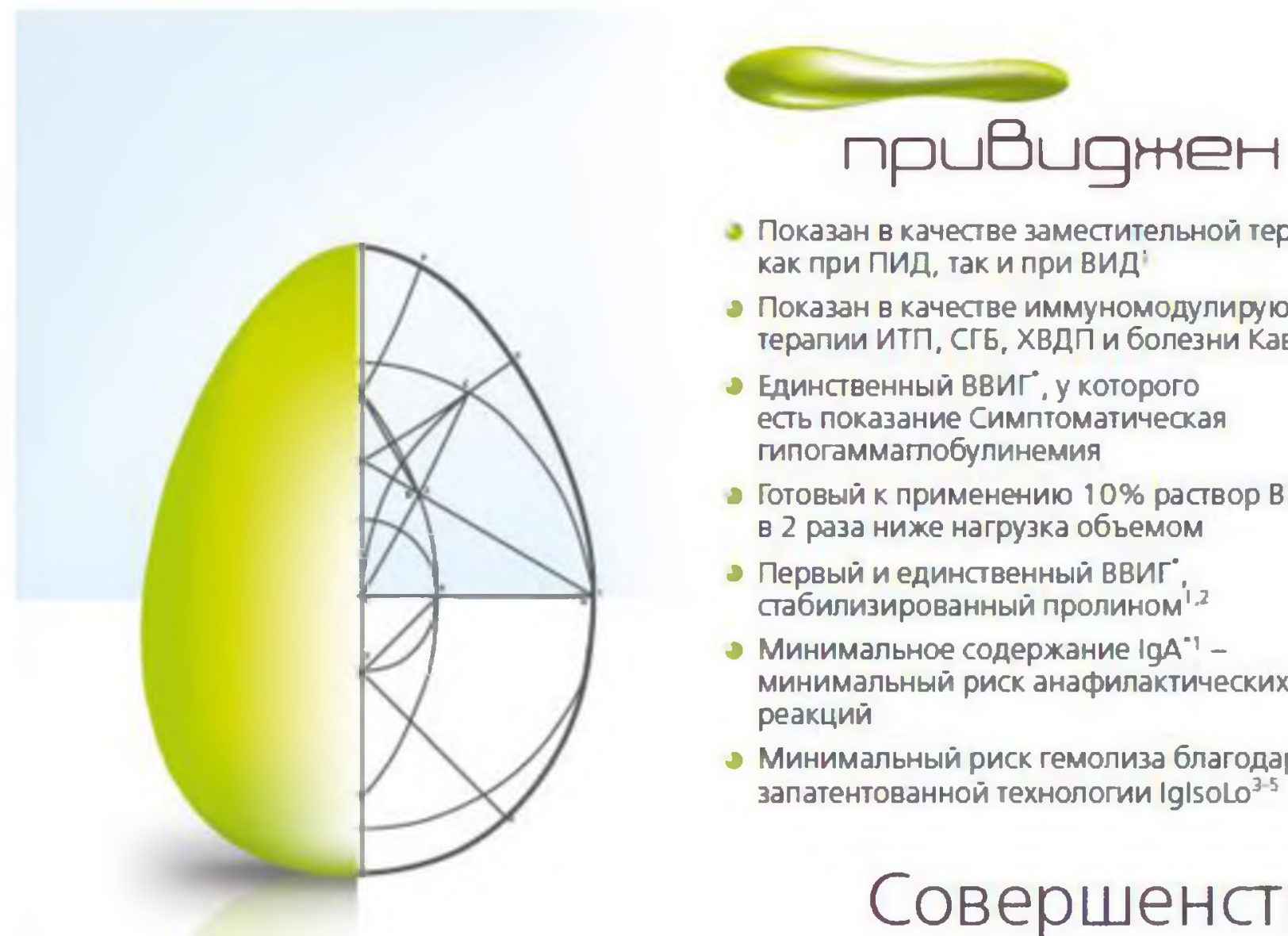

a Показан в качестве заместительной терапии как при ПИД, так и при ВИД

- Показан в качестве иммуномодулирующей терапии ИТП, СГБ, ХВДП и болезни Кавасаки

- Единственный ввИГ', у которого есть показание Симптоматическая гипогаммаглобулинемия

- Готовый к применению 10\% раствор ВвиГ' в 2 раза ниже нагрузка обьемом

- Первый и единственный ввигं, стабилизированный пролином',2

- Минимальное содержание IgA"1 минимальный риск анафилактических реакций

ง Минимальный риск гемолиза благодаря запатентованной технологии Iglsolo ${ }^{3-5}$

\section{Совершенство в простоте}

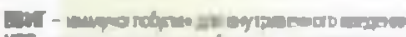

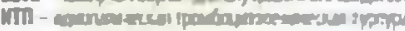

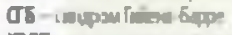

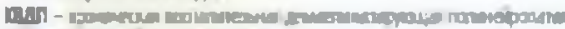

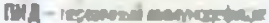

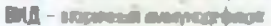

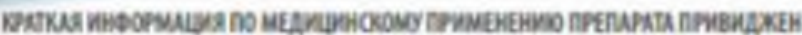

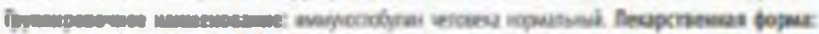

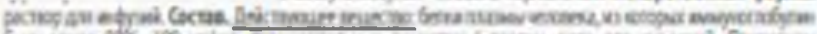

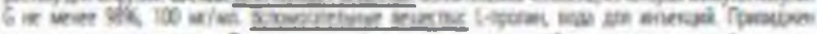

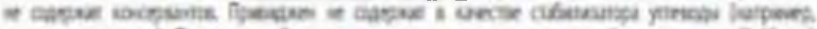

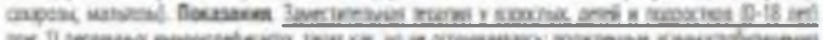

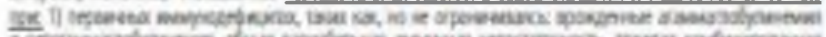

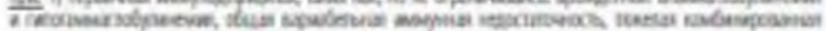

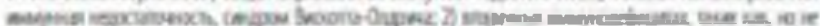

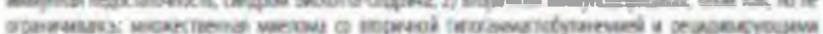

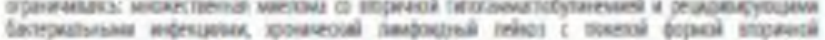

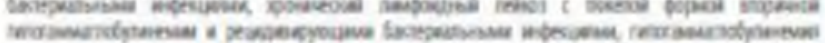

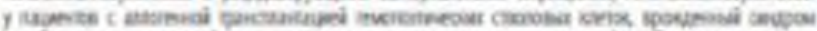

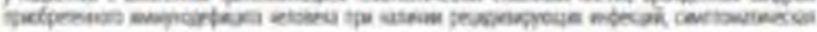

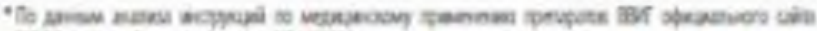

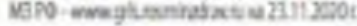

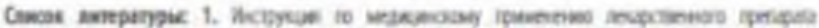

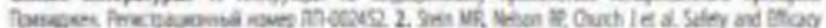

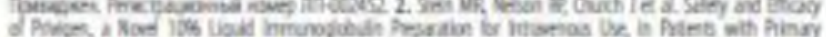

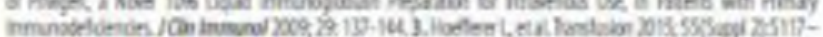

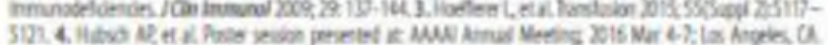

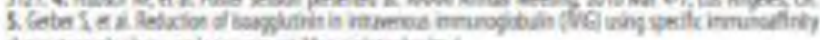

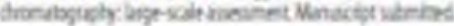

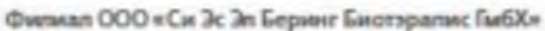

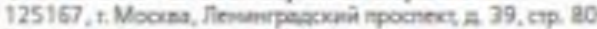

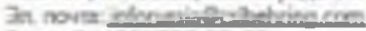

Ter: +7 (495) $78952 \cdot 39$

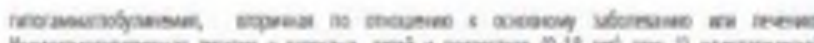

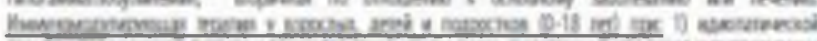

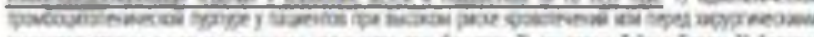

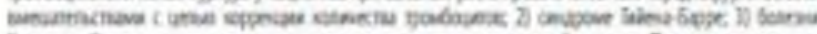

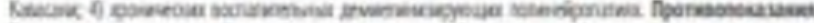

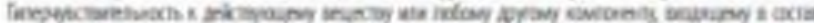

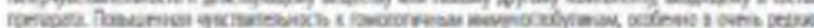

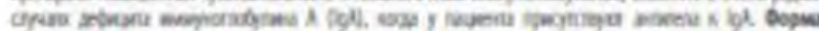

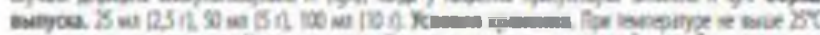

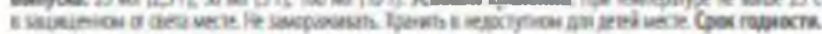

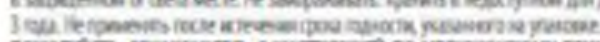

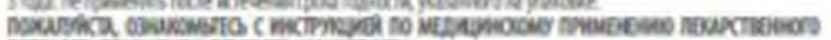

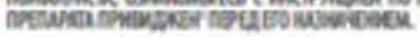




\section{ИММУНОТЕРАПИЯ}

\section{Глава 20. Методы иммунотерапии}

Актуальность проблемы восстановления иммунологических нарушений с помощью иммунокорригирующих препаратов в настоящее время несомненна и не требует обоснования. Однако при всей очевидности использование иммунотропных средств в комплексном лечении больных представляет собой сложную задачу и в настоящее время разработано недостаточно. Даже нет единого названия данного раздела терапии. В разное время этот вид терапии назывался по-разному: иммуномодулирующая, иммунокорригирующая, иммуноактивная, иммунотропная, более конкретно иммуностимулирующая или иммунодепрессивная. В последние годы в связи с бурным развитием биотехнологий необходимо выделить препараты, точечно действующие на определенные молекулы так называемая молекулярно-прицельная или молекулярно-таргетная (англ. target «цель, мишень») или просто таргетная терапия. Учитывая, что основой для производства таких препаратов являются биофармацевтические технологии таргетную терапию еще называют биологической терапией. Одним из основных методов лечения больных с первичными иммунодефицитами является заместительная терапия. Не всегда понятно каким образом иммуномодулирующие препараты вызывают эффект возвращения из любого положения (угнетения, стимуляция) к нормальному уровню функционирования, при котором звенья иммунной системы не меняются или колеблются в нормальных пределах. Важным акцентом в назначении иммунотропных препаратов является метод и место применения препарата: направлено - это на конкретный очаг или системно.

Таким образом, обобщающим термином способов лечения заболеваний человека с помощью методов и/или фармакологических средств, направленных на функции иммунной системы, является иммунотерапия $[1-3,27,32,38,50,63,64,78,83,96,121]$. Классификация средств иммунотерапии представлена на рисунки (рис. 124).

\section{ПО ЛОКАЛИЗАЦИИ}

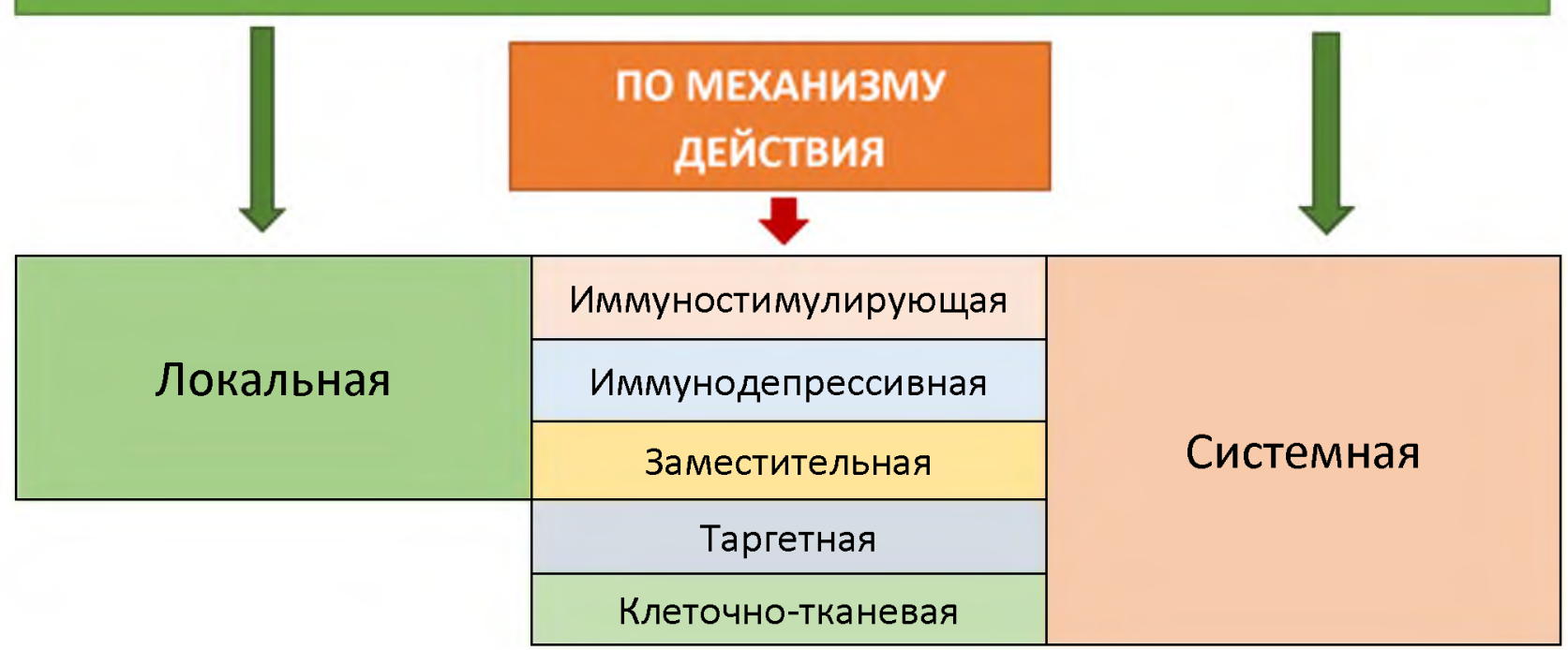

Рис.124. Классификация методов иммунотерапии 
Обычно считается, что именно назначение иммуноактивных препаратов - это и есть работа клинического иммунолога. Действительно иммунотерапия в клинической иммунологии - сложный лечебный процесс, направленный на восстановление нормального функционирования иммунной системы и достижение полноценной клиникоиммунологической ремиссии, вплоть до полного выздоровления. При применении иммуноактивных препаратов следует соблюдать следующие правила:

1. Опираться на достоверный клинический диагноз и определять степень иммунной патологии на основании клинических признаков иммунной недостаточности, данных лабораторных иммунологических обследований с обязательным учетом сопутствующих соматических заболеваний. Обязательно оценивать характер иммунных нарушений у больных, определять степень выраженности иммунных расстройств. Определить иммунологический диагноз.

2. Индивидуально подбирать иммунотропные препараты в зависимости от степени иммунных нарушений и их длительности. При возможности использовать индивидуальный подбор с учетом лабораторных тестов. Для больных с длительно протекающими и часто рецидивирующими иммунопатологическими процессами использовать несколько иммуномоактивных препаратов, имеющих различные точки приложения в иммунной системе, но необходимо учитывать, что иммуноактивные препараты способны нанести непоправимый вред больному, например, запустить тяжелый аутоиммунный процесс или приостановить продукцию собственных ИФН. Т.е. индивидуальный подход к назначаемой терапии.

3. Назначать иммуноактивную терапию с первых дней заболевания (вместе с этиотропными средствами). При этом антибактериальный препарат снижает функциональную активность микроба, а иммуномоактивный препарат повышает функциональную активность клеток иммунной системы, что позволяет добиться достаточного клинического эффекта при заболеваниях, торпидных к проводимой стандартной терапии, в комплексной терапии рецидивирующих инфекционно-воспалительных процессов, аллергических, онкологических и др. заболеваний, протекающих в сочетании с иммунными нарушениями, а также для стимуляции лейкопоэза, улучшения качества жизни при проведении химио- и радиотерапии. Т.е. раннее назначение препаратов.

4. Назначать в некоторых случаях (например, при нарушении фагоцитарного звена иммунитета) иммуноактивные препараты больным как с выявленными, так и с не выявленными нарушениями иммунного статуса - основанием для назначения препарата является клиническая картина. В тех случаях, когда обнаружены лишь изменения отдельных лабораторных показателей, но нет клинических признаков иммунной недостаточности, от введения иммуноактивных препаратов следует воздержаться. Применение только при болезни.

5. Применять иммуноактивные препараты целесообразно на фоне иммунологического мониторинга, который следует проводить вне зависимости от выявленных или исходных изменений в иммунной системе.

6. Помнить, что многие традиционные лекарственные вещества обладают иммунотропным эффектом, а также учитывать побочные реакции как различных препаратов на иммунную систему, так и иммуноактивных препаратов на другие органы и системы. Т.е. необходимо прогнозировать взаимодействие препаратов.

7. Учитывать возраст, биоритмы больного и другие особенности. Препарат полностью реализует свои эффекты только в оптимальной дозе в определенное время.

8. Возможно использовать иммуномодуляторы в виде монотерапии при проведении иммунореабилитационных мероприятий.

9. Осуществить коррекцию общего процесса полноценного питания, приема витаминных препаратов, микро- и макроэлементов. Некоторые из них обладают иммуномодулирующим действием, что необходимо соотносить с характером иммунных нарушений у пациентов. Важным компонентом иммунотропного лечения является использование энтеросорбентов, выводящих из организма различные токсины. 


\section{ИММУНОТЕРАПИЯ}

\section{Глава 21. Заместительная терапия}

Заместительная терапия длительное время успешно применяется в клинической практике, в виде введения специфических АТ и сывороток, иммуноглобулинов и свежезамороженной плазмы. В последние годы в связи с развитием биотехнологий и получения большого количества цитокинов к заместительной терапии можно отнести и коррекцию нарушений иммунной системы с помощью этих агентов.

Иммуноглобулиновые препараты. Опыт использования антител для профилактики и лечения инфекционных заболеваний имеет вековую историю. В период с 1891 по 1894 г.г. Эмиль Адольф фон Беринг совместно с Робертом Кохом разработали и впервые применили противодифтерийную сыворотку. В 1901 году Э. Берингу «...за работу по сывороточной терапии, главным образом за её применение при лечении дифтерии, что открыло новые пути в медицинской науке и дало в руки врачей победоносное оружие против болезни и смерти...» была присуждена первая Нобелевская премия по физиологии и медицине.

Один из активных иммуноглобулин-содержащих препаратов в виде свежезамороженной плазмы достаточно давно и с хорошим клиническим эффектом применяется в клинической практике. Методы спиртового фракционирования плазмы крови и деактивации $\mathrm{Fc}$ фрагмента антител позволили с 80-х годов XX-столетия наладить производство внутривенных иммуноглобулинов (ВВИГ), которые полностью заменили свежезамороженную плазму крови.

Специфические $\boldsymbol{A T}$, используемые с лечебной целью, выпускаются промышленностью в виде иммунных сывороток или активных в иммунном отношении фракций иммуноглобулинов. Их готовят из крови переболевших людей (гомологичные) или животных (гетерологичные). Гомологичные иммунные препараты обладают определенным преимуществом перед гетерологичными в связи с большой продолжительностью (до 1-2 мес.) их циркуляции в организме и отсутствием у них побочных эффектов. Сыворотки и иммуноглобулины, изготовленные из крови животных, действуют сравнительно недолго (1 2 нед) и способны вызывать побочные реакции, поэтому их применение оправдано только в случаях тяжелых заболеваний (дифтерия, ботулизм, столбняк, бешенство и пр.).

Эффективность иммунных сывороток (иммуноглобулинов) в значительной мере определяется оптимальной их дозой и своевременностью применения. Доза препарата должна соответствовать клинической форме заболевания и быть способной нейтрализовать не только циркулирующие в данный момент в организме АГ возбудителей заболевания, но и те, которые могут появиться в нем в промежуток времени между введениями препарата. Антимикробный и клинический эффект иммунных сывороток (иммуноглобулинов) тем выше, чем раньше они применяются. Назначение их после 4-5-го дня болезни редко дает выраженный положительный результат.

В настоящее время микробиологическая промышленность России и других стран производит иммунные сыворотки и иммуноглобулины для лечения больных различными инфекционными заболеваниями. Это предусмотрено в отношении возбудителей тех болезней, в патогенезе которых первостепенную роль играют экзотоксины (дифтерия, ботулизм, столбняк и др.), а также ряд опасных для здоровья людей болезней - сибирская язва, лептоспироз, бешенство, клещевой энцефалит и т.д. 
Дифтерия. Иммуноглобулин противодифтерийный человека для внутривенного введения. Только при лечении внутривенно, капельно (30-40 кап/мин). Разовая доза - 25 мл. В зависимости от тяжести патологического процесса до 15 трансфузий.

Ботулизм. Основным препаратом иммунотерапии больных ботулизмом является противоботулиническая лошадиная очищенная и концентрированная сыворотка типов А, В, $\mathrm{C}, \mathrm{E}$ и $\mathrm{F}$. С лечебной целью сыворотку вводят в максимально ранние сроки от момента появления первых симптомов ботулизма. До выявления типа ботулотоксина используют смесь моновалентных сывороток (типа А, В и Е). При выявлении типе токсина используют моновалентную сыворотку соответствующего типа.

Столбняк. Иммуноглобулин человека противостолбнячный. При экстренной профилактике столбняка у взрослых и детей, не получивших полного курса иммунизации столбнячным анатоксином или с неизвестным прививочным анамнезом. Однократно, внутримышечно $250 \mathrm{ME}$ ( 1 ампула) независимо от возраста.

Бешенство. Человеческий иммуноглобулин для профилактики бешенства. Для лечебно-профилактических мероприятиях при подозрении на бешенство рекомендуется немедленно применять иммунизацию, при любых повреждениях кожных покровов - укусах, любых ранах и глубоких царапинах на лице, голове, шее, кистях рук, стопах, на туловище, нанесенных животными больными бешенством, с подозрением на бешенство, находящимися под ветеринарным наблюдением и вне его, дикими.

Сибирская язва. Иммуноглобулин противосибиреязвенный лошадиный. С целью экстренной профилактики препарат назначают в случаях: прямого контакта с материалом, содержащим возбудитель сибирской язвы; при уходе за больными сибирской язвой животными; при убое и разделке туш больных животных; при приготовлении и употреблении в пищу мяса больных животных. Экстренно профилактическое введение препарата производится лицам, не привитым против сибирской язвы. С лечебной целью препарат назначают при среднетяжелом и тяжелом течении сибирской язвы.

Клещевой энщефалит. Применяют иммуноглобулин человека против клещевого энцефалита при экстренной профилактике (после укуса энцефалитного клеща) и лечение. Для профилактики (0,05 мл/кг, однократно): в возрасте до 12 лет - 1 мл, от 12 до 16 лет - 2 мл, от 16 лет и старше - 3 мл. Для лечения $(0,2$ мл/кг) - в первые дни по 3 мл с интервалом $10-$ 12 ч (до падения температуры). После введения необходимо наблюдение за пациентами в течение 30 мин (возможность развития аллергических реакций).

Внутривенные иммуноглобулины (ВВИГ) содержат в своем составе широкий спектр антител, направленных против наиболее часто встречающихся патогенов, а также блокирующих антител. В настоящий момент в РФ зарегистрировано 13 лекарственных препаратов ВВИГ: все они представляют собой готовые растворы для внутривенного введения. Десять препаратов 5-\% (предыдущее поколение) и только три (Привиджен, Гамунекс-С, Октагам) содержат 10-\% раствор нормального иммуноглобулина (Ig) человека. При таком разнообразии естественно возникают трудности с выбором препарата. Ситуация усугубляется еще тем, что в типовом формуляре ВО3 (2009 г.) содержится основополагающая фраза «препараты иммуноглобулинов различных производителей различаются и не могут рассматриваться как эквивалентные». Поэтому к подбору препарата ВВИГ следует относиться с повышенным вниманием, учитывая все особенности его способа производства и состава.

Подавляющее большинство антител в составе ВВИГ относится к классу $\operatorname{IgG}(>95 \%)$, при этом с точки зрения терапевтического действия важно, чтобы в препарате сохранялось естественное соотношение всех 4 субклассов IgG (IgG1-IgG4) как, например, в препарате Привиджен.

У ВВИГ достаточно много механизмов действия (табл. 105). По направленности их можно разделить на 2 группы: заместительные (в физиологических дозах) и иммуномодулирующие (в высоких дозах). Из этих механизмов вытекают показания к назначению этих препаратов. 


\section{Механизмы и действия ВВИГ}

\section{Таблица 105}

\begin{tabular}{|c|c|}
\hline Характер эффектов & Механизмы \\
\hline Заместительные & $\begin{array}{ll}\text { - } & \text { нейтрализация антигена } \\
\text { - } & \text { блокада Fc рецепторов на макрофагах } \\
\text { - } & \text { блокада классического пути активации комплемента } \\
& \text { (ингибиция C1q, C3 и C4 компонентов) } \\
& \text { модуляция продукции провоспалительных цитокинов }\end{array}$ \\
\hline Иммуномодулирующие & $\begin{array}{ll}\text { - } & \text { ингибирование синтеза аутоантител (по механизму обратной } \\
& \text { связи) } \\
\text { - } & \text { нейтрализация циркулирующих аутоантител по механизму } \\
& \text { идиотип-антиидиотипического взаимодействия } \\
\text { - } & \text { элиминация циркулирующих иммунных комплексов, } \\
& \text { диссоциация их отложений в тканях } \\
\text { - } & \text { изменение Th1-Th2 баланса в сторону Th1 }\end{array}$ \\
\hline
\end{tabular}

Заместительная терапия показана при заболеваниях, вызываемых недостаточной продукцией Ig. Это прежде всего первичные иммунодефициты (ПИД) с нарушением гуморального звена. В большинстве инструкций к препаратам ВВИГ указаны лишь 4 заболевания: врожденная агаммаглобулинемия и гипогаммаглобулинемия, общая вариабельная иммунная недостаточность, тяжелая комбинированная иммунная недостаточность, синдром Вискотта-Олдрича. Вместе с тем, накопленный клинический опыт в отечественных и зарубежных иммунологических центрах свидетельствует об эффективности ВВИГ при множестве других ПИД. Другим направлением заместительной терапии ВВИГ являются вторичные иммунодефициты (ВИД). Здесь также как и в случае с ПИД спектр нозологий по инструкции сильно ограничен. Это множественная миелома, хронический лимфоидный лейкоз, врожденный СПид у детей при наличии рецидивирующих инфекций. До последнего времени предполагалось, что назначение ВВИГ при других ВИД (например, тяжелые инфекции, ожоги, акушерско-гинекологическая патология) должно проходить в формате off-label. В прошлом году эту проблему решила компания CSL Behring, внеся в инструкцию препарата Привиджен новое показание «симптоматическая гипогаммаглобулинемия, вторичная по отношению к основному заболеванию или лечению». Это позволяет назначать препарат практически при любых ПИД и ВИД.

Иммуномодулирующая (высокодозная) терапия ВВИГ направлена на лечение аутоиммунных и аутовоспалительных заболеваний. Наиболее частыми показаниями в инструкциях ВВИГ являются идиопатическая тромбоцитопеническая пурпура, синдром Гийена-Барре, болезнь Кавасаки и хронические воспалительные демиелинизирующие полинейропатии. Но как и в случае с иммунодефицитами в литературе можно обнаружить десятки аутоиммунных нозологий, при которых в клинических исследованиях доказана эффективность ВВИГ.

Учитывая естественное происхождение ВВИГ, они являются достаточно безопасными с точки зрения применения. Побочные эффекты достаточно редкие и, как правило легкой степени тяжести. Однако частота и выраженность нежелательных явлений напрямую связана с используемым препаратом. На сегодняшний день уже хорошо описаны параметры производственного процесса и характеристики конечного препарата ВВИГ, которые сводят риски побочных эффектов от их применения к минимуму:

1. Вирусинактивация. В связи с тем, что ВВИГ являются препаратами крови человека сушествует риск переноса трансмиссивных вирусов. В Европе не регистрируют ВВИГ, не имеющих минимум 2 стадий вирусинактивации. Некоторые производители препаратов из крови считают это требование недостаточным и 
увеличивают количество процедур очистки от вирусов. Например, в производственном процессе препарата Привиджен предусмотрены 4 цикла вируинактивации.

2. Агрегация Ig. Количество комплексов из Ig напрямую коррелирует с частотой побочных эффектов. Поэтому производитель должен представить эту информацию либо в инструкции, либо по запросу.

3. Изогемагглютинины. Анти-А и анти-В агглютинины содержатся в плазме крови здоровых людей (фракции $\operatorname{IgM}$ и $\mathrm{IgG}$ ) и могут стать причиной гемолиза. В связи с этим производитель должен не только контролировать их содержание в конечном препарате, но и включить в производственный цикл технологические процедуры по снижению (а в идеале по полному отсутствию) изогемагглютининов в препарате. Например, компания CSL Behring при производстве препарата Привиджен использует иммуноаффинную хроматографию для специфического удаления антител к группе крови А и В.

4. Содержание $\operatorname{IgA.~У~пациентов~с~селективным~дефицитом~} \operatorname{IgA}$ переливание препаратов ВВИГ содержащих данный Ig несет потенциальный риск развития анафилактических реакций. Поэтому при производстве препаратов ВВИГ необходимо не только контролировать количество IgA, но и свести его содержание к минимуму.

Существенными факторами, осложняющими применение ВВИГ в практике, являются низкая температура, при которой они транспортируются и хранятся, а также скорость введения пациенту. Большинство препаратов ВВИГ в силу своего белкового происхождения должны хранится при температурах $+4-+8^{\circ} \mathrm{C}$. Использование специального стабилизатора пролина, позволяет хранить препарат Привиджен при комнатной температуре 3 года, что исключает его инактивацию при нарушении холодовой цепи. Время инфузии 5-\% ВВИГ в среднем составляет 6 часов 12 минут (расчет на пациента массой тела 50 кг). Использование «высокоскоростных» 10-\% препаратов (Привиджен, Октагам) снижает это время до 46 минут, что безусловно сказывается на качестве жизни пациента и его согласии на проводимую терапию.

Обогащенные иммуноглобулины - ВВИГ содержащие антитела класса IgG и обогащенные антителами классов $\operatorname{IgM}$ и $\operatorname{IgA}$ (Пентаглобин). Пентаглобин был разработан для лечения распространенных тяжелых бактериальных инфекций за счет специфических функций, которыми обладают иммуноглобулины классов А и М. Однако мультицентровые исследование применения стандартных иммуноглобулинов при лечении сепсиса не показали свою эффективность, поэтому препарат ушел с рынка как у нас в России так и в Европе. При этом необходимо отметить, что применение препарата было проведено без учета вариантов течения сепсиса (преобладание SIRS, CARS, MARS, PICS (см. главу 10), что не позволяет отвергать применение данного препарата в связи с его «физиологической целесообразностью» (содержит широкий спектр антител против микроорганизмов, для комплементопосредованного уничтожения микроорганизмов и повышения фагоцитарной активности моноцитов/макрофагов и гранулоцитов).

Гипериммунные спечифические иммуноглобулины - ВВИГ, содержащие антитела класса IgG с повышенной концентрацией против определенных возбудителей (Неоцитотект, Неогепатект и др.).

Неоцитотект является препаратом Ig, который изготовлен из плазмы доноров с высоким титром антител против возбудителя цитомегалии. Распределение подклассов IgG соответствует распределению в плазме здоровых доноров. Препарат применяется при профилактике ЦМВ-инфекции у пациентов с подавленной медикаментами иммунной системой, в частности после трансплантации органов, предотвращение манифестации заболевания после инфицирования ЦМВ, терапия ЦМВ-инфекции у пациентов с ослабленным иммунитетом, например, недоношенных детей, новорожденных, а также у пациентов с подавленным медикаментами иммунитетом или иммунодефицитом, вызванным другими причинами (например, СПИД). Препарат вводят в разовой дозе 1 мл на кг массы тела.

Показаниями к применению препарата Неогепатект являются: профилактика гепатита В у новорожденных, родившихся от матерей — носительниц поверхностного антигена вируса 
гепатита В: использование у лиц с повышенным риском заражения вирусом гепатита В до или одновременно с вакцинацией против гепатита В (в т.ч. перед операциями, повторной гемотрансфузией, гемодиализом), профилактика инфицирования трансплантата печени у пациентов, имеющих поверхностный антиген вируса гепатита B, профилактика гепатита В у взрослых и детей, подвергшихся опасности заражения гепатитом В (например, в случае нарушения целостности кожного покрова при уколе инъекционной иглой или непосредственного контакта со слизистой оболочкой).

Цитокинотерапия. В настоящее время, используя последние достижения молекулярной биологии, биохимии, иммунологии, генной инженерии, были созданы новые эффективные лекарственные средства - рекомбинантные препараты. Принципы создания таких препаратов заключается в следующем: 1) распознается участок ДНК человека, ответственный за синтез нужного белка; 2) этот участок вырезается и встраивается в ДНК живой бактерии (например, кишечной палочки или дрожжевой клетки); 3) пересаженный участок начинает работать и синтезировать нужные белковые молекулы. Далее эти биологически активные вещества выделяются и очищаются. Препараты, полученные таким способом, называют рекомбинантными. Они, являясь чистыми от посторонних биологически активных веществ, оказывают меньше побочных действий, их специфическая фармакологическая активность выше, чем у аналогичных природных препаратов.

Основные рекомбинантные препараты вместе с ферментами, гормонами, вакцинами и факторами свертывания крови являются цитокины, наиболее часто применяющиеся в медицине.

В клинической практике существуют три основных направления использования цитокинов:

1. цитокиновая иммунотерапия, при которой цитокины выступают в роли лекарственных средств - заместительная терапия;

2. антицитокиновая терапия, направленная на блокирование биологического действия или удаление избытка цитокинов из организма - таргетная терапия (см. главу 24);

3. цитокиновая генотерапия, применяемая с целью усиления противоопухолевого иммунитета, коррекции дефектов в системе цитокинов и их рецепторов - клеточнотканевая терапия (см. главу 25).

Разработка доступных методов оценки многих цитокинов позволила сформулировать понятие об иммуноцитокиновом статусе и определить круг иммунопатологии, при которых существенно нарушена их продукция и рецепция.

Интерфероны. Основная группа активно применяемых цитокинов (табл.106). Это биологически активные белки, которые синтезируются клеткой в процессе защитной реакции. Они секретируются во внеклеточную жидкость и через рецепторы действуют на другие клетки, повышая устойчивость к внутриклеточным микроорганизмам, в первую очередь вирусам. По структуре и биологическим свойствам ИФН подразделяются на три вида: ИФН$\alpha$, ИФН- $\beta$ и ИФН- $\gamma$.

Препараты ИФН-а применяются в первую очередь при вирусных инфекциях, среди которых наиболее изучены острые и хронические вирусные гепатиты, герпетические поражения, грипп, COVID-19? ОРВИ и др. Показана эффективность ИФН при лечении ЦМВИ, различных бактериальных заболеваний (гнойно-септической инфекции у новорожденных и хирургических больных, хламидиозе и др.). ИФН используются также при многих онкологических заболеваниях.

В России выпускается целая гамма разнообразных препаратов на основе рекомбинантного ИФН- $\alpha$. Прежде всего необходимо выделить препараты для локального (местного) применения в виде капель и спрея - гриппферон, альфарона, мазей и геля виферон, вагинальный и ректальны свечей - генферон, гиаферон и виферон, для перорального применения - реаферон-липинт, глазные капли - офтальмоферон, интерфераль. 


\section{Интерфероны и их препараты}

\begin{tabular}{|c|c|}
\hline $\begin{array}{c}\text { Препараты (торговые } \\
\text { названия) }\end{array}$ & Фармакологическое действие \\
\hline & Альфа-интерфероны \\
\hline $\begin{array}{l}\text { Альтевир, Альфарона, } \\
\text { Виферон, Роферон-А, } \\
\text { Интрон-А, Реальдирон, } \\
\text { Реаферон-ЕС, Интераль, } \\
\text { Альтевир, Виферон, } \\
\text { Гриппферон и др. }\end{array}$ & $\begin{array}{l}\text { Препятствует вирусному инфицированию клеток, изменяет свойства клеточной } \\
\text { мембраны, предотвращает адгезию и проникновение вируса внутрь клетки. } \\
\text { Инициирует синтез ряда специфических ферментов, нарушает синтез вирусной } \\
\text { РНК и белков вируса в клетке. Изменяет цитоскелет мембраны клетки, } \\
\text { метаболизм, предотвращая пролиферацию опухолевых (особенно) клеток. } \\
\text { Оказывает модулирующее влияние на синтез некоторых онкогенов, } \\
\text { приводящее к нормализации неопластической трансформации клеток и } \\
\text { ингибированию опухолевого роста. Стимулирует процесс презентации антигена } \\
\text { иммунокомпетентным клеткам, модулируетактивность киллеров, участвующих } \\
\text { в противовирусном иммунитете. }\end{array}$ \\
\hline \multicolumn{2}{|r|}{ Альфа-интерфероны пролонгированного действия } \\
\hline $\begin{array}{l}\text { Пегасис, ПегИитрон } \\
\text { Альгерон }\end{array}$ & $\begin{array}{l}\text { Препараты образуется путем присоединения к молекуле интерферона альфа } \\
\text { полимерной структуры - полиэтиленгликоля (ПЭГ), за счет чего обеспечивается } \\
\text { пролонгированное действие препарата аналогичное альфа-интерферонам }\end{array}$ \\
\hline \multicolumn{2}{|r|}{ Бета-интерфероны } \\
\hline $\begin{array}{l}\text { Аванекс, Ребиф, } \\
\text { Тебериф, Бетаферон, } \\
\text { Ронбетал, Инфибета }\end{array}$ & $\begin{array}{l}\text { Обладают противовирусным, антипролиферативным и противовоспалительным } \\
\text { действием. При рассеянном склерозе стимулирует противовоспалительные } \\
\text { цитокины, тормозит пролиферацию лейкоцитов с нарушением презентации } \\
\text { аутоантигенов, снижает темпы миграции лейкоцитов через ГЭБ. Является } \\
\text { антагонистом интерферона-гамма, повышает супрессорную активность } \\
\text { мононуклеарных клеток и снижает устойчивость Т-лимфоцитов к апоптозу, } \\
\text { вызывая гибель аутореактивных клонов. }\end{array}$ \\
\hline \multicolumn{2}{|r|}{ Гамма-интерферон } \\
\hline Ингарон & 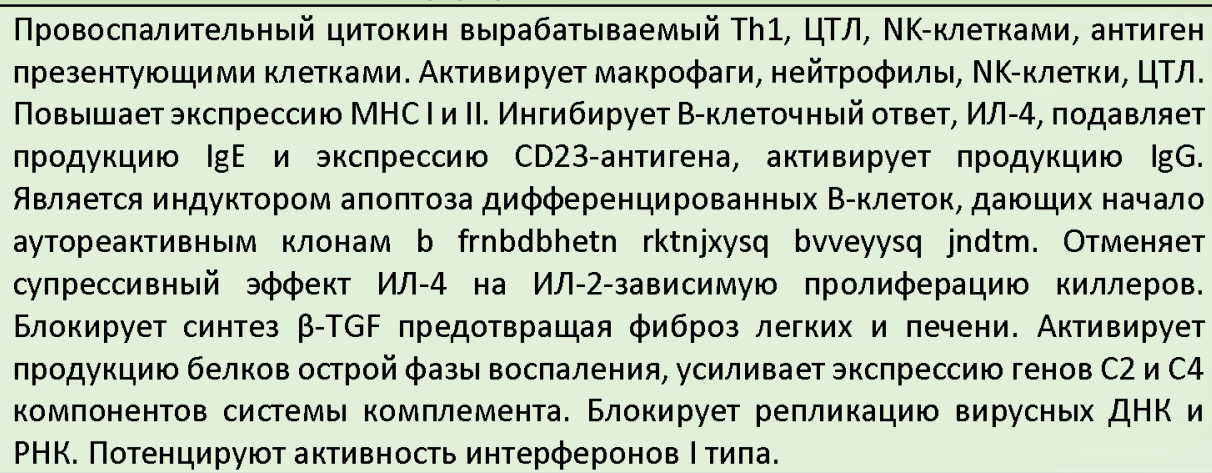 \\
\hline
\end{tabular}

При любой вирусной инфекции необходимо местное применение ИФН- $\alpha$, это определяется «физиологической целесообразностью» и идентичностью данных препаратов. Однако срок применения должен быть ограничен 3 днями от начала заболевания в связи с дальнейшим иммуносупрессивным действием интерферонов (эффект истощения).

В некоторых случаях так, например, при ВПЧ инфекции эти препараты являются единственными патогенетическими препаратами для лечения $\mathrm{c}$ обоснованными доказательствами.

Гораздо больше препаратов ИФН- $\alpha$ для системного применения. Это роферон-А (3-4,56-9 млн МЕ), альтевир флаконы (1, 3, 5, 10, 15 млн ME) или шприцы (3, 5, 10, 15 млн МЕ), альфарона (500 тыс.-1-3-5 млн ME), интрон А во флаконах объемом по 1 мл/10 млн МE (1 доза), 3 мл/18 млн ME (6 доз по 3 млн ME), 2,5 мл/25 млн ME (5 доз по 5 млн ME) или в шприцручках по 1,2 мл (6 доз по 3 млн ME - 18 млн ME; 6 доз по 5 млн ME - 30 млн ME; 6 доз по 10 млн МЕ - 60 млн ME), реальдирон (1-3-6-9-18 млн ME), реаферон-ЕС (ампулы 0,5-1-3-5 млн ME). 
Отдельно необходимо отметить препараты ИФН- $\alpha$ пролонгированного действия - пегасис шприцы (135 или 180 мкг/0,5 мл), пегИнтрон во флаконах (50-80100-120 мкг) или шприцах (50-80-100-120-150 мкг), альгерон (200 мкг/мл шприцы с градуировкой по 0,4, 0,5, 0,6, 0,8 или 1,0 мл).

Принципы применения препаратов ИФН, несмотря на активное и длительное использование в клинической практике, все еще можно сформулировать в самом общем виде. Это связано с тем, что ИФН влияют на многие реакции инфекционного, в частности противовирусного, и противоопухолевого иммунитета, но их направленность зависит от состояния иммунной и интерфероновой систем организма, а также дозы, кратности, способа введения препарата. Важным фактором являются индивидуальные особенности препарата, в частности тип ИФН, его лекарственная форма. Все это крайне усложняет разработку обоснованной тактики использования ИФН при каждом конкретном заболевании. Возможны лишь общие рекомендации, к которым всегда следует относиться критически.

Основные принципы применения препаратов ИФН.

- Адекватная оценка показаний и противопоказаний к назначению ИФН с учетом иммунного и интерферонового статуса больного.

- В Выбор оптимального режима дозирования (часто подбирается индивидуально с учетом переносимости).

- Правильный выбор препарата (учитывая тип ИФН и способ его получения, необходим предварительное индивидуальное лабораторное тестирование).

- Прогнозирование и контроль возникновения побочных эффектов с учетом дозировки, основной патологии, особенностей препарата. Снижение выраженности побочных эффектов за счет изменения режима дозирования, применения нестероидных противовоспалительных средств и т.д. При возможности типирование препарата или линейки препаратов in vitro.

- Адекватный контроль эффективности лечения (критерии и сроки значительно отличаются при разных заболеваниях и для различных препаратов).

- Обязательный иммунологический и интерфероновый мониторинг при проведении интерферонотерапии.

- Учет возможных лекарственных взаимодействий препаратов ИФН с другими лекарственными средствами.

Интерфероны - препараты крайне трудные для врача. Рациональное применение этих препаратов должно основываться на том понимании, что ИФН с иммунобиологической точки зрения - это активный иммуномодулятор, влияющий на процессы дифференцировки, рекрутирования, а также функциональную активность эффекторных клеток иммунной системы и прежде всего Т-лимфоцитов и моноцитов/макрофагов. Под действием ИФН повышается эффективность иммунного распознавания антигенами, усиливаются фагоцитарная и цитолитическая функции, направленные на элиминацию возбудителя или антигенно измененных клеток. Следовательно, ИФН относятся к группе лекарственных средств с четко охарактеризованным направленным действием на иммунную систему. Клиническое применение этих препаратов требует обязательного иммунологического контроля, поэтому выбор препарата должен осуществляться с учетом индивидуальных иммуномодулирующих эффектов и состояния иммунной системы (клинические данные, показатели иммунного и интерферонового статуса) больного. Большое значение при этом имеет типирование препаратов в лаборатории in vitro.

При инфекционных заболеваниях разовые дозы ИФН определяются спецификой патологического процесса и должны быть достаточными для проявления иммуностимулирующего и корригирующего его влияния. В качестве лабораторной оценки можно рекомендовать такие тесты, как активация макрофагального или нейтрофильного фагоцитоза, цитолитических NK-клеток, методы хемилюминесцентного анализа. 
Чтобы исключить явление рефрактерности эффекторных клеток к действию ИФН, системное введение препарата должно быть прерывистым с интервалом в $1-3$ дня. Следует избегать ежедневного введения более 3 -х дней подряд.

При онкологических заболеваниях тактика медицинского применения препаратов ИФН зависит от характера опухоли, клинического состояния больного и должна учитывать схему использования других методов терапии. Важное значение имеет хирургическое удаление опухоли. Курс интерферонотерапии может сочетаться с другими средствами химиотерапии, a также $\mathrm{c}$ радиотерапией. Необходимо учитывать, что наряду с чувствительными к интерферонотерапии опухолями (аденокарцинома почки, саркома легкого, злокачественная меланома, нейробластомы, опухоли лимфоидных эндокринных и генеративных органов) имеются и более устойчивые опухоли (желудка, прямой кишки, печени). Как правило, высокой чувствительностью обладают вирусиндуцированные опухоли - папилломы гортани, мочевого пузыря, назофарингеальная карцинома, базально-клеточный рак кожи.

Заслуживает внимания тактика использования препаратов ИФН с целью реабилитации иммунной системы после жестких курсов цитостатической и радиотерапии. Наиболее рационально с этой целью применять комплексные препарататы, например лейкинферон для инъекций.

Побочное действие препаратов ИФН. Нежелательные реакции на ИФН являются дозозависимыми. Условно подразделяются на ранние, возникающие чаще на первой неделе лечения, и поздние, развивающиеся на 2-6-й неделе терапии.

Ранние реакции: гриппоподобный синдром: лихорадка, миалгия, болезненность глазных яблок. Встречаются практически у всех пациентов и обычно не требуют отмены препарата. Меры профилактики - прием парацетамола перед введением ИФН- $\alpha$.

Поздние реакции (нередко бывают причиной отмены препарата): гематологические: анемия, тромбоцитопения, агранулоцитоз. Меры профилактики - систематический контроль гемограммы.

Можно выделить побочные эффекты препаратов ИФН со стороны различных органов и систем. Центральная нервная система: сонливость, заторможенность, депрессия, судороги, головокружение, нарушение зрения, ухудшение психического состояния, спутанность сознания, нарушение памяти и поведения (тревога, нервозность), бессонница. Редко выраженная сонливость, судороги, кома, нарушение мозгового кровообращения, временная импотенция и ишемическая ретинопатия, суицидальное поведение. Периферическая нервная система: парестезия, онемение кожи конечностей, зуд, тремор. Сердечно-сосудистая система: аритмия, транзиторная кардиомиопатия, артериальная гипотензия, инфаркт миокарда. Легкие (редко): кашель, одышка, отек легких, пневмония, остановка дыхания. Эндокринная система: аутоиммунный тиреоидит. Кожа: сыпь различного характера. ЖКТ: потеря аппетита, тошнота, рвота, изменение вкуса, сухость во рту, похудение, диарея, боль в животе. Редко - запор, метеоризм, усиление перистальтики, изжога, обострение язвенной болезни желудка и двенадцатиперстной кишки, кровотечение. Повышение активности аланинаминотрансферазы, щелочной фосфатазы, ЛДГ, гипербилирубемия. Другие побочные эффекты: гиперлипидемия, алопеция.

Противопоказания к применению препаратов ИФН. Абсолютные гиперчувствительность к препаратам ИФН, психоз (на момент лечения или в анамнезе), тяжелая депрессия, нейтропения или тромбоцитопения, декомпенсированные заболевания сердечно-сосудистой системы, декомпенсированный цирроз печени, неконтролируемые судороги, трансплантация органов (кроме печени), беременность, цирроз печени (кроме пегелированного ИФН). Относительные - аутоиммунные заболевания, неконтролируемый диабет.

Препараты ИФН- $\boldsymbol{\beta}$ представлены зарубежными препаратами авонекс, бетаферон, ребиф, инфибета, ронбетал и отечественным препаратом тебериф. Имеется пролонгированная форма ИФН- $\beta$ - плегриди. Все они в настоящее время применяются по одному показанию лечение рассеянного склероза. 
Единственным препаратом ИФН- $\boldsymbol{\gamma}$ в России с 2006 г. является ингарон. Он выпускается в двух лекарственных формах - лиофилизат для приготовления раствора для внутримышечного и подкожного введения флаконы $(100000$ и 500000 $\mathrm{ME)}$ и лиофилизат для приготовления раствора для интраназального введения (100000 ME). Это основной препарат для лечения недостаточности клеточно-эффекторного звена иммунитета.

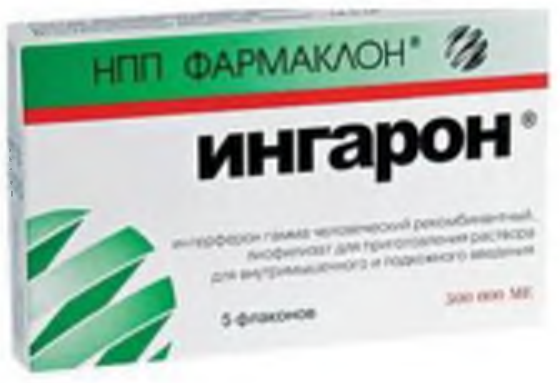

Интраназальная форма применяется для лечения и профилактики вирусных инфекций прежде всего ОРВИ. Ингарон эффективно стимулирует клетки мукозального иммунитета обладает иммуностимулирующим и противовирусным действием. Для лечения респираторных вирусных инфекций в том числе гриппа и COVID-19 по 2-3 капли в каждый носовой ход, 5 раз в день, в течение 5-7 дней. Ингарон можно использовать и для сезонной профилактики ОРВИ. Данная профилактика способна предотвратить все вирусные простудные заболевания в том числе COVID-19.

При недостаточности клеточно-эффекторного звена иммунитета средней и тяжелой степени применяется инъекционная форма ингарона (табл. 107).

Таблица 107.

\section{Рекомендуемые схемы применения ингарона}

\begin{tabular}{|c|c|c|c|}
\hline Нозология & Суточная доза & Кратность введения & Курс терапии \\
\hline $\begin{array}{l}\text { Хронический } \\
\text { вирусный гепатит В, } \\
\text { в/м или п/к }\end{array}$ & $500000 \mathrm{ME}$ & $\begin{array}{l}\text { В комплексной терапии совместно с } \\
\text { интерфероном альфа, монотерапия }\end{array}$ & $\begin{array}{c}6 \text { мес. } \\
\text { курсами 1-3 мес. с } \\
\text { перерывами 1-2 } \\
\text { мес }\end{array}$ \\
\hline $\begin{array}{l}\text { Герпесвирусная } \\
\text { инфекция п/к }\end{array}$ & $500000 \mathrm{ME}$ & Через день & 5 инъекций \\
\hline $\begin{array}{l}\text { Опоясывающий лишай } \\
\text { п/к }\end{array}$ & $500000 \mathrm{ME}$ & Через день & 5 инъекций \\
\hline $\begin{array}{l}\text { Папилломавирусная } \\
\text { инфекция, в т.ч. } \\
\text { аногенитальные } \\
\text { бородавки п/к } \\
\end{array}$ & $100000 \mathrm{ME}$ & После криодеструкции, через день & 5 инъекций \\
\hline $\begin{array}{l}\text { Профилактика } \\
\text { инфекционных } \\
\text { осложнений при } \\
\text { хронической } \\
\text { гранулематозной } \\
\text { болезни в/м или п/к }\end{array}$ & $500000 \mathrm{ME}$ & Ежедневно или через день & $\begin{array}{c}\text { 5-15 инъекций } \\
\text { при необходимости } \\
\text { повторить через } \\
\text { 10-14 дней }\end{array}$ \\
\hline $\begin{array}{l}\text { Туберкулез легких в/м } \\
\text { или п/к }\end{array}$ & $500000 \mathrm{ME}$ & $\begin{array}{l}\text { В комплексной терапии ежедневно или } \\
\text { через день }\end{array}$ & $\begin{array}{c}\text { Устанавливается } \\
\text { индивидуально, - } \\
\text { не более } 3 \text { мес. }\end{array}$ \\
\hline $\begin{array}{l}\text { Урогенитальный } \\
\text { хламидиоз п/к }\end{array}$ & $500000 \mathrm{ME}$ & Через день & 5 инъекций \\
\hline $\begin{array}{l}\text { Хронический } \\
\text { простатит п/к }\end{array}$ & $100000 \mathrm{ME}$ & Через день & 10 инъекций \\
\hline $\begin{array}{l}\text { Онкологические } \\
\text { заболевания в/м или } \\
\text { п/к }\end{array}$ & $500000 \mathrm{ME}$ & $\begin{array}{l}\text { Через день, зависит от режима } \\
\text { химиотерапии }\end{array}$ & $\begin{array}{c}\text { Устанавливается } \\
\text { индивидуально, } \\
\text { Курсами по 5-10 } \\
\text { инъекций (3-6 } \\
\text { курсов) }\end{array}$ \\
\hline
\end{tabular}


Другие цитокины начали массово внедрятся в медицинскую практику с 90-х годов прошлого столетия. Для получения цитокинов использовали методы естественного активирования клеток-продуцентов с последующим фракционированием материала и очистки или метод генной инженерии (рекомбинантные цитокины). В последнее время первый метод производства практически не применяется.

Препараты, приготовленные на основе цитокинов, являются основными препаратами для коррекции иммунных нарушений, развивающихся при инфекционных и онкологических заболеваниях, профилактики осложнений при радио- и химиотерапии онкологических больных (табл. 108).

Таблица 108

\section{Цитокины и их препараты}

\begin{tabular}{|c|c|}
\hline $\begin{array}{l}\text { Препараты (торговые } \\
\text { названия) }\end{array}$ & Фармакологическое действие \\
\hline \multicolumn{2}{|r|}{ Интерлейкин-1 бета } \\
\hline Беталейкин & $\begin{array}{l}\text { Стимулирует лейкопоэз, обусловленной применением цитостатиков или } \\
\text { воздействием ионизирующего излучения. Индуцирует выработку } \\
\text { колониестимулирующих факторов, усиливает пролиферацию и дифференцировку } \\
\text { клеток различных ростков кроветворения. Оказывает также } \\
\text { иммуностимулирующее действие (увеличивает функциональную активность } \\
\text { нейтрофильных гранулоцитов и лимфоцитов) }\end{array}$ \\
\hline \multicolumn{2}{|r|}{ Интерлейкин-2 } \\
\hline $\begin{array}{l}\text { Ронколейкин, } \\
\text { Пролейкин }\end{array}$ & $\begin{array}{l}\text { Активирует Т-лимфоциты и NK-клетки, участвующие в механизмах распознавания и } \\
\text { уничтожения опухолевых клеток. Способствует продукции антител В-клетками, } \\
\text { стимулирует секрецию цитокинов, факторов комплемента, а также запускает } \\
\text { механизмы высвобождения гормонов. }\end{array}$ \\
\hline \multicolumn{2}{|r|}{ Фактор некроза опухоли альфа 1} \\
\hline Рефнот & $\begin{array}{l}\text { Прямое противоопухолевое действие: цитотоксическое или цитостатическое } \\
\text { действие }\end{array}$ \\
\hline \multicolumn{2}{|c|}{ Гранулоцитарно-макрофагальный колониестимулирующий фактор (ГМ-КСФ) } \\
\hline $\begin{array}{l}\text { Лейкомакс } \\
\text { Неостим }\end{array}$ & $\begin{array}{l}\text { Регулирует гемопоэз и активирует созревание (пролиферацию и дифференцировку } \\
\text { клеток-предшественников) миелоидных и лимфоидных клеток (гранулоцитов, } \\
\text { моноцитов/макрофагов, Т-лимфоцитов). }\end{array}$ \\
\hline \multicolumn{2}{|r|}{ Гранулоцитарный колониестимулирующий фактор (Г-КСФ) } \\
\hline $\begin{array}{l}\text { Лейкостим } \\
\text { Граноцит } \\
\text { Лонквекс }\end{array}$ & $\begin{array}{l}\text { Стимулирующим клетки-предшественники нейтрофильного ростка костного мозга, } \\
\text { вызывает заметное увеличение количества нейтрофилов в периферической крови. } \\
\text { Способен стимулировать пролиферацию эндотелиальных клеток человека. }\end{array}$ \\
\hline Неуластим, Экстимия & Пэгелированный гранулоцитарный колониестимулирующий фактор \\
\hline \multicolumn{2}{|r|}{ Эритропоэтины } \\
\hline $\begin{array}{l}\text { Аэприн, } \quad \text { Бинокрит, } \\
\text { Эпокрин, Эпрекс, } \\
\text { Эральфон, Рекормон, } \\
\text { Эпостим, Эритростим, } \\
\text { Эпоратио, Эпомакс }\end{array}$ & $\begin{array}{l}\text { Стимулирует митоз и дифференциацию эритроидных клеток-предшественников. } \\
\text { Увеличивает число эритроцитов, ретикулоцитов, содержание гемоглобина, } \\
\text { улучшает кровоснабжение тканей. }\end{array}$ \\
\hline \multicolumn{2}{|r|}{ Тромбопоэтин } \\
\hline Револейд & $\begin{array}{l}\text { принимает участие в регуляции мегакариопоэза и выработке } \\
\text { тромбоцитов }\end{array}$ \\
\hline
\end{tabular}


Так же в эту группу относятся цитокины тромбопоэза и эритропоэза. Первые активно участвуют в формировании мукозального иммунитета, вторые в предотвращении формирования нарушении функций органов и систем и развитию полиорганной недостаточности.

Беталейкин (ИЛ-1 $\beta) \quad$ - лекарственная форма рекомбинантного ИЛ-1 $\beta$ человека. Препарат стимулирует кроветворение, иммунитет и раннее постлучевое восстановление. Кроме того, препарат ускоряет восстановление стволового потенциала и костномозгового кроветворения, особенно гранулопоэза, после поражающего действия цитостатиков и ионизирующей радиации. Это обусловлено его способностью инициировать вступление СК в митотический цикл и их мобилизацию в кровь, усиливать выработку гемопоэтических ростовых факторов, включать механизмы

мукозального иммунитета. Иммуностимулирующее действие препарата реализуется путем повышения функциональной активности нейтрофильных гранулоцитов, индукции дифференцировки предшественников иммунокомпетентных клеток, усиления пролиферации лимфоцитов, активации продукции цитокинов и увеличения антителообразования. Препарат вводят подкожно или внутривенно капельно. В качестве стимулятора лейкопоэза препарат применяют в дозе 15-20 нг/кг массы тела, для иммуносгимуляции - 5-8 нг/кг. Курс лечения состоит из 5 ежедневных инъекций или внутривенных инфузий. Продолжительность внутривенного введения составляет 120-180 мин. При необходимости проводят повторные курсы с интервалом 2 нед.

У отдельных больных могут наблюдаться озноб, головная боль, повышение температуры тела. Эти реакции продолжаются в течении 2-3 ч и не являются противопоказанием к продолжению курса лечения. При возникновении особо тяжелых побочных явлений их следует купировать введением парацетамола, анальгина, димедрола или их сочетаний. При крайне редко наблюдаемых выраженных общих, в том числе аллергических, реакциях допустимо применение кортикостероидов. Противопоказанием является индивидуальная непереносимость. Препарат не рекомендуется применять у больных в стадии септического шока и при выраженной лихорадке. Выпускается в ампулах по 50, 500 и 1000 нг.

Ронколейкин содержит в качестве активного компонента рекомбинантный интерлейкин-2 человека (rIL-2) - полный структурный и функциональный аналог эндогенного IL-2. Введение препарата компенсирует дефицит эндогенного IL-2 и восстанавливает его синтез собственными лимфоцитами организма. Биологические эффекты препарата опосредуются его связыванием со специфическими рецепторами, представленными на различных клеточных мишенях. Препарат направленно влияет на рост, дифференцировку и активацию Т- и В-лимфоцитов,

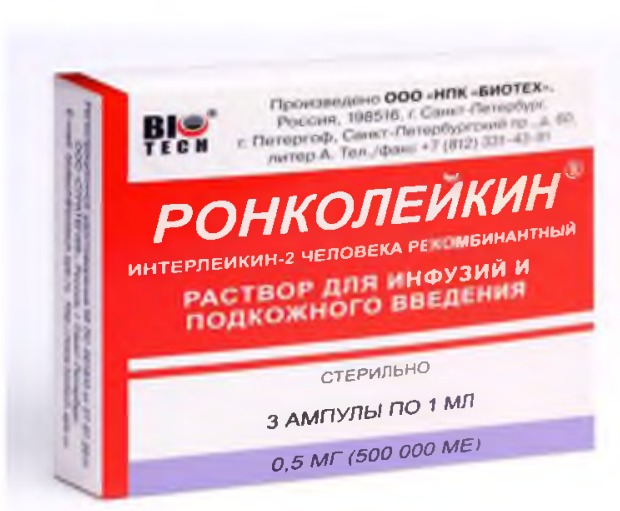
моноцитов, макрофагов, дендритных клеток. От его

присутствия зависит развитие цитолитической активности натуральных киллеров и цитотоксических Т-лимфоцитов. Расширение спектра лизирующего действия эффекторных клеток обусловливает элиминацию разнообразных патогенных микроорганизмов, инфицированных и малигнизированных клеток, что обеспечивает иммунную защиту, направленную против опухолевых клеток, а также возбудителей вирусной, бактериальной и грибковой инфекции.

Ронколейкин применяют в составе комплексной терапии иммунодефицитов, сопровождающего острые и хронические инфекционные процессы, для лечения септических состояний различной этиологии, при острых панкреатитах и перитонитах, эндометрите и 
послеродовом сепсисе, тяжелой пневмонии, других генерализованных и тяжелых локализованных инфекциях, инфицированных термических и химических ожогах; при туберкулёзе легких, а также при диссеминированных и местнораспространенных формах почечноклеточного рака. Лечение препаратом Ронколейкин можно сочетать с лечением всеми другими лекарственными средствами.

Взрослым препарат вводят 1 раз в сутки подкожно или внутривенно капельно по 0,25 1,0 мг с интервалами 1 - 3 дня, на курс - 1-3 введения. Инфузия всего объема раствора осуществляется капельно в течение 4-6 часов. При лечении тяжелого сепсиса проводят от одного до трех курсов Ронколейкина. Курс включает 2 в/в инфузии в дозе 0,5 мг через день. Критерием для назначения второго и третьего курсов Ронколейкина является сохраняющаяся в ходе лечения лимфопения (абсолютная и/или относительная). Курс лечения Ронколейкином диссеминированных и местнораспространенных форм почечноклеточного рака включает: однократное п/к или в/в введение препарата в дозе 0,5 мг за 24 часа до операции; в составе 8недельного курса иммунохимиотерапии по 2,0 мг в/в через день в течение первых четырех недель лечения. Повторные курсы проводят через 1 - 2 мес. У детей Ронколейкин применяют внутривенно капельно в возрастных дозировках..

Во время лечения в отдельных случаях возможны появление кратковременного озноба и повышение температуры тела, которые купируются обычными терапевтическими средствами и не являются противопоказанием к продолжению лечения. При подкожном введении препарата отмечались местные реакции - болезненность, уплотнение, покраснение в месте инъекции. Противопоказаниями являются повышенная чувствительность к ИЛ-2, беременность, аллергия к дрожжам, аутоиммунные и тяжелые сердечно-сосудистые заболевания, беременность.

Рефнот
рекомбенантного фактора некроза опухолейтимозина. По спектру цитотоксического и цитостатического действия на опухолевые клетки препарат соответствует фактору некроза опухоли $\alpha$ (ФНО) человека, однако препарат более чем в 100 раз имеет меньшую общую токсичность. Включает несколько путей уничтожение опухоли:

- непосредственное воздействие фактора некроза опухолей-тимозин альфа-1 (ФНО) на опухолевую клетку-мишень через соответствующие рецепторы на ее поверхности, в результате чего

происходит апоптоз клетки (цитотоксическое действие) или остановка клеточного цикла (цитостатическое действие);

- каскад химических реакций, включающий активацию коагуляционной системы крови и местных воспалительных реакций, обусловленных РЕФНОТ®-активированными клетками эндотелия и лимфоцитами и ведущий к геморрагическому некрозу опухолей

- блокирование ангиогенеза, приводящее к уменьшению прорастания новыми сосудами быстрорастущей опухоли и, как следствие, к снижению кровоснабжения вплоть до некроза центра опухоли;

- воздействие клеток иммунной системы, цитотоксичность которых оказалась тесно связана с наличием молекул ФНО на их поверхности или процесс созревания/активации этих клеток связан с ответом на ФНО.

Комбинации рефнота с $\gamma$-интерфероном обладают синергическим цитотоксическим эффектом. Происходит усиление противирусной активность рекомбинантного интерферона гамма в 100-1000 раз (на примере эксперимента против вируса везикулярного стоматита).

Рефнот увеличивает эффективность химиопрепаратов: актиномицина Д, цитарабина, доксорубицина против опухолевых клеток слабо чувствительных к ним, ликвидируя эту резистентность. Это позволяет рассматривать препарат как модификатор противоопухолевого 
действия химических цитостатиков в случаях множественной лекарственной устойчивости опухолевых клеток.

Рефнот не оказывает цитотоксического действия на нормальные клетки и в высоких концентрациях in vitro стимулирует пролиферацию клеток селезенки и лимфатических узлов. Усиливает продукцию антител на Т-зависимые антигены, оказывает стимулирующее влияние на цитотоксическое действие естественных киллерных клеток по отношению к опухолевым клеткам, оказывает стимулирующее влияние на фагоцитоз, усиливает экспрессию антигенов MHC I класса H-2K, CD-4 и CD-8, являясь фактором дифференцировки Т-хелперов и Ткиллеров

Факторы роста клеток костного мозга. Факторы роста миелоидных клеток костного мозга в организме продуцируются различными типами клеток: фибробластами, эндотелиальными клетками, макрофагами, Т-лимфоцитами. В настоящее время производятся генно-инженерными методами: 1) гранулоцитарный колониестимулирующий фактор (Г-КСФ) - филграстрим и ленограстим; 2) гранулоцитарно-макрофагальный колониестимулирующий фактор (ГМ-КСФ) - молграмостим.

\section{Человеческий}

колониестимулирующий фактор (Г-КСФ) гликопротеин, регулирующий образование функционально активных нейтрофилов и их выход в кровь из костного мозга. Филграстим, содержащий рекомбинантный Г-КСФ, заметно увеличивает число нейтрофилов в периферической крови уже в пределах первых 24 ч после введения, с небольшим увеличением числа моноцитов. У некоторых больных тяжелой хронической нейтропенией он может также вызывать незначительное повышение числа циркулирующих эозинофилов и базофилов по сравнению с исходным уровнем, но у части этих больных эозинофилия и базофилия могут наблюдаться еще до назначения препарата. Рост числа нейтрофилов зависит от дозы препарата. Функция нейтрофилов, образующихся в организме человека при введении филграстима, нормальна или усилена. После окончания лечения число нейтрофилов в периферической крови снижается на $50 \%$ в течение $1-2$ дней и до нормального уровня - в течение $1-7$ дней.

Торговые названия препаратов с действующим веществом филграстим - нейпоген, грастим, граностим, грасальва, лейкостим. Чаще всего в клинической практике применяют нейпоген и лейкостим.

Ленограстим также является генно-инженерным Г-КСФ. По фармакологическому действию мало чем отличается от филграстима, хотя спектр применения первого шире.

Торговые названия препаратов с действующим веществом ленограстим - граноцит.

Гранулоцитарно-макрофагальный колониестимулирующий фактор - рекомбинантный человеческий ГМ-КСФ (молграмостим) стимулирует пролиферацию и дифференцировку предшественников, содержание зрелых клеток в периферической крови, рост гранулоцитов, моноцитов и макрофагов. Повышает функциональную активность зрелых нейтрофилов усиливает фагоцитоз и степень выраженности «респираторного взрыва», повышает цитотоксичность в отношении злокачественных клеток. Обладает иммунотропной активностью, ускоряет созревание Т-лимфоцитов. Способен усиливать экспрессию антигенов II класса HLA на моноцитах и увеличивать продукцию AT. Терапевтический эффект наступает через 2 - 4 дня после введения. При миелодиспластических синдромах эффективно нормализует миелопоэз. Уменьшает время восстановления миелоидного кроветворения после трансплантации костного мозга у пациентов с острой лейкемией, не влияя при этом на общую выживаемость и время до развития рецидива. Устраняет лейкопению после химиотерапии, достоверно понижая частоту глубокой нейтропении и инфекционных осложнений, снижает потребность в антибиотикотерапии и обеспечивает возможность интенсификации химиотерапии. Повышает безрецидивную выживаемость больных с резистентными лимфомами. 
Показания к применению: лейкопения при патологических состояниях, сопровождающихся нарушением миелоидного кроветворения (в том числе при СПИДе и других инфекционных заболеваниях, миелодиспластическом синдроме), или на фоне противоопухолевой химиотерапии; первичная профилактика нейтропении и нейтропенической инфекции при высоком риске ее развития после химиотерапии (например, указания на развитие фебрильной нейтропении при проведении первого курса химиотерапии); для уменьшения миелотоксического действия противовирусных препаратов при лечении ЦМВИ у больных СПИДом, восстановления миелоидного кроветворения при трансплантации костного мозга; стимуляция высвобождения клеток предшественников гемопоэза из костного мозга в периферическую кровь для последующего их выделения методом лейкофереза и трансплантации (подготовка к противоопухолевой химиотерапии сверхвысокими дозами).

Торговое название препарата с действующим веществом молграмостим зарегистрированного в России - лейкомакс.

Как уже и отмечалось выше цитокины тромбопоэза и эритропоэза (табл.108) так же опосредованно оказывают влияние на иммунную систему. 


\section{ИММУНОТЕРАПИЯ}

\section{Глава 22. Иммуностимулирующие препараты}

Актуальность проблемы восстановления иммунологических нарушений с помощью препаратов не подвергается сомнению. В настоящее время фармацевтический рынок предлагает огромное количество препаратов, относящихся к иммуномодуляторам лекарственным препаратам, которые в терапевтических дозах восстанавливают нарушенные функции иммунной системы. В клинической практике достаточно сложно с этим разобраться. Существует большое количество классификаций иммуноактивных препаратов. Их подразделяют на подгруппы по происхождению, способам получения, химической структуре, влиянию на звенья иммунной системы и т.д. Чаще всего выделяют биологические препараты (микробного, вирусного, грибкового, растительного, животного происхождения, клетки культуры тканей) и химические вещества природного происхождения или химически синтезированные. По происхождению иммунотропные лекарственные средства можно разделить на три группы: полимерные, экзогенные и эндогенные. В некоторых классификациях используется патогенетический подход, предусматривающий действие различных иммуностимуляторов на основные звенья иммунной системы. Необходимость такой классификации диктуется практикой, поскольку клинико-иммунологическая разнородность иммунопатологических состояний определяет дифференцированный подход к терапии. Однако попытка разделения иммуностимуляторов по избирательности действия осложняется отсутствием селективности у большинства пререпаратов. Многие средства, отнесенные к иммуноактивным, воздействуют не только на иммунокомпетентные клетки но, прежде всего - на внутриклеточный метаболизм клеток, о чем мы уже писали (см.главу 19) Поэтому с позиций воздействия на различные звенья иммунной системы целесообразно классифицировать иммуностимулирующие препараты согласно групп представленных в таблице (рис.125).

\section{Иммуностимулирующая терапия}

\begin{tabular}{|c|c|}
\hline$\checkmark$ & $\nabla$ \\
\hline $\begin{array}{c}\text { С воздействием на адаптивный } \\
\text { иммунитет }\end{array}$ & $\begin{array}{c}\text { С воздействием на врожденный } \\
\text { иммунитет }\end{array}$ \\
\hline 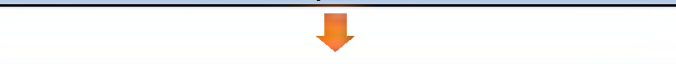 & 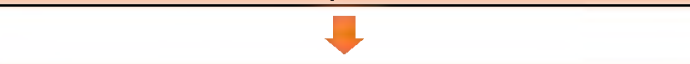 \\
\hline Вакцины & $\begin{array}{c}\text { Препараты бактериального } \\
\text { происхождения }\end{array}$ \\
\hline \multirow{2}{*}{$\begin{array}{c}\text { Аллергенспецифическая } \\
\text { иммунотерапия }\end{array}$} & Иммунорегуляторные пептиды \\
\hline & Индукторы интерферона \\
\hline \multicolumn{2}{|c|}{ Иммунометаболические препараты } \\
\hline
\end{tabular}

Рис.125. Классификация иммуностимулирующих препаратов. 
Вакцинация - это самое эффективное и экономически выгодное средство защиты против инфекционных болезней, известное современной медицине со времен Э.Дженнера. При вакцинации в организм человека вводится ослабленный или убитый болезнетворный агент (или искусственно синтезированный белок, который идентичен белку агента) для того, чтобы стимулировать иммунитет в борьбе с возбудителем заболевания

В настоящее время успешно борются при помощи прививок против вируснылх (оспа, корь, краснуха, паротит, полиомиелит, гепатит А и т.д.) и бактериальных (туберкулез, дифтерия, коклюш, столбняк, клещевой энцефалит и т.д.) инфекций. Чем больше людей имеют иммунитет к той или иной болезни, тем меньше вероятность у остальных (неиммунизированных) заболеть. Это может привести к возникновению эпидемии.

Выработка специфического иммунитета до протективного (защитного) уровня может быть достигнута при однократной вакцинации (корь, паротит, туберкулез) или при многократной (полиомиелит, АКДС). Ревакцинация (повторное введение вакцины) направлена на поддержание иммунитета, выработанного предыдущими вакцинациями.

Необходимо иметь в виду, что вакцинация не всегда бывает эффективной. На развитие поствакцинального иммунитета влияют факторы, связанные с:

a) самой вакциной (частота препарата, время жизни АГ, доза, наличие протективных $\mathrm{AГ}$, кратность введения, правильное хранение);

б) состоянием организма, прививаемого в целом (иммунная реактивность, возраст, наличие иммунных нарушений, наследственность);

в) факторами внешней среды (качество питания, условия труда и быта, климат, физикохимические факторы). Нами, было показано, что специфические АТ после введения живой паротитной вакцины практически не вырабатываются у детей, у которых накануне вакцинации определялись клинические признаки иммунных нарушений и/или происходили события, связанные с «воздействием» на иммунную систему (перенесли ОРВИ, переехали из другой климатической зоны и т.д.). Поэтому очевиден индивидуальный подход для каждого случая вакцинации, для конкретного коллектива, для конкретного региона нашей страны и мира в целом при максимальном охвате вакцинацией.

Различают следующие виды вакцин.

1. Живые вакиины, содержащие ослабленный живой микроорганизм. Примером могут служить вакцины против полиомиелита, кори, свинки, краснухи или туберкулеза. Они способны размножаться в организме и вызывать выработку защитных факторов, которые обеспечивают невосприимчивость человека к патогену. Утрата вирулентности у таких штаммов закреплена генетически, однако у лиц с иммунодефицитами могут возникнуть серьезные проблемы.

2. Инактивированиые (убитье) вакиины (например, цельноклеточная вакцина против коклюша, инактивированная вакцина против бешенства), представляющие собой патогенные микроорганизмы, инактивированные высокой температурой, радиацией, ультрафиолетовым излучением, спиртом, формальдегидом и т.д. Такие вакцины реактогенны и в настоящее время применяются редко (коклюшная, против гепатита $A$ ).

3. Анатоксины - это вакцины, состоящие из инактивированного токсина, продуцируемого бактериями. В результате специальной обработки токсические свойства его утрачиваются, но остаются иммуногенные. Примером анатоксинов могут служить вакцины против дифтерии и столбняка.

4. Рекомбинантные вакцины, получающие методами генной инженерии, примером могут служить рекомбинантная вакцина против вирусного гепатита $B$, вакцина против ротавирусной иифекиии.

5. Синтетические вакиины, представляющие собой искусственно созданные антигенные детерминанты (белки) микроорганизмов.

6. Aссоииированиые вакцины - вакцины различных типов, содержащие несколько компонентов (например, $A К Д С$ ). 
Помимо создания путем вакцинации в организме здорового человека определенного иммунитета с целью защиты (профилактическая вакиинация) от возможного заболевания существует еще и специфическая активная иммунотерапия (вакцинотератия), применяемая для лечения вялотекущих, хронических инфекций.

Вакцинация необходима, но перед этим обязательно следует пройти достаточно полное обследование и правильно оценить состояние прививаемого (с учетом выводов грамотного специалиста, основанных на результатах объективных исследований). Общеизвестно: любая вакцина - чужеродный белок, а потому «неизбежно небезопасна», поэтому при вакцинации следует провести максимально возможную иммунодиагностику, чтобы предотвратить осложнения не только ранние, но и поздние.

В России рекомендованы следующие виды вакцинации (табл.109).

Таблица 109.

\section{Национальный календарь профилактических прививок}

\begin{tabular}{|c|c|c|c|c|c|c|c|c|c|c|c|c|c|c|c|c|c|}
\hline $\begin{array}{l}5 \\
\frac{5}{0} \\
\frac{0}{0} \\
0 \\
0\end{array}$ & 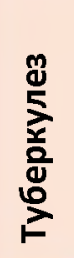 & 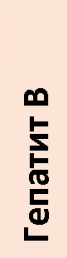 & $\begin{array}{l}\exists \\
\text { 호 } \\
5 \\
\text { 옹 } \\
\text { ㅈ }\end{array}$ & 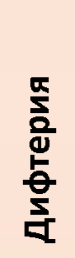 & 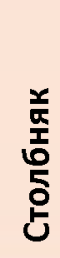 & 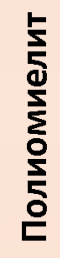 & 웅 & 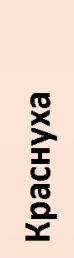 & $\begin{array}{l}\text { 롱 } \\
\text { 总 } \\
\text { 읃 }\end{array}$ & 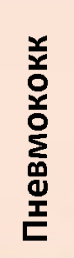 & 는 & 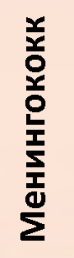 & 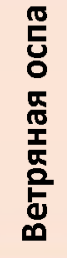 & 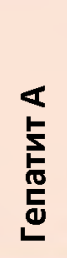 & 畐 & $\begin{array}{l}\text { 듣 } \\
\text { 른 }\end{array}$ & $\begin{array}{l}\stackrel{\text { ㄱ }}{\text { मे }} \\
\text { 응 }\end{array}$ \\
\hline Рождение & & B1 & & & & & & & & & & & & & & & \\
\hline 3-7 день & B1 & & & & & & & & & & & & & & & & \\
\hline 1 месяц & & B2 & & & & & & & & & & & & & & & \\
\hline 2 месяц & & B3 & & & & & & & & B1 & & & & & & & \\
\hline 3 месяц & & & B1 & B1 & B1 & B1 & & & & & B1 & & & & & & \\
\hline 4-5 месяц & & & B2 & B2 & B2 & B2 & & & & & B2 & & & & & & \\
\hline 6 месяц & & B3 & B3 & B3 & B3 & B3 & & & & & B3 & & & & & \multirow{16}{*}{$\begin{array}{l}\text { 오 } \\
\text { 돔 } \\
\text { ㅇ⿺ㄴ } \\
\text { 정 }\end{array}$} & \\
\hline 9 месяц & & & & & & & & & & & & B1 & & & & & \\
\hline 12 месяц & & B4 & & & & & B1 & B1 & B1 & & & B2 & \multirow{2}{*}{ B1 } & & & & \\
\hline 15 месяц & & & & & & & & & & P1 & & \multirow{13}{*}{ 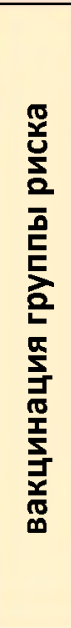 } & & & & & \\
\hline 18 месяц & & & P1 & P1 & P1 & P1 & & & & & P1 & & & & & & \\
\hline 20 месяц & & & & & & P2 & & & & & & & & B1 & & & \\
\hline 23 месяц & & & & & & & & & & & & & & & & & \\
\hline 2-3 года & & & & & & & & & & & & & & B2 & & & \\
\hline 4-5 лет & & & & & & & & & & & & & & & & & \\
\hline 6 лет & \multirow[t]{2}{*}{ P1 } & & \multirow[t]{2}{*}{ P2 } & \multirow[t]{2}{*}{ P2 } & \multirow[t]{2}{*}{$\mathbf{P 2}$} & & & & & & & & & & & & \\
\hline 7 лет & & & & & & & & & & & & & & & & & \\
\hline 9-11 лет & & & & & & & & & & & & & & & & & \\
\hline 12-13 лет & & & & & & & & & & & & & & & B & & \\
\hline 14 лет & & & P3 & P3 & P3 & P3 & B2 & B2 & B2 & & & & B2 & & & & \\
\hline 15-17 лет & & & & & & & & & & & & & & & & & \\
\hline старше 18 & & B1 & & & & & & & & & & & & & & & B1 \\
\hline
\end{tabular}

ГИ - Гемофильная инфекция

ВПЧ - Вирус папилломы человека инфекция

В1 В2 В3 В4 - вакцинация 1234

P1 P2 P3 - ревакцинация 123

\section{І. Плановые профилактические прививки.}

1. Вакцинация против дифтерии, столбняка и коклюша. Вакцинация (или основной

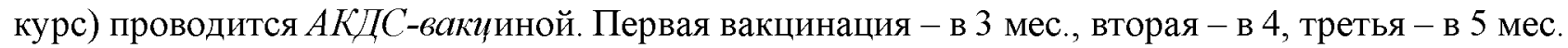

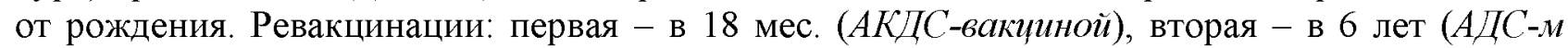
анатоксином), третья - в 11 лет (АД-м анатоксином), четвертая - в $16-17$ лет (АДС-м 
анатоксином), далее взрослым - однократно, через каждые 10 лет (АДС-м или АД-м анатоксином).

2. Вакцинация против полиомиелита. Курс вакцинации происходит в возрасте 3,4 и 5 мес от рождения. Ревакцинации: в $18 \mathrm{мес,} \mathrm{в} 2$ года и в 6 лет. Существует два типа полиовакцин: инактивированная $(И П В)$ - содержит убитые вирусы полиомиелита и вводится инъекцией, известна как вакцина Солка; живая полиовакцина (ЖПВ) или вакцина Сэбина. содержит безопасные ослабленные живые полиовирусы трех типов, которые вводятся через рот. Это наиболее часто используемая вакцина против полиомиелита.

3. Вакцинация против туберкулеза. Вакцинация на 4-7-й день жизни (как правило, в родильном доме). Ревакцинации: первая - в 7 лет, вторая - в 14 лет (проводится детям, не инфицированным туберкулезом и не получившим прививку в 7 лет). Для профилактики туберкулеза применяют БЦЖ вакцину (BCG - Bacillus Calmette Guerin vaccine). Она представляет собой живые, ослабленные микобактерии туберкулеза (тип bovis). Вакцинацию проводят обычно в родильном доме.

4. Вакцинация против кори, паротита (свинки) и краснухи трехвалентной вакциной или моновалентны.ми вакцинами. Вакцинацию проводят в 1 год, ревакцинацию в 6 лет. Вакцина против кори готовится из ее живых ослабленных вирусов. Во многих странах применяют тривакцины, содержащие помимо коревого - краснушный и паротитный компоненты.

5. Вакцинация против вирусного zепатита В. Вакцинация детей проводится по одной из двух схем. Первая схема рекомендуется в том случае, если мать новорожденного является носительницей HBsAg. У таких детей повышен риск заражения гепатитом, поэтому вакцинация должна начаться в 1-е сут после рождения перед прививкой против туберкулеза вакциной БЦЖ.

Вакцина против гепатита В может вводиться одновременно с любыми другими детскими вакцинами, поэтому для детей, не входящих в группу риска, более удобна вторая схема вакцинации, при которой вакцину вводят вместе с АКДС. Первая доза - на 4-5 мес жизни, вторая - через месяц (5-6 мес жизни). Ревакцинация проводится через 6 мес. (на 12-13 мес жизни).

Вакцина против гепатита $B$ готовится генно-инженерными методами. Все они содержат рекомбинантный поверхностный АГ вируса гепатита В - HBsAg. Применяют следующие вакцины: энджерикс $B$ (GlaxoSmithKline) - первая в мире рекомбинантная вакцина, производство которой было освоено в 1987 г., эувакс (Aventis Paster), HB Вакс II (Merck Sharp \& Dohme), биовак-B, Wokhard Ltd, (Индия), Шанвак, Shanta, (Индия), Рекомбинантная дрожжевая вакиина против гепатита $B$ (НПК «Комбиотех», Россия), вакцина против zеnатита $B$ ДНК-рекомбинантная (ФГУП НПО «Микроген», филиал «Вирион» г. Томск), регевак B (Медико-технологический холдинг МТХ, Россия).

\section{II. Профилактические прививки по эпидемическим показаниям.}

По эпидемическим показаниям прививается население, проживающее на энзоотичных территориях, а также прибывшие на эти территории лица и/или лица, подверженные риску заражения при работе над заготовками, хранением, обработкой сырья и продуктов животноводства. Лица, работающие с живыми культурами возбудителя, прививаются против муляремии, чумы бручеллеза, сибирской язвы, бешенства, лептостироза, клещевого энцефалита. По экстренным показаниям в очаге инфекции всем здоровым, ранее не привитым, рекомендуется вакцинация против брюшного тифа, менингококковой инфекции, вирусного гепатита $A$ и $B$, кори, паротита, дифтерии. По эпидемическим показаниям проводятся и прививки против лихорадки Ky, желтой лихорадки, холеры. Все эти виды иммунопрофилактики регламентированы законами РФ.

III. Специфическая активная иммунотерапия основана на применении препаратов из АГ возбудителей заболевания (вакцин). В острый период инфекционного заболевания противопоказана, так как она способна увеличить иммунодепрессивный эффект, обусловленный инфекционным процессом, и способствовать неблагоприятному его течению. 
Вакцины, как правило, следует назначать в период ремиссии болезней с целью обеспечить формирование полноценного иммунитета, способного предупредить развитие их рецидивов, или при затяжном и хроническом течении с незначительно выраженными клиническими проявлениями инфекционного процесса. Лечебные вакцины применяют внутривенно, внутримышечно, подкожно и внутрикожно. Наиболее эффективен внутрикожный способ.

Весьма важным требованием специфической активной иммунотерапии является правильный выбор рабочей дозы вакцины для каждого больного. Большие дозы препарата могут оказать иммунодепрессивное действие и вызвать рецидив заболевания, а малые вообще не дадут необходимого эффекта.

В период применения вакцин с лечебной целью противопоказано использование глюкокортикоидов, антибиотиков, цитостатиков и других веществ, угнетающих формирование иммунитета.

Важным условием эффективности специфической активной иммунотерапии считается использование в этот период препаратов, обеспечивающих активность метаболических процессов иммунокомпетентных клеток (метилурацил, нуклеинат натрия, пентоксил, витамины).

Бруцеллез. Многообразие клинических форм заболевания и механизмов поражения макроорганизма определяют разные подходы к методам специфической активной иммунотерапии больных. При остросептическом бруцеллезе она противопоказана в остром периоде заболевания и осушествляется только во время ремиссии с целью формирования иммунитета, способного предупредить развитие рецидива. В этих случаях в основном используют внутрикожный способ введения бруцеллезной вакцины.

Tуляремия. Для лечения больных с затяжным течением этого заболевания применяется туляремийная вакцина.

Токсоплазмоз. Одним из важнейших лечебных мероприятий при хроническом токсоплазмозе является вакцинотерапия токсоплазмином. Ее осуществляют внутрикожно по общепринятой методике.

Бактериальные инфекции и трихомониаз. Новый иммунологический метод лечения неспецифических бактериальных вагинозов, цистита, уретрита, пиелонефрита, простатита и др. (особенно при хроническом рецидивирующем течении). Вакцинация солкоТриховаком или солкоУроваком приводит к образованию неспецифических секреторных АТ, принадлежащих классу IgA, которые способствуют элиминации атипичных форм лактобацилл, трихомонад и других патогенных возбудителей. В результате этого восстанавливается нормальная микрофлора влагалища. Вакцинация обеспечивает длительную защиту от реинфекции.

Гонококковая инфекция. Гонококковая инактивированная жидкая вакцина (гоновакцина) позволяет проводить диагностику (установление излеченности гонореи), служит вспомогательным методом лечения гонорейной инфекции с 3-летнего возраста. Применяется после безуспешной антибиотикотерапии при вяло протекающих рецидивах, при свежих торпидных и хронических формах заболевания, для мужчин с осложненной и женщин с восходящей гонореей (после стихания острых воспалительных явлений), в гинекологической практике при лечении воспалительных процессов.

Гepnec. Для профилактики рецидивов герпетической инфекции применяется вакиина герпетическая, культуральная, инактивированная, сухая, которая представляет собой инактивированный ВПГ I и II антигенных типов, полученный путем репродукции в культуре клеток (витагерпавак) или на культуре клеток ткани фибробластов куриных эмбрионов (герповакс). Вакцина стимулирует клеточные механизмы резистентности организма человека к ВПГ І и II типов. Вакцинацию проводят в лечебных учреждениях под контролем врача и применяют в стадии ремиссии не ранее, чем через 5 дней после полного исчезновения клинических проявлений герпетической инфекции.

Как способ активного воздействия на иммунную систему, особенно при хронических инфекциях, следует рассматривать и производства аутовакцин. 
Реакции и осложнения после прививок. Различают обцие и местные послепрививочные реакции. Общие реакции проявляются умеренным повышением температуры тела, легким недомоганием. При введении вакцины подкожно появляется болезненность, реже припухлость в месте инъекции (местная реакция). После введения БЦЖвакцины могут быть подкожные «холодные» абсцессы (гнойники), воспаление местных лимфатических узлов. Как общая, так и местная реакции после прививок переносятся легко и продолжаются не более 3 дней.

Тяжелая общая интоксикация, припухлость, нагноение в месте введения вакцины расцениваются как поствакцинальное осложнение. Необходимо учитывать сроки и характер возможных осложнений после прививок:

1) общие тяжелые реакции с повышением температуры, иногда судорожные подергивания мышц, возникаюшие не позже 48 ч после прививок АКДС, АДС и АДС-м и не раньше 4-5 дней на вакцины против кори и эпидемического паротита (свинки);

2) появление признаков менингита возможно на 3 - 4-й неделе после введения вакцины против эпидемического паротита;

3) возникновение аллергических реакций на коже не позже 24 ч после введения любой вакцины;

4) катар дыхательных путей после введения вакцины против кори на 2-й неделе после прививки.

Медицинские отводы от прививок. В последнее время перечень заболеваний, считавшихся противопоказаниями для вакцинации, существенно сужен (табл. 110).

Таблица 110

\section{Перечень медицинских противопоказаний к проведению профилактических прививок}

\begin{tabular}{|l|l|}
\hline \multicolumn{1}{|c|}{ Вакцина } & \multicolumn{1}{|c|}{ Противопоказания } \\
\hline Все вакцины & Сильная реакция или осложнение на предыдущуюдозу \\
\hline Все живые вакцины & $\begin{array}{l}\text { Иммунодефицитное состояние (первичное), иммуносупрессия, } \\
\text { злокачественные новообразования, беременность }\end{array}$ \\
\hline БЦЖ вакцина & $\begin{array}{l}\text { Вес ребенка менее 2000 г, коллоидный рубец после предудущей } \\
\text { дозы }\end{array}$ \\
\hline $\begin{array}{l}\text { ОПВ (оральная полиомиелитная } \\
\text { вакцина) }\end{array}$ & Абсолютных противопоказаний нет \\
\hline АКДС & $\begin{array}{l}\text { Прогрессирующие заболевания нервной системы, афебрильные } \\
\text { судороги в анамнезе (вместо АКДСвводят АДС) }\end{array}$ \\
\hline АДС, АДСМ & Абсолютных противопоказаний нет \\
\hline ЖКВ (живая коревая вакцина), & Тяжелые реакции на аминогликозиды \\
\hline ЖПВ (живая паротитная вакцина) & Анафилактические реакции на яичный белок \\
\hline
\end{tabular}

Примечания: Плановая вакцинация откладывается до окончания острых проявлений заболевания и обострения хронических заболеваний. При нетяжелых ОРЗ, острых кишечных заболеваниях и др. прививки проводятся сразу же после нормализации температуры тела.

\section{Аллерген- специфическая иммунотерапия (АСИТ)}

Метод лечения аллергических заболеваний, который используется при невозможности полного прекращения контакта больного с причинно-значимым аллергеном. АСИТ можно рассматривать как иммуностимулирующую терапию в результате которой формируется толерантность к определённому АГ (аллергену).

Методика проведения АСИТ состоит во введении пациенту причиннозначимого аллергена, начиная с подпороговых доз, постепенно повышая его концентрацию. Лечение проводится в период ремиссии заболевания. После проведения 3-4 курсов специфической иммунотерапии обычно наступает стойкая клиническая ремиссия аллергического заболевания. 
Механизм терапевтического действия АСИТ до конца не изучен, однако в настоящее время установлено, что в результате СИТ происходит:

- переключение иммунного ответа с Th-2-зависимого типа на Th-1-зависимый тип, различающихся набором секретируемых лимфокинов (Тh-2 секретирует ИЛ-4, ИЛ-5, ИЛ-10, ИЛ-3, ИЛ-6; Th-1 - IL-2, ИФН- $\gamma$, ГМ-КСФ) и в результате не развиваются патохимическая и патофизиологическая стадии аллергической реакции;

- переключение изотипического спектра формирующихся AT c IgE на IgG-класс, лишенных способности сенсибилизировать ткани, но обладающих аллергенсвязывающей активностью, играющих роль блокирующих АТ;

- торможение синтеза специфических IgE;

- образование антиизотипических AT (анти-IgE) и блокада $\operatorname{IgE}$ на туч-ных клетках, базофилах и других клетках фиксаторах АТ;

- активируется супрессорная активность Т-лимфоцитов.

АСИТ назначают больным с аллергическим ринитом/конъюнктивитом, бронхиальной атопической астмой и аллергическими реакциями от ужалений насекомых. АСИТ целесообразна у больных, у которых доказано наличие специфических $\operatorname{IgE}$ к клинически значимым АГ. Она показана в тех случаях, когда, с одной стороны, элиминация причинного АГ невозможна, а с другой - если введение аллергена может положительно влиять на инволюцию клинических признаков заболевания. Еще одно важное условие для АСИТ наличие нужного стандартизованного аллергена. АСИТ используют в комбинации со всеми другими методами лечения с целью исчезновения симптоматики аллергии у больного.

Были определены очевидные преимущества АСИТ перед другими методами лечения. К таким преимуществам относятся:

- сохранение длительной ремиссии после завершения успешных курсов АСИТ;

- предупреждение расширения спектра аллергенов, к которым формируется повышенная чувствительность;

- предупреждение утяжеления течения заболевания;

- уменьшение потребности в противоаллергических лекарствен-ных препаратах.

Существуют различные варианты АСИТ:

- в зависимости от вида стандартизованных аллергенов (водно-солевые, глицериновые, модифицированные аллергены, аллергоиды и т.д.),

- способов их введения (подкожный, энтеральный, интраназальный и т.д.),

- времени и длительности курса лечения (предсезонный, круглогодичный и внутрисезонный),

- скорости проведения АСИТ (классический, ускоренный и др.).

Наиболее часто применяется предсезонный метод АСИТ, который проводится до сезона цветения растений. В отличие от этого метода круглогодичный не прерывается перед сезоном цветения. При этом способе после достижения максимальной дозы аллергена ее вводят $1-2$ раза в месяц.

Внутрисезонный метод проводят в случае позднего обращения больных, т.е. в период появления симптоматики заболевания, а отсутствие побочных реакций позволяет применять его у больных с высокой степенью чувствительности. Классический метод лечения поллиноза используют в амбулаторных условиях. Лечение начинают в ноябре-декабре, проводят 2 раза в неделю и заканчивают за 7 дней до цветения. Длительность лечения $4-5$ мес., повторный курс можно проводить через 6 мес.

Ускоренный метод - заключается в существенном сокращении сроков лечения до 3 - 4 недель. Только в стационаре аллергологического профиля, возможно, проводить ускоренный метод АСИТ.

Перед началом курса АСИТ проводится специфическое аллергологическое обследование (аллергологический анамнез, кожное тестирование, элиминационные и провокационные тесты) с целью выявления аллергенов, к которым имеется сенсибилизация. 
При проведениии АСИТ имеется определенный риск нежелательных побочных эффектов. Наиболее опасным осложнением является развитие анафилактических реакций. В этой связи очень важным является проведение четкой грани между безопасными местными реакциями и реакциями шоковых органов, не угрожающими жизни больных, хорошо отвечающих на лечение, и угрожающими жизни состояниями в виде анафилактического шока и ангиоотека жизненно важных органов.

Необходимо помнить, что АСИТ может проводиться только аллергологом, имеющим опыт проведения данного вида лечения. Так, в нашей стране проведением АСИТ занимаются только врачи аллергологи, что позволило отечественной аллергологии избежать печального опыта стран, в которых к выполнению АСИТ допускаются врачи других специальностей. Например, в Великобритании с 1957 по 1986 гг. зарегистрировано 26 смертельных случаев на фоне проведения АСИТ, где использовались нестандартизованные аллергены, отмечалось несоответствие выбранных начальных доз аллергена степени повышенной чувствительности пациента, неоправданное превышение доз вводимого аллергена, несвоевременное начало противоанафилактических мероприятий из-за отсутствия необходимых средств под рукой.

Угрожающим признаком развития немедленной системной реакции, позволяющим своевременно предупредить нежелательные побочные эффекты АСИТ является - появление в течение 30 минут после лечебной инъекции аллергена местной реакции, превышающей в размере 5-10 мм. С учетом этого врач меняет схему АСИТ, либо уменьшая дозу аллергена, либо сохраняя ее прежней, исключая очередную инъекцию в случае: предвестников начала аллергической симптоматики, возникновении инфекций, предшествовавшей интенсивной экспозиии аллергена, системных реакциях на предыдущие инъекции и т.д.

Чтобы избежать общих реакций, надо строго подходить к подбору больных для лечения и адекватно оценивать проявления местных реакций. Кроме того, рекомендуется регулярно контролировать содержание эозинофилов в периферической крови (не реже 1 раза в 10 дней). В том случае, когда отмечается нарастание количества эозинофилов (относительного и абсолютного), лечение прерывают и назначают курс антигистаминных препаратов на $5-7$ дней.

Необходимо помнить, что на фоне специфической иммунотерапии возможны обострения хронических очагов инфекций и заболеваний, ранее протекавших в латентной форме. Поэтому наряду с периодической оценкой развернутого анализа крови следует оценивать анализ мочи, биохимические показатели и т.д.

Назначение АСИТ осуществляется с учетом:

1) наличия доказательств связи клинических проявлений аллергии с IgEопосредованным механизмом, при котором АСИТ высокоэффективна;

2) надежный лечебный эффект достигается при длительном, по крайней мере 3-летнем лечении;

3) дети и молодые люди лучше поддаются этому виду лечения;

4) правила - при более тяжелой форме заболевания эффективность АСИТ будет ниже;

5) оптимальной схемы введения аллергена - степень риска системных реакций выше в период нарастания лечебных доз аллергена и сводится до минимума в период введения поддерживающих доз.

Противопоказаниями к проведению АСИТ являются:

1) обострение основного заболевания;

2) присоединение инфекционного процесса;

3) выраженные органические изменения (в легких при бронхиальной астме);

4) стероидозависимость (относительное противопоказание);

5) недостаточность кровообращения II и III стадии;

6) ревматизм и туберкулез в активной фазе;

7) онкологические заболевания;

8) язвенная болезнь;

9) беременность. 
Для повышения эффективности АСИТ и уменьшения риска нежелательных побочных эффектов современные исследования направлены на повышение качества аллергенов повышение иммуногенности и снижение аллергенности за счет химической и физической модификации аллергенов, что достигается полимеризацией (обработка формальдегидом, глутаровым альдегидом и др.) и получением сорбированных форм (на L-тирозине, на гидроокиси алюминия). Препараты таких аллергенов получили название аллергоидов. Их можно вводить в больших дозах, чем обычные экстракты, так как сорбирование увеличивает длительность всасывания введенного подкожно препарата. Одним из перспективных методов специфической иммунотерапии является метод с использованием депонированных аллергенов. С этой целью пыльцевые водно-солевые аллергены обрабатываются гелем гидроокиси алюминия, что обеспечивает медленное их поступление. Применение таких аллергенов позволяет значительно сократить число инъекций.

\section{Иммуностимуляторы бактериального происхождения и их синтетические аналоги.}

Это разновидность бактериальных вакцин, обладающих неспецифическим действием в основном на врожденный иммунитет и гуморальное звено адаптивного иммунитета. По способу получения различают следующие группы препаратов:

Лизаты и антигенные экстракты бактерий. Бактериальные иммуномодуляторы создавались как низкоиммуногенные «вакцины» с целью выработки временного стойкого иммунитета против бактерий. Большое значение в этой связи имеет система местного иммунитета слизистых, особенно синтеза секреторного иммуноглобулина A (sIgA) против компонентов лизата. Антиген-стимулированные клетки с поверхностным IgA попадают с циркулирующей кровью в лимфоидные органы, например Пейеровы бляшки. Развитие специфического иммунного ответа происходит при кооперации Т- и В-лимфоцитов, макрофагов или ДК. В дальнейшем специфический $\operatorname{sgA}$ вновь транспортируется на поверхность слизистых, препятствуя инвазии инфекционных агентов, их адсорбции, фагоцитозу и формированию ИК. Кроме того, активация цитотоксических Т-лимфоцитов приводит к уничтожению инфицированных клеток.

Препараты, содержащие лизаты бактерий, способствуют профилактике инфекций носоглотки и респираторного тракта, не вызывают формирования длительного иммунитета, поэтому правильнее называть их бактериальными иммуномодуляторами, которые можно разделить на две группы.

1. Иммуномодуляторы бактериального происхождения системного действия.

Бронхо-Ваксом и отечественный аналог Бронхомунал содержит лиофилизированные экстракты восьми возбудителей: Haemophilus influenzae, Diplococcus pneumonia, Streptococcus viridans, Streptococcus pyogens, Klebsiella pneumoniae, Klebsiella ozenae, Staphylococcus aureus, Neisseria (Branhamella) catarrhalis. Он стимулирует В-клетки, повышает уровень $\operatorname{sig} \mathrm{A}$, на слизистых и в слюне, бронхоальвеолярнй лаважной жидкости, функциональную и метаболическую активность макрофагов (в том числе альвеолярных).

Бронхомунал активизирует деятельность секреции простагландина E2 и $\mathrm{IL}-1$ альвеолярными макрофагами, усиливает активность макрофагов против инфекционных агентов и клеток опухоли, секрецию IL-2, IL-8, TNF- $\alpha$, нейтрофил-активирующего фактора, повышает реактивность естественных киллеров.. 
При назначении бронхомунала у больных с заболеваниями респираторного тракта и носоглотки повышается уровень сывороточных $\operatorname{IgM}, \mathrm{G}$, А и сохраняется до 100 - 150 дней, увеличивается иммунорегуляторный индекс $\left(\mathrm{CD}^{+} / \mathrm{CD}^{+}\right)$, функциональная активность $\mathrm{T}$ клеток.

Уро-Ваксом. Активный компонент: лиофилизированный бактериальный лизат 18 штаммов Escherichia coli. Капсула Уро-ваксома содержит 6 мг этого активного вещества. При приеме внутрь бронхо-ваксом стимулирует иммунную защиту организма и увеличивает сопротивляемость к инфекциям дыхательной системы. Иммунофармакологические исследования показали, что бронхо-ваксом увеличивает образование $\mathrm{IgA}$, секретируемого слизистой дыхательных путей и слюной, количество циркулирующих Т-лимфоцитов, индуцирует образование эндогенного ИФН. Клинически понижает частоту острых инфекций мочевого тракта, в особенности циститов, сокращает продолжительность их течения, уменьшает тяжесть симптомов, и вероятность обострений хронических заболеваний. При этом меньше потребность применения других лекарственных препаратов, в особенности антибиотиков.

Исмиген. Лизаты бактерий Staphylococcus aureus, Streptococcus pyogenes, Streptococcus viridans, Streptococcus pneumoniae, Klebsiella pneumoniae, Klebsiella ozaenae, Haemophilus influenzae b, Neisseria catarrhalis. Комбинированный иммуностимулирующий препарат бактериального происхождения для сублингвального применения. Представляет собой

поливалентный антигенный комплекс, включающий лизаты бактерий - наиболее часто встречающихся возбудителей респираторных инфекций. Лизаты, входящие в состав препарата, получены путем механического разрушения бактериальных клеток. Применяется при острых и рецидивирующие инфекции верхних и нижних дыхательных путей. По 1 табл./сут, в течение 10 дней. Профилактический курс включает 3 цикла по 10 дней с 20-дневными интервалами между ними.

2. Иммуномодуляторы бактериального роисхождения топического действия. ИРС-19 ыпускается в виде спрея для интраназального рименения и содержит лизаты 19 наиболее часто стречающихся возбудителей заболеваний верхних ыхательных путей: Streptococcus, Staphylococcus aureus, rafkya tetragena, Neisseria, Klebsiella pneuminiae, toraxella, Haemophilus influenzae и др.. Препарат овышает содержание лизоцима, стимулирует агоцитоз. Его специфическое действие связывают с величением синтеза секреторного IgA. Он действует реимущественно на систему местного иммунитета ерхних отделов респираторного тракта и носоглотки.

Назначение препарата не приводит к усилению синтеза IgE. По нашим данным, его воздействия не наблюдаются на показатели системного иммунитета, отмечается повышение IgA в слюне. ИРС-19 применяется с профилактической целью и в остром периоде заболеваний носоглотки и верхних отделов респираторного тракта на фоне базисной терапии, сокращая сроки заболевания и потребонсть в других вмешательствах.

Имудон. В состав препарата входят лизаты: Lactobacillus acidophylus, L.fermentum, L.helveticus, L.lactis, Strept. pyogenes, Enterococcus faecalis, Streptococcus sanglus, Staph.aureus, Klebsiella pneumoniae, Corynebacterium pseudodiphtheriae, Fusiformis fustformis, Candida albicans.

Препарат представляет собой поливалентный антигенный комплекс, включающий наиболее распространенных возбудителей рецидивирующих инфекций носоглотки. Имудон активирует фагоцитоз, повышает уровень лизоцима и $\operatorname{IgA~в~слюне.~}$ 
Липополисахариды бактерий. Препараты, выделенные липополисахаридами, образуются в процессе жизнедеятельности микроорганизмов.

Пирогенал. Препарат, который давно вошел в арсенал средств неспецифической иммуностимулирующей терапии. Он вызывает кратковременную (несколько часов) лейкопению, сменяющуюся лейкоцитозом, и повышает фагоцитарную функцию лейкоцитов. В организации неспецифической защиты против инфекции основное значение пирогенала связано с активацией фагоцитоза.

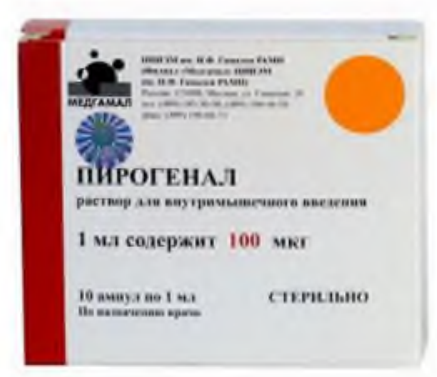

Как и другие ЛПС, пирогенал проявляет адъювантные свойства, повышая иммунный ответ к различным АГ. Мобилизация фагоцитарных механизмов, стимуляция образования АТ, гуморальных неспецифических факторов защиты могут быть причиной повышения антиинфекционной резистентности под влиянием данного препарата. Но это зависит от времени воздействия пирогенала по отношению к моменту заражения, дозы, частоты введения. Его способность стимулировать антибиотикотерапию, по-видимому, связана с противовоспалительным, фибринолитическим эффектами, с усилением регенеративных процессов в тканях.

Основная клиническая область использования пирогенала как средства неспецифической иммуностимулирующей терапии - хронические инфекционновоспалительные заболевания. Препарат оказывает пирогенное действие. Маленьким детям и лицам старше 60 лет его необходимо вводить с осторожностью, начиная с уменьшенных доз и постепенно повышая их только в случае хорошей переносимости препарата больными.

Применяется в/м, 1 раз в сутки. Инъекции производят через день. При необходимости разводят 0,9\% раствором натрия хлорида для инъекций. Препарат во вскрытой ампуле хранению не подлежит. Начальная разовая доза - 2,5 мкг. В последующие дни дозу постепенно увеличивают на 2,5-5 мкг. Максимальная разовая доза - 100 мкг. Полный курс — от 10 до 30 инъекций. В случае необходимости курсы инъекций повторяют не менее чем через 2-3 мес.

Продигиозан. Высокополимерный липополисахаридный комплекс, выделенный из микроорганизма $B$. prodigiosum. Относится к группе бактериальных полисахаридов, является средством, стимулирующим факторы неспецифической и специфической резистентности организма. Активирует Т-систему иммунитета. Влияние продигиозана в значительной степени связано со стимуляцией эндогенных иммунных систем организма, активацией образования ИФН, т.е. с интерфероногенной активностью. Кроме высокой эффективности при генерализованных инфекциях комплекс показан и при локальных гнойно-воспалительных процессах, ускоряет ликвидацию инфекции, продуктов некротического распада, рассасывание воспалительного экссудата, заживление поврежденных тканей, способствует восстановлению функций органов.

Весьма важно то, что продигиозан усиливает эффект антибиотиков при использовании их в субэффективных дозах и при инфекциях, вызванных антибиотикоустойчивыми штаммами.

Как и другие ЛПС продигиозан, не оказывает прямого воздействия на микроорганизмы. Повышение устойчивости к инфекциям целиком обусловлено антиинфекционными механизмами макроорганизма. Эффект продигиозана основан на энергичной мобилизации фагоцитарной активности макрофагов и лейкоцитов и увеличении их числа, на усилении поглотительной и переваривающей функций за счет повышения активности лизосомальных ферментов, опсонизирующего действия сыворотки крови.

Путь данного комплекса: стимуляция макрофагов продигиозаном - монокины лимфоциты - лимфокины - активация макрофагов. 


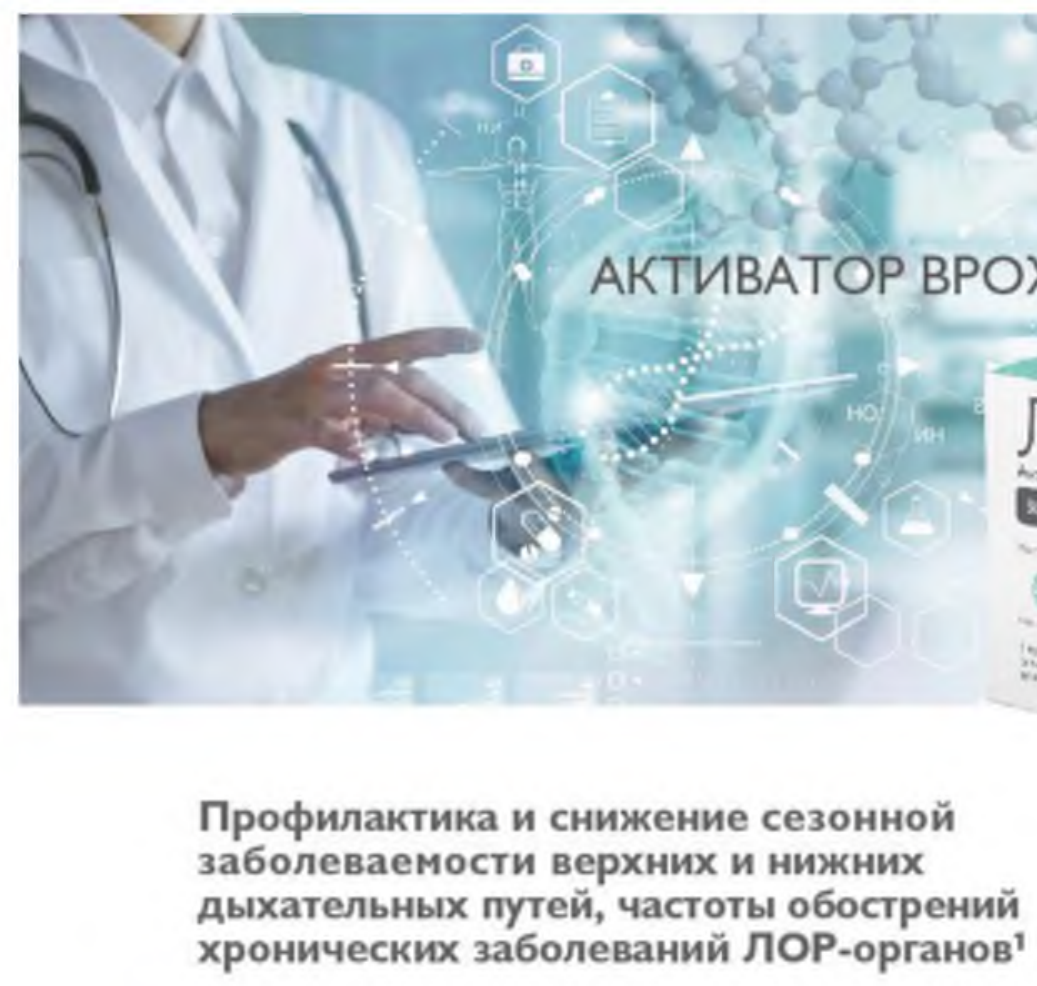

активатор врожденного и приобретенного иммунитета ${ }^{1}$

усиливает защиту организма от вирусных, бактериальных и грибковых инфекций ${ }^{1}$

영 повышает эффективность противобактериальных препаратов, отмечается синергизм в отношении противовирусных и противогрибковых препаратов

20. доказанный механизм действия (Институт биоорганической химии РАН, Institut Pasteur, Paris) $)^{2}$

형 по результатам доклинических исследований не оказывает канцерогенного 6 , эмбриотоксического и тератогенного действия, не вызывает хромосомных, генных мутаций'

[20) оказывает адъювантный эффект в развитии иммунологических реакций

\section{Ликопид}
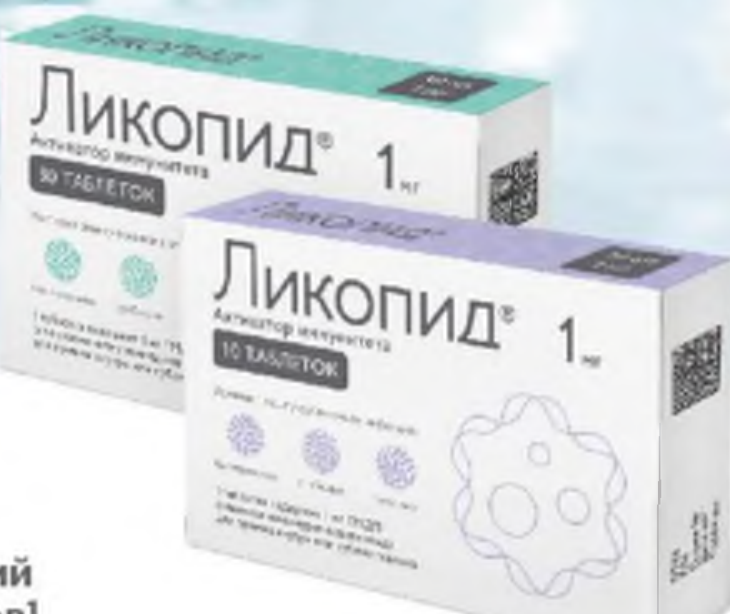

ГМДП является синтетическим воспроизведением универсального фрагмента клеточной стенки бактерий, отвечающего за иммуномодулирующий ответ. Действие препарата Ликопид" максимально приближено к процессу естественной иммуномодуляции, реализуемой в организме под действием бактерий. ${ }^{5}$

\section{Ликопид (ГМДП) относится к последнему поколению иммуномодуляторов микробного происхождения - минимальные биологически активные фрагменты (III поколение). ${ }^{3}$}

Клиничесие исследования препарата Ликопид" проводили в соответствии смеждународными стандартами GСP (по протоколу двойного слепого рандомизированного плацебо-контролируемого исследования) в ведущих исследовательских учреждениях мира, таких как Чартерхауское общество клинических исследований Королевского масонского госпиталя (Charterhouse Clinical Research Unit Limited, The Royal Masonic Hospital, London, UK), кафедра хирургии и кафедра онкологии Центра лечения рака госпиталя св. Георгия (UNSW Department of Surgery and Department of Oncology, Cancer Care Centre, The St. George Hospital, Australia). В России препарат исследовали в Институте иммунологии ФМБА России, Научном центре дерматовенерологии и косметологии, МНИИ глазных болезней им. Гельмгольца, РНИМУ им. Н.И. Пирогова, Первом МГМУ им. И.М. Сеченова, МГМСУ им. А.И. Евдокимова. ${ }^{4}$

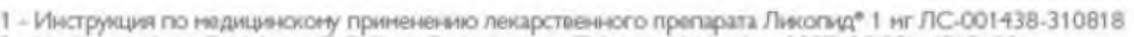

2- Meshcheryakova E, Makarov E, Philpott D, Andronova T, Nanov V. Vaccine. 2007; 25(23): 4515-20

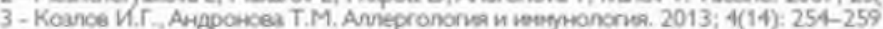

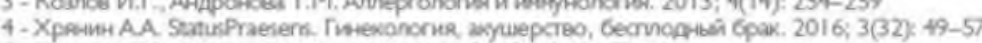

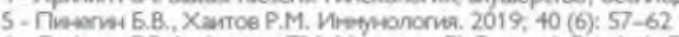

6- Gudyrev OS, Andronova TM. Nesterova EI. Research Reuits in Phamacology. $2018 ; 4(4), 97-106$

\section{АO $«$ Пептек}

117997, Москва, ул. Миклухо-Маклая, 16/10

Тел.: + 7495 1222530, +74951222503, e-mail: peptek@peptek.ru

www.licopid.ru www.peptek.ru 
Фрагменты пептидогликана клеточной стенки и РНК. Действующее начало этих препаратов - фрагменты клеточной стенки бактерий.
Ликопид
-действующее
вещество-

глюкозаминилмурамилдипептид (ГМДП) синтетический аналог структурного фрагмента оболочки (пептидогликана) бактериальных клеток. ГМДП является активатором врожденного и приобретенного иммунитета, усиливает защиту организма от вирусных, бактериальных и грибковых инфекций; оказывает адъювантный эффект в развитии иммунологических реакций.

Биологическая активность препарата реализуется посредством связывания ГМДП с внутриклеточным рецепторным белком

NOD2, локализованным в цитоплазме фагоцитов (нейтрофилы, макрофаги, дендритные клетки). Препарат стимулирует функциональную (бактерицидную, цитотоксическую) активность фагоцитов, усиливает презентацию ими антигенов, пролиферацию Т-и Влимфоцитов, повышает синтез специфических антител, способствует нормализации баланса Thl/Th2-лимфоцитов в сторону преобладания Thl. Фармакологическое действие осуществляется посредством усиления выработки ключевых ИЛ (IL-1, IL-6, IL-12), ФНО- $\alpha, \gamma$ интерферона, колониестимулирующих факторов. Препарат повышает активность естественных киллерных клеток. Его применение в комплексной терапии позволяет значительно повысить эффективность антибактериальной, противогрибковой и противовирусной терапии, сократить продолжительность лечения и существенно снизить дозу химиотерапевтических средств.

Провоспалительные цитокины, чей синтез повышает Ликопид, являются необходимыми медиаторами эффекторного противовоспалительного ответа. Между провоспалительными и противоспалительными медиаторами воспаления существует прямая корреляционная зависимость. Таким образом, Ликопид, запуская быструю инициацию воспалительного процесса, активирует естественные механизмы реализации иммунитета. Эти особенности Ликопида позволяют эффективно применять его при различных патологиях. Препарат не оказывает токсического действия на центральную нервную и сердечнососудистую системы, не вызывает патологических изменений со стороны внутренних органов.

\section{Иммунорегуляторные пептиды}

\section{Тимические иммунорегуляторные пептиды}

(тактивин, тималин, вилозен) - препараты, представляющий собой комплекс полипептидных фракций, выделенных из вилочковой железы (тимуса) крупного рогатого скота.

Обладают

способностью

стимулировать

иммунологическую реактивность организма: регулируют количество Т- и В-лимфоцитов, активируют деятельность реакции клеточного иммунитета и процессов регенерации и кроветворения в случаях их угнетения, усиливает

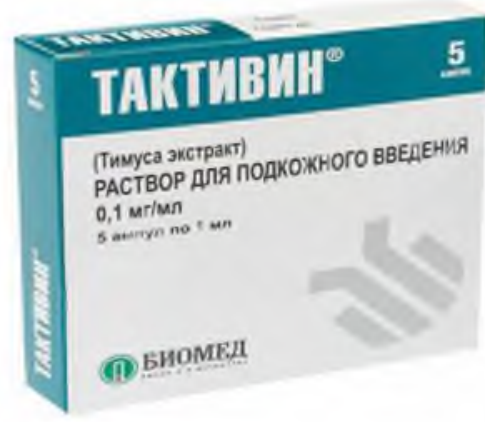
фагоцитоз. За счет основного эффекта происходит

индукция созревания, ускорение пролиферации и дифференцировки пре-Т-лимфоцитов, активация фагоцитоза. При иммунодефицитных состояниях нормализует количественные и функциональные показатели Т-системы и ИФН, другие показатели клеточного иммунитета, активирует деятельность продукции лимфокинов, в том числе. Обладая иммуномодулирующей активностью, стимулирует пролиферацию и дифференциацию Тлимфоцитов, подавляет развитие гиперчувствительности немедленного типа. Данные о 
влиянии на гуморальный иммунитет противоречивы. Существует мнение, что, усиливая проявление иммунных реакций, тимические пептиды снижают образование аутоантител.

Желательно перед назначением препаратов провести подготовку с целью повышения выброса из костного мозга предшедственников Т-клеток. Для этого можно рекомендовать стимуляторы лейкопоэза: метилурацил, изопринозин, натрия нуклеинат в течение 10 - 14 дней.

Аналоги гормонов тимуса. Тимоген - синтетически полученный дипептид, состоящий из остатков аминокислот - глутамина и триптофана. Механизм действия: иммуномодулятор, нормализует содержание Т-хелперов, индуцирует дифференцировку Тлимфоцитов, увеличивает концентрацию цАМФ в предшедственниках Т-лимфоцитов, модулирует показатели Т- и В-лимфоцитов, усиливает неспецифическую резистентность. По показаниям к применению он в основном сходен с другими иммуностимуляторами и используется в комплексной терапии взрослых и детей при острых и хронических инфекционных заболеваниях, сопровождающихся снижением показателей клеточного иммунитета, при угнетении репаративных процессов после тяжелых травм (переломы костей), некротических процессов, а также при других состояниях иммунодефицита. С профилактической целью используется для предупреждения осложнений при инфекционных заболеваниях, оперативных вмешательствах, лучевой терапии и химиотерапии опухолей и т.п.

Имунофан - препарат, обладающий иммунорегулирующим, детоксикационным, гепатопротективным действием и вызывает инактивацию свободнорадикальных и перекисных соединений. Фармакологические свойства пептидного иммуноксидредуктанта основаны на достижении коррекции иммунной и окислительно-антиокислительной систем организма. Действие препарата развивается в течение $2-3$ ч (быстрая фаза) и продолжается до 4 мес. (средняя и медленная фазы). В течение быстрой фазы (продолжительность до 2 - 3 сут) проявляется прежде всего, детоксикационный эффект - усиливается антиоксидантная защита организма путем стимуляции продукции церулоплазмина, лактоферрина, активности каталазы; препарат нормализует перекисное окисление липидов, ингибирует распад фосфолипидов клеточной мембраны и синтез арахидоновой кислоты с последующим снижением уровня холестерина крови и продукции медиаторов воспаления.

В течение средней фазы (начинается через 2 - 3 сут, продолжительность до $7-10$ ) происходят усиление реакций фагоцитоза и гибели внутриклеточных бактерий и вирусов. В результате активации фагоцитоза возможно незначительное обострение очагов хронического воспаления, поддерживаемых за счет персистенции вирусных или бактериальных АГ.

В течение медленной фазы (развивается на 7-10-е сутки, длится до 4 мес) проявляется иммунорегуляторное действие препарата - восстановление нарушенных показателей клеточного и гуморального иммунитета. В этот период наблюдается увеличение продукции специфических АТ. Влияние препарата на продукцию специфических противовирусных и антибактериальных АТ эквивалентно действию некоторых лечебных вакцин. В отличие от последних препарат не оказывает существенного воздействия на продукцию реагиновых АТ класса IgE и не усиливает реакцию гиперчувствительности немедленного типа. Он стимулирует образование IgA при его врожденной недостаточности. Действие имунофана не зависит от продукции ПГЕ2 и его назначение возможно в комбинации с противовоспалительными препаратами стероидного и нестероидного ряда.

Геnон, иммунофармакологические и противовирусные механизмы действия препарата, заключащиеся в стимуляции продукции ИФН- $\alpha$ и - $\beta$. Он мобилизирует и активирует макрофаги, ограничивает выработку цитокинов воспаления (ИЛ-1, $-6,-8$ и TNF), стимулирует продукцию АТ к различным АГ инфекционной природы, подавляет репликацию вирусов, повышает резистентность организма в отношении инфекций, вызванных вирусами, бактериями или грибами.

Клинический эффект курса лечения гепоном состоит в предупреждении рецидивов оппортунистических инфекций в течение $3-6$ мес. Короткий курс местного применения препарата позволяет лечить рецидивирующие инфекции слизистых и кожи, вызванные грибами Candida. Его применение оказывает противовоспалительное действие. 
Бестим Гамма-D-глутамил-триптофан натрия дипептид, обладающий иммуностимулирующим действием. Стимулирует клеточный и гуморальный иммунитет. Повышает антибактериальную и противовирусную резистентность. Фармакологическое действие определяется усилением дифференцировки и пролиферации предшественников Т-лимфоцитов, стимуляцией продукции ИЛ-2, увеличением экспрессии рецепторов ИЛ-2 и маркеров дифференцировки Т-клеток, восстановлением иммунорегуляторного индекса. Применение препарата в комплексной терапии заболеваний, сопровождающихся вторичными иммунодефицитами, значительно повышает ее эффективность. Препарат эффективен при включении в комплексную терапию вирусных заболеваний, сопровождающихся недостаточностью клеточного звена иммунитета.

Производные имидазола. Левамизол - препарат, являющийся эффективным противоглистным средством. Его влияние на иммунологические процессы обнаружено позднее. Левамизол стимулирует в основном клеточный иммунитет. Это первый препарат, имитирующий гормональную регуляцию иммунной системы, т.е. модулирование регуляторных Т-клеток. Способность левамизола имитировать тимусный гормон обеспечивается его имидозолоподобным воздействием на уровень циклических нуклеотидов в лимфоцитах. Возможно, что препарат стимулирует тимопоэтинрецепторы, благоприятно влияет на иммунологический статус путем восстановления эффекторных функций периферических Т-лимфоцитов и фагоцитов, стимуляции созревания предшественников Тлимфоцитов аналогично действию тимусных гормонов.

Левамизол представляет собой мощный индуктор дифференцировки, который вызывает быстрый эффект (через 2 ч при пероральном приеме). Повышение активности макрофагов с помощью левамизола играет большую роль в способности препарата усиливать иммунологические свойства организма.

Имиквимод (алдара, кераворт, вартоцид и пр.) в виде крема показан для местного лечения: наружных генитальных и перианальных бородавок, небольших поверхностные базальноклеточные карциномы, клинически типичных негиперкератотических, негипертрофических актинических кератозах на лице или волосистой части головы когда другие варианты местного лечения противопоказаны или менее целесообразны.

Имиквимод проявляет свое действие за счет увеличения уровня рецептора опиоидного фактора роста (OGFr) и стимуляции врожденную иммунную систему, через Толл-подобные рецепторы 7 (TLR7), за счет чего, секретируются IFN- $\alpha$, IL-6 и TNF- $\alpha$. Активируются клетки Лангерганса, клетки-киллеры (NK- и ЦТЛ), макрофаги и В-лимфоциты.

Препарат применяют наружно, предпочтительно на ночь перед сном и оставляют на коже в течение 6-10 ч. Крем наносят только на пораженные предварительно очищенные участки кожи тонким слоем и аккуратно втирают до полного впитывания. Обработанный участок кожи не следует закрывать повязками. Не допускается использование избыточного количества крема. По истечении указанного времени крем должен быть смыт теплой водой с применением мыла с нейтральным значением рН. Разовая (суточная) доза препарата - 10 мг крема на 1 см2 (полоса крема диаметром 2 мм и длиной 0,5 см). Максимальная площадь нанесения - 25 см2, что соответствует максимальной дозе препарата - 250 мг. Препарат применяют 1 раз в сутки, 3 раза в неделю (например, понедельник, среда, пятница или вторник, четверг, суббота), до полного исчезновения генитальных или перианальных остроконечных кондилом, но не более 16 нед. 


\section{Индукторы синтеза интерферонов.}

Среди иммуномодуляторов особое место занимают индукторы выработки эндогенного ИФН, группа которых разнородна по составу. Выделяют синтетические препараты (амиксин, циклоферон, полудан, неовир, амплиген) и природные соединения (кагоцел, панавир, рогасин, саврац). Клинические испытания показали широкий диапазон их иммуномодулирующей и противовирусной активности. Многие авторы эти препараты рассматривают как противовирусные средства. Индукторы ИФН являются препаратами с комбинированным эффектом: этиотропным, направленным непосредственно на вирус, и иммуномодулирующим, т.е. корригирующим нарушения системы иммунитета. Эти индукторы индуцируют синтез всех иммунологических классов ИФН: $\alpha, \beta$ и $\square$ в разных пропорциях. Все они хорошо сочетаются друг с другом - рекомбинантными ИФН, иммуномодуляторами и химиотерапевтическими средствами. Комбинированное применение с другими препаратами часто приводит к потенцированию эффектов индукторов ИФН.

Индукторы ИФН имеют ряд преимуществ перед рекомбинантными ИФН.

- Индукторы ИФН не обладают антигенностью.

- $\quad$ Естественный, но стимулированный синтез эндогенного ИФН не вызывает гиперинтерферонэмии, которая нередко возникает при использовании рекомбинантных ИФН, что в свою очередь приводит к побочным эффектам, т.е. отсутствуют симптомы передозировки.

- Однократное введение индукторов ИФН обеспечивает их длительную циркуляцию на терапевтическом уровне. Для достижения такого уровня экзогенных ИФН требуется многократное введение высоких доз рекомбинантных ИФН.

- Рекомбинантные ИФН, принимая участие в иммунных реакциях организма, стимулируют неспецифическую цитотоксичность иммуноцитов и вызывают экспрессию молекул HLA в тех популяциях клеток, которые обычно не экспрессируют эти АГ. Это может быть причиной усугубления аутоиммунного ответа организма человека.

- Некоторые индукторы ИФН (амиксин) обладают уникальной способностью запускать синтез ИФН в определенных популяциях клеток, что предпочтительнее, чем поликлональная стимуляция иммуноцитов рекомбинантными ИФН.

- Широко применяемые рекомбинантные ИФН являются препаратами ИФН- $\alpha$, что существенно ограничивает их противовирусные свойства, так как для эффективной противовирусной защиты необходимо наличие всех трех классов ИФН, синтез которых вызывается индукторами интерфероногенеза.

- $\quad$ И ч

Эффективность индукторов выработки ИФН показана при ряде вирусных заболеваний: амиксин - при герпетической инфекции, гриппе, ОРВИ, гепатитах, энцефалите; кагоцел - при гриппе, ОРВИ, герпесе; неовир - при герпетической инфекции, ОРВИ; полудан - при герпетической инфекции; ридостин - при гриппе, ОРВИ, бешенстве; рогасин - при гепатите А, В; соврац - при ОРВИ, гепатите А, энтеровирусных инфекциях.

Амиксин (лавомакс, тилорон) - известный отечественный препарат, является первым пероральным индуктором эндогенных ИФН- $\alpha, \beta, \gamma$. Он наиболее полно сочетает в себе все преимущества индукторов ИФН. Представляя собой поликлональный стимулятор, амиксин вызывает синтез ИФН в Т-лимфоцитах, энтероцитах кишечника, гепатоцитах, проникает через гематоэнцефалический барьер и индуцирует ИФН в клетках мозга. Стимулирует СК костного мозга, в зависимости от дозы усиливает антителообразование, уменьшает степень иммунодепрессии, восстанавливает соотношение $\mathrm{CD} 4+/ \mathrm{CD} 8+$. Эффективен против различных вирусных инфекций, в том числе против вирусов гриппа, других острых респираторных вирусных инфекций, вирусов гепатита и герпеса. У него отсутствуют мутагенный, тератогенный, эмбриотоксический, канцерогенный и другие токсические эффекты. Препарат не обладает антигенностью. Важная особенность амиксина - вызываемая им длительная 
циркуляция в организме терапевтической концентрации ИФН (50 - 100 ЕД/мл в сыворотке крови).

Неовир - низкомолекулярный синтетический супериндуктор ИФН. Представляет собой производное карбоксиметилакридона с молекулярной массой менее 300 . Повышает способность клеток-интерферонопродуцентов вырабатывать ИФН при индукции патологическим агентом (свойство сохраняется длительное время после отмены препарата) и создает в организме высокие титры эндогенных ИФН, идентифицированных как ранний ИФН$\alpha$ и $\gamma$. Активирует СК костного мозга, устраняет дисбаланс в субпопуляциях Т-лимфоцитов с активацией эффекторных звеньев Т-клеточного иммунитета и макрофагов. На фоне опухолевых заболеваний усиливает активность естественных киллерных клеток (обусловлена продукцией $\mathrm{LL}-2$ ) и нормализует синтез TNF. Стимулирует активность полиморфноядерных лейкоцитов (миграция, цитотоксичность, фагоцитоз). Оказывает противовирусное (в отношении РНК- и ДНК-геномных вирусов) и антихламидийное действие.

Циклоферон - метилглюкаминовая соль карбоксиметилакридона, представляющая собой синтетический аналог природного алкалоида Citrus Grandis, обладает пролонгированным противовирусным, противовоспалительным и иммуномодулирующим действием. Циклоферон стимулирует продукцию IFN- $\alpha, \beta, \gamma$ (до $60-80$ ЕД/мл и выше) лейкоцитами, макрофагами, Т- и В-лимфоцитами, эпителиальными клетками, а также тканями селезенки, печени, легких, мозга. Проникает в цитоплазму и ядерные структуры, индуцирует синтез «ранних» ИФН. Активирует Т-лимфоциты и естественные киллерные клетки. Способствует коррекции иммунного статуса при иммунодефицитных состояниях различного генеза, в том числе ВИЧ. Активен в отношении вирусов клещевого энцефалита, гриппа, гепатита, герпеса, ЦМВ, ВИЧ, различных энтеровирусов, хламидий. Проявляет высокую эффективность при ревматических и других системных заболеваниях соединительной ткани, подавляя аутоиммунные реакции и оказывая противовоспалительное и обезболивающее действие. Отличается низкой токсичностью и отсутствием мутагенных, тератогенных, эмбриотоксических и канцерогенных эффектов, обладает пролонгированным иммуномодулирующим действием. Препарат хорошо сочетается с традиционными средствами терапии.

Арбидол - активное вещество, которое оказывает противовирусное и иммуномодулирующее действие. Специфически угнетает вирусы гриппа А и В, тяжелого острого респираторного синдрома. Препятствует контакту и проникновению вирусов в клетку, подавляя слияние липидной оболочки вируса с клеточными мембранами. Обладает интерферониндуцирующим действием, стимулирует гуморальные и клеточные реакции иммунитета, фагоцитарную функцию макрофагов, повышает устойчивость организма к вирусным инфекциям. Уменьшает частоту развития осложнений, связанных с вирусной инфекцией, а также обострений хронических бактериальных заболеваний. Терапевтическая эффективность при вирусных инфекциях проявляется в снижении выраженности общей интоксикации и клинических явлений, сокращении продолжительности болезни. Относится к малотоксичным препаратам, не оказывает какого-либо отрицательного воздействия на организм человека при пероральном применении в рекомендуемых дозах

Полудан (полиаденур) - синтетический индуктор ИФН, состоящий из двухнитевого комплекса полиадениловой и полиуридиновой кислот. Он обладает иммуномодулирующим действием, индуцируя образование эндогенного ИФН- $\square$ и - $\square$. Показано применение полудана при гепатите В, герпетических кератитах и кератоконъюнктивитах.

\section{Иммунометаболические препараты}

Препараты дезоксирибонуклеиновой кислоты.

Различают препараты нуклеиновых кислот животного (деринат, ферровир и пр.) и грибкового происхождения (нуклеинат натрия). К этой же группе следует отнести производные пиримидина и пурина. 
Одним из старейших иммуноактивных препаратов, проверенных временем, является натрия нуклеинат, обладающий широким спектром биологической активности. Он способствует ускорению процессов регенерации, активизирует деятельность костного мозга и лейкопоэз, вызывает лейкоцитарную реакцию, увеличивает количество Т-лимфоцитов. Стимулирует миграцию и кооперацию Т- и В-лимфоцитов, фагоцитарную активность макрофагов и факторов неспецифической резистентности, процессы клеточного деления и дифференцировки. Усиливает синтез нуклеиновых кислот в лимфоцитах, повышает накопление цАМФ в лимфоцитах и функциональную активность неспецифических факторов защиты. Нуклеинат натрия увеличивает содержание РНК и белка в макрофагах в 1,5 раза и гликогена в 1,6 раза активность лизосомальных ферментов, следовательно, завершает фагоцитоз макрофагами. Препарат повышает содержание у человека лизоцима и нормальных АТ, если их уровень был снижен.

Деринат - препарат, в качестве биологически активного вещества которого выступает дезоксирибонуклеат натрия, полученный из вытяжки молок осетровых рыб. Активирует процессы клеточного и гуморального иммунитета, оптимизирует воспалительную реакцию и специфический иммунный ответ на бактериальные, грибковые, вирусные АГ, активизирует В-лимфоциты, T-хелперы, повышает фагоцитоз. Снижает чувствительность клеток к повреждению химиотерапевтическими препаратами и

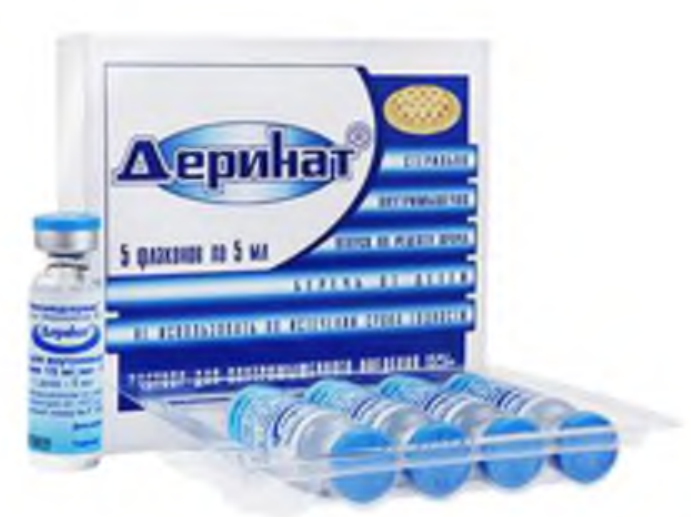
радиотерапией, что сопровождается понижением

кардио- и миелотоксического действия у онкологических больных и приводит к повышению стабильности и результативности терапевтического эффекта повторных курсов лечения. Деринат обладает высокими репаративными и регенеративными свойствами, стимулирует дренажно-детоксикационную функцию лимфатической системы в первую очередь в очаге воспалительной реакции, нормализует состояние органов и тканей при дистрофиях сосудистого происхождения. Увеличивает толерантность к физической нагрузке, снимает боль в икроножных мышцах, способствует заживлению различного типа гангренозных трофических инфицированных ран и глубоких ожогов и эрадикации Helicobacter pylori при язвенной болезни двенадцатиперстной кишки, улучшает сократимость миокарда, микроциркуляцию в сердечной мышце, восстанавливает функцию миоцитов, стимулирует заживление язв ЖКТ.

Ферровир - комплекс дезоксирибуноклеат натрия с железом. Представляет собой биологически активное вещество из вытяжки молок осетровых рыб (очищенная и стандартизованная комплексная соль дезоксирибуноклеат натрия с железом). Препарат оказывает иммуномодулирующее и противовирусное действие, активизирует противовирусный, противогрибковый и противомикробный иммунитет, проявляет противовирусное действие и к РНК-, и к ДНК-содержащим вирусам. Курсовое применение Ферровира при комплексной терапии ВИЧ-инфекции повышает уровень CD4+-лимфоцитов в крови на $1-1,5$ мес. При рецидивирующей герпетической инфекции сокращается продолжительность рецидифва и наступает длительная ремиссия. Применение этого препарата больными хроническим гепатитом С способствует снижению репликативной активности HCV и переводит процесс в латентную фазу.

\section{Производные пиримидина и пурина.}

В качестве средств, повышающих резистентность организма к инфекциям, с каждым годом все шире применяются производные пиримидина и пурина. Производные пиримидина интересны тем, что они обладают низкой токсичностью, активизируют деятельность белкового и нуклеинового обмена, ускоряют клеточный рост и размножение, вызывают противоспалительные действия. Наибольшее распространение в качестве стимулятора антиинфекционной резистентности получил метилурацил, который стимулирует лейкопоэз, 
эритропоэз. Производные пиримидина способны предупреждать снижение фагоцитарной активности лейкоцитов, которое наступает под влиянием антибиотиков, вызывать индукцию синтеза ИФН, увеличивать уровень иммунизации и уровень нормальных АТ. Механизм действия как стимуляторов иммуногенеза, по-видимому, связан с включением их в белковый и нуклеиновый обмен, вызывающий поливалентное влияние на иммуногенез и процессы регенерации.

Иммуностимуляторами также являются производные пурина: мерадин, 7-изопринозин, 9-метиладенин. Изопринозин - один из новых иммуностимулятров, который относится к иммуномодуляторам. Этот препарат обладает большой широтой терапевтического действия. Он изменяет иммунологическую реакцию на разных стадиях: стимулирует активность макрофагов, усиливает пролиферацию, цитотоксическую активность лимфоцитов, число и активность фагоцитоза. Известно, что изоприназин не оказывает влияние на функции нормальных полиморфноядерных лейкоцитов.

Метилурацил. Как стимулятор лейкопоэза метилурацил назначают при агранулоцитарной ангине, алиментарно-токсической алейкии, хроническом бензольном отравлении, лейкопении в результате химиотерапии злокачественных новообразований, при рентгено- и радиотерапии и других состояниях, сопровождающихся лейкопенией. Необходимо учитывать, что метилурацил, как и другие стимуляторы лейкопоэза, целесообразно назначать при легких формах лейкопении. При поражениях средней тяжести применение стимуляторов кроветворения показано лишь в случае возобновлений нарушенной регенерации кровяных клеток. При тяжелых поражениях кроветворной системы метилурацил запрещен.

Изопринозин. Активное вещество инозин пранобекса увеличивает суммарное число Т-лимфоцитов и выработку ими ИЛ-

2, активирует функцию NK-клеток и Т-хелперов, стимулирует хемотаксическую и фагоцитарную активность моноцитов, макрофагов (повышает в них синтез ИЛ-1) и полиморфноядерных клеток. Усиливает синтез РНК и рибосомального белка, одновременно препятствуя использованию рибосомальной РНК для размножения вируса.

Активными пластическими препаратами и, как следствие, стимуляторами пролиферации клеток являются стимуляторы регенерации и репарации. В соответствии с локализацией действия (и задачами фармакотерапии) стимуляторы регенерации и репарации условно подразделяются на общеклеточные (универсальные) и тканеспецифические.

Тканеспецифические стимуляторы процесса регенерации представляют собой препараты с разным механизмом работы, объединенные в подгруппы по избирательному действию на ту или другую ткань или систему органов. Средства, восстанавливающие образование форменных элементов крови в костном мозге, относятся к стимуляторам кроветворения. Витамин D и препараты кальция, фосфора и фтора, хондроитин-сульфат (структум), остеогенон и др. обладают способностью усиливать регенеративные процессы в костной ткани.

Восстановительные процессы в хрящевой ткани стимулируют и обеспечивают витамины C, E, хондроитин-фосфат и др. Одной из самых представительных является группа препаратов - стимуляторов регенерации и репарации слизистой оболочки ЖКТ. Эти средства способствуют ускорению процесса заживления эрозивно-язвенных дефектов слизистой оболочки ЖКТ. Механизм репаративного действия препаратов этой группы помимо стимуляции биосинтеза белка и клеточного деления включает торможение свободнорадикальных реакций и либерации лизосомальных ферментов. Дополнительный фактор, играющий важную роль в проявлении репаративного эффекта, представляет собой усиление местного синтеза простагландинов, способных улучшать микроциркуляцию в слизистой оболочке ЖКТ. К средствам, стимулирующим регенерацию и репарацию слизистой оболочки ЖКТ, относятся висмута трикалия дицитрат (де-нол), даларгин, натрия альгинат, вентрамин, 
поливинокс и др. В гастроэнтерологической практике репаранты назначают после достижения ремиссии, при резистентности к обычным методам, в том числе в случае длительно нерубцующихся язв и чаще пациентам пожилого возраста. В эту группу можно отнести и лонгидазу.

Лонгидаза (бовгиалуронидаза азоксимер) - представляет собой конъюгат протеолитического фермента гиалуронидаза с высокомолекулярным носителем из группы производных N-оксида поли-1,4-этиленпиперазина обладает всем спектром фармакологических свойств препаратов с гиалуронидазной активностью.

\section{Специфическим субстратом}

гиалуронидазы являются мукополисахариды гликозаминогликаны (гиалуроновая кислота, хондроитин, хондроитин-4-сульфат, хондроитин-6-сульфат, дерматансульфат) которые составляют основу межклеточного матрикса соединительной ткани. Благодаря своей ферментативной активности гиалуронидаза способна расщеплять такие гликозаминогликаны, a также их олигосахаридные производные. Разрушение данных молекул препятствует образованию коллагеновых волокон. В результате гидролиза (деполимеризации) уменьшается вязкость гликозаминогликанов, способность связывать воду и ионы металлов. Как следствие, увеличивается проницаемость тканей, улучшается их трофика, уменьшаются отеки, рассасываются гематомы, повышается эластичность рубцовоизмененных участков, устраняются контрактуры и спайки, увеличивается подвижность суставов.

Конъюгация фермента с азоксимером бромидом позволяет усилить активность фермента, но и привносит новые свойства, направленные на модуляцию выработки цитокинов и медиаторов воспаления. Данный носитель подавляет свободнорадикальные реакции, проявляет антиоксидантные и детоксикационные свойства. Помимо этого, ковалентная связь фермента с азоксимером бромида предотвращает от разрушения собственными протеазами, пролонгируя период пребывания в организме.

Традиционно лонгидаза используется для лечения и профилактики заболеваний, сопровождающихся образованием спаек и различных видов фиброза (пневмофиброза, фиброза простаты и др.). Эффект наиболее выражен на начальных стадиях патологического процесса.

\section{Синтетические стимуляторы клеток иммунной системы.}

Производные полиэтиленперазина.

Полиоксидоний ранее нами был описан как тканевой детоксикант, однако он является препаратом, прямо воздействующий на фагоцитирующие клетки и естественные киллеры, а также стимулирующий антителообразования. Восстанавливает иммунные реакции при вторичных иммунодефицитных состояниях, вызванных инфекциями, травмами, ожогами, злокачественными новообразованиями, осложнениями после хирургических операций, употреблением химиотерапевтических средств, в том числе цитостатиками и стероидными гормонами. При сублингвальном применении полиоксидоний активирует лимфоидные клетки, находящиеся в бронхах, носовой полости, евстахиевых трубах, тем самым повышая устойчивость этих органов к инфекционным агентам, а при пероральном - лимфоидные клетки, присутствующие в кишечнике, а именно В-клетки, продуцирующие секреторные IgA. Следствием этого является повышение устойчивости ЖКТ и дыхательного тракта к инфекционным агентам. Кроме того, при пероральном применении полиоксидоний активирует тканевые макрофаги, что способствует более быстрой элиминации возбудителя из организма при наличии очага инфекции. 
Наряду с иммуномодулирующим действием полиоксидоний обладает выраженной детоксицирующей и антиоксидантной активностью, которая определяется структурой и высокомолекулярной природой препарата. Повышает устойчивость мембран клеток к цитотоксическому действию лекарственных препаратов и химических веществ, снижает их токсичность.

Полиоксидоний в комплексной терапии позволяет повысить эффективность и сократить продолжительность лечения, значительно уменьшить использование антибиотиков, бронхолитиков, ГКС, удлинить срок ремиссии.

\section{Производиые аминофтальгидразита.}

Галавит - препарат, активным компонентом которого является производное фталгидразида. Он действует на моноцитарно-макрофагальное звено иммунитета: регулирует синтез цитокинов макрофагами (ИЛ-1, ИЛ-6, TNF- $\alpha$ и др.) и лимфоцитами (ИЛ-2), стимулирует бактерицидную активность нейтрофилов, усиливает фагоцитоз и неспецифическую защиту организма; повышает бактерицидную активность нейтрофильных гранулоцитов и неспецифическую резистентность организма к инфекционным заболеваниям, регулирует пролиферативную функцию Т-лимфоцитов, пролиферативную активность естественных киллеров (NК-клеток) и синтез АТ; обладает антиоксидантным и антидиарейным действием; регулирует репарацию тканей, уменьшает образование рубцов при заживлении, стимулирует синтез ИФН.

К иммуностимулирующим препаратам пытаются отнести и так называемые иммуномодуляторы растительного происхождения. Это достаточно большая группа препаратов, в которую ранее входило большое количество неспецифических стимуляторов растительного происхождения как фармакокопийных (экстракт алоэ, элеутерококка, сок каланхое, препараты женьшеня), так и различных сборов трав. Именно эта группа чаще всего «радует» нас новыми иммуноактивными препаратами, в дальнейшем не оправдывающими ожидания, хотя в нее входят и препараты достаточно активные.

Иммуномакс. Кислый пептидогликан с молекулярной массой 1000-40000 кД, усиливает иммунную защиту от вирусных и бактериальных инфекций. Иммунофармакологические механизмы действия препарата состоят в том, что иммуномакс активирует NК-клетки (цитолитическая активность возрастает в 3 раза); циркулирующие моноциты (усиление секреции ИЛ-8, ИЛ-1b и TNF- $\alpha$ ); нейтрофильные гранулоциты (секретируемый моноцитами ИЛ-8); тканевые макрофаги (изменение морфологии этих клеток, активности 5'- нуклеотидазы, усиление продукции бактерицидных субстанций); образование АТ против чужеродных АГ, растворимых и корпускулярных.

Кагоцел. Гетероцепный полимер молекулярной массой 120 - 130 кД, получаемый путем химического синтеза из растительного сырья - водорастворимой карбоксиметилцеллюлозы и госсипола. Последний представляет собой природный полифенол специфический пигмент хлопчатника. Кагоцел индуцирует продукцию ИФН и способствует образованию в организме человека так называемого позднего интерферона, являющегося смесью ИФН- $\alpha$ и ИФН- $\beta$, обладающих высокой противовирусной активностью. Стимулирует продукцию физиологических количеств ИФН- $\gamma$. Вызывает продукцию ИФН практически во всех популяциях клеток, принимающих участие в противовирусном ответе организма: Т- и Влимфоцитах, макрофагах, гранулоцитах, фибробластах, эндотелиальных клетках.

Иммунал и другие препараты эхинации пурпурной. Показана стимуляция выработки макрофагами цитокинов: ИЛ-1, TNF- $\alpha$ и ИЛ-6 и усиление антителозависимой цитотоксичности мононуклеаров периферической крови под действием экстракта эхинацеи. При применении экстракта корня эхинацеи в течение 1-2 нед. увеличивается число NК-клеток и моноцитов красного костного мозга и селезенки. Экстракт эхинацеи пурпурной in vitro стимулирует фагоцитоз гранулоцитов и моноцитов. Введение ее полисахаридов активизирует действие фагоцитоз нейтрофильных гранулоцитов, адгезии к эндотелию и мобилизации нейтрофилов из красного костного мозга, увеличивает продукцию антигенспецифичных IgG. 
Стимулирующее влияние на процессы регенерации оказывает - мумие, использующееся в народной медицине более 3000 лет. В зависимости от места сбора химический состав его может меняться, но в любом мумие содержится большое количество макро- и микроэлементов, окиси металлов, ряд витаминов, эфирные масла, пчелиный яд, смолоподобные вещества. Входящие в его состав компоненты активируют заживление ран и переломов, оказывают противовоспалительное, антитоксическое действие, улучшают адаптацию организма к неблагоприятным условиям. Однако создание на основе мумие лекарственного препарата затруднено, поскольку оно с трудом поддается стандартизации.

Мед и производные пчеловодства (прополис, заборус, маточное молочко и пр.) так же давно и успешно находит применение в лечении различных заболеваний.

Однако все эти препараты не имеют доказательной базы с позиций современной медицины. 


\section{ИММУНОТЕРАПИЯ}

\section{Глава 23. Иммунодепрессивная терапия}

В определенных условиях иммунные механизмы, играющие важную роль в защите организма от различных вредных воздействий, могут быть причиной нежелательных реакций, о чем отмечалось выше. В связи с указанными причинами получило развитие направление поиска лекарств, тормозящих иммуногенез, подавляющих продукцию АТ, пролиферативные процессы в лимфоидных (иммунокомпетентных) тканях и угнетающие биосинтез нуклеиновых кислот и/или устраняющие реакции, сопровождающиеся иммунными процессами. Иммуносупрессивные препараты, или иммуносупрессоры (иммунодепрессанты) - это класс лекарственных препаратов, применяемых для обеспечения искусственного угнетения иммунитета. Искусственная иммуносупрессия применяется, прежде всего, при трансплантации органов и тканей и лечении аутоиммунных заболеваний и заболеваний, предположительно (но пока не доказано) имеющих аутоиммунную природу. Класс иммуносупрессивных препаратов неоднороден и содержит препараты с различными механизмами действия и профилем побочных эффектов. Различается и профиль иммуносупрессивного эффекта: некоторые препараты более или менее равномерно подавляют все виды иммунитета, другие имеют особую избирательность по отношению к трансплантационному иммунитету и аутоиммунитету при сравнительно меньшем влиянии на антибактериальный, противовирусный и противоопухолевый иммунитет. Неодинаковы иммуносупрессивные препараты и по преимущественному влиянию на клеточный либо гуморальный иммунитет. Как оказалось, иммуносупрессивное воздействие оказывают многие вещества, однако с клинической точки зрения их можно разделить на препараты подавляющие иммунный ответ в целом и препараты устраняющие реакции, сопровождающие иммунные процессы, обладающие противовоспалительным и частично иммунодепрессивным действием (рис. 126).

\begin{tabular}{|c|}
\hline \multicolumn{1}{|c|}{ ИммунодепресСивная терапия } \\
\begin{tabular}{|c|c|}
\hline $\begin{array}{c}\text { Подавляющие иммунный } \\
\text { ответ в целом }\end{array}$ & $\begin{array}{c}\text { Устраняющие реакции, } \\
\text { сопровождающие иммунные процессы }\end{array}$ \\
\hline Цитостатики & $\begin{array}{c}\text { Нестероидные противовоспалительные } \\
\text { средства }\end{array}$ \\
\hline Глюкокортикоиды & Антигистаминные препараты \\
\hline Другие иммунодепрессанты
\end{tabular} \\
\hline
\end{tabular}

Рис. 126. Классификация иммунодепрессивных препаратов. 


\section{Препараты, подавляющие иммунный ответ в целом.}

Цитостатики. Особенно выраженная иммунодепрессивная активность присуща цитостатикам - алкилирующим средствам (циклофосфамид, хлорамбуцил, тиофосфамид, проспиоия хлорид и др.), антиметаболитам (меркаптопурин, фторурачил и др.), некоторым антибиотикам (дактиномицин и др.). Представители этих групп назначаются в настоящее время как иммунодепрессанты. Иммунодепрессивные препараты могут снизить тканевую несовместимость и быть весьма эффективными при лечении аутоиммунных заболеваний. Однако ныне существующие препараты не обладают достаточной избирательностью действия и их использование может сопровождаться побочными явлениями. Они подавляют продукцию ИФН, угнетают кроветворение (приводя к лейкопении, тромбоцитопении, анемии и даже панцитопении), возможно понижают общие защитные функции организма, активизируют вторичную инфекцию, развивают септицемии, при длительном употреблении они могут способствовать развитию злокачественных новообразований. Иммунодепрессанты должны применяться по строгим показаниям с соблюдением необходимых мер предосторожности.

Алкилирующие средства. Поводом к использованию этих соединений послужило влияние на организм отравляющего вещества - иприта. Было установлено, что иприт оказывает специфическое цитотоксическое действие на лимфоидные ткани и обладает противоопухолевой активностью. В настоящее время в медицинской практике используются менее токсичные соединения других химических групп.

Цитотоксическое действие алкилирующих соединений обусловлено в первую очередь алкилированием структурных элементов ДНК (пуринов, пиримидинов) и РНК (в меньшей степени), в результате чего нарушается стабильность, вязкость, целостность нитей ДНК и РНК, жизнедеятельность клеток, блокируется участие различных групп в метаболических реакциях, нарушаются митотическое деление и репликация клеток. Клетки при воздействии алкилирующих соединений останавливаются в G1-фазе и не входят в S-фазу. Высокой чувствительностью $\mathrm{\kappa}$ этим веществам обладают ядра клеток гиперплазированных (опухолевых) тканей и лимфоидной ткани.В настоящее время из этой группы наиболее широко применяются ииклофосфамид и ифосфамид.

Антиметаболиты. Это вещества, близкие по химической структуре к эндогенным продуктам метаболизма и ингибирующие в результате конкурентных отношений определенные биохимические процессы, что сопровождается нарушением функции клеток и торможением клеточного роста. К антиметаболитам, употребляемым в качестве цитотоксических средств, относят структурные аналоги фолиевой кислоты (метотрексат), пуринов (меркаптопурин, тиогуанин и др.), пиримидинов (фторурацил, тегафур, иитарабин и др.). Цитостатическое действие всех этих соединений связано с нарушением синтеза нуклеиновых кислот (ДНК и РНК). Антиметаболиты являются фазоспецифичными средствами, преимущественно действующими в S-фазе клеточного цикла.

В целом антиметаболиты обладают выраженным противоопухолевым действием и эффективны при ряде злокачественных новообразований. Преимущественно иммуносупрессивным действием характеризуются следующие цитостатики.

Азатиоприн (имуран). Синтетическое имидозольное производное 6-меркаптопурина, обладающее большим иммунодепрессивным действием и меньшим цитотоксическим. Мишенью для него служат активно делящиеся клетки за счет нарушения синтеза ДНК, что приводит к блоку редупликации генома клетки в S-фазу клеточного цикла. Азатиоприн, так же как метотраксат и циклофосфан, оказывает свое повреждающее действие на клетки во время митоза, поэтому он наиболее эффективен как до, так и после введения АГ, в то время, когда делятся активированные им Т- и В-клетки. 
Иммунодепрессивный эффект азатиоприна направлен на клеточное и гуморальное звено иммунитета, хотя препарат оказывает большее действие на Т-клеточноопосредованные реакции. К нему, в отличие от меркаптопурина чувствительны долгоживущие Т-лимфоциты селезенки и тимуса, которые редко рециркулируют и зависимы от тимических гормонов, в то время как долгоживущие Т-лимфоциты лимфоузлов и периферической крови к действию азатиоприна толерантны, но чувствительны к действиям меркаптопурина.

Действие азатиоприна на гуморальный иммунитет опосредованное. Снижение пролиферации В-лимфоцитов происходит вследствие угнетения выработки медиаторных факторов Т-хелперными клетками, поэтому в основном редуцируются Т-зависимые ответы АТ. Характерной особенностью является то, что он не меняет соотношение В- и Т-клеток в крови и лимфатических сосудах.

Азатиоприн не только действует на пролиферацию, но и ингибирует созревание и бластогенез клеток-предшественников в костном мозге. При применении этого препарата особенно страдают клетки-предшественники для Т-опосредованной цитотоксичности.

Кроме сказанного, азатиоприн нарушает процессы распознавания $\mathrm{A} \Gamma$ за счет торможения развития клеточных рецепторов на лимфоидных клетках.

Первичный иммунологический ответ препарат блокирует сильнее, чем вторичный. Он особенно эффективен на ранних этапах иммуногенеза.

Применяется в клинике при трансплантации органов и тканей во всех формах ревматических и аутоиммунных заболеваний.

Побочные реакции при назначании азатиоприна типичны для большинства цитостатических препаратов. Он противопоказан при выраженном угнетении гемопоэза и лейкопении, тяжелых заболеваниях печени.

6-Меркаптопурин. Применение (леупурин, меркалейкин, микаптин) резко снизилось после введения в клиническую практику азатиоприна. Первичная фармакологическая реакция меркаптопурина почти идентична азатиоприну.

Используют этот препарат только при лечении аутоиммунных заболеваний: гемолитической анемии, ревматоидного артрита, хронического гепатита, идиопатической тромбоцитопенической пурпуры, волчаночного нефрита, для лечения псориаза.

Циклофосфан (циклофосфамид, митоксан, цитоксан, эндоксаи). Относится к синтетическим хлорэтиламинам. Препарат - иммунодепрессант, проявляющий супрессорную активность как в отношении профилирующих, так и в отношении «покоящихся) иммунокомпетентных клеток. Клетками-мишенями для него являются Т-хелперы, предшественники и зрелые эффекторные клетки. В дозах 2-5 мг/кг сут препарат цитотоксичен для В-лимфоцитов и угнетает их стимулированную пролиферацию, истощаются В-зависимые пулы в селезенке и лимфоузлах без нарушения Т-зависимых регионов. Нормализация функции В-клеток в ходе иммунного ответа после отмены циклофосфана происходит более медленно, чем восстановление Т-клеточных функций.

Как иммунодепрессант циклофосфан в основном применяется при различных аутоиммунных и ревматических заболеваниях и в трансплантологии. Побочные эффекты такие же, как и для других цитостатиков: панцитопения, частичная или полная аллопеция, повреждение слизистой оболочки ЖКТ за счет ингибирования регенеративных процессов, оссалгии.

Метотрексат (аметоптерин, метиламиноптерии).

Это синтетический антагонист фолиевой кислоты, влияющий на гуморальный и клеточный иммунитет, но более выражен первый из эффектов.

Употребляется метотрексат как иммунодепрессант для профилактики отторжения костномозгового трансплантата при хронической реакции «трансплантант против хозяина». Обычно используют его в виде курсов в течение 100 дней после инфузии костного мозга, с последующим переводом на комбинацию азатиоприна с преднизолоном.

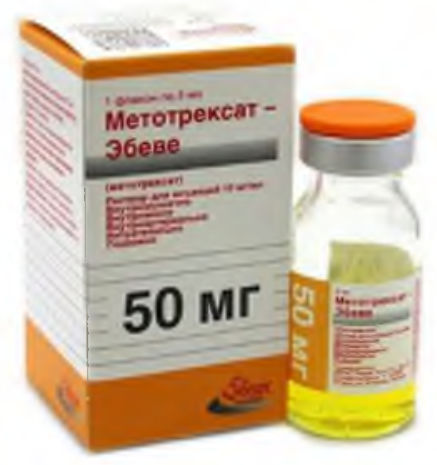


Показана высокая эффективность метотрексата при тяжелых формах псориаза, при псориатическом и ревматоидном артритах, а также для лечения аутоиммунных заболеваний соединительной ткани, включающих ограниченные формы гранулематоза вегенера, синдром Рейтера, полимиозита, дерматомиозита. Из этих заболеваний метотрексат наиболее эффективен при полимиозите и дерматомиозите. У больных он вызывает клиническое улучшение в ударных дозах 30 - 50 мг с недельным интервалом.

Побочные эффекты: угнетение кроветворения (особенно нейтрофилов и тромбоцитов), желудочно-кишечные расстройства, гепатонефротоксичность. Отмечаются и другие выпадение волос, кожные реакции, головные боли, отиты, конъюнктивиты. Метотрексат противопоказан при беременности, заболеваниях печени, при язвенной болезни

Винбластин. В отличие от вышеперечисленных акилирующих веществ и антиметаболитов по механизму действия является метафазным «ядом», так как электронномикроскопически показано, что сконденсированные и расположенные по экватору клетки хромосомы не могут расходиться к полюсам. Причина этого явления - отсутствие микротрубочек веретена давления. Винбластин, попав в цитоплазму иммунокомпетентной клетки, нарушает сборку веретена деления.

Арава (лефлуноми). Иммуномодулирующий препарат изоксазолового ряда, блокирующий синтез пиримидина. Применяется в активной фазе ревматоидного и псориатического артрита у взрослых пациентов. Как правило, препарат следует принимать продолжительное время.

\section{Агонисты иммунофилинов.}

Ццклоспорин А. Циклический олигопептид проникает в антиген-чувствительные клетки на стадиях G0 и G1 и блокирует синтез мРНК лимфокинов. Клетками-мишенями для циклоспорина являются $\mathrm{CD} 4^{+}$-лимфоциты, которые участвуют в развитии аутоиммунных болезней. Связываясь со специфическими внутриклеточными рецепторами (циклофилинами), он селективно ингибирует экспрессию генов, участвующих на ранних этапах активации Тлимфоцитов. К эффектам циклоспорина относят подавление транскрипции тРНК Т-клеточных цитокинов: ИЛ-2, ИЛ-3, ИЛ-4, ИФН, экспрессии мембранных ИЛ-2 рецепторов на Тлимфоцитах, хемотаксиса мононуклеарных фагоцитов, синтеза TNF и в меньшей степени ИЛ1 и экспресссии АГ II класса МНС на мембранах АПК.

В настоящее время изучается эффективность препарата при широком круге аутоиммунных и хронических воспалительных заболеваний, включая, псориаз, увеит, неспецифический язвенный колит, болезнь Крона, первичный билиарный цирроз и др. В ревматологии убедительные доказательства эффективности циклоспорина получены при ревматоидном артрите, при дерматомиозите/полимиозите, волчанке, системной склеродермии, болезни Бехчета и системных васкулитах.

\section{Природные макролиды.}

К ним относится Такролимус (програф, фуджимицин, такропик, протопик (мазь для наружного применения), адваграф (капсулы пролонгированного действия) продуцирующийся актиномицетом Streptomyces tsukubaensis. Подобно циклоспорину он является агонистом иммунофилина. Он подавляет формирование цитотоксических лимфоцитов, снижает активацию Т-клеток, зависимую от Т-хелперов пролиферацию В-клеток, а также формирование цитокинов ( $\mathrm{LL}-2, \mathrm{IL}-3, \gamma \mathrm{IFN})$. Такролимус более активен, чем циклоспорин, и более эффективен в меньших дозах.

Другим препаратом этой группы является рапамицин (сиролимус) - макролид, выделенный из Stephomyces higroscopicus. За счет ингибирование mTOR происходит блокада нескольких специфических путей преобразования сигнала, нарушается регуляция аутофагии, трансляции и транскрипции. Снижается активность Т- и В-лимфоцитов и как следствие угнетается иммунный ответ. Рапамицин активно используется для того что бы избежать отторжений органов при трансплантации. При обработке стентов для предотвращения рестеноза сосудов. Он подавляет развитие аутоиммунного процесса, что делает целесообразным испытания препарата при аутоиммунных заболеваниях 


\section{Глюкокортикоиды, или глюкокортикостерооиды}

Общее собирательное название подкласса гормонов коры надпочечников и их синтетических аналогов, по строению все являются стероидами. Они обладают разносторонним действием на организм. Воздействие ГКС на клетки состоит из нескольких последовательных этапов: свободного проникновения в клетку, связывания со специфическими рецепторными белками, трансформации комплекса ГКС-рецепторный белок в ядро, усиления транскрипции генетического кода со структурных генов с образованием РНК. В конечном счете происходит стимуляция специфической функции клеток. Следует учитывать, что при определенной патологической ситуации может возникнуть нарушение любого из перечисленных звеньев, что ведет к относительной ГКС недостаточности, которая может быть избирательной к отдельным клеточным структурам, страдающим от патологического процесса. В таких случаях дополнительное введение ГКС может оказаться не только бесполезным (без терапевтического эффекта), но и вредным (нежелательная стимуляция других органов и систем).

ГКС активно влияют на:

1. Белковый обмен - ограничения на уровне микросом включения аминокислот во вновь синтезируемые белки. Одновременно осуществляется катаболическое воздействие путем стимуляции расщепления аминокислот с превращением их углеродной цепи в глюкозу.

2. Углеводный обмен - индуцирует синтез ферментов глюконеогенеза, способствуя образованию глюкозы из аминокислот, уменьшает чувствительность к инсулину при одновременном повышении активности инсулиназы. В результате растет уровень сахара в крови, необходимый для высоких энергозатрат. Однако при длительном стимулирующем воздействии на инсулярный аппарат поджелудочной железы может произойти его истощение с развитием так называемого стероидного диабета. Обычно он протекает достаточно легко, купируется диетой, снижением и постепенной отменой ГКС.

3. Обмен жиров - мобилизация их периферических запасов. В результате расщепления жирных кислот происходит накопление в крови кетоновых тел, возникает гипергликемия. При продолжительном применении ГКС катаболизирующий эффект сочетается с отложением жировой ткани на спине, животе, щеках.

4. Минеральный обмен при введении ГКС усиливает реабсорбции натрия почечными канальцами при одновременном выведении с мочой калия и кальция. В случаях продолжительного применения могут развиться гипокалиемия, метаболический алкалоз, гипокальциемия с остеопорозом.

ГКС обладают мощным антистрессовым и противошоковым действием. Любой агрессивный фактор независимо от его характера вызывает стресс - стереотипную реакцию напряжения, которая протекает в фазах тревоги, сопротивления и истощения. В фазу тревоги происходит резкая активация надпочечников с выделением максимального количества ГКС, обеспечивающих выживание в экстремальных условиях. Если стрессор чрезмерный, то может наступить острая недостаточность коры надпочечников. Возникающая острая надпочечниковая недостаточность (синдром Уотерхауса-Фридериксена) проявляется резким падением артериального давления с ареактивностью сосудов к вазопрессорам, тахикардией, олигоанурией, гипотермией. Характерны миалгии, боли в эпигастральной области, рвота. При синдроме Уотерхауса-Фридериксена, как правило, выпадает функция как коркового, так и мозгового слоя надпочечников, что требует наряду с экстренным введением ГКС применения минералокортикоидов и катехоламинов. Фаза сопротивления возникает при продолжительном воздействии стрессора. Она характеризуется повышенным функционированием надпочечников и выделением дополнительного количества ГКС для обеспечения деятельности организма в чрезвычайных условиях. Обычно фаза сопротивления соответствует стадии разгара заболевания. Чем она тяжелее и продолжительнее, тем вероятнее наступление фазы истощения - недостаточности функции коры надпочечников, требующей дополнительного введения ГКС. Чем продолжительнее период разгара заболевания, тем вероятнее наступление фазы истощения надпочечников, а, следовательно, и необходимости дополнительного введения ГКС. 
Наряду с вышеописанными механизмами воздействия ГКС обладают иммунорегулирующим, противовоспалительным и противоаллергическим действием. Они угнетают активность клеток лимфоидного ряда, тормозят созревание и дифференцировку как Т-, так и В-субпопуляций лимфоцитов, вызывают апоптоз лимфоидных клеток и тем самым снижают количество лимфоцитов в крови. Глюкокортикоиды также тормозят продукцию антител В-лимфоцитами и плазматическими клетками, уменьшают продукцию лимфокинов и цитокинов разными иммунокомпетентными клетками, угнетают фагоцитарную активность лейкоцитов.

Вместе с тем эффекты ГКС на иммунную систему неоднозначны. Проявление иммуностимулирующего или иммуносупрессивного эффекта зависит от концентрации глюкокортикоидного гормона в крови. В сравнительно низких концентрациях глюкокортикоиды оказывают скорее иммуностимулирующее действие, в более высоких иммуносупрессивное действие, причём интенсивность иммуносупрессии прямо пропорциональна концентрации в крови и растёт практически линейно, вплоть до уровней, в 100 раз превышающих физиологические.

Глюкокортикоиды усиливают нейтрофилопоэз и ответ нейтрофильного ростка костного мозга на ростовые факторы Г-КСФ и ГМ-КСФ и на ИЛ, повышают содержание нейтрофильных гранулоцитов в крови, уменьшают повреждающее действие лучевой и химиотерапии злокачественных опухолей на костный мозг и степень вызываемой этими воздействиями нейтропении. Благодаря этому эффекту глюкокортикоиды широко применяются в медицине при нейтропениях, вызванных химиотерапией и радиотерапией, и при лейкозах и лимфопролиферативных заболеваниях.

ГКС угнетают эозинофилопоэз и вызывают апоптоз зрелых эозинофилов крови и тем самым снижают содержание эозинофилов в крови вплоть до полной анэозинофилии. Они оказывают мощное противовоспалительное действие, тормозят активность различных разрушающих ткани ферментов - протеаз и нуклеаз, матриксных металлопротеиназ, гиалуронидазы и т. п., синтез простагландинов, кининов и других медиаторов воспаления, тормозят экссудацию в очаг воспаления жидкости и белка, миграцию лейкоцитов (хемотаксис) и пролиферацию соединительной ткани. Понижают проницаемость тканевых барьеров и стенок сосудов, стабилизируют клеточные мембраны, приостанавливают перекисное окисление липидов, образование в очаге воспаления свободных радикалов и многие другие процессы, играющие роль в осуществлении воспаления.

ГКС свойственно сильное противоаллергическое действие, которое осуществляется различными механизмами: понижением продукции IgЕ-иммуноглобулинов, стабилизацией мембран тучных клеток и уменьшением высвобождения из них медиаторов аллергии, падением чувствительности периферических тканей к гистамину и серотонину с одновременным повышением чувствительности к адреналину и др.

Спектр использования ГКС достаточно широк и вытекает из механизмов действия, описанных выше. Сегодня практически нет ни одной области медицины, где бы не нашли применения ГКС. В настоящее время в арсенале врача имеется значительное количество гормональных препаратов, относящихся к этому классу. Чаще всего назначают преднизолон, который по противовоспалительному эффекту в 5 раз сильнее естественного гормона коры надпочечников кортизола и при этом в меньшей степени задерживает в организме натрий.

Этого нежелательного действия практически лишен метилпреднизолон, что делает его предпочтительным при лечении больных, склонных к отекам. Кроме того, он в минимальной степени обладает ульцерогенными свойствами. Метилпреднизолон при внутримышечном введении медленнее всасывается, что обеспечивает более продолжительный и равномерный 
терапевтический эффект. Из других ГКС особого внимания заслуживают триамцинолон и дексаметазон, которые выгодно отличаются от гидрокортизона (кортизола) и преднизолона еще более выраженной противовоспалительной активностью. Триамцинолон при высоком противовоспалительном потенциале и катаболическом эффекте в меньшей степени оказывает гипергликемическое и гипертензивное действие. Следовательно, его лучше назначать больным со склонностью к гипергликемии или артериальной гипертензии. В связи с достаточно сильно выраженным иммуносупрессивным эффектом триамцинолон может применяться при лечении больных с преобладающим аутоиммунным компонентом в патогенезе заболевания (хронический вирусный гепатит) или в случаях осложнений иммуноаллергического характера (полиартриты, миокардиты, нефропатии и др.).

Дексаметазон при более выраженных, чем преднизолон, противовоспалительном и противоаллергическом эффектах оказывает противошоковое действие, практически не влияя на водно-электролитный баланс.

Определение доз ГКС зависит от характера патологического процесса и целей их применения. При назначении глюкокортикоидов необходимо учитывать их эквивалентные дозы : по противовоспалительному эффекту 5 мг преднизолона соответствуют 25 мг кортизона, 20 мг гидрокортизона, 4 мг метилпреднизолона, 4 мг триамцинолона, 0,75 мг дексаметазона, 0,75 мг бетаметазона.

$$
\begin{gathered}
5 \text { мг преднизолона }=25 \text { мг кортизона }=20 \text { мг гидрокортизона }= \\
=4 \text { мг метилпреднизолона }=4 \text { мг триамцинолона }= \\
=0,75 \text { мг дексаметазона }=0,75 \text { мг бетаметазона }
\end{gathered}
$$

Важной проблемой лечения ГКС являются порядок и темп их отмены. Известно, что при поступлении в кровь ГКС срабатывает система отрицательной обратной связи, в результате чего угнетаются функции гипоталамуса-гипофиза-коры надпочечников, особенно при продолжительных курсах лечения. Может возникнуть ситуация, когда после отмены ГКС кора надпочечников не вырабатывает нужного количества эндогенных гормонов, необходимых для нормального функционирования организма. Возникает состояние, которое определяется как синдром отмены, характеризующийся нарастающей общей слабостью, вялостью, снижением аппетита, артериальной гипотензией. Депрессия системы гипоталамусгипофиз-кора надпочечников обычно наступает через 10 - 12 дней лечения. Следовательно, при коротких курсах она не успевает развиться, поэтому отмена ГКС может осуществляться сразу или в течение $2-3$ дней. При более продолжительных курсах лечения целесообразно придерживаться формулы: время применения оптимальных доз равно времени постепенной их отмены. Следует иметь в виду, что в случаях преждевременной отмены ГКС или преждевременного снижения их суточных доз может наступить обострение заболевания, которое часто неправильно трактуется как рецидив болезни. В случаях появления синдрома отмены или обострения патологического процесса следует возвратиться к предыдущей дозе. Снижение суточной дозы начинают со второй половины дня (с учетом биоритма естественной продукции ГКС). Если период отмены продолжительный, то суточные дозы уменьшаются через каждые $2-3$ дня и более. Побочные действия или осложнения ГКС терапии представляют собой результат усиления их физиологического действия и наблюдаются преимущественно при продолжительном употреблении.

Опасные для жизни осложнения - язвы ЖКТ («стероидные язвы желудка») и инфекционные осложнения. В связи с возможными осложнениями относительными 
противопоказаниями к назначению ГКС являются язвенная болезнь, сахарный диабет, гипертоническая болезнь, тяжелый атеросклероз, психические расстройства (за исключением инфекционно-токсической энцефалопатии), синдром Иценко-Кушинга, остеопороз, туберкулез, активная хроническая очаговая инфекция. Однако в случаях крайне тяжелого патологического процесса применение этих препаратов обусловлено жизненными показаниями.

Важным для эффективности применения препарата является метод его введения. Для лечения многих заболеваний с геперактивацией иммунитета местно применяются топические глюкокортикостероиды.

Интраназальные глюкокортикостероиды (НГКС). - это неоднородная группа препаратов обладая схожими лечебными свойствами они различаются по фармакокинетическим показателям, прежде всего по системе биодоступности. НГКС на основе беклометазона, будесонида или триамцинолона, имеющие биодоступность до $50 \%$, при длительном применении подавляли функцию коры надпочечников, с развитием надпочечниковой недостаточности при резкой отмене препарата. Препараты нового поколения мометазона фуроат, флутиказона фуроат и флутиказона пропионат этих нежелательных эффектов лишены. Т.е. их действие ограничивается на уровне мукозального иммунитета воздействуют на воспаление, эффективно уменьшая выраженность таких симптомов, как зуд, чихание, ринорея и заложенность носа, а также слезотечение.

Эффективно применяется при аллергическом ринит у взрослых, подростков и детей с 2 лет, остром синусите или обострение хронического синусита у взрослых (в т.ч. пожилого возраста) и подростков с 12 лет в составе комплексной терапии;, остром риносинусите без признаков тяжелой бактериальной инфекции у пациентов 12 лет и старше (когда антибиотики не рекомендуются), полипозе носа, сопровождаемый нарушением

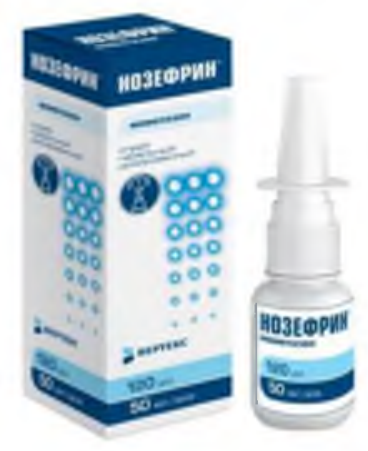
носового дыхания и обоняния, у взрослых (от 18 лет).

При наличии соответствующих показаний, соблюдении схем приема такие препараты могут применяться на протяжении длительного времени.

К ингаляционным глюкокортикоидам относятся беклометазон, будесонид, флутиказон, мометазон, триамцинолон. Ингаляционные глюкокортикоиды отличаются от системных по фармакологическим свойствам: действуют в минимальных дозах, сильное местное противовоспалительное действие, низкая системная биодоступность, быстрая инактивация. Ингаляционные глюкокортикоиды угнетают все фазы воспаления в бронхах и снижают их повышенную реактивность. Очень важное значение имеет их способность понижать бронхиальную секрецию (уменьшать объем трахеобронхиального секрета) и потенцировать действие бета2-адреномиметиков. Применение

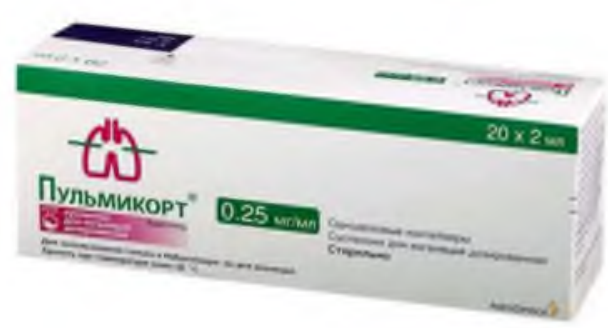
ингаляционных форм глюкокортикоидов позволяет

уменьшить потребность в таблетированных глюкокортикоидах. Важной характеристикой ингаляционных глюкокортикоидов является терапевтический индекс - соотношение местной противовоспалительной активности и системного действия. Из ингаляционных глюкокортикоидов наиболее благоприятный терапевтический индекс имеет будесонид.

Одним из факторов, определяющих эффективность и безопасность ингаляционных глюкокортикоидов, являются системы для их доставки в дыхательные пути. В настоящее время для этой цели используются дозированные и порошковые ингаляторы (турбухалер и др.), небулайзеры.

Показано, что ингаляционные глюкокортикоиды и бета-адреномиметики длительного действия (салметерол, формотерол) обладают синергическим эффектом. Это обусловлено стимуляцией биосинтеза бета2-адренорецепторов и повышением их чувствительности к 
агонистам под влиянием глюкокортикоидов. В связи с этим при лечении бронхиальной астмы эффективными являются комбинированные препараты, предназначенные для длительной терапии, но не для купирования приступов - например фиксированная комбинация салметерол/флутиказон или формотерол/будесонид.

Ингаляции глюкокортикоидами противопоказаны при грибковых поражениях дыхательных путей, туберкулезе, беременности.

Глюкокортикоиды нашли широкое применение в дерматологии для лечения различных заболеваний кожи неинфекционной природы: атопический дерматит, псориаз, экзема, красный плоский лишай и другие дерматозы. Они оказывают местное противовоспалительное, противоаллергическое действие, устраняют зуд (применение при зуде обосновано только в случае, если он вызван воспалительным процессом).

Наиболее низкой всасываемостью при аппликации на кожу отличаю галогенированных соединений (флуметазон, флуоцинолона ацетонид и др.), однако при нанесении их на обширные поверхности и длительном применении, развиваются побочные явления (атрофия кожи, телеангиэктазии, стероидные акне, стрии, инфекции). Этих недостатков лишены мометазона фуроата и метилпреднизолона ацепонат

Топические глюкокортикоиды отличаются друг от друга по химической структуре, a также по силе местного противовоспалительного действия. Согласно классификации по потенциальной активности местных стероидов выделяют 4 класса (табл. 111).

Таблица 111

\section{Классификация местных стероидов по активности}

\begin{tabular}{|l|l|}
\hline \multicolumn{1}{|c|}{ Степень активности } & \multicolumn{1}{|c|}{ Действующие вещества } \\
\hline Класс I - слабые & $\begin{array}{l}\text { Гидрокортизон (гидрокортизона ацетат) 0,5 и 1\% мазь } \\
\text { Преднизолон 0,5\% мазь }\end{array}$ \\
\hline Класс II - средней силы & Алклометазон (алклометазона дипропионат) 0,05\% мазь и крем \\
\hline Класс III - сильные & Бетаметазон (бетаметазона валерат, бетаметазона дипропионат, \\
& 0,05 и 0,1\% крем и мазь Гидрокортизон (гидрокортизона бутират) \\
& $0,1 \%$ мазь, крем, эмульсия, раствор Метилпреднизолона ацепонат \\
& $0,1 \%$ жирная мазь, мазь, крем, эмульсия Мометазон (мометазона \\
& фуроат) 0,1\% мазь, крем, раствор. Триамцинолона ацетонид 0,1\% \\
& мазь Флуоцинолона ацетонид 0,025\% мазь, крем, гель, линимент \\
Флутиказон (флутиказона пропионат) 0,005\% мазь, 0,05\% крем
\end{tabular}

Терапевтический эффект топических глюкокортикоидов зависит также от применяемой лекарственной формы. Способность к проникновению в кожу убывает в следующем порядке: жирная мазь $\Rightarrow$ мазь $\Rightarrow$ крем $\Rightarrow>$ лосьон (эмульсия)

При хронической сухости кожи проникновение глюкокортикоидов в эпидермис и дерму затруднено, поэтому при дерматозах, сопровождающихся повышенной сухостью и шелушением кожи, лихенизацией целесообразнее применять мази, т.к. увлажнение рогового слоя эпидермиса мазевой основой в несколько раз увеличивает проникновение ЛС в кожу. При острых процессах с выраженным мокнутием целесообразнее назначать лосьоны, эмульсии.

Поскольку глюкокортикоиды для местного применения снижают сопротивляемость кожи и слизистых оболочек, что может привести к развитию суперинфекции, при вторичном инфицировании целесообразно сочетание в одной лекарственной форме глюкокортикоида с антибиотиком, например крем и мазь Белогент (бетаметазон + гентамицин), аэрозоли Оксикорт (гидрокортизон + окситетрациклин) и Полькортолон ТС (триамцинолон + 
тетрациклин) и др., или с антибактериальным и противогрибковым средством, например Акридерм ГК (бетаметазон + клотримазол + гентамицин).

Применение глюкокортикоидов в офтальмологии основано на их местном противовоспалительном, противоаллергическом, противозудном действии. Показаниями к назначению глюкокортикоидов являются воспалительные заболевания глаза неинфекционной этиологии, в т.ч. после травм и операций - ирит, иридоциклит, склерит, кератит, увеит и др. С этой целью используются: гидрокортизон, бетаметазон, дезонид, триамцинолон и др. Наиболее предпочтительно применение местных форм (глазные капли или суспензия, мази), в тяжелых случаях - субъконъюнктивальные инъекции. При системном (парентерально, внутрь) использовании глюкокортикоидов в офтальмологии следует помнить о высокой вероятности (75\%) развития стероидной катаракты при ежедневном использовании в течение нескольких месяцев преднизолона в дозе более 15 мг (а также эквивалентных доз других препаратов), при этом риск возрастает с увеличением длительности лечения.

Глюкокортикоиды противопоказаны при острых инфекционных заболеваниях глаз. При необходимости, например при бактериальных инфекциях, используют комбинированные препараты, содержащие в своем составе антибиотики, такие как капли глазные/ушные Софрадекс (дексаметазон + фрамицетин + грамицидин) и др. Комбинированные препараты, в состав которых входят ГК и антибиотики, широко используются в офтальмологической и оториноларингологической практике. В офтальмологии - для лечения воспалительных и аллергических заболеваний глаз при наличии сопутствующей или подозреваемой бактериальной инфекции, например при некоторых видах конъюнктивита, в послеоперационном периоде. В оториноларингологии - при наружном отите; рините, осложненном вторичной инфекцией и пр. Следует иметь в виду, что один и тот же флакон препарата не рекомендуется использовать для лечения отита, ринита и заболеваний глаз во избежание распространения инфекции

\section{Другие иммунодепресанты}

Препараты золота. Обладают противовоспалительным, иммунодепрессивным, антипролиферативным действием. Механизм реализации эффектов до конца не выяснен, однако считается, что подавление клеточного иммунитета обусловлено поглощением вещества моноцитами и полиморфноядерными лейкоцитами, приводящим к угнетению фагоцитоза и блокаде лизосомальных ферментов. Снижает активность сульфгидрильных систем и энзимных комплексов лейкоцитов и лимфоцитов, обеспечивая в конечном итоге уменьшение концентраций иммуноглобулинов и ревматоидного фактора. Вызывает торможение антиген-индуцированной стимуляции лимфоцитов, угнетение моноцитарного и гранулоцитарного фагоцитоза, стабилизацию лизосомальных мембран, укрепление коллагеновых волокон с занятием иммунологически активных участков, способных спровоцировать аутоиммунный процесс. Одновременно падает синтез коллагена и простагландинов.

Тауредон. Один из базисных препаратов для лечения аутоиммунных заболеваний. В соответствии с фармакокинетикой препаратов золота ауротерапия начинается с пробной фазы (определение переносимости, подбор дозы, начиная с небольшой концентрации) с последующим переходом к фазе насыщения. Затем продолжают лечение в поддерживающей дозе, обеспечивающей стабильный уровень золота в тканях организма. Это лечение может продолжаться месяцы и годы; дозу при этом увеличивают или уменьшают с учетом степени активности заболевания.

Ауранофин. Препарат золота с противовоспалительной и иммуномодулирующей активностью. Перед началом терапии ауранофином следует провести исследования уровня гемоглобина, количества тромбоцитов, активности печеночных трансаминаз, концентрации мочевины, креатинина, количества белка в моче. В течение 1-го года лечения необходимо каждый месяц проверять картину периферической крови и количество белка в моче. В течение 2-го года лечения эти исследования можно проводить каждые $2-3$ мес. При протеинурии более 1 г/сут следует прекратить применение 
Ауротиомалат натрия. Средство для лечения ревматоидного артрита, является препаратом золота. Относится к разряду базисных (способных вызывать ремиссию) средств. Эффективен также при ювенильном ревматоидном и псориатическом артритах. Характеризуется медленным развитием лечебного эффекта. Показания: ревматоидный, ювенильный ревматоидный, псориатический артриты.

При отсутствии выраженного лечебного эффекта через 6-8 мес. терапию отменяют

Ауротиопрол. Препарат золота с противовоспалительной и иммуномодулирующей активностью. Применяется в базисной терапии ревматоидного артрита.

Пеницилламин (купренил, троловол, дистамин и т.д.). Особый препарат, выделенный в отдельную группу иммунодепрессантов, обладающий детоксицирующими свойствами. Фармакологическое действие - угнетает Т-хелперную функцию лимфоцитов, тормозит хемотаксис нейтрофилов и выделение лизосомальных ферментов, усиливает макрофагальную активность, подавляет синтез коллагена и нормализует соотношения между его растворимыми и нерастворимыми фракциями, способствуя угнетению склерозирующего процесса в тканях. Снижает уровень патологических макроглобулинов, в том числе ревматоидного фактора. Детоксирующие свойства обусловлены связыванием ионов меди, ртути, свинца, железа и кальция. Эффективен при гепатолентикулярной дегенерации (болезнь Вильсона-Коновалова), так как усиливает экскрецию с мочой избытка меди, нормализуя ее содержание в тканях. Угнетает ряд ферментов, участвующих в реакциях сульфгидрильно-дисульфидного обмена. При контакте с цисплатином превращается в дисульфид пеницилламин-цистеина, который в силу высокой растворимости легко экскретируется с мочой; этот эффект проявляется уменьшением образования цистеиновых камней в почках при цистеинурии.

Производные хинолина. Клинический опыт показывает, что хинолиновые производные (хлорохин, гидроксихлорохин) проявляют свой лечебный эффект после длительного применения и не влияют на остротекущие воспалительные реакции. Иммунодепрессивный эффект хлорохина (делагил) в процессе длительного лечения рассматривается как следствие общего антипролиферативного действия препарата со значительным угнетением иммунокомпетентных клеток. Множество новых эффектов обнаружено у хинолинов - фотопротективный, противовоспалительный, иммуномодулирующий, антиоксидантный, антимикробный, антипролиферативный, антиагреационный, гиполипидемический и гипогликемический. Один из возможных механизмов действия антималярийных препаратов - повышение $\mathrm{pH}$ цитоплазмы, что в свою очередь влияет на превращения АГ в макрофагах. Кроме того, антималярийные препараты подавляют синтез ИЛ-1, экспрессию ИЛ-2 рецепторов и индуцированное ИЛ-1 разрушение хряща. Другой механизм их действия - ослабление агрегации и адгезии тромбоцитов, что позволяет использовать их для профилактики послеоперационных эмболий и тромботических нарушений у больных СКВ с антифосфолипидным синдромом.

Делагил. В последние 20 лет применяется не как антималярийное средство, а как иммуносупрессивное. При этом главным общим показанием к его назначению служит наличие хронического аллерговоспалительного процесса, устойчивого к лечению обычными противовоспалительными средствами. Первые признаки улучшения обычно проявляются только через 3 - 6 нед после начала лечения, иногда позднее. Развитие максимального эффекта отмечается иногда лишь через $6-10$ мес непрерывной терапии, поэтому короткие курсы назначения делагила нерациональны.

Несмотря на длительность лечения хинолиновыми препаратами, переносимость их хорошая. Наиболее серьезными осложнениями при лечении такими препаратами являются сравнительно редко встречающиеся изменения глаз. С целью профилактики подобных осложнений больные в процессе хинолиновой терапии должны получать консультацию окулиста 1 раз в $3-4$ мес. При первом появлении жалоб на нарушение зрения препарат отменяют. При своевременной отмене хинолиновых средств изменения глаз претерпевают обратное развитие. Переносимость плаквенила по сравнению с хлорохином несколько лучше. В последние годы наиболее активным производным хинолина является лаквинимод. 


\section{Средства, устраняюшие реакции, которые сопровождают иммунные процессы}

Нестероидные противовоспалительные средства (НПВС) Данная группа препаратов нашла широкое применение при ревматических, неврологических, травматологических заболеваниях и инфекциях.

Противовоспалительный эффект препаратов в основном связан с подавлением экссудативной и пролиферативной фазой воспаления за счет прерывания циклооксигеназного пути метаболизма арахидоновой кислоты участвующих в синтезе простагландинов (ПГ), простациклинов и тромбоксанов. В настоящее время описано 3 различных изофермента ЦОГ. ЦОГ-1 нужен постоянно для регуляции синтеза гомеостатических и цитопротективньх ПГ в слизистой оболочке желудочно-кишечного тракта (ЖКТ), эндотелия, тромбоцитах и канальцах почек. ЦОГ-2 вырабатывается макрофагами, эндотелиальными клетками, синовиоцитами, фибробластами, гладкой сосудистой мускулатурой и хондроцитами под воздействием их цитокинами или факторами роста под действием бактериальных токсинов. ПГ так же стимулируют выработку ЦОГ по механизму положительной обратной связи. ЦОГ3 (или ЦОГ-1b) является ферментом нервной системы и, по-видимому, участвует в процессах регуляции температуры тела, влияя на синтез ПІГ в гипоталамусе. Торможение синтеза простагландинов (ПГЕ2, ПГІ2, ПГҒ 2a), тромбоксана А2, что приводит к уменьшению гиперемии, отека, боли. Одновременно снижается выброс других тканевых медиаторов воспаления (гистамина, серотонина, брадикинина, норадреналина). Угнетение образования тромбоксана А2 и активности гиалуронидазы способствует нормализации микроциркуляции. Препараты так же снижают энергетический обмен клетки, уменьшая АТФ в тканях очага воспаления. Блокируя синтез ПГ, препараты уменьшают проницаемость сосудистой стенки и проникновение в ткани плазменных факторов. При этом снижается активность гуанилатциклазы и уровень цГМФ, угнетается деление фибробластов, синтез коллагена, мукополисахаридов, образование ревматических гранулем и соединительной ткани. За счет редукцией синтеза ПГЕ2, под воздействием НГВС, снижается хемотаксис моноцитов, Тлимфоцитов, эозинофилов, полиморфноядерных лейкоцитов в очаге воспаления и тормозится деление лимфоцитов. Этим объясняется десенсибилизирующее действие НПВС.

Торможение синтеза ПГ, имеющих важное значение для течения физиологических процессов в тканях, может привести к возникновению ряда общих осложнений. Наиболее частым и опасным побочным эффектом являются эрозивно-язвенные изменения слизистой оболочки желудка. Высокий риск побочных эффектов со стороны желудочно-кишечного тракта характерен для бутадиона, индометацина, пироксикама, АСК. Частота этих осложнений снижается, если препараты принимают после еды, запивая большим количество воды, или в сочетании с антацидами

Опасным осложнением НПВС является бронхоспазм. Блокада ПГ может вызвать сдвиг метаболизма арахидоновой кислоты в сторону образования лейкотриенов и возникновению реагинового (анафилактического, атопического) синдрома. Наиболее часто это осложнение развивается при назначении АСК.

НПВС снижают диурез и вызывают отеки, так как подавляют образование почечных ПГ, участвующих в регуляции почечного кровотока, клубочковой фильтрации, секреции ренина и водно-солевого баланса. Падение уровня ПГ способствует задержке натрия и возникновению отеков (особенно характерно для бутадиона, диклофенака натрия, кетопрофена, кислоты мефенамовой).

Наряду с перечисленными, НПВС дают ряд других (не связанных с ПГ) побочных эффектов: изменения со стороны крови, печени, ЦНС, кожи. Тяжелые гематологические нарушения (лейкопения и даже агранулоцитоз, апластическая анемия) характерны для пиразолоновых производных (бутадион, амидопирин, анальгин); нарушения кроветворения могут вызвать индометацин, кислота мефенамовая. Различные формы поражения печени вплоть до токсического гепатита (длительное назначение) развиваются при применении 
бутадиона, индометацина, сулиндака, диклофенака натрия (ортофен). Побочные эффекты со стороны центральной нервной системы наблюдаются при лечении ацетилсалициловой кислотой (шум в ушах. снижение остроты слуха, головокружение, гипервентиляция), индометацином (головокружение. сильные головные боли, депрессия, иногда галлюцинации. судороги); со стороны кожных покровов (кожный зуд, ограниченная или генерализованная крапивница, эритродермия) - особенно при применении бутадиона, индометацина, оксикамов.

НГІВС нельзя назначать в первый триместр беременности, так как они обладают тератогенными свойствами, Лечение НІВС во второй половине беременности также рискованно, поскольку иногда способствует сужению (и даже закрытию) артериального протока и нарушению гемодинамики плода. Опасно назначение этих препаратов (особенно индометацина) в предродовом периоде - снижая уровень ПГ, они ослабляют сократимость матки и тормозят родовую деятельность.

Сочетание противовоспалительных, болеутоляющих и жаропонижающих свойств практически у всех НПВС связано с подавлением медиаторов воспаления (брадикинин, простагландины), вызывающих ощущение боли и лихорадки. Некоторую роль играет также блокада данными средствами периферических болевых рецепторов. НПВС не оказывают доказанного непосредственного влияния на иммунную систему. Имеются данные о том, что НПВС повышают уровень внутриклеточного кальция в Т-лимфоцитах, что ассоциируется с увеличением пролиферации Т-лимфоцитов и синтезом ИЛ-2. Одним из возможных механизмов противовоспалительного действия НПВС является прерывание активации нейтрофилов на уровне гуанозинтрифосфат-связывающего белка (G-белок). Таким образом, эффект НПВС может опосредоваться как минимум двумя механизмами: в низких концентрациях они взаимодействуют с комплексом арахидонат-циклооксигеназа, предотвращая образование стабильных простагландинов, а в высоких блокируют ассоциацию арахидоната c G-белком, который способствует клеточной активации.

Классификация НПВС базируется на основании способности блокировать различные форм ЦОГ (табл. 112),

Таблица 112

\section{Классификация НПВП по химической структуре}

\begin{tabular}{|c|c|}
\hline Вещество & Препарат \\
\hline \multicolumn{2}{|c|}{ Селективные ингибиторы циклооксигеназы-1 } \\
\hline Ацетилсалициловая кислота & Ацетилсалициловая кислота низкие дозы \\
\hline \multicolumn{2}{|r|}{ Ингибиторы циклооксигеназы-1 и -2 } \\
\hline Салицилаты & Ацетилсалициловая кислота (аспирин), дифлунисал (долобид) \\
\hline $\begin{array}{l}\text { Производные уксусной } \\
\text { кислоты }\end{array}$ & $\begin{array}{l}\text { Индометацин, ацеклофенак, диклофенак, кеторолак, } \\
\text { триметиамин }\end{array}$ \\
\hline $\begin{array}{l}\text { Производные пропионовой } \\
\text { кислоты }\end{array}$ & Ибупрофен (нурофен), кетопрофен, напроксен \\
\hline Производные пиразолона & Фенилбутазон (бутадион), метамизол (баралгин, анальгин) \\
\hline Оксикамы & Пироксикам, теноксикам (артоксан) \\
\hline \multicolumn{2}{|c|}{ Селективные ингибиторы циклооксигеназы-2 } \\
\hline Производные сульфонамида & Нимесулид (найз) \\
\hline Оксикамы & Мелоксикам (мовалис, амелотекс) \\
\hline $\begin{array}{l}\text { Производное индолуксусной } \\
\text { кислоты }\end{array}$ & Этодолак (нобедолак) \\
\hline \multicolumn{2}{|c|}{ Высокоселективные ингибиторы циклооксигеназы-2 } \\
\hline Коксибы & $\begin{array}{l}\text { Целекоксиб (дилакса, целебрекс), рофекоксиб (виокс), парекоксиб } \\
\text { (династат), эторикоксиб (аркоксиа, бикситор) }\end{array}$ \\
\hline Алканоны & Набуметон \\
\hline \multicolumn{2}{|r|}{ Ингибиторы ЦОГ-3 } \\
\hline Анилиды & Парацетамол \\
\hline
\end{tabular}


С клинической точки зрения необходимо отметить, что эффективность НПВП в целом зависит от дозы. Использование более высоких доз позволяет обеспечить более выраженное обезболивающее и противовоспалительное действие, при этом все НПВП в адекватных противовоспалительных дозах (средних и максимальных терапевтических) при длительном применении имеют равный обезболивающий потенциал. Противовоспалительный препарат выбирается на основании оценки безопасности его действия и возможных рисков осложнений со стороны ЖКТ и сердечно-сосудистой системы (табл. 113, 114). Однако до настоящего времени остается градация эффективности средних доз НПВC по силе противовоспалительного и анальгезирующего действия (рис. 127).

Таблица 113

\section{Алгоритм назначения НПВП согласно рекомендациям российских} экспертов (doi: 10.14412/1995-4484-2018-1-29)

\begin{tabular}{|c|c|c|c|c|}
\hline \multirow{2}{*}{\multicolumn{2}{|c|}{$\begin{array}{c}\text { Риски } \\
\text { осложнений }\end{array}$}} & \multicolumn{3}{|c|}{ со стороны сердечно-сосудистой системы } \\
\hline & & низкий & умеренный и высокий & очень высокий \\
\hline \multirow{3}{*}{ 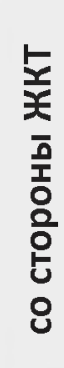 } & низкий & Любые НПВС & $\begin{array}{l}\text { целекоксиб, напроксен, кетопрофен, } \\
\text { низкие дозы ибупрофена (<1200 } \\
\text { мг/сут) }\end{array}$ & \multirow{3}{*}{$\begin{array}{l}\text { Избегать } \\
\text { назначение } \\
\text { любых НПВС }\end{array}$} \\
\hline & умеренный & $\mathrm{H} \Pi \mathrm{BC}+$ ИПП, с-НПВС & Напроксен + ИПП или целекоксиб & \\
\hline & $\begin{array}{l}\text { высокий и } \\
\text { очень } \\
\text { высокий }\end{array}$ & $\begin{array}{l}\text { Целекоксиб или } \\
\text { эторикоксиб + ИПп }\end{array}$ & Целекоксиб + ИПП & \\
\hline
\end{tabular}

ИПП-ингибитор протонной помпы

\section{Оценка факторов риска при назначении НПВП}

(doi: $10.14412 / 1995-4484-2017-485-492)$

\begin{tabular}{|c|l|l|}
\hline $\begin{array}{c}\text { Уровень } \\
\text { риска }\end{array}$ & \multicolumn{1}{|c|}{ ЖКТ } & \multicolumn{1}{|c|}{ сердечно-сосудистая система } \\
\hline низкий & $\begin{array}{l}\text { Отсутствие каких-либо факторов } \\
\text { риска }\end{array}$ & $\begin{array}{l}\text { Отсутствие заболевания, } \\
\text { SCORE <1\% }\end{array}$ \\
\hline умеренный & $\begin{array}{l}\text { Диспепсия, прием } \\
\text { глюкокортикоидов, } \\
\text { курение, возраст >65 лет }\end{array}$ & SCORE 1-4\% \\
\hline Высокий & $\begin{array}{l}\text { Язвенный анамнез, прием низких } \\
\text { доз аспирина и/или иных } \\
\text { антитромботических средств }\end{array}$ & SCORE >5\% \\
очень & $\begin{array}{l}\text { Кровотечение, перфорация в } \\
\text { анамнезе }\end{array}$ & $\begin{array}{l}\text { Клинически выраженная ИБС, инфаркт миокарда, } \\
\text { инсульт или транзиторная ишемическая } \\
\text { атака в анамнезе, ХСН ІІ ФК и выше, СД 2-го типа с } \\
\text { воражением органов-мишеней, хроническая } \\
\text { болезнь почек 3-й степени и выше }\end{array}$ \\
\hline
\end{tabular}

По эффективности НПВС в средних и максимальных терапевтических дозах при лечении хронической боли не уступают по эффективности «мягким» опиоидным препаратам, таким как трамадол, и более эффективны чем парацетамол. Использование НГВП в операционном периоде и в качестве дополнительного средства для контроля боли у онкологических больных позволяет повысить эффективность обезболивания, снизить потребность в наркотических анальгетиках. 


\section{ПРОТИВОВОСПАЛИТЕЛЬНОЕ ДЕЙСТВИЕ}

MAX

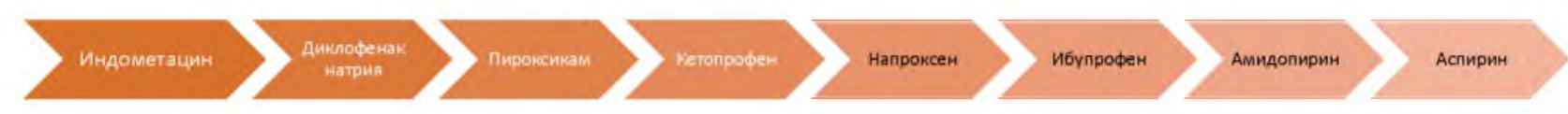

АНАЛЬГЕЗИРУЮЩЕЕ ДЕЙСТВИЕ

MAX

MIN

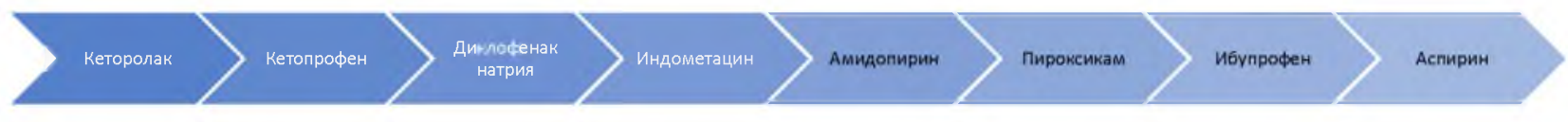

\section{Рис. 127. Эффективность НПВС}

Использование инъекционных форм НПВС (в/в и в/м введение), а также быстрорастворимых препаратов для приема внутрь может иметь преимущество в скорости наступления обезболивающего эффекта в сравнении с пероральным приемом стандартных препаратов. В то же время нет однозначных данных о том, что применение НПВС в виде инъекций или быстрорастворимых форм для приема внутрь имеет преимущество перед пероральными формами по выраженности обезболивающего и противовоспалительного действия при проведении лечения более 1 дня. Так же, как и локальные формы НПВС обладают доказанной обезболивающей и противовоспалительной эффективностью при лечении.

Длительное непрерывное использование НПВС обеспечивает лучший контроль симптомов, чем прием НПВС в режиме «по требованию». При этом длительное применение НПІВС способно уменьшить частоту рецидивов и замедлить прогрессирование хронических воспалительных заболеваний и должно рассматриваться как патогенетическая терапия этой группы болезней.

\section{Антигистаминные средства.}

Гистамин - это органическое соединение, биогенный амин, вырабатывается тучными клетками, базофилами, нейронами и клетками ECL (энтерохромаффиноподобные клетки желудка - особый тип нейроэндокринных клеток). Он является одним из эндогенных факторов медиаторов, участвующих в регуляции жизненно важных функций организма и играющих важную роль в развитии ряда заболеваний. В физиологических концентрациях гистамин необходим для поддержания нормальной жизнедеятельности, в более высоких - вызывает ряд патологических эффектов. Он участвует в развитии воспалительного процесса любой природы. Эффектами гистамина являются стимуляция секреции слизистой носа (ринорея), зуд, чихание, сокращение гладких мышц бронхов и кишечника, гиперемию тканей, дилатацию мелких кровеносных сосудов, повышение сосудистой проницаемости для воды, белков, нейтрофилов, образование воспалительного отека (заложенность носа). Гистамин вызывает усиление секреции желудочного сока, играет роль нейромедиатора. (см. главу 14). Повышают его выход так называемые либераторы гистамина (тубокурарин, морфин, яд крапивы, пчелиный и змеиный яды и др.). Либераторы могут также образовываться в организме при химических превращениях пищевых веществ (земляника, устрицы, желтки куриных яиц и пр.). Инактивация гистамина осуществляется несколькими путями: окислительное дезаминирование (гистаминаза), ацетилирование или метилирование, связывание гепарином или тканевыми белками.

Различные действия гистамин опосредованы разными гистаминовыми рецепторами (табл.115). 
Таблица 115

\section{Биологические мишени гистамина в организме человека}

\begin{tabular}{|c|c|c|}
\hline Рецептор & Экспрессия на клетках & Эффекты \\
\hline $\begin{array}{l}\text { Гистаминовый } \\
\text { рецептор Н1 }\end{array}$ & $\begin{array}{lr}\text { Гладкие } & \text { мышцы, } \\
\text { эндотелиальные } & \text { клетки } \\
\text { сосудов, сердце, цНС }\end{array}$ & 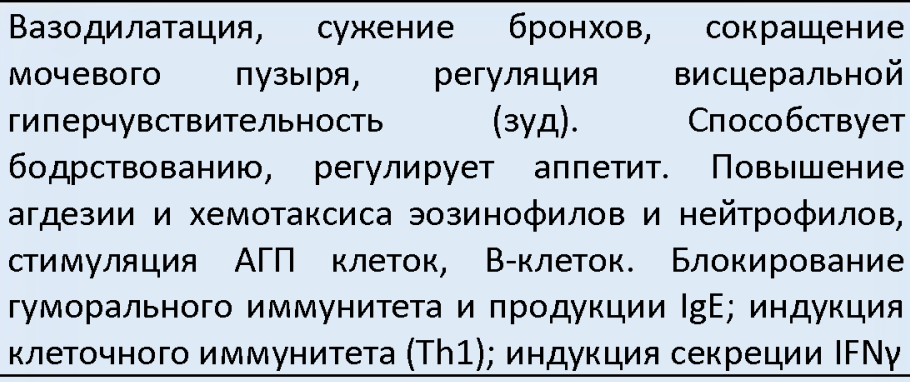 \\
\hline $\begin{array}{l}\text { Гистаминовый } \\
\text { рецептор Н2 }\end{array}$ & $\begin{array}{lr}\text { Париетальные } & \text { клетки, } \\
\text { гладкомышечные } & \text { клетки, } \\
\text { эпителиальные } & \text { клетки, } \\
\text { эндотелиальные } & \text { клетки, } \\
\text { кардиомиоциты, } & \text { клетки } \\
\text { молочных желёз, } & \text { матки, } \\
\text { клетки цНС, миелоидные и } \\
\text { лимфоидные } \\
\text { дендритные клетки }\end{array}$ & $\begin{array}{l}\text { Вазодилатации, стимуляции секреции желудочного } \\
\text { сока. Расслабление мочевого пузыря. Регулирует } \\
\text { работу желудочно-кишечного тракта. } \\
\text { Подавление активации и хемотаксиса нейтрофилов и } \\
\text { эозинофилов, индукция синтеза IL-10, подавление } \\
\text { синтеза АТ, пролиферации Т-клеток и производство } \\
\text { цитокинов }\end{array}$ \\
\hline $\begin{array}{l}\text { Гистаминовый } \\
\text { рецептор Н3 }\end{array}$ & $\begin{array}{l}\text { ЦНС, периферическая } \\
\text { нервная система, ЖКТ, } \\
\text { эндотелиальные клетки } \\
\text { сердце, легкие. }\end{array}$ & $\begin{array}{l}\text { Регуляция по типу отрицательной обратной связи } \\
\text { высвобождения нейромедиаторов (дофамина, ГАМК, } \\
\text { ацетилхолина, серотонина, норадреналина, } \\
\text { гистамина). Регуляция чувствительности (боль), } \\
\text { секрецию желудочного сока и прием пищи. }\end{array}$ \\
\hline $\begin{array}{l}\text { Гистаминовый } \\
\text { рецептор Н4 }\end{array}$ & $\begin{array}{l}\text { Костный мозг, базофилы, } \\
\text { тучные клетки, внутренние } \\
\text { органы (тонкий и толстый } \\
\text { кишечник, лёгкие, печень, } \\
\text { селезёнка, семенники, } \\
\text { тимус, трахея, миндалины). }\end{array}$ & $\begin{array}{l}\text { Полностью не охарактеризованы. Участвует в } \\
\text { восприятии зуда, воспалении, аллергии, когнитивных } \\
\text { функциях висцеральной гиперчувствительности. } \\
\text { Играет роль в секреции цитокинов, хемотаксисе } \\
\text { тучных клеток и эозинофилов. Сигнал к дегрануляции } \\
\text { эозинофилов }\end{array}$ \\
\hline $\begin{array}{l}\text { Хлоридный } \\
\text { канал, } \\
\text { управляемый } \\
\text { гистамином }\end{array}$ & $\begin{array}{l}\text { ЦНС (гипоталамус, таламус) } \\
\text { и эпителий кишечника. }\end{array}$ & $\begin{array}{l}\text { Быстрая выработка тормозящиго постсинаптические } \\
\text { потенциалы. } \\
\text { Секреция хлоридов связанная с секреторной диареей. }\end{array}$ \\
\hline
\end{tabular}

Учитывая, что при любых патологических процессах с выраженным воспалительным компонентом всегда повышен уровень гистамина в организме патогенетически целесообразным и клинически обоснованным является снижение активности гистаминовой системы в условиях ее повышенной активности. Подавить действие гистамина возможно либо через уменьшение количества свободного гистамина (торможение синтеза, активация метаболизма, торможение высвобождения из депо), либо через блокаду гистаминовых рецепторов. Антагонисты Н1 рецепторов, (блокаторы Н1), препараты, блокирующие действие гистамина на рецептор Н1 помогают облегчить аллергические реакции. Основной терапевтический эффект опосредован отрицательной модуляцией гистаминовых рецепторов, называются антигистаминными. Блокаторы Н2-гистаминовых рецепторов париетальных клеток слизистой оболочки желудка снижают продукцию соляной кислоты. Относятся к антисекреторным препаратам.

Все антигистаминные препараты подразделяются на 2 поколения в зависимости от их влияния на ЦНС (рис.128). 

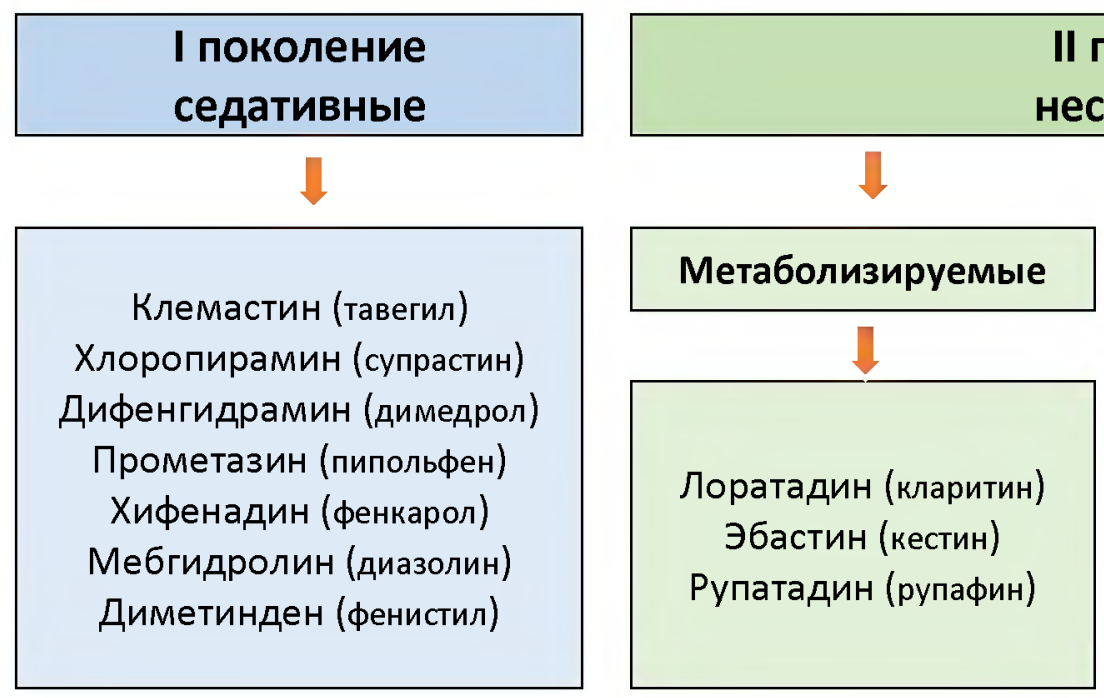

II поколение

неседативные

\section{Рис. 128. Классификация антигистаминных препаратов}

\section{Антигистаминные препараты I поколения}

H1-антагонисты первого поколения назначают при различных аллергических процессах: анафилактический шок, сенная лихорадка, аллергический дерматит, отек Квинке, крапивница, лекарственные аллергии и др. Антигистаминные средства вызывают и другие фармакологические эффекты. Они проникают через гематоэнцефалический барьер и как правило подавляют работу ЦНС. Нарушение функции ЦНС наблюдается даже при использовании минимальных доз этих средств. Н1-антагонисты первого поколения оказывают местноанестезирующее и болеутоляющее действие, потенцируют эффект анальгетиков, местных анестетиков, снотворных, барбитуратов, транквилизаторов, наркотиков (особенно дипразин). Все они (больше дипразин, меньше димедрол) тормозят тошноту, рвоту. Димедрол, дипразин, супрастин обладают адренолитическими, ганглиоблокирующими и центральными холинолитическими свойствами.

При длительном применении противогистаминных средств лечебный эффект постепенно ослабевает, что обусловливает целесообразность периодической замены одного препарата другим.

При приеме антигистаминных препаратов I поколения необходимо отметить их кратковременный эффект (вынужденный прием 3-4 раза в сутки), низкую избирательность действия (они так же блокируют рецепторы ацетилхолина, адреналина, серотонина, дофамина и ионные каналы, вызывая множество побочных эффектов: тахикардию, сухость слизистых оболочек, повышение вязкости мокроты). Они могут способствовать повышению внутриглазного давления, нарушать мочеиспускание, вызывать боли в желудке, запоры, тошноту, рвоту, увеличивать массу тела. Поэтому указанные препараты ограничены к применению среди пациентов с глаукомой, доброкачественной гиперплазией предстательной железы, сердечно-сосудистой патологией и т. д. Специалисты во многих странах призывают отказаться в лечении детей от этой группы препаратов или применять их под строгим контролем.

Однако у антигистаминных препаратов I поколения имеется очень важное преимущество - наличие инъекционных форм, незаменимых при оказании экстренной помощи, премедикации перед проведением некоторых видов диагностического обследования, хирургических вмешательствах и т.д. Кроме того, некоторые препараты обладают противорвотным действием, снижают состояние повышенной тревожности, эффективны при укачивании. Дополнительный антихолинергический эффект ряда препаратов указанной группы проявляется в значительном снижении зуда и кожных высыпаний при зудящих дерматозах, острых аллергических и токсических реакциях на пищевые продукты, лекарственные препараты, укусы и ужаления насекомых. 


\section{Антигистаминные препараты II поколения}

Как и препараты первого поколения назначают при различных аллергических процессах. Они отличаются высокой избирательностью действия на $\mathrm{H}_{1}$ - рецепторы, незначительно влияют на другие медиаторные системы (холинергические и др.), не проходят через гемоэнцефалический барьер (ГЭБ) (не влияют на ЦНС), не теряют активность при длительном применении. Многие препараты II поколения неконкурентно связываются с $\mathrm{H}_{1-}$ рецепторами, а образовавшийся лиганд-рецепторный комплекс характеризуется сравнительно медленной диссоциацией, обусловливающей увеличение продолжительности терапевтического действия (назначаются 1 раз в сутки), как правило, не вызывают привыкания. В связи с их более высоким профилем безопасности они предпочтительны для пожилых пациентов (старше 65 лет).

При сравнении различных препаратов необходимо отметить, что антигистаминное действие начинает развиваться значительно раньше у активных метаболитов. Они же обладают и большей безопасностью, не зависят от взаимодействия с другими лекарственными вешествами и продуктами. Так метаболизируемые антигистаминные препараты второго поколения необходимо с осторожностью принимать с антибиотиками макролидами, некоторые антимикотическими и противовирусными препаратами, антидепрессантами и др.. Необходимо при приеме этих препаратов исключить грейпфрукты и алкоголь.

Важнейшим свойством антигистаминных препаратов является их способность снижать экспрессию гистаминовых Н1-рецепторов, тем самым уменьшать чувствительность тканей к гистамину. По силе антигистаминного действия препараты II поколения можно расположить в следующем порядке: цетиризин $>>$ эбастин $>$ фексофенадин $>>$ лоратадин.

Подбор оптимального для каждого пациента лечебного средства, в том числе антигистаминного препарата, всегда осуществляется индивидуально и начинать его надо с современных, высокотехнологичных, эффективных и безопасных средств с учетом всех дополнительных эффектов: антисеротониновый эффект - когда в клинике отмечается выраженный зуд; антибрадикининовый эффект - выраженные отеки; спазмолитический эффект; стабилизирующий мембраны клеток депо медиаторов воспаления.

В клинической практике нашли применение препараты, стабилизирующие мембраны тучных клеток, тем самым предотвращающие выделение гистамина. Однако наступления желаемого действия при их использовании приходится долго ждать, и терапевтическая эффективность данной группы лекарств весьма умеренная, поэтому они применяются исключительно с профилактической целью.

Стабилизаторы мембран тучных клеток (кетотифен, кромолин натрия, интал, maйлед $u \partial p$ ) - средства, влияющие на клетку и прежде всего на мембраны тучных клеток, представляют собой препараты, препятствующие открытию кальциевых каналов и входу кальция в клетки. Они угнетают кальцийзависимую дегрануляцию клеток и выход из них гистамина (в тучных клетках депонировано 90 \% этого медиатора), фактора, активирующего тромбоциты, лейкотриенов, в том числе медленно реагирующей субстанции анафилаксии, лимфокинов и других биологически активных веществ, индуцирующих аллергические и воспалительные реакции. Стабилизация мембран тучных клеток обусловлена блокадой фосфодиэстеразы и накоплением в них цАМФ

Важным аспектом противоаллергического влияния стабилизаторов мембран тучных клеток является повышение чувствительности адренорецепторов к катехоламинам. Кроме того, препараты способны блокировать хлорные каналы и предупреждать таким образом деполяризацию парасимпатических окончаний в бронхах. Они препятствуют клеточной инфильтрации слизистой оболочки бронхов и тормозят развитие замедленной реакции гиперчувствительности. Некоторые из лекарственных средств этой группы (кетотифен и др.) блокируют $\mathrm{H}_{1}$-рецепторы (антигистаминное действие). Стабилизаторы мембран тучных клеток устраняют отек слизистой оболочки бронхов и предупреждают (но не купируют) повышение тонуса гладких мышц. Основное показание к их назначению - предупреждение 
бронхообструкции. Профилактический эффект развивается постепенно, в течение 2 - 12 нед. Стабилизаторы мембран тучных клеток хорошо сочетаются с другими средствами для профилактики бронхообструктивного синдрома. В ряде случаев их использование позволяет уменьшить дозу или прекратить прием кортикостероидов и бронходилататоров.

При аллергических заболеваниях можно использовать средства, усиливающие связывание гистамина. С этой целью назначают гистаглобин (гистаглобулин).

Часто назначают также средства, направленность действия которых противоположна медиаторам аллергии (функциональные антагонисты). К этим препаратам относят адреналин, эфедрин, мезатон (адреномиметики), эуфиллин, папаверин (спазмолитики) и др. 
От выявления роли иммунной системы в канцерогенезе до реализации ее обширного потенциала

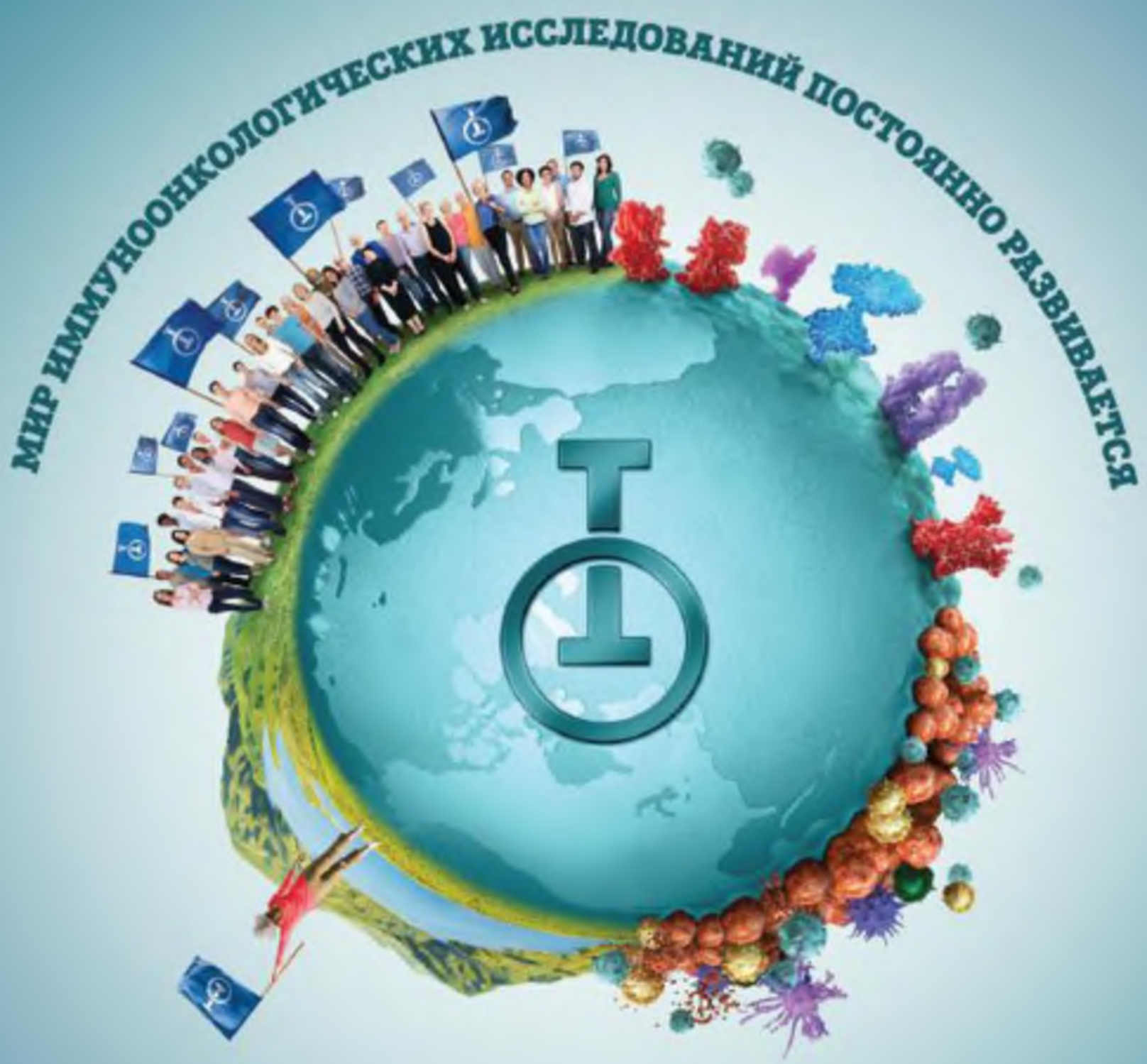

Приближаем инновационные научные достижения к пациентам

Nllı Bristol Myers Squibb

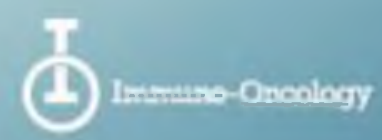

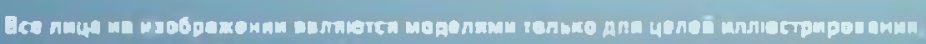

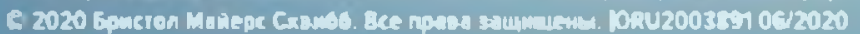




\section{ИММУНОТЕРАПИЯ}

\section{Глава 24. Таргетная иммунотерапия}

Таргетная терапия или молекулярно-таргетная терапия является одним из основных методов лечения рака и аутоиммунных заболеваний. Как форма молекулярной медицины, таргетная терапия блокирует рост раковых или гиперсенсибилизированных клеток, вмешиваясь в конкретные целевые молекулы. Большинство агентов для таргетной терапии являются клетки и молекулы иммунной системы поэтому имеет смысл выделить иммунотерапию с применением биофармацевтических препаратов, направленньх на конкретные мишени иммунной системы. В идеале при диагностики иммунных нарушений используя принципы топической диагностики у больного определяются те или иные мишени и в дальнейшем используя таргетную терапию проводится лечение.

По точки приложения таргентные препараты имеет смысл разделить на препараты блокирующие цитокины и другие молекулы иммунной системы, направленные на рецепторы клеток иммунной системы, и препараты, действующие на различные сигнальные пути клеток иммунной системы (рис. 129). Для этих целей используют малые молекулы или моноклональные антитела.

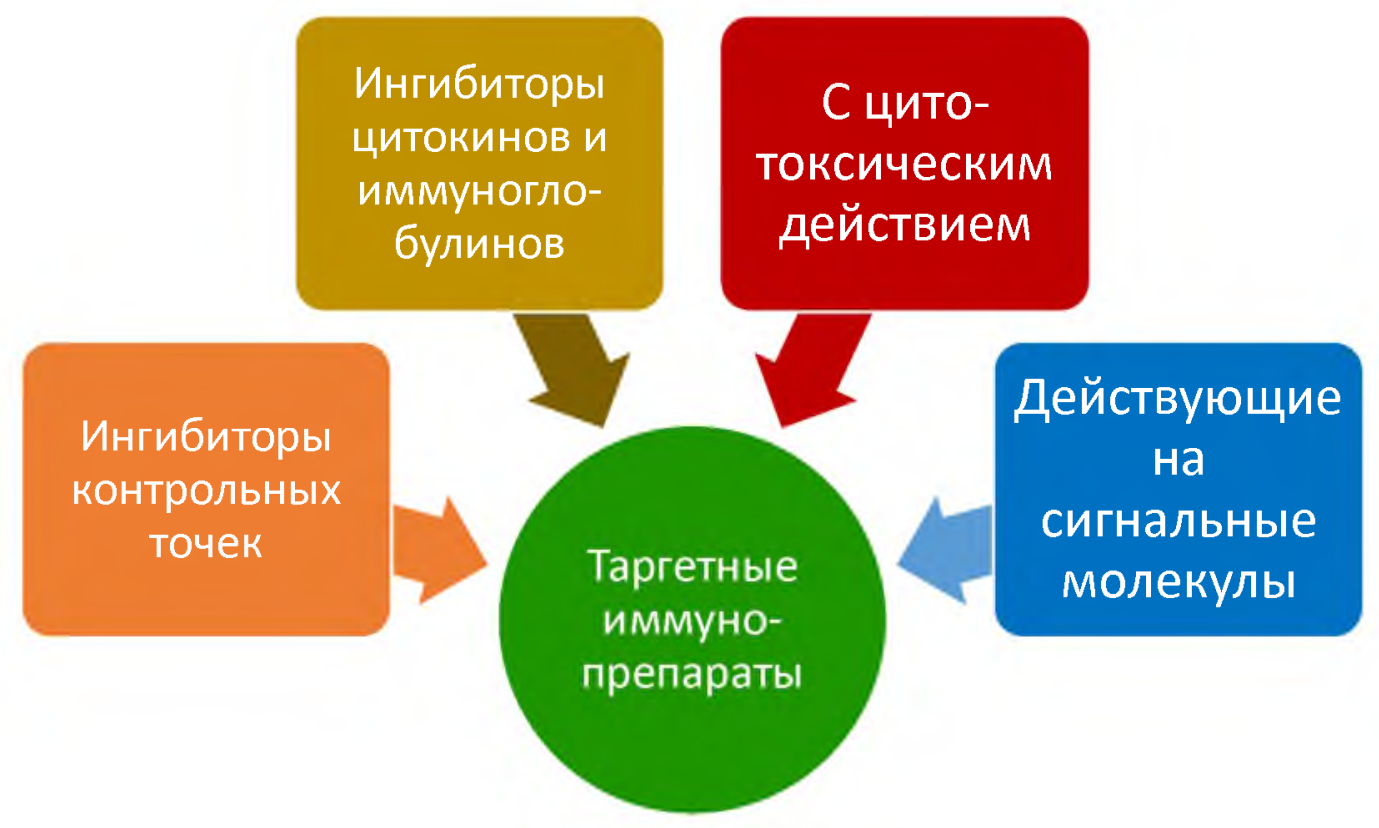

\section{Рис. 129. Классификация таргетных иммунопрепаратов}

В фармакологии к малым молекулам относятся практически все лекарственные вещества тем не менее с позиций таргетной терапии значение термина «малые молекулы» определяется как низкомолекулярные вещества, которые способны связываться с определёнными, чётко установленными, биологическими молекулярными мишенями - теми или иными специфическими биополимерами, такими, как тот или иной рецепторный, ферментный или регуляторный белок или нуклеиновая кислота, и действовать как эффектор, изменяя химическую структуру, пространственную конформацию, активность или функцию данного биополимера. Малые молекулы могут выполнять различные биологические функции, в частности служить передатчиками или блокаторами сигнала. 
Моноклональных АТ - это антитела строго заданной специфичности, которые синтезируются одним клоном, т.е. отдельной линией лимфоидных клеток. Моноклональные АТ получают путем слияния В-лимфоцита, вырабатывающего антитела заданной специфичности и опухолевой клетки, лимфоидной ткани - плазмоцитомы, обеспечивающей непрерывный рост образующегося гибрида. Слившиеся гибридомные клетки могут бесконечно размножаться и синтезируемые ими моноклональные АТ могут быть получены в неограниченном количестве. Таким образом получают моноклональные АТ к определенным АГ бактерий или вирусов, опухолевых клеток, лимфоцитов, гормонов, ферментов, медиаторов и т.д. С появлением моноклональных АТ в биологии и медицине связана современная эпоха исследований высокой точности. Их использование в повседневных исследованиях в клинической и лабораторной диагностиках сегодня стало уже рутинным методом. Первоначально для лечения использовались мышиные антитела, однако это приводило к реакциям гиперчувствительности и как следствие, снижению эффективности. Для уменьшения чужеродности были разработаны химерные, гуманизированные («очеловеченные») и полностью человеческие антитела. Все названия моноклональных антител оканчиваются на корень -mab. Для обозначения источника мAT к корню присоединяется субкорень: -отаb - мышь, хіmab - химерные, zumab - гуманизировнные, -хіzuчастично химерные и частично гуманизированные антитела, umab - полностью человеческие. Для определения цели лекарства определен субэлемент, предшествующий источнику антитела: - сі- для системы кровообращения, -li- для иммунной системы, -ne - для нервной системы и т.д. Если мАТ ПЭГилировано (присоединено к молекулам полиэтиленгликоля) для замедления его расщепления и снижения иммуногенности, добавляется слово пегол.

\section{Ингибиторы цитокинов (табл. 116).}

Группа препаратов ингибиторов ФНО (этанерчепт, инфликсимаб, адалимумаб, иертолизумаб, голимумаб) образует устойчивый комплекс как с растворимой, так и с мембранассоциированной формами человеческого ФНО-альфа, снижая его функциональную активность. Понижает концентрацию (связывает и ингибирует синтез) ИЛ-1, ИЛ-6, ИЛ-8, моноцитарного хемоатрактантного белка-1, оксида азота, металлопротеиназ (коллагеназа, стромелизин), и других индукторов воспаления и тканевой деструкции, а также уровень растворимых форм молекул адгезии - ICAM-1 и Е-селектина, отражающих активацию сосудистого эндотелия.

Канакинумаб - человеческое моноклональное антитело интерлейкину- $1 \beta$. Канакинумаб связывается с человеческим ИЛ-1 $\beta$, конкурентно ингибируя активацию генов под действием интерлейкина- $1 \beta$ и продукцию медиаторов воспаления - интерлейкина-6 и ЦОГ-2.

Дупилумаб рекомбинантное человеческое моноклональное антитело (IgG4), которое блокирует передачу сигналов ИЛ-4 и ИЛ-13. Эти интерлейкины выступают в качестве основных факторов воспаления 2-го типа, активируя множественные типы клеток (тучные клетки, лимфоциты, эозинофилы, нейтрофилы, макрофаги) и индуцируя множественные медиаторы (иммуноглобулин Е, гистамин, лейкотриены, хемокины и цитокины, включая эотаксин/CCL11, TARC/CCL17 и ИЛ-5), участвующие в воспалении 2-го типа. Блокирование пути передачи сигналов ИЛ-4/ИЛ-13 у пациентов снижает концентрации многих из этих маркеров воспаления 2-го типа, включая иммуноглобулин Е, периостин и множественные провоспалительные цитокины и хемокины (например, эотаксин, TARC), предотвращает последующие действия этих цитокинов и хемокинов, в т.ч. гиперплазию бокаловидных клеток, гиперреактивность гладкомышечных клеток дыхательных путей, эозинофильное воспаление в легких, другие воспалительные процессы в легких, а также предотвращает нарушение функции легких; при этом снижение выраженности эозинофильного воспаления в легких происходит независимо от нормального или повышенного уровня эозинофилов в крови. 


\section{Ингибиторы цитокинов}

Таблица 116.

\begin{tabular}{|c|c|}
\hline Препарат & Мишень \\
\hline Этанерцепт & $\begin{array}{l}\text { Ингибирует биологическую активность ФНО, являясь конкурентным ингибитором } \\
\text { связывания ФНО с его рецепторами на поверхности клетки }\end{array}$ \\
\hline Инфликсимаб & 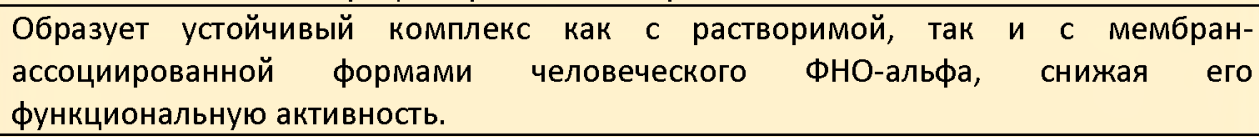 \\
\hline Адалимумаб & $\begin{array}{l}\text { Связываясь с ФНО, блокирует его взаимодействие с поверхностными клеточными } \\
\text { р55 и р75 рецепторами, и нейтрализует функции ФНО }\end{array}$ \\
\hline Цертолизумаба пэгол & $\begin{array}{l}\text { Нейтрализует связанный с мембраной и растворимый человеческий ФНО } \\
\text { дозозависимым способом. }\end{array}$ \\
\hline Голимумаб & $\begin{array}{l}\text { Образуют высокоаффинные стабильные комплексы антиген-антитело как с } \\
\text { растворимыми, так и с трансмембранными биоактивными формами ФНО- } \alpha \\
\text { человека, предотвращая связывание ФНО- } \alpha \text { с его рецепторами. }\end{array}$ \\
\hline Анакинра & Антагонист рецептора интерлейкина 1 \\
\hline Канакинумаб & $\begin{array}{l}\text { Связывается с человеческим ИЛ-І } \beta \text {, нейтрализуя таким образом его биологическое } \\
\text { действие }\end{array}$ \\
\hline Даклизумаб & Антагонист рецепторов интерлейкина-2 (ИЛ-2). \\
\hline Базиликсимаб & $\begin{array}{l}\text { Специфически связывается и блокирует а-субъединицу интерлейкин-2 (CD25) на } \\
\text { поверхности активированных Т-лимфоцитов. }\end{array}$ \\
\hline Дупилумаб & Блокирует передачу сигналов ИЛ-4 и ИЛ-13 \\
\hline Тоцилизумаб & Связывается и подавляет как растворимые, так и мембранные рецепторы ИЛ-6 \\
\hline Сарилумаб & $\begin{array}{l}\text { Специфически связывается как с растворимыми, так и с мембранными } \\
\text { рецепторами ИЛ-6(IL-6R } \alpha)\end{array}$ \\
\hline Левилимаб & Рекомбинантное человеческое моноклональное антитело к рецептору ИЛ-6 \\
\hline Олокизумаб & $\begin{array}{l}\text { Селективно связывается с человеческим ИЛ-6 не связывается в значительной } \\
\text { степени с другими молекулами семейства ИЛ-6 }\end{array}$ \\
\hline Устекинумаб & $\begin{array}{l}\text { Блокирует биологическую активность ИЛ-12 и ИЛ-23, предотвращая связывание р40 } \\
\text { с рецептором ИЛ-12R- } \beta 1 \text { экспрессируемым на поверхности иммунных клеток. }\end{array}$ \\
\hline Секукинумаб & Связывается и нейтрализует провоспалительный цитокин - ИЛ-17А. \\
\hline Иксекизумаб & Связывается с ИЛ-17А и подавляет его действие за счет нейтрализации активности. \\
\hline Гуселькумаб & Селективно связывается с белком ИЛ-23 \\
\hline Омализумаб & $\begin{array}{l}\text { Ингибирует связывание IgE с высокоаффинными рецепторами } \operatorname{lgE} \text { (FcعRI), } \\
\text { расположенными на поверхности тучных клеток и базофилов. }\end{array}$ \\
\hline Экулизумаб & $\begin{array}{l}\text { Ингибирует расщепления компонента комплемента С5 до С5a и С5b, предотвращая } \\
\text { образование комплекса терминального комплемента C5b-9, что приводит к } \\
\text { блокированию комплемент-зависимого клеточного лизиса }\end{array}$ \\
\hline
\end{tabular}

Даклизумаб (гуманизированные моноклональные мышиные антитела) и базиликсимаб (химерное моноклональное антитело против рецептора интерлейкина-2). Действуют как антагонисты рецепторов интерлейкина-2 путем связывания с альфа-цепочкой рецептора интерлейкина-2, который экспрессируется на поверхности активированных Т-лимфоцитов. В результате специфического связывания антитела с антигеном происходит угнетение активности Т-лимфоцитов и вследствие этого угнетается иммунный ответ.

Точилизумаб $и$ олокизумаб (рекомбинантное гуманизированное моноклональное антитело к человеческому рецептору ИЛ-6), сарилумаб $u$ левилимаб (человеческое моноклональное антитело (IgG1) к рецептору ИЛ-6), связывают и подавляют как растворимые, так и мембранные рецепторы ИЛ-6 (sIL-6R и mIL-6R). ИЛ-6 является многофункциональным цитокином, вырабатываемым различными типами клеток, участвующих в паракринной регуляции, системных физиологических и патологических процессах, таких как стимуляция секреции Ig, активация Т-клеток, стимуляция выработки белков острой фазы в печени и стимуляция гемопоэза. ИЛ-6 вовлечен в патогенез различных заболеваний, в т.ч. воспалительных, остеопороза и новообразований. Показалали свою эффективность при COVID-19. 
Устекинумаб полностью человеческое моноклональное антитело, которое блокирует биологическую активность ИЛ-12 и ИЛ-23, предотвращая связывание $\mathrm{p} 40 \mathrm{c}$ рецептором ИЛ-12R- $\beta 1$, экспрессируемым на поверхности иммунных клеток. ИЛ-12 и ИЛ-23 являются гетеродимерными цитокинами, которые секретируются активированными антигенпрезентирующими клетками, в частности макрофагами и дендритными клетками. ИЛ12 активирует NK-клетки, стимулирует дифференциацию CD4+ T-клеток до T-хелперов 1 (Th1), а также усиливает выработку интерферона гамма. ИЛ-23 стимулирует образование Тхелперов 17 (Th17) и увеличивает секрецию ИЛ-17А, ИЛ-21 и ИЛ-22.

Секукинумаб (полностью человеческое антитело) и иксекизумаб (гуманизированное моноклональное антитело к цитокину интерлейкин 17А. Связывают и нейтрализует провоспалительный цитокин - ИЛ-17А. Оказывает направленное действие на ИЛ-17 и ингибирование его взаимодействия с рецептором ИЛ-17, который экспрессируется разными типами клеток, включая кератиноциты и синовиоциты. В результате этого блоктруется высвобождение провоспалительных цитокинов, хемокинов и медиаторов повреждения тканей и снижает вклад ИЛ-17А в аутоиммунные и воспалительные заболевания. В клинически значимых концентрациях препаратов достигает кожи и снижает концентрацию местных воспалительных маркеров.

Гуселькумаб̆ селективно связывается с белком ИЛ-23 с высокой специфичностью и аффинностью. ИЛ-23 - регуляторный цитокин, который влияет на дифференцировку, распространение и жизнеспособность субпопуляций Т-клеток (например, Th17 и Тс17) и незрелых субпопуляций иммунных клеток, являющихся источником эффекторных цитокинов, включая ИЛ-17А, ИЛ-17Е и ИЛ-22, способствующих развитию воспалительных заболеваний. В исследованиях у людей было показано, что селективная блокада ИЛ-23 нормализует выработку этих цитокинов.

Омализумаб (ксолар, генолар) является гуманизированным моноклональным антителом, полученным на основе рекомбинантной ДНК; селективно связывается с иммуноглобулином (IgE). Омализумаб представляет собой IgGl каппа антитело, содержащее человеческую структурную основу с определяющими комплементарность участками мышиного антитела, связывающими IgE.

Омализумаб применяется при лечении персистирующей атопической бронхиальной астмы среднетяжелого и тяжелого течения, симптомы которой недостаточно контролируются применением ГКС, у пациентов 6 лет и старше; лечение хронической идиопатической крапивницы, резистентной к терапии блокаторами Н1гистаминовых рецепторов, у пациентов 12 лет и старше. Имеются исследования по применению омализумаба при атопическом дерматите.

\section{Ингибиторы контрольных точек}

Вторая группа таргетных иммуноактивных препаратов направлена на рецепторы клеток иммунной системы. Некоторые из них описаны выше т.к. рецепторы к цитокинам блокируются за счет применения мАТ селективно связывающиеся с рецепторами клеток иммунной системы блокируя его действия. Особенно это важно при иммунотерапии рака (табл. 117).

Терапия ингибиторами контрольных точек произвела революцию в онкологии. Терапия нацелена на иммунные контрольные точки, ключевые регуляторы иммунной системы, которые при стимуляции могут ослабить иммунный ответ на иммунологический стимул. Некоторые виды рака могут защитить себя от нападения, стимулируя иммунные контрольные точки. Терапия может блокировать тормозящие контрольные точки, восстанавливая функцию иммунной системы. 


\section{Таблица 117.}

\section{Ингибиторы контрольных точек}

\begin{tabular}{|l|l|}
\hline \multicolumn{1}{|c|}{ Препарат } & \multicolumn{1}{|c|}{ Мишень } \\
\hline Ипилимумаб & Связывается с CTLA-4 \\
\hline Ниволумаб & $\begin{array}{l}\text { Блокирует взаимодействие между рецептором PD-1 и его лигандами PD-L1 и PD- } \\
\text { L2 }\end{array}$ \\
\hline Пембролизума6 & Высокоаффинное антитело к PD-1 рецептору \\
\hline Дурвалумаб & Селективно блокирует взаимодействие PD-L1 с PD-1 или CD80 \\
\hline Авелумаб & $\begin{array}{l}\text { Авелумаб непосредственно связывается с PD-L1 и блокирует его } \\
\text { взаимодействие с рецепторами PD-1 и CD80 }\end{array}$ \\
\hline Атезолизумаб & $\begin{array}{l}\text { Непосредственно связывается с PD-L1 и блокирует его взаимодействие с } \\
\text { рецепторами PD-1 и CD80 }\end{array}$ \\
\hline
\end{tabular}

В настоящее время одобренные ингибиторы контрольных точек CTLA4, PD-1 и PD-L1. PD-1 является трансмембранным белком запрограммированной гибели клеток 1 (также называемым PDCD1 и CD279), который взаимодействует c PD-L1 (лиганд 1 PD-1 или CD274). PD-L1 на поверхности клетки связывается c PD1 на поверхности иммунных клеток, что подавляет активность иммунных клеток. Среди функций PD-L1 ключевая регулирующая роль в активности T-клеток. Опосредованная раком активация PD-L1 на поверхности клетки может ингибировать Т-клетки, которые в противном случае могли бы атаковать. Антитела, которые связываются либо с PD-1, либо с PD-L1 блокируют это взаимодействие, и позволяет Т-клеткам атаковать опухоль.

Ипилимумаб (Ервой). Рекомбинантное человеческое моноклональное антитело, связывается с цитотоксическим Т-лимфоцитассоциированным антигеном 4 (CTLA- 4). CTLA4 является ключевым регулятором активации Т-лимфоцитов. Ипилимумаб является ингибитором CTLA-4, блокирует тормозные сигналы каскада CTLA-4, увеличивая количество противоопухолевых Т-хелперов, которые в свою очередь вызывают рост числа прямых Ткиллеров. Показано, что блокада CTLA-4 также уменьшает регуляторную функцию Т-клеток, что может приводить к усилению иммунного противоопухолевого ответа. Ипилимумаб может селективно уменьшать количество Т-регуляторных клеток в области опухоли, приводя к росту отношения противоопухолевых Т-хелперов к Т-регуляторам, что способствует гибели опухолевых клеток.

Ниволумаб (человеческое мАТ) и пембролизумаб (гуманизированное мАТ) представляет собой высокоаффинное АТ к PD-1 рецептору, при ингибировании которого осуществляется двойная блокада сигнального пути PD-1, включающего лиганды PD-L1 и PD-L2 на опухолевых или антигенпрезентирующих клетках. В результате ингибирования связывания рецептора PD-1 с его лигандами пембролизумаб реактивирует опухольспецифичные цитотоксические Т-лимфоциты в микроокружении опухоли и, таким образом, реактивирует противоопухолевый иммунитет.

В периферической крови пациентов, которые получали пембролизумаб по 2 мг/кг каждые 3 недели или по 10 мг/кг каждые 2 или 3 недели, наблюдалось увеличение процентного содержания активированных (т.е. HLA-DR+) CD4+ и CD8+ Т-клеток после лечения всеми дозами и схемами без повышения общего числа циркулирующих Т-лимфоцитов.

Дурвалумаб полностью человеческое, высокоаффиное мAT (IgGlK), которое селективно блокирует взаимодействие PD-L1 с PD-1 или CD80 (B7.1), при этом не затрагивая взаимодействие между PD-1 и PD-L2. Селективная блокада взаимодействий между PD-L1 и 
PD-1 и PD-L1 и CD80 приводит к усилению противоопухолевого иммунного ответа, который может привести к элиминации опухоли за счет восстановления цитотоксической активности Т-клеток, их пролиферации и выработки цитокинов. Такими же эффектами обладают авелумаб (человеческий иммуноглобулин IgGl мAT против PDL1) и атезолизумаб (гуманизированное мАТ против PD-L1).

К сожалению, ингибиторами контрольных точек могут быть вызваны иммунологические побочные эффекты для большинства систем и органов организма. Чаще всего возникают осложнения в желудочно-кишечном тракте, эндокринных железах, легких на коже, и в печени, реже поражаются ЦНС, костно-мышечная и сердечно-сосудистая системы органы кроветворения (рис. 130).

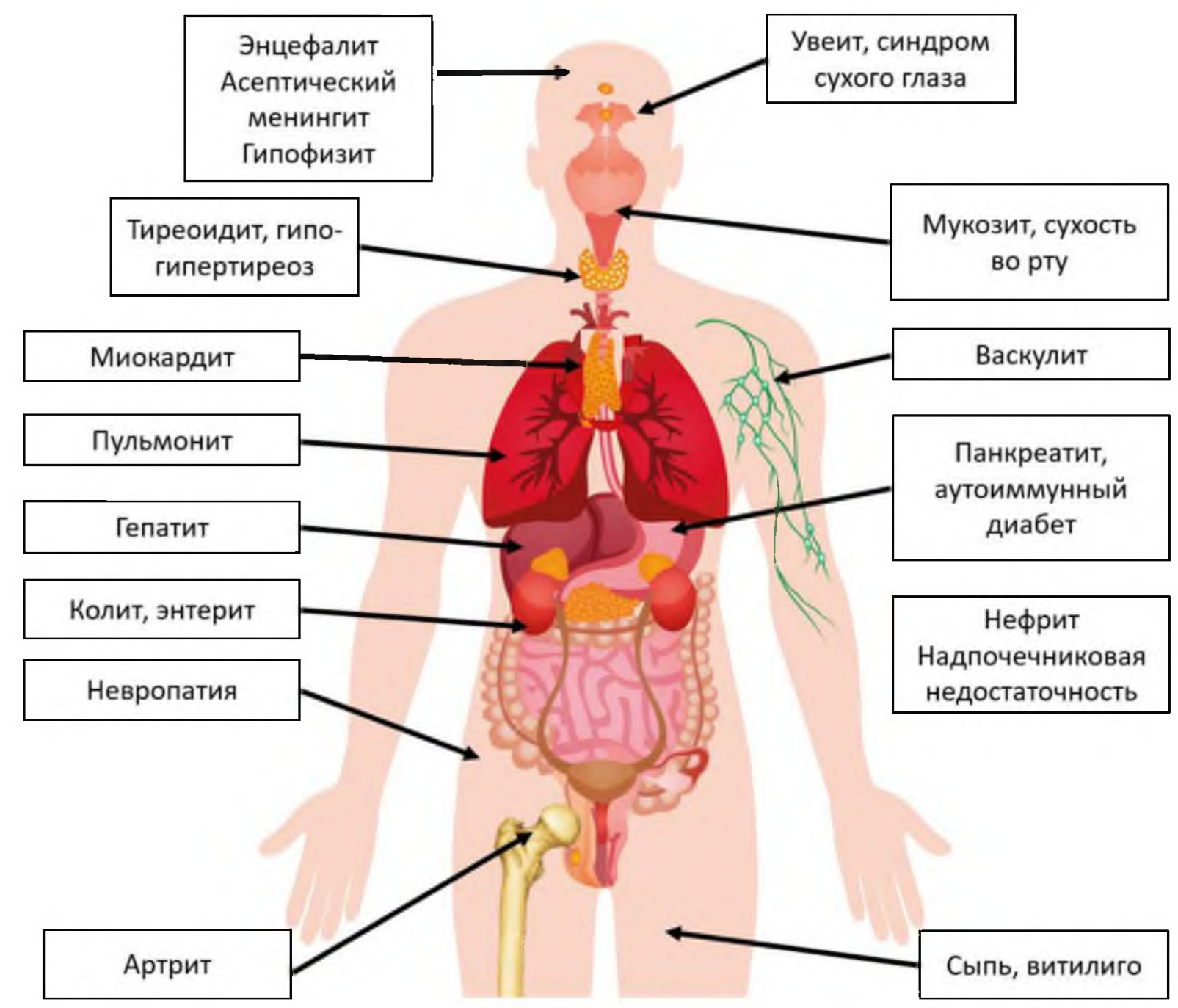

Рис. 130. Иммунозависимые побочные эффекты при использовании ингибиторов контрольных точек

Используя общие терминологические критерии для нежелательных явлений Национального института рака США (Common terminology criteria for adverse events grading СТСАЕ), тяжесть неблагоприятных событий и токсичность режимов необходимо как можно раньше распознать, классифицировать, и своевременно провести терапию (табл. 118), с привлечением врачей определенной специальности (дерматолог, эндокринолог, ревматолог и др.). 
Таблица 118. Критерии классификации нежелательных явлений (СТСАЕ)

\begin{tabular}{|c|c|c|c|}
\hline Степень по СТСАЕ & $\begin{array}{c}\text { Условия } \\
\text { наблюдения }\end{array}$ & Тактика & $\begin{array}{c}\text { Терапия } \\
\text { ингибиторами } \\
\text { контрольных точек }\end{array}$ \\
\hline $\begin{array}{l}\text { Бессимптомная } \\
\text { или легкая }\end{array}$ & Амбулаторно & Наблюдение & $\begin{array}{l}\text { Продолжать терапию с } \\
\text { тщательным } \\
\text { мониторингом }\end{array}$ \\
\hline Умеренная & Амбулаторно & $\begin{array}{l}\text { Системные глюкокортикоиды }(0,5-1 \\
\text { мг/кг/сут преднизолона) }\end{array}$ & $\begin{array}{l}\text { Временно воздержаться; } \\
\text { возобновить по } \\
\text { достижении 1-й степени } \\
\text { токсичности }\end{array}$ \\
\hline $\begin{array}{l}\text { Тяжелая, но не } \\
\text { жизнеугрожающая }\end{array}$ & Стационар & $\begin{array}{l}\text { Высокие дозы системных } \\
\text { глюкокортикоидов (1-2 мг/кг/сут } \\
\text { преднизолона или } \\
\text { метилпреднизолона); рассмотреть } \\
\text { дополнительные методы лечения, } \\
\text { если нет ответа в течение 48-72 ч }\end{array}$ & $\begin{array}{l}\text { Временно воздержаться; } \\
\text { возобновить по } \\
\text { достижении 1-й степени } \\
\text { токсичности, обсудить с } \\
\text { пациентом перспективы } \\
\text { лечения }\end{array}$ \\
\hline $\begin{array}{l}\text { Жизнеугрожающие } \\
\text { состояния }\end{array}$ & $\begin{array}{l}\text { Стационар/ блок } \\
\text { интенсивной } \\
\text { терапии }\end{array}$ & $\begin{array}{l}\text { Высокие дозы глюкокортикоидов (1-2 } \\
\text { мг/кг/суг преднизолона или } \\
\text { метилпреднизолон); рассмотреть } \\
\text { дополнительные методы лечения при } \\
\text { отсутствии ответа в течение 48-72ч }\end{array}$ & Прекращение терапии \\
\hline
\end{tabular}

В соответствии с рекомендациями Американского общества клинической онкологии (ASCO), Европейского общества медицинской онкологии (ESMO), рабочей группы, изучающей онкологическую токсичность иммунотерапии и Национальной комплексной онкологической сетью США (NCNN) для улучшения соответствующей оценки и лечения рекомендованы мероприятия, описываемые ниже.

Поражение кожи. Наиболее часто встречающееся осложнение (37-70 \% у пациентов с анти-CTLA-4 терапией и 17-37\% - анти-PD-1/PD-L1 терапией. В 3 \% случаев токсичность выше 3-й степени тяжести). Время возникновения от 2 недель до нескольких месяцев от начала терапии. Клинические проявления варьируют от зуда, витилиго, воспалительных высыпаний (реакции кожной гиперчувствительности, макулопапулезная, угревая, эксфолиативная и псориазообразная форма сыпи), буллезных дерматозов (буллезный пемфигоид, буллезная лекарственная реакция) до тяжелых и жизнеугрожающих (синдром Стивенса - Джонсона, токсический эпидермальный некролиз, синдром лекарственной гиперчувствительности с эозинофилией и системными проявлениями) состояний. Однако необходимо отметить, что развитие иммуноопосредованных осложнений поражения кожи коррелирует с лучшим клиническим ответом и большей выживаемостью пациентов.

Диагностика основана на анамнезе и данных физикального осмотра. Особое внимание необходимо уделить на процент площади пораженной кожи и наличие или отсутствие пузырей. Положительный признак Никольского (образования пузырей под действием механического давления) должен настораживать относительно развития синдрома Стивенса - Джонсона, при котором поражаются слизистые оболочки и наблюдаются системные проявления (лихорадка, слабость, сонливость, конституциональные симптомы).

Рекомендуемая тактика. За исключением буллезного поражения, большинство проявлений кожной токсичности 1-й и 2-й степени можно лечить с помощью местной терапии (смягчающие средства, мази с глюкокортикоидами) с продолжением терапии ингибиторов контрольных точек. При 3-4-й степени токсичности следует назначать внутривенный (в/в) метилпреднизолон (МП) в дозе 1-2 мг/кг в течение 3-5 дней с переходом на оральные формы 
из расчета 0,5-1 мг/кг с постепенным снижением дозы через 3-4 недели по мере разрешения кожных проявлений. Пациенты с поражением поверхности тела более $30 \%$ должны находиться в специализированном дерматологическом отделении. В стероидно-резистентных случаях альтернативным подходом считается применение в/в иммуноглобулина, ритуксимаба или циклоспорина в сочетании с ГК и локальной терапией.

Поражение желудочно-кишечного тракта. Частота развития осложнений при применении ингибиторов контрольных точек в виде колита составляет 8-27\%, диареи около $54 \%$, аутоиммунного гепатита 10-20\%, бывают и другие более редкие гастроинтестинальные осложнения в виде дисфагии, гастрита, дуоденита и панкреатита. При этом 37 \% смертельных исходов на фоне лечения связано именно с поражением ЖКТ. Время начала гастроинтестинальных осложнений обычно составляет 5-12 недель после начала терапии.

Диагностика. Симптомы поражения кишечника включают боль в животе, чаще спастического характера, тошноту, вздутие, кровь или слизь в кале, нарушение стула. Диагностическое обследование у пациентов с подозрением на развитие индуцированного колита включает стандартное лабораторное тестирование для исключения инфекционной и неинфекционной этиологии, включая общий анализ крови (ОАК), биохимическое исследование крови, бактериологический посев кала, определение С-реактивного белка (СРБ), кальпротектина и/или лактоферрина. На компьютерной томографии брюшной полости с контрастированием для индуцированного колита характерен застой в брыжеечных сосудах, утолщение стенки толстой кишки, растяжение кишечника и уплотнение периколитической клетчатки. При затруднении диагностики и/или для оценки тяжести колита следует провести прямую визуализацию толстой кишки с помощью колоноскопии (индуцированный колит преимущественно поражает нисходящую ободочную кишку). Наличие изъязвления при прямой визуализации, как правило, ассоциировано со стероид-рефрактерным течением колита, и в этих случаях необходимо как можно более раннее назначение ингибиторов ФНО$\alpha$ (инфликсимаба или адалимумаба). У пациентов с тяжелым колитом необходимо провести исследования для исключения туберкулезной инфекции, ВИЧ, вирусных гепатитов с целью подготовки к возможной терапии ингибиторами фактора некроза опухоли $(\Phi \mathrm{HO}-\alpha)$ при стероид-резистентном колите.

Рекомендуемая тактика. Пациентам с колитом 1-2-й степени токсичности следует воздержаться от терапии иИКТ, лечение следует возобновлять только в случае разрешения гастроинтестинальных проявлений. При развитии токсичности 3-4-й степени рекомендуется прекращение терапии анти-CTLA-4. Терапию анти-PD-1, PD-L1 можно возобновить при восстановлении состояния кишечника. Необходимо назначение системных глюкокортикоидов (в дозе $<10$ мг/кг/сут (в преднизоновом эквиваленте) при 2-й степени токсичности, 1-2 мг/кг/сут - при 3-4-й с постепенным уменьшением дозы в течение 4-6 недель при достижении 1-й степени токсичности). Следует проводить поддерживающую терапию при помощи регидратации, электролитных растворов и антидиарейных агентов. При отсутствии адекватного клинического ответа в течение 48-72 ч после терапии ГК следует начать терапию ингибитором ФНО- $\alpha$ (инфликсимабом) 5-10 мг/кг с повторной инъекцией через 2 недели. Повторная колоноскопия не является обязательной и может быть предложена для случаев 2-й степени токсичности или выше для мониторинга активности заболевания, для оценки достижения полной ремиссии, особенно при планировании возобновления терапии.

При поражении гепатобилиарной системы появляется повышение сывороточных печеночных ферментов - аланинаминотрансферазы или аспартатаминотрансферазы (в 2-10 \% случаев, при комбинированном лечении до 25-30\%, при этом токсичность 3-й степени регистрируется в $15 \%$ случаев). Симптомы развиваются преимущественно в течение первых 6-12 недель от старта лечения в большинстве случаев бессимптомно и проявляются только изменениями уровней печеночных ферментов. 
Диагностика. При ведении таких пациентов в обязательном порядке необходимо исключить вирусную инфекцию (хронические гепатиты В, C, D и E). Аутоиммунный гепатит на фоне лечения характеризуется отрицательными тестами на антинуклеарные антитела (ANA), антитела к гладкой мускулатуре, антитела к микросомам печени и почек. Достоверный диагноз аутоиммунного гепатита требует биопсии печени с обнаружением диффузной инфильтрации Т-клетками, выраженными синусоидальными гистиоцитарными инфильтратами и повреждением центральной вены. КТ и/или ультразвуковое исследование печени и желчевыводящих путей позволяют исключить метастатический процесс или желчнокаменную болезнь. У некоторых пациентов с ассоциированным гепатитом может отмечаться незначительная гепатомегалия, перипортальный отек или лимфаденопатия.

Рекомендуемая тактика. Пациентам необходимо назначить системные глюкокортикоиды в дозе, аналогичной для лечения колита, а в стероид-резистентных случаях (при отсутствии улучшения в течение 3 дней) к лечению следует добавлять азатиоприн или микофенолата мофетил в соответствии с рекомендациями по лечению аутоиммунного гепатита. Инфликсимаб не является подходящим вариантом лечения в ситуации иммуноопосредованного гепатита, в отличие от колитов, учитывая потенциальный риск идиосинкратической печеночной недостаточности.

Поражение эндокринной системы. Частота эндокринопатий, связанных с лечением ингибиторов контрольных точек составляет приблизительно $10 \%$. Чаще всего поражаются гипофиз, щитовидная и поджелудочная железы и надпочечники. Осложнения существенно возрастает при комбинированной терапии, чаще всего это гипотиреоз (17\%), гипофизит (13 $\%$ и и гипертиреоз (10\%). Диагностика поражения эндокринной системы в виде осложнений представляют значимую клиническую проблему, т.к. симптомы часто не распознаются врачами. Полиморфизм жалоб пациентов значительно затрудняет диагностику. Жалобы неспецифичны и включают тошноту, рвоту, головокружение, головную боль, изменение зрения, аритмии, повышенную потливость, необъяснимые колебания массы тела, чувство голода или жажды больше, чем обычно, выпадение волос, изменения настроения или поведения, усталость, вялость и общее недомогание.

Гunoфuзиm. Диагностика. У пациентов с подозрением на гипофизит следует обследовать систему «гипоталамус - гипофиз», включая определение свободного тироксина (T4), тиреотропного гормона (ТТГ), лютеинизирующего гормона (ЛГ), фолликулостимулирующего гормона (ФСГ), адренокортикотропного гормона (АКТГ) и кортизола, а также сывороточные электролиты. Для последующей тактики лечения крайне важно различать первичный и вторичный гормональный дефицит. Гипофизит может привести к вторичной надпочечниковой недостаточности и гипотиреозу. Неспособность распознать это заболевание имеет негативные последствия для ведения пациента. Магнитно-резонансная томография (МРТ) головного мозга с контрастированием должна быть назначена пациентам с эндокринными нарушениями, с впервые выявленными сильными головными болями и при нарушении зрения.

Рекомендуемая тактика. При развитии гипофизита рекомендуется воздержаться от любого вида терапии. При стабилизации состояния на фоне заместительной гормональной терапии лечение может быть возобновлено. При развитии гипофизита высокого уровня токсичности (3 и выше) пациентам необходимо назначить начальную пульс-терапию глюкокортикоидами с последующим назначением высоких доз per os. Необходимо контролировать уровень свободного T4, при дефиците которого следует назначать левотироксин. Ключевые понятия менеджмента включают высокий индекс клинических подозрений со стороны врача, определение локализации эндокринной дисфункции, назначение заместительной терапии гормонами и тщательный мониторинг. Ассоциированные с применением ингибиторов контрольных точек поражения эндокринной системы являются жизнеугрожающими, поскольку они часто необратимы и пациенты требуют пожизненной заместительной гормональной терапии. 
Наруиение функции иитовидной железы (гипотиреоз, гипертиреоз).Гипотиреоз является одним из наиболее распространенных эндокринных осложнений (более $6 \%$ ) он проявляться усталостью, непреднамеренным увеличением массы тела, непереносимостью холода, запорами, миалгией и сухостью кожи. Гипертиреоз, наоборот, достаточно редкое проявлением (не более 0,3-1 \%). Пациенты, как правило, жалуются на перебои в работе сердца, тахикардию, повышенную потливость, необъяснимую потерю массы тела, раздражительность, возбудимость, нарушение сна.

Диагностика. При физикальном обследовании при подозрении на гипотиреоз можно обнаружить зоб, брадикардию, диастолическую гипертензию, снижение сухожильных рефлексов. ТТГ и свободный Т4 должны быть проверены до начала терапии ингибиторов контрольных точек, в дальнейшем их контроль должен осуществляться каждые 4-6 недель или по мере необходимости. Важно отличать первичный гипотиреоз от вторичного, а также дифференцировать гипотиреоз от поздней фазы тиреоидита. Повышенный уровень ТТГ с низким значением свободного Т4 свидетельствует о биохимическом гипотиреозе, при обнаружении которого следует также исследовать уровень антител к пероксидазе щитовидной железы. При клинических признаках, вызывающих подозрение на возникновение болезни Грейвса (офтальмопатия, аритмия, неврологические симптомы), следует проверить наличие антител к рецептору ТТГ.

Рекомендуемая тактика. У пациентов с гипотиреозом и гипертиреозом 1-й степени токсичности терапия может быть продолжены на фоне тщательного мониторинга ТТГ и свободного Т4. Для токсичности 2-й степени и гипотиреозе следует назначать соответствующую заместительную гормональную терапию либо с продолжением терапии, либо с временной отменой до тех пор, пока у пациентов сохраняются симптомы с любым уровнем повышения ТТГ или у пациентов с бессимптомным течением и уровнями ТТГ $>10$ мME/л. Для пациентов без факторов риска доза заместительной гормональной терапии составляет 1,6 мкг/кг/сут. Для пожилых пациентов, пациентов с коморбидностями и низкой массой тела титрование дозы гормонов начинают с 25-50 мкг. В целом ТТГ следует контролировать каждые 2-3 недели во время титрования заместительной гормональной терапии до достижения нормального уровня ТТГ с повторным последующим тестированием ежегодно или в соответствии с клиническими показаниями. Токсичность 3-й и 4-й степени следует лечить как степень 2 при отсутствии признаков микседемы (нарушение ментального статуса, гипотония, гипогликемия, брадикардия, гипотермия), при наличии микседемы пациентам следует рекомендовать госпитализацию в эндокринологическое отделение.

У пациентов с гипертиреозом при токсичности 2-й степени терапию следует прекратить до возвращения показателей функции щитовидной железы к норме. К дополнительной терапии для облегчения симптомов гипертиреоза относят $\beta$-блокаторы. Глюкокортикоиды обычно не требуются для лечения гипертиреоза. Они применяются при развитии токсичности 4-й степени с жизнеугрожающими симптомами или при тиреотоксическом кризе. Пациента следует госпитализировать и начать терапию преднизолоном 1-2 мг/кг/сут, насыщенным раствором йодида калия или тиоамидами.

Поражение надпочечников. При подозрении на первичную надпочечниковую недостаточность рекомендуемое диагностическое обследование включает оценку уровней АКТГ, кортизола, электролитов $(\mathrm{Na}+, \mathrm{K}+)$ и глюкозы, проведение КТ надпочечников на предмет исключения метастазирования/кровоизлияния. До нормализации уровня гормонов и стабилизации состояния пациентов следует воздержаться от терапии ингибиторов контрольных точек при любом уровне токсичности. Для заместительной терапии первичной надпочечниковой недостаточности при 1-й степени токсичности следует рассмотреть преднизолон (5-10 мг/сут) или гидрокортизон (10-20 мг перорально утром, 5-10 мг перорально в полдень) или флудрокортизон $(0,1$ мг/сут) с титрованием дозы в зависимости от уровня симптомов. При 2-й степени токсичности дозы гормонов возрастают: преднизолон 20 мг/сут, гидрокортизон - 20-30 мг утром и 10-20 мг днем со снижением до поддерживающих доз в течение 5-10 дней [12]. При 3-4-й степени токсичности пациента 
необходимо госпитализировать в отделение неотложной помощи с введением ГК внутривенно (пульс-терапия) со снижением до поддерживающих доз в течение 7-14 дней после стабилизации состояния.

Поражение поджелудочной железы. Редкие случаи развития сахарного диабета 1-го типа на фоне терапии ингибиторами контрольных точек представляют собой актуальную проблему для клинициста в необходимости раннего выявления и дифференциации от гораздо более распространенных случаев нарушения гликемического контроля, связанного с метаболическим синдромом и сахарным диабетом 2-го типа. Факт развития ассоциированного сахарного диабета 1 типа требует бдительности со стороны онкологов, несмотря на очень низкую частоту возникновения. Впервые выявленная гипергликемия у пациентов без факторов риска развития сахарного диабета 2 типа (например, ранее существовавшее заболевание, прием глюкокортикоидов, отсутствие семейного анамнеза, отсутствие ожирения и др.) должна повысить уровень беспокойства лечащего врача по поводу сахарного диабета. Острое начало полиурии, полидипсии, снижение массы тела, нарушения сознания являются характерными признаками сахарного диабета. Необходимо обследовать уровень кетонов мочи и кислотно-щелочной статус, уровни инсулина и С-пептида для подтверждения диагноза, однако начало терапии не следует откладывать до получения результатов. Консультация эндокринолога необходима при подозрении на сахарный диабет даже без признаков диабетического кетоацидоза для установления диагноза и назначения корректной дозы инсулина.

\section{Поражение нервной системы.}

Неврологические токсические явления - достаточно редкие побочные проявления терапии ингибиторами контрольных точек $(<1 \%)$, однако они представляют особый интерес из-за их потенциальной клинической тяжести и фатальных последствий. Эти осложнения охватывают нарушения регуляции как центральной, так и периферической нервной системы, включают довольно широкий спектр неврологических расстройств. Пациенты могут страдать от головной боли, изменений психического статуса, двигательного или сенсорного дефицита, ненормального поведения, изменения личности, расстройств речи или двигательных нарушений. Первым шагом при таких состояниях необходимо исключить прогрессирования рака с поражением ЦНС, инфекций и метаболических нарушений как причин появившихся неврологических симптомов.

Асептический менингит. Диагностика асептического менингита на фоне иммунотерапии базируется на проведении МРТ головного мозга, исследовании уровня кортизола и АКТГ для исключения надпочечниковой недостаточности, люмбальной пункции с оценкой цитоза в СМЖ, уровня белка и глюкозы, проведении окрашивания по Граму, культурологического анализа, полимеразной цепной реакции (ПЦР) для исключения вирусных инфекций. Для асептического менингита в СМЖ характерно повышенное количество лейкоцитов с нормальным уровнем глюкозы, нормальная культура и окраска по Граму. При развитии индуцированного асептического менингита терапию следует отменить. Должна быть рассмотрена эмпирическая противовирусная (ацикловир в/в) и антибактериальная терапия до получения результатов СМЖ. При отрицательных ПЦР и культурологических исследованиях могут быть назначены гюкокортикоиды преднизолон 0,51 мг/кг или в/в метилпреднизолон 1 мг/кг при умеренных/тяжелых формах этого побочного эффекта.

Энщефалит. На МРТ головного мозга при индуцированном энцефалите в режиме T2/FLAIR (инверсия-восстановление с ослаблением сигнала от жидкости) можно выявить типичные изменения, которые наблюдаются при аутоиммунных энцефалопатиях или лимбических энцефалитах. В СМЖ характерно повышенное количество лейкоцитов с преобладанием лимфоцитов и повышенное содержание белка. Для исключения субклинической судорожной активности необходимо провести ЭЭГ, а для оценки возможных причин энцефалита проводят анализ ОАК, СРБ, антинейтрофильных цитоплазматических 
антител (при подозрении на васкулит, патологии щитовидной железы), включая антитела к тиреопероксидазе и тиреоглобулин.

Рекомендуемая тактика. При развитии индуцированного энцефалита терапию следует отменить. Как и в случае с асептическим менингитом, рекомендуется вводить ацикловир в/в до получения результатов ПЦР К лечению добавляют метилпреднизолон 1-2 мг/кг, а при наличии тяжелых или прогрессирующих симптомов или зон олигоклональных иммуноглобулинов на электрофореграмме иммуноглобулинов в СМЖ необходимо провести пульс-терапию метилпреднизолоном 1000 мг в/в ежедневно в течение 3-5 дней плюс в/в иммуноглобулины в дозе 2 г/кг в течение 5 дней. В стероид-резистентных случаях терапией выбора являются ритуксимаб и/или плазмаферез.

Muacmeния гравис (Myasthenia gravis). По экспертным оценкам, миастения встречается у $0,1-0,2 \%$ пациентов, получающих иммунотерапию. Это клиническое проявление манифестирует в течение 2-3 недель от начала лечения с интермиттирующими симптомами моторной слабости и усталости, которые часто ассоциированы с глазной и бульбарной дисфункцией.

Диагностика. Любые подозрения в пользу миастении требуют быстрой диагностики и лечения, учитывая возможность развития дыхательной недостаточности. Необходимо исследовать уровень специфичных для миастении антител к ацетилхолиновым рецепторам и против поперечнополосатых мышц, уровень мышечно-специфических киназ и липопротеина-4. Пациентам следует назначать электродиагностические исследования, включая тестирование нервно-мышечной передачи с итерационной стимуляцией нерва (repetitive nerve stimulation, RNS) или дрожания, исследование нервной проводимости для исключения невропатии, игольчатую ЭМГ для диагностики миозита и исследование функции внешнего дыхания. В целях дифференциального диагноза с миозитом необходимо определение миозит-специфических ферментов: креатининкиназы, альдолазы, скорости оседания эритроцитов и СРБ. Для исключения вовлечения ЦНС или сопутствующей патологии следует провести МРТ головного мозга и/или позвоночника в зависимости от преобладающих симптомов. Достаточно часто у пациентов, получавших иммунотерапию, наблюдалось сосуществование миастении, миозита и миокардита, поэтому назначение кардиологического исследования с проведением ЭКГ и трансторакальной эхокардиографии считается оправданным и целесообразным у всех пациентов с мышечной слабостью и миалгией.

Рекомендуемая тактика. Высокий уровень подозрения и быстрое начало терапии глюкокортикоидами в дозе 1-1,5 мг/кг/сут являются обязательными для предотвращения клинического ухудшения, которое может привести к дыхательной недостаточности и смерти. Пациентов с токсичностью 3-й или 4-й степени следует вести в условиях отделения интенсивной терапии, учитывая риск развития острой дыхательной недостаточности. Терапия высокими дозами глюкокортикоидами рекомендуется внутривенным иммуноглобулином в дозе 2 г/кг в течение 5 дней или плазмаферез в течение 5 дней. Пиридостигмин можно титровать для достижения оптимального облегчения симптомов начиная с 30 мг трижды в день и повышая до максимума - 120 мг. Следует избегать назначения лекарственных препаратов, способных усугубить миастению: b-блокаторы, препараты магния внутривенно, фторхинолоны, аминогликозиды и макролиды.

Периферическая нейротоксичность ингибиторов контрольных точек может проявляться как периферическая невропатия, вегетативная невропатия, синдром Гийена Барре и некротизирующий миозит.

Синдром Гийена - Барре. При подозрении на синдром Гийена — Барре диагностический подход включает следующие этапы: консультация невропатолога, МРТ позвоночника с контрастом или без него для исключение компрессионного поражения и оценки утолщения нервного корешка, проведение люмбальной пункции с оценкой СМЖ с обязательным выполнением цитологического исследования. Высокую диагностическую ценность имеет уровень сывороточных антиганглиозидных антител и их подтипов (например, анти-GQ1b для варианта Миллера — Фишера, связанного с атаксией и офтальмоплегией). 
Учитывая, что прогрессирующий синдром Гийена-Барре может привести к острой дыхательной недостаточности при развитии осложнения всех классов токсичности требуют отмены иммунотерапии и проведения неотложной терапии,. Рекомендуется госпитализация в стационар с возможностью быстрого перехода к мониторингу на уровне отделения интенсивной терапии. Терапию проводят внутривенными иммуноглобулинами в дозе 0,4 г/кг/сут в течение 5 дней с общей дозой 2 г/кг или плазмаферез плюс одновременный прием глюкокортикоидов в средних и высоких дозах. Необходимо также проводить постоянный мониторинг оценки функции внешнего дыхания.

Вегетативная невропатия При развитии вегетативной невропатии на фоне иммунотерапии необходимо в первую очередь провести скрининг на другие причины вегетативной дисфункции: сахарный диабет, надпочечниковая недостаточность, ВИЧ, парапротеинемия, амилоидоз, ботулизм, паркинсонизм и другие состояния, провести электродиагностические исследования для оценки сопутствующей полинейропатии, рассмотреть целесообразность тестирования на антитела, характерные для паранеопластической аутоиммунной вегетативной дисфункции (например, антиганглионарный рецептор ацетилхолина, антинейрональное ядерное антитело типа 1 и антитела к потенциал-управляемым кальциевым каналам N-типа). Дифференциальная диагностика в данной ситуации всегда сложная. Пациенты с вегетативной невропатией 1-й степени токсичности могут продолжить прием ингибиторов контрольных точек под тщательным наблюдением невролога с регулярным контролем симптомов; при развитии токсичности 2-4-й степени от терапии следует воздержаться. В лечебной тактике рекомендуется прием преднизолона в дозе 0,5-1 мг/кг при 2-й степени токсичности и пульстерапия метилпреднизолоном по 1000 мг/сут трижды при 3-4-й степени токсичности с последующим назначением оральных доз глюкокортикоидов.

Поперечный миелит. Предпочтительным методом исследования является МРТ позвоночника (с тонкими осевыми срезами в области предполагаемой аномалии) и МРТ головного мозга с контрастом и без него. Необходимо также проведение исследования СМЖ с оценкой зон олигоклональных иммуноглобулинов и онконевральных антител. В анализах крови следует уделить внимание уровню витамина В12, обследовать пациента на ВИЧ, сифилис, определить ANA, ТTГ, аквапорин-4, иммуноглобулин G.

Рекомендуемая тактика такая же как при энцефалите.

\section{Кардиоваскулярная патология}

Абсолютная частота кардиоваскулярных осложнений составляет $<1 \%$, однако истинная частота, вероятно, выше в связи с недооценкой кардиотоксичности этой терапии. Так вероятность развития миокардита у пациентов, получающих иммунотерапию, в 11 раз выше, чем у лиц, не получавших эту терапию, со средним временем начала через 30 дней после начала применения препаратов. Риск может быть увеличен при использовании комбинированной терапии. Сердечно-сосудистые осложнения в результате терапии могут быть потенциально смертельными. Наиболее часто регистрируемым поражением сердца является миокардит. Именно миокардит имеет самый высокий уровень летальности среди всех описанных иммунозависимых осложнений. Это осложнение может иметь молниеносное и прогрессирующее течение и быть жизнеугрожающим проявлением. Клинические проявления миокардита могут варьировать от слабости, боли в груди, острой сердечной недостаточности до нарушения проводимости, желудочковых аритмий, кардиогенного шока и внезапной смерти. Также могут иметь место острая ишемия миокарда, впервые выявленная систолическая дисфункция, перикардит и синдром Такоцубо.

Диагностика. Миокардит характеризуется повышенными уровнями сердечных ферментов (тропонин, промозговой натрийуретический пептид (про-BNP)) с дисфункцией левого желудочка или без нее и с признаками воспаления миокарда по данным МРТ сердца или позитронно-эмиссионной томографии. В случаях неопределенности в диагностике необходимо проведение эндомиокардиальной биопсии, хотя неинвазивным исследованиям отдается предпочтение. 
Рекомендуемая тактика. Терапия кардиальной токсичности требует учета степени развития сердечной недостаточности. Эффективное лечение требует тщательного мониторинга с помощью мультимодального терапевтического плана, состоящего из приостановки иммунотерапии (временный отказ при 1-3-й степени токсичности и полный отказ - при 4-й), высоких доз глюкокортикоидов (1-2 мг/кг преднизолона в сутки) и ранней консультации кардиолога и ревматолога для предотвращения острых кардиоваскулярных событий. В случае развития стероид-резистентного миокардита необходимо к лечению добавить микофенолата мофетил, инфликсимаб или антитимоцитарный глобулин. Однако конкретных данных, демонстрирующих эффективность этих иммуносупрессивных препаратов, нет. Нарушение проводимости является распространенной и потенциально серьезной причиной внезапной смерти, вызванной терапией, даже при отсутствии миокардита. В этом случае необходима консультация кардиолога для рассмотрения вопроса об имплантации кардиостимулятора или дефибриллятора; решение о продолжении иммунотерапии должно приниматься совместно с пациентом, кардиологом и онкологом.

\section{Поражение органов дыхания (пневмонит)}

Пневмонит, ассоциированный с иммунотерапией, определяется как развитие новых инфильтратов в легочной паренхиме при визуализации грудной клетки в сочетании с одышкой или другими респираторными симптомами, но в отсутствие признаков инфекции, сердечной дисфункции или прогрессирования опухоли. Клинические проявления поражения легких при применении ингибиторов контрольных точек неоднородны, начиная от бессимптомных рентгенологических изменений, болей в груди, кашля или одышки и заканчивая тяжелой дыхательной недостаточностью. Общая частота пневмонитов на фоне лечения колеблется от 0 до $10 \%$, со средним временем до начала 1-3 месяца. Пациенты, получающие комбинированную терапию, подвергаются повышенному риску развития поражения легких (соответственно 10 против $3 \%$ ), причем симптомы у этих пациентов проявлялись намного раньше. В исследовании причин смертельных токсических эффектов, связанных с иммунотерапией, пневмониты, ассоциированные с анти-PD-1/PD-L1, обусловливали $35 \%$ всех смертельных исходов. Клинические проявления пневмонита разнообразны и индивидуальны, могут включать кашель, хрипы, слабость, боль в груди или отсутствие симптомов вообще. В дополнение к типичным признакам пневмонита с CTLA-4- и с PD1/PD-L1-таргетной терапией были ассоциированы саркоидоподобные гранулематозные реакции, включая субплевральные микронодулярные инфильтраты, внутригрудную лимфаденопатию и плевральный выпот. При различной клинической картине клиницистам целесообразно осознавать возможность возникновения легочных реакций, связанных с осложнениями, поскольку они могут имитировать прогрессирование заболевания.

Диагностика. Физикальное обследование при пневмонитах может быть очень малоинформативным. Дифференциальная диагностика должна включать респираторную инфекцию, пневмоцистную пневмонию или аспергиллез (особенно при лечении высокими дозами глюкокортикоидов), прогрессирование опухоли, радиационно-индуцированный пневмонит, индуцированный миокардит и/или сердечную недостаточность. Диагностическая оценка базируется на исключении прежде всего инфекционной этиологии - бактериальный посев мокроты, исследования на предмет вирусной этиологии, бактериальный посев крови, сывороточный галактоманнан, компьютерная томография легких, при необходимости бронхоскопия с бронхоальвеолярным лаважем и биопсия легкого. Последнее исследование, как правило, не обладает высокой диагностической ценностью, но может быть полезно для исключения инфекции или оценки распространения лимфангитической опухоли. КТ грудной клетки с высоким разрешением является предпочтительным методом визуализации. При помощи этого исследования можно выявить помутнение по типу «матового стекла» или очаговые узловатые инфильтраты, преимущественно в нижних долях, при ассоциированных пневмонитах. Кроме того, пациентам следует проводить оценку функции внешнего дыхания и диффузионной способности легких к монооксиду углерода. КТ и спирометрию следует повторить через 3-4 недели после проведенного лечения для определения ее эффективности. 
Для исключения легочной тромбоэмболии необходимо провести КТ с внутривенным контрастированием.

Рекомендуемая тактика. Терапия гюкокортикоидами является основой лечения индуцированных пневмонитов, причем у более чем 80 \% пациентов разрешение поражения легких происходит на фоне изолированного лечения преднизолоном. Для лечения пневмонита 1-й или 2-й степени токсичности используют низкие дозы $(0,5-1$ мг/кг/сут) и тщательное наблюдение. Пневмониты с развитием более высокого уровня токсичности требуют высоких доз, иногда в виде пульс-терапии. Требуются также консультации пульмонолога и инфекциониста для исключения инфекционного процесса. В некоторых случаях может назначаться эмпирическая противомикробная терапия при невозможности полного исключения инфекции. У пациентов без клинического улучшения пневмонита в течение 48 72 ч с момента назначения преднизолона должны быть рассмотрены препараты второй линии, которые включают инфликсимаб 5 мг/кг, микофенолата мофетил в/в 1 г два раза в день, внутривенный иммуноглобулин в течение 5 дней или циклофосфамид. Ретроспективные исследования отмечают, что течение $86 \%$ пневмонитов улучшается на фоне лечения преднизолоном, однако вызывает беспокойство очень слабый ответ на дополнительную иммуносупрессию.

\section{Поражение органов зрения}

Распространенность офтальмологических осложнений составляет $<1 \%$ среди пациентов, получавших иммунотерапию. Офтальмологические поражения чаще проявляются как увеит и/или синдром сухого глаза. Глазные осложнения в среднем отмечаются через 2 месяца от начала терапии и чаще ассоциируются с другими осложнениями, поэтому в данном случае клиническое подозрение на другие побочные эффекты иммунотерапии должно быть высоким. Пациенты жалуются на боль в глазах, усиливающуюся при движении, покраснение склер, нарушение зрения, диплопию и светобоязнь. Менее характерные индуцированные поражения глаз включают воспалительную орбитопатию, кератит, хориоидальную неоваскуляризацию, серозную отслойку сетчатки, ретинопатию, нейроретинит и глазную миастению.

Диагностика и рекомендуемая тактика. Обычно большинство глазных осложнений не требуют прекращения иммунотерапии и разрешаются при назначении местного лечения. Все пациенты должны быть проконсультированы офтальмологом для исследования глазного дна с оценкой наличия лейкоцитов в передней камере глаза и степени воспаления. Тем не менее при наличии токсичности 2-3-й степени терапию следует временно прекратить. Искусственные слезы, топические глюкокортикоиды и циклоплегические препараты достаточно эффективны в управлении этой токсичностью, в редких случаях могут потребоваться системные гормоны. Нарушения зрения являются показанием к неотложной офтальмологической помощи для оценки необходимости специализированных вмешательств и прекращения терапии до улучшения состояния. Дополнительные терапевтические стратегии включают системные и местные (введение в стекловидное тело) глюкокортикоиды, применение ингибиторов ФНО. В частности, прием инфликсимаба можно рассматривать в стероид-резистентных случаях.

\section{Поражение почек}

Нефрит является наиболее распространенным клиническим проявлением почечной токсичности у пациентов на фоне терапии анти-PD-1/PD-L1 и чаще встречается у лиц с НМРЛ, получавших комбинацию химиотерапии и иммунотерапии, которая в настоящее время является стандартной терапией первой линии для пациентов с прогрессирующим НМРЛ. Существует значительная гетерогенность во времени возникновения повреждения почек: нефротоксичность на фоне терапии CTLA-4 возникает ранее (диапазон - 2-3 месяца) по сравнению с более поздним началом повреждения почек, ассоциированным с применением PD-1 (диапазон - 3-10 месяцев). Чаще всего при иммунотерапии возникает острый интерстициальный нефрит. Опосредованное повреждение почек варьирует от 1 до 2 \% в 
монотерапии и 4,5\% - в комбинированной терапии, однако ряд исследований выявили более высокую заболеваемость - в диапазоне от 9,9 до $29 \%$.

Диагностика. Почечные осложнения часто протекают бессимптомно, поэтому для своевременного выявления необходим регулярный мониторинг почечных показателей (сывороточный креатинин, электролиты, общий анализ мочи и УЗИ почек). При индуцированном нефрите можно выявить пиурию (68 \%), гематурию (16 \%) и/или протеинурию в анализе мочи и эозинофилию (21\%) в ОАК. У некоторых пациентов могут наблюдаться тошнота, рвота, усталость, изменение психического статуса, уменьшение количества мочи и ее прозрачности, периферические отеки или одышка.

Рекомендуемая тактика. Терапия должна быть временно приостановлена для оценки основной причины поражения почек. Если альтернативной причины не выявлено, предполагается, что у пациентов имеется иммуноопосредованная токсичность, при которой от терапии следует воздержаться. При 2-й степени токсичности следует назначать преднизолон в дозе 0,5-1 мг/кг/сут, а при 3-й - более высокие дозы в диапазоне 1-2 мг/кг/сут. Дополнительная иммуносупрессия, включая микофенолата мофетил, может рассматриваться в случаях, устойчивых к глюкокортикоидам, и при отсутствии эффекта от терапии в течение 3-5 дней. Биопсия почки не рекомендуется, пока не предпринята попытка лечения кортикостероидами, которые являются основой лечения.

Терапия безопасна у пациентов с исходной почечной недостаточностью неиммунного характера (например, нефрэктомия, поликистоз почек, диабетическая и гипертензивная нефропатия). Ограниченные данные свидетельствуют о том, что риск отторжения почечного аллотрансплантата на фоне терапии анти-CTLA-4 меньше, чем при лечении анти-PD-1.

\section{Иммунозависимые побочные эффекты по типу гиперчувствительности}

Данные о частоте иммунозависимые осложнений по типу гиперчувствительности сильно варьируют. Так, частота артралгии колеблется от 1 до $43 \%$, а диапазон других проявлений составляет $0,7-5,1 \%$.

Артралгия и артрит являются наиболее часто встречающимися иммунозависимые осложнения по типу гиперчувствительности. Имеет различное время манифестации от момента начала лечения (диапазон от 1 до 24 месяца). Клинические проявления артрита варьируют в клинических наблюдениях в виде олигоартритов, полиартритов и реактивных артритоподобных проявлений. Считается, что у пациентов, получавших комбинированную терапию, в сочетании с другими осложнениями с большей вероятностью вовлекаются крупные суставы, при монотерапии, чаще имели поражение мелких суставов и артрит был единственным осложнением. Эти пациенты также могут иметь признаки, характерные для реактивного артрита (такие как конъюнктивит или уретрит), и иногда жалуются на боль/скованность в спине или в шее, наводящую на мысль о сакроилеите и спондилите. Также у пациентов можно наблюдать симметричное поражение мелких суставов, напоминающее ревматоидный артрит, кроме того, эти пациенты часто проявляют серопозитивность по ревматоидному фактору и антицитруллинированному циклическому пептиду (анти-ЦЦП). Такие клинические сочетания значительно затрудняют проведение дифференциальной диагностики, они требуют тщательной оценки состояния пациента и клинико-лабораторных находок, клинических размышлений, что возможно только при высокой квалификации врача.

Диагностика. Пациентам должно быть проведено полное обследование костномышечной системы. Лабораторные исследования, включая ОАК, СРБ, ревматоидный фактор анти-ЦЦП, ANA и HLA-B27, могут помочь дифференцировать фенотипы артрита с целью индивидуального подхода к лечению. Также обязательно должна быть проведена визуализация суставов, включая рентгенографию, УЗИ или МРТ суставов, для оценки наличия выпота, синовита и его пролиферации, эрозивных поражений и тендовагинита.

Рекомендуемая тактика. Раннее распознавание артрита и консультация ревматолога имеют решающее значение для предотвращения эрозивного повреждения суставов и развития их функциональной недостаточности. Лечение может быть продолжено при токсичности 1-й степени с назначением анальгетических препаратов и нестероидных противовоспалительных 
средств. При токсичности 2-й степени от терапии следует воздержаться и возобновить ее при контроле симптомов и дозе преднизолона $\leq 10$ мг/сут. Для усиления анальгезирующего эффекта следует рассмотреть возможность назначения более высоких доз НПВС, при их неэффективности следует назначать перорально преднизолон 10-20 мг/сут в течение 4-6 недель с последующим постепенным снижением дозы в течение 1 месяца или внутрисуставное введение ГК при моноолигоартрите. При развитии токсичности 3-4-й степени терапию следует прекратить, возможно ее возобновление при улучшении состояния пациента. Необходимо назначать перорально преднизолон $0,5-1$ мг/кг/сут, при отсутствии улучшения через 4 недели или усугублении суставного синдрома необходимо добавить антиревматические препараты: биологические (антицитокиновая терапия, терапия ингибиторами рецептора ФНО- $\alpha$, интерлейкина-6 (ИЛ-6)) или синтетические (метотрексат, лефлуномид). В стероидно-резистентных случаях общепринятый подход заключается в инициации терапии метотрексатом с эскалацией дозы вплоть до назначения биологических агентов при отсутствии адекватного клинического ответа.

Особенностью ревматических осложнений, в частности индуцированных воспалительных артритов, является их склонность к стойкости и рецидивированию, несмотря на прекращение терапии, это может потребовать длительной иммуномодулирующей терапии от нескольких месяцев до нескольких лет после постановки диагноза.

Полимиалгия-подобный синдром. Одним из побочных эффектов иммунотерапии рака является тяжелая миалгия в проксимальных отделах мышц верхних и нижних конечностей, с сопутствующей выраженной слабостью, артралгией без признаков синовита, клинически напоминающей ревматическую полимиалгию. Необходимо отметить, что в реальной практике сам диагноз ревматической полимиалгии требует тщательной дифференциации и исключения онкопатологии.

Диагностика. Следует проводить дифференциальную диагностику с воспалительным миозитом, фибромиалгией, статин-индуцированной миопатией и другими видами миопатий. Важным шагом является определение миозит-специфических ферментов, прежде всего креатинфосфокиназы (КФК), альдолазы, АсАТ, для дифференциации с миозитом. Визуализация с помощью МРТ и электромиография (ЭМГ) позволяет оценить признаки миопатии или воспаления мышц.

Рекомендуемая тактика. При токсичности 2-3-й степени от применения ингибиторов контрольных точек следует воздержаться, назначить обезболивающие препараты и/или НПВС при необходимости. При 2-й степени токсичности доза преднизолона составляет $<10$ мг, при 3-й - 20 мг/сут. При уменьшении степени выраженности симптомов дозу глюкокортикоидов необходимо снижать через 3-4 недели. При отсутствии улучшения и 4-й степени токсичности наряду с приемом преднизолона рекомендуется использовать стероид-сберегающий агент метотрексат или ингибитор ИЛ-6 тоцилизумаб.

Гигантоклеточный артериит. У пациентов, получавших ингибиторы контрольных точек, шанс развития гигантоклеточного артериита в 13 раз выше, чем у пациентов, не получавших эту терапию. Среднее время начала этого осложнения составило 55 дней (диапазон - 21-98) с большей предрасположенностью у пожилых пациентов, пациентов европеоидной расы и у больных с меланомой. Симптомы аналогичны симптомам традиционной болезни, включая головную боль в височной области, привычный подвывих нижней челюсти, потерю монокулярного зрения, необъяснимую лихорадку и слабость.

Диагностика. Ранняя диагностика имеет жизненно важное значение для предотвращения глазных и цереброваскулярных осложнений. Необходимо провести полное обследование - ОАК и СРБ. Биопсия височной артерии является золотым стандартом диагностического теста и обеспечивает точный диагноз, но может быть заменена визуализацией височных артерий при УЗИ и контрастной МРТ.

Рекомендуемая тактика. Пациентам с подозрением на осложнения в виде гигантоклеточного артериита следует проводить лечение в соответствии с рекомендациями по лечению артериита. В случае отсутствия глазных симптомов лечение включает преднизолон 1 мг/кг/сут (максимальная доза - 60 мг/сут). Пациентам с угрозой или установленной потерей 
зрения на момент постановки диагноза следует начинать с внутривенного введения пульстерапии глюкокортикоидами в течение 3 дней с последующей пероральной терапией высокими дозами стероидов. Высокие дозы пероральных ГК следует назначать в течение 2-4 недель, после чего дозу следует снижать на 10 мг каждые 2 недели, пока не будет достигнута доза 40 мг/день; в дальнейшем рекомендуется более медленный темп схождения с дозы - 5 мг каждые 2 недели до 20 мг/сут. В случае рецидивирующих симптомов, несмотря на высокие дозы глюкокортикоидов, необходимо добавить биологические (антицитокиновая терапия, терапия ингибиторами рецептора $Ф Н О-\alpha$, интерлейкина-6 (ИЛ-6)) или синтетические (метотрексат, лефлуномид) препараты. Наиболее высокую эффективность продемонстрировал абатацепт, метотрексат и тоцилизумаб являются альтернативным подходом. Возобновление терапии ингибиторами ИКТ может быть рассмотрено по достижении дозы преднизолона $<10$ мг/сут при стойком контроле симптомов и после согласования тактики с ревматологом.

Миозит является редким осложнением терапии ингибиторов онтрольных точек, однако его течение отличается агрессивностью, резистентностью и ассоциируется с плохим прогнозом. Миозит чаще встречается при приеме ингибиторов PD-1/PD-L1. Поражение мышц может реактивироваться в результате ранее существовавшего паранеопластического полимиозита/дерматомиозита или быть миозитом de novo. Основным симптомом воспалительного миозита является слабость, преимущественно в проксимальных отделах мышц конечностей, с невозможностью находиться в вертикальном положении, поднимать руки и передвигаться или выраженным ограничением этих функций. У пациентов с миозитом de novo типичная сыпь, характерная для дерматомиозита, не наблюдается. Миозит может иметь молниеносное некротизирующее течение с рабдомиолизом, способен поражать жизненно важные скелетные мышцы, такие как миокард, дыхательные мышцы, и в этом случае требуется неотложное лечение, чтобы избежать фатальных осложнений.

Диагностика. Лабораторные тесты включают исследования уровня мышечных ферментов трансаминаз (АсАТ, АлАТ), лактатдегидрогеназы (ЛДГ), альдолазы; наиболее специфично повышение КФК и воспалительных маркеров. При подозрении на поражение миокарда необходимо исследовать уровень тропонинов, провести эхокардиографию. Нет никаких доказательств диагностического значения присутствия каких-либо конкретных аутоантител при иИКТ-ассоциированном миозите. На ЭМГ можно выявить типичные для миопатии изменения, на МРТ - сигнал повышенной интенсивности и отек пораженных мышц. Для подтверждения диагноза необходимо проведение биопсии мышц. Дифференциальная диагностика включает синдром хронической усталости, ревматическую полимиалгию, фибромиалгию, побочные явления сопутствующей терапии (например, статины, глюкокортикоиды) и мышечную дистрофию, при которых уровень КФК и воспалительных маркеров нормальный.

Рекомендуемая тактика. Пациентов с подозрением на миозит обязательно должен проконсультировать ревматолог. При развитии токсичности 1-й степени терапию можно продолжать. При значимом повышении уровня КФК, прогрессирующей мышечной слабости необходимо рассмотреть назначение пероральных глюкокортикоидов и рассматривать такого пациента, как с уровнем токсичности 2-й степени. При 2-й степени токсичности терапию следует отменить; возобновить прием возможно при контроле симптомов, нормализации КФК и дозе преднизолона $<10$ мг/сут. При сохранении симптомов, устойчивом повышении КФК в 3 и более раза и вовлечении миокарда доза преднизолона составляет $0,5-1$ мг/кг/сут. При развитии токсичности 3-4-й степени терапию следует сразу же отменить, пациента госпитализировать, проконсультировать у ревматолога и невропатолога, назначить преднизолон в дозе 1-2 мг/кг, особенно при значительном ограничении подвижности, сердечной и дыхательной недостаточности, дисфагии. При отсутствии эффекта в течение 4-6 недель пациенту следует предложить иммуносупрессивную терапию метотрексатом, азатиоприном или микофенолата мофетилом, также рекомендуется применение плазмафереза и внутривенных иммуноглобулинов в высоких дозах (из расчета $1-2$ г/кг). При 4-й степени токсичности рекомендуется пульс-терапия ГК с последующей пероральной терапией в 
высоких дозах. Ритуксимаб также можно использовать при миозите и 4-й степени токсичности, но рекомендуется соблюдать осторожность, учитывая его длительный период полувыведения.

Другие ревматические осложнения включают васкулит, синдром сухого глаза, волчаноподобные синдромы. Принципы лечения аналогичны тем, о которых сообщалось для других ревматических синдромов, вызванных ингибиторами контрольных точек. Начиная со 2-й степени токсичности рекомендуется отмена препаратов для лечения рака, назначение глюкокортикоидов и в дальнейшем иммуносупрессивной терапии.

Пациенты с ранее существовавшими аутоиммунными ревматическими заболеваниями могут подвергаться как более высокому риску токсичности развития осложнений, так и обострениям своего ранее существовавшего заболевания. Тем не менее многие из этих пациентов могут продолжать терапию ингибиторами контрольных точек, аутоиммунное заболевание в анамнезе не является абсолютным противопоказанием для назначения иммунотерапии рака. Этим пациентам необходим тщательный мониторинг и мультидисциплинарное ведение, так как они нуждаются в сопутствующем лечении своих ранее сушествовавших аутоиммунных заболеваний.

\section{Гематологические проявления}

Гематологические осложнения, индуцированные анти-PD-1/PD-L1/CTLA-4, включают аутоиммунную гемолитическую анемию, приобретенную тромботическую тромбоцитопению, гемолитический уремический синдром, иммуноопосредованную тромбоцитопению, лимфопению и приобретенную гемофилию.

Апластическал анемия встречается примерно у $11 \%$ пациентов, получающих иммунотерапию, причем с развитием 3-4-й степени токсичности в среднем у $5,4 \%$ (от 1,1 до $17 \%$ ). Анемия может трансформироваться в панцитопению с развитием аутоиммунной апластической и гемолитической анемии и миелодисплазии. Гематологическая токсичность различных ингибиторов контрольных точек одинакова.

Диагностика. Необходимо исключить сопутствующие возможные причины апластической анемии: прием лекарственных препаратов, воздействие радиации, токсинов, перенесенные недавно вирусные инфекции. Обязательными диагностическими исследованиями при развитии анемии у пациентов, получающих иммунотерапию, являются: ОАК, подсчет ретикулоцитов, вирусологическое исследование (цитомегаловирусная инфекция (ЦМВ), вирус герпеса человека 6, вирус Эпштейна - Барр, парвовирус), уровень витамина В12, фолатов, железа, меди, церулоплазмина, витамина $\mathrm{D}$, исследование функции печени и почек.

Рекомендуемая тактика. При развитии такого осложнения, как апластическая анемия, от иммунотерапии следует воздержаться; пациентам назначают препараты факторов роста, гемотрансфузию, при необходимости с ежедневной лабораторной оценкой. При развитии токсичности 2-4-й степени к терапии добавляют антитимоцитарный глобулин и гранулоцитарный колониестимулирующий фактор. При отсутствии положительной динамики на фоне проведенной терапии к лечению следует добавить иммуносупрессивную терапию (циклоспорин и алемтузумаб).

Аутоиммунная гемолитическая анемия. У пациентов с развитием аутоиммунной гемолитической анемии на фоне иммунотерапии необходимо тщательно собрать анамнез на предмет использования лекарственных препаратов, вызывающих гемолиз (рибавирин, рифампин, дапсон, интерферон, цефалоспорины, пенициллины, НПВП, хинин/хинидин, флударабин, ципрофлоксацин, лоразепам и др.), возможных укусов насекомых, пауков или змей накануне, провести скрининг пароксизмальной ночной гемоглобинурии и метгемоглобинемии. Среди дообследований с особым вниманием следует оценить выраженность анемии, наличие макроцитоза и признаков гемолиза: гаптоглобин, билирубин, количество ретикулоцитов, свободный гемоглобин. Рекомендуется исследование панели внутрисосудистой коагуляции, включая протромбиновое время (ПТ) и международное нормализованное отношение (МНО), проведение электрофореза белков и их фракций и оценку 
наличия криоглобулинемии. Кроме того, следует обратить внимание на уровни витамина В12, фолатов, железа, глюкозо 6 фосфатдегидрогеназы. При отсутствии очевидной причины гематологического поражения необходимо провести цитогенетический анализ костного мозга.

Рекомендуемая тактика. При развитии гематологической токсичности 1-й степени терапия может быть продолжен на фоне тщательного клинического наблюдения и лабораторной оценки. При развитии аутоиммунной гемолитической анемии 2-й степени токсичности и выше рекомендуется рассмотреть вопрос о постоянном прекращении применения терапии. При появлении токсичности рекомендуется начать пероральный прием преднизолона; при 2-й степени токсичности и выше - перейти на внутривенное введение и пульс-терапию метилпреднизолоном; при 3-4-й степени рекомендуется дополнительный прием фолиевой кислоты 1 мг/сут. Следует оценивать необходимость переливания крови в соответствии с существующими рекомендациями - трансфузия минимального количества эритроцитарных единиц, необходимого для уменьшения симптомов анемии или для возврата пациента к безопасному уровню гемоглобина (70-80 г/л). При отсутствии улучшения или ухудшении состояния на фоне назначения кортикостероидов или выраженных симптомов следует начать прием других иммунодепрессантов, таких как ритуксимаб, иммуноглобулины, циклоспорин А и микофенолата мофетил.

Лимфопения. При развитии лимфопении на фоне иммунотерапии необходимо уделить особое внимание возможным сопутствующим причинам — терапия препаратами, вызывающими деплецию лимфоцитов: флударабин, антитимоцитарный глобулин, цитотоксическая химиотерапия, облучение, аутоиммунное заболевание в анамнезе. Кроме того, необходимо выполнить рентгенографию органов грудной клетки для исключения тимомы, провести бактериологическое исследование для исключения инфекционной этиологии лимфопении (грибковые, вирусные, бактериальные инфекции, особенно ЦМВ/ВИЧ). Следует отметить, что лимфопения не является редким побочным проявлением терапии, и степень лимфопении следует оценивать по количеству CD4 лимфоцитов.

Рекомендуемая тактика. При развитии токсичности 1-3-й степени терапию возможно продолжать с еженедельным контролем ОАК. При развитии токсичности 4-й степени необходимо инициировать комплексную профилактику Mycobacterium avium, профилактику пневмонии Pneumocystis jirovecii и ЦМВ.

Тромбочитопения, индуцированная иммунотерапией по данным исследований, встречается сравнительно редко, и составляет в среднем $8 \%$ (от 1 до $28 \%$ ).

Диагностика. При развитии тромбоцитопении следует исключить другие возможные этиологические факторы, включая тромбоцитопеническую микроангиопатию, гемолитикоуремический синдром, синдром диссеминированного внутрисосудистого свертывания, миелодиспластический синдром. Необходимо оценить ОАК, уровень активности гаптоглобина, количество ретикулоцитов, билирубина, ПТ, активированного частичного тромбопластинового времени (АЧТВ), фибриногена, провести прямой тест на антиглобулин, серологическое исследование на ЦМВ, ВИЧ, вирус гепатита В и С.

Рекомендуемая тактика. Первым шагом при индуцированной тромбоцитопении является высокий индекс подозрений и своевременное распознавание. У большинства пациентов развитие этого осложнения любой степени токсичности требует прекращения иммунной терапии, консультации гематолога и назначения пероральных глюкокортикоидов при необходимости гемотрансфузии. Доза преднизолона при 1-2-й степени токсичности составляет 0,5-1 мг/кг/сут. При развитии токсичности 3-4-й степени следует назначить курсы плазмафереза в соответствии с существующими рекомендациями. Количество процедур зависит от клинического прогресса. После первого плазмафереза назначают пульс-терапию метилпреднизолоном по 1000 мг в/в ежедневно в течение 3 последовательных дней с последующим переходом на пероральный прием преднизолона из расчета 1-2 мг/кг/сут. Возможно применение дополнительных методов лечения, таких как в/в иммуноглобулин, рекомендуется однократное введение в дозе 1 г/кг. При неэффективности терапии глюкокортикоидами и в/в иммуноглобулина последующее лечение может включать спленэктомию, применение ритуксимаба, агонистов рецептора тромбопоэтина или более 
сильную иммуносупрессию

циклоспорином

А, микофенолата

мофетилом

и циклофосфамидом.

Гемолитико-уремический синдром. Развитие гемолитико-уремического синдрома на фоне иммунотерапии является жизнеугрожающим осложнением с высоким риском фатального исхода. Необходимо тщательно собрать анамнез с особым вниманием к приему препаратов высокого риска, оценить ОАК с определением количества ретикулоцитов и среднего объема эритроцитов, а при наличии макроцитоза исследовать уровень витамина В12 и фолатов, обратить внимание на наличие шистоцитов в мазке крови, что имеет решающее значение для диагностики, исследовать уровни креатинина, определить ADAMTS13 (для исключения тромбоцитопенической пурпуры), активность фракций комплемента - C3, C4, CH50 (антитела, ингибирующие комплемент, при подозрении на врожденные мутации генов). Учитывая, что в $90 \%$ случаев причиной гемолитико-уремического синдрома является инфекция, вызванная бактериями, продуцирующими веротоксин, - энтерогеморрагическим штаммом Escherichia coli (ЕНEC, серотип О157:H7 и О104:H4) или Shigella dysenteriae, необходимо провести исследования на эти возбудители. Кроме того, диагностический поиск включает проведение скрининга на ВЭБ, ЦМВ, вирус герпеса человека 6. Для исключения других причин гемолиза следует провести прямой тест на антитела (тест Кумбса), определение гаптоглобина и Лдг.

Рекомендуемая тактика. В случаях развития токсичности -1-2-й степени рекомендуется продолжать лечение с тщательным клиническим наблюдением и лабораторной оценкой. При развитии токсичности 3-4-й степени препараты необходимо отменить, инициировать терапию экулизумабом 900 мг в неделю № 4, 1200 мг на 5-й неделе и затем 1200 мг каждые 2 недели [13].

Приобретенная гемофилия. Диагностическая оценка у пациента с подозрением на гемофилию, индуцированную иммунотерапией, включает ОАК с определением числа тромбоцитов, фибриногена, ПТ, АЧТВ, МНО. При использовании ингибиторов контрольных точек были описаны коагулопатии, ассоциированные с дефицитом VIII фактора свертывания. Типичным признаком у пациентов с приобретенной гемофилией А является увеличение длительности АЧТВ с нормальным ПТ. Инструментальные методы показаны для верификации места кровотечения.

Рекомендуемая тактика. При развитии такого осложнения, как гемофилия, лечение следует немедленно прекратить, проконсультироваться с гематологами. При токсичности 1-й степени преднизолон назначают в дозе $0,5-1$ мг/кг/сут, 2-4-й - к преднизолону в дозе 1 мг/кг/сут добавляют ритуксимаб (375 мг/м2 в неделю в течение 4 недель) и/или циклофосфамид (от 1 до 2 мг/кг/сут). При 4-й степени токсичности могут использоваться факторы свертывания (фактор VII, VIII).

\section{Препараты с цитотоксическим действием}

В отличии от ингибиторов контрольных точек, группа мАТ к различным клеточным рецепторам вызывают гибель этих клеток, что позволило их рассматривать как противоопухолевые средства. В некоторых случаях эти препараты применяются при тяжелых аутоиммунных и аутовоспалительных заболеваниях и аллергиях (табл.119).

Механизм действия этих препаратов связан со специфической связью моноклонального антитела со определенным эпитопом и запуском механизмов ведущие к гибели «помеченных» клеток. Это может быть антителозависимая клеточно-опосредованная цитотоксичность, антителозависимый клеточный фагоцитоз, комплементзависимая цитотоксичность. Кроме этого, гибель клетки может быть за счет индукции программируемой клеточной гибели посредством Fс-независимого механизма. Так же может моноклональное антитело может блокировать определенный рецептор на клетки, что приводит к прерыванию внутриклеточных сигнальных цепей, блокаде биоактивных молекул, важных для реализации злокачественного фенотипа, индукции идиотип-антиидиотипического ответа. 
Таргетные препараты с цитотоксическим действием

\begin{tabular}{|c|c|}
\hline Препарат & Мишень \\
\hline Катумаксомаб & Против молекул адгезии клеток эпителия (ЕрСАМ) и CD3-антигена \\
\hline Ритуксимаб & $\begin{array}{l}\text { Обладающие специфичностью к CD20 антигену, обнаруживаемому на } \\
\text { поверхности нормальных и малигнизированных В-лимфоцитов }\end{array}$ \\
\hline Офатумумаб & $\begin{array}{l}\text { Связывается с эпитопом, включающим малую и большую внеклеточные петли } \\
\text { молекулы CD20 }\end{array}$ \\
\hline Обинутузумаб & $\begin{array}{l}\text { Избирательно взаимодействует с внеклеточным участком трансмембранного } \\
\text { антигена CD20 }\end{array}$ \\
\hline $\begin{array}{l}\text { Инотузумаб } \\
\text { озогамицин }\end{array}$ & Обладает специфичностью к CD22 \\
\hline Абатацепт & $\begin{array}{l}\text { Модулирует ключевой ко-стимулирующий сигнал, необходимый для полной } \\
\text { активации Т-лимфоцитов, CD28 }\end{array}$ \\
\hline $\begin{array}{l}\text { Брентуксимаб } \\
\text { ведотин }\end{array}$ & Экспрессирующим антиген CD30 клетки \\
\hline Изатуксимаб & Связывается с внеклеточным эпитопом CD 38 \\
\hline Даратумумаб & Связывается с белком CD38 \\
\hline Алемтузумаб & $\begin{array}{l}\text { Вызывает лизис лимфоцитов за счет взаимодействия с антигеном CD52, который } \\
\text { не подвержен модуляции и экспрессируется на поверхности всех В- и Т- } \\
\text { лимфоцитов, а также моноцитов, тимоцитов и макрофагов. }\end{array}$ \\
\hline Белимумаб & $\begin{array}{l}\text { Специфически связывается с растворимым BLyS Стимулятор В-лимфоцитов } \\
\text { (BLyS, также известен как BAFF и TNFSF13) }\end{array}$ \\
\hline Цетуксимаб & Связывается с рецепторами эпидермального фактора роста \\
\hline Натализумаб & $\begin{array}{l}\text { Селективный ингибитор молекул адгезии ( } \alpha 4 \text {-субъединица человеческого } \\
\text { интегрина), экспрессирующих на поверхности всех лейкоцитов, за исключением } \\
\text { нейтрофилов }\end{array}$ \\
\hline Ведолизумаб & $\begin{array}{l}\text { Связываются с } \alpha 4 \beta 7 \text {-интегрином и селективно блокируют взаимодействие } \alpha 4 \beta 7- \\
\text { интегрина с молекулами клеточной адгезии слизистой оболочки адрессином-1 } \\
\text { (MAdCAM-1), но не с молекулами клеточной адгезии сосудов-1 (VCAM-1). }\end{array}$ \\
\hline
\end{tabular}

В настоящее время эти препараты широко используются в клинической практике. Сегодня трудно назвать в онкологии область, в которой не применялись бы моноклональные антитела с цитотоксическим действием. За счет их применения достигнуты успехи при лечении рака молочной железы, легких и лимфомах.

В иммунологии эта группа препаратов представлена моноклональными антитела против клеток иммунной системы непосредственно участвующих в формирования того или иного заболевания, прежде всего аутоиммунной патологии.

Ритуксимаб химерные моноклональные антитела мыши/человека. Разрушает как нормальные, так и злокачественные В-клетки, имеющие на своей поверхности CD20, и поэтому используется для лечения заболеваний, которые характеризуются наличием слишком большого количества В-клеток, сверхактивных В-клеток или дисфункциональных В-клеток. Используется для лечения лейкемии и лимфомы, включая неходжкинскую лимфому, хронический лимфолейкоз и лимфому с преобладанием лимфоцитов подтипа лимфомы Ходжкина в т.ч. макроглобулинемию Вальденстрема. Является эффективным средством лечения ревматоидного артрита. Применение ритуксимаба (2x1000 мг) в сочетании с метотрексатом является эффективным методом лечения пациентов с РА, приводящее к устойчивому улучшению рентгенографических, клинических и функциональных результатов в течение $2-\mathrm{x}$ лет 
Имеются доказательства эффективности применении при других аутоиммунных заболеваний (рассеянный склероз, системная красная волчанка, хроническая воспалительная демиелинизирующая полинейропатия,

прогрессирующая

мультифокальная лейкоэнцефалопатия, синдром Шегрена и аутоиммунные анемии. Однако терапия ритуксимабом до сих пор не утверждена для лечения других аутоиммунных заболеваний, тем не менее она используется для лечения у отдельных пациентов, которые не отвечают на обычные методы лечения и/или у тех пациентов, которые не могут переносить или иметь противопоказания для традиционной терапии.

Офатумумаб - представляет собой человеческое моноклональное антитело, специфически связывающееся с эпитопом, включаещий и малую, и большую внеклеточные петли молекулы CD20 и приводит к В-клеточному лизису. Применяется для лечения пациентов с хроническим лимфоцитарным лейкозом при неэффективности ранее проводимой терапии. Не вызывает иммуногенности. Один курс двух инфузий по 700 мг является эффективным и безопасным у пациентов с активным рематоидным артритом на фоне метотрексата.

Окрелизумаб - рекомбинантное гуманизированное анти-CD20 моноклональное антитело. Применяется при первично-прогрессирующем и рецидивирующем рассеянном склерозе, однако точный механизм действия, за счет которого достигается клинический эффект полностью не установлен. При ревматоидном артрите и системной красной волчанке исследования на III фазы показали повышенную смертности от оппортунистических инфекций. При рассеянном склерозе такие результаты не наблюдались.

Белимумаб человеческие рекомбинантные моноклональные антитела, направленные против фактора В-клеточной активации (BAFF). За счет блокады BAFF угнетается жизнеспособность В-лимфоцитов, В т.ч. аутореактивных, снижается дифференцировка Влимфоцитов в плазматические клетки, вырабатывающие Ig. Белимумаб значительно снижал количество циркулирующих В-лимфоцитов, наивных и активных форм, плазматических клеток и субпопуляции волчаночных В-лимфоцитов. Белирумаб может блокировать секрецию $\mathrm{INF} \gamma$ и IL-2, это приводит к снижению патологии, связанной с CKB

Aбатаџеnm представляет собой генетический рекомбинантный растворимый белок, CTLA4 специфически связываясь с CD80 и CD86, ингибируя активацию Т-лимфоцитов (см. главу 4).

\section{Таргетные препараты действующие на сигнальные молекулы}

На различные сигнальные пути клеток иммунной системы избирательно действуют малые молекулы, которые оказывают иммунодепрессивное и противовоспалительное действие (табл. 120).

Таблица 120.

Таргетные препараты действующие на сигнальные молекулы

\begin{tabular}{|l|l|}
\hline \multicolumn{1}{|c|}{ Препарат } & \multicolumn{1}{c|}{ Мишень } \\
\hline Апремиласт & Ингибитор фосфодиэстеразы-4 \\
\hline Элотузумаб & $\begin{array}{l}\text { Связывается с белком SLAMF7 (представитель в семействе сигнальных молекул } \\
\text { активации лимфоцитов). }\end{array}$ \\
\hline Руксолитиниб & Селективный ингибитором Янус-киназ (ЈAK1 и JAK2). \\
\hline Тофацитиниб & Селективный ингибитор семейства янүс киназ \\
\hline Барицитиниб & Селективным и обратимым ингибитором Янус-киназы 1 и 2 (ЈАK1, 2) \\
\hline Упадацитиниб & Селективный обратимый ингибитор ЈAK1 \\
\hline Эверолимус & Ингибитор пролиферативного сигнала \\
\hline
\end{tabular}


Anремиласт - Ингибитор фосфодиэстеразы-4. При угнетении этого фермента возрастает количество цАМФ, что, в свою очередь, ведет к подавлению воспалительной реакции за счет модуляции экспрессии ФНО- $\alpha$, ИЛ-23, ИЛ-17 и других воспалительных цитокинов (угнетение) со стимуляцией синтеза некоторых противовоспалительных цитокинов, в т.ч. ИЛ-10. Это нашло применение при лечении бляшечного псориаза средней и тяжелой степени, при псориатическом артрите, у пациентов, которым показана фототерапия или системная терапия.

Элотузумаб - блокирует SLAMF7 (член семейства рецепторов SLAM активирующие клеточный иммунный ответов, регулятор функции NK-клеток, фактор опосредованного макрофагами фагоцитоза опухолевых клеток) который в большом количестве экспрессируется на миеломных клетках (CD319) независимо от типа цитогенетических аномалий также экспрессируется на натуральных киллерах, нормальных плазматических клетках, на некоторых Т-клетках, моноцитах, В-клетках и дендритных клетках. SLAMF7 не обнаруживается на клетках здоровых тканей и гемопоэтических стволовых клетках. Элотузумаб в комбинации с леналидомидом и дексаметазоном показан для лечения пациентов с множественной миеломой, получивших один или несколько предшествующих циклов терапии.

Ингибиторы Янус-киназы (якинибы). Группа лекарств, которые действуют путем ингибирования активности одного или нескольких ферментов семейства Янус-киназ (JAK1, JAK2, JAK3, TYK2), тем самым препятствуя JAK-STAT сигнального пути. Большинство цитокинов включая интерлейкины, интерфероны и колониестимулирующий фактор, и гормонов (эритропоэтин, пролактин и гормон роста) используют этот путь для передачи сигнала. Препараты, которые ингибируют активность этих киназ, блокируют передачу сигналов цитокинов.

Руксолитиниб ингибитор ЈАК1/ЈАК2, для лечения миелофиброза (среднего или высокого риска) и истинной полицитемии у пациентов с неадекватным ответом или непереносимость гидроксимочевины . [9]

Тофацитиниб блокирует ЈАК3 применяется при псориазе и ревматоидном артрите (умеренно или очень активным) у пациентов с неадекватным ответом или непереносимостью метотрексата.

Барицитиниб блокирует JАK 1/JAK2 применяется при ревматоидном артрите.

Упадацитиниб ингибирует ЈАК1 применяется при ревматоидном артрите. 


\section{ИММУНОТЕРАПИЯ}

\section{Глава 25. Клеточно-тканевая терапия}

Клеточно-тканевая терапия - профилактика или лечение болезней человека путем введения живых клеток и/или ткани, которые были отобраны, размножены и обработаны или изменены вне организма. Цель такой терапии - заместить, восстановить или улучшить функцию поврежденной ткани или органа.

В настоящее время в медицине необходимо выделить несколько направлений по развитию клеточно-тканевой терапии (рис. 131).

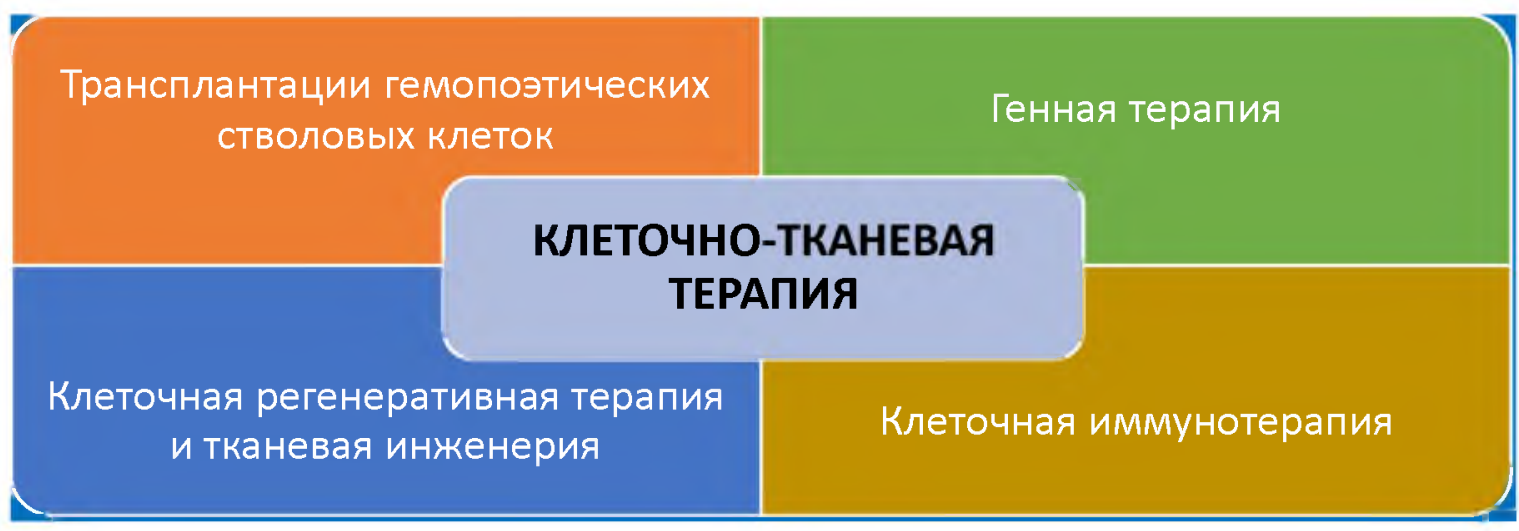

\section{Рис. 131. Разновидности клеточно-тканевой терапии.}

\section{Трансплантация гемопоэтических стволовых клеток.}

Первыми трансплантировать клетки человеку, не осознавая этого, уже давно начали трансфузиологи. При переливании крови в организм реципиента попадает небольшое количество содержащихся в крови донора стволовых клеток (СК). Недавно было показано, что эти клетки внедряются в ткани реципиента и дифференцируются. Как кровь, так и костный мозг содержат СК, дающие начало всем клеткам крови. Из донорских СК образуются нормальные, не пораженные раком лейкоциты и лимфоциты, что улучшает состояние пациента. Но наиболее эффективным является трансплантация гемопоэтических стволовых клеток (ранее называющееся пересадкой костного мозга).

Трансплантация гемопоэтических стволовых клеток - это медицинская технология, при которой производится перенос здоровых мультипотентных кроветворных стволовых клеток, полученных из костного мозга, периферической крови или пуповинной крови донора реципиенту. Донор и реципиент могут быть одним и тем же человеком (аутологичный трансплантат) или двумя разными людьми (аллогенный трансплантат)

Аутологичной трансплантации необходима при высокодозной химиотерапии и/или облучении приводящей к повреждению кроветворной системы. Тогда здоровые стволовые клетки забираются у пациента до начала лечения, и возвращаются ему после миелоаблативной (уничтожающей костный мозг) терапии.

Трансплантация аллогенных стволовых клеток используется при различных формах заболеваний, когда необходимо «заменить» костный мозг при опухолях иммунной системы (острый миелоидный лейкоз, хронический миелоидный лейкоз, острый лимфобластный 
лейкоз, лимфома Ходжкина и неходжкинская лимфома (рецидивирующая, рефрактерная), нейробластома, саркома Юинга, множественная миелома, миелодиспластические синдромы, глиомы и другие солидные опухоли) или у пациента сушествует врожденный дефект (талассемия, серповидноклеточная анемия, апластическая анемия, анемия Фанкони, злокачественный детский остеопетроз, мукополисахаридоз, дефицит пируваткиназы). Особую группу составляют первичные иммунодефициты (ТКИН, синдромами Вискотта-Олдрича, Оменна, Ниймигена, хроническая гранулематозная болезнь, гипер IgM синдром).

В процессе выполнения трансплантации гемопоэтических стволовых клеток выделяют несколько этапов

Подбор донора.

Оценка и тестирование донора - очень важные вопросы, влияющие на качество и безопасность донорства. Потенциальным донором стволовых гемопоэтических клеток может стать любой дееспособный человек в возрасте от 18 до 55 лет с отсутствием определенных заболеваний (табл. 121).

Таблица 121.

\section{Условия для доноров стволовых гемопоэтических клеток}

\begin{tabular}{|c|}
\hline \\
\hline 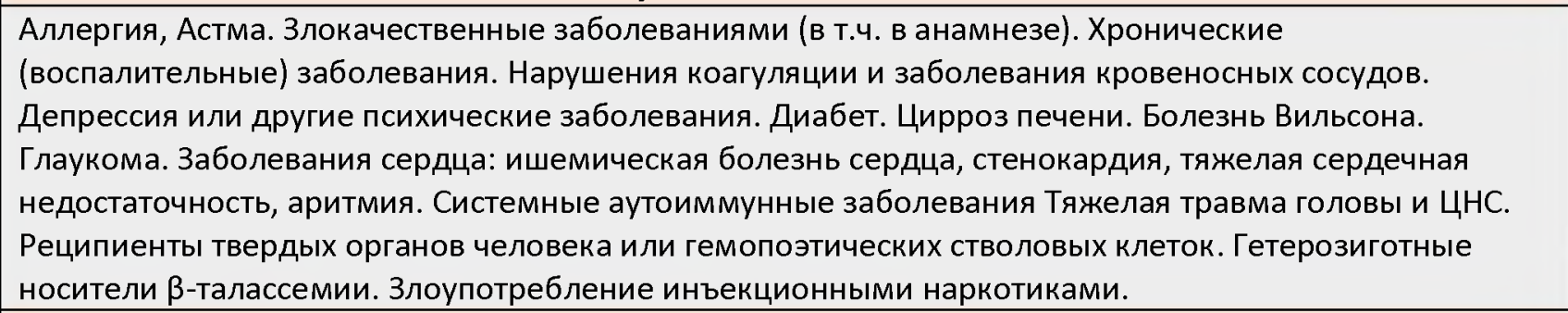 \\
\hline Отсутствие инфекционные заболевания (в т.ч. в анамнезе) \\
\hline $\begin{array}{l}\text { Бабезиоз. Бруцеллез. Болезнь Шагаса. Болезнь Крейтцфельдта-Якоба. ВИЧ-инфекции. Инфекции, } \\
\text { вызванные вирусом гепатита В (HBV) и вирусом гепатита С (HCV). Инфекции, вызванные } \\
\text { человеческим Т-лимфотропным вирусом І/II. Лейшманиоз. Проказа. Хроническая болезнь Лайма. } \\
\text { Малярия. Менингит. Остеомиелит. Ку-лихорадка. Сифилис. Тропические болезни. Туберкулез. } \\
\text { Токсоплазмоз. Тиф. }\end{array}$ \\
\hline Отсутствие контактов с людьми с инфекционными заболеваниями \\
\hline $\begin{array}{l}\text { При контакте с инфекционным заболеванием период отсрочки должен равняться инкубационному } \\
\text { периоду или, если он неизвестен, характер контакта и период отсрочки должны определяться } \\
\text { ответственным врачом. } \\
\text { Предыдущие половые партнеры людей с ВИЧ, ВГВ, ВГС допускаются через год после их последнего } \\
\text { полового контакта с лабораторным подтверждением на отсутствие инфекции. }\end{array}$ \\
\hline Временная отсрочка \\
\hline $\begin{array}{l}12 \text { мес. после эндоскопия с биопсией, пирсинга, татуировки, после переливания крови или } \\
\text { компонентов крови, после родов } \\
6 \text { мес. после крупной операции. } \\
4 \text { нед. после вакцинации } \\
\text { При АД выше } 180 / 100 \text { и признаках простуды пациентов следует принимать при отсутствии симптомов } \\
\text { и при хорошем самочувствии в день забора крови. }\end{array}$ \\
\hline
\end{tabular}

Для того, чтобы стать потенциальным донором костного мозга (быть зачисленным в регистр), необходимо пройти HLA-типирование. Данные регистрируются и входят в единую базу Всемирной ассоциации доноров костного мозга (https://wmda.info).

В поисках донора обычно обращается к разным родственникам пациента (братьям и сестрам), чтобы найти одинаковые маркеры HLA. Однояйцевые близнецы часто наиболее совместимы друг с другом. При отсутствии совпадений выполняется поиск в базе Всемирной ассоциации доноров костного мозга, в котором сейчас зарегистрировано более 38 миллионов добровольцев с информацией HLA 
В дальнейшем при совместимости с определенным пациентом решается вопрос о методах забора костного мозга или периферических стволовых кроветворных клеток

Забор и хранение гемопоэтических стволовых клеток.

В настоящее время существует два метода сбора стволовых клеток: классический сбор костного мозга и теперь более распространенное донорство стволовых клеток периферической крови. Кроме того, существует возможность с некоторыми ограничениями получения стволовых клеток из пуповинной крови.

Классический метод трансплантации стволовых клеток - это перенос красного костного мозга. Как правило, с помощью специальной иглы у донора из гребня подвздошной кости берут около 1 литра смеси костного мозга и крови. Из них выделяют стволовые клетки, при необходимости, очищают и затем переливают реципиенту.

Более щадящий метод является цитаферез. Этот в настоящее время наиболее распространенный способ забора стволовых клеток. За несколько дней до донорства костный мозг стимулируется подкожной инъекцией G-CSF, которые вызывают выход гемопоэтических стволовых клеток из костного мозга в кровь. В последующим используя аферез периферические стволовые клетки собираю. Забор осуществляют один - два раза в течение 3 4 часов.

В связи с высокой концентрацию гемопоэтических стволовых клеток в плаценте и пуповине перспективным является сбор пуповинной крови. Небольшого количество крови, полученное из пуповины (обычно около 50 мл), осложняет ее применение для взрослых. Требуется «наращивание клеток» и/или использовать несколько единиц пуповинной крови от разных доноров.

В отличие от других органов, клетки костного мозга можно замораживать (криоконсервировать) в течение длительных периодов времени, не повреждая слишком много клеток. Это необходимо для аутологичных трансплантаций. В случае аллогенных трансплантатов свежие клетки предпочтительней тем не менее допускается их хранение до 72 часов при температуре +4-8 градусов. Учитывая, что пуповинную кровь можно получить только во время родов, для ее хранения используются специальные банки пуповинной крови.

Проведение трансплантации.

Когда донор найден и подтверждена его совместимость, пациент подвергается кондиционированию. Цель этой процедуры уничтожение собственного костного мозга, подавление иммунитета с целью снизить риск отторжения донорских клеток. Проводят полную или неполную миелоаблацию. Для этого он получит химиотерапию с облучением, в течение десяти дней. Пациент находится в стерильной комнате (чистые помещения), потому что кондиционирование вызовет глубокую аплазию пациента, разрушив его иммунную систему. Велик риск развития инфекций.

Фактическая трансплантация проводится в виде инфузии, через которую приготовленный костный мозг получает пациент. Трансплантированные клетки будут размещаться в костях, постепенно восстанавливая всю ткань костного мозга и возобновляя производство различных клеток крови. Это происходит через 10-30 дней после трансплантации, в течение которых необходимо продолжать защищать пациента от инфекционных агентов. По истечении 3 месяцев иммунная система может быть восстановлена. Однако возможны осложнения в виде развития инфекций, веноокклюзионной болезни, мукозите, геморрагическом цистите.

Самое частое и опасное осложнение - реакция трансплантат против хозяина (РТПХ). Это атака «новых» иммунных клеток костного мозга на ткани реципиента. Острая РТПХ обычно возникает в первые 3 месяца после трансплантации и может поражать кожу, кишечник или печень. Для лечения РТПХ применяются препараты, угнетающие иммунитет (иммуносупрессоры),

Прогноз при трансплантации костного мозга широко варьируется в зависимости от типа заболевания, стадии, источника стволовых клеток, HLA-совместимого статуса и режима кондиционирования. Однако трансплантация дает шанс на выздоровление или долгосрочную ремиссию. В последние годы показатели выживаемости постепенно улучшаются. 


\section{Клеточная регенеративная терапия}

Этот раздел медицины занимается лечением различных заболеваний путем восстановления пораженных органов и тканей с помощью трансплантации клеток (клеточная терапии) и/или путем стимуляции эндогенных стволовых клеток.

Фундаментальные основы развития данного направления положили наши отечественные ученые А.А. Максимов и А.Я. Фриденштейн (рис.132).

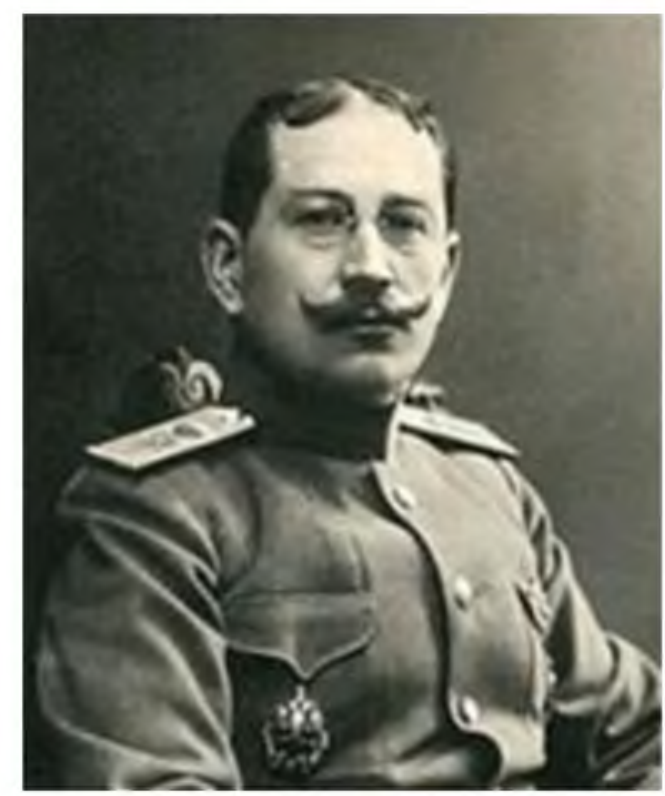

Александр Александрович Максимов (22 января (3 февраля) 1874 - 4 декабря 1928) обосновал теории кроветворения, ввёл понятие стволовые клетки.

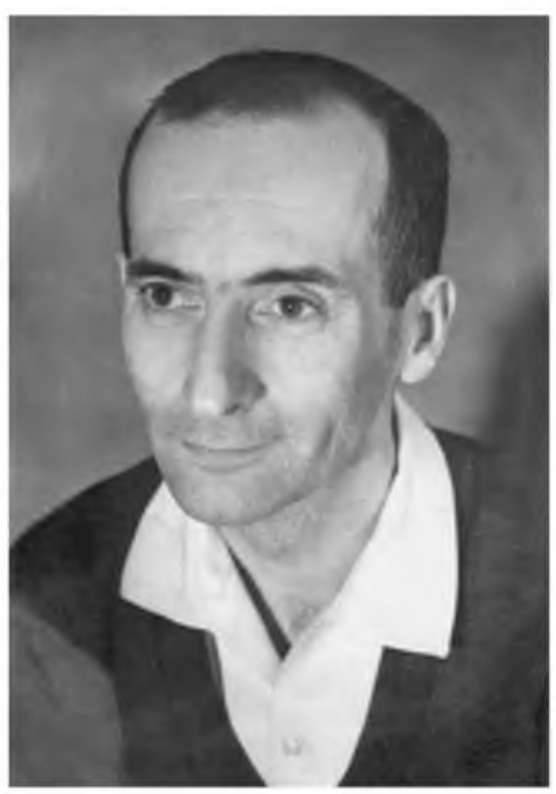

Александр Яковлевич Фриденштейн

(24 июня $1924-31$ августа 1997)

впервые описал мультипотентные мезенхимальные стволовые клетки

\section{Рис. 132. Ученые, создавшие основу регенеративной медицины}

В настоящее время к клеточным технологиям относят всю совокупность методов и практик всех этапов работы с клетками: технологии получения исходного биоматериала, всей работы in vitro и собственно клеточной терапии: заместительной и восстановительной, прямой и непрямой. Стволовые клетки являются самым важным объектом исследований и ключевым субстратом клеточных технологий - и клеточной терапии в первую очередь. Однако существует и другие подходы лечения разных заболеваний, основанных на применении иных типов клеток, не являющихся стволовыми. Описано применение клеточной терапии для регенерации практически всех типов тканей. В зависимости от типа ткани и патологии значительно отличаются уровни разработки клеточных продуктов. Это связано, с одной стороны, с методологическими особенностями производства и применения клеточных продуктов, с другой - с особенностями дифференцировки типов клеток, использующихся в регенеративной медицине, прежде всего мезенхимальных стволовых клеток (МСК).

\section{Регенерация кожных покровов}

Показаны хорошие результаты с применением аутологичного донорского материала. Аллогенные кожные трансплантаты в подавляющем большинстве случаев вызывают реакцию отторжения. В качестве альтернативы исследователи предлагают комбинированные продукты, состоящие из биоразлагаемой матрицы (как правило, на основе коллагена или фибрина) в сочетании с прогениторными и дифференцированными клетками (МСК, кератиноциты, фибробласты). Данный тип тканеинженерных продуктов используют при терапии ожогов, диабетической стопы, перианальных свищей, а также для 
послеоперационного восстановления стенок полых органов - пищевода, мочевого пузыря, некоторых отделов кишечника и трахеи. За рубежом уже зарегистрированы тканеинженерные продукты для регенерации кожи и слизистых на основе аллогенных фибробластов и

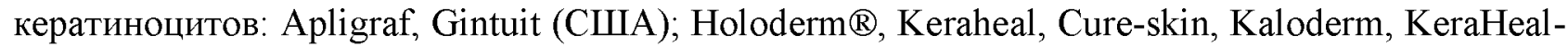
Allo (Южная Корея); ЈACE (Япония). В ЕС и Южной Корее зарегистрированы клеточные продукты Alofisel и Cupistem для лечения пери анальных свищей при болезни Крона, представляющие собой аллогенные МСК, выделенные из жировой ткани взрослых доноров.

Регенерация суставов и костей

Регенерация костей и суставов на основе жизнеспособных клеток человека наиболее используемая и изучаемая область применения в клинической практике методов лечения. Существует значительное количество зарегистрированных клеточных продуктов, предназначенных для регенерации хрящевой ткани на основе аутологичных хондроцитов, суммарный опыт применения которых насчитывает уже более десяти лет: MACI (США); ChondroCelect, Spherox (EC); JACC (Япония); Chondron, Cartistem (Южная Корея); Cartogen (Австралия, Сингапур).

Восстановление костной ткани сопряжено с рядом трудностей. Несмотря на возможность полной замены кости металлическим или композитным имплантом, невозможно достигнуть полного восстановления ее опорно-двигательной функции вследствие неполной регенерации сопутствующего двигательного аппарата (связок, сухожилий). Введение МСК в трансплантат позволяет обеспечить лучшее сродство тканей организма с реконструированным участком за счет дифференцировки используемых клеток в остеобласты и затем в остеоциты. Разработки клеточных продуктов, используемых для регенерации кости, реализованы в рамках значительного количества пилотных исследований. Однако в настоящее время зарегистрирован всего лишь один продукт - RMS Ossron (Южная Корея), состоящий из аутологичных остеобластов.

\section{Регенерация нервной ткани}

Способности нервной ткани взрослого человека к регенерации сильно ограничены, в связи с этим практически отсутствуют способы лечения нарушений, связанных с повреждениями органов нервной системы, обладающие доказанной эффективностью. Несмотря на значительное число исследований, посвященных применению клеточной терапии для регенерации нервной ткани, большинство из них проводилось на очень ограниченном числе пациентов, что связано преж де всего с трудностью доставки клеток к местам ее повреждения.

\section{Регенерачия сердечной мылииы}

Сердечная поперечнополосатая мышечная ткань имеет ограниченную способность к регенерации, поэтому полное восстановление миокарда после инфаркта практически никогда не происходит. Тем не менее считается, что под воздействием клеточной терапии происходит дифференцировка мультипотентных клеток в кардиомиоциты; ингибируется фиброз миокарда; экспрессия ангиогенных, антиапоптотических факторов и цитокинов, стимулирующих пролиферацию кардиомиоцитов. В настоящее время зарегистрированы следующие клеточные продукты, предназначенные для регенерации тканей сердца: из аутологичные миобластов скелетных мышц - HeartSheet (Япония), и аутологичные МСК Hearticellfram-AMI (Южная Корея).

Регенерация печени

Исследования по изучению безопасности, переносимости и клинической эффективности трансплантации аутологичных костномозговых мононуклеарных клеток и мезенхимальных стромальных клеток в комплексном лечении пациентов с хроническими гепатитами и циррозом печени показало безопасность и эффективность метода. Данный подход можно рассматривать как один из методов, предупреждающих дальнейшую прогрессию заболевания, а в случае декомпенсированных форм ЦП - как временное пособие, позволяющее дождаться трансплантации печени. 


\section{Генная терапия}

Под генной терапией подразумевается совокупность молекулярно-генетических и медицинских методов, направленных на внесение изменений в генетический аппарат клеток человека в целях лечения заболеваний.

Новые высокоэффективные и простые в использовании инструменты редактирования генома открывают возможность лечения наследственных, онкологических и инфекционных. заболеваний.

Концепция генной терапии заключается в устранении генетической проблемы в ее источнике. Если, например, при наследственном заболевании (обычно рецессивном) мутация в определенном гене приводит к выработке дисфункционального белка, можно использовать генную терапию для доставки копии этого гена, не содержащей вредной мутации, и тем самым производит функциональный белок. Эта стратегия называется генной заместительной терапией.

В настоящее время наиболее распространёнными методами геномного редактирования являются нуклеазы цинковых пальцев (ZFNs), эффекторные нуклеазы, подобные активаторам транскрипции (TALENs), и система CRISPR/Cas9.

Нуклеазы цинковых пальцев (ZFNs) представляют собой класс сконструированных ДНК-связывающих белков, которые облегчают целевое редактирование генома, создавая двухцепочечные разрывы в ДНК в указанных пользователем местах. Двухцепочечные разрывы важны для сайт-специфического мутагенеза, поскольку они стимулируют естественные процессы репарации ДНК клетки, а именно гомологичную рекомбинацию и негомологичное соединение концов (NHEJ). Благодаря внедрению установленных, проверенных на практике методов, эти процессы могут быть использованы для создания точно направленных изменений генома, в результате чего получаются линии клеток с точными и наследуемыми делециями, интеграциями или модификациями генов.

Эффекторные нуклеазы, подобные активатору транскрипции (TALEN), представляют собой рестрикционные ферменты, которые могут быть сконструированы для разрезания определенных последовательностей ДНК. Их получают путем слияния эффекторного ДНКсвязывающего домена TAL с доменом расщепления ДНК. Эффекторы, подобные активаторам транскрипции (TALE), могут быть сконструированы для связывания практически с любой желаемой последовательностью ДНК, поэтому в сочетании с нуклеазой ДНК можно разрезать в определенных местах. Рестрикционные ферменты могут быть введены в клетки для использования при редактировании генов или для редактирования генома in situ, метод, известный какредактирование генома с помощью инженерных нуклеаз .

Система CRISPR/Cas9 состоит из двух основных частей. Первой является белок, нуклеаза Cas9, которая способна вносить двуцепочечный разрыв в молекулу ДНК. Вторая представляет собой небольшую молекулу состоящие из прямых повторяющихся последовательностей, которые разделены уникальными последовательностями (спейсерами). Спейсеры заимствуются из чужеродных генетических элементов, с которыми сталкивалась клетка. В последующем распознавая эти спейсеры Cas9 разрезает ДНК. CRISPR/Cas9 можно использовать для редактирования ДНК в культуре клеток человека. Более того. выяснилось, что технология позволяет не только удалять ненужные гены, но и вставлять на их место другие. Для этого достаточно добавить ферменты, восстанавливающие ДНК.

Система доставки осуществляется путем загрузки генов в посредник, известный как вектор. Затем вектор «инфицирует» клетки-мишени, вводит ген в клетку и, таким образом, воспроизводит недостающий белок. В качества вектора могут выступать рекомбинантные вирусы и голая ДНК или комплексы ДНК.

К сожалению, в настоящее время в клинической практике эти методы лечения недоступны. Сегодня клинические исследования проводят для 6 наследственных заболеваний: мукополисахаридозов I и II типов, серповидно-клеточной анемии, $\beta$-талассемии, гемофилии В и врожденного амавроза Лебера 10. 


\section{Клеточная иммунотерапия}

Использование живых клеток в качестве «лекарства» представляет собой отход от традиционного взгляда на «лекарство» как на небольшую молекулу или антитело, выполняющее единственную функцию. Клетки - это динамические живые агенты, которые в отличии от обычных лекарств могут интегрировать ряд входных сигналов, реагировать на изменения в окружающей среде, взаимодействовать с другими клетками и посредством сложных сигнальных путей вызывают спектр ответов. В дополнение к этому клеточные препараты могут сохраняться в организме от месяцев до лет, тогда как большинство обычных лекарств метаболизируются и выводятся из организма вскоре после приема, добавляя еще одну проблему к сложности взаимодействия между пациентом и лекарством.

\section{Т-клеточная терапия.}

Существует три основных типа терапии на основе Т-клеток: лимфоциты, инфильтрирующие опухоль (TIL), TCR-T-клетки и CAR-T-клетки. Последние две технологии состоят из генетически измененных T-клеток, в которых опухолевая специфичность индуцируется ех vivo путем вставки рецептора химерного антигена (CAR) в случае CAR-Tклетки или, альтернативно, трансфекции TCR, специфичного к определенному опухолевому антигену, в T-клетку. клетка, создающая TCR-T-клетку. Напротив, TIL предпочтительно являются опухолеспецифичными до культивирования, поскольку они извлекаются из опухолевого материала и, как таковые, примированы in vivo увеличены и повторно введены пациенту.

\section{Врожденнье Т-клетки}

Гамма-дельта $(\gamma \delta)$ Т-клетки. Основой для применения этой группы клеток связано с тем, что они обладают чрезвычайно сильным противоопухолевым действием как in vitro, так и in vivo. Присутствие инфильтрирующих $\gamma \delta$ T-клеток было наиболее надежным предиктором положительных результатов при различных типах рака. Конструкции $\gamma \delta$ TCR и $\gamma \delta$ CAR-Tклеток находятся в настоящее время в эксперементе.

Природные киллерные Т-клетки (NKT). Существует несколько подходов для использования потенциала NKT-клеток для иммунотерапии рака которые показали свою эффективность, хотя терапия для клинического применения еще не одобрена.

Терапия на основе $N K$-клеток

В отличие от клеток адаптивной иммунной системы эффекторные клетки врожденного иммунитета, такие как NK-клетки, демонстрируют значительную цитотоксичность в отношении рака и инфицированных вирусом клеток без предварительной сенсибилизации

Клетки $L A K$

Это смесь NK-клеток, NKT-клеток (NKT) и CTL-клеток после инкубация с высокой дозой IL-2 способные более активно лизировать опухолевые клетки. Однако в клинической практике такой эффект не достигнут.

\section{Клетки CIK}

Добавление IFN $\gamma$ и стимуляции анти-CD3 к высоким дозам IL-2 привело к культивированию более цитотоксического набора клеток, названных клетками-киллерами, индуцированными цитокинами (CIK). Достигнут успех при их применении в клинических испытаниях, особенно у пациентов с гепатоцеллюлярной карциномой и глиобластомой. Однако клетки СIK еще не получили широкого распространения в клинической практике

CAR-NK клетки

Несколько групп показали эффективность использования клеток CAR-NK в качестве цитотоксических медиаторов против колоректального рака и клеточных линий острого миелоидного лейкоза в доклинических исследованиях in vitro. В настоящее время проводится несколько клинических испытаний, в которых набирают пациентов для оценки безопасности, осуществимости и эффективности CAR-NK при злокачественных новообразованиях. O результатах этих исследований на сегодняшний день не сообщается. 
Терапия дендритными клетками. Метод вызывает противоопухолевые реакции, заставляя дендритные клетки представлять опухолевые антигены лимфоцитам, что активирует их, заставляя их убивать другие клетки, представляющие антиген. Дендритные клетки в иммунной системе представляют собой антигенпрезентирующие клетки (АРС). При лечении рака они способствуют нацеливанию на раковый антиген.

Одним из методов индукции дендритных клеток для презентации опухолевых антигенов является вакцинация аутологичными опухолевыми лизатами или пептидами. Эти пептиды в сочетании с адъювантами для усиления иммунного и противоопухолевого ответа. Другие адъюванты включают белки или другие химические вещества, которые привлекают и/или активируют дендритные клетки, такие как GM-CSF. Наиболее распространенными источниками антигенов, используемых для дендритно-клеточной вакцины при глиобластоме (GBM) как агрессивной опухоли мозга, были лизат цельной опухоли, PHК антигена CMV и связанные с опухолью пептиды, такие как EGFRvIII.

Другая стратегия - выделить дендритные клетки из крови пациента и активировать их вне тела (рис.133). Дендритные клетки активируются в присутствии опухолевых антигенов, которые могут представлять собой один опухоль специфический пептид/белок или лизат опухолевых клеток. Эти клетки инфузируются и вызывают иммунный ответ.

Терапия дендритными клетками включает использование антител, которые связываются с рецепторами на поверхности дендритных клеток. К антителу могут быть добавлены антигены, которые могут вызывать созревание дендритных клеток и обеспечивать иммунитет к опухоли. Рецепторы дендритных клеток, такие как TLR3, TLR7, TLR8 или CD40, использовались в качестве мишеней для антител. Интерфейс дендритных

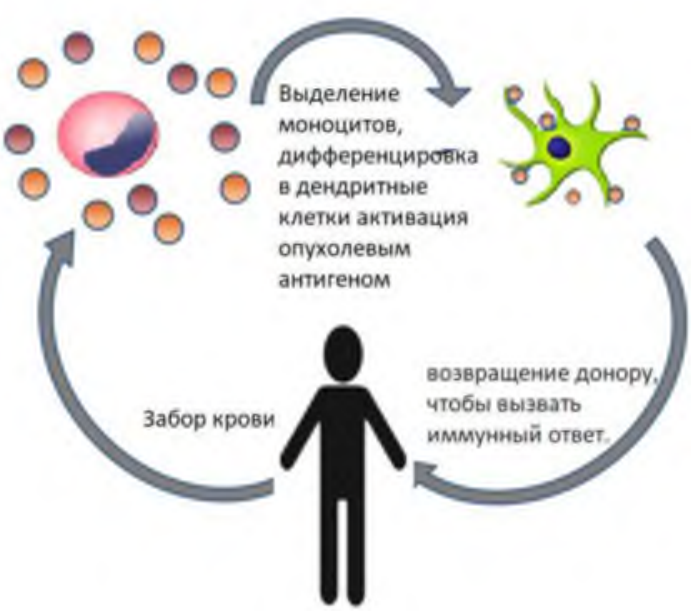

Рис. 133 Терапия дендритными клетками

клеток и NK-клеток также играет важную роль в иммунотерапии. Разработка новых стратегий вакцинации на основе дендритных клеток также должна включать в себя способность стимулировать NK-клетки. Крайне важно систематически включать мониторинг NK-клеток в качестве результата клинических испытаний противоопухолевых ДК. 


\section{Резюме и заключение вместе с эпилогом.}

Резюме заключается в том, что данная книга, она же и учебник, преподносит читателю, прежде всего врачу любой специальности, базовые знания о науке иммунология. Одной из главных задач данной книги-учебника является обоснование понимания иммунологии не только как науки об иммунитете к бактериальным и вирусным инфекциям, а как науки об иммуноэтиологии, иммунопатогенезе, иммунотерапии всех основных заболеваниях современного человека, к коим относятся такие патологии как рак, атеросклероз, аутоиммунные и аллергические заболевания. Пожалуй, действительно есть самое главное. Если, например, врач онколог поймет, основу патогенеза онкозаболевания, любого, составляет иммунопатогенез, то относиться он начнет по-другому к данному заболеванию. Он начнет думать о том, как найти и как использовать те лекарственные препараты, те БАДы, те методы физиотерапии, с помощью которых он сможет настроить функцию иммунной системы на борьбу с опухолью, чтобы в конце концов победить ее полностью и вернуть больному полноценное здоровье. И это касается врача любой специальности, имеется в виду медицинской специальности.

В данной книге-учебнике изложены азы иммунологических знаний, дающие возможность читателю начинать понимать роль иммунной системы, клеток ее составляющих, цитокинов ее регулирующих в механизмах возникновения того, или иного заболевания. Конечно же, для начала сложно понять, например, как это одна клетка, обладающая иммуносупрессорной активностью, может отвечать за неконтролируемый рост опухоли, или один иммуноглобулин Е лежит в основе многих аллергических заболеваний, или интерлейкин 6 обуславливает развитие цитокинового шторма при корона-вирусной инфекции, или многое и многое другое. Но это обязательно необходимо понять! Иначе медицина не сдвинется с места, несмотря на значительные успехи в «не иммунологических» её областях.

Да, иммунология достаточно сложная наука для ее сиюминутного понимания. Кстати, она еще к тому же и чрезвычайно дорогая для повседневного использования её методов в клинической практике. Все это так! Но в мире имеется уже более 200 лекарственных препаратов с предложением использовать их в качестве модуляторов функций, именно функций, иммунной системы притом или ином заболеваний. Но как врач может их эффективно использовать, если в его руках нет данных о нарушенных функциях иммунной системы, да о которых он имеет еще достаточно смутные представления? Ознакомление с данной книгой-учебником несомненно снизить у врача степень его смутности в отношении представлений о многокомпонентных, многоуровневых функциях иммунной системы в норме и при различных заболеваниях.

А теперь, место эпилогу. Конечно же степень знакомства у читателей с данной книгой учебником будет разная: от прочтения от начала до конца, от ознакомления с отдельными ее главами, от пробегания взглядом по оглавлению, до полного отложения книги в сторону. Беру на смелость утверждать, что в эти же рамки поместятся и знания врачей, и их профессионализм в решении задач оказания помощи данному, конкретному больному, и их значимость в решении проблем общественного здоровья.

Читайте, читайте про иммунную систему, друзья! Вас ждет больной у постели с вашими иммунологическими знаниями, он верит в ВАС.

Почетный вице-президент РНОИ

Научный руководитель НИИ фундаментальной

и клинической иммунологии

Иммунолог с 55-летним стажем

Академик РАН

В.А.Козлов 


\section{Авторский коллектив}

Козлов Владимир Александрович, академик РАН, научный руководитель НИИ фундаментальной и клинической иммунологии. Заслуженный деятель науки РФ. Почетный вице-президент РНОИ. Вице-президент Education Instruction Committee of World Federation of Chinese Medicine Societies, почетный член The World Immunopathology Organization (WIPO).

Савченко Андрей Анатольевич, д.м.н., профессор заведующий лабораторией клеточно-молекулярной физиологии и патологии ФГБНУ Федеральный исследовательский центр «Красноярский научный центр Сибирского отделения Российской академии наук», обособленное подразделение «НИИ медицинских проблем Севера».

Кудрявцев Игорь Владимирович, к.б.н., заведующий лабораторией иммунорегуляции ФГБНУ "Институт экспериментальной медицины", Санкт-Петербург; доцент кафедры иммунологии, Первый Санкт-Петербургский государственный медицинский университет им. И.П. Павлова, Санкт-Петербург.

Козлов Иван Генрихович, д.м.н., профессор, профессор кафедры организации и управления в сфере обращения лекарственных средств ИПО ФГАОУ ВО Первый Московский государственный медицинский университет им. И.М. Сеченова Министерства здравоохранения Российской Федерации (Сеченовский университет), Вице-президент Российского научного общества иммунологов

Кудлай Дмитрий Анатольевич д.м.н., профессор кафедры фармакологии Института Фармации ФГАОУ ВО Первый МГМУ им. И.М. Сеченова Минздрава России (Сеченовский университет). Ведущий научный сотрудник лаборатории персонализированной медицины и молекулярной иммунологии "ГНЦ Институт иммунологии" ФМБА России

Продеус Андрей Петрович, д.м.н., профессор, заведующий кафедрой иммунологии и аллергологии Высшей медицинской школы, главный внештатный специалист-иммунолог МЗ Московской области, главный педиатр ГДКБ №9 им. Г.Н. Сперанского Департамента здравоохранения г. Москвы

Борисов Александр Геннадьевич, Врач высшей категории, к.м.н.. Главный врач Института клинической иммунологии. Ведущий научный сотрудник ФГБНУ Федеральный исследовательский центр «Красноярский научный центр Сибирского отделения Российской академии наук», обособленное подразделение «НИИ медицинских проблем Севера». Ассистент кафедры инфекционных болезней и эпидемиологии с курсом ПО Красноярского государственного медицинского университета им. проф. В.Ф.ВойноЯсенецкого Минздрава России. 


\section{Список литературы}

1. Аллергология и иммунология / под ред. Л.С. Намазовой-Барановой, А.А. Баранова, Р.М. Хаитова: Союз педиатров России [и др.]. - М.: Изд-во «ПедиатрЪ», 2020. - 512 с. — (Практические рекомендации для педиатров).

2. Балдуева И.А., Нехаева Т.Л., Новик А.В., Данилова А.Б., Пипиа Н.П., Щербаков А.М., Беляев А.М. Противоопухолевые вакцины на основе дендритных клеток // Природа. 2018. № 6 (1234). C. 14-19.

3. Балдуева И.А., Новик А.В., Карицкий А.П., Кулева С.А., Нехаева Т.Л., Данилова А.Б., Проценко С.А., Семенова А.И., Комаров Ю.И., Пипиа Н.П., Славянская Т.А., Авдонкина Н.А., Сальникова С.В., Беляев А.М., Сепиашвили Р.И. Иммунотерапия рака: современное состояние проблемы // Аллергология и иммунология. 2015. Т. 16. № 4. С. 354.

4. Борисов А.Г., Савченко А.А., Соколовская В.К. Заболеваемость, связанная с нарушениями функции иммунной системы (на примере Красноярского края) // Здравоохранение Российской Федерации.-2014.-Т. 58, № 6.-С. 38-41.

5. Борисов А.Г. Клиническая характеристика нарушения функции иммунной системы // Медицинская иммунология.-2013.-Т. 15, № 1.- С.45-50.

6. Борисов А.Г. Кластерный анализ типов иммунных нарушений при инфекционновоспалительных заболеваниях// Российский иммунологический журнал.- 2014.- Т. 8(17), № 4.- С. $1002-1011$.

7. Борисов А.Г., Савченко А.А., Кудрявцев И.В. Особенности иммунного реагирования при вирусных инфекциях // Инфекция и иммунитет. 2015. Т. 5. № 2. С. 148-156.

8. Борисов А.Г., Савченко А.А. Особенности состояния клеточного и гуморального иммунитета при остром и хроническом вирусном гепатите B // Acta Biomedica Scientifica. 2012. № 3-2 (85). C. 53-57.

9. Борисов А.Г., Савченко А.А. Скрининг-тестирование с использованием программы «МедТест» для оценки состояния здоровья при проведении диспансеризации // Врач и информационные технологии 2013. № 1. С. $42-48$

10. Борисов А.Г., Савченко А.А., Смирнова С.В. К вопросу о классификации нарушений функционального состояния иммунной системы // Сибирский медицинский журнал. - 2008. - Том 23, №3 (выпуск 1).- С.13-18.

11. Борисов А.Г., Савченко А.А., Черданцев Д.В., Здзитовецкий Д.Э., Первова О.В., Кудрявцев И.В., Беленюк В.Д., Шапкина В.А. Типы иммунного реагирования при распространенном гнойном перитоните (с комментарием) // Хирургия. Журнал им. Н.И. Пирогова. 2016. № 9. C. 28-34.

12. Борисов А.Г., Савченко А.А., Кудрявцев И.В. Особенности иммунного реагирования при вирусных инфекциях // Инфекция и иммунитет. 2015. Т. 5. № 2. С. 148-156.

13. Борисов А.Г., Савченко А.А., Тихонова Е.П., Кудрявцев И.В., Калинина Ю.С. Анализ экспрессии CD57 и CD279 цитотоксическими Т-лимфоцитами различного уровня дифференцировки у больных ветряной оспой // Инфекционные болезни. 2017. Т. 15. № 4. С. 26-32.

14. Борисов А.Г., Савченко А.А., Кудрявцев И.В., Модестов А.А., Тоначева О.Г., Мошев А.В. Варианты иммунного реагирования при раке почки// Медицинская иммунология. 2017. Т. 19. № S. C. 227.

15. Будкова А.И., Лапин С.В., Серебрякова М.К., Кудрявцев И.В., Тришина И.Н., Маслянский А.Л., Арег А. Тотолян. Субпопуляционный состав В-клеток периферической крови у больных системной красной волчанкой // Медицинская иммунология. 2017. Т. 19. № 2. С. 175-184.

16. Бычкова Н.В. Применение метода проточной цитометрии для диагностики аллергических заболеваний // Справочник заведующего КДЛ. 2016. № 4. С. 21-30.

17. Бычкова Н.В. Анализ содержания ДНК методом проточной цитометрии. Возможности применения в клинической практике. Тверь, 2015.

18. Васильева Е.В., Кудрявцев И.В., Максимов Г.В., Вербов В.Н., Серебрякова М.К., Ткачук А.П., Тотолян Арег А. Влияние ВИЧ-инфекции и туберкулеза на степень дифференцировки Т-лимфоцитов периферической крови // Инфекция и иммунитет. 2017. Т. 7. № 2. С. 151-161.

19. Воробьёв С.В., Емелин А.Ю., Кузнецова Р.Н., Кудрявцев И.В. Роль иммунной реакции в патогенезе болезни Альцгеймера и возможности противовоспалительной терапии // Неврологический вестник. 2020; T. LII (3): 55-62. 
20. Головкин А.С., Асадуллина И.А., Кудрявцев И.В. Пуринергическая регуляция основных физиологических и патологических процессов // Медицинская иммунология. 2018, Т. 20, № 4, стр. 463-476.

21. Головкин А.С., Зурочка А.В., Хайдуков С.В., Кудрявцев И.В. Современные методы и подходы к изучению апоптоза в экспериментальной биологии // Медицинская иммунология. 2012. T. 14. № 6. C. 461-482.

22. Головкин А.С., Кудрявцев И.В., Дмитриев А.В., Калинина О.В. Фиброзные изменения сердечно-сосудистой и дыхательной систем после перенесенной COVID-19: вклад факторов иммунной системы и генетическая предрасположенность // Российский кардиологический журнал 2020; 25 (10). doi: 10.15829/1560-4071-2020-4087.

23. Головкин А.С., Матвеева В.Г., Кудрявцев И.В., Григорьев Е.В., Великанова Е.А., Байракова Ю.В. Субпопуляции моноцитов крови при неосложненном течении периоперационного периода коронарного шунтирования // Медицинская иммунология. 2012. Т. 14. № 4-5. С. 305-312.

24. Головкин А.С., Серебрякова М.К., Жидулева Е.В., Муртазалиева П.М., Титов В.А., Иртюга О.Б., Моисеева О.М., Кробинец И.И., Кудрявцев И.В. Экспрессия рецепторов пуринергического сигналинга на Т-лимфоцитах периферической крови здоровых доноров // Трансляционная медицина. 2017. Т. 4. № 5. С. 46-60.

25. Данилова А.Б., Балдуева И.А. Нейтрофилы как компонент опухолевого микроокружения // Вопросы онкологии. 2016. Т. 62. № 1. С. 35-44.

26. Заботина Т.Н. Иммунологические нарушения у онкологических больных как основа таргетной иммунотерапии // В книге: Опухолевые маркеры: фундаментальные и клинические аспекты. Материалы конференции, посвященной памяти советского и российского ученого Гарри Израйлевича Абелева. 2018. С. 34-35.

27. Заботина Т.Н., Короткова О.В., Черткова А.И., Захарова Е.Н., Табаков Д.В., Джгамадзе Н.Т., Савостикова М.В., Артамонова Е.В., Хайленко В.А., Коваленко Е.И., Кадагидзе 3.Г. Лимфоциты, инфильтрирующие опухоль при раке молочной железы. связь с клиникопатологическими параметрами // Бюллетень экспериментальной биологии и медицины. 2018. Т. 166. № 8. C. 200-203.

28. Зурочка А.В., Хайдуков С.В. Изменение представлений об оценке иммунного статуса человека, новые проблемы и подходы к их решению // Медицинская иммунология. 2007. Т. 9. № 2-3. С.339-340.

29. Зурочка А.В., Хайдуков С.В., Кудрявцев И.В., Черешнев В.А. Проточная цитометрия в биомедицинских исследованиях / Екатеринбург: РИО УрО РАН, 2018. - 720 с.

30. Иммунология: структура и функции иммунной системы / Под ред. Р.М. Хаитова. M.2013. - $280 \mathrm{c}$.

31. Ильина И.И. Аллергия - болезнь цивилизации// Качество жизни. 2005. № 4. С. 10-14.

32. Кадагидзе 3.Г., Черткова А.И., Славина Е.Г., Заботина Т.Н. Современные методы противоопухолевой терапии и иммунная система // Евразийский онкологический журнал. 2018. Т. 6. № 3-4. С. 707-710.

33. Кадагидзе 3.Г., Славина Е.Г., Заботина Т.Н., Черткова А.И., Короткова О.В., Борунова А.А. Иммунофенотипический профиль лимфоцитов крови у онкологических больных //Российский биотерапевтический журнал. 2013. Т. 12. № 2. С. 38.

34. Кадагидзе 3.Г., Черткова А.И., Заботина Т.Н., Короткова О.В., Славина Е.Г., Борунова А.А. Новые возможности регуляции противоопухолевого иммунного ответа // Злокачественные опухоли. 2015. № 1 (12). С. 24-30.

35. Кетлинский С.А., Симбирцев А.С. Цитокины. СПб.: Фолиант, 2008. 552c.

36. Киселевский М.В., Власенко Р.Я., Заботина Т.Н., Кадагидзе З.Г. Прогностическая значимость опухоль-инфильтрирующих лимфоцитов // Иммунология. 2019. Т. 40. № 1. С. 73-82.

37. Козлов В.А. Клетки-супрессоры - основа иммунопатогенеза аутоиммунных заболеваний // Медицинская иммунология. 2016. Т. 18. № 1. С. 7-14.

38. Козлов В.А., Борисов А.Г., Смирнова С.В., Савченко А.А. Практические аспекты диагностики и лечения иммунных нарушений: Руководство для врачей. Новосибирск: Наука, 2009. $274 \mathrm{c}$.

39. Козлов В.А., Черных Е.Р. Современные проблемы иммунотерапии в онкологии // Бюллетень Сибирского отделения Российской академии медицинских наук. 2004. № 2. С. 13-19.

40. Кудрявцев И.В. Т-клетки памяти: основные популяции и стадии дифференцировки // Российский иммунологический журнал. 2014. Т. 8. № 4 (17). С. 947-964. 
41. Кудрявцев И.В., Борисов А.Г., Васильева Е.В., Кробинец И.И., Савченко А.А., Серебрякова М.К., Тотолян А.А. Фенотипическая характеристика цитотоксических Т-лимфоцитов: регуляторные и эффекторные молекулы // Медицинская иммунология. 2018. Т. 20. № 2. С. 227-240.

42. Кудрявцев И.В. Т-клетки памяти: основные популяции и стадии дифференцировки // Российский иммунологический журнал. 2014. Т. 8 . № 4 (17). С. 947-964.

43. Кудрявцев И.В., Борисов А.Г., Кробинец И.И., Савченко А.А., Серебрякова М.К. Определение основных субпопуляций цитотоксических Т-лимфоцитов методом многоцветной проточной цитометрии // Медицинская иммунология. 2015. Т. 17. № 6. С. 525-538.

44. Кудрявцев И.В., Борисов А.Г., Васильева Е.В., Кробинец И.И., Савченко А.А., Серебрякова М.К., Тотолян А.А. Фенотипическая характеристика цитотоксических Т-лимфоцитов: регуляторные и эффекторные молекулы // Медицинская иммунология. 2018. Т. 20. № 2. С. 227-240.

45. Кудрявцев И.В., Борисов А.Г., Кробинец И.И., Савченко А.А., Серебрякова М.К., Тотолян А.А. Хемокиновые рецепторы на Т-хелперах различного уровня дифференцировки: основные субпопуляции // Медицинская иммунология. 2016. Т. 18. № 3. С. 239-250.

46. Кудрявцев И.В., Елезов Д.С. Анализ основных популяций цитотоксических Тлимфоцитов периферической крови на основании уровня экспрессии CD27, CD28, CD45R0 и CD62L // Российский иммунологический журнал. 2013. Т. 7. № 2-3 (1) (16). С. 57-61.

47. Кудрявцев И.В., Субботовская А.И. Опыт измерения параметров иммунного статуса с использованием шестицветного цитофлуориметрического анализа // Медицинская иммунология. 2015. T. 17. № 1. C. 19-26.

48. Кудрявцев И.В., Борисов А.Г., Кробинец И.И., Рак А.Я., Савченко А.А., Серебрякова M.К. Особенности экспрессии поверхностных рецепторов семейства KLR цитотоксическими Tклетками различного уровня дифференцировки // Российский иммунологический журнал. 2016. T. 10. № 3 (19). C. 297-302.

49. Кудрявцев И.В, Борисов А.Г., Волков А.Е., Савченко А.А., Серебрякова М.К., Полевщиков А.В. Анализ уровня экспрессии CD56 и CD57 цитотоксическими Т-лимфоцитами различного уровня дифференцировки // Тихоокеанский медицинский журнал. 2015. № 2. С. 30-35.

50. Кукес В. Г. Клиническая фармакология. - М.: ГЭОТАР-Медиа, 1999. - 528 с.

51. Лазанович В.А., Маркелова Е.В., Просекова Е.В., Кудрявцев И.В., Смолина Т.П., Павлов В.А. Анализ экспресии C3aR, C5aR1 (CD88) на миелоидных клетках у пациентов с сепсисом // Патологическая физиология и экспериментальная терапия. 2017. Т. 61. № 1. С. 72-77.

52. Лазанович B.A., Маркелова Е.В., Смирнов Г.А., Павлов В.A. TOLL-рецепторы на моноцитах и их клиническая значимость у пациентов с сепсисом // Российский иммунологический журнал. 2014. Т. 8. № 3 (17). С. 825-828.

53. Лазанович В.А., Маркелова Е.В., Караулов А.В. Клиническая значимость экспрессии TLR2, TLR4 на клетках миелоидного ряда и сывороточного уровня цитокинов у пациентов с сепсисом // Иммунопатология, аллергология, инфектология. 2015. № 2. С. 71-76.

54. Литвинова Л.С., Гуцол А.А., Сохоневич Н.А., Кофанова К.А., Хазиахматова О.Г., Шуплецова В.В., Кайгородова Е.В., Гончаров А.Г. Основные поверхностные маркеры функциональной активности Т-лимфоцитов // Медицинская иммунология. 2014. Т. 16. № 1. С. 7-26.

55. Луговская С.А., Почтарь М.Е., Тупицын Н.Н. Иммунофенотипирование в диагностике гемобластозов. М.-Тверь: ООО «Издательство Триада», 2005. 168 с.

56. Маев И.В., Цуканов В.В., Третьякова О.В., Каспаров Э.В., Кучерявый Ю.А., Андреев Н.Г., Васютин А.В. Терапевтические аспекты лечения язвенных кровотечений // Фарматека. 2012. № 2 (235). C. 56-59.

57. Матвеева В.Г., Головкин А.С., Чернова М.Н., Шукевич Д.Л., Григорьев Е.В. Динамика поверхностной экспрессии триггерного рецептора, экспрессируемого миелоидными клетками-1 (TREM-1) на различных субпопуляциях моноцитов в раннем послеоперационном периоде прямой реваскуляризации миокарда // Бюллетень ВСНЦ СО РАМН. 2012. Т. 3. № 85. С. 116-120.

58. Матвеева В.Г., Головкин А.С., Григорьев Е.В. Субпопуляционный состав моноцитов - прогностический маркер тяжелых осложнений системного воспалительного ответа после операции коронарного шунтирования // Комплексные проблемы сердечно-сосудистых заболеваний. 2014. № 4. C. 5-12.

59. Матвеева В.Г., Головкин А.С., Кудрявцев И.В., Григорьев Е.В., Чернова М.Н. Динамика CD14+CD16+ субпопуляций моноцитов при неосложненном системном воспалительном 
ответе в периоперационном периоде коронарного шунтирования // Медицинская иммунология. 2012. T. 14. № 4-5. C. 391-398.

60. Медицинская микробиология и иммунология/ У. Левинсон ; пер. с англ. под ред. дра мед. наук, проф. В. Б. Белобородова. - М. : БИНОМ. Лаборатория знаний,2015.

61. Новик А.В., Балдуева И.А., Проценко С.А., Нехаева Т.Л., Семенова А.И., Данилова А.Б., Латипова Д.Х., Анохина Е.М., Комаров Ю.И., Ахаева 3.Ю. Современные методы иммунотерапии метастатической меланомы // Вопросы онкологии. 2016. Т. 62. № 5. С. 580-587.

62. Новик А.В. Анемия и метаболические расстройства у онкологических больных // Практическая онкология. 2009. Т. 10. № 3. С. 131-140.

63. Новик А.В. Принципы современной иммунотерапии//Фарматека. 2018. № 7. С.10-18.

64. Новик А.В., Проценко С.А., Балдуева И.А. Использование оценки состояния адаптивной иммунной системы у больных со злокачественными солидными опухолями в качестве предиктивных или прогностических факторов: систематический обзор // Эффективная фармакотерапия. 2020. Т. 16. № 33. С. 58-75.

65. Новиков Д. К. Клиническая иммунология : учебное пособие / Д. К. Новиков, П. Д. Новиков. - Витебск : ВГМУ, 2006. - 392 с.

66. Новиков Д. К. Клиническая иммунология и аллергология: учебник /Д. К. Новиков, П. Д. Новиков, Н. Д. Титова. - Минск: Вышэйшая школа, 2019. - 495 с.

67. Основы клинической иммунологии и аллергологии: уч. пособие / под ред. Л.С. Намазовой-Барановой, Л.В. Ганковской, Н.Г. Астафьевой - М.: Педиатръ, 2016. - 152 с.

68. Пашнина И.А., Кшнясев И.А., Козлова Е.С., Скоробогатова О.В. Экспрессия CD5 на В-лимфоцитах у детей с различной активностью ювенильного идиопатического артрита // Российский иммунологический журнал. 2014. Т. 8 (17). №2(1). С. 129-131.

69. Пипиа Н.П., Балдуева И.А., Данилова А.Б., Авдонкина Н.А., Новик А.В., Нехаева Т.Л., Гафтон Г.И., Емельянова Н.В. Иммуносупрессивный потенциал периферических регуляторных Т-лимфоцитов в процессе опухолевой прогрессии у больных метастатическими саркомами мягких тканей // Вопросы онкологии. 2018. Т. 64. № 3. С. 400-407.

70. Савченко А.А., Борисов А.Г. Основы клинической иммунометаболомики. Новосибирск: Наука, 2013.- 263 с.

71. Савченко А.А. Определение активности NAD(P)-зависимых дегидрогеназ в нейтрофильных гранулоцитах биолюминесцентным методом // Бюллетень экспериментальной биологии и медицины. 2015. Т. 159. № 5. С. 656-660.

72. Савченко А.А., Борисов А.Г., Анисимова Е.Н., Беленюк В.Д., Кудрявцев И.В., Решетников И.В., Квятковская С.В., Цейликман В.Э., Зорин А.Н. Исследование фенотипа лейкоцитов крови у больных онихомикозами с помощью метода Hematoflow // Инфекция и иммунитет. 2015. Т. 5. № 4. С. 339-348

73. Савченко А.А., Борисов А.Г., Кудрявцев И.В., Мошев А.В. Роль Т- и В-клеточного иммунитета в патогенезе онкологических заболеваний // Вопросы онкологии. 2015. № 6. С. 867-875.

74. Савченко А.А., Здзитовецкий Д.Э., Борисов А.Г. Иммунометаболические нарушения при распространенном гнойном перитоните. Новосибирск: Наука, 2013.-142 с.

75. Савченко А.А., Здзитовецкий Д.Э., Борисов А.Г., Лузан Н.А. Хемилюминесцентная активность нейтрофильных гранулоцитов и уровни концентрации цитокинов у больных распространенным гнойным перитонитом // Цитокины и воспаление. 2013. Т. 12. № 1-2. С. 115-119.

76. Савченко А.А., Кудрявцев И.В., Борисов А.Г. Методы оценки и роль респираторного взрыва в патогенезе инфекционно-воспалительных заболеваний // Инфекция и иммунитет. 2017. Т. 7. № 4. C. 327-340.

77. Семикина Е.Л., Копыльцова Е.А., Алешкин В.А., Топтыгина А.П. Возрастные особенности формирования гуморального звена иммунного ответа у детей // Медицинская иммунология. 2012. Т. 14. № 4-5. С. 289-294.

78. Серебряная Н.Б. Нуклеотиды как регуляторы иммунного ответа // Иммунология. 2010. T. 31. № 5. C. 273-280.

79. Симбирцев А. С. Цитокины в патогенезе и лечении заболеваний человека. СПетербург: Фолиант, 2018. - 512 с.

80. Симбирцев А. С. Иммунофармакологические аспекты системы цитокинов // Бюллетень сибирской медицины. 2019. Т. 8. № 1. С. 84-95 
81. Сохоневич Н.А., Хазиахматова О.Г., Юрова К.А., Шуплетова В.В., Литвинова Л.С. Фенотипическая характеристика и функциональные особенности Т- и В-клеток иммунной памяти // Цитология. 2015. Т. 57. № 5. С. 311-318.

82. Смирнова О.В., Титова Н.М., Каспаров Э.В., Елманова Н.Г. Хемилюминесцентная активность нейтрофильных гранулоцитов в прогрессировании механической желтухи в зависимости от уровня билирубина и генеза желтухи // Медицинская иммунология. 2016. Т. 18. № 3. C. $269-278$.

83. Радкевич А.А., Каспарова И.Э., Винник Ю.С., Горбунов Н.А., Каспаров Э.В., Усольцев Д.М., Иванов В.А., Галонский В.Г. Репаративный десмогенез после замещения соединительно-тканных дефектов тканевыми имплантатами из никелида титана. // Сибирский медицинский журнал (Иркутск). 2009. Т. 91. № 8. С. 151-153.

84. Топтыгина А.П. Лимфоидный фолликул - территория иммунного ответа // Иммунология. 2012. Т. 33. № 3. С. 162-168.

85. Топтыгина А.П. Т-клетки памяти // Иммунология. 2008. Т. 29. № 5. С. 311-316.

86. Топтыгина А.П., Семикина Е.Л., Копыльцова Е.А., Алешкин В.А. Возрастная динамика экспрессии изоформ CD45 Т-хелперами и Т-цитотоксическими лимфоцитами крови здоровых доноров // Иммунология. 2014. № 4. С. 229-232.

87. Топтыгина А.П., Семикина Е.Л., Петричук С.В., Закиров Р.Ш., Курбатова О.В., Копыльцова Е.А., Комах Ю.А. Изменение уровня субпопуляций Т-регуляторных клеток и Тхелперов 17 в периферической крови здоровых людей в зависимости от возраста // Медицинская иммунология. 2017. Т. 19. № 4. С. 409-420.

88. Тотолян А.А. Роль хемокинов и их рецепторов в иммунорегуляции // Иммунология. 2001. № 5. C. 7-15

89. Тотолян А.А., Балдуева И.А., Бубнова Л.Н., Закревская А.В., Зуева Е.Е., Калинина Н.М., Лисицина 3.Н. Стандартизация методов иммунофенотипирования клеток крови и костного мозга человека // Клиническая лабораторная диагностика. 2002. № 1. С. 44-50.

90. Тотолян А.А., Фрейдлин И.С. Клетки иммунной системы / СПб.: Наука, 2000. 213 с.

91. Хаитов Р.М., Пинегин Б.В., Ярилин А.А. Руководство по клинической иммунологии. Диагностика заболеваний иммунной системы: Руководство для врачей. 2009. 352 c.

92. Хаитов Р.М., Гариб Ф. Ю. Иммунология. Атлас. ГЭОТАР-Медиа, 2020 г. 416 с.

93. Хаитов Р.М.. Иммунология. Учебник. ГЭОТАР-Медиа, 2018. 496 с.

94. Хаитов Р.М., Елисютина О.Г., Данилычева И. В. Аллергология и клиническая иммунология. Клинические рекомендации. ГЭОТАР-Медиа, 2019 г. 352 с.

95. Хаитов Р.М.. Иммунология. Структура и функции иммунной системы. Учебное пособие. ГЭОТАР-Медиа, 2019. 328 с.

96. Х Хаитов Р.М., Балаболкин И. И., Шульженко А. Е., Алленов С. Н., Атауллаханов Р.И.. Иммунотерапия. Руководство для врачей. ГЭОТАР-Медиа, 2020 г. 768 с.

97. Хайдуков С.В. Подходы к стандартизации метода проточной цитометрии для иммунофенотипирования. Настройка цитометров и подготовка протоколов для анализа // Медицинская иммунология. 2007. Т. 9. № 6. С. 569-574.

98. Хайдуков С.В., Байдун Л.В., Зурочка А.В., Арег А.А. Стандартизованная технология «Исследование субпопуляционного состава лимфоцитов периферической крови с применением проточных цитофлюориметров-анализаторов» // Российский иммунологический журнал. 2014. Т. 8 , № 4 (17). C. 974-992.

99. Хайдуков С.В., Зурочка А.В. Возможности проточной цитофлюориметрии в диагностике инфекционных заболеваний. Часть 1 // Инфекция и иммунитет. 2011. № 1. С. 59-66.

100. Хайдуков С.В., Зурочка А.В. Возможности проточной цитофлюориметрии в диагностике инфекционных заболеваний. Часть 2 //Инфекция и иммунитет. 2011. № 2. С. 113-120.

101. Хайдуков С.В., Зурочка А.В. Возможности проточной цитофлюориметрии в диагностике инфекционных заболеваний. Часть 3 // Инфекция и иммунитет. 2011. № 3. С. 221-230.

102. Хайдуков С.В., Зурочка А.В. Вопросы современной проточной цитометрии. Клиническое применение. Челябинск: Челябинская государственная медицинская академия, 2008. $195 \mathrm{c}$.

103. Хайдуков С.В., Зурочка А.В. Проточная цитометрия как современный метод анализа в биологии и медицине // Медицинская иммунология. 2007. Т. 9. № 4-5. С. 373-378.

104. Хайдуков С.В., Зурочка А.В. Расширение возможностей метода проточной цитометрии для иммунологической практики// Медицинская иммунология. 2008. № 1. С.5-12. 
105. Хайдуков С.В., Зурочка А.В. Цитометрический анализ субпопуляций Т-хелперов (Th1, Th2, Treg, Th17, Т-хелперы активированные)// Медицинская иммунология. 2011. № 1. С. 7-16.

106. Хайдуков С.В., Зурочка А.В., Тотолян Арег А., Черешнев В.А. Основные и малые популяции лимфоцитов периферической крови человека и их нормативные значения (методом многоцветного цитометрического анализа) // Медицинская иммунология. 2009. № 2-3. С. 227-238.

107. Хайдуков С.В., Зурочка А.В., Черешнев В.А. Многоцветный цитометрический анализ. идентификация Т-клеток и их субпопуляций по экспрессии $\alpha \beta$-TCR и $\gamma \delta$-TCR // Медицинская иммунология. 2008. Т. 10. № 2-3. С. 115-124.

108. Хайдуков С.В., Зурочка А.В., Черешнев В.А. Цитометрический анализ в клинической иммунологии. УрО РАН, Екатеринбург, 2011. $220 \mathrm{c}$.

109. Цуканов В.В., Родина Д.В., Борисов А.Г., Савченко А.А. Взаимосвязь иммунологических показателей и степени вирусной нагрузки при остром вирусном гепатите В // Медицинская иммунология. 2011. Т. 13. № 2-3. С. 181-188.

110. Цуканов В.В., Каспаров Э.В., Тонких Ю.Л., Васютин А.В. Новые аспекты неалкогольной жировой болезни печени. // Российский журнал гастроэнтерологии, гепатологии, колопроктологии. 2015. Т. 25. № 4. С. 34-38.

111. Цхай В.Б., Круглова Д.Ю., Борисов А.Г., Савченко А.А. Некоторые иммунологические показатели при патологии шейки матки, ассоциированной с папилломавирусной инфекцией // Медицинская иммунология. 2012. Т. 14. № 3. С. 207-212.

112. Черданцев Д.В., Первова О.В., Шапкина В.А., Дятлов В.Ю., Трофимович Ю.Г., Борисов А.Г., Беленюк В.Д., Гвоздев И.И., Амельченко А.А. Современный подход к лечению пациентов с распространенным гнойным перитонитом // Сибирское медицинское обозрение. 2016. № 6 (102). C. 24-35.

113. Черешнев В.А., Шмагель К.В. Иммунология. М.: Изд-во «МАГИСТР». 2013. 448 с.

114. Чуров А.В., Олейник Е.К., Олейник В.М. Роль трансформирующего фактора роста $\beta$ в формировании иммуносупрессии в онкогенезе// Цитокины и воспаление. 2009. Т. 8. № 3. С. 11-15.

115. Ярилин А.А. Иммунология. М.: ГЭОТАР-Медиа, 2010. 752 с.

116. Ярилин А.А. Основы иммунологии. Медицина, Москва, 1999. 608 с.

117. Abbas A., Lichtman A., Pillai S. Basic Immunology 6-ed. - Elsevier, 2019. — 336 p.

118. Actor J.. Introductory immunology. Basic Concepts for Interdisciplinary Applications. Academic Press. 2019 - 196 p.

119. The Autoimmune Diseases ed N. Rose, I. Mackay - Academic Press. 2020 - 1450 p.

120. Bogitsh B., Carter C., Oeltmann T. Human Parasitology. - Academic Press, 2018 - 422 p.

121. Clinical Immunology: Principles and Practice. Elsevier, 2019. - 1318 p.

122. Hematology, Basic Principles and Practice. Elsevier, 2018. - 2650 p.

123. Immuno-Oncology Cellular and Translational Approaches. Tan S - Elsevier, 2020. $259 \mathrm{p}$.

124. Jawetz, Melnick, \& Adelberg's Medical Microbiology. - McGraw-Hill. 2019 - 897 p.

125. Keogan M. T., Wallace E. M., O'Leary P. Concise Clinical Immunology for Healthcare Professionals - New York, 2006. - $426 \mathrm{p}$

126. Male D., Male V., Peebles, Jr. R. S. Immunology - Elsevier Health Sciences, 2020 - 482 p.

127. Punt J.,Stranford S, Jones P., Owen J. Kuby Immunology - W. H. Freeman and Company. $2019-1905 \mathrm{p}$.

128. Perricone C., Shoenfeld Y. Mosaic of Autoimmunity: The Novel Factors of Autoimmune Diseases - Elsevier, 2019 - 1136 p.

129. Roitt's Essential Immunology Peter J. Delves, Seamus J. Martin, Dennis R. Burton, Ivan M. Roitt. Wiley-Blackwell, 2017. - 576 p.

130. Sompayrac L., How the Immune System Works. - Wiley. 2019 - 169 p.

131. Tsukanov V.V., Kasparov E.V., Tonkikh J.L., Amelchugova O.S., Vasyutin A.V., Bronnikova E.P., Shtygasheva O.V., Butorin N.N., Fassan M., Rugge M. Peptic ulcer disease and Helicobacter pylori infection in different siberian ethnicities // Helicobacter. 2017. T. 22. № 1. C. e12322.

132. White G. R., Vanbergen O. Crash Course Haematology and Immunology. - Elsevier Health Sciences, $2018-200$ p. 